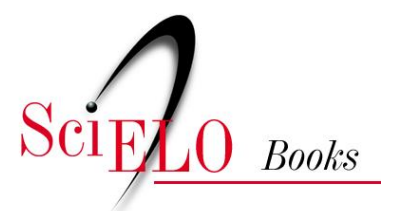

\title{
Identidade e cidadania
}

como se expressa o judaísmo brasileiro

\author{
Helena Lewin (coord.)
}

\section{SciELO Books / SciELO Livros / SciELO Libros}

LEWIN, H., coord. Identidade e cidadania: como se expressa o judaísmo brasileiro [online]. Rio de Janeiro: Centro Edelstein de Pesquisas Sociais, 2009, 821 p. ISBN: 978-85-7982-018-2. Available from SciELO Books $<$ http://books.scielo.org $>$.

\section{(2)(1)(2)}

All the contents of this chapter, except where otherwise noted, is licensed under a Creative Commons Attribution-Non Commercial-ShareAlike 3.0 Unported.

Todo o conteúdo deste capítulo, exceto quando houver ressalva, é publicado sob a licença Creative Commons Atribuição Uso Não Comercial - Partilha nos Mesmos Termos 3.0 Não adaptada.

Todo el contenido de este capítulo, excepto donde se indique lo contrario, está bajo licencia de la licencia Creative Commons Reconocimento-NoComercial-CompartirIgual 3.0 Unported. 


\section{BIBLIOTECA VIRTUAL DE CIÊNCIAS HUMANAS}

\section{IDENTIDADE E CIDADANIA}

\section{Como se expressa o judaísmo brasileiro}

\section{Helena Lewin (coordenadora)}




\section{Identidade e cidadania Como se expressa o judaísmo brasileiro}

Copyright (c) 2009, Helena Lewin

Copyright (c) 2009 desta edição on-line: Centro Edelstein de Pesquisas Sociais

Ano da última edição: 2005, Programa de Estudos Judaicos

Nenhuma parte desta publicação pode ser reproduzida ou transmitida por qualquer meio de comunicação para uso comercial sem a permissão escrita dos proprietários dos direitos autorais. A publicação ou partes dela podem ser reproduzidas para propósito não comercial na medida em que a origem da publicação, assim como seus autores, seja reconhecida.

ISBN: $978-85-7982-018-2$

Centro Edelstein de Pesquisas Sociais

www.centroedelstein.org.br

Rua Visconde de Pirajá, 330/1205

Ipanema - Rio de Janeiro - RJ

CEP: 22410-000. Brasil

Contato: bvce@centroedelstein.org.br

Rio de Janeiro

2009 


\section{SUMÁRIO}

\section{APRESENTAÇÃO}

\section{AGRADECIMENTOS}

\section{ANOS DE PRESENÇA JUDAICA NO BRASIL}

O legado do judaísmo à civilização brasileira Anita Novinsky

\section{CApítulo}

RESGATE HistóRICO DA VIVÊNCIA JUDAICA NO BRASIL

Da Península Ibérica para Pernambuco... Eles vieram para ficar............9 Tânia Neumann Kaufman

Um conflito de identidades: judeus e cristãos-novos no Brasil Bruno Feitler

Origens da intolerância aos cristãos-novos no Brasil Colônia

Renata Rozental Sancovsky

As denúncias de uma tradição:

das velas do shabat às fogueiras da inquisição

Aleksandra Lavor Serbim Umbelino

Os marranos e a interculturalidade em Pernambuco Claudia Simonne Carneiro Gouveia

Mulheres da nação cristã-nova:

as marranas do Rio de Janeiro (século XVIII)

Lina Gorestein

"Gente da Nação":

os judaizantes e a preservação do judaísmo no Brasil João Henrique dos Santos

Comunidades judaizantes em Minas Gerais. Neusa Fernandes

Judeus no sul do Brasil, Porto Alegre-RS:

da dispersão grupal à construção institucional e comunitária .... Ieda Gutfreind
Em terras gaúchas: a história da imigração judaico-alemã

Gladis Wiener Blumenthal

Resiliência, judaísmo e cultura organizacional. Izabella Lucena

Prestamistas judeus no Rio de Janeiro (1920-1960) Fábio de Sá Earp e Fania Fridman

Os judeus da Leopoldina Márcio André Sukman

Imigrantes judeus do Oriente Médio

e sua inserção em São Paulo e no Rio de Janeiro

Rachel Mizrahi

Judeus do Egito no Rio de Janeiro:

uma imigração peculiar (1956/1957)

Joëllle Rouchou

\section{2a CApítulo}

\section{O DISCURSO DO JUDAÍSMO BRASILEIRO}

ATRAVÉS dA Literatura E dA ARTE

O olhar judaico: memória e testemunho Bella Jozef

Literatura de imigrantes: a literatura iídiche no Brasil Rifka Berezin

Para além do incêndio: a escrita feminina de Cíntia Moscovich ........ 203 Nancy Rozenchan

Homenagem ao intelectual judeu Jacó Guinsburg. Berta Waldman

Entre o cheder e a rua:

figurações do judaico e do brasileiro na prosa de Samuel Bawet...... 219 Rosana Kohl Bines

Carta exílio: Rui Barbosa e o processo do Capitão Dreyfus

Sarah Lerner Sadcovitz

O padre António Vieira (1608-1697) e os judeus:

as referências a São Paulo. 
As influências do hebraico no português:

uma busca genealógica

Isabel Arco Verde Santos e Andréa de Melo Souza

A temática judaica nos poemas de Borges

Leonor Scliar-Cabral

Por uma estética contra a ordem:

dois contos de Jorge Luis Borges sobre o nazismo

Lyslei de Souza Nascimento

Vozes consoantes:

os artistas judeus e a MPB nos anos de Vargas.

Orlando de Barros

\section{$3^{\circ}$ CAPítulo}

\section{Testemunhos E Histórias de VIDA}

O cálice sagrado: a saga da família Blajberg de Ostrowiec .

Israel Blajberg

Individual dactiloscópica:

Bruno Wiczer, a trajetória de um imigrante Fábio Koifman

Hershell Pencak (B5156): memórias da dor

Maurício Pencak

Na busca de raízes: desvendando mistérios e trajetórias Micheline Raccah

Bat Yam ou Yemanjá, uma fiel consumidora Renée Avigdor

\section{PARTE 2}

\section{VERTENTES DIFERENCIADAS}

\section{DO COMPORTAMENTO JUDAICO BRASILEIRO}

\section{$1^{\circ}$ Capítulo}

\section{IDENTIDADE E ETNICIDADE}

Identidade judaica:

significados e pertinência em jovens judeus liberais paulistanos

Sylvana Hemsi
A América e a reconstrução da identidade judaica.....

Pedro P. Geiger

Identidade em conflito: o segredo do padre Sanctos Saraiva

(1834-1900), um "judaizante" na corte de D. Pedro II

Paulo Valadares

Identidade judaica na família

do poeta marrano Antônio Serrão de Castro

Benair A. Fernandes Ribeiro

O judaísmo e a boa cidadania ..... Yossef [Maurício] Zukin

Em busca de uma identidade:

o comportamento de consumo de judeus bem-sucedidos Carlos Blajberg

Identidade, cidadania:

como se expressa o judaísmo na Amazônia!

Oro Serruya

O dilema da educação judaica formal

numa comunidade judaica diáspora.

Anita Brumer

Educação para a diversidade

Cheila Szuchmacher Huf

Mulheres judias, profissionais brasileiras:

entre a identidade e cidadania.

Helena Lewin

O pacto da memória:

interpretação e identidade na fonte bíblica

Cláudia Andréa Prata Ferreira

A diáspora brasileira:

solução neurótica, anomalia e viver parcial?

Leopoldo O. C. de Oliveira

Criação de uma fundação de estudos e pesquisas sefaradis. Max Nahmias

3


Imigração e território:

o papel de Israel na construção da identidade judaica da Diáspora.....558 Adriana Spilki e Anita Brumer

A construção o de um lugar judeu no Recife

Rosa Bernarda Ludemir

Censo 2002: perfil da comunidade judaica do Rio .598 Daniel Sasson

Atividade judaica na visão ampla do terceiro setor.

Edda Bergmann

\section{CAPÍtulo \\ O DIÁLOGO INTER-RELIGIOSO: \\ UMA VIA DE MÃo DUPLA}

Eu e tu: diálogo plural Hélio Albuquerque

Dabru Emet.

Leon Mayer

Educação para o diálogo

O Shabat e o diálogo entre judeus e adventistas no Brasil Reinaldo Siqueira

Neopentecostais e neo-ortodoxos em São Paulo:

diferenças e semelhanças nas estratégias

de recrutamento de novos membros

Matha Topel

\section{$3^{\circ}$ CApítulo}

\section{Política e Comportamento Judaico}

\subsection{O DisCURSO ANTISSEMITA E SUAS MÚLTIPLAS EXPRESSÕES}

Demônios renascidos das cinzas:

reflexões acerca da intolerância no século XX e XXI. Maria Luiza Tucci Carneiro

As comunidades judaicas e o exercício da cidadania:

do direito à vida, à liberdade e à segurança.
Relações entre a polícia política

e a comunidade judaica na era Vargas

Isabela Andrade Lima

Humanus ou a construção do antissemitismo

Saul Kirschbaum

\subsection{MILITÂNCIA POLÍTICA DOS JUDEUS BRASILEIROS}

Nem bandidos, nem heróis:

os militantes judeus de esquerda mortos sob tortura no Brasil

[1969/1975]

Beatriz Kushnir

Judeus e Estado no Brasil: repensando o conceito de integração

Esther Kuperman

“Quando o calo aperta...”:

uma análise do imaginário político de jovens judeus

da cidade do Rio de Janeiro

Marcelo Gruman

3.3 DISCUTINDO O CONFLITO

ISRAEL / PALESTINA SOB A PERSPECTIVA BRASILEIRA

Brasil e Oriente Médio nas Nações Unidas:

equidistância, pragmatismo e realismo.

Norma Breda dos Santos

Brasil e Israel:

da partilha da Palestina ao reconhecimento diplomático 773

Alberto Kleinas Tullo Vigevani

O conflito no Oriente Médio e a possibilidade da paz.

Nizar Messar

$\mathrm{O}$ veto brasileiro ao sionismo e

o "pragmatismo responsável" do governo Geisel

Monique Sochaczewsk

História de um conflito 


\section{APRESENTAÇÃO}

A Universidade do Estado do Rio de Janeiro por intermédio de seu Programa de Estudos Judaicos, vinculado à Sub Reitoria de Extensão e Cultura, apresenta este volume intitulado Identidade e Cidadania: como se expressa o judaísmo brasileiro composto de textos que foram apresentados durante o III Encontro Brasileiro de Estudos Judaicos, realizado de 23 a 25 de Abril de 2002, nesta Universidade.

O objetivo acadêmico-institucional do Programa De Estudos Judaicos da Universidade do Estado do Rio de Janeiro centra-se em promover a ampliação de conhecimentos nessa área de saber, filiando-se à tradição de estudos multidisciplinares que alargam o horizonte de apreensão de seu conteúdo e de suas implicações metodológicas. Em seu sentido amplo, o Programa de Estudos Judaicos deve ser considerado como um centro de reflexão, pesquisa e produção de saberes no campo da história, cultura, religião e sociologia do judaísmo e de Israel, além de estudos especializados sobre a comunidade judaica brasileira e sua configuração social.

Considerando, portanto, as premissas norteadoras do Programa De Estudos Judaicos e a obrigatoriedade de sua presença nas atuais discussões que estão a ocorrer dentro das ciências sociais sobre questões étnicas e raciais assim como àquelas referentes à construção da cidadania, direitos e democracia, e as sobre movimentos sociais, globalização e transformações científicas e tecnológicas, além das complexas mudanças em relação aos conceitos de tempo e espaço, e; considerando as relevantes modificações que se desdobram no interior do judaísmo brasileiro e mundial, resolveu o Programa de Estudos Judaicos dar continuidade a sua programação de realizar Encontros Nacionais a cada três anos, tendo promovido o primeiro Encontro em outubro de 1994.

Em assim sendo, o presente livro tem como objetivo permitir a ampla circulação e interação de ideias decorrentes das questões discutidas no III Encontro Brasileiro de Estudos Judaicos, tendo em vista possibilitar pleno acesso à variada temática judaica discutida, então, quando professores, pesquisadores, e alunos pós-graduados, de todo país, estiveram reunidos em torno das múltiplas leituras, olhares, interpretações e problematizações sobre o judaísmo brasileiro e sua moderna identidade, foco central desse Encontro.

A organização deste livro, composta de duas Partes, I e II, segue o programa desenvolvido durante o referido Encontro, contendo capítulos e módulos.

A inauguração desta publicação coube à Professora Dra. Anita Novinsky, que abriu o III Encontro ao proferir a conferência "O Legado Do Judaísmo À Civilização Brasileira: O Princípio De Liberdade Em Joaquim Nabuco" na qual abordou a questão da herança cultural judaica no Brasil, no sentido de sua participação na construção de uma mentalidade de luta a favor da igualdade social, tão bem caracterizada na figura de Joaquim Nabuco e em seu engajamento no processo de abolição da escravatura.

A Parte I, intitulada "500 Anos de Presença Judaica no Brasil", desdobra-se em três capítulos. O primeiro "Resgate Histórico da Vivência Judaica no Brasil" representa-se por uma multiplicidade de trabalhos cujos autores analisam o fenômeno dos cristãos-novos no país desde o descobrimento, ou achamento, do Brasil por Portugal, passando pelos vários períodos da historiografia brasileira e suas inserções no cenário nacional, apresentando as formas vigentes de adaptação desse segmento ou sua rejeição por parte da sociedade brasileira e suas autoridades constituídas. Ainda nesse capítulo, deu-se ênfase à presença judaica no Nordeste Brasileiro à época do Brasil Holandês, e sua importância histórica nos empreendimentos econômicos açucareiros, demarcando um período de grande tolerância religiosa caracterizadora da dominação holandesa. Concomitantemente, vários estudos apresentados tratam dos primeiros fluxos imigratórios judaicos que se sucederam no Império, dirigidos, principalmente, para o Norte do Brasil; outros pesquisam a chegada dos judeus imigrantes da Europa Central e Oriental, já no século XX, e a construção de uma sólida infraestrutura comunitária urbana após a experiência agrícola no sul do país.

"O Discurso do Judaísmo Brasileiro Através da Literatura e da Arte" é o tema do segundo capítulo, que cobre um amplo espectro de indagações intelectuais sobre a variedade da produção do discurso judaico no Brasil, via as falas de escritores nacionais sobre a temática acima, caracterizando-os por seu conteúdo e estilo, sublinhando a contribuição da chamada literatura dos 
imigrantes, além da presença feminina, dos cancioneiros e daqueles que se vão inspirar nos textos bíblicos e cabalísticos.

O terceiro capítulo, "Testemunhos e Histórias de Vida", refere-se ao registro vivido de familiares e de casos específicos, em sua condição existencial judaica.

A Parte II, "Vertentes Diferenciadas do Comportamento Judaico Brasileiro", inicia-se com o capítulo "Identidade e Etnicidade", que abarca textos referidos à discussão desses dois conceitos, aplicados em fontes primárias e secundárias, ao mesmo tempo que compara historicamente seus diferentes desempenhos ao longo da evolução da sociedade brasileira, e a especificidade da inserção comunitária judaica em seu interior. Nesse capítulo inclui-se, também, a questão referente ao espaço e à territorialidade vinculada à demografia judaica no Brasil, tendo em vista a imbricação temática desta com a dimensão da identidade judaico-brasileira.

O segundo capítulo da Parte II, "Diálogo Inter-Religioso: Uma Via de Dupla Mão" apresenta uma sólida análise sobre a configuração atual dos debates que se estão processando entre as grandes religiões monoteístas para discutir suas convergências e diferenças, assentando-se na visão pluralista da democracia moderna e da cidadania, na qual o processo educativo tem o papel primordial de dirimir conflitos que se ancoram na intransigência e no preconceito.

Para finalizar, o terceiro capítulo "Política e Comportamento Judaico" trata de questões contemporâneas no campo da ordem política nacional e internacional, compondo-se de três módulos. O primeiro, " $O$ Discurso Antissemita nas suas Múltiplas Expressões" fala sobre o discurso político discriminatório em relação aos judeus brasileiros em vários momentos da modernidade nacional, enquanto o segundo módulo, "Militância Política dos Judeus Brasileiros", trata da questão do envolvimento dos judeus brasileiros nas lutas políticas que caracterizaram a conjuntura nacional do período militar.

O terceiro módulo refere-se ao painel "Discutindo o Conflito Israel/ Palestino sob a Perspectiva Brasileira" cujos participantes debruçaram-se, analiticamente, sobre a temática referida ao Oriente Médio no qual israelenses e palestinos encontram-se em conflito além da tensa problemática relacionada com as questões da identidade étnico-religiosa e da soberania político-nacional relacionadas a esses dois povos. As discussões, entre outros enfoques, enfatizaram a visão brasileira e suas relações internacionais vis a vis os seus diferentes interesses de ordem econômica e política naquela região. 


\section{PARTE 1}

\section{AGRADECIMENTOS}

500 ANOS DE PRESENÇA JUDAICA NO BRASIL

Uma publicação de natureza acadêmica, como esta, que se oferece ao público sob responsabilidade do Programa de Estudos Judaicos da Universidade do Estado do Rio de Janeiro, engloba a participação de vários atores que se dedicaram para que sua produção fosse realizada dentro das exigências de orientação intelectual-científica como determinam as premissas universitárias de competência e relevância.

A realização do III Encontro Brasileiro de Estudos Judaicos congregou professores e pesquisadores de todo o país, especializados nessa área de conhecimento, gerando um profícuo debate em relação à variada temática consagrada aos estudos judaicos e, por sua vez, produzindo um significativo resultado, ora objeto da presente divulgação.

O Programa de Estudos Judaicos da Universidade do Estado do Rio de Janeiro reitera seus agradecimentos à Diretoria Executiva e ao Conselho Diretor da Sociedade Israelita Religiosa Chevra Kadisha do Rio De Janeiro, que com sua reconhecida sensibilidade em relação às questões do judaísmo como prática e ação social, possibilitou a publicação desta obra, decorrente de seu inestimável apoio financeiro.

Garante-se, assim, o acesso ao conteúdo deste III Encontro Brasileiro de Estudos Judaicos a todos os Centros de Educação do Brasil, judaicos e não judaicos, objetivando o conhecimento desta temática, além de converter-se em fonte de consulta para pesquisas, material de aula, debates e outras atividades pedagógicas. 


\section{O legado do judaísmo à civilização brasileira}

Anita Novinsky ${ }^{1}$

$\mathrm{O}$ estudos sobre a imigração judaica para o Brasil nos séculos coloniais têm feito consideráveis progressos. O papel que os judeus representaram na construção e colonização do Brasil está hoje constatado em diversos trabalhos científicos. Durante os três séculos coloniais, ininterruptamente, portugueses de origem judaica, conhecidos como cristãos-novos e denominados marranos na historiografia judaica, procuraram fugir do ambiente de terror que se havia constituído em Portugal e na Espanha depois do estabelecimento de uma Corte de Justiça, criada inicial e exclusivamente para punir os judeus: o Tribunal do Santo Ofício da Inquisição.

Convertidos todos os judeus, através da violência, ao Catolicismo, muitos deles procuraram chegar ao Novo Mundo, em busca de um sonho de liberdade. Vieram atrás deste velho sonho, que desde a destruição de Jerusalém e da perda da sua pátria, lhes foi negado por todas as nações: a liberdade. A discriminação legal proibia no mundo ibérico, aos descendentes dos judeus, cargos, honras e educação superior. E em todas as naus que saiam do Tejo, embarcavam judeus, legal ou clandestinamente, violando as leis que os impediam de sair de Portugal.

Hoje, com a abertura dos arquivos da Inquisição e a publicação de novas fontes, uma outra História do Brasil começa a emergir, já pressentida pelos nossos ilustres historiadores como Varnhagen, Capistrano de Abreu, Rodolfo Garcia, Eduardo Prado, Paulo Prado, o que levou este último a publicar uma coleção que denominou Para melhor se conhecer o Brasil. Na Universidade de São Paulo, uma equipe de historiadores se dedica hoje a desvendar manuscritos que contam a história deste "outro" Brasil, que palpitava nas "sociedades secretas" espalhadas pela Bahia, Rio de Janeiro, Minas Gerais, São Paulo, Goiás, Paraíba e outras regiões. E eu me orgulho dessa nova geração de historiadores, que foram meus alunos, como Ronaldo Vainfas, Laura de Melo e Souza, Luis Mott, Maria Luiza Tucci Carneiro,

\footnotetext{
${ }^{1}$ Professora Dr ${ }^{\mathrm{a}}$ da Universidade de São Paulo.
}

Lina Gorenstein, Lana Lage, Luis Nazario e outros, que este espaço não me permite citar, cujas obras já são um marco na historiografia brasileira.

Há uma pergunta que muito frequentemente me tem sido feita, tanto por colegas como por curiosos, e que eu faço a mim mesma: se os judeus, bem ou mal convertidos, marcaram com sua presença três séculos da história colonial, atuando em todos os níveis, econômico, político, social, o que ficou dessa presença na nossa cultura, qual foi o legado que nos deixaram? Dos negros nos ficaram a musica, as danças, a culinária, as crenças; dos índios, a toponímia, o banho e outros costumes, mas o que nos legou essa numerosa população judaica de suas tradições, de seus rituais, de suas crenças religiosas e de sua cultura. Ainda não temos um retrato nítido desse legado, mas a sua riqueza já chamou a atenção de um ilustre professor francês Nathan Wachtel, ex-diretor do Laboratoire d'Antropologie Lévi-Strauss de Paris, que hoje ministra no College de France um curso sobre os marranos portugueses. Apesar desse tema exigir pesquisas mais exaustivas e aprofundadas, já temos elementos consideráveis, susceptíveis de reflexão, que mostram uma corrente de pensa- mento que se estende do século XVI ao XX, uma rede de ideias, cuja continuidade pode ser detectada ao compararmos os documentos, percorrendo os séculos, uma diacronia de ideias que nos mostra que, por mais forte que tenha sido a influência da sociedade ampla sobre os cristãos-novos, certos traços da filosofia de vida judaica permaneceram.

A realidade que os judeus convertidos enfrentaram no Novo Mundo não foi sempre a de seus sonhos. As nações ibéricas, nas suas ambições expansionistas, transferiram para a América sua legislação discriminatória e sua política racista e antissemita e montaram um sistema de fiscalização que fazia de cada cidadão um cúmplice em potencial. Mesmo assim, na multirracial e pluricultural sociedade americana, o racismo e a intolerância não conseguiram vencer totalmente. Nem o Estado português, nem a Igreja conseguiram impor de maneira absoluta as suas regras. Os brasileiros subverteram a ordem e os cristãos-novos conseguiram penetrar nos mais altos círculos das elites coloniais, compraram títulos de nobreza e conseguiram, muitas vezes, apagar suas origens judaicas. Foram eles os antepassados de muitas famílias brasileiras de hoje. Pagaram, porém, um preço, a liberdade em troca da identidade judaica.

Nem todos os cristãos-novos, porém, tiveram a mesma sorte. Apesar de nunca se ter instalado oficialmente um Tribunal da Inquisição no Brasil, 
1076 homens e mulheres foram presos na colônia e levados para Portugal, entre judeus, negros, índios, mamelucos, acusados de heresias diversas. $\mathrm{O}$ judaizante constituiu seu maior numero ${ }^{2}$. Para estes, o Novo Mundo não foi a sonhada Terra Prometida, mas o próprio inferno. Foi necessário esperar que o Brasil se tornasse independente de Portugal, para que, gradativamente, se modificasse o cenário da sociedade, preparando o Brasil de hoje.

Alguns resultados das pesquisas históricas realizadas no Brasil tem sido surpreendentes. Em relação à demografia, a afirmação do "Familiar" do Santo Oficio, Diogo Corrêa, em uma carta enviada do Rio de Janeiro aos Inquisidores de Lisboa, de que "três partes da gente que há são todos judeus", pode ter sido exagerada, mas não desprovida de fundamento ${ }^{3}$.

No estado em que se encontram as pesquisas, podemos dizer que aproximadamente $30 \%$ da população branca e livre nos séculos XVII e XVIII tinha origem judaica e que os judeus entraram intimamente na composição étnica do povo brasileiro.

Mas, ao lado das novas técnicas econômicas e inovações cientificas que os cristãos-novos introduziram na América (lembremos que foi o cristão-novo, José Henriques Ferreira, quem fundou no Rio de Janeiro, em 1772, a primeira Academia de Ciências se estudava história e literatura e que foi fechada por ignorância dos dirigentes da Metrópole ${ }^{4}$, trouxeram também uma nova concepção do homem e uma ética, que se ligam à tradição que herdaram do Sinai: o conceito da liberdade. Talvez não seja apenas coincidência que grande número de batalhadores pelos direitos humanos tenham sido judeus.

A nostalgia da liberdade alimentou durante séculos a mente e o coração dos poetas e escritores judeus. Nas páginas rotas dos processos da Inquisição encontramos frequentes referências ao que os cristãos-novos chamavam "liberdade de consciência".

${ }^{2}$ Veja NOVINSKY, Anita. Inquisição: Prisioneiros do Brasil, Ed. Expressão e Cultura, Rio de Janeiro, 2002.

${ }^{3}$ Inquisição de Lisboa, Processo 13.852. Manuscrito. Arquivo Nacional da Torre do Tombo, Lisboa. Apud Anita Novinsky, Cristãos-novos na Bahia, Ed. Perspectiva, $2^{a}$. edição,1992, pp. 68 e 69, nota 22, cópia pertencente ao arquivo particular de Anita Novinsky.

Veja Anita Novinsky "Um Judeu Sefaradi fundador da Primeira Academia de Ciências no Brasil "in: Confarad I - o resgate da Cultura Sefaradi, org. Diane Lisbona Kuperman, Rio de Janeiro, 2001, pp. 78-84
O conceito de liberdade faz parte da essência mesma do judaísmo e cravou-se fundo na alma dos cristãos-novos, porque os judeus o receberam no Sinai. Esse sonho com a liberdade, os judeus o carregaram durante 2000 anos, enquanto perambulavam pelo mundo, sem solo e sem destino. A ideia de liberdade foi pelos judeus santificada e transformada num preceito religioso, que todo judeu tem obrigação de lembrar.

Durante a Páscoa, os judeus recordam que foram escravos e que devem abominar a escravidão. A festa religiosa da Páscoa é uma festa da liberdade e essa é a primeira ordem moral dos direitos humanos: a liberdade. A essa celebração da liberdade está ligado também o respeito ao direito do estrangeiro. $\mathrm{O}$ direito e o respeito ao estrangeiro, que está na base dos direitos humanos, também está profundamente enraizado no direito judaico. $\mathrm{O}$ filósofo Emmanuel Levinas o lembra: "vós e os estrangeiros, vós sereis iguais diante do Eterno". O Deus Único devolve assim aos homens a unidade do gênero humano". Essa inacreditável mensagem e exorbitante revelação levaram Levinas a dizer que o monoteísmo não é uma aritmética do Divino, mas é o Dom, talvez sobrenatural, de ver o homem semelhante ao homem, sob a diversidade das tradições históricas. No universalismo dos Profetas, de Amos a Jeremias, encontramos a ideia de que toda humanidade é responsável em sua dignidade intrínseca. No Gênese está escrito: "todos os homens são feitos a imagem de Deus"e no Levítico "Não ofenderás ao estrangeiro, nem oprimirás, porque vós fostes estrangeiros no Egito". Aos judeus devemos a ideia de liberdade perante a Lei, tanto divina, como humana e a santidade da vida. A ética judaica é uma declaração de igualdade.

Ironicamente, foram justamente esses conceitos de igualdade e liberdade de todos os homens, princípios básicos do Judaísmo, que levaram à discriminação e ao antissemitismo. O historiador Yehuda Bauer, da Universidade Hebraica de Jerusalém, um dos maiores estudiosos do antissemitismo, explica em uma de suas obras as origens desse ódio aos judeus, que não se iniciou na Idade Média, nem tão pouco com a Igreja, mas tem suas origens já na antiguidade. Para Yehuda Bauer, a origem do fenômeno antissemita encontra-se na diferença entre a cultura e civilização judaica e a civilização dos outros povos. O Judaísmo apoiava-se em três princípios fundamentais: liberdade de todos os homens, igualdade de todos os homens perante a lei e o direito de cada indivíduo, mesmo o mais humilde, de criticar a autoridade do soberano, isso é criticar o poder. Se esses princípios 
fossem aceitos as sociedades da antiguidade se desagregariam ${ }^{5}$. Imaginemos a Mesopotâmia, o Egito, a Grécia, Roma sem escravos. Igualdade perante a lei no Egito Antigo e na Babilônia? A autoridade dos governantes era inquestionável! Imaginemos um homem comum criticar Nero! Mas o profeta Natan criticou o Rei David e pressagiou sua derrota. Os judeus não adoravam nem reis nem imperadores como a Deus.

Quando os judeus se dispersaram pelo mundo, carregaram consigo sua diferença. Muitas vezes foram atacados como uma minoria estrangeira e perigosa, principalmente durante as crises políticas e econômicas Mas essa tradição de liberdade, igualdade e justiça acompanhou-os durante todo percurso na Diáspora. Entre os judeus religiosos, ela se revela nos sonhos de redenção messiânica; entre os judeus laicos, nas ideias de uma sociedade democrática, igualitária e justa.

Essa herança de liberdade e igualdade não se apagou nos descendentes dos judeus, mesmo séculos depois da conversão ao catolicismo, e seu eco ressoou longamente, mesmo após os marranos terem sido absorvidos ou eliminados da sociedade colonial.

Transpondo o Atlântico, os descendentes dos judeus trouxeram para o Novo Mundo esses sonhos de liberdade, que se manifestaram nos sertões da Bahia, nas selvas de Goiás, nas montanhas de Minas Gerais, na São Paulo dos bandeirantes.

E importante frisar que os cristãos-novos não foram perseguidos no Brasil somente pelo seu cripto-judaísmo, mas, fundamentalmente, por suas ideias e sua mentalidade. Em Ouro Preto foi preso, no século XVIII, Diogo Nunes Henriques, por dizer que "cada homem era livre para adorar Deus conforme sua consciência" e Domingos Nunes, também de Minas, foi queimado em Portugal porque defendia a igualdade de todos os homens ${ }^{7}$. A mentalidade inquisitorial não podia aceitar esses princípios. Essa tradição

5 "Antissemitism as a European and World Problem", in: Patherns of Prejudice, vol 27, 1993, pp. 15-24.

${ }^{6}$ Inquisição de Lisboa. Processo ${ }^{\circ} 7487$, Diogo Nunes Henriques. Manuscrito, Arquivo Nacional da Torre do Tombo, Lisboa, cópia de microfilme, pertencente ao arquivo particular de Anita Novinsky.

${ }^{7}$ Inquisição de Lisboa, Processo 1779, Domingos Nunes. Manuscrito, Arquivo Nacional da Torre do Tombo, Lisboa, cópia de microfilme, pertencente ao Arquivo particular de Anita Novinsky. de amor pela liberdade se prolonga e se enraíza na civilização brasileira e vem desaguar no século XIX no pensamento e nas ideias de um ilustre brasileiro, Joaquim Nabuco.

As origens judaicas de Joaquim Nabuco remontam a Barcelos, em Portugal, onde viveram seus antepassados. Hoje com as novas pesquisas, temos elementos para reconstituir a vida da família e o judaísmo de seus ancestrais. O processo de Maria de Sá, antepassada de Joaquim Nabuco condenada no século XVII, esclarece as suas origens ${ }^{8}$. Será que Joaquim Nabuco sabia que era de origem judaica? E que membros de sua família tinham sido presos e acusados de serem judaizantes? Maria de Sá foi torturada três vezes e, segundo Paulo Valadares, um outro membro da família consta ter sido queimado. Talvez, com o aprofundamento da pesquisa, possamos reconstituir outras vidas que nos forneçam elementos para encontrar as influências que Nabuco sofreu. Homem de grande cultura, sabemos que lia a Ética de Spinoza, conhecia o Velho Testamento e não lhe deve ter passado despercebido o antissemitismo e a xenofobia que em seu tempo se espalhavam por toda Europa. Também deve ter tomado conhecimento da efervescência do movimento sionista, quando em 1897 se realizou o $1^{\circ}$ Congresso Sionista na Basiléia, com a presença do fundador do Estado Judeu, Teodor Herzl.

Joaquim Nabuco escreveu o primeiro grande libelo contra a escravidão, criticando a legislação brasileira sobre os escravos. Sua luta pela liberdade dos escravos levou-o a apelar ao Imperador D. Pedro II e ao Papa Leão XIII. Em 1880, acenava aos trabalhadores com leis que dignificavam o trabalho. Quando em Londres, escreveu "O Abolicionismo", e convocou todas as forças que podiam articular-se contra o sistema escravocrata. Fundou a Sociedade Brasileira contra a Escravidão, um manifesto pela libertação dos escravos.

Joaquim Nabuco foi muitas vezes derrotado em suas ideias, mas também recebeu as maiores honrarias, sendo um dos estadistas mais influentes do II Império. Ministro da Justiça, embaixador em Washington, foi eleito primeiro-secretário perpétuo da Academia Brasileira de Letras. O

\footnotetext{
${ }^{8}$ Inquisição de Lisboa, Processo 5445, Maria de Sá, manuscrito, Arquivo Nacional da Torre do Tombo, Lisboa. Cópia de microfilme pertencente ao arquivo particular de Anita Novinsky. As pesquisas sobre as origens de Joaquim Nabuco foram feitas por Paulo Valadares a quem agradeço as fontes e as informações que me forneceu.
} 
imperador D. Pedro II ofereceu-lhe o titulo de Visconde, que Nabuco recusou, "porque somos todos iguais". Foi íntimo amigo de Machado de Assis, que mostrou em seu poema "A cristã-nova", quão profundamente conhecia os crimes cometidos contra os judeus?.

Mas os vínculos conscientes que possam ligar Joaquim Nabuco a seus antepassados judeus interromperam-se. Resta aos pesquisadores desvendar os mistérios ainda ocultos.

O que é importante na história do Brasil é conhecer suas origens, é não esquecer. $\mathrm{O}$ perigo, como diz Tzetan Todorov é o apagamento da memória, porque a cultura é essencialmente objeto da memória e o imperativo bíblico é lembrar. Os cristãos-novos que desapareceram da história como "judeus" são os representantes, na nossa memória, de todos os judeus que tiveram de abandonar sua identidade para poder sobreviver.

Os acontecimentos de 11 de setembro de 2001 mostraram que os ideais de igualdade dos antigos hebreus falharam. O perigo hoje acena para toda humanidade. Se os fundamentalistas vencerem, qualquer tipo de fundamentalismo, o valor supremo do Judaísmo, que é a Vida, desaparecerá da face da terra. Se nós temos uma verdade e acreditamos na nossa verdade, como Joaquim Nabuco acreditou no abolicionismo, temos o direito de ensiná-la aos outros e de compartilhá-la com os outros, mas não temos o direito de impô-la pela força ou violência.
${ }^{9}$ Veja NOVINSKY, Anita, O Olhar judaico em Machado de Assis, Ed. Cultura, Rio de Janeiro, 1990.

\section{$1^{\circ}$ Capítulo}

\section{RESGATE HiSTóRICO DA VIVÊNCIA JUDAICA NO BRASIL}

\section{Da Península Ibérica para Pernambuco...} Eles vieram para ficar

Tânia Neumann Kaufman

propósito dessa comunicação é trazer alguns referenciais para reflexão sobre as imagens, as ideias e os valores da cultura ibérica através dos sefaradim, presentes no imaginário e no sistema de valores da população nordestina, particularmente em Pernambuco. Toma-se como ponto de partida

quest
${ }^{1}$ Doutora em História / USP. Coordenadora do Grupo Interdisciplinar de Estudos sobre Judaísmo no Programa de Pós- Graduação em Antropologia da UFPE. 
ão: c até que ponto, a integração de judeus em novas sociedades, sempre apoiada no sistema de adequação intercultural, foi consistente em Pernambuco, ao ponto, de permanecer na memória cultural da população nordestina, mesmo que de forma atávica ou silenciada?

Pensando na composição da população brasileira e na contribuição de uma. pluralidade de grupos étnicos, chama a atenção manifestações de fenômenos simbólicos singulares, através dos quais, vai se cristalizando o imaginário do povo sobre: ditos populares, folclore, ritos indígenas, candomblé, samba de roda, umbanda, cultos pentecostais, e também com a polissemia dos cultos populares do catolicismo. Como manifestações coletivas, não é de estranhar a presença de fenômenos resultantes de um sincretismo religioso-cultural afrocatólico-indígena, também com influências cristã-nova e judaica, dispersas no espaço nacional. Muitas vezes, são rotuladas como manifestações folclóricas ou são vistas como resíduos das culturas dos referidos grupos étnicos.

Todavia, novos conhecimentos sobre os elementos da cultura judaica vêm sendo agregados através do reconhecimento da presença do cristãonovo, inserido nos contingentes que participaram dos descobrimentos geográficos ibero-portugueses. Portanto, nessa condição, para falar de cultura brasileira, é preciso focalizar o conjunto dos elementos do cotidiano físico, simbólico e imaginário da população brasileira, em cada região do país, vistos nos modos de viver: alimentação, vestuário, habitação, práticas de cura, ritos da morte, relações de parentesco, divisão do trabalho e, ao mesmo tempo, devem ser analisadas as crenças, os cantos, as danças, os jogos, a caça, a pesca, o fumo, a bebida, os provérbios... Estes modos de viver estão fundados em sincretismos socioculturais-religiosos, desdobrando-se em manifestações dotadas de seus próprios significados e, ao mesmo tempo, assimilando os elementos de outras culturas.

Basta escutar o que se conta em muitas famílias cujas origens estão localizadas no sertão nordestino. As histórias nos chegam através de indagações sobre costumes identificados, que aparentemente são estranhos em relação aos hábitos da vizinhança. Além dos mais conhecidos - jogar fora a água acumulada em casa quando morria uma pessoa, a interdição para comer carnes de coelho, peixes sem escama, carne de porco, casamentos endogâmicos, eles contam: ...quando morria uma pessoa na nossa família, minha avó contava que durante um mês se comia numa mesa baixa de pernas curtas, onde se deitava o morto e todos sentados no chão...

...tinha uma senhora de 97 anos que morava na beira da estrada. Ela ficava olhando as pessoas que passavam e dizia: já vai para a sinagoga?

...na casa do meu avô, quando morria uma pessoa, os homens não faziam a barba durante um mês.

O que se conta... Quem Conta...

A trama que conecta os fatos do passado ao mundo contemporâneo tem como vertente de observação o que se conta... quem conta... e como são contadas as histórias sobre a vinda dos sefaradim ${ }^{1}$, dos cristãos-novos ${ }^{2}$ e criptojudeus para o Brasil, após os acontecimentos da Diáspora de 1492, da Espanha e de 1497, de Portugal. No presente, está a comunidade formada no século XX por judeus ashkenazim ${ }^{3}$, melhor caracterizada mais adiante no texto.

A busca desses vestígios vem norteando os estudos e pesquisas desenvolvidos pelo Arquivo Histórico Judaico de Pernambuco em parceria com o Grupo Interdisciplinar de Estudos sobre Judaísmo da Universidade Federal de Pernambuco. E, como parte dessas preocupações, na condição de pesquisadora e de docente, estamos trabalhando nessas entidades a cultura judaica em Pernambuco através de um diálogo entre a história e a antropologia, desde o final dos anos 1980.

Buscando o que se conta e quem conta sobre a vida judaica "escutamos" as palavras de narradores que viveram a história, tanto nos escritos coevos sobre cotidianos coloniais e dos historiadores, como nas "falas" dos que primeiro aportaram na cidade do Recife, no início do século XX.

Tomamos como referência os caminhos já trilhados por historiadores que enfatizavam as implicações da Inquisição sobre a vida judaica na Península Ibérica e no Brasil e os estudos antropológicos dos que se

1 Sefaradim ou sefarditas - Oriundos de Sefarad (nome hebraico da Espanha). Judeus provenientes da Espanha (Sefarad, em hebraico) que, após o decreto de expulsão firmado pelos reis católicos, em 1492, emigraram para Portugal e, em segui- da, para os Países Baixos, Inglaterra, ou para o Norte da África, o Império Otomano, Itália e Sul da França. Falam o ladino ou judeu-espanhol. Variantes: sefardi, sefardita, sefaradita.

${ }^{2}$ Cristãos-novos - judeus convertidos de maneira forçada ao cristianismo e cripto-judeus os cristãos-novos que praticavam o judaísmo de forma disfarçada

${ }^{3}$ Habitantes de Ashkenaz - Alemanha e falavam a língua iídiche (judeu-alemã). 
dedicam ao que sobrevive das antigas oralidades ocultas que aparecem sob formas de vestígios disfarçados e que triunfam sempre que algum fato estimula sua emergência. Pareceu-nos que, sob novas posturas epistêmicas, abordar esses assuntos, já visitados e revisitados por historiadores, favoreceriam outros olhares, outras escutas e outras escritas sobre a problemática judaica no âmbito das ciências humanas.

Foi uma experiência positiva para tal propósito, a compilação dos fatos que ocuparam maior espaço na memória dos homens e que ficaram registrados de forma dispersa na historiografia brasileira. Orientados por uma classificação temática em torno do lugar ocupado pelos cristãos-novos, pelos marranos ou cripto-judeus, pelos judeus sefaradim e ashkenazim nas sucessivas migrações, desde o século XVI, esse produto se oferece como fontes para novas pesquisas.

Esse investimento gerou um Banco de Dados e um Banco de Imagens, ambos funcionando como suporte para os pesquisadores. Estão organizados por autores e por tema e disponibilizados no Arquivo Histórico Judaico de Pernambuco (Centro de Cultura Judaica de Pernambuco) e no Grupo Interdisciplinar de Estudos sobre Judaísmo da UFPE.

Um fato relevante foi o encontro com a obra do Professor José Antônio Gonsalves de Mello, historiador pernambucano e com as pesquisas da Professora Anita Novinsky, da Universidade de São Paulo. Foi uma revelação de fenômenos impregnados de significados elucidativos sobre a perenidade de uma vida judaica na formação da sociedade brasileira. Vislumbramos as amplas possibilidades de uma mudança do olhar da história a ser partilhada por pesquisadores interdisciplinares, interessados na recuperação dessa memória histórica. Percebemos que sua obra já está sacralizada como sólido fundamento de uma práxis que revelou ao mundo o que ocorreu durante a construção do Brasil ao longo do período compreendido entre o início do seu povoamento e o final do século XVII e, mais tarde, no século XX.

Pode-se imaginar o que significa para as novas gerações de antropólogos e historiadores estudar as marcas do cotidiano dos colonos, dos moradores e dos senhores de engenho, registradas nos documentos por ele estudados. Os modos de nascer, de comer, de morar, de rezar, de festejar, de morrer ou de ser sepultado no transcurso do tempo. Muitas dessas práticas sobrevivem até hoje.
O Professor Antônio Gonsalves "olhou" o espaço privado do lar onde, ousadamente, protestantes, cristãos-novos e adeptos de outras religiões praticavam às ocultas suas crenças e seus ritos. Ele mostrou como era seguida a Lei de Moisés pelos cripto-judeus através de práticas sincréticas herdadas dos antepassados. Lamentando a ausência de dados provenientes de fontes judaicas, dedicou grande parte de seu tempo aos estudos sobre o valor da nação judaica do Recife holandês onde nasceu a cultura sefaradi na América. Chamou a atenção para a importância de personagens no mundo dos judeus ibéricos reunidos em Pernambuco. Foi ele que divulgou o local onde funcionou num primeiro andar de certo sobrado da rua dos Judeus, a sinagoga Kahal Zur Israel. Descreveu não apenas as práticas judaicas, mas também as ligações que os judeus no Brasil mantinham com centros judaicos europeus; contou como redigiram memoriais e consultas sobre encaminhamentos necessários à vida econômica e à vida religiosa. Já é possível devolver a um tempo e a um espaço da vida colonial, a presença do elemento de origem judaica, sob novas abordagens.

A historiadora Anita Novinsky desvendando os processos que engendravam o silenciamento das práticas judaicas expõe a dimensão histórica do marranismo, concentrando o processo do conhecimento histórico no próprio sujeito alvo das práticas judaizantes. Os conteúdos dos processos por ela estudados revelam os passos de uma intensa vida judaica nos subterrâneos da sociedade colonial. Ela foi em busca do lugar onde a história foi produzida e atavicamente silenciada.

Desse modo, uma nova ordem de discussão ficou estabelecida. Durante os últimos anos a cultura judaica instigou a produção acadêmica promovendo um novo posicionamento dos judeus nas programações temáticas dentro da literatura em geral. Hoje, marranos, cristãos-novos, cripto-judeus estão presentes nas ciências humanas como objeto e como tema de trabalhos relevantes redimensionados epistemologicamente.

A nossa proposta é explorar as tendências ocultas dos feitos praticados na sociedade colonial, em nome de uma hegemonia religiosa durante os séculos XVI até o século XVIII, e depois no século XX. Olhar a maneira como os acontecimentos dessa história ficaram confinados no passado, porém de forma apenas silenciada, e chegaram até o presente, trazendo fatos que, hoje, são transformados em saber acadêmico, mediados por uma proveitosa interdisciplinaridade. 


\section{Um roteiro cultural judaico em Pernambuco}

Na sequência das ações, um dos passos foi a elaboração de um roteiro cultural judaico que nos permitisse reunir os fragmentos de um passado, aparentemente não relacionável ao presente, mas que permaneceram como ilhas submersas numa história a ser construída aproveitando-se os resíduos culturais. Existe uma zona entre o passado e o presente da comunidade judaica do Recife (séculos XVI-XVII e séculos XX-XXI) que guardou elementos de uma memória coletiva silenciada por circunstâncias históricas.

Com a inauguração do Centro de Cultura Judaica de Pernambuco, em 2001, a Sinagoga Kahal Zur Israel, vem funcionando como lugar que centraliza o conhecimento sobre a cultura judaica. Como monumento histórico revitalizado vem funcionando também como instrumento de percepção de uma divisão do tempo, em função de um antes e um depois dos eventos que resultaram na perenidade da presença judaica na região. Os passos perdidos dos judeus na historiografia brasileira são agora recuperados, porque eles referenciaram e estruturaram uma memória coletiva, definindo o seu lugar na História e no quadro espacial onde eles ocorreram. A memória assim valorizada não aceita o desenraizamento das origens e consequências do movimento migratório, primeiro dos cristãosnovos, depois o dos judeus portugueses de Amsterdã, desde o século XVI.

Sim, porque eles vieram para ficar. Em Pernambuco, suas vivências foram como âncora e plataforma da identidade sefaradi. Viveram paradoxalmente seus ritos e costumes entre as práticas sincréticas e/ou clandestinas. Silenciaram aparentemente enquanto os desajustamentos dos tempos e dos homens nas sociedades, medieval e moderna, desmanchavam valores e tradições. Todavia, foram suficientemente sólidos como grupo étnico-religioso para se lançar no futuro, trazendo do passado resíduos culturais para, mais uma vez, com eles, recriarem suas tradições.

Com base nessa memória, o circuito cultural judaico para a cidade do Recife. A ideia foi trabalhada na perspectiva da preservação, intervenção e manutenção de um patrimônio histórico cultural para disponibilizá-lo ao trade turístico. Inclui, também uma finalidade social, no sentido da inserção desses novos conhecimentos em propostas pedagógicas de atualização do saber da história e da cultura local. Além do caráter didático, sua utilização como fator de atração para o turismo local valoriza a organização de uma memória histórica reveladora de aspectos de um passado não tão distante no tempo e bem próximos, num espaço.

No roteiro destacam-se como marcos dos passos perdidos dos judeus em Pernambuco, o Engenho Camaragibe, pertencente a Diogo Fernandes e Branca Dias, cristãos-novos que receberam terras de Duarte Coelho na metade do século XVI; a casa de Branca Dias em Olinda, onde ela vivia grande parte do tempo; a Casa de Guarda dos Judeus (Excubiae Iudeorum), antiga fortaleza que abrigou, durante um curto período uma milícia de soldados judeus; a Ponte Maurício de Nassau, construída por Baltazar da Fonseca, cristão novo; a antiga Ilha Cheira-Dinheiro, atual pontal do Pina, cujas terras pertenciam a André Gomes Pina, rico cristão-novo que lá se instalou pela proximidade da Sinagoga no Bairro do Recife. E, finalmente, a própria Sinagoga Kahal Zur Israel, localizada numa área conhecida atualmente como o Recife Antigo.

Somos instigados a olhar cada um desses espaços ao mesmo tempo em que se observam mapas antigos, ilustrações que mostram como eram antes. A atmosfera judaica de cada um deles sobrevive hoje nas velhas histórias. Seus habitantes não foram embora sem avisar, apenas esconderam-se dos deuses estranhos.

\section{O que se conta... sobre o Engenho Camaragibe}

É rico o imaginário sobre este espaço que foi cenário de episódios importantes de resistência cultural judaica. Vejamos o que se conta na Primeira Visitação do Santo Ofício às Partes do Brasil. Denunciações e Confissões de Pernambuco 1593-1595 Coleção Pernambucana Vol.XIV. Recife: FUNDARPE. 1984. (p.75 Em registros de 16 de novembro de 1593)

...haverá quarenta anos pouco ou menos que nesta vila morava Anrique Mendes mouco cristão novo que depois foi pera Porto Seguro o qual era costumado todas as luas novas de agosto hir com sua mulher Violante Rõiz e com toda a mais casa e família em carros enramado e com festas desta vila ao lugar de Camaragibi que está daqui quatro ou simquo léguas e la se estavão hu e dous meses, e era fama pública nesta terra geralmente dito por todos assim nobres o principais como mais gente e povo que no dito Camaragibi avia esnoga onde se ajuntavam os judeus 
desta terra e faziam suas cerimônias e que nas ditas luas novas de agosto iam ao dito Camaragibi a celebrar a festa do jejum do Gujppur...

\section{Na página 251, um outro registro de 2 de abril de 1594}

... e denunciando disse que haverá vinte anos que morando em Camaragibi Branca Dias christã nova defunta mulher de Diogo Fernandes de Camargibi e outro Diogo Fernandes genro dela que ora está em Lixboa mercador na rua Nova e Duarte Fernandes irmão do dito Dioguo Fernandes cristãos novos que estavam por feitores de Bento Dias Santiago nos seus engenhos do dito Camaragibi nesta Capitania ele denunciante ouviu dizer em pubrica fama jeralmente por todos, honrados, altos e baixos desta terra e por ho mais povo e gente della, com muita frequentação e escandallo que os dittos Branca Dias e seu genro Fernandes e Duarte Fernandes viviam no ditto Camaragibi na lei judaica e faziam suas ceremonias e faziam a esnoga e que com elles se ajuntavão e faziam o mesmo Franscisco Pardo christão novo que ora he lavrador e morador no mesmo Camaragibi e outros muitos christãos novos que lhe não lembrão...e pello ditto Simão Vaz om os dittos parentes e com outros que elle não sabe todos christãos novos fazem no mesmo Camaragibi, e faziam com o ditto Manoel Vaz quando aqui estava a esnoga no ditto Camaragibi e as dittas ceremonias judaicas...

\section{...sobre Duarte Saraiva}

José Antônio Gonsalves de Mello (1989:224) conta sobre os serviços religiosos no Recife, antes da construção da Sinagoga, feitos na casa de Duarte Saraiva, desde 1636, seguindo um costume antigo, inclusive na Holanda.

João de Siqueira disse na Bahia (em 25 de novembro de 1636), há pouco chegado aí vindo do Recife, que "se ajuntava a judiaria em casa de Duarte Saraiva”, o mesmo disseram Manuel Martins da Costa (mesma data) e Salvador das Neves (23 de outubro de 1637). Matias de Albuquerque, em Lisboa, acrescentou (31 de maio de 1645), referindo-se a fatos de 1636, que Duarte Saraiva "dogmatizava aos judeus, ensinando-lhes a lei de Moisés". Segundo Manuel Martins da Costa, Saraiva era "homem já velho de mais de meia estatura e cheio de cãs". Saraiva nascera cerca de 1572 e, portanto, em 1636 unha por volta de 64 anos de idade...

\section{...sobre a Sinagoga Kahal Zur Israel}

Sobre a Sinagoga conta-se também que havia umas cazas de esnoga na Povoação do Recife. Para confirmar a existência desse espaço religioso que aglutinava a vida judaica na época, existem os registros históricos compilados da obra Inventário das armas e petrechos bélicos que os holandeses deixaram em Pernambuco e dos prédios edificados ou reparados até 1654. $2^{a}$ edição. Recife 1940. Eles apresentam os indicadores para o reconhecimento da localização do prédio onde funcionou a Sinagoga no século XVII. Explica-se no livro:

...há de servir para nele se escreverem as cazas, que se acharem na Povoação deste Recife, e na de outra banda de S. Antônio, assim as que se obrarão de novo por Flamengos ou Judeus, como as em que houver benfeitorias, que possam pertencer à Fazenda Real...

O Inventário do livro identifica a construção como:

...Humas cazas grandes de sobrado da mesma banda do rio, com fronteira para a rua dos Judeos, que lhes servia de synagoga, a qual he de pedra e cal com duas lojas por baixo, que de novo fabricarão ditos Judeos: ao presente estão nella aquartelados soldados, e não se faz menção do aluguel de altos, nem de baixo até haver pessoa, que entre a morar nellas. Mandou o Mestre de Campo Geral Francisco Barreto se carregasse os setenta mil reis de aluguel destas cazas, que hé o de hum ano, ao Mestre de Campo João Fernandes Vieira por conta de seus soldos pela caza por um creado seu; e esta deprecação fez o dito Mestre de Campo João Fernandes Vieira ao Provedor da Fazenda por hum escripto seu de que eu Escrivão da dita Fazenda dou fé. Recife o primeiro de Julho de seis centos cincoenta e cinco.

O prédio definitivo foi concluído por volta de 1640 e 1641, conforme documento enviado ao conselho dos XIX, com data de janeiro de 1641. A sinagoga estava situada no sexto lote do terreno, situado na Rua dos Judeus, antiga Rua do Bode (denominada pelos holandeses de Bockestraet), em edifício de dois sobrados, com dois andares, construído em pedra e cal abrigando duas lojas, escolas e, no primeiro piso, a sinagoga propriamente dita. Estabelecida no andar superior, o salão da sinagoga, a exemplo da sinagoga de Amsterdã, tinha encostada à parede da frente, voltada para o leste, a arca com os rolos da Tora e, ao centro, o local de leitura e pregação. Após a expulsão dos holandeses em 1654, a Rua dos Judeus, anteriormente 
conhecida como Rua do Bode, veio a ser denominada Rua da Cruz e, a partir de 1870, teve seu nome mudado para do Bom Jesus, embora, em 1802 tenha recebido o nome de Rua dos Mercadores, sem grande repercussão. Trata-se de um espaço demarcado pelo sagrado e pelo profano, sendo hoje um logradouro com intenso transito de pessoas, com objetivos de negócios e de lazer. Outrora foi um espaço onde viveu uma comunidade com seus cotidianos marcados por atividades consagradas às práticas religiosas do judaísmo e também às relações sociais e econômicas com a sociedade maior.

\section{...sobre o prédio da sinagoga}

Quando os holandeses se retiraram a edificação foi doada a João Fernandes Vieira, pelos seus feitos na Insurreição. Em 14 de outubro de 1679, o prédio foi passado para os Padres da Congregação do Oratório de Santo Amaro (depois chamados da Madre de Deus). Nessa ocasião o prédio já estava em ruínas. No terreno a Congregação construiu dois sobrados, os quais com a extinção desta em 1830, passaram para o patrimônio da Santa Casa da Misericórdia do Recife e tinham no século passado, os números 12 e 14. Na sala da frente, numa das paredes laterais do primeiro andar do prédio, Fernandes Vieira construiu um altar com um nicho, ladeado e encimado de entalhes ornamentais. Numa das reconstruções foi notado a existência de um arco de pedra lavrada, fechado por parede de tijolo, ao passo que as demais eram todas de pedras irregulares. Com a demolição da parede foi encontrado o aludido oratório em perfeito estado de conservação tendo, o então proprietário da edificação, oferecido a capela do hospital da Ordem Terceira do Carmo do Recife, construído na época.

O prédio permaneceu com suas características originais por mais de dois séculos, até que foi demolido no início do século $\mathrm{XX}$, quando da "reurbanização e modernização" promovida no Bairro do Recife, ainda o núcleo central da cidade por força da forte influência dos modelos adotados pelos europeus em suas cidades, dando lugar a uma nova edificação que veio a ser ocupada pelo Banco de Crédito Real de Pernambuco e por uma loja de material elétrico.

A identificação definitiva dos imóveis pode ser feita, já na última década do século XX, pelo sistema adotado pelo arquiteto e historiador pernambucano José Luiz Mota Menezes. Utilizando a superposição de mapas existentes, feitos ao longo do período colonial até nossos dias, possibilitou uma criteriosa análise cartográfica para a identificação correta.

Durante as escavações, além dos objetos de grande importância para o resgate da história daquela edificação, revelou-se o piso original do século XVII, setenta centímetros abaixo do atual. $\mathrm{O}$ achado mais importante, entretanto, foi o poço original da época, que alimentava a mikvah ${ }^{4}$, confirmando desta forma que as atuais casas situadas à Rua do Bom Jesus (antiga Rua dos Judeus), sob números 197 e 203, são aquelas que foram construídas no terreno onde antes existira o prédio anteriormente descrito, para a sinagoga. A presença no local de um Tribunal Rabínico especialmente consultado, composto de três autoridades no assunto, analisou os achados e confirmou tratar-se da piscina ritual, com base nas medidas do local. Acrescente-se, como dado a confirmar a veracidade da mesma, o fato da existência do poço no interior do prédio.

\section{Palavras finais}

A formação das duas Congregações é o reconhecimento de que houve dois momentos distintos em que os judeus se organizaram como comunidade. Porém, as historiografias brasileira e judaica reafirmam a ideia de que não houve solução de continuidade no que se refere à presença de judeus no Nordeste brasileiro.

Basta analisar a atual configuração da coletividade formada nos primeiros anos do século XX. Hoje, no Recife, é possível identificar quatro categorias de judaísmo: o judaísmo ortodoxo, representado pelo Beit Chabad; os judeus ashkenazim, seguindo uma linha liberal, apoiados muito mais no sionismo do que na religião; os marranos convertidos e, por fim, os que se autoidentificam como marranos, porém não são convertidos. É interessante notar que hoje, assim como nos tempos da formação da comunidade Zur Israel, no século XVII, pouco a pouco, surgem grupos de diferentes partes da região nordestina interessados em encontrar, em suas genealogias, os elos perdidos com o judaísmo.

Existe no Recife um movimento formado por pessoas que se autoidentificam como judeus marranos. Anteriormente se consideravam

\footnotetext{
${ }^{4}$ Piscina destinada ao ritual judaico do banho de purificação.
} 
católicos ou protestantes e agora reivindicam o retorno ao judaísmo. Mas não concordam com a conversão, conforme exige a ortodoxia judaica. Manifestam o desejo de serem aceitos como judeus na condição de retornados, pois, segundo eles, não lhes cabe a responsabilidade de terem sido, mesmo que circunstancialmente, afastados do judaísmo em períodos anteriores. Eles buscam, inclusive, a identidade religiosa através de estudos formalmente organizados em uma das sinagogas existentes. Participam de grupos já institucionalizados e, por estarem relativamente integrados à comunidade judaica do Recife, de forma consciente, estimulam essa revisão na historiografia pernambucana e judaica.

Não é a resistência e continuidade da presença judaica que se deseja explicar, ao longo de épocas diferentes e distantes no tempo? É preciso estar atento, pois em toda obra elaborada pelo homem estarão os vestígios da mentalidade e dos sentimentos do grupo e da sociedade que os envolvia.

\section{Um conflito de identidades: judeus e cristãos-novos no Brasil}

Bruno Feitler

A

ocupação pelos holandeses de uma parte do Nordeste do Brasil entre 630 e 1654 causou distúrbios de vários tipos na vida da população local. A chegada dos judeus portugueses, que acompanharam os holandeses na travessia do Atlântico, e a formação de uma comunidade judaica estruturada, transformaram radicalmente o horizonte religioso nordestino. Esta presença de judeus confessos provocou tensões e gerou sentimentos diversos nos cristãos-novos (isto é, as pessoas de origem judaica, mas legalmente católicas) que conviveram ou entraram em contato com eles. Vários cristãos-novos judaizantes aproveitaram da relativa liberdade religiosa vigente no Pernambuco holandês para tornarem-se abertamente judeus, e isso desde a chegada dos primeiros judeus praticantes ${ }^{2}$.

Certos judaizantes, porém, preferiram permanecer fora da comunidade judaica oficial, enquanto outros cristãos-novos, nem judaizantes, nem católicos fervorosos, guardaram suas distâncias. Os judeus tiveram então que adotar certas práticas missionárias para tentar levar estes últimos dois grupos ao judaísmo, utilizando métodos de pressão e de influência que transcendiam a simples polêmica religiosa ${ }^{3}$. A missão dos judeus de fazer com que os cristãos-novos "retornassem" ao judaísmo de seus antepassados, acrescida do catolicismo a que estavam acostumados a viver, e algumas vezes, do judaísmo deturpado que alguns deles seguiam, acabou por revelar a originalidade de seus próprios sentimentos, o que produziu por sua vez, para além das tensões e do conflito, uma nova dimensão identitária.

\footnotetext{
${ }^{1}$ Doutor em História / École des Hautes Etudes en Sciences Sociales - Paris
${ }^{2}$ O livro de José Antônio Gonsalves de MELLO continua sendo a obra de referência sobre os judeus em Pernambuco: Gente da Nação: Cristãos-novos e judeus em Pernambuco 15421654, Recife, Fundação Joaquim Nabuco/Massangana, 1996.

${ }^{3}$ Sobre esta missão em terras brasileiras, assim como sobre outros desenvolvimentos do tema tratado neste texto, veja a segunda parte do meu livro: Bruno FEITLER, Inquisition, juifs et nouveaux-chrétiens au Brésil: le Nordeste - XVIIème et XVIIIème siècles, Lovaina, Presses Universitaires de Louvain, 2003 (no prelo).
} 
Os judeus de origem portuguesa chegados da Holanda ou de outras partes do velho mundo (como Hamburgo, Veneza ou o Império Turco) ao Brasil, tinham uma imagem complexa, mas, ao mesmo tempo, fortemente estabelecida de sua própria identidade. Este conjunto de fatores diversos, característicos dos indivíduos desse grupo, originava-se da combinação de uma cultura ibérica carregada de catolicismo e do mito da pureza de sangue, e de uma cultura judaica. Cultura essa que eles tiveram em parte que recriar do vazio que os separava das conversões forçadas dos séculos XIV e XV. Esta combinação, somada à própria história pessoal da maioria dos membros da comunidade judaica do Recife holandês - pessoas nascidas e criadas no catolicismo ibérico e só depois de uma certa idade "tornadas" ao judaísmo - fez com que elas tivessem uma visão bastante ampla do que era o seu próprio grupo.

Isto fica bem claro quando se estuda o funcionamento da Santa Companhia de Dotar Orfans e Donzelas Pobres, fundada em Amsterdã em 1615 , e que também teve seus representantes no Brasil holandês a partir de 1639. Os regulamentos dessa fundação caritativa mostram claramente que não era necessário ser judeu praticante para fazer parte da "Nação", pois as jovens suscetíveis de serem dotadas podiam morar "entre St. Jean-de-Luz e Dantzig, incluindo na França, nos Países-Baixos, na Inglaterra e na Alemanha", e os benfeitores da companhia "em qualquer parte do mundo". O laxismo é evidente, se considerarmos que na época em questão os da "Nação" ainda não podiam declarar-se abertamente judeus nem na França nem na Inglaterra. Os regulamentos também indicam que os benfeitores deviam "pertencer à nossa Nação Hebraica, portugueses ou castelhanos, ou seus descendentes", sendo aceitos em "linha masculina ou feminina", o que contradiz as noções básicas de quem é ou não é judeu.

Em outros casos, a comunidade era mais estrita, adotando contudo noções ibéricas de família e de honra e não as regras rabínicas. As filhas de uma relação ilegítima só eram elegíveis se o pai fosse da "Nação" e as filhas de uma judia com um não judeu não eram aceitas. Por outro lado, quando um recém-chegado da península ibérica se apresentava aos chefes da comunidade de Amsterdã para nela se integrar, normalmente fechava-se os olhos para a presença de cristãs-velhas na sua genealogia, a menos que esta ascendência fosse muito notória ou recente ${ }^{4}$. Assim, para os judeus do Recife, podia tecnicamente ser membro da "Nação" qualquer pessoa que tivesse ao mesmo tempo uma origem ibérica e raízes judaicas, englobando então não só os judeus praticantes, mas também muitos católicos; sinceros ou não 5 . Os judeus de origem ibérica viam-se na obrigação de fazer "tornar" ao judaísmo essas pessoas que eram vistas por eles, e também pela população de origem cristã-velha, devido aos estatutos de pureza de sangue e a ideologia racista que os estatutos subentendiam, como judeus. Isso, mesmo quando esses cristãos-novos, apesar da consciência de sua origem judaica, continuavam praticando o catolicismo.

A sociedade compartimentada da época não concebia a existência de indivíduos fora dos grupos religiosos organizados. Assim, em Portugal e nos seus domínios, todos tinham que seguir sem desvios tudo o que mandava a igreja católica. A conquista holandesa criou uma situação inédita no Nordeste, pois sendo terra católica, foi conquistada por protestantes que permitiram a prática do judaísmo. Todo um leque de opções religiosas se abriu para a população local que, visto a desorganização da igreja católica e o pouco poder político da instituição sinagogal, não tinha muito que temer dos órgãos de controle religioso. Mesmo assim, para a maioria da população, era impossível desligar-se completamente de todo sistema religioso organizado. Deste modo, qualquer influência social, econômica, familiar ou sentimental vinda de um grupo externo àquele a que uma certa pessoa pertencia acabava por se transformar igualmente, pelo menos de maneira formal, em influência religiosa.

A conversão religiosa podia assim não ser, muitas vezes, mais que a aparência externa, a fachada de uma passagem que ocorria em outro nível que não o do sentimento religioso. O processo de "retorno" ao judaísmo de muitos cristãos-novos se fez então não pela transformação de um criptojudaísmo em judaísmo oficial, mas pela aceitação por este ou aquele cristão-novo de suas origens sociais judaicas e a consequente integração à

${ }^{4}$ Miriam BODIAN, Hebrews of the Portuguese Nation: Conversos and Community in Early Modern Amsterdam, Indianapolis, Indiana University Press, 1997, p. 134-138. Sobre os representantes da Companhia no Brasil, veja I. S. EMMANUEL, "New Light on Early American Jewry", American Jewish Archives, n 7 (1955), p. 34-35.

5 Sobre o problema da definição da "gente da Nação", ver Yosef KAPLAN, From Christianity to Judaism, Me Story of Isaac Orobio de Castro, New York, Oxford University Press, 1989 e Minam BODIAN, Op. cit. 
comunidade judaica oficial, encarnada no Nordeste holandês pela congregação Tsur Israel e seus membros.

Vamos ver um exemplo, entre vários outros, desse tipo de "conversão": Manoel Gomes Chacão, cristão-novo originário de Trancoso em Portugal, morava, no época dos holandeses, na Taquara, na capitania de Itamaracá. Aproveitando-se da instabilidade vigente, seus inimigos (na realidade, membros da família de sua mulher) devastaram várias vezes suas propriedades com a ajuda de soldados portugueses. A fim de se proteger, ele se mudou em agosto de 1642, com sua família, para o Recife

E tanto que aly foy logo os judeus que hauia naquelle lugar trataraõ de persuadir a elle confitente e a sua molher maria Soares de Liaõ e a seus filhos Joaõ que entaõ seria de doze pera treze annos e francisco que seria de sette pera oito dizendolhe que eraõ christaõs nouos e que por essa rezaõ eraõ obrigados a ter crença na Ley de Moyzes e largar a fee de Christo ajudandose para o persuadirem de alguns passos da escritura que lhe mostrauaõ na Biblia sagrada, e entendiaõ os lugares da escritura que lhe traziaõ, e o que nelles se continha era que Deus dera a Ley de Moyzes no Monte Sinay e que por ella obrara muitos milagres (...) (e) outros muitos passos de que em particular naõ he lembrado, e os judeos que principalmente tratavaõ de o persuadir era o Gagaõ por nome Izac Aboac (...) e nisto gastaraõ até dez ou doze de dezembro em que elle confitente persuadido das rezões que elles lhe dauaõ parecendolhe melhor a Ley de Moyzes que a de Christo Senhor Nosso se apartou em seu coraçaõ della e se passou a crença da Ley de Moyzes 6 .

Vale frisar que o primeiro motivo alegado pelos judeus era o fato de Manoel e sua família serem de origem judaica, e que só em seguida eles trouxeram à tona os detalhes religiosos, teológicos, da matéria.

Para integrar a comunidade judaica, Manoel teve que se separar de sua mulher e filhos, que não quiseram acompanhá-lo nessa nova fase de sua vida. Ele é finalmente circuncidado no dia 25 de março de 1642. Contudo, um ano após sua circuncisão, Manoel decide retornar ao catolicismo. Estando de passagem pela Taquara, onde havia morado com sua família enquanto católico.

\footnotetext{
${ }^{6}$ Arquivos Nacionais/Torre do Tombo (ANTT), Inquisição de Lisboa, processo 7533.
}

"mouido das reprehenções e perguntas que lhe fizeraõ seus amigos por hauer largado a fee de Christo Senhor Nosso e uendo que sua molher e seus filhos perseueraraõ nella, e que o ditto seu filho mais uelho per nome Joaõ se ueyo para a dita sua may quatro dias despois que se apartou delle confitente, e arguido tambem de sua consciencia, conhecendo o erro em que estaua, se resolueo outra vez a largar a crença da Ley de Moyzes e tornarsse à fee de Christo Senhor Nosso".

Ainda essa vez, a escolha do grupo religioso passou antes de tudo por necessidades sociológicas e afetivas, só que vivenciadas de modo oposto ao anterior. O conflito identitário vivido por Manoel resolveu-se em detrimento de sua identidade judaica - no seu caso o reflexo do modo como que era visto pela sociedade - e em favor da identificação mais estrita e emocional, vivida no âmbito local e familiar.

Assim, a existência de uma "Nação" judaico-portuguesa, noção social com uma forte conotação identitária, implicava - tanto da parte dos seus membros quanto da parte dos que não participavam dela (os cristãosvelhos) - a aceitação de uma diferença religiosa que, teoricamente, distinguia as pessoas entre judias e cristãs. Entretanto, na prática, isso não ocorreu, pois uma boa parte das pessoas da "Nação" (judeus ou cristãosnovos para os católicos), era na realidade católica. Se os portugueses cristãos-velhos podiam aceitar a existência de um cristão-novo católico, com todas as restrições e preconceitos possíveis sobre a sinceridade desse catolicismo, este não era o caso das pessoas da "Nação" praticando abertamente ou às escondidas o judaísmo. Para estes, era natural que toda pessoa da "Nação" deixasse as "terras de idolatria" para as "terras de liberdade" para cumprir seu destino de judeu.

$\mathrm{Na}$ Holanda (ou em Hamburgo, Veneza, etc.), os judeus tinham poucos meios para influenciar as pessoas da "Nação" que viviam no mundo ibérico, e boa parte daqueles que partiam para as "terras de liberdade" o faziam predispostos a voltar ao judaísmo. No Brasil holandês a situação era bastante diferente, pois os judeus encontravam sua "matéria prima" no próprio local onde moravam. Eles tiveram que se mobilizar para cumprir sua missão: pôr em prática meios para ajudar os que desejavam reintegrar-se ao judaísmo, com a distribuição de livros, por exemplo, mas também utilizar métodos menos tradicionais e mais agressivos, como a opinião da população cristãvelha, afim de convencer um público, que mesmo sendo da "Nação", não estava necessariamente predisposto a abandonar o catolicismo. 
A missão judaica nas terras brasileiras só podia ter tido resultados contrastados, muito mais incertos que os que se podem observar na Europa, onde existia, segundo as épocas, uma contestação ao establishment sinagogal e onde não foram raras as conversões ao cristianismo. A facilidade com que os homens puderam cruzar as fronteiras religiosas no Brasil holandês (para as mulheres a coisa era menos fácil), fez com que muitas pessoas que não teriam feito a viagem para as "terras de liberdade", e mesmo pessoas que não eram judaizantes, pudessem passar por uma experiência judaica. Alguns se adaptaram - nesse caso a missão judaica teve sucesso - mas, por vezes, essa missão não teve o efeito desejado, pois certas pessoas acabaram por preferir permanecer no seio da Igreja, mesmo praticando ritos judaicos (estudaremos a seguir esses casos mais detalhadamente), e outras quiseram voltar à situação anterior, abandonando as práticas, ou em todo caso, o modo de vida judaico, para retornarem ao catolicismo.

Esse tipo de conflito de identidades repetiu-se várias vezes durante o período, com as consequentes conversões e reconversões de cristãos-novos entre judaísmo e catolicismo. Contudo, essas não foram as únicas consequências da influência da comunidade judaica oficial sobre os cristãos-novos: certas pessoas, que formam na verdade o grupo mais conhecido, integraram completamente a comunidade, partindo em seguida, em 1654, com a vitória final dos luso-brasileiros sobre os holandeses, para lugares onde o judaísmo era permitido. Outras pessoas - e esse é o grupo mais difícil de se cernir - ficaram o tempo todo à margem, recebendo certas influências dos judeus, convivendo com eles, mas sem se desligar de modo tão radical quanto aqueles que se fizeram circuncidar, da sociedade em que viviam antes da conquista holandesa. Este foi o caso, por exemplo, da família Valença Caminha, moradora em terras do engenho Salgado, em Ipojuca, sul de Pernambuco. Pedro da Costa Caminha e as chamadas "as Valenças", isto é, sua mãe, avó, tias e primas, apesar do contato com os judeus, jamais integraram a comunidade judaica.

As Valenças recebiam judeus para a celebração do Shabat em sua casa e essa convivência certamente modificou a sua prática do judaísmo, sem entretanto provocar um conflito identitário. O relato de um vizinho das Valenças mostra como elas incorporaram essa influência:

"indo elle testemunha a caza das ditas molheres por muitas uezes achou a hua dellas lendo por hum liuro maneiro mais pequeno que hum Briuiario de quarto, e as outras muito atento escutando, e quando elle testemunha chegaua ellas se escondiaõ com muita pressa por cuia rezaõ elle testemunha naõ chegou a uer a forma do liuro, se era de Letra de maõ, se impressa, nem pôde numqua destinguir se a reza era em Latim se em portugues, ou em que Lingua, e sabe elle testemunha que se recolhiaõ em sua camara e outras uezes em hu ejrado alto lauando primeiro as maõs.f...) E falando elle com ellas muitas uezes na materia da Confissaõ as uiu nas acssois zombar e dizer que o que hua uez diziaõ em hua confissaõ diziaõ em todas as mais, e estando doentes como as elle testemunha uiu muitas uezes jamais as ouuiu chamar pello nome de Jesu nem fazer autos porque se mostrassem serem christris, e que morando elle dito testemunha iunto a e//as em hum partido de canas e uindo a ouuir missa lhe diziaõ ellas pera que se canssaua em hir ouuir missa dizendolhe (como anda Vossa Mercê emganado) e destas sircunstanssias, e de lhe auer dito a mulata com quem andaua (e que era da casa) que ellas eraõ iudias, e que quando lia hua por hu liuro se aleuantauaõ todas e logo se tornauaõ a sentar, e elle comsiguo formou iuizo perfeito de que e//as eraõ iudias e por tais as tem".

Pedro da Costa Caminha, o único membro masculino conhecido da família, também frequentava os judeus, tanto em Ipojuca quanto no Recife, onde pegava livros judaicos emprestado. Entretanto, pelo menos no caso de Pedro, um certo conflito interno parece presente, pois ele não se sentia tão à vontade com os judeus quanto as mulheres de sua família, tentando esconder dos outros a influência religiosa que recebia ${ }^{8}$.

A firmeza cripto-judaica das Valenças repete-se em outro grupo de cristãos-novos. Ambrósio Vieira, plantador de cana nos arredores da Paraíba, assim como seu genro Manoel Rodrigues da Costa e seu sobrinho e futuro genro João Nunes do Paço, frequentavam os judeus instalados na cidade da Paraíba, acompanhando o culto através de livros em espanhol e chegando até a participar da vida comunitária, pois Ambrósio doou uma pequena quantidade de cana de açúcar numa coleta feita em benefício dos judeus pobres da Holanda. Apesar desse convívio, Ambrósio e os seus (com uma única exceção) não integraram a comunidade oficial, segundo uma testemunha, por medo de que os holandeses perdessem Pernambuco ${ }^{9}$. A

${ }^{7}$ ANTT, Inquisição de Lisboa, livro 230, fl. 272-272 v.

${ }^{8} I d$., fl. $267,273 \mathrm{v}$ e $275 \mathrm{v}$.

${ }^{9}$ ANTT, Inquisição de Lisboa, livro 217, fl. 522-524 v. 
recusa da circuncisão, subentendia, assim, no caso de Ambrósio, a vontade irrestrita de continuar vivendo em suas terras da várzea do Paraíba do modo que fazia mesmo sob o domínio português e católico. Não houve, nesse caso, um conflito identitário, mesmo se uma das filhas de Ambrósio chegou a se casar com um membro influente da comunidade de Recife (o famoso Baltazar da Fonseca, construtor da ponte entre Recife e Antônio Vaz), morrendo provavelmente na Holanda como judia ${ }^{10}$. Contudo, como no caso das Valenças, a missão judaica influenciou o modo como a família paraibana vivenciava suas crenças e sua identidade, sem conseguir entretanto trazê-la de modo efetivo para a comunidade oficial.

Nos dois tipos de caso aqui analisados, podemos perceber que, tanto num caso como noutro, os cristãos novos certamente se identificavam com os judeus, incluindo-se assim no largo espectro das "pessoas da Nação", mas isto ocorreu ao mesmo tempo em que outros elementos identitários vieram frear ou inverter o processo de integração ao judaísmo, processo que, vale lembrar, era visto pelos judeus como um retorno. Certas vezes, esses contatos entre judeus e cristãos-novos causaram conflitos de identidade, provocando indecisões e reviravoltas, como no caso de Manoel Gomes Chacão. Em outros casos, como no das Valenças ou da família de Ambrósio Vieira, esses contatos acabaram por revelar a originalidade dos seus sentimentos, o que produziu por sua vez, para além das tensões e do conflito, a consciência de uma nova dimensão identitária que transcendia o fator religioso, e que não se moldava completamente nem no catolicismo nem no judaísmo.

\footnotetext{
${ }^{10}$ Egon e Frida WOLFF, Dicionário biográfico: judaizantes e judeus no Brasil, 1500-1808,
} Rio de Janeiro, ed. dos autores, 1986.
Origens da intolerância aos cristãos-novos no Brasil Colônia

\section{Renata Rozental Sancovsky}

processo de colonização portuguesa no Brasil apresentou, entre outras questões culturais, algumas práticas legislativas de discriminação religiosa. A política lusitana com relação a descendentes de judeus e cristãos-novos, erradicados na colônia, sugere-nos a permanência de um modelo medieval de intolerância.

Jacques Le Goff afirma ser a Idade Média o período em que "se formou a essência do sistema de valores e de comportamentos do Ocidente"2 Alicerçada em um projeto universalista de cristandade, a mentalidade persecutória medieval caracterizou-se, sobretudo, pela tomada de procedimentos proibitivos e de exclusão.

$\mathrm{Na}$ Idade Média, encontramos as raízes do segregacionismo religioso e cultural, política persecutória dirigida aos judeus ibéricos e, principalmente, aos cristãos-novos.

O Tribunal do Santo Ofício da Inquisição, predominante na política religiosa ibérica a partir do século XVI, é comumente apontado pela historiografia como o cerne das conversões arbitrárias e discriminações religiosas a judeus, cristãos-novos e judaizantes em Portugal, Espanha e suas respectivas colônias na América. A ordem legal e simbólica $^{3}$, outrora construída por tais sociedades metropolitanas, alicerçadas pela Inquisição, teria sido, segundo interpretações tradicionais, absolutamente autônoma e original, quando comparada a quaisquer outras tendências ibéricas de discriminação.

1 Doutoranda em História Social pela USP. Mestre em História Social pela UFRJ. Pesquisadora do Laboratório de Estudos sobre a Intolerância da USP, c000rdenado pela Prof $^{\mathrm{a}}$ Dra. Anita W. Novinsky. Pesquisadora do Programa de Estudos Medievais da UFRJ. Coordenadora Acadêmica e Professora do Centro de História e Cultura Judaica (CHCJ).

${ }^{2}$ Cf. LE GOFF, Jacques. “As Raízes Medievais da Intolerância.” In: A Intolerância: Foro Internacional sobre a Intolerância Rio de Janeiro: Bertrand Brasil, 2000. p. 38-41.

${ }^{3}$ CARNEIRO, M. L. Tucci. "A Transferência do Preconceito Racial contra os CristãosNovos para o Brasil-Colônia.." In: Preconceito Racial no Brasil Colônia: Os Cristãos-Novos São Paulo: Brasiliense, 1985. 
Entretanto, neste trabalho, fruto de um projeto de doutoramento orientado pela Prof ${ }^{\mathrm{a}}$ Dra. Anita Novinsky, ${ }^{4}$ apresentamos novas propostas de análise acerca da questão judaica e cripto-judaica na Península Ibérica. Buscaremos desvelar alguns dos fundamentos religiosos e culturais que orientaram autoridades eclesiásticas em toda a Península Ibérica a restringir e extinguir o Judaísmo do convívio social.

Afirmemos inicialmente que o fenômeno marrano, que marcou três séculos da História Ibérica na época moderna, teve seus precedentes na própria Península Ibérica, porém, nove séculos antes (séculos VI e VII).

O processo de conversão da Península Ibérica Visigoda ao catolicismo, consumado em fins do VI século pelo monarca Recaredo (586 d.C), inaugura um novo momento na relação entre judeus e cristãos no mundo ibérico alto-medieval ${ }^{5}$.

A adoção do catolicismo pelo Reino Visigodo, legitimado nas Atas do III Concílio de Toledo (589 d.C $)^{6}$, ocorre paralelamente à elaboração de um projeto político de unidade religiosa. Buscava-se uma ideal interação entre episcopado e monarquia, entre poderes eclesiásticos e civis. Nesse contexto, portanto, identificamos a construção de uma "questão judaica"”.

Disposta em inúmeros núcleos comunitários ou aljamas, a comunidade judaica visigoda é tida, a partir desse momento, como símbolo de uma realidade peculiar, uma micro organização que, por seu caráter autônomo, insistia em escapar ao efetivo controle das autoridades.

Da mesma forma que no Brasil-Colônia encontramos cristãos-novos ocupando os mais diversos setores profissionais e alcançando consideráveis graus de enriquecimento, principalmente como senhores de escravos e no comércio açucareiro, na Península Ibérica Visigoda veremos proliferarem

${ }^{4}$ CARNEIRO, M. L. Tucci. "A Transferência do Preconceito Racial contra os CristãosNovos para o Brasil-Colônia..” In: Preconceito Racial no Brasil Colônia: Os Cristãos-Novos São Paulo: Brasiliense, 1985.

${ }^{5}$ Sobre o processo de conversão e o III Concílio de Toledo ver: GARCIA MORENO, L. A. Historia de España Visigoda. Madrid: Cátedra, 1990. p. 230-240.

${ }^{6}$ VIVES, J. (Ed.) Concílios Visigóticos e Hispano-Romanos. Barcelona/Madrid: Consejo Superior de Investigaciones Cientificas - Instituto Enrique Florez, 1963 v.1 III e IV Concilios de Toledo. p. 107-145; 186-225, respectivamente

${ }^{7}$ GARCIA IGLESIAS, L Los Judíos en la España Antigua. Madrid: Cristiandad,1978. p. 8386. 8-111 Concílio de Toledo, cânone XIV. Cf. VIVES, J. Op. cit. p.129. decretos eclesiásticos que impunham obstáculos legais às práticas econômicas judaicas das aljamas.

O III, IV e VI Concílios de Toledo $(589,633,636)$ denunciam, por exemplo, a existência de relações de poder entre senhores judeus e escravos domésticos cristãos. Estes últimos, eram geralmente convertidos por seus senhores ao Judaísmo. Na visão do episcopado visigodo, a gravidade do proselitismo judaico em sociedade se concretizava pelo ato da circuncisão do escravo, marca perene do compromisso espiritual e físico com o Deus de Israel ${ }^{8}$. Impõe-se ainda restrições aos serviços fiscais e contábeis prestados por judeus a membros da nobreza laica visigoda.

A identidade judaica no Reino Visigodo do século VII constituía-se em um desafio para as autoridades formais, fossem Reis ou Bispos. Era tida como elemento destoante do modo de vida idealizado para os fiéis seguidores da Ortodoxia cristã.

No ano de 616 d.C, diversas comunidades judaicas foram forçadas a se converter ao catolicismo, por ordem do monarca visigodo Sisebuto (612621 d.C $)^{9}$. Desde então, o Judaísmo passou a ser praticado em segredo e suas comunidades forjaram estratégias e mecanismos de preservação de sua religião proibida, resistindo a um século de intolerância ${ }^{10}$.

Esta suposta solução de Sisebuto, com o aval dos poderes eclesiásticos, inaugura, na realidade, um dos mais sérios momentos da questão judaica visigoda. Eis que surgem novos sujeitos históricos para compor o complexo mosaico social ibérico. Trata-se do Cripto-judeu e do Judaizante ${ }^{11}$.

Para a comunidade judaica remanescente, os cripto-judeus são tidos como supostos traidores, coniventes com a política efetuada pelo governo. $\mathrm{Na}$ ótica monárquica e eclesiástica, os "novos cristãos" são elementos de incessante desconfiança, posto que permanentemente acometidos por uma

${ }^{8}$ III Concílio de Toledo, cânone XIV. Cf. VIVES, J. Op. cit. p.129.

9 ORLANDIS, J. "Una Política Ineficaz" In: Historia de la España Visigótica. Madrid: Gredos, 1977

${ }^{10}$ GARCIA IGLESIAS, L. "Motivaciones de la Politica Antijudía del Reino Visigodo en el Siglo VII." Actas del Coloquio - Estructuras Sociales durante la Antigüedad. Instituto de Historia Antigua - Faculdad de Filosofia y Letras - Universidad de Oviedo, 1977.

${ }^{11}$ GARCIA MORENO, L.A. "Iglesia y Sinagoga: Judaizantes, Cripto-judíos y Marranos" In: Los Judias de la España Antigua: Del Primor Encuentro al Primor Repudio. Madrid: Rialp, 1993. p. 90-136. 
infidelidade potencial. Infidelidade que se traduziria na judaização, ou seja, no retorno às antigas práticas religiosas judaicas.

Entre os segmentos populares visigodos, atesta-se igualmente a rejeição social: a presença de judeus convertidos, infiltrados em seus cotidianos, é tida como uma afronta ou mesmo intromissão aos modos de vida originariamente cristãos ${ }^{12}$.

A partir de então, recairia sobre os novos conversos ao catolicismo todo o peso da intolerância visigoda à cultura judaica.

Um cânone do IV Concílio de Toledo, por exemplo, estabelece a obrigatoriedade de crianças judias, ao atingirem a faixa etária de sete anos ${ }^{13}$, serem afastadas de suas famílias $e$ encaminhadas a uma educação prioritariamente cristã $\tilde{a}^{14}$.

Além da diluição dos núcleos familiares das aljamas, a política visigoda sobre as comunidades judaicas alcançara outras dimensões de maior gravidade. Em um documento, denominado Placitum, o Rabinochefe da congregação de Toledo deveria não somente acatar a sua própria conversão como também a de toda sua comunidade.

A partir dos decretos do Monarca Sisebuto e da promulgação do Placitum, todo e qualquer monarca que ascendesse ao trono visigodo deveria, segundo consta em Atas Conciliares, prometer ou mesmo jurar erradicar o Judaísmo da Península Ibérica. Afirma-se efetivamente, o antissemitismo como compromisso político dos Reis perante os poderes católicos.

Da mesma forma como veríamos, nove séculos mais tarde, com a política segregacionista aos conversos no Brasil-Colônia do XVI, a preocupação das autoridades visigodas do século VII com a infidelidade dos conversos traduziu-se em uma série de leis e cânones.

Uma das principais tentativas era a de ordenar, aos membros do episcopado e às inúmeras dioceses espalhadas pelo território, que em dias

\footnotetext{
${ }^{12}$ ORLANDIS, J. "Hacia una Mejor Comprensión de la Cuestión Judia en la Espolia del Siglo VII." In: Hispania y Zaragoza en la Antigüedad Tardia. Zaragoza, 1984. p.123-142.

${ }^{13}$ A faixa etária de sete anos é determinada a posteriori pelo XVII Concílio de Toledo (694), cânone VIII. Cf. VIVES, J. op. cit p.584-586.

${ }^{14}$ Idem. IV Concílio de Toledo, cânone LX. p. 212
}

específicos de festividade judaica, todas as autoridades locais se certificassem de que não haveriam cripto-judeus exercendo práticas rituais de sua antiga fé.

Uma prática muito comum conforme a legislação, era a realização de refeições coletivas em praça pública, geralmente acompanhadas pelo bispo da diocese local.

Nessas refeições, era obrigatório o consumo da carne de porco pelos conversos. Vemos que a Igreja possuía amplos conhecimentos acerca dos antigos hábitos alimentares da religião judaica, a ponto de saber exatamente quais animais seriam aptos ou não, segundo os judeus, para o consumo. Ao ingerirem essa carne, os cripto-judeus estariam, na visão das autoridades cristãs, mostrando seu concreto abandono do Judaísmo.

Não obstante percebamos tentativas concretas e bem sucedidas de contornar os controles sociais impostos pela monarquia e episcopado, o antissemitismo na Península Ibérica Visigoda demonstrou-nos de que maneira o preconceito - como ato de estereotipar, impondo juízos sobre o outro $-{ }^{15}$ contribui para tornar ainda mais complexas as relações humanas em sociedade.

Em nome do enquadramento social, os poderes visigodos, civis e eclesiásticos, formularam as bases de um modelo protocolar de intolerância ortodoxa, pautada na fé. Seus métodos principais eram a conversão, a aculturação, a punição material e corporal, e o exílio.

O filósofo francês de origem aristocrata, Montesquieu (1689-1755), foi um dos primeiros pensadores europeus a refletir sobre as implicações históricas dos códigos visigóticos para a sociedade ocidental.

Em seu clássico "O Espírito das Leis", referindo-se muito provavelmente às atuações da ordem dominicana no processo inquisitorial ibérico na Era Moderna, emite o seguinte juízo:

(...) Devemos ao código dos visigodos todas as máximas, todos os princípios e todas as concepções da inquisição de hoje; e os monges nada mais fizeram senão copiar, contra os judeus, as leis feitas outrora... As leis dos visigodos são pueris, (...) elas não atingem de 
modo algum o objetivo; cheias de retóricas e vazias de sentido, frívolas nas bases e gigantescas no estilo $(. . .)^{16}$.

Encontramos, portanto, na política visigoda sobre a questão judaica, no século VII princípios e lógicas de discriminação que orientaram, na modernidade, as práticas inquisitoriais em Portugal, Espanha e América Colonial.

${ }^{16}$ MONTESQUIEU. L'Esprit des lois. XXVIII, 1. Apud. POLIAKOV, L. De Maomé' aos Marranos: História do Anti-Semitismo ii. $2^{\mathrm{a}}$ ed. São Paulo: Perspectiva, 1996. p. 14. (Estudos, 64).
As denúncias de uma tradição: das velas do shabat às fogueiras da inquisição

Aleksandra Lavor Serbim Umbelino ${ }^{1}$

\section{Apresentação}

— ste trabalho faz parte de meus estudos no Programa de Pós-graduação 1 da UFPE (mestrado), o qual trata do rito judaico do Shabat e sua importância para o fortalecimento da identidade da comunidade judaica.

Porém, nesta comunicação ele será apresentado no contexto do período colonial pernambucano, no qual devido a presença do Visitador do Santo Ofício a essa Capitania houve diversas denunciações e confissões.

Baseado do empenho de grandes historiadores como José Antônio Gonsalves de Mello, foi possível estudar os documentos vindos da Torre do Tombo, que originaram a grandiosa obra: Confissões e Denunciações de Pernambuco 1593-1595.

A importância desta obra é de valor ainda não calculado para os estudiosos da área das ciências sociais, pois, segundo Professor Leonardo Dantas, "ela se revela como o mais importante documentário sobre a vida social da antiga capitania... A presença da Inquisição em Pernambuco veio revelar a vida dos residentes em Pernambuco, Itamaracá e Paraíba de forma crua, de maneira totalmente diferente da que era vista pelos primeiros cronistas que aqui aportaram". conhecemos também como se davam as relações econômicas, a produção de alimentos, a formação das redes familiares, as profissões e ofícios da época, sistema de transporte, vestimentas, disposição das moradias, etc., tornando-se sem dúvida um rico instrumento de para quem deseja fazer uma etno-história da sociedade pernambucana da época, respaldando a visão antropológica do costume a ser estudado - o rito do Shabat.

${ }^{1}$ Psicóloga, Mestranda em antropologia pela UFPE, Pesquisadora do Grupo Interdisciplinar de Estudos sobre Judaísmo e do Arquivo Histórico Judaico de Pernambuco.

${ }^{2}$ Leonardo Dantas Silva, na Nota do Editor das Confissões e Denunciações de Pernambuco. 


\section{Contextualização da época das denunciações:}

O primeiro visitador, o Inquisidor Heitor Furtado de Mendonça, aporta em Recife em 21 de setembro de 1593. Extasiado com a potência que era esta Capitania ele fica por essa terra até 1595. A sua chegada irá mudar bastante o cotidiano dos pernambucanos, pois agora seus comportamentos estarão sob a mira do Santo Ofício. Disse Gilberto Freyre que: "A Inquisição escancarou sobre nossa vida íntima da era colonial seu olho enorme, indagador" .

A partir de agora todos são denunciadores em potenciais e, também, correm o risco de serem denunciados, seja lá por que motivo for.

\section{Por que denunciar:}

Sob forma de juramento, as pessoas comuns iam denunciar seus vizinhos, amigos, e até parentes, tendo como mais forte impulso as ameaças de penas espirituais e a certeza de que o que faziam era o correto perante os olhos de Deus, obtendo assim um certo alívio espiritual.

Morar sob o mesmo teto e constituir laços de parentesco criavam uma recíproca e perigosa confiança de que os cultos judaicos secretos seriam sempre secretos.Lipner diz que:

Seja porque a analogia de origem determine também a semelhança da ação ou reação em idênticas circunstâncias - o que torna possível, pela sucessiva repetição, identificar com mais certeza tais práticas; seja porque só no ambiente familiar, dada a solidariedade que o caracteriza, diminuam em número e intensidade as cautelas normalmente adotadas para ocultar as práticas da religião secreta diluindo-se, assim, a densa clandestinidade que envolve invariavelmente tais atos de judaísmo. Era ademais, através das denúncias arrancadas a parentes, num ambiente de estranha simbiose entre o pavor e a solenidade, durante sessões de cruéis e teatrais tormentos, que o Santo Ofício arregimentava novas vítimas para as fogueiras, na presunção de que os segredos do culto proibido seriam captados com mais facilidade entre os membros pertencentes à mesma família.

\section{O Shabat e as denunciações:}

O que é o Shabat:

O Shabat representa um símbolo sagrado para o povo judeu, sendo um dos mais antigos rituais do judaísmo. Ele é o único ritual do judaísmo inserido nos Dez Mandamentos (na Torah), sendo o quarto Mandamento Divino. Nele lê-se:

Lembra-te do dia do Sábado (Shabat) para consagrá-Lo. Seis dias trabalharás e farás todas as tuas obras. Mas o dia sétimo é Sábado para o Eterno, teu Deus; tu não farás nenhum trabalho, nem teu filho, nem tua filha, nem teu servo, nem tua serva, nem teu animal, nem o estrangeiro que mora nas tuas cidades. Pois, em seis dias fez Deus os céus e a terra, o mar e tudo que neles há; e repousou (cessou sua obra) no dia sétimo. Por isso abençoou Deus o dia do Sábado, e o consagrou. Êxodo 20:8-124.

Deste modo, ele é especial por ser um dia de consagração e comemoração. Por ser este um dia tão especial, é necessária toda uma preparação como se vestir com as melhores roupas, arrumar toda a casa, preparar comidas especiais. Porém os momentos do Shabat iniciam-se ao pôr-do-sol da sexta feira, indo até o pôr-do-sol do sábado.

O seu recebimento é realizado numa cerimônia chamada Cabalat Shabat (recebimento do sábado), na qual são acesas duas velas, simbolizando respectivamente Guardar e Observar o Shabat.

\footnotetext{
${ }^{3}$ Prefácio de Casa Grande e Senzala.
}

$\overline{{ }^{4} \text { A Bíblia Sagrada, tradução: Almeida. }}$ 


\section{Estatísticas:}

De todas as práticas judaicas referidas aos cristãos-novos, o Shabat era a denunciação mais presente, como mostra a tabela abaixo:

\begin{tabular}{|l|c|}
\hline \multicolumn{1}{|c|}{ Motivo da denúncia } & Percentagem nas denunciações \\
\hline Shabat & $22,6 \%$ \\
Descrença em santos e imagens católicas & $16,7 \%$ \\
Blasfêmia da fé e ritos católicos & $10,7 \%$ \\
Negação de Jesus como deus & $10,7 \%$ \\
Fazer esnoga e festas judaicas & $9,5 \%$ \\
Cerimônia judaica de morte & $9,5 \%$ \\
Descrédito na autoridade católica & $4,8 \%$ \\
Assumir ou ter fama de judeu & $4,8 \%$ \\
Costumes alimentares judaicos & $4,8 \%$ \\
Possuir a Torá em casa & $3,6 \%$ \\
Possuir literatura hebraica & $2,4 \%$ \\
\hline
\end{tabular}

\section{Possíveis explicações:}

Por que era o Shabat a prática judaica mais denunciada? Existem algumas observações que podem esclarecer mais esta questão. Diante do contexto social da época, era comum as pessoas transitarem livremente umas pelas casas das outras. A própria arquitetura facilitava isto, com muros baixos e comunicações entre uma casa e outra. Desse modo a vida particular era bem mais facilmente exposta ao público. Daí, esconder um rito proibido pela condição de ser cristão-novo era difícil.

Lipner diz que:

As casas no período colonial, além de situadas em ruas estreitas e serem de meias paredes, comunicavam-se frequentemente pelos quintais, permitindo falarem-se as vizinhas das janelas fronteiras ou traseiras, confinantes, e expondo aos olhos dos curiosos a intimidade de seus moradores. Tal curiosidade, própria já da natureza humana, e facilitada pelo sistema arquitetônico da época, encontrou um novo e vigoroso estímulo durante a visitação do Santo Ofício às partes do
Brasil, quando entrou em pleno funcionamento esse meio primário de espionagem, posto em prática pelo Tribunal da Fé. ${ }^{5 ،}$

E o rito do Shabat era de todos o que mais exigia uma maior exposição visual, pois era necessária toda a preparação na sexta feira como tomar banho, vestir roupas limpas e lavadas, enfeitar os cabelos, fazer comidas especiais, e o principal - durante os momentos do Shabat tais denunciados não trabalhavam, o que era bastante destoante frente a sociedade, já que naquela época o sábado era um dia de trabalho normal Alguns exemplos de relatos de denunciantes mostram bem o pensamento da época frente ao Shabat:

Branca Dias guardava os sabbados, porque sendo costume da ditta Branca Dias em todos os outros dias da semana fiar algodão e andar vestida do seu vestido da semana, ella denunciante vio a ditta Branca Dias nos sabbados não fiar nunca e vio que nos dittos sabbados pella menhaã se vestia uma camisa lavada e apertava a cabeça com seu toucado lavado e vestia nelles ho melhor vestido que tinha que era uma saia azul clara que ella tinha de festa a qual não costumava vestir nos dias da semana...

lhe lembra muito bem que vio aos dittos Diogo Fernandes e Branca Dias guardarem os sabbados todos sendo dias de trabalho não trabalhando nelles nem fazendo serviço algum de casa como costumavam fazer nos outros dias de semana e costumado ditta Branca Dias a fiar sempre algodão pella semana quando vinhão os sabbados guardava a roça e não fiava nelles sendo dias de trabalho ${ }^{7}$ ،

...sempre todas as sestas feiras á tarde despois da vespera espanavão as paredes e alimpavão a casa e a louça e sempre nos sabbados todos sendo dias de trabalho guardarão e não trabalharão nada e nos dittos sabbados vestido camisas lavadas e se toucavão com toalhas e toucados e se afeitavão e vestiam dos milhores vestidos, assim como os cristãos velhos costumão fazer ao domingo e estas cousas de guardar todos os sabbados sendo dias de trabalho e nelles se vestirem de camisas e toucados lavados e milhores vestidos de festa,

${ }^{5}$ ELIAS LIPNER - “Os Judaizantes nas Capitanias de cima”. São Paulo: Ed. Brasiliense, 1969. PP 68.

${ }^{6} \mathrm{PP} 30$.

${ }^{7}$ PP 54 a 57. 
começando tambem a guardar das sestas feiras a tarde não trabalhando nada nas tardes das sestas feiras... ${ }^{8}$

As pessoas que já tinham um certo conhecimento sobre este rito, já ficavam a espiar seu vizinho, como mostram diversos relatos:

e vio que a ditta Ines Fernandes em todo o ditto tempo de tres annos os sabbados que erão dias de trabalho guardava estando sempre nelles deitada em hua rede lendo por livros sem fazer outro nenhu serviço nem trabalho sendo ella costumada em toda a semana ordinariamente trabalhar, cosendo, lavrando, fazendo trancinha, e outras cousas, na sua almofada e somente nos sabbados sendo dias de semana não fazia nenhum trabalho como ditto tem, e isto atentou ella denunciante e vio no ditto tempo, per muitos sabbados em que de preposito olhava, e a ditta referida a chamava muitas vezes nos sabbados que olhasse pera a ditta denunciada como estava na rede sem trabalhar...

(...) Denunciou mais que há quarenta e quatro, ou quarenta e cinco annos que nesta villa morava outro Antonio Diaz da/cunha o felpudo cristão novo o qual elle denunciante vio alguns sabbados que nelle atentou sendo dias de trabalho não hir ao trabalho e serviço das roças e nelles andar vestido do milhor vestido de festa que tinha e costumado em toda semana, e nos dias domingos e dias santos hir a roça somente nos sabbados inda que erão dias de trabalho não ia a roça e se lançava em huã rede e elle vio isto alguns sabbados como ditto tem e disto podendo tambem testemunhar Domingos Bezerra o Velho. ${ }^{10}$

...O ditto Lopo Martins lhe dixe que ho ditto ourives era hum judeu que guardava sempre os sabbados que elle denunciante nelle atentou (que forão muitos) vio que sendo sabbados de trabalho o ditto ourives não trabalhava nelles e tinha a tenda fechada e vio que nos mesmos de trabalho folgava o ditto ourives e andava passeando pella rua com camisa lavada vestida e vestido com vestido milhor que o da semana e que nestas cousas atentou elle de propósito e as vio como diz...
Os suspeitos eram mais vigiados:

Diogo Fernandes e a ditta sua molher Branca Dias cristão novos sendo então sabbado dia de trabalho ás dez dias do dia vinhão ambos juntos vestidos de festa com seus roupõis de frisa.., de nova de galante que não costumavão vestir na semana e elle com camisa lavada muito alva, e ella com toucados alvos e lavados e por ser sabbado e elles gente de sospeyta logo isto pareceo mal a todos. ${ }^{12}$

\section{Os Cristãos-velhos testavam os suspeitos propositalmente:}

...O ditto Lopo Martins lhe dixe que ho ditto ourives era hum judeu que guardava sempre os sabbados... lhe dixe elle denunciante que lhe vendesse huns pensamentos de ouro de orelha pêra sua molher e o ditto ourives lhe responde ${ }^{\circ}$ que não nos tinha, então no dia seguinte que era domingo pela menhaã ante missa saindo elle denunciante a elle e lhe pedio que lhe vendesse os dittos pensamentos e ho ditto ourives lhe vendeo então os dittos pensamentos por mil rs. e vendo elle denunciante estas causas em que elle de propósito atentava tinha ruim presumpção do ditto ourives...

E além de não trabalharem nos sábados, eles nem sempre faziam questão de comparecer às missas dos domingos:

(...) Denunciou mais que ouvio a muitas pessoas em geralmente não lhe lembra quais que Thomaz Nunes cristão novo mercador que foi desta Capitania pera o Reyna guardava os sabbados e que nos domingos pellas menhaãs caminhava pera Roça ou pera esta villa por não ouvir missa. ${ }^{14}$

Escravos também acabavam colaborando com as denunciações:

...vio que Ines Fernandes cristaã nova molher do ditto Balthesar Leitão se vesti ${ }^{\circ}$ de festa com huã saya de tafeta azul e jubão de olanda lavado e toucado na cabeça lavado e em todo o ditto dia de sabbado sendo de trabalho guardou e não trabalhou, por que nos mais dias da semana a vio estar com bui saia de pano fiando e no ditto sabbado não tomou roga nem fez outro serviço algum, e vendo ella denunciante aqui//o sem sospeitar mal perguntou a Lucrecia sua escrava brasilla se queria hir sua sorã fora, a qual lhe responde ${ }^{\circ}$ que

\footnotetext{
${ }^{8}$ PP 149 a 152

${ }^{9} \mathrm{PP} 65$.

${ }^{10} \mathrm{PP} 75$ a 77

${ }^{11} \mathrm{PP} 315$.
}

${ }^{12} \mathrm{PP} 50$ e 51

${ }^{14} \mathrm{PP} 90$ e 91. 
não, então lhe tornou a perguntar que pois não hia forapera que se vestia e enfeitava assim e a ditta Lucrecia lhe responde que sempre a ditta sua senhora Ines Fernandes aos sabbados se vestia daquela maneira e afeitava e não trabalhava inda que fossem dias de trabalho... ${ }^{15}$

Era também vantagem para os escravos e servos de cristãos-novos que guardassem o sábado, pois estes não trabalhavam no dia de sábado:

Denunciou mais que no ditto tempo pouco mais ou menos, vio tambem ser fama pubrica geralmente ditto por todos assim principais como mais povo desta terra que Diogo Fernandes e sua molher Branca Diaz cristão novos jd defuntos senhores de engenho de Camaragibi ora chamado Santiago, guardavão todos os sabbados sendo dias de trabalho, e nelles se vestiam de festa, e não hiam ao engenho como nos outros dias da semana costumavão, e nos dittos sabbados não obriga- vão a trabalhar a gente no seu engenho ${ }^{16}$.

...e nelles não usavão do serviço e trabalho que costumavão nos mais dias da semana de ir aos canaveais e fazer prantar e mondar e outras cousas semelhantes de beneficio da fazenda, mas sómente mãodavão nos dittos sabbados fazer negros qualquer serviço leve ${ }^{17}$..

\section{Considerações finais:}

Branca Dias e Diogo Fernandes foram das pessoas mais denunciadas, o que mostra o quanto eles foram significativos para a constituição de uma coesão grupai que reforçou a identidade judaica da época. Tanto que mesmo anos depois, quando eles já eram "defuntos", ainda eram os mais lembrados como guardadores do sábado. Seus descendentes acabaram pagando a pena e sendo condenados pelo Tribunal Santo Ofício. Mas, apesar de todo o perigo real de condenação às fogueiras da Inquisição, o ritual do Shabat não deixou de ser vivenciado, mesmo que às escondidas, trancado entre paredes. Desse modo, sendo ele um referencial de identidade, possibilitou a continuidade de um grupo social que se sustentou coeso e em integração com os aspectos religiosos e sociais.
Manter as chamas das velas acesas permitiu que uma tradição não sucumbisse nas cinzas das fogueiras. Ao contrário, como no mito grego da fênix, este ritual se renova e ressurge das cinzas na atual comunidade judaica pernambucana, tanto no grupo Renascer (de linha liberal), quanto no Beith Chabath (de linha ortodoxa), ainda é possível observar as chamas das velas recebendo o grande dia de consagração judaica.

\footnotetext{
${ }^{15}$ PP 106 e 107

${ }^{16} \mathrm{PP} 75$ a 77.

${ }^{17} \mathrm{PP} 80$ e 81
} 


\section{Os marranos e a interculturalidade em Pernambuco}

\author{
Claudia Simonne Carneiro Gouveia ${ }^{1}$
}

E mbora significativamente importante tanto no aspecto econômico quanto no social, a primeira comunidade judaica oficial foi antecedida em nossa capitania por um grupo de cristãos-novos e marranos, no século XVI, que residiam basicamente em Olinda, mantendo muitos deles seus engenhos e fazendas em outras localidades tais como, São Lourenço da Mata, Jaboatão e Cabo. Eram indivíduos integrados à população na qual viviam, exercendo os mais diversificados ofícios, como senhores de engenho, lavradores, mercadores, feitores, alfaiates, mestres, tabeliães, ourives, boticários, guardas, cirurgiões, etc.

Se por um período puderam sentir-se em casa na colônia, a intranquilidade não tardou a chegar; apesar de aparentemente incorporados aos habitantes de Pernambuco, nem por isso deixaram de ser constantemente vigiados pelos próprios vizinhos que, impelidos pelo monitório do Santo Ofício e em busca do perdão da graça, procuravam os vestígios da "antiga" religião para denunciá-los.

Porém, é necessário conhecer os episódios que deram origem à dispersão destes que, em sua maioria, conservaram a origem judaica, independente da denominação que receberam.

\section{Marranos e Cristãos-novos.}

\section{Diferentes designações para uma mesma vivência}

Possivelmente, a origem do termo marrano advém da proibição do consumo de carne de porco pelos judeus, fazendo-se assim uma relação entre judeu converso, cristão-novo e porco, sendo utilizado pelos espanhóis na referência aos falsos convertidos ao catolicismo, isto é, aos que

\footnotetext{
${ }^{1}$ Psicóloga, Mestre em Antropologia pelo Programa de Pós-Graduação em Antropologia Universidade Federal de Pernambuco e pesquisadora do Grupo Interdisciplinar de Estudos sobre judaísmo do PPGA-UFPE e do Arquivo Histórico Judaico de Pernambuco.
}

continuaram praticando o judaísmo, e permaneceram assim designados, mesmo após a migração para Portugal saídos do reino de Castela.

Os judeus espanhóis, cuja perseguição começa em 613 d.C., sob o reinado do visigodo Sisebuto, forçados à conversão pela união de interesses entre Tomás de Torquemada, sacerdote católico, e os reis de Aragão e Castela, Fernando e Isabel, dezoito anos antes do decreto de expulsão de 1492, enfrentaram a Inquisição, cujo intuito era limpar a heresia dos marranos e expulsar da Espanha os judeus ainda leais à sua fé. Torquemada, neto de judeu, alegava que se permanecessem na Espanha os judeus continuariam influenciando seus irmãos a voltar à sua antiga religião. Os reis concordaram com o argumento dos dominicanos de que poderiam usar os bens dos judeus para financiar a guerra contra os mouros, embora tenham sido obrigados a negociar com o Papa Sisto IV que também queria os bens dos judeus para a Igreja. Resultado: trinta mil marranos condenados à morte e queimados vivos pela Inquisição e dezenas de milhares submetidos à tortura física.

Dando seguimento aos acontecimentos, sabe-se que os marranos e judeus recorreram ao reino vizinho, onde, no século $\mathrm{XV}$, tiveram que se submeter à política de Dom Manuel, que influenciado pela relação e pelos interesses que tinha com os reis da Espanha, condicionou a estada dos judeus em Portugal à conversão - o que os fez serem designados cristãosnovos em oposição aos cristãos velhos - ou à expulsão, promovendo mais uma diáspora, que desta vez vem alcançar o Brasil.

\section{Os primórdios da presença judaica no Brasil}

Não desejados em seus locais de origem os judeus viram-se "incluídos" nos projetos colonizadores, o que serviu a dois objetivos: 1. As metrópoles não os tinham mais na população; 2. e os judeus conseguiam um exílio, mesmo que semivoluntário, gerado pela necessidade de escapar da Inquisição na Península Ibérica. Os cristãos-novos tiveram participação garantida nos descobrimentos portugueses como cientistas e informantes de rotas, pois eram destacados profissionais nas áreas de conhecimento náutico, médico, etc. (Kaufman, 2000).

Deve ter sido grande o número de cristãos-novos trazidos nas frotas dos arrendatários nas primeiras viagens às costas do Brasil, para dar cumprimento às referidas cláusulas contratuais. É de presumir-se 
ainda que nos decênios posteriores êsse número aumentou consideràvelmente - de um lado, pelo recrudescimento das perseguições contra os judeus na metrópole, antes e por ocasião do estabelecimento da Inquisição em 1536, e de outro lado, pelo tácito privilégio de inviolabilidade concedido pelo rei aos elementos povoadores da colônia." (Lipiner, 1969:15).

Como forma de resgatar a consciência histórica da sociedade, nunca é demais lembrar que a corrente migratória judaica de Portugal e Espanha para o Brasil ocorreu devido ao confisco de bens, às conversões compulsórias e à expulsão dos que não quiseram se converter, o que veio a calhar para Portugal que, com dificuldade para colonizar as terras recémdescobertas, necessitava de mão-de-obra qualificada, grandes investimentos de capital e aporte de recursos humanos, gerando a formação de sociedades e parcerias. Sabendo o quão difícil seria povoar uma terra baseando-se apenas na população da metrópole e sem o capital necessário, Portugal tratou de fechar os olhos para o preconceito contra os judeus, passando a utilizá-los como elemento colonizador e financiador.

\section{A presença judaica em Pernambuco no século XVI}

Desde o século XVI, os cristãos-novos tomaram parte na colônia nos aspectos econômico e social. Como "faziam parte de uma elite que ditava costumes, estabelecia normas e, de certa forma, exercia o controle da vida econômica da colônia, é provável que nessas condições fosse fácil criar e sustentar estratégias para disfarçar a vida judaica que transcorria nos subterrâneos da sociedade colonial (Kaufman, 2000:16).

Estava a colônia entregue, assim, aos seus sonhos de ouro quinhentistas quando os cristãos- novos, que formavam uma parte considerável dos habitantes, passaram a ser atemorizados com insistentes rumôres sôbre o bicho-papão do século. Não se tratava do monstro imaginário com que se amedrontam as crianças, mas de um verdadeiro e fanático tribunal que vinha - segundo se murmurava da metrópole às partes do Brasil, com todo o seu séquito de fogueiras, cadafalsos e cárceres, para converter em desencanto, e quiçá pesadelo, o tímido sonho de liberdade religiosa nutrido pelos judaizantes. Êstes sentiam ir-se-lhes encolhendo o coração gradativarnente, à medida que viam encolher-se a imensidão do
Atlântico que julgavam antes existir entre si e seus perseguidores Não estava longe a Inquisição. (Lipiner, 1969:32).

Alarmados pelas notícias que chegavam da metrópole de familiares presos pelo Santo Ofício, ficaram então os cristãos-novos da colônia na iminência de serem delatados em virtude das torturas sofridas por aqueles; segundo boatos que corriam em Olinda, estes já tratavam de se desfazer dos seus negócios possivelmente na preparação de uma fuga, sendo, provavelmente, também incentivados pelo auto-de-fé realizado na cidade no qual um cristão-novo foi levado à matriz para em um cadafalso ouvir a leitura das sentenças condenatórias, de acordo com Lipiner (1969).

Mesmo disfarçando suas práticas judaicas, muitos cristãos-novos não escaparam da Inquisição, sendo denunciados ao Tribunal do Santo Ofício instalado em Pernambuco entre 1593 e 1595.

Apesar do mal-estar criado pela visitação do inquisidor, muitos cristãos-novos continuaram seguindo sua vida, demonstrando uma resistência religiosa e, por que não dizer, cultural, características reveladas pelos denunciantes, segundo Lipiner (1969:46) "...desde a velada $e$ sutilíssima reserva mental, em tôdas as suas engenhosas ramificações, até a rude e simples propaganda anti-cristã."

Ou seja, comportamentos e atitudes que demonstravam uma vivência religiosa dupla, como, por exemplo, frequentar a igreja aos domingos comemorar o shabat aos sábados, que vale salientar não era a única cerimônia judaica realizada, como se encontra na denúncia de Felippe Cavalcanti contra Anrique Mendes:

... o qual era acostumado todas as luas novas de agosto hir com sua molher Violante Roiz e com toda a mais casa e familia em carros enramados e com festas desta villa ao lugar de Camaragibi que está daqui quatro ou simquo legoas e laa se estavão hu e dous meses, e era fama pubrica nesta terra... que no ditto Camaragibi avia esnoga onde se ajuntavão os judeus desta terra e faziam suas cerimonias.. (Primeira Visitação, 1984:75).

A propósito, ao que parece, sinagogas existiram em grande número na capitania; por exemplo, Camaragibe foi citada como terra das sinagogas, visto que a maioria dos engenhos que pertenciam a cristãos-novos dispunham das mesmas. Sendo o principal o engenho Camaragibe, conhecido como o centro espiritual dos cristãos-novos no século XVI este 
“... possuía uma sinagoga e uma "toura"(provavelmente não uma Sefer Torah, mas sèmente uma mezuzah)... foi provàvelmente organizado por Diogo Fernandes e sua mulher, Branca Dias, o primeiro casal de cristãosnovos que se conhece, estabelecido no Brasil. Para a celebração do Yom Kippur, os judaizantes de Pernambuco iam a Camaragibe. Em Olinda tinham um Shammash para os convocar ao culto divino de Camaragibe" (Wiznitzer, 1969: 20).

E mesmo a falta de local apropriado não impedia a prática dos rituais judaicos - a esnoga - como a que acontecia aos sábados na casa de Branca Dias e Diogo Fernandes em Olinda. O casal sofreu treze denúncias, várias delas de antigas alunas de Branca Dias - que mantinha um pensionatoescola em sua casa, sendo auxiliada pelas filhas - cuja diferença na rotina de funcionamento da residência nas sextas-feiras chamou a atenção daquelas, isto é, a limpeza da casa, a troca da roupa de cama, a preparação de uma refeição especial, a troca da roupa pessoal e o descanso aos sábados.

Antigas alunas da escola de Branca Dias delataram que, auxiliadas por meninas escravas, elas limpavam e lavavam a casa tôda as sextas-feiras, e que ninguém ali trabalhava aos sábados. Denunciaram que Branca Dias e suas filhas tinham vestido os seus melhores trajes num sábado, dia em que Branca compartilhava suas refeições com as filhas. Preparava-se então para tôda a família Fernandes uma iguaria de côr amarelada. Segundo as filhas mais novas de Branca tal iguaria era composta de grãos moídos, carne, óleo, cebolas e temperos (...) Também se denunciou que as lâmpadas eram limpas tôdas as sextas-feiras, e munidas de óleo e pavio novos (...) Diziam-se que Diogo, seu irmão Duarte e seu genro Diogo, todos êles administradores do engenho e da fazenda de Camaragibe, viviam de conformidade com a Lei Judaica, seus ritos e costumes. Afirmouse ao mesmo tempo que, ulteriormente, os novos administradores dêsse engenho, membros da família Vaz, prosseguiam em suas atividades judaizantes... (Wiznitzer, 1966:21).

Prosseguindo sobre a questão da resistência religiosa desse grupo do século XVI, outra característica era a forma como os cristãos-novos comportavam-se na igreja, bem como suas atitudes em relação aos rituais e símbolos católicos. Embora as denúncias predominantemente tratem do shabat, talvez porque seus ritos sejam mais fáceis de identificar, muitos cristãos-novos também eram delatados porque:
...Nas igrejas, durante os ofícios religiosos, ao ser mencionado o nome de Jesus, ou alçada a hóstia pelo sacerdote, no altar, enquanto todos faziam reverência e inclinavam a cabeça, êles, mal contendo os naturais impulsos sacrílegos, não faziam reverência alguma. Antes permaneciam sempre direito em pé, ou mesmo sentados (...).

Alguns ainda, embora aparentemente acompanhassem os cristãosnovos nos gestos de reverência, murmuravam para si frases ou expressões restritivas, como o cirurgião Fernão Soeiro da vila de Olinda, que, ao ser alçada a hóstia, de joelhos e batendo nos peitos, dizia em voz baixa e repetidamente as seguintes palavras: 'eu creio o que creio. (Lipiner, 1969:47).

Mais um exemplo desses "impulsos sacrílegos”, como denomina o autor acima, é uma denúncia contra Branca Dias feita por Maria Alvares que relata:

...trazendo ao pescoço huãs contas de rezar com huã cruz pendurada nellas, correndo lhe a cruz pera diante dos peitos, tomou com a mão a cruz e dizendo pera a cruz doute ao demo a lançou pera detras das costas... (Primeira Visitação, 1984:202).

Alguns sinais de judaísmo sob vigilância nas atitudes da população diziam respeito aos ritos fúnebres judaicos, quais sejam:

...se por morte dalguns ou dalgumas, comeram ou comem em mesas baixas, comendo pescado, ovos e azeitonas, por amargura, e que estão detrás da porta, por dó, quando algum ou alguma morre, e que banham os defuntos, e lhes lançam calções de lenço, amortalhandoos com camisa comprida, pondo-lhe em cima uma mortalha dobrada, à maneira de capa, enterrando-os em terra virgem, e em covas muito fundas, chorando-os, com suas literias cantando, como fazem os judeus, e pondo-lhes na bôca um grão de aljôfar ou dinheiro douro, ou prata, dizendo que é para pagar a primeira pousada, cortando-lhes as unhas, e guardando-as, derramando e mandando derramar água dos cântaros, e potes, quando algum ou alguma morre, dizendo que as almas dos defuntos se vêm aí banhar, ou que o Anjo percuciente lavou a espada na água. (Lipiner, 1969:73).

O costume de após um enterro trocar todas as águas de casa por águas frescas - ficou ao que parece perpetuado entre a população do interior nordestino que ainda joga a água fora após a morte de alguém para que sua alma não venha banhar-se nessa água. Na sua denúncia, contra Branca Mendes, Barbara Castellana relata que: 
...quando morria alguma pessoa na villa mandava lançar fora toda agoa dos potes que em casa avia, e depois dos defuntos enterrados mãodava trazer agoa fresca pera casa e quãodo mandava vazar os potes perguntada alguis vezes pellos filhos que erão meninos por que a mão dava vazar respondia que não era bom beber aquella agoa porque morreu tal pessoa e isto de lançar agora fora... (Primeira Visitação, 1984:99).

Vê-se assim que as denúncias e confissões não se restringiam às blasfêmias e descrença em rituais católicos; algumas envolviam a realização de cerimônias, ao que parece, sem a consciência de que se tratava de um rito judaico, mas sob a alegação de ser um costume passado de mãe para filha - o que por si só já chama a atenção, visto que na cultura judaica cabe a mulher o papel de transmitir os ensinamentos - como pode-se observar na confissão de Guiomar Soeira:

...lhe morreu em casa uma negra brasila... logo como a levaram mandou ela confessante vazar fora a água dos potes da cantareira da sua câmara, de que ele confessante bebia e mandou trazer égua fresca da fonte... que não teve tenção ruim, nem sabia que era cerimônia de judeus... o aprendeu de sua mãe Maria Alvares, a qual ela viu três ou quatro vezes morrendo-lhes escravos em casa... mandar vazar a água dos potes e trazer égua fresca da fonte... (Primeira Visitação, 1984:108)

Pelo exposto a Inquisição não só contava com a população em geral para delatar os cristãos-novos, como também podia contar com hábitos tão arraigados como involuntários apresentados pela comunidade alvo, isto é:

...a Inquisição espreitando pelos buracos de suas portas e pautando as inquirições com luxo de sutilezas e não pequena dose de malícia, pelo monitório, apanhava-os em suas malhas. Identificava-os para a fogueira pelas crendices, superstições, ritos e preconceitos que traziam a tonalidade íntima e suave de reminiscências ou influxos ancestrais, a que tôdas as pessoas se apegam, com maior ou menos avidez nos variados períodos de sua vida... (Lipiner, 1969:82).

Talvez a Inquisição só não contasse com a assimilação de vários costumes judaicos pela população em geral, como relata Lipiner:

$\mathrm{O}$ inquisidor deve ter ficado atônito ao verificar que os cristãosnovos haviam deixado traços de sua imaginação nas crendices e superstições dos cristãos velhos e mamelucos da colônia... (1969:69).
O costume de vazar fora a égua dos cântaros, por morte de alguém em casa, considerado pelo inquisidor como principal rito judaico, era tão difundido entre a população da colônia, que até os cristãos velhos o praticavam... (1969:73).

(...) Roque Garcia... disse que 'tanto cria êle no que diziam aquêles negros como nos Evangelhos de São João, e pedia dessas palavras perdão e penitência. Esta expressão, que deu escândalo quando proferida por cristão-nôvo, assim como outras semelhantes, igualmente profanadoras e sacrílegas, vêm sendo repetidas, nas confissões e denunciações, por autênticos cristãos velhos, certamente por influência dos judaizantes que deixaram traços de tradição anticristã em diversas áreas da vida cotidiana da Colônia... (1969:79).

\section{Uma herança judaica não reconhecida}

Tendo sido tão presentes em Pernambuco colonial como pensar que os judeus não contribuíram para a formação da população pernambucana geneticamente e também no que se refere aos costumes e tradições?

Sobreira, um estudioso das evidências judaicas na cultura nordestina cita em seu trabalho elementos semítico-sefarádicos na formação da população do Nordeste, tais como: o hábito de usar mantilhas negras, bem como envolver os mortos em peças de linho branco sem costura nem cortes; o hábito de abater galinha cortando o pescoço e vertendo o sangue no solo, não sem antes testar o fio da faca na própria unha; o culto à honra; a poligamia; o nomadismo; o apego ao estudo e às letras; a desconfiança; o batismo dos filhos com nomes retirados do Antigo Testamento; os casamentos endogâmicos; a resistência ao sofrimento.

Vale salientar que segundo Câmara Cascudo, grande estudioso da cultura brasileira:

no Brasil, o judeu, não estando segregado nas Judiarias, não se distinguia na massa populacional. Era vigário, ouvidor, membro da governança, oficial, mercador, mestre-escola, dono de engenho, relacionado com todas as classes e participando de todas. (1978:38)

Este autor, investigando nas mais diversas fontes, desde livros a "vozes antigas e familiares", pôde ver as reminiscências de um povo na vivência de usos e costumes brasileiros, tais como: "o tabu do sangue, repugnância às carnes dos animais encontrados mortos, balançar o corpo na oração, a bênção 
com a mão na cabeça, o horror da blasfêmia, respeito ao cadáver e aos objetos de uso pessoal do defunto..." (1978:9). Costumes que não param por aí.

Quem não se pegou questionando qualquer ser reflexivo se está pensando na morte da bezerra? A origem dessa frase deve-se à torá, o pentateuco mosaico escrito em hebraico, segundo Câmara Cascudo (1978), que para os oficiais do Santo Ofício e seus informantes era representada por figuras de touro, bois, bezerros, etc. Quem não conhece alguém que arrume sua casa às sextas-feiras? Seria resquício da espera dos sábados, ou seja, do shabat judaico? A celebração semanal dos judeus da criação do mundo por Deus. Quem nunca ouviu alguém exclamar: lamba as unhas, isto é, conforme-se com o que já tem, ou considere-se feliz? Lamber as unhas de ambas as mãos era um gesto de exorcismo popular judeu, quando se ouvia que alguma mulher tivera um parto ruim, do qual apenas a frase ficou entre nós. E as crendices populares brasileiras de não varrer a casa para fora, ou de varrer a casa à noite da porta para dentro, para que a felicidade não vá embora? Superstições que faziam parte do cotidiano dos cristãos-novos moradores da Bahia e de Pernambuco.

Para Anita Novinsky, que dispensa apresentações, é necessário refletir sobre as raízes do Brasil e o drama que viveram nossos antepassados. Nesta comunicação quisemos demonstrar que nossas raízes vêm do século XVI, raízes que originaram costumes tomados muitas vezes como brasileiros, mas que parecem ser um legado de nossos ascendentes judeus, resultantes da manutenção de seus princípios culturais e religiosos, através das práticas judaizantes feitas algumas vezes às escondidas, outras inconscientemente explícitas, influenciando de tal modo a população da colônia a ponto de serem assimiladas como hábitos.

Estas são apenas algumas pistas do legado judeu que recebemos e o intuito da pesquisa que desenvolvemos é revelar a influência da cultura judaica na nossa formação e no nosso comportamento.

\section{Referências Bibliográficas}

CASCUDO, Luís da Câmara. Mouros e Judeus na tradição popular do Brasil...

KAUFMAN, Tânia Neumann. Passos Perdidos - História Recuperada: A Presença Judaica em Pernambuco. Recife: Edição do autor, 2000.
LIPINER, Elias. Os Judaizantes nas Capitanias de Cima. Estudos sobre os Cristãos novos no Brasil nos Séculos XVI e XVII. São Paulo: Editora Brasiliense, 1969.

PRIMEIRA Visitação do Santo Ofício às partes do Brasil; Denunciações e Confissões de Pernambuco 1593-1595. Prefácio de José Antônio Gonsalves de Mello. Recife, FUNDARPE. Diretoria de Assuntos Culturais 1984. $509+158$ p. II. (Coleção pernambucana - 2. fases, 14).

SOBREIRA, Juarez Caesar Malta. Influência dos Judeus Sefaradins no Nordeste Brasileiro (Universidade Federal de Rondônia). Comunicação apresentada no Congresso Internacional América-92, 1992.

WIZNITZER, Arnold. Os Judeus no Brasil Colonial. Tradução de Olívia Krãhenbuhl. São Paulo: Livraria Pioneira Editora, Editora da Universidade de São Paulo, 1966. 


\section{Mulheres da nação cristã-nova: as marranas do Rio de Janeiro (século XVIII)}

\section{Lina Gorestein ${ }^{1}$}

$\mathrm{D}$ esde o final do século XVI no Rio de Janeiro se estabeleceu uma comunidade cristão-nova ativa e solidária, que se manteve unida especialmente através de casamentos endogâmicos e da discriminação a que esteve submetida.

No início do século XVIII, quando o Tribunal do Santo Ofício da Inquisição de Portugal investiu contra essa comunidade, $300{ }^{2}$ cristãosnovos foram presos e enviados para Lisboa para ser julgados como hereges judaizantes. Mais de 1000 foram denunciados, mas, por variadas razões, não chegaram a ser presos ${ }^{3}$.

Mais da metade dos prisioneiros eram mulheres, e a documentação deixada pela Inquisição, especialmente os processos a que foram submetidas - milhares de páginas manuscritas - é fonte riquíssima e praticamente a única em que a voz dessas mulheres pode ser escutada.

Os Inquisidores consideravam as mulheres como um dos maiores perigos para a sociedade católica, uma vez que acreditavam que o Judaísmo, a religião dos antepassados dos cristãos-novos, era transmitido às novas gerações pelo sangue, pela memória feminina e até mesmo através do leite materno.

\footnotetext{
${ }^{1}$ Doutora em História, USP.

${ }^{2}$ Lina Gorenstein Ferreira da Silva "O sangue que lhes corre nas veias."- Mulheres cristãsnovas do Rio de Janeiro. São Paulo, FFLCH-USP, Doutoramento, 1999 (mimeo), parte I, cap. II “A ação do Santo Ofício", p.73. Até o momento, as pesquisas indicam que além de 300 cristãos-novos moradores no Rio de Janeiro, foram presos também cristãos-novos naturais da cidade, porém moradores em outras localidades, como em Minas Gerais e em Portugal Se contabilizarmos esses presos, e também aqueles que foram presos no Rio de Janeiro, mas não chegaram a ser processados por terem falecido antes de serem entregues ao Tribunal em Lisboa, chegamos ao número de 167 mulheres e 158 homens, totalizando 325 cristãos-novos naturais ou moradores no Rio de Janeiro presos entre 1703 e 1740. Mas esse número não é definitivo e novas pesquisas podem indicar outros nomes. Ver Anita Novinsky Inquisição: Prisioneiros do Brasil (séculos XVI-XIX). Rio de Janeiro, Expressão e Cultura, 2002. ${ }^{3}$ Lina Gorenstein Ferreira da Silva "O Sangue que lhes corre nas veias". Op. cit., p. 73.
}

Os cristãos-novos estavam isolados do Judaísmo tradicional e imersos em um mundo cristão; sua crença sofrera alterações profundas; não tinham livros judaicos, ninguém para instruir seus filhos no hebraico, sem as tardes de sábado para o estudo e debate. O Judaísmo não era nem profundo nem ortodoxo, era uma transmissão oral de conhecimentos daqueles que melhor lembravam as tradições judaicas. Mesmo os que escolheram manter o Judaísmo, tinham que ser ao mesmo tempo católicos praticantes ${ }^{4}$.

Muitas das práticas que permaneceram eram de domínio doméstico: os hábitos alimentares, de higiene e purificação, o shabbat e as celebrações tinham todas que ser realizadas dentro das casas "a portas fechadas". O cripto-judaísmo era praticado no lar, era uma religião secreta, e era também uma religião de domínio feminino, ao contrário do Judaísmo tradicional, praticado e transmitido principalmente nas sinagogas, domínio masculino ${ }^{5}$.

O cripto-judaísmo foi um dos elementos constitutivos da identidade das marranas fluminenses, e é esse aspecto que abordarei nesta comunicação. O título desta mesa - "Uma identidade errante" - engloba não somente o sentido de movimento, de migração desses marranos, mas especialmente o fato de não haver uma só identidade, ou seja, a identidade dos cristãos-novos era composta por várias facetas e variou de acordo com a época e a região onde viviam. O fenômeno cristão-novo, como bem o mostrou nossa mestra Anita Novinsky, não foi homogêneo, nem no tempo nem no espaço.

Os cristãos-novos tinham que conhecer o Judaísmo; não o Judaísmo tradicional, não a ética, a moral, a religião e os costumes judaicos, mas o Judaísmo do Santo Ofício; quem tinha "mancha de sangue" tinha que saber o que declarar no Tribunal.

O estigma do sangue "impuro" significava discriminação, exclusão6. Houve a necessidade dos cristãos-novos de formar uma comunidade, de se integrar com os seus "iguais" comunidade que no Rio de Janeiro se baseou principalmente na endogamia (casamentos entre cristãos-novos); comunidade

\footnotetext{
${ }^{4}$ Lina Gorenstein Ferreira da Silva Heréticos e Impuros - A Inquisição e os cristãos-novos no Rio de Janeiro, século XVIII. Rio de Janeiro, Secretaria Municipal da Cultura, Departamento Geral de Documentação e Informação Cultural, Divisão de Editoração, 1995.

${ }^{5}$ Lina Gorenstein Ferreira da Silva "O sangue que lhes corre nas veias", Op. cit., parte II, cap. II "O Cripto-judaísmo".

${ }^{6}$ Ver Erving Goffman Estigma - notas sobre a manipulação da identidade deteriorada. $4^{\text {a }}$ ed., Rio de Janeiro, Ed. Guanabara, 1988
} 
formada por um duplo movimento: o interno e o externo: os cristãos-novos se uniam por vontade própria e por imposição da comunidade ampla, cristã-velha.

Esses fatores contribuíram para a formação de uma identidade particular, cristã-nova, baseada na ancestralidade e na exclusão ${ }^{7}$. Ancestralidade significava uma origem comum que não era esquecida e nem era permitido esquecer - e uma religião - praticada ou não, real ou não, mas que tinha que ser conhecida e confessada na mesa do Santo Ofício.

No Rio de Janeiro setecentista, sabia-se quem era cristão-novo e por que via o sangue judeu chegara até aquela pessoa: pela família materna ou pela família paterna. Na primeira metade do século XVII uma parcela significativa da população livre da cidade era reconhecida como cristãnova; no início do século XVIII, ao menos $25 \%$ dessa população era sabidamente cristã-nova. Cronistas contemporâneos assinalaram a presença "judaica" na região e no final do século XVII um viajante francês, Froger dizia que cerca de três quartos dos brancos do Rio de Janeiro eram judeus ${ }^{8}$.

Definir o que é um judeu e o que é identidade judaica é uma questão complexa; as categorias sociológicas convencionais, como religião, nacionalidade e grupo étnico não são suficientes; por exemplo, embora a religião tenha sido um componente importante da vida judaica, é claramente inadequado descrever os judeus simplesmente como um grupo religioso; a dificuldade em descrever os judeus como grupo se reflete na dificuldade paralela para descrever a identidade judaica 9 .

Quando falamos em identidade judaica, sabemos que está fundamentada em vários fatores, construída sem dualidades fundamentais

\footnotetext{
${ }^{7}$ Lina Gorenstein Ferreira da Silva "O sangue que lhes corre nas veias", Op. cit., parte III, cap.III "Identidade".

8 François Froger Rélation d'un voyage fait en 1695, 1696 et 1697 aux cotes dAfrique, détroit de Magellan, Brésil, Cayenne et Isles Antilles par une escadre des vasseaux du Roi, commandée par M. de Gennes faite par Sieur Froger, Inginieur volontaire sur le vaisseau le Faucan Anglois. Amsterdam, chez les héritiers d'Antoine Schelte, MDCXCIX, p.65

${ }_{9}^{9}$ David M.Gordis e Yoav Bem-Horin (ed.)jetvish Identity ia America. Los Angeles, University of Judaism, 1991, p. VII. Ver o artigo de Bruce Phillips "Sociological Analysis of Jewish Identity", pp.3-28, onde o autor faz uma revisão da bibliografia sobre a análise sociológica da identidade judaica a partir de conceitos desenvolvidos após a II Guerra Mundial.
}

durante a vida do judeu enquanto indivíduo e enquanto membro de um grupo, não foi destruída ou modificada pela discriminação.

Já o cristão-novo, de origem judaica, educado como cristão, porém excluído como "novo" e tendo que saber - e muitas vezes assumindo o cripto-judaísmo - não tinha mais a identidade judaica (não me refiro àqueles que haviam sido judeus, à primeira geração de conversos, nem a seus descendentes imediatos, cujos pais e avós haviam sido judeus).

Assim, as dificuldades para definir o que é a identidade judaica multiplicam-se quando se tenta compreender qual era a identidade dos cristãos-novos. Era uma identidade judaica? Uma identidade cristã-nova? Ou somente um ethos $^{10}$ - não tendo chegado ao estágio de internalização suficiente para construir uma identidade?

Nossas pesquisas indicam que as cristãs-novas fluminenses apresentavam uma identidade cristã-nova e não somente um ethos. Não mais a identidade judaica, mas uma identidade própria - uma vez que além do ethos - a parte externa de seu comportamento também estava internalizada a consciência de que eram cristãs-novas, não judias e nem cristãs.

Anita Novinsky afirma que os inquisidores criaram uma novo conceito de identidade, sem qualquer prática religiosa como indício de Judaísmo: caracterizavam os cristãos-novos suspeitos através do comportamento ou através da "identidade". O comportamento era a prática do cripto-judaísmo; a "identidade" não implicava nem em práticas nem em comportamentos, mas somente no fato de admitir que cria na Lei de Moisés ${ }^{11}$.

A identidade judaica pode ser considerada como uma identidade étnica condicionada por dois fatores, o religioso e o nacional (enquanto povo e não um estado). Na identidade cristã-nova, esses fatores também estão presentes; são considerados uma "nação" pelos cristãos-velhos: "nação dos cristãosnovos" e não dos judeus - e por eles próprios como uma comunidade - ou nação - que antigamente estivera conectada a outra nação - a dos judeus.

\footnotetext{
${ }^{10}$ Anita Novinsky "Juifs et nouveaux chrétiens du Portugal". In Henri Méchoulan (org.) Les juifr d'Espagne: histoire d'une diaspora, 1492-1992. Paris, Liana Levi, 1992, pp.75-107

${ }^{11}$ Anita Novinsky "Juifs et nouveaux chrétiens du Portugal". In Henri Méchoulan (org.) Les juifr d'Espagne: histoire d'une diaspora, 1492-1992. Paris, Liana Levi, 1992, pp.75-107.
} 
Izabel de Barros Silva ${ }^{12}$, cristã-nova do Rio de Janeiro, depois de presa e reconciliada pelo Santo Ofício recebeu licença para voltar ao Rio de Janeiro. Preocupava-se com sua família, especialmente com seus filhos e com seus sobrinhos, filhos de sua irmã Catarina Marques, que havia morrido em 1712, no navio em que ia presa para Lisboa. Moravam com seu tutor, o padre Matias Gonçalves, cura da freguesia de Jacarepaguá, no engenho em que haviam nascido e se criado.

Ela teve com esse padre um conflito, quando este aconselhou sua tutelada Maria da Silva a se casar com Manoel do Vale, também cristãonovo. Isabel foi contra esse casamento desejando que a dita sua sobrinha, suposto fosse da nação dos cristãos-novos, não casasse com pessoa da mesma nação pela não desencaminhar, e fez com que os sobrinhos fossem morar com ela.

Através da documentação fluminense, é possível perceber que os cristãos-novos consideravam-se como uma comunidade, uma "nação", porém, uma nação cristã-nova, e não judia, embora conectada ao Judaísmo pela ancestralidade, pela memória e pela discriminação que existia contra eles tanto na esfera oficial como entre a população cristã-velha.

Assim, quando falamos em "nação cristã-nova", em identidade cristãnova, o fator religioso não é mais a religião judaica - é a crença na Lei de Moisés para a salvação da alma; é uma religião sincrética e secreta e nem sempre é uma religião vivenciada (embora sempre admitida). Uma religião fruto da educação cristã, da memória judaica e da intolerância. Essa identidade cristã-nova muitas vezes resultou na personalidade que Anita Novinsky chamou de "homem dividido"13.

Sua crença declarada era o cripto-judaísmo, intimamente relacionado à memória judaica ${ }^{14}$. A memória judaica das mulheres fluminenses já havia

\footnotetext{
${ }^{12}$ Lina Gorenstein Ferreira da Silva "O sangue que lhes corre nas veias", Op. cit., parte II, cap. II "Tradição familiar e sociedade".

${ }_{13}$ Anita Novinsky Cristãos-novos da Bahia. São Paulo, Perspectiva, 1972.

14 Anita Novinsky "Os cristãos-novos no Brasil - um resgate histórico" Os judeus portugueses - Entre os Descobrimentos e a Diáspora. Lisboa, Fundação Caloustre Gulbekian/Associação Portuguesa de Estudos Judaicos, 1998. P.163
}

esmaecido no século XVIII. A história judaica era pouco conhecida por elas, inclusive o êxodo do Egito - pouquíssimas comemoravam Pessach ${ }^{15}$.

Um dos aspectos fundamentais do Judaísmo são as orações e para as mulheres cristãs- novas do Rio de Janeiro, entre mais de 60 processos, somente quatro mulheres confessaram conhecer algumas orações: Catarina Soares Brandoa, Izabel Gomes da Costa, Joana de Barros e sua sobrinha Ines de Oliveira; uma irmã de Ines, Izabel de Barros, declarou que rezava orações judaicas, sem no entanto, especificá-las ${ }^{16}$ e não encontrei menção ao Shemd. Eram orações já muito distanciadas das orações judaicas tradicionais, e muitas vezes, resultavam em orações que podemos considerar no mínimo, confusas.

Por exemplo, a cristã-nova Izabel Gomes da Costa havia sido ensinada na Lei de Moisés por sua avó, também chamada Izabel Gomes da Costa, quando tinha 13 anos, que lhe disse que rezasse duas orações; a primeira deveria rezar às sextas-feiras e sábados à noite ${ }^{17}$ :

Bendito, louvado, exaltado, glorificado seja o nome de Ds para sempre dos sempre jamais sem fim,

Aqui venho Senhor deitar-me aos vossos pés arrependidamente a chorar meus pecados Perdoai-me por Vosso Divino Amor, por Vossa Divina Misericórdia meus pecados, Não atendais ao rigor de minhas grandes culpas e pecados

Os peixes do mar com seus saltenhos,

As águas com os marmúrios de suas sombras,

As fontes com suas correntes,

Os animais com seus grandores,

As águas com os marmilrios de suas sombras,

As árvores com suas flores,

Assim Rei Senhor Meu

Mandai um anjo que nos de a mão

Anjos, arcanjos, querubins, cheros, dominações, potestades, gerarquias

Sois aquele Senhor que fizestes o céu, a terra e o mar, e as areas e todas as causas criadas nos santos meninos e nos santos homens, nos

\footnotetext{
${ }^{15}$ Lina Gorenstein Ferreira da Silva "O sangue que lhes corre nas veias", Op. cit., parte III, cap.II "O cripto-judaísmo".

${ }^{16}$ IAN/TT, IL, Processo de Catarina Marques, n.11.498, testemunho de Izabel de Barros.

${ }^{17}$ IAN/TT, IL, Processo de Izabel Gomes da Costa, n. 688, confissão de 14 de outubro de 1712.
} 
santos sol, nos santos lua, nos santos céu, nos santos estrelas, nos santas $p(. . \bullet)$

nos santos mar, nos santos areas, nos santa terra,

nos santos jardins dos santos lares nos santos jasmins,

raios que abrazam cielos que abraza a tocar as campainhas, a tocar las trombetas que o senhor a(...)

As primeiras frases dessa oração remetem aos Salmos de David: exaltação ao nome de Deus e um pedido de perdão pelos pecados como no Miserere; segue-se o louvor do milagre da criação, a exaltação da natureza; nas orações vespertinas, louva-se Deus como criador da noite; a natureza é louvada geralmente nas orações matutinas ${ }^{18}$. A última frase da oração - que está em espanhol - não parece pertencer a ela e devemos notar também a grafia da palavra Deus - está escrito somente D's, à maneira judaica.

A outra oração deveria ser rezada nos demais dias da semana:

Por aquela obra tão maravilhosa que fizestes olhos do vosso servo Abraão

Mandeis Rei meu um anjo lhe a mão e a sentença contra ele,

Para aquela era tão maravilhosa que fizestes olhos do vosso servo Arão,

Mandai Senhor um anjo dar-lhe dar a mão e a sentença contra ele;

E com as mesmas palavras nomeava Elias, Moisés, Adão, Labão,

Ozias, Abacut, Absalão, David, Sansão, Faraó, Judá, Benjamim,

Esaii, Abel, Caim, Josué, Jacob, Noé, Daniel, Job, Jonatas, Salomão,

Amão, Elizeu, Lot

Mandai Senhor vosso servo Noé e vosso servo Eliseu

tirar da irada Bibolina de Jerusalem,

Assim mandais Senhor um anjo lhe dar a mão e a sentença contra ele

Nessa oração, que vem sem a indicação de a que horas deveria ser rezada - talvez à noite, como a anterior - há a referência explícita ao episódio bíblico do sacrifício de Isaac, que era um assunto popular entre os cristãos-novos $^{19}$. Segue-se um apelo para que Deus envie um anjo e uma

\footnotetext{
${ }^{18}$ David Giglitz Secrecy and Deceit - The Religion of the Crypto-Jews. Philadelphia and Jerusalem, The Jewish Publication Society, 1996, p.446-448

${ }^{19}$ Elvira Cunha de Azevedo Mea "Orações judaicas na Inquisição portuguesa- século XVI" in Yosef Kaplan Jews and Conversos - Studies in Society and the Inquisition. Jerusalém, The Magnes Press, The Hebrew University, 1985., p.163 e Samuel Schwartz Os cristãosnovos em Portugal no século XX. Lisboa, Universidade Nova de Lisboa, Instituto de Sociologia e Etnologia das Religiões, 1993 (fac-similado da edição de 1923)., p37.
}

enxurrada de nomes de personagens bíblicos: vinte e cinco. Em algumas orações de cristãos-novos foram identificados personagens bíblicos; Schwartz apresenta orações em que eles aparecem, às vezes três ou quatro, porém sempre dentro do contexto de uma história da Bíblia ${ }^{20}$, nem sempre a história está de acordo com a Bíblia, mas sempre tem uma lógica.

Na oração de Izabel Gomes não há nem história, nem lógica. Entre os personagens que louva, dois vilões da história judaica: o Faraó (da história de Moisés) e Amão (da história de Ester), o que mostra a enorme confusão que ela fazia, identificando sua ignorância da história judaica. Entretanto, não era a única que desconhecia a história bíblica; Giglitz indica que Amão fora considerado algumas vezes como um santo por cristãos-novos ${ }^{21}$.

Izabel havia sido ensinada pela avó, Izabel Gomes da Costa; que era filha de Beatriz da Costa, irmã de Izabel Mendes, a primeira e única moradora do Rio de Janeiro a ser presa no século XVIII, convicta criptojudia e conhecedora da religião, da história judaica e que declarou inclusive saber hebraico. Assim, em três gerações, todo o conhecimento de história judaica, toda crítica ao cristianismo presente na antepassada desapareceram. $\mathrm{O}$ fato de ser uma das poucas cristãs-novas a conhecer orações criptojudaicas - ainda que certamente muito modificadas - revela que nessa família a memória judaica continuava presente.

Para as cristãs-novas fluminenses acredito que se possa considerar a memória judaica como pertencente a uma comunidade - e não somente aos núcleos familiares; há uma uniformidade em suas declarações que indicam um denominador comum; a memória judaica, parte constitutiva de sua identidade, também uma identidade híbrida e uma identidade "dividida", capturada entre dois mundos.

Estavam assimiladas à sociedade fluminense; eram senhoras de engenhos, donas de partido de cana, proprietárias de escravos, casadas com médicos, advogados, mercadores e homens de negócios.

Realizavam negócios com cristãos-velhos, comprando, vendendo, cuidando da manutenção de suas propriedades.

\footnotetext{
${ }^{20}$ Samuel Schwartz, p.85, p.117 e p.119.

${ }^{21}$ David Giglitz, Op. cit., p.356.
} 
Relacionavam-se com seus vizinhos cristãos-velhos, que sabiam de seus movimentos e de suas vidas. Um familiar do Santo Ofício, vizinho de Catarina Gomes Pereira, declarou que sabia que a dita mulher era muito retirada no governo de sua casa, não visitando nem sendo visitada ${ }^{22}$.

Muitos cristãos-velhos conheciam as mulheres presas desde a infância, sendo vizinhos e amigos de seus pais e maridos; declararam ter com as presas muita comunicação.

Eram externamente boas católicas, iam as igrejas, davam esmolas, e faziam todas as obras de boas cristãs.

Os cristãos-velhos sabiam perfeitamente qual a origem das pessoas: quem era ou não cristão-novo e por que via - se havia ou não rumor ou fama de cristão-novo nas famílias e até mesmo se algum parente já havia sido reconciliado pelo Santo Ofício ${ }^{23}$. Mantinham relações de compadrio com cristãos-velhos; batizavam seus filhos, e eram batizadas por eles; cristãosvelhos de destaque na sociedade colonial eram padrinhos de cristãs-novas.

Casavam-se também com cristãos-velhos; cerca de 36\% das mulheres cristãs-novas eram casadas com cristãos-velhos; a documentação examinada até o momento indica que as mulheres se casavam fora da comunidade cristãnova mais do que os homens cristãos- velhos, diversamente do que acontecera na Bahia, onde mais homens cristãos-novos casaram-se com mulheres cristãs-velhas ${ }^{24}$.

Assimiladas à sociedade colonial, porém não integradas ${ }^{25}$. As cristãsnovas que foram denunciadas, mas não chegaram a ser presas, especialmente as que eram casadas com cristãos-velhos, ou os filhos de casamentos com cristãos-velhos, assimilaram-se mais rapidamente e

\footnotetext{
${ }^{22}$ IAN/TT, IL, Processo de Catarina Gomes Pereira, n. 11.084., Inquirição do Rio de Janeiro. ${ }^{23}$ Por exemplo, sabiam que a irmã de Ines Ayres, Beatriz Ayres, moradora em São Paulo, havia sido reconciliada pelo Santo Ofício, assim como parentes de Francisco de Siqueira Machado.

${ }_{25}^{24}$ Anita Novinsky Cristãos-novos na Bahia, Op. cit.

${ }^{25}$ Nesse trabalho, utilizo "assimilação" enquanto tornar-se semelhante; ou seja, as cristãsnovas "assemelhavam-se" aos cristãos-velhos no comportamento, nas atitudes, na ligação estreita com a cultura ibérica, na mentalidade. "Integração" seria assim o "tornar-se inteiro", integralizar - o que realmente aconteceu somente com o fim da distinção entre cristãosnovos e velhos. Ver Norbert Elias O processo civilizador - uma história dos costumes. Rio de Janeiro, Zahar, 1990, parte I, especialmente os conceitos de civilização, kultiviert e kultur
}

atingiram a integração também mais rapidamente quando esta foi possível com o final da distinção entre cristãos-novos e cristãos-velhos.

A documentação do Rio de Janeiro indica que a transmissão da memória judaica não era tarefa exclusiva das mulheres, e os casamentos de homens com cristãs-velhas não foram em número expressivo $\mathrm{O}$ sincretismo era parte integrante da religião confessada por todos os cristãos-novos da colônia (como indicam as pesquisas realizadas até o momento).

As cristãs-novas fluminenses viviam divididas entre o cristianismo e o judaísmo; porém, sem contato com judeus - não sabiam que os judeus as considerariam como cristãs e consideravam-se cristãs - embora novas.

A identidade cristã-nova não dependia do cripto-judaísmo vivenciado; todas as cristãs-novas do Rio de Janeiro confessaram a crença na Lei de Moisés para salvação de suas almas, e conheciam algumas práticas e cerimônias. Poucas revelaram um conhecimento maior.

Todas tinham uma identidade cristã-nova fundada em uma memória judaica; e todas elas viviam entre dois mundos: o católico e o judaico.

Com o correr do tempo, desenvolveram uma identidade própria, forjada em grande parte pelos fatores que fizeram com que sobrevivessem como grupo: a "pureza de sangue", que manteve a discriminação contra os cristãos-novos e a perseguição do Santo Ofício, tornando essencial a continuidade de um judaísmo, considerado enquanto crença e práticas religiosas, e, certamente, um judaísmo bastante distanciado do ortodoxo. 
"Gente da Nação": os judaizantes e a preservação do judaísmo no Brasil

\section{João Henrique dos Santos ${ }^{1}$}

Por todos os lugares onde se instalaram, os portugueses 'de nação' tiveram sempre o cuidado de vincar bem a sua separação em relação aos judeus de outras origens - os que não provinham da Península Ibérica. Necessariamente associados aos espanhóis, muitas vezes confundindo-se com eles, dadas as relações familiares, culturais, bisaricas e de vizinhança, que existiam entre uns e outros, mantiveram uma conveniente distância quanto aos alemães e polacos. Alguns chegaram a acrescentar ao nome as iniciais S. T, de 'Sefarad Tahor', 'Sefardim Puro”. (António Carlos Carvalho)

\section{Introdução}

A conversões massivas de judeus ao cristianismo desde o século IX da A era cristã, embora condenadas e declaradas sem valor em bulas papais, ocorria com bastante frequência, sobretudo na Europa Ocidental e particularmente na Península Ibérica após o processo da Reconquista aos mouros ${ }^{2}$. Tais conversões eram sempre acompanhadas de legislação antijudaica que recrudescia sempre mais. Tudo isso levou os judeus a desenvolverem mecanismos de preservação de identidade, ritual e culto que lhes permitissem a um tempo sobreviver fisicamente, enquanto asseguravam a continuidade do judaísmo, desde os tempos da dominação visigótica na Espanha ${ }^{345}$

\footnotetext{
${ }^{1}$ Professor da Universidade Gama Filho (RJ).

2 ALCALA, A. - Tres cuestiones en busca de respuesta: invalidez del bautismo "forzado", "conversión" de judias, trato "cristiano" al converso, in Judíos, Sefarditas, Conversos - la expulsión de 1492 y sus consecuencias, Ángel Alcalá (ed.), Ed. Âmbito, pp. 523-544, Madri, 1995.

3 TAVARES, M. J. E - Os judeus em Portugal no Século XIV, Ed. Guimarães, 2000, Lisboa.

${ }^{4}$ GITLITZ, D.M. - Secrecy and Deceit - the Religion of the Crypto-Jews, Jewish Publication Society, Philadelphia, 1996

${ }^{5}$ MORENO, L. G. A. - Los judíos de la Espolia antigua. Ed. Rialp, Madri, 1993.
}

O edito espanhol de 31 de agosto de 1492, determinando a imediata expulsão dos judeus do território espanhol, e o edito português de 5 de dezembro de 1496, dando prazo de um ano para a conversão dos judeus ou sua expulsão do Reino, seguido do batismo forçado de toda a população judaica que ainda não havia conseguido sair de Portugal, o dito "batismo em pé”, em 1497, foram o ápice das medidas que visavam a exterminar não os judeus, mas o judaísmo, como recorda o Prof. Yitzhak Baer, em sua obra "Historia de los judio en la Esparza cristiana" 6789 . As conversões forçadas em Portugal e, particularmente, o citado episódio do batismo em pé, fez com que, a partir de então, surgissem aqueles que passaram a ser conhecidos como cristãos-novos, em contraposição àqueles que descendiam de famílias que sempre foram católicas, os "crist iosvelhos". Sobre os cristãos-novos vigiava a Inquisição, instituída em Portugal em $1536{ }^{10} 11121314$.

\section{A descoberta da América e do Brasil e o cripto-judaísmo na América}

A descoberta da América em 1492 pode ter significado esperança de estabelecimento em terras mais seguras para aqueles que secretamente permaneciam fiéis ao judaísmo na Espanha, no que se refere à presença da Inquisição ${ }^{15}{ }^{16}$

A situação dos cristãos-novos portugueses foi diversa, pois foram autorizados pelas ordenações manuelinas a se estabelecer no Brasil desde 1502, antes, portanto, do estabelecimento da Inquisição em Portugal, sendo

\footnotetext{
${ }^{6}$ BAER, Y. - Historia de los judios en ia España cristiana. Riopiedras, Madri, 2001

${ }^{7} \mathrm{ROTH}, \mathrm{N}$. - Conversos, Inquisition and the expulsion of the Jews from Spain. University of Wisconsin Press, 1995.

${ }^{8}$ NOVINSKY, A. e D. Kuperman (orgs.) - Ibéria Judaica: Roteiros da Memória. Edusp, São Paulo, 1996.

${ }^{9}$ ALTABE, D. E - Spanish and Portuguese Jewry before and after 1492. Sepher-Hermon, N. York, 1992.

${ }^{10}$ LIPINER, E. - Os baptizados em pé, Ed. Vega, Lisboa, 1998

${ }^{11}$ AZEVEDO, J.L. História dos cristãos-novos em Portugal. Clássica, Lisboa, 1989.

${ }^{12}$ LIPINER, E. - O tempo dos judeus segundo as Ordenações do Reino. Nobel, S. Paulo, 1982

${ }^{13}$ BODIAN, M. - Hebrews of the Portuguese Nation, Indiana University Press, Indiana, 1997.

${ }^{14}$ KAYSERLING, M. - História dos judeus em Portugal. Pioneira, S. Paulo, 1971.

${ }^{15}$ KATZ I.J. \& M.M. Sereis (ed.) - Studies on the history of Portuguese Jews from their expulsion in 1497 through their dispersion. Sepher-Hermon, N.York, 1996.

${ }^{16}$ COELHO, A. B. - Cristãos-Novos Judeus e os Novos Argonautas. Ed. Caminho, Lisboa, 1998
} 
constantemente incentivados pela Coroa a empreender mais negócios na Colônia recém-descoberta ${ }^{17} 18$.

Os primeiros relatos europeus sobre cripto-judeus americanos são, segundo Lewin ${ }^{20}$, os de Daniel Levi de Barrios (Miguel de Barrios) e de Menasseh ben Israel (Manoel Dias Soeiro). Este, em sua obra "Esperança de Israel”, tentou desenvolver uma teoria messiânica americanista, segundo a qual os ameríndios tinham contato com comunidades cripto-judias ocultas na América no século XVII. Ben Israel tenta sustentar essa afirmação mesclando uma profecia de Moisés com o apócrifo IV livro de Esdras, que se refere às "dez tribos perdidas que Salamanasar levou cativas no tempo do rei Oséias”. Assim ele via convergências entre a lei judaica e leis e costumes dos ameríndios, concluindo ele que estes aprenderam-nas dos judeus quando com eles conviviam. Ben Israel cita dois cronistas célebres da época, Alonso de Ercilla e Garcilaso de la Vega para corroborar a ideia de que os ameríndios estariam em contato com comunidades cripto-judaicas.

\section{As denominações dadas aos judeus}

Havia desde o século XVI uma concreta preocupação, por parte das autoridades inquisitoriais, com atividades dos judaizantes no Brasil. À guisa de esclarecimento, no presente trabalho, as definições de converso e de judaizante são as mesmas empregadas pelo Professor Jaime Contreras ${ }^{21}$, da Universidade de Alcalá de Henares, que é corroborada por Lipiner ${ }^{22}$ : "judaizante faz referência a uma realidade - e a um problema - totalmente diferente de judeu. Judaizante era aquele cristão convertido do judaísmo que, no segredo de sua vida individual ou familiar, resistia a aderir à sua nova religião e a abandonar os preceitos da antiga. Do ponto de vista da Igreja era onde se localizava 'a heresia' de apostasia que irremediavelmente se haveria de extirpar. (...) Conversos, em princípio são aqueles convertidos do judaísmo

\footnotetext{
${ }^{17}$ BOXER, C. - A Igreja e a expansão ibérica (1440-1770). Edições 70, Lisboa, 1981.

${ }^{18}$ COELHO, A. B. - Clérigos, mercadores, "judeus" e fidalgos. Ed. Caminho, Lisboa, 1994.

${ }^{19}$ WIZNITZER, A. - Os judeus no Brasil colonial. Pioneira, S. Paulo, 1966.

${ }^{20}$ LEWIN, B. - Los cripto-judíos - un fenómeno religioso y social, Ed. Milá, Buenos Aires, 1987.

${ }^{21}$ CONTRERAS J. -Judíos, judaizantes y conversos en la península ibérica en los tiempos

de la expulsión, in Judíos, Sefarditas, Conversos - la expulsión de 1492 y sus consecuencias,

Ángel Alcalá (ed.), Ed. Ambito, pp. 457-477, Madri, 1995.

${ }^{22}$ LIPINER, E. - Os baptizados em pé, Ed. Vega, Lisboa, 1998.
}

que, com maior ou menor dificuldade, apostaram em viver na sociedade majoritária dos cristãos, ainda que estes nem sempre tolerassem essa aposta".

Nas palavras da Professora Maria Ángeles Fernández Garcia ${ }^{23}$, da Universidade de Granada, "para os inquisidores e para toda a sociedade cristã-velha os conversos seguem sendo os judeus de sempre. Nem todos os conversos são acusados de judaizar, mas o simples fato de sua origem é suficiente para fazê-los suspeitos de sua adesão à religião mosaica".

Faz-se necessário recordar que, por força dos editos expulsórios, formal e oficialmente não havia mais judeus na Espanha e em suas colônias desde 1492 e, desde 1497, em Portugal continental e ultramarino. Assim, a Inquisição não tinha jurisdição sobre judeus mas somente sobre os batizados que praticassem religião diversa da católica romana. $\mathrm{O}$ simples fato de ser de "casta de judeus", "casta de conversos" ou "gente da nação" constituía, ainda segundo Garcia, a acusação mais grave perante a Inquisição ${ }^{24} 25$.

O Padre Antonio Vieira testemunhou que "Judeu" e "Português" eram sinônimos na Europa, embora a denominação de "gente da nação portuguesa" tenha sido dada inicialmente pela municipalidade de Antuérpia, em 1511, aos mercadores portugueses lá residentes. Os próprios judeus portugueses assim se chamavam com as variantes de "os da nação", "homens de nação", "nação judaica portuguesa", "mercadores de nação portuguesa". Preferiam usar tais denominações a Judeus, Sefardim ou Portugueses, nomes que lhes eram dados pelos outros povos ${ }^{26}$.

\section{A ação inquisitorial no Brasil}

A preocupação inquisitorial refletiu-se em uma série de medidas antijudaicas adotadas entre 1570 e 1630 e nas visitações do Santo Ofício na Bahia e Pernambuco (1591-5), Olinda (1599) e Salvador (1610). Não obstante o expressivo percentual de cristãos-novos no Brasil, o foco dos

${ }^{23}$ GARCÍA, M. A. F. - Criterios inquisitoriales para detectar ai marrano: los cripto-judíos en Andalucía en el siglo XVI, in Judíos, Sefarditas, Conversos - la expulsión de 1492 y sus consecuencias, Ángel Alcalá (ed.), Ed. Ambito, pp. 478-504, Madri, 1995.

${ }^{24}$ BETHENCOURT, F. - História das Inquisições: Portugal, Espanha e Itália. Cia. das Letras, Rio de Janeiro, 2000.

${ }^{25}$ MENDONÇA, J. L. e A. J. Moreira - História dos principais actos e procedimentos da Inquisição em Portugal. Casa da Moeda, Lisboa, 1980

${ }^{26}$ CARVALHO, A. C. - Os judeus do desterro de Portugal. Quetzal Editores, Lisboa, 1999 
visitadores era centrado na sodomia e blasfêmia ${ }^{27} 2829{ }^{30}$. Nesse período somente $21 \%$ das denunciações foram por judaizar (201 de 950), das quais resultaram 8,2\% das condenações (40 em 486), segundo Gitlitz ${ }^{31}$ e $\mathrm{Novinsky}^{32}$.O que se extrai desses números é que as condenações por acusações outras que não judaizar atingiram $65 \%$ dos denunciados, ao passo que as condenações por judaizar não ultrapassaram $19 \%$.

Essas visitações foram um marco divisor nas relações entre as populações cristãs nova e velha, que até então conviviam harmonicamente, sobretudo no Nordeste. A partir delas, a população cristão-velha passou a observar atentamente, com fins denunciatórios, os "ajudengados", a "gente da nação", e estes, por sua vez, passaram a redobrar os cuidados na transmissão dos usos, ritos e costumes judaicos 334353637 .

Um breve hiato nesses cuidados ocorreu durante a ocupação holandesa em Pernambuco, durante um quarto do século XVII, de 1630 a 1654, quando a liberdade trazida pelos holandeses permitiu que os primeiros judeus chegassem ao Brasil como judeus (e não mais como cristãos-novos) e tivessem total liberdade religiosa e civil, podendo ascender aos cargos da administração pública, o que lhes era vedado pela legislação portuguesa de pureza de sangue 383941 . Deve ser recordado que nessa época fundaram-se

${ }^{27}$ VAINFAS, R. - Trópico dos pecados. Campus, Rio de Janeiro, 1989.

${ }^{28}$ PIERONI, G. - Os excluídos do Reino. UnB, Brasília, 2000.

${ }^{29}$ PIERONI, G. - Vadios e Ciganos, Heréticos e Bruxas. Bertrand Brasil e Biblioteca Nacional, Rio de Janeiro, 2000.

${ }^{30}$ NOVINSKY, A. e M. L. T. Carneiro (orgs.) - Inquisição: Ensaios sobre mentalidade, heresias e arte. Edusp, S. Paulo, 1987.

${ }^{31}$ GITIITZ, Op. cit.

${ }^{32}$ NOVINSKY, A. - Inquisição: rol dos culpados. Expressão e Cultura, Rio de Janeiro, 1992.

${ }^{33}$ NOVINSKY, A. - Cristãos novos na Bahia. Perspectiva, S. Paulo, 1992

34 RIBEMBOIM, J. A.- Senhores de Engenho - Judeus em Pernambuco Colonial 15421654. 20-20 Comunicação e Editora, Recife, 1998.

MELLO, E. C. - O nome e o sangue. Topbooks, Rio de Janeiro, 2000

${ }^{36}$ MELLO, J. A. G. - Gente da Nação. Massangana, Recife, 1996.

${ }^{37}$ LIPINER, E. - Os judaizames nas capitanias de cima, Ed. Nobel, S. Paulo, 1969.

${ }^{38}$ KAUFMAN, T. N. - Passos perdidos, história recuperada - A presença judaica em Pernambuco. Ed. Bagaço, Recife, 2000.

${ }^{39}$ HERKENHOFF, P. (org.) - O Brasil e os Holandeses 1630-1654. Sextante Artes, Rio de Janeiro, 1999.

${ }^{40}$ MELLO, E. C. - Olinda restaurada. Topbooks, Rio de Janeiro, 1998.

${ }^{41}$ LIPINER, E. - Op. cit. O tempo dos judeus.. as duas primeiras sinagogas das Américas, Kahal Tzur Yisrael (a Rocha de Israel) e Magen Avraham (o Escudo de Abraão). O primeiro rabino das Américas, Isaac Aboab da Fonseca, que liderou espiritualmente a Tzur Yisrael, mereceria, por si só, um destaque à parte, pois após sua saída do Brasil teria estado pelas Antilhas e em Nova Amsterdã e, de volta à Holanda, em 1666, encabeçou o movimento sabataísta em Amsterdã, seguindo o falso messias de Esmirna, Sabbetai Tzvi ${ }^{42}$.

\section{Alguns usos dos judaizantes no Brasil}

Ao nome cristão, dado no batismo, era acrescido um segundo nome judaico, usualmente durante a brit mild, quando esta podia ser realizada. Ainda que a época preferida para a circuncisão fosse, como determina a lei judaica, o oitavo dia após o nascimento do filho, se não houvesse possibilidade de esta se realizar então, haveria outras oportunidades posteriores de fazê-lo, cabendo ressaltar, contudo, que muitos não o fizeram, visto ser esta um sinal indelével de adesão ao judaísmo, merecendo, portanto, especial interesse da parte dos inquisidores e "familiares" (oficiais do Santo Ofício; meirinhos) da Inquisição.

Podemos citar como exemplo de nomes mudados (ou de duplicidade ou até triplicidade de nome) entre os cristãos-novos portugueses e brasileiros os casos de Abraão Gatel, que adotou o nome de Jerónimo Henriques; Isaac Latam, chamado Lourenço Vaz; Salomão Aben (ou Ben) Haim, chamado Luís Álvares. Isaac de Castro Tartas chamou-se também Thomas Luiz, Izaque Meató e Joseph de Lis; enquanto que David Franco era conhecido por Simon Dietrichsen entre os negociantes de Hamburgo, mas quando negociava com espanhóis era conhecido como Simon Rodriguez ou Simon Ruiz de Málaga $^{43}$. Exemplifica bem o caso do nome judaico sobreposto ao nome cristão o caso de Miguel Henriques, queimado em vida no auto-de-fé de 10 de maio de 1652 em Lisboa, que, durante seu processo disse ter recebido o nome de Mizael, devendo só por esse nome ser chamado a partir de então, tendo mesmo assinado seu processo como $\mathrm{Mizael}^{44}$. O já citado Menasseh ben Israel tinha o nome cristão de Manoel Dias Soeiro.

\footnotetext{
${ }^{42}$ CARVALHO, A. C. - Op. cit.

${ }^{43}$ Idem ibidem.

${ }^{44}$ LIPINER, E. - Op. cit. - Terror e Linguagem etc.
} 
Razões de segurança poderiam obrigar a família a não realizar a circuncisão no oitavo dia após o nascimento do varão, uma vez que se fossem cristãos novos estariam certamente sob a vigilância leiga ou eclesiástica particularmente naquele dia, e realizar o preceito seria a confissão tácita da adesão ao judaísmo.

Também a tevild, a lavagem de purificação ritual de pessoas e objetos, era conduzida sob a máxima discrição, sendo disfarçada quando possível, o que incluía o processo da tahard (purificação ritual) após o falecimento de algum judeu.

Era através da educação que se mantinha acesa a chama do judaísmo. A educação tem um papel central no judaísmo, sendo, segundo a lei judaica, um comando divino. No recesso do lar, as crianças e jovens eram ensinadas a observar preceitos e práticas judaicas sem que, muitas das vezes, lhes fosse explicada a razão da observância e, principalmente, sem que a relacionassem ao judaísmo.

Existe uma coletânea de hábitos dos cristãos-novos no Nordeste do Brasil, recolhida por Luís da Câmara Cascudo ${ }^{45}$ e outros folcloristas e que já foi objeto de comunicação anterior ${ }^{46}$, dentre as quais podem ser destacados cobrir com terra o sangue vertido de animais abatidos; verter fora a água dos vasilhames das casas onde houvesse morrido alguém, até que se desse o sepultamento; nunca apontar as estrelas; não varrer o lixo passando-o com a vassoura pelos umbrais da porta. Também se ensinava a evitar os reimosos (alimentos impuros ou combinações impuras de alimentos segundo a lei judaica).

Estes costumes eram derivados de preceitos bíblicos (como, p.ex., cobrir com terra o sangue de animais abatidos e observar as regras dietéticas judaicas) ou derivadas de midrashim (histórias baseadas na Bíblia judaica), como o hábito de verter a água de todas as vasilhas da casa onde houvesse um morto, pois se dizia "que o Anjo da Morte visitou aquela casa e lavou o sangue de sua espada nas vasilhas de água que encontrou".

As explicações agregadas eram vinculadas à superstição, como por exemplo ensinar que apontar as estrelas faria nascer verrugas nos dedos de

\footnotetext{
${ }^{45}$ CASCUDO, L. C. - Mouros, franceses e judeus, Ed. Perspectiva, S. Paulo, 1984.

${ }^{46}$ SANTOS, J. H. - Da preservação da identidade judaica pelas festas e pela oralidade. II
} Encontro Brasileiro de Estudos Judaicos, UERJ, Rio de Janeiro, 1999. quem o fizesse, e foram assimiladas e incorporadas aos usos e costumes da população cristão-velha, sendo muitos desses hábitos até hoje preservados no interior do Brasil ${ }^{47}$. Recorde-se que o dia judaico se inicia ao despontar das primeiras estrelas em sua véspera, sendo assim comum o hábito de judeus apontarem as estrelas para saber se o shabat ou qualquer outro dia de festa ou preceito já havia se iniciado/acabado.

\section{Conclusão}

Tal como o protagonista de "Le bourgeois gentilhomme", de Molière, que descobriu que falara toda a sua vida em prosa sem o saber, também muitos cristãos-velhos praticaram e praticam atos e ritos judaicos sem saber da origem de tais práticas e sem que eles próprios tenham tido qualquer ligação com o judaísmo.

A dimensão dos judaizantes vai muito mais além daquilo a que lhes reduziu a tacanha mentalidade inquisitorial. Seus hábitos e costumes se enraizaram de tal forma no Brasil que foram parcialmente absorvidos pela majoritária população cristã velha brasileira.

Este autor não consegue imaginar que judaísmo poderia haver no Brasil (e também, mutatis mutandis, nas colônias espanholas na América) sem o trabalho de resistência, na maior parte das vezes subversivo, dos judaizantes que, com o risco da própria vida, sob a capa de bons cristãos, perseveravam na prática judaica e na preservação da identidade judaica ${ }^{48}$.

Talvez aos judaizantes possa ser aplicada a passagem do Livro do Apocalipse:

Estes que estão trajados com vestes brancas, quem são e de onde vieram? (...) Estes são os que vieram da grande tribulação.(Apocalipse 7:13-14)

\footnotetext{
${ }^{47}$ CASCUDO, L. C. - Dicionário do folclore brasileiro, Ediouro, Rio de Janeiro, 1977.

${ }^{48}$ NOVINSKY, A. - Consideraciones sobre los cripto-judios hispano-portugueses: el caso de Brasil, in Judíos, Sefarditas, Conversos- la expulsión de 1492 y sus consecuencias, Ángel Alcalá (ed.), Ed. Ambito, pp. 513-522 Madri, 1995.
} 


\section{Comunidades judaizantes em Minas Gerais}

Neusa Fernandes ${ }^{1}$

A

mais variada documentação indica a imigração judaica para Minas como um movimento pioneiro em terras completamente desconhecidas.

O cristão-novo Fernão Dias foi o primeiro desbravador e fundador de Minas Gerais. Paulista rico, Fernão Dias foi encarregado pelo rei D. João IV, em 1674, de organizar expedições que fossem buscar as riquezas minerais. Seu filho, Garcia Rodrigues Paes, cristão-novo pela via materna, abriu as picadas do chamado "Caminho Novo", que se tornaria a Estrada Real.

Antonio Rodrigues Arzão foi o primeiro bandeirante a achar ouro nas Gerais. Era cristão-novo. Também o era Luis do Couto, cortador de baleia, na Bahia, que se mudou para Minas, logo no início do povoamento.

Primeiros povoadores foram, também, os cristãos-novos Francisco de Lucena Montarroyos, que se assentou em terras do sítio Nossa Senhora do Carmo, e Duarte Nunes, que, em 1694, descobriu ouro em Itaverava.

Vários dos conhecidos bandeirantes e entradistas do ouro e pedras preciosas eram cristãos-novos, como Manuel da Borba Gato, Bartolomeu Bueno da Silva (pai e filho), Sebastião de Barros e Antonio Raposo Tavares.

Da mesma origem de judeus, Manuel Nunes Vianna veio para Minas, onde se dedicou à pecuária e ao comércio de ouro e de escravos.

Filho de Antônio Nunes Viegas, Manuel Nunes Vianna veio para o Brasil ainda jovem, fixando-se na Bahia, nos fins do século XVII. Nascido em Vianna do Minho, Portugal, morreu na Bahia, em 1738, deixando o filho Miguel Nunes de Souza Vianna como seu herdeiro.

Contemplado com sesmaria às margens do Rio São Francisco, nela desenvolveu a criação de gado. Pouco tempo depois, já era proprietário de fazenda em Cachoeira ${ }^{2}$ e de várias outras que fundou no caminho da Bahia

\footnotetext{
${ }^{1}$ Historiadora.

${ }^{2}$ Campos de Cachoeira era a principal cidade do Recôncavo baiano.
}

para Minas Gerais. Trabalhou também com escravos e com o ouro, adquirindo nome e fortuna.

Amealhou grandes rebanhos, por sua própria conta e como administrador das propriedades de D. Isabel Maria Guedes de Brito - uma das maiores latifundiárias do Brasil, filha de Antônio Guedes de Brito.

Negociava o gado, sediado na fazenda Jequitahi, de sua propriedade, em sociedade com o seu primo Manoel Roiz Soares. Comandando várias propriedades rurais, acabou por monopolizar o comércio de carne para Minas ${ }^{3}$.

Trabalhou também com escravos e com ouro, adquirindo nome e fortuna, explorando minas de ouro em Caete e Catas Altas, em sociedade com o primo Manoel Rodrigues Soares.

Aliou-se a outros contrabandistas e protegeu todos os que se dedicavam a mesma atividade, utilizando-se da estrada proibida a caminho de Salvador.

Manuel Nunes Vianna liderou os emboabas, na luta pela posse das minas de ouro. Por esse fato, ficou conhecido como o "Rei dos Emboabas", tendo sido o primeiro governante "aclamado em toda a América".

Como ditador nas minas, Manuel Nunes Vianna foi ferido em Cachoeira do Campo e derrotou os paulistas em Sabará. Dividiram-se as opiniões, quanto ao tratamento destinado aos muitos prisioneiros feitos. Nunes preferiu libertá-los. Os libertados juntaram- se aos fugitivos, concentrados na região do Rio das Mortes, assim chamada desde 1700 . Neste local, junto ao afluente Rio Grande, num capão de mato, ocorreu o encontro de forças que dizimou milhares de paulistas. O lugar ficou conhecido como Capão da Traição, depois Arraial de Motozinhos, hoje denominado Chagas Dória, subúrbio de São João Del Rei.

Outras revoltas foram chefiadas por Manuel Nunes Vianna: na Barra do Rio das Velhas (1718) e em Catas Altas (1719). O próprio ouvidor do Rio das Velhas comentou as insurreições, em carta dirigida ao ouvidor a Raphael Roiz Pardinho, ouvidor da comarca de São Paulo:

${ }^{3}$ In: FERNANDES, Neusa. A Inquisição em Minas Gerais no século XVIII. Rio de Janeiro: EDUERJ, 2000, p. 89. 
(...) no que toca aos cabeças do motim supponho v.m.q. o principal delles hé Mel Nunes Vianna (...) o famoso (...) bem conhecido pellos seos levantamentos e pellas suas insolencias veyo a este Pais (... $)^{4}$.

Como governador, nomeou secretário o carmelita frei Simão da Santa Tereza e teve por mestre de campo Antônio Francisco da Silva. Pela força, impediu o governador D. Fernando de Lencastro Martins Mascarenhas de entrar em Ouro Preto.

Temeroso das consequências, enviou Nunes Vianna para Lisboa, o seu amigo Frei Francisco de Menezes, levando de presente a El-Rei uma arroba e sete marcos de ouro, representando o quinto que arrecadara e incumbido de apresentar a Sua Majestade os protestos da mais profunda obediência e lealdade e de obter dele um indulto geral em favor dos revoltosos 5 .

Manuel Nunes Vianna foi também conhecido organizador de comboios. Aproveitava a estação das secas e partia com seus vizinhos e seus escravos, levando armas, redes e "peças africanas" para vender. Transportava suas carregações e mercadorias, utilizando os caminhos legais, e passava nos postos oficiais, denominados Registros, pagando o imposto cobrado e submetendo-se à inspeção da Alfândega. Seu nome consta de uma anotação no Registro, nos anos de 1716 e 1717. A única que faz sua descrição física e traz a sua assinatura de próprio punho:

Passa Manuel Nunes Vianna, homem de mediana estatura, cara redonda, olhos pardos, cabelo preto, com sua carregação que consta de vinte e três caras de molhados. Rio Grande, 14 de maio de 1717.

Com essas atividades e o contrabando, Manuel Nunes Vianna adquiriu nome e a amizade do secretário particular do governador Artur de Sá - José Rebelo Perdigão - que o nomeou para superintendente das Minas do Ribeirão do Carmo ${ }^{6}$.

O novo governador Antônio Albuquerque Coelho de Carvalho, sucessor de D. Fernando, foi a Minas, logo depois da posse. Sabedor de sua chegada, Manuel Nunes Vianna enviou, como seu procurador, o carmelita

${ }^{4}$ In: "Cartas para Raphael Roiz Pardinho ouvidor da comarca de São Paulo para ouvidor do Rio das Velhas". Motins promovidos por Manuel Nunes Vianna no sertão do Rio das Velhas. In: Revista do Arquivo público Mineiro, ano 5, pp. 213 e 217, 1718

${ }^{5}$ MENEZES, Furtado. Clero Mineiro (1.553-1889). Rio de Janeiro: Americana, 1933, p. 148.

${ }^{6}$ Hoje, cidade de Mariana. frei Miguel Ribeiro, que foi secretário de Albuquerque, para apresentar a homenagem e a obediência dos moradores de Minas.

Outros fatos demonstraram o relacionamento ambíguo de Manuel Nunes Vianna com Portugal. Em 1715, Manuel Nunes Vianna foi acusado de agitador e de contrabandear muitas arrobas de ouro, juntamente com o seu primo Manuel Rodrigues Soares. Entretanto, o ouvidor Luis Botelho de Queirós, associado ao negócio, defendeu-os e conseguiu livrá-los das acusações ${ }^{7}$.

Com medo da Inquisição, nessa ocasião, sua meia-irmã, Joana, parda, casada com um carpinteiro cristão-novo, na Bahia, fugiu com o marido para o Sítio Nossa Senhora da Penha, de propriedade do cristão-novo Miguel de Mendonça Valladolid ${ }^{8}$, amigo pessoal de Manuel Nunes Vianna.

Apesar de ter sido expulso da Capitania, por exercer o poder, desautorando e modificando as ordens da Metrópole, ter liderado o movimento dos Emboabas e de ter chefiado os motins no sertão, ainda assim, livrou-se da ordem de prisão, em 1723, ordenada pelo Vice-Rei. Estas ocorrências não impediram que Manuel Nunes Vianna fosse nomeado Mestre de Campo, nem que recebesse o ofício de escrivão da Ouvidoria do Rio das Velhas e Carta de Mercê do Rei de Portugal, pelos relevantes serviços.

Nessa ocasião, o cristão-novo Miguel de Mendonça Valladollid esteve na região das Minas Gerais e atestou ser Manuel Nunes Vianna judaizante.

Vale lembrar que, presenteando e se apoiando sempre nos amigos religiosos, Manuel Nunes Vianna mantinha um relacionamento pessoal com o Rei. Estando em Portugal, entre 1725 e 1728, recebeu em 1727, do próprio monarca, ofício para ser entregue ao comerciante Francisco Pinheiro.

Surpreendentemente, apesar de cristão-novo, conseguiu ser aceito na Ordem de Cristo. Embora semialfabetizado, Manuel Nunes Vianna possuía uma biblioteca e foi apontado como financiador da edição do livro

${ }^{7}$ In: Testamentália de Francisco Pinheiro, fundo do Hospital de São José. APUD Furtado, Júnia Ferreira. Homens de Negócio. São Paulo: USP, 1996, p. 88. Tese de Doutoramento. Exemplar datilografado.

Outra posição tem Carla Maria Junho Anastasia In: Vassalos Rebeldes: violência coletiva nas Minas na primeira metade do século XVIII. Belo Horizonte: UFMG, 1995, p. 142, que vê nas "tentativas da Coroa de preservar a acomodação do sistema", a explicação do relacionamento paradoxal com o potentado.

${ }^{8}$ Processo Inquisição Lisboa n ${ }^{\circ} 9.973$. 
Compêndio do Peregrino da América, atendendo ao pedido do autor Nuno Marques Pereira. Consta ter sido também o responsável pelo aparecimento do terceiro volume da obra Décadas, de autoria de Diogo do Couto.

Sua grande família era composta de tratantes, comerciantes de pedras nas Minas Gerais. Seus sobrinhos Domingos Nunes e David Mendes da Silva além de negociarem pedras e ouro, também exploravam o comércio de escravos. Todos vieram da Bahia para Minas Gerais, seguindo as pegadas do rico Manuel Nunes Vianna, a quem não se pode deixar de ligar aos negócios sugeridos nos processos, uma vez que era prática comum nos negócios realizados os cristãos-novos serem da mesma família ou da mesma região, ou envolvidos por laços de amizade.

Muitos desses cristãos-novos, homens de negócio em Minas Gerais foram vítimas da Inquisição. De acordo com os processos inquisitoriais, essas famílias formaram verdadeiras comunidades judaizantes. Reuniam-se nas casas uns dos outros, para as práticas e rituais da Lei de Moisés, além de ensinarem a religião entre eles.

Outra família bastante enredada nas Minas Gerais e que teceu uma rede comercial e religiosa importante foi a do cristão-novo Francisco Nunes de Miranda.

Foram quatro gerações da família Nunes de Miranda. A primeira se radicara na terra natal: Vila de Almeida, Portugal. A segunda, em terras espanholas. A terceira radicou-se no Brasil, entre 1730 e 1732, vivendo entre a Bahia, Rio de Janeiro e Minas Gerais. Foram todas vítimas da Inquisição ${ }^{9}$. Pertenciam à numerosa família, envolvida com diversas atividades mercantis. Formam médicos, artesãos, agricultores e, concomitantemente, comerciantes de escravos.

A perseguição inquisitorial iniciada em 1669 trouxe a família para o Brasil. Francisco Nunes de Miranda passara pelas regiões espanholas de Sanfelices de Los Galegos, Vilar Murpin, Castelo Rodrigo e por Vila de Almeida, em Portugal.

Em 1702, encontrava-se em Salvador, na Bahia, onde adquiriu muitas propriedades, entre casas, terrenos, oficinas e curtumes, comprados ao

\footnotetext{
${ }^{9}$ Ver: SANTOS, Suzana Maria de Sousa. Marranos e Inquisição. (Bahia, século XVIII). São Paulo: USP, 1997. Dissertação de Mestrado.
}

sacerdote Manoel Roiz Braga que herdara do pai João Roiz Braga. Tudo valia cerca de 200.000 réis. Nesse mesmo ano, exerceu a medicina na Santa Casa da Misericórdia da Bahia.

Francisco Nunes de Miranda foi o primeiro judaizante do Brasil entregue à Inquisição de Lisboa, no século XVIII. Preso em 1700, foi sentenciado a ouvir do Santo Ofício o veredicto que se tornou público no ano seguinte.

Também presos foram seus irmãos Antônio Nunes, Manuel Nunes de Almeida, o sobrinho Francisco Nunes de Miranda, homem de negócio, Antônio de Miranda, Felix Nunes de Miranda, David de Miranda e Pedro Nunes de Miranda ${ }^{10}$. Sua filha Maria Bernal de Miranda foi presa, no Rio de Janeiro, em 1726 e teve a mesma sentença do pai.

Sobrinho do médico do mesmo nome, Francisco Nunes de Miranda era natural da Vila de Almeyda e foi morador na Bahia, no Rio de Janeiro e em Minas Gerais, possuindo casas nas regiões de Curralinho e Rio das Mortes, em Minas Gerias. Solteiro, foi homem de negócio bem sucedido. Como rico comerciante, tinha também relações com Francisco Pinheiro e com o parente colateral, Joseph de Castro, que transportava escravos da Costa de Mina e de Angola para o Brasil, principalmente para Minas Gerais.

O próprio Francisco Pinheiro fazia transações com o seu irmão Antônio Pinheiro Netto, que se instalou, em 1712, nas Minas, onde abriu comércio. Francisco Pinheiro fazia negócio, também, com seu sobrinho João Pinheiro Netto, morador de Vila Rica, com seu compadre Francisco da Cruz e com João Alvares, cunhado de seu irmão, estabelecidos em 1725 em Sabará.

Possuíam sistema de contas entre eles, criando laços de dependência, dentro das relações de clientelismo e parentesco, a exemplo de David de Miranda $^{11}$, que durante os anos de 1721 a 1724, foi importador de tecidos de Lisboa e, em empreendimento com o seu irmão Francisco Nunes de Miranda, estendeu esse negócio até as minas, onde vendia roupas confeccionadas com os panos comprados. Concomitantemente, aliou-se ao cunhado, Diogo de Ávila Henriques ${ }^{12}$, que, por sua vez, era sócio de Antônio Ruiz, do mineiro Lino Gomes e do irmão Diogo de Avila. Os dois

${ }^{10}$ Processo Inquisição Lisboa $n^{\circ} 9002$.
${ }^{11}$ Processo Inquisição Lisboa $n^{\circ} 7.489$.

${ }^{12}$ Processo Inquisição Lisboa ${ }^{\circ} 2.121$ 
irmãos mantinham relações comerciais, na Bahia e em Minas Gerais, com Jerônimo Rodrigues ${ }^{13}$ e Gaspar Henriques ${ }^{14}$. Este também negociava sítios e fazendas, a crédito, juntamente com o cunhado João de Morais. Realizavam vários tipos de transações, incluindo transportes $\mathrm{e}$ carregamentos, comércio de tecidos e de escravos.

Outro cristão-novo, Manuel Nunes Sanches ${ }^{15}$, veio para o Brasil ainda adolescente, por volta de 1710 , fixando-se na Bahia. Seus primos moravam em Curralinho e seu irmão, Marcos Mendes Sanches, em Serro Frio, região de Minas Gerais.

Homônimos seus foram seu avô, um sobrinho, filho de sua irmã Leonor Henriques com Francisco Nunes Payva e seu primo, filho de seu tio Henrique Fróes.

Como rico homem de negócio, assistiu em Sabará, Itaverava, Curralinho, Ouro Preto, Congonhas, Pitangui, Ribeirão do Carmo, Serro Frio e Itaubira. Possuía sítio em Cachoeira e uma fazenda em Minas Novas do Fanado, onde cultivava milho e legumes. Tinha também um sítio de lavrar ouro em Sabará e outro, em sociedade com de André da Silva Vianna, em Paraopeba.

Toda a família foi considerada judaizante e processada pelo Tribunal do Santo Ofício. Verdadeiras ou não, as acusações são de crime de judaísmo e revelam práticas judaizantes, comuns a todos os presos. Embora haja grande variedade de comportamentos diferenciados, dentro do fenômeno marrano, a grande maioria confessou ter abraçado a Lei de Moisés e voltado ao cristianismo por ocasião da prisão. Todas essas afirmações são iguais às que foram encontradas em processos de outros estudos do Brasil. Todos foram presos, tiveram os seus bens confiscados e confessaram práticas judaicas. Essas confissões não constituem provas definitivas de seus judaísmos, porque, muitas vezes, eram obtidas sob pressões e torturas, mas permitiram aos inquisidores atingirem seus objetivos que iam da conquista do espaço e do poder até à posse das riquezas sempre escassas no Tribunal, apesar das verbas disponíveis.

\section{Referências Bibliográficas:}

\section{Fontes Primárias}

1.1- Fontes Primárias manuscritas:

1.1.1- Arquivo Nacional da Torre do Tombo Processo Inquisição Lisboa ${ }^{\circ}$ 9.973

\section{Bibliografia}

\section{1- Bibliografia específica:}

ANASTASIA, Carla Maria Junho. Vassalas, rebeldes: violência coletiva nas Minas na primeira metade do século XVIII. Belo Horizonte: UFMG, 1995.

FERNANDES, Neusa. A Inquisição em Minas Gerais no século XVIII. Rio de Janeiro: EDUERJ, 2000.

SALVADOR, José Gonçalves. Os cristãos-novos em Minas Gerais durante o ciclo do ouro (1695-1755). São Paulo: Pioneira, 1992, p. 11.

SILVA, Lina Gorenstein Ferreira da. Heréticos e Impuros. Rio de Janeiro: Prefeitura Municipal, 1995.

\section{2- Periódicos:}

SILVA, Lina Gorenstein Ferreira da. A Inquisição e o pioneirismo dos cristãos-novos nas Minas Gerais. In: Revista do Instituto Histórico e Geográfico Brasileiro. Rio de Janeiro: 159, n 401, out/dez., 1998.

\footnotetext{
${ }^{13}$ Processo Inquisição Lisboa $n^{\circ} 10.003$.

${ }^{14}$ Processo Inquisição Lisboa $n^{\circ} 6.486$.

${ }^{15}$ Processo Inquisição Lisboa ${ }^{\circ} 2.141$.
} 
Judeus no sul do Brasil, Porto Alegre-RS: da dispersão grupal à construção institucional e comunitária

\section{Ieda Gutfreind ${ }^{1}$}

A

comunicação situa-se no campo da História e é um recorte de um projeto mais amplo em andamento. As fontes com as quais trabalhamos são em grande maioria orais, extraídas do acervo do Departamento de Memória do Instituto Cultural Judaico Marc Chagall (ICJMC), sediado em Porto Alegre. Nosso propósito é identificar instituições criadas por judeus na capital do estado do Rio Grande do Sul (RS), destacando que correspondem a momentos e situações específicas, respondendo a vontade de grupos que buscavam espaços para satisfazer necessidades de múltiplas ordens, sejam religiosas, culturais ou sociais.

Partimos do pressuposto de que a homogeneização do judeu brasileiro é uma construção que envolve interesses do próprio grupo, bem como advém de percepções ou preconceitos externos. Yehoshua, em Viagem no fim do milênio, um Romance de Idade Média (2001), ambientado no final do século dez, oferece-nos indicativos do traçado milenar das fronteiras entre as comunidades judaicas askhenazim e sefaradim, que ainda hoje demarcam afinidades e diferenciações dramáticas para Israel. Acrescentamos que não apenas para Israel, mas entre os judeus da Diáspora distinções internas impõem-se.

Outros tantos séculos transcorreram ao tempo enfocado no romance acima, mas ainda podemos visualizar diferenças, embora mais tênues, entre os diversos grupos de judeus, em sua maioria askhenazim, que imigraram para o Brasil, radicando-se no Rio Grande do Sul, a maior parte deles na capital do Estado. Os imigrantes judeus, neste caso, são em sua maioria askhenazim, mas, mesmo entre eles, no interior da língua comum, o iídiche, há especificidades, encontradas na alimentação, no vestuário, na pronúncia e significado de palavras. Maiores distinções ocorrem, entretanto, entre os askhenazim e os sefaradim, o que nos sinalizaria neste grande conjunto, as razões do significativo número de instituições edificadas por grupos de

${ }^{1}$ Doutora em Sociologia/UNISINOS/RS judeus na capital do estado gaúcho. Iniciamos com a situação inicial do imigrante judeu em uma colônia agrícola, seguimos com seu deslocamento para os centros urbanos, onde deram início as suas práticas cotidianas religiosas, culturais e sociais e finalizamos com o momento posterior, quando tais instituições são subsumidas por supraentidades, tornando visível a ruptura da rigidez que separava os vários agrupamentos.

Introduzindo nossa temática, historicamente a imigração judaica no Rio Grande do Sul teve seu início oficial, com a vinda de imigrantes, sob a chancela da Iewish Colonization Association (ICA), nos primeiros anos do século XX. Famílias vindas da Bessarábia foram instaladas no interior do estado gaúcho, onde deveriam desenvolver atividades agrícolas. No projeto de colonização da ICA estava prevista e foi implantada uma infraestrutura para satisfazer suas necessidades religiosas, educacionais e sociais. A construção de uma sinagoga, da escola, de biblioteca, de espaços de lazer facilitaram a convivência e a continuidade de uma forma de vida trazida da Europa. As práticas religiosas, a alimentação, a comunicação com a manutenção do iídiche, as comemorações religiosas, aproximavam os imigrantes, muitos dos quais deram início a laços de amizade entre famílias e de parentesco, através de casamentos. O miniam estava assegurado para qualquer situação que o exigisse.

Se, por um lado, na colônia, o "mundo askhenazim" com suas tradições trazidas da Europa reconstruía-se, por outro, mudanças ocorriam com a introdução de novos alimentos à dieta, a substituições das roupas pesadas pelas típicas do gaúcho que muitos imigrantes adotaram, a convivência das crianças na escola com outras de fora da colônia, e a colaboração de adultos não judeus nas lides agrícolas.

A primeira colônia de judeus, Philippson, próxima à cidade de Santa Maria, no centro do Estado gaúcho, aproximava os colonos entre si, porém a harmonia era rompida por choques entre estes e a administração e, paralelamente às amizades que se formavam, ocorriam desavenças inclusive entre vizinhos. No livro de memórias de Alexandr (1967), localizamos uma descrição das posições político-sociais assumidas pela administração, o que sem dúvida deveria gerar insatisfações entre os colonos:

Representava a ICA um senhor vindo da França com plenos poderes para resolver todas as questões e dificuldades dos colonos. Deveria orientá-los na lavoura, fornece-lhes toda a assistência necessária. 
Para ele e sua família fora reservada a casa do antigo proprietário da fazenda. Era um sobrado pintado de branco, com todo o conforto possível, próprio para pessoas acostumadas a viver em Paris. A casa ficou sendo conhecida por administração ou sobrado. Rodeava-a um imenso jardim florido e bem tratado, Atrás do sobrado estendia-se um grande pomar com variedade de frutas, tais como laranjas de diversas qualidades, bergamotas, pessegueiros e parreiras. A casa e o pomar eram protegidos por uma cerca de arame farpado, bem fechada, a fim de impossibilitar as incursões indesejáveis. Dois cães gigantescos temidos pela sua ferocidade e dois caboclos do lugar, conhecidos pela sua ligeireza no facão, montavam guarda ali. Às sextas feiras, porém, esse Éden proibido, era franqueado às famílias trazidas para Filipson, sendo- lhes, então, permitido comer dos frutos que quisessem e levar algum aos entes queridos que, por qualquer motivo, não pudessem comparecer ali. Atendia-as, e com solicitude, os dois peões, com os longos facões pendurados no lado direito da cintura, ao alcance da mão. Os cães, nessas ocasiões, ficavam presos. Todavia, vez por outra, quando esqueciam de prendê-los, voltava sempre alguém dessa tão almejada visita com o seu único traje de festa rasgado, quando não com um pedaço de perna a menos. Por esse motivo, tal visita, com o decorrer do tempo, acabou por ser completamente suprimida por parte dos colonos mais briosos... (Alexandr, 1967, p. 16).

A realidade material acima foi um tanto diversa para os colonos, quando da chegada, sendo assim relembrada pela memorialista:

Para abrigar parte das famílias, foi construído um galpão enorme, de tábuas, todo pintado de preto, pois nem todas as casas estavam terminadas por ocasião da vinda das levas de emigrantes... As casas ainda não estavam prontas para receber os moradores. Trabalhava-se febrilmente, havendo-se estabelecido, de modo tácito, um processo de cooperação em que todos se auxiliavam mutuamente (...). Era total o desconforto. Todos dormiam no chão, numa promiscuidade deprimente... (Ibid., 1967. p. 15,17)

Administração e colonos conflitavam-se, inclusive motivados pelas diferenças etnoculturais, nas quais avultava a dificuldade de comunicação, o que nos permite reconhecer a gama cultural diferenciada entre os colonos e os responsáveis pela gerência dos negócios da colônia, e esse fato não foi exclusivo da colônia de Philippson, abrangendo as demais, conforme a citação:
Muitos dos executivos e administradores da ICA eram sefaradis. Podemos citar o Administrador de Quatro Irmãos (colônia], Dr. Marcos Pereira, assim como seus sucessores, Drs. Davi Levi, Jacob Massis e Elie Saltiel.(...) Os agricultores dos projetos da ICA eram todos askhenazis e falavam, basicamente, o russo e o idish (dialeto judeu alemão) ao passo que os administradores da /CA se expressavam, basicamente, em francês e ladino (judeu espanhol). (Nelson Menda, 1999,p. 02)

De um administrador temos a seguinte avaliação:

... já lhe disse que justamente a maior dificuldade minha era a língua eu não conhecia o ídish, e todo mundo falando ídish... (Nestor Pontremoli. Entrevista n. 227, 1988, p. 25)

Colonos e descendentes insatisfeitos, críticos da situação em que viviam, com as novas atividades para as quais muitos não estavam habilitados, nas Histórias de Vida que constam no Acervo do Departamento de Memória ICJ MC, apresentam suas queixas: ...tinha um galpão onde botavam todos os colonos que traziam e lá ficavam em comunidade, até que cada um ganhava a sua colônia, ganhava um arado, uma junta de bois. E diziam: agora te vira. E os colonos se viraram a torto e direito... (Sara Gerber. Entrevista n. 395, p. 3).

Philippson teve curta duração e seus moradores dirigiram-se para a cidade mais próxima, Santa Maria, muitos deles já se conheciam, uns seguiram outros e, poucos anos após, em 1923, ergueram uma sinagoga ${ }^{2}$. Um grande número, porém, rumou para a capital do estado, Porto Alegre, buscando a aproximação com familiares aí residentes ou alternativas de mudança em suas vidas. A memorialista que seguimos, Frida Alexandr nos relata a notificação dada ao administrador, por um colono, quando da saída,

\footnotetext{
${ }^{2}$ Um morador de Santa Maria, assim a descreve: “... Havia uma \{sinagoga] de madeira. isso foi em 1924, 1925. Há uma lembrança depois de uma sinagoga, vamos dizer, majestosa para a época, no interior do estado \{Santa Maria). Que eu me lembre era um edifício de dois pisos, com pé direito muito alto e que abrigava colégio na parte térrea, abrigava também o zelador da sinagoga... .Na parte superior havia o salão da sinagoga mesmo e um tipo de um mezanino, camarote, que era para senhoras ficarem lá na sinagoga. Havia também um grande, um ótimo palco. Os judeus sempre cultivaram o teatro, sempre.. .era como se fosse um centro cultural-religioso, que abrigava a sinagoga; o colégio, o baile era feito também na sinagoga, era um conglomerado, vamos dizer, que se centralizava num edifício só...É, ela deve datar mais ou menos de 1928,1930. Eu me lembro que estudei lá o hebraico e o iídiche..." (Jacob Knijinik. Entrevista n. 146. 1988, p. 07-08)
} 
acusado de ter se apossado da Torá que chegara para a sinagoga da colônia. Esse imigrante será localizado quando das fundações das sinagogas União Israelita e Centro Israelita, ambas em Porto Alegre.

Guarde o seu revólver. Não vim pedir satisfação pela perseguição que moveu contra mim e minha família. O contrário, vim agradecerlhe por ter-me forçado a abandonar a colônia. Estou ganhando meu pão honestamente, em Porto Alegre, vendendo pelas ruas, galinhas, quadros de santos ou ferro velho. Tudo preferível a este inferno... Vim buscar minha família. Pode dispor a colônia. (Ibid., 1967 , p. 26)

A sociedade maior, como, por exemplo, a de Santa Maria, muitas vezes não identificava esse grupo de imigrantes como judeus, denominando-os russos ou russinhos. Funcionava o sistema de homogeneização de um grupo diferenciado internamente. Uniformidade que será parcialmente rompida quando um pequeno número, com algum tipo de peculiaridade comum agrupar-se em torno de uma instituição, situação que ocorrerá em Porto Alegre.

Nessa mesma época, nos inícios do século passado, quando havia um maior número de judeus no interior do Rio Grande do Sul que na capital, a dificuldade para reunir dez homens quando das festividades religiosas era superada por encontros nas poucas residências existentes. Contemporâneos à época historiam um encontro promovido por um judeu sefaradi que se destaca nesses inícios de vida judaica, Salomão Levy, oriundo de Marrakesh, que possuía uma loja na cidade. Na residência desse judeu marroquino, no ano de 1909, foram comemorados o Rosh Hashand e Yom Kipur e dela fizeram parte judeus askhenazim de origem russa e austríaca. Há informações de que ocorreram naquele mesmo ano outras reuniões em residências ${ }^{3}$.

${ }^{3}$ Leão Back em Comunidades Judaicas afirma que na residência do Sr. Júlio Lubianca também ocorreram orações, por ocasião destes dias religiosos. (Departamento de Memória Marc Chagall. Cx n. 31 Maço I, doc. n. 5 n. 18 pág. Série Comunidades Judaicas do Rio Grande do Sul, traz informações.

Nos depoimentos do acervo do Departamento de Memória do ICJMC há referências a esse tipo de reuniões para comemorar as festividades religiosas do calendário judaico. Identificamos uma estratégia utilizada no seguinte relato: "Meu pai, Bernardo, e o tio Isac foram fundadores da Sinagoga da União Israelita. Quando chegamos em (1909) havia apenas oito famílias de israelitas, então meu pai pagava a passagem para judeus [virem] de Pelotas e Rio Grande, para completar o miniam para Rosh Hashand e Yom Kipur.' (In: Eizirik, 1984, p.37).
Liderados por Salomão Levy no ano seguinte (1910) um pequeno grupo de judeus fundou uma associação religiosa que se denominou União Israelita, mas que teve curta duração. Quando o número de judeus residentes em Porto Alegre aumentou, teve início a criação de instituições, com indivíduos agrupando-se a partir de identidades geográficas e linguísticas.

Os preconceitos intragrupos são por demais conhecidos, conforme vimos, sejam entre os askhenazim ou entre esses e os sefaradim. Retiramos dos depoentes que colaboram na construção deste texto, excertos nos quais a assertiva fica evidenciada.

É. Eu tenho uma coisa que eu comecei a estudar agora, os sefaradim. Até o pessoal fica meio danado da vida, porque nós somos asquenazi aqui, em Porto Alegre, a grande maioria. Eu tenho uma passagem que... foi uma assembleia do Colégio Idish, era aqui no Bom Fim. Então, houve uma assembleia de necessidades do Colégio e tal...Eu estava lá, os meus filhos (lá estudavam]. Aí, lá pelas tantas um camarada pediu para falar em iídiche. Um outro disse que não, que tinha que falar em português e coisa e loisa. Aí eu disse inocentemente: Ah, então tá bom! Uma assembleia do Colégio Idish, que o sujeito não entende iídiche? O que é que a fazendo aqui dentro? (Solon Slavutzki. Entrevista n. 323, 1990, p.63-64).

...nós sempre nos demos bem, mas nós aqui, eles lá: os costumes são meio diferentes, cada um tem os seus jornais, seus costumes, seus hábitos e não da' certo. Casamento sim, eles se casam e se dão. Mas agora em festas e coisas... a não ser da Federação que convida toda coletividade, aí a gente sempre se ajuda. (Jóia Castiel Menda. Entrevista n. 062, 1987, p. 03).

A identificação de diferenças, embora apresentando unidade religiosa, mas não na forma das suas práticas, torna-se clara, quando da criação dessas instituições, e é o propósito do texto. As instituições criadas são sinalizações das aproximações de judeus, motivadas por traços étnico- culturais comuns. A avaliação de um depoente com experiência institucional em várias sinagogas das várias que foram construídas em Porto alegre, é feita nos seguintes termos: ...os (judeus) que vieram da Europa, eram gente com muita cultura judaica, eles sabem o que é uma sociedade. E eles se diferenciavam um pouco dos judeus que já estavam há mais tempo no Brasil e se congregavam, e eles já eram mais ricos também, se congregavam mais no Centro Israelita e os mais antigos ainda se 
congregavam no União Israelita. Então, os novos, os que vieram especialmente da Polônia, acharam melhor ter uma sociedade separada. Não sei porque razão, só sei que fizeram uma sociedade separada. E lá realizavam festas, espetáculos teatrais, e assim era a vida que eu me lembro daquele tempo. A questão é a seguinte: isto tudo, parece que foi, tudo isto aconteceu rapidamente, entre, entre 1935 e 1937, foi praticamente de um relance, porque em 1937 praticamente pararam as atividades judaicas aqui... Então a vida judaica, pelo que sei, morreu praticamente no Rio Grande do Sul. (Halpern. Entrevista n. 014. 1988, p. 05-06).

O depoente refere-se à declaração do Estado Novo, de 1937, decretado pelo presidente brasileiro Getúlio Vargas, vigorando até 1945; de cunho marcadamente nacionalista, dentre as múltiplas coerções políticas, econômicas, sociais, identificamos apenas as proibições de manifestações de grupos imigrados ou seus descendentes. Já outro depoente avalia, afirmando:

Aqui (referindo-se ao Poilish Farband) eram os Poilish idn...não se misturavam.., tinha esse preconceito social... na Barros Cassai (União Israelita), eram os judeus ricos, o Poilish Farband era um dos mais pobres... na Henrique Dias, o Centro Israelita eram os médios....A SIBRA era uma sociedade dos Judeus alemães.... (Natdlio Engelman. Entrevista n. 357, 1991, p.10).

Observamos que o judeu, além de visualizar-se diferente de outro judeu, muitas vezes tem dificuldade em definir sua origem, nestes casos, via de regra, identifica-se a partir do local que selecionou como sua origem, critério que será utilizado quando da criação institucional:

Eu sou húngaro, romeno. Eu não sei o que sou, porque sou da Transilvânia. Uma época a Transilvânia era parte da Hungria. Parte da Transilvânia ficou Hungria e a outra Romênia... mas eu me considero romeno. O resto são polacos, russos, bessarabes, litviners (grifo nosso), cada um no seu lugar... (Maximilian Glaser. Entrevista n. 101, 1991, p. 19)

$\mathrm{O}$ excerto acima nos deixa explicita as formas utilizadas pelo judeu para hierarquizar, criando uma pirâmide social a qual compõe-se de seu grupo em destaque, e as demais distribuídas a partir das condições econômicas ou, contabilizando no tempo, a época da imigração familiar. As instituições refletem este recurso.
Para efeitos didáticos organizamos em momentos, os agrupamentos de judeus que se radicaram em Porto Alegre: a) já nos referimos ao momento inicial, quando se aproximaram independentemente de suas origens étnicas; exemplificamos retornando à reunião que ocorreu na residência familiar do sr. Levy, prática comum nos primeiros anos do século XX; b) No momento seguinte, ocorreu a criação de instituições a partir, ratificamos, de laços identificadores comuns e, algum tempo após, c) ocorreu a criação de uma instituição de cunho social que abrigará os membros da comunidade judaica, independentemente de suas peculiaridades; d) o último momento que tratamos, refere-se ao do projeto de criação da Unificada e o da Federação, o primeiro deles vinculado à criação do Estado judeu e o outro indicativo de múltiplos fatores, dentre estes a criação de uma identidade que passaria a demarcar uma comunidade, a judaica.

Passemos à criação das instituições, refletindo acerca das razões de sua criação e o grupo que a empresou.

A sinagoga União Israelita, um ano após a primeira tentativa - 1909 -, é recriada. Seus componentes, não são exclusivamente askhenazim, pois Salomão Levy ai se encontra e há outros sobrenomes que remetem a judeus sefaradim.

O objetivo imediato para sua criação repousava na necessidade de um local para os judeus enterrarem seus mortos. Poucos dias após as comemorações das grandes festas, iniciaram as buscas e a compra do terreno para o cemitério, cujo preparo foi feito pela própria comunidade, que, em um domingo, cercou o terreno e nesse mesmo ano já acolhe membros da coletividade (Eizirik, 1984, p. 38). No período que antecede a construção da sede da sinagoga, os serviços religiosos e as comemorações sociais eram realizados em residências alugadas e a maior parte era composta de judeus oriundos das fronteiras do então Império Russo.

Poucos anos após teremos uma segunda sinagoga, o Centro Israelita Porto Alegrense. Sua criação, ao que a documentação indica, resultou da exclusão de sócios da sinagoga União Israelita. Segundo uma fonte: ... em 14 de outubro de 1917 quatro sócios: M.B., D.B., L.K. e A. S. foram excluídos da sociedade por desrespeito aos membros da 
diretoria e difamação à U.I (União Israelita), com publicações na imprensa local ${ }^{4}$.

Esse fato é corroborado por um outro documento ${ }^{5}$, que afirma:

Em 1917, devido a questões e a incompatibilidades internas surgiu uma nova Associação que não se diferenciava da primeira, a União Israelita, com os mesmos objetivos, sob o nome de Centro Israelita Porto Alegrense.

A inauguração da sede foi em 1925 e consta que havia uma estátua de Moisés na fachada, em sua parte superior. Críticas fizeram-se ouvir, a diretoria reuniu-se e a imagem foi substituída por uma estrela de Davi. Nessa sinagoga funcionou o primeiro Colégio Idish e peças teatrais eram apresentadas pelas crianças nas comemorações anuais da escola. Nela como na União Israelita, ocorriam não apenas as cerimônias religiosas, mas uma gama variada de atividades sociais e culturais.

Concordamos com o autor da citação acima, acerca da proximidade dos objetivos do Centro Israelita com os da União Israelita e agregamos que, provavelmente, muitos dos imigrantes que chegaram nos anos 20 encaminharam-se para essa última sinagoga localizada no bairro Bom Fim, onde a grande maioria fixou residência nas ruas que a circundavam, pois facilitava o deslocamento para as orações da manhã e do anoitecer.

Os judeus sefaradim, como os demais, inicialmente reuniam-se em residências, posteriormente alugaram uma residência na qual exerciam seus compromissos religiosos, e muitos deles frequentavam as sinagogas já existentes, acima identificadas. No início da década de 1920, os sefaradim, conforme dizem, iniciaram uma ventura buena: a partir de reuniões e de assembleias propuseram a criação da sua sinagoga, o Centro Hebraico Riograndense, inaugurado oficialmente em 1922, que, no entanto tardou vários anos para ter sua sede própria concluída.

Como as demais, neste local, além dos ofícios religiosos realizavamse festividades de aniversários, casamentos, bailes de carnaval, convenções, palestras, almoços e chás comemorativos, etc.

\footnotetext{
${ }^{4}$ STIFELMAN, Doutor Marcos. Reminiscências II (cont.). Periódico União Israelita ano III n. 1 agosto 1995 AV. 5755 p. 3.

${ }^{5}$ FALBEL, Nachman. Comunidade Judaica do Rio Grande do Sul, p. 10-11 Departamento de Memória ICJMC Cx n. 31 maço n. 1 doc. 5 pág. 18 Série Comunidades Judaicas no RS.
}

A justificativa de um depoente nos permite o entendimento da criação dessa sinagoga:

A fundação de uma entidade qualquer tem uma razão de ser. Naquela época de 1922, os poucos sefaradís provenientes da Turquia e que aqui fundaram os alicerces de suas vidas e negócios, necessitavam satisfazer suas necessidades espirituais. É bem verdade que fd funcionavam a União Israelita e o Centro Israelita, onde assistiam as solenidades religiosas. Havia, algo, porém, que clamava pela união daqueles poucos em torno de uma entidade própria: era o rito sefaradí, um pouco diverso do askenazi, a língua comum, que era o espanhol, e a origem comum, a Turquia. (Aron Menda, 1962. p. 62)

A vinda progressiva de judeus poloneses oferece condições para que se reúnam em uma sinagoga, que foi fundada em 1931. Denominada Associação Israelita Brasileira Poilisher Farband, quando do Estado Novo passou a chamar-se Associação Israelita Brasileira Maurício Cardoso.

Um depoente, cujo pai durante longos anos fez parte da diretoria, exemplifica que nesta sinagoga: ...eram só poloneses, praticamente, com raras exceções, pelos seguintes fatores: ...naquela época o pessoal se (delimitava. De cada região fazia o seu grupinho. Então ali era o Poilisher Farband [dos poloneses]. Na Barros Cassal \{União Israelita\} eram os que vinham da Rússia.. .então cada um tinha a sua sociedade, criaram a sua sociedade. Então ali ficou centralizado mais para os judeus poloneses... (Natdlio Engelman. Entrevista n. 357, 1991, p.6).

Vários depoentes recordam as atividades de assistência gratuita de vários médicos durante muitos anos, além do empréstimo aos associados de instrumentos como seringas, ventosas, termômetros, comadres... Essa filantropia também era exercida com o auxílio de uma caixa de socorros mútuos, com empréstimos em dinheiro.

No espaço desta sinagoga ocorriam eventos sociais como espetáculos em iídiche, bailes, reuniões dançantes, bazares e leilões. Um incêndio a destruiu em 1947, foi reconstruída e há alguns anos em seu espaço foi erguido um prédio que abriga várias instituições judaicas, inclusive a Federação Israelita, estando o andar térreo ocupado pela sinagoga Poilisher Farband. Esse espaço abriu-se para a realização de múltiplos eventos, não mais se caracterizando apenas como sinagoga e tampouco de judeus poloneses. 
No ano seguinte, 1932 foi fundado o Linat Hatzedek por judeus da Europa Oriental, húngaros, romenos, além de outros. Foi criado como uma sociedade Beneficente de Socorros Mútuos e sua nominação Linat Hatzedek, traduzido no iídiche indica assistência noturna gratuita ao doente, atividade a qual a Instituição dera grande valor. Paralela à atividade beneficente, foi fundada uma sinagoga que chegou a ter mais de duzentos sócios, diminuindo sensivelmente seu número com a morte da sua primeira geração, não sendo renovado pelas novas. Um associado e presidente por longos anos avalia o papel da instituição da seguinte forma:

Esqueci a data...1932...vieram alguns imigrantes, outros jd estavam bastante tempo aqui e... sabe com é, judeus nunca se entendem entre si, então forneciam um novo shill... (nele \} tinha.., ajuda médica, um ambulatório completo.. .com o tempo.. .a gente não precisava.., isso foi abandonado...(masi se alguém estava doente e não tinha quem ficar com ele, um dos sócios ficava com ele, levava no médico, trazia do médico... (Maximilian G laser. Entrevista n. 101, 1991, p. 01).

$\mathrm{Na}$ década de 1930, o afluxo de judeus alemães aumentou proporcionalmente ao avanço nazista. Os compromissos religiosos dos judeus alemães eram realizados em outras sinagogas de Porto Alegre, porém suas singularidades os levam a buscar um espaço religioso, social e cultural próprio. Em 1936 surge a SIBRA - Sociedade Israelita Brasileira de Cultura e Beneficência.

A construção da SIBRA coloca-se na mesma linha de raciocínio das demais, e uma depoente relembra que jovem, recém-chegada, em 1934, redigiu uma carta para familiares na Alemanha. Queixava-se dos insetos que a assustavam e do escândalo para sua família que presenciou que juntaram dinheiro na sinagoga do Centro Israelita em pleno Pessach! Igualmente recorda que frequentaram o Poilisher Farband e o Linat Hatzedek, mas não permaneceram, por não aceitarem os hábitos toscos ou comportamentos inadequados de alguns de seus associados. Após essas experiências em sinagogas askhenazim seu pai realizou um minian com um pequeno grupo tão religioso quanto ele, na própria casa, o que igualmente não foi agradável, tendo que retornar a frequentar o Linat Hatzedek.

Nesse meio tempo, um judeu alemão vindo de São Paulo, onde já havia uma sinagoga de alemães, traz a ideia da fundação de uma para os seus conterrâneos em Porto Alegre. Iniciando como os demais, alguns membros desse grupo alugaram uma casa no bairro Bom Fim, posteriormente se mudaram para outro local e é após algum tempo que foi adquirido um terreno e realizada a construção do prédio atual.

Chamamos a atenção que internamente havia diferenciações na SIBRA, destacando-se os que vieram primeiramente, oriundos de pequenos lugarejos, bastante religiosos, mas com conhecimentos restritos". Posteriormente, imigraram judeus alemães das grandes cidades como Berlim, mais liberais, com nível educacional distinto e que gradativamente passaram a exercer a liderança da comunidade. Embora tais distinções internas:

...na SIBRA a gente teve a chance de encontrar outros imigrantes em situações parecidas, embora não fossem idênticas. E houve, então, encontros e começou além da vida, vamos dizer, de um minian, aparte religiosa, começou aparte social, da gente se encontrar, ter com quem conversar sobre o passado. Porque também tínhamos um passado similar. Porque é diferente poder participar daquilo que se vivenciou como se fosse apenas a história que está se contando e fim... Aí se jogava ping-pong, encontravam-se rapazes e moças, entre os quais meu atual marido e outros também que se encontraram assim... Vários casais foram se formando...nós casamos em 1941, outros em 1940, outros (jd) em 1942. E ai veio a integração mesmo. Todos jd falando português. Todosjá trabalhando...(Berta Herz. Entrevista n. 016, 1987, p. 26-27)

Durante longo período os judeus askhenazim, sejam os vindos da Rússia, Polônia, Lituânia, Bessárabia, em relação aos alemães, identificavam nítidas diferenças, mantendo significativo afastamento, atualmente bem mais atenuado. $\mathrm{O}$ depoimento abaixo ainda trás as marcas desta diferenciação:

Bom, aqui em Porto Alegre o judeu alemão não se mistura conosco. Eles têm a SIBRA (...J, mas eles não se misturam conosco. Também acho que eles pouco se identificam como judeus, os nomes deles jd não são judeus, então eles quase não se identificam como judeus. E o alemão geralmente, pelo menos aqui em Porto Alegre, como em São Paulo, tem a CIP, o alemão é reformista, a religião deles. Nós somos ortodoxos, nós somos conservadores... (Leão Nudelman. Entrevista n. $029,1989, p .16)$

Em contrapartida, conforme o que desenvolvemos acima, é possível observar a reciprocidade de sentimentos do judeu alemão em relação ao 
askhenazim. Sua associação satisfazia as necessidades de seus membros: política interna, momentos culturais e uma vida social intensa.

Tardiamente, em relação às demais sinagogas, temos o retorno do ritual religioso ortodoxo com a entrada do Beit Chabad, em Porto Alegre, a partir de 1981. A preocupação inicial do seu representante foi com a criação de uma escola, atuando através da educação para incentivar um retorno à reflexão religiosa como modo de vida.

Os serviços religiosos durante longo período foram realizados na sinagoga Linat Hatzedek. Segundo um depoente, o Beit Chabad teria se retirado desta sinagoga por lhe ter sido negado a cedência da sinagoga e os associados não permitirem a troca de nomes. Ainda o depoente afirma:

...o Linat Hatzedek podia ser Beit Chabad. Podiam levar tudo para o Beit Chabad, podiam tomar parte, podiam falar, mas não mudar o nome... (Maximilian G laser. Entrevista n. 101, 1991).

Utilizando uma linguagem pós-moderna, organizados em tribos, o judeu askhenazi por sua origem geográfica e linguística, subdividido, mas não de forma rigorosa ou excludente, permanece em suas respectivas organizações institucionais respondendo com segurança que frequenta a sinagoga que era do seu avô ou, então, afirmando que após o casamento mudou de sinagoga.

As aproximações entre askhenazim e sefaradim tornaram-se mais frequentes alguns anos após o término do Estado Novo e quando o Círculo Social Israelita, um clube social fundado em 1930, que alugava locais para promover reuniões sociais, tornou-se o ponto de confluência onde passaram a acorrer os judeus, independente de origem ou prática religiosa. Agregamos o Círculo Social Israelita por sua significação na comunidade judaica - um espaço de sociabilidade - voltado para encontros culturais e sociais, buscando a integração social de membros, sejam os jovens ou as gerações mais velhas, situando-se acima da divisão geográfica, linguística, um tanto ou bastante preservada nas sete sinagogas existentes em Porto Alegre. Nomeação simbólica - círculo - em seu seio abrigava os judeus de Porto Alegre, extensivo ao interior do estado sulino.

O Círculo desempenhou um importante papel quando do movimento de criação do Estado Judeu, promovendo conferências e debates nas décadas de 40 e 50, colaborou na aproximação entre askhenazim/sefaradim, e igualmente no interior do grande grupo askhenazim. O Círculo simboliza dentre as instituições, um elemento fundador na criação da existência de uma comunidade judaica, acima das diferenciações estabelecidas pelas instituições religiosas.

O Círculo Social Israelita, a partir de 1937, passou a ocupar "os altos do Cinema Baltimore", transferindo-se, a partir dos anos 60, para uma imensa sede, ainda no bairro tradicionalmente judeu, o Bom Fim. Na segunda metade da década de 1980, une-se a outra sede sócio-esportiva da comunidade judaica, o Grêmio Esportivo Israelita, ambas sob novo nome: A Hebraica.

Embora as ideias sionistas tenham sido trazidas por muitos imigrantes que continuaram no esforço pró-criação de um estado judeu, e outros tantos tenham aderido ao movimento, é nas décadas de 1930 e 1940 que observamos uma grande mobilização pró-estado-judeu. Irmanados em um ideal comum, atarefados em torno de uma causa comum quebram-se as barreiras intragrupos. As polarizações, embora ainda se façam sentir tenuemente, tomam nova direção, com os judeus distinguindo-se não tanto por sua origem geográfica quanto entre pró e antissionistas. As programações não estão mais voltadas especialmente para o consumo sociocultural interno das respectivas sinagogas e, por extensão, as demais instituições, mas sim dirigidas para um projeto externo, com fundamentos políticos. Abriam-se espaços para que as agremiações se tornassem Unificadas e que uma Federação se alçasse acima de todas as instituições. A primeira, a Unificada, surgiu em 1945, criada, segundo vários depoentes, por um emissário estrangeiro; aliás, tal representante do sionismo internacional teria sido o responsável pela criação de várias organizações, dentre as quais a WIZO, Pioneiras e, especialmente, a Unificada.

Enviado pelo movimento Sionista Mundial para o Brasil, Josef Tchornitzky marcou época em Porto Alegre, pois "lançou a ideia de fazer uma Unificada, que não existia...”. Empenhou-se e obteve êxito na criação da Organização Sionista Unificada do Brasil, setor Rio Grande do Sul, com amplo apoio de sionistas históricos e de última hora.

A Federação Israelita do Rio Grande do Sul, por sua vez, filiando-se a Confederação Israelita Brasileira, inicia suas atividades em 1961, tomando para si a função de um órgão superior ao conjunto das instituições judaicas do Rio Grande do Sul, esforçando-se para atuar como um órgão supraintegrador do conjunto das instituições existentes. 
O depoimento de um dos presidentes da Unificada assim justifica a ideia de criação de uma Federação:

Sempre na condução dos assuntos da Unificada, sempre me batia a ideia de que o Movimento Sionista prosperaria se houvesse uma comunidade forte e as entidades locais fossem também fortes, respeitadas e tivessem uma vida ativa, porque do contrário toda a ideia do sionismo seria realizada na base da guerra. Quer dizer, tu tens um judaísmo dentro de ti que te impulsiona de tal forma, que tu acabas tendo que realizar a tua vida sionista fazendo alia', ou não. Nesta hora do..., ou não, é que então surgiu a ideia da Federação e ela se alicerçou mais, porque eu também fui membro da Magbit, do Fundo Comunitário, fui ativista e levei uma certa ocasião uma proposta de que parte da arrecadação que se fizesse do Fundo, revertesse para as entidades locais. Evidente que não tive nenhum sucesso, mas toda essa história foi criando em mim a sensação de que precisava de alguma coisa... Daí lançou-se a ideia, então, da Federação e foi lutada, porque as pessoas que compunham a diretoria da Unificada não tinham muito a ver com a ideia de Federação e não foram muito receptivas,... Mas, foi fundada a Federação, e eu fui um dos vice-presidentes (...1 foi em abril de 61, que se fundou a Federação... (Gildo Milman, 27 de agosto de 2001, p. 4-5)

Iniciando com pequenas reuniões com membros de uma mesma família, acrescentando amigos, os judeus que se radicaram no Rio Grande do Sul terminaram agrupando-se a partir de suas origens étnico-geográficas. O elo unificador, a sinagoga, cumpria funções não apenas religiosas, mas de assistência social e cultural. Algumas destas instituições mais fechadas que outras, respondiam plenamente às necessidades grupais.

Com o Círculo Social Israelita, uma instituição de cunho nitidamente sociocultural, transformando-se em um espaço dissociado do religioso, passaram a integrar pessoas até então afeitas a uma determinada instituição.

O projeto do Estado judeu galvanizava a atenção e uma outra instituição, supra, a Unificada, igualmente é formada por judeus de distintos grupos e, com a criação da Federação observamos que o período de divisores étnico-culturais, embora ainda fazendo-se sentir, subsumido por interesses maiores: o Circulo Social Israelita, a Unificada e a Federação, representam este outro momento da história dos judeus em Porto Alegre, mesmo que o período anterior continuasse presente.

\section{Referência Bibliográfica:}

ALEXANDR, Frida. Filipson: Histórias da Primeira Colônia Judaica no Rio Grande do Sul. São Paulo: Fulgor, 1967.

ARON MENDA. Centro Hebraico Riograndense. In: Seleções Sionistas. Porto Alegre: Organização Sionista Unificada. Ano IV, n.1, set/out, 1962.

BRUMER Anita Identidade em Mudança: Pesquisa Sociológica sobre os Judeus no Rio Grande do Sul. Porto Alegre: Federação Israelita .do Rio Grande do Sul, 1994.

EIZIRIK, Moisés. Aspectos da Vida Judaica no Rio Grande do Sul. Porto Alegre, Escola Superior de Teologia São Lourenço de Brindes; Caxias do Sul: Editora da Universidade de Caxias do Sul, 1984.

FAERMANN, Martha Parglender. A Promessa Cumprida. Porto Alegre: Metrópole, 1990.

GRITTI, Isabel Rosa. Imigração Judaica no Rio Grande do Sul. A Jewish Colonization Association e a Colonização de Quatro Irmãos. Porto Alegre: Martins Livreiro, 1997.

IOLOVITCH, Marcos. Numa Clara Manhã de Abril. Porto Alegre: Movimento, 1987.

YEHOSHUA, A. B. Viagem ao Fim do milênio: Romance da Idade Média. Tradução do Hebraico Milton Lando. São Paulo: Companhia das Letras, 2001.

NELSON MENDA. 1748/1948 - 200 anos de Presença Sefaradi no Extremo Sul do Brasil. Rio de Janeiro: Centro Hebraico Riograndense, 1999.

NICOLAIEWSKY, Eva. Israelitas no Rio Grande do Sul. Porto Alegre: Editora Garatuja, 1975.

SCLIAR, Moacyr. Judaísmo: Dispersão e Unidade. São Paulo: Ática, 1994.

VERBA, Arão. Resgatando a Memória da Primeira Imigração Judaica para o Brasil: Colônia de Phillipson. s/1: s/e, 1997. 
Acervo do Instituto Cultural Judaico Marc Chagall:

Departamento de Memória: Histórias de Vida (Depoimentos)

Entrevista n. 014. Josef Szulin Halpern, 1988. ICJMC/ DEPTO. DE MEMÓRIA: HISTÓRIA DE VIDA Entrevista n. 016. Berta Herz, 1987. ICJMC/ DEPTO. DE MEMÓRIA: HISTÓRIA DE VIDA

Entrevista n. 029. Leão Nudelman, 1989. ICJMC/ DEPTO. DE MEMÓRIA: HISTÓRIA DE VIDA

Entrevista n. 062. Jóia Castiel Menda. ICJMC/ DEPTO. DE MEMÓRIA: HISTÓRIA DE VIDA Entrevista n. 101. Maximilian Glaser, 1991. ICJMC/ DEPTO. DE MEMÓRIA: HISTÓRIA DE VIDA Entrevista n. 146. Jacob Knijinik, 1988. ICJMC/ DEPTO. DE MEMÓRIA: HISTÓRIA DE VIDA

Entrevista n. 227. Nestor Pontremoli, 1988. ICJMC/ DEPTO. DE MEMÓRIA: HISTÓRIA DE VIDA Entrevista n. 323. Solon Slavutzki, 1990. ICJMC/ DEPTO. DE MEMÓRIA: HISTÓRIA DE VIDA

Entrevista n. 357. Natálio Engelman, 1991. ICJMC/ DEPTO. DE MEMÓRIA: HISTÓRIA DE VIDA Entrevista n. 395. Sara Nagelstein Gerber ICJMC/ DEPTO. DE MEMÓRIA: HISTÓRIA DE VIDA Entrevista Gildo Milman. Concedida a Ieda Gutfreind em 27 de agosto de 2001

Núcleo de Estudos e de Integração de Pesquisa em História Oral NEIPHO - Documentos:

BACK, Leão. Série Comunidades Judaicas do Rio Grande do Sul. Departamento de Memória Marc Chagall. Cx n. 31 Maço I, doc. n.5 p.14 n. 18

FALBEL Nachman. Comunidade Judaica do Rio Grande do Sul. Departamento de Memória ICJMC Cx n. 31 maço n. 1 doc. 5 pág. 18 Série Comunidades Judaicas no Rio Grande do Sul.

STIFELMAN, Doutor Marcos. Reminiscências II (cont.). Periódico União Israelita ano III n. 1 agosto 1995, AV. 5755 p. 3.
Em terras gaúchas: a história da imigração judaico-alemã

Gladis Wiener Blumenthal

Eu não senti discriminação até o dia $1^{\circ}$ de abril de 1933, que foi o dia oficial de boicote aos judeus. Poucos dias depois me proibiram de entrar no tribunal e dois meses depois, já emigrado para França, eu recebi a minha expulsão da Ordem dos Advogados. (...) estava completamente integrado à vida e à cultura germânica e foi Hitler quem me mostrou caminho de volta ao judaísmo, que não mais fazia parte de minha vida, nem como advogado e nem como cidadão. Herbert Caro, tradutor, jornalista e crítico musical.

\section{Introdução}

T inguém emigra por acaso. A maioria dos emigrantes tem motivos que se relacionam com sua sobrevivência física, econômica ou religiosa. Poucos emigram por puro espírito aventureiro. $\mathrm{O}$ presente artigo evidencia alguns dos resultados obtidos com o projeto "A história e a contribuição da imigração judaico-alemã à cultura e ao desenvolvimento do Estado do Rio Grande do Sul", implementado, de 1998 até 2001 no âmbito da Sociedade Israelita Brasileira de Cultura e Beneficência (SIBRA), instituição criada em 1936 por esses imigrantes em Porto Alegre, capital do Estado do Rio Grande do Sul. Além do resgate da história, o projeto objetivou organizar e analisar o acervo da instituição, levantar e catalogar documentos e objetos pessoais e familiares que os acompanharam na imigração, bem como divulgar os resultados obtidos, através de duas mostras e da edição de um livro, que servisse de fonte de pesquisas futuras, preenchendo a lacuna existente em termos bibliográficos. O depoimento de vinte e duas pessoas (SIBRA, 2001), protagonistas diretos na sua maioria, ou seus filhos, oportunizou a coleta de dados sobre sua vida na Europa, sua trajetória até a chegada no Rio Grande do Sul, suas experiências marcantes durante a adaptação à nova terra e nos anos subsequentes, e sobre o papel que a SIBRA, desempenhou nesse processo. Procurar-se-á evidenciar as

${ }^{1}$ Mestre em Educação pela Universidade Federal do Rio Grande do Sul. 
características dessa leva imigratória, sua adaptação à nova terra, a superação paulatina das dificuldades enfrentadas e o papel da SIBRA como "espaço de identidade" (Carneiro, M.L.T, 1996) e de ajuda mútua, os seus sérios conflitos de identidade aguçados pelas políticas do governo brasileiro (Blumenthal, G.,2001) e as contribuições dadas à cultura e ao desenvolvimento do Estado sulino do Brasil.

\section{A imigração judaico-alemã rio período colonial}

Os judeus estiveram presentes em toda a história do Brasil colonial, inclusive no Rio Grande do Sul.

No século XIX, se estabeleceram judeus alemães no Rio Grande do Sul. Pelos dados do Fundo Documental Imigração, Terras e Colonização do Arquivo Histórico do Rio Grande do Sul, na pesquisa realizada por Leia Heineberg, historiógrafa do referido Arquivo, pode-se afirmar que judeus alemães aqui chegaram com as imigrações alemãs patrocinadas pelo governo brasileiro a partir do ano de 1824. Poucos se identificaram como judeus. Embora com nomes tipicamente judaicos, preenchiam os documentos oficiais geralmente como protestantes, evangélicos, católicos ou acatólicos. Muitos deles vieram jovens e solteiros, na aventura de encontrar um mundo melhor, com menos perseguições, fronteiras definidas e mais trabalho que em seu país de origem. O primeiro judeu alemão que não omitiu sua religião e do qual só se conhece o nome, Sigmund, saiu do porto de Hamburgo na Alemanha. Com 38 anos de idade, esse ourives chegou a São Leopoldo em 1824, portanto com a primeira leva oficial de imigrantes alemães vindos ao Rio Grande do Sul. Alguns municípios desse Estado que tiveram colonização alemã, como Taquara, Igrejinha e Nova Petrópolis, possuem ou tiveram ruas denominadas Judengasse, a ruela dos judeus, o que evidencia sua presença marcante nas mesmas.

No século XX, antes da década de 30, poucos judeus alemães aportaram no Rio Grande do Sul. Vieram, em geral, por motivos profissionais e aqui ficaram. É o caso de Kurt Weil, que chegou jovem e, mesmo não fazendo parte de nenhum movimento imigratório, foi de fundamental importância para os imigrantes fugidos do nazismo, que buscavam um novo começo de vida. Anita Brumer, no livro Identidade em Mudança, no qual relata os resultados da pesquisa sociológica sobre os judeus do Rio Grande do Sul realizada de 1991 a 1994, a ele se refere como "um tipo de consulado judeu em Porto Alegre". Seu trabalho, realizado às vezes nos bastidores, junto a amigos advogados e a outros profissionais, em muito auxiliou os judeus alemães a regularizar suas vidas no Brasil.

Com a oficialização do nazismo e a subida de Hitler ao poder na Alemanha, iniciou-se o que no presente estudo se denomina a imigração judaico-alemã no Brasil e, em particular, no Rio Grande do Sul, entendendo-se como tal a que abrangeu judeus de fala e cultura alemã, incluindo, portanto, os provenientes de países pertencentes ao antigo Império Austro-Húngaro, desde que tenham emigrado premidos pela ascensão do nazismo.

\section{Caracterização}

Ao contrário de outros agrupamentos e levas imigratórias que vieram para o Rio Grande do Sul, a maioria dos judeus alemães que aqui chegaram não tinham tido sérios problemas até a ascensão de Hitler ao poder.

De um modo geral, pode-se dizer que os judeus que viviam na Alemanha, até a década de 30 do século XX, estavam profundamente integrados à vida e à cultura de seu país. Os do meio urbano, especialmente os das grandes cidades, tinham assimilado muito da cultura alemã, com a qual estavam profundamente identificados. Inseridos na sociedade alemã, dela participavam ativamente em todos seus aspectos: político, econômico, social e cultural. Possuídos de forte sentimento de pertencimento à Alemanha, consideravam-se cidadãos alemães antes de tudo. Diziam-se, numa tradução literal, cidadãos alemães de fé "mosaica" (e não judaica!). A religião judaica em geral desempenhava papel secundário em suas vidas, conforme se depreende da citação introdutória, extraída do contundente depoimento dado ao Instituto Cultural Judaico Marc Chagall por Herbert Caro, advogado e intelectual proveniente de Berlim, e que no Brasil se destacou como tradutor (de Thomas Mann, inclusive), como jornalista e crítico musical.

Já os do meio rural e os habitantes de pequenas cidades eram geralmente menos aculturados. Tinham, na sua maioria, menos anos de escolaridade, viviam mais fechados entre si embora não em guetos ou steitl e, comparados aos antes descritos, eram mais religiosos no sentido de que mantinham mais as tradições judaicas e praticavam os rituais littárgicos no seu cotidiano. 
Os primeiros judeus alemães fugidos do nazismo chegaram ao Rio Grande do Sul em 1934 e um número significativo aporta até 1937. No ano final da década e no início da seguinte continuam chegando, embora com menos intensidade. Poucos, durante e depois da guerra. Infelizmente, não há registro oficial de seu número. O levantamento da chegada progressiva desses imigrantes permite afirmar que chegaram cerca de quatrocentas pessoas nas décadas de 30 e 40, dentre elas algumas provenientes do antigo Império Austro-Húngaro. Não se trata de uma imigração grupal, incentivada pelo governo brasileiro ou por alguma organização judaica. É uma imigração em que uma família incentiva e "chama" a outra(s), por laços de família e/ou de amizade. O idioma alemão e a sobrevivência à perseguição decorrente da ascensão do nazismo são seus elementos de agregação. Forçados a sair rapidamente, os imigrantes judeus alemães, provenientes das mais diferentes regiões da Alemanha, com hábitos de vida diferenciados, têm um elo em comum, a língua alemã, embora com distintos dialetos. $\mathrm{O}$ iídiche era falado apenas por alguns que viviam na fronteira com a Polônia.

A maioria se radicou em Porto Alegre, a capital do Estado, morando no centro da cidade ou em outros bairros afastados, como Caminho do Meio, especialmente na Rua Ramiro Barcelos e imediações e Rio Branco, na zona chamada Colônia Africana, cercanias da Rua Castro Alves. Alguns, no vizinho bairro do Bom Fim, "afastado do centro da cidade no início do século XX, (...) o bairro de baixa classe média" (Kliemann, 1992, in: Brumer, 1994), onde se concentrava grande parte dos imigrantes judeus recém-chegados e os já aqui residentes. Poucos se transferiram posteriormente para outras cidades. Trata- se, pois, de uma imigração eminentemente urbana, ao contrário da que chegou ao Rio Grande do Sul no início do século, proveniente da Europa Oriental.

Uns embarcavam na Alemanha, em geral via Hamburgo; outros viajavam à Itália ou à França e lá tomavam um navio, os "Generais" (Osório, San Martin e Artigas) e os "Mont" (Sarmiento, Pascoal, Rosa). Desembarcavam no porto do Rio de Janeiro, no de Santos e, grande parte deles, no da cidade de Rio Grande, o principal porto marítimo do Estado, onde era feita a alfândega por intermédio do serviço de um despachante. Vinham geralmente na segunda de três classes e a viagem levava em torno de três semanas. Os que ainda tinham possibilidade financeira melhor vinham com o Cap Arcona, mais luxuoso e mais rápido, duas semanas. $\mathrm{Na}$ última viagem desse navio, em abril de 1939, veio Charlotte Laub com seus filhos Werner e Renate. Werner relata que naquela época o governo alemão não permitia mais a saída de bens materiais e pecuniários, a não ser utensílios domésticos de pequeno porte, inclusive objetos de prata e de cristal, além de 10 marcos em moeda corrente. A opção de viajar em cabinas de primeira classe era, portanto, um modo de empregar o dinheiro da família em benefício próprio em vez de perdê-lo. Em Rio Grande, eram recebidos por judeus que lá moravam ou por amigos e parentes, quando alguém desses já antes para cá emigrara. Algumas poucas famílias de judeus alemães, como os Wolff, os Scholem, os Strumpf, os Gomma, os Flesch, a Senhora Gans, os Michels, radicou-se na referida cidade. De Rio Grande a Porto Alegre, tomavam um navio menor, um "vapor" como se dizia na época: um Ira ou um da companhia marítima Lóide. Após uma viagem de um dia e uma noite, chegavam a seu destino. Pensões baratas, localizadas na zona portuária, foram o primeiro abrigo. A pensão "Moritz" situada à Rua Sete de Setembro, cercanias da João Manoel, é citada com carinho por muitos entrevistados, apesar das baratas, dos ratos e de outras experiências chocantes lá vivenciadas.

Um fato chama atenção de quem analisa a vinda desses imigrantes: o período no qual aqui aportaram. Nos primeiros anos parece ter havido certa predominância dos provenientes de pequenas aldeias rurais e de cidades menores, a sugerir como teriam sentido com mais intensidade, e talvez mais precocemente, os efeitos da política nazifascista. Assim, os que por último deixaram a Alemanha eram, em geral, os mais aculturados e atuantes na sociedade alemã.

Embora em seu país de origem fossem comerciantes de gado, atacadistas, lojistas, gerentes de banco, banqueiro, profissionais liberais, intelectuais, no Brasil as ocupações mais comuns foram as de representantes comerciais, comerciantes e prestadores de serviço. Poucos judeus alemães se tornaram mascates. Era alto o nível de profissionalização entre as mulheres, algo que no Brasil, na época, ainda não era tão usual. Isso talvez explique o fato de a maioria ter-se engajado rapidamente no mercado de trabalho, ainda que em ocupações diferentes das suas originais como, aliás, aconteceu com grande parte dos imigrantes.

Outro ponto a destacar refere-se ao nível educacional e cultural dos recém-chegados. Vários possuíam título universitário e, muitos, o curso 
secundário completo. No Brasil, alguns médicos, como Alexander Preger, Hugo Rottmann, Otto Goldberg, Siegfried Kronfeld, Walter Bouscher e Walter Silber, dentre outros, revalidaram seus diplomas. Talvez pela peculiaridade de sua profissão, pode-se dizer que o mesmo não aconteceu com os poucos advogados que para cá se transferiram. Provenientes de ambientes em que a música, a literatura e outras expressões artísticas faziam parte do cotidiano, procuraram incentivar seus filhos ao estudo, ao amor pelas manifestações artísticas, à obtenção de títulos universitários e à inserção em atividades liberais, acadêmicas, comerciais e industriais. Alguns frequentaram escolas estaduais e o Colégio Israelita, na época denominado Idishe Shule, mas a maioria foi matriculada em escolas particulares da cidade, ainda que fossem escolas confessionais, de custo elevado, como o Colégio Bom Conselho, de freiras, o Americano, metodista e o Farroupilha, escola alemã de orientação luterana.

\section{As dificuldades de entrar no Brasil \\ e o papel da SIBRA no processo de adaptação}

A história da imigração judaico-alemã pode ser caracterizada, para efeitos didáticos, por três momentos distintos diretamente ligados à política imigratória oficial do governo do então presidente do Brasil, Getúlio Vargas, que permaneceu no poder durante todo o período em que ela ocorreu: o primeiro até 1936, o segundo de 1937 a 1941 e o terceiro, a partir daquele ano.

No primeiro período, que denominamos o da abertura, até 1936, eram relativamente fáceis a entrada, a permanência e o trabalho no país. No Rio Grande do Sul já viviam, além dos alemães acima mencionados, judeus oriundos da Europa Oriental (Polônia, Bessarábia e Romênia), cuja vinda, nas primeiras décadas do século $\mathrm{XX}$, tinha sido patrocinada pela ICA gewish Colonization Association). De origem polonesa ou russa, falavam o iídiche, que a maioria dos judeus alemães desconhecia. Para Porto Alegre vieram também judeus vindos do norte da África, da Turquia e da Grécia que falavam o ladino.

Pode-se dizer que a imigração judaico-alemã começa, propriamente, em 1934, com a chegada a Porto Alegre da família de Max Stobezki, que veio com sua esposa Paula e suas duas filhas, Berta Ruth e Betti Gerda. Vieram para esta cidade porque aqui já vivia desde a década de 20 uma irmã de Max com sua família, emigrados da Polônia. Aqui instalados, os Stobezkis chamam a família Wirth, seus cunhados e sobrinho, e a família Warschawski, bons amigos da Alemanha. A essa, seguiram-se diversas outras, meses depois. Embora não todas, a maioria das famílias que iam chegando tinha algum grau de parentesco ou de amizade já na Alemanha. Esse pequeno grupo foi o núcleo que gerou a formação da comunidade judaico-alemã em Porto Alegre nos anos seguintes.

À medida que mais famílias fugidas da Alemanha nazista aqui aportavam, foi crescendo nelas a necessidade de conviver entre si. Esse sentimento fez com que, já nas primeiras Grandes Festas religiosas do ano de 1934, nos meses de setembro e outubro, elas se reunissem e as comemorassem na casa de Max Stobezki.

A necessidade de convívio social, de ter um lugar para rezar e para trocar experiências, levou essas famílias a reorganizar-se na nova terra. Nasce, assim, a SIBRA, Sociedade Israelita Brasileira de Cultura e Beneficência. As pessoas ouvidas no decorrer do projeto evidenciam que seus problemas de adaptação foram sensivelmente minimizados pela assistência que logo lhes prestava a SIBRA. Como entidade legalmente constituída, coube também a SIBRA representar e defender os interesses de seus associados perante o poder público, como na obtenção de vistos de entrada, de permanência e até de certidões de naturalização, uma vez que muitos requereram a cidadania brasileira. Além disso, a SIBRA dava seu aval em fianças.

Durante e após o processo de adaptação, a SIBRA funcionou para o imigrante como um "espaço de identidade" no sentido de um "espaço de pertencimento", onde sua identidade judaica pôde ser (re)construída. Foi, também, um "espaço agregador", de trocas afetivas, sociais e culturais. Foi um "espaço de e para ajuda mútua". Para lá era encaminhado desde o momento de sua chegada no porto. Acolhido, tivesse ou não dinheiro tinha assegurado um prato de comida, uma fiança em casos de hospitalização ou na compra de remédios, uma ajuda na procura de familiares e de uma atividade "profissional". Quem tinha pouco ajudava a quem não tinha nada. Além disso, foi um "espaço de reconstrução do self", onde recebia uma palavra de conforto, um conselho oportuno, uma mão amiga que o auxiliava na reconquista de sua autoestima perdida.

Nos anos compreendidos entre 1937 e 1941, que denominamos segundo período, a simpatia política do governo getulista e de diversos 
integrantes do alto escalão inclinava-se para as ditaduras nazifascistas. Isso se evidenciou através do estabelecimento de crescentes restrições e limitações impostas por dispositivos legais que, de modo explícito, dificultavam e até mesmo impediam a imigração judaica. Um deles, de 1937, estabelecia um novo sistema de cotas para a entrada de imigrantes no país, atingindo diretamente a imigração judaico-alemã, que se intensificava nessa época: apenas $20 \%$ do número de imigrantes de mesma origem que haviam ingressado no país entre 1844 e 1933 poderia vir a ingressar a partir da data de vigência desse dispositivo legal. Vistos de entrada brasileiros emitidos em países europeus foram dificultados. Scliar, em Caminhos da Esperança, à página 52, ressalta que "uma circular reservada foi mandada aos consulados brasileiros no exterior recomendando negar visto de entrada aos judeus". Essa circular secreta, de número 1127, foi enviada pelo Ministério do Exterior com autorização de Getúlio Vargas. Instruía os consulados a não darem vistos de entrada a judeus e seus descendentes, a não ser em casos de serem os requerentes capitalistas, industriais ou intelectuais de especial interesse para o Brasil (Lesser, apud Wolf, 1999, p.26). No entanto, há relatos de imigrantes atestando que alguns diplomatas, por seu espírito humanitário e desobedecendo a ordens superiores, salvaram suas vidas.

Nessa época, o imigrante já radicado no país podia obter autorização do governo brasileiro para a entrada de filhos e de pais ainda residentes na Europa, e apenas deles, mediante a comprovação do parentesco e do pagamento da taxa correspondente a um despachante. $\mathrm{O}$ documento oficial que permitia a vinda desses familiares era denominado Carta de Chamada. Sua obtenção constituía um problema para os imigrantes. Além de cuidar da sua própria sobrevivência, tinham que economizar para poder pagar a Carta de Chamada. Era, entretanto, o único modo de tentar trazer cada um dos familiares que ainda restavam na Alemanha, salvando-lhes as vidas. Como em geral vinha, primeiramente, parte da família - por vezes os jovens solteiros ou recém-casados - ou, só o marido, os demais aguardavam e muitos jamais aqui aportaram. Como se pode perceber, essas Cartas de Chamada, já existentes desde o começo do processo imigratório judaicoalemão, tiveram sua abrangência reduzida e sua obtenção dificultada pela legislação vigente durante este, que denominamos segundo período. Pela circular 1.249 do referido Ministério, datada de 1938, eram permitidas "chamadas de parentes até o segundo grau a serem feitas por judeus que morassem legalmente em território brasileiro" (Lesser apud Wolff, 1999, p.26), dentro de certo prazo. Frieda Wolff, em seu livro Nossas três vidas e outras histórias, relata experiências pessoais que teve nessa época. Entre elas, conta como a política antissemita do Itamaraty impediu a vinda e a salvação de milhares de pessoas.

A situação dos imigrantes no Brasil tornou-se ainda mais crítica com a promulgação da Constituição Brasileira de 1937. Depreciativamente alcunhada "polaca", tinha o autoritarismo e o centralismo como características principais, inspirada que foi nas Cartas fascistas da Itália e da Polônia. O regime político daquela época, encabeçado por Getúlio Vargas, ficou conhecido na história como o "Estado Novo". Correspondia à tendência de boa parte das nações de desprezar os valores liberaldemocráticos por considerá-los incapazes de promover o bem-estar coletivo. Seu objetivo declarado, o de restaurar a autoridade nacional e de garantir o poder do Estado contra a ação desagregadora do privatismo e do regionalismo, exacerbou o nacionalismo.

Nesse segundo período, se fortalece a chamada Ação Integralista Brasileira, entidade política que pretendia a implantação de um sistema de governo de cunho antidemocrático. Seus membros usavam uniformes verdes, promoviam desfiles e saudavam a moda romana, como os nazistas e fascistas o faziam. Eram bem organizados e atuantes. A propósito, Grete Bejzman conta como seu pai Max Blumenthal, ao assistir a um desfile de integralistas em Porto Alegre, em plena Avenida Oswaldo Aranha, uma das mais movimentadas da cidade e a principal do Bairro Bom Fim, onde se concentrava a comunidade judaica, ficara chocado e aterrorizado. A semelhança entre os desfiles dos integralistas com os espetáculos nazistas era evidente, o que levou Max a exclamar, textualmente: O que eu vim fazer aqui?

Getúlio Vargas procurou manter o Brasil em posição de neutralidade na II Guerra Mundial, iniciada em 1939, e com isso obter vantagens econômicas para o país. Para comprovar sua isenção, seu ministério era composto tanto por simpatizantes do Eixo como por defensores dos Aliados.

Em 1941, o Brasil, por pressões econômicas passa a integrar o bloco dos Aliados. A borracha brasileira e a base aeronaval no litoral do Rio Grande do Norte foram, entre outras, as portas de entrada do capital financeiro americano necessário à construção da usina siderúrgica de Volta Redonda, a primeira do Brasil. Em represália, os submarinos alemães afundaram vários navios brasileiros, causando mais de 600 mortes. Em 
1942, ocorreram manifestações populares em todas as grandes cidades brasileiras pedindo vingança, o que levou o governo brasileiro a declarar guerra aos alemães e seus aliados. Inicia-se, assim, o terceiro período, que, além de se caracterizar por importantes restrições impostas aos imigrantes judeus alemães, traz à tona o dilema do que denomino como a "pseudodupla identidade" ou a "não identidade".

A SIBRA, nesta ocasião também se manifesta. Em 12.12.1940, o governo federal editou um decreto que exigia que dois terços dos diretores de instituições devessem ser brasileiros Por força dessa disposição legal, foi mudada a composição da direção da SIBRA ainda que com certa dificuldade, já que eram poucos os judeus alemães que à época eram naturalizados. Em ofício de 24 de agosto de 1942, endereçado ao General Valentim Benicio da Silva, então comandante da $3^{\text {a }}$ Região Militar, a diretoria se solidariza com a posição do governo, manifesta seu propósito de "... contribuir com todas as suas forças para o mais completo êxito da Nação e das armas brasileiras" e oferece "os serviços de todos os seus sócios ainda fisicamente aptos para a defesa do Brasil, colocando-os à disposição do exército brasileiro", além de enumerar algumas de suas profissões. Desnecessário dizer que o governo não os aceitou.

\section{Identidade judaica: preservação ou ruptura?}

Entre as medidas restritivas impostas no Brasil aos súditos do Eixo, os imigrantes provenientes da Alemanha, Itália e Japão, havia limitação ao direito de ir e vir dentro do país sem uma licença especial e a proibição de usar, em lugares públicos, sua língua materna. Por isso, para a população enfurecida, falar uma dessas línguas já era suficiente para ser considerado inimigo do Brasil. Durante algumas manifestações em Porto Alegre houve, inclusive, quebra de lojas e locais cujos proprietários eram de origem alemã, italiana ou japonesa.

Nessa época, os imigrantes judeus alemães, que já tinham chegado a um bom convívio com a sociedade local, passaram outra vez por humilhações e constrangimentos. Por um lado, não tinham mais a cidadania alemã cassada por Hitler; por outro, ainda não tinham conseguido a nacionalidade brasileira. E muitos deles, especialmente os mais idosos, continuavam a falar alemão. Essa situação levou-os a sentirem-se de novo cerceados. Um fato, relatado por diferentes entrevistados, ficou marcante na vida da comunidade. Certa noite meia dúzia de sócios, na sua maioria idosos, jogavam o Skat, tradicional jogo de cartas trazido da Alemanha e falavam alemão durante a fase do "leilão" do jogo, na sede da SIBRA. Devido à denúncia anônima feita por um vizinho, a polícia, que exercia o controle com extremado rigor, invadiu a sede. Entendendo que a vinda da polícia era por causa do uso do alemão, passaram rapidamente a traduzir todas as palavras do leilão do jogo para o português. Não obstante, a polícia prendeu os participantes como se fossem criminosos de alta periculosidade. Era véspera de Iom Kipur, o Dia do Perdão, o feriado religioso mais importante do calendário judaico. Entre os presos estava Max Blumenthal, o Chazan (cantor sacro) da comunidade e que no dia seguinte deveria conduzir as rezas durante o serviço religioso, o que provocou uma comoção em todos. Convalescente de prolongada doença, o tifo, e por morar com sua família no mesmo endereço, obteve uma cela "especial", a dos presos comuns. Tremendamente humilhado, chegou em casa apenas algumas horas antes do início do Iom Kipur e chorou como uma criança, segundo o depoimento sua filha, que conclui: "Aquela deve ter sido a reza de $\mathrm{Kol}$ Nidre ${ }^{2}$ mais emocionada de sua vida."

A limitação do direito de ir e vir era um problema para os judeus alemães, vistos como "súditos do Eixo". Para se deslocar de uma cidade a outra tinham necessidade de obter uma permissão, o chamado SalvoConduto Especial para estrangeiros, documento expedido pela Delegacia de Ordem Política e Social da Repartição Central de Polícia. Essa exigência tolhia o trabalho de muitos judeus alemães que, em sua maioria, provia o sustento da família. Era intransferível por conter a foto de seu portador e a permissão especial para viajar especificava o ponto de origem e o de chegada. A cada outro destino, novo salvo-conduto precisava ser emitido. Sua apresentação podia ser exigida a qualquer momento. Geralmente ocorria quando os imigrantes, com sua maleta de trabalho, se deslocavam usando ônibus de linha regular, mesmo que o destino fosse cidade próxima a Porto Alegre. Em destaque, com letras maiúsculas, como a indicar um certo temor das autoridades com entradas e saídas ilegais do país, lê-se no documento o seguinte, respeitando na transcrição a grafia original: "O presente salvo-conduto não pode ser visado ou revalidado para as

${ }^{2}$ Reza que inicia o serviço religioso no anoitecer da véspera de Iom Kipur. Repetida três vezes em volume cada vez mais forte, costuma comover as pessoas pelo chamamento que faz ao necessário arrependimento dos maus atos praticados durante o ano findo. 
localidades da fronteira ou litoral", para inibir a entrada ilegal de imigrantes no país. Essa exigência tolhia o trabalho de muitos judeus alemães que, em sua maioria, provia o sustento da família.

As palavras de Herbert Caro, em seu discurso de agradecimento na Câmara de Vereadores pela outorga do título de Cidadão Emérito de Porto Alegre, evidenciam claramente o sentimento decorrente desta "pseudodupla identidade":

Minha situação era semelhante à dos metecos da Grécia antiga, que eram tolerados, podiam negociar em Atenas ou Corinto, mas não tinham direitos de cidadania e corriam o risco de serem expulsos a qualquer instante. Essa minha situação tornou-se-me dolorosamente clara, quando o Brasil entrou na II Guerra Mundial. Foi a única vez que ele me magoou. Pois, apesar de minha própria guerra conta Hitler ter começado muito antes de 1942, o Governo brasileiro equiparou-me aos nazistas, porque entrei no país com um passaporte alemão. Ao mexer em documentos amarelados pelo tempo, encontrei há pouco numa e na mesma pasta dois, um tanto contraditórios: num deles, o Secretário de Justiça da Prússia comunicava-me em abril de 1933, a proibição de continuar advogando, com as lacônicas palavras que traduzo textualmente: "porquanto é de origem não ariana"! E no outro, provido de minha fotografia e assinatura, a Polícia desta Capital dava-me a "permissão especial" de afastar-me por um dia de janeiro de 1945 do Município de Porto Alegre, afim de participar de um churrasco em Guaíba, e me fazia essa concessão complacente, apesar de eu ser um "súdito do Eixo Berlim-Roma-Tóquio"! Estigmatizado, perseguido, enxotado pelo país que me dera refúgio assim passei vários anos, sempre temendo que confiscassem minha biblioteca ou até me trancafiassem sob algum pretexto. Há algumas semanas, ouvi neste recinto como um ilustre vereador proclamava o axioma: "Todos os homens têm direito a uma nacionalidade." Ora, eu não tinha nenhuma!"

Evidenciam-se várias contradições no comportamento do imigrante judeu alemão, quanto a sua identidade judaica. Há por um lado, um movimento de reaproximação ao judaísmo. Práticas e ritos religiosos não realizados na Alemanha passam a ser valorizados, ainda que realizados através de inúmeros conflitos internos entre os sócios da SIBRA. Verifica-se um envolvimento efetivo com a comunidade judaica da cidade e, em especial, com a da SIBRA. Vários se tornam ativistas nas organizações sionistas; são fundadores da primeira loja da B'nei Brith e na SIBRA nasce a ideia e dela saem os fundadores do Lar dos Velhos judaico, denominado Dr. Maurício Seligman. É a SIBRA que lhes fornece o que nos primeiros tempos é seu único documento de identidade: uma carteirinha de sócio. Sua importância é incomensurável, pois além de apresentar os dados pessoais, atesta que o portador é sócio de uma instituição israelita e, portanto, não se trata de um nazista, embora o forte sotaque alemão. Por outro lado, preserva o uso do idioma alemão em seus lares, obrigando a nova geração a aprendê-lo. Os filhos são colocados, preferencialmente, na escola alemã da cidade, ainda que isto signifique um alto gasto financeiro. No seu cotidiano mantém hábitos e costumes trazidos da velha pátria. As atas da diretoria, bem como as circulares de publicação interna são escritas em alemão até a década de 60 . Nos serviços religiosos usa livros sacros escritos em hebraico, traduzidos para aquele idioma, entoa melodias compostas por Levandowsky e nas rezas a pronúncia hebraica é mantida conforme feita na Alemanha. Se, por um lado, há um movimento forte na direção da integração à sociedade brasileira (aulas de português são ministradas aos sócios da SIBRA desde o início de sua fundação, biblioteca é ativada), por outro lado percebe-se forte ligação com tudo que tenha a ver com a vida levada no país de origem. Se, por um lado há um movimento no sentido de resgatar e preservar a identidade judaica, existe, paralelamente, uma dificuldade de romper com os valores da cultura alemã. A questão que se coloca é: Imigração ou exílio? O sentimento de ruptura, talvez, leve algumas gerações para ser elaborado.

\section{Outras dificuldades na adaptação}

Além das dificuldades impostas pelo governo, os judeus alemães tiveram que enfrentar outros problemas. Logo nos primeiros anos, muitos contraíram doenças graves. O tifo foi a pior delas. Alguns óbitos foram registrados e famílias inteiras foram contaminadas. Organismos desacostumados com o novo meio ambiente passaram por um longo período de adaptação. Tudo era novo e constituía um desafio: o clima; o vestuário inadequado; os alimentos, muitos deles desconhecidos; a composição química da água diferente; os hábitos higiênicos, só para citar alguns.

O convívio com os judeus de outras procedências que já aqui estavam radicados nem sempre foi muito fácil. Preconceitos originados na Europa; culturas, idiomas, ritos e costumes religiosos diferentes foram 
alguns dos obstáculos a serem vencidos. Porém, o auxílio que aqueles prestaram, geralmente por iniciativa individual, certamente contribuiu para uma melhor adaptação dos judeus alemães à nova terra.

Toda leva imigratória, durante seu processo de adaptação enfrenta problemas mais ou menos comuns. Dificuldades, umas menores, outras maiores, precisam ser superadas. Assim aconteceu com os judeus alemães. Como se viu até agora, a peculiaridade dessa imigração foi o motivo que a ocasionou e a premente necessidade que tiveram seus integrantes de, a par de tratar da sua própria sobrevivência, auxiliar seus familiares a sair da Alemanha para escapar da morte. Forjou-se, entre eles, um elo muito forte, talvez único: solidários, conseguiram vencer as barreiras.

No final da década de 30 e no início da de 40 ocorre o nascimento da primeira geração de judeus alemães gaúchos. Estes, assim como seus pais e avós, com o passar dos anos, integram-se paulatinamente à sociedade gaúcha e brasileira. Frequentam escolas e universidades, assumem atividades profissionais nas mais diferentes áreas, destacando-se no cenário estadual e nacional.

\section{Referência Bibliográfica:}

BECKER, Klaus. Os judeus alemães no tempo do Império. In: / Simpósio do Sesquicentendrio da Imigração Alemã. São Leopoldo, 1975.

BLUMENTHAL, G.W (org.). Em terras gaúchas: a história da imigração judaico-alemã. Porto Alegre: SIBRA, 2001.

BRUMER, A. Identidade em mudança: pesquisa sociológica sobre os judeus do Rio Grande do Sul. Porto Alegre, Federação Israelita do Rio Grande do Sul, 1994.

CARNEIRO, M.L.T. Brasil, um Refúgio nos Trópicos. São Paulo: Estação Liberdade, 1996.

CARO, Herbert et al. SIBRA - Sociedade Israelita Brasileira de Cultura e Beneficência. Brochura comemorativa ao $500^{\circ}$ aniversário da SIBRA. Porto Alegre: Ética, 1986.

COTRIM, Gilberto. História e Consciência do Brasil. São Paulo: Saraiva, 1996..
História Global. Brasil e Geral. São Paulo: Saraiva, 1999.

DEPOIMENTOS ORAIS espontâneos de imigrantes e de seus descendentes.

INSTITUTO CULTURAL JUDAICO MARC CHAGALL. Entrevistas do acervo. Porto Alegre, Rio Grande do Sul.

PHILIPPI, Bruno. Denkschrtft zur Erinnerung an die Grundung bis zum 25 jdhrigen Jubileum. Publicação de circulação interna. Porto Alegre: 1961 [datil.)

SANTOS, Ana M., NEVES, Guilherme P. et al. História do Brasil. São Paulo: Enciclopédia Interativa CD-ROM ATR, 1998.

SCLIAR, M. Caminhos da Esperança: a presença judaica no Rio Grande do Sul. Porto Alegre: Pallotti, 1990.

SIBRA - SOCIEDADE ISRAELITA BRASILEIRA DE CULTURA E BENEFICÊNCIA. Entrevistas do Acervo. Projeto: A História e a Contribuição da Imigração Judaico-Alemã à Cultura $e$ ao Desenvolvimento do Estado do Rio Grande do Sul. Porto Alegre, 1998 a 2001. SIBRA-BRASIL/MC/SAC/PRONAC.

WOLFF, Frieda e WOLFF, Egon. Nossas três vidas e outras histórias. Rio de Janeiro: Sete Letras, 1999. 


\section{Resiliência, judaísmo e cultura organizacional}

Izabella Lucena ${ }^{1}$

\section{Introdução}

- ste artigo refere-se à experiência que foi compartilhada com os demais membros do III Encontro Brasileiro de Estudos Judaicos sobre a proposta que havia sido apresentada ao Curso de Mestrado do Programa de Pós-graduação em Antropologia da Universidade Federal de Pernambuco, para realizar um trabalho de pesquisa sobre inter-relações entre Resiliência Humana, Judaísmo e Cultura Organizacional.

Por tratar-se de temas relativamente novos (resiliência e cultura organizacional) no campo da Antropologia, enfocou-se, durante a apresentação, pontos explicativos sobre os porquês de reunir tais assuntos em um mesmo trabalho e alguns pontos teóricos, substancialmente importantes para o entendimento dos conceitos, bem como a respeito de como estes seriam abordados na pesquisa que estava para se desenvolver. Desse modo, em virtude da necessidade de não ultrapassar o limite de laudas recomendado para publicações como a presente, será apresentada nesta ocasião, resumidamente, parte do arcabouço teórico que fundamentava a pesquisa. Contudo, ficarão explicados os passos condicionantes para a elaboração do projeto e, ainda, as partes nas quais deveria se dividir o trabalho.

A minha experiência com organizações na área de recursos humanos, somada a alguns conhecimentos adquiridos a partir dos estudos que desenvolvi sobre o judaísmo e a participação dos judeus na formação econômica, étnica e cultural do Brasil, mais particularmente em Pernambuco, desencadeou uma série de questões que me levaram a tal pesquisa.

${ }^{1}$ Para Joël de Rosnay, o homem simbiótico é o homem do futuro: um ser em estreita simbiose com um organismo planetário, o cibionte; um macro-organismo constituído pelo conjunto dos homens e de suas máquinas, das nações e das grandes redes de comunicação. Trata-se de uma metáfora que ele utiliza para iluminar novas práticas, como perspectiva para o terceiro milênio.
Por que os judeus, pressionados pelas diásporas, não se diluíram no mundo como grupo étnico-cultural? Era uma das perguntas que ansiava por respostas. Partindo do geral em direção ao particular, pretendia entender, também:

Como os imigrantes judeus, que formam a atual comunidade do Recife, e suas gerações subsequentes conseguiram sair das bordas sociais, fundar e consolidar-se em organizações empresariais, participando ativamente das instâncias formadoras do Estado?

Para responder a essas indagações, seria necessário identificar, numa densa rede de elementos, inter-relações de influência mútua existentes entre:

- as características básicas da Resiliência identificadas por Conner (foco, flexibilidade, pró-ação, positividade e organização);

- preceitos fundamentais da tradição judaica;

- ritos e cerimônias praticados pelos membros dessa comunidade; fatores apontados como elementos básicos para a continuidade do grupo que se autodenomina judeu.

Com a hipótese levantada de que o fator resiliência estava implícito nas possíveis respostas às duas primeiras perguntas, uma outra se estruturou:

Até que ponto a resiliência apresentada por essa comunidade está impressa na cultura de uma empresa liderada por alguns de seus membros, atuando como fator de equilíbrio e desenvolvimento frente às mudanças sofridas e implementadas?

Eram muitas as questões. À medida que o interesse era saber sobre a capacidade de resiliência de um determinado grupo, bem como seus efeitos na esfera individual e na cultura de uma empresa, vislumbrava também enfocar a dimensão antropológica da dinâmica catalisadora de um grupo etnicamente diferenciado dentro da maioria em que está inserido.

Para o desenvolvimento do trabalho algumas etapas precisavam ser cumpridas. Primeiro, seria necessário defender teoricamente a importância da ligação entre os temas - resiliência, judaísmo e organizações.

A segunda etapa caracterizar-se-ia pela busca de se compreender como as experiências vividas pelos judeus, ao longo da história, intensificaram a capacidade básica da resiliência dessa coletividade, instaurando no 
imaginário, através da transmissão cultural e relações sociais, elementos alimentadores do comportamento resiliente, ação que teria por objetivo defender o conceito de resiliência judaica. Um panorama sobre a trajetória do povo judeu ao longo da história deveria ser montado, objetivando destacar as respostas apresentadas pelo grupo em questão frente às adversidades. Nessa etapa, seriam comparadas as cinco características básicas da resiliência, segundo Conner, com alguns preceitos fundamentais, festividades e fatores de continuidade da coletividade judaica.

A terceira concentrar-se-ia na necessidade inicial de contextualizar a atual comunidade do Recife, o que significaria: percorrer as causas que motivaram a migração; a fase de integração e adaptação à nova sociedade receptora, principalmente como está hoje organizada. Em seguida, um estudo de um caso seria desenvolvido, sobre uma pequena empresa familiar, do ramo da Construção Civil, fundada e dirigida por judeus, membros da comunidade recifense e filhos de imigrantes, para identificar relações entre a resiliência judaica e a cultura corporativa. E, finalmente, seriam apresentadas as considerações a respeito das possíveis descobertas.

Com o trabalho, pretendia oferecer passos, ainda que pequenos, que pudessem contribuir para se pensar a multifacetada subjetividade das culturas das organizações, bem como da resiliência humana, numa perspectiva transdisciplinar, em que a Antropologia, a Psicologia, a História, a Administração e outras áreas afins, que mescladas, gerassem um enriquecimento necessário a novas práticas.

\section{A ligação entre os temas}

\section{Pesquisando a Resiliência}

A resiliência - um dos mais novos objetos de estudo das Ciências Sociais e Humanas - já sofreu algumas interpretações equivocadas, possivelmente por ter sido um termo importado da Física, originalmente referindo-se à resistência dos materiais. Aplicado ao comportamento humano, esse conceito apresenta complexidade, ou, resumidamente, pode ser entendido como: a capacidade humana universal para lidar com as adversidades, que, por sua vez, nos possibilita atuar com flexibilidade frente aos percalços e condições de mudança e reverter situações ameaçadoras em oportunidades para soluções criativas e elaborações construtivas.
Pesquisas sobre resiliência têm sido desenvolvidas na Inglaterra, nos Estados Unidos e no Canadá há cerca de 20 anos, de forma mais especulativa, e mais especificamente, há dez anos. Esses estudos, na maioria das vezes, voltam-se para o desenvolvimento emocional de crianças e adolescentes em condições de adversidade ou risco. Nos países andinos, em Portugal e no Brasil, nessa linha de abordagem, as investigações não datam de mais que cinco anos, em média. As áreas que demonstraram maior interesse pelo tema foram a de educação e a de projetos sociais. Essa realidade, pelo caráter embrionário e restrito, justifica parte da motivação para desenvolver esta pesquisa no contexto de uma organização.

As leituras e observações, a partir da prática psicoterápica com adultos e de consultoria organizacional na área de Recursos Humanos, permitiram-me entender que a propriedade da resiliência, tanto como característica individual, como corporativa, faz grande diferença no desempenho das pessoas e das empresas diante das situações conflitantes de crise e mudança.

As pesquisas sobre resiliência, no atual contexto mundial, caracterizado pela acelerada velocidade das mudanças, grandes quebras de paradigmas e vertiginosas curvas, inversamente proporcionais, dos avanços tecnológicos (crescentes) e do processo de humanização (decrescente), em que a lógica da competitividade destrói a da solidariedade, evidentemente ganham relevância acentuada. Elas podem oferecer dados valiosos para uma tomada de postura reflexiva sobre uma perspectiva social mais justa, na qual ganhar não implique necessariamente ter de destruir o concorrente e em que as estratégias organizacionais permitam e estimulem resultados compensatórios, estabelecendo compromissos ético-sociais.

Em 1807, o cientista inglês Thomas Young (conhecido como precursor da noção de resiliência na Física), já estudava as relações entre a força exercida sobre um material e a deformação que esta produzia (Tavares, 2001:15). Com a continuação das pesquisas, passou a ser possível se avaliar o grau de resiliência de um material a partir da capacidade que este tinha de retornar ao estado normal quando suspensa a pressão anteriormente exercida.

A aplicação desse conceito às experiências humanas realizadas pela Sociologia, Psicologia ou Medicina se trata de uma proposta recente, contudo vem ganhando importante legitimidade como suporte de medidas 
preventivas, sobretudo por priorizar a parte "sã" das pessoas, estimulando seus potenciais para atingir uma melhor qualidade de vida.

Nas últimas cinco décadas, a humanidade foi levada a enfrentar mais mudanças que nos últimos cinco séculos. A capacidade de criação da mente humana tem sido maior que a habilidade para assimilar os resultados de suas próprias invenções. Diante de tantas informações e exigências, em tão curto espaço de tempo, ficamos desnorteados, consequentemente deparamonos com o que Alvin Toffler chamou de "Choque do Futuro". A quantidade de mudanças sobrepostas imprime em nossa realidade uma natureza nebulosa e caótica, o que nos faz parecer impotentes diante delas.

É importante ressaltar que não estou me referindo à mudança. Sobre o assunto, Herádito já discutia na Grécia Antiga, lembrando que "nenhum homem põe o pé duas vezes no mesmo rio". D. Helder Câmara, 2400 anos depois, aproximadamente, defendia: "é preciso mudarmos muito para continuarmos os mesmos" (1989: em conferência). A mudança, longe de ser uma novidade, é uma condição imposta à vida. Estou me referindo, sim, à velocidade com que ela se processa e à complexidade de sua ressonância. "O mundo está mudando tão rapidamente que a confusão e a disfunção tornaram-se mais a regra do que a exceção" (Conner,1995:29).

Diante desse cenário, alguns atributos da resiliência tornam-se habilidades fundamentais para o modus vivendi atual, no qual a grande maioria dos humanos está inserida:

- $\quad$ capacidade para enfrentar situações novas, planejadas ou não;

- recuperar-se mais rapidamente após os impactos iniciais das mudanças;

- sair fortalecido de uma experiência adversa;

- visualizar oportunidades, apesar das limitações opressoras;

- encontrar soluções ecologicamente comprometidas;

- preservar uma qualidade de saúde física e emocional, mesmo durante as crises.

Essas qualidades estão explícitas em muitas das definições de resiliência apresentadas por importantes pesquisadores da área.

Pelas conceituações fornecidas, pode-se entender a resiliência como uma capacidade humana universal, sendo mais ou menos desenvolvida em cada pessoa, através de estratégias específicas. No entanto, não significa técnicas simplistas, como: pequenos estímulos para respostas imediatas.

Desenvolvê-la implica em transformação no modo de pensar, alteração na forma de perceber a realidade, para, então, atingir consequentes mudanças de atitudes, e isso demanda tempo e dedicação. Existe uma ideia, geralmente compartilhada pelos estudiosos sobre a resiliência, de que buscar desenvolver a própria resiliência e ajudar pessoas e organizações a serem cada vez mais resilientes é um dos caminhos, não só para enfrentarmos as adversidades e as mudanças que se impõem à nossa trajetória, mas também para promovermos as mudanças em direção à construção de um espaço planetário, onde seja possível integrar as diferenças, respeitando-as. Um mundo em que a diversidade étnica, social, cultural, política, econômica, religiosa, ideológica, ou de qualquer outra natureza, faça mais sentido, ao invés de apenas conflitos infrutíferos ou destrutivos. Finalmente, onde a nebulosa caótica que parece nos devorar possa ser percebida como base plena de oportunidades para uma nova ordem. "A nova cultura do homem simbiótico' é um dos catalisadores do futuro" (Rosnay, 1997:350).

Uma utopia realizável (...) uma utopia destinada a dar sentido às nossas ações cotidianas com o objetivo de construirmos juntos o mundo de amanhã (apud, 1997:12).

\section{Pesquisando a Resiliência na Cultura Judaica}

A opção por pesquisar a resiliência no contexto da cultura judaica foi impulsionada pelos estudos que desenvolvi como pesquisadora do AHJPE (Arquivo Histórico Judaico de Pernambuco) e do GIEJ-PPGA (Grupo Interdisciplinar de Estudos sobre Judaísmo do Programa de Pós-Graduação em Antropologia da UFPE), através dos quais, além de ter-me aprofundado nas leituras sobre a presença judaica em Pernambuco, pude manter contato com muitos membros da comunidade, o que facilitou imensamente o meu acesso para a realização deste trabalho.

As categorias "mudança" e "continuidade", que são intensamente recorrentes em toda a trajetória histórica dos judeus, demonstram que a sobrevivência deles está marcadamente atrelada às soluções adaptativas encontradas em sua dinâmica enquanto coletividade. 
O acervo étnico-histórico-cultural, resultante das experiências de séculos de diásporas vivenciadas pelos judeus, mostra-nos, sem economia, um vasto repertório de respostas dadas às adversidades enfrentadas, que não são apenas individuais, mas, sobretudo, coletivas. Foram elaboradas com o propósito de garantir a sobrevivência, contudo implícito estava o caminho para a preservação da coletividade étnica, religiosa, cultural, mesmo inserida em outras sociedades e envolvida em "fricções interétnicas" (Oliveira, 1976:06).

Isso leva a acreditar que, possivelmente pode ter havido um particular desenvolvimento da resiliência básica desse grupo, haja vista a flexibilidade integrativa apresentada. Além disso, a resiliência, como competência inconsciente, ao tornar-se parte do patrimônio cultural, teria sido transmitida de geração a geração, através das relações sociais, resguardadas, obviamente, as devidas proporções desse incremento em cada comunidade e face aos diferentes modos com que se distribuíram no tempo e no espaço e aos variados contatos e conflitos interétnicos permitidos pelo caráter recursivo de perseguição.

Um possível estranhamento a essa suposição pode ser minimizado por algumas respostas plausíveis à seguinte indagação:

Por que os judeus, que praticamente viveram sempre como uma minoria, rejeitada e perseguida, inclusive exposta ao extermínio programado, não se comportaram como vítimas incompetentes à auto-organização?

As respostas até hoje não são suficientemente satisfatórias nem capazes de abranger toda a subjetividade que a questão envolve. Todavia isso não impede de abordar possíveis fatores condicionantes à postura que eles assumiram.

Os atributos concernentes às características básicas da resiliência positividade, foco, flexibilidade, organização e pró-ação - (Conner, 1995: 209-211) são facilmente identificáveis, quando se aprofunda o estudo do judaísmo. Essas características desempenharam um papel preponderante no processo de aculturação, integração e sobrevivência dos judeus e, particularmente, dos imigrantes que deram origem à comunidade que iria compor o universo da pesquisa, como apontam as pesquisas de Kaufman (2000: 189-195)
Destarte, adotei o termo Resiliência Judaica para me referir à manifestação da resiliência através das respostas coletivas apresentadas por esse grupo. $\mathrm{O}$ termo proposto engloba um conceito popularmente conhecido entre os judeus como Judische Kopf ou ídiche Kop, que, literalmente, significa "Cabeça de Judeu”. Essa expressão é utilizada para caracterizar a condição na qual há uma pressão sobre o indivíduo, que, encurralado, é capaz de reverter a situação e recontextualizar-se (Bonder, 1995:08), capacidade que expressa sua força na atitude do não desistir, mesmo diante de situações aparentemente impossíveis. Considera sempre a possibilidade de sobrevivência e de respostas criativas baseadas numa forma inovadora de perceber a realidade, o que se relaciona diretamente com o conceito de resiliência.

\section{Pesquisando a Resiliência Judaica nas Organizações}

As organizações vistas como cultura ou portadoras de uma cultura específica são importantes veículos de fomentação do conhecimento antropológico. Todavia, a impressão que se tem é de que a Antropologia tardou a compreender o quão fértil é o terreno das organizações, como objeto de investigações etnográficas.

O antropólogo Pedro Jaime Jr., entretanto, lembra que a "tentativa" de aproximar a Antropologia e as organizações não é tão recente como parece. Ele rememora que, já no início do século XX (entre o final da década de 20 e o início da década de 30), existiu tal aproximação, decorrente do chamado "Estudo de Hawthorne", coordenado por Elton Mayo e com a contribuição das teorias de Radcliffe-Brown e Malinowski. Contudo, já por volta da década de 50, muitos antropólogos americanos, que haviam se aproximado das organizações, foram abandonando a área, movidos pelo "tabu" predominante da época: não eram considerados como "verdadeiros antropólogos" os que se dedicavam a esses estudos, pois o que parecia ser o objeto de estudo antropológico eram as "sociedades primitivas". No início da década de 80 , a Antropologia americana retorna às pesquisas etnográficas em empresas públicas e privadas (Jaime Jr.,1996:106). No século atual, o antropólogo Guilhermo Ruben, coordenador do estudo pioneiro no Brasil sobre as organizações complexas, confessa que ainda enfrenta, o que não chega a ser uma hostilidade, um certo ceticismo por parte dos colegas antropólogos sobre essa área de pesquisa (Nassif, 2002:73). 
Alguns conceitos clássicos da Antropologia, como cultura, mito, parentesco, representações e gênero, passaram a interessar às pesquisas da Administração de Empresas. Dedicar atenção às empresas, vendo-as como uma organização de pessoas que se relacionam, se desenvolvem e compartilham pressupostos, crenças e valores particulares, foi fundamental. Porém, por terem sido estudos inicialmente desenvolvidos, de certa forma, alheios à disciplina de origem (a Antropologia), alguns deslizes foram cometidos com relação à incapacidade de atentar para as devidas relativizações e possíveis variações interpretativas e aplicativas dos modelos culturais pesquisados.

Quando, na década de 70, começa a se tornar explícito o sucesso do Japão - um país com absurdas perdas decorrentes da II Guerra Mundial surge, nos EUA, que se sentiam ameaçados, uma sede perturbadora, por entender o então chamado "Milagre Japonês". Iniciam-se investimentos em pesquisas e desenvolvimento de publicações sobre a administração japonesa. Surgem os best-sellers da administração que passam a orientar, como gurus, os modelos de gestão, quase todos criados sob o contexto do universo americano e com pretensões de aplicabilidades universais, desconsiderando questões como a de que o sucesso japonês estava relacionado à especificidade da sua própria cultura.

Faz-se necessário considerar que, incutido nos modelos que se passou a "comprar", surgiu "embalado", um conjunto de implicações conceitual, teórica e metodológica que, na maioria das vezes, se tornaram inadequadas à sua aplicabilidade numa outra realidade nacional ou, simplesmente, em uma outra organização.

la cultura aparece como una forma de ser, de percibir y de percibirse, una manera de sentir, de expresarse y de ser creativo dentro de las coordenadas organizativas. La estrategia de una empresa cara a su evolución y posible desarrollo debe tener muy en cuenta los parámetros cultura/es propios. No todo modelo que tratamos de implantar porque ha dado resultado en otros ámbitos empresariales puede ser eficaz en el mastro (Gasalla, 2000:89).

Não se pode esquecer que as organizações são hoje o grande palco das transformações mais evidentes no cenário global. Os produtos desenvolvidos podem alterar o meio ambiente, transformar nossa estrutura biológica, modificar nossas relações interpessoais, acelerar nossa destruição, garantir nossa sobrevivência, enfim, podem gerar potentes resultados para a nossa preservação ou para o nosso extermínio.

É importante refletir sobre os fracassos dos resultados de planejamentos que não levaram suficientemente em conta o componente cultural das organizações, tentando implementar puras transferências de projetos e estratégias. Grandes fusões e expansões de multinacionais têm gerado enormes perdas, tanto econômicas como sociais, mesmo quando "tudo" indicava que o plano parecia perfeito.

Para ilustrar essa perspectiva, pode-se contar com os resultados da pesquisa coordenada por Edwin Black, os quais comprovaram como uma ideologia política pode mobilizar os interesses econômicos da cultura de uma empresa e como estes podem ser devastadores para a sociedade. $\mathrm{O}$ trabalho relata, com riqueza de detalhes, como foi o caso da participação da IBM nas estratégias nazistas, que, ao desenvolver um "grande avanço tecnológico", as máquinas Hollerith, ofereceu meios para identificar os judeus que seriam exterminados aos milhões, graças à tecnologia "fabricada sob medida para o cliente". Sem dúvida o desenvolvimento econômico da empresa foi enorme, mas as consequências para a humanidade foram assombrosas.

Os detalhes sórdidos, ou maravilhosos, que podem brotar das organizações, dependem diretamente da cultura com a qual compartilham os seus componentes. Essa é uma outra questão que torna relevante o olhar antropológico sobre as culturas das empresas.

\section{Duas abordagens fundamentais}

\section{Pensamento Complexo para Problemas Complexos}

$\mathrm{O}$ recorte para a operacionalização da pesquisa dar-se-ia no meio da atual comunidade judaica de Pernambuco, um grupo que traz as marcas de uma descendência que, ao mesmo tempo, viveu bastante dispersa e coesa; paralelamente muito sofrida e alegre; e simultaneamente rejeitada e incluída.

Diante desse antagonismo presente no grupo escolhido, entende-se que os fenômenos enfocados são de natureza complexa. Compreender como os judeus e a cultura deles sobreviveram a terríveis fatos históricos; entender como uma pequena empresa sobreviveu à crise, enquanto outras bem maiores faliram; ou, ainda, estudar como a resiliência pôde ter se desenvolvido mais 
nesse grupo, incorporando-se à cultura de uma empresa dirigida por seus membros, são exemplos que deixam clara a necessidade de uma abordagem que não se limite à visão linear de causa e efeito, mas que possa, junto a essa, somar uma visão mais ampla, que, pautada num modo diferente de pensar, seja capaz de integrar tanto os princípios da ordem, da lógica, das partes isoladas, como também os da desordem, da incerteza, do todo.

São fenômenos que exigem intercâmbio entre várias disciplinas. Como pesquisadora, precisaria ter uma visão mais ampla, ou seja, transdisciplinar; adotar uma mescla flexível dos olhares da Antropologia, da Psicologia, da Administração, da História. Assim apoiei- me numa abordagem que permitisse compreender a linearidade e a não linearidade; entender, dialogicamente, a ordem, a desordem e a organização; que ajudasse a elucidar o sentido das relações entre estresse e resiliência, perseguição e sobrevivência, pressão e flexibilidade, perigos e oportunidades, história local e história geral. Enfim, uma abordagem que propusesse um caminho para a reunião do que é individual e do que é global: o Pensamento Complexo.

O Pensamento Complexo teve seu nome forjado numa palavra de origem grega - complexus -, isto é, "aquilo que é tecido em conjunto"; tratase de um pensamento que reúne e integra. Mas é Edgar Morin, um judeu francês, sociólogo, antropólogo, historiador e filósofo e, ainda, apaixonado pelas artes, que convida, mais didaticamente, a pensar a complexidade humana, ao elaborar um denso material bibliográfico em favor dessa reforma do pensamento através da transdisciplinaridade. Argumenta que a visão mecanicista, fruto de uma inteligência compartimentada, reducionista, disjuntiva, fraciona os problemas, destruindo qualquer possibilidade de compreensão e reflexão em longo prazo, porque vê as partes isoladamente, desconectadas do todo, terminando inconsciente e irresponsável. Para ilustrar esse argumento, relembra que grande parte da expressão da racionalidade tecnoburocrática ocorreu na URSS, exemplificando o caso dos rios, que foram desviados para irrigar, mesmo com o calor, as plantações de algodão. Disso resultaram a salinização do solo, o comprometimento das águas subterrâneas e a estiagem do mar de Aral. Os especialistas ocidentais convidados a resolver tais problemas, não foram capazes de elaborar uma estratégia complexa que pudesse "planejar o desplanejamento e programar a desprogramação" (Morin, 2000:208), lembra o autor, como sugerira Maurice Allais, um economista liberal.
Para Morin, o pensamento da complexidade se apresenta como "um edifício de muitos andares" (2000:204), nas bases do qual, sem dúvida, se encontram as teorias sistêmica, cibernética e da informação.

As ideias de von Neuman, Maturana, Varela e Prigogine, entre outros importantes cientistas e pensadores sobre auto-organização, formam um outro andar. E a esse edifício, acrescenta elementos que orientam a construção cognitiva do pensamento complexo. São sete princípios, entre os quais destaca três, que são básicos para tratar a complexidade: o princípio dialógico, o princípio de recursão e o princípio hologramático.

\section{O princípio dialógico}

une dois princípios ou noções antagônicas que aparentemente deveriam se repelir simultaneamente, mas são indissociáveis e indispensáveis para a compreensão da mesma realidade. (...) O problema é pois, unir as noções antagônicas para pensar os processos organizadores, produtivos e criadores no mundo complexo da vida e da história humana (o exemplo partícula-onda).

O princípio da recursão

o princípio da recursão organizacional vai além do princípio da realimentação (feedback); ele ultrapassa a noção de regulagem para a de autoprodução e auto-organização. É um círculo gerador no qual os produtos e os efeitos são eles próprios produtores e causadores daquilo que os produz.

O princípio hologramático

coloca em evidência esse aparente paradoxo de certos sistemas nos quais não somente a parte está no todo, mas o todo está na parte. Desse modo, cada célula é uma parte de um todo - o organismo global - mas o todo está na parte: a totalidade do patrimônio genético está presente em cada célula individual. Da mesma maneira, o indivíduo é uma parte da sociedade, mas a sociedade está presente em cada indivíduo enquanto todo, através da sua linguagem, sua cultura, suas normas (Morin, 2000:204-205).

A partir desses princípios, o autor defende que é necessário ampliar a definição de "auto-organização" para o de "autoeco-organização", ou seja, um conceito que tenha valor hologramático. 
Analisando a organização empresarial e considerando-a um organismo vivo, Morin exemplifica, mais uma vez, o princípio hologramático. A empresa situa-se num meio, que, por sua vez, se encontra integrado num sistema eco-organizado ou ecossistema. Ao produzir seus produtos ou serviços, está também se autoproduzindo, então ela não é só produtora, mas também produto de si mesma. Sua produção interfere no ecossistema, e este na sua produção; dessa forma, constantemente está se autoeco-organizando (Morin, 1990:127).

O que me conduzia a optar por esta abordagem na minha pesquisa antropológica sobre resiliência era o fato de ser uma proposta para um pensamento que interpreta e relativiza, une e relaciona, procurando compreender interconexões entre uma gama de elementos comportamentais, culturais e organizacionais.

\section{Lembra Morin que:}

O modo complexo de pensar não tem somente a sua utilidade para os problemas organizacionais, sociais e políticos. O pensamento que afronta a incerteza pode esclarecer as estratégias do nosso mundo incerto. $O$ pensamento que une pode esclarecer uma ética da reunião e da solidariedade. O pensamento da complexidade tem igualmente os seus prolongamentos existenciais que postulam a compreensão entre os humanos (2000:213).

\section{Sobre etnicidade}

Nos debates contemporâneos que norteiam a noção de etnia, conceito criado no início do século XIX, vestígios das relações ambíguas que essa ideia manteve com as noções de raça, povo ou nação, ainda podem ser encontrados.

Criado por Vacher de Lapouge, zoologista, como assim se definia, o termo surgiu para tentar responder à questão pungente na época: "O que faz as populações se atraírem ou se separarem?” Ele justificava a criação do novo vocábulo, afirmando que era para evitar a confusão entre raça e outro tipo de agrupamento formado "a partir de laços intelectuais, como a cultura ou a língua” (Poutignat e Streiff-Fenart, 1998:34). Para Lapouge, raça poderia ser percebida através de características morfológicas e qualidades psicológicas, haja vista a existência de agrupamentos que se formavam, podendo englobar indivíduos de raças distintas, mas que compartilham organização política, ideias ou costumes comuns. Também pretendeu diferenciar esses tipos de agrupamentos do que se concebe como nações, pois esses grupos poderiam subsistir, mesmo com a extinção ou fragmentação do grupo que os produziu, independente da organização política que os originou.

Desde o início da década de 1970, o termo "etnicidade" era bem discutido nas ciências sociais anglo-saxônicas, mas só em 1981, numa mesa redonda promovida pela Associação Francesa dos Antropólogos, foi introduzido no meio acadêmico francês por Françoise Morin; mesmo assim, permaneceu quase sem ser trabalhado ou debatido. Segundo Poutignat e Streiff-Fenart, havia um certo desinteresse das ciências sociais francesas para com as relações interétnicas e a questão das minorias, com exceção dos trabalhos desenvolvidos por Roger Bastide ou George Balandier (1998:22).

Para se chegar ao que hoje se compreende sobre etnicidade, muitos caminhos conflitantes foram percorridos. O termo já esteve atrelado a uma visão etnocêntrica, quando, nos meados da década de 1940, Warner, considerado um dos primeiros autores americanos a utilizar o termo, nomeava de ethnic todos os grupos da comunidade pesquisada por ele que não eram anglo-americanos. Possivelmente, as raízes etimológicas da palavra "etnicidade", como nos lembra Poutignat e Streiff-Fenart, podem ter influenciado tal ideia. Na Grécia Antiga, o termo ethnos era usado para fazer referência aos povos bárbaros (carregado, também, de uma conotação etnocêntrica) ou aos gregos que não compartilhavam do modelo comum à Cidade-Estado. No século XIV, a tradição eclesiástica designava a palavra latina ethnicus para falar dos pagãos que se opunham aos cristãos (1998:23).

Só a partir da década de 1970, o debate em torno da etnicidade ganha força nas ciências sociais americanas. Nasce, em 1974, uma revista especializada, e uma enorme quantidade de material começa a ser produzido. De acordo com Poutignat e Streiff-Fenart, esse período pode ser considerado como "a emergência da indústria acadêmica da etnicidade" (1998:24).

Contudo, Fredrik Barth, um antropólogo norueguês, é quem marca a virada na concepção sobre a identidade étnica. Com a atenção voltada à complexidade dos fenômenos relativos à etnicidade, em 1969 as ideias de Barth são publicadas. Surge, então, um novo tipo de pesquisa, 
proporcionando material para a construção de sua teoria sobre Organizações Sociais e Fenômenos Culturais.

O diferencial abordado por Barth, sobre a questão da etnicidade, deuse fundamentado nas fronteiras étnicas. Pode-se dizer que essas ideias revolucionaram o debate e a compreensão sobre os fenômenos da etnicidade, pois contrariavam a visão simplista que atribuía a diversidade cultural ao isolamento social e geográfico. Enfim, a concepção estática de grupo étnico fora substituída por uma outra, mais flexível e dinâmica.

\section{Barth sugere:}

Precisamos de um ponto de vista, que não confunda os efeitos das condições ecológicas sobre o comportamento, com os da tradição cultural, mas que permita se separarem esses tais fatores e se investiguem os componentes ecológicos, culturais e sociais criadores da diversidade (Barth,1976:15).

Através de pesquisas, Barth descobriu dois fatores importantes, os quais justificam a inadequação desse ponto de vista, em que a diversidade parecia definida e imutável. Primeiro: as fronteiras persistem, apesar da transformação na participação e na pertença que a mobilidade, o contato e a troca de informações entre os atores possam propiciar. Segundo: as relações sociais estáveis e persistentes são mantidas através dessas fronteiras e se baseiam justamente nas diferenças entre os grupos. Ou seja, os contatos interétnicos ou a interdependência entre grupos não necessariamente desmancham um grupo pela aculturação.

Se um grupo conserva sua identidade quando os membros interagem com outros, isso implica critérios para determinar a pertença e meios para tornar manifestas a pertença e a exclusão. Os grupos étnicos não são simples ou necessariamente baseados na ocupação de territórios exclusivos; e os diferentes modos pelos quais eles se conservam, não só por meio de um recrutamento definitivo, mas por uma expressão e validação contínuas, precisam ser analisados (apud, 1976:17).

Assim, defende que o ponto central da pesquisa sobre etnicidade deve ser a fronteira étnica que define o grupo e não a matéria cultural que este abrange.

Os elementos culturais são passíveis de variações, porque a cultura é essencialmente dinâmica, sendo elaborada e recriada continuamente. Tais mudanças não implicam, entretanto, em alterar a identidade do grupo. Ao concordar com essa ideia, pode-se dizer que os traços culturais são produzidos pelo grupo étnico.

Em razão dessa disjunção entre cultura e etnicidade, geralmente se admite que o grau de enraizamento das identidades étnicas nas realidades culturais anteriores é altamente variável, e que toda cultura "étnica" é, em certa medida, "remendo". A etnicidade não é vazia de conteúdo cultural (os grupos encontram 'cabides' nos quais pendurála), mas ela nunca é também a simples expressão de uma cultura já pronta. Ela implica sempre um processo de seleção de traços culturais dos quais os atores se apoderam para transformá-la em critério de consignação ou de identificação com um grupo étnico. Concorda-se igualmente em reconhecer que os traços ou os valores aos quais as pessoas escolhem para prender suas identidades não são necessariamente os mais importantes, os que possuem 'objetivamente' o maior poder $.5 \mathrm{k}$ demarcação (Poutignat e Streiff= Fenart, 1998:129-130).

Para a maioria dos autores contemporâneos dedicados ao assunto, ... a etnicidade não se define como uma qualidade ou uma propriedade ligada de maneira inerente a um determinado tipo de indivíduos ou de grupos, mas como uma forma de organização ou um princípio de divisão do mundo social cuja importância pode variar de acordo com as épocas e as situações (Poutigant e Streiff-Fenart, 1998:124-125)

Essa visão foi mobilizada pelas ideias desenvolvidas por Barth, que, ao focar o estudo da etnicidade nas fronteiras, concebeu esse fenômeno mais como um conjunto dinâmico de inter-relações que se transformam do que um elemento central da organização social.

No caso de estudos sobre a etnicidade judaica, deve-se levar em consideração que se trata de um grupo que engloba especificidades, como: não habita o mesmo território; adota uma língua (o hebraico) ritualmente utilizada, mas não compartilhada por todos; não tem uma integração econômica, política ou social; não possui ligações fundadas em interesses comuns, mas que persiste há milênios. Para uma melhor compreensão, fazse necessário dedicar atenção às fronteiras, ou seja, às linhas de demarcação desenhadas pelos "traços culturais diferenciadores". Um dos objetivos do estudo a que me propus realizar era mostrar como a resiliência coletiva contribuiu para a persistência deste grupo, organizando a vida social e 
estimulando uma postura pautada fundamentalmente na possibilidade de superação através de ação conjunta.

\section{Considerações finais}

Somada ao que foi possível expor nesta ocasião, fica a disponibilidade para compartilhar oportunamente os demais dados obtidos através da operacionalização da pesquisa.

Dentre o universo de inter-relações e reflexos possíveis de serem encontrados na complexa trama conceituai a ser explorada pela proposta apresentada - Resiliência, Judaísmo e Cultura Organizacional - a Resiliência Judaica parece abrir uma nova perspectiva para se pensar sobre os fenômenos da etnicidade judaica e suas fronteiras, à medida que se considere que essa capacidade humana, expressa pela coletividade, com raízes numa visão de mundo reforçada pelo milenar aparato religioso, ajudou, dialogicamente, a transformar, adaptar, organizar e reorganizar, preservando, mantendo e assegurando simultaneamente elementos fundamentais da multifacetada identidade de um povo único, sobre o qual, talvez, seja possível comentar ter sido um dos que mais experimentaram situações adversas, considerando-se a conjunção entre a cronicidade histórica e a variação geográfica que entremeou toda a trajetória de sua existência.

Entretanto, mais importante do que compreender que a Resiliência Judaica pode ter desempenhado um importante papel para a continuidade da coletividade é considerar dois pontos fundamentais para estudos como este:

O primeiro é lembrar que a resiliência é uma capacidade humana universal, que pode ser desenvolvida através dos processos inconscientes próprios da natureza humana, mas, também, através de estratégias voltadas a esse objetivo. Logo, falar de Resiliência Judaica não significa estabelecer que a propriedade da resiliência, como fenômeno coletivo é patrimônio exclusivo desse grupo.

O segundo e mais importante ponto que vale ser destacado é que, ao se discutir a manifestação da Resiliência Judaica, não se está fazendo referência sobre ser "todo indivíduo judeu" uma pessoa com a resiliência mais desenvolvida. O perigo de não se levar em conta esse ponto é deixar-se cair, mais uma vez, nos infundados propósitos que geraram ideias distorcidas sobre os judeus, como os exemplos das superstições medievais ou da ideologia antissemita difundida pelos ideais nazistas.

Para as pessoas, as famílias, as comunidades e para o universo organizacional, principalmente pela força com que seus produtos e serviços podem modificar rapidamente as sociedades e o meio ambiente, o estudo da resiliência tem grandes contribuições a oferecer, uma vez que, além de ajudar a nos portarmos como agentes de transformação frente aos percalços e a atuarmos como arquitetos, ao invés de vítimas do próprio destino, contribui para buscarmos soluções comprometidas com valores humanos construtivos.

Afinal, somos elos de uma mesma corrente, fios da mesma teia, filhos da mesma terra, seres inconclusos, em busca de "encontrar no outro a nós mesmos". É neste sentido que pretendo dedicar-me a estudos antropológicos dessa natureza.

Ah... o Homem... um animal sem asas com pegadas na lua. (Izabella Lucena, 2001)

\section{Referências Bibliográficas:}

BARTH, Fredrik. Los Grupos Étnicos y Sus Fronteras. México: FCE, 1976.

BLACK, Edwin. IBM e o Holocausto. Rio de Janeiro: Campos, 2001.

BONDER, Nilton. O Segredo Judaico de Resolução de Problemas: a utilização da ignorância na resolução de problemas. Rio de Janeiro: Imago, 1995

CONNER, Daryl R. Gerenciando na Velocidade da Mudança. Rio de Janeiro: Infobook, 1995.

GASALLA, José Maria. La Nueva Dirección de Personas. Madri: Pirámide, 2000.

JUNIOR, Pedro Jaime. Etnografia, Antropologia $e$ Universo Organizacional. RAP, Rio de Janeiro, nov/dez, 1996. 
JUNIOR, Pedro Jaime. Ligações Perigosas: breves reflexões sobre a Antropologia e a Administração. RAP, Rio de Janeiro, p.108-134, jul/ago, 1996.

KAUfMAN, Tânia Neumann. Passos Perdidos, História Recuperada: a presença judaica em Pernambuco. Recife: Edição do Autor, 2000.

MORIN, Edgar, LE MOIGNE, Jean-Louis. A Inteligência da Complexidade. São Paulo: Petrópolis, 2000.

MORIN, Edgar. Introdução ao Pensamento Complexo. Lisboa: Instituto Piaget, 1990.

NASSIF, Maria Inês. Antropologia - Capitalismo com Cara Brasileira. Revista Pesquisa Fapesp, São Paulo, Edição 73, 2002.

OLIVEIRA, Roberto Cardoso. Identidade, Etnia e Estrutura Social. São Paulo: livraria Pioneira, 1976

POUTIGNAT, Philippe, STREIFF-FENART, Jocelyne. Teorias $d a$ Etnicidade. São Paulo: UNESP, 1998.

PRIGOGINE, Ilya. O Fim das Certezas. São Paulo: UNESP, 1996.

ROSNAY, Jõel. O Homem Simbiótico. Petrópolis: Vozes, 1997.

RUBEN, Guilhermo, SERVA, Mauricio, CASTRO, Marco Luiz de. Resíduos e Complementaridade: das relações entre a teoria da Administração e a Antropologia. RAP, Rio de Janeiro, p. 68-80, maio-junho, 1986.

TAVARES, José (Org.). Resiliência e Educação. São Paulo: Cortez, 2001.

TOFFLER, Alvin. Choque do Futuro: do Apocalipse à Esperança. Lisboa: Edição Livros do Brasil, 2001.
Prestamistas judeus no Rio de Janeiro

$(1920$ - 1960)

Fábio de Sá Earp ${ }^{1}$ e Fania Fridman ${ }^{2}$

\section{Introdução}

Z ste artigo aborda um tema ainda pouco explorado na historiografia, a Z inserção econômica do imigrante judeu no Brasil, especificamente no Rio de Janeiro, a partir da década de 20. Nossa intenção é discutir uma das formas de integração social - a venda de porta em porta, klienteltshik em iídiche - à luz de um duplo enfoque, o da história urbana da cidade do Rio de Janeiro e o da aplicação das categorias econômicas agrupadas em torno das categorias de organização industrial, cenários de experiências anteriores de cada um dos autores.

O enfoque na história urbana não apenas remete a uma linha de pesquisa tradicional explorada por Fania Fridman, como resgata sua memória enquanto participante da colônia judaica carioca, composta de uma boa quantidade de histórias pessoais. Aí está presente um estranhamento da autora em relação à abordagem deste tema através da aplicação das teorias institucionalistas e neo-scumpeterianas de organização industrial, como barreiras à entrada em mercados, custos de transação, economias de escala e economias de escopo. Por outro lado, manifesta-se outro estranhamento, o de Fabio Sá Earp, em relação à familiaridade de sua parceira quanto a personalizar o que parecem ser os elementos que permitem a configuração do formato organizacional das firmas e de sua integração em determinados mercados.

Este duplo estranhamento transformou-se em um ponto forte do trabalho, na medida em que os autores tiveram que desenvolver um esforço nem sempre fácil em direção ao consenso. O elemento comum foi o tratamento do conjunto de relações pessoais que representou a principal vantagem competitiva dos imigrantes judeus para sua entrada no mercado

\footnotetext{
${ }^{1}$ Doutor em Economia / UFRJ

${ }^{2}$ Doutora em Planejamento Urbano / UFRJ
} 
brasileiro, por intermédio do conceito de colônia, uma rede de relações pessoais que forneceu informalmente elementos econômicos e não econômicos que permitiram superar as barreiras. Neste ponto, partindo-se do estudo clássico de Ben-Porath (1980) sobre firmas, família e amizade na formação de laços mercantis, foram incorporadas as categorias desenvolvidas por Manuel Castells (1997) sobre a configuração de identidades sociais.

Este estudo está dividido em três partes. Na primeira, configuram-se as barreiras à entrada do imigrante em sua tentativa de inserção no mercado de trabalho brasileiro. Na segunda, mostra-se como a atrofia da rede comercial formal abria espaço para a atuação de mascates. Finalmente, estuda-se o papel estratégico de uma colônia para a mascateação, e, em especial, o comportamento da colônia judaica carioca para dar suporte a seus membros.

\section{Barreiras à entrada do imigrante no mercado brasileiro}

A principal barreira à integração do imigrante no mercado urbano é a falta de informações do mesmo acerca das instituições vigentes. Dessas instituições a mais importante e de mais difícil aprendizado é a língua - o que já implica uma vantagem considerável para os oriundos de Portugal e, em segundo plano, do mundo latino. Além da barreira linguística, existem a necessidade de conhecer os usos e costumes vigentes no novo local, a urgência em conseguir moradia, aprender a deslocar-se pelo novo ambiente geográfico, etc. O maior problema para o recém-chegado, portanto, é sustentar-se até que tenha ultrapassado tal barreira e seja capaz de elaborar alguma estratégia de integração no mercado.

O segundo obstáculo à integração é o fato das relações econômicas no Brasil serem, muitas vezes, dependentes de vínculos de confiança pessoal. Isto se explica pela atrofia das instituições jurídicas voltadas para a garantia do cumprimento de contratos, desde a qualidade dos produtos envolvidos até o prazo para os pagamentos ${ }^{3}$. Todos os custos envolvidos no descumprimento de tais compromissos são custos de transação com que as vítimas terão de

\footnotetext{
${ }^{3}$ Esta deficiência do judiciário brasileiro ainda hoje se apresenta, o que faz com que as firmas sejam obrigadas a embutir em suas margens de lucro uma reserva elevada para devedores duvidosos e que se tenha criado uma instituição tipicamente brasileira, a "leniência contratual" que faz com que o prazo para pagamentos de dívidas possa ser dilatado informalmente em função da dificuldade para execução das mesmas.
}

${ }^{4}$ Trata-se, de uma maneira geral, daqueles que conseguiram programar sua emigração, portanto vender seus bens a preços relativamente satisfatórios. Os emigrantes de última hora, que esperavam que a perseguição se revelasse insuportável para deixar o país, frequentemente se desfaziam de seu patrimônio na "bacia das almas", trazendo pouco mais do que a roupa do corpo ou alguma joia de família.

5 Por exemplo, os judeus sefaraditas (oriundos do Marrocos, Ilha de Rodes, Síria, Líbano, Egito, Grécia e Turquia) falavam ladino, língua que uma vez mesclada com algumas palavras de português pode ser compreendida por qualquer brasileiro. 
barganha, e podiam entrar no comércio atacadista ou varejista, como mostram os diversos casos relatados por Fausto $(1997)^{6}$.

No caso de profissionais liberais, a integração se deu de forma diferenciada antes e depois dos anos 20. Nesses períodos estava em jogo sua capacidade de comunicação com a clientela - a barreira linguística e seu "bom nome". Por isso, sua atuação ficava frequentemente ligada ao espaço da colônia e seu sistema informal de ajuda mútua; por exemplo, um médico polonês ficava restrito aos clientes que falavam sua língua ou alguma outra que dominasse, como o iídiche. A partir dos anos 30, com a regulamentação corporativa das profissões liberais, acrescentou-se uma outra barreira à entrada no mercado: a aceitação da validade de seu diploma, por vezes perdido ou oriundo de alguma faculdade não reconhecida pelas autoridades corporativas brasileiras. Por isso, o imigrante profissional liberal poderia permanecer em uma situação de clandestinidade, não por realizar uma atividade proibida, mas por falta do reconhecimento de sua habilitação ${ }^{7}$.

Já para os artesãos especializados, como barbeiros, alfaiates ou ourives, o vocabulário específico não se constituía em uma barreira difícil de superar, podendo partir de uma atuação restrita à clientela da colônia e rapidamente chegar a atingir o grande público. Neste caso, parece que o maior obstáculo estaria em conseguir um ponto comercial, o que poderia ser feito diretamente (alugando-se o imóvel a um patrício) ou indiretamente (com um aval fornecido pela colônia). Assim, estes imigrantes tendiam a concentrar-se nos bairros onde moravam seus iguais, tanto para superar obstáculos do lado da oferta (o ponto comercial) quanto do lado da demanda (a clientela), segundo uma variante étnica do distrito industrial marshalliano.

Outro tipo de profissional qualificado eram os especialistas em comércio, que ao mesmo tempo contornavam a barreira linguística e ainda dominavam a arte da barganha. Estes podiam empregar-se como compradores ou vendedores das firmas da colônia (Fausto, 1997). Ainda

\footnotetext{
${ }^{6}$ A barganha é uma forma de negociação tão difundida que é difícil entender porque ainda não mereceu um estudo sério; talvez porque sua prática revele a grande flexibilidade de preços livremente negociados no mercado, afastando-nos do equilíbrio - e afugentando os economistas. ${ }^{7}$ No Rio de Janeiro era famoso o Doutor Munk, médico judeu de origem húngara que clinicava clandestinamente no interior da colônia. Altamente respeitado, era frequentemente convocado como árbitro de querelas comerciais e familiares surgidas entre membros de sua clientela (Kornis, 1999).
}

entre os profissionalmente qualificados citamos os gráficos e linotipistas que formaram suas pequenas empresas ou trabalhavam para os periódicos judaicos escritos em iídiche. Aliás, esta parece ter sido uma atividade no Rio de Janeiro em que a participação de imigrantes de várias nacionalidades foi predominante.

No caso de imigrantes destituídos de capital ou de qualquer habilitação profissional especial, uma opção era a agricultura, para o que eram oferecidas diversas facilidades pela Jewish Colonization Association. Aqueles que preferissem fixar-se no meio urbano tinham que enfrentar as restrições anteriormente citadas. Observe-se que um componente da renda familiar era o trabalho feminino autônomo, como o de costureira ou doceira. Estas atividades, porém, eram mal remuneradas, servindo apenas de complemento ao sustento da família. A partir dos anos 30, foram promulgadas leis restritivas à imigração, fechando-se as fronteiras aos que não eram cristãos, europeus e agricultores ${ }^{8}$. Este obstáculo foi parcialmente superado mediante o instrumento da carta de chamada, enviada pelos imigrantes já estabelecidos ${ }^{9}$, ou pela apresentação de títulos de compra de terra ${ }^{10}$.

O Brasil não passava por um processo de industrialização acelerado como o existente nos EUA, onde havia uma demanda elevada por mão-deobra industrial com diversos graus de qualificação. Mesmo nos EUA, porém, o acesso ao emprego geralmente passava pela filiação a sindicatos controlados pelas colônias e ligados a partidos políticos ${ }^{11}$. Na ausência de tais facilidades no Brasil, o imigrante ficava restrito aos serviços urbanos. Além da óbvia possibilidade de tornar-se um assalariado (uma das funções era a de condutor de bondes, aqueles que cobram as passagens), poderia tornar-se um mascate, caso que observaremos a seguir.

\footnotetext{
${ }^{8}$ No Rio de Janeiro era famoso o Doutor Munk, médico judeu de origem húngara que clinicava clandestinamente no interior da colônia. Altamente respeitado, era frequentemente convocado como árbitro de querelas comerciais e familiares surgidas entre membros de sua clientela (Kornis, 1999).

${ }^{9}$ Solomon (1999).

${ }^{10}$ Foi importantíssimo o papel desempenhado pela Companhia Paraná Plantations.

${ }^{11}$ Sobre a assimilação do imigrante nos EUA e o papel das colônias ver Muhlstein (1991), capítulos 6 e 7.
} 


\section{A atrofia da rede comercial formal e o espaço para o mascate}

Segundo Malamud "um percentual muito reduzido entre os imigrantes possuía profissão. A maioria pertencia à classe média baixa, que na sua terra natal se havia dedicado ao pequeno comércio ou à intermediação. Por isso tornar-se um vendedor ambulante representava para eles uma ocupação mais fácil e mais promissora. Para transformar-se em um mascate, havia ainda, necessidade que alguém apresentasse o candidato aos estabelecimentos fornecedores para lhe assegurar o crédito. A mercadoria era fornecida para pagamento em 90 ou 120 dias. Neste ínterim o mascate, se trabalhador, capaz e esforçado, criava para si uma base econômica: "a maioria dos prestamistas vivia no primeiro período de sua atividade fazendo uma economia severa em todos os sentidos, para poder adquirir uma situação mais estável, ou seja um equilíbrio financeiro"12.

$\mathrm{O}$ mascate atuava tanto em bairros das grandes cidades quanto no interior. Um caso exemplar foi o da imigração de judeus oriundos da França, do Oriente Próximo e do norte da África para a Amazônia durante o boom da borracha. Uns poucos conseguiram levantar o montante de capital necessário para a prática do comércio internacional, aproveitando sua rede de conhecimentos no exterior. A grande maioria, porém, ficou restrita ao pequeno comércio, explorando as dificuldades oriundas da precariedade da rede local de transportes: foram os regatões ${ }^{13}$. Estes personagens atuavam em duas pontas; na primeira, às margens dos mais distantes igarapés, vendiam bens de consumo aos seringueiros e compravam sua produção de borracha e, secundariamente, castanhas e outros frutos do extrativismo. $\mathrm{Na}$ outra ponta, em Belém e Manaus, vendiam sua carga e adquiriam o estoque para sua próxima viagem.

Os judeus eram apenas um dos grupos de mascates amazônicos. Havia também portugueses e turcos. A vantagem competitiva dos judeus e dos sírio-libaneses ${ }^{14}$ estava na capacidade de alavancar crédito para suas operações de compra do estoque inicial, mediante o comprometimento dos

${ }^{12}$ Malamud (1988:28).

${ }^{13}$ Solomon (1999), Blay (1997).

14 Tuzzi (1999). Como mostra este autor, são notáveis as semelhanças entre os mascates judeus e sírio-libaneses; a principal diferença entre ambos parece estar no fato de estes últimos serem muito mais numerosos aos judeus, podendo espalhar- se por todo o país. Uma colônia com perfil semelhante à dos judeus era a dos armênios (Grun, 1999). frutos da viagem. Esse crédito era repassado à margem dos igarapés, igualmente contra o comprometimento da produção futura. Não foram encontradas informações sobre os mecanismos de financiamento, garantias e taxas de juros. Importante é destacar que foram essas práticas que deram origem a redes de crédito comercial que foram repassadas para o resto do país, com a migração que se seguiu à decadência da borracha amazônica.

Maiores informações foram obtidas para o caso do mascate urbano, sobretudo no sudeste do país. No caso do Rio de Janeiro o comércio de bairro, naquela época, estava reduzido a uns poucos armazéns de comestíveis, padarias, botequins e lojas de artesãos, como barbeiros e eletricistas. Os mascates urbanos vendiam, sobretudo, tecidos, roupas prontas, cosméticos e quinquilharias em geral ${ }^{15}$.

A principal explicação para a ausência do comércio formal nos bairros, principalmente os dos subúrbios da zona norte da cidade do Rio de Janeiro parece estar no baixo poder aquisitivo da população, que gerava três restrições: (i) não se atingia a escala ${ }^{16}$ que permitisse a instalação de distribuidoras monoproduto, como roupas feitas; (ii) havia economias de escopo em distribuidoras multiproduto de secos e molhados, mas não de

\footnotetext{
${ }^{15}$ A partir dos anos 60, os rádios de pilha e outros produtos eletrônicos baratos passaram integrar as canastras dos ambulantes, como ainda acontece com os camelôs.

${ }_{16}$ Os conceitos de economias de escala e escopo de distribuição e custos de transação estão aplicados tal como definidos em Chandler. Os ganhos de escala aparecem quanto o aumento na quantidade distribuída de um produto gera um custo médio menor, pelo uso mais intensivo de um insumo qualquer. Os ganhos de escopo aparecem quanto o mesmo resultado aparece pela distribuição de um novo produto em paralelo ao primeiro, igualmente pelo uso mais intensivo de um insumo. Custos de transação são aqueles envolvidos nas transferências de bens e serviços (normalmente compra e venda de mercadorias), referentes a problemas derivados do não pagamento de dívidas ou da diferença de opiniões do comprador e do vendedor em relação à qualidade e à quantidade dos produtos. "Transaction costs economies are (...) closely related to those of scale and scope. the economies of scale and those of scope within a single unit of production and distribution permit that unit to expand the output of goods and services, in rum, increases proportionately the number of recurring commercial transactions and contractual relations the enterprise must carry on with other operating units. Just as changes in the processes of production and distribution within units have a powerful impact on the nature of transactions between units (as they are defined in contractual relations), so do changes in contractual relations affect the operations carried on within units." (Chandler 1990:17-8)
} 
outros bens de consumo, em função do custo de instalação ${ }^{17}$; e (iii) a necessidade de oferecer crédito ao consumidor incapaz de realizar operações à vista (seja em função da periodicidade variável do fluxo de renda de trabalhadores autônomos, seja em função do alto preço unitário do bem, face à renda disponível) e do elevado custo de transação embutido nas operações de crédito diante tanto da lei da usura quanto da pequena capacidade do aparelho judicial para garantir os contratos.

A vantagem comparativa do mascate deriva de um trade-off entre seu esforço físico e sua capacidade de reduzir custos de instalação, de estocagem e de transação. Os custos de instalação e estocagem são quase nulos na medida em que o negócio não inclui um imóvel, com seus custos de aquisição (ou aluguel) e impostos. O mascate os substituía carregando seu reduzido estoque em uma mala de mão ou uma carroça e recolhendo encomendas - e assim repassando o custo da estocagem ao atacadista, o que se constitui num antepassado do just in time. Em troca, o profissional incorria no ônus de carregar uma canastra com um mostruário tão variado quanto possível, de forma a apropriar-se de economias de escopo diante da variabilidade da demanda por tal tipo de produtos relativamente supérfluos para uma clientela relativamente pobre.

A capacidade de reduzir custos de transação reside na capacidade de conceder crédito. Ainda que os armazéns vendessem informalmente a crédito - o sistema do caderno - tratava-se de operações de curto prazo, geralmente de uma a quatro semanas. A concessão de crédito por prazos mais dilatados esbarrava na dificuldade para financiar seus próprios estoques - sobretudo porque a lei da usura limitava em $12 \%$ a taxa anual de juros - e na fragilidade dos direitos de propriedade, que daria poucas garantias de sucesso caso se levasse o inadimplente à barra dos tribunais - o que, por sua vez, reduzia a capacidade do armazém em obter crédito dos fornecedores.

O mascate, por sua vez, tinha maior disponibilidade de informações sobre o cliente, na medida em que conhecia sua moradia e, através de contatos

\footnotetext{
${ }^{17}$ Um armazém de secos e molhados opera em condições de higiene incompatíveis com a distribuição de roupas, sobretudo em um momento em que a indústria de plásticos ainda não desenvolvera o filme de polietileno, capaz de defender o tecido contra a poeira. O desgaste de um estoque de tecidos em um armazém expressaria uma deseconomia de escopo capaz de afastar o empresário deste tipo de atividade. O mesmo, suponho, pode ser aplicado aos demais produtos comercializados pelo mascate.
}

com a vizinhança, podia ter uma avaliação mais precisa sobre a solvabilidade de cada devedor. Assim o crédito poderia ser concedido ao consumidor através do sistema de cartões de controle da dívida, sempre em duas vias, uma com o prestamista, outra com o cliente. Este sistema era denominado pela palavra iídiche klienteltshik. Não existem evidências acerca das taxas de juros praticadas em tais operações. Segundo a entrevista de Ochs, uma boa aproximação seria o mascate adquirir o produto com $30 \%$ de desconto sobre o preço no varejo e repassá-lo com juros simples de $3 \%$ ao mês.

O sistema não tinha valor legal para defesa do credor, mas era a única maneira pela qual a população de baixa renda podia ter acesso àqueles bens, tendo interesse, portanto, em honrar o compromisso informal. À medida que aumentava a confiança entre as partes, podiam chegar a financiar bens de valor elevado, como os eletrodomésticos. Desta forma, passava-se de uma atividade comercial e financeira baseada na exibição da amostra para uma atividade essencialmente financeira: o mascate transmutava-se em prestamista.

A clientela não podia ser expandida para além dos limites da população de baixa renda em função do forte preconceito das camadas de rendas média e alta contra as operações a crédito. Comprar "à prestação" denotava pobreza ou ainda pior, a incapacidade de viver dentro do limite de seus meios. Apenas nos anos 60 desapareceu o preconceito, com a extinção da lei da usura e o forte estímulo ao crédito direto ao consumidor através das chamadas financeiras (Sociedades de Crédito, Financiamento e Investimentos) alavancando as transações com bens de consumo duráveis, e com o Sistema Financeiro da Habitação fazendo o mesmo com o crédito habitacional.

Os mascates prestamistas frequentemente eram pouco menos pobres do que seus clientes, morando nos mesmos bairros e sofrendo discriminação - no Rio de Janeiro eram chamados de "judeus da prestação", em São Paulo de "russos da prestação". É digno de nota que o preconceito vingava mesmo entre imigrantes judeus de classe média: a família da mãe de Bons Fausto ${ }^{18}$, de origem turca, não fazia compras com esses profissionais e ainda alertava suas empregadas para que não se deixassem enganar pelos "russos"19.

\footnotetext{
${ }^{18}$ Fausto (1997:166-7).

${ }^{19}$ Note-se aqui o preconceito do judeu sefaradi contra o asquenazi, fugido às pressas do nazismo e destituído de recursos para conseguir uma melhor condição social. Isto é tão mais
} curioso quanto (i) nem por isso deixavam de dar-lhe crédito; e (ii) o próprio pai de Bóris 
A colônia, segundo Ochs, proporcionava dois elementos fundamentais para a entrada do imigrante no negócio de mascate: o menino e o pacote. $\mathrm{O}$ menino era um imigrante capaz de orientar-se pela cidade e de falar tanto a língua de seus pais quanto o português. Sua função era intermediar os negócios do mascate, ensiná-lo a andar pela cidade e servir de intérprete. O pacote era um conjunto de mercadorias obtidas a crédito junto aos atacadistas da colônia, que lhe permitia constituir sua canastra e começar a operar. Com o correr do tempo o mascate aprendia a língua e o menino se tornava dispensável (tendo, em troca, ganho algum dinheiro e, sobretudo, aprendido a arte da barganha), entretanto, o crédito obtido para a reposição do pacote continuava sendo a chave para a sobrevivência. A importância da colônia como rede de negócios parece justificar que se dedique algum esforço a defini-la.

\section{A colônia como rede de solidariedade}

A forma pela qual o imigrante supera sua desvantagem competitiva diante dos nacionais é a inserção em uma rede de solidariedade, a colônia. Este grupo é formado a partir do estabelecimento de uma identidade comum, por exemplo, de origem religiosa (como a judaica) ou de origem nacional (polonesa) ou regional (do Oriente Médio). Uma colônia pode ainda ter subconjuntos de ordem linguística (sefaradis, que falam ladino, e os asquenazis, que se expressam em iídiche $)^{20}$. Em geral os laços de solidariedade e coesão são maiores quando há uma ameaça qualquer aos seus membros, como aconteceu na Europa com o antissemitismo, do que a falta de informação sobre o lugar e a língua. Neste sentido, quando a primeira geração de filhos de imigrantes, ao passar pelo processo de escolarização do país, obteve as mesmas informações que os nacionais, reduziu fortemente sua dependência da rede de solidariedade criada por seus pais.

Fausto, que os discriminava, achava que burlar o cliente na qualidade e no peso da mercadoria era uma "exigência da vida prática" no comércio.

${ }^{20}$ Observe-se que as diferenças culturais entre os judeus, oriundos de diversas partes do mundo, eram muito maiores do que aquelas existentes entre qualquer outro grupo de imigrantes (Grun, 1999). Por mais estranhos que calabreses e vênetos pudessem se sentir uns em relação aos outros, seus dialetos eram mutuamente compreensíveis; o mesmo não acontecia entre os que falavam ladino e í́diche, corruptelas, respectivamente, do espanhol quinhentista e do alemão.
A dependência mútua cria laços de confiança entre os participantes, o que facilita as transações ${ }^{21}$ de todo tipo, inclusive as comerciais e financeiras. A colônia possui muitas das características de uma família, o que nos permite estabelecer comparações entre as transações interfamiliares e aquelas realizadas no seio da comunidade. Pode-se, portanto, tentar aplicar-lhe os elementos básicos da economia da família, tal como propostos por Ben-Porath (1980). Segundo este, a relação entre os membros da família é um tipo de contrato que se caracteriza por (a) estender-se por longo e indeterminado período de tempo; (b) englobar grande quantidade de atividades; (c) não estar previa nem claramente definido, muitas vezes sendo contingente ou decidido como resposta a novos eventos (pathdependency); (d) ser um pacote fechado que não pode ser alterado facilmente, dada a alta interdependência entre os membros; (e) estabelecer relações de débito e crédito que geralmente não se expressam monetariamente, pois criam dívidas simbólicas que dificilmente podem ser liquidadas (já que seu "valor" dificilmente pode ser "medido" e "pago"); (f) executar as dívidas sem o recurso à justiça comum; $(g)$ criar uma identidade coletiva que afeta as transações de cada um dos membros com os não membros. A mais importante característica do contrato familiar é a identidade dos participantes, não sendo, portanto, transferível ou negociável (embora um não membro possa ingressar no grupo por casamento).

As transações de mercado, ao contrário, envolvem uma unidade de preço que pode se expressar em termos de uma unidade de conta monetária, e os valores envolvidos independem da identidade dos participantes - neste caso apenas as relações entre preços e quantidades importam. A identidade dos participantes não é importante neste tipo de transações, desde que os direitos de propriedade estejam garantidos pela lei - incluindo-se aí tanto o pagamento das dívidas quanto a qualidade e a quantidade das mercadorias transacionadas. Quanto mais esses direitos de propriedades forem garantidos, menores os custos de transação envolvidos.

\footnotetext{
21 "In a broadest sense, a transaction consists on activities or transfers of property rights by or between at least two individuals or groups, the activities of the participants being interdependent (...) Market transactions are a subset of all transactions no matter how we defines the whole ser or what language is used to describe nonmarket transactions." (BenPorath, Op. cit.:2)
} 
Em uma estrutura institucional deficiente em garantias de direitos de propriedade, os custos de transação podem ser reduzidos mediante a confiança mútua entre as partes. O conhecimento da identidade dos participantes é uma informação capaz de gerar essa confiança, sobretudo quando ambos sabem que seu relacionamento será permanente, dada a dificuldade de qualquer um evadir-se. Os laços de confiança são ainda reforçados pela presença de tratamento privilegiado, como presentes e favores, criando estruturas de dívida simbólica. A participação em atividades comuns, como cultos religiosos e festas de família, é um reforço adicional. A colônia funciona, assim, como uma família ampliada para o imigrante.

A construção da identidade pode resultar de três processos: de legitimação, de resistência e de projeto ${ }^{22}$. A legitimação é introduzida pela participação do indivíduo nas instituições dominantes na sociedade, como o sistema de ensino, que o levam a aceitar como normal e desejável aquela determinada identidade. A resistência ocorre quando um determinado grupo $e ́$ estigmatizado ou perseguido, sendo obrigado a construir trincheiras culturais para sobreviver. Já o projeto surge quando a cultura é utilizada para redefinir sua identidade no bojo de uma tentativa de transformação da sociedade como um todo. Caso o intento seja bem sucedido, este passará a reproduzir a nova identidade através da legitimação.

A identidade do imigrante no Brasil parece ser um caso típico de resistência diante da barreira informacional e do preconceito étnico, voltado para a integração na sociedade brasileira (observe-se que no mesmo período o movimento sionista desenvolvia uma identidade de projeto, voltado para a construção do Estado de Israel). Segundo Castells, a identidade criada a partir da resistência gera a formação de comunidades, isto é, "forms of collective resistance against otherwise unbearable oppression, usually on the basis of identities that were, apparently, clearly defined by history, geography, or biology, making it easier to essentialize the boundaries of resistance" ${ }^{23}$. A comunidade produz uma cultura que permite aos excluídos a exclusão daqueles que os excluem.

A coesão da comunidade será tão maior quanto o sejam as forças que tentam excluir seus membros, impedindo-os de desfrutar dos mesmos

\footnotetext{
${ }^{22}$ Castells (1997:8)

${ }^{23}$ Castells (1997:9)
}

direitos dos demais. Esta coesão é particularmente forte na comunidade judaica, por conta do desenvolvimento ao longo de quase dois milênios do que podemos chamar de cultura da diáspora, surgida após o massacre de Massadah e a política de realocação populacional promovida pelo imperador Tito. Ao longo da diáspora, os judeus aprenderam a construir instituições ágeis. Uma das mais importantes foi a minidn, um grupo de dez homens para a reza. A existência do minidn dispensa a existência de uma sinagoga, o que permite a reprodução dos laços (não apenas religiosos) mesmo na clandestinidade.

Sempre que as condições políticas permitiram, as comunidades judaicas da diáspora estabeleceram organizações formais com finalidades religiosas, culturais e econômicas ${ }^{24}$. Sinagogas foram fundadas (apesar da vinda de judeus para o Brasil ter ocorrido desde o início da colonização portuguesa, com a perseguição religiosa promovida pela Inquisição durante pelo menos três séculos, o primeiro templo data, no Rio de Janeiro, dos primeiros anos dos novecentos), seguidas por clubes (Grêmio Juvenil Kadima, o Clube Juventude Israelita e o Clube dos Cabiras), colégios (Externato Misto Dr. Weizmann, Colégio Maghen David, depois Hebreu Brasileiro, e a Escola Scholem Aleichem), bibliotecas (em 1915 surgiu a biblioteca Scholem Aleichem e anos depois as bibliotecas H. N. Bialik e I. L. Peretz, esta última de vida efêmera) e federações de entidades (a Federação Sionista é de 1922). Em 1910 foi fundado o Centro Israelita do Rio de Janeiro, de minoria francesa que, em 1924, transformou-se na agência local daJewish Colonization Association OCA).

Já na segunda década do século, ao lado das primeiras sinagogas, surgiram as entidades beneficentes com finalidades econômicas: no Rio de Janeiro a Achiezer ("ajuda ao irmão"), a Relief (Sociedade Beneficente Israelita de Amparo aos Imigrantes), cujas origens encontram-se na Achiezer e a Froien Farein (Sociedade Beneficente das Damas Israelitas). A Relief era responsável pela recuperação dos refugiados judeus recémchegados à Ilha das Flores, a obtenção de documentos e de postos de

\footnotetext{
${ }^{24}$ Todas as colônias criam organizações; as sociedades de ajuda mútua, criadas inicialmente para fornecer serviços médicos e empréstimos quando seus membros estivem impossibilitados de trabalhar, encontravam-se pelo menos entre portugueses (Leite, 1999), espanhóis (Martinez, 1999), alemães (Seyferth, 1999), sírio-libaneses (Truzzi, 1999), no Brasil, e entre os judeus argentinos (Klich e Tolcacher, 1999).
} 
trabalho, a sua acomodação e as primeiras refeições e pelo fornecimento das primeiras informações necessárias para "recomeçar a vida". Uma parte dos seus recursos provinham da JCA e de instituições judaicas americanas (Hias eJoint) e europeia (Emigdirect). No final dos anos 30 a Relief também se responsabilizou pela assistência médica com a inauguração de uma policlínica. A Froien Farein foi criada para resolver assuntos familiares e sociais. Àquela época uma de suas tarefas primordiais foi a de impedir que moças se tornassem vítimas da máfia da escravatura branca (Zvi Migdal, cuja sede ficava em Buenos Aires).

Cabe acrescentar a União dos Prestamistas, uma cooperativa surgida para defender os interesses dos vendedores ambulantes, com a obtenção de mercadorias e serviços a preços baixos, cuja vida foi breve. A Guemiluth Chessed Farain (Sociedade de Empréstimos de Favor) foi fundada por imigrantes ortodoxos com a finalidade de tornar-se uma caixa de empréstimos sem juros. Seus recursos eram constituídos por donativos e contribuições de sócios. Nos final dos anos 20, foi organizado o Banco Israelita Brasileiro, uma cooperativa cuja finalidade era desenvolver o comércio e a indústria da comunidade ${ }^{25}$. A Lai Spar Casse (Caixa de Empréstimos e Poupança) também foi fundada com auxílio da JCA e da Sociedade Beneficente Israelita e Amparo aos Imigrantes. Constituía-se em uma cooperativa sem fins lucrativos ainda que fossem cobrados juros baixos $^{26}$. Desta forma, além dos laços pessoais a colônia constituiu organizações capazes de socializar os custos de integração do imigrante, eventualmente acima das possibilidades de seus familiares ${ }^{27}$.

A coesão da colônia implica um tratamento diferencial nas transações segundo a identidade do parceiro (os membros têm preferência frente aos não membros) mas não exclui a discriminação social em seu interior. Além do recorte sefaradis/asquenazis ainda podemos encontrar, pelo menos no Rio de Janeiro, uma discriminação espacial, diferenciando os judeus "do Flamengo", "do centro" e "dos subúrbios". Os primeiros eram aqueles de maior poder aquisitivo, os "do centro" podiam tanto ser proprietários de lojas e pequenas manufaturas residentes no segundo andar de seus sobrados, quanto trabalhadores muito pobres que moravam em cortiços. Finalmente,

\footnotetext{
${ }^{25}$ O Banco teve que ser vendido em 1964.

${ }^{26}$ Existe até hoje.

${ }^{27}$ Solomon (1999), Malamud (1988) e Lozinski (1997).
}

os dos "subúrbios" estavam acima da linha da miséria típica dos moradores dos cortiços, mas ou eram pobres bastante para não poderem morar em locais com melhores condições urbanas ou por não quererem abandonar a convivência com a comunidade. Casos exemplares são os bairros de Madureira e o de Nilópolis, este último na baixada fluminense.

Mas a mais importante restrição segregava aqueles que traíam o código de ética dos negócios. Este código permitia tudo o que resultasse de uma livre barganha entre as partes, mas punia com o ostracismo aqueles que não pagavam suas dívidas. Os maus pagadores, conhecidos por tzvekes (pregos), eram aceitos nas atividades comunitárias, mas excluídos de qualquer tipo de negócios e de convites para as reuniões particulares. O sistema era particularmente eficiente dada a concentração geográfica (e mais tarde a difusão do telefone) que permitia uma rápida circulação de informações, tanto relevantes como mexericos. Esse sistema de ostracismo servia para reduzir os custos de transação nas operações de crédito informal.

As atividades não econômicas da comunidade permitiam, além da reprodução da vida social em um meio pouco acolhedor, a seleção de parceiros para atividades econômicas. Tal seleção não se limitava aos serviços profissionais (comércio e crédito, inclusive o trabalho assalariado). $\mathrm{Na}$ medida que seus membros prosperavam e abriam ou ampliavam suas empresas, havia uma preferência pela contratação de membros da comunidade $^{28}$. Em especial contadores, advogados e vendedores eram escolhidos pela sua familiaridade com as práticas contábeis e mercantis correntes nas comunidades judaicas internacionais - outra vantagem comparativa em relação aos brasileiros ${ }^{29}$. Esse foi um importante impulso para que as novas gerações fossem encaminhadas para as universidades.

Mas a educação dos filhos acabou por constituir-se em um elemento desagregador. Na medida em que jamais se fundou uma universidade judaica, os jovens judeus que se dirigiam ao ensino superior adquiriam não apenas conhecimentos, mas uma rede de relações que ampliava suas possibilidades de integração econômica e social sem depender da colônia. Livres da barreira linguística em meados do século, estes judeus penetraram

\footnotetext{
${ }^{28}$ O mesmo se encontra entre armênios (Grun, 1999) e sírio-libaneses (Truzzi, 1999) no Brasil e entre os judeus argentinos (Klich e Tolcacher, 1999).

O mesmo comportamento se encontra entre os sírio-libaneses (Truzzi, 1999). ${ }^{29}$ O mesmo comportamento se encontra entre os sírio-libaneses (Truzzi, 1999).
} 
no mercado de trabalho e contraíam casamentos exogâmicos, frequentemente sem conversão. Eles mesmos e seus filhos foram adquirindo uma identidade de classe média ou de elite brasileiras que diluíram as fronteiras, agora desnecessárias, da colônia ${ }^{30}$.

\section{Conclusão}

A inserção econômica dos imigrantes judeus no Brasil - e em particular no Rio de Janeiro - foi um processo no qual aqueles personagens buscaram atividades nas quais as barreiras à sua entrada não fossem relevantes. Algumas destas atividades constituíram-se em nichos de mercado dominados por aqueles profissionais que conseguiam estabelecer vantagens competitivas, naquela conjuntura. O comércio ambulante de bairro foi uma destas áreas de excelência para os judeus. Sua vantagem decorria, sobretudo, de poderem oferecer uma mercadoria essencial para uma clientela de baixa renda - o crédito, que lhe era por sua vez transmitido através de relações de confiança pessoal formada entre os membros do grupo de identidade conhecido como colônia. Enquanto aquelas condições institucionais se mantiveram, o sistema operou com sucesso; quando mudou a conjuntura histórica, os judeus estavam prontos para abandoná-lo.

Este artigo não pretende ser mais do que um convite ao debate entre economistas e historiadores, quanto às possibilidades de realizarem pesquisas em comum. Acessoriamente, propõe que este encontro possa ocorrer não apenas sobre os temas nobres da moda, mas igualmente nos assuntos relevantes para o cotidiano de cada um de nós.

\section{Referências Bibliográficas:}

BEN-PORATH, Yoram (1980). "The F-Connection: Families, Friends and Firms and the Organization of Exchange". Population and Development Review, vol. 6, n. 1, March.

BLAY, Eva A. (1997). "Judeus na Amazônia”, in Bila Sorj (1997).

CARNEIRO, Maria Luiza Tucci (1996). Brasil um refúgio nos trópicos. A trajetória dos refugiados do nazi-fascismo. São Paulo, Estação Liberdade.

\footnotetext{
${ }^{30}$ Sorj (1987b), Grin (1997), Grun (1997), Bernardo Sorj (1997).
}

CASTELLS, Manuel (1997). The power of identity (The information age, vol. 2). Pasdtow, Malden e Oxford: Blackwell Publishers.

CHANDLER, Jr, Alfred D. (1990). Scale and Scope. The dynamics of industrial capitalismo Cambridge (Mass.) and London: The Belknap Press of Harvard University Press.

FAUSTO, Bóris (1997). Negócios e ócios. São Paulo: Companhia das Letras.

(1998). "Imigração: cortes e continuidades". In L. M. Schwarcz (org.), História da vida privada no Brasil, volume 4. São Paulo: Companhia das Letras.

(1999). Fazer a América. São Paulo: EDUSP. Fridman, Salomão (1999). Entrevista.

GOLDMAN, Xie (1999). "Era uma vez, em Nilópolis". In ASA Judaísmo e Progressismo, ano X, n.58.

GOMES, Ângela de Castro (2000). Histórias de imigrantes e de imigração no Rio de Janeiro. Rio de Janeiro: Editora Sete Letras.

GRIN, Mônica (1997). "Diáspora minimalista: a crise do judaísmo contemporâneo", in Bila Sorj (1997). Grun, Roberto (992). Negócios e famílias: armênios em São Paulo. São Paulo: Editora Sumaré.

(1997). "Intelectuais na comunidade judaica brasileira", in Bila Sorj (1997).

(1999). "Construindo um lugar ao sol: os judeus no Brasil", in Fausto (1999).

IGEL, Regina (1997). Imigrantes judeus, escritores brasileiros. São Paulo: Perspectiva.

KLICH, Ignacio e LESSER, Jeffrey (eds.) (1998). Arab and Jewish immigrants in Latin America. Images and realities. London/ Portland: Frank Caos Ed.

e TOLCACHIER, Fabiana (1999). "Panorama da imigração judia para a Argentina", in Fausto (1999).

KORNIS, George (1999). Entrevista. 
LEITE, Joaquim C. (1999). “O Brasil e a imigração portuguesa (18151914)", in Fausto (1999).

LONDON, Esther (1999). Vivência judaica em Nilópolis. Rio de Janeiro, Imago.

LOZINSKY, Saádio (1997). Memórias da imigração. Reminiscências e reflexões. Rio de Janeiro: Garamond.

MALAMUD, Samuel (1988). Recordando a Praça Onze. Rio de Janeiro, Livraria Kosmos Editora.

MARTINEZ, Elda E. G. (1999). “O Brasil como país de destino para os imigrantes espanhóis”, in Fausto (1999).

MENEZES, Lená M. (1992). O comércio do prazer nas ruas do Rio (18901930). Rio de Janeiro: Arquivo Nacional.

MUHLSTEIN, Anka (1991). A Ilha Prometida. A história de Nova Iorque do século XVII aos nossos dias. São Paulo: Companhia das Letras.

NORTH, Douglas (1991). Institutions, institutional change and economic performance. Cambridge: Cambridge University Press.

OCHS, Smil (1998). Entrevista. Puretz, Bertha (1999). Entrevista.

SOLOMON, Marcelo (1999). Aspectos sócio-econômicos da imigração judaica para o Brasil. Rio de Janeiro: IE/UFRJ, Monografia de Bacharelado, mimeo.

SORJ, Bila [org.) (1997). Identidades judaicas no Brasil contemporâneo. Rio de Janeiro: Imago. (1997a).

"Normalizando o povo judeu: a experiência da Jewish colonization Association no Brasil”, in Bila Sorj (1997).

SORJ, Bernardo (1997). "Sociabilidade brasileira e identidade judaica", in Bila Sorj (1997).

TRUZZI, Oswaldo M. S. (1997). Patrícios. Sírios e libaneses em São Paulo. São Paulo: Editora Hucitec.

(1999). "Sírios e libaneses e seus descendentes na sociedade paulista", in FAUSTO (1999).
VELTMAN, Henrique (1996). A história dos judeus em São Paulo. Rio de Janeiro, Editora Expressão e Cultura.

(1998). A história dos judeus no Rio de Janeiro. Rio de Janeiro, Editora Expressão e Cultura.

WOLFF, Egon e WOLFF, Frieda (1979)Judeus nos primórdios do Brasil República. Rio de Janeiro, Centro de Documentação da Biblioteca Israelita H.N. Bialik. (1996).

. Fatos históricos e mitos. Rio de Janeiro, Xenon Editora.

WILLIAMSON, Oliver (1985). The economic institutions of capitalism: firms, markets, relational contracting. New York: Free Press.

WORCMAN, Susane (1991). Heranças e lembranças. Imigrantes judeus no Rio de Janeiro. Rio de Janeiro, ARI:CIEC:MIS 


\section{Os judeus da Leopoldina}

Márcio André Sukman ${ }^{1}$

\section{Introdução}

$\mathrm{O}$

Museu Judaico do Rio de Janeiro, criado em 1977, é o centro de registro da presença judaica no Rio de Janeiro. Seu acervo, formado por uma diversa biblioteca, objetos, peças religiosas e fotos, representa a vida dos judeus cariocas e brasileiros. Trata-se de um tesouro à disposição das pessoas, porventura interessadas, mas sobretudo é uma herança a ser deixada às próximas gerações. Voltado para esse escopo, o Museu, seção estadual Rio de Janeiro, do Arquivo Histórico Judaico Brasileiro, iniciou, a partir do final do ano de 2000, o projeto "Memória". Seu objetivo maior é recuperar a história e a memória da origem e do desenvolvimento das diversas comunidades judaicas instaladas no estado do Rio de Janeiro.

O projeto é conduzido pelo grupo de historiadores e antropólogos Fábio Koifman, Diego Terry, Marcelo Gruman, Michel Gherman, Monique Sochachevsky, William Martins e Márcio Sukman, cujos trabalhos são realizados de forma voluntária. A coordenação é realizada pelo Sr. Max Nahamias, presidente do Museu Judaico do Rio de Janeiro e pelo professor Geraldo Beauclair - titular do curso de História Contemporânea da Universidade Federal Fluminense. Essa prestigiada instituição acadêmica é conveniada, desde 2000, ao Museu, com o fim de realizar inúmeras atividades.

A primeira pesquisa, "A Comunidade Judaica dos Subúrbios da Leopoldina", já iniciada, tem por objeto o resgate do cotidiano dos imigrantes judeus oriundos, principalmente, do leste europeu, que se dirigiram para os bairros da Zona da Leopoldina ${ }^{2}$. Sua chegada remonta às primeiras décadas do século $\mathrm{XX}^{3}$ e alcançou o auge de seu desenvolvimento

\footnotetext{
${ }^{1}$ Bacharel em Direito / UERJ

${ }^{2}$ Segundo definições urbanísticas essa região se estenderia do bairro de São Cristóvão até o limite com o município de Duque de Caxias.

3 (Depoimento de Avrom Resnik- setembro de 2000)
}

por volta dos anos 40-50, quando lá funcionavam várias instituições ${ }^{4}$. Apesar do esvaziamento, com a migração para outros bairros ainda hoje, lá residem por volta de uma dezena de famílias.

A atividade comunitária, atualmente, está limitada aos serviços religiosos organizados na sinagoga - Beit Haknesset Ahavat Israel frequentada por judeus residentes na localidade, antigos moradores e, curiosamente, por pessoas que nunca habitaram o bairro. Sua preservação é realizada, sobretudo, por uma família, que lá reside e, portanto, garante a sua manutenção, como a constituição dos minianim.

O ambiente nessa congregação remonta a anos anteriores. Os jornais, revistas e periódicos comunitários mais recentes, os quais estão em cima das mesas da sinagoga, são datados do início dos anos 90. Nas cadeiras e bancos, velhos senhores falam das recordações durante o animado kidusch realizado após a reza. A última cerimônia de casamento realizada nessa sinagoga de Olaria, de um casal residente em Copacabana, ocorreu no ano de 1991. A crescente favelização da área e o aumento da violência nos últimos anos têm dificultado e, por vezes, inviabilizado o acesso dos frequentadores à sinagoga. Foi justamente essa realidade que nos causou grande surpresa e atiçou nossa curiosidade de investigadores - um centro de memória viva, reflexo de um trabalho de resistência cultural, que precisava ganhar o conhecimento comunitário e institucional.

Nosso trabalho de pesquisa está centrado, primordialmente, na metodologia da história oral, com entrevista de imigrantes e seus filhos, moradores e ex-moradores, a partir do conceito de trajetória de vida ${ }^{5}$. Nesse modelo, o entrevistado é estimulado a falar sobre toda sua vida comunitária, religiosa, profissional, familiar - desde o nascimento na Europa ou no próprio bairro - até os dias atuais. É sempre importante lembrar não constituir a história oral aquela "outra história", considerada imparcial por trabalhar diretamente com o objeto de pesquisa. Trata-se de uma seleção de suas recordações, que o entrevistado faz de sua vida, tendo algum fatos privilegiados em detrimento de outros. Junto à realização de

\footnotetext{
${ }^{4}$ A comunidade chega a contar com duas sinagogas, movimentos juvenis e um centro comunitário, que contava com colégio, grêmio e uma biblioteca.

${ }^{5}$ Utilizaremos para esse fim a noção de trajetórias de vida proposta por Franco Ferraroti que trabalha com a ideia de biografias coletivas para entender um determinado momento
} histórico na compreensão de seus agentes. 
entrevistas, é realizada a coleta de material iconográfico e documental, adquirido tanto dos entrevistados como das instituições comunitárias, com destaque para o periódico "O Espelho" produzido pelo grêmio local, por volta de meados do século e nos documentos e periódicos do Centro Israelita da Leopoldina.

Enfim, além da análise documental, outro de nossos objetivos é a formação de um banco de dados e um acervo de depoimentos - gravados em fita cassete, vídeo cassete e transcritos -, que estarão disponíveis para consulta e pesquisa aos interessados. Está prevista, ainda, a publicação de um livro tratando dos resultados das pesquisas efetuadas e, posteriormente, um documentário sobre a trajetória da comunidade

\section{Contexto histórico}

A comunidade judaica dos subúrbios da Leopoldina é composta, em sua maioria, por judeus ashkenazitas, oriundos do Leste Europeu e, em reduzido número, de imigrantes de origem sefaradita, que habitavam a região do norte da África e Oriente Médio. Por isso, antes de entrarmos nas análises em solo brasileiro, torna-se necessário recompor, rapidamente, o processo imigratório da Europa para as "Américas".

Desde o século XIX, as populações judaicas na Europa Oriental já sofriam uma gradual deterioração de suas condições de vida. Transformações de ordem estrutural, social e política, como a proletarização maciça dos trabalhadores, as políticas restritivas governamentais às comunidades e o forte antissemitismo, em países como Rússia, Polônia e Romênia, obrigavam aos judeus a buscarem melhores condições de vida em outras terras. Isso foi possibilitado inicialmente pela JCA (Jewish Colonization Association), instituição internacional, cuja finalidade era possibilitar aos judeus recomeçarem uma nova vida, num "Novo Mundo".

O Brasil, especialmente, se transformou numa boa opção, a partir dos anos 20, quando os Estados Unidos da América, Canadá e Argentina passaram a recusar o recebimento de novas levas de judeus europeus. De início, os imigrantes se dirigiram para as colônias agrícolas situadas no sul do país mas, em razão da falta de estrutura e de preparo técnico, se deslocaram para os grandes centros urbanos, como o Rio de Janeiro. No ambiente urbano, a leva imigratória tomou vigor, a partir da relevante atitude dos primeiros judeus, criadores de um eficiente mecanismo de acolhimento dos parentes, conterrâneos e, até, esposas prometidas. O crescimento acelerado da população judaico-carioca, na década de 20, de 10 para 30 mil habitantes ${ }^{6}$, é seu maior retrato.

O Rio de Janeiro, desde de 1870, sofria uma grande expansão da sua malha urbana, com a população se deslocando para habitar novas áreas, ou pequenos núcleos já existentes, tanto na zona sul, quanto na zona norte. Especificamente nesta última área, o trem possibilitou uma eficiente ligação com o centro da cidade, promovendo um rápido crescimento dos bairros, do qual podem ser destacados Olaria, Ramos, Bonsucesso e Penha. Oferecendo áreas e aluguéis mais baratos que os das zonas Sul e Central, tornaram-se um destino convidativo para os imigrantes judeus ou recém-chegados, cujos recursos financeiros eram bastante limitados.

\section{A região da Leopoldina}

$\mathrm{O}$ ato de emigrar foi visto como uma ameaça aos judeus, especialmente para aqueles oriundos da Europa Oriental. Significava o afastamento do judaísmo praticado em países como Polônia e Rússia, onde, na maioria das vezes, ficavam segregados da sociedade maior, em pequenas vilarejos. Por isso, quando chegavam ao novo país, buscavam ao máximo transplantar e reproduzir a forma de vida da terra natal. A instalação de instituições, sejam sinagogas, escolas, organizações assistenciais, sejam estabelecimentos comerciais, como açougues e armazéns, garantiam uma sociabilidade própria e uma interdependência forte dos membros da coletividade. A construção desse espaço cultural, social e étnico se insere, portanto, dentro de uma estratégia de delimitação das fronteiras de seu grupo, permanecendo a estrutura social na qual viviam no velho mundo, até uma melhor compreensão dos códigos da sociedade maior.

Samuel Malamud, um dos maiores memorialistas da comunidade judaica carioca, dizia que as instituições judaicas "lembravam as organizações idênticas da Europa Oriental, de cunho religioso e orientação demasiadamente rígida" "Malamud também afirmava que a Praça Onze, principal bairro dos judeus no Rio de Janeiro, "dava impressão de um

\footnotetext{
${ }^{6}$ (Lesser, 29.1995)

7 (Malamud, 46 1988)
} 
enorme gueto, sem muralhas ou restrições" " . Na zona da Leopoldina, as primeiras análises efetuadas, nos levam a crer, ter essa estrutura comunitária se consolidado a partir da década de 30 .

No entanto, a comunidade da Leopoldina não pode ser representada apenas como uma fiel reprodução do "shtetl" da Europa Oriental. As demandas das novas gerações, já nascidas em solo brasileiro, diversas daquelas dos imigrantes, obrigavam a realização de mudanças. Era necessária a criação e a transformação das instituições comunitárias, como a escola, o grêmio e o movimento juvenil, para essa nova realidade..

A escola primária "Mendele Mocher Sforim" situava-se no prédio Centro Israelita da Leopoldina. Sua grade curricular, composta pelas matérias obrigatórias junto com as judaicas, demonstrava a preocupação dos imigrantes em possibilitar uma educação voltada tanto para a manutenção das tradições, como para o engrandecimento pessoal enquanto cidadão. Sua existência, entretanto, seguiu uma trajetória bastante inconstante. Devido às brigas internas e à falta de uma infraestrutura econômica mais estável, segundo informam os primeiros depoimentos, teve seu funcionamento diversas vezes interrompido. O projeto de estabelecimento de um curso ginasial não chegou a se consolidar, o que obrigava os jovens, e por consequência toda a família, a se dirigirem a outros bairros, como a Tijuca, onde funcionava o Colégio Hebreu Brasileiro.

O Grêmio Stefan Zweig, fundado em 1942, localizado também num dos salões do Centro, era o ponto de reunião da juventude leopoldinense, principalmente de Olaria e Ramos. Sua finalidade encerrava-se no desenvolvimento de atividades de aproximação dos jovens judeus de diferentes bairros da Zona da Leopoldina, evitando, assim, a assimilação ao meio não judaico. Dessa forma, ao contrário dos movimentos juvenis, o Grêmio não defendia a imediata emigração (aliáh), mas o fortalecimento da juventude judaica leopoldinense. $\mathrm{O}$ artigo assinado por Samuel Wainer, para a edição do periódico "O Espelho", é bastante elucidativo acerca da importância destinada ao grêmio recreativo para a continuidade da vida comunitária:

Com essas agremiações fortes e bem organizadas, não haverá motivo para temer a assimilação. Essas associações se preocupam em manter os jovens unidos, evitando a dispersão daqueles que por razões as

\footnotetext{
${ }^{8}$ (Malamud, 46. 1988)
}

mais diversas, não conseguem ir para Eretz (leia-se Israel). Essas agremiações desempenham o ponto de união de todos os jovens judeus independente de cor político partidária.

O periódico “O Espelho", produzido pelo grêmio, trazia toda a agenda social a ser realizada no mês, com uma programação que alcançava tanto os dias úteis, quanto o fim de semana. As atividades eram diversas, como sessões cinematográficas, noites dançantes, torneios de xadrez e tênis de mesa, palestras com temas gerais ou especificamente judaicos e jogos do tipo pergunta e resposta. Nos meses de verão era montada uma barraquinha na Praia de Ramos, o que evitava a dispersão durante o período de férias escolares.

Um trecho do editorial do periódico "O Espelho", de fevereiro de 1951, assinado pela Diretoria gremista, ressalta, de forma ainda mais clara, seu papel preponderante de combate à assimilação:

Valeu, porém esse esforço, porque vemos atualmente o grêmio concorrido como nunca fora antes, os sócios unidos e irmanados. O Grêmio tornou-se o ponto de reunião obrigatório da juventude. Valeu nosso esforço porque evitamos que muitos filhos e filhas se dispersassem para outras paragens. Porque sabemos que aqui eles estão melhor que em qualquer outro lugar ignorado

A preocupação comunitária também se dirigia à manutenção da cultura judaica, com a existência da biblioteca que levava o nome do autor Simon Dubnow. Ela oferecia aos seus frequentadores livros editados em português, divulgando a literatura brasileira e parte da literatura iídiche já traduzida para a língua nacional. Possuía também vários clássicos em iídiche, ainda por serem traduzidos, como os de I. L. Peretz., cujo conto "Bontzie, o taciturno" foi publicado na edição de dezembro de 1950 de "O Espelho" e encenado por membros do grêmio.

Contudo, mais significativo que essa efervescência cultural, era o intercâmbio realizado entre os jovens dos diferentes bairros. Era comum as visitas entre os grêmios Chaim Weisman do Méier, I L Peretz de Madureira, o clube Cabiras da Cinelândia, o Macabeus da Tijuca e o Stefan Zweig. Passeios para as cidades próximas, como Petrópolis, Teresópolis e até a Ilha de Paquetá também eram realizados. Justamente dessas atividades, semelhantes ao "shidur" - espécie de namoro e casamento típico dos "shtetls" da Europa Oriental - saíram a maioria dos casamentos dos 
jovens da Leopoldina. Raros eram os casos, segundo os depoimentos, de união entre judeus do bairro de Olaria.

Se a manutenção de casamentos endogâmicos recebia uma atenção especial, ao que parece, a prática religiosa não tinha um papel preponderante no universo comunitário.

Como sugere um dos primeiros depoimentos, grande parte das pessoas não respeitava a tradição alimentar kasher, como também, nem sempre era fácil reunir 10 homens para rezar:

É! Eu era garoto, devia ter uns 14, 15 anos, ficava sentado na varanda da minha casa e aí eu via sair um velho disparado da sinagoga e ir no prédio em frente catar judeu. Eu via que ia sobrar para mim e eu fugia (...)

A sinagoga, montada provisoriamente no salão do prédio do Centro, era o fiel retrato desse desinteresse. Seu funcionamento era irregular, com exceção dos dias de shabat e, sobretudo, nos grandes feriados religiosos, quando se tentava, com muita dificuldade contratar um chazan. Nas festas de Rosh Hashaná (Ano Novo Judaico) e o Yom Kipur (Dia do Perdão), em razão da maior assistência, era alugado uma salão, situado na Rua Uranos junto à Rua Antônio Rego. Para lá se dirigia a maioria dos judeus residentes, cuja origem remontava à Polônia, permanecendo os "russos" no salão do Centro. Mesmo quando a sinagoga foi estabelecida, em sua sede própria, funcionando até hoje na rua Juvenal Galeno, nunca chegou a ter o culto conduzido por um rabino. Não só a falta de apego à religião, como, provavelmente, as dificuldades financeiras, não possibilitaram sua contratação.

Também, as relações entre as várias identidades judaicas da região da Leopoldina se estabeleceram de uma forma peculiar, diversa da região do centro da cidade. Neste último bairro, askhenazitas e sefaraditas construíram seu próprio espaço religioso e cultural - o primeiro grupo na Praça Onze e o segundo na região do Saara - com instituições comunitárias separadas e um limitado contato intercomunitário. Olaria, habitada por imigrantes da Europa Oriental, em sua grande maioria, era fundamentalmente um ambiente askhenazita. Os pouco sefaraditas, lá residentes, em razão de seu reduzido número, não puderem construir o próprio espaço. Em seu lugar, procuraram, ao que parece, a inserção nesse judaísmo europeu, reproduzindo essa identidade como se fosse própria.
Em nossa pesquisa, pinçamos dois exemplos de filhos de imigrantes sefaraditas, frequentadores da zona de Olaria, os quais negaram existir qualquer problema de relacionamento com os askhenazitas. "Meus amigos eram askhenazim”, justifica um deles. Um outro bom exemplo da boa relação entre os integrantes desses grupos, está no depoimento de um exmorador do bairro, filho de poloneses e que fala iídiche fluentemente:

Quando eu vim para o Hebreu Brasileiro encontrei um colega sefaradi que falou assim:

Quando perguntarem se você é askhenazi ou sefaradi, você diz que é sefaradi.

Mas porque?

Porque você vai jogar bola nas aulas de iídiche!

Então eu fui sefaradi por quatro anos.

Quanto ao aspecto profissional, os primeiros depoimentos confirmam terem os imigrantes judeus procurado atividade de "clientelchik", ou seja vendedores "de porta em porta”. Em geral, por não possuírem recursos, pegavam mercadorias em consignação com outros judeus e se dirigiam a bairros mais afastados ou cidades vizinhas, para vendê-los. A partir de um certo acúmulo de capital, oriundo dessa atividade, montavam um estabelecimento comercial ou industrial. Foi justamente esse enriquecimento que possibilitou à comunidade se estruturar e consolidar suas instituições, como a fundação da sinagoga de Olaria, em sede própria, na Rua Juvenal Galeno.

De outro lado, nos interrogamos se o enriquecimento também não teria contribuído para sua dispersão. Novas necessidades e demandas por melhores escolas, postos de trabalho, atividades comerciais mais lucrativas, podem ter levado grande parte das famílias a procurar novos bairros. Será com a continuação das entrevistas com os antigos moradores, ávidos por externar suas memórias, que poderemos saber se nossa hipótese é plausível. É com base nesse mapa do tesouro, que o Museu Judaico quer revelar e preservar as grandes riquezas de nossa comunidade.

\section{Referências Bibliográficas:}

ABREU, Maurício de A. Evolução urbana do Rio de Janeiro. IPLANRIO: Rio de Janeiro. 1997. 
BENCHIMOL, Jaime Larry. Pereira Passos: um Haussmann tropical: a renovação urbana da cidade do Rio de Janeiro no inicio do século $X X$. Secretaria Municipal de Cultura, Turismo e Esportes, Departamento Geral de Documentação e Informática: Rio de Janeiro. 1992.

BERNADES, Lysia M.C, SOARES, Maria Therezinha de S. Rio de Janeiro: Cidade e Região. Secret. Mun. de Cultura, Turismo e Esportes, Departamento Geral de Documentação e Informação Cultural, Divisão de Editoração: Rio de Janeiro. 1995.

CHALHOUB, Sidney. Cidade Febril: cortiços e epidemias na corte imperial. Companhia das Letras: Rio de Janeiro, 1999.

COARACY, Vivaldo. Memórias da cidade do Rio de Janeiro. Itatiaia: 3. ed. Belo Horizonte; Editora da Universidade de São Paulo: São Paulo. 1998.

EDMUNDO, Luiz. O Rio de Janeiro do meu tempo. Conquista: Rio de Janeiro. 1957.

FELLER, Aiala; WORKMAN, Karen (coords). Heranças e Lembranças Imigrantes Judeus no Rio de Janeiro. ARI/MIS: Rio de Janeiro. 1991.

FERRAROTI, Franco. Histoire et Histoires de Vie - La Méthode Biographique Dans Les Sociales. Librairie de Méridiens: Paris. 1983.

GERSON, Brasil. História das ruas do Rio: e da sua liderança na história política do Brasil. Lacerda Ed.: 5.0 ed. Rio de Janeiro. 2000.

GRIN' Monica. Etnicidade e Cultura Política no Brasil - O Caso de Imigrantes Judeus do Leste Europeu. In. Revista Brasileira de Ciências Sociais n.28.

LAPA, José Roberto do Amaral. A cidade: os cantos e os antros (Campinas 1850-1900). Edusp: São Paulo. 2000.

LESSER, Jeffrey. O Brasil e a Questão Judaica. Imago: Rio de Janeiro. 1995.

Negociando a Identidade Nacional. UNESP: São Paulo.
LINHARES, Rodovia Presidente Dutra: modernização e transformação para a cidade de Nova Iguaçu. Monografia em História apresentada ao departamento da UERJ: Rio de Janeiro. 1998.

LOZINSKY, Saadio. Memórias da Imigração: Reminiscências e Reflexões. Hai: Rio de Janeiro. 1997.

MALAMUD, Samuel. Recordando a Praça Onze. Kosmos: Rio de Janeiro. 1988.

PECHMAN Robert. A gênese do mercado urbano de terras, a produção de moradias e a formação dos subúrbios no Rio de Janeiro. Dissertação de mestrado apresentada a Pós-graduação do IPPUR. UFRJ: Rio de Janeiro. 1985.

SANTOS, Noronha. As freguesias do Rio de Janeiro. Edições O Cruzeiro: Rio de Janeiro. 1965.

SORJ, Bila (Org.) Identidades Judaicas no Brasil Contemporâneo. Imago: Rio de Janeiro. 1997.

THOMPSON, Paul. A voz do passado. Paz e Terra: Rio de Janeiro. 1992.

VAZ, Lilan Fessler. Uma história da habitação coletiva na cidade do Rio de Janeiro: Estudo da Modernidade através da moradia. Tese de Doutorado.Universidade de São Paulo / Faculdade de arquitetura e urbanismo: São Paulo. 1994.

\section{Periódicos}

"O Espelho"

"Periódico do Centro Israelita da Leopoldina" Entrevistas

Sr. Avram Reznik, 09/2000

Sr. Oushia Sanchovchi, 10/2000

Sr. Manoel Exelrud, 12/2001 Sra. Manieta Exelrud, 12/2001 Sra. Helena Honiger, 12/2001 Sr. Max Paskin, 01/2002

Sra. Rebeca Zukin, 01/2002 


\section{Imigrantes judeus do Oriente Médio e sua inserção em São Paulo e no Rio de Janeiro ${ }^{1}$}

Rachel Mizrahi ${ }^{2}$

$\mathrm{O}$ s judeus, apesar das guerras, das baixas expectativas de vida, das perseguições antissemitas, acompanhando o crescimento geral da população mundial, atingiram no alvorecer do século passado, o número de 12 milhões de seres. Destes, cerca de meio milhão vivia no Oriente Médio, compondo a quinta comunidade, depois da Rússia, do Império AustroHúngaro, Estados Unidos e Alemanha ${ }^{3}$.

No milenar contato com povos dos velhos continentes, os judeus absorveram valores e padrões de comportamentos possibilitando a existência de diferenciados grupos culturais. Ao lado da maioria asquenazi em terras europeias, temos os sefaraditas, de idioma ladino, os judeus da Itália, os do Magreb (norte da África), os iraquianos, os sírio-alepinos, os iemenitas, os persas, os de Bukhara do Ubequistã, os falashas da Etiópia e outros mais. A convivência de 13 séculos entre judeus e árabes aproximouos em larga medida, alimentando uma tradição judaico-islâmica, paralela a judaico-cristã do mundo ocidental ${ }^{4}$. Embora intensa, a "arabização" não atingiu a religião e as tradições judaicas.

A expulsão dos judeus da Espanha em 1492 e a conversão forçada em Portugal de 1497 produziram a Diáspora Sefaradi, levando judeus e cristãos novos a buscarem refúgio em outras áreas europeias e nas do Império Otomano. Nas terras mediterrâneas, os judeus ibéricos posicionaram-se em núcleos urbanos da Itália, Bálcãs e Africa do Norte, constituindo uma rede familiar de relações socioeconômicas, tornando

${ }^{1}$ O texto é parte do Os judeus do Oriente Médio em São Paulo e Rio de Janeiro. Ateliê Editorial, São Paulo, no prelo.

${ }^{2}$ Doutora em Sociologia / USP

${ }^{3}$ Justin McCarthy. Jewish Population in the late Ottoman Period. In, Avigdor Levy. The Jews of Ottoman Empire. Princeton, N.J. Washington, D.C. 1994, p.375.

${ }^{4}$ Avigdor Levy. The Jews of the Ottoman Empire. N. Jersey: The Darwin Press, Inc., 1992, Introdução. válida a ideia de que o Mediterrâneo era um mar sefaradi ou "Mare Nostrum Sephardicum", utilizada por alguns historiadores.

Bayasid II, sultão do Império Otomano (1481-1512), conhecendo a relevância dos refugiados e as circunstâncias de saída da Espanha, recebeu os sefaraditas em seus vastos domínios, questionando o bom-senso dos reis católicos Fernando e Isabel ao decretar a expulsão em 31 de março de 1492. O sultão e seus sucessores valeram-se dos préstimos e conhecimentos dos sefaradis não só para a expansão e desenvolvimento do comércio regional e internacional, como no incremento das finanças, da diplomacia, nos negócios bancários, na corretagem e na ourivesaria. Os refugiados judeus foram designados pelos dirigentes otomanos a importantes cargos políticosadministrativos, participando, inclusive, da estratégia de colonização de áreas do vasto Império. Os positivos contatos entre eles permitiram que laços de identidade se solidificassem ao longo dos séculos, numa convivência de mútuo e duradouro respeito.

Foi curioso o encontro cultural entre os sefaradis e os diversos grupos de judeus do Oriente Médio. O orientalista Issachar Ben Ami, professor da Universidade Hebraica de Jerusalém, estudando a interação cultural produzida, assinalou que os contatos entre os sefaradis e os judeus-orientais seguiram três caminhos distintos: assimilação total dos exilados com os autóctones; preservação completa ou parcial da cultura dos exilados e, a influência direta e recíproca entre os dois grupos ${ }^{5}$. Ben Ami acrescentou que os processos de interação dependeram da aproximação e afastamento dos envolvidos, em função das condições locais e da realidade numérica dos envolvidos.

Os otomanos conquistaram terras do ocidente e oriente, formando um imenso Império Em meados do século XVI, os otomanos conquistaram Jerusalém. Sua expressividade está ligada ao "Muro das Lamentações", parte da grande ala do Segundo Templo, erguido em 518 a.C. sobre os alicerces do Primeiro, inaugurado por Salomão em 960, antes da era comum. Em torno da velha Jerusalém, uma comunidade, o ishuv original subsistia pela filantropia. Ao norte, Safed, transformada em núcleo administrativo otomano, foi ocupada por cabalistas espanhóis, entre os

5 Ben Ami Issachar. Sephardi and Oriental Jewish Heritage. Universidade Hebraica de Jerusalém, 1982. In, Identidade Sefaradi: Aculturação e Assimilação. Novinsky e Kuperman. Ibéria Judaica. Roteiros da Memória. São Paulo, EDUSP, 1996, p.343 e seg. 
quais, Isaac Ben Salomão Luria (1534-1572) que transformou a cidade em centro de estudos místicos.

Os judeus do Império Otomano, organizados em comunidades autônomas - Millets ${ }^{6}$ - viviam sob a supervisão de um religioso, o chahani ${ }^{7}$. Preservando o idioma materno e costumes típicos, as comunidades, onde viviam alguns asquenazis ${ }^{8}$, puderam reforçar suas identidades culturais e religiosas.

Dos grupos culturais do Oriente Médio, dirigimos atenção aos moçárabes ou judeus-orientais ${ }^{9}$ e aos sefaradis, situados em cidades próximas aos dirigentes otomanos. Os primeiros, de expressiva tradição judaica oral, viviam em terras de maioria árabe-muçulmana. Os sefaradis, atentos e observantes dos preceitos religiosos e familiares utilizavam-se do ladino ou judezmo, espanyol ou didjio, misto de palavras espanholas, portuguesas, árabes, hebraicas e turcas. $\mathrm{O}$ trauma da expulsão parecia não ter sido por eles superado, pois tanto portugueses como espanhóis em diversas terras otomanas, permaneceram ligados às origens e tradições judaicas ancestrais ibéricas.

Na primeira década do século passado, os conflitos regionais, a pobreza, o desemprego e o serviço militar obrigatório, exigido pelos nacionalistas turcos - "Jovens Turcos", constituíram-se em fatores que levaram judeus e outros grupos étnico-religiosos do Oriente Médio a emigrar. A maioria optou por terras da América, particularmente os Estados Unidos. Dados demográficos revelam entrada de quase 3.000.000 de judeus no país, entre 1876 a $1926^{10}$. O sistema de cotas, adotado pela política imigratória americana nas primeiras décadas do século $\mathrm{XX}$, levou a que os responsáveis pelas embarcações dirigissem os imigrantes para países da

${ }^{6}$ Ellis Rivkin. Uma história de duas diásporas. In: NOVINSKY E KUPERMAN, (org). Ibéria Judaica: Roteiros da Memória. São Paulo: EDUSP, 1996, p. 267 e seg.

7 O termo hebraico Chaham, sábio, é, comumente, expresso em português com ch inicial. A partir de 1836,0 Chaham de Istambul estendeu poder a todas as comunidades judaicas do Império Otomano. In, Norman Stillman, Op. cit. p.30 e seg.

${ }^{8} \mathrm{O}$ antissemitismo levou algumas famílias asquenazis se transferirem da Rússia e da Europa Oriental às terras otomanas.

${ }_{9}$ Apesar de portarem valores culturais distintos, há quem classifique os judeus-orientais como sefaradis. Os professores da Universidade de Jerusalém, entre os quais Margalit Bejarano utilizam-se dos termos diferenciadores.

${ }^{10}$ Sachar. Jewish Publication Society, 1967
América Latina. A Argentina e o Brasil receberam juntas, no mesmo período, perto de 300.000 imigrantes judeus.

No período, a maioria de judeus europeus, estabelecida em várias cidades brasileiras, dividiu espaço com os judeus do Império Otomano, procedentes da ilha de Rodes e das cidades de Esmirna, Salônica, Istambul, Sidon, Beirute, Jerusalém e Safed.

Identificados pela religião e tradições, os imigrantes judeus no Brasil, expressando- se em idiomas diferentes, organizaram-se separadamente, tomando como matriz suas comunidades de origem. O Rio de Janeiro e, depois, São Paulo atraíram maior número de imigrantes judeus.

Embora a maioria dos sefaradis, predominantemente, tenha procurado a Argentina, o Chile e o Uruguai, número representativo, em médias posições, originários das cosmopolitas cidades otomanas, acomodou-se em bairros residenciais do Rio de Janeiro, São Paulo, Santos e outras cidades brasileiras. O dinamismo econômico levou, nos anos 30, São Paulo a superar a capital do país, pois $2 / 3$ de sua população era procedente dos velhos continentes, notadamente italianos.

Por falar um idioma próximo ao português, a maior parte desses imigrantes integrou- se rapidamente entre as médias e altas camadas da sociedade brasileira. Ligaram-se a negócios de importação e exportação de café, cereais, frutas, tecidos finos, tapetes orientais, seguros e minérios. Além do ladino, os sefaradis comunicavam-se em francês, aprendido em colégios confessionais católicos e nas escolas da Alliance Israélite Universelle de suas cidades de origem.

Os judeus-orientais, instalados na Mooca, bairro étnico da região leste de São Paulo, identificavam-se pelo idioma e costumes com muçulmanos e cristão-maronitas, imigrantes que chegaram do Oriente Médio nas últimas décadas do século XIX. Embora procedentes do Império turco-otomano, esses imigrantes, em maior número, preferiam ser designados como "sírio-libaneses", em vista da conotação pejorativa do termo "turco" no período. Vivendo do comércio atacadista da Rua Oriente, no Brás, os sírio-libaneses vendiam diversas mercadorias aos judeusorientais, conhecidos como os "turcos da prestação" por se ocuparem do comércio ambulante e prestamista. Os asquenazis, na mesma profissão, eram conhecidos como os "judeus da prestação". 
A maioria dos asquenazis de São Paulo escolheu viver no Bom Retiro, bairro contíguo ao Brás e a Mooca, próximos à Hospedaria dos Imigrantes. Esses imigrantes expressavam-se em iídiche, misto de palavras eslavas, alemãs e hebraicas, o que dificultou a comunicação com os nacionais e judeus de outras origens, apesar da identificação religiosa.

De uma maneira geral, não compreendendo as diferenças, os diversos grupos de judeus, mutuamente se rejeitavam. Aos poucos e, principalmente, movidos pela observância do Kashrut, os do Oriente Médio, em menor número, aproximaram-se dos asquenazis que se responsabilizaram pelos primeiros estabelecimentos, instituições e pela construção das primeiras sinagogas, construídas em São Paulo.

Embora procedentes de uma mesma região, os judeus do Oriente Médio, sefaradis e orientais, diferenciados pelo idioma e costumes, organizaram-se e construíram sinagogas próprias. $\mathrm{O}$ regionalismo predominou.

Os judeus da Mooca, embora se expressassem num mesmo idioma, o árabe, construíram duas sinagogas: a Sinagoga Israelita Brasileira, conhecida como a dos, de Siadne" (nome árabe da cidade de Sidon) e, a União Israelita Paulista, dos de Safadie" (nome árabe da cidade de Safed). O funcionamento dos dois templos numa mesma rua, a Odorico Mendes, não dividiu os imigrantes que compuseram uma só comunidade na Mooca.

A União Israelita Paulista, fundada por judeus da cidade de Safed, pautou pela preservação das tradições e receptividade a imigrantes de várias kehilot do Oriente Médio. Além dos de Safed e Jerusalém, receberam os sefaradis (chamados de "espanhóis"), judeus marroquinos, egípcios e, também, os beirutenses ${ }^{11}$. Os originários de Sidon, antiga cidade libanesa, predominavam na Sinagoga Israelita Brasileira.

O crescimento numérico da comunidade judaica da Mooca foi notável. As famílias, numerosas, permitiram a endogamia. As duas sinagogas, construídas entre 1930 e 1935, tornaram-se pequenas com a entrada de mais famílias que se transferiram do Rio de Janeiro, como os Nigri e os Kalili, impossibilitando a acomodação de imigrantes da mesma origem, refugiados dos países árabes, que chegaram a partir dos anos 50 .

\footnotetext{
${ }^{11} \mathrm{Na}$ década de 50, Jacques Eskenazi, de Beirute revelou sentir-se mais à vontade na "Sinagoga dos Amar" do que na "dos Nigri"
}

Em 1924, os sefaradis não encontrando rabinos da origem, buscaram chazanim judeus-orientais para a direção dos rituais da sinagoga, inaugurada em 1929. Assilam Cohen e Habibe Menram, ambos de Beirute e, Elias Mizrahi, de Safed, co-fundadores da Sinagoga da União Israelita Paulista, na Mooca, foram contratados para ajudar Isaac Hayon, Mair Cohen Arias e, depois a Jacob Mazaltov na condução das rezas e serviços comunitários.

Cerimônias típicas identificavam os sefaradis. Entre elas, citamos a das "Siete Candeias" (sete velas) e o Bat-Mitzvá. "Fadar uma Menina" ou a festa das "Siete Candeias" é a cerimônia onde sete pessoas homenageiam o nascimento de uma menina; o Bat-Mitzvá celebra a assunção da responsabilidade de uma jovem de 12 anos ao judaísmo. Comum nas comunidades judaicas brasileiras de hoje, esta cerimônia não era observada por asquenazis e judeus-orientais antes dos anos 60. Em 1938, a comunidade judaica de São Paulo, assistiu pela primeira vez, a oficiada pelo istambuli Jacob Mazaltov, rabino da Sinagoga Israelita Brasileira do Rito Português, popularmente conhecida como Sinagoga da Abolição. Na oportunidade, Gabriel Kibrit, amigo de Mazaltov, participante da Sinagoga Israelita Brasileira conseguiu reunir jovens de sua comunidade da Mooca à comemoração sefaradi.

A receptividade foi marca sefaradi. Judeus, originários de diversos países, frequentaram as sinagogas no Rio de Janeiro e a de São Paulo. No início dos anos 30, os judeus alemães, conduzidos pelo rabino Fritz Pinkus, de linha liberal, instalaram-se, pouco depois da chegada, no amplo salão da Comunidade Israelita Sefaradi. O grupo não conseguia acomodar-se entre os asquenazis, de linha conservadora.

A proximidade entre os rabinos Mazaltov e Pinkus, contribuiu para que algumas das cerimônias de casamentos e preparação ao Bat-Mitzvá de sefaradis e asquenazis fossem organizadas por eles, em comum acordo.

Além dos asquenazis, os sefaradis recepcionaram em sua sinagoga, judeus da Itália, da Bulgária, da Grécia, da Iugoslávia, do Marrocos e os imigrantes da década de 50 , refugiados dos países árabes ${ }^{12}$. Os sefaradis dos Bálcãs voltaram ao ocidente, em nova diáspora, diante do antissemitismo

${ }^{12}$ A liberalidade levou-os a perder o controle administrativo e religioso da Sinagoga da Abolição, em fins dos anos 60 . 
alemão que adentrava pela Europa Oriental. Muitos, não conseguindo sair de seus países, acabaram por perecer em campos de concentração nazistas.

Os imigrantes judeus-italianos dividiram-se entre o culto da Sinagoga da Abolição e o da Congregação Israelita Paulista dos judeu-alemães, a CIP. Destacamos na sinagoga sefaradi, Enzo Ventura, de Trieste que emigrou em 1939. No início dos anos 50, quando o rabino Mazaltov deixou a sinagoga, Enzo Ventura tornou-se "diretor de culto" do templo. Aluno de David Prato, grande rabino de Trieste, Ventura reformulou o trabalho, iniciado na Itália, "A Bíblia, em versos", e editou-a em português. Da mesma forma, a experiência musical de Leonelo Abramo Morpurgo, spalla do Teatro Verdi de Trieste, possibilitou a introdução na CIP de partituras musicais, ainda hoje usadas pelo coro que Morpurgo introduziu ${ }^{13}$.

Em 1933, os sefaradis da Abolição, preocupados com a recreação e integração das famílias, fundaram o CIBAT utilizando-se do salão, situado no plano inferior do templo, para a realização dos "primeiros encontros literários e recreativos" da comunidade sefaradi de São Paulo. Os judeusorientais criaram na Mooca, o Grêmio Sinai em 1942 e depois, o Centro Recreativo Hebreu Brasileiro.

Na ONU, a partilha, em 1947, criando o Estado de Israel e o Estado Palestino, intensificou as posturas nacionalistas e o antissemitismo árabe. Sancionada a partilha, a Grande Sinagoga de Alepo, na Síria, foi incendiada, fato que chocou os judeus, pois no templo, possivelmente o mais antigo do mundo, guardavam-se manuscritos preciosos ${ }^{14}$. Os dirigentes sírios passaram a controlar seus 24.000 judeus, impedindo-os de emigrar para Israel. Negociantes que precisassem viajar poucos quilômetros de suas residências deveriam apresentar-se, obrigatoriamente, à polícia e depositar valor em dinheiro, restituído somente no retorno. As restrições e violências contínuas levaram a que agentes operacionais israelenses buscassem resgatar famílias judias sírias, conduzindo-as a Israel através do Líbano, Turquia, países da Europa e dos Estados Unidos. Essas operações, realizadas em momentos diferentes, levaram à divisão de famílias sírias por diferentes continentes.

\footnotetext{
${ }^{13}$ Michel Laub. A Saga de vidas belas dos judeus italianos no Brasil. São Paulo: Revista República, abr. 1999, ano 3, n.30.

${ }^{14}$ O "Códice de Alepo", o Keter, com perda parcial, foi levado a Israel ao Instituto BenZvi.
} Rifca Berezin. Coletânea de Lembranças de Alepo. In, Morashá, ab, 1997.
A instabilidade europeia, decorrente da Guerra Fria, levou grupos de famílias judias da Síria a investirem nas possibilidades econômicas dos países latino-americanos. No período, o Brasil apresentava-se como opção desejável. Entre os judeus da cidade de Alepo que se instalaram em São Paulo estão os Safra e os Safdié, famílias de antigos e expressivos empresários do Oriente Médio que investiam nos setores financeiros e bancário.

Em número próximo a 70.000, os judeus do Egito viviam em antigas, prósperas e integradas comunidades no Cairo, Alexandria e outras cidades. Em 1952, ao derrotar o General Naguid, Gamal Abdel Nasser tornou-se único detentor do poder no país. Liderando a Liga Árabe, o presidente Nasser conseguiu direta oposição de todos os países árabes à "política expansionista" de Israel. Impedidos de emigrar a Israel, os judeus do Egito dividiram-se entre a França, Inglaterra, Itália e países da América.

A HIAS ("Hebrew Immigrant Aid Society"), organização judaica de ajuda ao imigrante, considerou a terra brasileira como local ideal de asilo aos imigrantes da segunda metade do século passado. Além de extensões de terra não ocupadas, o país estava em fase de expansão econômica, não apresentando como a Argentina, histórias de antissemitismo. No Brasil, imigrantes de várias origens religiosas, entre os quais, muçulmanos e judeus, viviam em harmonia e muitos ocupavam cargos na administração pública, sem que a etnia e a crença religiosa fossem lembradas e questionadas.

A emigração dos judeus egípcios ao Brasil, a partir de 1956, foi negociada entre os dirigentes egípcios e os rabinos Haim Nahoum Effendi e Aron Angel. O grão-rabino Nahoum Effendi que havia ocupado cadeira no Senado egípcio, com mais de oitenta anos, conseguiu tornar gradual o novo êxodo de famílias judias. Buscou o rabino regularizar a documentação, apresentando as famílias refugiadas aos dirigentes comunitários brasileiros.

No Brasil, limites expressos pelo chefe do Departamento de Imigração, do Ministério da Justiça à admissão dos refugiados judeus do Egito, foram contornados por Israel Klabin, industrial do Rio de Janeiro, a conselho de Augusto Frederico Schmidt ${ }^{15}$. O Presidente Juscelino Kubitschek permitiu a livre entrada de imigrantes judeus ao Brasil. Parte dos imigrantes de Alexandria, cidade balneária do Egito, foi atraída pelo

${ }^{15}$ O funcionário, ligado ao político brasileiro Filinto Muller, havia exigido 50 dólares de cada imigrante judeu-egípcio. 
Rio de Janeiro, porto de mar e capital do país. A Congregação Religiosa Beth-El e o CIB, clube recreativo sefaradi de Copacabana, recepcionaram os novos imigrantes hoje, maioria frequente.

Grande número dos refugiados judeus dos países árabes fixou-se em São Paulo, cidade com amplas possibilidades de absorção a imigrantes de todas as origens. A experiência em negócios, a formação acadêmica e o domínio de línguas estrangeiras fizeram com que os judeus do Egito, da Síria e do Líbano se posicionassem em empresas próprias ou multinacionais, abertas a profissionais especializados e bilíngues ${ }^{16}$.

Em São Paulo, os novos imigrantes do Oriente Médio passaram a frequentar a Shaar Hashamaim, nome da Sinagoga da Abolição, situada na Bela Vista, próxima do centro. Samuel Del Giglio, presidente da Congregação, o rabino Diesendruck e Elias Mizrahi, chazan que falava o árabe, recepcionaram aos novos imigrantes. A antiga sinagoga sefaradi, diante do número e assiduidade dos participantes, ganhou ânimo ${ }^{17}$.

Em pouco tempo, no início dos anos 60, a religiosidade do judeuegípcio, Davide Douek, levou o gibraltino Isaac Levy, então presidente comunitário, a convidá-lo para diretor de culto. Reconstruída a sinagoga, agora Templo Israelita Brasileiro Ohel Yaccov, a entonação das rezas da sinagoga sefaradi assume a entonação da maioria egípcia predominante.

Preocupados com a integração comunitária e com a formação religiosa das crianças e dos jovens, libaneses e alepinos propuseram-se a construir a sinagoga e uma escola. Em outubro de 1959, nas dependências da Sinagoga da Abolição, a família Safra e mais famílias constituíram a Congregação e Beneficência Sefardi Paulista e empreenderam a construção do templo na Rua Bela Cintra, no bairro de Cerqueira César. Poucos anos depois, outro maior foi construído no bairro de Higienópolis. A escola Talmud Torá,

\footnotetext{
16 A instalação de indústrias automobilísticas, eletromecânicas e farmacêuticas e de instituições financeiras e bancárias em São Paulo, permitiu aos novos imigrantes, pela formação universitária, a ocupação de cargos de diretoria destas organizações. Joe Piccioto, por exemplo, tornou-se um dos gerentes da Philco e, Gastão Levi, empregado da Gilette, tornou-se coordenador mundial da empresa em Boston.

17 A partir de 1952, cerca de 1.500 famílias judias egípcias chegaram ao Brasil, número considerado massivo, pois nunca antes tão grande número de judeus, em curto espaço de tempo, havia chegado ao Brasil. A localização, as pequenas dimensões das sinagogas e o regionalismo limitaram o interesse dos novos imigrantes pelas sinagogas da Mooca.
}

supervisionada por religiosos e chazanim da comunidade sírio-alepina e libanesa, iniciou programa educativo religioso às crianças e jovens da comunidade. Em 1964, a Congregação inaugurou o primeiro templo. O grande contribuinte, Jacob Safra, havia falecido pouco antes, em 1963.

No período, algumas famílias egípcias, ressentindo-se das dimensões da Abolição, propuseram a construção de outra sinagoga. Seus imensos e iluminados templos no Cairo e Alexandria contrastavam com a simplicidade da construção sefaradi. A crescente entrada de novos imigrantes da mesma origem foi primordial para a tomada da decisão.

Em 1959, Joseph Farhi encabeçou a compra de um terreno de $700 \mathrm{~m}^{2}$, em Higienópolis, bairro onde muitos imigrantes egípcios haviam fixado residências. Durante as obras, algumas famílias acomodaram-se na casasinagoga da Rua Brigadeiro Galvão, desocupada pelos judeu-alemães em vista da inauguração da Congregação Israelita Paulista, a CIP, na Rua Antonio Carlos. Os judeus do Egito permaneceram no imóvel por vários anos até a finalização das obras de sua sinagoga. Doações concedidas pelos irmãos Laniado, somada ao apoio de Edmond Safra ${ }^{18}$ permitiram a construção de um templo amplo e majestoso, inaugurado no Rosh Hashand de 1967. Adotando o nome de Congregação Mekor Haim, os imigrantes homenagearam o grão-rabino do Egito, Haim Nahum Effendi.

A fundação de novas sinagogas, próximas aos locais de residências dos fiéis, levou a que os dirigentes da Sinagoga da Abolição tivessem dificuldades em manter fiéis para as rezas diárias. Embora Davide Douek, idealmente projetasse uma sinagoga, núcleo de grande praça na Bela Vista, em dezembro de 2001, acabou por aceitar a proposta do sefaradi Senor Abravanel, popularmente conhecido como Sílvio Santos. Com negócios na região, o empresário propôs a permuta do terreno da sinagoga por outro, na região dos Jardins, próximo das moradias dos sócios. Os participantes da sinagoga, convocados a uma Assembleia Geral, concordaram com a construção de um novo templo, em outro local. Antecipamos que o projeto arquitetônico prevê um edifício amplo e moderno com amplas janelas, emolduradas pelos belos vitrais da antiga sinagoga e voltadas a uma área aprazível e ajardinada.

${ }^{18}$ A Sinagoga Mekor Haim foi construída com a colaboração dos fundadores e participantes. Jacob Laniado, ao falecer, doou à comunidade o valor de US\$25.000, utilizado no início das obras. 
Na Mooca, em fins da década de 60, os dirigentes da Sinagoga Israelita Brasileira enfrentavam problemas diversos. As frequentes enchentes do Rio Tamanduateí, determinando a transferência de muitas famílias para outros bairros e a possível participação na sinagoga de descendentes, originários de "casamentos mistos", cujos pares não haviam feito a conversão, passou a preocupar os religiosos. Os dirigentes passaram a acalentar a ideia da construção de uma nova sinagoga em Higienópolis, local para onde algumas famílias da Mooca se transferiram. Em abril de 1974, nos festejos de Pessach, foi inaugurado um amplo e moderno templo. Em junho de 1985, Isaac Michaan, nascido em São Paulo e participante do grupo Beit Chabad, foi convidado para chefe espiritual de uma comunidade que permaneceu por mais de 60 anos sem condução rabínica. Embora saudosos "dos tempos da Mooca", os integrantes da sinagoga da Congregação Monte Sinai aos poucos acabaram aceitando as diretrizes do rabino. O trabalho do religioso provocou a "inversão do processo assimilativo" desejado pelos antigos fundadores que se transferiram para Higienópolis ${ }^{19}$.

Hoje, as antigas sinagogas da Rua Odorico Mendes, na Mooca, são frequentadas por idosos, ainda residentes no bairro e os poucos que vêm participar do shabat e das Grandes Festas. As duas sinagogas ainda estão separadas e os fiéis preocupam-se em manter os templos ativos. A proposta da fusão da União Israelita Paulista com a Sinagoga Israelita Brasileira, sugerida em 1985 por Isaac Amar, não foi aceita por algumas famílias.

\section{A inserção sefaradis e judeus-orientais em São Paulo e Rio de Janeiro}

Minoria do conjunto imigrante, os judeus do Oriente Médio, instalados nas cidades de São Paulo e Rio de Janeiro, encontraram abertas todas as oportunidades oferecidas pela economia brasileira, em rápido processo de crescimento ${ }^{20}$.

\footnotetext{
${ }^{19}$ A aceitação do religioso na sinagoga não era unânime. Alguns criticavam a "exagerada" ortodoxia do rabino Isaac Michaan. Sabe-se que antigos participantes das sinagogas da Mooca transferiram-se para sinagogas asquenazis, de linha liberal. Recentemente, Isaac Michaan afastou-se da Congregação e substituído por David Azulay, também participante do Beit Chabad.

${ }^{20}$ Os dados estatísticos sobre a população de judeu-brasileiros são variáveis. Sérgio De La Pergola elaborou a pesquisa em 1990 de 100.000 . No momento, a CONIB, apoiada pelas Federadas Estaduais, procede o recadastramento das famílias judias brasileiras.
}

Número expressivo de sefaradis, imigrantes das primeiras décadas do século passado, ocupou-se com a torrefação e o comércio do café. O corretor Vital Sion, ponte entre o comissário e o exportador, foi "rei do café" em Santos; seu sócio e primo Moise Hazan e os Curiel partilharam do mesmo sucesso, na cidade santista e no Rio de Janeiro; Isaac Vaena, além do café, negociava diversos produtos na Bolsa de Mercadorias de São Paulo, em escritórios situados no triângulo formado pelas São Bento, Direita e 15 de novembro, ruas do centro antigo da cidade.

No Largo do Café, popularmente conhecido como o Beco dos Turcos, muitos imigrantes judeus do Oriente Médio de São Paulo encontravam-se para fazer negócios e saber das novidades políticas e comunitárias. Neste espaço, o ladino, o francês, o turco, o grego, além do português, misturavam-se num verdadeiro mundo sem fronteiras. David Nahoum, que falava vários idiomas, transformou-se em intermediário dos negócios e amizades. Seu Bar e Café Juca Pato era frequentado por eminentes intelectuais da sociedade paulistana dos anos 40 e 50.

Além dos altos negócios do café, os sefaradis ligaram-se a diversos empreendimentos comerciais nas duas maiores cidades brasileiras. Estabelecidos em lojas de importação de tecidos finos, rendas e tapetes orientais, esses imigrantes tiveram oportunidade de conhecer e relacionar-se com expressivos políticos e empresários. Participantes de clubes exclusivos e elegantes do Rio de Janeiro, os Menaché, os Mussafir, os Chuek e os Cherem investiram em imobiliárias das décadas de 50 e 60, responsáveis pelos belos edifícios de Copacabana e Ipanema, bairros nobres da cidade. Interessante apontar que a liberalidade ou a imperceptível identidade religiosa desses sefaradis levou a antropóloga Vivian Flanzer considerá-los "um grupo invisível", no qual a religião não se confundia com o social ${ }^{21}$.

Ao lado da sinagoga sefaradi Beth El, o amplo espaço social da CIB, em Copacabana, foi espaço onde se realizaram peças de teatro com atores hoje famosos ${ }^{22}$. No meio jornalístico destacaram-se Rubens Amaral e Isaac

${ }^{21}$ Vivian Flanzer. Muros invisíveis em Copacabana. Uma etnografia dos rodeslis na cidade do Rio de Janeiro nos anos 20 e 30. In: Judaísmo, Memória e Identidade. Vol 1. UERJ, p. 81 a 90 .

${ }^{22}$ Cláudio Correa e Castro, Roberto de Cleto, Jonas Block, Yom Tov Azulay que, da carreira diplomática, passou a diretor de cinema, e o escritor e animador Daniel Azulay apresentaram-se no espaço. 
Ruben Israel ${ }^{23}$. Na cidade, na primeira década do século, a personalidade do judeu-brasileiro David José Pérez, de origem marroquina, destacava-se como responsável pelo "A Columna" primeiro jornal judaico escrito em português. Poucos anos depois, José Esquenazi Pernidji, especialista em Direito Internacional sobressaia-se na revista "Comentário", fonte de informação dos meios universitários brasileiros do período. Sua dedicação aos estudos de História Judaica permitiu que representasse o Brasil em vários encontros internacionais. Na década de 60, além de Pernidji, destacaram-se o paulista Narciso Kalili e a singular figura do carioca Sefior Abravanel, conhecido como Sílvio Santos, filho de judeus de Esmirna e Salônica, hoje transformado em grande comunicador da televisão brasileira.

Em São Paulo, os Hasson, os Alalu, os Sereno, os Benbassati e os Stamati proporcionaram à elite paulistana o luxo e a beleza dos tapetes orientais e dos tecidos finos. Na cidade mineira de Governador Valadares, área de exploração e beneficiamento de minerais, Jaime Algranti, de São Paulo, foi um dos pioneiros na exportação da mica para os Estados Unidos. Associado aos irmãos Raphael e José, a família projetou-se também na exploração da caseína.

Embora, a maioria dos imigrantes da Mooca tenha garantido sobrevivência no comércio ambulante, as famílias Nigri e Sayeg, entre outras, iniciaram-se na indústria têxtil. Os Nigri e os Zitune, entre outros, investiram no setor imobiliário e em empresas de engenharia e arquitetura. A Tecnisa, a Coni, a Construtora Elias Victor Nigri, a dos Zitune e a Terepins e Kalili constituem hoje, empresas de expressão. Na indústria têxtil, foi notável a P. Sayeg. A tradicional Tecelagem Francesa, Tecidos Hasson, a Têxtil de Rendas Acácia e a Padronagem são apontadas, entre outras, como grandes distribuidoras de tecidos.

Nos meios artísticos do Rio de Janeiro e São Paulo, destacam-se concertistas e musicistas de importância, entre os quais, o consagrado Arnaldo Cohen, Eduardo Hazan, Roberto Sion, Cláudio Roditi, Rosette Houli Vaissman e Esther Fuerte 'Wajman. Nas artes plásticas, entre outras, citamos Mônica Barki e Minam Nigri Scheirer, Matilde Algranti Salomon e Diana Dorothèa Danon, hoje documentando, em desenho, as obras de

${ }^{23}$ Isaac Rubem Israel recomendou a Roberto Marinho, da rede Globo, a importação de aparelhagem técnica que permitiu a liderança da empresa nos meios de comunicação brasileira. Relato de Anna Barki Bigio a RM. São Paulo, 1999. construção do metrô paulistano. No cancioneiro ladino, destaca-se a cantora Fortuna. Parte de seu repertório e a entonação do canto ladino foi-lhe passada por senhoras sefaradis de São Paulo.

Sefaradis e judeus-orientais projetam-se nos cenário cultural e universitário. Destacamos do conjunto, a pesquisadora Ida Hasson Voloch no Instituto Manguinhos, o endocrinologista Rubem Azulay, ambos do Rio de Janeiro; o professor Dr. Isaac Amar na Faculdade de Medicina, o cientista-social Bóris Fausto e o psicanalista Renato Mezan posicionam- se como eminentes pesquisadores da Universidade de São Paulo. No período de 1997 a 2001, Jacques Marcovitch ocupou o cargo de Reitor da mesma universidade. Marcovitch, que chegou ao Brasil com a família do Egito, aos 16 anos, conseguiu tão bem se posicionar nos meios intelectuais que, não passa pela cabeça de ninguém perguntar-lhe se é brasileiro. De professor titular da Faculdade de Economia, Administração e Contabilidade (19972001), passou a diversas posições acadêmicas, entre as quais, a de Coordenador da Área de Assuntos Internacionais do Instituto de Estudos Avançados da USP, no período de 1993 a 97. Recebeu prêmios e distinções nacionais e internacionais e publicou vários livros e artigos em revistas científicas no Brasil e no exterior ${ }^{24}$. Hoje, ocupa-se, oficialmente, de projetos administrativos para a cidade de São Paulo.

Além das profissões, artes e ciências, imigrantes e descendentes de judeus do Oriente Médio destacam-se em empresas do Terceiro Setor e, em fundações culturais. Do conjunto, destacamos os Safra e os Safdié, famílias que participam do núcleo de patrocinadores dos grandes eventos culturais do país. O apoio financeiro dessas famílias a numerosos projetos tem permitido a restauração de antigas sinagogas, museus e resgate de obras históricas e artísticas brasileiras e estrangeiras. Salientam-se, também, por divulgar em espaços próprios e públicos, a arte brasileira e internacional.

${ }^{24}$ Henrique Rattner (org.). Brasil no Limiar do século XXI. Alternativas para a Construção de uma sociedade sustentável. São Paulo, FAPESP e EDUSP, 2001, p. 366. 


\section{Judeus do Egito no Rio de Janeiro: uma imigração peculiar (1956/1957)}

\section{Joëllle Rouchou ${ }^{1}$}

B

risa fresca do Mediterrâneo. Praias lotadas. Sucos de frutas frescas. Noites estreladas e harmonizando todas essas imagens, o cheiro de jasmim que perpassava toda Alexandria. Essas imagens e cheiros estão presentes na memória dos imigrantes judeus do Egito que foram expulsos de seu país natal logo após a guerra do Canal de Suez, em 1956. Cerca de 400 vieram para o Brasil, que naquele momento abria possibilidade de nova vida, com um presidente - Juscelino Kubitschek - concedendo vistos de entrada aos refugiados. Sem muito planejar a vinda, eles desembarcaram num país onde foram aceitos, que os acolheu, a quem permanecem gratos.

Esse texto é parte da tese de doutorado a ser defendida na ECA/USP em 2003, que trata da imigração dos judeus do Egito para o Rio de Janeiro nos anos 56/57. Dentro do imenso panorama da imigração no Brasil, a pesquisa vai estudar o caso desses judeus que já haviam migrado de outros países para o Egito e, mais uma vez, tiveram de trocar seus endereços. Essa história é contada em depoimentos orais nos quais se registra o sofrimento desse grupo de pessoas que migrou para o Rio de Janeiro.

Vieram todos de Alexandria ou do Cairo, com pouco dinheiro no bolso, largando seus bens, lojas, sinagogas, clubes e amigos para trás. A recorrência à história oral advém de seu potencial para aproximar experiências vividas no presente com lembranças do passado nas quais aparecem com ênfase dimensões da identidade forjada entre esse grupo a partir de seus referenciais étnico-culturais, de suas afinidades alimentares, religiosas, celebrações e relações com o universo próximo e distante pautados no ser imigrante judeu.

Nossa narrativa tem como ponto inicial de referência a guerra do Canal de Suez (1956/1957) que forçou a saída de todos os estrangeiros do Egito. O grupo era composto por famílias que vieram juntas de navio. A

\footnotetext{
${ }^{1}$ Jornalista, doutoranda ECA / USP
}

maioria era de comerciantes, professores, músicos, de classe média. Seus relatos contam suas vidas e adaptação ao Rio. Os imigrantes foram selecionados em diversas faixas etárias para conhecer como é transmitida essa memória. Qual Egito é percebido e apreendido por eles? Como viviam antes? Como foi a travessia? Como foi chegar? Por que escolheram o Brasil? Arrependeram-se dessa escolha? O que significa ser judeu no Egito? E judeu do Egito no Rio de Janeiro?

Provavelmente nem todas as perguntas serão respondidas uma vez que ainda estou trabalhando na pesquisa de campo e colhendo depoimentos. Iremos nos limitar aqui a conhecer a história da vinda de seis imigrantes. Para a tese serão doze. Percebemos que as identidades se misturam, há alternância de pertencimentos, ora são cariocas, ora são judeus, em outros momentos são árabes. A fala revela essas diferenças. Se a língua desse grupo era o francês, ela vem misturada em seus relatos com palavras em árabe e, cada vez mais, expressões em português. Os depoimentos são dados em francês, apesar de minha primeira pergunta ser feita em português, a saber, como foi a vinda ao Brasil. A língua da memória, da afetividade, da resistência, é a francesa. Como também faço parte desse grupo - eu mesma nasci no Egito, e vim com meus pais em abril de 1957, então com três meses de idade - eles preferem falar na língua materna, na qual se sentem mais confortáveis. Outras questões identitárias, culturais são fundamentais para o trabalho, mas não daremos conta nesse espaço de cobrir todas elas como a culinária e os hábitos religiosos. Optamos pelo ponto que consideramos o impulso de todas as questões: a expulsão do Egito e como isso repercute em cada um.

Antes de ouvirmos as vozes dos entrevistados, iremos viajar até o Egito para conhecer a trajetória dos judeus no Egito, uma relação conturbada, por momentos feliz e harmônica e, em outros, cruel e ingrata. Em permanente tensão.

\section{Judeus no Egito}

A comunidade judaica no Egito é uma das mais antigas da diáspora. Antes da destruição do primeiro Templo por Nabucodonosor em 586 a. C., já havia judeus no Egito, "trazidos pelo fundador da 26a Dinastia, Psamético I 
(664-610 a. C.) para integrar suas tropas mercenárias, juntamente com marinheiros e mercadores fenícios",2.

Em 1517, os turcos otomanos conquistaram o Egito dos mamelucos que ficou por mais de trezentos anos como uma das províncias do Império Otomano. "Os otomanos, no auge de seu poder, foram tolerantes e os judeus ocuparam posições importantes na administração financeira e na arrecadação de impostos. Quase todos os governadores turcos enviados ao Egito (pelo Sultão) entregavam a responsabilidade da administração financeira a agentes judeus que eram conhecidos como 'sarraf-bashi' (turco: chefe dos tesouros ou chefe tesoureiro). Esses 'ministros das finanças' arrecadavam os impostos e eram os encarregados da casa da moeda. Os governadores tinham também médicos judeus que eram designados a altos cargos no governo ${ }^{3,}$.

Durante o governo do Sultão Suleiman o Magnífico (1520-1566) havia paz e segurança para os habitantes do Império e em consequência uma expansão econômica (e agrícola) e um aumento da população. Ele introduziu as 'capitulações' que eram pactos, ou contratos entre os sultões otomanos e os países cristãos da Europa, em relação aos direitos dos súditos de cada um, quando residindo no país do outro. Muitos judeus que imigraram de fora dos domínios otomanos foram beneficiados por esses acordos que tinham grande importância para sua situação legal. Eles assim obtiveram o status de pessoas protegidas e lhes foram garantidos direitos extraterritoriais e proteção contra ataques à propriedade e à vida. Já no final do século XVI, os sultões otomanos introduziram as leis discriminatórias em relação aos adeptos de todas as religiões não muçulmanas, que eram considerados infiéis. "A tirania do governo turco e o declínio político-econômico do Império, afetaram o nível cultural do judaísmo egípcio e a comunidade não mais foi liderada, como no século XVI, por renomados rabinos ${ }^{4,}$.

As condições econômicas e políticas dos judeus do Egito não melhoraram até o início do séc XIX com a introdução de reformas econômicas pelo governador Muhammad Ali (1805-1849). Como resultado dos programas de desenvolvimento do governo de Muhammad Ali, a

\footnotetext{
${ }^{2}$ LEFTEL, Ruth A comunidade sefaradita egípcia de São Paulo; tese de doutoramento, História/USP maio de 1997.

${ }^{3}$ Idem
}

${ }^{4}$ Ibidem economia do Egito floresceu e imigraram ao Egito judeus de países europeus. Nesse período, os judeus tinham função central nas atividades de desenvolvimento do país. Eles auxiliaram no estabelecimento de indústrias e juntamente como os coptas tornaram-se a viga mestra do negócio bancário internacional que atuava no Egito.

Os conflitos mais radicais só começariam na segunda metade do século 20, mas se estenderiam a praticamente todos os países onde os judeus viviam no Oriente Médio e no Norte da África. Esses conflitos foram consequência do nascimento do nacionalismo árabe, de um lado e nacionalismo judeu, do outro. "A medida em que se definiam as perspectivas da criação de um Estado judeu na Palestina, o relacionamento entre judeus e muçulmanos foi se tornando cada vez pior"." Após a construção do Canal de Suez em 1869 e o rápido desenvolvimento que o Khedive Ismail conseguiu de 1863 a 1879, muitos estrangeiros estabeleceram-se no Egito, incluindo judeus de países da Europa, da África e da Ásia. "De um censo realizado em 1897 verifica-se havia neste ano 25.200 judeus no Egito, dos quais 12.507 eram cidadãos estrangeiros ${ }^{6}$." Com a ocupação britânica do Egito em 1881, a situação dos estrangeiros, entre os quais os judeus, melhorou ainda mais. Estes foram ocupando lugar de destaque na economia e na sociedade. Assim, no período que vai do final do século XIX até a primeira metade do século XX, os judeus participaram enormemente do desenvolvimento econômico do país, apesar de serem população minoritária.

Esse modelo efêmero de conviviabilidade vai ser interrompido, entre outras causas, por um movimento de nacionalismo árabe - WAFD - cl wafd el Mizri (Delegação do Egito). Em novembro de 1918, um grupo de políticos uniu-se para representar o povo egípcio numa delegação Wafd em Londres nas negociações de paz, após o colapso do Império Otomano. "Esta delegação deu origem ao movimento que foi iniciado por Saad Zaglul (1860-1927) e direcionando principalmente contra o Protetorado da GrãBretanha (que começou em 1914 e terminou em 1922) e em segundo plano contra o Rei Fuad do Egito ${ }^{7}$.

\footnotetext{
${ }^{5}$ DECOL, René Daniel. Imigrações urbanas para o Brasil: o caso dos judeus. São Paulo, Tese de Doutorado, Dept. de Demografia, IFCH/UNICAMP, 1999.

${ }^{6}$ LEFTEL Op. cit.

${ }^{7}$ Idem
} 
O poder no Egito no final do século XIX, virada do século XX, era exercido, de fato, pelas múltiplas comunidades instaladas no Cairo e em Alexandria. A cada negócio ou transação de qualquer espécie, constituía-se uma comissão mista que convocava os representantes de cada comunidade que buscava trazer à ordem. Segundo Robert Ilbert "as fundações comunitárias e as sociedades beneficentes tinham um papel central. Elas compensavam o poder ausente. Eram organizadas seja sobre um suporte religioso, seja um suporte nacional, e foram quase todas criadas após $1860^{8}$." O puzzle sobre o qual o Egito liberal ia se construir estava sendo composto".

Antes dos conflitos do século XX, os judeus do Egito não estavam sujeitos a limitações geográficas, econômicas ou ocupacionais. Não havia profissões interditadas nem lugares proibidos. Embora tendessem a se aglomerar em bairros próprios nas cidades muçulmanas, isto constituía um processo espontâneo e não uma restrição. Concentravam-se nas ocupações que envolviam contato com os "infiéis", e, portanto, desprezadas pelos muçulmanos, como a diplomacia e os negócios bancários ${ }^{10}$. A hostilidade contra os judeus vai aparecer quando da questão da partilha da Palestina e terá sua explosão na guerra do Canal de Suez. Não parece que as diferenças religiosas entre os nativos e os estrangeiros fossem a base dos conflitos, uma vez que houve momentos de harmonia entre as diversas etnias, nacionalidades e crenças.

A partir do final da Segunda Guerra, começam perseguições à comunidade sefaradita egípcia, que em 1948 contava com 75 mil indivíduos. Após a guerra de independência de Israel esse número cai para 40 mil em 1955, para chegar em 1982 com 250 indivíduos $^{11}$.

Logo após a Guerra de 1956, o governo tomou medidas drásticas contra os cidadãos de nacionalidade inglesa ou francesa, muitos foram detidos e expulsos do Egito e suas propriedades confiscadas, e contra a comunidade judaica simpatizante ao sionismo. Boa parte dos líderes judeus do Cairo e Alexandria foi presa. Metade dos quase mil detidos ou presos foi

\footnotetext{
${ }^{8}$ ILBERT, Robert Alexandrie: 1830-1930 Cairo: IFAO (Institut Français D'Archéologie Orientale) 1996. Vol I;

${ }^{9}$ idem.

${ }^{10}$ in Lewis, 1990, p. 33, citado in DECOL, Op. cit.

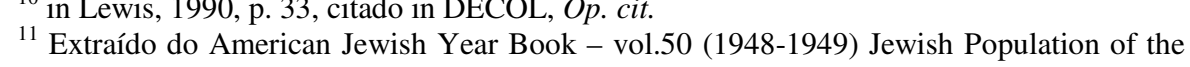
World, in Leftel, R opus cit. p.65.
}

confinada numa escola judaica do Cairo. Outros 500 chefes de família foram intimados a comparecer a postos policiais, nos quais thes foi ordenado deixar o país - muitos sozinhos, sem poder avisar a família - em dois até, no máximo, sete dias. Suas contas bancárias foram congeladas e suas propriedades sequestradas e colocadas sob custódia do Ministro das Finanças. Essa Proclamação veio acompanhada de uma lista de mais de 400 nomes, dos quais pelo menos $95 \%$ eram judeus. Esses indivíduos representavam a maior parte da vida econômica judaica no Egito e suas contribuições eram a sustentação principal das instituições religiosas, sociais, educacionais e de beneficência judaicas. Houve também demissão em massa de judeus de seus empregos; firmas foram sequestradas. A deportação continuou em 1957, enquanto outros foram compelidos a abandonar o país após serem despojados de seus meios de subsistência ${ }^{12}$.

Essa pequena contextualização mostra o momento em que a imigração dos judeus do Egito vem para o Rio de Janeiro. Com prazos exíguos para deixarem seu país - até então - os judeus mandaram para diversos consulados seus pedidos de visto: EUA, Canadá, França, Brasil. O Brasil vai receber esses imigrantes com vistos concedidos pelo presidente Juscelino Kubitschek. "Em setembro de 1956, o então presidente Juscelino Kubitschek interveio pessoalmente, a pedido da United Hias Service, no Instituto Nacional de Imigração e Colonização (INIC), para que este autorizasse a imigração de mil famílias da África do Norte, principalmente do Marrocos. Como consequência da Guerra do Sinai, para os judeus egípcios (...) a HIAS, (...) intercedeu perante o governo marroquino, com o auxílio do Embaixador da Espanha em Marrocos, para que este permita transferir a quota dos judeus marroquinos para os judeus do Egito ${ }^{13}$."

Segundo Leftel, a embaixada brasileira no Cairo tinha a instrução de não limitar o número de vistos, porém de emiti-los ordenadamente, para que houvesse infraestrutura para recebê-los. A única exigência do governo brasileiro era a apresentação de um atestado de saúde e outro de idoneidade moral, sendo para este último importante não ter sido o imigrante comunista. O governo egípcio permitiu que os emigrantes levassem apenas 20 libras egípcias por pessoa (cada libra valia de 3 a 4 dólares na época). Além das 20 libras foi lhes permitido levar objetos de uso próprio, porém

${ }^{12}$ LEFTEL, R Op. cit.

${ }^{13}$ LEFTEL, R Op. cit. 
nada de valor (joias, obras de arte, etc.). Por esta razão, foram forçados a vender seus bens a preços irrisórios, para poder pagar a passagem até o porto europeu, do qual a HIAS encarregou-se de trazer a maioria ao Brasil e comprar provisões para a viagem, roupas e utensílios. Os imigrantes receberam visto permanente. A maioria destes imigrantes, em torno de $60 \%$, era apátrida, uma parte tinha nacionalidade italiana (20\% aproximadamente), outra parte (15\% aproximadamente) nacionalidade francesa e os 5\% restantes tinham nacionalidade grega, espanhola ou britânica, enquanto um número bem reduzido tinha nacionalidade tunisiana ou marroquina. Apenas duas famílias tinham nacionalidade egípcia ${ }^{14}$.

Decol $^{15}$ analisa dados do censo e concluiu que não foram apenas os judeus vítimas do nacionalismo árabe. Outras minorias em terras árabes, como cristãos, foram igualmente atingidas. Em sua tese, demonstra que $19,41 \%$ dos nascidos no Egito que chegaram ao Brasil a partir dos anos 20 eram católicos, proporção praticamente igual à de judeus (39\%), ficando outras religiões com $20 \%$. Em termos de período de chegada, destaca-se a década de 50, especialmente a segunda metade, e os anos 60. Mais de 70\% dos egípcios residentes no Brasil por ocasião do censo de 1991 declararam ter chegado ao país entre 1950 e 1964, independente da religião.

\section{História oral resgata relatos familiares}

Nem todas as perguntas formuladas neste trabalho serão respondidas a contento, mas ouvir a voz desses imigrantes - que acredito mais correto serem chamados de refugiados do governo Nasser - é cumprir com o objetivo primordial da História Oral: dar voz aos esquecidos. Munida do poder que somente a História Oral outorga, ouvimos os relatos de imigrantes egípcios no Rio de Janeiro, e - milagre da História Oral - é possível perceber as sutilezas no tom das vozes, quando embargam ou se irritam lembrando das tristezas ou alegrias do passado. Esse pesquisador "de fora" tem o distanciamento de tempo e do vivido, o que lhe permite uma análise mais profunda. $\mathrm{O}$ ambiente que cerca esse entrevistado pode ser descrito pelo pesquisador que vai agregar às vozes sua análise e impressões sobre o fato, sempre baseado na vivência que teve com o entrevistado.

\footnotetext{
${ }^{14}$ Idem.

${ }^{15}$ DECOL, R Op. cit.
}

As histórias das vidas de seis imigrantes: Aída Blumenstine, Tâmara Egler, Sonia Rokab. Oswaldo Rokab, Becky Michaan e Maurice Michaan, serão em parte reveladas nesse texto, com enfoque em suas lembranças. $\mathrm{O}$ objetivo é conhecer um pouco mais de perto esse grupo através de depoimentos de alguns deles, como desenham suas identidades, como se relacionam na sociedade carioca. Eles contam sua vinda ao Brasil em 1957. Cada um tem seu relato, suas impressões sobre a cidade de Alexandria onde viveram a maior parte de suas vidas e da qual não imaginavam ter que sair um dia. A nostalgia, misturada com saudade e o gosto amargo da expulsão, transformam suas histórias em registro importante para a história da construção da cidade do Rio de Janeiro e do Brasil.

O que chama atenção, além das referências exatas a monumentos, lojas, cinemas, teatros, praias, é a memória de cada um sobre a viagem e a instalação de suas famílias no Rio. Enquanto Léon lembra exatamente de quanto investiu em sua fábrica, o preço dos objetos, do quilo do algodão, Sonia, lembra dos cheiros e perfumes de sua cidade, do pôrdo-sol cor de abóbora, das lavadeiras à beira do Nilo, e do Rio como cidade nova e hospitaleira. Ela lamenta não assistir mais ao pôr-do-sol do norte da África, e Aída lembra com bom humor as trapalhadas da língua, os tempos difíceis em busca de emprego. Becky Michaan passou por espiã, foi presa, casou-se com Maurice Michaan, que ia visitá-la na cadeia. Ela foi acusada de participar de movimento sionista, apenas porque seu nome figurava na agenda de uma militante da causa sionista. A socióloga Tâmara Egler passou pelo Canal do Panamá antes de chegar ao Brasil, e lembra da mãe sempre com o conjunto de panelas pronto para ser embarcado caso tivessem que partir de surpresa.

A história oral que se utiliza da entrevista - um método criativo e cooperativo - quebra as barreiras entre a história acadêmica e o mundo exterior. É uma história do povo, construída em volta dele e por ele: é um meio de transformação radical da significação social da história. No caso dos judeus do Egito é a única maneira de conhecer de perto a saga desse grupo, que não registrou em livros, documentos ou arquivos sua história.

O que fascina na História Oral é seu compromisso com a vinculação ao momento presente. A História Oral pode subverter a interpretação do passado, a partir do próprio passado. Com isso, a realidade imediata estará todo tempo organizando a busca de explicações a qualquer passado. 
Lendo Paul Thompson fica mais confortável ouvir os relatos desse grupo, quando ele afirma que as diferentes maneiras como uma história é contada é tão importante quanto seu conteúdo ${ }^{16}$.

No nosso caso vale ouvir/ler a fúria de Leon Lévy ao contar sua inexplicável saída de Alexandria:

Fomos obrigados a deixar o Egito logo após o armistício... depois da guerra do Sinai, o governo egípcio decretou duas leis que os ingleses, franceses e australianos que declararam guerra, também teriam de deixar o país, e os sionistas também.. Bem... Eles começaram sequestrando os bens.(...) eles sequestraram a maioria das fábricas de judeus, que são considerados sionistas, e deram 15 dias para deixar seu país. Eu era egípcio, minha mulher e' filha de franceses, e eles consideraram meu filho de 6 anos como inimigo público $\mathrm{n}^{\circ} 1$ ! E lhe deram 15 dias. Então, nesse momento, era dia 12 de dezembro, fui ao governo pedir para que deixassem minha mulher ficar aqui. Mas eles não aceitaram... Eles expulsaram minha mulher, eles expulsaram minha sogra e eles expulsaram meu filho. Eles tinham 15 dias para deixar o país. Fui obrigado a deixar o país... Não quiseram me dar um passe. Naquele momento não se podia deixar o país sem o exit visa, o visto de saída.

$\mathrm{J}-$ Em que ano?

L - Dezembro, 1956. Eu pedi, implorei. Muito. Eles não aceitaram. Fui obrigado a deixar o país. Agora tem uma coisa: pedi ao cara: escuta, eu tenho de voltar. Eu estava bem aqui. Você não pode sair' Levo minha mulher, instalo-os e volto. 'Por quê? Case com outra!' Mas meu filho! 'Você terá outros filhos'. Então fui obrigado a devolver meu passaporte e eles me deram um laisser-passer. 'Você perde tudo que tem aqui'. Paciência. Fui obrigado a sair;

Deixei o país dia 27 de dezembro. Quinze dias depois do aviso.” J Por que o Brasil?

L - Porque foi o único país que nos concedeu o visto de entrada. Eu estava lá (na embaixada do Brasil no Cairo) no dia 24 de dezembro de 1956... Estava fechado. Então gritei, eu estava muito nervoso. Eu tinha que sair no dia seguinte. Não, dia 27 Por que você está

\footnotetext{
${ }^{16}$ R. SAMUEL, P. THOMPSON (ed), The myths we live by, Routledge, London and New York, 1990, pp 3-21: p.2 apud Hélène Wallenborn.
}

gritando? Está fechado! Não podia fazer nada. É véspera de natal. Volte depois do natal, dia 27. Mas dia 27 eu tenho de ir embora ${ }^{17}$.

A família Lévy era uma das mais tradicionais no Egito, e a história da vinda de Leon é saborosa, com ingredientes de teimosia que se mantiveram até quase o final da vida. Leon faleceu no ano de 2000, reclamando ainda de alguns hábitos cariocas que insistia em não incorporar. Leon sentia ainda uma certa tristeza na expulsão.

tivemos que sair em 15 dias como se fossemos criminosos, minha sogra, minha mulher, meu filho e eu, com 350 libras, que representavam 350 dólares.

Léon contou sua vida profissional. Conta, com orgulho, como montou várias fábricas com os irmãos no Rio, mal falando português. Suas memórias se direcionam para o lado prático, fala de seus irmãos (dez ao todo) sempre tendo como pano de fundo a vida profissional. Precisa ser perguntado sobre sua esposa, como a conheceu, para então falar da vida íntima.

Ao contrário, Sônia nem se lembra de quanto pôde carregar em moeda para deixar o Egito, perguntada sobre o assunto, não sabia. O que a marcou e o que se lembra com mais detalhes da época, era a irrealidade daquele momento. Ela já havia se casado com Osvaldo Rokab, um italiano boêmio:

Viemos 17 pessoas da mesma família no navio em 57. Os sogros, meus pais. Talvez por isso eu não percebesse o lado trágico da História. Na minha idade não se via o lado trágico. Talvez meus pais o realizassem. Deve ter sido muito mais difícil para eles do que para nós mais jovens. Nós tínhamos 21, 22, 23 anos (...) Tínhamos uma impressão estranha que parecia quase irreal. Era como se estivéssemos divididos. Nos víamos agindo, agíamos, mas não entendíamos a gravidade da situação. O Egito me deixou lembranças extremamente coloridas, extremamente luminosas. É um país lindo. (...) Nunca vi um por de sol tão espetacular ${ }^{18}$.

Lágrimas caíam de seus olhos durante a entrevista. Às vezes, ela pedia para parar a gravação para acalmar-se e depois retornava, pronta para mais algumas horas de conversa. Enquanto Sônia e Léon sentiram-se mais confortáveis em falar em francês, Aída, que chegou no Rio de Janeiro em abril

\footnotetext{
${ }^{17}$ Leon Lévy entrevista concedida no Rio de Janeiro em outubro de 1999.

${ }^{18}$ Entrevista de Sonia Rokab. Rio de Janeiro, dezembro 1999
} 
de 1957 com a irmã, os pais, o cunhado e a sobrinha recém-nascida, preferiu falar em português. A primeira lembrança ao chegar no Rio e encontrar uma prima carioca que não falava francês, foi a de ser alvo de chacota:

Entendi, depois de um esforço, que ela me convidava para tomar um sorvete, e fui. Vi na parede o negócio que estava marcado o que a gente ia comer, a única palavra que eu conseguia entenderem todo esse painel é cocô. Aí eu disse 'Je veux du cocô' e todo mundo ficou olhando pra mim, nãoera 'cocô', era côco. (...) todo mundo começou a rir e eu achando que eu tinha feito uma graça!Só mais tarde que eu entendi que eu estava falando de coisas que não se fala em ambiente público ${ }^{19}$

$\mathrm{O}$ fato das duas mulheres terem lembranças mais divertidas ou emocionais do que a de Leon, não pode tornar-se regra e fazer-se a partir de dois depoimentos uma análise de gênero. Becky Michaan, 67 anos em 2001, acabou presa por um crime que não cometeu:

Era amiga de Marcelle Ninio, que fazia 'boicotage' no Cairo, e eu não sabia. Eu trabalhava na embaixada do Japão quando vieram me avisar: tua amiga Marcelle foi presa. Era uma grande terrorista e pegou 25 anos de prisão. Hoje ela mora em Tel Aviv - há duas ruas com o nome dela. (...) Ficaram uns três meses atrás de mim. Foram na minha casa para ver se tinha algo. Fui depor no Ministério do Interior. Não sabia nada dela. Era 1953. Casei dois anos depois. Dia 2 de novembro de 1956 quando a guerra 'eclatou' a primeira presa fui $\mathrm{eu}^{20}$.

Becky chorou muito ao lembrar desse episódio que há muitos anos não contava. Era a primeira lembrança quando perguntei como foi a saída do Egito. Mas, valente, não quis interromper e seguiu sua história:

A situação não estava boa para nós. Voltei para casa às $19 \mathrm{~h}$. O porteiro falou: pegaram seu marido. Fiz minha mala. E disse ao porteiro: você vai comigo de táxi. Fui ao Ministério do Interior. Jd conhecia as caras. Cadê meu marido? Me responderam: Agora que você veio ele vai embora. Era a pior prisão do mundo era a Citadelle. Uma escravidão - 280 mulheres de Ismaelia, de Alexandria. Havia dois baldes; um de xixi e um de água. Fiquei sete dias. Levaram num colégio israelita, feito Liessin. Só mulheres. Sem visitas. Era um colégio na sinagoga - Abraham Beth Esh. Ficamos lá dois meses.

Todo dia chamavam algumas mulheres - campo de concentração.

\footnotetext{
${ }^{19}$ Entrevista de Aída Blumenstine, em Miami, janeiro de 2000.
${ }^{20}$ Entrevista com Beky Michaan, no Rio de Janeiro, em 2001.

${ }^{20}$ Entrevista de Aída Blumenstine, em Miami, janeiro de 2000.
Entrevista com Beky Michaan, no Rio de Janeiro, em 2001.
}

Dia 03 de janeiro de 1957 - soltaram 4, 5 mulheres. As que chamavam eram francesas, inglesas e holandesas; os parentes pegavam e levavam diretamente para avião. As apátridas iam de navio para Israel. No dia 4 de janeiro fui para o ministério do exterior e estava livre. Mas me ameaçaram: 'se você fizer qualquer coisa...' Voltamos para casa. Ele fez tudo para ir embora. Vendeu apartamento, móveis, a fábrica de chinelos. Saiu janeiro. Fevereiro viajou minha irmã. Fui embora em março. Cheguei no Rio de Janeiro em abril de 1957, recebidos por trovões. Eu queria ter ido para Genebra, mas Maurice queria o Brasil. Começamos a vida no Brasil com 9 contos de réis, 6US\$ para um conto de réis.

Essa negociação misteriosa que a memória faz com o próprio indivíduo para trazer de volta um passado que se atualiza quando está sendo contado. Para Muxel:

A memória familial é primeiramente feita de uma história pessoal e sua reconstrução. Há romance nela. Uma ficção real através da qual o indivíduo, mobilizando seu passado, se dá um sentido. Isso mais ou menos voluntariamente e claramente mais ou menos conscientemente, mas o inconsciente é também um romancista fecundo ${ }^{21}$

A força do relato pessoal - apenas possível graças ao espaço conquistado pela História Oral, podem dar a dimensão da dor, da alegria e do humor e apontar para o estado de espírito em que se encontra - e se encontrava à época do ocorrido - o entrevistado. Esse grupo se define pela vida agradável que levava no Egito antes da Guerra de Suez e compartilha do duro momento de abandonar sua vida, país, a angústia e aflição de não saber ao certo para onde ir, como ir, que país é esse para onde vão. Essa marca fica impressa nas memórias de cada família que vai retransmitir a seus filhos à sua maneira, com seu enredo particular. Mas esse momento é um marco na identidade do grupo. Para Philippe Joutard:

(...) a memória é um elemento constitutivo da identidade. Assistimos, hoje, ao crescimento da força de todas as identidades, de sexo, de grupo, de religião, de nações, o que seria uma reação à globalização e a uma certa uniformização cultural (ao mesmo superficial). (...)Este fortalecimento das identidades, perfeitamente compreensível, pode ser a melhor ou a pior das coisas. Porque há identidades abertas e identidades fechadas e, sejamos realistas, espontaneamente a

\footnotetext{
${ }^{21}$ Muxel, A. Op. cit. p10
} 
identidade se fecha, porque defende o que acredita ser sua 'integridade', reage contra tudo que lhe parece estrangeiro, é exclusivista, e o perigo da xenofobia e do racismo não está distante. É em nome da memória e da identidade que os protestantes e católicos irlandeses vêm se matando, hd décadas, e que ocorreram os enfrentamentos que conhecemos na antiga Iugoslávia. (...) Sobre este ponto, estamos na linha de frente, a história oral tem pesada responsabilidade: manejamos a 'dinamite' e, até, o 'nuclear'. Trazer à luz o patrimônio oral, instrumentalizado, pode contribuir para fortalecer as identidades simplificadoras, maniqueístas, que excluem, portadoras do ódio e da morte. Tenho a ilusão de acreditar que podemos ajudar as identidades fechadas a se abrirem, desempenhando nosso papel pleno de historiadores e historiadoras, $e$ não o de simples memorialistas. $O$ memorialista se contenta em escutar, recolher fielmente, sem jamais intervir nem tomar a mínima distância; seu silêncio vale aprovação, para não dizer adesão. $O$ historiador não deixa de ouvir e recolher, mas sabe que deve se distanciar, que a simpatia necessária, virtude cardeal do bom entrevistador, não deve cegá-lo nem privá-lo da lucidez. ${ }^{22}$.

A experiência de Tamara é a visão de uma garota que brincava em 1956 nos jardins do rei, ainda tinha boneca, sofreu uma reviravolta, viu-se dentro de uma situação de guerra.

A minha infância foi passada no jardim e, quando veio a Guerra, nós, a minha família, a minha mãe é uma pessoa muito perceptiva, então nós não esperamos a eclosão da Guerra, que apesar dessa condição absolutamente confortável tanto familiar quanto econômica, de um crescimento que a minha família estava vivenciando. Teve um dia assim, nós estávamos passando férias numa praia, você sabe, lá tinha assim, a cidade e a praia, era tudo muito próximo, mas quando chegavam as férias, nós alugávamos uma casa e a gente então ia para aquele lugar passar as férias. E de vez em quando meus pais voltavam à noite pra fazer alguma coisa na cidade, enfim, pegar alguma coisa, e numa dessas idas a minha mãe passou por uma praça pública aonde tinha dois bonecos judeus que tavam sendo malhados, era uma execução. Naquele momento a minha mãe falou pro meu pai: nós vamos embora, porque nós não podemos ficar aqui. Então eu

22 JOUTARD, Philippe in FERREIRA, Manieta de Moraes, FERNANDES, Tânia Maria e ALBERTI, Verena (orgs) História Oral: desafios para o século XX/. Rio de Janeiro: Editora Fiocruz/Casa de Oswaldo Cruz/CPDOC-FGV, 2000. p.43. me lembro, num dia eu voltei da escola e minha mãe falou assim: eu vou te contar um segredo, e ela tava com uma caixa de, é uma caixa onde eu colocava ..., eu tinha uma amiga que morava do lado da nossa casa, ela não era judia, ela chamava Doris e nós duas passávamos a tarde fazendo roupa de boneca, e eu tinha uma caixa com as roupas de bonecas que eu ia fazendo à tarde, a mamãe me deu essa caixa e falou você vai dar essa caixa de presente pra sua amiga que nós vamos viajar e você não pode levar isso e você não pode contar pra ninguém que a gente vai viajar. E foi assim feito. Uma semana depois nós viajamos eu, minha mãe e meu irmão. E meu pai ficou no Egito para vender o que tínhamos. E nós fomos para Itália.

Em que ano?

1956. (...) Então, da noite pro dia, eu me lembro do navio, foi um navio italiano que a gente chegou. Eu não lembro da chegada, eu acho que a gente chegou em Gênova e pegamos um trem pra Milão. $\mathrm{Eu}$, minha mãe, meu irmão, nós fomos pra Milão. E, de repente, um novo mundo. A minha mãe me disse: a gente fecha a porta e não olha pra trás. Só olha pra frente. Ela deixou uma casa, a família, uma condição econômica, e eu me lembro que ela levou na mala uma frigideira, uma caneta, um relógio, eu tenho o relógio dela até hoje, aí, um conjunto de potes de alumínio que colocava um dentro do outro. Tinha assim café coado, açúcar, farinha pra colocar as coisas, essa peças a gente tem até hoje. O essencial pra sobrevivência, uma panela, uma frigideira e aqueles potes ${ }^{23}$.

Esses relatos iniciais são apenas as impressões de saída de cada um. Um dos motivos que levou Maurice a escolher o Brasil como destino para sair do Egito foi o livro de Stephan Zweig que acabara de ler em 56, Brasil, o país do futuro. Nascido em 1926, Maurice é tenista aficionado, não perde um torneio em Roland Garros, paixão que cultiva desde o Egito. Becky costuma dizer que ele "é casado com uma raquete".

Entrei aqui no Brasil como sapateiro. Queria o Brasil, tinha esperança. Vi minha família em Israel. Tavam todos na pior ${ }^{24}$.

A preocupação com o trabalho era uma constante nos relatos: o que fazer nesse novo país? Tinham de enfrentar uma nova questão a de

\footnotetext{
${ }^{23}$ Entrevista com Tâmara Egler.

${ }^{24}$ Entrevista com Maurice Michaan, Rio de Janeiro, 13 de outubro de 2000
} 
recomeçar uma vida em solo completamente estrangeiro. Oswaldo Rokab pensou até em ir para o Canadá:

A escolha do país foi rapidamente decidida. A maioria dos países fechavam as portas aos estrangeiros mais velhos. $\mathrm{Eu}$, por exemplo, poderia trabalhar nos Estados Unidos. Tinha a possibilidade de ir aos EUA, mas nossos pais não poderiam. Não poderiam de forma alguma. Considerávamos a Europa como um país velho. Seria muito difícil de recomeçar a vida. Então pensamos num país jovem. O Canadá me parecia um país muito frio. E depois o Brasil nos parecia realmente o país do futuro, o país que nos acolheria a todos. E foi exatamente o que aconteceu. Saímos todos como uma grande tribo, éramos 17 no navio ${ }^{25}$.

Nenhum dos entrevistados reclamou de sua escolha. Rapidamente encontraram empregos, integraram-se em grupos de judeus ou de não judeus, trabalham em diversas atividades, alguns já se aposentaram. Estão acostumados a lidar com um país pluriétnico. Se o Egito era cosmopolita um salad-bowl onde conviviam várias etnias, eles chegaram numa cidade que é um melting-pot, onde tudo se mistura, onde o sincretismo religioso, a praia, a culinária ajudam na integração e inserção na sociedade. O domínio das línguas estrangeiras sempre foi um ponto a mais não somente na integração como na admiração da população local. Afinal quem são esses estrangeiros que vieram da África, falam francês, inglês, árabe e italiano têm religião própria e se integram rapidamente no contexto da cidade do Rio de Janeiro?

\footnotetext{
${ }^{25}$ Entrevista com Oswaldo Rokab, Rio de Janeiro, dezembro de 1999.
}

\section{2a Capítulo}

\section{O DISCURSO DO JUDAÍSMO BRASILEIRO \\ ATRAVÉS DA Literatura E DA ARTE}

\section{O olhar judaico: memória e testemunho}

Bella Jozef

Uais as formas de expressão do judaísmo no fazer literário? Como definir o que é uma obra judaica?

A essas e outras questões instigantes que diariamente a crítica de jornal e a acadêmica têm diante de si e a este universo de questionamentos pretendo trazer alguns esclarecimentos provenientes de minha vivência e de minhas reflexões em contato com a literatura nos últimos anos.

Inicialmente, pergunto:

Quais as condições propícias à existência de uma condição judaica? Se existe uma condição judaica, existirá uma literatura judaica?

Para alguns, ela nutre-se da referência ao passado, de uma nostalgia pelos valores condenados pela história. Para outros, ela não existe por não possuir língua comum nem território nacional.

Fazer depender a tradição literária judaica da utilização de uma língua única é desconhecer a quinta-essência da cultura.judaica: o plurilinguismo, fenômeno intrínseco da vida do povo e uma de suas características estruturais.

Com exceção de um breve período do século XIII ao VI a C., durante o qual o povo judeu parece só ter utilizado o hebraico, todas as outras épocas são marcadas pelo uso simultâneo de várias línguas e isto bem antes

${ }^{1}$ Doutora em Letras e Literatura/UFRJ 
da destruição do Templo. O hebraico, língua sagrada, litúrgica, sábia, permanece o idioma da unidade na diversidade judaica.

\section{Então, o que é literatura judaica?}

Quando um poeta afirma que sua obra se caracteriza pela busca interior, a postura crítica com que se coloca diante do mundo, a necessidade de interrogação constante, tudo isso será judaico, apenas judaico? Talvez qualquer judeu que escreva de algum modo sobre seu judaísmo e qualquer judeu que escreva esteja recriando valores que não são apenas judaicos. $\mathrm{O}$ que quero dizer é que toda recriação judaica será diferente da que a inspirou. Vejamos de que maneira temos força suficiente para incorporar e tornar próprios, dentro de uma identidade judaica clara e forte, elementos de fora que não possam diluir a identidade, mas que se tornem parte dela. Segundo o sociólogo americano Thorstein Veblen, os judeus atuam dentro da cultura ocidental e ao mesmo tempo não se sentem amarrados a ela, por isso sempre lhes será mais fácil inovar dentro dessa cultura.

Mas como responder à pergunta: o que é a literatura judaica?

Diz-nos Jorge Luís Borges que Racine não entenderia se alguém lhe negasse o direito ao título de poeta francês por haver buscado temas gregos e latinos. A temática de escritores judeus mundo afora é tão vasta como a de Racine. E continua Borges: Creio que Shakespeare ter-se-ia assombrado se houvessem pretendido limitá-lo a temas ingleses e lhe houvessem dito que, como inglês, não tinha direito de escrever Hamlet, de tema escandinavo, ou Macbeth, de tema escocês.

Com Borges, podemos responder a uma parte da pergunta que não é a temática que definirá a origem do escritor. O escritor judeu produz uma escrita judaica embora não trate especificamente de temas judaicos.

Porém onde encontrar o escritor francês em Racine, o escritor inglês em Shakespeare ou o escritor judeu em Clarice Lispector? Eles estão lá, o francês em Racine, o inglês em Shakespeare e o judeu em Clarice Lispector.

Cabe-nos, ainda, perguntar:

O que será o olhar judaico? O olhar judaico existe? As diferenças não serão maiores que as similitudes?
Conceituar o olhar judaico supõe, a nosso ver, um pluralismo de diferenças que persistem e persistirão através das simplificações. Questiona-se a esfinge, mas a resposta é um problema.

A questão do olhar situa-se no centro do debate da cultura contemporânea, quando tudo é feito para mostrar-se ao olhar. A chamada "civilização da imagem" modificou o ato de olhar e alterou a constituição da realidade ao questionar o real. A cidade contemporânea corresponde ao novo olhar. Essa dificuldade em reconhecer-se nos objetos e nos outros atravessa a obra de Walter Benjamin, que introduz a problemática de um olhar que possa ser correspondido, de um olhar que olha.

Assim como a mão colocada diante dos olhos pode esconder a montanha mais elevada, a rotina do cotidiano pode impedir-nos de ver o brilho enorme e as maravilhas secretas que povoam o mundo.

Para escapar da banalidade do cotidiano, Clarice Lispector instaura a poesia do instante, através da simulação brilhante da cor. Veja-se em A hora da estrela: "É uma história em tecnicolor".

O superego é o Olho do Pai e, mais tarde, o de Deus, poder e autoridade em virtude do elo estabelecido na psicanálise com o Pai, autoridade política e imperativo moral.

Jeová é aquele a quem não se esconde nada: "Se subir ao céu, tu ali te achas, se descer ao inferno presente nele estás [...] porque as trevas não serão escuras para ti e a noite será iluminada como o dia" (Salmos, 138, 8).

Lembremos que Os deuses de Raquel, de Moacyr Scliar, iniciam-se com: "Eu sou aquele cujo verdadeiro nome não pode ser pronunciado. Admito, contudo, ser chamado de Jeová... Sou o que tudo vê". (p.9).

Nas lendas e nos sonhos, o inconsciente é sempre representado sob um aspecto tenebroso. De Eros-Cupido até o "velho rei" do folclore de vários países, passando por Édipo, são todos cegos. A cegueira é uma enfermidade da inteligência. No conto "Amor" (de Laços de família), o cego, contraditoriamente, conscientiza a protagonista. 


\section{Clarice Lispector e a Cabala}

A palavra, na Cabala, é instrumento todo-poderoso de posse da realidade. Para Clarice, seu alcance é limitado, daí a necessidade da procura de nova linguagem por parte da narradora, para "o encontro do eu com o eu" (Um sopro de vida, 65).

A Cabala conferiu à linguagem a tarefa de refletir (de ser) manifestação direta da divindade. Para o cabalista, o idioma não é produto de conjecturas que animariam a busca de segredos divinos, mas um produto divino que permite aos iniciantes penetrar no mundo onde suposições humanas se transformam em certezas da Deidade: "Desde Moisés se sabe que a palavra é divina" (A hora da estrela.,95).

A vontade de Clarice de ver na palavra mais do que a aparência e a aceitação do verbo como instrumento de criação (e não como mero símbolo arbitrário para designar os elementos do real) aproxima-a dos cabalistas. Não queremos dizer que fosse conscientemente, através do estudo dos textos sagrados, mas como uma intuição, a poderosa e mágica intuição de Clarice Lispector.

O olhar rompe os limites, momento extremo de liberdade, momento em que a narradora se liberta de si mesma, oferecendo sua essência que é sinônimo de liberdade. Aproxima-se do momento genésico pela força do olhar: momento do desejo e da inspiração. Puro fulgor que acende a centelha: "Sou sozinha eu e minha liberdade". Clarice quer subtrair-se à ausência de tempo entrando em outro tempo. A hora da estrela é dedicada aos profetas do presente: "e que a mim me vaticinaram a mim mesmo a ponto de eu neste instante explodir em: "Sei de muita coisa que não vi" (p.7).

Macabéia é "símbolo universal da humildade oprimida" (Scliar). Sente como uma dor a não familiaridade do lugar. Sua morte interrompe o desenvolvimento que é o da própria indiferença: "este livro é um silêncio. Este livro é uma pergunta" (p.21), declara o narrador que se delineia aos olhos do leitor através de outro personagem: "escrevo por não ter nada para fazer no mundo" e "ao escrever me surpreendo um pouco pois descobri que tenho um destino".
A tentativa de ver-se é forma de identidade. Ver-se a si próprio: "Encontrar-se consigo própria era um bem que ela até então não conhecia" (HE, 51).

Macabéia, com sua experiência inautêntica, é o protótipo do ser alienado, ironicamente o oposto das mulheres dos bíblicos Macabeus.

A obra tem perguntas e a interrogação é a resposta: "O homem irá buscar no próprio profundo e negro âmago de si mesmo o sopro de vida que Deus (lhe) dá?"

Não há um antes nem um depois: "Como começar pelo início, se as coisas acontecem antes de acontecer?" (p.15). O narrador, ao afirmar "vivemos exclusivamente no presente" (p.23) pressupõe a repetição indefinida do que ocorre no relato. Uma referência ao que vem depois “esta história será o resultado de uma visão gradual" $(\mathrm{p} ; 15)$ - afasta no mito o que poderia suceder num futuro real.

A Bíblia será um dos textos essenciais citados: "A senhora compreende, a Bíblia é o maior dever do homem. Estou dizendo isso mas querendo dizer nessa palavra que a mulher também é homem, compreende" (O lustre, p.163).

\section{Moacyr Scliar e a tradição}

Os textos de Moacyr Scliar não se esgotam no plano da literariedade. Há uma trama no nível denotativo e um símbolo conotativo ou alegórico. A parte externa encobre uma interior e alusiva, muitas vezes invisível à primeira abordagem, mas não menos presente e funcional que sua contraparte visível. São formas de perceber a tradição e de recriá-la.

Scliar estabelece um diálogo com o texto bíblico, reescrevendo seus mitos como em "As pragas", de A orelha de Van Gogh (1989).

O profeta é aquele para quem a hospitalidade é devida, prometida. Ele pode chegar a qualquer momento, pode realizar o acontecimento da sua vinda a cada instante: "Raquel tem a sensação ...J de que alguém a espia pela porta aberta" (Os deuses de Raquel, 27)..."a claridade que vem lá de dentro deslumbra-a" (idem, 42). A imagem da porta é retomada várias vezes. O objeto torna-se palavra. Existe uma interação criadora com o externo. 
No conto "O olho enigmático" (do livro do mesmo nome, 1986), o olhar tem papel ativo sobre o que é olhado, no caso, um quadro. Mas o personagem terá de refazer "o quadro" que se apagou, enquanto no conto "Na minha sua cabeça, o Holocausto" (idem, 19), o personagem incorpora, ironicamente, a sujeira do mundo, que é preciso tirar dele.

\section{Samuel Rawet e o imigrante}

O olhar do estrangeiro resgata o significado, pois é capaz de olhar as coisas como se fosse pela primeira vez, deixando-as aparecerem como são: resgata as figuras banalizadas de nosso imaginário para tirar dele uma identidade e um lugar. $\mathrm{O}$ imigrante judeu carrega uma profunda memória histórica como membro de um povo que se reconhece através do ato de pertencer a um pacto milenar estabelecendo o signo das origens e da identidade. Do olho de Ida, em "A prece", de Samuel Rawet, escapa um fogo interior, "um olho truncado pelo clarão", alguma coisa ficou no passado, ao acender as velas do "shabat", enquanto Judith tem "os olhos presos em nada" (idem, 28), mas é nos olhos da irmã que "vislumbrara acidentalmente um brilho que era a rememoração dos sonhos" (p.30)..

\section{À guisa de conclusão:}

O judaísmo, como visão de mundo, projeta-se como uma nacionalidade construída sobre ideais e éticas. O judeu é um ser voltado para o futuro mas que olha o passado, tentando reconciliar com o presente a imobilidade de um espaço geográfico fechado.

Ser judeu é reconhecer uma pertinência, ato decisório de uma vontade abstrata, enraizada na memória aceita de um destino não escolhido. O judeu é também o outro, eu e o outro. Visão do universal mas ao título da singularidade datada em nome do outro. A passagem em direção ao outro, respeito pela alteridade do outro, a palavra que passa através da linguagem. A palavra que abre a possibilidade do não ser, a perda da palavra que ficou e se conserva para viver a perda da origem.

Também é viver e contar sua memória. Reproduzir os gestos e os sons transmitidos pelas gerações, carregar em si a continuidade: a revisão do passado constitui o resgate de um legado cultural. Sentir e ver o temporal e o atemporal, com fé inquebrantável no homem e no direito do espírito. Ver a existência em deslumbramento contínuo diante de uma paisagem nova.

Dentre as variantes que o judaísmo assume, falando diferentes línguas, manejando diferentes concepções de mundo, o escritor judeu escreve sobre a literatura do passado bíblico, do Holocausto, da repressão e do exílio, o sentido da morte e da vida, como testemunha e sobrevivente. Com obras de múltiplos significados, ampliou os espaços do imaginário e dos territórios ficcionais do patrimônio coletivo universal.

Cada autor fala, a seu modo, de sua experiência, do ponto de vista pessoal. Sem as acumulações da memória, não temos cultura. Ser judeu, diz Elie Wiesel, "é viver com memória". A memória é sobrevivência e um dos traços do relacionamento dos judeus com o mundo.

Esses testemunhos mostram, uma vez mais, o poder da palavra contra o esquecimento. O povo judeu tem sobrevivido, desde sempre, pela palavra. Segundo a tradição, todos possuem a obrigação de transmitir sua experiência, de forma criativa, para explicar sua existência. "Lembre-se", diz o pai a seu filho. Herdeiros de uma tradição, os judeus compartilham um passado comum, uma herança cultural comum e uma memória comum. A consciência histórica tem unido as gerações que vão transmitindo a tradição como herança pessoal e coletiva.

Para Kant, o judaísmo é uma comunidade política, enquanto Voltaire o considerou uma religião. Para nós, o judaísmo é uma forma de vida, uma forma de autoconhecimento através da escrita. O que podemos oferecer ao mundo é o que somos. Ser judeu significa, sobretudo, a busca de valores morais e éticos.

Podemos dizer que ser judeu é o que cada um acha que é, o que os outros acham e o que você pensa que os outros acham? Ou em palavras do psiquiatra R.D. Laing sobre a identidade: “... O que constitui a identidade de nossa pessoa, não é apenas o fato de nos olhar, mas é também o fato de ver os outros nos olhar, a reconstituição e a modificação da visão que os outros têm assim de nós... mesmo se uma visão que o outro tem de mim é recusada, ela é incorporada, entretanto, sob a forma recusada, de modo a fazer parte de minha identidade pessoal" (1965, p.5). Para Celso Lafer, "a identidade não é um dado, mas um construído. A construção da identidade individual opera através da diferença e ecoa um dos aspectos básicos da 
doutrina liberal, que é o de valorizar os seres humanos, não por aquilo que têm em comum uns com os outros mas pelo que os caracteriza na sua especificidade [...] A construção da identidade coletiva, por contraste com a individual, opera pela semelhança e traduz uma visão compartilhada que têm um conjunto de indivíduos de um bem comum que os une e aproxima".

De tudo, quisemos oferecer uma amostragem de uma das diversas facetas da cultura judaica. A definição do "que é ser judeu" não é dada por nenhuma contribuição em particular: a resposta está na soma dos diversos escritores. Suas obras originam-se da reflexão e convidam à reflexão.

Desde que existem, os judeus desenvolveram um modo de ser, de existir e de escrever. O judaísmo é uma forma de vida. E para viver, a comunicação. A fala, elo que liga gerações. A escrita, parte integral de nossa civilização. Ambas conferem permanência ao conhecimento. Ler é existir. Existir é conhecer. Conhecimento para a vida. Orientação para a vida. Olhar.

O olhar crítico de Clarice Lispector, Moacyr Scliar e Samuel Rawet sobre a realidade provém da libertação, através do imaginário, dos entraves do cotidiano. Olharam as origens para narrar a circunstância presente do imigrante Produziram um discurso novo e diferente no branco da página, onde não há enunciados prévios, sem sacrificar um passado histórico revalidado, sem imitar gestos alheios e sem ocultar a diferença. Ampliaram o cânone literário brasileiro, construindo uma literatura sobre outro significado do diferente.

Os escritores judeus - desgarrados e fragmentados, violadores e transgressores, seguidores de suas tradições e cheios de culpa por fazê-lo e por sobreviver, entre saber e alma, crença, coração, sujeito e objeto da História, vítimas de obscurantismos, foram os camaleônicos criadores, em iídiche, ladino, francês, inglês, espanhol e português - em quantas línguas existam - foram mártires e heróis, estiveram presentes em épocas de luz e de sombra. Seguiram à vanguarda da justiça, impulsionadores da modernidade.

Como novos descobridores, enviaram suas cartas-relação, suas crônicas da nova terra que os recebia, exaltando-a, perplexos e cheios de esperança.

\section{Referências Bibliográficas:}

BORGES, Jorge Luis. Discusión. Buenos Aires: Emecé, 1957,p.151-162.

LISPECTOR, Clarice. Laços de família. 19 ed. Rio de Janeiro, Francisco Alves Editora 1990

. A hora da estrela. $4^{\mathrm{a}}$ ed. Rio de Janeiro: Livraria José Olympio ed. 1978.

. Um sopro de vida, Rio de Janeiro: Editora Nova Fronteira, 1978. RAWET, Samuel. Contos do imigrante. Rio de Janeiro: Livraria José Olympio Editora, 1956.

SCLIAR, Moacyr. Os deuses de Raquel. Rio de Janeiro: Editora Expressão e Cultura, 1975.

O ciclo das águas. Porto Alegre: Editora Globo, 1977.

. O olho enigmático. Rio de Janeiro: Editora Guanabara, 1986.

. A orelha de Van Gogh. São Paulo: Companhia das Letras, 1989. 


\section{Literatura de imigrantes: a literatura iídiche no Brasil}

\section{Rifka Berezin ${ }^{1}$}

A

língua iídiche foi o principal veículo de comunicação criado pelos judeus asquenazitas na Europa, no decorrer do último milênio. E esta língua cumpriu o papel fundamental de propiciar a ligação entre os imigrantes judeus asquenazitas que começaram a chegar ao Brasil, de diferentes países da Europa Oriental nos fins do século XIX.

Aqui chegados, dedicaram-se à organização da vida comunitária judaica e, quase ao mesmo tempo, davam início à sua criação literária em língua iídiche já que seus leitores eram falantes deste idioma. Já no ano de 1915 foi fundado em Porto Alegre o primeiro jornal de língua iídiche, com a colaboração de pessoal vindo da Argentina e dos judeus das colônias da ICA. Este jornal denominado "Di Mentcheit" - (a Humanidade) teve curta duração. E foi neste que as primeiras criações literárias dos jovens escritores foram publicadas no Brasil. Todos estes colaboradores tornaramse bastante conhecidos do público leitor de língua í́diche: Yossef Halevi (Argentina), Natan Becker (Rio de Janeiro), Marcos Frankental (Quatro Irmãos) - que mais tarde viria a ser o redator do jornal iídiche de São Paulo, - Melech Raicher (Santa Maria), Baruch Schulman (Curitiba) e outros. Todos os escritores citados continuaram escrevendo em outros locais e em outros jornais ao longo dos anos vinte, trinta, quarenta e cinquenta.

Mais tarde, em 1923, Aron Kaufman fundou o "Vokhnblat" (O Semanário Israelita) no Rio de Janeiro. Esse jornal circulou ao longo dos anos por todo o Brasil onde houvesse judeus asquenazitas. E, nesse periódico, eram impressas as criações literárias da nova literatura iídiche rio Brasil. São passados, pois, mais de oitenta anos desde que a nova literatura iídiche começou o seu processo de desenvolvimento na nova Terra.

\footnotetext{
Professora Titular da USP.
}

A literatura iídiche-brasileira é nova quanto à sua temática, quanto ao seu público leitor, suas formas de expressão e sua visão do novo mundo. Ela tem marcantes diferenças da literatura iídiche de tempos passados.

Ela, naturalmente, tem sua origem e ligação com a literatura desenvolvida na velha Europa - ela é organicamente ligada com as fontes e ainda se alimenta delas, mas tem um caráter bastante diferente. Essa diferença é acentuada principalmente pela influência que recebeu das novas formas e modelos da literatura universal e brasileira.

Trata-se de uma literatura judaico-brasileira, ligada literariamente tanto à velha literatura iídiche como à literatura brasileira. A língua de expressão é o iídiche. A temática é do imigrante judeu-brasileiro, da terra do Brasil e do homem brasileiro.

Esta literatura em língua iídiche revelava e refletia, por um lado, o encontro do imigrante com a terra brasileira e, por outro, os conflitos individuais decorrentes do processo de aculturação a uma nova sociedade. A nova literatura descreve o deslumbramento de recém-chegado com a bela natureza tropical, com a cidade grande, com a multiplicidade de tipos humanos, com a beleza da mulher brasileira e a sensualidade da mulata. E o escritor-imigrante cantou, em poesia e prosa, na língua que lhe era familiar, o iídiche, esse mundo novo que lhe parecia encantado, em comparação com o seu lugar de origem.

A literatura do imigrante judeu expressa também a solidão e o desarraigamento do recém-chegado, assim como os esforços sobrehumanos para superar a crise motivada pela saudade do lar e dos familiares, pela quebra dos padrões tradicionais e a incorporação de novos e pela luta para a sobrevivência em terra estranha. Esses escritores escreviam sobre a profissão de quase todos os imigrantes: a "klientele" ou "pedlerai", isto é, a venda de porta em porta de diferentes mercadorias, à prestação. Assim sendo, apesar de se tratar de literatura ou ficção ela não deixa de ser uma fonte histórica para o estudo de certos aspectos da vida do imigrante asquenazita e da nova sociedade judaico-brasileira que aqui se organizava.

Entre os imigrantes asquenazitas vindos diretamente da Europa Oriental ou em alguns casos da Argentina, aportaram escritores, artistas e intelectuais judeus de expressão iídiche. Na quase totalidade eram jovens, mas velhos demais para adotar o português como língua de criação literária 
na nova terra. Poucos conseguiram expressar-se também em português. Esse fato limitou o contato da maioria desses escritores de língua iídiche com intelectuais e escritores brasileiros.

Os escritores colaboravam nos jornais de língua iídiche, o "Vokhnblat" desde 1923, mais tarde também em outros jornais que foram surgindo nas décadas de trinta e quarenta. Em 1939 começou a ser publicada uma revista literário-cultural, o "Velt Schpiguel" (O Espelho do Mundo) na qual colaboraram muitos dos escritores e intelectuais judeus da época.

Já na década de 20, viera à luz no Rio de Janeiro um livro impresso em iídiche. Trata- se de uma antologia de poesia e prosa de Schabetai Karakuschansky e Schimon Landau sob o título "Tziun" (Signo), totalmente traduzido para o hebraico pelos autores e levando o subtítulo: "O Primeiro Livro Judaico no Brasil" (Rio de Janeiro). Oito poemas e um ensaio de Schabetai Karakuschansky foram publicados mais tarde na Antologia "Undzer Baitrog" (Nossa Contribuição) Rio de Janeiro, 1956 e, na Antologia "Brasilianisch" (Brasiliana) Argentina, 1973 foram incluídos três dos seus poemas.

Em 1930, foi publicado o primeiro romance da vida judaicobrasileira, "Don Domingos Kraitzveg" (A Encruzilhada de Dom Domingos), escrito por Leib Malakh, pseudônimo de Leib Zaltzman. Ele viveu antes na Argentina onde publicou poemas, críticas literárias e peças teatrais. Chegou ao Brasil em 1929 e durante alguns anos publicou, além do seu romance, vários contos nos jornais locais. Algumas de suas narrativas encontram-se na Antologia "Brasilianisch" (Brasiliana).

Naquela época também foi publicado no Rio de Janeiro, Nilópolis, 1932 o livro "Naie Heimen” (Novos Lares) de Adolfo Kischinovsky. É um livro de contos que têm como tema a vida dos imigrantes judeus e sua ocupação inicial mais característica, a "klientele", a venda de porta em porta, à prestação. Um de seus contos, "Moral" (Moral) foi incluído na Antologia "Brasilianisch", 1973.

Um grande escritor dos primeiros tempos da nova literatura iídichebrasileira foi Menasche Halpern que já era um escritor conhecido na Europa. Publicou em 1934 no Rio de Janeiro seu livro de memórias “Oisn Altn Brunem" (Da Velha Cisterna). Mais tarde publicou outras obras de valor literário. Na Antologia “Undzer Baitrog”, Rio de Janeiro, 1956, foram incluídos um poema e um ensaio deste escritor.

Dentre os escritores pioneiros quero citar ainda a escritora Rosa Schafran Palatnik que chegou ao Rio de Janeiro em 1936. Ela já tinha obras publicadas e até mesmo um prêmio literário obtido na Europa. Como todos os escritores da época, publicou contos em diversos jornais. Esta escritora talentosa, além dos seus contos sobre a Polônia, escreveu também sobre o homem e a realidade brasileira. Publicou o livro "Kroschnik - Rio" em 1953 e, mais dois livros de contos. Dos escritores mencionados, somente de Rosa Palatnik encontramos uma coletânea de contos traduzidos para o português no livro "Dois dos Justos" com introdução de Nelson Vainer, tradução de José Steinberg, capa e ilustrações de Dália Szafran, 1975, Rio de Janeiro. Também Hersch Schwartz que chegou no Brasil em 1926 começou a publicar os seus contos em vários jornais da época e publicou o seu livro "Der Onheib” (O Início) em 1954 no Rio de Janeiro.

São muitos os escritores em língua iídiche também em São Paulo e outras cidades do Brasil. De São Paulo quero citar Meir Kucinski que além de grande escritor produziu vários trabalhos de crítica literária. Uma antologia de contos de Kucinski "Imigrantes, Mascates e Doutores" foi traduzida para o português e publicada pela Editora Ateliê, São Paulo, 2002.

A vida literária dos judeus no Brasil em língua iídiche foi intensa, com muitas publicações em jornais e livros.

Temos conhecimento também do grande interesse que os escritores e intelectuais de língua iídiche demonstraram pela literatura brasileira. Encontramos traduções para o iídiche de Monteiro Lobato. Sabemos, mas ainda não localizamos, que existe uma tradução para o iídiche de Machado de Assis e de outros escritores.

Quero completar essas considerações observando que grande parte desta literatura iídiche-brasileira tem qualidades literárias mas, dificilmente será conhecida pelas novas gerações se não for traduzida para o português.

Trata-se de uma literatura brasileira em língua iídiche, de imigrantes judeus, que traz à luz o esforço, a luta, as dificuldades e os ideais daqueles que, temerosos e deslumbrados aportaram no Brasil na esperança de aqui reconstruir suas vidas. E, na medida que essas obras forem traduzidas para o português tomaremos conhecimento desta criação literária e também de 
muitos aspectos da vida dos imigrantes judeus no Brasil, fundadores de nossas comunidades judeu-brasileiras.

\section{Referências Bibliográficas:}

BEREZIN, Rifka e CYTRYNOWICZ, Hadassa (organizadoras ). Contos de Kucinski: Imigrantes, Mascates e Doutores. Editora Ateliê, S. Paulo, 2002.

GUINSBURG, Jacó. Aventuras de uma Língua Errante. São Paulo: Editora Perspectiva, 1996.

"Nossa Contribuição"- A primeira coletânea iídiche no Brasil, Rio de Janeiro, 1956

PALATNIK, Rosa - Dois dos Justos. Tradução de José Steinberg, Rio de Janeiro, 1975.

RAIZMAM, Itzhak Z. - Um quarto de século da imprensa judaica no Brasil (1915-1940) (em iídiche)- Museu de Arte, Safed, Israel, 1968.

ROBLANSKY, Samuel (organizador).Antologia "Brasiliana"- La literatura idish en Brasil. Buenos Aires, 1973.
Para além do incêndio: a escrita feminina de Cíntia Moscovich

Nancy Rozenchan

I evando em conta a proposta deste evento, "Identidade e cidadania: como se expressa o judaísmo brasileiro?", voltei-me para a escrita da gaúcha Cíntia Moscovich, nascida em 1958, escritora, tradutora, jornalista, consultora literária e diretora do Instituto Estadual do Livro do Rio Grande do Sul. Ela é autora premiada de três livros: $O$ reino das cebolas - contos e narrativas, de 1996, Ed. Mercado Aberto, esgotado, segundo me consta; Duas iguais - Manual de amores e equívocos assemelhados, Ed. L\& PM, 1998 e Anotações durante o incêndio, Ed. L\&PM, primeira edição, 2000 e segunda edição, 2001.

Pode-se dizer que a autora conta com o respeitável background do maior número de escritores judeus de um mesmo estado com livros publicados, ao menos uns quinze. Grande parte destes autores usou como pano de fundo a vida rural das colônias da ICA, única na experiência judaica brasileira. Outros já são autores urbanos. Sem dúvida, um grupo literário nada desprezível. E, provavelmente, poder-se-ia ainda acrescentar os escritos em iídiche. Se esta produção prolífica se deve à gama maior de experiências da comunidade no sul, é algo que deve ser analisado.

Numa entrevista à Revista Vox n. 3 da Imprensa Oficial do Rio Grande do Sul, Moacyr Scliar tece considerações sobre a história da "literatura étnica"; segundo ele, a literatura de imigração tem uma história natural com três momentos. O primeiro é o momento da chegada ao país. Aí não há lugar para a literatura: os imigrantes não dominam o idioma e, além disso, sua prioridade maior é a sobrevivência. Depois vem uma geração (geração num sentido genérico) que já tem uma vida mais folgada, que domina a língua (às vezes à perfeição) e que possui motivos sociais e psicológicos para escrever; a experiência de vida, o conflito com os pais. É gente que, na infância, principalmente, tem uma vida em casa (ouvindo um idioma diferente, comendo alimentos diferentes, participando de festas

${ }^{1}$ Doutora em Cultura e Literatura da USP 
diferentes) e outra na rua ou no colégio - daí o conflito, que se transforma em fator desencadeante e mesmo em matéria-prima para a literatura, com muitos exemplos de excelente literatura. Depois vêm gerações adaptadas e que, se sentem necessidade de escrever, é por outra razão. De modo que literaturas étnicas seguem um ciclo, o que não impede, claro, um ressurgimento de etapas anteriores nas mais recentes.

De todas as etapas citadas, considero que Moscovich situa-se mais ou menos no terceiro segmento, dos mais jovens, em que o conflito na identidade, fator desencadeante de um certo momento da literatura, é apenas um registro ou um comentário atenuado do passado.

Como disse um jornalista do sul - Fabrício Carpinejar - Moscovich não pode ser reduzida à categoria de autora nova-feminina-gaúcha-judaica, já que com sua voz, uma das mais provocantes da narrativa brasileira, e com a coragem de que dispõe, não limita a sua escrita a temáticas da experiência judaica ou a qualquer outro destes segmentos: feminina, gaúcha. Exemplo disto foi a novela Duas iguais, que abordou com uma ótica expressiva o amor de duas jovens adolescentes, uma delas judia, avaliando o homossexualismo como sequência de uma verdadeira amizade. Como pano de fundo nesse livro, a morte do pai da narradora/personagem judia, um casamento que não pode se sustentar e mais uma vez uma perda, na morte prematura da companheira.

Mas é em dois dos contos do terceiro livro que iremos nos deter. Quase todos os contos do livro têm como personagem central uma mulher. Quatro dos onze contos de Anotações durante o incêndio destacam-se pela temática judaica. O livro divide-se em duas partes: A Fumaça, com cinco, e O Fogo, com seis contos. Esclareça-se que, com uma exceção, não se trata de algum incêndio mas dos registros do estado de explosão das personagens envolvidas, as anotações como que do meio do incêndio.

É ainda Carpinejar quem chama a atenção para o fato de que o "incêndio" começa das mais banais faíscas e conflitos familiares. Lembrando o mencionado título do livro, Anotações durante o incêndio, ocorre um ou outro desses momentos quentes quando uma fagulha ameaça tudo, como no aparente contraste do conto "O homem que voltou ao frio". O ritmo frenético da narrativa acompanha a sequência vertiginosa dos acontecimentos que beiram uma catástrofe. Catástrofe? Depende do enfoque. Quando do ponto de vista da personagem Ethel, com 17 anos no início da trama, sim. A chegada do telegrama - primeira centelha - que abre de supetão o conto, aterroriza a protagonista. Sente-se completamente perdida sem saber o que fazer. Por outro ângulo, talvez nem seja tão catastrófico: não há nenhum anúncio de guerra, crime ou incêndio que seja. Quem se anuncia é um finlandês, voluntário como Ethel num programa de jovens no kibutz, que não sabe que o brasileiríssimo "apareça lã em casa" não significa o que estas palavras representam em qualquer outra língua. E Edward, que não conseguiu se converter ao judaísmo em Israel, chega com a feiúra, ou melhor, com a cara e a coragem, sem dinheiro, sem emprego, para casar com Ethel, a fim de que, ao menos, os seus filhos sejam judeus. Tratasse disso um escritor de uma etapa anterior da escrita "étnica", o tom utilizado seria certamente mais trágico. Atitude inadmissível em geração de imigrantes - o casamento com um não judeu, assume em Moscovich um tom mais "light" por vários critérios, alguns dos quais merecem mais destaque: parafraseando apenas aparentemente $\mathrm{O}$ espião que saiu do frio, de John Lê Carré, o pretendente que desembarca no sul do Brasil, também é alguém que será colocado de lado como o famoso espião que não conseguiu sair do frio; é branco feito um doente, usa um exagerado casaco de peles, é feio, tem a sensaboria do estrangeiro, os óculos, o jeito de inseto de corpo descomunal e de cabeça minúscula e alva, cabelos lisos e ralos; são traços mais do que suficientes para apresentar uma personagem ridícula que não oferece risco algum de vir a ser um candidato a marido da moça filha única. Conquanto haja alguma demonstração da moça de tentar ser gentil com o rapaz que se encontra meio perdido nos trópicos, não há como escapar ao misto de desdém e repúdio. Enquanto Ethel tem a sensação de náusea no aeroporto, no pai, a quem ela recorrera em busca de socorro, esboça-se um sorriso de escárnio. Nesse ambiente, a jovem protagonista sabe indicar a sua posição em relação aos eventos, que é central na obra de Moscovich (p. 31) "Mas permaneci de pé, retribuindo os sorrisos, dentro de uma felicidade espantada e infame." A felicidade nunca é integral.

Não há no conto atração da judia (de cujo ponto de vista a narrativa é desenvolvida) pelo não judeu, muito menos amor, como se poderia talvez esperar, se a obra pertencesse a um período anterior. Ao contrário, uma série de elementos intertextuais bastante óbvios, de textos e contextos sobejamente conhecidos, além de servir para descrever sensações, sentimentos, ajuda ainda a tornar esse relacionamento indesejado algo abominável. A par do título mencionado, destaca-se, em ordem crescente de 
número de manifestações, a kafkiana comparação do rapaz com um inseto, seja pelo corpo descomunal, seja pela semelhança com o inseto devido ao casaco de peles, o fato de o rapaz mal conseguir fincar o pé uma vez no "castelo", se pode metaforicamente considerar a casa de Ethel e o desejo de casamento como "castelo" e não saber por que não pode fazê-lo, comparação ao protagonista de "O processo", e outros elementos aos quais voltarei mais adiante.

Nota-se neste conto de Moscovich uma habilidade particular em utilizar recursos na abordagem do tema já quase desgastado do casamento misto. A paródia de que ela faz uso - paródia pós-moderna, conforme a conceituação de Linda Hutcheon - estratégia eficiente para promover um acerto de contas e uma reação, de maneira crítica e criativa com elementos culturais predominantes, permite uma relação dialógica entre a identificação e a distância. A autora identifica-se com o tema do indesejado candidato não judeu a namorado ou marido, presente nos mais diversos escritores daqui ou dos Estados Unidos, e, ao mesmo tempo, distancia-se da abordagem que pode ter sido mais comum no passado, que já tinha um modelo conhecido de rejeição, como o de Sholem Aleichem em O violinista no telhado ou no livro que o originou, Tevie, o leiteiro. A versão gaúcha atual dilui a forte carga que este tema sempre possuiu, ainda que o desconforto causado por ele seja bastante intenso, mantido por sensações humanitárias e não por amorosas. Não existe uma paixão ou desejo por parte da moça. Suas expectativas são outras, típicas dos de sua geração: faculdade e um casamento dentro dos padrões dos de seu grupo. Ao mesmo tempo, Ethel não pode ser acusada de indiferença. Sente e lamenta o desacerto do rapaz com a realidade que é tão distante dele. Num contraponto jocoso com o espião que saiu do frio, Edward, que não possui nenhum atributo que seja da categoria de espiões, não consegue perceber o que está por lhe acontecer, deve voltar para o frio, para a geladeira finlandesa de sua vida. Para acentuar isto, o processo de rejeição e consequente afastamento do rapaz é narrado através de uma série de símiles pertencentes ao contexto do genocídio judaico da II Guerra Mundial, especificamente os que destacam as atrocidades nazistas. Sempre segundo a concepção de Ethel, o pai age como comandante de um campo de extermínio ao assumir o controle do carrinho de bagagem no aeroporto ato aparentemente pueril, mas que na realidade esconde o fato de quem passará a ser o dono da situação. Ethel, perdida em relação às atitudes a serem tomadas e tendo delegado poderes ao pai, "se sentia debaixo de um chuveiro que, ao invés de liberar água, ameaçava sufocá-la com um gás letal." (p.32) "A caminhada até o estacionamento, é num silêncio constrangido - o silêncio de um forno crematório." (p.32) "O Ford Galaxie do pai era um Auschwitz particular" (p. 33) "e mais uma vez ela se sentia má porque fizera com que ele caísse numa emboscada: saía gás do chuveiro." (p. 33) E, mais adiante, "Sentia-me a maldita que havia encaminhado um homem a um campo de concentração." (p.38) E ainda: "Fazia já uns quatro meses que Edward fora deportado" (p. 39), algo que, ao pé da letra, é quase verdadeiro.

O contexto ideológico que a autora apresenta, a perspectiva que permite ao artista falar para o discurso a partir de dentro deste discurso, conforme Hutcheon - aqui o terna do casamento com não judeu, dissolvido nas agravantes da feiúra, da pobreza, etc. - entremeado com as breves frases que remetem ao campo de concentração e que expressam a visão como que do outro lado, da vítima maior, indicam como esse conto, um exemplo bem acabado da escrita atual, dá conta de uma antiga temática judaica; antes, uma catástrofe, agora, pouco mais que um incômodo: com um tênue cinismo que se insinua na mente do leitor mais avisado, cinismo que compactua com laivos de galhofa, que quase resvala para o mau gosto.

Salva do incêndio, porém com cicatrizes causadas pelas "faíscas", Ethel conduziria o contato distante com o candidato preterido pela vida afora, até receber a notícia de seu falecimento, ponto final definitivo do relacionamento, amargo alívio como solução para a complexa temática.

O tom de Moscovich muda diametralmente em um outro texto do livro, pertencente à sessão "O Fogo", em que há realmente um incêndio. A relação dialógica da paródia pós-moderna entre a identificação e a distância dá lugar a uma identificação incondicional com o legado judaico, sua preservação e papel primordial na sobrevivência judaica. O conto "Aquilo que não principia e nem acaba", que Scliar qualificou de digno de um I.B. Singer, tem como primeiro incidente um incêndio no shtetl, em plena festa de Purim, o carnaval judaico, em que o menininho Shmil é salvo pela mãe e, na corrida desenfreada para escapar ao fogo, consegue agarrar um gráguer, a matraca usada na celebração toda vez que se pronuncia o nome do mal intencionado ministro Haman, cujo propósito era exterminar o povo judeu. Em cena dantesca ante o extermínio que se esboça, imagens 
chagallianas que compõem o pano de fundo desse conto se sucedem vertiginosamente, é Haman que o garotinho imagina morto pendurado pelo pescoço com a língua pendendo, são as mulheres com seus ói-ói-Ois, as crianças na fuligem, os homens nos xales de orações, o velho que repete o Shmd Israel, a proclamação do chazan de que foram os demônios que atearam fogo ao gueto. Em meio a isso, o ruído espontâneo do gráguer na corrida, a despedida daquele mundo, ainda com o aceno do gráguer a um homem que meio alheio àquele inferno lhe sorriu com os olhos azuis.

Moscovich não traz aqui uma identificação específica com o mundo atual na vivência de sua personagem. Samuel, - imagina-se que agora no Brasil - em sua vida ascética e presa à tradição, é dono de um antiquário em que a sua própria pessoa parecer ser mais um dos objetos expostos na loja empoeirada. Ele é tão antigo quanto a história de seu povo. Não tem uma característica que o particularize. Nada há que se destaque ali, dono ou objetos, exceto o velho gráguer conservado com cuidado. Elo de vinculação com a tradição, símbolo da própria sobrevivência, a matraca é única em seu significado. Talvez não mais só símbolo da existência judaica, mas fator maior da incompreensível sobrevivência. Shmil e o gráguer compõem uma unidade indissolúvel. Na busca do sentido disto e de uma resposta, Moscovich voltou-se nesse conto ao mago que, pelos seus escritos, tentou colocar um pouco de ordem nos universos que abordou, Jorge Luis Borges. É sabido que, para este fim, Borges se ocupou de diversos temas e subterfúgios: sorte, violência, presença do Outro, natureza da linguagem, mundos imaginários, metaficção, labirintos, sonhos. Das suas muitas obsessões, a nossa autora foi se valer de um complexo texto do autor do país vizinho, "O Livro da Areia", do livro homônimo, de 1975.

Num dos maiores momentos de sua criação de fantasia, a personagem do conto de Borges vem a possuir o Livro de Areia, um livro sagrado, e trata de vendê-lo. O narrador olha o livro e é incapaz de ver a primeira ou a última página, porque o número de páginas é infinito; o livro não tem começo ou fim e a leitura se altera de uma vez para a outra. Fascinado, o narrador o adquire, torna-se obcecado a ponto de somente pensar nele. Por fim, deixa-o de lado, empilhado com muitos outros em seu porão.

Borges tratou aqui do infinito na forma do misterioso livro, simbolizando a constante busca humana pela existência do mundo. Do texto de Borges depreende-se que esta busca é infindável e, portanto, sem sentido. Creio que se deve mencionar paralelamente, e em contraste, um outro livro que cabe nesta história, ainda que a escritora não o tenha mencionado. Quando o Rei Assuero, do livro de Ester, numa noite de insônia pede que se leia o livro de memórias do reinado, não são os seus feitos ou os dos ministros que se destacam, mas o ato salvador de Mordechai, indicativo da futura sobrevivência do povo.

Pois bem, Moscovich muda um pouco o rumo apontado por Borges. O estranho - de olhos azuis - que entra na loja de Shmil - Shmil que naquela cidade poderia ser chamado de Samuel, mas nunca o desejou, continuará sempre sendo Shmil - propõe-lhe a troca do Livro de Areia pelo gráguer, quase tão velho quanto o seu dono.

Barganha concluída, Shmil é acometido pela mesma obsessão que o narrador borgiano. Discerne no livro, dentre textos incompreensíveis, cenas que pertenciam ao seu passado longínquo, ao seu povo: o relato de Purim, a imagem do Haman pendurado e ainda o Shmd, trechos do Kadish. Teve noção de que o livro era monstruoso e ele também o era, uma vez que percebia, com olhos e as mãos que o apalpavam, a obscenidade que o livro propunha, que infamava e corrompia a humanidade - a tentativa de saber e poder mais do que o Criador. Como em Borges, não pode queimá-lo pelo medo que a combustão também fosse infinita e sufocasse o planeta de fumaça.

O suplício de Shmil tem, porém, um fim. Ao avistar em uma das folhas a imagem de um gráguer igual ao que ele possuíra, - no livro de Ester é o feito de Mordechai que brota do livro de memórias - sente-se salvo, murmura o mesmo Baruch Hashem (Bendito seja o nome - Deus) que a mãe pronunciara em sua infância para apaziguá-lo repetindo que Haman - o mal - a destruição - estava morto.

Shmil recupera o gráguer arrancando com força a folha com o desenho do livro. Seu mundo está salvo, ele não buscará o infinito, a "chave" da continuidade está simbolicamente em suas mãos, está dentro dele, como o "Baruch Hashem" da mãe, como o "Shmá Israel": a transmissão de geração a geração, a confiança na vitória, a fé inquestionável. Ato contínuo, o livro é lançado na carroça do lixeiro que passa providencialmente. Fá-lo depois de beijar a mezuzd ao passar pela porta da loja.

Este é o último conto do livro que tem uma temática judaica como pano de fundo. A simplicidade de um símbolo, que nem se pode dizer que 
seja judaico - a matraca - é a chancela do legado recebido de que o mal tinha sido eliminado e a fé nisto é que importava, mesmo que ele nem se lembrasse mais porque conservava o instrumento ou que este agora não passasse de uma folha de papel. A busca de respostas e saídas impossíveis é uma das marcas da escrita de Moscovich.

E ainda umas palavras sobre a escrita feminina, sem que se note uma tendência conhecida de dialogar com tradições literárias eminentemente masculinas para subverter as suas normas. Nesses dois contos, Moscovich transita por um viés curioso: no primeiro texto destaca-se um discurso que trai o espanto da voz feminina narradora ante um tema que em autores anteriores vinha com frequência pela voz autoritária-prevalecente masculina daquele a quem cabia o papel de fazer cumprir a lei. A tal voz não precisou ser dispensada aqui. Continua a cumprir o seu papel. Mas a posição feminina é destacada pelo fato de a narrativa ser transmitida pela voz feminina da protagonista-narradora, perplexa ante uma situação indesejada. Não ocorre um embate entre ela e o lado/papel masculino, pois não se trata aqui de uma possibilidade de um casamento misto e, sim, justamente do oposto.

E, quanto ao segundo conto, é fato notório que o livro de Ester no qual se relata o Purim, é essencialmente feminista, em particular no que se refere à atitude da rainha Vashti. Ester, em várias das cenas em que é figura central, não lhe fica atrás. Ao escolher um protagonista masculino para o seu conto, parece-me que a autora não precisou dispensar os antecedentes de gênero subjacentes. E, se quiser, pode-se vê-los reforçados por duas brevíssimas menções à mãe, uma iídiche mame, apaziguadora e salvadora no passado distante de Shmil e, quando de posse do Livro de Areia, ele a funde no seu sonho com o barulho impreciso que parece conduzir à memória-festa destruidora/salvadora de Purim e o livro extraordinário que ele tem em mãos representando passado e futuro.

A voz feminina forte de Moscovich é segurança de enfrentamento e continuidade; não desconstrói modelos culturais: indica uma linha própria.

\section{Referências Bibliográficas:}

CARPINEJAR, Fabrício, in Bonde n. 16, agosto de 2001, Porto Alegre, www.bonde.com.br/
MOSCOVICH, Cíntia, Anotações durante o incêndio. Porto Alegre, L\&PM, $2001-2^{\circ}$. ed.

SCLIAR, Moacyr, Entrevista, in Revista Vox n. 3, Porto Alegre, www.corag.rs.gov.br/revistas/ 


\section{Homenagem ao intelectual judeu Jacó Guinsburg}

\section{Berta Waldman ${ }^{1}$}

$\mathrm{N}$ pensamento judaico, sábio e culto são conceitos equivalentes, e quem possui cultura e sabedoria é conhecido como talmid chacham (discípulo de sábios), título que carreia uma verdadeira honraria, pois representa o máximo em valorização e reconhecimento social. É interessante observar que o ponto alto do conhecimento é marcado pelo título talmid, aluno, aquele que tem sempre diante de si o horizonte do que há para aprender e não aquilo que já sabe. Observe-se, ainda, que conhecimento e sabedoria caminham juntos e marcam um patamar acima do mero entendimento, pois impõem a obrigação maior de partilhá-los com os que sabem menos ou são menos afortunados.

O talmid chacham sempre foi o herói ideal da tradição judaica; ele tem na mira a sabedoria máxima, isto é, a virtude. Por isso, do chacham espera-se não apenas que seja culto, mas que leve em conta as pessoas, tenha um comportamento ético e busque a justiça. Este padrão foi estabelecido por Moisés e pelos profetas e tem por fim ancorar o conhecimento à ação - lugar da justificativa para o conhecimento. É a transitividade do conhecimento em ação que confere autoridade ao chacham e é esse tipo de autoridade que se prende ao nome do professor Jacó Guinsburg, conforme se pode auferir a partir de vários fatores, dos quais vamos lembrar alguns.

O conjunto das atividades do homenageado desenha o perfil de um intelectual "anfíbio" e ubíquo que, enquanto interfere na produção intelectual brasileira, mantém um interesse vivo pela cultura judaica, tentando construir uma ponte entre ambas. É essa tentativa que marca, a meu ver, a particularidade desse trajeto intelectual, que vou tentar delinear em suas grandes linhas.

Filho de imigrantes, ele próprio imigrante nascido na Bessarábia, o professor Guinsburg chegou ao Brasil com três anos de idade, pouco depois

${ }^{1}$ Professora Titular de Literatura/USP. Diretora do Centro de Estudos Judaicos/FFLCH/USP. da Revolução de 1924, tendo levado uma vida de garoto pobre, no bairro do Bom Retiro, São Paulo.

Como todo garoto judeu, aos treze anos cumpriu o rito religioso de ingresso na comunidade (bar mitzvá), datando dessa época sua iniciação no hebraico. O iídiche certamente foi aprendido em casa, como aconteceu com todos nós, filhos de imigrantes de origem ashkenazita, tendo sido essa nossa língua materna.

Desde cedo, o prof. Guinsburg interessou-se por atividades políticas, tendo participado de movimentos estudantis de esquerda, opondo-se imediatamente ao integralismo, consciente da ameaça que esse movimento representava para ele como cidadão e como judeu. Tinha dezoito anos quando estourou a II Guerra Mundial. Nesse período, a livraria Elo, dos Irmãos del Picchia, na Rua Senador Feijó, foi um dos lugares que frequentou, junto com estudantes de Direito que faziam oposição ao regime getulista, escritores e poetas, como Oswald de Andrade, Rossini Camargo Guarnieri, Domingos Carvalho da Silva, e ainda pesquisadores de música e folclore, como Rossini Tavares de Lima, e muitos outros. Ali, segundo depoimento seu, conversava-se e debatia-se sobre tudo - particularmente sobre literatura, arte e política. Esse foi, na opinião do homenageado, um dos cadinhos da Esquerda Democrática, e um dos quartéis generais da atuação dos acadêmicos de Direito contra Getúlio Vargas, reprimida violentamente por Coriolano Góes.

Sua presença quase diária nessa livraria não o impediu de envolver-se simultaneamente com atividades sociais e políticas na comunidade judaica, marcando sua relação não só com as lutas do povo brasileiro pela democracia e pela renovação da sociedade, como também seu vínculo com aqueles que estavam sendo chacinados no grande Reich alemão.

Presidente do Departamento Juvenil do "Centro Cultura e Progresso", o prof. Guinsburg dedicou-se à política, à literatura, ao estudo do marxismo, e também à literatura e à história judaicas, proferindo palestras e dirigindo debates no mencionado Centro, sem descurar, por outro lado, dos temas universais.

A formação da Editora Rampa, em 1947, foi um marco em seu caminho. Esta aventura de mocidade teve como saldo positivo a publicação de quatro títulos: Antologia Judaica, Joias do Conto Iídiche, A Mãe, de 
Scholem Asch, e Contos, de I.L.Peretz, que alcançou repercussão junto à crítica, tendo merecido comentários estimulantes de Otto Maria Carpeaux, Osório César, e, através de correspondência particular, de Carlos Drummond de Andrade e Tristão de Athayde.

Em 1954, convidado a trabalhar na recém criada Difusão Europeia do Livro - DIFEL, o prof. Guinsburg cooperou com alguns projetos de grande importância cultural e editorial: a publicação da série Saber Atual, a coleção Clássicos Garnier, uma "Brasiliana" moderna, sob o título Corpo e Alma do Brasil, Presença da Literatura Brasileira, Presença da Literatura Portuguesa, entre outros. Em função desse trabalho, manteve contatos com Sérgio Buarque de Holanda, Antônio Cândido, Sérgio Milliet, Haroldo de Campos, Gerard Lebrun, Florestan Fernandes, Maria José Werebe, Octavio Ianni e outros expoentes da inteligência brasileira, ao lado de figuras internacionais, como Sartre e Simone de Beauvoir.

Enquanto estava vinculado à DIFEL, o prof. Guinsburg entra em contato com Anatol Rosenfeld, intelectual dotado de espírito crítico aguçado e grande mestre, que aglutinou ao seu redor um círculo de amigos que compreendia além de Guita e Jacó Guinsburg, Regina e Bons Schnaiderman, Roberto Schwartz, Zulmira Ribeiro Tavares, Giselda Leirner, entre outros, a quem ministrava aulas de filosofia, que se estendiam a questões que aconteciam no Brasil e no mundo, nos mais variados terrenos.

Ainda neste período, a convite de Décio de Almeida Prado, tornou-se colaborador do "Suplemento Literário" de O Estado de São Paulo, responsável pela seção de Letras Judaicas. Tal incumbência permitiu-lhe abordar e difundir valores e nomes da literatura judaica em iídiche e em hebraico. Foi na redação desse jornal que conheceu Sábato Magaldi, com quem acabou travando sólida amizade.

O contato com Anatol Rosenfeld, Sábato Magaldi e, anteriormente, Ruggero Jacobbi avivaram no professor Guinsburg outro foco de interesse: o teatro. Tendo acompanhado desde a juventude espetáculos de teatro amador em língua iídiche e portuguesa, sofreu o impacto das representações do "Grupo Universitário de Teatro", de Décio de Almeida

Prado, de "Os Comediantes", e também da moderna arte de encenação trazida por Jacob Rotbaum, diretor e professor de teatro judeu, que mais tarde trabalhou com Ida Kaminska na Polônia, tendo antes permanecido em São Paulo por longo período, quando dirigiu os grupos de teatro amador do Centro Cultura e Progresso, onde realizou montagens de excelente nível artístico. Foi sob o impacto dos trabalhos apresentados pelo TBC, bem como das temporadas paulistas de grupos cariocas e das leituras mais específicas feitas por iniciativa própria ou por sugestões de Anatol Rosenfeld e Sábato Magaldi, que começou a se familiarizar com aspectos mais profundos da história e da teoria dramáticas, sem esquecer sua passagem pela França, de onde veio o impulso fundamental neste processo que o conduziria para pontos centrais dos estudos da cena contemporânea.

Assim começou a escrever sobre teatro e a traduzir peças teatrais, tornando-se professor de Crítica Teatral e mais tarde de Estética Teatral na Escola de Arte Dramática, tempos depois incorporada à USP.

Em 1965, funda, com um grupo de amigos, a Editora Perspectiva, com vistas a concretizar um programa bastante ambicioso. O primeiro item compreendia a edição de uma Judaica, que abarcaria quatro mil anos de criação cultural do povo judeu. Seriam doze volumes - que depois se tornaram treze - dispostos segundo uma diacronia que se detinha nos pontos altos de expressão coletiva e individual. A execução desse projeto representou um insano trabalho de pesquisa, tradução, organização e redação de ensaios e análises, coordenado e realizado em grande parte pelo prof. Guinsburg, embora tenha contado com numerosas colaborações de nível, como as de Anatol Rosenfeld, Zulmira Ribeiro Tavares, Bons Schnaiderman, Rifka Berezin e outros.

Apesar de esses volumes serem muito utilizados por professores e alunos do curso de Língua e Literatura Hebraica, aqui da USP, e por muitos outros leitores de fora da Universidade, curiosamente, não houve, até hoje, uma manifestação de peso sobre o conjunto da coleção, ao contrário do que ocorreu com a Antologia Judaica, que mereceu diferentes artigos na imprensa iídiche, além da brasileira, e o mesmo se diga em relação à publicação das Joias do Conto Iídiche e dos Contos de I.L.Peretz. A questão é que a imprensa judaica em iídiche se desativou com o tempo, pontuando o empobrecimento da vida cultural judaica, daí, talvez, o pequeno impacto comunitário de publicações da importância dos treze volumes da coleção, e mesmo de outras obras básicas sobre o judaísmo. Se o impacto comunitário não se fez sentir, o caso de Guershom Scholem serve 
de exemplo da importância da publicação junto ao público brasileiro que reconhece, hoje, a relevância deste pesquisador.

Outro caso importante, que o professor Guinsburg costuma mencionar, diz respeito a Agnon. Trata-se, sem dúvida, do maior ficcionista de língua hebraica, não só do século XX, mas de todos os tempos. Ele é um escritor profundamente expressivo, não só de sua geração, como da vida judaica nas encruzilhadas espirituais da modernidade. Esse autor foi lançado pela Editora Perspectiva, por coincidência justamente na época em que lhe atribuíram o Prêmio Nobel (em 1966). Na ocasião, o Professor Guinsburg já havia organizado a coletânea de relatos que denominou Novelas de Jerusalém e aconteceu que logo depois a Academia Sueca distinguiu o autor. Em seguida, foram editados mais relatos seus no Brasil. Assim mesmo, fora do âmbito universitário lê-se este ou aquele conto de Agnon, mas ele ainda não tem circulação efetiva entre os leitores de língua portuguesa, nem mesmo na comunidade.

$\mathrm{O}$ projeto da Editora Perspectiva não se cinge, no entanto, à mera divulgação de uma cultura específica. Constituía já seu objetivo, além de continuar ampliando a Judaica com outras obras de importância, desenvolver, em outra etapa, a publicação de textos de vanguarda e da bibliografia fundamental em Humanidades, particularmente os títulos que vieram à luz nas correntes renovadoras dos anos 50 e 60, tanto no Brasil como no exterior. Nasceu assim a coleção Debates. Outras coleções vieram juntar-se a ela, sempre com uma diretriz mais ou menos parecida: unir qualidade e importância do texto à qualidade da edição.

Outra atividade que exigiu os esforços do Prof. Guinsburg, além do ensino de teatro, consistiu no trabalho realizado no âmbito do então recémcriado Centro de Estudos Judaicos, ligado à Faculdade de Filosofia, Letras e Ciências Humanas, da Universidade de São Paulo. Chamado a colaborar em sua formação, participou de seu primeiro Conselho como diretor de publicações. Nessa posição coordenou a edição de textos universitários de interesse do Centro. Além disso, coube-lhe a responsabilidade pelo curso de Literatura na área de Hebraico, cujos programas organizou, tendo no início ministrado as aulas pessoalmente e, ao fim, delegado o magistério a outros professores, sob sua orientação. Desligado dessa atividade, o programa de pós-graduação de Língua Hebraica, Literatura e Cultura Judaicas conta ainda com a participação do professor na tarefa de orientação, mantida até hoje.
Em 1996, publicou uma obra da maior importância - Aventuras de uma Língua Errante: Ensaios de Literatura e Teatro Iídiche, que tem por protagonista o iídiche, língua em extinção a partir do extermínio de seus falantes durante a II Guerra Mundial, livro muito bem recebido pela crítica. Embora o ponto de partida dessa obra tenha sido seu doutorado, o resultado final apresenta-se como o roteiro de uma viagem pessoal, feita de idas e vindas que atam sua atividade crítica pelos territórios do iídiche e de suas criações, pontuada principalmente por seus autores e atores.

Quero observar, ainda, que o Professor Guinsburg está vivendo a década de seus setenta anos escrevendo uma prosa cada vez mais viva, com parte de sua obra por reunir em livro, e outra parte ainda na cabeça, por redigir. Vai entrando assim para a companhia reduzida e admirável dos escritores para quem a idade foi ocasião de desdobramentos intelectuais novos, tão insubstituíveis quanto os anteriores. Penso nos seus colegas e amigos, exemplos de todos nós, Sérgio Buarque de Holanda, Décio de Almeida Prado, Antônio Cândido, Bons Schnaiderman.

Não posso fechar essa saudação sem antes evocar o primeiro livro de ficção do Professor Guinsburg, O que aconteceu, aconteceu, publicado no ano 2000. Nele, as águas da cultura iídiche, hebraica e brasileira confluem, amarrando uma história de vida pessoal marcada pelo compromisso com a palavra. Se for verdade que há aí o esforço de se deslocar do lugar da crítica, do ensaio, da tradução, para se implicar no universo ficcional, é também verdade que o peso dessas três atividades está presente na construção de um processo peculiar de línguas calcadas, em que uma língua se faz ouvir através de outra. O tom do suporte oral, como da escrita da literatura iídiche, são mimetizados em alguns contos. Mais do que isso: os idiomas em contato (português e iídiche) intercambiam signos, contexto linguístico e semântico, a ponto de o modo de ser de uma língua transportar-se para outra, criando, tradução encoberta, um texto iídiche escrito em português. A visão de mundo, o modo de ser das personagens, a forma de perguntar e de responder, a ironia, confrontos que fazem faísca e produzem humor, a solução para os conflitos, enfim, o autor alcança explorar, na primeira parte do livro, um potencial expressivo de linguagem tal, que fica depositada nas vozes das personagens imigrantes em coro com a do narrador uma história da imigração dos judeus no Brasil. Também o hebraico ressoa em algumas narrativas de Guinsburg. Ao contrário do iídiche, o hebraico manterá uma distância da intimidade do idioma falado, por ter sido historicamente escrito e fundamentalmente 
litúrgico, até o momento de sua revitalização. Assim, os ecos de cada uma dessas línguas, na coletânea de contos, têm a ver com sua própria história. A primeira aparece em seu suporte oral, marcando o tom das falas, o brilho das imagens. A segunda deixa, no uso lexical rebuscado e na sintaxe erudita, o rastro de uma língua de base escrita, que soa estranha em português. Menciono esses elementos e não outros da coletânea para apontar um certo denominador comum entre os demais trabalhos do professor Guinsburg e seu texto ficcional, pois nele o autor alcança, no nível da expressão, inscrever a ponte entre o Brasil e o judaísmo buscada em suas outras atividades.

Como arrematar a saudação a uma vida de constante trabalho, de compromisso com a palavra, e que tem como expectativa mais trabalho ainda?

Permitam-me citar a adaptação de uma agadd (lenda judaica) que conta o seguinte:

O jovem estudioso do Talmud, tendo completado um profundo estudo, procurou rabi Elias, o Gaon de Vilna, e pediu-lhe a sua opinião. Rabi Elias olhou para o visitante com grande carinho:

- Filho - disse ele - você tem de enfrentar a dura realidade. Se quiser ser um escritor de livros profundos, terd de resignar-se a oferecê-los de porta em porta, como um vendedor de panelas, e a passar fome até os 40 anos.

- E depois que fizer 40 anos? - quis saber o jovem autor, cheio de esperanças.

Rabi Elias deu-lhe um sorriso encorajador:

- Quando chegar ld, você estará acostumado!
Entre o cheder e a rua:

figurações do judaico e do brasileiro na prosa de Samuel Bawet

\section{Rosana Kohl Bines}

uando em 25 de agosto de 1984, o escritor judeu brasileiro Samuel Rawet foi encontrado morto em seu apartamento, descansava a seu lado, sobre a mesa, uma grossa pilha de folhas manuscritas. Não se tratava, porém, de nenhum original inédito de Rawet, como esperava o escritor Fausto Cunha, quando foi ao apartamento do amigo, em busca de escritos para publicação póstuma ${ }^{2}$. A pilha manuscrita tinha a grafia de Rawet, mas não a autoria. Aparentemente, por um longo período de tempo, Rawet esteve a copiar a mão, palavra por palavra, os poemas de amor da escritora mexicana Sor Juana Ines de la Cruz. O que teria levado este escritor judeu, contemporâneo, um cético impiedoso, cuja literatura persegue o desespero e o desamor, a empenhar-se em tão delicada tarefa de transcrever fielmente os versos amorosos de uma freira católica do século XVII?

$\mathrm{Eu}$ resistirei à tentação de especular sobre as razões de fundo, por detrás desta aproximação insólita, para fixar-me, ao invés, na imagem de superfície, do escritor como copista, tão evocativa do célebre conto de Jorge Luiz Borges "Pierre Menard: Autor de Quixote". Como vocês devem se lembrar, Pierre Menard é apresentado ao leitor como um escritor francês do século XX, que reescreve o romance Dom Quixote de Miguel de Cervantes, datado do século XVII, copiando-o letra por letra, sem alterar sequer a pontuação original. Nos é dito que o Quixote de Pierre Menard é um feito ainda mais importante do que a obra prima de Cervantes. Posto que não há mérito especial em se escrever como Cervantes quando se é de fato

\footnotetext{
${ }^{1}$ Mestre em Literatura / Universidade de Chicago

${ }^{2}$ Fausto Cunha foi um grande amigo de Samuel Rawet, desde os tempos em que participavam juntos do círculo literário Café da Manhã, liderado pela escritora Dinah Silveira de Queirós, nas décadas de 50 e 60. Fausto Cunha narrou sua visita ao apartamento de Rawet ao escritor Renard Perez, outro integrante do grupo Café da Manhã, com quem me encontrei em duas ocasiões e a quem sou extremamente grata por dividir comigo suas memórias de Rawet. Todas as minhas tentativas de entrevistar Fausto Cunha foram frustradas.
} 
Cervantes. A mais árdua tarefa é chegar ao Quixote de Cervantes, tal qual o autor o concebeu, mas através das experiências de alguém vindo de outro século, dono de outras crenças, outra sensibilidade e padrões estéticos.

$\mathrm{O}$ ataque a noções de autoria, originalidade e verdade garantiu a Borges um lugar proeminente nos estudos da literatura e da teoria crítica contemporâneas. Borges tornou-se ícone maior de um certo fazer literário debruçado sobre si mesmo, apartado do "mundo real" e dos "referentes concretos" e preocupado tão somente em expor a ficção do texto, o texto enquanto repetição de outros textos, numa elaborada cadeia de citações autorreferenciais, que não apontam para nada além das circunscrições da própria escrita.

Se eu trago Borges e "Pierre Menard" para compor este retrato derradeiro de Rawet em sua última empreitada literária, é menos para firmar afinidades, do que para marcar, por oposição, o grande fosso que separa estes dois escritores.

$\mathrm{Na}$ ficção de Borges, estamos diante de um autor que simula um controle absoluto sobre as maquinações da sua escrita, posta em movimento sem o menor traço de modéstia quanto ao valor artístico da obra. Borges parece sempre narrar de um posto altivo e confiante, a divertir-se às nossas custas, quando nos guia e nos perde nos labirintos calculados de sua prosa ${ }^{3}$. Nos textos de Rawet, ao contrário, sentimos o pulso de um escritor jamais inteiramente à vontade com os artifícios de sua narrativa. Hábil contista, dotado de "um instrumental literário de grande precisão," na avaliação de Jacó Guinsburg ${ }^{4}$, Rawet criou textos densos, de contorno ensaístico, que lhe renderam alguns elogios e muito estranhamento. Estranhamento causado pela dificuldade em situar a prosa imbricada e soturna de Rawet dentro dos parâmetros de uma escrita brasileira, identificada desde o nosso primeiro modernismo de 22, pelos traços solares da espontaneidade e da coloquialidade, num projeto de afirmação nacional centrado na recusa da dicção empolada, demasiado séria e profunda, produzida na matriz europeia.

\footnotetext{
${ }^{3} \mathrm{O}$ crítico René de Costa dedicou um capítulo de seu livro sobre Borges às formas empregadas pelo autor para divertir- se com o leitor. Ver René de Costa,. Humor in Borges. Detroit: Wayne University Press, 2000. pp. 49-55. Estas páginas abordam a função do humor no conto "Pierre Menard, autor de Quixote".

${ }^{4}$ Jacó Guinsburg. "Os imigrantes de Samuel Rawet". In: Paratodos (revista), no 30, Rio-São Paulo: $1^{\text {a }}$ quinzena de agosto de 1957.
}

Thomas Mann, Kafka, Beckett, Joyce, Artaud, são os nomes recorrentes em que a crítica brasileira se apoia, quando lê Samuel Rawet. Se o escritor envereda pelas raias do absurdo, Kafka e Beckett comparecem para dar sustentação à analise comparativa. Se os críticos estudam a confluência dos tempos na obra de Rawet, é a vez de citar Proust como fonte de influência. $\mathrm{O}$ mergulho das personagens rawetianas na "infinitude do mundo interior" é compreendido à luz de Joyce e Thomas Mann, enquanto o ritmo desenfreado de seus textos, reminescente da prosa psicótica de Artaud 5 . A Rawet, este "ilustre escritor estrangeiro" ", como foi chamado, não se ofereceu a segurança de uma genealogia brasileira. Sua filiação permaneceu atrelada, aos olhos da crítica, a um certo "alhures," a uma geografia e tempo para além das fronteiras nacionais. As poucas tentativas de dar a Rawet uma cara brasileira soam forçadas, caricatas até, como nos mostra esta resenha publicada em 1956 no Diário de Notícias, por ocasião do lançamento de "Contos do Imigrante," o livro de estreia do autor e seu trabalho mais acessível:

Chegar e partir ficaram impressos na sensibilidade do menino que se fez homem e é hoje tão brasileiro (eu o conheço bem) como qualquer um de nós: toca samba em caixa de fósforos, fala na nossa gíria, dança as nossas músicas e canta - desafinadamente, é certo principalmente em noites de lua, canções brasileiras que falam de nosso céu, estrelas e mulatas... O menino de ontem era polonês, o homem de hoje é brasileiro ${ }^{7}$.

A resenhista tenta resolver certo desconforto com relação à biografia imigrante de Rawet pelo estabelecimento de uma linha divisória absolutamente rigorosa entre o menino de ontem e o homem de hoje. Nenhum vestígio de estrangeiridade penetra a fôrma do brasileiro essencial. A ansiedade em relação ao passado polonês de Rawet fica evidente tanto

\footnotetext{
5 A alusão a escritores estrangeiros como estratégia para avaliar a obra de Rawet está presente, entre outros textos, em Assis Brasil, "As Viagens de Rawet", s/d; Gilda Salem Szklo, "A Experiência do trágico: recordando Rawet", Suplemento Literário 950,15 de dezembro de 1984; Hélio Pólvora, A Força da Ficção. Rio de Janeiro: Vozes, 1971; Dando Gomes, "Na toca de Samuel Rawet, o solitário caminhante do mundo", Suplemento Literário, 5 de março de 1977; Maria Lucia Verdi, "Obsessões temáticas: uma leitura da obra de Samuel Rawet'“, diss., Universidade de Brasília, 1989.

${ }^{6}$ Arthur Engrácio. "O contista Samuel Rawet”, Jornal Cultura. Nov. 1970.

${ }^{7}$ Eneida. "Contos do Imigrante." In: Diário de Notícias (jornal). Rio de Janeiro: 30 de março de 1956.
} 
pelo exagero estereotipado com que a jornalista procura vender a imagem de um escritor genuinamente brasileiro, quanto pelo gesto de emprestar a sua própria autoridade enquanto brasileira nata (quando enfatiza "Eu o conheço bem"), como estratégia para dissipar suspeitas e dar o aval de boa conduta a este escritor de passaporte duvidoso.

Não é de se surpreender que, na sequência desta mesma resenha, o tom ufanista da caixinha de fósforos não se sustente, frente às dificuldades que a linguagem de Rawet impõe ao leitor. A resenhista faz esta ressalva: "Creio que Rawet esteja tentando contar de maneira diferente, esquecido de que o bom mesmo é contar de maneira simples e comum ${ }^{8}$.

Esta polarização de categorias e critérios, que alinha o "difícil," ao estrangeiro e o "descomplicado" ao brasileiro se incorpora à prosa de Rawet de forma dilacerada. Oscilações bruscas de registro, por vezes no interior de um mesmo parágrafo, forçam uma coexistência improvável entre a agressividade abrupta do palavrão e as sutilezas desdobráveis da prosa reflexiva. Eu cito um trecho de Rawet, do livro Eu-Tu-Ele:

Basta nascer com uma cabeça, tronco, membros, um caralho ou uma boceta entre as pernas para ser homem ou mulher, basta? ... Ou é preciso renascer, filtrado pela dor, para compreender que o máximo a fazer é formular a pergunta, sem tentar obter solução para o problema, se problema existe. Formular a pergunta, simplesmente e passar a vida colhendo de si mesmo fragmentos de respostas...

O gesto de comprimir, em uma única formulação, modos tão disparatados de dizer não vai sem certa dose de violência, deixando entrever as tensões e conflitos de uma identidade hifenada de judeubrasileiro, que se traduz como linguagem partida. Entre a palavra chula e a palavra filosófica, não há mediação, só atrito e faísca. Não se vislumbra a via do diálogo. O hífen marca antes um abismo entre duas figuras, duas condutas, duas gramáticas que se tomam por irreconciliáveis. De um lado, Rawet, o judeu imigrante, educado no cheder, afeito aos livros e a indagação intelectual, ávido leitor e escritor sofisticado. De outro, Rawet, o carioca suburbano, educado na pedagogia das ruas, boêmio, malandro e desbocado, para quem o palavrão é sinônimo de "prosa saborosa,

\footnotetext{
${ }^{8}$ Idem.

${ }^{9}$ Samuel Rawet. Eu-Tu-Ele. Rio de Janeiro: Livraria José Olympio, 1971. pp. 45-46.
}

brasileira"10. O embate entre estas duas polaridades se trava em linguagem e é feroz. Reminiscências de infância, ligadas ao judaísmo aprendido no cheder na Polônia assumem ares de afetação exagerada, que marcam, sarcasticamente, com um sinal de menos, a herança livresca do passado, da qual busca se desvincular. Esta passagem que eu cito está no ensaio autobiográfico "Devaneios de um solitário aprendiz da ironia," publicado em xerox em 1970, com dinheiro do próprio bolso, pela "puta-que-o-pariu" editora: "Ah, as neves da minha infância, ah, as doçuras das varadas que levei porque chutei uma bola na rua. Foram contar ao velho barbudo (já então havia delatores) e o homem espumou na sala do prédio da sinagoga ${ }^{11}$."

A rivalidade que se estabelece entre o espaço disciplinar, opressivo do cheder e o espaço da insubmissão, da bola chutada na rua, provoca um efeito de montanha russa na leitura dos textos de Rawet, sempre imprevisíveis na alternância de rompantes e silêncios, de grosserias e sutilezas filosóficas que beiram o hermético ${ }^{12}$. Esta estética irregular, creio eu, revela muito alem da biografia conturbada de um escritor que conheceu cedo a doença e os processos de desagregação mental, que informam algumas de suas declarações violentas de antijudaísmo e auto-ódio. A virulência com que Rawet busca desassociar sua imagem da cultura letrada e do povo do livro revela também as enormes pressões e expectativas de todo um contexto literário nacional, afinado com a palavra prosaica como signo de brasilidade. Entoando este coro, Samuel Rawet confirma:

A América Latina está deixando de se embasbacar com uma erudição boba, europeia. Se tem uma coisa que detesto é a erudição. Faço exceção apenas para um escritor argentino que realmente é uma

\footnotetext{
${ }^{10}$ Samuel Rawet. "Devaneios de um solitário aprendiz da ironia" (1970). Publicação em xerox, edição do autor. p. 16. Agradeço à Clara Apelbaum, irmã de Samuel Rawet, o acesso a este e outros textos inéditos do autor.

${ }^{11}$ Idem, p. 10.

12 Quanto à alternância de registros na prosa de Rawet, há um trecho do conto "Aprendizado" que descreve magistralmente o processo, através da fala de um personagem, narrada em discurso indireto livre: "Também ele soubera apoderar-se desta arte, mais artifício, toda feita de sutilezas e grosserias, de expectativa e oportunidade, de insolência e submissão, de silêncios e rompantes, de anulação e prepotência. Conhecia a palavra exata para o momento preciso, a frase picante ou obscena no ambiente adequado, o tom humilde para o momento preciso, a frase picante ou obscena no ambiente adequado, o tom humilde
diante do superior útil, o grosseiro diante do inferior, o arrogante quando o poderoso em nada o podia prejudicar.- In: Diálogo. Rio de Janeiro: GRD, 1963. pp. 55
} 
figura admirável e que consegue, com erudição, fazer criação. É o Jorge Luiz Borges ${ }^{13}$.

O trunfo de Borges é o impasse de Rawet. Para quem apostou todas as suas fichas no manejo da língua portuguesa e na possibilidade incerta de nela criar raízes, fazer literatura é atividade de alto risco. Em jogo, questões vitais de identidade e pertença. Quando Rawet copia Ines de la Cruz, portanto, não adentra o universo borgiano dos jogos de linguagem, dos espelhos e miragens. As perguntas que a literatura de Rawet levanta não são em última instância sobre a literatura em si. Debatendo-se entre o cheder e a rua, a literatura de Rawet carrega um sentido de urgência, quando vai de encontro à vida, com seus chamamentos e exigências, aos quais o escritor jamais deixou de emprestar sua voz contundente. E é sobretudo quando perde a medida e a compostura, que chegamos mais perto do vigor desconcertante de uma obra, já há mais de duas décadas sem publicação em português, e que merece encontrar uma nova geração de leitores. Quem dá o primeiro lance?

\footnotetext{
${ }^{13}$ Samuel Rawet. Entrevista dada a Ronaldo Conde. “A necessidade de escrever contos”. In: Correio da Manhã (jornal). 7 de dezembro de 1971.
}

\section{Rui Barbosa e o processo do Capitão Dreyfus}

Sarah Lerner Sadcovitz ${ }^{1}$

Trabalho cuja breve exposição iremos fazer inseriu-se no Programa de Pós-Graduação em História da Universidade do Estado do Rio de Janeiro, dentro da linha de pesquisa 'Estado e Sociedade'.

O interesse pelo tema surgiu por ocasião do centenário do Caso Dreyfus, quando foram publicados, no Brasil e, principalmente, na França, inúmeros livros e artigos em jornais e revistas. Sobre este acontecimento tão marcante da história contemporânea do Ocidente, muitos historiadores e pensadores se detiveram, refletindo sobre seu papel na França e na Europa, no final do século XIX, e sobre seus desdobramentos no século XX. Entre eles, destacamos a filósofa alemã Hannah Arendt e os historiadores franceses Pierre Nora e Jean Denis Bredin.

Hannah Arendt, na sua obra clássica Origens de totalitarismo: I. o antissemitismo, instrumento de poder, dedica o quarto capítulo ao Processo Dreyfus, que considera como uma espécie de ensaio geral para o espetáculo genocida do nosso próprio tempo, uma antevisão da barbárie nazista do século XX. Pierre Nora, no livro História: novos problemas, o considera talvez como o primeiro acontecimento moderno na história da França: acontecimento moderno, para o autor, é aquele que se torna histórico por ser conhecido, seja através da imprensa, do rádio, da televisão ou de qualquer meio de comunicação de massa, que são a própria condição da sua existência. $\mathrm{O}$ historiador julga que determinados acontecimentos têm afinidades tão intensas com certos meios de comunicação que lhe parecem inseparáveis. E é assim que ele vê o Caso Dreyfus.

Já Jean-Denis Bredin, no livro $O$ caso Dreyfus, destaca as suas especificidades, que fizeram com que se tornasse um marco na história contemporânea. O Caso Dreyfus foi o acontecimento fundador do poder da imprensa que, pela primeira vez, exercia uma forte influência sobre a vida

${ }^{1}$ Historiadora. 
pública da França. Os jornalistas que nele se envolveram eram frequentemente escritores ou homens públicos que encontravam nos diários e gazetas o melhor veículo para a defesa de suas ideias: o grande fórum de debates não estava no Parlamento francês, mas, sim, na imprensa. Promoveu também, pela primeira vez, o engajamento coletivo dos intelectuais na vida da cidade e a sua entrada no cenário político francês - a partir de então, passaram a constituir um grupo de influência e de pressão que se transformou em uma das constantes da vida política francesa.

Outro aspecto que Bredin aborda é que o "Caso" serviu à ordem republicana e reforçou a democracia parlamentar, em oposição às forças do Exército e da Igreja, que mantinham a esperança de uma volta à França tradicional. Seria, portanto, a morte do sonho monárquico, o fim da nostalgia do retorno ao Antigo Regime.

Porém, "Laffaire", como ficou conhecido, revelou também a submissão do poder político ao poder da imprensa e, mais ainda, a dupla face da imprensa: de um lado, veículo contra o arbítrio e contra injustiça, e, do outro, veículo de calúnia e fanatismo, instrumento dócil para aqueles que a fazem e para aqueles a quem se destina.

As notícias da traição, do julgamento e da cerimônia de degradação militar do Capitão Dreyfus chegaram também ao Brasil que, naquela ocasião, viva aos conflitos relativos à implantação da República. O Jornal do Commércio, do Rio de Janeiro, um diário com posição de destaque no mais importante centro político e jornalístico do país, publicou artigos enviados de Paris por seus correspondentes, relatando os acontecimentos que então convulsionavam a França.

$\mathrm{Na}$ mesma ocasião, Rui Barbosa, que se encontrava exilado em Londres, para onde fora a fim de abrigar-se das arbitrariedades praticadas pelo Marechal Floriano Peixoto, convidado a colaborar com aquele periódico, deixou-se seduzir e fascinar por um assunto que lhe fez renascer o desejo de lutar pela justiça: o processo do oficial judeu Alfred Dreyfus, acusado de trair sua pátria, a França.

Impressionado com o que lera na imprensa inglesa e com a crueldade da cerimônia da degradação militar, relatada nos jornais de 7 de janeiro de 1895, Rui intuiu que algo de errado havia em um processo feito a portas fechadas, sem provas e sem que o acusado tivesse o direito de defesa.
Decidiu, então, escrever para o público leitor do Jornal do Commércio, a primeira das "Cartas de Inglaterra", na qual defendia, contra a opinião geral da França, o infeliz acusado.

Este artigo tornou-se um marco histórico e sobre ele e seu autor algumas obras foram escritas. Homero Senna, no livro Uma voz contra a injustiça: Rui Barbosa e o Caso Dreyfus, aponta a primazia de Rui como defensor do grande injustiçado, observando que o próprio Dreyfus, tomando conhecimento do texto de Rui, o considerava o seu primeiro advogado. Lúcia Lippi de Oliveira, por sua vez, em A questão nacional na Primeira República, considera como a tese principal do artigo de Rui: a forma inquisitorial que o processo ganhou na França seria impossível de acontecer na Inglaterra do seu tempo, onde a justiça estava acima das conveniências do governo, das crises políticas e do furor das tormentas populares.

Mário de Lima Barbosa, no livro Rui Barbosa na política e na história, ressalta que, no notável escrito de Rui, estava o primeiro grito da justiça defendendo o oficial, sendo, por isto, traduzido para o francês e publicado sob o título - Le Premier Plaidoyer pour Dreyfus. Paulo Amora, em Roteiro de $R u i$, acrescenta o combate que Rui trava, no texto, ao militarismo, e Rolando Monteiro, na obra Ruy e o exílio, comenta que a figura do inocente assemelhava-se a de Rui, exilado "sem culpa". As cartas vinham da Inglaterra, mas o que retratavam eram, direta ou indiretamente, as ocorrências e as preocupações presentes sobre o Brasil. Lúcia Miguel Pereira, no prefácio de Cartas de Inglaterra, afirma que o propósito do seu autor era o exame da República brasileira em confronto com a monarquia inglesa.

Já Raimundo Magalhães_Júnior, na contribuição Rui, o Homem e o Mito, provocou não só uma polêmica ao negar o papel de Rui Barbosa como o primeiro defensor de Dreyfus - artigos em jornais revistas, debates, como também a publicação de livros refutando suas ideias: Rui e a Questão Dreyfus: refutação a Raimundo Magalhães Júnior, de José Soares de Mello e Rui, o mito e o mico, de Osvaldo Orico.

Finalmente, Jean Hauser, em "Ruy Barbosa et L’Affaire Dreyfus”, observou que Rui Barbosa, no exílio, provavelmente experimentava, com intensidade, os sentimentos de Dreyfus, vítima, como ele, um, da injustiça dos homens, o outro, do seu amor pela verdade. 
No entanto, os textos pesquisados relativos aos primeiros anos da República brasileira, apontando para a arbitrariedade, a violência e a perseguição que então imperavam e que terminaram por atingir Rui, e, principalmente, as cartas que do asilo, na Legação do Chile, e do exílio enviou à sua esposa, que podem ser lidas em Cartas à noiva, e ao seu primo e amigo Antônio D'Araújo Ferreira Jacobina, encontradas em Mocidade e exílio, cartas que desnudavam seus sentimentos e nas quais se confessava infeliz, solitário, caluniado e, principalmente, injustiçado, levaram-nos a propor uma releitura do histórico texto.

Procurando no texto - documento os rastros do processo que o produziu e a marca daquele que o enunciou, tentando ir além da evidência da sua significação imediata, pretendeu-se demonstrar, no trabalho, que, ao protestar contra a injustiça sofrida pelo Capitão Dreyfus, evocava também Rui Barbosa sua dolorosa situação pessoal: pela voz do oficial judeu francês, fazia ouvir seu clamor contra a injustiça de que igualmente se julgava vítima. Rui escreveu sobre Dreyfus não só como um jornalista indignado lutando pela verdade, mas, acima de tudo, como um inocente identificando-se com outro inocente, pois ambos foram condenados sem provas e sofriam as agruras do exílio e do abandono sem merecê-las. O Caso Dreyfus transformou-se em um caso emblemático, através do qual Rui Barbosa apresentou a sua própria defesa. Alfred Dreyfus e a França são vistos como a metáfora de Rui Barbosa e do Brasil daqueles dias.

Roger Chartier, no livro A História cultural, entre práticas $e$ representações, concebe o texto como um espaço aberto a múltiplas leituras, como o produto não só de uma escrita, mas também de uma leitura, uma construção do seu leitor, que nele pode perceber algo que foge à intenção do autor. Desta forma, Chartier anula o clássico corte entre leitura e escrita e afirma que a leitura de um texto pode escapar à passividade que frequentemente lhe é atribuída: ler, olhar ou escutar são uma série de atitudes intelectuais que, longe de submeterem o consumidor a toda poderosa mensagem ideológica e ou estética que supostamente o deve modelar, permitem, na verdade, a reapropriação, o desvio, a desconfiança ou a resistência.

Vistos desta maneira, os textos foram tratados utilizando-se a proposta metodológica sugerida pelo Prof. Dr. Orlando de Barros, durante o curso Semiologia, Linguística e História, por ele ministrado no Mestrado em História Política da UERJ, em 1998, e que consiste em desvendar um texto - problema por meio de técnicas de análise e conhecimentos tomados de empréstimo à Linguística e à Semiologia. Ainda que o historiador não lance mão dos métodos linguísticos, ele fará sempre alguns empréstimos conceitos, perguntas, referências.

A obra de Raoul Girardet Mitos e mitologias políticas, inspirada em Gaston Bachelard e Claude Lévi-Strauss, forneceu o arcabouço teórico para a análise que se pretendeu fazer, pois foi possível perceber, tanto no contexto do Brasil quanto no da França, a construção do que o historiador chama de mitos políticos, mais precisamente o mito da Conspiração, ao qual vem associado o mito do Salvador.

Ao abordar a questão da pluralidade do termo mito, Girardet destaca três concepções básicas: a dos antropólogos e historiadores do sagrado, entre os quais Mircea Eliade tem uma posição de destaque, a dos seguidores de Roland Barthes e a dos leitores de Georges Sorel.

Os antropólogos e os historiadores do sagrado consideram o mito como uma narrativa que se refere ao passado, mas que conserva, no presente, um valor eminentemente explicativo, uma vez que fornece um certo número de chaves para a sua compreensão. Para Roland Barthes e seus seguidores, no entanto, a noção de mito confunde-se com a de mistificação, uma vez que ele altera os dados da observação experimental e contradiz as regras do raciocínio lógico. Finalmente, os leitores de Georges Sorel (que, embora antissemita, foi um "dreyfusard") veem o mito como apelo ao movimento, incitação à ação, considerando-o um estimulador de energias de potência excepcional.

Para Girardet, o mito político deve ser visto através da tripla dimensão por meio da qual ele se estrutura e se afirma: é fabulação, deformação ou interpretação objetivamente recusável do real, exerce uma função explicativa que possibilita uma certa compreensão do presente, que se mostra caótico, e tem um papel altamente mobilizador.

Tomando de empréstimo de Gilbert Durant o conceito de constelações mitológicas, isto é, conjuntos de construções míticas sob o domínio de um mesmo tema, reunidas em torno de um núcleo central, e privilegiando o caso francês nos limites cronológicos dos dois últimos séculos, o historiador examina, na sua obra, quatro grandes conjuntos 
mitológicos - a Conspiração, a Idade de Ouro, o Salvador e a Unidade. Para o presente trabalho, o que nos interessa é o mito da Conspiração, ao qual se associa o mito do Salvador.

Os homens da Conspiração ou do Complô são homens que constituem, no interior de toda comunidade consciente de sua coerência, um corpo estranho que só se submete às suas próprias leis - eles são o Estrangeiro, o "partido do estrangeiro", um perigo permanente para a segurança e a independência da pátria. Representam também as trevas, as forças do mal, o Demônio.

A denúncia de um Complô maléfico é utilizada pelo poder estabelecido para livrar-se de seus suspeitos ou de seus opositores e legitimar os expurgos e as exclusões, bem como para camuflar suas próprias falhas e fracassos. Esta denúncia, segundo Girardet, jamais deixa de se inscrever em um clima psicológico e social de incerteza, de temor, de angústia, de ameaça, de forte tensão social, enfim.

A crença na existência de um Complô demoníaco leva ao apelo ao Salvador, aquele que é o restaurador da ordem, o conquistador de uma nova grandeza coletiva, o Herói que canaliza todos os fervores de esperança de determinados grupos. Em torno dele, na submissão, na devoção e no entusiasmo, uma vida coletiva se reestrutura.

O que acontecia na França, no final do ano de 1894, quando Rui Barbosa estava exilado na Inglaterra? $\mathrm{O}$ que acontecera anteriormente no Brasil, para que Rui Barbosa estivesse, nesta ocasião, exilado na Inglaterra?

Pairava sobre a França, a ameaça de uma guerra contra a Alemanha. Vacuidade, inquietação, angústia, temor, incerteza e... traição! Denunciavase um complô judaico aliado a uma potência estrangeira: os judeus conspiravam para arruinar a França e o ouro alemão aliciava cúmplices e espiões contra a Pátria. Um ódio espalhava-se por Paris, voltado para o principal inimigo estrangeiro, o alemão, e para os judeus, os mais estrangeiros entre os estrangeiros. As Forças do Mal.

Multidões enfurecidas, gritando: Morte! Morte aos judeus!

Antigermanismo. A França para os franceses!

Porém a direita francesa estava alerta e vigilante. Dela faziam parte os verdadeiros patriotas, que não mediam sacrifícios para defender a Pátria.
Quem não pensasse como ela, estaria definitivamente no campo oposto. A direita e o Exército, o Exército que se confundia com a Pátria, o Exército com a sua missão purificadora, o Exército, o Salvador. As Forças do Bem.

Pairava, sobre o Brasil, a ameaça da derrubada da República. Vacuidade, inquietação, angústia, temor, incerteza e... a Revolta da Armada! Denunciava-se um complô de monarquistas e lusos, os inimigos primordiais, a favor da Restauração. Um ódio espalhava-se pelo Rio de Janeiro, nos primeiros anos da República, voltado para o principal inimigo estrangeiro, o português. Os portugueses e os monarquistas. As Forças do Mal.

Multidões enfurecidas, gritando: Mata galego!

Lusofobia. O Brasil para os brasileiros!

Porém os jacobinos eram as sentinelas vigilantes da República, os verdadeiros patriotas, que não mediam sacrifícios para defendê-la. Quem não pensasse como eles, estaria, definitivamente, no campo oposto. Os jacobinos e o Exército, o Exército que era a República. Seu herói, Floriano Peixoto, O Salvador, purificaria, com a espada, o sangue do corpo social corrompido. As Forças do Bem.

Mito da Conspiração maléfica, nacionalismo exacerbado, xenofobia, o Exército Salvador.

O que nos possibilitou cruzar dois homens - Rui Barbosa e Alfred Dreyfus, atingidos, um, o construtor da República brasileira, por um violento e injusto acidente da sorte, o outro, um devotado oficial da artilharia francesa, por um trágico erro que o impediu de seguir o seu caminho? Um texto, uma carta escrita do exílio e publicada em um jornal do Rio de Janeiro. Nela, o jornalista e advogado brasileiro defendia o militar francês, que considerava injustamente condenado.

Porém, teria sido só o texto? Não seria possível estabelecer outros pontos de encontro? Em que aspectos estas duas vidas correram paralelas possibilitando, assim, estabelecer uma identificação entre elas, transitar de uma para outra e concluir que Alfred Dreyfus são a metáfora de Rui Barbosa e do Brasil daqueles dias?

Dreyfus era um soldado inteiramente devotado ao Exército francês e foi ele condenado, degradado, deportado. Rui foi o redator das primeiras leis do regime republicano, fez parte do Conselho de Ministros, foi o $1^{\circ}$ 
Vice - Presidente da República e foi por ela humilhado, violentamente afastado de tudo que lhe era fundamental para a existência, exilado. Considerados traidores, foram vistos como homens do Complô, homens das sombras, demônios, gênios do mal que espalhavam o veneno e a infecção. Eram vítimas do ódio e do desprezo. Representavam as Trevas.

Porém ambos se consideravam inocentes dos crimes pelos quais eram acusados e proclamavam veemente esta inocência. Seu passado era sem mácula, haviam andado sempre no caminho do dever e da honra. Foram injustiçados, condenados sem provas, passavam por privações e sofrimentos homéricos. Deus os abandonara. Até quando? No entanto, a veneração pela Pátria os faria resistir. Não tinham outro sentimento, outro desejo, outra inspiração a não ser servi-la.

Vendo o texto como um espaço aberto a múltiplas leituras, ousamos fazer a nossa. Interrogamos o texto, procuramos retirar os véus que o encobriam, buscamos o mundo que lhe era exterior e ouvimos os seus ecos. Lemos as cartas que Rui escreveu para sua esposa e para seu primo, nas quais desnudava a sua alma. Desta forma, foi possível ouvir, na histórica primeira das "Cartas de Inglaterra", para além da defesa do oficial judeu francês, a sua voz condenando o governo ditatorial brasileiro e seus seguidores, e, mais do que isto, protestando veemente contra as injustiças de que se considerava vítima e proclamando sua inocência e seu martírio. $\mathrm{O}$ Capitão Dreyfus falava por Rui, ambos eram a mesma voz que clamava:

Por minha mulher e meus filhos, juro que sou inocente.

Crede-me, senhores, sou um mártir!

Durante muito tempo, os papéis históricos de Rui Barbosa, ao escrever a primeira defesa do grande injustiçado, e do Jornal do Commércio, ao publicá-la, ficaram ignorados. Não só no estrangeiro, como no próprio Brasil. Coube à História tirá-los do esquecimento. Mas isto não basta. É preciso refletir, hoje mais do nunca, sobre as questões que foram levantadas pelo jornalista na sua Carta do Exílio. Autoridades, cidadãos e imprensa continuam a condenar por impressões, a antecipar sentenças, a sentenciar sem provas, a confundir inocentes e culpados. Em nome dos interesses superiores da pátria, continua-se a violar, frequentemente, os direitos do homem e do cidadão. Não só no Brasil, como no estrangeiro.
Mais de cem anos depois do Caso Dreyfus. Mais de cem anos depois do exílio de Rui Barbosa.

\section{Referências Bibliográficas:}

ARENDT, Hannah. Origens de totalitarismo: I. O antissemitismo instrumento de poder. Rio de Janeiro: Documentário, 1975.

LE GOFF, Jacques, NORA, Pierre. História: novos problemas. Rio de Janeiro: Francisco Alves, 1988.

BREDIN, Jean-Denis. O caso Dreyfus. São Paulo: Scritta, 1995.

SENNA, Homero. Uma voz contra a injustiça: Rui Barbosa e o Caso Dreyfus. Rio de Janeiro: Fundação Casa de Rui Barbosa; 1987.

OLIVEIRA, Lúcia Lippi. A questão nacional na $1^{\circ}$ República. São Paulo: Brasiliense, 1990.

BARBOSA, Mário de Lima. Rui Barbosa na política e na história 18491914. Rio de Janeiro: Briqiet, 1916.

AMORA, Paulo. Roteiro de Rui. Rio de Janeiro: Casa de Rui Barbosa, 1957.

MONTEIRO, Rolando. Ruy ia exílio. Brasília: Senado Federal, 1976.

BARBOSA, Rui. "Cartas de Inglaterra". In: . Obras completas de Rui Barbosa, volume XXV, Tomo, 1898. Rio de Janeiro: Ministério de Educação e Saúde/Casa de Rui Barbosa, 1946.

MAGALHÃES, Júnior, Raimundo. Rui, o homem e o mito. Rio de Janeiro: Civilização Brasileira, 1964.

MELLO, José Soares de. Rui e a Questão Dreyfus. $1^{\circ}$ volume. São Paulo: Revista dos Tribunais, 1968.

ORICO, Osvaldo. Rui, o mito e o mico. Rio de Janeiro: Record, 1965.

HAUSER, Jean. "Ruy Barbosa et l'Affaire Dreyfus." Revue Rencontre Chretiens et juifs, Paris (7) Septembre, 1968, p. 8.

BARBOSA, Rui. Cartas à noiva. Prefácio de Maria José Queiroz. Rio de Janeiro: Fundação Casa de Rui Barbosa/Civilização Brasileira, 1982. 
Mocidade e exílio. São Paulo: Companhia Editora Nacional, 1934, $2^{a}$ edição, 1940.

CHARTIER, Roger. A história cultural, entre práticas e representações. Rio de Janeiro - Lisboa: Difel/Bertrand, 1990. GIRARDET, Raoul. Mitos e mitologias políticas. São Paulo: Companhia das Letras, 1987.
O padre António Vieira (1608-1697) e os judeus: as referências a São Paulo

Florence Lévi ${ }^{1}$

Como se sabe, contra o padre António Vieira (1608-1697), o célebre jesuíta e missionário, foi intentado um processo da parte do Tribunal do Santo Ofício da Inquisição (entre 1663 e 1667). Vieira era acusado de judaísmo.

Não me aplicarei a mostrar os signos do seu judaísmo - o que já foi feito de maneira brilhante pela Professora Anita Novinsky. Minha comunicação está focalizada sobre a importância da figura de São Paulo para o Jesuíta, nomeadamente no que respeita às suas ideias sobre a conversão universal, condição necessária ao advento do Quinto Império, Reino de Cristo sobre a terra, que tanto esperou durante a sua vida inteira o padre A. Vieira.

Vieira nunca afirma uma opinião ou uma certeza sem se referir às “autoridades”, a principal das quais é a Bíblia, as Escrituras Sagradas (tanto o Velho Testamento como o Novo). Ora, lendo e relendo os escritos de Vieira, reparei quanto São Paulo o influenciou, tanto quanto São Francisco Xavier - a quem, aliás, dedica sermões panegíricos. Embora não dedique sermões panegíricos a S. Paulo, manifesta, em vários lugares da sua obra, sua admiração pelo "apóstolo". Este é qualificado de "o grande apóstolo", "o grande Paulo"; " "aquele grande homem, por antonomásia chamado o Apóstolo" ( $S$. da Epifánia $)^{4}$,. "o maior de todos os pregadores" $(S$. da Sexagésima $)^{5}$; "o maior pregador do mundo" ( $S$. da $2^{a}$ Dominga da

\footnotetext{
${ }^{1}$ Doutora em Literatura Universidade de Paris III

${ }^{2}$ Clavis Prophetarum, Livro III, Edição crítica, fixação do texto, tradução, notas e glossário de Arnaldo do Espírito Santo, Biblioteca Nacional, Lisboa, 2000, p. 97.

${ }^{3}$ História do Futuro, introdução, actualização do texto e notas por Maria Lenor Carvalhão Buescu, Imprensa Nacional-Casa da Moeda, 2a ed., Lisboa, 1993, p. 165.

${ }^{4}$ in Sermões, Obras completas do padre António Vieira, Lello \& Irmão - editores, Porto, 1993, vol. 1, p. 445.

${ }^{5}$ Ibid., p. 105.
} 
Quaresma, 1651) ${ }^{6}$; "famosíssimo orador" (S. de Sta Catarina) $)^{7}$;"o grande mestre das gentes" (S. da Quinta Dominga da Quaresma, 1651) .

Com efeito, São Paulo foi "o vaso de eleição para a conversão universal, assim de Gentios como de Judeus, e primeiro modelo e exemplar dos ministros e obreiros do Evangelho ". Compreendemos então porque Vieira quase se identifica com São Paulo

\section{A conversão universal}

Retomando o que escreve S. Paulo, Vieira lembra que todos descendem de Abraão e que "do delito dos Judeus, diz S. Paulo, se seguiu a salvação de todas as gentes. E se do seu delito e infidelidade se seguiram as riquezas do Mundo, que será de sua fé, e da sua obediência a Cristo? ${ }^{10 ،}$

Vieira refere-se aqui, e em vários outros trechos da sua obra (Defesa, Clavis Prophetarum, Apologia das Coisas Profetizadas, História do Futuro), ao capítulo 11 da Epístola aos Romanos que corresponde particularmente ao seu pensamento e às suas convicções profundas.

Se os Judeus caíram, esta queda não é definitiva, antecipa um erguer e uma ressurreição. Caíram na medida em que não creram no Evangelho. $\mathrm{O}$ qual estava destinado em primeiro lugar aos Judeus, aos Gentios em segundo lugar. Com efeito, nos Atos dos Apóstolos (13, 46-47) está escrito:

Vobis opportebat primum loqui verbum Dei; sed quoniam repellitis illud, et indignos vos iudicatis aeternae vitae: ecce convertimur ad gentes, sic enim praecepit nobis Dominas.

Assim como o predestinado quando está em pecado está caído da graça sanctificante, mas não está caído da graça da eleição, e é certo que se há de converter e salvar, assim o Povo judaico, no presente pecado, obstinação e cegueira em que está, é certo que está fora da graça de Deus e caído da graça sanctificante; mas, ainda que os particulares do dito povo que morrem no tal pecado e cegueira, se

\footnotetext{
${ }^{6}$ Ibid., p. 891.
}

${ }^{7}$ Ibid., vol. 3, p. 1054-1055.

${ }^{8}$ Ibid., vol. 4, p. 151.

${ }^{9}$ Defesa perante o Tribunal do Santo Ofício, Publicações da Universidade de Bahia, Bahia, 1957, T. II, p 157

${ }^{10}$ Ibid., p. 36. condenem, o mesmo povo, que não morre e se tem conservado e conserva, é certo que se há de levantar do pecado, em que está caído, e se há de converter a Cristo, e a sua fé, para que todo se salve, como conclue o mesmo S. Paulo: et sic omnis Israel salvas fiat ${ }^{11}$.

Reparemos nesta citação quantas vezes Vieira usa da palavra "certo": três vezes. Pode- se perguntar donde ele tira esta certeza. É uma certeza fundada nas palavras de S. Paulo, mas também nas profecias do Antigo Testamento, o que não é contraditório, pois o Antigo Testamento prefigura o Novo. (Isto afirma muitas vezes Vieira, e pode-se ver também em inúmeras asserções nas quais ele interpreta o Antigo Testamento em função do Novo). Aliás, como o nota Vieira, o mesmo S. Paulo reivindica sua filiação judaica: "Não reprovou Deus o seu povo, que tanto amou; porque eu, a quem ele depois de sua paixão elegeu por seu apóstolo, sou israelita, descendente de Abraão, da tribo de Benjamim". (Ep. Rom. 11, 1) ${ }^{12}$

A conversão futura dos Judeus, "com que a Igreja há de acabar de aperfeiçoar sua grandeza" "13 é profetizada nas trovas de Bandarra, assim como no Velho Testamento e no Novo. No Velho Testamento, trata-se do Capítulo 4 do Deuteronômio, dos capítulos 11,$11 ; 14,1$ e 59 de Isaías. Aliás, S. Paulo traduz este trecho de Isaías (Cap. 59): "Virá de Sião o libertador e afastará de Jacob a impiedade. E terão de mim esta aliança, quando eu tirar os seus pecados" (Rom. 11, 26-27).

Vieira comenta estas profecias dizendo:

Assim que a conversão do povo Judaico não só está decretada por Deus ab aeterno, e anunciada pelos Profetas, senão prometida também aos antigos Patriarcas por pacto expresso de Deus, o qual assim como lhes prometeu que havia de livrar seus descendentes do cativeiro temporal do Egipto, e metê-los de posse da terra de promissão, assim lhes prometeu igualmente que os havia de livrar do cativeiro e miséria espiritual em que hoje vivem, e passd-los à liberdade de filhos de Deus, unindo-os ao grémio de sua Igreja. E isto

${ }_{11}^{11}$ Ibid., p. 36.

${ }^{12}$ Cit. in Memorial a favor da gente de Nação Hebreia, Sá da Costa, Obras Várias, vol. IV, p. 122.

Apologia das Coisas Profetizados, Organização e Fixação do texto de Adma Fadul Muhana, Cotovia, Lisboa, 1994, p. 107. 
é o que disse em palavras mais escuras Isaías, e declarou expressamente S. Paulo ${ }^{14}$

Outros profetas falaram da conversão futura dos Judeus:

Oséias (3, 4-5):

Depois disto os filhos de Israel voltarão e buscarão o Senhor seu Deus e David, seu rei, e no fim dos tempos olharão com respeitoso temor para o Senhor e para seus bens.

Ezequiel (37, 21-24):

Isto diz o Senhor Deus: "Eis que vou tomar os filhos de Israel do meio das nações, para onde foram, juntá-los-ei de todas as partes e os tornarei a trazer para a sua terra; formarei deles uma só nação na terra, sobre os montes de Israel, e será um só rei que os comande a todos, e nunca mais formarão duas nações, nem se dividirão para o futuro em dois reinos. Não se mancharão mais com os seus ídolos, nem com as suas abominações, nem com todas as suas iniquidades; tirá-los-ei salvos de todos os lugares em que pecaram e os purificarei; serão o meu povo e eu serei o seu Deus. O meu servo David reinará sobre eles, e será um só o pastor de todos eles; observarão as minhas leis, guardarão os meus preceitos e praticá-los-ão"15.

Finalmente, S. Paulo confirma tudo isto na Epístola aos Romanos cujo objetivo era ensinar aos Romanos que não deviam aborrecer aos Judeus, porque "da cegueira, e miséria presente em que viam os Judeus, não deviam tirar jactância, desprezo, nem aborrecimento, senão humildade, temor e compaixão" "16 . Com efeito, S. Paulo pergunta assim: nunquid Deus repulit Populum suum? e responde de maneira categórica: Absit. (em conformidade, aliás, com o Salmo 94, 14: “O Senhor não repelirá o seu povo. Nem abandonará a sua herança.”). Notemos que Vieira comenta essa Epístola aos Romanos da mesma maneira que S. Agostinho, nomeadamente.

\section{O povo judaico / o povo gentílico}

Por outras palavras, Vieira afirma frequentemente que o povo judaico é o povo eleito por Deus, baseando-se sobre o Velho Testamento. Porém,

\footnotetext{
${ }^{14}$ Ibid., p. 109.
${ }^{15}$ Ibid., p. 111.

${ }_{16}^{16}$ Ibid., p. 111.
Ibid. 11.
}

num mesmo movimento, diz que os Judeus recusaram o Evangelho e que terão que o aceitar e converter-se. Assim serão unidos os dois povos até agora distintos: o povo judaico e o povo gentílico. Como outros escritores barrocos, Vieira usa de metáforas emprestadas do teatro: o palco do mundo é representado por duas figuras: o povo judaico e o povo gentílico. Permitome citar um trecho cumprido da Apologia das Coisas Profetizadas porque o estilo de Vieira se revela aí particularmente brilhante:

E assim como vemos nas representações das nossas comédias que aquelas figuras que têm dito o seu papel, e não hão de tornar ao teatro, se despem logo; porém as outras que hão de representar até o fim e conclusão da comédia esperam com os mesmos vestidos e com as mesmas insígnias; assim tem acontecido e se tem visto nesta grande comédia de Deus. Os Romanos, os Cartagineses, os Suevos, os Alanos, os Citas, os Geias, e muitas outras nações de que não há' hoje mais que a memória, e se extinguiram totalmente, são figuras que representaram o seu papel nesta comédia, e despiram o nome e o vestido, porque não hão de tornar mais ao teatro. Porém o Povo Judaico, e o Povo Gentílico, a Sinagoga, e o Gentilismo, que são aquelas figuras principais que se hão de dar as mãos no fim da comédia, necessariamente se hão d.e conservar no mesmo estado, na mesma representação, e na mesma figura, e essa é a razão porque hoje se conservam distintos estes dois Povos, e quando no fim se desatar o enredo, e se descobrir a traça do supremo Autor desta comédia, então pasmaremos todos, e pasmará o mundo à vista da admirável Providência deste segredo, e mistério; e então exclamará com São Paulo no mesmo lugar em que se refere esta maravilha: $\mathrm{O}$ altitudo sapientiae, et scientiae Dei, quam incomprehensibilia sunt iudicia eius, et inuestigabiles uiae eius ${ }^{17}$.

Com a lógica que o padre Vieira costuma praticar, ele afirma que estes dois povos têm que ser distintos para unirem-se depois. O problema consiste em que o povo judaico foi esmagado e em consequência podia-se pensar que tinha perdido as suas características. Mas, pelo contrário, Vieira consagra muitas páginas dos seus escritos a demonstrar que o povo judaico, sendo uma Nação, não pode extinguir-se. Como reparou o Professor Nathan Wachtel na sua aula sobre Vieira, no Collège de France, em 2000, a

${ }^{17}$ Em português: "Ó profundidade das riquezas da sabedoria e da ciência de Deus ! Quão incompreensíveis são os seus juízos e imperscrutáveis os seus caminhos !” (Rom, 11, 33). Apologia das Coisas Profetizadas, p. 157-158. 
argumentação de Vieira, aqui, é quase etnológica e pretende, pelo menos, ser científica. Remeto para vários trechos: Apologia das Coisas Profetizadas, p. 158, Defesa I, p. 317, Defesa II, p. 112. Na verdade, ele empresta o seu raciocínio de Justo Lipsio ${ }^{18}$ :

Até aqui Justo Upsio, o qual como tão erudito e versado em todas as histórias do mundo, tem por uma das maiores maravilhas dele que vivendo a nação Hebreia sem pátria, nem lugar certo, antes envolta e misturada com todas as nações da África, da Ásia, e da Europa, no meio desta mesma união, se conserve tão dividida, e no meio desta confusão tão distinta, que nem em Itália falando Italiano sejam Italianos; nem em Holanda falando Holandês sejam Holandeses \{...), senão que entre todas se conservem sempre distinta e separadamente Judeus, sendo conhecidos não só entre si, senão para com todos por tais ${ }^{19}$.

E tudo isto permite também afirmar, primeiro, a existência das dez tribos perdidas num lugar escondido e incógnito - A Terra Austral, provavelmente -, segundo, que essas tribos perdidas voltarão e serão restituídos à sua Pátria ${ }^{20}$.

Uma das causas de reprovação pelo Tribunal da Inquisição está no fato de Vieira afirmar que a conversão do povo judaico devia ser anterior à do povo gentílico, em vez de dizer, segundo os cânones da Igreja, que devia ser universal. $\mathrm{Na}$ verdade, como sempre se pode reparar no processo de Vieira, os inquisidores são de má fé e simplificam o pensamento do réu, no fim de o culpar de "erro judaico", apesar de Vieira ter matizado o melhor possível as afirmações ou argumentações que lhe são censuradas. Com habilidade, os inquisidores argumentam referindo-se também à S. Paulo que citam: "Porventura Deus só o é dos Judeus? Não o é ele também dos Gentios? Sim, certamente ele o é também dos Gentios" (Rom. 3, 29); "Não há distinção entre judeu e grego" (Rom. 10, 12) ${ }^{21}$.

\footnotetext{
${ }^{18}$ Justo Lipsio foi um humanista flamengo (1547-1606). Aderiu ao luteranismo, mas as opiniões por ele sustentadas no seu De Religione (1590) tornaram-no suspeito aos reformadores, e ele tornou de novo ao catolicismo.

${ }^{19}$ Apologia das Coisas Profetizadas, p. 156-157.

${ }^{20}$ Cf. Florence Lévi, "La prophétie et le pouvoir politico-religieux au XVIIe siècle au Portugal et en Hollande : Vieira et Menasseh ben Israel", in La Prophétie comme arme de guerre dos pouvoirs (XVe-XVIIe siècles), Presses de la Sorbonne Nouvelle, 2000, p. 433-445.

${ }^{21}$ Os Autos do Processo de Vieira na Inquisição, edição, transcrição, glossário e notas de Adma Muhana, Editora UNESP, São Paulo, 1995, p. 295-296.
}

Vieira, respondendo às críticas dos inquisidores, explica, com bastantes pormenores, que, conforme a doutrina de São Paulo, "primeiro havia de procurar, e mandar Cristo, que a lei Evangélica se pregasse ao povo Judaico, e depois ao Gentílico; e que por os Judeus não aceitarem a dita lei, como consta dos Atos dos Apóstolos, não se lembra em que lugar, ficaram entrando no primeiro lugar da conversão os Gentios: e que depois deles entrarão no segundo, e último, os Judeus, como expressamente afirma São Paulo no capítulo 11 na Epístola aos Romanos. 22، Com algumas metáforas, tenta provar isto - metáforas que também não são do gosto dos Inquisidores:

$$
\text { Esaú e Jacob }
$$

Esaú e Jacob representam duas gentes e dois povos, como é escrito na Génese 25. Estes dois povos são o povo judaico e o povo gentílico. Vieira refere-se à S. Paulo para dizer que o segundo, o povo gentílico, menor, "teve tanta graça com Deus que foi escolhido por ele, sendo o outro reprovado, e o venceu e lhe levou o morgado, como Jacob a Esaú."23 No entanto, sabe-se que a aversão de Esaú contra Jacob, acabou ao fim de muitos anos: abraçaram-se. Donde conclui Vieira que "assim virá também tempo em que o Povo Judaico chorando muitas lágrimas de arrependimento, se abrace com o Gentílico em verdadeira união de fé e amor, conhecendo, adorando e servindo, conformemente e sem distinção alguma, a Cristo, e vivendo, como filho maior, na casa do mesmo Pai. ${ }^{24 ،}$

\section{- O filho pródigo}

Com a parábola do filho pródigo, Vieira tenta demonstrar a mesma anterioridade do povo judaico que finalmente será acolhido com festas na Igreja.

22 Ibid., p. 294. Cf. igualmente Apologia..., p. 115: "Por isso Cristo não pregou a nação alguma dos Gentios, senão somente aos Judeus, como ele mesmo disse : non sum missas nisi ad oues, quae perierunt domas Israel" (Eu não fui enviado senão às ovelhas desgarradas da casa de Israel) (Mateus, 15, 24).

${ }^{23}$ Defesa I, p. 313

${ }^{24}$ Ibid., p. 313-314. 


\section{- Raquel e Lia}

Como escreve António Saraiva, a narração de Raquel e Lia é interpretada por Vieira num sentido favorável aos Judeus: "Jacob é Cristo, apaixonado pela bela Raquel, o povo judeu; Labão é o diabo; Lia, indesejada, mas finalmente fecunda, é o povo gentio que se transforme na Igreja, pela sua introdução subreptícia e fraudulenta no leito de Jacob Cristo ${ }^{25}$."

Vieira distingue o povo e a Igreja. Do ponto de vista da Igreja, a Igreja dos Gentios é representada em Raquel, por ser mais moça, e a dos Judeus em Lia, por ser mais velha; "Pois é certo que primeiro foi a Igreja da lei escrita, que a da Graça; e pelo contrário, enquanto povo, o povo hebreu é representado em Raquel mais moça e o povo Gentílico em Lia mais velha, porque nesta consideração também o povo Gentílico é mais antigo, e o Hebreu mais moderno ${ }^{26,}$.

No Processo, Vieira explica que, de um certo ponto de vista, o povo judaico é o mais antigo, mas que de um outro ponto de vista, é o contrário. Ou seja, o povo judaico é o mais antigo quanto à Fé e conhecimento do verdadeiro Deus; o povo judaico é o mais moderno quanto a natureza e nascimento.

\section{A parábola da oliveira}

Para provar a futura conversão dos Judeus, Vieira apoia-se essencialmente em São Paulo. Além das parábolas que acabamos de ver, serve-se abundantemente da parábola da oliveira (Ep. Rom. 11, 16-25). Vamos ver agora como e por que razões isto foi censurado pelo Tribunal da Inquisição.

Encontramos os desenvolvimentos relativos a esta parábola em três lugares: na Apologia das Coisas Profetizadas, na Defesa II e nos Autos do Processo.

Vieira comenta a parábola enunciada por S. Paulo, trecho por trecho.

- "Se as primícias são santas, também a massa, e se a raiz é santa, também os ramos":

\footnotetext{
${ }^{25}$ António Saraiva, História e Utópia. Estudos sobre Vieira, ICALP, Lisboa, 1992, p. 104.

${ }^{26}$ Autos do Processo, p. 284.
}

Para Vieira, "são dois exemplos, um legal, outro natural, com que o Apóstolo demonstra a futura santidade dos convertidos Judeus, ou a possibilidade conatural dela. ${ }^{27}$ “" Isto conforme ao Levítico, 15. Portanto, Vieira comenta assim o exemplo "legal":

As primícias da lei da graça foram os Apóstolos de Cristo, pois se estas primícias foram da mesma nação, do mesmo sangue e da mesma massa de que hoje são os judeus, que muito será que recebendo eles a mesma fé que receberam os Apóstolos, e mais depois de ensinados com tantos castigos, e alumiados com tantos desenganos, e provocados com tantas emulações, venham a ser tão santos como eles foram, ao menos mui parecidos e mui chegados na santidade a eles ${ }^{28}$.

$\mathrm{O}$ segundo exemplo, natural, Et si radix sancta, et rami, quer dizer que as raízes foram os Patriarcas e os Profetas, e os ramos os Apóstolos. S. Paulo, a seguir, compara o povo hebreu de que os Patriarcas foram as raízes à oliveira mansa, frutífera, e o povo gentílico ao aleastro ou zambujeiro, árvore estéril, agreste. Porém, não se devem ensoberbecer os Gentios porque "não sois vós os que sustentais e dais a virtude às raízes, senão as raízes a vós." $\mathrm{E}$, se Deus castigou e não perdoou aos ramos naturais da oliveira, aos enxertados e estranhos pode suceder a mesma desgraça. E podem vir a ser ramos cortados. "E se vós (continua o Apóstolo) que hoje sois ramos unidos podeis vir a ser ramos cortados, e de Cristãos podeis vir a ser hereges, da mesma maneira os Judeus, que hoje são hereges, podem vir a ser Cristãos, e de ramos que hoje são cortados da Igreja, ramos unidos a ela. E de citar S. Paulo: "Pois Deus é poderoso para os enxertar de novo. (Rom. 11, 23) ${ }^{29,}$

\section{Segue-se o trecho que foi criticado pela Inquisição:}

E finalmente (que é o principal intento do Apóstolo) se aqueles em quem era natural a infidelidade, e a fé contra natureza, se fizeram fiéis, e tão fiéis, estes em quem a fé é como natural e que a herdaram hd tantos mil anos de seus avós, por que não serão tão fiéis como eles, e não só tanto, senão muito mais? Quanto magis ${ }^{30}$...

\footnotetext{
${ }^{28}$ Ibid., p. 122-123.

${ }^{29}$ Ibid., p. 125.

${ }^{30}$ Ibid.
}

${ }^{27}$ Apologia das Coisas Profetizadas, p. 122 
Os inquisidores não aguentaram esta argumentação. Repreendem o réu por ter afirmado que a fé, religião e santidade nos Gentios eram não naturais, ou contra Natureza, e nos Judeus, eram próprias, e naturais, como também nos ditos Gentios, o era a Infidelidade, torcendo para isto violentamente o verdadeiro sentido da figura de que ali usa o sagrado Apóstolo, dos ramos do azambujeiro enxertado na oliveira ${ }^{31}$.

O réu responde dizendo que traduziu ao pé da letra as palavras usadas por São Paulo: contra naturam e secundum naturam; o que não quer dizer que ele acha natural a fé nos Judeus, nem natural a infidelidade nos Gentios, mas porque havendo os Judeus herdado a Fé, e Religião dos Patriarcas seus progenitores, destes, como das raízes aos ramos, se lhes comunicava a Fé, não natural, mas como natural, ou conaturalmente, e da mesma maneira aos Gentios se comunicava a Idolatria e Infidelidade de seus progenitores, não por the ser natural ou conforme à natureza, mas por ser mais conforme a ela, que os filhos herdem os vícios dos pais ${ }^{32}$.

Na verdade, Vieira quer chegar, como São Paulo, à revelação de "um segredo ou mistério da Providência divina":

que uma parte de Israel caiu na cegueira até que tenha entrado a plenitude dos Gentios, e assim todo o Israel se salve" (Rom.11, 25$26)^{33}$.

Por outras palavras, Deus quis que os Judeus e os Gentios recebessem a fé não junta, senão alternadamente, de sorte que primeiro fossem fiéis os Judeus e infiéis os Gentios, como sucedeu no tempo da lei escrita, e que depois fossem fiéis os Gentios, e infiéis os Judeus (posto que não todos eles, senão parte) como hoje vemos, e que finalmente depois que todos os Gentios receberem a fé, e entrarem por ela à Igreja, então se converterão também, e se unirão a ela todos os Judeus, para que todos se salvem ${ }^{34}$.

No entanto, subsiste uma contradição: como se pode conciliar a conversão dos Judeus e a sua esperança "material" de serem restituídos à sua Pátria ? Vieira poderia ser chamado "o grande conciliador" (é de reparar que, por seu lado, Menasseh ben Israel escreveu um livro intitulado $\mathrm{O}$ Conciliador). Na Defesa perante o Tribunal do santo Ofício, ele explica que esta esperança é totalmente justificada, dado as inúmeras misérias ("afronta, cativeiro, miséria") dos Judeus ao longo dos tempos, ligadas à dispersão e ao desterro. Se esta esperança pode ser considerada como "ímpia, herética e blasfema" na medida em que os Judeus esperam ser restituídos à sua Pátria "não pela fé e conhecimento do Messias, que já veio, senão pela potência do Messias, que dizem há de vir", é "lícita e louvável" a partir do momento em que os Judeus crerão o que crêem os católicos. Ou seja, quando os Judeus já não forem cegos. Com efeito, o que preexiste a tudo o que acabamos de ver é o pressuposto segundo o qual os Judeus são cegos.

\section{A cegueira dos judeus}

Numerosos são os lugares em que Vieira fala da cegueira dos Judeus, tanto na História do Futuro como na Defesa. Cegueira simbolizada pelo véu de Moisés. Com efeito, no Êxodo (34, 27-35) diz-se que Moisés, depois de ter recebido as Leis, quando falava ao povo de Israel, punha um véu sobre o rosto, porque os filhos de Israel tinham medo do esplendor que irradiava do rosto de Moisés. Mas Vieira não interpreta esse ato desta maneira. Retoma a interpretação de S. Paulo (2 ${ }^{\mathrm{a}}$ Epístola aos Cor. 3) segundo a qual o véu de Moisés simboliza a cegueira dos Judeus, que só terminará com a sua conversão a Cristo:

Usque in hodiernum diem, cum legitur Moisés, velamen positum est super cor eorum; cum autem conversi fuerit ad Dominum, auferetur velamen. Alude ao véu com que Moisés cobria o rosto, porque os Judeus não podiam ver a luz dele, e diz que o mesmo véu se passou ao coração dos Judeus, e que por isso não entendem a Moisés, quando o lêem, mas que o entenderão e o véu se lhe tirará, quando se converterem ao Senhor; Cum autem conversi fuerit ad Dominum, auferetur velamen. Ambas as clausulas vêm a dizer o mesmo, porque uma diz que se há de acabar a cegueira do Povo Judaico, e outra que se há-de converter ${ }^{35}$.

Nos vero omnes, revelata facie, gloriam Domini speculantes, in eamdem imaginem transformamur a claritate in claritatem. Falava o Apóstolo do véu da infidelidade com que os Judeus têm cobertos os

\footnotetext{
${ }^{35}$ Defesa perante o Tribunal do Santo Ofício, T. II, p. 30
} 
olhos para não ver a Cristo, e diz que nós, os Cristãos, que somos os membros de que se compõe a Igreja, temos tirado pela Fé aquele véu e, com os olhos abertos e desempedidos por meio da própria especulação e estudo, imos crescendo de claridade em claridade, não já passando das trevas à luz, senão de uma luz para outra, sempre maior e mais clara, transformando-se por este modo a Igreja na imagem do seu mesmo esposo, Cristo ${ }^{36}$.

Nos Autos do Processo, encontra-se a mesma ideia, mas com uma precisão que permite assegurar a dita conversão dos Judeus, depois deles terem tirado o véu, a saber a "eficácia da divina graça":

(...) porque ainda que no princípio não quiseram receber a Cristo, por não vir ao mundo com potência temporal, a causa principal, e mais alta, foi o castigo de seu pecado, e a cegueira, que lhe estava profetizada, na qual hão de durar obstinadamente enquanto tiverem os olhos cobertos com o véu de Moisés, e sua lei, mas que postquam ablatum fuerit velamen, como diz São Paulo, hão de crer, e receber a Cristo pelos (mesmos) motivos, e razões, por que ao principio não quiseram crer, e receber, convertendo-se então pela eficácia da divina graça o escândalo judaico da Cruz, em motivo da Fé e adoração ${ }^{37}$.

A cegueira dos Judeus é sinônimo de "erro", erro consistindo em crer na vinda de um Messias, em vez de crer em Cristo. Vieira repete isto muitas vezes, explicando que o erro dos Judeus é olhar adiante em vez de olhar para trás:

Para acharem o seu Deus e o seu Rei (que é Cristo Deus e Rei juntamente) hão de buscá-lo os Judeus, tornando para trás: revertentur filii Israel et quarent ${ }^{38}$. E esta é a razão porque o não acharam nem têm achado até agora, porque o buscam para diante, no tempo futuro, sendo que o hão de buscar para trás, no tempo passado ${ }^{39}$.

No entanto, reconhece que os Judeus e os Cristãos esperam ambos um Messias (porque Messias e Cristo, ambos, significam ungido). Aplica-se a enumerar as diferenças entre um e outro, para concluir:

\footnotetext{
${ }^{36}$ História do Futuro, p. 188-189.

${ }^{37}$ Autos do Processo, p. 169.

${ }^{38}$ Oseias

${ }^{39}$ Defesa, T. II, p. 27
}

De maneira que este fingido Messias dos Judeus de nosso tempo é total e essencialmente diverso do verdadeiro Messias em que cremos os Cristãos ${ }^{40}$.

Na História do Futuro (p. 278), a propósito da pedra que derruba a estátua sonhada por Nabucodonosor, pelo contrário, Vieira escreve o seguinte:

Assim o dizem conformemente neste lugar não só todos os Padres e expositores católicos, senão também os hereges e até mesmo Rabinos, os quais acertam em dizer que nesta Pedra está profetizado o Reino do Messias, e erram somente em não crerem que o Messias é Cristo.

\section{A nação hebreia}

Os juízos emitidos por Vieira sobre a Nação Hebreia são muito positivos, como se pode ler no texto intitulado "Memorial a favor da gente de nação hebreia" (Obras Várias, II, Sá da Costa) e atribuído a Vieira:

Que nação, por mais belicosa e celebrada que seja no Mundo, chegou a conseguir as vitórias e triunfos de tão bárbaras e feras nações como a hebreia, sujeitando a seu império e obediência por armas, trinta e um reinos e reis, como refere a Escritura Sagrada, na história de Josué? (p. 120)

Mas já ficamos longe de São Paulo... Talvez não tanto, porque se pode dizer que a maioria das argumentações e convicções de Vieira em torno dos Judeus é baseada sobre a crença profunda em Cristo. Ora, ao mesmo tempo em que se reivindica como Judeu, São Paulo tenta converter os Gentios e os Judeus à lei da Graça. Nunca fala do Messias, porque para ele, como para Vieira, já chegou.

\section{Conclusão}

Então, como explicar o "filojudaísmo" expresso por Vieira quando aborda a questão dos velhos e dos novos cristãos ? Não posso, dentro do tempo que me é outorgado, falar disto. Portanto, minha conclusão é a seguinte: reparemos numa grande ambivalência no discurso de Vieira sobre os Judeus. Por um lado, manifesta uma admiração indubitável pela Nação

${ }^{40}$ Ibid., p. 148. 
hebreia (cf. Memorial a favor da gente de nação hebreia), apoiando-se quase sempre sobre as palavras de São Paulo, por outro lado não se cansa em falar da cegueira do povo judaico, e retoma alguns estereótipos, tal como a sua cobiça, o seu gosto do comércio, etc. Mas, o raciocínio é dialético, e a contradição resolve-se precisamente na solução que se impõe e que é o que Vieira quer demonstrar, a saber a necessária conversão do povo judaico à fé de Cristo.

\section{As influências do hebraico no português: uma busca genealógica}

\section{Isabel Arco Verde Santos e Andréa de Melo Souza}

Q e o linguista americano Steven Roger Fischer vivesse no ano de 586 $\checkmark$ a.E.C. na região da Judéia, ele certamente seria mais um profeta apontando o destino da língua hebraica. Afinal, por muito menos ele profetizou que o português no Brasil, dentro de 300 anos desapareceria tornando-se um portunhol, segundo entrevista à revista VEJA, de 5 de abril de 2000 .

Ora, imaginem o cenário. Israel vivia um tempo de monarquia, dividido em dois reinos: Israel, o reino do norte, e Judá, o reino do sul. O Império Assírio chegou devastador sobrepondo-se ao reino do norte, que se apresentava desgastado com gradativa decadência do governo. Isto aconteceu em 722 a E.C. Judá resistiu por pouco mais de duzentos anos, antes de ser dominado pela Babilônia, império que se sobrepôs à Assíria.

O que é uma língua sem seu povo? O que é uma língua sem seu espaço?

O domínio Babilônio pôs abaixo o grande símbolo da unidade hebreia: o templo. Agora, dispersos, era preciso não deixar morrer a história, a promessa, o futuro. $\mathrm{O}$ que dizer então da língua? Quem poderia imaginar que hoje, mais de dois mil anos depois, o hebraico estivesse vivo e, mais que isso, que na profecia de Fischer ainda figurasse como uma das línguas que sobreviveriam aos próximos 300 anos por sua significação religiosa.

O templo não tardou muito a ser reconstruído e a tornar-se o centro religioso da vida dos judeus. Mas, em 70 E.C., o templo foi pela segunda vez destruído, agora pelos romanos. Nova dispersão. O retorno parece mais difícil. A esperança de reconstrução também.

Desde a primeira dispersão muitos judeus se estabeleceram em diversos lugares e já não retornaram. Preservar a identidade à distância não é algo fácil. A dificuldade com relação à identidade já é perceptível na primeira seção do livro de Provérbios, que alguns autores localizam no século VIII a.E.C., ou, nos conflitos vividos por Daniel, no cativeiro 
babilônico. A religião unificava, mas também trazia outros conflitos, pois à medida que o povo se distanciava e mais distante ficava da língua, mais anseio tinha de rezar de forma que entendesse o que falava. Este reclame foi vivido aqui no Brasil, por exemplo, quando a Igreja Católica entendeu necessário abolir a missa em latim em favor do português.

Ora, se a liderança religiosa cedesse a este apelo das comunidades distantes, com certeza perderia o grande elo de união entre os judeus: a língua. Desta forma podemos dizer que a grande responsável, num primeiro momento, pela preservação do povo não foi a religião, mas sim a língua. No entanto, não podemos negar que a religião também preservou a língua, afinal, era na liturgia, sinagogal ou doméstica, na qual a fé era exercitada, que a língua se mantinha viva.

E é esta língua litúrgica que permanece viva. É a partir desta língua litúrgica, do hebraico das rezas, que a literatura se desenvolve. É a partir desta língua litúrgica que surgem outras línguas que, num movimento dialógico com os diversos falares dos judeus, vão tomando formas próprias, como é o iídiche, o ladino e outras que, representantes de um momento, não persistem, como o judeu-eslávico, o judeu-grego, o judeu-francês e outras tantas.

Este diálogo filológico, que vai além da influência, chegando à criação de uma nova estrutura linguística, só evidencia a força que o hebraico tem. A força que o falante traz consigo.

Foi pensando nisto que resolvemos estudar as influências do hebraico no português.

Na introdução do seu livro "Breve história dos judeus no Brasil", Salomão Serebrenick afirma:

A história dos judeus no Brasil constitui um caso único; pois de nenhum outro país se pode dizer que nele os judeus tenham vivido ao longo de toda a sua existência, contribuindo substancialmente para o seu desenvolvimento econômico e social.

De fato, desde o descobrimento do país - evento este do qual participaram, tendo inclusive ajudado nos seus preparativos - até a época presente, os judeus, quase sem intermitência, aberta ou disfarçadamente, estiveram integrados nos processos de formação da nacionalidade (SEREBRINICK, 1962).
É certo que, a princípio, não podemos deixar de lembrar que no Brasil a história dos judeus viveu a clandestinidade imposta pela Inquisição. E que só a partir de 1770, quando parece saciada a voracidade inquisitorial poderíamos entender uma liberdade maior, ainda que comedida nos diversos setores da vida brasileira.

$\mathrm{O}$ que se tem levantado e divulgado com relação à presença e participação de judeus na história do Brasil é bem significativa. As relações com D. Pedro II é outra questão que não é mais ignorada, inclusive pela presença dos pergaminhos da Torah que foram adquiridos pelo Imperador, e hoje de posse do Museu Histórico da Quinta da Boa Vista, evidenciando ainda mais seu interesse e simpatia com a cultura judaica.

A partir disto, poderíamos concluir que a influência da língua hebraica no português foi igualmente significativa, transformadora e influenciadora. Afinal, segundo Gladstone de Melo: "A língua é o reflexo mais direto, é o termômetro mais sensível da vitalidade e das oscilações de uma cultura." (MELO, 1971) E foi nesta certeza que passamos a procurar esta confirmação, através de dicionários etimológicos.

O estudo etimológico de uma língua acaba revelando ao pesquisador a história de seu falante, história essa que transcende até mesmo o próprio falante. Foucault, em sua Ordem do Discurso resgata esta ideia. Embora objetive falar sobre o discurso, ao pronunciar o desejo de que a palavra se estenda para além dele, diz:

Ao invés de tomar a palavra, gostaria de ser envolvido por ela e levado bem além de todo começo possível. Gostaria de perceber que no momento de falar uma voz me precedia há muito tempo; bastaria, então, que eu encadeasse, prosseguisse a frase, me alojasse, sem ser percebido, em seus interstícios, como se ela me houvesse dado um sinal, mantendo-se, por um instante suspensa. (FOUCAULT, 2002:5)

Em se tratando de questões linguísticas o estudo etimológico procura exatamente o que Foucault almeja no discurso: a palavra primeira, seu encadeamento, seu prosseguimento, seus interstícios.

Logo no primeiro dicionário consultado, poucas palavras foram apontadas pelo autor como de origem hebraica. E, na maioria das palavras levantadas, pouquíssimas apresentavam uma fácil significação, devido ao 
uso raro apresentado. Como no primeiro dicionário, outros não trouxeram grandes diferenças. O que é, por exemplo, bato?

Bato vem da raiz, que seria uma medida de capacidade. Algumas referências a esta palavra são encontradas em I Reis 7:26, 38; 2 Crônicas 2:10; 4:5; Ezequiel 45:10, 11, 14; Isaías 5:10 e Esdras 7:22. De bato nós temos batométrico, batometria - medida das profundezas do mar.

\section{O que é siclo?}

Siclo vem da raiz e identificava a moeda dos hebreus - uso hebreus em referência aos antigos judeus. Aliás, só por curiosidade, a moeda de Israel hoje é o shéqel chadash (novo shéqe1). Gênesis 23:15, 16, Êxodo21:32 e inúmeras outras referências.

\section{O que é sidônio?}

Natural da cidade de Sidon, na Fenícia.

Claro que, por outro lado, temos palavras como aleluia, amém, hosana. Mas, mesmo para essas, que são muito usadas em ambiente litúrgico chegando até a extrapolá-lo, não temos, muitas vezes, por parte das pessoas que as usam uma certeza quanto a seus significados.

É certo que, uma parte das palavras que aparecem nos dicionários apontando para uma origem hebraica, são de uso bíblico. Referem-se a nacionalidades, como moabita, filisteu, sidônio; outras fazem referência a objetos do antigo sacerdócio como o efode, urim e tumim ou entidades celestes como Querubim e Serafim. Estas últimas palavras são transliterações, devido à dificuldade em defini-las.'

Outras palavras como jeovista ou javeísta ou javista, e eloísta são adjetivos que dizem respeito a questões que envolvem os nomes de origem. Da mesma forma como temos edênico, abraâmico, mosaico, adâmico, davídico, salomônico, aarônico.

Não é de se estranhar a inclusão destas palavras nos dicionários. Afinal, a Bíblia ainda bate o recorde de livro mais vendido, traduzido e lido no mundo; isto já seria o suficiente para que se incluíssem todas as palavras de seu corpo em qualquer dicionário, pois, sendo um livro de tamanha popularidade justificaria que seu vocabulário fosse devidamente desvendado por qualquer dicionário.
Por outro lado, mesmo as palavras de uso mais comum na liturgia carecem de melhor entendimento por parte dos fiéis. Afinal, o que é hissopo? Bem, os dicionários trazem como definição: "Planta medicinal da família das labiadas” (segundo o Aurélio). Mas, e daí? Quando se lê o salmo 51:7: "Purifica-me com hissopo e ficarei limpo", até que ponto é possível entender o significado do texto com a definição apresentada pelo dicionário.

\section{Segundo o dicionário de Dubois:}

Há dois tipos de definição: (a) definição referencial (ou ostensiva), que é a que se faz por referência à coisa que o signo denota; (b) definição semântica (ou lógica), que é a que se faz por meio de signos que pertencem a um sistema construído, a uma língua artificial ou metalíngua (DUBOIS, 1987).

Com isto, percebemos que mesmo ao se propor definir o termo, do que se esperaria obter o entendimento de seu contexto, as definições deixam a desejar, sendo necessário, como neste caso, consultar um dicionário de botânica para se perceber a utilização do hissopo e, assim, compreender melhor seu uso no texto.

A partir disto, entendemos que a inclusão destas palavras de origem bíblica no dicionário não se dá por causa da influência judaica, mas por uma necessidade cristã, pois objetivam ajudar o leitor e estudioso da bíblia, ou teólogo, a compreender melhor os termos usados no livro sagrado. Palavras estas que poderíamos acrescentar às já citadas aba, adonai, jubileu, messias, levita, satã, semita entre outras.

Algumas destas palavras, no entanto, alcançam significados outros, mesmo que relacionados à ideia primeira, conforme apresentada no texto bíblico. Um exemplo disto está na palavra babel. Se bem que no seu próprio uso bíblico indica confusão, bagunça, o que novamente nos aproximaria da intenção do autor bíblico. Por outro lado, amém, tem assumido nos dias de hoje um uso mais vulgar e corrente deixando de expressar somente a concordância dos fiéis às palavras elevadas ao Eterno, mas figurando hoje como qualquer concordância a desejos e ânsias futuros. Da mesma forma, a palavra aleluia tem sido usada como interjeição de alívio.

Depois deste pequeno passeio pelas poucas palavras apontadas pelos dicionários como de origem hebraica, perguntamos: Como pode o judeu ter 
tanta expressão na história de nosso país e o hebraico não figurar como influenciador em potencial do português no Brasil? Por outro lado é notória e expressiva a influência do árabe em nossa língua.

Com relação a esta influência, eis a explicação:

o árabe foi um povo invasor e dominador, estava na plenitude de sua vitalidade, na fase expansionista da força nacional; a sua língua tinha um passado glorioso e rico, era instrumento de adiantada cultura e de opulenta literatura. (MELO, 1971)

A permanência árabe na Península Ibérica foi de oito séculos, a partir de 711. Ou seja, o português, como língua do conquistador, ao chegar ao Brasil já o faz após um longo período de contato com o árabe. Mas este contato não chegou a influir na fonética e estrutura do português, tendo em vista os dois povos terem preservado suas culturas.

Com o Império árabe crescente, o hebraico dialoga culturalmente com seu companheiro semita. Aliás, este fato não pode ser desprezado, pois tal período de feliz convivência é chamado nos estudos literários hebraicos de Idade de Ouro.

Enquanto isto, o português está sendo gerado tendo como origem o latim. A presença cristã é, por mais paradoxal que seja, um grande difusor do hebraico. Independente do antissemitismo presente no cristianismo já dos primeiros séculos, o interesse em traduzir a Bíblia levou muitos pais da Igreja a fazerem estudos dos textos originais.

A presença do árabe no português é marcante, segundo os dicionários etimológicos. Clarinda de Azevedo Maia comenta:

Pode considerar-se extremamente rico o legado árabe no léxico português: já foram apontadas algumas centenas de vocábulos com essa origem, na sua quase totalidade substantivos e referentes a quase todos os domínios da atividade humana: abrangem quase todos os sectores da vida material, sendo praticamente inexistentes os arabismos referentes a sentimentos, noções abstratas,qualidades morais. Centremo-nos naqueles que entraram em português por via oral, quer através dos moçárabes, portanto em período anterior à Reconquista, quer através dos mouro, que permaneceram em localidades do Sul de Portugal, mesmo após a recuperação desses territórios pelos reconquistadores setentrionais. Sob o ponto de vista formal, a maioria dos substantivos começa por ai-, o artigo definido árabe. (MA1A, 1995)

De fato, é comum o registro do acréscimo do árabe no português em cerca de mil palavras. Tal fato ainda é reforçado por palavras que podem causar estranheza ao falante brasileiro, pois muitas delas, apontadas como de origem árabe, parecem-nos totalmente desconhecidas.

A presença do árabe na Península Ibérica foi muito marcante, o que justifica a presença destas palavras. Se falarmos em termos da influência na língua espanhola, perceberemos um registro bem maior.

O problema é que, ao apresentar a origem como oriunda do árabe, deixam, para o estudioso do hebraico, uma pergunta: as palavras são de origem árabe ou foram introduzidas pelos árabes?

Tal questionamento não se resume a dar o mérito da palavra a alguém, pois é certo que, se tais palavras foram introduzidas no léxico, o foram em consequência desta significante presença na Península Ibérica, mas, da mesma forma que num primeiro momento conseguimos chegar a evidências de palavras ditas latinas que tinham antecedente hebraico, encontramos mesma suspeita com relação ao árabe.

É certo que o árabe e o hebraico são línguas de origem comum, ambas semitas pertencentes ao mesmo tronco, tendo centenas de palavras com a fonética muito parecida denunciando o parentesco, algumas delas palavras, inclusive, trazem o mesmo significado, como é o caso de shalom [hebraico] e salam [árabe].

O hebraico sofre influências da língua árabe na idade Média. Alguns dos nomes da História Judaica escreveram em uma língua que combinava o árabe e o hebraico, como foi o caso do judeu-árabe, uma língua híbrida, na qual o árabe era escrito em caracteres judaicos. Como o árabe nesta época tornou-se uma língua cotidiana e necessária para o comércio, sua utilização também foi valorizada entre escritores judeus como Yehuda HaLevi, Maimônides, Rabi Ibn Pakuda, entre outros, que escreveram várias de suas obras em judeu-árabe.

Outra língua que carrega características árabes é o ladino. Falada ainda hoje, combina espanhol antigo, hebraico, árabe, turco, grego e vocábulos medievais franceses. 
A questão aqui, porém, não é tirar o mérito de entrada da palavra no léxico, mas perseguir sua origem primeira.

Umberto Eco tem sido uma voz neste sentido. Preocupado com a origem até mais profunda da língua, buscando a língua primeira, a língua adâmica, como apresenta em sua obra Em busca da língua Perfeita, Eco ainda desenvolveu alguns trabalhos nos quais chega mesmo a concluir pela influência hebraica anterior ao latim na língua inglesa, chegando a algumas conclusões que bem se aplicam ao português.

De seu trabalho, fica mais clara a dificuldade de se trabalhar etimologicamente, pois corremos o risco de nos rendermos a um trabalho que acabe por perseguir a chamada língua perfeita.

A busca pelo hebraico, porém, não pretende prová-la como a língua perfeita, mas questionar a falta de percepção dessa língua na língua portuguesa, o que, com certeza, consiste numa lacuna que precisa ser investigada.

A discreta participação da língua hebraica no léxico da língua portuguesa pode ganhar, assim, maior dimensão se investigada para além do que se tem apontado.

A procura por esta anterioridade se dá de maneira diferente, pois, enquanto no latim a grande influência se dá em termos de religião, no árabe a procura se processa por serem línguas do mesmo tronco linguístico.

A dificuldade para acharmos o hebraico se dá não só pelo meio de entrada das palavras no léxico português, mas pela própria história dos judeus na Península Ibérica, dolorosa história, que entendeu a necessidade do secreto, do segredo, para que pudesse sobreviver. O judeu chega ao Brasil fugindo de Portugal e da inquisição e mesmo assim, ainda é perseguido. A história dos judeus é por isso fragmentada:

Comunidades como a italiana, alemã, sírio-libanesa ou japonesa, muito mais recentes, tiveram condições para apresentar-se de forma mais orgânica e contínua. Apesar do susto que os descendentes de algumas delas sofreram durante o período em que o país esteve em guerra com o Eixo (1942-1945). A comunidade israelita (o nome"judeu" ou "judaico" tinha conotações pejorativas) foi confinada e confinou-se durante grande parte destes cinco séculos, obrigada a um distanciamento e forçada discrição (DINES, 1999).
A língua, assim, reproduz a história do próprio povo, preservando-a mesmo que velada e escondida. Sua presença tem na Bíblia sua maior expressão e palavras que, pelo seu valor religioso não puderam ser omitidas, traduzidas e bem pouco modificadas.

A questão religiosa e do secreto são também interessantes quando analisadas. A crença na língua hebraica, que se entendia como sagrada, o que era pregado inclusive pelos pais da Igreja, justifica seu principal campo de influência. Por outro lado, o caráter secreto que acompanha a história judaica, melhor exemplificado no misticismo judaico ou cabala, concorre para o seu velamento.

Palavras de origem árabe e hebraica se confundem. Abd, que significa servo, é sinalizada como de origem árabe. No entanto, apresenta origem hebraica, com mesmo significado. Na Bíblia, é comum a expressão servo de Deus, como em árabe abdala - servo de Alá.

Da mesma forma temos a palavra do português "aberto", que segundo Wagner e José Pedro Machado também derivaria do árabe Fatich, tendo forma primitiva no hebraico Patach, ocorrendo aqui um decalque linguístico.

Este questionamento encontra voz também em trabalhos como o do epigrafista português Carlos Castelo que questiona a consideração para o nome Bensafrim (localidade no Algarve), que no Léxico Etimológico da Língua Arábica em Portugal, composto por ordem da Academia Real das Ciências de Lisboa em 1789, e segundo o seu autor, Fr. João de Sousa, indica sua origem como do árabe: Benasafarim - Benassaharin. Significando a dos Feiticeiros, a partir da derivação do verbo Sahara - encantar, enfeitiçar.

Castelo reclama pela origem hebraica do nome que encontra melhor explicação a partir das palavras hebraicas Ben - filho - e Soferim - escriba, escritor.

Partindo desta possibilidade, poderíamos suspeitar de outras palavras como cadimo, apresentado no Vocabulário Português de Origem Árabe de Jose Pedro Machado, significando antigo, velho. No hebraico temos kadum como anterior, antigo.

Em alguns trabalhos etimológicos o que podemos observar com relação à indicação da origem árabe das palavras é o fato do autor das obras 
ter grande influência nesta área de pesquisa. É o caso, de José Pedro Machado, autor de Vocabulário Português de Origem Árabe, Palavras a Propósito de Palavras - Notas Lexicais, Estrangeirismos na Língua Portuguesa, Ensaios Literários e Linguísticos, Ensaios HistóricoLinguísticos, Ensaios Arábico-Portugueses e O Grande Livro dos Provérbios, entre outros. Seu Dicionário Etimológico da Língua Portuguesa traz, inclusive, um quadro linguístico do árabe, no qual o leitor pode fazer a equivalência para o português.

Além destes dois caminhos de encontro com o hebraico no léxico português, ainda há aquele que aponta para o preconceito e depreciação. O termo judiar, por exemplo, tem dado o que falar ultimamente, quando dicionários como o Aurélio e o atualíssimo Houaiss estão sendo objetos de ação na Justiça, por incluírem em seus verbetes a designação pejorativa para a palavra.

O preconceito, no entanto, fica marcado também em palavras que, originárias do hebraico, acabam sendo usadas de forma depreciativa, como acontece com desmazelo (negligência, desleixo, desalinho - de mazal), malsim (delator, traidor - de mashlin, lashon), zote (pateta, idiota, parvo, tolo - de zot /solo, base, subterrâneo - zotah/ pequeno, baixo, menor), ou tacanho (que tem pequena estatura, acanhado; pequeno; estúpido, inhenho, avarento/talvez de qatan). Ou mesmo, palavras relacionadas a questões financeiras, como é o caso de cacife, cacifeiro, cacifar e cacifo.

Resgatar este elo hebraico-Português seria, acima de tudo, resgatar o valor do judeu no processo histórico brasileiro. Nossa pesquisa já tem ido além destes pequenos apontamentos e apresenta-se cada vez mais como um agradável desafio em busca de nossas origens. Talvez este seja um caminho para vencer também o preconceito. Assim, parafraseando Foucault, poderemos perceber as falas que nos antecederam e escreveram nossa história, abrindo uma nova página para se recontar, viver e escrever uma nova história.

\section{Referências Bibliográficas:}

DUBOIS, Jean. Dicionário de Linguística. 3. ed, São Paulo: Cultrix, 1987.
MELO, Gladstone Chaves de. A língua do Brasil. 2. ed, melhorada e aumentada, Rio de Janeiro: Fundação Getúlio Vargas, Coleção Estante de Língua Portuguesa. Série Universidade, 6, 1971.

MAIA, Clarinda de Azevedo. História da língua portuguesa; guia de estudo. Coimbra: Faculdade de Letras, 1995.

ECO, Umberto. Em busca da Língua Perfeita. São Paulo: Edusc.

SEREBRENICK, Salomão e LIPINER, Elias. Breve História dos Judeus no Brasil. Rio, Biblos, 1962. À disposição no site: http://www.geocities.com/Athens/Forum/4720/livro10.htm

FOUCAULT, Michel. A Ordem do Discurso. São Paulo: Loyola, 2002.

DINES, Alberto. 500 anos: A presença judaica no Brasil. In Revista Morasba, Ano VIII n.26 dezembro 1999. À disposição no site: http://www.morasha.com.br/) 


\section{A temática judaica nos poemas de Borges}

Leonor Scliar-Cabral

\section{Introdução}

influência judaica nos poemas de Borges transparece não apenas nas inspirações explícitas de vários de seus poemas ("Spinoza", "Paris, 1856", dedicado a Henrich Heine, no qual Borges se refere ao destino de ser homem e ser judeu, e "Rafael Cansinos-Assens": "Bebeu como quem bebe um vinho bento/Os Salmos e os Cantares da Escritura/ E sentiu que era sua essa doçura/E sentiu que era seu aquele intento./Israel o chamava"), mas sobretudo pela cosmogonia refletida na estruturação formal, pela temática e pelo método, recortado da Cabala.

Dado o limite de espaço, restringir-me-ei, neste trabalho, a abordar mais especificamente a influência da Cabala no texto de Borges que eu traduzi para o português El otro, el mismo (Borges, 1999).

Pode-se definir a Cabala, literalmente, como recepção, a partir da raiz KBL, no caso, referindo-se à "recepção oral das tradições religiosas e dos segredos recônditos das Escrituras" (Sosnowski, 1986:13, as traduções são da autora). Concorda com esta definição Oberlander Niselkowska (1988:19): “A Cabala é uma via de transmissão oral, que passa de geração a geração e que põe ênfase especial no significado simbólico dos textos sagrados, em seu sentido mais secreto e oculto".

O objetivo dos cabalistas, conforme Sosnowski (Op. cit.: 14), é "recuperar o segredo da criação". Oberlander Niselkowska (Op. cit.: 20) desenvolve esta ideia: "Para a Cabala judaísmo é um sistema de símbolos místicos que refletem o mistério de Deus e do universo. E o objetivo do cabalista é descobrir e inventar as claves que conduzem à compreensão desse simbolismo".

${ }^{1}$ Doutora em Literatura UFSC.

\section{Algumas fontes cabalísticos em Borges}

Embora o ponto de partida, conforme o próprio Borges, em entrevista à revista Raíces (fev. 1971:37), tenha sido a leitura de Der Golem de Gustav Meyrink (Borges, 1970:121), sem dúvida, os dois encontros que teve com Gershom Scholem foram decisivos, bem como a leitura de sua obra Major Trends in Jewish Mysticism (Scholem, 1941). Na verdade, Scholem "revolucionou a visão que se tinha do judaísmo e do papel do misticismo no pensamento ocidental. E transformou o estudo da Cabala, que havia sido descuidado, se não desprezado, num tema de séria dedicação científica" (Oberlander Niselkowska, Op. cit.: 19). O tributo a Scholem ocorre no poema considerado por Borges como o melhor que escreveu (entrevista a Sosnowski, Op. cit.: 3), "O Golem":

(O cabalista que oficiou de nume

Ao ser enorme chamou-o de Golem;

Estas verdades as refere Scholem

Em um douto lugar de seu volume.)

$\mathrm{Na}$ entrevista concedida a Sosnowski, Borges ainda menciona as outras fontes em que se abeberou para o estudo da Cabala: a tradução por Longfellow da Divina Comédia, os trabalhos de Trachtenberg (1961), Waite (1960), Sérouya (1964, Franck (1843, refutado pelo rabino converso Drach, autor de La Cabbale des Hébreux vengée, do mesmo ano, cf. menciona Serfaty,1988:9) e o verbete da Encyclopaedia Britannica. O próprio Borges refere como suas fontes, além dos já citados, o Talmud, Sanhedrín, 65b e, obviamente, o Livro da Criação bem como Eleazar de Worms. A influência do Rabi Moisés Cordovero (1522- 1570) que escreveu no séc. XVI o livro Pardis Rimonim (inspirado no versículo do "Cântico dos Cânticos": "tuas plantas são um jardim de Granada" (Regardie, 1978:23)) não é reconhecida explicitamente, embora apareça um Nahum Cordovero em "El inmortal” de El Aleph (Soslowski, Op. cit.:24, nota 36). Nessa mesma nota, Soslowski declara que, em sua entrevista, Borges confessou sua inocência em relação ao nome de Cordovero.

Assinalar as fontes cabalísticas que perpassam recorrentemente os poemas de El otro, el mismo implica entrecruzar as correntes filosóficas que as alimentaram e que formam o tecido subjacente para entender o pensamento de Borges, desde Pitágoras, Platão, (particularmente o mito das cavernas, a metáfora da projeção das sombras e a concepção de memória, 
estas duas últimas as que mais recorrem em El otro, el mismo); o neoplatonismo de Alexandria; a escola cabalística de Gerona (a "Espanha do Islã, da cabala", mencionada por Borges em "Espanha"), com Isaac, el Ciego e Nahmanides (ou Abi hokma, o "pai da sabedoria", ou Bonastruc de Porta); o Zohar; o pensamento de ibn Gabirol, baar Hiyya, Yehuda há-Leví, A. ibn Ezra, ibn Paquda, Abraham ben S'muel Abulafia e ibn Chicatella. Posteriormente, Pico de la Mirândola (1463-94), J. Reuchlin (1455 - 1522), Spinoza e von Rosenroth (séc. XVII).

\section{O método}

Borges, em "Una vindicación de la Cábala" afirma não reivindicar a doutrina e sim os procedimentos hermenêuticos ou criptográficos que a ela conduzem (Borges, 1966:55), através do método de posse mais eficaz para conhecer, a linguagem, porém, segundo ele, "a raiz da linguagem é irracional e de caráter mágico" ("Prólogo" de El otro, el mismo"). A "linguagem pode simular a sabedoria" ("Outro poema dos dons") e pode ser até prisão ("O Golem”):

Gradualmente (como nós) viu-se ele

Aprisionado na rede sonora

Do Antes, Depois, Ontem, Enquanto, Agora,

Direita, Esquerda, Eu, Tu, Outros, Aqueles.

Em "Uma bússola", Borges expõe a opacidade da palavra que demanda iniciação para decifrá-la:

Passam Cartago e Roma, minha vida

Que não entendo, eu, tu, ele, a agonia:

Ser enigma, acaso, criptografia

$\mathrm{E}$ as vozes de Babel desentendidas.

Atrás do nome há o que não se cita;

São os nomes secretos de "Emanuel Swedenborg":

Apenas os chamava por secretos

Nomes os celestiais anjos. Olhava

O que não veem os olhos terrenais:

O cabalista se propõe teleologicamente a aprendizagem de como se deu a criação, já que esta ocorreu através de fórmulas verbais, como a fórmula instauradora: "Faça-se a luz" a partir de "No princípio era o Verbo". Dos sete caminhos sugeridos (caminhos que se encontram na Árvore da Vida (Sephirot), para a compreensão da Torah, apenas os três últimos compõem a iniciação do cabalista; o sexto caminho, é constituído por três métodos hermenêuticos aos quais Borges faz alusão nos poemas de El otro, el mismo: a Gematria (vide as relações desta raiz com geometria e gramática), que reduz a palavra a valores numéricos, somando o valor de cada letra, e assim estabelecendo relações com outras palavras de soma idêntica; o Nôtarikôn, ou seja, cada letra de uma palavra serve como sigla de outras que desvelam o segredo contido na primeira, portanto, é o verdadeiro método de cifragem (vide acima, os objetivos dos cabalistas) e permutação; o sétimo caminho é o Sancta Sanctorum, reservado aos profetas. Dos caminhos, o sexto é referido constantemente por Borges em El otro, el mismo. Exemplo de Gematria, encontramos em "Poema do quarto elemento":

Água, eu te suplico. Por este sonolento

Enlace de numéricas letras que te digo,

Recorda-te de Borges, teu nadador e amigo.

Exemplo de Nôtarikôn, em "Poema conjecturai":

Mas por fim eu descobri

a recôndita chave de meus anos,

o fado de Francisco de Laprida,

a letra que faltava, esta perfeita

forma que soube Deus desde o princípio.

$\mathrm{O}$ instrumento:

É cifra da diáspora e do vento

Afim com essa chave do santuário

Que alguém lançou ao céu, quando a incendiou

O romano com fogo temerário,

E que a divina mão no azul captou. ("Uma chave na Salônica”)

Exemplo de permutação em "O Golem”:

Sedento de saber o que Deus sabe, Deu-se Judá Leão a permutações De letras e a complexas variações

E ao fim pronunciou o Nome que é a Clave,

A Porta, o Eco, o Hóspede e o Paço, 
O método que a Cabala enfatiza é o da busca, tal como aparece em "O Golem":

Sabemos, sim, que houve um dia

Em que o povo de Deus ia em procura

Do Nome, em vigílias na judiaria.

Atinge-se, assim, o alvo supremo que é a recuperação da Luz, depois do exílio (o mundo das sombras), defrontando-se, por fim com a Verdade de Deus e o seu Palácio ou última esfera, ou seja, os arquétipos, depois da morte:

Que sentiria ao ver-se face a face

Com os Arquétipos e os Esplendores? ("Baltasar Gracián”)

O exílio é o mundo dos mortais, o mundo das sombras:

Deus retornou-me ao mundo dos mortais,

A espelhos, cifras, nomes e umbrais (“Alexander Selkirk”).

O exílio:

\author{
A áspera terra \\ É meu castigo e a incestuosa guerra \\ De Cains e de Abéis e de sua cria. \\ depois da expulsão do Jardim ("Adam Cast Forth"). \\ A morte é a liberação para a Luz ("Everness"): \\ Somente do lado oposto do ocaso \\ Verás os Arquétipos e Esplendores.
}

$\mathrm{Na}$ última esfera se pode recuperar a palavra perdida ("Rafael Cansinos-Asséns"):

Cansinos a ouviu como o profeta

$\mathrm{Na}$ esfera secretíssima a secreta

Voz do Senhor, da flâmea sarça ardente.

A busca é desvendar a cosmogonia que se oculta sob as aparências ("O alquimista"):

Na obscura visão de um secreto ser Que se oculta nos astros e no lodo, Lateja outro sonho de que o todo

É água, como Tales julgou ver.

Outra visão terá; a de um eterno
Deus que em tudo é e o olhar ubíquo pousa, Como explica o geométrico Spinoza

Num livro bem mais árduo que o Averno..

\section{Temas constantes}

\subsection{O universo foi criado pela palavra}

A importância da palavra e das letras que a constituem é tal na Cabala que ela se confunde com a própria criação ou com Deus:

E, feito de consoantes e vogais,

Nome terrível ha' de haver, que a essência

Cifre de Deus e que a Onipotência

Guarde em letras e sílabas cabais.

Adão e os astros tê-lo-ão achado

No Jardim. A ferrugem do pecado

O apagou (os cabalistas contaram):

$\mathrm{E}$ as gerações por vir o extraviaram.

Nestas duas estrofes de "O Golem", Borges está se referindo ao tetragrama, conhecido pelo rubro Adão no Paraíso e dele despojado depois do pecado original, quando se dá o grande exílio: somente o arrependimento e as penitências dos ritos de iniciação permitirão reencontrar a face de Deus e retornar ao seu Palácio de Luz (a décima esfera).

Cabe, no entanto, uma observação: o nome de Deus somente recupera as vogais quando é pronunciado. $\mathrm{Na}$ escrita, só figuram as quatro consoantes (o tetragrama). Como linguista, considero o sopro divino a metáfora do ar que sai dos pulmões e faz vibrar as pregas da glote, para a produção das vogais e assim dar vida às letras (consoantes) que estariam mortas ("O outro"):

Séculos depois diria a Escritura

Que o Espírito assopra onde quer.

A palavra também se confunde com o Universo: Todas as coisas são palavras lidas

Na língua em que Algo ou Alguém, noite e dia, Escreve essa infinita algaravia

Que é a história do mundo. ("Uma bússola") 
Este Universo tanto pode ser metaforizado como a Biblioteca, o Livro, a Palavra Secreta, quanto por uma Letra (o Aleph). Mas pode também ser o Mapa refletido no cristal que "Spinoza" brune em vigília:

\author{
Liberto da metáfora e do mito, \\ Um cristal árduo lavra: é o infinito \\ Mapa d'Ele que é os astros e os constela. \\ O cristal, um dos arquétipos ("Um poeta do século XIII"): \\ E que o arcano, o incrível deus Apoio, \\ Lhe havia revelado aquele arquétipo, \\ Um ávido cristal que apreenderia \\ O quanto a noite encerra ou abre o dia: \\ Dédalo, labirinto, enigma, Édipo?
}

Note-se, no entanto, a aceitação do conceito cabalístico de que o macrocosmo (a cosmogonia da Árvore da Vida, ou Sephirot) se espelha microcosmicamente em cada homem, como em "a circulação de meu sangue e dos planetas" ("Insônia"). Assim ocorre com a Biblioteca infinita (o Universo) espelhada na biblioteca humana e seus limites ("Limites"):

\author{
Cessa a noite através do cristal gris \\ E, do cimo dos livros que partida \\ Sombra espalha pelo tampo impreciso, \\ Uma folha que nunca será \\ Ou em "Leitores": \\ Tal, também, é minha sorte. Existe algo \\ Imortal e essencial que sepultei \\ Nessa biblioteca do antigo, sei, \\ Em que li a história do fidalgo.
}

\subsection{A mudança de uma letra é fatal}

Conforme os preceitos cabalísticos, cada uma das 22 letras do alfabeto que constituem uma palavra e as posições que ocupam não são ao acaso. Apagamentos, inserções ou permutas podem ter consequências fatais, como em "O Golem":

Talvez houvesse um erro na grafia

Ou no Sacro Nome que articulou;

Mesmo com tão alta feitiçaria,

Falar, o aprendiz de homem não falou.
Com as 22 letras e as 10 esferas, se constrói a cosmogonia: as palavras, portanto, não são obras do acaso humano, mas sim, paradoxalmente, do Acaso indiferente (o Fado, ou Destino ou Deus). Em “Texas",

\author{
Aqui também o místico alfabeto \\ Dos astros, que hoje ditam a meu cálamo \\ Nomes que o infatigável labirinto \\ Dos dias não arrasta: \\ pois tudo já está previamente escrito ("Fragmento"): \\ Até uma hora que já sabe o Destino,
}

Ou:

São faces do Acaso indiferente (“A Carlos XII)

mas de forma mais contundente em "Édipo e o enigma":

Quadrúpede na aurora, alto no dia

E com três pés errando pelo vão

Âmbito do entardecer, assim via

A eterna esfinge ao inconstante irmão,

$\mathrm{O}$ homem, e à tarde um homem vaticina

Decifrando aterrado, no cristal

Da monstruosa imagem, o fatal

Reflexo de seu destino e ruína.

Somos destituídos de livre-arbítrio ("Ode escrita em 1966”):

Se o Eterno

Espectador deixasse de sonhar-nos

Um só instante, nos fulminaria,

Branco e brusco relâmpago, Seu olvido.

\subsection{O nome é a nossa identidade e a própria coisa}

A palavra não só é a criação, o Universo, mas também nossa própria identidade: "tu és uma palavra em um índice" ("A um poeta menor da antologia");

Em "Odisseia, livro vigésimo terceiro", Ulisses, paradoxalmente atinge o anonimato: Dizendo que seu nome era Ninguém?

Enquanto em "Camden, 1892", o velho Walt Whitman se reconhece ao espelho: Eu fui Walt Whitman.

Sem o nome:

O rosto, ao se mirar nos desgastados 
Cristais da noite, não se reconhece. ("O instante")

Onde buscar teu nome, onde teus traços?

Essas são coisas que o antigo olvido

Guarda. ("A um poeta saxão")

A resposta somente será conhecida ao deixarmos o mundo das sombras e retornarmos ao nosso arquétipo ("O mar"):

Quem é o mar, quem sou? Hei de saber

$\mathrm{O}$ dia que à agonia suceder.

A partir da epistemologia platônica sobre se a palavra é a própria coisa (o debate de o Crátilo), Borges opta pelas "palavras essenciais" de "Um saxão" e afirma categórico em "Mateus XXV, 30":

Disse estas coisas (estas coisas, não estas palavras,

Que são minha pobre tradução temporal de uma única palavra):

As palavras são arquétipos, a essência:

Se (como o grego no Crátilo di-lo)

Da coisa o nome é sua ideia pura,

Nos sons de rosa a rosa é e perdura

E todo o Nilo, na palavra Nilo.

(Lembremos que "rosa" é a metáfora do povo escolhido)

Que a palavra é a própria coisa, para Borges, não há dúvida: para eliminar a fome, basta que:

Seja apagado teu nome da face da Terra

verso repetido paralelisticamente no início e final do poema "A fome".

\subsection{Memória e olvido, sonho e sombras: o mito das cavernas}

De todas as ideias de El otro, el mismo a do mito das cavernas e seus desdobramentos neoplatônicos e cabalísticos é a que mais recorre. Conforme vimos, após o pecado original, o rubro Adão é exilado e deverá errar pela Terra, o vale das sombras, ele próprio, uma sombra. Tem, contudo, a memória imperfeita dos arquétipos ou Arquétipo que lhe chegam cifrados, desvendáveis se percorrer os caminhos cabalísticos até o rito supremo que é a morte. O "Prólogo" de El otro, el mismo encerra com "o sonho sobre o qual me inclinarei depois de morto". Em "Do inferno e do céu", Borges assinala o quanto são distantes as lembranças do que precedeu a queda:
Nem o fundo dos anos também guarda

Um remoto jardim.

A concepção platônica de arquétipo (o orbe intemporal) e sua projeção imperfeita aparecem em "O sono":

sonhos, que bem podem ser truncados

Reflexos dos tesouros de umbra instável,

De um orbe intemporal inomináve

Que o dia nos espelha deformado.

A sombra se replica, como quando se reescreve um símbolo matemático encaixado, cada vez mais sombra (“A uma espada em York Minister"):

E sou sombra na sombra ante o guerreiro

Cuja sombra está aqui.

Também em "O tango":

Em quais escuros becos, em que ermos

Do outro mundo se instalará a dura

Sombra de quem era uma sombra escura

Muraria, essa navalha de Palermo?

Pois:

Uma mitologia de punhais

Lentamente se anula no esquecer-se;

Esta reescritura dos símbolos encaixados em múltiplos espelhos, como na linguagem matemática, também é utilizada em relação ao sonho ("Spinoza"):

o homem que assim tece

Quieto os sonhos de um claro labirinto.

Não o turva afama, sonhos reflexos

No sonho de outro espelho convexo,

Somente quando o planeta milenar for esquecido, ao retumbar o Juízo nas trombetas, ocorrerá o retorno à contemplação do rosto incorruptível que:

há de ser, para os réprobos, Inferno, porém para os eleitos, Paraíso. ("Do inferno e do céu") 
A mesma ideia retorna em "Poema conjetural":

No espelho desta noite é que me alcanço o insuspeitado rosto eterno. O círculo se fecha.

Há no olvido terreno, a piedade de Deus para com os homens. Em "Do inferno e do céu":

Em Sua misericórdia, nem jardins

Nem luz de uma esperança ou de lembrança.

Em "Édipo e o enigma":

Aniquilar-nos-ia ver a ingente Forma de nosso ser; piedosamente Deus nos depara sucessão e olvido.

E em "A um poeta menor da antologia": Porém os dias são uma rede de triviais misérias, e haverá melhor sorte que a cinza

de que esta' feito o olvido?

O mesmo esquecimento das coisas triviais ("Página para recordar o coronel Suárez, vencedor de em Junín”):

Os dias inúteis

(os dias que se espera esquecer, os dias que se sabe que se hão de esquecer),

\section{Pelo menos:}

Uma há, dentre as memórias todas tuas,

Que se perdeu irreparavelmente;

"Os limites" impõem o esquecimento dos versos do poeta persa e da própria história (o Ródano, Cartago). Sem espaço e tempo, ao contrário dos arquétipos intemporais, não existe memória terrena.

Somente ao longe se ouve

ao alvor, rumorejar

Laborioso da turba se afastando;

São quem me quis amar e me olvidar;

Espaço e tempo e Borges me deixando.

Para desejar em “O despertar”, do outro lado:

$\mathrm{Ah}$ ! Se aquele outro despertar, a morte,

Deparasse-me um tempo sem memória

Do nome meu e do que tenho sido!

$\mathrm{Ah}$ ! Se nessa manhã houvesse olvido!
Desejo que se cumpre em “A quem já não é jovem”:

Aqui te espreita o espelho sem sondagem

Que sonhará e esquecerá a imagem

Dos derradeiros dias e agonias.

Só uma memória é eterna, a de Deus ("Everness"):

Só não há uma coisa. É o esquecer.

Deus, que salva o metal, salva a escória

E cifra em Sua profética memória

As luas que já' foram e as que hão de ser.

Tudo está aí

Ideia que se repete em "Ewigkeit":

Sei que uma coisa não há. O olvidado;

Sei que na eternidade perdura e arde

O precioso e o muito esperdiçados:

Essa lua, essa frágua e essa tarde.

E em “Manhã de 1649”:

Vai hoje à morte, sabe, e não ao olvido,

Ou em "Buenos Aires":

Minha sombra aqui, pela menos vã

Sombra final ligeira irá, quimera.

Gravar em versos ou em livros é a saída para o esquecimento terreno (“Um saxão"):

Para cantar as glórias ou lembranças,

Cunhava operosos nomes e ações:

\section{Como o fez Homero:}

No primeiro dos vastos e milhares

Hexâmetros de bronze, a vista cega,

Invoca o fogo arcano ou a musa e lega

A ira de Aquiles em cantares. 


\section{Ou "Emerson":}

E outros compus que não há de apagar

O obscuro olvido.

Ou "Edgar Allan Poe":

Da morte triunfal os glaciais

Símbolos congregou.

Ou Borges em "Uma rosa e Milton”, um de seus sonetos preferidos:

$\mathrm{Tu}$, branca rosa ou vermelha

Ou amarela de um jardim fanado,

Deixa magicamente teu passado

Imêmore no verso qual centelha

Somente assim a rosa será' salva do esquecimento.

A lembrança fica também nas narrativas que podem ser apócrifas ("Os compadritos mortos") ou na tradição oral e escrita de "O Golem":

Verde está ainda e viva a memória

De Judd Leão, que era rabino em Praga.

Ou gravada em canção ("O tango"): Embora a adaga hostil, ess'outra adaga, O tempo, os perdessem em maldição, Hoje, ultrapassado o tempo e a aziaga Morte, os mortos no tango viverão.

Ou simplesmente em palavras ao entardecer ("A um poeta menor de 1899"):

Não sei se teu labor o conseguiu,

Meu vago irmão maior, ou se exististe,

Mas estou só e o olvido em que caíste

Que restitua aos dias tua sutil

Sombra para este já cansado alarde

De umas palavras em que esteja a tarde.

Ou mesmo no canto de um pássaro (“Texas”):

Aqui também o pássaro secreto

Que por sobre os fragores da história

Canta para uma tarde e sua memória;

Ou:

No íntimo do pátio, sob as parras,

Quando os dedos temperam a guitarra. (“Os compadritos mortos”).
Mas a lembrança não fica no mármore terreno ("Carlos XII”):

E o mármore, ao final, será o olvido.

Que, afinal, não será lido (“A quem me está lendo”):

Te espera o mármore

Que não lerás.

Pois:

Não há mármore a guardar tua memória; (“Um soldado de Lee”)

O sonho é o refúgio:

Para apagar ou mitigar a sanha

Do real, buscava, pois, pelo sonhado

E lhe deram um mágico passado

Os ciclos de Rolando e da Bretanha. ("Um soldado de Urbina").

O sonho (e o arquétipo) é mais real do que o real e precede a criação ("O mar"):

Antes que o sonho (ou o terror) que gera

Mitologias e cosmogonias,

Referindo-se a Quixote em “Leitores”:

Seus empenhos, que as crônicas pontuais

Narram, e os tragicômicos desplantes,

Quem as sonhou foi ele, não Cervantes:

Em "O despertar":

Entra a luz e ascendo torpemente

Desde os sonhos ao sonho partilhado

$\mathrm{E}$ as coisas readquirem seu esperado

E devido lugar.

Ou em "Alexander Selkirk":

Sonho que o mar, aquele mar, me encerra

E do sonho saúdam-me as salvas

De Deus, que santificam as frias alvas

Em “Uma espada em York Minister":

E somente o passado é verdadeiro. 
O sonho precede o conhecimento, como está no Pentateuco, nos sonhos de José:

As lentas folhas volta a criança e grave

Sonha com vagas coisas que não sabe. ("Leitores")

E, como os arquétipos que habitam a 10" esfera, é intemporal ("Sarmiento"):

E em sua larga visão como num mágico

Cristal que a um só tempo encerra as três faces

Do tempo que é depois, antes, agora,

Sarmiento o sonhador segue sonhando-nos.

Também em "Jonathan Edwards (1703-1785)":

Longe da cidade, longe do foro

Clamoroso e do tempo, que é mudança,

Edwards, eterno já, sonha e avança

À sombra de copados ramos de ouro.

Hoje é ontem e amanhã.

Em “Os enigmas”, a previsão do rito de passagem para a $10^{\mathrm{a}}$ esfera:

Eu que agora sou quem está cantando

Amanhã serei o morto, o iniciado

Habitante de um orbe despovoado,

Mágico, sem depois, antes ou quando.

Assim afirma a mística.

Como no Letes:

Que errante labirinto, que brancura

Cega de resplendor ser-me-á a sorte,

Ao entregar-me ao fim desta aventura

A experiência incógnita da morte?

Quero beber seu cristalino Olvido,

Ser para sempre; mas jamais Ter sido.

O Letes que aparece explicitamente em "Ao vinho":

Que os outros em teu Letes bebam um triste olvido;

Em "Mateus XXV, 30", o sonho aparece "como um tesouro enterrado "enquanto a memória", "o homem não olha sem vertigem".
O mito das cavernas em suas múltiplas versões recorre, assim, em vários poemas de El otro, el mismo na lembrança e olvido, nos arquétipos, nas sombras, sonhos e quimeras:

$$
\begin{aligned}
& \text { Destas ruas que afundam o poente, } \\
& \text { Há uma (eu não sei qual) que percorri } \\
& \text { Já pela última vez, indiferente, } \\
& \text { E, sem o adivinhar, me submeti } \\
& \text { A Quem prefixa onipotentes normas } \\
& \text { E uma secreta e rígida medida } \\
& \text { Às sombras, e aos sonhos e às formas } \\
& \text { Que destecem e tecem esta vida. }
\end{aligned}
$$

\section{Visão pessoal de Borges}

Não se conclua, porém, uma coincidência entre a visão de Borges e a do cabalista: “A perspectiva destas aproximações é diametralmente oposta. Para o cabalista o mundo tem sentido; este reconhece na Sagrada Escritura a fonte desse sentido e do mistério da Criação; os iniciados podem conceber a possibilidade de revelar esse segredo" (Sosnowski, Op. cit.: 9).

Para Borges, a Cabala é um método de busca primordialmente estética. Na realidade, o processo de criação estética se choca com a aceitação de que o ser humano é apenas o veículo para explicação da palavra divina, que não pode ser alterada. Há no âmago da criação estética um desafio prometeico e até onipotente de seguir os passos divinos e assim criar novos universos, conforme a profissão de fé borgeana em "Uma rosa e Milton":

$\mathrm{O}$ fado tem-me posto

Este dom de nomear por vez primeira

Essa flor silenciosa, a derradeira

Rosa que aproximou Milton ao rosto,

Sem vê-la.

E em "Composição escrita em um exemplar da gesta de Beowulf

Será (me digo) que de um suficiente

E mais secreto modo a alma sabe

Que é imortal e que seu vasto e grave

Círculo tudo abarca onipotente. 
Ou em "A um poeta saxão":

Hoje não és outra coisa que minha voz Quando revive tuas palavras de ferro.

Portanto, Borges assume ("Ewigkeit"):

O por meu barro abençoado

Não vou negá-lo eu como um covarde.

A onipotência do poeta aparece em "Edgar Allan Poe":

$$
\begin{aligned}
& \text { Assim como no espelho, do outro lado, } \\
& \text { Solitário entregou-se ele a seu fado } \\
& \text { Complexo de inventor de pesadelos. } \\
& \text { Do outro lado, talvez, da ignota morte, } \\
& \text { Siga erigindo textos, só e forte, } \\
& \text { Atrozes, belos e ouse escrevê-los. }
\end{aligned}
$$

Esta dicotomia entre os propósitos do cabalista e os do poeta está claramente manifesta no "Prólogo" de El otro, el mismo". Referindo-se às diferenças entre "O Golem" e "As ruínas circulares", Borges afirma: "o sonhador sonhado está em uma, a relação da divindade com o homem e talvez a do poeta com a obra, na que depois redigi."

Refazer o que escreve é uma necessidade para o escritor, conforme os célebres rascunhos (borradores) aos quais se refere Borges ("Prólogo"; "Um poeta do século XIII;): a palavra não vem pronta, como a grande realidade acima das coisas.

Não só a palavra divina é matéria para o poético: o humano, o amor que em rubras bocas arde, também ("Baltazar Gracián”).

Finalmente, Borges dá graças ao divino ("Outro poema dos dons"):

$$
\begin{aligned}
& \text { Pelo fato de que o poema é inesgotável } \\
& \text { E se confunde com a soma das criaturas } \\
& \text { E não chegará jamais ao último verso } \\
& \text { E varia segundo os homens. }
\end{aligned}
$$

\section{Referencias bibliográficas:}

BORGES, J.L. 1966. Discusión. Buenos Aires, Emecé, 4 ed.

1970. El informe de Brodie. Buenos Aires, Emecé.
1999 Obras completas II, São Paulo, Globo.

FRANCK, A. 1843. La Kabbale, ou La philosophie religieuse des Hébreux. Paris, Hachette.

OBERLANDER NISELKOWSKA, B. 1988. Gershom Scholem y la cabala descubrimiento del archipiélago. Escudo, 66 (2ª́poca): 18-23.

REGARDIE, I. 1978. Un jardín de granadas, una introducción a la Cábala. Madri, Luis Cárcamo.

SCHOLEM, G. 1941. Major trends in Jewish Mysticism. New York, Schocken.

SERFATY, M. G. 1988. La cabala de los rabinos de Gerona. Escudo, 66 (2 $2^{\mathrm{a}}$ época) 5-12.

SÉROUYA, A. 1964. La Kabbale. Paris, Presses Universitaires de France.

SOSNOWSKI, S. 1986. Borges y la cabala. La búsqueda del verbo. Buenos Aires, Pardes.

TRACHTENBERG, J. 1961. Jewish magic and superstition. A study in folk religion. Cleveland and New York, Meridian.

WAITE, A. E. 1960. The holy Kabbalah (A study of the Secret Tradition in Israel as unfolded by the Sons of the Doctrine for the Benefit and Consolation of the Elect dispersed through the Landas and Ages of the Greater Exile). New Hyde Park, N. Y Univ. 


\section{Por uma estética contra a ordem:} dois contos de Jorge Luis Borges sobre o nazismo

\section{Lyslei de Souza Nascimento ${ }^{1}$}

B

eatriz Sarlo afirma, em seus estudos sobre Borges, que ele sempre resistiu a um uso político da literatura ${ }^{2}$. No entanto, na trama de alguns de seus relatos é evidente uma resistência e uma desconstrução da ordem que é imposta cultural e politicamente. Para Sarlo, a literatura é uma das armas contra o poder consolidado pela arbitrariedade de decisões incompreensíveis ou por força de mitos que reforçam uma situação de dominação e esse é um tema reiterado em Borges.

A partir desse ponto de vista, alguns textos borgianos se colocam em um campo histórico de forças que enfrentam ideologias políticas totalitárias, a fim de redefinir espaços e dar, pela ficção, voz a culturas que foram silenciadas e, às vezes, até esquecidas. Borges expõe, através da sua literatura, a lógica de um mundo onde prevalece a desordem e o princípio da lei está oculto ou ausente. $\mathrm{O}$ escritor, que sempre confessou sua aversão a uma literatura que fosse presa a pressões ideológicas, no prólogo ao livro de contos $\mathrm{O}$ informe de Brodie, pronuncia uma espécie de manifesto à liberdade de escrever:

Só quero esclarecer que não sou, nem jamais fui, o que antes se chamava um fabulista ou um pregador de parábolas e, atualmente, um escritor comprometido. Não aspiro a ser Esopo. Meus contos, como os d'As Mil e Uma Noites, pretendem distrair ou comover e não persuadir. Este propósito não quer dizer que me encerre em uma torre de marfim. Minhas convicções políticas são demasiadamente conhecidas; filiei-me ao partido conservador - o que é uma forma de ceticismo - e ninguém me taxou de comunista, nacionalista ou antissemita. Acredito que com o passar do tempo mereceremos que não existam governos. Nunca dissimulei minhas opiniões, nem mesmo nos duros anos, mas não

\footnotetext{
Doutora em Literatura / UFMG.

${ }^{2}$ SARLO, Beatriz. Borges, un escritor en las orillas. Buenos Aires: Anel, 1995. p.177.
}

permiti que interferissem em minha obra literária, a não ser quando fui assaltado pela exaltação da Guerra dos Seis Dias ${ }^{3}$.

Esse texto poderia bem anteceder e ser uma chave de leitura dos contos "O milagre secreto", e "Deutsches Requiem" . Neles, a intervenção e a reversão da ordem estabelecida dá-se, reiteradamente, através de desdobramentos, imagens especulares, ambiguidades e reversibilidade de papéis quando se refere à representação da realidade.

$\mathrm{Na}$ medida em que Borges, pela ficção, entrelaça, aos abusos e desmandos que intentam obliterar a voz e o direito, as ambíguas e sutilíssimas formas de se burlar o poder e a força, ele efetua a transformação da ordem em espetáculo, minando, dessa forma seus tentáculos. As estratégias da ordem que são instauradas para negar o direito e a memória dos homens - são esgarçadas, submetidas a saques, trocas e apropriações e o discurso totalitário é atravessado por artimanhas, plágios irônicos e desvios deslegitimadores.

\section{Um milagre urdido em segredo}

No conto "O milagre secreto" a reversão do silêncio e da morte, dáse, sobretudo, pela imposição de um tempo mágico que insurge dentro da história e instaura a desconstrução através de recursos irônicos que trazem para o texto o excesso de lucidez que causa males e infortúnios.

Segundo alguns críticos, instaura-se nesse conto um tempo sagrado que emerge do tempo profano - o tempo do relógio e do calendário, a que o ser humano classifica como passado, presente e futuro ${ }^{6}$. O tempo sagrado seria, por essa perspectiva, uma brecha criada pela ficção no tempo profano. Um tempo da irrupção de uma outra instância que iria, em transcendência, recriar possibilidades diversas de formas paralelas.

No conto de Borges, a janela que se abre no discurso e que instaura um outro tempo de natureza fantástica abre uma brecha na máquina de

${ }^{3}$ BORGES, Jorge Luis. Obras Completas II. Buenos Aires: Emecé, 1989. p. 399. A Guerra dos Seis Dias (junho de 1967) foi um conflito armado entre Israel e as nações árabes, Egito, Jordão e Síria, apoiados pelo Iraque, Kuwait, Arábia Saudita e Sudão.

${ }^{4}$ BORGES, Obras Completas I, 1989. p. 499.

${ }^{5}$ BORGES, Obras Completas I, 1989. p. 576

${ }^{6}$ Cf. HENRIKSEN, Zheiyla. Tiempo sagrado y tiempo profano en Borges y Cortazar. Madrid, 1992 
morte e de esquecimento representada pelo nazismo. Ítalo Calvino, anos depois, nas Seis propostas para o próximo milênio, na sua primeira conferência dedicada à leveza, de uma certa forma, reescreve esse outro olhar que Borges parece instaurar nesse conto: "às vezes, o mundo inteiro me parecia transformado em pedra: mais ou menos avançada segundo as pessoas e os lugares, essa lenta petrificação não poupava nenhum aspecto da vida. Como se ninguém pudesse escapar ao olhar inexorável da Medusa ${ }^{7}$.

O espetáculo do mundo e o ritmo picaresco e aventuroso da escrita, afirma Calvino, procuram retirar o peso, a inércia e a opacidade do mundo. Tais características aderem à escrita, quando não se encontra um meio de se fugir a elas. O reino do humano condenado ao peso necessita de uma mudança do ponto de observação. Na literatura sempre se abrem outros caminhos a explorar, novíssimos ou bem antigos, estilos e formas que podem mudar nossa imagem do mundo ${ }^{8}$.

Este modo é a leveza. Para Calvino, uma forma de se escrever o mundo fundamentada em outra lógica que não a imposta e preestabelecida. $\mathrm{O}$ escritor ou artista que salta ágil sobre os obstáculos e sobreleva o peso do mundo demonstrando que sua gravidade detém o segredo da leveza e se contrapõe àquilo que muitos julgam ser a vitalidade dos tempos e que pertence ao reino da morte, como, diria Calvino, um cemitério de automóveis enferrujados ${ }^{9}$.

Configuraria, portanto, "O milagre secreto" um exemplo de narrativa que se utiliza de estratégias as quais Calvino chamou de leveza, de dissolução da opacidade e do peso do mundo através da escrita e da memória. No conto, o personagem Jaromir Hladík, ao saber que vai ser executado pelos nazistas que invadiram Praga, pede a Deus que lhe conceda um ano de vida para terminar a escrita de uma peça que estava escrevendo.

A epígrafe do conto é um fragmento do versículo (259 ou 261) do Alcorão: "E Deus o fez morrer durante cem anos e depois o animou e lhe disse: - Quanto tempo estiveste aqui? - Um dia ou parte de um dia, respondeu" 10 . Esse resíduo do Alcorão, além de colocar o leitor diante de

\footnotetext{
${ }^{7}$ Cf. CALVINO, 1992.p. 16

${ }^{8}$ Cf. CALVINO, 1991. p. 19-20.

${ }^{9}$ Cf. CALVINO, 1991. p. 24

${ }^{10}$ BORGES, Obras Completas I, 1989. p. 508
}

um enigma, referenda a construção poética de Borges através de fragmentos esparsos dos mais inusitados acervos culturais.

Ao trançar esse texto ao relato da morte de um escritor judeu, Borges parece ter em vista a construção de um tecido amplo, tão amplo que pode fazer convergir, sem conflito, sem superposição, as vozes que, fora da ficção, muitas vezes se elevam como inimigas. No discurso literário, a riqueza cultural das nações coopera para o enriquecimento do tecido literário. No relato muçulmano, entabula-se uma alegoria a propósito do poder de Deus. Recorre-se a uma disputa entre Nemrod, um monarca que reinou na Babilônia, e o patriarca Abraão ${ }^{11}$.

Esse conflito reverbera no conto através da metáfora do jogo de xadrez e também da peça inconclusa do personagem escritor intitulada $O s$ inimigos. Esse jogo de espelhos entre as peças do jogo de xadrez e os personagens, na ficção e dentro da ficção, o teatro dentro do conto, busca, sobretudo, embaralhar as referências e perder o mapa da origem das citações. Ao reduplicar os acervos culturais através das disputas que são contrapostas na narrativa, Borges efetua um deslocamento da condição linear e, talvez, irreversível, salvo pela ficção, de algumas dessas disputas milenares e compõe, dessa maneira, uma rede em que o leitor se vê irremediavelmente preso.

A introdução do conto "O milagre secreto" é notável por sua precisão nas referências a lugar e tempo:

$\mathrm{Na}$ noite de catorze de março de 1939, num apartamento da Zelnergasse de Praga, Jaromir Hladík, autor da inconclusa tragédia Os inimigos, de uma Vindicação da Eternidade e de uma interpretação das indiretas fontes judaicas de Jakobe Boehme, sonhou com um extenso xadrez ${ }^{12}$.

Os fragmentos textuais que se espelham na narrativa de Borges contrastam com a exatidão da introdução. Essas referências quase sempre revelam também complexas apropriações da realidade que funcionam como pontos estruturantes da narrativa. A começar pelo prenome do protagonista - não muito comum em espanhol -, que estabelece um diálogo com um

${ }^{11}$ ALCORÃO Sagrado. São Paulo: Otto Pierre Editores Ltda, 1980. p. 31. Livro 3, 5a Seção, $1^{\text {a }}$. Parte: p. 258-259.

${ }^{12}$ BORGES, Obras Completas I, 1989. p. 508 
texto pertencente à literatura de língua alemã. Jaromir é o nome de um personagem do romance Der Golem, de Gustav Meyrink ${ }^{13}$.

Sabe-se que Borges começa a estudar alemão em Genebra em 1916, logo depois da publicação do romance que se deu em 1915. Anos mais tarde, publicou o poema "O Golem". No arquivo literário do escritor argentino, o texto de Meyrink foi acessado algumas vezes de forma notável, para a construção ficcional desse poema e dos contos "O milagre secreto" e "As ruínas circulares".

Tanto no poema quanto nas narrativas reitera-se a condição de reversibilidade do homem enquanto criador e criatura e a possibilidade da construção da realidade a partir de um espelhamento entre o sonhado e o vivido. Nesses textos, um sonhador cria um homem para finalmente descobrir que ele mesmo é também o sonho de um sonhador. No poema, o espelhamento entre o criador e a criatura promove essa atmosfera onírica em que o indivíduo encontra-se preso num tempo cíclico e num destino de aparências e simulações.

O sobrenome Hladík, segundo Daniel Balderston, é referência a um obscuro romancista tcheco da virada do século, Václav Hladík (18681913) ${ }^{14}$. Entre escritores canonizados e conhecidos em todo o mundo ocidental, Borges embaralha outros não tão conhecidos, mas que, no entanto, estão presentes nos verbetes da Enciclopédia Britânica ou em histórias falsas ou ficcionais da literatura. Essa é uma estratégia comum da narrativa borgiana que não se furta a inventariar verbetes falsos, proliferar conhecimentos simulados e inventar bibliografias de escritores inexistentes.

A mais importante rua de Praga, em que Hladík vive, cujo nome alemão é Zeltnergasse, agora conhecida como Celetná, foi onde, no número 3, residiu a família de Kafka de 1896 a 1906. Nessa mesma rua, no número 12, foram localizados os negócios de Hermann Kafka de 1906 a 1912. Ao

\footnotetext{
${ }^{13}$ Etimologicamente, Jaromir é um nome tcheco, composto pelas palavras: jar, jaro, jarni (primavera) e mir (paz). Literalmente, Jaromir significa primavera da paz. Hladík significa desejar; logo, Jaromir Hladík significaria primavera de paz desejada, de acordo com o Etymologicky Slovnic, citado por HURTADO, Haydée Bermejo, DE TUMA, Mercedes Paglialunga. Consideraciones en torno a "El milagro secreto", de Jorge Luis Borges. In: Cuadernos del Sur. Bahia Blanca, 1984, jan / dec, n. 17. p. 68.

${ }^{14}$ BALDERSTON, Daniel. Out of context: historical reference and the representation of reality in Borges. Durham / Londres, 1976. p. 37-47.
}

entrelaçar ruas, números e escritores, Borges redesenha a cidade de Praga encenada na escritura e a eleva à condição de ficção, fazendo-a ser atravessada por escritores que se encontram no terreno virtual da literatura.

$\mathrm{O}$ uso dos nomes alemães para muitos dos lugares no conto é resultado de um conhecimento de Borges dos acontecimentos históricos e sociais que marcaram a cidade. Durante muito tempo, Praga e o resto da Boêmia fizeram parte do Império Austro-Húngaro e, ao fim da II Guerra Mundial, era substancial a população que falava alemão, como foi o caso de Kafka, Max Brod e Franz Werfel, por exemplo. Durante o período republicano, por vontade da maioria da população, os nomes alemães foram substituídos por nomes tchecos.

Borges utiliza outros nomes próprios como Jaroslav, que pode ser uma referência, segundo Balderston, a outro romancista tcheco, Jaroslav Hasek (1883-1923), autor do romance The adventures of the good soldier Svejk in the World War (1921-1922). Esse mesmo nome reaparece no protagonista da peça de Hladík, Los enemigos, como Jaroslav Kubin. O sobrenome, Kubin, pertenceria a um artista de Praga Alfred Kubin, amigo de Kafka e de Max Brod, informa Balderston.

Numa série de espelhamentos, repetições e referências cruzadas entre ficção e realidade, Borges homenageia personalidades austríacas, como Meyrink, e tchecas, como Kafka, Max Brod e Alfred Kubin. Tecer uma rede literária com esses nomes certamente é uma homenagem, mas também é, antes de tudo, a construção de uma vibrante tradição literária de escritores e artistas que, em meio à adversidade, edificaram suas obras multiculturalmente, e minaram o poder das instituições. Assim, além da língua, ou da condição de anexado - como Praga e Áustria - numa literatura menor, os textos foram se configurando enquanto resistência ${ }^{15}$.

Apesar da insistência de alguns teóricos, como a sueca Zheyla Henriksen, na afirmação de que é um tempo sagrado que emerge do tempo profano no conto de Borges, destaco, sobretudo, a possibilidade de, em meio à adversidade, criar-se um espaço/tempo, como diria Calvino, uma

${ }^{15}$ Cf. DeleuZE, G., GUATARRI, F. Kafka, por uma literatura menor. Trad. Júlio Castafion Guimarães. Rio de Janeiro: Imago, 1977. 
tentativa de reconhecer quem e o que, no meio do inferno, não é inferno, e preservá-lo, e abrir espaço ${ }^{16}$.

Esse espaço/tempo criado pelo personagem-escritor, no momento em que está para ser fuzilado pelos soldados nazistas, poderia ser uma intervenção divina. O milagre secreto, então, prefiguraria uma possível redenção do escritor e de sua obra. No entanto, algo da ordem do humano se urde sob os desígnios da escritura borgiana. Transcorrido o instante fugaz do que se pensa ser um ano, a inevitável descarga da bala atinge o escritor. Para esses personagens que desafiam a morte, um outro tempo, um outro espaço precisa ser vislumbrado.

Em "O milagre secreto" o que parece sobreviver à morte é a memória literária do personagem. Sua obra inconclusa espelhada no jogo de xadrez contrapõe "os inimigos". Há para o leitor um impasse entre uma inimizade que atravessa as instâncias narrativas e caminha inevitavelmente para a morte e para o fim de todas as narrativas possíveis.

No drama inconcluso de Jaromir Hladík, os personagens que aparecem na primeira cena e morrem na segunda reaparecem na terceira. Um homem que já havia sido morto na primeira cena retorna na terceira e assim, infinitamente. $\mathrm{O}$ cenário final é o mesmo em que se começou a peça: o relógio marca as mesmas sete horas, o sol se reflete nos cristais e o ar traz de novo uma apaixonada música húngara. A repetição anula o desenvolvimento da narrativa e demonstra, como queria Hladík, que o tempo é uma falácia ${ }^{17}$.

Se o tempo é uma falácia à disposição do argumento, na narrativa esse tempo só pode se dar através de uma vindicação da eternidade, um tempo sem futuro e sem passado. Por isso, a exatidão na referência ao tempo e ao espaço no princípio do conto estabelece conexões entre Borges, Kafka e outros tantos escritores que permeiam o universo, que, tal qual uma biblioteca, é infinito e especular.

Ligam-se, portanto, os livros escritos por Hladík ao projeto borgiano de solapar, através da narrativa, a transcendência do "milagre secreto". A tragédia inconclusa Os inimigos, a Vindicação da Eternidade e uma análise

${ }^{16}$ Cf. CALVINO, Ítalo. As cidades invisiveis. Trad. Diogo Mainardi. São Paulo: Companhia das Letras, 1991. p. 150

${ }^{17}$ BORGES, Obras Completas!, 1989. p. 510 das fontes judaicas indiretas de Jakob Boehme constituem provas inquestionáveis do exercício intelectual judaizante de Hladík.

Além disso, seu sobrenome materno era judaico, seu sangue era judeu, ele havia assinado um protesto contra a anexação da Áustria à Alemanha, conseguida por Hitler em 1938 e desfeita em 1945, após o término dali Guerra Mundial. Hladík traduziu o Sepher Yezirah - o livro judaico da criação. Enfim, Jaromir Hladík é um homem marcado para morrer. E ele morrerá mil mortes antes que o tiro fatal o atinja. A estrutura desse e de outros relatos de Borges cria, sob a forma de inclusão, reflexão ou bifurcação, a repetição, que é cíclica e impiedosa, mas que no instante fugaz de sua manifestação se apresenta como uma possibilidade.

A identidade judaica de Hladík é denunciada e Julius Rothe o condena à morte. Não existe, segundo a narrativa, homem que fora de sua especialidade não seja crédulo. Assim, ao folhear um catálogo da editora que publicara o livro judaico traduzido por Hladík, Rothe reafirma a culpa e a identidade do personagem. O efusivo catálogo exagerou comercialmente o renome do tradutor e ele, ironicamente, é condenado como judaizante.

A tarefa de tradutor, seu nome e suas preocupações em relação ao texto judaico o conduzem à morte. No entanto, esse mesmo texto judaico dará a ele a possibilidade de burlar a morte, mesmo que imaginariamente.

A obra inconclusa será aberta eternamente, mas o seu criador se contentará com o tempo que remonta às Escrituras para circunscrever e enganar a morte. $\mathrm{O}$ tema do milagre urdido secretamente no conto de Borges remete ao episódio da doença do rei de Judá, Ezequias, filho de Acaz, e sua cura milagrosa. Ele tinha 25 anos quando começou a reinar e reinou por 29 anos em Jerusalém. De acordo com a narrativa bíblica, foi vitorioso nas batalhas e em todos os empreendimentos obtinha êxito ${ }^{18}$.

O Livro de Reis afirma que Ezequias guardava os antigos mandamentos de Moisés, sob esses mandamentos reinava sobre Judá e vencia poderosos inimigos. Além disso, Ezequias fez construir o açude e o aqueduto que levava água para dentro de Jerusalém. Esse empreendimento, em caso de guerra, era fundamental à sobrevivência. Então, ele adoece. Uma úlcera mortal lhe aflige o corpo. Isaías, o profeta, entrega-lhe a dolorosa mensagem de que Deus

${ }^{18}$ BIBLIA Sagrada. II Reis, cap 19-20. 
ordenara que ele colocasse em ordem a sua casa porque morreria. $\mathrm{O}$ rei, no entanto, era obstinado e cria nas promessas que tanto prezava. Orou, pois, e pediu a cura para a úlcera. Antes mesmo que o profeta saísse da parte central da cidade, lhe é ordenado que voltasse e profetizasse a cura do rei, porque Deus lhe havia ouvido as preces e visto as suas lágrimas.

Ao rei é ordenado, então, que vá à casa do Senhor para dar graças tanto pelos 15 anos que seriam acrescentados à sua vida, quanto pela vitória sobre os assírios que lhe seria concedida. Ezequias pede ao profeta um sinal de que tudo isso se cumpriria. Este responde ao rei que a sombra do relógio podia adiantar ou atrasar. Ezequias escolhe que o sinal seja que a sombra do relógio se atrase: "Então o profeta Isaías clamou ao Senhor; e fez retroceder dez graus a sombra lançada pelo sol declinante no relógio de Acaz"19.

O apego e a fé na tradição dos pais - a observação dos mandamentos de Moisés - garantem ao rei a sobrevivência diante da morte. O tempo, marcado pelo relógio de sol construído pelo pai, retrocede e lhe confirma o milagre da cura e do adiamento da morte. A casa de Ezequias necessitava ser posta em ordem. Deus lhe concede esse tempo para o trabalho, para a tarefa de terminar os empreendimentos iniciados.

Em Borges, no entanto, o milagre secreto não é apenas o apego à tradição dos pais, mas uma especulação sobre a possibilidade de se deter o tempo petrificado e introduzir nele um outro tempo, o tempo fluido da memória, da atualização da tradição. Não para terminar materialmente a peça inacabada, mas para construir uma espécie de fantasmagoria ou desejo de viver e trabalhar os vestígios da memória. O tempo concedido ao escritor judeu é, portanto, o tempo da memória. Memória da leitura dos livros, não só a do seu livro especificamente, a peça Os inimigos - que como uma caixa chinesa ou o jogo de xadrez duplica ao infinito as possibilidades de sobrevivência à morte pela lembrança - mas também de outros tantos textos que se urdem no tempo possível da ficção.

O milagre secreto em Borges parece ser, então, não um milagre de Deus, do Deus que prolonga o tempo de Ezequias, mas o milagre da memória que mantém precariamente vivas as narrativas do mundo. Nesse

\footnotetext{
${ }^{19}$ BÍBLIA Sagrada. II Reis. Cap.20, ver. 11. Esse relógio de sol, construído pelo pai de
Ezequias, o rei Acaz, consistia, segundo parece, de uma série de degraus em redor duma

${ }^{19}$ BÍBLIA Sagrada. II Reis. Cap.20, ver. 11. Esse relógio de sol, construído pelo pai de
Ezequias, o rei Acaz, consistia, segundo parece, de uma série de degraus em redor duma coluna. A hora era indicada pela sombra nesses degraus.
}

sentido, a memória - com suas perdas irreparáveis e os seus vestígios passíveis de serem narrados - é o triunfo do escritor nesse tempo de morte, é trabalho do homem e para o homem.

A literatura poderia, assim, ser vista como um trabalho sempre inconcluso que não se manteria por milagres secretos, letras perdidas entre as páginas de uma biblioteca, um arquivo morto que parece só poder levar a ensaios equivocados sobre a cegueira, mas no sutil e fugaz momento em que a memória permite acessar resíduos e pegadas de textos passados e revitalizá-los no presente.

\section{O último suspiro do carrasco}

Como uma espécie de narrativa especular, o conto "Deutsches Requiem" reelabora o tema da morte e da escrita a partir de um ponto de vista, no mínimo, inusitado. Contrapondo-se à voz do personagem judeu Jaromir Hladík, do conto "O milagre secreto", a voz narrativa desse outro conto é de Otto Dietrich zur Linde - um torturador nazista - que, na noite que precede a sua execução, rememora sua vida e sua luta pela construção do Terceiro Reich comparando-as à construção da Alemanha e ao futuro do mundo.

Como responsável por um campo de concentração, coube-lhe a tortura e o testemunho do suicídio de um poeta judeu chamado, emblematicamente, David Jerusalém, a quem, segundo afirma, admirava profundamente. Esperando a morte sem nenhum temor ou remorso dos atos praticados, Otto Dietrich zur Linde acredita que o nazismo impôs uma nova ordem ao mundo e, a partir dessa condição, um novo homem foi produzido graças às suas ideias e atuações. $\mathrm{O}$ seu destino é visto por ele como heroico. Ele concebe o nazismo como uma missão e, dessa forma, pode morrer serenamente porque está convicto de que a ordem sonhada pelo nazisocialismo triunfou.

O título é uma explícita referência a Ein Deutsches Requiem, (O Réquiem Alemão, 1868) de Johannes Brahms. O vocábulo latino "réquiem" diz respeito à parte do ofício dos mortos, na liturgia católica, que principia com as palavras latinas requiem aeternam dona eis, ou seja "dai-lhes o repouso eterno". A palavra também se refere à música executada nesse ofício. Nessa concepção, o réquiem é uma oração pela paz dos mortos que esperam angustiados a terrível ameaça do juízo final. 
O Réquiem Alemão se dirige aos vivos para convencê-los de que o fim da existência terrestre não deve ser temido, já que traz consigo a paz e a libertação definitiva de todos os males e preocupações mundanas. Trata-se de um canto de felicidade e de serenidade absolutas. As trombetas do Juízo estão despojadas de todo horror apocalíptico, e integradas como um signo feliz e glorioso de uma vida nova ${ }^{20}$.

Os versos do réquiem de Brahms foram retirados da Bíblia. São versos do livro do Profeta Oséias, capítulo 13, verso 14: "Tragada foi a morte na vitória. Onde está, ó morte, o teu aguilhão? Onde está, ó inferno, a tua vitória?"21

A composição de Brahms é o primeiro ofício dos mortos escrito em língua alemã, mas não se trata da tradução literal do serviço fúnebre tradicional da Igreja Católica. Brahms escolheu e recortou os textos entre os versos da tradução da Bíblia de Lutero. Os textos provêm do chamado Antigo Testamento (Oséias 13: 14) e do Novo também (I Co. 15:55), incluindo referências do Livro da Revelação ou Apocalipse (Ap. 14:13). Numa espécie de mosaico, o réquiem de Brahms reitera a fé como meio de sobrevivência e de redenção universal.

A universalidade dessa composição assume, certamente, em Borges uma reflexão ainda maior. O mistério da morte tal como ela se apresenta através da ficção, é condição de todos os homens. Nesse sentido, as humilhações, os fracassos ou a morte de Otto zur Linden, ou dos nazistas, por extensão, não é a morte de todos os alemães, assim como a sua imaginada vitória não pertence a ideia do nazismo, mas também, de forma assustadora, ao poeta David Jerusalem.

A ironia da narrativa borgiana está presente na epígrafe retirada do Livro de Jó, Capítulo 13, verso 15: "Ainda que me tire a vida, nele confiarei”. Nesse capítulo do famoso livro, o fiel Jó é arrasado por intrigas diante de Deus, que permite ao inimigo tocar na carne, flagelando-o com doenças, matando-lhe os filhos, e nos bens do sincero e temente Jó. Nesse trecho, Jó declara sua confiança em Deus: “Ainda que Ele me mate, n’Ele

${ }^{20}$ CARRANZA, Luiz Rodrigues. Requiem por un fim de siglo. In: Anthropos - Revista de documentación científica de la cultura. Una teoria de la invención poética del lenguaje. n. 142 / 143, mar. / abr. 1993. Barcelona, Editorial Anthropos, 1993. p. 87-91.

${ }^{21}$ BIBLIA Sagrada. I Coríntios. Cap. 15, ver. 55. esperarei; contudo, os meus caminhos defenderei diante d'Ele. Também isso será a minha salvação porque o ímpio não virá perante Ele. Ouvi com atenção as minhas razões, e com os vossos ouvidos a minha demonstração. Eis que já tenho ordenado a minha causa, e sei que serei achado justo"22.

Tal como Jó, Otto Dietrich julga-se justificado. Não conhece nem a esperança nem a angústia e vive o presente. Afirma o narrador que esperava ser um soldado de uma guerra inexorável e, no entanto, ferido por duas balas quando passava por trás de uma sinagoga, amputaram-lhe as pernas: tudo, naqueles anos, era diferente, afirma, inclusive o sabor do sonho. Eu nunca fui plenamente feliz, acrescenta, mas é sabido que a infelicidade requer paraísos perdidos ${ }^{23}$.

A liturgia católica, a música de Brahms e os textos bíblicos juntamente com a história factual e a filosofia são reelaborados por Borges e esse discurso da tradição ocidental, da morte e da finitude é reencenado por indivíduos que são atravessados pela memória de todos esses textos. $\mathrm{O}$ personagem Otto Dietrich é civilizado, culto, artista, e sua fé no nazismo o justifica. Borges percebe que admirar a música, a filosofia e a arte e ser um torturador e assassino é um projeto estético nazista e não uma contradição.

Susan Sontag em "Fascinante Fascismo" adverte que, embora comumente se pense que o nacional-socialismo represente somente a brutalidade e o terror, isso não é bem verdade. O nacional-socialismo e o fascismo representam um ideal, ou ideais que persistem até hoje, em maior ou menor grau sob outros rótulos. O ideal de vida como arte, o culto à beleza, o fetichismo da coragem, a dissolução da alienação em sentimentos extáticos de comunidade, o repúdio ao intelecto, a concepção de uma família do homem (sob a paternidade de líderes) são ideais que sobrevivem e comovem muitas pessoas ${ }^{24}$.

O "novo homem" do conto de Borges é engendrado, segundo o narrador, por um fato moral, um despojar-se do velho homem, que está viciado, para vestir o novo que é tentado, em um torpe calabouço, por antigas ternuras da piedade. $\mathrm{O}$ novo, sem afeto nem compaixão, é a

${ }^{22}$ BÍBLIA Sagrada. Jó cap. 13 ver. 15. p. 523.

${ }^{23}$ BORGES, Obras Completas I, 1989. p. 579.

${ }^{24}$ SONTAG, Susan. Fascinante Fascismo, In: Sob o signo de saturno. Trad. Albino Poli Jr. Porto Alegre: L\&PM, 1986. p. 59. 
manutenção da ordem até a morte, a qualquer preço e a configuração de uma estética que Borges, de uma certa forma, anteviu.

Nesse sentido, a narrativa de Borges é denunciadora. Ela evidencia a desumanização do homem e a sua consequente transformação em autômato que se autojustifica. Daí a busca em muitos dos seus textos, como nesse, das raízes da violência. Não obstante, Borges não se detém na descrição pormenorizada, não faz catálogo nem inventário da inscrição do sofrimento no corpo do indivíduo; ao contrário, reserva a referência do domínio da violência ao silêncio ou ao território estético.

A tortura à qual é submetido o poeta David Jerusalem não passa de um gesto. A relação de Otto Dietrich com o escritor judeu é pautada pela luta contra a compaixão que seria, nesse contexto, o único elo possível entre os seres vivos e, para o torturador, retorno a um passado selvagem. Dessa forma, o discurso do torturador nazista é contraposto, em discrepância, com a sua simpatia pelo escritor judeu e o afastar de si a piedade, que seria, para ele, a mácula que deveria ser esquecida pelo novo homem:

Era este um homem de cinquenta anos. Pobre de bens deste mundo, perseguido, negado, vituperado, havia consagrado seu gênio a cantar a felicidade. Acredito recordar que Albert Soergel, na obra Dichtung der Zeit, o equipara com Whitman. A comparação não é feliz; Whitman celebra o universo de um modo prévio, geral, quase indiferente; Jerusalem alegra-se de cada coisa, com minucioso amor. Jamais emprega enumerações, catálogos. Ainda posso repetir muitos hexâmetros daquele profundo poema que se intitula Tse Yang, pintor de tigres, que está como que raiado de tigres, que está como carregado e atravessado de tigres transversais e silenciosos ${ }^{25}$.

David Jerusalem conseguiu em seus textos a captação de uma ordem múltipla, o infinito em cada individualidade metaforizada pelos tigres transversais e silenciosos, elementos que, no campo do imaginário, como a escrita, atravessam a ordem. Assim, no discurso do seu algoz, David Jerusalem não é referência a um indivíduo, mas a todos os homens vitimados pela violência. Ao simbolizar todos os homens num único homem, vítimas e algozes de si mesmos, sua voz não é unívoca, mas plural. A tortura infligida por Otto Dietrich a David Jerusalem - um ponto cego no texto que omite sua descrição e penúria - transparece no desejo de civilização e na violência. $\mathrm{O}$ escritor judeu enlouquece e, nesse território do desespero, suicida-se.

Suicidando-se, o escritor judeu impôs sua vontade e se liberou da tortura, a partir disso, acabou por se inscrever no discurso e na memória do seu carrasco. Otto Dietrich pensa que o suicídio de Jerusalem representa o triunfo do nazismo, mas a morte, nesse círculo infinito e insondável, a pirueta final, o suicídio da vítima que desse modo se vê livre da tortura, é uma vitória, sob o ponto de vista da vontade, mas, no reino solitário da loucura, em que o personagem vislumbrou o único ato de autonomia, emerge, paradoxal, a liberdade na morte.

O testemunho da morte do escritor judeu transmigra, ironicamente, para a narrativa do seu torturador e ali se inscreve como uma força subliminar, silenciosa. $\mathrm{O}$ réquiem construído por Borges arma textos, dilui fronteiras, rearranja acervos inusitados e, sob os auspícios da literatura, deixa confluir citações, nomes falsos, arquivos nefastos e registros da memória.

\footnotetext{
${ }^{25}$ BORGES, Obras Completas I, 1989. p. 578-579
} 


\section{Vozes consoantes: os artistas judeus e a MPB nos anos de Vargas}

\section{Orlando de Barros ${ }^{1}$}

A entrada de imigrantes judeus no Brasil manteve-se regularmente na década de 20, incrementando-se na de 30 , mormente em virtude da tensão política na Europa, havendo então uma propensão persecutória que, de fato, se instalou, vindo a provocar o Holocausto. Até 1937, quando a burocracia de Vargas, à frente Francisco Campos, no Ministério da Justiça, pôs em prática uma política restritiva aos "semitas" ou "israelitas", a busca de abrigo no Brasil se incrementou. É claro que muitos desses judeus chegados ao Brasil eram das mais variadas origens sociais e profissionais, e dentre eles, muitos eram artistas, não sendo poucos os que se dedicavam à música. Constitui, pois, um assunto muito interessante a introdução e assimilação desse contingente à criação musical brasileira. É justamente o que queremos avaliar nesse trabalho, posto que a questão integra um dos pontos essenciais do estado de ser dos judeus brasileiros, a assimilação, da mesma forma como privilegia também um ponto essencial da cultura brasileira, mormente a carioca, a da "originalidade" e "autenticidade" da música popular, um dos aspectos fortes dessa cultura.

Nas diversas instâncias em que a questão da imigração de "semitas" foi examinada, na década de 30, seja no CIC ou no Ministério da Justiça e Negócios Interiores, conforme os pareceres técnicos ou documentos legais restritivos, um dos pontos essenciais foi justamente o da assimilação cultural. De resto, ao sabor de uma transiência de ideias alienígenas antissemitas, ainda mais presentes, principalmente até 1938, pelas manifestações fascistas do integralismo brasileiro, não raro o tema da inassimilabilidade dos judeus volta e meia esteve à baila, em declarações de homens públicos e na imprensa, chegando mesmo a vir em letras de canções. É possível que muito disso se possa atribuir a um antissemitismo difuso, de caráter religioso tradicional, de origem ibérica e colonial, mas será no calor da hora varguista que a questão da assimilação cultural dos

\footnotetext{
${ }^{1}$ Doutor em História/USP / Professor do IFCH/UERJ.
}

judeus se instaurou como ideia restritiva de peso, capaz de operar decididamente em favor do impedimento da imigração de judeus, com dramático resultado, naquele momento de emergência na Europa. Veja-se, por exemplo, a instrução seguinte, aos cônsules no estrangeiro:

Não haverá inconveniente em dizer-se ao Israelita, naturalmente com discrição e evitando-se ferir susceptibilidades, que o visto lhe é negado porque a sua admissão não responde aos interesses do Brasil que, na imigração, procura unicamente indivíduos que se assimilem na população brasileira, o que raramente se dá com os Israelitas².

\section{E esse outro exemplo:}

Até mesmo na relação de candidatos a cargos públicos encontramos, em proporção crescente, nomes de estrangeiros ou filhos de estrangeiros de assimilação difícil ao meio brasileiro: judeus e orientais, v. gratia. $(\ldots)^{3}$

\section{E, ainda, por fim:}

(...) A entrada maciça de judeus no território brasileiro se tem verificado, nestes últimos tempos, com notória constância. Ora, o judeu é absolutamente inassimilável e mais do que qualquer outro povo concorre para o desnaturamento da população. A falta de ligação afetiva com a terra de nascimento não oferece a menor garantia de fidelidade a de adoção. Eles formam uma estranha comunidade a parte, cujas relações com o resto da sociedade se limitam exclusivamente aos negócios, e em geral aos negócios de mera especulação. A verdade', escreve uma judia, Elizabeth Stern, 'é que o judeu se exclui a si próprio; o orgulho de sua raça e de sua fé constrói um muro entre ele e o resto da humanidade'. (I am a Woman anda Jew, p. 226) (.... $)^{4}$

Assim, chegava-se mesmo a apelar para obras de proselitismo antissemita, comuns na época, para estribar as restrições à imigração dos judeus, muitas vezes aditando à "inassimilabilidade" outros conceitos desqualificadores, como os de parasitas da economia popular, financistas

\footnotetext{
${ }^{2}$ Apud Fábio Koifman, Quixote nas trevas, o Embaixador Souza Dantas e os refugiados do Nazismo, Rio de Janeiro, Record, 2002, p. 129. O autor transcreve o documento, do qual

${ }^{3}$ Idem, p. 141.
Idemos parte.

${ }^{4}$ Idem, p. 154.
} 
cosmopolitas, incapazes de amar a terra de adoção e de se sacrificar por ela, subversivos de todas as naturezas, mascates que enfeavam as cidades, invasores de bairros de onde encravavam sua cultura e crença particulares. Com efeito, embora raro, o preconceito contra os judeus chegou também à cultura popular. Por exemplo, referindo- se às presenças dos regentes Kosarin, Bountman e Gluckmann no meio cultural popular carioca, assim se refere a eles Orestes Barbosa, fazendo coro com a voz oficial influenciada pelo integralismo: "Estes e outros judeus que tudo fazem para entravar o surto do que é do Brasil" Orestes Barbosa expressava uma corrente então comum, a que se opunha à participação de estrangeiros (e de seus filhos) na cultura e na vida nacional, sendo o notável poeta e compositor também um lusófobo conhecido.

Noel Rosa, "sutil e contido", também se opunha aos "estrangeirismos", e não deixou de se render ao preconceito sublimado do tempo. Pode-se considerar que as passagens em suas letras que se referem aos "prestamistas" sejam meros registros de um estado da sociedade de então, mas é inevitável o estabelecimento de uma relação com os termos ou ideias vizinhas, e nela se estabelecem inequivocamente disforia e desabono aos judeus. Seja esse trecho de "São coisas nossas", de 1930:

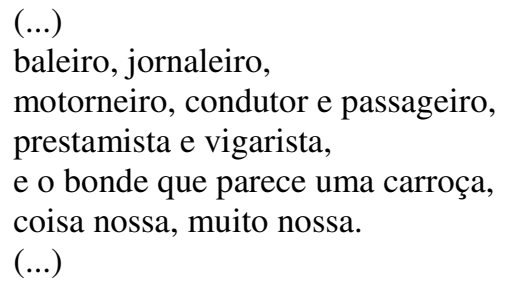

$\mathrm{Se}$, nesse trecho, o prestamista aparece achatado entre os termos dêiticos de estados sociais e profissionais dos que se transportavam nos bondes, fica a dúvida se o mencionado "vigarista" deve ser entendido como tal ou se é um qualificativo do prestamista. E, ainda, em "Voltaste", de 1934, novamente o prestamista aparece, sem saber se ele é judeu ou "turco", mas em qualquer caso "semita", que tanto fazia para as restrições

\footnotetext{
5 Apud João Máximo e Carlos Didier, Noel Rosa, uma biografia, Brasília, Editora Universidade de Brasília, 1990, P. 244.

"A expressão a respeito de Noel Rosa "sutil e contido" é de Máximo e Didier, Op. cit., p. 244. Quanto aos estrangeirismos, é possível ver a opinião de Noel Rosa na canção "Não tem tradução (cinema falado)", de 1933.
}

oficiais, que os tinham como imigrantes indesejáveis, em qualquer caso. Da mesma forma, é bom dizer que também o prestamista aqui aparece como um oposto aos interesses populares, como um credor inoportuno:

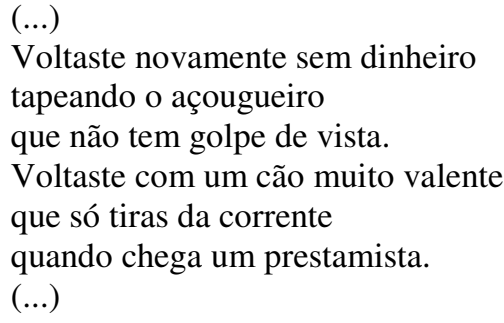

Também, em 1941, ao sabor da vigência das portarias restritivas do ministro Francisco Campos, temos outra citação desqualificadora. É no samba de breque "Amigo urso", de Henrique Gonçalez ${ }^{7}$. Trata-se de um simulacro de carta que um credor escreve a um devedor, cobrando uma dívida:

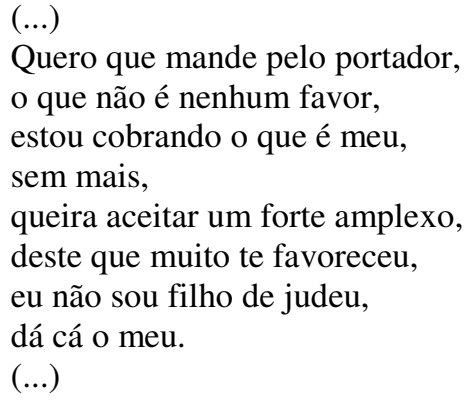

$\mathrm{Na}$ direção do preconceito tradicional, de origem religiosa, também ocorre, curiosamente, uma desqualificação na canção "Dona História" , de data incerta, da autoria de Moreira da Silva, aliás intérprete da supracitada "Amigo urso", que versa sobre o tema da traição, trazendo como paradigma o mito do traidor congênere, representado por Judas Iscariotes, que se apresenta como um arquétipo histórico e "naturalizador" da "permanência" da vilania da traição. E, assim, citamos as canções que conhecemos que, de

\footnotetext{
7 "Amigo urso", samba (Henrique Gonçalez), intérprete: Moreira da Silva. RCA Victor 34754B, M52179. Gravado em 12.4.41, e lançado em jun. de 1941. Fonte: CD "O. Silva, A. Miranda, M. da Silva, O. Amaral - Coqueiro Velho", Revivendo.

8 "Dona História, com licença", samba (Moreira da Silva), intérprete: Moreira da Silva. Não temos outra indicação de arquivo, exceto que é de 1942.
} 
uma maneira ou outra, apresentam ou aludem a situações baseadas nas crenças tradicionais ou em fragmentos discursivos que bolem com o substrato antissemita. E muitas outras deve haver, sincréticas, a pedir exegese e explicação, de qualquer sorte indicativas de um tempo já superado e definitivamente desmentido pela presença do judeu no Brasil, pelas suas relações objetivas, de insofismável integração na sociedade brasileira, em todos os planos.

Tendo em mente a questão da assimilação cultural, sempre se deve indagar a respeito da questão da "exposição" dos judeus recém-chegados ao Brasil à cultura popular brasileira, isto é, levando em conta a ambiência judaica e as situações que propiciaram o estreitamento de seus contatos com a criação cultural popular. E, nesse caso, se deve considerar como paradigmática a situação particular do judeu no Rio de Janeiro, local de maior importância para a criação e difusão musical, dos anos 20 aos 40, e mesmo depois.

Desde a Primeira Grande Guerra, os judeus chegados ao Rio procuravam preferentemente as áreas centrais ou suburbanas, para, mais adiante, melhorando de vida, procurar os bairros da orla marítima. Notória é a população judaica da Praça Onze e arredores, compreendendo também parte da Cidade Nova. Mas não é desconhecido também que os judeus habitavam a região da Lapa, a rua da Misericórdia e as vizinhas, e os arredores da Praça Tiradentes, desde os anos 20, pelo menos. A habitação dessa área decorreu de muitas razões. Em primeiro lugar pelo fato de que havia um sem número de pensões e hotéis baratos, lugares de imediato abrigo para imigrante recém-chegado, que, mais tarde, acostumado com os arredores, preferia residir nas proximidades de seu local de chegada. Depois, porque, havendo já uma concentração inicial, o arribante encontrava um ambiente social, cultural e religioso que lhe era propício. E, ainda, fator muito importante, essas localidades eram de prédios predominantemente antigos, muitos datando dos anos 70 do século anterior, de baixo valor de compra ou de locação.

Além disso, deve-se considerar também que as áreas habitadas pelos judeus no centro da cidade contavam com uma estrutura de serviços e equipamentos urbanos de importância, como eletricidade, gás, água, e transporte, sem contar com muitas escolas públicas, especialmente o Colégio Pedro II, considerado modelar, e que serviu a gerações de alunos judeus. Outro fator de grande importância foi a região ser muito bem servida de transporte barato, em virtude dos bondes que passavam pela Visconde de Itaúna (substituída pela avenida Presidente Vargas na reforma urbana de Dodsworth), e pelo trem suburbano, convenhamos, utilíssimo para os "prestamistas", para conceder que muitos judeus, de fato, o eram, sendo o transporte em direção aos seus fregueses habituais fator essencial.

Ocorre que as áreas preferidas pelos judeus no Rio de Janeiro eram também aquelas de grande importância para a criação e reprodução da cultura popular. A Praça Onze foi, até 1941, o local carnavalesco por excelência, lugar das escolas de samba nascentes, dos desfiles de blocos, do lançamento dos sambas e marchas carnavalescas, que os compositores testavam para obter gravação, edição e irradiação. Nas proximidades ficava o famoso dancing Kananga do Japão, que reunia os "pés-de-valsa" habituais, músicos, dançarinas, e um sem número de frequentadores ciliares, que procuravam tirar proveito da concentração de gente.

Também ali ficava a Casa da Tia Ciata, importante polo concentrador e conservador cultural das práticas religiosas dos negros, de criação musical e de danças afro-brasileiras. Constituía um ponto de convergência da população negra e "baiana", por isso conhecida como a Pequena África do Rio de Janeiro 9 . Ali se produziu muito de música popular, sendo um lugar frequentado, para usar um termo da época, pelos "bambas" de então, como Pixinguinha, Heitor dos Prazeres, Bucy de Almeida, Baiaco e muitos malandros famosos, como este último.

A Lapa, então lugar de cabarés e cassinos, estes mais tarde clandestinos, também possuía seus cafés, conhecidos por reunir os compositores populares. Foi conhecida área de prostituição e de vida noturna intensa, sendo seus arredores também uma localidade de habitação popular. Contígua estava a Praça Floriano, com a qual findava a avenida Rio Branco, lugar onde começou, em 1916, a formar-se a Cinelândia. Ao longo da grande avenida, e em suas transversais, na década de 20, havia um sem número de casas de espetáculos, da mais variada natureza. Entre a Lapa e a Cinelândia, havia o Passeio Público, onde clubes, cassinos e um parque serviam muito à vida artística e boêmia. Esse mesmo complexo

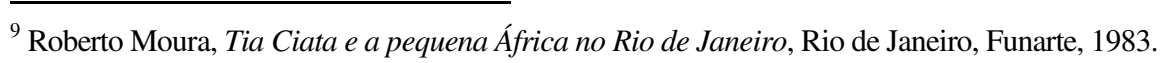


compreendia a Carioca, onde ficavam o Lírico e o Café Nice, e onde ficou até a década de 20 o teatrinho da Velha Guarda ${ }^{10}$.

Na Praça Tiradentes, e em seus arredores, também havia muito de espetáculo e diversão. Lá ficavam os teatros de revistas, um dos pontos fortes do entretenimento carioca, entre eles casas importantes, como o São José, o Recreio e o Carlos Gomes, e também o João Caetano, que servia a outro público, e não muito distante, o Fênix, a Maison Moderne, o República (na Gomes Freire), as cervejarias e parques, que, no passado, foram precedidos pelos chopes berrantes ${ }^{11}$. Zona boêmia e alegre mais ou menos desinterditada, sobremodo à noite, essas áreas centrais da cidade não deixaram de transitar entre o "crime e o pecado", como a elas se referiram alguns cronistas da época, em virtude da presença da delinquência, da prostituição e da corrupção, que engendravam ${ }^{12}$. Com efeito, se na Lapa, área de prostituição, moravam judeus, muitos mais habitavam a Cidade Nova, que se iniciava pela Praça Onze, se estendendo até o Mangue, zona de prostituição consentida, particularmente nas ruas Pinto de Azevedo e do Carmo. Ao fim da Cidade Nova, vinha o Largo do Estácio, lugar de sambistas famosos, e, logo em seguida, o Morro de São Carlos, onde nasceu a primeira escola de samba.

Explicado o ambiente urbano em que os judeus habitaram como adventícios moradores, cabe indagar se seria mesmo possível, de qualquer modo, que eles pudessem instituir seu enclave, tal como denunciara a burocracia antissemita, mesmo se o quisessem. De qualquer modo, se os guetos existiram na Europa, bem o sabemos que foram os produtos de uma segregação externa, e não o contrário, embora reforçado pela necessidade de autoproteção e preservação da cultura e da tradição judaica. Podemos supor o quanto de constrangimento devia provocar aos austeros judeus, com sua ética

${ }^{10}$ Ver Luiz Edmundo, O Rio de Janeiro do meu tempo, Rio de Janeiro, Conquista, 1957, v. 2 e 3. Ver também Jota Efegê Uoão Ferreira Gomes), Figuras e coisas da música popular brasileira, Rio de Janeiro, Funarte, 1978. 2 vs. Jota Efegê Uoão Ferreira Gomes), Meninos, eu vi, Rio de Janeiro, Funarte/INM, 1985. Bororó (Alberto de Castro Simoens da Silva), "Gente da madrugada [Flagrantes da vida noturnal", Rio de Janeiro, Guavira, 1982.

${ }^{11}$ Os chopes berrantes eram bares animados com a música dos gramofones. Grande novidade no começo do século, definharam a partir de 1910. Ver, a propósito, João do Rio, A alma encantadora das ruas, Rio de Janeiro [19081, Biblioteca Carioca, 1995.

${ }^{12}$ Ver, a propósito, Benjamim Costallatt, Mistérios do Rio, Rio de Janeiro, Biblioteca Carioca, 1995, bem como Ribeiro Couto, A cidade do vício e da graça, Rio de Janeiro, Arquivo Público, 1998 (Coleção Fluminense), ambas obras escritas em 1922 e publicadas em 1924. religiosa sempre à frente, conviver com o convite ao desvio permanente, pois não devia ser fácil educar os filhos num ambiente muitas vezes perigoso. Mas o que se observa, ao cabo do tempo, é justamente uma tolerância, produto da ausência de conflito ou choque de monta, ou, pelo menos, nenhum chegou a nosso conhecimento até agora. Sendo assim, o mínimo que podemos supor é que predominou - se não foram laços de total integração com o ambiente -, pelo menos, uma inegável tolerância; aliás, de parte a parte.

Numa outra perspectiva, as mesmas áreas habitadas pelos judeus, ou suas cercanias, eram aquelas onde se produziam a canção popular e outros gêneros da cultura de massa. Não só havia as casas de entretenimento onde se reproduziam as criações, mas também o local predominante dos compositores e autores. Nesse aspecto, devemos demonstrar o quanto se produziu de assimilação e aceitação dos elementos culturais populares brasileiros, não fosse também uma oportunidade que não se podia perder, para um sem número de artistas judeus, cantores, instrumentistas, arranjadores e orquestradores, dançarinos e pessoal técnico. Os imigrantes que aqui chegavam sob a classificação de "artistas" não foram poucos, principalmente desde o começo dos anos 30 até 1937, e registremos que isso foi de real desagrado para a burocracia antissemita. A imprensa registrou isso em alguns momentos, às vezes, de modo jocoso; mas, de qualquer modo, dando um registro precioso do espírito do tempo. Eis, por exemplo, como uma crônica do jornal "A Noite" viu, sob o título Assunto novo, assinado por Puck, pseudônimo de quem não queria mesmo se expor naquela hora, o incremento da chegada dos judeus perseguidos na Europa:

A alegria ou a dor no Rio de Janeiro tem destinos idênticos: a letra de samba. Se o indivíduo está contente, disposto a distribuir a sua felicidade, é a caixa de fósforos quem a transmite aos conhecidos; se está melancólico é ainda a mesa do "café" quem recolhe o produto da sua tristeza, misturadas com os compassos do chapéu de palha. O marido abandonado, o barracão vazio são ainda ótimos motivos, fornecidos pelo noticiário cotidiano, para serem transformados em melodias de sucesso.

Todos os grandes acontecimentos da vida carioca terminaram os seus dias na pauta musical das nossas marchinhas. Qualquer fato de repercussão pode ser encontrado nas colunas desses jornais de modinhas, onde os "crooners" improvisados vão catar o reforço para o repertório interpretado à hora do banho. Se você deixou de ter uma notícia de sensação, não precisa 
se aborrecer: aguarde o aparecimento das últimas letras de samba: lá estarão, em verso, todos os detalhes das tragédias, ou das comédias que preocuparam a cidade.

A história do Rio cabe inteirinha dentro do samba e das marchas. O carnaval tem registrado, com precisão matemática, todas as oscilações do espírito carioca. As suas fases de melancolia ou de prazer podem ser descobertas diante da audição de todos os sucessos. Veremos como a evolução musical é o espelho fiel da transformação espiritual. E se algum dia, um psicólogo quiser desvendar os recantos da alma da cidade, o seu primeiro trabalho será a consulta a discos carnavalescos, onde estão gravadas as vacilações do nosso subconsciente...

Os refugiados atualmente presentes no Rio ainda não seguiram esse itinerário comum. Até agora não apareceu o samba do refugiado:

"No meu barraco encontrei um refugiado..."

Ou então, a marchinha saltitante e irreverente, cheia de alegria:

"Refugiada - ô-ô I Refugiada - ô-ô I Você é o meu amô"..."

Que diabo! Ou os nossos compositores estão dormindo ou na superprodução de assunto, coisa muito explicável, numa época em que todo mundo sofre da mesma enfermidade... ${ }^{13}$

O texto em questão, tão rico em alusões, registra, com efeito, em primeiro plano, o incremento dos ingressos de refugiados, a tal ponto significativo que se poderia tomá-lo como tema carnavalesco. A canção carnavalesca tinha, na época, muito do espírito da revista de ano, servindo para registrar e repassar os acontecimentos marcantes. Mas, num segundo plano, e de uma maneira mais profunda, também alude a um outro plano consequente, o da integração dos refugiados à realidade carioca. Alguns desses refugiados não eram judeus, mas é verdade que a maioria o era, e bem estavam a par disso as autoridades, tanto que se sucediam as portarias e atitudes restritivas, produzidas sob a alegação de "segurança" do Estado, para prevenir as infiltrações de espiões e agentes de toda espécie, quando não fosse simplesmente pela entrada do imigrante tido por "indesejável" à integração na sociedade brasileira.

\footnotetext{
13 “A Noite”, 16.1.1941, Edição de 11 horas, p. 4.
}

Mas a crônica de Puck aponta em direção contrária. Supõe uma atitude relaxada e espontânea do carioca, mediante uma de suas representações culturais predominantes, a canção popular, ante a recepção do refugiado. Instala, pois, uma contradição essencial, entre a atitude oficial e a popular, esta última francamente tolerante e simpática. De qualquer sorte, não deixa de ser curioso o fato de que o jornal que estampa a crônica em questão ser "A Noite", que, naquela altura, constituía-se numa espécie de porta-voz oficial do regime, sob controle do DIP, uma vez que o patrimônio do grupo "A Noite" se incorporara à União no ano anterior à edição em apreço.

Fato é que se deu uma entrada significativa de artistas judeus no Brasil, desde os anos 20, número muito aumentado nos 30. Muitos deles eram violinistas e praticantes de outros instrumentos de corda, causando uma melhoria significativa na execução musical. Examinando, por exemplo, a lista dos músicos da Rádio Mayrink Veiga, constata-se que o naipe de cordas é predominantemente de executantes judeus, provenientes do leste europeu ${ }^{14}$. Também na Rádio Nacional podemos vê-los, sob a batuta de um violinista judeu que ali se tornou um regente permanente, Romeu Ghipsman. É sabido que o violino tinha imensa popularidade e tradição entre os judeus, sendo de origem judaica alguns dos maiores virtuoses internacionais. Mas a chegada dos violinistas foi registrada na imprensa carioca como advento dos "ciganos". É claro que os ciganos, também perseguidos na Europa, tinham motivo para arribar à nova terra. Mas, é claro que os "ciganos" em questão eram, na sua maioria, refugiados judeus, que se introduziam nos mais diferentes espetáculos, encontrando trabalho e fazendo de tudo para encontrar um lugar ao sol. Eis como, noutra crônica, Puck registra o acontecimento, sob o título de Um pouco de sentimentalismo:

Todos os violinistas ciganos da Europa se refugiaram na América. E trouxeram, além do violino e do "Danúbio Azul", essa faculdade admirável de encantar o público, capaz de despertar igual sentimento lírico num par de vinte anos, que comemora o nascer de um romance, e um casal que festeja as Bodas de Ouro. As suas melodias, carimbadas pelos "vistos" de todos os "bas-fonds" europeus, cujas peregrinações se estendem de Paris ao Cáucaso, invadiram subitamente o Rio de Janeiro, cidade que vive, precisamente, os primeiros romances de amor.

\footnotetext{
${ }^{14}$ Arquivo Nacional, Rádio Mayrink Veiga, Livro de Registro de Pessoal
} 
Faltava-nos isso: o "virtuose" que sai da penumbra, misterioso qual um fantasma, para benzer o chope ou o uísque com que se festeja a primeira página de um romance. Esse Paganini sem glória, que nasceu e morrerá no anonimato, porque a fortuna se opôs a que seguisse o curso numa grande escola, será o grande padroeiro dessa nova fase de lirismo que invadia a cidade.

Copacabana está cheia de violinos que vieram de cabaré em cabaré, atravessando muitas garrafas de champanhe, parar no Rio de Janeiro, metrópole cuja história lhes era desconhecida, cujo povo lhe era estranho. Porém o "virtuose" que aprendeu a colorir romances em Viena, sabia que o Rio era igual às outras capitais onde sempre sobra um pouco de tempo para o amor.

Quando desembarcou, a Baía de Guanabara o recebeu de braços abertos, como se fosse o detalhe que lhe faltava. Agora sim, seria possível realizar grandes aventuras noturnas, com passeios ao luar, confissões amorosas e momentos de enlevo. Porém o artista de cabelos louros e tristonhos olhos azuis não sabia que o samba estava à sua espera, irritado com a invasão do intruso, candidato á sua coroa, disposto a derrotá-lo e asfixiá-lo.

Preparou-se então o grande complô. E o "virtuose" cujos dedos alisavam, trêmulos, a "Serenata de Schubert", inesperadamente, viuse cercado pela multidão de cuícas e tamborins. E não teve outro remédio. Enquanto os seus companheiros se retiravam furtivamente, ele, o violinista romântico, lançava aos ventos os primeiros compassos de "Amélia" 15 .

Aqui, fora o notável registro pitoresco do momento, também se ressalta o tema da integração, pois o sucesso do instante, o samba carnavalesco "Amélia", se apresenta como um paradigma cultural da terra, que o violinista arribante adotou em seu repertório de adaptação ${ }^{16}$. Mas, se "cigano" é bem possivelmente "judeu", também certamente é "russo", dado que muitos espetáculos de grupos que se exibiam como "moscovitas" se anunciavam no Rio de então, em casas de luxo, como os cassinos da orla marítima, justamente nos anos em que se incrementavam as perseguições na

\footnotetext{
15 “A Noite”, 6.6.1942, Edição de 11 horas, p. 4 e seguinte.

16 A canção em apreço é "Ai! Que saudades da Amélia", samba (Ataulfo Alves, Mário Lago), intérprete: Ataulfo Alves e sua Academia de Samba. Odeon 12106A, M6869, gravado em 27.11.1941. [Carnaval de 19421. Fonte: LP "Os Grandes Carnavais do Passado - v. 4". Moto Discos, 1989
}

Europa. Dentre essas exibições, uma das mais interessantes foi a de um grupo que provocou grande frequência às casas onde se exibiu. Assim a ele se referiu o "Diário da Noite":

O coronel Nagaetz é talvez um dos mais brilhantes e imprevistos renovadores dos motivos musicais e coreográficos do folclore russo. Agora mesmo, com o concurso de artistas famosos recentemente chegados da Europa, está dirigindo o "Coro Russo Baian", admirável conjunto de orquestras de balalaicas, solistas e dançarinos que estreará hoje à noite, dando-lhe aspectos imprevistos de originalidade e beleza, no "Grill-room" do Cassino Atlântico. São danças antigas cossacas, russas e ucranianas, acompanhadas de canções magníficas e realçadas por um vestuário de grande riqueza e espetacularidade. Os bailarinos de Nagaetz deixaram um sulco de aplausos em Londres, Madri, Berlim e Viena e sua aparição no "Grill” da casa de diversões do Posto 6, constituirá um dos mais belos acontecimentos da temporada. A bailarina Nagaetz e mais quatro bailarinos típicos criarão números especiais, absolutamente originais e evocando as mais interessantes estilizações coreográficas cossacas e ucranianas ${ }^{17}$.

O problema da identificação dos judeus nos espetáculos da época é grande, pois muitas vezes o refugiado adota nome artístico que não permite saber sua origem precisa, e bem o fazia, não só pelas exigências da profissão, mas também porque o clima oficial antissemita sugeria prudência ao recém-chegado, que ainda desconhecia que, admitido no Brasil, superadas as dificuldades da entrada, cessavam os problemas e ficava garantida uma vida sem constrangimentos no país. Muitos desses artistas, depois de fazerem sucesso momentâneo, com seus escamoteados nomes artísticos, acabavam por se fundir e desaparecer do plano artístico, integrando-se na vida comum. E para os pesquisadores, não restam senão dúvidas, dada a impossibilidade de uma identificação eficaz, passadas seis décadas. Eis um registro que muito ilustra o que afirmamos, pois a artista em questão, depois das récitas mencionadas, pouco aparece em seguida em espetáculos de primeira classe:

Norka Rouskaya, acaba de se apresentar ao nosso público no Copacabana. Nas duas únicas récitas que nos ofereceu, a festejada artista visitante teve oportunidade de realçar os méritos de que é

17 “A estreia, hoje, no Cassino Atlântico, do Coro Russo Baian”, no "Diário da Noite", 30.5.1936,1a. p., com foto do casal Nagaetz. 
portadora, interpretando com apurada técnica e rara sensibilidade, ao violino, cantando ou dançando, autores difíceis, dos mais consagrados. Em Kreisler ou Debussy; Mozart, Schubert ou Schumann, Rossini ou Mignone; Strauss, Chopin ou Massenet, Norka Rouskaya esteve sempre firme, recebendo, por isso fartos aplausos ${ }^{18}$.

Pouco se vê, mais tarde, o nome de Norka Rouskaya, da mesma maneira que outros artistas, certamente por terem tido outras oportunidades na vida, ou porque, quem sabe, procurou outro destino. Mas, na imprensa, aqui e ali, volta e meia, tomamos conhecimento deles, às vezes participando ativamente das campanhas beneficentes durante a guerra, seja em espetáculos organizados pela Legião Brasileira de Assistência, seja em campanha de auxílio às tropas que se enviariam em expedição à Itália. Como exemplo, citemos o espetáculo realizado no estádio do Fluminense, em 19 de janeiro de 1943, em benefício do fundo de guerra, em que um grupo de artistas do Corpo de Baile do Municipal, ao lado de esportistas, se esforçava para aumentar a arrecadação de dinheiro. $\mathrm{O}$ grupo de artistas era formado por bailarinas judias: Madeleine Rosay, Yuco Lindberg, Gertrudes Wolff, Leda Yuqui e Lorna Kay ${ }^{19}$.

Muitos desses artistas apresentam nomes artísticos que podem identificar claramente sua origem judaica. Outros não, mas, em alguns casos, pudemos identificar seus nomes verdadeiros. No primeiro caso estão, por exemplo, Ghita Yamblonski e Moisés Friedman. No outro caso, podemos citar: Madeleine Rosay (Madalene Rosenzveig), Ivone Martin (Ivone Stevanovich), Lia Renée (Renée Grossman), Lidia Stuart (Lidia Rempalski) e Madame Lou (Helena Soulknovsky). Em muitos outros casos, as informações da imprensa não permitem uma identificação conclusiva: Marcel Klass, Paulo Marra (Paulo Marra Monnerat) e Rzepecki Staniseaw (Eric Rzepecki). Klass foi tenor de prestígio, sendo uma estrela dos cassinos e muito participou das campanhas mencionadas. Já Rzepecki, que chegou como refugiado, tornando-se um técnico inovador no teatro e no cinema e, mais tarde, na televisão, às vezes é identificado como judeu, às vezes não. É o mesmo que se passa com Ziembinski, sendo este um dos refugiados trazidos ao Brasil pelo visa salvador do embaixador Souza Dantas, em Paris ${ }^{20}$.

\footnotetext{
18 "No Copacabana", em "Fon-Fon", 17.7.1941, Ano XXXV, n. 29, p. 28.

19 "Em benefício do fundo de guerra", em "A Noite", 5.1.1943, Edição final, p. 8

${ }^{20}$ Koifman, Op. cit., p. 204
}

Assim, esperamos ter estabelecido o fato de que não foram poucos os artistas judeus que entraram no Brasil como imigrantes nos anos 20 e, como refugiados, nos 30, e que eles logo acabaram por participar ativamente dos espetáculos no Brasil, especialmente no Rio. Cabe fazer um levantamento daqueles que lograram maior sucesso na nova pátria. Nunca é demais lembrar que sua contribuição, pela assimilação dos gêneros culturais da terra, foi de grande monta, na música principalmente, mas também no teatro e no cinema. De resto, também contribuíram significativamente para a instauração de uma face importante da modernidade de então, a fixação da cultura de massa, seja no rádio, nas gravações, nas edições de partituras e no cinema. Curioso que, nesse caso, se produzia uma contradição curiosa: esses artistas vinham contribuir decididamente para a modernização do país, fato alheio à burocracia antissemita, que não atentava para a meta fundamental do regime a que servia, o da modernização do país, o da industrialização e o da superação do atraso estrutural e cultural em que o país estava mergulhado havia tempo.

No caso dos que mais se destacaram nas diversas mídias da cultura de massa, deve-se dar relevo aos regentes, compositores e instrumentistas. Alguns lograram celebridade, como Simon Bountman, Romeu Ghipsman, Arnold Gluckmann, Inácio Kolman e Georges Moran. Outros eram meros executantes nas orquestras empregadas nas gravações e restaram esquecidos. Mas a audição atenta de velhas gravações, às vezes nos permite descobertas muito interessantes. Ouvindo a introdução da clarineta na canção "Comendo Bola", marcha de Hekel Tavares e Luís Peixoto, gravada na Columbia por Jaime Redondo, em dezembro de 1929, constata-se que o executante ainda estava se adaptando aos gêneros da terra nova, pois o fraseado e o tratamento tonal são, indisfarçavelmente, os comuns da clarineta nas peças klezmers em que o instrumento é utilizado ${ }^{21}$.

Vamos, pois, considerar como mais relevante a contribuição musical dos artistas judeus que deixaram obra gravada. Mas, antes de fazê-lo, é bom

21 "Comendo Bola", marcha, (Hekel Tavares, Luís Peixoto), escrita para teatro de revista, peça política referente à campanha de Vargas em 1929, 'Mineiro com botas', de Luís Peixoto e Marques Porto, montada no República pela Companhia Margarida Max e Empresa Manuel Pinto e Cia. Gravada na Columbia pelo cantor Jaime Redondo, em Dez.1929. A comparação que fizemos foi com a faixa 7 do CD "Klezmer, yidish swing music", Soldore, Paris, 2002 música intitulada "Freilicher Yontov", original gravado em 1941 e transcrito na recente gravação digital 
abrir espaço para dar conta de que muito dela se deu no cinema brasileiro, e isso de diversos modos. Fizemos um levantamento dos filmes produzidos entre 1933 e 1955 e constatamos fatos interessantes. Em 1933, no filme "Onde a terra acaba", dirigido por Otávio Gabus Mendes, encontramos Romeu Ghipsman, regente e violinista, às voltas com a sonorização dos discos, fase transitória do cinema falado ${ }^{22}$. Ghipsman continuou a atuar em filmes: em 1937, sob direção de Oduvaldo Vianna, fez o filme, infelizmente inacabado, "Alegria", executando à frente da Orquestra da Rádio Nacional a partitura musical de Radamés Gnattali, filme esse em que aparece também Marcel Klass, no papel de um pianista de $\operatorname{bar}^{23}$. Dois anos depois Ghipsman voltaria à frente da mesma orquestra, na fita dirigida por Mesquitinha "Onde estás, felicidade?"24 O último registro cinematográfico de Ghipsman data do mesmo ano de 1939, "Romance proibido", dirigido por Adhemar Gonzaga, filme bem produzido, em que se destaca um bailado em grande figuração, num cenário brasileiro marajoara, com criação coreográfica e execução de Eros Volusia, vendo-se como figurante Fada Santoro, sendo que Ghipsman aparece regendo orquestra de 40 instrumentistas ${ }^{25}$.

Mais que Ghipsman, Simon Bountman, também regente e violinista, teria um papel relevante e constante em filmes de grande importância, sobretudo aqueles que, fixado o gênero chanchada, demarcariam o início do cinema industrial brasileiro. Em 1935, Bountman fez "Alô, Alô, Brasil!", dirigido pelo norte-americano Wallace Downey, o primeiro filme sonoro brasileiro a fazer sucesso, que ficou como modelo para os filmes seguintes do gênero ${ }^{26}$. Em 1935, com "Estudantes", também dirigido por Wallace Downey, Bountman e sua Orquestra voltariam às telas ${ }^{27}$. E de novo no ano seguinte, agora com o sempre lembrado (restaurado e reprisado nas telas e na televisão de hoje), "Alô! Alô! Carnaval", dirigido por Adhemar Gonzaga, que se constituiu num clássico do gênero, Bountman aparece em

\footnotetext{
${ }^{22}$ Cf. Alice Gonzaga, 50 anos de Cinédia, Rio de Janeiro, Record, 1987, p. 42. Infelizmente, nenhum filme do tipo que procuramos pôde ser encontrado em Fernão Ramos, História do cinema brasileiro, São Paulo, Círculo do livro / ed. Art, 1987, não obstante haver um catálogo substancial ao fim da obra, que se mostra, nesse caso, bastante incompleta.

${ }^{23}$ Idem, p. 70.

${ }^{24}$ Idem, p. 75.

${ }^{25}$ Idem, p. 77.

${ }^{26}$ Idem, P. 44.

${ }^{27}$ Idem, p. 46.
}

alguns trechos com sua Orquestra, inclusive na célebre cena na qual as irmãs Carmen e Aurora Miranda cantam o famoso "Cantores de rádio"28

Já a produção de 1941 "O dia é nosso", dirigida por Milton Rodrigues, teve orquestração e regência de Arnold Gluckmann ${ }^{29}$. Depois da guerra prossegue a cooperação de judeus nas fitas brasileiras. Moisés Friedman é o autor da canção "Zumba", do filme "Um beijo roubado", de 1946, dirigido por Leo Marten $^{30}$. Em 1948, Leon Gombang foi o responsável pela trilha musical e a regência de "Obrigado, doutor", dirigida por Moacyr Fenelon ${ }^{31}$. Nessa altura, já se pode dizer que o judeu havia sido "naturalizado" na cultura brasileira, não raro se apresentando em tipos como, às vezes, se fazia aos "turcos". Se o humorista Jorge Murad havia fixado o pitoresco "Turco Salomão" em seus programas de rádio, bem podia outro ator fazer o mesmo com o judeu. E assim o fez o compositor e cantor Adoniran Barbosa, representando um vendedor de móveis "israelita", em 1955, no filme estrelado por Arnaldo Weiss "Carnaval em lá maior", dirigido por Adhemar Gonzaga ${ }^{32}$.

Arnold Gluckmann (1894-1951), austro-húngaro, chegou ao Brasil provavelmente em 1917, vindo a ter pela vida a fora um papel muito relevante, sobretudo no rádio, tanto no Rio como em São Paulo, tendo falecido nessa última cidade ${ }^{33}$. Gluckmann, de quem temos uma foto, tinha tez morena e ficara calvo ainda moço. Era bom pianista e iniciou a vida como tal, com grande dificuldade devido ao número de competidores. Como de hábito nesses casos, demonstrou as qualidades de pianos à venda ou de partituras em lojas de editoras. Consta que suas incursões pelos gêneros

\footnotetext{
${ }^{28}$ Idem, p. 47.

${ }^{29}$ Idem, p. 98 .

${ }^{30}$ Idem, p. 111 .

${ }^{31}$ Idem, p. 146 .

${ }^{32}$ Idem, p.153-4.

${ }^{33}$ Máximo e Didier, Op. cit. p. 389 e nota 22: “... dizem que Arnold Gluckmann morreu em São Paulo, aos 54 anos, a 13 de maio de 1951, tendo chegado ao Brasil com 23 anos de idade". Nesse caso, Gluckmann teria nascido em 1897 e só poderia ter entrado no Brasil em 1920. Entretanto, Abel Cardoso Alves dá Gluckmann como nascido em 1894, e falecido aos 57 anos. E, assim, se de fato o regente chegou ao Brasil com 23 anos, ele aqui teria chegado em 1917. Preferimos essa data pela usual precisão de Cardoso Alves, além de ter sido ele um diligente radialista que muito colheu das memórias do rádio paulistano e brasileiro. Cf. Abel Cardoso Junior, Francisco Alves: As mil canções do Rei da Voz, Curitiba, Editora Revivendo, 1998, p. 53
} 
eruditos lhe renderam algumas exibições nas casas de destaque, como acompanhante de cantores líricos ou em duo de câmara, com violino. E assim conheceu o influente maestro Francisco Braga, que o recomendou como chefe de orquestra da recém-inaugurada (em 1924) Rádio Club do Rio de Janeiro. Mesmo depois, continuou esporadicamente como regente de música erudita. Em geral o descrevem como simpático, mas muito irritadiço em tudo que se referisse à perfeição da execução musical sob sua responsabilidade.

Tendo iniciado os programas de operetas vienenses, então muito populares, na Rádio Club, em 1936, por motivo do afastamento de seu assistente habitual, recebeu a colaboração de Noel Rosa, e com ele escreveu a opereta radiofônica de costumes cariocas "A noiva do condutor", que acabou não sendo transmitida, mas que resultou em algumas das mais importantes canções de Noel Rosa, tendo Gluckmann escrito várias outras, de gêneros brasileiros e internacionais ${ }^{34}$. Diz Abel Cardoso Júnior que Gluckmann gostava tanto do Brasil que se naturalizou brasileiro e veio a adotar um pseudônimo que não deixava dúvidas quanto a isso, Pery Pirajá, com o qual assinou algumas partituras. Tal foi o caso de "A Cruz das estrelas", uma valsa lenta, com letra de Oswaldo Santiago, "oferecido com grande distinção ao popular cantor brasileiro Francisco Alves",35. Sua admiração pelos compositores brasileiros, especialmente Noel Rosa, é fato conhecido. Mas não chegou a gravar muito, limitando sua atuação ao rádio. Uma exceção é o belo fox-canção "Era uma vez...", de Alberto Ribeiro e João de Barro, em interpretação de Arnaldo Amaral e Neide Martins, com a Orquestra do Rádio Club do Brasil, regida por ele, para a gravadora Columbia, e que entrou para a trilha musical do filme "Foot-Ball em Família", de $1939^{36}$.

Não sabemos muito sobre Romeu Ghipsman, exceto que nasceu na Ucrânia na virada do século e teve formação erudita em violino ${ }^{37}$. Chegou ao Brasil nos anos 20 e, no começo dos 30, apresentava-se no programa Case, na

\footnotetext{
${ }^{34}$ As informações sobre Gluckmann foram colhidas em Máximo e Didier, Op. cit., pp. 3839, e em Cardoso Júnior, Op. cit., passim, bem como no Arquivo do A.

${ }_{36}^{35}$ Cardoso Júnior, $O p$. cit.

${ }^{36} \mathrm{O}$ A. tem esse registro fonográfico em seu arquivo, e é o disco no. 55067A, MI 54, gravado em maio de 1939, e lançado em julho do mesmo ano. Quanto ao filme "Foot-Bal em Família", não encontramos ficha técnica. A canção em apreço apareceu em regravação recente, no CD "No tempo do fox", da Revivendo.

${ }^{37}$ Depoimento ao A. de Eduardo Ghipsman Valverde Magalhães, neto do regente Romeu Ghipsman residente em Juiz de Fora, por telefone, em junho de 2002.
}

Rádio Mayrink Veiga com artistas eruditos brasileiros, como os pianistas Mário Azevedo e Arnaldo Estrella, e a cantora lírica Violeta Coelho Netto de Freitas, numa época em que o programa admitia duas repartições, o clássico e o popular. Ali Romeu Ghipsman apresentava-se como solista ou acompanhante ao violino. Por essa época, também se apresentava nos cassinos do Rio, não sendo raro que os anúncios o qualificassem como "meteur-en-scène" dessas casas. Mais tarde teria uma oportunidade ímpar na música popular brasileira, à frente da orquestra da Rádio Nacional, dividindo com outros regentes a responsabilidade de acompanhar os maiores cartazes do rádio, nos mais diversos gêneros dos compositores populares mais conhecidos. Muitos dos espetáculos beneficentes do período de guerra têm Ghipsman como figura de destaque, conforme o noticiário da imprensa, mormente o de "A Noite"38.

Ghipsman também organizou orquestra e fez com ela algumas gravações, em certos casos verdadeiros clássicos da música popular. Tal é o caso de "Enquanto houver saudade", de Custódio Mesquita e Mário Lago, imorredouro sucesso de 1938, gravado na RCA Victor por Orlando Silva, com a Orquestra Victor Brasileira, com um belo acompanhamento ao violino de Romeu Ghipsman. Com a Orquestra Romeu Ghipsman, temos outro clássico, de 1941, o samba de exaltação "Canta, Brasil, cenas brasileiras", de Alcyr Pires Vermelho e David Nasser, em interpretação de Francisco Alves, para a gravadora Odeon. Sua orquestra estava ativa ainda no fim de 1951, ocasião em que gravou a "Fantasia brasileira n ${ }^{\circ}$ ", de Radamés Gnattali".

Outro regente de sucesso dessa época foi Harry Kosarin, que chegou ao Brasil depois da Primeira Guerra, proveniente dos Estados Unidos. No arquivo

\footnotetext{
${ }^{38}$ Outras informações colhidas em Máximo e Didier, Op. cit., p.324-5 [tratando do Programa Casé]. Também, entrevista de Casé a Luiz Carlos Saroldi, em 1979, Rádio Jornal do Brasil $\mathrm{AM}$, que o A. tem gravado em fita magnética. Da mesma forma, constam diversas menções em trechos digitados de "A Noite" (BN. Seção de Periódicos), no período da guerra, constantes do Arquivo do A.

39 "Enquanto houver saudade", valsa, (Custódio Mesquita e Mário Lago), intérprete: Orlando Silva, com Orquestra Victor Brasileira. Violino: Romeu Ghipsman. RCA Victor, 11.5.1938. Fonte: LP "Custódio Mesquita - História da Música Popular Brasileira”, n. 29, Abril. 1971. "Canta, Brasil. Cenas brasileiras", samba, (Alcyr Pires Vermelho e David Nas- ser), intérprete: Francisco Alves, com Orquestra Romeu Ghipsman. Odeon 12003A-B, M663-4, gravado em 20.5.1941. Fonte: LP "Chico Viola, Tributo a Francisco Alves" EMI/Odeon. "Fantasia brasileira n. 1", erudito, (Radamés Gnattali), intérprete: Orquestra sob regência de Romeu Ghipsman, com Radamés Gnattali ao piano. Fonte: fita magnética cassete "Assim era o rádio, v. 36”, Collector's/MIS, “20 Anos da Rádio Nacional, n. 1”, 12.9.1956, lado B.
} 
da SBAT (Sociedade Brasileira de Autores Teatrais) colhemos informação que Kosarin foi representante da congênere norte-americana, a ASCAP, para assuntos referentes aos direitos autorais das músicas aqui executadas, sendo a SBAT agente constituído no Brasil para a execução das cobranças. Em virtude desse papel de Kosarin, algumas vezes vemos uma ou outra discordância a respeito dos valores cobrados, motivo pelo qual não poucas vezes vemos desabono à sua conduta nas atas das reuniões do conselho. Kosarin tinha orquestra própria, com nome bem pitoresco, a "Harry Kosarin e seus Almirantes", ainda ativa nos anos 30. Com ela, gravou a marchinha "Assim, sim", de Francisco Alves, Noel Rosa e Ismael Silva, com Carmen Miranda, na Victor, com grande sucesso ${ }^{40}$.

Com a vinda de Kosarin para o Brasil veio também outro importante regente, arranjador e orquestrador, Simon Bountman (1900-1977). Boutman nasceu na Palestina e pouco depois de sua chegada ao país, formou orquestra própria com os remanescentes da primeira orquestra de Kosarin, à qual incorporou outros elementos. Com esse conjunto, pouco depois excursionou à Espanha, para tocar jazz, o novo gênero musical que fazia sucesso no mundo, depois da Primeira Guerra. Voltou ao Brasil, acompanhando a Companhia Velasco, de revistas e zarzuelas, provavelmente em 1924, e passou a tocar no Cassino do Copacabana Palace Hotel. Com um elenco de dez elementos fixos, desde fevereiro de 1928, somente ele e Inácio Kolman eram estrangeiros, sendo que o número de instrumentistas variava, ocasionalmente, nas gravações. Sua orquestra mudava de nome e elementos, conforme a gravadora e a ocasião: na Parlophon, era a Simão Nacional Orquestra, e, mais tarde, Orquestra Copacabana; e também Orquestra Columbia, quando fazia gravações nessa empresa $^{41}$.

Mas foi com a Orquestra Odeon, gravando discos para a fábrica do mesmo nome, que granjeou o prestígio que goza até hoje. A lista das gravações é impressionante, sendo que, em nosso arquivo, temos cerca de 200 registros catalogados. Os nomes de canções famosas se sucedem nesse alentado catálogo; assim como os nomes de grandes intérpretes e

40 "Assim, sim", marchinha carnavalesca (Francisco Alves, Noel Rosa, Ismael Silva), intérprete: Carmen Miranda, com Harry Kosarin e seus Almirantes. Victor 33581A, M65502, gravado em maio de 1932, e lançado em dezembro de 1932. Fonte: CD "Carmen Miranda", Revivendo.

${ }^{41}$ Cardoso Júnior, Op. cit., p. 53. compositores. Entre as canções, para falar de algumas: "Ladrãozinho" (1935), "Cadê Mimi" (1935), "Feitiço da Vila" (1934), "Fruto proibido" (1935), "Adeus batucada" (1935), "Cantores de Rádio" (1936), "Boneca de pixe" (1938), "Escrevi um bilhetinho" (1938), "Na Baixa do Sapateiro" (1938), "Recenseamento" (1940). Dentre os intérpretes que gravaram com Boutman citemos Francisco Alves, Mário Reis, Carmen Miranda, Aurora Miranda, Carlos Galhardo, Augusto Calheiros, Gastão Formenti, Gilberto Alves, Odete Amaral, Gilda de Abreu, João Petra de Barros, Roberto Paiva, Almirante, Barbosa Junior, Nuno Roland, Dircinha Batista, Joel e Gaúcho, Castro Barbosa e Jonjoca, e muitos outros além desses.

Dentre os compositores gravados por Bountman, autores de partitura musical ou letras, citemos os principais: Ari Barroso, Capitão Furtado, Laurindo de Almeida, André Gargalhada, José Gonçalves, Ari Kerner, Custódio Mesquita, Orestes Barbosa, Nássara, Aldo Cabral, Benedito Lacerda, Gastão Vianna, Roberto Martins, Mário Rossi, Osvaldo Santiago, José Maria de Abreu, Mário Rossi, Georges Moran, Assis Valente, Vicente Paiva, Milton Amaral, Sinval Silva, Hervê Cordovil, Alberto Ribeiro, João de Barro, Lamartine Babo, Joubert de Carvalho, André Filho, Herivelto Martins, Alcyr Pires Vermelho, Augusto Vasseur, Marques Porto, Luís Peixoto, Sá Roris, J. Cascata, Leonel Azevedo, e muitos outros, para falar dos mais frequentes. Somando-se as canções conhecidas às inolvidáveis interpretações dos cantores mais conhecidos, bem como ao conjunto das obras da época de ouro da música popular brasileira, segundo Lúcio Rangel, só mesmo muito poucos, um Pixinguinha ou um Gnattali, podem superá-lo no tipo de trabalho que realizou.

Bountman também tem sido sempre mencionado como um notável arranjador e orquestrador, mas, nesse caso, há alguma controvérsia. Máximo e Didier dão conta que muitas das orquestrações assinadas por Bountman são, em verdade, de Arnold Gluckmann ${ }^{42}$. Cardoso Júnior, a propósito da canção "Só para gozar" (J. C. Rondon, 1927), gravada por Francisco Alves, cita um recorte de 1931: "J. Rondon tem feito as mais originais orquestrações, matéria em que se tem revelado um verdadeiro mestre. J. Rondon é o braço direito de Simon Bountman e com ele forma uma dupla de grande finalidade musical" ${ }^{\prime 3}$. Entretanto, dado que Bountman efetuou uma lista tão grande de gravações,

\footnotetext{
${ }^{42}$ Máximo e Didier, Op. cit., p. 383.

${ }^{43}$ Cardoso Júnior, Op. cit., p. 53.
} 
podemos dar como certo que a ele se pode creditar um número extenso de arranjos e orquestrações, e que eles se integram no melhor do que se produziu em seu tempo.

Inácio Kolman, que, como Bountman, era remanescente da orquestra de Kosarin, também foi importante para a canção da época. Nas orquestras de Bountman foi primeiro saxofonista e muito se pode ouvi-lo nas suas gravações. Mas formou também suas próprias orquestras, sendo regente titular em cassinos e em algumas gravações. Duas dessas orquestras transientes chegaram a gravar grandes sucessos entre 1933 e 39, ao que sabemos: a Orquestra Lido e a Orquestra do Cassino da Urca, com as quais gravou a versão brasileira de "Mente, por favor (Say it isn't so)", em 1933, da célebre marchinha "Joujoux e balangandãs", em 1939, e "Iaiá Boneca", também em $1939^{44}$.

Kolman também foi compositor, e tão bem adaptado ao meio musical popular de seu tempo que escrevia letra e música, perfeitamente adequadas ao ambiente profissional da época. No tempo da Orquestra Panamericana, de Bountman, estabeleceu relações com Francisco Alves, então jovem cantor e crooner da orquestra. E foi esse cantor que gravou quatro das canções de Kolman. A marchinha carnavalesca "Autolotação" (1928?) é particularmente interessante, referindo-se às mudanças que ocorriam no Rio e aos novos hábitos que se incorporavam na modernidade de então. Compôs também, mais ou menos por essa época, os sambas "Língua de prata" e "Olhos negros", bem como o fox-trot "Foi um sonho"

Havendo, pois, uma participação tão ativa de artistas judeus, nas mais diversas atividades, no Rio e em São Paulo, principalmente, é de se perguntar se as relações com os profissionais brasileiros eram de perfeita integração.

44 “Mente, por favor" (Say it ins't so), fox-trot (Irving Berlin, versão de Raul Roulien). Intérprete: Raul Roulien, com I. Kolman e sua Orquestra Lido. Victor 33648B, M65669, gravado em fev. 1933. Fonte: LP "Gastão Formenti / Alda Verona / ${ }^{\circ}$ tília Amorim / Raul Roulien - Sempre Sonhando", Revivendo. "Joujoux e balangandãs", marcha (Lamartine Babo). Intérpretes: Mário Reis e Maná, com I. Kolman e a Orquestra do Cassino da Urca. Columbia 55155, gravado em 8.8.1939. Fonte: LP "Mário Reis", Continental, 1988. "Iaiá Boneca", marcha (Ari Barroso). Intérprete: Mário Reis, com I. Kolman e a Orquestra do Cassino da Urca. Columbia 55189, gravado em 13.11.1939. Fonte: LP "Mário Reis", Continental, 1988

45 A respeito das canções "Autolotação", "Língua de prata", "Olhos negros" e "Foi um sonho", ver Cardoso Júnior, Op. cit., respectivamente às pp. 87 (contém letra), 91, 136 e 187.
Não cremos que se deva levar muito em conta as citações desqualificadoras com as quais abrimos esse ensaio. No mais da conta as relações foram as melhores possíveis, e os artistas judeus estrangeiros foram muito bem recebidos. Encontraram trabalho regular e apoio do pessoal brasileiro. Alguns se mostraram muito simpáticos à situação dos judeus em face da perseguição. Oswaldo Santiago foi parceiro de vários compositores judeus, os quais procurou congregar na sociedade de direitos autorais que fundou. Davi Nasser, também "semita", como filho de libaneses, é o autor da letra de "Linda judia" e traz também à canção as sabidas boas relações que havia entre judeus e "turcos" brasileiros no comércio popular.

Entre os compositores, Custódio Mesquita foi o mais simpático aos judeus. É o autor da música da bela valsa sentimental "Linda judia", na qual oferece nova pátria e proteção à judia perseguida e desterrada, canção essa corajosamente cantada em 1940 por Francisco Alves ao microfone da Rádio Nacional, emissora controlada pelo DIP, órgão do MJNI, ministério no qual se localizava a brigada antissemita. A estreia de Custódio como compositor deuse em 1930, com a canção "O amor é um prejuízo", cuja letra era de um seu amigo e vizinho de Laranjeiras, Isaac Feldman. Custódio também escreveu uma revista teatral no tempo da guerra, "Ilha das Flores", na qual trata das agruras dos recém-chegados, em sua triagem e quarentena na zona portuária. Em 1941, casou-se com Helene Moukhine, bailarina de origem russa, nascida de refugiados em Istambul, e que viera para o Brasil graças à piedade de Jardel Jércolis, então associado a Custódio nas montagens de luxo do Teatro República, que a contratou em Paris em 1940, pouco antes da ocupação de Paris pelos nazistas ${ }^{46}$.

Deixamos, por fim, o exemplo mais notável e bem sucedido de integração cultural de compositor de origem judaica, Georges Moran. Em setembro de 2001 fomos curador de uma exposição realizada no Museu Judaico do Rio de Janeiro, em memória do centenário desse compositor, que ocorrido no ano anterior. Como Moran é quase desconhecido hoje em dia, deixando de constar das enciclopédias e textos de música popular, ensejamos uma extensa pesquisa junto ao Arquivo Nacional, à Biblioteca Nacional, sociedades de direitos autorais, editoras musicais e gravadoras, além de recolher material em coleções particulares e recolher memória em entrevistas. Com isso colhemos documentos, fotografias e reunimos umas 30 de suas

${ }^{46}$ Barros, Orlando de, Op. cit., passim. 
canções. O resultado foi a exposição aludida, para a qual preparamos também uma lista de sua discografia completa e de sua musicografia, sendo muitas dessas peças inéditas e não gravadas. Escrevemos um capítulo de livro que se publicará ainda em 2002, além de ter escrito o texto do folder da exposição. E é esse texto que, como um pequeno resumo de uma vida tão preciosa para a música popular, reproduzimos adiante.

Em 5 de julho de 2000, cumpriu-se o centenário de nascimento de Georges Moran, músico e compositor russo, natural de São Petersburgo. Moran deixou a Rússia em 1923, indo para a Alemanha, onde obteve um passaporte de apátrida. Ali conheceu Frida Pimsler, com quem se casou em Berlim, em 1931. Georges, Frida e Renée - a filha nascida em 1932 -, deixaram a Alemanha, em 1934, indo para a França, pois, em 1933, os nazistas haviam chegado ao poder, provocando o início de grande êxodo. Em 1934 ainda não havia, como haveria depois de 1937, no Estado Novo, objeção da alta burocracia aos imigrantes de origem judaica. Assim, muitos judeus se abrigaram no Brasil, entre os quais a família Moran.

Obtendo o visto brasileiro, a família embarcou no porto do Havre, em 9 de junho de 1934, viajando por três semanas na desconfortável terceira classe do vapor Bagé. O salvo-conduto francês assim descreve Moran: altura mediana, cabelos castanhos, orelhas normais, barbeado, olhos cinza, nariz médio, fronte alta, tez mate, forma oval dos olhos.

No Brasil, Moran não demoraria a se tornar um compositor de música popular bem conhecido, na voz dos mais destacados intérpretes, como Orlando Silva, Carlos Galhardo, Silvio Caldas, Francisco Alves. Moran é, portanto, um caso curioso: um compositor russo-brasileiro, hoje pouco lembrado, que formou dentre aqueles de uma época brilhante, talvez não igualada, da música popular brasileira.

Moran teve educação secundária, tendo estudado piano e violino na Rússia. Consta que começou a atuar no Brasil como músico excêntrico, tocando balalaica. Esgotando-se a novidade, fez parte de diversos pequenos conjuntos, quase sempre tocando violino ou piano. O Cadastro de Estrangeiros o registra em 1941 como de "profissão de artista músico", mas já havia cinco anos que iniciara sua carreira de compositor no Brasil, com diversas canções publicadas por editoras musicais, tendo gravado outras, com grande sucesso de público, sobretudo em 1938. Ainda que a vida profissional de Moran fosse um tanto precária, sujeita a altos e baixos, é fato que tinha bom tino profissional, trabalhando em revistas teatrais, em shows dos cassinos e nas estações de rádio, tendo se associado ao Sindicato dos Músicos Profissionais, sendo ainda sócio fundador da UBC e da ABCA, e foi também dos primeiros compositores populares a conseguir aposentadoria, em 1969.

Depois de ter trabalhado por 16 anos no Brasil, era a seguinte a sua situação, segundo um documento oficial: “... já trabalhou como compositor de músicas, como músico, como maestro, sempre sem estacionamento definitivo". Entretanto, diz um atestado assinado por Lamartine Babo, então secretário da UBC: "Atesto (...) que o sr. Georges Moran é (...) autor de numerosas obras musicais cujos direitos autorais arrecadados lhe proporcionam o bastante para a sua subsistência". Noutro documento vemos que "seus meios de vida orçavam em 5.000,00 [cruzeiros) mensais", ressalvando que não possuía bens nem economias em banco. Moran procurava então convencer as autoridades da imigração que tinha capacidade de subsistir no Brasil.

Viveu seus últimos anos em São Paulo, em modesta habitação, onde foi acometido por um derrame cerebral, ficando, desde então, muito desassistido, até que sua filha, tomando conhecimento de suas atribulações, o socorreu. Internado no Lar João XXIII, teve tratamento condigno, vindo a falecer, pouco depois, em 1974.

Como compositor, Moran não foi dos autores mais prolíferos. Listamos um total de 73 canções, sendo 49 gravadas, datando as duas primeiras de julho de 1937, em disco de Carlos Galhardo. Suas canções seguem a tendência habitual de então, a lírico-amorosa, às vezes bastante açucarada, aliás fator muito favorável para a adaptação de Moran ao ambiente da canção brasileira desse tempo. São exemplares, nesse sentido, "Como tu, ninguém" ou "Maldito amor". São aspectos interessantes nas canções de Moran a presença de uma poética sensual, e a dificuldade técnica constante em boa parte delas, sempre criando barreiras de interpretação que só se superavam com os cantores da qualidade de um Orlando Silva.

Quanto à fronteira musical russo-brasileira de Moran, vê-se que sua criação reflete uma mescla. Mesmo que brasileiras, pode-se dizer que há em algumas canções um certo exotismo, algo um tanto alienígena, como em Zíngaro, Balalaica, Exilado, Ninotchka, e em outras ainda. Isso pode ter se dado também por força dos arranjos e orquestrações, que procuravam mostrar musicalmente o que havia de "russo" naquele compositor "brasileiro". Os 
arranjos de Radamés Gnattali para as canções de Moran seguem essa linha, tanto para as gravações quanto para as transmissões radiofônicas. Moran ocupou-se dos gêneros então correntes: sambas, sambas-canção, marchinhas, mas preferiu as valsas e os foxes.

Moran foi íntimo da poética cancioneira do Brasil de seu tempo? É fato que chegou a dominar a língua portuguesa muito bem. Algumas de suas canções tiveram letras inteiramente compostas por ele. Escreveu canções com parceiros do mundo das letras, como Davi Nasser e J.G. de Araújo Jorge. Da parceria Moran - Davi Nasser, há "Exilado", de 1943, canção autobiográfica, e curiosa também pelo fato de ter Nasser, três anos antes, escrito para Custódio Mesquita os poemas de "Linda judia", que mencionamos, e "Beduina", que tratavam do imigrante fustigado que se abriga na "pátria brasileira". Mas foi com Osvaldo Santiago, parceiro constante e amigo dileto, que chegou ao ponto mais elevado de rendimento poético-musical.

Moran proporcionou aos intérpretes notáveis performances. Orlando Silva, à frente de todos, com "Balalaica", "Zíngaro" e "Como tu, ninguém". Carlos Galhardo, com "Perfume de mulher bonita", "Linda Butterfly", e com a difícil "Dois navios", canção exótica, com seu raro ostinato introdutório ao piano. Sílvio Caldas com "Kátia", "Se tu soubesses" e "Meu amigo violão". E Francisco Alves, com a valsa "Oi, Iaiá Baiana".

Apreciando o conjunto da obra de Moran, pode-se dizer que, enquanto tão bem enquadrado no plano da criação brasileira do tempo, ele parece ter contribuído também, com suas harmonias surpreendentes e inovadoras, com sua melodia de fragmentos tão diversos, para a renovação da música popular brasileira dos anos 50. Como imigrante judeu, o exemplo de Moran desmente a burocracia antissemita do Estado Novo, para quem os judeus eram incapazes de se assimilar. Na sua marchinha "Katucha", tão bem mesclada de elementos russos, judaicos e brasileiros, ele mostra perfeitamente ter compreendido, a seu modo, a miscigenação, efetiva marca da pátria adotada:

$$
\begin{aligned}
& \text { (...) } \\
& \text { Vamos fazer a união } \\
& \text { Da balalaica e do violão }{ }^{47} \text {. }
\end{aligned}
$$

\footnotetext{
${ }^{47}$ Barros, Orlando de, texto do folder da exposição "Georges Moran, da balalaica ao violão", Museu Judaico do Rio de Janeiro, setembro de 2001.
}

\section{Capítulo}

\section{TESTEMUNHOS E HiSTóRIAS DE VIDA}

\section{O cálice sagrado: a saga da família Blajberg de Ostrowiec}

\author{
Israel Blajberg
}

Da árvore frondosa do Judaísmo na Polônia sofrida, sementinhas atravessaram os 7 Mares e vieram germinar abençoadas em terras brasileiras, israelenses e americanas.

\section{Introdução}

Z ste não é um paper acadêmico sobre uma Família famosa, mas estória coloquial-familiar, comum a muitas outras que imigraram buscando futuro melhor no Brasil e em outros países. A diferença seria que, neste caso, alguém conseguiu achar tempo livre em meio às preocupações da vida diária para buscar nomes, datas, sentar e escrever.

Escrevi para meus filhos, para os filhos e netos de imigrantes, e interessados em geral que desejem saber mais sobre nossos antepassados, como outros já o fizeram, conforme trabalhos citados na bibliografia ao final.

Recordar é Viver; este texto singelo relembra para as novas gerações dos Blajberg e para os interessados no assunto o caminho percorrido desde Ostrowiec até os nossos dias, ajudando, modestamente é verdade, nossa sociedade galútica judaico-brasileira a manter suas raízes e tradições pelas futuras gerações vindouras.

${ }^{1}$ Professor em Engenharia Eletrônica UFF. 
Foram longos meses de trabalho, aproveitando brechas em meio a rotina diária e nos fins de semana, mas a busca pelo passado não termina nunca, pois temos um amplo futuro pela frente, e cada dia é mais um.

Como recompensa, a emoção de haver tentado se esforçar pela preservação de nossos valores familiares e judaicos, e a eterna esperança de que as sementinhas continuem dando frutos ...

\section{O cálice sagrado}

Em 1997, visitei Israel com minha esposa Marlene, para rever tios e primos, após 26 anos da última visita, ainda solteiro, em 1971.

Beer-sheba. Casa de minha tia Amira. Nos conta sobre a visita de seu falecido marido, meu tio Yerachmiel, a Ostrowiecz, alguns anos antes do seu passamento em 1994. Lá chegando, encontra Josek, seu amigo de infância católico. Sobressaltado, o bom polaco lhe pede que não se demore. Poderia haver gente indisposta contra ele. Talvez achassem que Yerachmiel viera reclamar de volta as propriedades e utensílios dos Blajberg, perdidas no turbilhão do Holocausto.

Josek se despede e lhe põe nas mãos um pequeno cálice de prata. Yerachmiel, que saíra de Ostrowiecz com apenas 8 anos, reconhece imediatamente o cálice que seu avô utilizava no Seder de Pessach, e que talvez seu bisavô e quantos e quantos antepassados mais tenham feito a benção, sobre aquela peça sagrada.

Nada mais havia a fazer. As pratarias, paramentos, os livros de oração, desaparecidos para sempre? Yerachmiel parte pela segunda vez, agora para nunca mais voltar. mesinha.

Sentados no sofá, contemplamos emocionados aquele cálice sobre a

Recordo mentalmente os retratos de meus avós paternos Shlomo e Chana Frejda, lá na parede da minha biblioteca, no Rio de Janeiro distante. Posso ver como se estivesse diante deles, que nunca conheci, suas feições ternas e leve sorriso nos quadros reproduzidos de antigos retratos.

Neste momento me veio a ideia de que esta história tinha que ser preservada e transmitida a todas as nossas gerações, pois ali estava o símbolo material de que a árvore frondosa não havia sido abatida, pelo contrário, aquela pequena peça atravessara talvez os séculos e se salvara ali em Beer-sheba, para indicar que a nossa fé inquebrantável permanecia intacta, e que com as bênçãos divinas prosseguiria pelo tempo infindável a guarnecer a mesa do Seder dos Blajberg.

Quis levar comigo este Cálice Sagrado para o Brasil. Como o primeiro Blajberg a nascer fora da Polônia depois de muitos séculos, e não havendo mais sobre a face da Terra filhos homens vivos de Shlomo e Mindla, considerava-me herdeiro natural do cálice do meu Avô. Sem coragem de fazer a proposta a Amira, contentei-me em tirar um retrato do Cálice.

Com esta comunicação, contamos a historia de uma família que jamais perdeu a fé e a esperança, a Saga dos Blajberg que se salvaram, e do cálice que julgado perdido, reapareceu pelas mãos de Josek, redimindo-se do passado e simbolizando o futuro da continuidade judaica.

\section{Uma árvore frondosa}

Ostrowiecz, Polônia, era uma cidade judaica. Tudo parava no Yom Kippur, no século passado a população judaica chegava a $80 \%$. As origens da família remontam a expulsão dos judeus da Península Ibérica, quando se radicaram em Bleiberg ${ }^{2}$, Alemanha, cujo nome deriva da mina de chumbo lá existente, a qual após totalmente exaurida originou a estância turística de Bad Bleiberg. Os judeus entraram na Polônia sob o Grande Rei Kazimierz, passando o nome a se grafar Blajberg.

Ostrowiec, em cujo brasão municipal até hoje se encontra uma Estrela de David, é uma cidade rodeada de montanhas envoltas em nuvens onde, diz a lenda, as bruxas se escondem. Hoje as bruxas continuam por lá, mas os judeus, pelo menos até hoje, se foram e só voltam a passeio. (Bib. 1). Dessa cidade originou-se um fluxo razoável de imigração para o Brasil, principalmente o Rio de Janeiro, onde chegou a haver uma sociedade dos judeus de Ostrowiecz, sediada no Edifício Balança-mas-não Cai, na Rua de Santana, 77, na Praça XI. A cidade é citada como uma comunidade de

\footnotetext{
${ }^{2}$ Alemão, montanha de chumbo
} 
relativa importância. Muitos brasileiros hoje em dia, vêm a ser a segunda e terceira geração daquelas levas migratórias.

A Família Blajberg, da Polônia judaica, esteve abrigada durante séculos sob a árvore frondosa do Judaísmo na Polônia sofrida. Quase abatida durante o Holocausto, a árvore renasceu em outras terras, ainda que um pouco daquele importante passado cultural ainda subsista na Europa, mas sem as dimensões daquela época.

O Patriarca da Família, Shlomo, era de Ostrowiec, filho de Avigdor e Ethel. Casou-se com Chana Frejda (Ana), nascida em Rosbadov, na Galitzia polonesa, próximo à fronteira com a Áustria. Tiveram onze filhos, cujas trajetórias iremos descrever, menos as de três que faleceram ainda muito jovens. Shlomo tinha uma sociedade, operava com empréstimos e câmbio de moeda estrangeira, trocando dólares por zlotys. Tinha alguns recursos, o que aliado a sua premonição da tragédia que estava por vir, possibilitou que salvasse seis filhos, menos os dois mais velhos, que já estavam casados e com filhos pequenos. In memoriam de nosso avô Shlomo, meu irmão mais novo leva seu nome. Já Yehoshua e Mindla, os casados, permanecem presentes nos nomes judaicos de nossos filhos mais velhos Carlos (Yehoshua Baruch) e Silvia (Brandia Mindla).

Com a herança materna, Chana e sua irmã Laika se estabeleceram na Cracóvia (Krakow) com venda de papel por atacado. Laika mais tarde emigrou para o Canadá. Krakow era a antiga capital da Polônia, tem um castelo famoso e a mais antiga universidade do país.

Todos os filhos homens estudaram na Escola Hebraica Mizrachi, mais tarde fechada, e as meninas na Escola Polonesa.

Chana era sionista, e gostava muito de Grinbaum, que era o representante da Comunidade Judaica no Senado polonês. Costuma dizer que Grinbaum iria estabelecer um estado para os judeus. Ela desejava que seus filhos saíssem do Mizrachi, e fossem estudar no Ginásio Hebraico na Cracóvia, mas isso nunca foi possível.

No Shabat, Chana costumava reunir a família e recepcionar Shabat Hamalka com canções e histórias, conhecia bem a Bíblia. Ela queria ter ido para a Palestina, mas nunca pôde realizar esse sonho. Hana costumava cantar com os filhos em casa as melodias do poema judaico Yentl. Mais tarde, em Israel, Efrat, a filha de Yerachmiel colaborou na produção de um livro em Yiddish com estas músicas (Bib. 9).

Ao estourar a II Guerra Mundial, os pais continuavam em Ostrowiec, com Yehoshua e Mindla, os dois filhos mais velhos, netos e a sétima filha, Lola. Chana tinha então 68 anos.

Com a entrada dos alemães em Ostrowiec, em 1939, Shlomo pagou a um vizinho para esconder Lola e o neto Hilik, filho de Mindla, mas não adiantou, e todos foram levados para Treblinka, com exceção de Lola, que escapou ao Holocausto e chegou a Israel após o término da Guerra. Etale, Lola e seu marido Shlomo Politanski visitaram Ostrowiec em 1991, mas não encontraram mais a casa onde moraram e, muito menos, a rua onde se situava. O prédio da Sinagoga ainda existe, mas hoje virou um cinema, e nada indica que fora aquele prédio um templo santo no passado. Os vários cemitérios não existem mais, apenas um subsistiu, porém muito menor que a sua dimensão original, após mais de 200 anos.

A princípio, Etale não queria voltar a Ostrowiec, mas foi convencida por Edna, esposa do seu filho Yacov (Kobi). Após a visita, Etale mudou de ideia, e passou a recomendar que todos visitem Ostrowiec, pois não é suficiente apenas ouvir a história, mas sim testemunhar in loco os fatos ocorridos.

Ostrowiec é hoje uma moderna cidade industrial que a globalização fez semelhante a qualquer outro aglomerado urbano de Primeiro Mundo, não faltando desde a pizza italiana até a musica americana, passando é claro pelo MacDonald.

No colorido material de divulgação e rico CD multimídia que recebi do Prefeito, destinado a potenciais investidores estrangeiros, em sua introdução histórica não pudemos encontrar alguma referência da importante contribuição judaica ao longo dos séculos, ou mesmo sobre o papel do operariado judaico na Fundição, que parece ter sido importante.

Por outro lado, contactos pela Internet, via Correios e com o Consulado Polonês no Rio revelaram que a Comunidade Judaica de Ostrowiec não foi esquecida. Inclusive, recebemos um importante livro do Prefeito, Zydzi Ostrowieccy, os Judeus de Ostrowiec, uma publicação oficial do Muzeum Historyczno-Archeologiczne, de 1996 (Bib. 10), o que sem dúvida é um fato que demonstra a vontade de manter viva a memória judaica da cidade. 


\section{Caminhos para a Salvação}

Graças à visão de meus avós Shlomo e Ghana, que nunca conheci, seis dos oito filhos se salvaram do Holocausto.

Foram como que sementinhas daquela árvore, que atravessaram os 7 Mares e vieram germinar nas terras abençoadas do Brasil, Israel e Estados Unidos.

Os custos da salvação eram elevados, da ordem de 120 libras esterlinas em ouro per capita, para despesas de vistos, passaporte, passagens além dos necessários valores para contornar as dificuldades habituais criadas nestes casos pela burocracia polonesa, agravadas pelo clima reinante com a ascensão do nazismo na Alemanha, e as vésperas da guerra.

\section{Yehoshua - ficou com os Pais Shlomo e Ghana e desapareceu no Holocausto}

Shiale era o irmão mais velho, tendo dois filhos pequenos. Não havia condições para que viajasse para o exterior, seriam quatro despesas, além das dificuldades naturais da fixação em um novo país.

Cuidava da firma em Krakow, e aos 21 anos foi convocado para servir ao Exército Polonês. Após dar baixa, casou-se com Perla, natural de Opatow (Apt), cidade muito próxima (vide mapa). As duas crianças frequentavam a Escola Hebraica. Esther, irmã de Perla, dominava bem o hebraico. Yehoshua tinha também uma loja e uma pequena fabrica de escovas de cabelo.

\section{Mindla - ficou com os Pais Shlomo e Ghana e desapareceu no Holocausto}

Também casada e com dois filhos pequenos; Mindale estudou em uma escola polonesa. Boa parte do tempo ajudava a mãe, Ghana, a cuidar dos outros 9 irmãos menores. Contemplando seu rosto meigo e sorridente em antigo retrato, nos recordamos de uma passagem da Torah: "Lea, a Profetisa, tinha olhos ternos" (Gênesis 29:17).

Pouco sabemos sobre estas quatro crianças. Nossa dor é grande. Nas marchas forçadas das cidades para a estação do trem, rumo aos campos de concentração, se uma criança chorava os nazistas atiravam nela sem piedade.
Se existe consolo, "Quando a alma parte deste mundo, ela sobe pela Caverna da Machpelá \{local em Hebron onde os patriarcas estão enterrados \}, já que lá é o portal do paraíso." (Zôhar Vayechi 219 - 250)

\section{Abram - viajou para o Brasil}

Abram, o terceiro filho, nasceu na véspera de Pessach $^{3}, 14$ de abril de 1910. Sempre quis sair da Polônia, não lhe agradava o trabalho com o pai, nem a discriminação dos polacos (Bib. 7). Ghana não queria que Abram fosse para o Brasil. Pedia que tivesse mais paciência, ela iria conseguir um visto para a então Palestina. Abram trabalhava com o pai nas operações financeiras. Os negócios iam bem, os fregueses gostavam de serem atendidos por Abram.

Entretanto, Abram decidiu viajar para o Brasil, a fim de escapar do Serviço Militar, viajando junto com seu amigo Muskies, que foi para o Brasil visitar a sua irmã, em 1929.

Assim, conseguindo finalmente convencer o pai a assinar seu passaporte, aos 29 de novembro de 1929, partiu. Shlomo não teve coragem de acompanhá-lo, Abram nunca o tinha visto chorar. Ele era mais alto que o filho, na estação do trem o abraçou, e disse:

"Meu filho, tenho um pressentimento que nunca mais vou ver você a única herança que lhe deixo é um nome a zelar"

Parecia que estava adivinhando. Sua irmã o levou para Varsóvia e de lá foi para Cherbourg, onde tomou um navio inglês para o Brasil.

Abram chegou ao Rio em 23 de dezembro de 1929, calor insuportável, sabia por alto da América Latina, que não havia preconceitos. A entrada do porto de noite era uma maravilha, logo começou a gostar só por isso. No dia seguinte foi para o Relief na Rua São Cristóvão, 139, hoje Joaquim Palhares, associação que prestava o primeiro apoio aos recémchegados. Só um dia lá ficou.

\footnotetext{
${ }^{3}$ Hebraico, Páscoa Judaica, comemora a saída dos judeus do Egito.
} 
A miséria era grande entre os judeus na Praça XI. Os correligionários auxiliavam a se iniciar para trabalhar clientele ${ }^{4}$; Abram passou algum tempo no Rio, morando posteriormente em Uberlândia, de onde retornou ao Rio em 1944, casando-se com minha mãe, Perla.

Em certo momento, Abram escreveu para Chana, contando não ter mais dinheiro, ao que ela lhe enviou mais. Até 1937, quando Etale seguiu para a Palestina, Abram quase não deu notícias. Sua mãe Chana chorava muito, e tentou se comunicar de varias maneiras com Abram, mas não havia jeito. Nessa época, a economia polonesa não ia bem, e Chana costumava dizer que Abram havia levado embora a sorte, dada a falência que se abatera sobre os negócios da família.

Anos depois, após o estabelecimento do Estado de Israel em 1948, Faigale Kozlovsky, que morava no Uruguai, veio visitar a sua irmã e contou para Etale que eu, Israel, havia estado em Montevidéu em princípios da década de 60.

Etale pediu a Faigale que tentasse se comunicar com Abram. Ela se encontrou com Abram em trânsito pelo Aeroporto do Galeão na viagem de volta, e a partir daí foi restabelecido o contato de Abram com a família em Israel, seus quatro irmãos que lá estavam.

Em 1980 e 1992 Abram se permitiu um luxo, viajar a Israel para visitar os quatro irmãos. Quase nunca havia tirado férias, uma ou duas vezes estivera em São Lourenço com amigos. O maior jornal de Israel, Maariv, estampou a foto do reencontro com os irmãos, após exatos 51 anos.

\section{Os 4 Vatikim (Veteranos) - Moshe, Ada, Lola, Yerachmiel-Israel.}

Moshe, o quarto filho, foi mandado para a então Palestina, como membro do Hanoar Hatzioni. Em 1937, tornou-se um dos fundadores do Kibutz Usha, próximo a Haifa, quando a região era predominantemente árabe. Ao falecer, o Kibutz editou um livro em sua homenagem. Durante anos e anos cuidou das vaquinhas do kibutz, excepcionais produtoras de leite, nunca aceitou convites para entrar na política, enquanto colegas seus iam para a Knesset e até viraram Ministros.

\footnotetext{
${ }^{4}$ Yiddish. klienteltáik, clientele, vendedor a prestação, que visita a sua clientela de porta em porta
}

Em 1971, passei o Pessach no kibutz, com Moshe, sua esposa Leika, uma simpática canadense, e seu filho Ami. Neste dia Moshe, embora fosse um dos fundadores do kibutz, estava ajudando a servir o Seder, indo e vindo da cozinha, onde depois ficou lavando os pratos.

Sua casa era uma das mais confortáveis do kibutz, quase uma mansão. Em 1997, ao retornar, constatei que as vacas continuavam dando leite, mas o kibutz já não era o mesmo. O restaurante coletivo superlotado no Seder de 26 anos atrás, praticamente não era mais utilizado, e uma fabrica de óculos operava nos mais modernos padrões de marketing, com empregados, vendedores externos, veículos, nada que lembrasse um kibutz.

Ada, a sexta filha, carinhosamente chamada de Etale, recebeu o nome In Memoriam da avó materna. Etale não teve oportunidade de continuar seus estudos, e participava de Movimento Juvenil Sionista na Polônia. Certa vez esteve em Lodz, para participar de uma Machané (acampamento). Seu pai Shlomo foi visitá-la e descobriu que ela estava passando fome, levandoa então a um restaurante, onde comeu Gefilte Fish, descrevendo depois a situação para Chana, que a partir daí passou a procurar maneiras de enviá-la para a Palestina.

Seu irmão Moshe, que estava recém-chegado na Palestina, conseguiu então com as lideranças locais que Etale fosse aceita em Nahalal, uma escola agrícola para meninas, cuja Diretora era Hana Meizel.

Assim, pouco depois de Moshe, Etale viajou para a Palestina, onde mais tarde conheceu um jovem soldado britânico, Ovadia Gotlieb, um elegante rapaz que fumava um aristocrático cachimbo. Depois de casados, Ovadia passou anos no Quênia, supervisionando obras da Solel Boneh. Retornando a Israel, continuou no ramo da construção civil, levantando-se invariavelmente as primeiras horas da manhã para dirigir-se a obras nas proximidades de Tel-aviv.

Lola, a sétima filha, ainda estava com os pais ao rebentar a II Guerra Mundial, em $1^{\circ}$ de setembro de 1939. Shlomo, porém achou uma maneira de salvá-la, escondendo-a com uma família católica amiga. Lola era loura e de olhos azuis, mais próxima do biótipo polaco, e assim não despertaria suspeitas.

Entretanto, a situação estava perigosa, e Lola tinha que fugir. Para tanto, era preciso ter um documento da Gestapo para viajar, mas ela não tinha a necessária certidão de batismo. Lola armou-se de coragem e foi a 
uma igreja; inventou uma história de que ia casar-se, mas não podia por ter extraviado a sua certidão de batismo. O Padre recusou-se, ciente de que uma falsificação poderia custar-lhe a vida. Lola então fez que ia embora, dizendo, Padre, então vou viver com meu noivo assim mesmo, sem casamento. Nesse momento, o sentimento de piedade cristã do religioso falou mais alto, acedendo então em conceder-lhe uma certidão.

Com o papel, Lola teve suficiente destemor para entrar na boca do leão, foi à Gestapo, obtendo o salvo-conduto que lhe permitiu viajar pela Polônia. Trabalhava como empregada domestica, sem notícias da família. Às vezes, alguém comentava que ela parecia judia. Era o suficiente para fugir imediatamente para outra cidade.

Ao término da guerra, Lola foi enviada para um campo de refugiados na Bélgica. Nada sabia sobre o que acontecera a seus pais, irmão, cunhada e sobrinhos.

Já quase sem esperanças, certo dia, ouve pelos alto-falantes do campo que às 14 horas deveria dirigir-se à Administração a fim de atender a uma chamada telefônica de Nova Iorque. Era a sua tia, Hesse Mintz, que havia localizado o seu nome nas listas de refugiados. Lola reencontrou os irmãos em Israel, tendo se casado com Shlomo Politanski, indo morar em Hadera.

Yerachmiel, o oitavo filho, era o caçula, ao nascer sua mãe Chana já tinha 49 anos, e foi o ultimo a sair da Polônia. Sua viagem custou mais caro que as demais, pois já se falava em guerra, e os preços da salvação tornavam-se cada vez mais altos. Alguns anos depois se casou com Amira, uma morena de cabelos pretos originaria de Bukhara, tendo ido morar em Beer-Sheva, em 1947, quando esta cidade era pouco mais que um acampamento de beduínos às portas do Deserto do Negev. Amira, recémformada em Enfermagem no Hadassa em Jerusalém, realizou os primeiros partos da cidade, aquela época com apenas 220 almas judaicas. Yerach, como era chamado, entrou para o ramo de sorvetes, negocio altamente rentável nesta cidade calorenta. Amira se aposentou em 1987, após 40 anos de trabalho como Enfermeira.

\section{Mayer - internado em Trinidad y Tobago e depois para os Estados Unidos}

Mayer, o quinto filho, não conseguiu um visto para a Palestina, a esta altura era muito difícil.
Após Moshe ter ido para a Palestina, Mayer ficou um pouco mais, queria estudar em uma escola comercial. Chana concordou, e dizia que ela iria rezar na sinagoga no lugar de Mayer, para que ele pudesse ter tempo. Ela considerava os estudos muito importantes para seus filhos, tendo se preocupado muito quando Moshe parou de estudar para viajar a Palestina.

Mayer acabou internado às vésperas da guerra na possessão inglesa da ilha de Trinidad y Tobago. Outros amigos que lá estavam se dirigiram ao Brasil, inclusive um que anos depois viria a se tornar pai de um menino que no futuro iria ser Deputado Federal pela Bahia, inclusive em certo momento líder de importante partido na Câmara.

Mayer conseguiu ir para San Diego, aquela época um areal semidesértico próximo a Los Angeles. Casou-se com Bluma, e teve sucesso no comércio. Resolveu americanizar o nome, e de Mayer Blajberg transformou-se em Myron Blake, sendo suas filhas, duas perfeitas lourinhas americanas, denominadas Linda e Barbara, nomes perfeitos para a região californiana vizinha ao México, ao lado de Tijuana, mas, apesar disso, hoje ambas são ortodoxas.

\section{Século XXI}

Os amados irmãos se foram, menos Etale, a luz que continua iluminando a família em seus 80 e poucos anos de vida. Herdeira da intuição nata de seus pais, sua palavra é ouvida e respeitada. Tão forte de espírito, teve a grandeza de receber em sua casa em Tel-aviv um estudante num programa de intercâmbio. Era um jovem alemão, como alemães foram os que lhe tiraram tão brutalmente seus pais Shlomo e Mindla, seu irmão Yehoshua, esposa e filhos, além de tios e inúmeros outros parentes. Por ser Etale uma pessoa tão especial, mais tarde a própria família do estudante a convidou para passar uns dias na casa deles, na Alemanha.

Entre todos os descendentes diretos e agregados pelo casamento, a família hoje totaliza 35 pessoas em Israel, sete no Brasil, oito nos Estados Unidos. Se incluirmos ainda primos e respectivos descendentes dos sete irmãos, o total aumentaria bastante.

Sabemos que existem ainda inúmeros primos em $1^{\circ}$. e $2^{\circ}$. grau, além de tios já falecidos, nos Estados Unidos e Canadá principalmente. Infelizmente, 
o contacto com esses ramos da América foi muito tênue. Se nada for feito, seus nomes poderão se perder na poeira dos tempos, para nossa tristeza.

Assim continua a Saga da Família Blajberg de Ostrowiecz. No Cemitério Velho de Vila Rosali, em São João de Menti, a matzeiva ${ }^{5}$ de Abram, testemunha de que nunca se desviou da recomendação paterna, desde 1994 nos alenta e sinaliza o caminho em direção ao futuro, palavras que certamente poderiam estar na matzeiva de todos nossos antepassados:

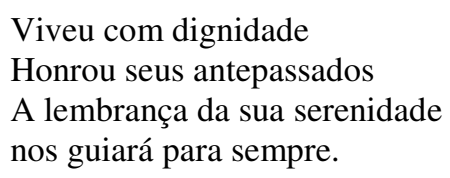

\section{Anexo: Ostrowiec - o fim de uma Comunidade Judaica.}

Ostrowiec era uma cidade de maioria judaica até meados da década de 20. A progressiva tendência migratória devido ao antissemitismo, falta de perspectivas e busca de melhores oportunidades no exterior inverteu paulatinamente esse quadro, até primeiro de setembro de 1939 com a invasão da Polônia pela Alemanha Nazista. Consta que a então Palestina, o Rio de Janeiro, e Toronto no Canadá foram os principais polos receptores desse fluxo migratório.

O percentual da população judaica caiu de $80 \%$ em 1860 para $38 \%$ em 1942, chegando em seguida próximo a 0\% com a deportação dos judeus para os campos de concentração.

Toda a comunidade judaica remanescente foi aniquilada em 1942, com o envio indiscriminado de jovens e adultos, homens e mulheres, velhos e crianças, para o extermínio hediondo no campo de concentração de Auschwitz, no que posteriormente ficou conhecido como Holocausto, crime inominável contra a Humanidade.

No gráfico da população total, vemos que houve um decréscimo populacional da ordem de 2 mil habitantes durante a I Guerra Mundial (19141918). Já durante a II Guerra Mundial (1939-1945), o decréscimo foi bastante acentuado, da ordem de 18 mil habitantes, correspondendo quase que integralmente a população judaica da cidade na ocasião, de $38 \%$ do total.

\footnotetext{
${ }^{5}$ Hebraico, lápide tumular.
}

Somente em 1960 a população de Ostrowiec voltou ao nível de 1939, mas a esta altura praticamente não havia mais judeus residentes.

\section{Referência Bibliográfica:}

1 - Pinkas - O Livro da Comunidade, 800 págs. Inglês (136 pp), Yiddish (560 pp), e Paginas Negras de Yzkor (104 pp).

Ostrowiec - A Memorial Book (Sefer Ostrovce, Ostrovcer Izkor-Buch), published by the Society of Ostrovtser Jews in Israel, with the cooperation of the Ostrovtser Societies in New York and Toronto.

Artigo de Moshe Blajberg, Hanoar Hazioni, p. 248.

Retratos do Heder Or Torah - Mizrachi, pp 34 e 219.

Abram Blajberg, 9 anos, é o segundo no alto à esquerda.

2 - Journey to Poland - In Search of a Vanished Jewish World, Beit Hatfusot, Museum of the Jewish Diaspora, Tel-aviv, 1990

3 - Yacov Rubinstein, Livro em Yiddish publicado em Ashdod, Israel, 1987. O autor, originário de Ostrowiecz, viveu no Brasil de 1928 a 1980, ano em que fez aliá. Era tio-avô de minha esposa Marlene Rubinsztajn Blajberg.

4 - "Ostrowiec: The Witches Survived, the Jews are Deacr, Harry Stein (Brochsztajn), Colonel, (Ret), USA, publicado na revista "The Kielce-Radom Special Interest Group Journal (v. $4 \mathrm{n}^{\circ} .2$ Spring 2000, pp 3-8).

5 - Moszek Niskier - De Ostrowiecz ao Rio de Janeiro. Notável relato pelo médico e ativista. 1991.

6 - Chaia Zisman, Estórias que fazem História, 1993, (Sara Zisman, filha do Sr. Berl Swarcman (Gueilhe Beie), e Da. Regina, livro sobre sua família, Szwarcman, originária de Ostrowiecz).

7 - II ENCONTRO BRASILEIRO DE ESTUDOS JUDAICOS PRESENÇA JUDAICA NO BRASIL DOS 500 ANOS: A Construção do Judeu Brasileiro - 23, 24 e 25 de novembro de 1999. Comunicação: Abram Blajberg - Uma Lição de Vida - Autor: Israel Blajberg. 
8 - Ciclo de Painéis sobre a Contribuição dos Judeus ao Desenvolvimento Brasileiro, ABL, Coord. Arnaldo Niskier, set 1998, cujos pais eram originários de Ostrowiec.

9 - The Hebrew University of Jerusalem, Anthology of Yiddish Folksongs, Sinai Leichter - The Mordechai Gebirtig Volume Vol. Five. Tribute - The Editorial Board places on Record its appreciation to the people whose financial contribution made this publication possible: Mrs. Efrat Toussia-Cohen, Jerusalem, Israel, in memory of her father, Yerachmiel Bleiberg of Ostrovetz, Poland (1923-1994), and his parents Chana and Shlomo Bleiberg and family, who were killed by the Nazis.

10 - Zydzi Ostrowieccy - Zarys Dziejow (The Jews of Ostrowiec), Waldemar R. Brociek, Adam Penkalla, Regina Renz - Muzeum Historyczno-Archeologiczne, Ostrowiec Swietokrzyski, 1996, ISBN 83-904020-1-7, 152 pp, Polish, English resume, 6 pp.

\section{Sites na Internet:}

www.jewishgen.org/KRsig/,

www.shtetlinks.jewishgen.org/,

www.holocaustnames.com/index.html,

www.63.99.109.185/memorial/welcome.html,

www.63.99.109.185/memorial/Shtetl/Ostrowiec/shtetllinks_ostrowiec.htm, www.netjudaica.com.br/sgjb/,

www.ancestry.com/,

www.jewishgen.org/,

www.bh.org.il/Names/index.htm,

www.jewishgen.orgJRI-PL/,

wwwjewishgen.org/jgff/jgffweb.htm,

www.ceveh.com/ahjb/bol-20-publicacoes.htm,

www.wojckr.w.interia.pl, www.wojckr.w.interia.pl,

www.polbox.com/w/wojc,

www.polishcities.pl/mapy/ostrosjpg,

www.polishcities.pl,

www.um.ostrowiec.pl,

\section{Fontes consultadas}

M. Szostak, Prefeito de Ostrowiec Ewiêtokrzyski.

Adrian Adamsk, Agencja Rozwoju Lokalnego S.A., Ostrowiec Ew.,Agencia Local de Desenvolvimento.

URZ¥D STANU CIWILNEGO, Ostrowiec Ew., Registro Civil Municipal.

ARCHIWUM PASISTWOWE w STARACHOWICACH, Starachowice, Arquivo do Estado. 


\section{Individual dactiloscópica: Bruno Wiczer, a trajetória de um imigrante}

Fábio Koifman ${ }^{1}$

$\mathrm{D}$

urante os três anos em que me dediquei à pesquisa relativa a atuação do Embaixador Luiz Martins de Souza Dantas na Europa durante a II Guerra Mundial, tive a oportunidade de recolher uma vasta documentação específica sobre a entrada de estrangeiros no Brasil durante o Estado Novo, época de rígido controle dos residentes alienígenas - termo corrente na época - temporários e permanentes ${ }^{2}$.

Especialmente a documentação relativa aos estrangeiros que entraram no Brasil nesse período, em centenas de casos, foi convertida em extensos prontuários. Se por um lado, tais papéis registram para a posteridade a desconfiança das autoridades para com certos grupos de estrangeiros - além da opressão - e as demoradas tramitações burocráticas daqueles que, em algum momento, optaram por viver ou apenas se refugiar no país; por outro, se converteram em registro e fonte única de apuração das origens e trajetórias de vida de milhares de pessoas.

Por uma série de fatores culturais, a maioria dos brasileiros (incluemse aí também as gerações descendentes de imigrantes), salvo raras exceções, não possui exatamente a tradição de registrar as suas mais remotas origens e demais histórias familiares. Essas acabam resguardadas na frágil história oral, quando não são perdidas por completo.

Em se tratando de experiências traumáticas, tive a oportunidade de me deparar com diversos casos em que o imigrante refugiado das perseguições antijudaicas europeias - em especial, do nazismo -, uma vez

\footnotetext{
${ }^{1}$ Mestre em História pela UERJ.

2 A pesquisa se relacionava ao meu mestrado em história na UERJ, concluído em 2001. Publicado Quixote nas trevas: o embaixador Souza Dantas e os refugiados do nazismo. Rio de Janeiro: Record, 2002.
}

chegado ao Brasil, propositadamente, tratou de contar a respeito do seu passado de forma seletiva aos seus descendentes diretos ${ }^{3}$.

Isso se deu pelos mais diferentes motivos. Entre outros, em razão do trauma, pela ideia de não mencionar lembranças desagradáveis; pela lógica de "apagar o passado" e reconstruir uma nova vida ou até assumir nova identidade ou religião; ou ainda, pela simples crença de que tais experiências em nada contribuiriam para a felicidade dos filhos e netos, quando por aqui constituíam família. Muitos preferiram não contar as histórias de terror que protagonizaram àqueles sob a sua proteção.

Providenciei a microfilmagem de centenas desses prontuários, visando não só a pesquisa daquele momento, mas também um estudo micro e macroscópico relacionado ao tema da entrada de estrangeiros durante o Estado Novo. Dessa forma, em muitos casos, encaminhava o pedido de cópia da documentação após uma leitura superficial de cada processo, com a intenção de uma análise mais atenta em um momento posterior. Tal procedimento fez com que a leitura e o estudo mais completo da documentação existente em meu próprio arquivo particular revelassem, em muitas oportunidades, absolutas "surpresas". Relatos extraídos não dos próprios refugiados, mas sim da documentação oficial, que, por mais estranho que possa parecer ao estudioso não habituado ao exame desse tipo de fonte, em muitos casos revelam registros impressionantes e de todo não anotados pela história.

O tema do presente artigo trata exatamente de uma dessas "surpresas". Em uma das muitas madrugadas de trabalho no ano 2000, li o prontuário do Serviço de Vistos do MJNI (Ministério da Justiça e Negócios Interiores) de número 234/43, relativo ao refugiado Bruno Wiczer. Impressionou-me de tal forma a trágica vida daquele jovem austríaco - a documentação data do início da década de 1940 - que não pude mais dormir aquela noite, imaginando que fim teria tido o refugiado que havia passado por tantos episódios traumáticos em sua vida. Imaginava que Wiczer se teria suicidado ainda nos anos 40.

Com o nascer do sol e o adiantado da manhã, tratei naquele mesmo dia de buscar localizar alguma informação que pudesse complementar a

${ }^{3}$ Idem. Na pesquisa, foram coletados 55 depoimentos, sendo que a grande maioria de imigrados da Europa no período que aqui tratamos. 
documentação para esclarecer que fim teria tido aquele protagonista de tantos sofrimentos. E pude descobrir.

As informações que descrevo a seguir obedecem a trajetória de vida de Wiczer, de forma a buscar induzir o leitor às mesmas dúvidas, surpresas e reflexões que tive.

Bruno Wiczer nasceu no dia 12 de julho de 1917, em Viena, Áustria. Filho de Elkan (Elkuna) Wiczer e Toni (Antônia) Wiczer - nascida Grun (ou Gruen) $)^{4}$. Seus documentos informam que ele tinha "cor branca, cabelos e olhos castanhos". E que a sua profissão era a de alfaiate, embora em outros registros também apareçam as de técnico tecelão, contramestre e, ainda, representante de confecções da empresa Sporting L. Lukes.

Para chegar ao Brasil, teve o passaporte visado pelo consulado em Zurique, Suíça, em 28 de fevereiro de 1939. O visto n. ${ }^{\circ} 76$ foi assinado "J. Fabrino", forma com a qual o cônsul José Fabrino de Oliveira Bayão, desde 13 abril de 1935 naquele posto, assinava os vistos que concedia. Ao escrever no passaporte de Wiczer que o visto obedecia ao artigo 25, letra A, do Decreto 3.010, de 20 de agosto de 1938, Fabrino deixava claro às autoridades brasileiras que aquele estrangeiro entraria no país em caráter "temporário". Dessa forma, poderia ficar por seis meses no Brasil.

Em abril de 1939, Wiczer se dirigiu ao porto francês de Marselha e embarcou para o Brasil a bordo do navio Alsina, o mesmo que ficaria retido pelas autoridades militares responsáveis pelo bloqueio inglês, com carga e centenas de passageiros, por cinco longos meses no porto de Dakar, norte da África, no primeiro semestre de $1941^{5}$.

No dia 21 de abril de 1939, Bruno Wiczer chegou ao Rio de Janeiro. No mesmo dia, obedecendo às normas vigentes, os burocratas do MJNI iniciavam o prontuário do estrangeiro recém-chegado. Foi nesse período que Wiczer providenciou a sua carteira de estrangeiro, a de número "8.704".

Da mesma forma que outros milhares de refugiados, Wiczer obteve um visto temporário, unicamente pelo fato desse tipo de visto, até então, poder ser obtido com maior facilidade do que o permanente. Sua intenção,

\footnotetext{
${ }^{4}$ Essas informações e as demais que aparecem a seguir no texto têm como origem o prontuário SPMAF/RJ de Bruno Wiczer e o prontuário do "Serviço de Vistos" do MJNI.
}

${ }^{5}$ Sobre esse incidente do vapor Alsina, ver Fábio Koifman. "Quixote...Op. cit. p. 241 e seguintes como comprovaremos adiante, não era a de regressar imediatamente à Europa. Assim, em 31 de maio de 1939, requereu a transformação do seu caráter de permanência de "temporário" para "permanente".

O pedido seguiu os trâmites burocráticos. No dia 3 de julho de 1939 , Ociola Martinelli, que fora pouco antes nomeado como delegado de estrangeiros da Capital, oficiou ao então secretário geral do MRE, Cyro de Freitas Valle, consulta sobre a existência de "quota" para a nacionalidade alemã.

Por meio da observação de centenas de prontuários e demais correspondências assinadas por Martinelli, posso afirmar, sem margem de dúvida, que o homem nomeado para assumir a recém criada delegacia de estrangeiros possuía convicções antissemitas. Alguns de seus procedimentos nessa época, especialmente os relacionados à expulsão de refugiados, revelam uma crueldade que tem poucos paralelos entre os burocratas estadonovistas. A conduta judeófoba do diplomata Cyro de Freitas Valle foi amplamente registrada pela historiografia que se debruçou sobre o assunto ${ }^{6}$.

A nacionalidade de Wiczer foi apontada como sendo alemã pelo fato de a Áustria, naquele momento, ter sido anexada à Alemanha, por mais que Wiczer seguisse afirmando e se apresentando como austríaco.

A “quota” a que fez referência Martinelli obedecia aos percentuais de absorção de imigrantes permitidos pelo governo. Esses percentuais, surgidos a partir da Constituição de 1934, naquele momento eram controlados pelo CIC (Conselho de Imigração e Colonização), a quem competia o aumento das quotas, entre outras atribuições.

Entretanto, o encaminhamento do pedido de Martinelli tinha como razão principal sua má vontade em relação ao que era solicitado. Obedecia aos sempre recorrentes fins protelatórios. Dirigir o assunto a Freitas Valle, que o enviaria ao CIC, era certeza de obter uma negativa em relação ao assunto, em razão do proponente não ser "ariano", termo largamente utilizado na época. Outros cidadãos alemães, comprovadamente "arianos", não sofriam com os mesmos percalços burocráticos em suas tentativas de transformar seus "status" de permanência.

${ }^{6}$ Entre outros, em especial, ver a obra de Avraham Milgram. Os Judeus do Vaticano. Rio de Janeiro: Imago, 1994 
Durante o ano de 1938, o MJNI tratou de regularizar a permanência de todos os estrangeiros que ingressaram legal ou ilegalmente no Brasil. Mesmo daqueles chegados portando visto de turista e que haviam estendido a permanência de forma irregular. Se não possuíssem registros policiais, recebiam parecer positivo da "Comissão de Permanência de Estrangeiros", criada naquele mesmo ano. A ideia do governo era a de legalizar e fichar todos os estrangeiros, para melhor controlá-los e tratar de expulsar os que fossem criminosos (crimes políticos ou comuns). O projeto da burocracia consistia em, a partir dessa organização, não mais permitir a estratégia, tão recorrente por parte dos refugiados, diante da dificuldade de obtenção do visto permanente, de entrar no Brasil como turista e mudar essa condição já em terras tropicais. Estratégia essa, justamente, a ainda utilizada por Wiczer. Nos anos seguintes, o governo tratou de restringir ao máximo a emissão de vistos temporários aos judeus ainda em território europeu? ${ }^{7}$.

Wiczer tivera sorte em conseguir entrada em território brasileiro, mas o processo de fechamento a novos refugiados, assim como o controle e expulsão desses indesejáveis, já estava sendo incrementado desde meados de 1937, cada vez com maior rigor. O conflito na Europa e a recusa das representações diplomáticas estrangeiras em emitir títulos de viagens ou autorização de regresso aos países de origem para os seus nacionais de ascendência judaica - especialmente romenos, russos, húngaros e alemães fez com que essas expulsões não pudessem ser viabilizadas ${ }^{8}$.

Em 25 de outubro de 1939, atendendo a nova solicitação de Wiczer, Martinelli oficiou pedido de transformação de visto, dessa vez ao ministro do MJNI, Francisco Campos. Era uma época na qual os departamentos e ministérios se acusavam mutuamente pelo que apontavam como entrada excessiva de refugiados judeus, e a decisão sobre o tema da permanência e entrada no Brasil se tornava objeto de disputa política intensa entre diversos ministérios ${ }^{9}$.

Em 3 de janeiro de 1940, o pedido de Wiczer foi indeferido pelo DNI (Departamento Nacional de Imigração), pois, segundo anotou o diretor

\footnotetext{
${ }^{7}$ Sobre todo o processo de implementação da legislação específica aqui tratada, ver Fábio Koifman "Quixote... Op. cit. pp. 103-190.

${ }^{8}$ Em alguns casos, a polícia expulsava o estrangeiro através da fronteira com as Guianas. Diante da reclamação desses governos, em algumas oportunidades expulsaram certos estrangeiros, a pé, pela fronteira com o Uruguai. Fábio Koifman, "Quixote...Op. cit.

${ }^{9}$ Para maiores informações, ver Fábio Koifman. "Quixote...Op. cit.
}

Dulphe Pinheiro Machado, "falta a individual dactiloscópica e o interessado não justificou o pedido de permanência, na forma da lei".

Machado, que durante o Estado Novo ocupou interinamente o MTIC (Ministério do Trabalho Indústria e Comércio) e, por muito tempo, foi membro do CIC, também estava inserido no grupo do qual fazem parte Labieno Salgado dos Santos, Ernani Reis e os demais judeófobos já aqui mencionados. Da mesma forma que os outros, tratou de impedir a regularização da permanência de Wiczer, por julgá-lo indesejável.

O parecer de Machado foi encaminhado à Comissão de Permanência de Estrangeiros e ao MJNI. Em 4 de março de 1940, o pedido de Wiczer foi indeferido, dessa vez com uma rubrica de Francisco Campos. Como se pode notar, nesse período, os mais importantes membros do governo tratavam pessoalmente ou estavam envolvidos com os pedidos individuais de cada um dos estrangeiros que desejavam permanecer no Brasil. O controle dos que tentavam entrar no país tinha uma atenção ainda maior. $\mathrm{O}$ tema da entrada e permanência dos refugiados no Brasil passava a ser uma questão de máxima importância.

Wiczer insistia. Em 28 de outubro de 1941, em um momento histórico no qual tampouco o governo alemão - que desde 1935 já relegara a uma condição inferior de nacionalidade os apontados como judeus conferia aos israelitas nenhum tipo de reconhecimento em relação a sua nacionalidade ou cidadania alemã, Wiczer novamente solicitou ao governo brasileiro sua permanência a "título precário". Uma vez mais, seu processo não foi concluído em virtude de não ter atendido todas as exigências.

Era uma época difícil para Wiczer. Antes de chegar ao Rio de Janeiro, esteve internado por um período no Campo de Concentração de Dachau, próximo à cidade de Munique.

Nos primeiros meses no Brasil, teve que se submeter a uma operação seria a terceira, desde que saiu de Dachau - e tinha a saúde debilitada. Não pude apurar exatamente a forma ou as origens de seus ferimentos. Ele afirmou que adoecera em decorrência de sequelas de seu período de internação.

Em 1941, seus tios e primos, no total de 40 pessoas, ainda na Europa e buscando uma fuga desesperada, embarcaram a bordo do navio "Struma". A viagem desse navio, entre a Romênia e a Palestina, ficou famosa em decorrência de seu trágico fim. Impedidos de chegar ao seu destino pelo 
bloqueio inglês, todos os 769 passageiros acabaram mortos, pois o navio foi "torpedeado por um submarino alemão nas águas do mar Negro"10.

Em $1^{\circ}$ de julho de 1942, o pai dele, Elkan Wiczer, que fora "cônsul Geral da Áustria e do Paraguai em Bucarest", foi executado em Paris pelas tropas nazistas. Completando essa tragédia pessoal, no dia 19 de setembro de 1942, a mãe de Wiczer morreu em Londres, vítima do bombardeio alemão sobre a capital inglesa.

Em 19 de outubro de 1942, Wilson Lima, diretor do DNI (Departamento Nacional de Imigração), solicitou que se providenciasse a “individual dactiloscópica", forma corrente de identificação individual, já arguida pela burocracia anteriormente. Em 31 de outubro de 1942, o DNI remeteu o passaporte de Wiczer com o indeferimento e o pedido da "individual dactiloscópica".

No dia 2 de dezembro de 1942, os funcionários do DNI informavam que o estrangeiro, mesmo "chamado por memorandum", não havia comparecido àquele serviço. Cinco dias depois, o chefe do serviço da delegacia de estrangeiros, Climério Belo, encaminhou ao delegado Theobaldo Neumann um ofício sugerindo que a "individual datiloscópica" de Wiczer poderia ser obtida por meio de uma cópia fotostática da que ele havia deixado registrada no Instituto Felix Pacheco.

E dessa forma procederam. Em 7 de janeiro de 1943, o diretor do Instituto Felix Pacheco, Cláudio de Mendonça, encaminhou a cópia solicitada. A polícia da Capital estava preocupada e fazia questão que Wiczer "tocasse piano"11. Sem sucesso, copiou o registro de outro instituto, onde o

${ }^{10}$ Conforme a discrição de Bruno Wiczer em sua petição as autoridades brasileiras. Prontuário de Bruno Wiczer, Serviço de Vistos do MJNI. A viagem do "Struma" iniciou-se em dezembro de 1941, tendo a bordo de um navio próprio para o transporte de carga, 400 mulheres e crianças entre os 769 passageiros judeus fugitivos do nazismo. Sem ter licença de desembarque em porto algum e sem condições de navegabilidade, foram expulsos à força de Istambul em 23.2.1942. Apenas a uma mulher, em trabalho de parto, foi permitido o desembarque na Turquia. Em alto-mar, a casa de máquinas explodiu e o navio afundou. Somente um dos passageiros, David Stoliar, sobreviveu. Ainda não existe uma versão definitiva sobre as causas que levaram ao afundamento. Uma das versões aponta os russos como responsáveis pelo torpedeamento do "Struma". Revista Morashá, Edição 30. São Paulo, Setembro de 2000; "A Notícia" de Santa Catarina, 6.5.2001.

${ }^{11}$ Expressão utilizada nas delegacias cariocas para descrever a reprodução datiloscópica de todos os dedos das mãos de uma pessoa que está sendo fichada. estrangeiro havia realizado tal procedimento na época em que emitiu a sua carteira de residente temporário, anos antes, logo que chegou ao Brasil.

Em 4 de março de 1943, o policial Climério Belo pediu ao então delegado de estrangeiros Theobaldo Neumann que encaminhasse ao MJN as cópias datiloscópicas. Semanas depois, no dia 29 de março, Wiczer, então com 26 anos, dirigiu ao MJNI seu pedido datilografado de duas páginas. Era uma solicitação de licença ao Ministro para ir à Argentina. Residente na rua Cândido Mendes n. ${ }^{\circ}$ 32, no bairro da Glória, na então Capital Federal, informou que

(...) sua existência no Brasil teria corrido normal e feliz, não fora a operação a que houve de submeter-se devido aos maus tratos recebidos no campo de concentração de Dachau, próximo a Munich, para onde o levaram as tropas nazistas de ocupação em virtude de ter sido o requerente segundo-tenente do exército da Áustria. (...)

E a seguir, tratou de resumidamente historiar a sua breve e trágica trajetória de vida anterior a sua chegada ao país. Relatou seus "desequilíbrios de ordem material" e também "outros fatores morais que vieram perturbar-lhe o rumo de sua vida".

Wiczer informou ao Ministro que naquele momento sabia "apenas da existência de uns parentes residentes em Buenos Aires, para onde deseja seguir a fim de trabalhar como técnico de indústrias têxteis em que se especializou em Viena, na sua mocidade.” E para tanto, solicitou um visto de saída do país, "uma vez que deseja conviver com os poucos elementos de sua família tragicamente reduzida e infelicitada."

Ressaltou que não desejava se retirar do Brasil, "país onde viveu os sentimentos de humanidade que não mais existem nas latitudes guerreiras". Entretanto, como já não podia mais "prestar serviços à Nação" e tampouco, naquele momento, dispunha dos "meios capazes de garantir-lhe a subsistência", nada podendo oferecer ao país como gratidão "inscreveu-se como doador de sangue aos soldados brasileiros", já havendo doado 500 gramas. Informou também que havia ofertado à Embaixada francesa "seus trabalhos militares", mas que diante do colapso que sobreveio àquele país, transferiu a oferta à Embaixada inglesa.

Concluiu o pedido dizendo confiar no "elevado espírito de generosidade de Vossa Excelência e na tolerância das leis brasileiras" no sentido de obter o 
visto de saída, "para cumprir o seu destino na esperança de conviver e trabalhar com os derradeiros parentes que ainda sobrevivem na Argentina."

Nos primeiros dias de maio de 1943, Ernani Reis - secretário do Ministro do MJNI e membro da Comissão de Permanência de Estrangeiros e do CIC - fez uma consulta à Delegacia de Estrangeiros, em caráter de urgência, a respeito de Wiczer. A resposta com o histórico seguiu em 3 de maio. No dia 27 de maio de 1943, Theobaldo Neumann comunicou a Ernani Reis, que "Bruno Wiczer estava sujeito a multa e prisão, por ter infringido a lei”, embora aquela delegacia não registrasse antecedentes criminais dele. A multa e a prisão tinham relação a diversos crimes: a sua permanência no país por período superior ao permitido, a não apresentação ou resposta às intimações, ao seu não registro de endereço à polícia, entre outros. Naquele momento eram implementadas regras ainda mais rígidas aos estrangeiros, especialmente aos "súditos do Eixo". Os refugiados judeus, originários de países como a Alemanha, a Áustria e a Romênia, que já não eram mais reconhecidos formalmente como cidadãos por esses países, eram considerados por parte das autoridades brasileiras como "súditos do Eixo".

Em 2 de junho de 1943, Bruno Wiczer foi à polícia dar andamento ao seu pedido de "Permanência Precária". No dia 14 de junho de 1943, Ernani Reis indeferiu o pedido de saída para a Argentina, pois Wiczer não comprovara a sua nacionalidade, e declarou que "somente os súditos do Eixo estão sujeitos à licença deste Ministério para ausentar-se do país" e propôs o arquivamento do processo. Como na maioria das vezes, o parecer de Reis foi acatado na íntegra pelo ministro do MJNI Marcondes Filho.

As informações do prontuário 234/43 do Serviço de Vistos terminavam nesse ponto. Com a notícia do falecimento de ambos os pais, do restante da família, com problemas de saúde, sem condições de manterse, Wiczer ainda teve o seu pedido de saída do Brasil arquivado pelo MJNI.

Uma consulta à lista telefônica do Rio de Janeiro revelou somente um assinante com o sobrenome Wiczer, a senhora Nizia Lemos Lydia Wiczer. Na manhã seguinte à primeira leitura da documentação, telefoneilhe perturbado e inseguro de se tratar de parente de Bruno. Não imaginava que ele teria vivido muito além da década de 1940. Em um rápido diálogo, constatei ser a viúva de Bruno Wiczer. Viúva de seu terceiro casamento. As informações que lhe forneci eram absolutamente novas. O marido sempre fora uma pessoa extremamente alegre, simpática e divertida. Contou-me que Wiczer se casou sempre com mulheres muito belas, sendo uma delas atriz, e que ela mesma, ao casar-se, contava 20 anos a menos que o marido. Falou-me sobre a existência de um único filho - Henrique Paulo - , do primeiro casamento de Wiczer, que vivia em São Paulo.

Wiczer sobreviveu e soube recomeçar a sua vida no Brasil, não deixando que suas trágicas experiências passadas o impedissem de buscar a felicidade.

Nas semanas seguintes, como o assunto permanecesse em meus pensamentos, tratei de apurar as demais informações relativas a Wiczer no Arquivo Nacional. Localizei outro prontuário, dessa vez o da SPMAF/RJ (Superintendência de Polícia Marítima e Aérea Federal do Rio de Janeiro) de n. ${ }^{\circ} 8704$, que revelou a continuação do fichamento de Wiczer nos anos seguintes, descrito a seguir.

Em 18 de junho de 1943, o MJNI oficiou a Alvim Belis de Souza, delegado de estrangeiros, para saber se Wiczer tinha "maus antecedentes, ou é suspeito". No dia 29 de julho de 1943, o delegado Alvim Souza oficiou a Ernani Reis, informando que Wiczer havia fugido do Campo de Concentração até a Suíça, onde obtivera o visto, e que "ambos pais haviam sido fuzilados em Paris pelos alemães". Disse que Wiczer se achava em péssima situação financeira, sendo auxiliado por um amigo chamado Helmut Huetbr (ou Huetter). Informou ainda que o estrangeiro tinha um atestado do "Austrian Action", com sede na rua Almirante Alexandrino, onde constava como "adversário do atual regime alemão".

Esse tipo de argumento e documentação não convencia nem sensibilizava Ernani Reis. Em 5 de agosto de 1943, em novo parecer, Reis redigiu novo histórico, informando que "as informações policiais são boas", não escondendo algum sarcasmo. E escreveu que "a informação de que o suplicante fugiu de um campo de concentração na Alemanha não é corroborada pelo passaporte, que foi expedido em Colônia aos 26 de julho de 1938, e prorrogado em Zurique, aos 7 de fevereiro de 1939, pelo Consulado Alemão. Ora, é pouco provável que a polícia alemã tenha deixado de dar aviso de fuga aos consulados na Suíça." E pediu novos esclarecimentos à polícia. E assim foi. Em 17 de agosto de 1943, oficiou-se ao Delegado de Estrangeiros.

A resposta foi dada em 14 de outubro de 1943 pelo novo delegado, Annibal Martins Alonso, depois de ordenar uma sindicância policial. Além 
dos dados já mencionados, esclareceu-se que Wiczer vivia "a expensas de amigos, em virtude de não poder exercer atividade remunerada" e que "o progenitor foi cônsul honorário da Áustria em Bucareste, e na França, de 1922 a 1926, tendo sido fuzilado em um Campo de Concentração em julho de 1942".

Esclareceu o policial que em 14 de março de 1938, três dias depois da invasão da Áustria, Wiczer foi preso em Loben, pela Gestapo, sob acusação de "ser patriota, antinazista e judeu". Sem julgamento, foi transferido para o Campo de Concentração de Dachau. Por interferência de sua mãe, e mediante o pagamento de 10.000 marcos, conseguiu ser internado em um sanatório, em Viena, a fim de ser submetido a uma cirurgia, necessária devido a graves ferimentos que tinha sido vítima. Após a cirurgia, foi levado para Colônia, na Alemanha, onde conseguiu do Chefe de polícia, um passaporte para ingressar na Suíça. Em Zurique, foi novamente operado. E logo depois embarcou para o Brasil. Essa, pelo menos, foi a história que Wiczer relatou ao policial Aurélio Mendes Lobão, em 7 de outubro de 1943.

Em novo parecer de Ernani Reis, datado de 22 de outubro de 1943, o burocrata redigiu uma vez mais o histórico do caso e comentou, com vaidade, a respeito de suas suspeitas relacionadas à versão dos fatos anteriormente apresentados sobre a fuga de Wiczer, sobre os quais havia suspeitado: "Vê-se que eu tinha razão quando duvidei da fuga propriamente dita".

Como não dispunha de meios para providenciar a expulsão e tampouco país algum aceitaria receber o refugiado, Ernani Reis aprovou a permanência de Wiczer "a título precário". Esse tipo de status havia sido regulado pela portaria 4.941 de 24 de julho de 1941. Diante da impossibilidade de expulsar de imediato os estrangeiros indesejáveis, o MJNI concedia uma permanência "a título precário" com a ideia de não conceder uma permanência de fato e, no eventual fim das hostilidades na Europa, quem sabe, despachar de volta aos países de origem os refugiados naquela condição temporária.

Em 23 de novembro de 1943, Wiczer finalmente ficava com sua documentação em ordem. No dia 3 de dezembro de 1943, a polícia comunicou o fato a Bruno Wiczer, que, no mesmo dia, retirou o seu passaporte no MJNI. Em 15 de dezembro de 1943, a polícia remeteu novas "individuais datiloscópicas" de Wiczer ao MJNI.
No dia 11 de janeiro de 1944, Wiczer pediu de volta a certidão de nascimento (emitida pela Comunidade Cultural Israelita de Viena), pois precisava para se casar, no que foi atendido. Dez dias depois, para provar seus dados, que não era casado, sua filiação etc., Wiczer pediu nova declaração ao Delegado de Estrangeiros. Em 25 de janeiro, o chefe de serviço, Hoonholtz Martins Ribeiro, encaminhou ao delegado de estrangeiros, Anibal Martins Alonso, o pedido, uma vez que essa delegacia era a que dispunha dos dados necessários em arquivo para atendê-lo.

Cumprindo a legislação, que exigia dos estrangeiros a devida autorização prévia, por parte das autoridades policiais, de qualquer mudança de domicílio, em 30 de dezembro de 1944, Wiczer já do Paraná, solicitou licença à delegacia de estrangeiros para se mudar para a cidade de Curitiba.

No dia 31 de janeiro de 1945, a polícia indeferiu o pedido ao perceber a infração: Wiczer mudara antes de pedir a licença. Tal ato determinaria uma longa troca de correspondência entre diversas autoridades de diferentes Estados brasileiros. Duas semanas depois, em 15 de fevereiro do mesmo ano, a delegacia de estrangeiros do Rio de Janeiro entrou em contato com a de Curitiba e comunicou o fato ao delegado Isaías de Aquino Soares, titular na capital.

O DOPS (Delegacia de Ordem Política e Social) do Paraná respondeu em 8 de março de 1945, comunicando que Wiczer partira no dia 2 do mesmo mês para São Paulo, sem autorização deles.

A delegacia do Rio de Janeiro oficiou o fato em 3 de abril de 1945 à delegacia de São Paulo. Em 22 de maio de 1945, Paulo Alfredo Silveira da Mota, delegado Especializado de Estrangeiros de São Paulo respondeu que Wiczer não havia comparecido ali e que nada sabia sobre ele.

O delegado de estrangeiros do Rio de Janeiro, Gilberto Paiva de Lacerda, emitiu um rádio para Curitiba em 27 de junho de 1945:

(...) Solicito vossa senhoria melhores esclarecimentos transferência residência estrangeiro Bruno Wiczer, visto serem negativas informações prestadas delegacia estrangeiros São Paulo (...).

Em 10 de julho recebeu resposta de Curitiba: Wiczer estava em Fortaleza, Ceará. Três meses depois, em 10 de outubro de 1945, o delegado do Rio de Janeiro, Gilberto Lacerda, telegrafou (ou o fez por meio do rádio) ao chefe do SRE (Serviço de Registro de Estrangeiros) de Fortaleza, Ceará: 
"Solicito informar esta delegacia sobre se figura nesse serviço estrangeiro Bruno Wiczer, austríaco, segundo consta encontrasse nessa capital."

Os cearenses responderam no mesmo dia que não havia registros e tampouco constava que Wiczer residia em Fortaleza. Aparentemente essa mensagem não foi recebida no Rio de Janeiro. Sem resposta, foi encaminhada nova tentativa ao Ceará em 3 de maio de 1946, reiterando o pedido anterior.

A resposta de Joaquim de Lima, chefe do SRE de Fortaleza, chegou em 10 de maio de 1946. Uma vez mais reiterava que não havia notícias ou registros de Wiczer em Fortaleza.

No dia 27 de maio de 1946, um funcionário do Departamento Federal de Segurança Pública oficiou ao seu chefe informando que estava tentando cobrar a multa de Wiczer pelo fato dele se mudar sem autorização, mas que:

(...) Até a presente data, este Serviço não consegui localizar o citado alienígena, visto que o mesmo transfere-se constantemente de um para outro Estado, sem dar, ao que parece, satisfação alguma às autoridades. (...)

Em 30 de maio de 1946, o chefe de serviço mandou oficiar aos Estados do Paraná, São Paulo e Ceará que comunicasse sobre a passagem de Wiczer, "para as medidas cabíveis". Vendo que era inútil e de pouco bom senso manter a troca de correspondência sobre aquele caso, e já num prenúncio de que o controle sobre os estrangeiros efetuado pelo Estado já estava cambiando seus procedimentos, em reflexo das mudanças gerais da estrutura de governo, mandou arquivar o processo.

No dia 7 de junho de 1946, com a delegacia de estrangeiros já extinta, Dalmo G. de Oliveira, chefe de serviço do MJNI, oficiou a Walfrido Piloto, Chefe do SRE de Curitiba, conforme as ordens recebidas. Mesmo procedimento adotou em relação a Paulo Alfredo Silveira da Motta, Delegado Especializado de Estrangeiros de São Paulo, e a Joaquim Lima, no Ceará.

O processo foi encaminhado ao chefe da seção de arquivo em 11 de junho de 1946. Com o prontuário preste a ser encerrado, começaram a surgir dos Estados as respostas a comunicação sobre o arquivamento. No dia 19 de junho, São Paulo respondeu que não possuía registros de Wiczer.
Em 11 de junho de 1946, um ofício do Ceará reafirmava que a polícia local desconhecia qualquer informação sobre Wiczer.

Entretanto, em 4 de julho de 1946, chegou ao Rio de Janeiro nova e diferente resposta de Curitiba. Informava que em 21 de fevereiro de 1945, já havia multado Wiczer e que, em 19 de junho de 1945, ele havia entrado com um pedido de permanência definitiva, mas que, depois disso, novamente desaparecera.

Não podendo contar com o depoimento pessoal de Wiczer, temos aqui um indício de que aconteceu com ele o que frequentemente se passava com muitos dos estrangeiros no Brasil, especialmente naquele período: eram alvos de extorsões por parte das autoridades policiais. Especificamente no caso dos refugiados, a ameaça de expulsão ou prisão, com a volta forçada à Europa, foi utilizada largamente por policiais inescrupulosos e desonestos, com o fim de achacar estrangeiros. Qual seria o motivo que levara as autoridades policiais de Curitiba a demorarem quase um ano e meio para comunicarem que a multa - razão de tanta correspondência interna da polícia - já havia sido aplicada?

No período entre julho de 1946 e dezembro de 1951, a documentação não nos revelou nada sobre a vida de Wiczer. O Estado Novo terminara. As estruturas policiais de controle aos estrangeiros foram sendo "desarmadas", embora os condicionamentos psicológicos das autoridades não "desarmassem" de imediato certos procedimentos e posturas conduzidas ao longo de todo o período anterior, de pelo menos uma década de especial atenção e desconfiança em relação aos estrangeiros.

Já desquitado, em 7 de dezembro de 1951, Bruno Wiczer, apresentando-se como comerciante, solicitou a sua naturalização.

No dia 7 de março de 1952, o MJNI mandava o SRE de Curitiba cobrar de Wiczer as multas de 1946. Em 15 de abril de 1952, Paulo Brasil, do Departamento Federal de Segurança Pública, oficiou ao Chefe do SRE de Curitiba, acusando o recebimento da "individual dactiloscópica", e comunicou que o naturalizando ainda figurava como permanente a título precário, "não tendo esse Serviço comunicação de que esteja ele com sua situação no Brasil devidamente legalizada". Informou ainda que, desde maio de 1946, "esse Serviço procura localizar o referido advena \{estrangeiro\}, visto que, o mesmo está obrigado ao cumprimento das exigências (...) dada a sua situação irregular 
no país". Concluiu solicitando ao Ministério que "seja este SRE informado da atual situação de legalidade do estrangeiro no território nacional".

Hershell Pencak (B5156): memórias da dor

Em 1954, novamente morando no Rio de Janeiro, Wiczer conseguiu naturalizar-se brasileiro.

Somente em 2002, resolvi procurar o Sr. Henrique Paulo Wiczer para complementar o presente artigo. Não foi com surpresa que ouvi dele o mesmo relato concedido pela Senhora Nizia Wiczer. Embora os dados (nome dos pais, data de nascimento etc.) fossem coincidentes e ficasse mais do que comprovado tratar-se da mesma pessoa, o Sr. Henrique Paulo jamais escutara tais relatos de seu pai.

Bruno Wiczer faleceu em 1985 e jamais contou a nenhum de seus parentes nada sobre o seu passado na Europa. Tratou de reconstruir a sua vida fazendo com que se lembrassem dele sempre como um homem alegre e simpático. A polícia se preocupou tanto em obter e registrar a "individual dactiloscópica", linhas e marcas da vida que Bruno Wiczer conseguiu ocultar, com sucesso, daqueles com quem conviveu e amou.

\section{Bibliografia e Fontes}

Documentais:

Prontuário do Serviço de Vistos do MJNI (Ministério da Justiça e Negócios Interiores) de número 234/43

SPMAF/RJ (Superintendência de Polícia Marítima, Aérea $e$ de Fronteiras do Rio de Janeiro) de n. ${ }^{\circ} 8704$.

Depoimentos:

Henrique Paulo Acir Semelman Wiczer, por telefone, em 2002. - Nizia Lemos Lydia Wiczer, por telefone, em 2000.

\section{Bibliografia (livros e periódicos):}

KOIFMAN, Fábio. Quixote nas trevas: o embaixador Souza Dantas e os refugiados do nazismo. Rio de Janeiro: Record, 2002.

Revista Morashá, Edição 30. São Paulo, Setembro de 2000.

“A Notícia”. Santa Catarina, 6.5.2001.
Maurício Pencak

\section{Apresentação}

- $\mathrm{m}$ recente artigo, o escritor Juva Batella analisa o livro A Noite, do Prêmio Nobel da Paz, Elie Wiesel. Batella responde àqueles que dizem que tudo já foi escrito sobre o Holocausto. Afirma que, se obtivéssemos o relato individual de cada uma das vítimas da grande tragédia que se abateu sobre nosso povo, ainda assim muito teria a ser dito.

Esse modesto trabalho é o resgate de uma dívida. A infância e juventude - minha e de meus irmãos - foi permeada pelas inúmeras histórias que nosso pai, Hershell (Henrique), sobre a Guerra. Infelizmente não as compilei com ele em vida. O enorme trabalho de memória feito pelo cineasta Spielberg, só veio a ocorrer anos após seu falecimento e, confesso, senti uma enorme frustração de que o relato de meu pai lá não constasse.

Além de cobrir essa dívida simbólica para com sua memória, pretendemos deixar uma pequena contribuição para as gerações que se seguem.

Começamos as gravações em 13 de setembro de 2001, dois dias após os terríveis atentados que vitimaram o povo norte-americano e lançaram o planeta numa nova quadra de sua história. Nesses meses, assistimos também, a triste deterioração das relações entre Israel e a população árabe-palestina, situação que nos abala porquanto nossa identidade judaica e sionista.

Monstros, que imaginávamos completamente extintos, voltam a despertar. Discursos totalitários e intolerantes disfarçados em meio a fraseologia pseudo- revolucionária, justificam a destruição de milhares de vidas inocentes. Ataques terroristas em Israel, mas também em outros países - não esqueçamos os atentados na Argentina - buscam matar o máximo de indivíduos judeus. Na França, país que granjeou a fama de firme defensora do convívio entre diferentes e dos direitos humanos, em poucos meses, acumularam-se mais de 360 atos de agressão ou vandalismo nitidamente antissemitas. Recentemente assistimos, estarrecidos e 
impotentes, o sacrifício do jornalista norte-americano e judeu, Daniel Pearl, por essas mesmas forças do mal.

Esperamos que esse trabalho acrescente um pequenino elo na grande corrente que mantém o povo judeu. A perpetuação da memória é uma das garantias de nossa sobrevivência e que, com isso, continuemos a contribuir para a melhoria da Humanidade, ética e materialmente.

Auschwitz - Pequena cidade da Polônia (Oswiecim, em polonês), a $40 \mathrm{Km}$ de Cracóvia. Foi, durante a II Guerra Mundial, a sede do mais bárbaro campo de concentração organizado pelos nazistas.

Em 14 de junho de 1940, os alemães edificaram um campo de concentração num dos subúrbios da cidade. Em 1941, ampliaram-no para "desenvolver tratamentos especiais aos prisioneiros", construindo as unidades de Budy, Harmenze (para mulheres), Birkenau e Auschwitz II. Auschwitz passou a ser um enorme campo de concentração para milhões de judeus de toda a Europa. Em 1943, entravam em funcionamento quatro gigantescos fornos crematórios. Os prisioneiros, até então mortos por asfixia numa câmara de gás com capacidade para 500 pessoas, passaram a ser assassinados aos milhares: em junho de 1944 foram asfixiadas e queimadas, num só dia, 23 mil pessoas.

Os pertences dos mortos eram enviados à Alemanha. As roupas eram distribuídas entre as famílias alemães, e os valores - inclusive o metal dos dentes de ouro - destinados ao erário do Estado germânico. Nos seis edifícios, após a derrota dos nazistas, foram encontradas, metodicamente empilhadas, 836.255 peças de roupas femininas e 34.882 masculinas.

A 18 de janeiro de 1945 os alemães, perseguidos pelos Aliados, evacuaram rapidamente os 58.000 prisioneiros de Auschwitz; foram abandonadas no campo cinco ou seis mil pessoas, cujo estado físico não lhes permitia locomover-se.

A Comissão Médica e Legal Soviética, que chegou a Auschwitz imediatamente após a saída dos alemães, calculou que o número de prisioneiros assassinados naquele campo ia a mais de quatro milhões; esse cálculo foi confirmado pelos empregados da estação de Auschwitz, segundo os quais, de 1942 a 1944, foram ali desembarcados, por via férrea, 3.850.000 prisioneiros. (extraído da enciclopédia UNIVERSO, volume I, ano 1973, Editora Delta/Editora três)

\section{Breve relato sobre a Polônia}

As tribos eslavas que vieram originar o povo polonês, estabeleceramse em seu futuro solo pátrio em torno dos anos 600/800 D.C. Originalmente pagãos, essas tribos converteram-se ao Catolicismo Romano, fazendo da Igreja uma de suas instituições nacionais mais perenes.

Os séculos XV e XVI são cenários do grande movimento de perseguição às comunidades judaicas na Península Ibérica. Esse processo, conhecido pelo nome de INQUISIÇÃO, esteve sob administração das Ordens religiosas católicas consorciadas às Casas Reais dominantes na época. Essa enorme onda de perseguição antissemita, culminou com o assassinato, conversões forçadas, pilhagens de bens e a expulsão de centenas de milhares de judeus, primeiro da Espanha e depois de Portugal.

$\mathrm{Na}$ busca de novos lares, onde pudessem reconstituir suas vidas e manter seu culto religioso, os judeus procuraram outras regiões da Europa. Em torno do Século XVII, os reis católicos poloneses fizeram um convite para que os judeus lá se instalassem. Outras importantes comunidades judaicas se desenvolveram por toda a Europa Centro-Oriental: Alemanha, Bessarábia, Rússia, Boêmia, Hungria, etc., tendo fases de florescimento e diversos episódios de grave risco para sua existência.

A Polônia moderna recuperou sua independência após a I Guerra Mundial (1914-1918). Seu território, que se encontrava dividido entre o Império germânico, a Rússia Czarista e o Império Austro-Húngaro, voltou a se unificar após os Acordos de Paz que se seguiram ao fim do conflito.

O renascimento da Polônia deu-se sob controle de um militar de forte viés autoritário, o Marechal Pilsudsky. Às vésperas da II Guerra Mundial, a população polonesa girava em torno de 30 milhões de habitantes, sendo que $10 \%$ formava a expressiva minoria judaica (na capital, Varsóvia, a população judaica chegava a um terço do total).

O sentimento nacional polonês, durante o período sem soberania, refletia-se fortemente em torno da Igreja Católica. A mistura do sentimento nacionalista apaixonado com as arraigadas convicções religiosas, criou um fértil terreno para o desenvolvimento de profundas e duradouras manifestações de espírito antissemita. 
Foi nessa Polônia, prensada entre a Alemanha humilhada após a I Guerra Mundial e a Rússia récem-bolchevique, que nosso pai nasceu. Em 1933, o Partido Nazista ascende ao poder na Alemanha e nuvens sombrias voltam a se formar sobre a Europa, e particularmente sobre o povo judeu. Em $1^{\circ}$ de setembro de 1939 eclode a II Guerra Mundial, com a invasão da Polônia pelas tropas alemães. O destino de dezenas de milhões de pessoas será dramaticamente afetado pelos acontecimentos que se seguiram.

O trabalho foi feito a partir de entrevistas com minha mãe, Chana (Anita) Pencak, e meu irmão imediatamente mais velho, Mauro Valter Pencak. Do texto, constam também, relatos por mim ouvidos.

P- Mauro, você mandou uma correspondência para a Holanda, correto? Fale disso.

Mauro- Duas vezes. No Jornal do Brasil, há algum tempo atrás, vi um anúncio dizendo que tinha uma Comissão fazendo intermediação junto às Seguradoras que, porventura, tivessem feito seguros para os judeus na era do Holocausto...

Eu mandei o cupom, o recorte, e me mandaram todos os folhetos. Tinha um telefone grátis que veio no apêndice do folheto e disseram que tinha que esperar mais um pouco, porque já tinham feito contato com as Seguradoras. Nunca mais mandaram resposta, mandei mais duas cartas para a Holanda e até agora não chegou nada. Eu acho que esteja perdido o caso...

P- Na verdade, o que nos moveu foi o senso de justiça. Queremos, como descendentes, algum reconhecimento pelo sofrimento lavrado à nossa família. Mauro, você, dentro da família, é notabilizado por ter uma memória fantástica, papai nasceu quando?

Mauro - 15 de novembro de 1924.

P- Uma coincidência! No dia da Proclamação da República.

Mauro- É, 35 anos depois.

P- Quando ele faleceu?

Mauro - 24 de junho de 1985.

P- Você se recorda? Depois de toda uma vida de luta, papai veio a falecer de que mal?
Mauro- Câncer de cólon de intestino.

P- Depois de quanto tempo de convalescença?

Mauro- Um ano e dois meses.

P- Foi uma luta...

Mauro- Uma luta terrível (silêncio), operou, ficou oito meses sem sequelas, engordou, comeu. Estava sentado na mesa, de repente ele se levantou com ânsia de vômito e, desde lá, voltou. Teve que tomar transfusão de sangue, de novo internado.

P- A doença que muitos judeus evitavam até falar o nome. Falavam “aquela doença”. Mauro- E pelo que me consta, papai não soube do que morreu.

P-Mauro, vamos falar um pouco sobre as raízes familiares do papai. Por parte de pai...

Mauro- Nosso avô era Nusyn Pencak.

P- Fale um pouco sobre a estrutura da família de nosso avô.

Mauro- O nome do avô paterno de nosso pai era Mendel.

P- Que, por acaso, é meu nome (os judeus recebemos um nome perante a Torá).

Mauro- Nosso avô casou com sua prima em primeiro grau, Laja Frajdla (Lea Frida). P- Nossa avó paterna, correto?

Mauro- É, e que veio a falecer em 6 de novembro de 1976.

P- Como era a estrutura da família de nosso avô, ele tinha irmãos?

Mauro- Tinha o tio Zelig, Schuel (Saul), Laibus(Luis).

P- Esses nós conhecemos no Brasil, vieram antes da Guerra.

Mauro- Se não me engano, ainda tinham mais dois...

P-Mas esses, a Guerra ceifou.

Mauro- O nosso pai tinha três irmãos: Velvo, de 1918; Sara, de 1920; Schoshnm (Shoshana ou Sophie), de 1922; e papai, de 24. 
P- Qual era o sobrenome de solteira de nossa avó paterna?

Mauro- Zaltstreiger. Ela tinha vários irmãos: Iankl (Jacó), Tanachn e Moishe (Moisés)

P-Localize os que vieram antes e depois da Guerra.

Mauro- Antes da Guerra, só o tio Moishé. Os outros vieram depois da Guerra.

P-Vamos buscar lembrar agora, dados de infância do papai.

Mauro- Pelo que eu sei, ele estudou ate o quarto ano ginasial, até a Guerra começar.

P- Qual a idade que nosso pai tinha quando começou a Guerra?

Mauro- Nem 15 anos completos.

P- Mas já tinha, então, feito Bar-Mitzvá?

Mauro- Com certeza.

P- Coisa que muitos jovens judeus da época não tiveram possibilidade de fazer. Voltando à infância, comente alguns episódios.

Mauro- Lembro que ele contava que uns meninos poloneses antissemitas ameaçaram lhe dar uma surra, no trajeto que ele fazia para a escola. Ele pediu emprestado ao senhorio do pai dois cachorros, e os moleques fugiram assustados.

P- Vamos esclarecer a situação vivenciada pela população judaica. Os cidadãos judeus poloneses viviam duas realidades, tinham uma educação judaica, quando crianças, numa instituição chamada...

\section{Mauro- "Cheider".}

P- Ou seja, papai estudava num “Cheider”e numa escola pública polonesa. Existia muita pobreza no meio da população judaica, mas a família do papai tinha um negócio, qual era?

Mauro- Eles tinham uma padaria.

P- Você se lembra do endereço? Papai alguma vez comentou?

Mauro- Acho que era Rua Stodolna...

\section{P- Rua Stodolna 12.}

Mauro- Você se lembra melhor. Muitas coisas o papai "bloqueou" e não comentava. Ele se referia à Polônia como “Alter Haim”..

\section{P- Traduza.}

Mauro- Antigo lar. Muito antissemitismo...

P- Vamos para o período da Guerra. Qual foi a primeira vez que ele teve contato com tropas alemães?

Mauro- Contou que estava jogando lixo fora, com seu pai, quando passaram motociclistas das tropas nazistas. Um soldado que estava no carona, perguntou: Juden? Quando acenaram afirmativamente, o soldado passou a mão pela garganta, dizendo Kaput! Papai dizia que Hitler baseou a maioria dos campos de concentração na Polônia, porque sabia que lá ia encontrar respaldo, pois a maioria dos poloneses era antissemita.

P- Para além do sentimento antissemita, havia o fato da enorme concentração de judeus na Polônia.

Mauro- $10 \%$ da população, mais ou menos três milhões.

P-Vamos continuar o relato.

Mauro- Penso que a mamãe está mais apta. Ela tem mais informações.

P- Mãe, vamos falar sobre a infância do papai. Em qual cidade ele nasceu?

Chana- Ostrowtzin (Ostroviec).

P- Vamos falar sobre sua raízes familiares. Tinham posses? Eram pessoas religiosas? Fale um pouco.

Chana- A família do vovô Nusyn era de pessoas religiosas, tradicionais, não eram rabinos. Eles tinham padaria e levavam uma vida como classe média.

P- Sobre as origens da família da vovó Léa?

Chana- Os pais da vovó Léa eram um pouco mais ortodoxos...Bom, já estamos falando da família Zaltstreiger, não sei qual era a profissão.

P- A família da vovó Léa era de Ostrowiec? 
Chana- Não, eram de Ieglinsk.

P- Eles tinham laços familiares.

Chana- Vovó Léa, com seu futuro marido, Nusyn, eram primos de sangue, em primeiro grau.

P- Como eram os vínculos?

Chana- A mãe da vovó Léa e a mãe do vovô Nusyn eram irmãs.

P- Era uma coisa normal, esses casamentos tão próximos?

Chana- Muito normais, a gente ouvia falar muito nisso.

P-Diferente, então, da maioria dos judeus da Europa Oriental que viviam em dificuldades, a família do papai tinha uma estrutura de classe média.

Chana- Sim, classe média. Não digo que viviam em riqueza.

P- Ouvi comentários sobre a bondade do vovô Nusyn, o respeito que granjeou por suas atitudes perante os menos favorecidos.

Chana- Vovô Nusyn era uma pessoa muito boa. Ele sempre tinha convidados para Shabat e todo pedinte não saía de mão vazia. Ele sempre ajudava, sempre foi elogiado. Tanto é que, quando foi casar a filha Sarah, o "Mechitn"(compadre, pai do noivo), que era um dos grandalhões de uma outra cidade, falou: "Mechitn Nusyn, todo rico tem inimigo e você só tem amigos". Houve também o comentário do senhorio, um católico de nome Kajek e que falava Idish: "Nusalan, chite far danen guite fran, far den sonen el ier der chiten (Nusyn, Cuide-se de seus "bons" amigos, que dos teus inimigos te protejo). Ele ouvia os comentários, em idish, dos vizinho invejosos, e os interrompia mandando-os ir trabalhar. Respondia que Nusyn e toda a família acordavam cedo para ir trabalhar na padaria, e nada deviam a ninguém.

P- Como era a estrutura da família?

Chana- Velvo, mais velho; Sarah, que casou antes da Guerra e já tinha um filhinho de três anos; Shoshn e o papai, que era o caçula.

P- Todos ajudavam na padaria?

Chana- Todos, menos o papai que era o caçula.
P- Eles tinham funcionários judeus ou católicos?

Chana- Acho que na padaria eram católicos. A empregada em casa era judia.

P- Eles tinham empregada doméstica? Isso revela uma certa posse.

Chana- Sim, tinham judeus pobres que precisavam trabalhar.

P- Em 39 inicia-se a Guerra. Eu me recordo de papai ter comentado que chegaram a discutir a possibilidade de fugirem para a Rússia.

Chana- Pode ser, mas disso não me recordo.

P- A Guerra começou em I de setembro de 1939, com a Alemanha invadindo a Polonia. O que papai relatou? Eles sabiam o que estava ocorrendo com os judeus na Alemanha?

Chana- Eu acho que eles não sabiam tanto.

P- Papai contou como foi a fase inicial da Guerra? Como os alemães começaram a desenvolver sua política?

Chana- Foi por etapas. Primeiro, os alemães queriam se estruturar. Precisavam de comida, pães...

P- As tropas alemães?

Chana- Sim. E o que aconteceu? Ou apontaram, ou viram que a padaria do vovô Nusyn era mais estruturada, então entraram lá e falaram: "precisamos dessa quantidade de pão!".

No princípio eles pagavam, eram muito espertos. E voltavam e pediam cada vez mais. Então, a vovó Léa ficou muito assustada e falou: "Nusln, ist tsi guit (Nusyn, é bom demais...). Sabe, a vovó era mais medrosa e tanto falou que o vovô Nusyn disse para os alemães procurarem outra padaria maior, pois não conseguia dar conta. E conseguiu jogá-los para outra padaria, talvez não judeus. Vovó ficou muito assustada...

Aos poucos eles começaram...você sabe, primeiro procuraram os comunistas, políticos, e aí partiram para os judeus. Todo mundo começou a ficar com medo. Lá era comum ter porões e então se esconderam. Os jovens saíram para ir trabalhar em fábricas...

P- Você está falando jovens judeus. 
Chana- Naturalmente! Os católicos eles não mexeram: os católicos ainda apontavam “iuden', “iuden”.

\section{P- Em quais fábricas?}

Chana- Lá mesmo, em Ostrowtzin. Eles começaram a sentir que não adiantava se esconder, pois todos iam morrer de fome. Esconderam os pais no porão, os filhos foram trabalhar. A Sarinha já estava casada e com um filhinho de 3 anos...

P- Você se lembra do nome da criança?

Chana- (silêncio) não...

P-Vamos Id, continuando.

Chana- E o marido da Sarinha serviu o exército polonês, antes da guerra.

P- Quando os vovós se esconderam, alguém ocupou a padaria?

Chana- Provável. Eles abandonaram, largaram tudo. Esse detalhe me lembro, quando os alemães começaram, eles juntaram roupa de corpo, roupa de cama e pediram para o senhorio guardar.

Não sei se o porão era na casa ou na padaria. Desculpe os termos, no porão defecavam, urinavam, pessoas começaram a perder a razão. Os filhos iam para a fábrica, e à noite também voltavam para o porão.

P- Você se lembra qual tipo de fábrica era? Roupa, armas...

Chana- Acho que era fábrica de tecidos... não tenho certeza.

P- As fábricas eram administradas por alemães?

Chana- Sim. Os alemães tomaram conta, entraram e começaram a administrar tudo. É como se fosse prefeitura. Tinham, ainda, administradores "poilishes"(poloneses), mas foram perdendo poder.

P- Estávamos então no início da Guerra. Quando os alemães começaram a concentração dos judeus? Lembro-me que papai falou, primeiro ficaram num campo da cidade.. dali, ele viu o vovô Nusyn ser transportado..
Chana- Bom, na fábrica eles ainda não estavam presos, conseguiam se movimentar, ainda voltavam para casa. Eles conseguiram tirar os pais do porão e levar para a fábrica.

Perguntei: "Henrique, como? Ele falou: "Anita, freignicht, mot guikent" (não pergunte, conseguíamos).

As pessoas no porão já estavam começando a ficar malucas. Os alemães começavam a fazer buscas, procurando pessoas escondidas, aumentando o pânico.

\section{P- Dando batidas.}

Chana- É. Eles buscavam disfarçar a marca no chão, jogando algo em cima para não aparecer a tampa do porão. Em cima se chama.. tem um nome...

P- Clarabóia, sótão.

Chana- É, em cima, quem se escondeu foi Anne Frank...Bom, retomando, tiraram os pais do porão e esconderam na fábrica. Ficaram um tempo e aí começou o processo de concentrar as pessoas.

\section{P- Você se lembra de datas?}

Chana- Deve ter sido, mais ou menos, 40 ou 41.

P- Em 42, eles decidem pela "Solução Final”.

Chana- Acho que foi em $41 \ldots$ seu pai?

P- Como foi a concentração, qual foi a última vez que nosso pai viu

Chana- Eles faziam fila, duas três, quatro filas. Papai falava: "Mot nicht gueviss vi tzloifen, vi zé tsa besse"(Não sabíamos para onde correr, onde seria melhor). Eles sentiam, uma fila era para levar..

\section{P- De onde para onde?}

Chana- De Ostrowtzn para os trens, vagões. Papai dizia que se corria de uma fila para outra. Papai estava numa fila, o Velvo estava numa fila, vovô Nusyn estava numa fila.. .o Velvo e o pai deviam estar numa fila.. .a mãe estava numa fila. A última vez que ele viu o Velvo e o pai foi na fila. Os alemães mandaram: "esta fila vai para cá, esta fila vai para lá". 
A fila que a vovó e o papai estavam, não foi para o extermínio.. .(pausa), e essa foi a última vez que o papai viu o Velvo e o vovô Nusyn.

P- Estamos emocionados, mas continue mãe.

Chana- Se mataram logo ou não, ele não sabe. Ele não teve mais notícias. P- Ele não soube para onde aquela fila foi?

\section{Chana- Não.}

P-Se foi para um bosque, se foi para Auschwitz?

Chana- Não, papai não teve mais notícias.

P- No pátio desta seleção, foi a última vez que ele os viu?

Chana- Foi a última vez.

P- Mãe, você se recorda, ainda, de mais um episódio passado em Ostrowiec.

Chana- Seu pai, ele estava trabalhando na fábrica e buscava, ao máximo, evitar apanhar, tinha muito medo de ser espancado. Ele não conseguiu explicar qual foi a situação, qual o "pecado", o que acharam que ele tinha feito demais, Deve ter sido um antissemita, alguém com raiva dele. Espancaram ele de paulada, de cintada, e os pais ainda estavam dentro da casa...

\section{P- No porão?}

Chana- É, escondidos no porão. Então, ele chegou, de noite, todo machucado, tão dolorido que a mãe teve de fazer compressas. Como, eu não sei.. .pois estavam no porão. E eu perguntei: como é que depois você foi trabalhar? Parece que durante dois dias ele não foi trabalhar, mas acabou retornando. Foi um episódio que o espancaram gratuitamente. trem?

P- Retornando ao relato, papai, vovó Léa e a tia Shoshn pegaram o

Chana- Não, eles continuaram na fábrica.

P-Até quando?

Chana- Acho que até 42.
P- Você se lembra o ano que papai foi transferido para Auschwitz? Como foi a viagem de trem?

Chana- Botavam no trem e viajavam, viajavam. Tem o episódio que contavam até dez..

P- Mãe, deixe eu relatar. Pensava que era uma fantasia de infância ou que tinha lido em algum lugar, mas vejo que foi um relato feito pelo papai. Os trens, muitas vezes, paravam, dando passagem a outros com tropas ou armas. Quando as composições diminuíam a velocidade, muitas pessoas pulavam dos vagões. Quando os SS faziam a recontagem, viam que o vagão estava aberto e pessoas tinham escapado. Então, como punição para os que não tinham denunciado as fugas, eles organizavam filas, contavam até dez e o décimo era fuzilado. Papai falou em duas oportunidades, uma vez ele foi o nono e na outra vez foi o décimo primeiro. Achava que era uma fantasia e não queria dar esse relato. Estou emocionado, pois você confirmou o que estava na minha reminiscência. Papai relatou sobre Auschwitz.

Chana- As seleções com Mengele. Ele passou por duas, três seleções. Mauro- Papai falou que Mengele indicava o destino dos prisioneiros com o polegar, para lado ou para outro.

P- Papai sempre sendo considerado apto a trabalhar.

Chana- Ele achava que o papai era alto, ainda tinha um pouquinho de pele, era apto a trabalhar.

P- Para trabalhar até a última gota...

Chana- Até a última gota. Tanto, que ele aguentou onze dias e...

P- Mas isso é depois, vamos deixar para frente. Vamos ainda falar sobre Auschwitz. Era um campo que tinha dois aspectos: era campo de trabalho, visando o esforço de guerra nazista e era campo de extermínio.

Chana- Papai ficou no campo de trabalho.

P-O que ele fez em Auschwitz? Quais serviços?

Chana- Uma vez a Shoshn me disse.. trabalhos de pavimentação, terra, asfalto. A tia Shoshn andava depressa com os carrinhos.

P- Mãe, você se recorda do episódio com os ciganos? 


\section{Chana- Não.}

P- Esse relato do papai me recordo. Numa noite, ele viu chegar trens com pessoas em vestes diferentes e identificou-as como ciganas. Ele calculou algo entre dez mil e quinze mil pessoas. Na manhã seguinte não se encontravam mais, ou seja, os alemães exterminaram a todos numa madrugada!

Chana- Papai comentou o episódio de quando uma pedra que transportava, caiu e machucou seu pé. Ele tentou esconder o inchaço, com medo de que fosse executado, mas chegou a um ponto em que começou a mancar e ter febre. O capataz mandou-o para a enfermaria e, para o papai, foi o melhor momento na Guerra. Lá, recebeu roupas quentes e limpas, assim como melhor alimentação, no caso, uma sopa mais grossa. Ele tentou aumentar o período de repouso, usando um artifício. Quando sabia que o médico vinha lhe tomar a temperatura, esfregava o termômetro para dar a impressão que continuava com febre.

\section{P- Você falou em outros relatos.}

Chana- No campo de concentração eles tinham muita fome. Dizia que, para eles, era um YOM TOV (feriado religioso, em hebraico) quando conseguiam pegar as cascas de batata, cozinhar e fazer aquela comidinha para eles; isso, quando não eram pegos, se fossem pegos eles eram castigados. Eles sentiam se os guardas estavam olhando, aí pegavam as cascas e cozinhavam...como, eu não sei. Dizia que era uma festa quando conseguiam pegar as cascas, um YOM TOV. Comentou que o sonho deles, enquanto estavam em Auschwitz, era um dia... pudessem se sentar à mesa e comer pão a vontade.. (silêncio)

\section{P- Estamos emocionados}

Chana- Ele sempre dizia: sentar e comer pão a vontade. Relatou, também, uma agressão sofrida pela vovó Léa. Preocupada em conseguir cascas de batatas e, assim, fazer panquecas para a filha Shoshn, a vovó correu atrás dos latões de lixo, sendo flagrada por uma guarda feminina. Essa mulher deu-lhe uma paulada, abrindo a testa da vovó Léa e a colocou de castigo, ajoelhada sobre pedras. Depois, a tia Shoshn a socorreu em prantos Perguntando: "Mame, farwus du ost guemacht dus? (mamãe, por quê você fez isso?)
P- A Guerra foi chegando ao fim, já estávamos em 45. Quem foi libertado primeiro?

Chana- A vovó e a tia Shoshn, pelas tropas russas. Acho que em janeiro de 45 .

P- Certo. Lembro que papai foi mandado para a Alemanha, para Bergen-Belsen. Ele foi jogado num vagão, como outros milhares de prisioneiros sobreviventes, iniciando uma viagem de dez, doze dias.

\section{Chana- Onze noites e onze dias.}

\section{P- E como papai sobreviveu?}

Chana- Deram um pedaço de pão para onze dias, só que não deu. Perguntei, como você sobreviveu? Nevava, eles botavam a mão, jogavam na boca, passavam pelo rosto, com isso eles sobreviveram.

P- Ele falou de detalhes, em Bergen-Belsen?

Chana- Não me lembro...

P- Eu me recordo. Papai contou que foram libertados na primeira ou na segunda - não me recordo bem - semana de abril de 45, por tropas inglesas. Ele contou que os soldados aliados, atordoados pela visão dos “katzenikes"( $e$ ' uma abreviação para prisioneiros de campo de concentração, gíria negativa para caracterizar o estado de depauperação física), ofereceram, imediatamente, sua rações, só que foi um desastre. A boa intenção gerou algumas dezenas de mortes, pois as rações eram concentradas, papai contou que as rações eram à base de sardinha, muito fortes. Os prisioneiros engoliram e muitos morreram de disenteria, ele comenta que teve um estalo e, aos pouquinhos, começou a beber leite. Não me esqueço, pouquinho a pouquinho, onde, depois de alguns dias ele se sentiu melhor e partiu para alimento sólido.Bom, foram libertados e ai a ONU criou uma Comissão de refugiados, para juntar os familiares. Relate como foi, a vovó na Polônia, o papai na Alemanha. Como foi o reencontro dos familiares sobreviventes?

Chana- Criaram um Comitê e começaram a chamar os sobreviventes, fizeram listas com os nomes e levavam de uma cidade para outra. Então, uma pessoa viu o nome do papai e, depois, encontrou a vovó na Polônia. Ele disse: -"Senhora Pencak, eu vi o nome de seu filho na lista". 
Quando ela escutou isso, começou a gritar, desmaiou, dizia não poder ser. Ele ainda disse: -'Tomara que eu encontre os meus filhos, como eu encontrei o nome de seu filho." Papai, quando soube da sobrevivência da mãe e da irmã, foi para a Polônia. Quando lá chegou, estava tão magro...pesando 44 quilos, ele tinha 1,70 metro de altura. Com o corpo cheio de feridas, ainda teve que ser escondido e tratado pela vovó, para que os poloneses não dissessem que estava com lepra.

P- Um jovem de 21 anos, com 1,70 metro de altura, 44 quilos... Terminada a Guerra, a vovó Léa retorna ao que seria a casa do antigo senhorio, onde tinha deixado roupas, pertences. Como foi o reencontro dela com a mulher do antigo senhorio, o senhor Kajek?

Chana- O diálogo foi simples, ela disse: -'Eu vim aqui pegar minhas coisas que deixei."."Você não deixou nada, eu não tenho nada, eu não sei de nada!" Vovó Léa continuou: -’Mas eu deixei, eu não tenho nada, só estou com a roupa do corpo. Estou precisando de uma roupa, estou precisando de um lençol, estou precisando de um sapato. Estou assim, do jeito que você está me vendo, uma maltrapilha. "De tanto a vovó conversar e chorar e pedir, ela tirou uma peça ou duas de roupa e deu dizendo: -"Você não volta mais aqui, pois meus filhos podem te delatar..."

P- Mas a Guerra já tinha terminado! A Polônia estava sob ocupação russa, a ameaça deve ter sido de outra natureza...

Chana- Sim, é possível.

P- Houve também o episódio envolvendo o irmão do cunhado do papai.

Chana- Sim, uma reunião familiar...

P- O cunhado do papai, Joseph Strenger, havia casado com a tia Shoshn, depois da Guerra.

Chana- Sim, esse caso foi em Cracóvia. Média.

P- É um grande centro, tem a Universidade da época da Idade

Chana- Certo. O papai foi visitar e ficar uns dias com a irmã, eles estavam numa reunião, uma confraternização. Estava a irmã, o cunhado, o irmão do cunhado, o papai e mais alguns amigos. Chegou uma determinada hora que papai cansou e saiu, com a titia Shoshn e o marido. De repente, uns antissemitas, não sei se polacos ou "ukrainen" (ucranianos), entraram e mataram algumas pessoas, inclusive o irmão do cunhado do papai. Ele contou que se ficasse mais dez minutos, também poderia ter sido morto.

P-imagine... isso foi depois da guerra! Eu me recordo, papai falou que essa ação foi denunciada às autoridades russas. Parece que fizeram um cerco à área onde estavam esses bandidos e os capturaram. Bom, terminada a Guerra, a família do papai, como milhares de outros sobreviventes, deslocaram-se do solo europeu. Qual foi a trajetória quando saíram da Polônia? Antes disso, comente a tentativa de indenização pelas perdas, pois a família do papai tinha bens antes da Guerra. Parece que foi uma pequena indenização, uma coisa simbólica.

Chana- Foi muito pequena. $\mathrm{O}$ papai disse que foi muito pouco, não foi aquilo que eles tinham que receber. Ele não sabe se outros vieram na frente... ninguém sabia dizer ao certo, toda a documentação tinha sumido. Polônia?

P- Bom, então retornando, qual foi a trajetória do papai após a

Chana- A vovó começou a se comunicar com o irmão que estava no Brasil, o tio Moisés Zaltstreiger. Ele logo começou a agilizar os papéis, dizendo que todos viessem para cá. Inclusive, o papai queria ir para Israel e a vovó, com medo de nova guerra, disse não...

\section{P- Para a Palestina, Israel ainda não era independente.}

Chana- É, Israel só depois de 48. A vovó disse não, vamos para o Brasil, lá você tem seus tios, lá vai ser melhor. Inclusive, ele disse que já estava namorando uma moça e que combinaram ir para a Palestina, mas a mãe, de tanto falar, fez ele desistir.

O tio Moisés preparou a documentação, eles saíram da Polônia e foram para a França, para Paris.

\section{P- Como foi a estadia em Paris?}

Chana- Eles foram para um centro comunitário e ficaram lá seis meses. Comendo por conta da Associação, eles não tinham dinheiro. Às vezes, o papai queria fazer alguma coisa, comprava algo para revender, para ver se conseguia um dinheirinho, mas era difícil. 
Ele não teve lembranças boas dessa estadia em Paris. Disse que era muito controlado, tinha muita gente. Não passavam fome, não era como na Guerra...

P- Eu me recordo, papai disse que na França teve contato com emissários do Palmach (grupo avançado do Haganah, estrutura militar judaica na Palestina). O Palmach fazia linhas clandestinas de judeus até os portos, tendo um esquema de transportes a partir de Marselha, pelo Mediterrâneo, até o desembarque na Palestina.

Papai comentou a primeira vez que viu pessoas negras, tomou um choque, eram soldados americanos. Ele nunca tinha visto! Depois, na costa africana, quando estavam vindo de navio para o Brasil, jogavam moedas ao mar e os habitantes vinham a nado pegar. Nunca me esqueço desse relato.

Chana- Parece que os habitantes mandavam cigarros para o navio.

P- Papai desembarcou, então, em 1948, e aí começa a saga brasileira. Mãe, vamos lembrar que também faremos um apanhado sobre o deslocamento de sua família. Inclusive lembrar as perdas, pelo seu lado familiar, na Guerra.

Então voltando, papai vai morar num bairro bem carioca.

Chana- Marechal Hermes. Naquela época, muitos dos judeus moravam em subúrbios, Marechal, Madureira..

P- Tinha uma sinagoga em Nilópolis.

Chana- Sim, sinagoga, cemitério e escola. Tanto é que, Nilópolis era mais longe, mas estava mais adiantada em questões judaicas.

P- Como ele começou a sobreviver? Jovem, solteiro, querendo reconstruir a vida.

Chana- Quem os trouxe para o Brasil foi o tio Moisés. No início, todos ficaram na casa dele; a vovó com o papai, o tio Tanchu com a "miman" (tia) Laialan (Léa). Eles casaram depois da Guerra. Foram bem tratados, mas a estadia demorou pouco, alugaram uma casa em Marechal e foram todos para lá.

O tio Moisés falou "agora vocês vão começar a trabalhar". Papai pegou mercadoria, Precisando pagar tudo, não foi nada dado, é bom frisar.
Papai não era "clinteitshik", ele era... como mascate, caixeiro-viajante. Todo dia tinha de trabalhar em outro lugar.

P- Mãe, você fez referências aos tios do papai, Tanchu e sua esposa. Fale um pouco deles.

Chana- Ele era um dos irmãos da vovó Léa, quando ela se casou ele se deslocou para perto da irmã, em Ostrowiec. Lá, ele começou a comercializar com cereais. Ele era solteiro, conheceu uma moça de família de classe média, de uma família religiosa. Casaram e ficaram numa situação boa...

P- Você se lembra do nome dessa esposa do tio?

Chana- Não... não me lembro.

P- Eles tiveram filhos?

Chana- Não tiveram filhos.

P- Então, o titio Tanchu intermediava a venda de trigo, ele tinha contato com fazendeiros poloneses.

Chana- Sim, sendo que, nas horas vagas ele ajudava na padaria. Ele fornecia os cereais para a irmã, era um circuito só.

P- Na Guerra, o que acontece com o tio Tanchu?

Chana- Eles foram todos pegos para trabalhar na fábrica, mas eles ainda podiam ir para casa. Ele, então, foi a um fazendeiro amigo e perguntou se podia ficar escondido na propriedade, num celeiro. $O$ fazendeiro o escondeu juntos aos cavalos., no estábulo. Ele ficou lá um tempo, toda noite o fazendeiro levava comida, mas tudo escondido, inclusive da mulher e dos filhos.

P- Você sabe a punição que os alemães davam aos não judeus que escondessem judeus?

Chana- Acho... que também eram mortos.

P- É, eram mortos, eram fuzilados.

Chana- Justamente, ele falou "estou arriscando minha cabeça, minha família, mas vou fazer isso, vou te esconder". Quanto tempo foi não sei, mas um belo dia ficaram sabendo e tacaram fogo. Ele saiu correndo do 
esconderijo e o fazendeiro descobriu que já tinha gente sabendo, por causa do ato de vandalismo. O fazendeiro disse: "Tanchu, chegou a hora de você procurar outro refúgio, porquê já tem gente demais sabendo disso. Estou arriscando minha cabeça, dos meus filhos e você vai ser pego". Ele teve que sair de lá, fugir à noite e foi para a fábrica onde os sobrinhos estavam trabalhando. Ele era uma pessoa jovem, com muita coragem e, uma noite, ele falou para o papai: "olha, Hershelle, eu vou fugir para o bosque, seja o que Deus quiser, você vem comigo? "não, não vou, tenho medo, não quero deixar minha mãe".

P- Ou seja, papai não acompanhou o tio na fuga?

Chana- Não, não abandonou nem a mãe, nem a irmã. Aí, numa oportunidade, o tio Tanchu saiu correndo, atravessou as cercas, os alemães viram e começaram a atirar, eu me lembro que isso ele contava. Como serviu o exército, sabia que tinha que correr em ziguezague, para as balas não o atingirem.

\section{P- Então ele correu de onde?}

Chana- Da fábrica para o bosque, e lá ficou até o final da Guerra.

P- E é esse tio que vai acompanhar a vovó e o papai para o Brasil. Ele perdeu a primeira esposa, correto?

Chana- É. Quando a Guerra terminou, todos foram procurar seus entes, querendo saber quem ficou vivo. Primeiro se encontrou com a vovó Lea e a tia Shoshn, ficaram todos morando juntos. Ele, como era o homem da casa, começou a comercializar outra vez, o que era eu não sei bem.

P- $O$ tio voltou a casar.

Chana- Sim, ele conheceu a tia "Laialan"...

P- Ela também foi sobrevivente de campo?

Chana- Foi, ela perdeu marido e filho.

P- Casaram e não tiveram filhos. Bom, com esse relato preservamos a memória dos tios. Retornando ao papai, ele só vendia à vista?

Chana- Só à vista.

P- Nesse período, qual era a área geográfica que papai vendia?
Chana- Primeiro, ele começou pelos subúrbios. Depois ele começou a esticar: Barra Mansa, Volta Redonda, Barra do Pirai, Magé, Raiz da Serra, Caxias, Santo Aleixo.

P- Qual era a mercadoria que ele preferia?

Chana- Tecidos em corte... gabardine!

P- Mãe, tem um momento que para nós é sempre pesado, mas é importante lembrar, o encontro do papai com KAPOS. Vamos explicar, KAPOS eram policiais judeus, recrutados pelos alemães para fazer o trabalho interno entre os concentrados. Esse foi um trabalho considerado sujo, eram judeus oprimindo outros judeus. Como foi esse encontro?

Chana- Papai tinha chegado a pouco e morava em Marechal Hermes. Um belo dia, saindo para trabalhar, deu de cara com um Kapo! Um, de três irmãos que foram Kapos...

P- Da cidade do papai?

Chana- Sim, da cidade.

P- E os três irmãos eram Kapos?!

Chana- O mais velho era o pior de todos.

P- Foi esse, o que ele encontrou?

Chana- Não, foi o segundo. O mais novo, ninguém mexeu com ele, morou aqui, trabalhou normalmente.

P- Mãe, como ha' descendentes dessas pessoas e para evitar quaisquer constrangimentos ou danos, vamos evitar falar em nomes. Então, papai encontrou um desses irmãos que foi Kapo. Como foi o encontro?

Chana- Quando esta pessoa viu o papai, ficou com medo, "gelou" e disse: -"Hershell, Hershell, não me bate! Não me pegue! eu não tenho culpa, eu não fiz nada!" Papai respondeu:

"Eu não vou te bater porquê você tem idade de ser meu pai, mas você fez, você tem culpa e outras pessoas vão te castigar." culpa?

"Mas, pelo menos, você pode me ajudar, dizer que eu não tenho 
"Não. Eu não vou te bater, mas não vou dar testemunho a seu favor, porquê você fez!"

P- Mãe, tem o episódio em que passaram com uma lista na loja do papai...

Chana- Foi a esposa desse homem que papai encontrou. Passou com uma lista para papai assinar.

P- Do que tratava a lista?

Chana- Era um abaixo-assinado, onde dizia que o marido não fez nada, que não tinha culpa, para as filhas dele...

Mauro- Não serem excomungadas da comunidade.

Chana- Para que as filhas pudessem frequentar locais e colégios judeus.

P- E o papai?

Chana- Assinou. Ele disse que ela não tinha culpa...

P- Nem as crianças.

Chana- Também.

P- Qual o ano em que vocês se conheceram?

Chana- Em agosto de 1950 e fiquei noiva em 5 de setembro.

P- Qual o ano em que vocês casaram

Chana- Casamos em 6 de julho de 1952. O irmão mais velho de vocês nasceu em 18 de abril de 1953 .

P- Mãe, vamos fazer agora o retrospecto da família Judenherc, seu sobrenome de solteira. Qual é a cidade de origem de sua família?

Chana- Schidlowiec. Uma cidade bem pequena.

P-Bem pequena, compara à Ostrowiec...

Chana- Não tem comparação! Era um "schteitalan”(povoado).

P- Qual é a origem do vovô Abraham e da vovó Eva, seus pais? Eram religiosos? Eram comerciantes?
Chana- A linhagem de meus avós não tem rabinos. Era gente cumpridora da religião...

P- Do vovô e da vovó?

Chana- Dos dois.

P- Qual era o sobrenome de solteira de sua mãe?

Chana Orembach. Meu avô Iosef (José), pai de minha mãe, tinha uma padaria, mas em proporções pequenas. Não eram pessoas abastadas...

\section{P- E o vovô Abraham?}

Chana- Vovô Abraham também não veio de família de rabinos, mas de uma família religiosa. O pai dele era.. .como é que eu vou explicar?! O pai dele preparava selas para montaria e ferraduras. Eles vendiam em feiras para os polacos, chamavam as feiras de "iehid". Os compradores também iam a sua casa para negociar as peças. Eles eram pessoas muito pobres, a vida sempre muito difícil.

P- E os pais da vovó Eva?

Chana- Já comentei, eles tinham uma padaria.

P-Bom, os vovós se casaram, você se lembra o ano?

Chana- É só calcular.. papai veio para cá.. minha mãe deve ter casado em 32 ou 33.

P- Vovô Abraham e vovó Eva tiveram 4 filhos. Quando o vovô veio para o Brasil, qual era a situação em termos de filhos?

Chana- Quando meu pai veio para o Brasil tinha três filhos, e a vovó Eva estava grávida da quarta, a titia Esther.

P-Que é a caçula.

Chana- Ficou dois anos... vovô começou a trabalhar "clinteltschik" (clientela a prazo), em dois anos conseguiu juntar um dinheiro e mandou "shiftcarten", era assim que se chamava.

\section{P-Mãe, o que é "shiftcarten"?}

Chana- Passagem de navio! Dois anos de meu pai estar aqui, nós viemos. Já com mais uma filha de um ano e meio. 


\section{P- Vocês chegaram em que ano?}

Chana- O vovô chegou em 33, nós, em junho de 35.

P- Mãe, fale um pouco você menina, de sua juventude. Têm alguns episódios interessantes, você era aluna de escola pública e participou de alguns eventos do Estado Novo.

Chana- Foi em 7 de Setembro, nós participávamos das paradas no campo do Vasco (São Januário).

P- Tinha também o Dia da Nação.

Chana- É. Eu marchei como enfermeira, podia ter meus dez, onze anos.. .a vovó me preparou... uma pena não se tirar tanto retrato. Eu me lembro do presidente Getúlio Vargas, e do Villa-Lobos regendo.

P- Você fala que, menina ainda, participava dos corsos no carnaval. Pegavam um bonde na Praça Onze e iam até a Candelária.

Chana- (risos) A gente fazia blocos de rua, eu botava as calças do meu irmão e ele botava nossos vestidos! Todo mundo dava uns trocadinhos para cada bloco, depois o mais velho, que tinha organizado, dividia o dinheiro por todos. A gente voltava para casa e dizia: "olha mamãe, o que nós ganhamos!" (risos) Era uma felicidade só!

P- Bom, vocês moravam na Praça Onze?

Chana- É, na Vila Judaica, a "iídiche vila".

P- Mãe, durante a Guerra, vocês ouviram notícias das atrocidades nazistas na Europa? Você se lembra de algo?

Chana-(pausa)Bom, o que eu me lembro.. .meu pai lia muito bem em hebraico, ele recebia jornais em "iídiche" e hebraico. Os jornais diziam que estavam perseguindo os judeus, matando, mas não tinha a dimensão que soubemos depois. Não, não tínhamos ideia do que os alemães estavam fazendo. Só com o fim da Guerra, as notícias começaram a chegar e, também, com o relato dos sobreviventes que vieram.

\section{P-Seu pai falava "iídiche" e hebraico.}

Chana- Sim. Tanto na parte laica, como na religiosa, ele era muito letrado. Era muito bom, também, em matemática. Indo um pouco mais à frente, na quarta, quinta série, ele nos ajudava nos problemas mais difíceis. Eu lia em "iídiche" e meu pai nos ajudava, à noite, depois de chegar cansado da clientela.

P- A sua família era sionista? Existia o debate sobre a criação do Estado de Israel?

Chana- Eu me lembro que a vovó Eva falava muito do vovô Iosef. Na Polônia, eles falavam muito de política nas horas vagas, reuniam-se na pracinha...

P-Vovô Iosef era o pai da Vovó Eva, era o seu avô.

Chana- Falavam muito em política, o que era a política? Palestina! Ele era tão fervoroso em falar, que a vovó Eva dizia que ele chegava roquinho em casa.

P- Ou seja, nosso bisavô Iosef, era um grande sionista! Você só estudou em escola pública, ou também em alguma instituição judaica?

Chana- Estudei em escola pública e meus pais colocaram um "melamed" para nos ensinar em casa. Hoje, se eu sei alguma coisa em hebraico e da reza, foi graças ao "melamed".

Depois abriu uma escolinha, o professor era um "hazan"(cantor litúrgico) de sobrenome, Steinberg. A escolinha era na Praça Onze, na rua Benedito Hipólito.

P- Vovô Abraham era cardíaco e veio a morrer em 1948. Você fez um comentário sobre a data.

Chana- Sim, primeiro ele enfartou em 46. É uma lembrança muito forte para mim (silêncio). $\mathrm{O}$ médico disse que ele não podia mais trabalhar daquela maneira, pois trabalhava muito em morros, em subidas no bairro de São Cristóvão. Nós tínhamos que viver, comer.. .aí, meu irmão Manoel, que estava com 14 anos, teve de sair do colégio. Ele era um ótimo aluno e teve que parar os estudos, para poder ajudar, fazer as cobranças. Aos poucos, o vovô voltou a trabalhar nas ruas planas, nos morros, só o tio Manoel. Em 48 ele teve o segundo enfarte... 


\section{P- Depois da criação do Estado de Israel?}

Chana- Ele viu, pulava de alegria. Meu pai era um grande sionista, ele morreu em 6 de junho de 1948.

P- $O$ Estado de Israel foi criado em 15 de maio. Houve comemoração na "iídiche" vila?

Chana- Nas ruas, não. Houve muita alegria nos lares. Eu me lembro da vibração de meu pai, assim como teu pai vibrou com as vitórias de Israel, em 67 e em 73.

P- A Guerra acabou em 45, vocês começaram a receber as notícias imediatamente?

Chana- Sim, já comentei sobre isso. Recebíamos, também, cartas dos parentes sobreviventes.

P- Mãe, você também teve perdas em sua família.

Chana- Muitos, demais.

P- Meu segundo nome, Peres, é uma homenagem.

Chana- Ao irmão de minha mãe, Peretz. Pelo lado da minha mãe, família Orembach, meu tio Peretz...

\section{P- Já casado? Tinha filhos?}

Chana- Ele casou, se separou, não tinha filhos. Meu tio Peretz e todos os familiares da minha mãe foram tragados pelo Holocausto. Só sobreviveu a Minam.

\section{P- Uma prima.}

Chana- Uma prima, da família todinha... Era uma família enorme, muitos primos, muitos tios.

P- O nome dela, hoje, é Minam Virtzer, ela era Orembach de solteira?

Chana- Não, porquê ela era filha de uma irmã do vovô Iosef.

P- Hoje, a Minam e seu marido, Moishé, estão em...

Chana- Israel! Têm dois filhos. Tentaram entrar clandestinamente em Israel, de barco. Os ingleses prenderam o barco e os mandaram para
Chipre, onde ficaram num campo de prisioneiros dois anos. Quando chegou a vez dela, disseram: "agora você está libertada, já pode ir para Israel." Ela perguntou: "e o meu marido?" Os ingleses falaram "seu marido, não, pois ele vai lutar contra a gente". britânico.

P- Então, Israel ainda não era independente, era o mandato

Chana- É, então foi antes da independência. Ela disse: "não, eu perdi todo mundo na Guerra, eu não quero perder meu marido. Vou ficar com ele, até vocês o libertarem, também."

P- Do lado do vovô Abraham, vocês tiveram notícias?

Chana- Só sobrou uma tia minha, irmã de teu avô. Veio quase nos últimos navios, em 38. Tanto é, que ela não pode desembarcar no Rio e teve que descer em Niterói.

P- Qual o nome dela?

Chana- Sarah Léa. Era, também, uma pessoa muito letrada.

P- Bom, em 52 você casou com o papai. Foram viver em?

Chana- Madureira. Moramos lá 17 anos.

P- Ele saiu da situação de mascate e abriu uma loja.

Chana- Abriu a loja em 58.

P- A loja perdurou até o ano de?

Chana- 1985.

P- Tem o episódio do tiro que papai levou, comente.

Chana- Isso foi...em 56. Eu estava grávida do Mauro.

P- Você estava grávida do segundo filho. Papai foi fazer uma cobrança em Vaz Lobo, não é isso?

Chana- Não foi cobrança. Papai foi vender em Vaz Lobo, oferecendo mercadoria, aí o rapaz disse: "eu vou querer, espera aí, que eu vou pegar o dinheiro." Então veio com o revólver e deu um tiro à queimaroupa. Comentaram que ele pediu mercadoria e ele não quis dar; papai jurou para mim que ele não pediu nada. Na época não se falava em drogas, 
o sujeito deveria estar drogado. Ele entrou, saiu com um revólver, deu um tiro que pegou na virilha. Papai desceu correndo, começou a pedir socorro no meio da estrada, sangrando, pedindo "pelo amor de Deus, para, para!". Alguém teve pena, parou o carro e o levou... para Marechal Hermes, para o Carlos Chagas.

P- Ou seja, não morreu na mão dos nazistas e poderia ter morrido na mão de um vagabundo.

Chana- Podia ter morrido!

P- Bom, papai sobreviveu à Guerra, constituiu uma família, construiu um negócio, formou um patrimônio, educou seus filhos. Papai participava da vida da Comunidade? Papai era um bom judeu?

Chana- Papai não era um fanático, mas era um judeu de coração. Era um sionista e um judeu de coração, sempre participou de ajuda de "Magbit", de "Maot Chitim". Não ajudava mais porque tinha épocas que não dava.

P- É, isso nós fomos testemunhas. Ele realizou um sonho, conheceu o Estado de Israel. Vocês conheceram no ano de?

Chana- Em 1982. Quando estávamos nos aproximando e vimos as luzes ao longe, as lágrimas começaram a rolar. Ele perguntou: "Anita, o que você está chorando?!".

Estava chorando de alegria, era véspera de Shavuot, fomos recebidos no aeroporto com cerveja, com tanta alegria, era Erev Shavuot. Papai começou a dançar com as pessoas no aeroporto, tamanha a alegria.

P- Mãe, estamos concluindo os principais dados que gostaria de colocar nesse trabalho. Você tem liberdade para fornecer outras informações, episódios que se lembre, outros dados.

Chana- Quero registrar o relato de uma vizinha nossa de Madureira, Dona Lola Fishman. Ela esteve numa situação em que falam das 6.000 mulheres sobreviventes.

P- Fale sobre isso.

Chana- Já no final da Guerra, 6.000 mulheres foram libertadas de uma só vez pelos Aliados, ou americanos, ou russos, não sei. A senhora Lola
Fishman estava nesse grupo e toda vez que se aproximavam do forno crematório...

P- Para a câmara de gás e depois para o forno.

Chana- Sim, para a câmara. Ela, já cansada de tudo aquilo, ia se deixando levar e, toda vez que se aproximava da porta, alguém a empurrava e ela voltava para a parte de trás do grupo. Nisso, elas foram libertadas e Dona Lola sobreviveu.

\section{P- Mais alguma coisa, mãe?}

Chana- Bom, eu posso acrescentar que papai não teve sorte quanto às indenizações de Guerra, como outros. Gostaria também de dizer que papai, dentro de seus limites, sempre buscou a educação dos filhos, tanto na parte laica, como na parte judaica. Nossos quatro filhos foram a Israel. Estudaram em colégios judaicos: Barilan, Max Nordau...

P- E o famoso I.L. Peretz, mãe?

Chana- Vocês começaram em Madureira, no I.L.Peretz, meu filho caçula fechou o I.L.Peretz...

\section{P-Fechei o Bialik, também...}

Chana- No Méier, depois mudamos para Copacabana. Você e a Simone estudaram em colégios judaicos, você no Max Nordau e depois, Barilan. A Simone, sempre no Barilan. Queria colocar você no Barilan, mas disseram o que o teu hebraico era fraco; hoje "pagam" para o aluno entrar e naquela época recusavam. Aceitaram no Max Nordau, mas dois anos depois, estava se aproximando o "Bar Mitzvah", botei uma professora particular de hebraico e você entrou no Barilan.

P- Mãe, o que os alemães gravaram no antebraço esquerdo do papai?

Chana- Um número de controle, B 5156.

\section{P- Onde papai está enterrado?}

Chana- Em Vila Rosali, no Cemitério Israelita, novo. No antigo, está a vovó Léa e o meu pai. 


\section{Na busca de raízes: desvendando mistérios e trajetórias}

Micheline Raccah

"Quelque autre te dira, d'une plus forte voix les faits de tes aieux et les vertus des Rois..."

Jean de la Fontaine.

Q ou uma francesa de Paris que se apaixonou pelo Brasil e pela cidade $\checkmark$ do Rio de Janeiro foi amor a primeira vista!

Desde 1992, estou morando aqui e me sinto uma carioca; como eu não posso dizer: carioca da gema, então, eu sou carioca de coração.

Eu pertenço a uma família cosmopolita, cujas raízes se encontram espalhadas na Babilônia, na Catalunha, na Espanha, na Turquia, em Jerusalém, na Itália, na Líbia e no Egito. Uma família que deu ao Judaísmo uma linhagem de Rabinos que dedicaram a vida toda ao estudo da Lei e do Talmude.

Eu sou a bisneta do Rabino-chefe de Alexandria, Eliahu Bekhor Hazan, que morreu em 1908; eu acho que ele foi o último chefe religioso da Dinastia Hazan.

Tudo o que eu sei sobre a minha família eu descobri sozinha, pedacinho por pedacinho. É exatamente como se eu tivesse puxado um por um, os fios duma meada muito confusa, emaranhada mesma.

Eu sou uma criança da guerra; eu tinha oito anos em 1939 e meu pai, que tinha uma visão profética dos acontecimentos da época, nunca falava a respeito de sua identidade judaica.

$\mathrm{Na}$ escola, eu queria frequentar o catecismo, assistir à missa como todas as outras crianças; cada vez que eu perguntava, a resposta era sempre a mesma: Você não deve, você não pode. Até que um dia, minha mãe, irritadíssima, falou: Você não pode, porque seu pai é judeu, mas é um segredo, entendeu? Você não deve falar disso para ninguém. Estávamos em 1936!
Eu fiquei estarrecida... Se minha mãe tivesse falado: seu pai é um assassino, não teria sido pior. A palavra "Judeu" não fazia sentido nenhum para mim, eu não sabia de nada.

Alguns anos mais tarde, eu me dei conta que meu pai queria que eu fosse educada sem religião alguma, para que eu pudesse escolher aos 18 anos; mas, um dia, durante a guerra, ele precisou produzir uma certidão de batismo para mim. Então, de repente, eu fui batizada, fiz comunhão, confirmação, tudo acelerado, para poder produzir a famosa certidão, mas, como sempre, sem explicação nenhuma.

Meu pai (filho de Isaac Raccah e de Vitoria Hazan) nunca se alistou como judeu, nunca colocou no peito a estrela amarela; com certeza, foi isso que salvou a vida dele e... a minha!

Portanto, pela força dos acontecimentos, eu sou católica; mas, para mim, isso não quer dizer nada. Eu acredito em Deus, sim, mas eu acredito também que, esse Deus é o mesmo para todo mundo; cada um o chama pelo nome que quer; de qualquer jeito; o que me atrai no judaísmo, não é especificamente a religião, mas a história, a cultura e as tradições.

Em 1949, um ano após a criação do Estado de Israel, meu pai, à beira da morte, me falou pela primeira vez da nossa família, das nossas raízes judaicas, de meu bisavô, dizendo que ele esperava que eu honrasse a memória de meus antepassados e... ele me deixou...

Então, pela primeira vez, eu me comportei, como uma verdadeira filha judia; eu atravessei a cidade toda à procura dum Rabino Sefaradi para rezar o Kadish.

Entretanto... muito tempo passou: eu casei, tive dois filhos.... Meu marido faleceu... Em 1965, eu viajei até Izmir, sem saber que depois da Espanha, essa cidade era o berço de nossa família.

Quando eu comecei a viajar pelo Brasil em 1981, eu encontrei minhas tias, aqui no Rio. Minha tia Fortunée era a irmã mais jovem de meu pai; com 16 anos, ela casou em Alexandria com um rapaz brasileiro, de origem sírio-libanesa: Kaluf Chuecke; ele a trouxe para o Rio no final de 1926. Minha outra tia, Clémentine, que já tinha 92 anos, veio morar aqui depois dos acontecimentos de 1957 no Egito. 
Em 1982, eu fiquei alguns dias na casa da Fortunée, na Avenida Atlântica; lá, eu descobri emocionada uma foto muito desgastada de meu bisavô; eu levei essa foto comigo para França e mandei fazer uma restauração cuidadosa.

Essa foto foi o ponto de partida de tudo. Alguns anos depois, em 1988, meu irmão (ele nasceu em 1944, no final da guerra) que é bibliotecário, viajou para Alexandria, a convite do Centro Cultural francês, como supervisor duma equipe de bibliotecários locais.

Ele aproveitou a oportunidade para se apresentar ao Presidente da comunidade judaica, tão reduzida e idosa que não conseguiam reunir o número mínimo de dez pessoas para constituir o Minyam... (o Presidente morreu pouco tempo depois); eles conversaram e ele confiou a meu irmão um livrinho sobre a vida dos Rabinos-Chefes de Alexandria em geral, e de nosso bisavô em particular.

Foi a primeira luz sobre a história de nossa família; mesmo quando eu visitei Israel em 1985, eu não sabia de nada; eu não sabia que meus antepassados formavam uma dinastia de Rabinos-Chefes na Palestina, desde o início do domínio do Império otomano. Eles eram chamados "Rishon Le Tsion", o olho de Sion. - Esaïe, 1,2. -

Anos mais tarde em 1997, eu vi na revista "La Lettre Sépharade" um artigo assinado Laurence Hazan. Eu fiquei perplexa, liguei para ela (ela é Presidente duma associação de Genealogia e de História Sefaradi: Etsi) e a gente se encontrou.

Com ela, eu aprendi muitas coisas: que meu bisavô tinha um irmão mais jovem que era jornalista e editor na Turquia - Aaron de Yosef Hazan que havia publicado em ladino durante 41 anos um jornal chamado: "A Buena Esperanza". "Lo che Moshe Rabenu fue para el pueblo de Israel, Aaron de Yosef Hazan fue para la communidad de Izmir ". Aprendi o sobrenome e o nome de minha bisavó: Dinah Bardaky. Era a filha do Rabino-Chefe da comunidade asquenazi de Jerusalém no século XIX; os dois casaram em Jerusalém e tiveram uma família numerosa: 6 meninos e 3 meninas.

Eu acho que minha avó Vitoria era a caçula, era muito religiosa e passava muito tempo com o pai dela, a estudar e comentar o Talmude.
No livro, escrito em português, "Primeira Comunidade Israelita Brasileira" de Abraham Ramiro Bentes, encontrei um histórico da família Hazan, mais especificamente da parte espanhola, portuguesa e marroquina. Comecei a pesquisar nas bibliotecas, consultei quase todas as enciclopédias judaicas, em castelhano, inglês, alemão, francês... e a cada passo encontrei os mesmos personagens, além de algumas exceções como Abraham b. Isaac, “o Gherondi”, o chazan do Centro Cabalista de Gerona. Ele era poeta, autor de hinos devocionais na Espanha, no século XIII foi o autor do hino: "Ahhot Quetana", cantado na noite de Rosh Hashanah em todas as Sinagogas do ritual Sefaradi. Fora dele, a história da minha família começava quase sempre com o domínio do Império otomano sobre a Palestina. No Brasil, eu tentei de tudo para encontrar o livro de Ramiro Bentes, mas, em todos lugares, era sempre a mesma resposta: "Está esgotado".

Tudo mudou em 2001, quando eu recebi um computador de presente!

Por acaso, eu tinha comprado um livro sobre o primeiro Congresso Sefaradi no Rio de Janeiro "I Confarad” (org. Diane Lisbona Kuperman); no penúltimo capítulo, sobre a presença Sefaradi no extremo Sul do Brasil, o autor Nelson Menda falava de Joseph Pontremoli. Como eu sabia que Laurence Hazan pesquisava sobre a família Pontremoli, ofereci-me para traduzir o capítulo inteiro para que ela pudesse entender melhor o contexto geral. Na resposta, ela perguntou se eu sabia que havia um site sobre a família Hazan, na Internet. Esse site vem da Turquia, da cidade de Izmir, berço de nossa família. A primeira parte conta a história de nossos antepassados, a segunda é a tradução em inglês dum livro escrito pela Sociedade de Izmir em homenagem à memória de Aaron de Yosef Hazan.

Foi minha longínqua prima Gizel que o traduziu do turco para o inglês; eu mandei um e-mail para ela e a gente começou a se comunicar.

Recentemente, ela me mandou vários e-mails provenientes do mundo inteiro e algumas fotos também.

Pela primeira vez, eu vi uma foto de minha bisavó na casa de um dos filhos dela, em Alexandria, quatro anos depois da morte do Rabino Eliahu, em 1912. Foi uma emoção muito grande, quase chorei. Tinha também algumas informações sobre ela e o pai dela (Eles são originários da cidade de Pinsk, na Bielo-Rússia) e tudo isso vinha da Austrália... 
Outra notícia proveniente de Israel: Dois professores da Universidade Bar Ilan, perto de Tel-aviv, estão preparando um livro sobre a vida, o pensamento e a obra do Rabino- Chefe Eliahu Bekhor Hazan, meu bisavô.

Bat Yam ou Yemanjá,

Ele é o autor de:

uma fiel consumidora

Taalumot Lev (Leghorn- Alexandria, 1877-1902): respostas em 4 partes.

Neveh Shalom (Alexandria, 1894): sobre o ritual e as costumes da comunidade de Alexandria.

Zikhron Yerushalayim (Leghorn, 1874): sobre o amor a Terra Santa.

Kontes Yishma Moshe (Leghorn,1874 -Tradução italiana, 1877): a propósito do famoso filantropo Ka'id Nissim Shamama...

Existem também inúmeros manuscritos ainda não publicados.

\section{Milagre da Internet!}

Outro Milagre! Eu entrei em contato com Frida Wolf e quando eu perguntei se ela tinha o livro que eu procurava tanto, ela me indicou Ana Bentes, que me ofereceu com muita gentileza, o livro escrito pelo pai dela: "Primeira Comunidade Israelita Brasileira"; e minha família fazia parte dessa comunidade, na Amazônia! É incrível, não é?

Por enquanto, o círculo está quase se fechando, eu me sinto realizada; mas o passado fala alto o tempo todo, ele reclama e vai reclamar até que todas as peças desse quebra-cabeça consigam se encaixar direito. Espero poder estar sempre atenta e disposta a lhe dar ouvidos.

Renée Avigdor ${ }^{1}$

\section{Introdução}

( presente trabalho pretende mostrar como, no atual cenário religioso brasileiro, o judaísmo se tornou uma opção religiosa. $\mathrm{O}$ atual mercado religioso é rico em ofertas, muitas religiões estão expostas para serem consumidas. O judaísmo, mesmo disponível apenas para uma minoria, não é mais aquela religião a que as pessoas aderem para agradar a família do noivo ou da noiva - impedir um casamento exogâmico. Para identificar a religião, no caso o judaísmo, como um produto, partimos de um estudo de caso, a história de vida de Laura que relata a adesão ao judaísmo.

Partimos de um estudo de caso de conversão, mas por que não tratamos como mais um caso de conversão? A atual realidade religiosa expressa a transformação da sociedade e da religião, permite uma liberdade de circulação entre as diversas religiões o que sugere uma falta de comprometimento religioso.

Laura, nossa informante, é membro da Comunidade Shalom, foi nesta congregação que ela se converteu e é frequentadora desde que decidiu formalizar o seu desejo de se tornar judia.

A Comunidade Shalom, sinagoga conservativa ${ }^{2}$ de São Paulo, oferece um curso de introdução ao judaísmo, em outras palavras, conversão. Nesse contexto, as conversões se diferenciam daquelas realizadas em outras sinagogas da cidade; as congregações ortodoxas de São Paulo, não oferecem conversões desde a década de 70 . As conversões que acontecem

\footnotetext{
${ }^{1}$ Mestranda do Programa de Pós-Graduação de Língua Hebraica, Literatura e Cultura Judaicas FFLCH - USP.

${ }^{2}$ Conservativismo e conservativo - preferimos o uso do termo Conservative em inglês e suas variáveis, à tradução literal, evitando associar a esta corrente a ideia de Conservador relativo ao judaísmo ortodoxo.
} 
na $\mathrm{CIP}^{3}$ são, visando principalmente a uma cerimônia de casamento judaico, para evitar a exogamia. Nosso interesse é estudar as conversões em que o indivíduo decide aderir ao judaísmo para satisfazer a uma necessidade única e exclusivamente pessoal.

Abordar a religião como produto é uma tendência na sociologia da religião; para entendermos o conceito de mercado religioso recorremos a Prandi que nos esclarece:

Essa ideia de mercado religioso pode ser descrita, em outros termos, como pluralismo religioso, ... Não há mais uma única fonte de transcendência capaz de dar sentido à vida e à sociedade como um todo. A religião está tão diversificada quanto tudo o mais (Prandi $1997)^{4}$.

\section{Por que tratar o judaísmo como uma opção religiosa?}

Mesmo não sendo popular como outras religiões, o judaísmo tornouse, nos dois últimos séculos, uma religião mais aberta, seguindo a via de muitas das grandes religiões. Pace nos explica este movimento da seguinte forma: "a acentuada tendência de muitas das grandes religiões mundiais históricas e das novas religiões a apresentar sua mensagem em termos éticos (paz no mundo, os direitos humanos, a defesa do ecossistema, etc.) mais do que em termos teológicos e escatológicos: indicadores todos de um fenômeno que poderíamos chamar, conforme Isambert (1975) de "secularização interna" mais ou menos desejada pelos próprios

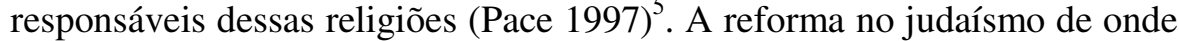
se originaram as correntes Reformistas e Conservativas, para citarmos as mais conhecidas do público judaico brasileiro, seriam a expressão deste fenômeno a "secularização interna". Este movimento surgiu na Alemanha no século XIX, o judaísmo "modernizou-se" para não perder seus fiéis, que se sentiam atraídos pelas correntes protestantes e visavam a assimilação. "Diferentemente da percepção tradicional, os reformistas consideram que a

\footnotetext{
${ }^{3}$ CIP - Congregação Israelita Paulista, fundada em 1936, maior congregação do Brasil em número de sócios, liderada desde 1975 pelo rabino Henry Sobel, de linha reformista.

${ }^{4}$ PRANDI, Reginaldo. A Religião e o Planeta Global. In: ORO, Ari Pedro e STEIL, Carlos Alberto (Orgs.): Religião e Globalização. 2a edição, Petrópolis, Editora Vozes, 1999 pág. 67.
5 PACE, Enzo. Religião e Globalização. In: ORO, Ari Pedro e STEIL, Carlos Alberto Alberto (Orgs.): Religião e Globalização. 2a edição, Petrópolis, Editora Vozes, 1999 pág. 67.
5 PACE, Enzo. Religião e Globalização. In: ORO, Ari Pedro e STEIL, Carlos Alberto (Orgs.): Religião e Globalização. 2a edição, Petrópolis, Editora Vozes, 1999 pág. 33.
}

religião judaica deve interagir e estar afinada com os desafios em que a sociedade moderna coloca aos seus membros" (Sorj 1997), não tendo em nenhum momento a intenção de buscar adeptos externos ao grupo.

Em nosso contexto, cenário religioso judaico em São Paulo, o processo de "abertura" do Judaísmo é em grande parte fruto da atuação de rabinos. Tratando-se de uma questão que se resolve exclusivamente com o "sacerdote", - sacerdote como profissional religioso ${ }^{7}$; a conversão, o converso são assuntos exclusivos do rabino; a direção, o público comunitário ou seja os laicos são excluídos desses "assuntos" da sinagoga. O converso e o rabino discutem a possível conversão. Os rabinos, mesmo sendo funcionários das sinagogas, têm autonomia no que diz respeito a esta questão, porém esta autonomia está dentro dos limites dos movimentos religiosos, os rabinos são obrigados a obedecer as regras internas do movimento ao qual pertencem.

\section{O caso de Laura - uma opção pessoal}

Através do estudo da história de vida de Laura - nome fictício tentaremos mostrar como se dá a aproximação de uma pessoa originalmente externa ao grupo e como podemos tratar da religião como bem de consumo.

Laura tem 36 anos, professora de esportes na Hebraica, é solteira, de classe média alta, concluiu sua conversão em dezembro de 2000 na Comunidade Shalom - São Paulo. Os caminhos que levaram Laura ao judaísmo são, em um primeiro momento, seu pai que lhe falou de judaísmo, ainda em sua infância; em seguida, sua curiosidade a levou a ler sobre religiões e psicologia, que para Laura estão intimamente relacionadas. Quando adulta, torna-se sócia e funcionária da Hebraica. Há quase uma década envolvida em um ambiente de trabalho judaico, é na Hebraica que Laura realiza seu desejo de mudar de identidade religiosa e dá início a sua conversão com o rabino Adrian Gottfried, da Comunidade Shalom de São Paulo.

${ }^{6}$ SORJ, Bila, Conversões e Casamentos "Mistos": A Produção de Novos Judeus. In: SORJ, Bila (Org.) IdentidadesJudaicas no Brasil Contemporâneo. São Paulo, Imago, 1997 pág. 78 ${ }^{7}$ Usamos aqui o termo sacerdote no sentido weberiano, que significa: profissional religioso, diferentemente do entendimento do termo sacerdote usado no judaísmo primitivo, correspondente ao cargo ocupado pelos descendentes de Aarão responsáveis pelos cerimoniais dos Templos (o de Salomão e o II) 
No início, Laura nos conta, o pouco que sabia sobre judaísmo que aprendeu com seu pai:

O meu pai frequentava a casa de pessoas da comunidade judaica. No Rio, os meus médicos todos eram judeus, sempre tiveram muitos amigos ... E meu pai que é um cara apaixonado por Freud, sempre falou de Freud, de judaísmo, de Moisés e o monoteísmo, então a coisa sempre foi muito frequente na minha casa. Meu pai tinha muitos amigos judeus, meu irmão é circuncidado, meu irmão gêmeo, eu sou gêmea de um homem, então ele foi circuncidado quando ele nasceu.

Nossa entrevistada se converteu dentro da corrente conservativa. De acordo com a linha conservativa, o fiel deve cumprir os mandamentos, observar as regras dietéticas $-K_{\text {Kashrut }}^{8}$ e o Shabat ${ }^{9}$. A Comunidade Shalom não "obriga" o fiel a cumprir estes mandamentos, deixando o público comunitário, incluindo os novos fieis - conversos, livres para decidir o quê e quando cumprir. O rabino Adrian Gottfried afirma que é através do estudo que o fiel pode vir a ser mais observante, isto é, o estudo eleva o aspecto espiritual que leva ao cumprimento das mitzvot ${ }^{10}$ mandamentos.

Não questionamos se Laura é ou não judia por cumprir ou não certos mandamentos, porque uma vez que ela passou pelos rituais de conversão e foi legitimada por uma autoridade religiosa, no caso o rabino da corrente conservativa, que estabelece os critérios de entrada no grupo, Laura é judia.

Laura nos conta sobre seu envolvimento com o judaísmo, como o interesse foi se transformando em comprometimento, culminando na decisão de formalizar seu compromisso:

E cada vez eu fui conhecendo mais a religião e gostando mais, então há uns 10 anos eu jejuo, eu sigo todas as tradições, antes de me converter eu já seguia. ... jejuar é menos tempo, uns cinco anos, mas assim Rosh Há Shana ${ }^{11}$, eu ia na sinagoga, eu comemorava, uma coisa assim foi indo meio light. Quando eu vi, eu estava envolvida até o pescoço. ...Há

\footnotetext{
${ }^{8}$ Kashrut/kasher: leis dietéticas, (hebraico, significa "apropriado") termo para qualificar o alimento que é permitido comer, segundo as leis dietéticas judaicas.

${ }^{9}$ Shabat:(hebraico, para o dia de descanso obrigatório "Sabá") O Shabat Judaico vai do anoitecer da sexta-feira ao sábado à noite.

${ }^{10}$ Mitzvá (hebraico,significa "mandamento"; pl.” mitzvot") Termo usado originalmente para

os mandamentos divinos na Bíblia, mas que mais tarde veio a se referir a qualquer boa ação.

${ }^{11}$ Rosh Há Shaná (hebraico, significa "cabeça do ano"), isto é a festa do Ano-novo.
}

uns três anos eu resolvi me converter mesmo assim, foi como eu falei no dia da minha conversão, quando me perguntavam que religião você é e eu falava: meia calabresa meia catupiry! Porque eu não tinha uma religião, eu não podia dizer que era judia, apesar de me sentir judia, então isso me incomodava também. Porque assim, meu amor a Deus, o meu lado judaico, eu sempre tive e nunca tive que provar nada pra ninguém. Eu não saber o que eu era, como uma palavra, que religião você é pro forma mesmo, isso me incomodava...Minha conversão foi muito natural, foi indo, sabe quando você acorda e já esta toda formada, não foi uma coisa: eu acordei e falei vou ser judia, quando eu acordei, eu já era judia.

Deste longo trecho, extraímos algumas conclusões: em primeiro lugar percebemos como o envolvimento de Laura com o Judaísmo foi uma coisa gradual, que leva quase uma década para ser formalizado. Vemos, também, como Laura utiliza os meios de comunicação para satisfazer seu interesse, lendo livros sobre religião. Esse envolvimento foi tomando proporções, no início, cumprindo as obrigações religiosas espontaneamente, ela foi percebendo sua identidade judaica, tomando mais espaço até o momento que Laura decide, por uma necessidade individual, definir-se como judia, isto é, formalizar a sua identidade.

A adesão formal a uma religião exige a passagem por rituais, no caso, para a adesão ao judaísmo existe uma série de rituais de iniciação. Vemos como a passagem por estes rituais é uma necessidade pessoal, de Laura, de formalizar, de estabelecer, para ela mesma e para o grupo, a fronteira entre estar dentro ou fora do grupo. De acordo com o discurso de Laura, temos a impressão de que esta é uma certeza, no entanto, questões muito práticas ainda a impediam de concretizar esse desejo, e na frase seguinte ela nos revela:

Mas eu falava, vou me converter vou casar com Goy e vai dar a maior confusão, e ai tem homem na parada, então isso me segurou um pouco para falar a verdade... Porque eu não sabia com quem eu ia casar. Se eu casasse com um não judeu, como é que ia ser? complicava, né, quer dizer nem sou judia e ia casar com um cara que não é judeu, e ele tem que ser judeu. Isso me bagunçava um pouco a cabeça.

$\mathrm{Na}$ construção de sua nova identidade religiosa, Laura se depara com problemas concretos como a questão do casamento, e enfrenta sua insegurança com relação a identidade judaica que está prestes assumir, justificando as várias interrupções do processo por motivos financeiros: porque que eu parei, 
foi por causa do dinheiro, porque estou trabalhando, sempre tinha alguma coisa que eu tinha que parar o curso de conversão... E sempre na hora do vamos ver, eu parava, eu não tinha uma data exata pra fazer a conversão, agora eu voltei e falei, então, em dezembro, vamos fazer a conversão.

\section{Mercado religioso}

Para esclarecer o conceito de mercado religioso, Donnadieu afirma que hoje, aderir a uma religião é o mesmo que adquirir um bem de consumo. "Ao contrário da concepção durkheimiana, a religião perdeu sua dimensão coletiva, fundamentada no vínculo social e na identidade de grupo, a dimensão coletiva foi substituída pela satisfação individual do fiel/consumidor" (Donnadieu 2001) ${ }^{12}$. Tratamos a religião como produto, para isto nos apropriamos de conceitos do campo econômico como: bem de consumo e mercado. Na sociedade ultramoderna, os produtos se tornaram cada vez mais padronizados; isto é verdadeiro também para os produtos simbólicos, o que facilita e agiliza o processo de produção, mas ao mesmo tempo, esses produtos tornam-se cada vez mais exclusivos atraindo o consumidor que está em busca de algo único" (Hervieu Leger) ${ }^{13}$

Como isto ocorre na religião? O sujeito em seu processo de construção do sistema de crenças, vai em busca da verdade espiritual que corresponderia a "sua verdade", identificando-se com o que há de disponível no mercado religioso, incorporando elementos que podem pertencer ao sistema religioso budista, umbandista, cristão, protestante ou judeu. A construção do sistema de crenças pessoal, Hervieu-Léger define como bricolagem:

Os indivíduos compõem livremente sua "solução de crença" pessoal, mas o fazem utilizando fontes simbólicas que estão disponíveis, inseridas em fronteiras/limites determinados. Esta composição

\footnotetext{
12 DONNADIEU, Gerard. Vers un Marché du Religieux? Le Nouveau Paysage du Croire. Futuribles, Paris, ${ }^{\circ}$ 260, p.5 -21, Jan.2001. pág. 11 texto original em francês traduzido pela autora.

${ }^{13}$ HERVIEU-LÉGER, Danièle, Quelques Paradoxes de la Modernité Religieuse. Crise de Funiversel, planétarisation culturelle e renforcements communautaires. Futuribles, Paris, no 260. P-99-110, Jan.2001.p 107
}

depende do ambiente cultural e com as possibilidades de acesso de que o sujeito dispõe. (Hevieu-Leger 2001) ${ }^{14}$

Esta bricolagem se expressa no âmbito individual, particular e é exclusivo.

O indivíduo não enfrenta obstáculos ou faz sacrifícios, ao contrário, a conversão hoje não engendra nenhum comprometimento ou mesmo coerção, seja familiar, social ou profissional, o sujeito pode transitar entre várias religiões ao longo de sua vida. Destacamos o fato da conversão ter se tornado, atualmente, algo fácil, rápido e simples de ser realizado. A conversão à Renovação Carismática Católica ou ao Neo - Pentecostalismo, formas superficiais e afetivas do catolicismo e protestantismo, pode ilustrar nossa afirmação; o converso está diante de um sistema teológico simplificado, o que agiliza a conversão que se realiza no âmbito do emocional (Hervieu-Leger) ${ }^{15}$.

Diferentemente dessas religiões, a adesão ao judaísmo significa meses de estudos e familiarização com a cultura judaica. No judaísmo, a conversão não se realiza apenas no âmbito do emocional; trata-se de um longo e caro processo, que para ser formalizado, o candidato passa por vários rituais, que começam pela primeira entrevista com o rabino, quando o candidato tem de convencê-lo de que a sua intenção é "sincera", faz parte deste ritual a tentativa do rabino desencorajar o candidato, rejeitando-o três vezes.

Bila Sorj explica a conversão como um longo processo de estudo, porque "a instituição que converte procura socializar, transmitir ao convertido aquilo que, para ela, distingue os judeus" (B. Sorj) ${ }^{16}$.

$\mathrm{Na}$ Comunidade Shalom, o curso de introdução ao judaísmo tem duração de um ano; o candidato passa por um exame final - o Beit Din ${ }^{17}$ -

\footnotetext{
${ }^{14}$ Idem. P.102 trecho original em francês traduzido pela autora. "Les individus composent librement leur "solution croyante" personnelle, mais ils le font eu utilisant des ressources symboliques dont la disponibilité demeure ensereé dans certames limites. Les premières tiennent à l'environnement culturel, les secondes aux possibilités d'accès dont dispose le sujet lui-même."

${ }^{15}$ Ibidem. p 108

${ }^{16}$ SORJ, Bila, Conversões e Casamentos "Mistos": A Produção de Novos Judeus. In: SORJ, Bila (Org.) Identidades Judaicas no Brasil Contemporâneo. São Paulo, Imago, 1997pag. 77 17 Beit Din (hebraico, literalmente "casa de julgamento") Tribunal religioso geralmente constituído de três juízes que trata de assuntos relativos a questões civis, divórcio e prosélitos.
} 
quando ele é avaliado por três rabinos. Neste momento, o novo fiel já deve ter escolhido seu nome em hebraico que lhe vai ser "dado" em mais um ritual, todo o processo é concluído com um banho - a mikve ${ }^{18}$. Ao final deste longo processo, o novo fiel recebe um certificado - sua carteira de identidade judaica - que é redigido pelo rabino. Estes são os rituais que permitem ao converso ser admitido no grupo.

O custo da conversão é alto, não é apenas um comprometimento religioso, é também um investimento financeiro. Segundo o rabino Adrian Gottfried, o candidato, para dar início ao curso de conversão, deve associarse à congregação e contribuir mensalmente, pois ele vai ser parte da comunidade e vai usufruir dos serviços oferecidos ao público comunitário.

Desta forma percebemos que o converso não terá apenas interiorizado os conceitos da religião judaica, mas, desde o início, ele fará parte da congregação. Este fato sugere um comprometimento financeiro, que parece estranho ao universo religioso, porém, tratando-se de "produto e consumidor" parece óbvio que apareça o fator que estava faltando: o dinheiro. Como Prandi nos esclarece: "os brasileiros, em geral, costumam pensar a religião como uma coisa pública e como do direito de todos. Ninguém precisa filiar-se, pois já se nasce católico e assim se permanece enquanto se viver, sem nenhum compromisso"19 ... "Qualquer católico pode passar a vida inteira sem dar um centavo para a igreja"20 "A expansão das religiões cuja filiação depende de gastos elevados em ritos de iniciação ou contribuição financeira sistemática, obrigatória e em montantes expressivos ... tem alterado substancialmente a concepção que se faz entre religião e compromisso financeiro; a religião vai deixando de ser entendida como pública, isto é, gratuita, em direito de todos no entender de nossa cultura, para se tornar privada. É preciso pagar para se fazer parte dela ${ }^{21}$."

Vemos que a religião tornou-se um bem de consumo caro, o investimento do converso, muitas vezes, ultrapassa suas possibilidades

\footnotetext{
${ }^{18}$ Mikve (hebraico, significa "reunião", "ajuntamento") Piscina de água "viva", acumulada da chuva ou de uma finte, que é usada no ritual de purificação. Prosélitos devem mergulhar no mikve, como parte da conversão ao judaísmo, sendo essa a origem do batismo cristão.

${ }^{19}$ PRANDI, Reginaldo. Religião Paga, Conversão e Serviço. In: PIERUCCI, Antônio Flavio e PRANDI Reginaldo, A Realidade Social das Religiões no Brasil: Religião, Sociedade e Política. $1^{a}$ edição, São Paulo, Hucitec, 1996. P. 257 - 273. p 266

${ }^{20}$ Idem pág. 267

${ }^{21}$ Ibidem pág. 268
}

financeiras. Uma comparação, aproximando extremos, são os gastos nos rituais de adesão ao candomblé ou às grandes somas entregues aos pastores das novas igrejas evangélicas.

No processo de formação do sistema de crenças pessoal, o indivíduo recorre a todas as ofertas do campo simbólico. "Do ponto de vista do indivíduo moderno ... [a religião\} constitui a procura de emoções e de sentido para além dos limites tradicionais que separam as diferentes religiões.., a religião está liberada do controle institucional .... transforma-se em uma nova fonte de imaginação simbólica e ganha uma nova visibilidade .... uma World-religion visível e que se pode consumir sem ter que prestar contas às instituições tradicionais do tipo religioso, tudo isto está em parte, presente no fenômeno do New Age" (Pace 1997) ${ }^{22}$.

\section{Bricolage - um exemplo}

Observemos como Laura se apropria e resignifica o simbolismo do elemento água em sua experiência de conversão. De forte significado simbólico em várias religiões, a água, não é aqui um aspecto de sincretismo, mas é o catalisador da bricolagem, é a partir de sua apropriaçãoidentificação com o elemento água que Laura estrutura seu universo religioso. Vemos no trecho a seguir, o relato de Laura sobre seu exame de conversão e sobre a escolha de seu nome:

Depois eles perguntaram qual era a importância da água no judaísmo, eram 3 rabinos ... E eles foram perguntando e eu fui falando o que eu achava. Meio loco né, no segundo dia Deus separou a terra e o mar; Moisés, tem o Midrash ${ }^{23}$, Moisés descendo do rio, Moisés quando sobe no monte Sinai o povo pede água, isso é importante, é a hora que ele briga, que Deus briga com ele e fala que ele não vai entrar na terra prometida e tudo por causa da água que o pessoal pedia, Noé água, e aí me perguntaram quando chovia em Israel, e ai eu falei em Israel não chove muito. Tem reza de água, é a única coisa que eu não sabia, é que você pede pra que chova por causa das colheitas, todo o calendário judaico é o lado das colheitas, o lado agrícola, e as

${ }^{22}$ PACE, Enzo. Religião e Globalização. In: ORO, Ari Pedro e STEIL, Carlos Alberto (Orgs.): Religião e Globalização. 2' edição, Petrópolis, Editora Vozes, 1999.P- 25-42. pág. 35.

${ }^{23}$ Midrash: (hebraico, significa "busca", "procura") Método homilético de interpretação bíblica no qual o texto é explicado diferentemente de seu significado literal. 
grandes festas... Então tudo é baseado nisso, e tudo isso é água, então todos os problemas deles é água, problema de guerra é água, eles brigam pela água, isso eu não falei, o problema de guerra.

Mesmo quando fala sobre sua profissão, professora de natação:

a minha grande força é água e ele (seu irmão gêmeo) é terra, ele treina corrida e eu natação.

Ao fim da entrevista, com o gravador já desligado, Laura me pergunta se quero saber como ela escolheu o seu nome em hebraico, diante de minha afirmativa ela conta:

Então era pra ser Hanna, mais aí eu pedi pro Adrian quais eram os nomes relacionados com água, e ele falou, Gal - "onda", Galit"ondinha", e Bat Yam - "filha do mar", e escolhi Bat Yam, porque tem a ver com água, e, na umbanda, eu sou filha de yemanjá,

\section{Considerações finais}

Diante das limitações deste trabalho, utilizamos muito pouco do material recolhido na entrevista. Nossa intenção era mostrar como o judaísmo, religião que até pouco tempo era considerada uma religião "fechada", hoje faz parte da oferta de produtos simbólicos, disponíveis a todo aquele que se interessar a incorporá-lo em sua bricolagem pessoal. Vivemos em um tempo em que a sociedade é regida pela lógica liberal sentido econômico - e neste sentido entendemos como as decisões individuais são valorizadas. Entendemos como a lógica liberal transforma a religião em um bem de consumo que visa a um bem estar individual.

Recorremos a Françoise Champion que nos esclarece como "O importante não é o fato de uma crença ser falsa ou verdadeira mas o que ela pode propiciar em termos de bem estar, de felicidade pessoal, e de ajuda nas dificuldades" (Champion 2001) ${ }^{24}$.

Vimos como o judaísmo institucional adapta-se às necessidades contemporâneas e torna-se mais compatível com a realidade de seus membros e ao mesmo tempo mais atraente aos que estão em um processo de construção de sua "verdade espiritual". Assim percebemos como

${ }^{24}$ CHAMPION, Françoise. Univers mystique-ésotérique et croyances parallèles. Futuribles, Paris, no 260, p.49-60, Jan.2001.pág. 57 trecho original em francês traduzido pela autora. elementos do Judaísmo e de tantas outras religiões podem ser reinterpretados, resignificados nos sistemas de crenças individuais.

\section{Referências Bibliográficas:}

CHAMPION, Françoise. Univers mystique-ésotérique et croyances paralelles. Futuribles, Paris, no 260, p.49-60, Jan. 2001.

DONNADIEU, Gerard. Vers un Marché du Religieux? Le Nouveau Paysage du Croire. Futuribles, Paris, no 260, p.5-21, Jan. 2001.

HERVIEU-LÉGER, Danièle. Quelques Paradoxes de la Modernité Religieuse. Crise de l'universel, planétarisation culturelle et renforcements communautaires. Futuribles, Paris, no 260. P-99-110, Jan.2001.

PACE, Enzo. Religião e Globalização. In: ORO, Ari Pedro e STEIL, Carlos Alberto (Orgs.): Religião e Globalização. $2^{\mathrm{a}}$ edição, Petrópolis, Editora Vozes, 1999.P- 25 -42.

PRANDI, Reginaldo. A Religião e o Planeta Global. In: ORO, Ari Pedro e STEIL, Carlos Alberto (Orgs.): Religião e Globalização. $2^{\circ}$ edição, Petrópolis, Editora Vozes, 1999. p - 63-70.

PRANDI, Reginaldo. Religião Paga, Conversão e Serviço. In: PIERUCCI, Antônio Flavio e PRANDI Reginaldo, A Realidade Social das Religiões no Brasil: Religião, Sociedade e Política. P edição, São Paulo, Hucitec, 1996. P. 257 - 273.

SORJ, Bila, Conversões e Casamentos "Mistos": A Produção de Novos Judeus. In: SORJ, Bela (Org.) Identidades Judaicas no Brasil Contemporâneo. São Paulo, Imago, 1997. P. 67-86. 


\section{Capítulo}

PARTE 2

VERTENTES DIFERENCIADAS DO COMPORTAMENTO JUDAICO BRASILEIRO

\section{IDENTIDADE E ETNICIDADE}

Identidade judaica: significados e pertinência em jovens judeus liberais paulistanos

Sylvana Hemsi

O objetivo deste trabalho é compreender como está configurada a identidade judaica e a pertinência ao judaísmo em um grupo de jovens judeus liberais paulistanos, através do referencial teórico da psicanálise, de pesquisa qualitativa, observação participante em grupos institucionais para jovens na cidade de São Paulo e análise de documentos da comunidade judaica relativos a esta faixa etária.

Consideramos que a identidade judaica se estabelece em duas vertentes. A primeira, individual, pode ser observada através do comportamento, mas se realiza sobretudo nas percepções subjetivas em relação a determinadas situações. A segunda, a vertente coletiva, pode ser analisada na participação efetiva na coletividade e também no marco da vida judaica em sua interação com o mundo não judaico (Della Pergolla, 1999).

O sentimento de pertinência, que buscamos avaliar, também está vinculado a diferentes experiências e contextos e à circunstância especifica na qual se encontra o sujeito no momento presente. Podemos dizer, portanto, que se trata de um complexo que envolve emoção, ação, contexto e oportunidade.

Este trabalho utilizou a definição ampla de judeu, cujo critério é a autodefinição do indivíduo que se declara judeu; sem obrigação da prática religiosa, permitindo incluir múltiplas expressões de identidade, como os aspectos psicológicos, culturais, étnicos, sociológicos e linguísticos.

${ }^{1}$ Mestre em História / USP. 
Com tal propósito, avaliamos os principais aspectos que caracterizam a identidade judaica e examinamos como a educação formal, por um lado, e a educação não formal, por outro, agem sobre esse processo de construção buscando revelar os desejos e valores que constituem o sentido de "ser judeu".

Analisamos a transmissão recebida, a relação dos jovens com a religião e as práticas religiosas, a importância dos avós na transmissão do judaísmo, sentimentos com relação a Israel, exemplos de conduta dados pelos pais e pela comunidade, vivências de discriminação, sentimentos com relação ao holocausto, ambiguidades e afetos com relação a "ser judeu".

O momento atual do jovem foi priorizado: o sentimento de pertencer a uma comunidade, as preferências com relação a namoro e casamento, o círculo de amizades, suas posições frente à conversão, à morte, à preconceitos; sentimentos com relação a morar em São Paulo, inserção da comunidade judaica nesta cidade e, por fim, as perspectivas de continuidade: a importância dada ao judaísmo, projeções com relação aos filhos: atitudes, desejos e valores.

Os parâmetros utilizados para a montagem do roteiro das entrevistas foram embasados no modelo quádruplo da consciência humana, especificado por Wilber (1997) no seu trabalho "Uma Teoria Integral da Consciência" e o referencial teórico utilizado para a análise das mesmas foi baseado na análise do discurso segundo o modelo proposto por Dominique Maingueneau.

Foram entrevistados durante o ano de 2001 e 2002, 20 jovens na faixa etária de 18 a 28 anos, de ambos os sexos, solteiros, estudantes universitários e pós-universitários, selecionados a partir da técnica de amostragem Bola de Neve, apresentada por Comelius. Esta faixa etária foi escolhida por ser um momento da vida em que novos grupos de referência se delineiam na vida do jovem e a inserção na sociedade se dá de maneira mais autônoma. É também um momento significativo de escolhas afetivas e profissionais, caracterizadas, sobretudo, pela descoberta de conflitos e dicotomias, nas quais o jovem afirma suas opções.

Foram entrevistados 12 jovens do sexo masculino e 8 do sexo feminino, procurando levar em consideração variáveis como: terem estudado em escola judaica e em escola laica durante o ensino fundamental, pais com casamentos endogâmicos e exogâmicos, frequência em atividades não formais da comunidade judaica paulistana - clubes, movimento juvenil, sinagogas - na medida em que estas instituições possibilitam a formação e a transmissão da identidade judaica.

É importante ressaltar que grande parte dos entrevistados frequentou os movimentos juvenis Dror, Chazit da Congregação Israelita Paulista e Chufshá da Comunidade Shalom de São Paulo, durante os anos de 1994 a 1999.

Os jovens entrevistados são netos de imigrantes e pertencem a classe média e média alta. Seus pais são, em sua grande maioria, profissionais liberais bem sucedidos, atuando nas áreas de Humanas e Exatas. Propiciaram aos seus filhos o estudo nas mais conceituadas escolas particulares de São Paulo, a frequência em clube judaico, o conhecimento de línguas estrangeiras, e viagens para o exterior. Desta maneira, os jovens se integraram naturalmente em São Paulo, participando de grupos dentro e fora da comunidade judaica.

Seus pais lhe propiciaram também uma educação flexível, baseada no diálogo e no respeito às diferentes ideias e conceitos, valorizando nos filhos a independência de valores. De acordo com as entrevistas, eles ofereceram a possibilidade de opção e questionamento sobre os mais variados temas, inclusive a forma como o judaísmo é praticado na família. Radicalmente diferente da educação recebida pelos seus pais (pautada pela rigidez de modelos, ambiguidades, medos e conflitos), estes jovens tiveram a oportunidade de escolher a maneira como querem ser judeus.

Porém, esta abertura para questionamentos também foi fruto da dificuldade dos pais em transmitir conteúdos judaicos. Os entrevistados expressaram que sentiram falta de compreensão nos seus ensinamentos sobre judaísmo, no modo como rezavam, e desinteresse dos mesmos em aprender para poder transmitir.

A comemoração das festas judaicas foi traduzida como "uma reunião em família", que agradava aos jovens, pois o ambiente familiar gerava apoio, segurança, continência, união e reafirmava o sentimento de pertinência.

Vejamos dois exemplos:

Tinha o Pessach, que meu avô fazia naquele hebraico que ninguém nunca sabia o que estava acontecendo. Tinha Chanucá que a gente acendia as velas, mas só por acender. Nunca tinha ouvido nenhuma explicação. Tinha Rosh Hashana que a gente ia ao final buscar minha avó na sinagoga e no final de Yom Kipur também ia buscar, o que 
era um inferno. Minha mãe vem de uma família normal, sabe judeus normais. Fazia Shabat em casa, mas nunca deram explicações. A gente fazia as festas, mas não se explicava por quê. (K.)

$\mathrm{Eu}$ acho extremamente interessante a proteção e o trabalho em conjunto que a família faz. Você tem reuniões familiares. As festas judaicas fazem com que você tenha pelo menos algum contato com sua família. Acho que todo apoio que a família te dá é muito importante para todo o desenvolvimento profissional e pessoal. $\mathrm{O}$ judaísmo dá valor à família, aos amigos e sentir a importância desse meio é o que eu tenho visto no judaísmo no dia a dia. (A .)

Os elementos preponderantes da transmissão do judaísmo dos jovens foram os cursos preparatórios para Bar/Bat Mitzvá e principalmente a participação e frequência em movimento juvenil. Através da inserção nestes grupos, os jovens aprenderam não só cultura e religião judaica, mas principalmente encontraram um local de pertinência, onde sentiram respeito por suas ideias, continência da instituição, apoio do rabino e principalmente reconhecimento. Na função de madrich (monitor), sentiram-se responsáveis por transmitir o judaísmo para seus colegas, tendo para isso que estudar e se aprofundar.

Além da transmissão específica do judaísmo, outros temas de interesse, como drogas, sexualidade e política eram discutidos nesses grupos de uma maneira autônoma, propiciando aos jovens a possibilidade de expressão de seus conflitos e ansiedades. Sabemos que na adolescência a procura por outros modelos de identificação fora do ambiente familiar é prioritária. Nesse sentido, a sinagoga da comunidade Shalom, por exemplo, foi relatada como uma segunda casa, com expressões como "eu gostava do velho sofá", "eu conhecia os pais de todo mundo", "o rabino sabia quem você era, é alguém que te reconhece e te chama pelo nome", "eu me sentia em casa". O grupo de jovens se tornou o grupo de amigos de hoje. Sentiram-se integrados, pertencentes e reconhecidos e passaram a compreender e a valorizar o significado de ser judeu, o que gerou posteriormente uma atuação comunitária efetiva.

A partir dessas vivências, e com a possibilidade oferecida pelos pais de optar por outros caminhos, alguns conflitos entre pais e filhos surgiram. Os jovens afirmaram que passaram a se interessar mais pela religião judaica que seus pais, procurando se aprofundar nos conteúdos, exercitar algumas tradições em família, buscando, em ultima instância, um sentido das práticas religiosas nas suas vidas. O jejum de Yom Kipur, por exemplo, foi relatado como um momento importante de "poder parar e refletir", "passar o dia na sinagoga para entrar em sintonia", visando encontrar um sentido espiritual e não ser apenas uma prática realizada de modo mecânico e sem significado.

Estas posturas têm provocado em muitas famílias mudanças de atitudes. Segundo os jovens, alguns pais passaram a exercer mais as tradições judaicas em casa, além de passarem a frequentar a mesma sinagoga que seus filhos. Já, outros pais, não concordam com a forma de "ser judeu" dos seus filhos. Um exemplo disso é dado por um jovem que afirmou que tem se dedicado muito a compreender a religião judaica e que passou a praticar algumas tradições, tais como não comer carne de porco e respeitar o Shabat, mas seus pais "tem medo que ele se torne religioso", preferindo até que ele se case com uma moça não judia para não correr este "risco".

Em comparação com a geração anterior, os jovens se sentem mais judeus que os pais, em termos de fé, espiritualidade, prática religiosa e atuação comunitária. Muitos consideram que seus pais estão perdidos, a procura de um caminho judaico, de um sentido ou significado para as práticas religiosas nas suas vidas.

O sentimento de pertinência ao judaísmo dos jovens estudados traduziu-se num orgulho da sua identidade judaica que gerou o desejo de aprimorar os conhecimentos através de cursos, viagens a Israel, trabalhos na comunidade e principalmente pelo desejo de transmitir esta identidade para seus filhos, através da inserção dos mesmos no ensino judaico não formal, em instituições da comunidade e, principalmente, no seio de sua própria família.

Todos afirmam ter preferência pelo casamento endogâmico, alegando facilidades na relação com o cônjuge e principalmente na educação dos filhos. No caso de casamento exogâmico, todos afirmaram que gostariam que o cônjuge se convertesse, se isto fosse o seu desejo, mas eles têm o propósito de educar seus filhos como judeus. Todos pretendem realizar os ritos de passagem da circuncisão, do Bar e Bat Mitzvá e inserir seus filhos em movimentos juvenis e clubes da comunidade e acreditam que a realização das tradições em família é a maneira mais adequada para instaurar um "viver judaico" e para a construção da identidade. Eles dão importância também à memória do holocausto sofrida pelo povo judeu e por muitos dos seus avós e consideram fundamental esta transmissão para as futuras gerações. 
A maioria dos entrevistados atua em trabalhos voluntários nas instituições da comunidade judaica e não judaica, valorizando sobremaneira a prática da tzedaká (caridade) e aqueles que não atuam, manifestaram o desejo de fazê-lo.

Após as mudanças políticas realizadas na Comunidade Shalom de SP, local onde grande parte dos entrevistados frequentou até o ano de 1999, a procura de um novo local de pertinência religioso tornou-se prioritário para estes jovens. Atualmente não se identificam com nenhuma sinagoga e principalmente com nenhum rabino, e mesmo os que não participaram desta comunidade e frequentavam outras sinagogas, como por exemplo, a Congregação Israelita Paulista, afirmam que não se sentem integrados, o que gerou um distanciamento da comunidade judaica, como explicita um dos jovens:

Uma coisa que me tira do judaísmo, e está me tirando é porque eu não vejo outro lugar que eu me encontro, um templo, um local em que eu possa me sentir bem, pertencendo, mas ainda estou procurando e acredito que seja possível encontrar. (E.).

Ou, a afirmação de uma jovem que passou a frequentar outra sinagoga:

É uma pena que está virando, de uns tempos pra cd, uma bagunça e um falatório na sinagoga. A gente senta sempre para trás e é lá é enorme. E um barulho, aquele monte de gente conversando, uma falta de respeito. Acho que tira um pouco o clima, e a gente começa a conversar também. Vou exatamente três vezes por ano, e pra mim aquilo é importante. Eu ir Id, sentar, rezar, ficar na minha. E você vê aquela bagunça, um monte de gente entrando e saindo, acho muito ruim. (I)

Ao serem indagados que sugestões teriam para os representantes da comunidade com relação a uma atuação para jovens mais efetiva, as respostas apontaram para um incentivo e valorização do trabalho voluntário nas instituições judaicas e não judaicas e atividades culturais ou sociais que integrassem os jovens judeus. Para muitos entrevistados, estas atividades deveriam ser abertas para outros jovens não judeus, pois a maioria dos entrevistados acredita ser importante a inserção dos judeus no mundo não judaico e vice-versa.

O significado do que é ser judeu traduziu-se na possibilidade de poder ser judeu sem ser religioso, pelo sentimento - "sinto-me judeu", pela relação com a família e suas raízes, com a história do povo judeu, pela pertinência a uma comunidade e principalmente pela possibilidade de poder ser judeu de acordo com o sentido e significado que esta identificação traz na vida de cada um. $\mathrm{O}$ discurso deste entrevistado retrata bem este sentido:

Ser judeu é se sentir judeu. Não importa o que um acha que é o judaísmo. É você fazer seu judaísmo, é interpretar as leis da forma que você quiser interpretar, mas lógico, num parâmetro certo,mas interpretar do jeito que você acha que deve ser interpretado. Fazer suas regras baseadas nas leis que você se propôs a seguir. É estar sempre participando, tentando introduzir judeus na comunidade. Saber o que é, estudar a religião e estar seguindo da sua forma, se você acha importante faz isso, se não achar, não faz. Mas estar seguindo de alguma forma, estar lendo, se aprofundando, interpretando do seu jeito e depois passando para os seus filhos. (E.)

Para concluir, podemos analisar o fluxo da transmissão do judaísmo na família em três gerações, a partir desta pesquisa e de uma pesquisa anterior que realizamos em 1997 com a geração dos pais destes entrevistados. Podemos observar que na geração dos avós destes entrevistados, em sua maioria imigrantes fugidos da guerra, os judeus se agruparam de maneira categórica em decorrência do antissemitismo, não existindo questionamentos da identidade judaica, fora de uma interpretação de caráter político ou de classe social. E, desta maneira, transmitiram o judaísmo para seus filhos, pais destes entrevistados, através de normas rígidas, repetindo tradições muitas vezes sem explicação, gerando nos seus filhos um sentimento ambíguo de culpa e conflitos, que se sentiram obrigados a dar continuidade a um judaísmo que pouco significado e sentido fazia nas suas vidas.

Os pais destes entrevistados, por sua vez, procuraram dar a seus filhos a oportunidade de questionamentos, calcada também na falta de conhecimentos, e delegaram para instituições e representantes da comunidade judaica, como o movimento juvenil, a escola judaica formal e o rabino, a tarefa de ensinar o judaísmo para seus filhos. Já os nossos entrevistados, puderam participar destes grupos de educação não formal e na procura de um sentido vão buscar os aspectos da religião que trazem significado, não separando inclusive o judaísmo do resto do contexto social brasileiro.

Quando este jovem retorna para sua família com estes conhecimentos, encontram resistência nos seus pais que têm medo que seus filhos se tornem religiosos, ou sejam muito diferentes deles próprios. Existe um fosso entre as 
gerações que permanece - os pais passam a correr atrás dos seus filhos, frequentando os mesmos locais de pertinência. Os filhos começam a criticar os pais na maneira como são judeus. Afirmam querer passar para seus (futuros) filhos a essência daquilo que acreditam: o orgulho, o sentimento, a crença e a valorização de ser judeu. Se sentem responsáveis pela continuidade do judaísmo em SP. É esta a perspectiva a partir destes jovens...

\section{Referências Bibliográficas:}

DELlAPERGOLA, Sérgio. Assimilación/ Continuidad Judia: Tres Enfoques. In Encuentro y Alteridad - Vida y cultura judia en América Latina. México: Ed. Fondo Cultura Económica, 1999.

HEMSI, Sylvana Identidade Judaica: Um Modelo Paulistano Liberal. Dissertação de Mestrado apresentada à Área de Língua Hebraica, Literatura e Cultura Judaicas da Universidade de São Paulo, 1997.

MAINGUENEAU, Dominique. Novas Tendência em Análise do Discurso. Ed. da Unicamp e Pontes Editora, 3ª edição, Campinas, SP, 1997.

WILBER, Ken. An Integral theory of Consciousness - In Journal of Consciousness Studies V. 4, N.1, 1997, pp 71-92.

\section{A América e a reconstrução da identidade judaica}

Pedro P. Geiger ${ }^{1}$

D ertence ao conhecimento comum, a ideia de que a natureza dos sentimentos de identidade judaica varia muito, entre as pessoas que se consideram membros da Judeidade, assim como variou muito no transcorrer da longa história do povo judeu.

O presente trabalho, na forma de ensaio, pretende focalizar o papel do descobrimento da América, seu povoamento e desenvolvimento, na evolução dos sentimentos de identidade judaica. Não apenas nas populações localizadas propriamente nas Américas, mas no Mundo inteiro, tendo em vista a influência histórica da experiência americana para o quadro mundial contemporâneo em geral.

O trabalho assume duas posturas básicas. Primeiro, comunga com a ideia dos "ciclos longos" exposta por Braudel (Braudel, 1972). Propõe-se que a paisagem social do mundo contemporâneo expressa, de forma dominante, a forte influência do desenvolvimento americano, com suas características próprias estabelecidas desde o descobrimento do novo continente. Segundo, se apoia na ideia das "semicausas" apresentada pelos Estoicos gregos e as quais se referiam a fenômenos de superfície A proposição das "semicausas" se opunha à ideia de "causas", que ocorreriam em fenômenos de profundidade dos corpos. A ideia, retomada por Gilles Deleuze (1998), é aplicada quando se propõe considerar a espacialidade da vida social como sendo um fenômeno de superfície e as contingências geográficas, como "semicausas" da vida social. Eventos na superfície terrestre, como a mobilidade horizontal humana, atuariam como "potenciais para a desconstrução e reconstrução de memórias, de sistemas organizados, de formas de comportamento" (Vidal e Souza, 1997).

No Brasil, por exemplo, o "nativismo", expressão criada para descrever o desenvolvimento, na época colonial, de um sentimento de brasilidade, é associado, pela referida autora, a que o desenvolvimento deste

${ }^{1}$ Geógrafo / IBGE 
sentimento se difundia, particularmente, entre populações que se moviam e penetravam o interior das terras "virgens", como a dos "bandeirantes". No trabalho, o deslocamento de populações para novas estruturas socioespaciais, é apresentado como semicausa de processos de identidade.

\section{O papel da América na história do mundo e da Judeidade}

A análise da América na história mundial colocará, em evidência o fato de que as formas específicas das construções socioespaciais, realizadas no novo continente, criando-se formatos geográficos próprios, tiveram um papel específico para o seu desenvolvimento. Note-se, de passagem, que uma análise desta natureza serve ao entendimento da diferença existente entre Geografia Histórica e História Geográfica.

Trata-se de uma questão discutida por Chris Philo (Philo, 1994), para quem, enquanto a primeira trata da descrição de antigas paisagens e organizações espaciais, a segunda se concentra sobre o papel das contingências geográficas no desenvolvimento histórico. No presente trabalho, o interesse se volta para a segunda opção.

Assim, invoca-se o fato de, na América, diversos países assumirem dimensão continental, ou semicontinental, caso do Canadá, dos Estados Unidos, México, Brasil e Argentina. O fato dos Estados Unidos terem se tornado o primeiro modelo de uma "economia nacional capitalista avançada de dimensão continental" (Geiger, 1995); de possuírem duas longas costas oceânicas livres (de gelo); de terem ficado à margem dos campos de batalha das duas guerras mundiais, mas nas quais se envolveram vitoriosamente, seriam algumas situações geográficas decisivas para a sua posição hegemônica atual e influência mundial. Note-se que este padrão de enormes espaços unidos, em economia capitalista avançada, está sendo replicado, na atualidade, através da formação de mercados comuns de países.

Esta hegemonia econômica e militar assumida pela América do Norte, que incorpora o Canadá, e tenta integrar o México, é acompanhado pela difusão de valores sócio político, que serão tratados mais adiante, e que tem influído na situação contemporânea da Judeidade. Embora se esteja aludindo ao papel dos Estados Unidos em particular, contudo, uma série de características é comum às Américas, se bem com menor intensidade nos outros países, como a atração de levas de imigrantes para os amplos espaços, os investimentos de capitais provenientes do exterior, a mobilidade horizontal e vertical, muito mais elevada do que na Europa.

$\mathrm{Na}$ Europa, regra geral, a nação precedeu ao estabelecimento do Estado. Ainda no presente se observam grupos étnicos lutando pelo estabelecimento de seus estados independentes. Nas Américas, o Estado vem antes. Uma vez proclamada a independência, inicia-se a construção nacional, englobando a população presente, independente de origem étnica, cultural ou de sangue. A naturalização dos imigrantes é admitida. Todas estas razões expostas, até agora, levaram à afirmação de que, "na América, a geografia substitui a história".

Assim, na América, a Judeidade não apareceu, historicamente, como que formando uma camada nacional alienígena, que veio a cobrir nações dadas como pré-existentes. A não ser no caso de descendentes de ameríndios, no ato da formação nacional, todos os outros grupos étnicos são descendentes de colonos ou vieram de fora, encontrando-se em condições relativamente iguais neste particular. (Foi observada certa manifestação de vantagem, por parte de descendentes de correntes mais antigas da colonização, frente aos chegados através de correntes de migração mais recente, Hobsbawm, 2000).

Por outro lado, a proclamação da independência era feita, nos países da América, evocando valores universais desenvolvidos a partir do iluminismo europeu. Poucos anos separam a Revolução Americana da Revolução Francesa, ambas tendo influenciado a independência dos outros países americanos, como no caso do Brasil. Com a diferença de que, na América, os princípios universais são formalmente proclamados no próprio ato da criação nacional, a Nação tendo início como uma instituição laica. Resulta que, na América, não se apresentou, propriamente, uma questão de "emancipação" para a Judeidade.

Veja-se, por exemplo, a diferença entre dois importantes eventos da história judaica, embora, na verdade, separados por longo período de tempo. Na França, Napoleão convocou uma assembleia de notáveis, judeus, para que lhe respondessem sobre a aptidão dos judeus serem bons cidadãos franceses, enquanto mantendo uma identidade judaica. Já na Conferência de Lideres Judeus Americanos, em Pittsburgh, 1889, a ênfase está no suporte à Revolução Americana, considerada como comprometida com os valores universais sustentados pelo Judaísmo. "Desejamos, fortemente, ver o 
Judaísmo tendo um importante papel na vida espiritual da humanidade, tornando popular uma abordagem social do Judaísmo ... Na era moderna, de uma cultura universal do coração e do intelecto, a vinda da grande esperança messiânica de Israel, pelo estabelecimento do Reino da verdade, justiça e paz entre os homens". (Sorj e Grin, 1993: 138). Assim, enquanto na França os judeus se viam às voltas com a sua situação na emergência de um forte Estado/Nação, mas dotado de um passado de tradições, no outro lado do Oceano abria-se, já, a perspectiva de "Um Mundo Só".

$\mathrm{Na}$ América, no entanto, houve, também, uma questão de emancipação, a dos negros. Não se nega a existência de diversos preconceitos e a difusão de discriminações trazidas da Europa. Inclusive o antissemitismo. No entanto, as ideologias preconceituosas, na América, contradiziam o discurso da Revolução Americana, com os princípios formais das Constituições estabelecidos desde a origem dos Estados.

Enquanto na Europa a discriminação continha, historicamente, uma origem e caráter "nacional", misturado com religião, na América prevalecia o sentido sociocultural. Esta diferença sutil faz uma grande diferença, pois aponta para o peso dado, num e noutro continente, para cada termo da expressão Estado/Nação. Nação teria um peso relativamente maior na Europa, do que na América. Assim, na Europa, a assimilação significava romper todas as ligações com a cultura anterior, adotar os valores históricos do passado, da nação de adesão. Note-se, por exemplo, a frequência com que, na Europa, judeus selavam a sua adesão às nações locais através da conversão religiosa, uma etapa para o reconhecimento da cidadania plena, não só pelo Estado, mas pela Nação. Na América, a assimilação expressa, mais, uma integração mais profunda na cultura secular do Estado, a aceitação dos valores inscritos em Constituições.

Por outro lado, a existência de uma camada segregada, estabelecida com a instituição da escravidão, no Brasil, como nos Estados Unidos, fez com que, regra geral, a população negra passasse a ocupar o nível inferior da estrutura social. Uma posição que, na Europa, estava reservada à Judeidade. Por todas estas razões, é que, apesar da permanência de formas discriminatórias, o cruzar o Oceano teve, em certa medida, para muitos judeus, significado próximo àquele sentido pelos Pilgrims, o de um Êxodo.

Através de sua própria história, os povos americanos se comprometeram, ideologicamente, com a descolonização. A independência dos países americanos se mostrou favorável à expansão capitalista. No caso do Brasil, a Inglaterra, que 50 anos antes resistira à independência norteamericana, atuou a favor da separação do nosso país de Portugal, objetivando o crescimento do comércio, o seu e o mundial. Contudo, interesses particulares e políticos impediram que os países europeus promovessem um movimento geral de descolonização. Pelo contrário, certas potências lutaram duramente, ainda após a II Guerra, para manter as suas colônias. No entanto, assistiu-se a um processo geral de descolonização política, em escala mundial, com o pleno suporte da antiga União Soviética e dos Estados Unidos. Era uma etapa necessária para o movimento de "um sistema mundial de capitalismo nacional, para um capitalismo mundial organizado num sistema de nações". (Scott, 1989).

A criação de Israel tem atrás de si uma longa história, mas a sua efetivação também pode ser inscrita no quadro geral da descolonização. Quando as Nações Unidas foram criadas, o número de seus membros se contava em meia centena. Na atualidade, são quase 200. Não se pode pensar a globalização sem passar pela descolonização política. Através dos Estados Unidos, principalmente, a América se tornou a principal base territorial para os movimentos contemporâneos como os da globalização, transnacionalismo, pluri e multiculturalismo, pós-modernismo, todos com forte influência na evolução da identidade judaica.

\section{Territorialidade e memória judaica}

Os "pais" da Judeidade eram chefes de clãs, criadores de gado, seminômades, dados como fundadores do monoteísmo. Os homens que se deslocavam de um lugar para o outro aprofundaram o olhar sobre o mundo, sobre o universal; Deus é criador do Mundo, é Universal. É interessante comparar o número de deuses, os "lares", dos sedentários habitantes da "cidade antiga" (Coulanges, 2001), ao "Deus Único" dos hebreus em movimento. Deuses relacionados aos domicílios e famílias das aglomerações organizadas em polis. A proposição de um só Deus tem sido também associada ao aparecimento da forma de organização em império, que inclui diversas cidades, o caso de Akenaton, no Egito Antigo. Como se sabe, para Freud, o monoteísmo de Moisés seria uma produção da cultura egípcia. Nos antigos impérios, os deuses também passaram a ser organizados em hierarquias. 
Os seminômades hebreus se ajustavam ao mundo das cidades e impérios em desenvolvimento, sem perder, totalmente, comportamentos e ideologias anteriores. Tornam-se israelitas com o 'pai' Jacob, Israel, que seguiu os seus filhos, para se estabelecer no Egito. Ao deixarem o Egito, invocam promessas divinas para reclamar territorialidade em Canaã. Contudo, aparecem divididos no deserto, quando alguns querem voltar ao Egito ou quando outros querem continuar errando no deserto, em vez de entrar em Canaã. A identificação de lugares sacros não tem a ver com uma territorialidade própria, pode ocorrer fora de Israel, o caso do Monte Sinai, e o ícone mais sagrado, a Arca da Aliança, é um objeto móvel. O estabelecimento do reinado, contra as recomendações do profeta Samuel, e a construção do Templo de Jerusalém, para imobilizar a Arca, são outros exemplos do ajustamento contínuo às forças do ambiente externo, um aprendizado que as populações judaicas passaram a seguir, enquanto mantinham compromissos com seu 'gênero de vida' historicamente estabelecido.

Esta dualidade foi observada, seguidamente, nas práticas espaciais da Judeidade. Pelo século V antes de Cristo, quando Ciro proporcionou a reconstrução do Templo, a maioria dos judeus permaneceu na Babilônia. $\mathrm{Na}$ época da difusão do Cristianismo, a maioria da Judeidade vivia espalhada pela bacia do Mediterrâneo e seu entorno. Periodicamente, durante as festas religiosas, judeus visitavam Jerusalém. Por outro lado, vivendo fora de Israel, sustentando comunicações entre diferentes lugares geográficos, os descendentes dos antigos seminômades, criadores de gado, em número crescente, iam se ocupar no comércio e no artesanato. $\mathrm{Na}$ literatura de língua inglesa, os judeus eram traders.

Portanto, desde a Antiguidade, a Judeidade vivia a territorialidade de uma forma dualista. De um lado, os territórios são parte de um Mundo que pertence a Deus, logo, abertos, livres, para qualquer pessoa; do outro lado, cada pedaço de território é dado por Deus para a posse de um determinado povo, que deve aceitar e tratar bem o estrangeiro. A preocupação com a sorte do estrangeiro aparece, repetidamente, no mandamento bíblico.

Para o geógrafo francês Jean Luc Piveteau, ela criou o seu próprio modelo centro/periferia, o centro localizado em Jerusalém, todo o Mundo em torno sendo a periferia (Piveteau, 1993). Segundo os profetas, com a chegada do Messias, Jerusalém manterá a sua singularidade, mas o Mundo todo será Centro, com o reconhecimento triunfal do Deus monoteísta, e a territorialidade perderá sentido. (O que inspirou a ideologia da evangelização cristã do Mundo, a Igreja acima do poder leigo, territorializado. Por outro lado, a Cabala apresentou a sua teoria sobre a dispersão judaica como uma missão para alargar o espaço dominado pela presença divina entre os homens). É possível, pois, levantar a hipótese de que os sentimentos de exílio, entre os judeus, foram associados mais às dificuldades impostas para a manutenção das ligações com Jerusalém do que ao fato de morarem fora de Israel. Ou seja, um sentimento associado ao clima político do Mundo.

A observação da memória aparece como um comando bíblico da fé judaica. $\mathrm{O}$ que pode explicar o porquê da prática da memória ter se tornado tão insistente e profunda, na tradição judaica. A tradição da releitura frequente da Bíblia e do Talmude expressa o culto da memória. A releitura conduz a reinterpretar o que está escrito e, deste modo, a tradição judaica compreende uma constante reinterpretação e reconstrução de tudo. "Não existe resistência sem memória e sem universais", cita Godard, no seu filme "O Elogia do Amor”. Sem dúvida, foi através do culto da memória e de princípios éticos universais que a Judeidade encontrou as forças não apenas para sobreviver, mas para encontrar novos caminhos de ajustamentos e renovações.

Por princípio, a memória trata do espaço/tempo. A "memória modela, ou sugere, um espaço próprio, singular, enquanto o espaço faz a memória operar, permanecer. A memória semiotiza o espaço, e o espaço estabiliza a memória A síntese dos dois tempos, em movimento, interpenetrados, é o território... Para que o tempo (que pode ser o de um indivíduo, ou, de um ser coletivo) se expresse em si, necessita se tornar personificado em espaço. Torna-se um lugar ou um local simbólico, uma paisagem ou um território. $\mathrm{O}$ fato de cada lugar ter a sua própria história o torna um território de memória. $\mathrm{O}$ espaço é identificado como o lugar da memória, na medida em que assume o caráter de um lugar (um se espacial emergente), de um local simbólico (espaço transcendente), de uma paisagem (propriedade coletiva, fora do mercado), ou de um território (o todo, maior que as partes)"(Piveteau, 1995:113-123).

A memória judaica se encontra repleta de lugares e territórios cobrindo, na realidade, o Mundo inteiro, incluídos locais imaginários como o Jardim de Éden. Do Egito a Brooklin, da Mesopotâmia a Frankfurt, de Alexandria a Vilno, de Tashknet a Toledo, etc., etc., são países, regiões, 
cidades, bairros, partes da geografia histórica dos judeus. É no espaço que se farão as diferenças entre os sefarditas e os asquenazitas, entre o israelense e o judeu. E é no espaço, primeiro na América, depois em Israel, que estes ramos se reencontram.

Alguém pode querer arguir a respeito da contradição entre os votos universalistas da tradição judaica e a proposição de 'povo eleito'. A ideia de povo eleito pode ser tomada em termos relativos, quando o paganismo prevalecia e os profetas proclamavam a utopia de um futuro de equidade para todos os povos, cabendo ao povo eleito o papel de arauto. O Cristianismo herdou a utopia do povo universal, mas foi conduzido, no passado, a tentá-lo pela força. Na época presente, o lema da 'unidade na diversidade', que vem se desenvolvendo como a nova utopia, expressa, de certo modo, a convergência com o modo tradicional judaico de se ver e ver o Mundo.

\section{Os judeus na América}

Uma série de aspectos mencionada na seção 1 ajuda a entender a maior facilidade da assimilação na América, em comparação ao ambiente europeu.

$\mathrm{Na}$ Europa, apesar de expulsões que ocorreram em diversos países, criaram-se, ao longo da história, regiões com alta densidade de população judaica, estabelecida por séculos. Na América, com os seus largos espaços, levou tempos para que se formassem áreas de elevada densidade de presença judaica. Canadá, Estados Unidos e Brasil, cada um destes países é maior que a Europa, incluída a Rússia até os Montes Urais. Os largos espaços se encontravam abertos à colonização e migrações internas, para a dispersão, e, nos primeiros séculos, não se observaram áreas de densidade muitas elevada, de população judaica. Em 1800, a população judaica em toda a América ainda era de apenas cerca de 18.000, dos quais 10.000 na América do Norte, 5.000 na Argentina, 2.000 no Brasil e 1.000 em Curaçao. A diluição favorecia a assimilação. Não tivesse havido um contínuo movimento migratório da Europa para a América, é possível que algumas comunidades étnicas teriam desaparecido. O fluxo, proveniente dos mesmos locais europeus, restabelecia a presença de comunidades lá onde tendiam a desaparecer.

A migração da Europa para as Américas se intensificou, de modo geral, a partir dos meados do século XIX. Então começaram a se formar regiões e cidades com concentração de população judaica. Nessa época, as correntes migratórias de judeus para as Américas representavam, em sua maioria, a transferência de populações de regiões rurais, agrícolas, para regiões em urbanização e industrialização. Nessas áreas, como Nova Iorque, Filadélfia, Pittsburgh, Chicago, Buenos Aires, São Paulo, Rio de Janeiro, iniciava-se a sucessão local de gerações, mantendo a identidade judaica.

Uma diferença da condição geográfica pode ser observada entre a América e a Europa. Na Europa, as grandes cidades, como Frankfurt nos séculos XVIII e XIX, se constituíam nos ambientes mais favoráveis para a assimilação, locais de Reforma e de conversões de setores da elite intelectual judaica. A vida tradicional judaica era mais bem preservada nas regiões menos desenvolvidas, nas pequenas vilas dos "stetels". Na América, a situação é inversa, É verdade que a assimilação foi elevada e cresce nas grandes cidades, mas foi sempre maior nas áreas rurais e nas pequenas localidades, até o desaparecimento de pequeninas comunidades. Há casos de migração de famílias de pequenas para grandes cidades, para escapar à assimilação. A existência de instituições comunitárias nas grandes cidades ajuda a sobrevivência. O geógrafo americano Ira Sheskin vem analisando a questão da distribuição regional e por tamanho de cidades da população judaica nos Estados Unidos. (Sheskin, 2001) No Brasil, José Sacchetta Ramos Mendes (Mendes, 2002) e outros estão fazendo trabalhos na mesma direção.

Diferença entre as culturas e formas de organização das comunidades dos diversos países da América expressam as diferenças gerais, culturais e políticas, dos respectivos países. É dito que nos Estados Unidos "a instância específica religiosa é parte integrante da vida social, enquanto que na América Latina a secularização dos costumes ... é mais semelhante ao ambiente contemporâneo europeu" (Cesari, 2001). Este quadro estaria reproduzido no papel maior que a sinagoga tem na vida social judaica na América do Norte, quando comparado com o Brasil, por exemplo. Lá a sinagoga seria, com maior frequência, a base para a localização de outras atividades institucionais para a vizinhança, como para ensinar hebraico, promover recreação, etc. A diferença pode também ser observada no grau de centralização ou descentralização na organização das instituições. A vida política brasileira e sua estrutura institucional são, tradicionalmente, altamente centralizadas e hierarquizadas, enquanto os Estados Unidos guardam a tradição da profunda descentralização e forte autonomia dos 
poderes estadual e local. Do mesmo modo, as comunidades judaicas no Brasil apresentam a tendência a se organizar de forma hierarquizada e centralizada, representando cidades, estados e o país, aparentemente, mais do que nos Estados Unidos. Organizam-se clubes recreacionais com papel representativo para a cidade ou para certas correntes ideológicas presentes entre os judeus da cidade. É o caso da Hebraica, no Rio e em São Paulo, e da Associação Sholem Aleichem, A.S.A., no Rio de Janeiro.

\section{Exílio, êxodo, diáspora}

Rigorosamente, o termo exílio é aplicado no caso de expulsão forçada. $\mathrm{O}$ termo passou a ser associado, também, a um estado de alma de pessoa deslocada de um lugar, mesmo quando de forma voluntária. $\mathrm{O}$ paradigma do exílio compreende motivações como perseguições, guerras. Por outro lado, o paradigma do êxodo é associado a desejos de renovação e estabelecimento de nova ordem legal. Enquanto exílio pode se aplicar a uma só pessoa, o êxodo se refere ao movimento de um conjunto de pessoas. No paradigma do exílio, no qual se descrevem resistências, o romance é construído; no paradigma do êxodo, no qual figuram conquistadores, vencedores, constrói-se o épico.(Ezrahi, 2000: 27-30).

No início da colonização da América, com a Europa menos desenvolvida culturalmente e socialmente, presa de intolerâncias, a procura do novo continente adquiriu um sentido de êxodo para diversas correntes de migrantes, como para os Puritanos.

Por 1600, a população judaica no Mundo era de cerca de 1.000.000, 45,6\% na Europa, 41,45\% na Ásia, a maioria destes, no Oriente Médio, o Irã compreendido. Com o andamento do Iluminismo, em 1800, a população mundial judaica se elevara para 2.500.000; agora, com 76,8\% na Europa, ou 1.919.000. Destes, viviam na Rússia 800.000; na Áustria, 470.000; na Alemanha, 1.750.000, três quartos da Judeidade europeia. Nessa época, a Ásia figurava com apenas 14\%; a África, com 7,6\%, e os 18.000 na América representavam apenas $7 \%$. Nesse quadro, com certa melhoria da condição de vida de comunidades judaicas na Europa, partir de áreas de comunidades estabelecidas para a América podia misturar sentimentos de exílio e de êxodo.

"Estamos todos no exílio", diria o escritor Jorge Luís Borges, referindo-se à nostalgia em relação ao ambiente cultural europeu, mas, também, como uma reflexão filosófica a respeito do significado de viajar pelo espaço e pelo tempo.

O fato é que, com o engrossamento das correntes migratórias para a América, a partir dos meados do século XIX, mover-se para o novo continente adquiriu diversos ou múltiplos significados, segundo diferentes setores da população judaica. Para alguns, era o exílio de um exílio, ganhando, portanto, sinal positivo, o do êxodo. Poderia representar a missão cabalística de estender a periferia em torno de Jerusalém. A citada autora Ezrahi menciona a visão da América, de Cynthia Ozick, como a de uma nova Yavne. Por outro lado, a partir do século XIX, ampliavam-se as práticas políticas entre os judeus europeus, de modo que muitos migrantes judeus, tanto como os gentios, traziam da Europa suas convicções ideológicas, como as sionistas e as socialistas, e continuaram a desenvolvêlas nas novas terras.

Para muita gente, cruzar o Oceano tinha a intenção de "fazer a América" juntar uma boa poupança e retornar. Porém, se era possível ganhar dinheiro, porque voltar? E se não havia sucesso, onde arranjar os fundos para voltar? o fato é que, para a maioria esmagadora dos migrantes, a "velha" Europa ia se tornando um "novo" lugar de memória. As fantasias e a literatura em torno do stetel passaram a ser produzidos na América.

A atmosfera móvel, americana, passou a envolver os diferentes setores judaicos que iam se instalando no novo continente. A elevada mobilidade horizontal e vertical, isto é, a ascensão de classe, uma característica americana, passou a imprimir mudanças na estrutura social e geográfica da população judaica das Américas num ritmo não conhecido na Europa. Neste processo, as comunidades judaicas passam a ser parte de um mosaico de diversos grupos étnicos que integram as cidades americanas, paisagem mais frequente na América do Norte.

Diáspora significa a divisão de um grupo étnico entre diversos países, vivendo, simultaneamente, a cultura e identidade do país de presença e guardando, de forma mais ou menos intensa, heranças culturais prévias, de forma organizada. A falta de formas organizadas acelera a assimilação, daí o papel da instituição religiosa na preservação da Judeidade. A diáspora judaica se caracteriza pela difusão por, praticamente, todos os países do Mundo. Isto ocorre com religiões, e alguns querem ver a Judeidade como uma expressão religiosa. A questão é que é uma religião de natureza 
"nacional" em sua origem, na qual os seguidores assumem ser (realmente ou virtualmente, uma vez que se deram conversões, inclusive de povos inteiros, como no caso dos kazars) descendentes dos mesmos "pais e mães".

$\mathrm{Na}$ América, longe das origens geográficas, num mosaico de comunidades de diferentes origens étnicas, desenvolveram-se forças da assimilação cultural e forças de resistência, em cada comunidade. Todos querendo, ou tendendo a, se tornar americanos, aprender a falar o inglês, o espanhol ou o português. A primeira geração nascida na América é ainda, mais ou menos, influenciada pela identidade paterna, mas se integra mais ou menos profundamente nas sociedades locais. No caso dos judeus, começa a esquecer a língua iídiche. Essa geração faz o reconhecimento do espaço americano como espaço de ascensão social, uma vez que os seus membros foram enviados para obter educação universitária, pelos seus genitores imigrantes. Muitas vezes, o filho mais velho ajudava os pais na manutenção dos irmãos menores nas escolas. A segunda geração assume a identidade mais completa do país de nascimento. Com a mesma, se inicia a multiplicação dos casamentos mistos. E se abrem os caminhos da assimilação total. Contudo, um contra movimento está se desenvolvendo, que se manifesta no retorno de setores jovens a práticas religiosas fortes.

\section{Mudanças contemporâneas num mundo de diásporas}

Desde a Segunda Grande Guerra, mudanças históricas importantes vêm transformando o Mundo e afetando a vida e a identidade judaica. Como foi dito anteriormente, o desenvolvimento do continente americano, particularmente o dos Estados Unidos, constituiu o eixo central desta evolução.

Algumas destas mudanças não trazem a influência direta americana. A mais trágica, o Holocausto. No entanto, elas influíram na vida americana. A América abriga, na atualidade, a maioria da população judaica mundial, embora Israel esteja se encaminhando para ocupar este primeiro lugar.

Um número de judeus de áreas mais desenvolvidas, como Alemanha e Bélgica, conseguiu deixar a Europa antes do início da guerra, alterando a composição social das comunidades de certas cidades. O estabelecimento de uma comunidade judaica de origem alemã no Rio de Janeiro, traça um capítulo importante na história da cidade, trazendo novos estilos de desenvolvimento cultural. $\mathrm{O}$ nazismo teve o papel de restabelecer fortes resistências em núcleos de sobreviventes e de seus descendentes, como este, contra a assimilação total. Note-se que na atualidade a A.R.I., fundada por este grupo no Rio de Janeiro, passou a integrar pessoas de outras origens europeias, voltadas igualmente para a preservação da identidade judaica e práticas religiosas não ortodoxas.

Porém, após a Guerra, praticamente cessou o fluxo de migrantes da Europa Central e Oriental, que restabelecia os padrões tradicionais, substituindo as camadas erodidas pela assimilação. $\mathrm{Na}$ atualidade, se observa migração, não em números elevados como no passado, de judeus da antiga União Soviética, depois da queda do regime stalinista, e de Israel.

Por outro lado, o Holocausto atingiu forte a alma judaica, mesmo daqueles que se encontravam no limite de uma identidade judaica, tendo influído na manutenção de ligações e no suporte a Israel, diminuindo a profundidade da assimilação.

Outros eventos tiveram a sua origem fora da América, mas receberam um suporte decisivo, para a sua realização, dos Estados Unidos. Já foi mencionada a descolonização política contemporânea, sem a qual a globalização não poderia se realizar. Episódio emblemático foi o episódio dos Estados Unidos, em 1956, obrigando a Inglaterra e a França a abortarem a tentativa de retomar o canal de Suez, nacionalizado por Nasser.

A criação de Israel é um evento cuja origem se situou fora da América, mas que teve e tem o apoio decisivo dos Estados Unidos para a sua realização. De certo modo, Israel se inscreve no processo da descolonização e, também, na pós-modernidade.

Uma das características do estilo pós-moderno consiste em abstrair o tempo, por exemplo, colocando lado a lado composições cujas linhas foram criadas em épocas históricas diferentes. Neste sentido, a criação de Israel como que restabelece o antigo modelo espacial da Judeidade, com sua dualidade estrutural de territorialidade exclusiva, Israel, e territorialidade sem soberania própria, a diáspora. Foi dito, no início deste trabalho, que a ocupação de Canaã foi um ajuste de uma população descendente de seminômades criadores de gado, ao Mundo de cidades/estado e impérios (o modo asiático de produção, de Marx). Do mesmo modo, o Estado de Israel resultou de um ajuste ao mundo dos movimentos de libertação nacional e da descolonização aceito pela ampla maioria da Judeidade, quando a era do 
racionalismo foi capaz de produzir o Holocausto ou quando a utopia internacionalista da União Soviética foi desmistificada.

De certo modo, o enfraquecimento contemporâneo da instituição Estado, em muitas funções, enquanto cresce a instância cultural e a sua relação com a instituição Nação, é como retornar a antigos modelos. Contudo, a pós-modernidade não significa um recuo no tempo. É possível construir novos edifícios com velhos tijolos. A construção de Israel, enquanto é mantido o quadro diaspórico, é parte de uma profunda renovação, tanto da história judaica, quanto da história do Mundo.

Num certo sentido, as modernas tendências do Judaísmo foram estratégias de assimilação, incluído o Sionismo, ao reivindicar sua meta de 'normalizar' o povo judeu, isto é, fazê-lo dispor de uma base territorial e de um Estado, como outros povos (Sorj e Grin, 1993:10).

Ezrahi aborda a mesma questão, em outros termos: a despeito do fervor revolucionário do Sionismo inicial, e sua proclamação de descontinuidade em relação ao passado judaico, a força de sua reconexão com o antigo espaço original, parece como que realimentando um sentido mais amplo de teologia e fechamento... Já que Israel se torna a transformação de um sonho em realidade (is real, é real, em inglês), a manutenção do sonho, pela Judeidade, [a utopia universal], passa para a Diáspora.

Finalmente, um processo geral de mudança, ora em desenvolvimento pelo Mundo inteiro, que possui fortes raízes na experiência americana, expressa o desdobramento de um movimento de longa duração, iniciado com os descobrimentos. (Existe mesmo um grupo de historiadores, no âmbito da International Society for Comparative Studies of Civilizations, ISCSC, conhecido como "os quinhentistas", que considera o marco do século XVI como o da raiz dos atuais movimentos mundiais). Vejam-se alguns aspectos e algumas expressões que descrevem essas mudanças.

O "encolhimento da Terra" é uma expressão associada ao progresso tecnológico, quando as comunicações de imagens passaram a se realizar em tempo real. Falou-se anteriormente da elevada mobilidade da população, particularmente nos Estados Unidos. O turismo de massa, em longas distâncias, é uma "invenção" da cultura consumista americana. Assim, "num Mundo onde cada um se torna um turista, ... na aldeia global, a figura estranha de Judeu, exilado, começa a mudar de significado" (Ezrahi, 2000:8).
$\mathrm{O}$ avanço tecnológico sustenta a maior facilidade de se viajar. $\mathrm{Na}$ atualidade, os migrantes e os seus descendentes mantêm ligações com os seus países de origem de forma mais frequente. Um brasileiro que vive em Nova Iorque pode assistir a um canal de tevê brasileiro em tempo real; acessar, pela Internet, os jornais daquele dia; voar para o Brasil de um dia para o outro. No continente americano, esses fatos passaram a se integrar num quadro que já era o de um espaço de encontro de culturas diversas. Deste modo, se criavam os alicerces do pluriculturalismo e das tendências de migrantes e seus descendentes procurarem manter mais de uma identidade nacional. No passado, apenas países europeus, para os quais a nacionalidade era fundada no sangue, ofereciam a cidadania para os descendentes de seus emigrados. Atualmente, a prática se difundiu, com certa aquiescência oficial pela identidade nacional dual. Em 1994, por exemplo, a Constituição brasileira recebeu uma emenda, pela qual brasileiros poderiam aceitar outra identidade nacional, sem perder a brasileira, em certas circunstâncias, como oportunidades de trabalho.

O que se vê é a multiplicação de diásporas, de diversos povos, e a formação das "novas tribos". (Kotkin, 1992). Em Miami, moram atualmente cerca de 150.000 brasileiros, um deles pensando até em se candidatar a prefeito da cidade. Quando, em Nova Iorque, na rua 46 Oeste, Little Brazil, (ver o estudo de Margolis, 1994), vê-se turistas brasileiros preferindo comprar em lojas de brasileiros, com o "jeitinho" brasileiro (por exemplo, remédios, sem a receita médica), assiste-se a uma paisagem da nova cultura tribal.

A elevada densidade de viagens aéreas que se observa no presente compreende o movimento de executivos e funcionários das empresas transnacionais, de pessoal de tantas organizações públicas internacionais, de acadêmicos em programas de intercâmbio, etc. Todas essas relações são parte de um mundo em globalização, para cujo desenvolvimento foi indispensável o progresso tecnológico, particularmente nos transportes e nas comunicações. Manuel Castells nos fala da "cidade informacional". Outros falam da "idade da migração" (Castells e Miller, 1998). Os novos comportamentos associados à elevada mobilidade inspiraram, também, o aparecimento de novas teorias, como a "teoria do trânsito", com a sua proposição de uma "cultura de trânsito" (Gregory, 1994). Na atualidade, cerca de 100.000.000 de pessoas vivem fora de seu país de nascimento. Essa elevada mobilidade geral tende a enfraquecer o mote do "judeu errante". 
É verdade que entre os milhões de deslocados se encontram refugiados e exilados. Que é possível distinguir entre "cosmopolitas privilegiados", pessoas que possuem a liberdade da mobilidade, com setores definidos por uma hipermobilidade, e pessoas discriminadas, para as quais são levantadas barreiras a suas necessidades de locomoção (Mitchell, 2000). Este, porém, tornou-se um dos mais importantes temas do debate político do presente. Por outro lado, é de se notar que essas discriminações referemse menos a judeus. $\mathrm{O}$ fato é que o mundo de diásporas se encontra em crescimento, fazendo diminuir o sentimento judeu de unicidade e exílio.

Todos esses desenvolvimentos conduzem à visão contemporânea de um mundo de "unidade na diversidade". Esta visão se opõe, até certo ponto, à ideia modernista da homogeneidade, mas mantém as proposições da equidade. Para o filósofo checo Martin Matustik, a bandeira da Internacional foi demasiado abstrata, e acabou sendo utilizada por objetivos hegemônicos. Que o pluriculturalismo pode representar uma possível transição ao ideal internacionalista. Ele relaciona esse movimento à mobilidade geográfica contemporânea.

Este movimento de mobilidade e de criação de crises de identidade alimenta questões ideológicas e éticas, que cobrem temas de moralidade, autorrealização, autodeterminação, e de suas relações com questões de tradições e revolução (Matustik, 1993).

Todos estes desenvolvimentos contemporâneos não ocorrem de forma uniforme no Mundo.

São mais presentes nas chamadas "sociedades abertas", do Centro. No entanto, mesmo nestas, existem contracorrentes e confrontações. As reações incluem os fundamentalismos clericais. De qualquer forma, neste mundo da globalização, no qual certas instâncias estatais estão sendo enfraquecidas, enquanto outras são reforçadas; no qual a cultura vai ocupando espaços crescentes, a Filosofia e a História tornando-se interesse de públicos crescentes, está se criando um quadro no qual a questão da identidade judaica está sendo reconstruída.

A assimilação completa pode ser reduzida quando as pessoas passam a se preocupar mais com a História, quando passam a compreender que não há essa pessoa com uma, única, identidade. As pessoas passaram a se abrir mais às propostas da preservação, que integram os movimentos ambientalistas e podem transferir os ideais da biodiversidade para os da preservação das culturas.

É deste modo que os casamentos mistos se tornam, com mais frequência, avenidas de duas mãos, as famílias comemorando as festividades do Natal e mantendo a cerimônia do Pessach. Quando a proposição cabalística de substituir a pergunta "quem eu sou?", pela de "qual eu sou?" vem sendo relembrada, o sentimento de exílio pode declinar, substituído pelo sentimento de ser, simultaneamente, cidadão de seu país de nascimento, e suporte de uma diáspora judaica e do Estado de Israel.

\section{Referências bibliográficas}

BRAUDEl, F. 1972, The Mediterranean and the Mediterranean World in the Age of Philip II, Harper and Row.

GASTEIS, Stephen, e MILLER, Mark, J., 1998, The Age of Migration, New York, London, Guilford Press.

CESARI, Jocelyne, 2001, A expansão do islamismo no Mundo, Le Monde Diplomatique, abril.

COULANGES, Fustel de, 2001, A Cidade Antiga, São Paulo, Editora Claret.

DELEUZE, Gilles, 1998, A Lógica do Sentido, 4ª edição, São Paulo, Editora Perspectiva S. A.

EZRAHI, Sidra de Koven, 2000, Booking Passage, Berkeley, Los Angeles, London, University of California Press.

GEIGER, Pedro P, 1995, América, América, Geografia e Meio Ambiente no Brasil: 21-45, São Paulo, HUCITEC.

GREGORY, Derek, 1994, Geographical Imaginations, Oxford, Blackwell.

HOBSBAWM, Eric, 2001, O Novo Século, São Paulo, Cia. das Letras.

KOTKIN, Joel, 1992, Tribes, New York, Random House.

MARGOLIS, Maxine, N, 1994, Little Brazil, Imigrantes brasileiros em Nova Iorque, Campinas, Papirus. 
MATUSTIK, Martin, 1993, Postnational Identity, Critical Theory and Existential Philosophy in Habermas, Kierkegaard and Ravel, New York, London, Guilford Press.

MENDES, José Sacchetta Ramos, 2002, Subsídio para a demografia judaica do Estado de São Paulo no século XX, inédito.

MITCHELL, Don, 2000, Cultural Geography, A Critical Introduction, Oxford, Blackwell.

PHILO, Chris, 1994, History, Geography and the Still Greater Mystery of Historical Geography, Human Geography, Society, Space and Social Science: 252-282, Derek Gregory, Ron Martin and Graham Smith, editors, Minneapolis, University of Minnesota Press.

PIVETEAU, Jean Luc, 1993, La Territorialité des Hebreux, L'affaire d'un petit peuple il y a longtemps ou un cas d'école pour le III millénaire? L'Espace Géographique, XXII (1): 26-34.

1995, Le Territoire, est-il un lieu de mémoire ? L’Espace Géographique, XXIV (2):113-123.

SCOTT, Allen J., 1989, Regions and the World Economy, the Coming Shape of Global Production, Competition and Political Order, Oxford, Oxford University Press.

SHESKIN, Ira M., 2001, The Size and Spatial Distribution of American Jewish Communities, 97' Annual Meeting, The Association of the American Geographers, New York, NY.

SORJ, Bernardo e GRIN, Mônica, 1993, Judaísmo e Modernidade, Metamorfoses na Tradição Messiânica, Rio de Janeiro, Imago.

VIDAL e SOUZA, Candice, 1997, A pátria geográfica, sertão e litoral no pensamento social brasileiro, Goiânia, Universidade Federal de Goiás.

\section{Identidade em conflito: \\ o segredo do padre Sanctos Saraiva (1834-1900), um "judaizante" na corte de D. Pedro II}

Paulo Valadares

Padre Sanctos Saraiva foi uma celebridade no Brasil nas últimas décadas do séc. XIX, pois era uma "figura singular de erudito, sacerdote (ou ex-sacerdote), filólogo, cientista, professor, poeta, polemista, tradutor e exegeta", como enumerou suas atividades o jesuíta Arthur Rabuske, um de seus biógrafos ${ }^{2}$. Sua singularidade estava não apenas no enorme leque de interesses que ele pesquisava, mas também em sua própria figura misteriosa, de quem se dizia ser filho de um rabino sírio, ter vivido em locais e situações tão diferentes. Conviveu com orientalistas em Londres, discutiu hebraico com D. Pedro II, colheu plantas e minerais na Serra da Cantareira. Pregou para bispos e viveu como rústico agricultor no interior de Santa Catarina. Hoje ele é uma figura quase ignorada no ambiente intelectual brasileiro. Nosso interesse é recuperar este personagem para a história cultural brasileira e devolver aos cristãos-novos portugueses um de seus vultos mais interessantes.

\section{Quem foi Sanctos Saraiva}

Francisco Rodrigues dos Sanctos Saraiva nasceu em Vila Seca de Armamar, na região de Lamêgo, em 22 de fevereiro de 1834, filho do "rabbino hespanhol da Syria" António dos Sanctos Saraiva e Anna Rita Rolla. Esta é a informação consagrada que com o passar dos anos e desídia dos pesquisadores tornou-se a verdade oficial. Estranhando o caso de judeu sefardita retornar a Portugal, os magrebinos são exceção, e ignorando a existência de uma família Saraiva no Império Otomano, fomos à pesquisa e

\footnotetext{
${ }^{1}$ Mestrando em História Social / USP.

${ }^{2}$ Francisco Rodrigues dos Santos Saraiva: Algo de sua vida e obra, máxime no Rio Grande do Sul e em Santa Catarina, em Revista do Instituto Histórico e Geográfico de Santa Catarina, $3^{a}$ fase, $n^{\circ} 5,1984$, pp. 119-157. Agradeço a Sra. Arma Lopes Vieira, de Imaruí, e ao Dr. Mário Gentil Costa, Florianópolis, a cessão de grande parte da bibliografia sobre o nosso personagem
} 
encontramos, graças a ajuda de Maria das Dores Almeida Henriques e Maria Dulcinéia B. Cabral de Sena, a sua certidão de batismo no Arquivo Distrital de Viseu.

A certidão de batismo é o principal documento individual do mundo ibérico até a proclamação das repúblicas. Com a união da Igreja e Estado, o batismo católico é a porta para o ingresso na cidadania plena. Para o genealogista ele é importante, pois traz a data e o local do nascimento, os nomes dos pais e avós, também os padrinhos, identificando suficientemente o personagem.

No caso de Sanctos Saraiva, confirmou-se parcialmente o seu aniversário, apenas o ano é diferente, ele nasceu em 1831. O dados genealógicos são descritos pelo documento: "filho de António dos Santos, Mesão Frio, Mondim (outro nome é ilegível) e Ana Rita. Neto paterno de Joaquim dos Santos, Jeronima de S. José da freguesia de Mondim e materno de José Rodrigues Saraiva e Anna Cardoza desta freguesia ${ }^{3}$. O que se percebe nesta documentação é que Sanctos Saraiva é filho e neto de portugueses. Nada nos autoriza a tomar como legítima a versão do "rabbino syrio", pois nos parece a criação deste ancestral mítico apenas uma forma de desvencilhar-se do passado católico ou legitimar- se como hebraísta.

A família Saraiva tem origem em Trancoso, difundindo-se por migração de seus membros por toda a região, sendo muitas vezes reconhecidos como cristãos-novos ${ }^{4}$. O mais importante destes ramos é a família Saraiva, inicialmente de Mesão Frio, depois estabelecida em Barcelos, começada por dois irmãos cristãos-novos, que se casaram com filhos de Mestre Thomaz da Victória, "Rabino que lhe ensinava a sua seita" e que são troncos de uma farta descendência com este apelido Saraiva ou Cardoso, espalhada pelo nordeste de Portugal" ${ }^{5}$. A lista dos "99 chefes de

\footnotetext{
${ }^{3}$ Arquivo Distrital de Viseu, fl. 30/30, v., maço 17, ${ }^{\circ}$ 1, freguesia de Armamar (1831).

${ }^{4}$ João Nunes Saraiva, nascido em Trancoso, foi banqueiro de Felipe IV. Denunciado como judaizante participou de dois autos-de-fé. V. "El Proceso Inquisitorial de Juan Nútiez Saravia, banquero de Felipe IV", de Antonio Dominguez Ortiz, Hispania (Tomo XV, n ${ }^{\circ}$ LXI, Madrid, pp. 559-581).

${ }^{5}$ Luis de Eivar Guerra, "Lista dos judeus q[ue] se baptizaram em Barcellos e das gerações q[ue] deltas procedem" (Armas e Troféus, II Série, Tomo 1, 1960, Lisboa). No titulo "Da Casa do il4lestde Thomaz Rabino" (pp. 286-291) ele reconstruiu seis gerações da família Saraiva. A onomástica é semelhante a da família do Padre Sanctos Saraiva. P.ex., Filipa
}

família" atingidos pelo pogrom de Vila Nova de Fózcoa, composta por António Joaquim Ferreira Pontes, traz entre eles membros desta estirpe ${ }^{6}$. António José Saraiva (1917-1993), autor de "Inquisição e Cristãos-Novos" reconhecia-se como sendo de origem judaica ${ }^{7}$. Creio que o Padre Sanctos Saraiva viesse dessa mesma origem. Não tenho ainda a ligação entre uma e outra linhagens, mas os indícios que tenho apontam nesta direção.

Outra família Saraiva, ou outro ramo da mesma, foi para Amsterdã, onde trocou de nome ${ }^{8}$. O mais famoso deles foi o comerciante Duarte Saraiva (1570-1650), nascido em Amarante, que na comunidade holandesa era conhecido como David Senior Coronel - a ele foi dedicado o livro "Conciliador" do rabino Manasseh ben Israel'. David Senior Coronel era um homem muito rico e viveu também no Recife Holandês. Flávio Mendes Carvalho, autor de "Raízes Judaicas no Brasil. O Arquivo Secreto da Inquisição", afirmava que a família cearense Saraiva Leão, da qual fazia parte, descendia de um irmão do parnas (dirigente comunal) holandês ${ }^{10}$. Porém na Diáspora sefardita este nome não prosperou, sendo encontrado apenas entre os judeus de Hamburgo.

Cardosa, filha de um Saraiva, casou-se com Francisco Rodrigues e tiveram filhos, netos e bisnetos com o sobrenome Saraiva (séc. XVI e XVII).

${ }^{6} \mathrm{O}$ pogrom de Vila Nova de Fozcoa atingiu os cristãos-novos desta cidade e foi descrito por um dos autores que registrou o fato assim: "Escorraçando as que não tinham sido varejadas pelas balas, como a do barão de Vila Nova de Fozcoa, as dos Campos Henriques, dos Lopes Cardoso, dos Cavalheiros, dos Campos, dos Almeidas, dos Navarros, dos Margaridas, dos Saraivas. dos Tavares. O êxodo é em massa, tal qual nos tempos de Israel sob a lança dos filisteus. Das noventa e nove famílias foragidas, no terror do ferro e do fogo, umas acolhemse aos concelhos de Além Douro, outras poisam mais longe, no Porto e em Lisboa". Cf. Sousa Costa, "Páginas de Sangue. Brandões. Marçais \& Co." (1919), p. 200. Veja também, J. Silvério de Campos Henriques de Andrade, "A quadrilha dos Marçais , p. 265.

${ }^{7}$ Carlos Câmara Leme, "Eu sou Israelita", em Jornal Público/Fim de Semana (Lisboa, 0102-1991)

${ }^{8}$ Nos registros de casamentos da comunidade holandesa há um só Saraiva constando daquele rol. É Mozes Isaac Saraiva, que se casou com Rachel David Jessurun, em 20 de Siwan de 5449. V. "Handleiding bij de index op de Ketuboth van de Portagee-lsraelietische Gemeente te Amsterdam van 1650-1911", organizado por D. Verdoomer e H.J.W. Snel.

${ }^{9}$ O livro era dedicado aos "Nobilissimos, y magnificos seãores, ...David Senior Coronel; ...Doctor Abraham de Mercado,....Jahacob Mvcate;..Ishac Castanho; Y mas Señores de nuestra nascion, habitantes en el Recife de Phernambuco" (1651).

${ }^{10}$ Flávio Mendes Carvalho (1954-1996) foi neto materno de Osmundo Saraiva Leão. V. Obituário, em Gerações/Brasil, novembro/96 e abril /97, vol.3, 1 e 2, pp. 13-4. 


\section{Ashaveros}

Usando a imagem literária de Ashaveros, pode-se afirmar que Sanctos Saraiva foi também uma espécie de "judeu errante", ele viveu em dois continentes, quatro países e em muitas cidades. Nascido em Vila Seca de Armamar, morou em Lamego, estudou na Universidade de Coimbra, onde teria cumprido um doutorado em "Teologia e Direito", ao que parece em 1850. Sua formatura teria coincidido com a revolta da "patuleia", quando então ele expatriou-se para Londres, onde se especializou nas áreas que lhe dariam notoriedade. "D'essa convivência com o mundo scientífico londrino, onde pontificavam sábios orientalistas hebreus, surgiu a multiforme cultura d'esse homem, que estava fadado a maravilhar os seus contemporâneos com o seu saber" ${ }^{\prime 1}$. De Londres, ele foi a Roma, e usando os contatos que fizera na Inglaterra, recebeu a direção de uma paróquia no Brasil.

Em 1860, por falar inglês, é nomeado capelão da "Companhia de Mineração Morro Velho" em Minas Gerais. Ele ficou pouco tempo na região, pois assustado com a intolerância do clero mineiro, mudou-se para o Rio Grande do Sul, onde assumiu em 23 de junho de 1862 como "vigário encomendado" da Paróquia de S. Francisco de Paula de Cima da Serra, apesar de caráter inamovível do seu cargo, cinco meses depois já estava na Paróquia de S. Sepé.

Nos pampas ele vive várias aventuras: "viajava elle de S. Gabriel para S. Sepé, quando, no penetrar em uma casa de negócio, á beira da estrada, afim de comprar alguma coisa, appareceu um individuo de má catadura, que, de um modo brutal, atirou uma moeda sobre o balcão, dizendo ao dono. - Dême dois vintens de cachaça! Sendo-lhe offerecida a bebida o padre Saraiva recusou e agradeceu. O gaúcho insistiu, e ainda nova recusa. Não notára aquelle que o dono do negócio lhe piscava o olho para que aceitasse. $\mathrm{O}$ tal homem voltou á carga: - Pois há de beber, por bem ou por mal! Sem perder a presença de espírito, o padre Saraiva sacou de uma pistola, e encostou o cano ao peito do valentão, dizendo- lhe: Monte a cavallo, e já ! E desappareça

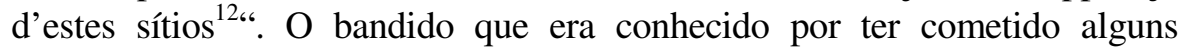
homicídios fugiu frente à firmeza do barbudo misterioso.

\footnotetext{
${ }^{11}$ Eliezer dos Sanctos Saraiva, “O Sabia das Picadas” (1939), p. 15.

${ }^{12}$ Eliézer dos Sanctos Saraiva, Op. cit., p. 17.
}

Em 1865 ele retornou a Portugal onde permaneceu por cinco anos; ao que tudo indica, passou este tempo estudando nas bibliotecas locais. Nessa época mantém relações com o historiador Alexandre Herculano, autor de "História da Origem e Estabelecimento da Inquisição em Portugal". Voltou ao Brasil em 1870 para o Rio de Janeiro, onde mantém contatos com o Imperador. É nomeado reitor do Colégio Dom Pedro d'Alcântara, em Botafogo, com trezentos alunos. Em 1875 vai para o interior de Santa Catarina, onde adquire uma propriedade rural e labuta incógnito até 1891. É o lugar onde viveu por mais tempo. Dali vai a Pelotas, no Rio Grande do Sul, onde lecionou em dois colégios "Ateneu Pelotense" e "Colégio Evolução". Em 20 de maio de 1892 chegou a S. Paulo, onde a convite de G.W. Chamberlain, lecionou na "Escola Americana" e no "Mackenzie College".

\section{Na corte de D. Pedro II}

No período em que Sanctos Saraiva viveu o seu apogeu criativo, o Brasil tinha como chefe de Estado, D. Pedro II, que mantinha no Rio de Janeiro a Corte política, ao mesmo tempo em que estimulava um ambiente intelectual. D. Pedro d'Alcântara, como ele preferia ser chamado durante os trabalhos eruditos, era o que se podia chamar de "orientalista". Ele falava, lia e escrevia em hebraico. Frequentou sinagogas na América e na Europa, numa delas chegou a fazer aliá, lendo a Torá na Sinagoga Central de Londres, em Upper Street, convidado pelo rabino Barnett-Myers. Participou do "III Congresso de Orientalistas de S. Petersburgo" (1876), onde discutiu as inscrições do rei moabita Méscha, os Samaritanos e a primitiva toponímia do Eretz Israel. Terminou por fazer uma peregrinação a Terra Santa, visitando a Jerusalém, Belém, "onde colhi umas florzinhas em memória de Rute ${ }^{13}$ ". Havia mesmo um filossemitismo latente na Corte que culminou com o engenheiro André Rebouças propondo a criação de um Estado Judeu na região de Palmas, no Paraná, em 1889.

Segundo o próprio D. Pedro d'Alcântara, ele começou aprender hebraico com o "judeu sueco" Leonhard Akerblom ${ }^{14}$, Cônsul dos Países

${ }^{13} \mathrm{O}$ diário imperial desta viagem foi publicado por Reuven Faingold sob o título "D. Pedro II na Terra Santa. Diário de Viagem - 1876" (1999).

${ }^{14}$ Leonhard Akerblom (Solleftea, 1830- 1896), filho de Carl Magnus e Catharina Margareta (Eneroth) Akerblom, era Doutor em Filosofia pela Universidade de Uppsala. Ele começou a carreira diplomática representando os países nórdicos no Brasil e terminou sua carreira como 
Nórdicos no Brasil, que foi sucedido nesta função por professores exclusivos, um deles, o alemão C. F. Seybold, acompanhou até o último dia de vida do monarca brasileiro. Assim, com professores particulares ele foi aprendendo a seu hebraico, até que um dia resolveu fazer uma avaliação do progresso destes estudos, já conhecendo a fama do Padre Sanctos Saraiva, convidou-o ao Paço de S. Cristóvão, onde o recebeu em audiência privada. Quem conta é Eliézer dos Sanctos Saraiva, filho do erudito.

Depois de se ter excusado receber a quem quer que fosse, D. Pedro, mandando que o introduzissem no seu gabinete de estudo, disse-lhe:

- Agora o sr. é o padre Saraiva e eu D. Pedro: nada de formalidades, vamos conversar, e diga-me com franqueza, o que pensa de meus estudos.

Durante cerca de duas horas estiveram ambos em amistosa palestra, que versou sobre questões philologicas, sobre o hebraico de que o monarcha era apaixonado cultor e sobre os meios de interpretar os textos mais complicados das linguas orientaes.

Depois d'este encontro, o imperador, por varias vezes em conversa com seus intimos, enalteceu os meritos invulgares do padre Saraiva, dizendo que nunca se lhe tinha deparado vulto mais extraordinario e eminente, sem exceptuar os mais celebres sábios da Europa ${ }^{15}$.

As entrevistas se sucederam entre o monarca e o sacerdote. Sempre tendo como mote o estudo do hebraico. Saraiva escreveu inclusive uma monografia, defendendo o idioma bíblico: "Acerca da necessidade e utilidade das línguas bíblicas no Império do Brasil, como poderoso auxiliar das ciências eclesiásticas e da filologia". A amizade sincera entre ambos ultrapassou o campo político. Tanto que após um atentado contra a vida do Imperador, o republicano Saraiva manifestou-se contra o atentado, e, quando da Guerra do Paraguai, o pacifista Saraiva compôs um poema em

"generalkonsul" da Suécia em Lubeck. Akerblom foi casado com a brasileira Louise Marie Josephine Meyrad, com quem teve uma filha, Marie Louise (1869), que se casaria com o médico Hans Naegli, de Genebra. Marte Louise Ingeborg Naegli, nascida em 1894, foi a última descendente de Akerblom. V. Axel Paulin, "Svenska Oden o Sydamerica", pp. 1503. Nele há uma fotografia de Akerblom e afirma que ele mio era judeu. Agradeço a Nair Pacheco e Maillie Fjalgren, da representação diplomática sueca pelo auxilio bibliográfico; a Ian Hamilton (Genealogiska Fureningen, Estocolmo), a Ulf Goranson e Hakan Hallberg (Uppsala Universietsbibliotek), por outras informações e contatos.

${ }^{15}$ Eliézer dos Sanctos Saraiva, Op. cit., p. 20-1. hebraico para celebrar o Imperador. Este poema, ainda inédito, foi descoberto por Reuven Faingold quando selecionava material para um exposição sobre as relações do monarca brasileiro com os judeus, e chamase "Lashilton shel Brasil - Petrus Beit: Shira Leiom Hazikaron kol Umah begvul Hamilchama al Paraguai" (Ao Governo do Brasil - Pedro II: Poema para o Dia da Recordação de toda a Nação na Guerra do Paraguai) ${ }^{16}$.

Nesta passagem pelo Rio de Janeiro ele pesquisou e escreveu o principal trabalho de sua bibliografia, que é o "Novíssimo Dicionário LatinoPortuguez, etymológico, psosodico, historico, geographico, mythologico, biographyco, etc. redigido segundo o plano de L. Quicherat ... Rio de Janeiro - BML. Garnier". Ele não está datado, mas acredita- se que foi impresso em Havre em 1881. Considerado pelos especialistas como o melhor escrito sobre o assunto. No final de sua vida ele redigia um "Dicionário Etymologico da Lingua Portuguesa", no qual só chegou à letra "A".

\section{O segredo}

O ex-padre Sanctos Saraiva foi produto do meio cristão-novo. Muito religioso, ligado ao Transcendente não pode efetivamente ser um "sacerdote", pois a sua crença não era a crença de sua religião. Não lhe adiantou a formação sacerdotal católica, pois ele não se convenceu desta crença. Por volta de 1875, ele abandonou definitivamente o sacerdócio e o catolicismo. Não se filiou a nenhuma igreja protestante, porém manteve com os presbiterianos boas relações intelectuais, e o seu filho único, recebeu um nome vetero-testamentário, Eliézer, cuja escolha reflete a sua trajetória peculiar. Já que o primeiro Eliézer, originario de Damasco (talvez uma projeção do mito do "rabbino syrio"), abandonou a idolatria, para reconhecer a verdade monoteísta, tornando-se homem de confiança do patriarca Abraão ${ }^{17}$.

Sua despedida do sacerdócio foi registrada num manifesto de título agressivo, "O Catholicismo Romano ou a Velha e fatal Ilusão da Sociedade", rio qual formulou suas ideias religiosas, escrito em 1888 e

\footnotetext{
${ }^{16}$ Luzes do Império. D. Pedro II e o Mundo Judaico" (S. Paulo, 1999), Prof. Reuven Faingold (Curador), p. 17

${ }^{17}$ ("Ele é socorro", Bereishit, 15:2), outros nove personagens bíblicos receberam o mesmo nome, inclusive um filho de Moisés e um profeta.
} 
republicado em $1932^{18}$. Esse livro foi reeditado como uma reação à "campanha obscurantista, que mira jungir definitivamente o Brasil ao solio papal", conforme a prosa arrevesada de Mattathias Gomes dos Santos, vicepresidente da Colligação Nacional Pro-Estado Leigo, assustado com a aproximação entre o Estado Novo e a Igreja Católica. Uma reação que culminou na lei apresentada pelo deputado Jorge Amado, descendente de cristãos-novos sergipanos, reconhecendo a liberdade de cultos religiosos, no final da década de quarenta.

Sanctos Saraiva deixou escritos que não foram publicados e outros que se perderam no anonimato de publicações obscuras do interior do país. Mesmo assim é possível encontrar em sua bibliografia alguns títulos que remetem a sua condição de "judaizante". São poemas que estão na periferia do judaísmo, mas que fazem parte desta herança cultural. São eles; "Cântico de Moysés" (1863), "Poema sobre a Terra Santa" (1864) e principalmente "Harpa d'Israel" (1898), uma tradução tirada diretamente do hebraico e comparada com a versão de Antonio Pereira de Figueiredo. A estes se deve acrescentar uma tradução que ele fez do "Livro de Hhanokh"19, cuja autoria é atribuída ao rabino Aharon HaLevy.

\section{Final}

Francisco Rodrigues dos Sanctos Saraiva morreu no Hospital Samaritano em S. Paulo, em 3 de junho de 1900. Mas o seu corpo foi levado para Santa Catarina, onde foi sepultado ao lado de sua companheira Ana Felícia, mãe do seu filho Eliézer ${ }^{20}$. Deste modo, quase sorrateiro, terminou a vida desta figura tão peculiar. Mesmo assim é possível encontrar na sua trajetória alguns traços comuns a tantas biografias de cristãos-novos

\footnotetext{
${ }^{18}$ Há um exemplar na Biblioteca Mário de Andrade (S. Paulo) e que trás um carimbo curioso: "Livraria do Globo. L. Marrano (...)"

${ }^{19}$ Jornal do Comércio, Desterro, dezembro de 1888

${ }^{20}$ Eliézer dos Sanctos Saraiva nasceu em Picadas do Norte, S. José, 13 de novembro de 1879 e morreu em S. Paulo, em 19 de junho de 1944. Formado engenheiro, trabalhou no Observatório Astronômico de S. Paulo e lecionou idiomas no Mackenzie College. Dirigiu uma escola chamada "Instituto Sanctos Saraiva", onde Oswaldo Aranha e Marcondes Filho foram seus alunos. Autor de "O sábio das Picadas", uma biografia paterna. Pertenceu ao Instituto Histórico e Geográfico de Santa Catarina. Casado com Lígia "dos Sanctos Saraiva”, não teve filhos. Agradeço a Adonias Costa da Silveira (Instituto Presbiteriano Mackenzie, 08-07-1997) pela ajuda em compor a biografia deste personagem.
}

anônimos. Que sem acreditar nos dogmas católicos, inconformados com a hegemonia da Igreja, mas sem acesso ao Judaísmo, procuraram outras saídas religiosas, atraídos pelo Protestantismo histórico, ao qual levaram suas convicções, dando a este, um caráter filossemita. Outros, como o Padre Sanctos Saraiva, foram educados como católicos e flertaram com o Protestantismo, enfim não foram judeus, nem cristãos integrais, apenas cristãos-novos ou juif en potentiel, como na classificação de I. S. Revah, ou o "homem dividido" de Anita Novinsky. 


\section{Identidade judaica na família do poeta marrano Antônio Serrão de Castro}

\section{Benair A. Fernandes Ribeiro ${ }^{1}$}

A s condições especialíssimas criadas em Portugal após o decreto de expulsão dos judeus, seguido pela conversão forçada (expulsão dezembro de 1496 conversão - março de 1497) geraram situações contraditórias para as famílias judaicas, mesmo para aquelas que tinham condições de sair de Portugal em busca de terras onde pudessem dar continuidade à vida, dentro de suas crenças e tradições. Muitas famílias em fuga vagaram de terra em terra, geralmente escondendo suas origens, suas crenças, solidárias às vezes, divididas pelas denúncias em outras, pelo sofrimento em caminhos de desencontros. Magnífico exemplo dessa saga dos judeus de Portugal no século XVI é a história de Beatriz de la Luna, a esposa do banqueiro Francisco Mendes, que forçado pela ameaça da conversão preferiu sair de Portugal com toda família indo para a Inglaterra, onde morreu. Após sua morte, a viúva toma as rédeas dos negócios da família e dá início a uma vida errante, sempre fugindo das perseguições e acabando por construir uma rede internacional de solidariedade e proteção a seus compatriotas que fugiam da ação da Inquisição, culminando por se tornar uma figura feminina ímpar, dirigindo um complexo financeiro extraordinário a partir de Constantinopla, cidade onde mais tempo permaneceu ${ }^{2}$.

A característica básica da comunidade judaica nos finais do século XV de coesão e solidariedade comunal foi cingida com a conversão forçada e o início da perseguição sistemática àqueles que, mesmo tendo condições de saírem de Portugal, por inúmeras razões não o fizeram.

Após a criação do fenômeno cristão-novo - ou seja, os judeus que não quiseram ou não puderam sair de Portugal, transformados à força em cristãos eles dispersaram-se em pequenas comunidades: Bragança, Chaves, Vinhais,

\footnotetext{
${ }^{1}$ Doutoranda em História / USP

${ }^{2}$ Sugestão de leitura para o conhecimento dessa vida errante a que os judeus foram obrigados, o encantador romance histórico de Catherine Clément "A Senhora-Gracia Nasi e a saga dos judeus no século XVI" publicado pela Editora 34 em 1ª edição de 2001.
}

Moncorvo, Mogadouro, Miranda do Douro, Vila-Flor, e muitas outras, além de uma grande concentração em Lisboa. Nesses locais os cristãos-novos criaram e desenvolveram um sistema de autodefesa para sobrevivência, o que gerou uma forma de vida e uma visão de mundo sui generis. Eram cristãosnovos, guardando nos primeiros tempos ainda uma identidade judaica centrada na Lei Velha, que lhes dava força para a resistência, mais ou menos passiva, mais ou menos discreta, sempre baseada nos valores éticos e religiosos do judaísmo de preservar a vida, acima de tudo.

Acontece, e este é o ponto crucial da questão da identidade errante, que na verdade já não eram mais judeus, mas também não eram cristãos eram cristãos-novos! Lina Gorenstein expôs o que seja esta questão e as múltiplas facetas que ela apresenta ${ }^{3}$.

Diante deste quadro complexo do que pode ser "identidade judaica" e como ela se manifesta em Portugal, percebemos que subjaz na sociedade portuguesa o elemento judeu que, convertido à força ao cristianismo, num primeiro momento se mantém fiel aos seus valores religiosos, sua ética, sua tradição - a solidariedade comunal, por exemplo, e o faz de maneira subreptícia - em segredo, "portas adentro" - é o cripto-judaísmo.

Frente à violência das perseguições muitos se convertem sinceramente ao cristianismo e tentam se integrar à comunidade cristã, o que também é problemático, porque desde a conversão forçada até o tempo de Pombal - são conhecidos, identificados e abertamente nomeados pela população e pelas autoridades instituídas como "cristão-novo" e não como simplesmente "cristão", ou seja, não são verdadeiramente aceitos pela comunidade cristã e o vocábulo "judeu” permanece na memória popular, na documentação oficial, na literatura, etc., aflorando pejorativa e discriminatoriamente em momentos de tensões sociais.

Entre os cristãos-novos - realidade social e cultural que tem sua existência mantida por quase três séculos pelos próprios mecanismos repressores - a Inquisição - que atuavam, segundo sua ótica, para extirpar das terras portuguesas (Reino e Colônias) o que na documentação do Santo Ofício se configurava como a "heresia judaica"; encontramos, na medida em que nos afastamos da data inicial dessa criação sui generis do cristão-

${ }^{3}$ SILVA, Lina Gorenstein Ferreira da, O sangue que lhes corre nas veias, tese de doutorado defendida junto ao departamento de História da Universidade de São Paulo, 1999. 
novo, uma prática cripto-judaica que vai se tornando cada vez mais difusa muito longe do que entendemos por judaísmo mais ortodoxo ou mais próximo das antigas tradições do povo judaico.

Entretanto os cristãos-novos, por questões de sobrevivência, tiveram de viver num mundo cristão e viver exteriormente como cristãos. Era de suma importância a exteriorização desse cristianismo imposto goela abaixo! Com o passar das décadas esse cristianismo se sobrepõe e o que resta é a consciência de uma ascendência judaica - uma memória judaica.

A Inquisição, criada para "salvar" a religião de Cristo das "heresias, verdadeiras ou imaginárias", estava muito mais interessada em manter um mecanismo de denúncias - que permitiria e justificaria sua existência - do que realmente nas práticas religiosas dos cristãos-novos.

A farta documentação existente; os inúmeros processos contra os cristãos-novos estudados pelo nosso grupo de pesquisa sob a orientação de Anita Novinsky, nos leva a crer que, embora no aspecto formal o processo Inquisitorial nos mostre do começo ao fim uma condução processual, para pensarmos que o que estava em jogo era a religião cristã atingida pela prática cripto-judaica dos acusados, nos demonstra o contrário na verdade. Nas entrelinhas dos manuscritos analisados encontramos outras questões subjacentes muito mais importantes. $O$ que realmente incomodava a Inquisição não era a prática cripto-judaica, embora, externamente, seja isto o que sobressai.

Nos processos que estudei e, estou convencida disso, o que mais incomodava os inquisidores era a forma contestadora e crítica expressa durante toda a vida pelo poeta marrano português, chefe da família Serrão de Castro, quer fosse através de seus poemas, quer através dos discursos feitos na Academia dos Singulares - prestigioso centro de literatura e cultura de Lisboa nos finais dos século XVII. Para demonstrar esta minha posição, vejamos:

Antônio Serrão de Castro, cristão-novo, foi um prestigiado poeta da primeira Academia de Letras fundada em Portugal - a Academia dos Singulares. Foi preso após duas denúncias de outros cristãos-novos: a acusação era bastante vaga e correspondia exatamente, em todos os detalhes, com as instruções para o reconhecimento de práticas de judaizantes contidas nos Monitórios, que eram pregadas na Igrejas: não comer carne de porco, guardar os sábados de trabalho, fazer jejuns em determinados dias da semana, etc.

\section{Analisando as acusações vemos o seguinte:}

$1^{\text {a }}$ testemunha: Fernão Perez Coronel - cristão-novo, antigo companheiro do poeta na Academia dos Singulares, só o denunciou depois de estar preso por 5 anos e sob tortura, quando o preso denunciava todo mundo: pai, mãe, irmãos, amigos, vizinhos, na esperança de salvar sua vida.

$2^{\text {a }}$ testemunha: Jorge Ribeiro (outro cristão-novo) o acusa de judaizante imediatamente após a prisão. Era a aplicação do mecanismo de defesa dos cristãos-novos criado ao longo de quase dois séculos de existência da Inquisição: melhor confessar logo e denunciar o maior número de pessoas possíveis para livrar-se da perseguição e da morte certa se assim não o fizesse.

O processo demonstra claramente que essa testemunha foi movida por inveja e rancor. Divergências que existiam entre a testemunha e o acusado por este lhe ter dedicado uns versos satíricos, desmoralizando-o em virtude de questões profissionais ${ }^{4}$. A querela nada tinha a ver com questões ou práticas religiosas.

Há no processo mais 13 testemunhas de acusação: vários vizinhos com os quais também se havia desentendido, todos os seus parentes mais próximos, que foram presos logo depois do poeta. Pelos depoimentos desses vizinhos, mais clara ainda fica a singularidade das supostas práticas judaicas. Uma das testemunhas declara que era, assim como toda sua família, praticante do judaísmo, mas não sabia quando deveria fazer o Jejum do Dia Grande (Yom Kipur) e outros jejuns, conforme determinava a Lei de Moisés e por esta razão havia recorrido aos conselhos de Antônio Serrão de Castro que, por sua vez, também não o sabia ${ }^{5}$. Parece-nos bastante estranho que pessoas praticantes de judaísmo não soubessem com

${ }^{4}$ Instituto dos Arquivos Nacionais/Torre do Tombo - IAN/TT - Lisboa; Inquisição de Lisboa, Proc. n. ${ }^{\circ} 4910$ fls.(148/1491). Jorge Ribeiro, Pedro Ribeiro e Luiz Álvares, todos da mesma família, eram intermediários de companhias teatrais espanholas contratadas para se exibirem no Pátio das Comédias em Lisboa. Por terem recebido críticas de Antônio Serrão de Castro em relação à qualidade das apresentações teatrais, se tornaram inimigos o que foi suficiente para que denunciassem por vingança o poeta ao Santo Ofício como judaizante. ${ }^{5}$ IAN/TT - Inquisição de Lisboa, Proc. n. ${ }^{\circ} 9797$. 
clareza a época certa de se fazer os jejuns, em especial o denominado na documentação como o "do Dia Grande".

Entre os depoimentos dos membros da família Serrão de Castro a questão se complica ainda mais. Era importante para os inquisidores provarem a prática judaica através da obtenção de confissão de alguns pontos considerados fundamentais:

- $\quad$ prática de jejuns, em especial o do Yom Kipur e o da Rainha Ester;

- guardar os sábados de trabalho, respeitando o sabath;

- crença na Lei de Moisés para a salvação da alma;

- recusa de certos alimentos como: porco, lebre, peixe sem escamas;

- forma de fazer as orações.

A família de Antônio Serrão de Castro (três filhos, três irmãs, dois sobrinhos e uma prima) foi presa logo depois do poeta e permanecendo nos cárceres da Inquisição por quase 10 anos. A família tem comportamentos bastante contraditórios em relação ao cripto-judaísmo. Todos resistem ao longo período de sofrimento, submetidos a longos interrogatórios, sem confessar nada 6 . Nenhum tenta esconder sua origem ou argumentar sua "pureza de sangue". Viviam todos num mesmo bairro de grande concentração de cristãos-novos, a maioria dos quais se dedicava ao comércio ou a atividades liberais. Os 10 integrantes da família Sertão de Castro, exteriormente, demonstravam à exaustão levarem uma vida pia e cristã. Em suas casas foram encontrados pelos esbirros do Santo Ofício objetos de culto cristão como oratórios, crucifixos, imagens de santos, etc., mas nenhum objeto ou indício de prática judaica.

${ }^{6}$ Esses interrogatórios, surpreendentemente, acontecem num período em que o Tribunal do Santo Ofício em Portugal estava com seus poderes oficialmente suspensos por uma Bula do Papa Clemente X de Outubro de 1674, documento pelo qual o Papa proibia a realização de autos-de-fé, ordenava a libertação dos presos que ainda não tivessem sentenças e a cessação de qualquer outra atividade processual. Ver: RIBEIRO, Benair A E, Um Morgado de Misérias - Subsídios para o Auto de um Poeta Marrano, Dissertação de Mestrado apresentada ao Departamento de História da Universidade de São Paulo, Maio 2001 pp.104/114.
Nos depoimentos, durante os longos anos de cárcere, a resistência à assunção de culpa e à confissão de práticas judaicas são realmente impressionantes. A confissão só surge mediante tortura e depois de 10 anos nos cárceres, com uma única exceção - a prima do poeta, Caterina de Castro, confessa em 1676, mas nem por isso foi solta, permanecendo junto com os demais até 1682 quando receberam suas sentenças e foram expostos e penitenciados em auto-de-fé público em Lisboa.

Pela forma como era conduzido o interrogatório, percebemos que os inquisidores mais se preocupavam com o maior número de denúncias que podiam obter do que com a religiosidade dos cristãos-novos. As denúncias faziam a máquina inquisitorial girar e conservavam a estrutura intrincada do Tribunal, justificando sua existência e permitindo sua permanência.

É muito difícil e precipitado se afirmar que todos os acusados eram realmente praticantes de judaísmo. Diante da perseguição àqueles que, apenas por serem descendentes de judeus, eram a priori considerados hereges pela mácula da impureza do sangue, havia os que realmente praticavam o cripto-judaísmo, os que eram simplesmente cristãos-novos praticando o cristianismo, alguns dele convencidos piamente, outros nem tanto, duvidando e ocasionalmente expondo essas dúvidas, o que os levava certeiramente para os cárceres, pois os "olhos e ouvidos" da Inquisição se espalhavam por todas as partes através do grandioso número de funcionários delatores - "os familiares".

Os que eram possivelmente cripto-judeus mesclavam em suas crenças alguns elementos da crença judaica, resíduos fragmentados da religiosidade dos judeus ibéricos com elementos da religião cristã que eram obrigar a externar publicamente. Viver entre dois credos cinge a personalidade. Segundo Gitlitz $^{7}$ não era um judaísmo nem ortodoxo nem profundo. Não havia livros judaicos (apenas uma pequena minoria pôde esconder os livros) para estudar e instruir os filhos, somente havia uma transmissão oral que com o passar dos anos cada vez mais se distanciava da verdadeira religiosidade judaica. Embora o mesmo autor afirme que todos os cristãos-novos eram cripto-judeus, não concordamos com isso, em razão do que encontramos nas análises dos processados. Por outro lado, se não

${ }^{7}$ GITLITZ, David M. Secrecy and Deceit: The Religion of the Crypto-Jews, Philadelphia and Jerusalem: The Jewish Publication Society, 1996.pp.99 e passim 
eram cripto-judeus, conheciam o cripto-judaísmo e esse conhecimento fazia parte de sua realidade.

Nos processos aparece uma preocupação insistente dos inquisidores com a questão da "salvação da alma na Lei de Moisés" ao que corresponde a automática e apressada resposta dos acusados de que criam e viviam na Lei de Moisés para salvação de suas almas. Tal como aparece nos processos, trata-se de um entendimento de salvação da alma individual, o que não se conecta com a ideia de salvação comunal do preceito judaico mais tradicional. Essa transferência de crença na Lei de Moisés (comunal) para uma salvação da alma(individual) é uma ideia do mundo cristão em que os cristãos-novos foram obrigados a viver. Ainda segundo Gitlitz, a confluência da ideia judaica de virtude através da obediência à Lei e a ideia cristã de salvação através da crença é o mais expressivo sinal do sincretismo religioso da religião dos cripto-judeus.

Entre as irmãs de Antônio Serrão de Castro há uma contradição significativa em seus depoimentos. Enquanto as duas mais velhas, Inês e Francisca, confessam que aprenderam com sua mãe as práticas judaicas, o que é negado pelos outros irmãos, a mais nova, Paula, aparece como transmissora das práticas para o filho, às escondidas do marido cristão-velho. Paula é, talvez, dentro da família a que mais se aproxima das crenças judaicas. Além de confessar que ensinara o filho e isto é confirmado por ele, foi observada por vigias durante os anos de prisão que relataram à Mesa do Santo Ofício a prática de jejuns e formas específicas de fazer as orações que indicariam seu cripto-judaísmo. Mesmo nesse caso, em que as evidências cripto-judaicas são mais fortes, fica a pergunta. Como alguém, cristã-nova, conhecedora da ameaça que pairava sobre sua cabeça, casada com um cristão-velho, vivendo num mundo cristão sob pressão constante, conseguiria transmitir ao filho uma crença que nem ela mesmo sabia direito o que era?

Quanto à crença do próprio poeta Antônio Serrão de Castro, é mais difícil ainda se afirmar qualquer coisa. Nega insistentemente durante todo seu longo processo a prática judaica. Somente depois de 10 anos de cárcere, duas sessões de tortura e o conhecimento de que toda sua família já havia confessado é que ele sucumbe e diz na sua Sessão de Crença que era praticante da Lei de Moisés e que para "contemporizar" com o mundo vivia como cristão. A lucidez, expressa na sessão de crença, sobre sua condição de vida no momento em que tinha a espada de Dâmocles sobre sua cabeça, demonstra o quanto os cristãos-novos tinham conhecimento das fórmulas de práticas judaicas criadas pela própria Inquisição.

O filho do poeta Antônio Serrão de Castro - Pedro Serrão - era um jovem de 20 anos, estudante de Teologia, quando foi preso. Este foi mais além na demonstração de quão frágil é a afirmação de que todos os cristãosnovos eram cripto-judeus e, portanto, hereges merecedores da perseguição atroz que a Inquisição que lhes dedicou, segundo a ótica de alguns historiadores. Esse jovem, ao ser preso, portava consigo um "Livro de Horas de Nossa Senhora" e um outro sobre "Meditações da Paixão de Cristo", um cilício e disciplinas de aço (objetos usados pelos cristãos para autoflagelação e penitências) ${ }^{8}$. Se era necessário aos cripto-judeus disfarçarem suas crenças e expressar publicamente seu cristianismo, penso que a autoflagelação é um exagero que não se coaduna com a mentalidade libertária e crítica dos cristãos-novos. Esse jovem, foi defendido, durante os interrogatórios de seu processo, por seus mentores da Ordem dos Padres Oratorianos e por diversos cristãos-velhos que afirmaram sua sinceridade cristã. Resistiu a todos os sofrimentos dos cárceres e da tortura, sempre clamando sua fé em Cristo. Nada adiantou. Seus algozes não queriam um verdadeiro cristão! Queriam um judaizante que denunciasse outros, para não cessar nunca as atividades do Tribunal e isto não encontraram. Foi condenado à morte. Por "ato de misericórdia", sua sentença determina que "levado à Ribeira d'ela, aonde afogado morra morte natural, e ao depois de morto será queimado e feito per fogo em pó de maneira que nunca de seu corpo e sepultura possa haver memória". Morto estrangulado e jogado à fogueira para não deixar memória de seus nefandos atos de "cristianismo!"

Para concluir, podemos dizer que a identidade judaica não pode ser acoplada de forma simplista aos cristãos-novos, pelo simples fato de serem descendentes de judeus existentes em Portugal na época da conversão forçada ou de judeus de outras regiões que ocasionalmente possam ter passado por Portugal, mesmo durante a existência do Tribunal do Santo Ofício. A existência dos cristãos-novos é uma realidade diferente da existência dos judeus na Península Ibérica. Sua identidade não pode ser nem judaica nem cristã. São seres divididos entre uma memória judaica e uma existência cristã. Sua identidade é, como afirma Lina Gorenstein

$\overline{{ }^{8} \text { IAN/TT - Inquisição de Lisboa, Proc. n. }}{ }^{\circ} 9797$. 
Ferreira da Silva (nome expressivo da fusão entre judeu e cristão-novo) em sua tese de Doutorado, "uma identidade cristã-nova".

O judaísmo e a boa cidadania

\section{Referências bibliográficas:}

Yossef [Maurício] Zukin ${ }^{1}$

AZEVEDO, João Lúcio, História dos Cristãos-novos portugueses, Lisboa: Clássica Editora, 1918.

BAIÃO, Antônio, Episódios Dramáticos da Inquisição Portuguesa Homens de Letras e de Ciências por ela condenados. Vol. I e II, Lisboa: Seara Nova, 1972/73.

GITLITZ, David M. Secrecy and Deceit - The Religion of the Crypto-Jews, Philadelphia and Jerusalem: The Jewish Publication Society, 1996.

NOVINSKY, Anita W. Cristãos-novos na Bahia, São Paulo: Ed. Perspectiva, 1972

Um Novo Conceito de Marranismo, in I Colóquio Internacional O Patrimônio Judaico Português, Livro de Comunicações, Lisboa: associação Portuguesa de Estudos Judaicos, 1996, pp. 31-38.

. Considerações sobre os cripto-judeus Hispano-portugueses - $O$ caso do Brasil. Congresso Internacional, Nova Iorque, 1992, s/l Ed. Ambito, 1995.

RIBEIRO, Benair A F. Um Morgado de Misérias - Subsídios para o Auto de um Poeta Marrano, Dissertação de Mestrado defendida junto ao departamento de História da Faculdade de Filosofia, Letras e Ciência Humanas da Universidade de São Paulo, CAPH: -2001.

SILVA, Lina Gorenstein Ferreira da, $O$ sangue que lhes corre nas veias, Tese de Doutoramento defendida junto ao Departamento de História da Faculdade de Filosofia, Letras e Ciência Humanas da Universidade de São Paulo, CAPH: 1999.

Heréticos e Impuros, Rio de Janeiro: Coleção Biblioteca Carioca,

Série Publicação Científica, 1995. 
atingir um equilíbrio entre os dois, mas nenhum sistema político foi capaz de consumar esse equilíbrio.

O Rebe de Lubavitch explica ${ }^{2}$ que os seres humanos são naturalmente distintos em suas crenças e ambições. Tais diferenças geram, frequentemente, conflitos entre indivíduos e em toda a sociedade. Suprimir esta diversidade seria violar as liberdades individuais, e é, por conseguinte, inaceitável; e, no entanto, permitir a todas as pessoas uma liberdade sem controle também é inaceitável, pois o que impediria os interesses de uma pessoa de causarem danos a outra pessoa ou à sociedade?

Muitos governos reagiram a esse paradoxo optando por um extremo ou por outro. $\mathrm{O}$ totalitarismo toma posição em prol do bem geral à custa do bem individual. Não precisamos lembrar, no entanto, do incalculável infortúnio que essa forma de governo, na maioria dos casos, causou à espécie humana.

Por outro lado, a democracia alimenta exatamente o individualismo que o totalitarismo reprime; ela proclama que todos os homens nasceram iguais e possuem o direito de lutar por suas crenças sem restrições. Mas a democracia contém um defeito inerente, visto que seu fator essencial de motivação é o interesse pessoal. Com o passar do tempo, os valores essenciais de uma comunidade podem começar a se esfacelar sob o peso acumulado de milhões de desejos e necessidades individuais. Medite sobre as dezenas de conflitos, em dúzias de cidades americanas, onde a liberdade de expressão dos indivíduos entrou em choque com padrões comunitários de moralidade.

Já que as pessoas estão fadadas a ter crenças imensamente diferentes, quem teria de definir os padrões de moralidade e justiça que devem reger a todas as pessoas? A que ponto um governo intervém para impedir que um indivíduo cause dano a si mesmo ou aos outros? Como evitarmos o abuso do poder por líderes governamentais?

$\mathrm{O}$ único governo que pode equilibrar com êxito as necessidades individuais e sociais é um governo justo fundado na crença em D'us. $\mathrm{O}$ defeito essencial de todos os governos, sejam fascistas ou democráticos, é que eles são baseados nas regras humanas. Qualquer governo fundado apenas no julgamento humano está fadado a ficar sujeito ao preconceito, subjetividade, e à arbitragem de indivíduos e de grupos. Mas D’us, que criou todas as pessoas iguais, também lhes

\footnotetext{
${ }^{2}$ Rabino Menachem Mendel Schneerson, Rumo a Uma Vida Significativa, A sabedoria do Bebe (2001), adaptado por Simon Jacobson, Editora Maaayanot, S. Paulo, Brasil, pp. 198-200.
}

deu um sistema absoluto de moral e de justiça. Uma sociedade que anseia ser justa precisa ser baseada em tais valores éticos. O próprio alicerce da civilização reside nos princípios básicos conhecidos como as Sete Leis de Noé transmitidas no Sinai ${ }^{3}$.
1. Crença em Deus
2. Respeito e louvor a D'us
3. Respeito à vida humana
4. Respeito à família
5. Respeito aos direitos dos outros e à propriedade
6. Criação de um sistema judicial
7. Respeito a todas as criaturas

Sem essas leis como um fundamento de governo, uma sociedade ou terá despotismo, em que as vidas dos indivíduos estão comprometidas e possivelmente maltratadas, ou anarquia, em que cada pessoa busca suas próprias necessidades, sem respeito pela lei.

O voto de cidadania que está imbuído em cada judeu é colocado em prática principalmente pelo dever de transmitir e difundir essas leis gerais para todos os indivíduos, em todas as nações.

Essa "missão" judaica de transmitir e dar exemplos sobre esses princípios morais divinos está profundamente relacionada ao exercício de cidadania e ao compromisso e responsabilidade de cada judeu com a nação onde reside e o mundo todo na sua amplitude e profundidade. Esses princípios ajudam a solucionar conflitos básicos ligados à própria noção do bem comum e do bem individual que está na base de questões específicas entre o judeu e a sociedade.

Vemos cada vez mais conflitos entre a liberdade individual e as necessidades da sociedade - a questão de se uma pessoa deve ajudar outra a tirar a sua própria vida, por exemplo, ou se o governo deve alertar uma comunidade quanto ao paradeiro de um detento liberto. Tais temas são complicados, e precisam ser decididos caso a caso. Sob quaisquer circunstâncias, precisamos respeitar os direitos dos indivíduos, pois a santidade de uma comunidade se baseia na

\footnotetext{
${ }^{3}$ Maimônides, Código de Leis, Lei dos Reis 8:10-11.
} 
santidade de cada vida individual; por conseguinte, limitar os direitos de uma pessoa, é uma agressão a toda a comunidade. Por outro lado, existem ocasiões em que o interesse pessoal, ainda que possa caber dentro dos limites da lei, ameaça uma comunidade inteira.

A chave para a solução desse conflito reside no reconhecimento de que a individualidade não é uma inimiga da comunidade e de que a comunidade não é uma inimiga da individualidade. Considere o corpo humano "um mundo em miniatura". Cada órgão, ainda que participe de um certo número de tarefas compartilhadas, também tem suas funções individuais específicas. O que aconteceria se um determinado órgão abandonasse abruptamente suas funções individuais e se dedicasse apenas ao bem comum do corpo? Em longo prazo, isto seria desastroso tanto para o órgão como para o organismo, pois o corpo só está apto a funcionar por intermédio da integração de seus elementos independentes que realizam tarefas individuais.

O mesmo pode ser dito para um indivíduo dentro de uma sociedade, um grupo minoritário dentro de uma nação, ou de uma nação dentro da comunidade de nações. A liberdade de expressão, por exemplo, é vital para uma sociedade saudável e vigorosa, estimulando as pessoas a investir e a contribuir de uma maneira que acabará por beneficiar a comunidade inteira.

Uma nação civilizada precisa basear-se em um alicerce de moralidade ética que é atemporal e incondicional. Ao mesmo tempo, a sobrevivência de uma nação depende de seu constante progresso e crescimento. Assim como um indivíduo precisa equilibrar suas necessidades com o bem da comunidade, qualquer nação precisa equilibrar suas necessidades com a comunidade de nações.

Já que todas as nações fazem parte da mesma "aldeia global", elas são todas responsáveis umas pelas outras, e o descuido de uma nação acaba por afetar todas as outras. Cada nação precisa de ajuda e cada nação precisa estar pronta a ajudar. É irresponsável olhar para o outro lado quando uma nação está necessitada",5.

A educação é fundamental para equilibrar as necessidades individuais e as necessidades coletivas. Para que um governo se dedique de verdade ao

\footnotetext{
${ }^{4}$ Midrash Tanchuma, Pekudei 3

${ }^{5}$ Op. cit. , pg. 201
}

bem-estar de seus cidadãos - seu bem-estar físico, emocional e, sobretudo, espiritual -, precisa fazer da educação seu objetivo essencial, sem o qual todas as outras questões são discutíveis. Um governo e seus líderes precisam não apenas ensinar os cidadãos como buscar soluções racionais para problemas complexos, mas ensiná-los a como viver. Precisa instruí-los que a conduta humana deve seguir leis divinas que todos nós recebemos de D’us. Está é a única garantia que os direitos individuais serão preservados sem comprometer o bem comum"'.

O princípio de separação da igreja e dos estado não deve ser compreendido erroneamente como uma negação de D'us e da religião. Esta separação é necessária para que o governo não possa impor a religião de alguém a todos os cidadãos, mas tal precaução não deve ser posta em prática à custa da crença em D'us, a qual é compartilhada por todas as confissões ${ }^{7}$.

A única maneira de assegurar que as pessoas obedeçam a uma norma moral é inculcar nelas consciência permanente de valores. Punir uma pessoa depois dela ter cometido um crime, por exemplo, é atacar não a causa do problema, mas seu sintoma. Evidentemente, uma criança que foi educada sem temor e respeito a D'us em seu coração, não terá temor e respeito algum por qualquer autoridade - seus pais, seus professores, oficiais de justiça. Ela precisa aprender e aceitar o conceito de um código moral divino a que todos nós devemos obedecer. Ela precisa se dar conta de que as leis do homem têm como raízes uma coisa muito mais eterna: os Dez Mandamentos ${ }^{8}$.

\section{A missão cidadania}

O exercício da cidadania se refere não só ao próprio judeu, onde quer que ele se encontre, como a todas as pessoas, judeus e não judeus, com quem o judaísmo entra em contato, sem proselitismo.

Um dos objetivos do judaísmo é construir uma moradia para D'us nesse mundo. Os valores da cidadania são um dos pilares importantes dessa construção, tanto a nível local como global. D'us nos criou por uma razão para perseguir ativamente uma vida virtuosa e aperfeiçoar esse mundo

\footnotetext{
${ }^{6}$ ibid, pp. 202-202

${ }^{7}$ ibid, pp. 202-203

${ }^{8}$ ibid, pg. 203
} 
imperfeito. Não podemos preencher ou justificar a nossa existência sem a responsabilidade de cada um pelo mundo.

\section{Filosofia}

Percebe-se a importância do altruísmo voltado para a cidadania na filosofia judaica já á partir do primeiro judeu, o patriarca Avraham (Abraão). Enquanto dez gerações antes Noach (Noé) esteve preocupado em se salvar e aos seus filhos, Abraão esteve sempre preocupado em salvar aos outros e ao mundo inteiro.

Quando faz muito frio, há duas formas de aquecer-se. Uma é vestir um casaco de pele (assim como fez Noe); a outra, acender uma fogueira. A diferença é que o casaco de pele aquece a pessoa que o veste, enquanto a fogueira, qualquer um que dela se aproxime.

Abraão rezou por Sodoma e Gomorra para que não fossem aniquiladas, mesmo sem conhecer as pessoas daquela terra, notória por sua perversidade.

Se eu não for por mim, quem será por mim? E se for apenas por mim mesmo, o que sou? E se não for agora, quando??

O Rebe de Lubavitch descreveu o período histórico em que vivemos como um estado de emergência, "onde as chamas da confusão devastam. Quando as chamas ardem, todos são responsáveis por salvar os companheiros" 10 .

Quando vemos alguém em necessidade, precisamos mostrar-nos sensíveis. Quando vemos injustiça, precisamos protestar. Quando vemos imperfeição, precisamos fazer tudo o que for possível para melhorar a situação. Isso significa fazermos uma fogueira no lugar de vestirmos um casaco de pele ${ }^{11}$.

Sem sombra de dúvida, aonde quer que sejamos levados, é sempre de modo a refinar e purificar o mundo. Todos os judeus são emissários de D'us, cada um de acordo com o que a Providência Divina decretou para si. Nenhum de nós está livre dessa tarefa sagrada colocada sobre os nossos

\footnotetext{
${ }^{9}$ A Ética dos Pais, 1:14

${ }^{10}$ Op. cit., pg. 189

${ }^{11}$ ibid, pg. 192
}

$\operatorname{ombros}^{12}$. Aonde quer que você vá, quem quer que você conheça, procure uma oportunidade de ajudar, de inspirar, de dar apoio.

A cidadania e um dever já que todos nós temos um grande débito com as famílias que nos criam, com os amigos que nos orientam, com os educadores que nos ensinam e, no caso da cidadania, com as nações que nos protegem. É óbvio que devemos restituir esse débito fazendo o que quer que esteja ao nosso alcance para melhorar a sociedade ${ }^{13}$.

\section{Ecologia também é cidadania:}

Também somos responsáveis pelo meio ambiente à nossa volta. $\mathrm{O}$ ser humano é a joia da criação, mas cada coisa em particular em nosso mundo físico - animal, mineral e vegetal - também está carregada de energia divina e propósito, e deve ser tratada em conformidade com isto. O judaísmo ensina que devemos utilizar o meio ambiente com responsabilidade, para propósitos inteiramente produtivos e finalidades superiores, e devemos protegê-lo de forma tão vigilante quanto protegemos a nós mesmos ${ }^{14}$. Responsabilidade é uma das grandes dádivas que D'us nos concedeu - a dádiva de sermos participantes ativos no dinâmico desenrolar do destino do mundo ${ }^{15}$.

\section{Respeito ao governo:}

Qual é o papel do governo? O Rebe de Lubavitch explica que o governo deve equilibrar os bens comunitários e individuais e isso só é possível quando a sociedade é governada por princípios de moralidade e justiça, lei e ordem, sob um D'us ${ }^{16}$.

\section{O profeta Jeremias escreve:}

Procurai a paz da cidade (...) e orai por ela a D'us, porque na sua paz vós tereis $\mathrm{paz}^{17}$.

\footnotetext{
${ }^{12}$ Rabino Menachem Mendel Schneerson, Hayom Yom, 5 Adar 1. 1943

${ }^{13}$ Op. cit., pg. 192

14 ibid, pg. 194

${ }^{15}$ ibid, pg. 195

${ }^{16}$ ibid, pg. 197

${ }^{17}$ Jeremias, 29:7
} 
Em 1978, o Rebe de Lubavitch, fez apelo aos governos do mundo para que proporcionassem "uma educação que desse maior importância ao desenvolvimento dos direitos humanos fundamentais e aos compromissos de justiça e moralidade" 18 .

\section{História}

Na sua história, aprendemos como o judaísmo valorizou e exerceu a cidadania tanto em particular como em público, inclusive exortando cidades inteiras a seguirem o bom caminho. Esse foi o caso na história bíblica de Jonas (Ioná). Está escrito que "A palavra do Eterno veio a Jonas, filho de Amitai, dizendo: levanta-te, vai a grande cidade de Nínive, e clama contra ela, porque sua malícia subiu a minha Presença" ${ }^{\text {"19. }}$. Em seguida, Jonas tenta se eximir de tamanha responsabilidade, quando acontece o famoso episódio da baleia, onde Jonas finalmente aceitou o mandamento Divino de ir até Nínive. É importante ressaltar que Jonas era judeu e Nínive era uma cidade onde justamente faltavam valores como a cidadania e muitos outros, e onde não moravam judeus. Então está descrito como "Jonas começou a entrar na cidade, fazendo a jornada de um dia, e clamou e disse: ainda quarenta dias, e Nínive será subvertida" ${ }^{20}$. Então o povo se arrependeu e voltou ao bom caminho.

Na nossa história recente, o Rebe de Lubavitch, residente nos Estados Unidos da América, se dedicou especialmente à educação nos Estados Unidos e no mundo, sendo esse um dos pilares fundamentais da cidadania. Em seu mérito, O Congresso [Americano] finalmente indicou o aniversário do Rebe como "Dia da Educação nos Estados Unidos" e o Rebe recebeu cartas de apreço dos Presidentes Carter, Reagan, Bush e Clinton. Em 1990, George Bush escreveu ao Rebe:

A tradição moral de nossa nação - na verdade, o desenvolvimento de toda a civilização ocidental - foi profundamente influenciada pelas leis e ensinamentos contidos na Bíblia. Era uma visão bíblica do homem, uma afirmação de dignidade e do valor da pessoa humana

\footnotetext{
${ }^{18}$ Op. cit., pg. 197

${ }^{19}$ Livro de Jonas, 1:1-2

${ }^{20}$ ibid, $3: 4$
}

feita à imagem do Criador, que inspirou os princípios que fundaram os Estados Unidos ${ }^{21}$.

Na história do Brasil, os judeus estão presentes até mesmo antes do descobrimento do Brasil. E nem tudo foi fácil ao longo dos 500 anos de presença dos judeus no Brasil, especialmente nos momentos de perseguição durante o período colonial. No entanto, segundo o Ministro da Cultura do Brasil, foi uma benção que o Brasil pudesse ter a presença do povo judeu desde as origens do país, trazendo consigo cerca de cinco mil anos de história, sabedoria e uma visão do mundo que enriquece o pensamento da jovem nação brasileira ${ }^{22}$.

Os judeus tiveram um papel preponderante também no povoamento e desenvolvimento da região amazônica do Brasil, pois eles foram pioneiros em muitas atividades e se destacaram pelas suas lideranças e contribuições no campo econômico e social daquela região. A sociedade amazônica acolheu os judeus que ali chegaram, dando-lhes abrigo, refúgio, agasalho e trabalho, sem prejuízo de sua identidade, memória, crenças, religião e valores ${ }^{23}$.

Percebe-se que o Brasil também estimula o exercício saudável da cidadania brasileira de sua população, pois proporciona as mesmas condições ecológicas de existência no social e no cultural para culturas regionalmente diversas ${ }^{24}$. A civilização brasileira é generosa porque é aberta à convivência com todas as raças e todas as culturas ${ }^{25}$.

\section{Leis}

No código de leis do judaísmo, encontramos várias leis que demonstram como o judeu tem o dever de ser um bom cidadão e de se comportar de forma honesta, moral e ética em qualquer nação onde resida.

\footnotetext{
${ }^{21}$ Op. cit., pg. 197

${ }^{22}$ Ministro Francisco Weffort na Edição Histórica de Inauguração do Beit Lubavitch do Rio de Janeiro-Brasil em 2000

${ }^{23}$ Samuel Benchimol, Eretz Amazônia (1998), Editora Valer, Manaus-AM, Brasil.

${ }^{24}$ Gilberto Freyre, O Luso e o Trópico (1961), Editora Neogravura, Lisboa, Portugal, pg.312.

${ }_{25}$ Darcy Ribeiro, O povo Brasileiro - a formação e o sentido do Brasil (1997). Editora Schwarcz Ltda. S. Paulo, Brasil, pg. 455.
} 
Em relação ao comércio, por exemplo, existem várias leis com ênfase no cuidado que se deve tomar para não enganar ou trapacear uma pessoa, sendo esta uma proibição da Torá.

Existe uma lei geral sobre fraude em preços ${ }^{26}$, baseada no versículo que está escrito no Levítico ${ }^{27}$ :

Assim, quando vocês comprarem ou venderem para seu próximo, não enganem um ao outro.

Tudo que é vendido de acordo com medida, peso e número, mesmo se a discrepância entre o que foi tratado e o que foi entregue ou pago é menor que o valor padrão de fraude (um sessenta avos do preço total) o valor devido deve ser retornado à pessoa de direito ${ }^{28}$.

Isso se aplica no caso do vendedor enganar o comprador ou vice versa. Do mesmo modo é proibido enganar em relação a trabalhadores, troca de dinheiro, etc. ou até mesmo enganar alguém com palavras, assim como está ensinado no Levítico ${ }^{29}$, "Vocês então não estarão enganando um ao outro. Vocês temerão o D'us de vocês, que eu sou D'us, o Senhor de vocês" ${ }^{\text {"30 }}$.

Os líderes da comunidade são obrigados a ajudar as organizações governamentais na verificação do cumprimento da lei local, apontado autoridades, por exemplo, para inspecionar lojas e detectar fraudes nas medidas e pesos.

Uma pessoa não pode vender um artigo com defeito sem avisar ao comprador sobre o defeito, ou vender uma carne que não teve o abate ritual, levando a crer que sim. Em suma, o judeu deve sempre falar a verdade e agir com retidão e com o coração puro.

\section{Trabalho}

No meu campo de trabalho, compreendo o exercício da cidadania já a partir de algumas das minhas áreas de atuação. Em primeiro lugar, como professor, tenho o dever de formar alunos que irão trabalhar no mercado de

\footnotetext{
${ }^{26}$ Bava Metsia 56b, Kidushin 426

${ }^{27}$ Levítico, 25:14.

${ }^{28}$ Kidushin 42b.

${ }^{29}$ Levítico, 25:17.

${ }^{30}$ Kitsur Shulchon Oruch, pg. 265
}

trabalho, e ser cidadãos do Brasil em todos os sentidos, do voto consciente, ao trabalho com ética e moral, ao pagamento de impostos e principalmente ao exemplo como bom profissional. Em segundo lugar, e não menos importante, como empresário voltado à atividade de prevenção e detecção de fraudes em sistemas de telecomunicação, percebe-se uma vocação natural, condizente com o judeu, de procurar o bem e afastar o mal. Como é dito nos Salmos, "sur me' rá va'assé tov" (Afasta-te do mal e faz o bem) ${ }^{31}$.

\section{Conclusão}

O judeu pode contribuir muito para o bem comunitário do Brasil, por meio do seu exercício da cidadania, do incentivo à cidadania dos outros indivíduos, e por meio da difusão de outros valores que ultrapassam a definição de cidadania e que se referem aos valores das sete leis de Noé que são fundamentais para a prosperidade de uma nação.

Segundo as palavras do Rebe de Lubavitch:

Se lembrarmos de nossa responsabilidade para com os outros, D'us abençoarei cada um de nós, e a comunidade inteira, com prosperidade e sucesso.

\footnotetext{
${ }^{31}$ Salmos, 34:15 32- Rumo a Uma Vida Significativa, p. 196.
} 
Em busca de uma identidade: o comportamento de consumo de judeus bem-sucedidos

Carlos Blajberg ${ }^{1}$

\section{Introdução}

\section{Questão principal}

To limiar de um novo milênio, em meio a uma sociedade complexa, é cada vez maior a quantidade e a diversidade de bens e serviços oferecidos ao consumidor. Cabe ao Marketing - através do comportamento do consumidor - estudar e compreender as razões por trás dos hábitos e padrões de consumo em determinados segmentos da sociedade.

O estudo do comportamento do consumidor procura compreender as razões da formação dos hábitos do mesmo. Portanto, utiliza-se de ciências correlatas, centradas em atividades humanas, como a Economia, a Sociologia, a Psicologia e a Antropologia. Este trabalho visa estreitar a parceria entre o Marketing e a Antropologia do Consumo, numa perspectiva interdisciplinar.

Torna-se importante compreender as dimensões culturais presentes no comportamento de consumo de determinados grupos sociais urbanos. Tal compreensão também é importante em relação ao universo simbólico, composto por um sistema de classificações que define suas identidades. Com o auxílio deste sistema, uma espécie de mapa cultural, é possível coletar subsídios sobre a formação dos hábitos de consumo dos integrantes desse grupo social urbano. Neste trabalho o mesmo será constituído por judeus bem-sucedidos.

Portanto, a questão pode ser formulada do seguinte modo: 'é possível compreender alguns aspectos do comportamento de consumo de judeus bem-sucedidos através de suas práticas culturais?

\footnotetext{
${ }^{1}$ Mestre em Administração / COPPEAD/UFRJ.
}

\section{Objetivos}

Este estudo possui um objetivo principal e outros intermediários. O objetivo principal consiste em compreender se os padrões de consumo encontrados no grupo de judeus bem-sucedidos podem ser explicados através de suas práticas e dimensões culturais.

Tais dimensões são encontradas a partir dos valores e práticas constantes no discurso dos elementos deste grupo. São obtidas por meio de descrição profunda do comportamento de consumo dos mesmos. A metodologia empregada, através da pesquisa de campo etnográfica, fornece os subsídios para a elaboração do universo simbólico do grupo social em questão.

Os objetivos intermediários são:

1. Estreitar as relações entre o Marketing e a Antropologia, no sentido de aprimorar a compreensão do fenômeno do consumo;

2. Verificar a existência de nichos de mercado para esse grupo social, que embora pequeno em termos de população relativa, representa um públicoalvo extremamente segmentado e com elevado potencial de consumo;

3. Analisar se, no mercado do Rio de Janeiro, há uma visão empresarial de mercado voltada para o consumo de etnias específicas, denominada de Marketing étnico.

\section{Referencial teórico}

A revisão bibliográfica encontra-se dividida em três seções. A primeira compreende as teorias da Antropologia que serão utilizadas: o arcabouço teórico sobre cultura, o conceito de trabalho de campo, além do contexto histórico da sociedade judaica, produzindo uma espécie de panorama cultural do povo judeu. Finalizando, uma análise sobre o encontro das culturas judaica e brasileira.

A segunda seção compreende as teorias sobre o comportamento do consumidor. Diversas teorias são apresentadas, fornecendo diversos ângulos possíveis para vislumbrar este campo do Marketing. Essa seção representa a maior parte do referencial teórico deste trabalho. 
A terceira seção engloba aspectos religiosos do consumo, de forma a analisar as relações entre a religião e o consumo; e se há de fato uma perspectiva judaica no mundo dos negócios e do consumo. Nessa seção também estão os conceitos sobre o denominado Marketing étnico, difundido nos Estados Unidos, embora seja praticamente desconhecido no Brasil.

\section{Metodologia}

Será abordada em quatro seções a metodologia adotada, que consistirá na pesquisa de campo etnográfica.

A primeira seção apresenta o conceito de etnografia. Também traça um panorama da etnografia a partir de seus primeiros estudos até chegar aos dias atuais, nos quais a presença deste tipo de pesquisa é cada vez mais disseminada no estudo do comportamento do consumidor. As limitações associadas a esta metodologia se encontram após a apresentação de suas características, no decorrer das seções.

$\mathrm{Na}$ segunda seção o universo e a amostra do trabalho serão detalhados assim como apresentados os critérios de seleção dos mesmos. A coleta dos dados realizada através das entrevistas e de observação participante está na terceira seção.

Finalmente, a abordagem interpretativista está descrita na quarta seção. Trata-se da forma pela qual serão realizados o tratamento e a análise das informações obtidas pelos processos descritos na seção anterior.

\section{Conclusões}

A análise do discurso é desenvolvida neste capítulo. Através da mesma foi possível verificar: o simbolismo do ato de consumo junto aos integrantes do grupo; os canais e características de consumo; novas dimensões de consumo, como a internet; a hierarquia de consumo dos informantes; e finalmente como o consumo étnico está representado através de produtos e serviços feitos sob medida para os integrantes da comunidade em questão.

Portanto neste capítulo serão apresentadas as conclusões deste trabalho. Diversas inferências serão apresentadas nas seções a seguir, retiradas a partir do rico material extraído através da pesquisa de campo etnográfica realizada com os informantes. Duas foram as principais fontes de captação de material através da pesquisa etnográfica: as entrevistas em profundidade e as observações participantes. Este material gerou a análise do discurso, desenvolvida durante todo o capítulo cinco.

É importante relembrar neste momento a pergunta básica apresentada: "é possível compreender alguns aspectos do comportamento de consumo de judeus bem-sucedidos através de suas práticas culturais?'

Quatro aspectos serão abordados neste capítulo: a lógica do discurso dos informantes; a network judaica; possíveis nichos de mercado; e por fim as contribuições assim como as interrogações que serão legadas por este paper para eventuais pesquisas futuras.

Busca-se verificar a existência de padrões de consumo determinados pelos hábitos socioculturais dos informantes. Esta lógica segue alguns aspectos como, por exemplo, os mecanismos que estão por trás da tomada de decisão de consumo, assim como o universo simbólico dos informantes.

Também é desenvolvida a questão da network judaica. Ou seja, o quão verdadeiro é o conceito pré-concebido que afirma que os judeus formam redes de contato e auxílio entre seus integrantes. $\mathrm{E}$ até que ponto esta rede impacta nos seus hábitos de consumo.

Os possíveis nichos de mercado vislumbrados a partir do discurso dos informantes serão analisados. $\mathrm{Na}$ medida em que haja demandas reprimidas ou mal-atendidas pela atual oferta de produtos e serviços, há também nichos de mercado que têm como target principal o universo de informantes estudados.

Por fim, discutir-se-á de uma forma mais ampla as contribuições legadas por este trabalho. O paper contribui para um maior estreitamento entre as relações do Marketing e da Antropologia, no sentido de aprimorar a compreensão do fenômeno do consumo.

Também serão abordados os questionamentos que poderão ser gerados pelo paper, e até mesmo atuarem como motivadores de estudos futuros. Possíveis alterações nas fronteiras da amostra ou na metodologia utilizada poderiam eventualmente proporcionar resultados distintos. 


\section{A lógica do discurso dos informantes}

Esta primeira seção do capítulo conclusivo busca trazer à tona a lógica que está implícita (ou explícita) no cerne dos discursos dos informantes. Desta forma, é possível analisar em profundidade como o universo cultural do grupo estudado encontra-se alinhado com seus padrões de consumo. Como exemplos dos aspectos deste universo cultural há símbolos, mitos, rituais, linguagens, valores, crenças e percepções, todos elementos presentes no discurso dos informantes.

A partir da emergência desta lógica é possível responder a questão: 'Pode-se compreender alguns aspectos do comportamento de consumo de judeus bem-sucedidos através de suas práticas culturais?'. A resposta à pergunta acima é 'sim, é possível compreendê-los'. O grupo estudado demonstrou um discurso coeso e homogêneo. E este mesmo discurso apresentou uma lógica em comum, definindo um padrão de consumo para o grupo.

Há elemento presente na maioria absoluta dos discursos que pode ser denominado como consumo temporal: a relevância atribuída pelos informantes ao consumo com o propósito da imobilização do patrimônio. Ou seja, a tendência de adquirir bens de alto valor agregado, como imóveis (principalmente) ou veículos. O objetivo primário é o de garantir que o patrimônio da família estará seguro contra possíveis adversidades, como inclusive uma eventual ausência da figura patriarcal do próprio informante.

Um fato que também foi bastante frisado nos depoimentos é a questão da partilha. Em grande parte dos casos, estes bens como imóveis e veículos eram adquiridos num número que fosse múltiplo do número de filhos. Assim ficava claro o intuito de uma possível divisão para seus descendentes. Por exemplo, um informante que tinha duas filhas e um filho possuía seis imóveis. O consumo temporal também significa que os informantes apresentam uma elevada capacidade de poupança interna, devido à constante preocupação com o futuro, materializado através de seus filhos e de sua aposentadoria. Daí surgem investimentos em produtos financeiros orientados para fundos mais conservadores, como os de renda fixa e até mesmo a caderneta de poupança.

Um dos informantes comprou até mesmo um título do Governo de Israel no valor de alguns milhares de dólares, cuja importância só poderia ser resgatada num prazo de cinco anos, para presenteá-lo a seu filho mais velho. Diversos depoimentos confirmaram a tendência desta cultura da poupança e do resguardo contra adversidades, cultura e comportamento que foi possível observar na geração subsequente - passada de pai para filho, numa espécie de ritual: "Veja, quando meu filho tinha seis anos de idade já levei o pequeno numa agência bancária para ele abrir uma conta de poupança. Assim ele começou a valorizar o dinheirinho que ganhava".

A questão do consumo étnico também foi observada como presente nos padrões de consumo do grupo. Possivelmente o judaísmo ou o 'ser judeu', talvez seja uma das mais antigas e tradicionais identidades que ainda existam na face da terra. Como uma forma de se buscar e preservar esta identidade, os informantes utilizam o consumo de produtos e serviços de natureza étnica como elos para permitir a continuidade desta trajetória milenar.

Os serviços principais como escolas, clubes e outros ligados aos ritos de passagem (casamento, Bar-Mitzvá, Bat-Mitzvá) ou à preservação dos valores culturais (cursos, viagens) foram citados em todos os depoimentos como forma essencial de se preservar a própria identidade judaica, assim como de seus familiares. É como se as execuções dos ritos de passagem nos padrões reconhecidamente judaicos assegurassem a pertinência dos informantes e de suas famílias à tradição judaica. Portanto, o consumo daquela série de serviços de natureza étnica colabora de forma decisiva para a contínua construção da identidade.

Entretanto, no comportamento de consumo de judeus bem-sucedidos não há elementos de competitividade entre os mesmos. Como exemplos desses elementos ausentes há desde a obtenção de prestígio social e a ostentação pura e simples, até o consumo conspícuo ou características de emulação social. Também não se verificaram características de insaciabilidade de consumo, pois a perspectiva de consumo temporal se movimenta num sentido oposto. Tal fato pode ser comprovado pelos depoimentos dos informantes, cujas finanças sempre estiveram equilibradas. Ou seja, os mesmos jamais contraíram dívidas ou empréstimos bancários com o intuito de consumir algum produto ou serviço.

Como integrantes de um grupo de natureza étnica, o depoimento desses judeus bem- sucedidos deixou configurada a importância do meio social - sua aceitação social. Em diversas passagens, ficou patente o quanto era importante para os informantes inserirem a si próprios e a seus 
familiares num ambiente judaico. Este objetivo possuía alta importância em termos da hierarquia de consumo: nem que fosse preciso adquirir um imóvel em determinados condomínios sofisticados em Teresópolis com o propósito de se aproximar de integrantes da comunidade.

$\mathrm{Na}$ realidade, a importância do meio social para os informantes comprova que a aceitação social junto a seus pares é fundamental para aqueles. Um exemplo é o consumo de objetos judaicos dotados de grande valor simbólico e que são colocados de forma estratégica em suas residências, na sala de estar ou nos cômodos principais. Assim a identidade judaica permanece patente para seus convidados, que são muitas vezes integrantes do próprio grupo estudado.

Outro elemento percebido nos padrões de consumo é a construção da autoimagem. Esta característica caminha juntamente com o sentimento de coesão do grupo. Os informantes possuem vínculos muito fortes com algumas instituições comunitárias, sendo algumas de origens filantrópicas. Ao serem questionados sobre o motivo pelo qual ainda permaneciam sócios de clubes ou instituições das quais não participavam mais no seu dia-a-dia, eles afirmaram: "veja bem, eu ainda continuo sócio daquele clube porque muitos outros utilizam seus serviços e como membro da comunidade judaica eu preciso colaborar para a manutenção de instituições deste tipo. Nem eu nem meus familiares frequentamos esta instituição, mas eu me sinto no dever de contribuir". O sentimento de coesão do grupo é tão intenso que muitos informantes ainda pagam mensalidades de clubes ou cursos sem sequer frequentá-los. Sem mencionar entidades filantrópicas, cujas doações contribuem para a construção de uma autoimagem de dignidade e honradez a partir de seus valores culturais. Além da manutenção da imagem de networking gerada pelos não integrantes da comunidade.

O fato da dimensão cultural deste grupo ter se formado há muitos séculos e ter sido preservada no seu âmago talvez contribua para diversas das características abordadas. Ainda que haja uma constante influência das culturas das sociedades nas quais os mesmos estiveram inseridos (pósDiáspora), a estrutura básica da identidade judaica assim como seus valores têm sido preservados. Assim, o consumo consiste numa das formas pelas quais os informantes buscam reforçar esta mesma identidade judaica. As características principais de consumo temporal, étnico, a importância do meio social e a construção da autoimagem contribuem para a definição dos padrões de consumo dos informantes.

Um dos mais estabelecidos preconceitos sobre os judeus é o que afirma que os integrantes das comunidades judaicas são bastante unidos, formando importantes redes de contato (networks). Aqui serão buscados subsídios para um maior entendimento sobre a existência ou não destas networks e como as mesmas concorrem para a formação do padrão de consumo dos informantes.

Primeiramente, é importante verificar que há uma série de fatos que contribuem para a formação deste preconceito. Alguns destes fatos, provenientes dos Estados Unidos, confirmam que os judeus representam 2\% da população americana e $45 \%$ dos top 40 milionários da lista Forbes $400^{2}$. De outro lado, constituem um terço de todos os multimilionários (patrimônio pessoal acima de um milhão de dólares) americanos, são $20 \%$ dos professores das principais Universidades americanas, são sócios de $40 \%$ dos principais escritórios de advocacia de Nova Iorque e Washington e, por fim, representam 25\% de todos os americanos laureados com o Prêmio Nobel.

Alguns fatos como os citados acima passaram a contribuir para a ideia pré-concebida que os judeus, em todos os lugares em que vivem, detêm poder e, assim sendo, organizam-se em networks. Tal percepção se disseminou a partir dos Estados Unidos até outros países. Geralmente o tamanho e grau de união da comunidade judaica de um determinado país é diretamente proporcional à intensidade destes preconceitos. Em diversas passagens apuradas junto aos informantes, ficou claro que contatos pessoais provenientes de atividades sociais judaicas são muito importantes para suas relações comerciais.

Estas relações podem consistir-se em benefícios como obtenção de novos clientes ou até mesmo formação de parcerias entre empresas. Alguns informantes confirmaram que preferem fazer negócios com integrantes da comunidade judaica, porque "quando se faz negócios com pessoas com os mesmos valores e crenças, enfim, com a mesma cultura, o entendimento durante a negociação fica muito mais fácil", segundo um informante.

${ }^{2}$ A revista de negócios Forbes publica anualmente um ranking anual com os 400 americanos mais ricos. 
Verificar a origem do sobrenome é uma forma utilizada comumente pelos informantes para se ter uma boa ideia da probabilidade do outro ser judeu. Mas aqui também se parte de um preconceito, pois na realidade há muito judeus cujos nomes possuem origem ashkenazim, ou seja, possuem sufixos típicos alemães ou russos, como 'Berg', 'Man', 'Vitz', entre outros.

Esta maior predisposição para se fazer negócios ocorre também quando a comunidade se encontra ciente que a alta gerência da empresa é constituída de integrantes da comunidade. Um exemplo clássico é o dos irmãos banqueiros Safra: Joseph, Moise e Edmond, cuja história familiar remonta ao século XIX, na Síria. O mais velho dos irmãos, Joseph, era banqueiro, proprietário de um banco nova-iorquino, o National Republic Bank. O banco, bem-sucedido, era um dos cinquenta maiores bancos norteamericanos em volume de recursos.

Devido a problemas pessoais, Joseph decidiu vender seu banco ao HSBC (Hong Kong and Shangai Banking Corporation), um dos maiores bancos do mundo, em 1999. Após a venda ter sido concretizada, um semnúmero de contas e investimentos de clientes judeus foram cancelados. Este fato representou um efeito colateral inesperado para o HSBC ficando caracterizado o quanto os integrantes da comunidade prezavam o fato da empresa ser administrada por um judeu. Esta história acima foi citada por um dos informantes. $\mathrm{O}$ mesmo afirmou verificar sempre quem faz parte da alta gerência dos bancos nos quais ele depositava seus investimentos. Portanto as networks existem e desempenham importante papel na comunidade. No entanto, não se trata de algo exclusivo dos judeus, pois os demais grupos étnicos também possuem suas redes de contato específicas. Além disso, networks judaicas possuem relevância devido ao caráter de preservação dos integrantes, representando uma variável na definição dos padrões de consumo dos informantes.

Conforme pôde ser observado através dos depoimentos dos informantes, a afirmação da identidade judaica é corroborada através do consumo de determinados produtos e serviços de natureza étnica. Há algumas categorias que se vêm profissionalizando de forma mais acelerada, como a de serviços direcionados para as festas judaicas. Foi somente durante os anos noventa que surgiram e se desenvolveram grupos de dança e música cujos nomes se tornaram conhecidos por toda a comunidade.
Outro setor que vem crescendo e possui como público-alvo um segmento mais específico é o de mídia, como jornais, revistas e programas de TV (a cabo e aberta). No entanto, o que se verifica no mercado brasileiro é que há uma série de nichos de mercado que podem ser explorados de uma forma mais efetiva. Como exemplos há a categoria de produtos carregados de valor simbólico, desde menorahs até mezuzás, entre outros. Atualmente, é bastante difícil encontrar esta categoria de produtos no Rio de Janeiro.

O Brasil por ser uma sociedade de classes relativamente aberta e portadora de uma cultura multiétnica não apresenta, de forma plenamente configurada, nichos especializados de negócios que atendam unicamente a segmentos populacionais específicos ao ponto de configurarem-se como mercados de consumo de tipo identitário de relativo porte comercial.. Contudo, essa conjuntura não implica negar a preferência demonstrada em negociar com seus pares devido a tradição de confiança mútua tecida ao longo do tempo, que serve como uma garantia simbólica trazida para o mundo dos negócios. Também se torna importante frisar que o comportamento observado não é de exclusividade do grupo judaico na medida em que está presente em todos, ou quase todos, os grupos imigrantes, funcionando, portanto, como mecanismo de solidariedade entre seus membros e de fortalecimento de sua cultura transplantada.

Para terminar, uma sugestão, existe de espaço no mercado para um portal judaico baseado na dicotomia 'globalização X tribalização'. 'Globalização' na medida em que o usuário teria uma experiência de consumo (via e-commerce) de produtos de natureza étnica de todo o mundo, inclusive Israel e Estados Unidos. Por outro lado, a 'tribalização' dar-se-ia pela participação de membros da comunidade local na geração de conteúdo para o portal, com artigos, entrevistas e participações. Os depoimentos dos informantes deixaram claro que há setores se desenvolvendo rapidamente, havendo oportunidades e nichos de mercado para atender às demandas que porventura ainda não estejam sendo atendidas.

\section{Contribuições e interrogações legadas pelo trabalho}

As contribuições deste paper, assim como possíveis interrogações legadas pelo trabalho, poderão atuar como elementos motivadores para futuros estudos, enriquecendo as pesquisas sobre o Marketing e mais especificamente sobre as relações entre a Antropologia e o Comportamento do Consumidor. 


\section{Referências bibliográficas:}

ARNOULD, E., WALLENDORF, M. Market-oriented ethnography: interpretation building and Marketing strategy formulation. Journal of Marketing Research, Vol. 31, November 1994, p.484-504.

ATKINSON, P., HAMMERSLEY, M. Ethnography and participant observation. In: DENZIN, N., LINCOLN, Y. (Org.) Handbook of qualitative research. Thousand Oaks: Sage, 1994.

BARNAVI, E. (Org.) A historical atlas of the Jewish people - from the time of the patriarchs co the present. New York: Schocken Books, 1992.

BAROUKH, E., LEMBERG, D. Enciclopedia práctica del judaismo. Barcelona: Ediciones Robin Book, 1995.

BELK, R. Possessions and the extended self. Journal of Consumer Research, Vol.15, September 1988, p.139-168.

BELK, R., WALLENDORF, M., SHERRY JR, J. The sacred and the profane in consumer behavior: theodicy on the odyssey. Journal of Consumer Research, Vol.16, June 1989, p.1-38.

BENCHIMOL, S. Eretz Amazônia. Manaus: Valer Editora, 1998.

BOHANNAN, P. ' Progresso ' da Antropologia. In: GUIMARÃES, A. (Org.) Desvendando máscaras sociais. 3. ed. Rio de Janeiro: Francisco Alves, 1990.

BUARQUE DE HOLANDA, A. Novo dicionário da língua portuguesa. Rio de Janeiro: Nova Fronteira, 1986.

CAHILL, T. A dádiva dos judeus. Rio de Janeiro: Objetiva, 1999.

CAMPBELL, $\mathrm{C}$. The romantic ethic and the spirit of modern consumerism. Oxford: Blackwell, 1987.

CELSI, R., ROSE, R., LEIGH, T. An exploration of high-risk leisure consumption through skydiving. Journal of Consumer Research, Vol.20, June 1993, p.1-23.

COSTA, J. The social organization of consumer behavior. In: SHERRY JR, J. (Org.) Contemporary Marketing and consumer behavior: an anthropological sourcebook. London: Sage, 1995.
DAMATTA, R. Relativizando. Rio de Janeiro: Rocco, 1987.

Carnavais, malandros e heróis. Rio de Janeiro: Rocco, 1997.

DELENER, N. The effects of religious factors on perceived risk in durable goods purchase decisions. The Journal of Consumer Marketing, Vol.7, No.3, summer 1990, p.27-38.

. Religious contrasts in consumer decision behavior patterns: their dimensions and Marketing implications. European Journal of Marketing, Vol.28, No.5, 1994, p.36-53.

DOUGLAS, M., ISHERWOOD, B. The world of goods: Towards anthropology of consumption. Middlesex: Penguin Books, 1979.

DUARTE, D. Rota de passagem. Veja, Edição 1592,7 de abril de 1999, p.86-87.

FALK, P. The scopic regimes of shopping. In: FALK, P., CAMPBELL, C. (Org.) The shopping experience. London: Sage, 1997.

FONTANA A. FREY, J. Interviewing: the art of science. In: DENZIN, N., LINCOLN, Y. (Org.) Handbook of qualitative research. Thousand Oaks: Sage, 1994.

FREUD, S. Moisés e o monoteísmo. Rio de Janeiro: Imago, 1997.

GEERTZ, C. A interpretação das culturas. Rio de Janeiro: Zahar, 1978.

GORE, J. Ethnic Marketing may become the norm. Bank Marketing, Vol.30, September 1998, p.12-14.

HERZL, T. The Jewish state. New York: Dover, 1988.

HOFSTEDE, G. Culturas e organizações. Lisboa: Edições Silabo, 1997.

HOLBROOK, M. What is consurner research? Journal of Consumer Research, Vol.14, June 1987, p.128-132.

HOLBROOK, M., HIRSCHMAN, E. The experiential aspects of consumption: consumer fantasies, feelings, and fun. In: ENIS, B., COX, K., MOKWA, M. (Org.) Marketing classics. 8. ed. New Jersey: Prentice Hall, 1990. 
HUDSON, L., OZANNE, J. Alternative ways of seeking knowledge in consumer research. Journal of Consumer Research, Vol.14, March 1988, p.508-521.

KELLER, S. The Jews in literature and art. Min: Kõnemann, 1992.

KOTLER, P. Behavioral models for analyzing buyers. In: BLISS, P. Marketing and the behavioral sciences. 2. ed. Boston: Allyn and Bacon, 1968.

LEVIN, G. Shops make the most of ethnic niches. Advertising Age, Vol.61, September 1990, p.29.

LEWIN, H. A economia errante: a inserção dos imigrantes judeus no processo produtivo brasileiro. In: Judaica Latinoamericana Estudios Histórico-sociales. Jerusalem: Editorial Universitaria Magoes, 1997.

LÉVI-STRAUSS, C. Tristes trópicos. São Paulo: Companhia das Letras, 1996.

LIEBECK, L. Ethnic selections season greeting cards. Discount Store News, Vol.35, April 1, 1996, p.93-96.

MALAMUD, S. Recordando a Praça Onze. Rio de Janeiro: Kosmos, 1988.

MALINOWSKI, B. Uma teoria científica da cultura. Rio de Janeiro: Zahar, 1975

. Objetivo, método e alcance desta pesquisa. In: GUIMARÃES, A. (Org.) Desvendando máscaras sociais. 3. ed. Rio de Janeiro: Francisco Alves, 1990.

MÁXIMO, J., DIDIER, C. Noel Rosa: uma biografia. Brasília: UNB, 1990.

MCCRACKEN, G. Culture and consumption. Bloomington: Indiana University Press, 1988.

MCGRATH, M., SHERRY JR, J., HEISLEY, D. An ethnographic study of ao urban periodic marketplace: lessons from the midville farmers market. Journal of Retailing, Vol.69, No.3, fali 1993, p.280-319.

MILLER, C. Jewish group calls on Marketing to fill synagogue. Marketing News, Vol.3 1, January 20 1997, p.12.
MILLER, D. Could shopping ever really matter? In: FALK, P., CAMPBELL, C. (Org.) The shopping experience. London: Sage, 1997.

PATTERSON, M. Direct Marketing in postmodernity: neo-tribes and direct communications. Marketing Intelligence and Planning, 16 / 1, 1998, p.68-74.

PETERSON, M. (Org.). The portable Thomas Jefferson. New York: Penguin Books, 1977.

ROCHA, E. O que é etnocentrismo. São Paulo: Brasiliense, 1984.

. A sociedade do sonho: comunicação, cultura e consumo. Rio de Janeiro: Mauad, 1995.

SARTRE, J. Anti-Semite and Jew. New York: Schocken, 1987.

SCHOUTEN, J., MCALEXANDER, J. Subcultures of consumption: an ethnography of the new bikers. Journal of Consumer Research, Vol.22, June 1995, p.43-61.

SCHWANDT, T. Constructivist, interpretivist approaches co human inquiry. In: DENZIN, N., LINCOLN, Y. (Org.) Handbook of qualitative research. Thousand Oaks: Sage, 1994.

SCLIAR, M., FINZI, P. TOKER, E. Humor judaico. 4. ed. São Paulo: Shalom, 1990.

SILBIGER, S. The Jewish phenomenon. Atlanta: Longstreet Press, 2000.

TOCQUEVILLE, A. Democracy in America. Disponível na Internet via http://xroads.virginiasedu/ hyper/detochoc_indx.html. Arquivo consultado em 1999.

VEBLEN, T. A teoria da classe ociosa. São Paulo: Pioneira, 1965.

VELTMAN, H. A história dos judeus no Rio de Janeiro. Rio de Janeiro: Expressão e Cultura, 1998.

VERGARA, S. C. Projetos e relatórios de pesquisa em administração. São Paulo: Atlas, 1997. 
VIDICH, A., LYMAN, S. Qualitative methods: their history in sociology and anthropology. In: DENZIN, N., LINCOLN, Y. (Org.) Handbook of qualitative research. Thousand Oaks: Sage, 1994.

WALLENDORF, M., ARNOULD, E. "My favorite things": a cross-cultural inquiry into object attachment, possessiveness, and social linkage. Journal of Consumer Research, Vol.14, March 1988, p.531-547.
Identidade, cidadania: como se expressa o judaísmo na Amazônia!

Oro Serruya

\section{A identidade é a definição do ser em si mesmo.}

o aspecto teológico, a mais antiga referência, é a do próprio Deus. Na passagem bíblica da Sarça Ardente, quando Moisés assistia à moita se consumindo, o Senhor disse: Moisés, Moisés..., eis-me aqui; eu sou Deus, Deus do teu Pai Abraham, Isaac e Jacob. Deus se identificou!

Quando Deus mandou Moisés falar com Faraó para deixar o povo Judeu sair do Egito... Ele pensou: ...Se o faraó me perguntar quem foi que te mandou, como vou explicar? Deus respondeu: Eu sou aquele que sou, que sempre existiu. Isso é identidade.

No aspecto Biológico Humano, ou seja na espécie humana, só existe uma família, e a identidade se caracteriza pelas diferentes etnias.

No aspecto Biológico vegetal, a Árvore que é um ser vivo, sem alma, do reino vegetal, inanimado, se diferencia, pelas várias famílias botânicas.

Assim, o conceito de identidade somente faz sentido quando temos um ente a identificar. No caso um grupo social. Para identificar esse grupo, temos de recorrer a outros dois conceitos sociológicos distintos e interdependentes que são: o conceito de sociedade e o conceito de cultura .

Cidadania, por sua vez, vem da palavra latina - Cívitas - que formou a palavra cidade e significa - "o que vive nas cidades", o cidadão habitante da cidade, consciente de sua identidade e que trabalha para realizar o Bem comum, que é uma das características do ser humano.

Os antigos latinos diziam - Serva órdinem et órdo sérvabíté te. (Respeita a ordem e ela te ajudará)

No Judaísmo encontramos no tratado de Pirke Avot - A Ética dos pais - que diz - "Somos todos responsáveis uns pelos outros". Este sentido 
deveria nortear todos os povos, e, neste sentido, a comunidade Judaica da Região Amazônica tem registrado algumas ações e iniciativas em benefício da Amazônia.

A história da comunidade Judaica da Amazônia aparece em livros de Samuel Benchimol, Abraham Bentes e Eidorf Moreira, dentre outros, e o impacto da chegada dos Judeus na Amazônia ocorreu diferentemente da cultura europeia, pois traziam uma bagagem cheia de religiosidade, que diferia dos gregos e romanos, aqueles que influenciaram a cultura europeia, a mesma trazida para o Brasil no início da sua história e que causou impacto com a cultura existente aqui, o que resultou num ambiente onde os personagens principais eram o dominador e o dominado.

Já os judeus se integraram, sem perder sua identidade, provavelmente, por conservarem princípios de justiça e os preceitos da Torah. E assim a Cidadania e Identidade interagem, propiciando a adaptação dos Judeus na Amazônia.

Acontecemos eticamente quando nos relacionamos uns com os outros e os percebemos como portadores de humanidade.

Então, considerando a reunião dessas diferentes culturas, as ideias de cidadania, política, o Estado, Poder, violência, justiça, nos perguntamos: O que mudou? A concepção do mundo, a sociedade. O que não mudou? A Ética que sempre se plantou pelo respeito ao outro. mesmo".

A Ética nasce com a máxima de D’us, “Ama a teu próximo como a ti

Um dos principais fatores de caracterização de uma sociedade, é a forma interativa, que implica na forma de manifestação de valores nas relações sociais, onde encontramos enfim o conceito de cultura integrado na dinâmica social. Percebemos assim que quando tratamos de identidade de comunidade, estamos nos referindo aos aspectos socioculturais.

Tais características é que vão identificar a comunidade e é assim que o aspecto sociocultural (traços culturais) é o mecanismo identificador. É o parâmetro que nos permite observar o Judeu e afirmar "esse é Judeu", ou observar um índio e dizer "esse é um índio".
E dentro do que nós chamamos de identidade sociocultural, temos um elemento eminentemente político que é fundamental para manutenção da estrutura social em qualquer organização.

É um principio universal que hoje chamamos de cidadania.

A história registra que esses mesmos princípios de urbanidade, de cidadania, de ética, em algumas culturas antigas chegaram a ter um valor superior às normas morais ou religiosas. Violar certos princípios de respeito ao seu semelhante, ao meio ambiente, e até à fauna e à flora chegava a ser mais condenável do que infringir uma norma moral ou religiosa.

No ocidente, foram os gregos que delimitaram a forma da valoração do ético herdada pelos Romanos, e que ainda persiste como base do pensamento ocidental. Mas, se formos avaliar bem, tais princípios são em essência universais, e não estão adstritos às culturas ocidentais. Nós vemos esse mesmo princípio ético de respeito ao semelhante e ao meio em que vive, se olharmos a cultura indiana, recheada de religiosidades, na qual matar qualquer entidade viva é o mesmo que matar um ser humano. Nas culturas das sociedades pré-colombianas e, principalmente, nas culturas indígenas vemos exatamente os mesmos princípios éticos de respeito, de consideração pelo semelhante, pelos animais, pelos rios, pelas florestas, pela sua casa, pela sua vizinhança, e até pelos seus inimigos.

E mesmo nós, integrantes da cultura semita, observamos em tantos preceitos os princípios éticos de respeito como máxima de conduta. Algo como a resposta de Jesus: qual é o maior mandamento? "Amar a Deus sobre todas as coisas", e acrescentou: "e o segundo é semelhante ao primeiro, amar ao seu próximo como a si mesmo”.

Destacamos esse episódio não por questão religiosa. Mas sim porque a expressão utilizada no mandamento se refere à "Tsedaká" - justiça - que é o mesmo princípio básico de conduta social esculpido em nossas referências mais remotas, ressaltado na Torah, nos Profetas e no Talmud. Todos os grandes sábios e rabinos que discorreram sobre a postura ideal para o convívio em comunidade fizeram referência à Tsedaká.

Assim, podemos relacionar a cidadania judaica, consagrada na Tsedaká, com o mesmo princípio universal de respeito e consideração perante o seu semelhante e ao meio físico e social do qual faz parte. 
Lembramos Maquiavel, a introdução da Responsabilidade que é uma configuração social. Esse ensinamento, nós o repassamos para nossas crianças dentro do princípio da tsedaká (justiça), pois quando crescerem não se desviarão dele.

Levíticos 11:1 pág. 193 fala sobre a Kacherut, preceito observado com mais intensidade por $30 \%$ da comunidade Israelita no Pará, nos últimos 40 anos, que diz respeito a alimentação de acordo com as leis mosaicas, mas também se refere aos cuidados com o sofrimento dos animais.

Rabi Akivá, um dos mártires da história judaica, que foi morto no século I pelos romanos, determinou até mesmo que é proibido tirar a vida de um animal selvagem sem que lhe seja dado um julgamento justo perante uma corte de 23 juízes, o mesmo direito reservado aos humanos. Sem dúvida isto não foi dito para ser olhado ao pé da letra, mas sim para enfatizar a santidade e a importância de todas as criaturas vivas. O Talmud (chulin, 60b) desencoraja as caçadas especializadas como esporte, colocando-as na categoria das crueldades com animais, prática condenada pela Bíblia, costume também observado pelos Judeus Amazônidas.

De Tu Bishvat "ano novo das árvores" foi fortalecido o sentimento de amor e respeito para com o mundo vegetal; tu Bishvat na comunidade Israelita do Pará é comemorado pelo CISA com a participação de representantes de diferentes credos religiosos, autoridades civis, militares e intelectuais e com rica programação educacional cultural e religiosa.

Aqui nós vamos perceber que a cidadania, enquanto princípio universal, é uma das pilastras da ordem social, da organização de um povo em sociedade, e, consequentemente, esse princípio de cidadania é importantíssimo à identidade sociocultural.

Quando um grupo ou um povo pretere, ignora, passa por cima de tais princípios de respeito mútuo e busca dominar ou subjugar a identidade alheia, ou por outro lado, quando se tenta não subjugar o outro, mas submeter a outra ordem, a outra cultura, a outros princípios, abdicando dos ensinamentos de nossos pais, dos nossos ancestrais, dos nossos antepassados, nós acabamos por infectar a identidade sociocultural com o germe da destruição.

É importante ressaltar que a identidade sociocultural, principalmente no caso dos índios e do povo Judeu, não está entre o Kocá e a Kipá, não se refere estritamente à indumentária, mesmo que o estereótipo também integre o conjunto de valores do seguimento sociocultural, mas sim, e principalmente, na forma e nos padrões de conduta no processo interativo.

Ou seja, como tratam seus semelhantes, seus filhos, vizinhos, amigos, seus inimigos, os desconhecidos, que grau de respeito se tem por cada integrante do meio social considerado.

No vocabulário do povo indígena, não existe posse... não se diz: “a terra é nossa", não ensinam a competir, ensinam a repartir, e reagem com amor a toda rejeição

No contato com os povos indígenas, nós podemos apreciar tantos outros valores, e eles estão salvaguardando muito bem. A terra, não é vista como objeto de lucro. Para o índio, a terra é mãe, é o lugar vital. Destruir a natureza é destruir o próprio solo. Eles não têm uma visão capitalista, isto é, não se relacionam com a natureza sob a égide da propriedade, do domínio e nem da posse nem de forma predatória, embora esta cultura nos dias atuais esteja em perigo pelos problemas sociais que enfrenta.

No âmbito das comunidades indígenas, não se discute o direito objetivado e codificado na cidadania urbana.

Outro exemplo é o de uma comunidade indígena de uma ilha da Oceania, onde a máxima do valor social deles era a traição. O homem mais valoroso será o mais astuto, que conseguia fazer amizade com outros índios de outras tribos e quando o nível de confiança já estava bastante acentuado ele convidava o amigo para um banquete em sua tribo, mas não lhe dizia que o convidado é que seria o banquete. Eles eram canibais.

Essa conduta já não é seguida nem por eles mesmos, pois uma cultura desprovida de cidadania não tem como subsistir na face da terra. (No caso específico desses índios, é importante informar que a cultura da traição foi implantada naquela comunidade depois de uma experiência, que eles relatam como sendo a "visita do mal personificado". Antes disso havia cidadania no meio deles).

"A ausência de cidadania faz com que a cultura desapareça".

Até aqui nós observamos que a identidade sociocultural e a cidadania são elementos importantíssimos para a manutenção da vida em comunidade. 
Assim, não é difícil perceber a facilidade de adaptação do judaísmo no cenário amazônico.

A Amazônia no ponto de vista ambiental e cultural é cheia de riquezas, ao lado desta riqueza existe uma degradação da Amazônia ambiental e humana. A pobreza cultural e material atinge todas as classes sociais, o que é um paradoxo diante das suas riquezas.

Existem na região manifestações contra o trabalho escravo, processos de privatização das águas, internacionalização, de divisão do Estado, processo de invasão das terras indígenas.

Todos esses problemas contrastam com a rica diversidade. São problemas resultantes de políticas, e de estrutura patrimonial e burocracia estamental que persiste até hoje.

Toda a economia iria girar em torno do capitalismo mercantil politicamente orientado por interesses de dominação irracionais, interesses particulares. Não havia reinversão. Esta mesma relação seria aplicada ao Brasil, dando inicio a cultura do saque, uma estrutura de dominação que remonta a Portugal dos séculos X e XII.

A Amazônia globalizou-se antes do Brasil se globalizar. A bandeira do desenvolvimento, levantada pelo capitalismo predatório, transformou o processo de integração da Amazônia ao mundo em triste realidade de entrega deste grande patrimônio às economias mais fortes, detentoras do controle financeiro globalizado.

Seus cidadãos estão preocupados e existe um clamor por uma Amazônia baseada na harmonia cósmica entre a pessoa humana e a natureza, entre todos os povos e todos os seres que nela habitam.

E assim observando a Hileia Amazônica que abrigou em seu seio grande massa judaica, ainda nos perguntamos o que é a Amazônia? Não conhecemos todas suas características e peculiaridades que, apesar da rarefação populacional e do distanciamento de centros Administrativos, representa o gigantismo territorial, onde é impossível descaracterizar ou isolar a presença judaica na constituição da nação brasileira nos trópicos, que se compõe de índios, negros, europeus e outros, além da contribuição desses Judeus nas áreas da ciência, do comércio, e aqueles que se destacam na diversificação da literatura, artes, poesias, entre outras.
Esta presença remonta ao tempo da questionável presença, na região, das naves do rei Salomão, em parceria com os fenícios do Rei Hiran entre 800 e 850 AC, que de acordo com o amazonólogo e folclorista Dr. Camillo Vianna - importante estudioso dos assuntos Amazônicos - daí vem a possível origem da denominação do Rio Solimões.

No principio, existia a vida plena, havia os rios, as florestas, as várzeas, e seus habitantes aquáticos, terrestres e os pássaros de todas as cores e de todos os cantos, distribuídos por um enorme tapete verde cerrado. Havia, também, seus administradores, nativos que para sobreviver no meio desse ambiente selvagem não possuíam, porém, qualquer selvageria.

Por mais que se tente reproduzir a Mata Atlântica ou outras regiões de floresta fora do centro-norte, nenhuma se compara à densidade e à força impactante da Amazônia.

Ela própria se defende. É incrível como ela não precisa de nós. Nós é que precisamos dela!

Hoje o Corpo de Fuzileiros Navais e o Exército Brasileiro são os mais bem preparados em todo o mundo para sobrevivência na selva. E grandes corporações militares de países desenvolvidos, enviam anualmente dezenas de pessoas para aprenderem com os nossos soldados como sobreviver na selva. E, muitos deles não conseguem terminar o curso. Imaginem os mariners norte-americanos, os boinas pretas e outros pelotões de elite desistindo de exercícios de treinamento porque não suportam o ambiente da Floresta Amazônica.

É importante frisar que estamos nos referindo ao ambiente in natura, à mata virgem, à floresta natural. A Amazônia é um lugar bastante habitado, com mais ou menos 20.000 .000 habitantes, e não apenas por seres próprios da floresta tropical, mas também por comunidades humanas, organizadas em sociedades com princípios, valores, normas, preceitos e cultura muitos bem elaborados. Portanto, para que a sobrevivência na floresta fosse possível, tornava-se essencial que toda conduta social fosse baseada em cidadania, baseada no respeito mútuo, na urbanidade, integração social e ambiental. E nesse aspecto, todas as comunidades que se estabeleceram na Amazônia foram mais ou menos iguais. 
Inúmeras grandes nações indígenas, de troncos linguísticos diversos, habitaram a Amazônia em perfeita harmonia com o meio, sem degradação e sem serem exterminados por ela.

A ocupação da Amazônia pelos colonizadores diferiu do resto do país justamente pela distância dos centros administrativos da colônia. Mas houve momentos de grande salto econômico, após a independência, e, principalmente, na época áurea da borracha, quando Santa Maria de Belém do Grão-Pará começou a tomar ares de grande cidade, para os padrões da época. O desenvolvimento foi tão grande que fomentou até a revolta separatista chamada "revolta dos cabanos". O avanço econômico atraiu os interesses de muitos investidores estrangeiros, assim como muitos aventureiros, quer seja para fugirem da instabilidade política, quer seja da miséria que crescia na Europa do século XIX, e que buscavam nas Américas alternativas de vida.

Assim a Amazônia foi invadida por diversas culturas.

Com a invasão cultural e a consequente miscigenação com os povos locais, os princípios éticos que antes norteavam as relações sociais foram um pouco abalados. Pois a cultura imposta não valoriza a ética e a cidadania como máximas sociais e isso engendrou diversos conflitos. As nações locais começaram a perder sua identidade sociocultural. Hoje temos em torno de $5 \%$ apenas da população indígena que havia na Amazônia no inicio da colonização. E nesses poucos sobreviventes pouco restou dos princípios e valores sociais. Quando muito, valem-se dos estereótipos, que não revelam a essência da postura ética. Tribos como Uai-uai ou os Mundurucu, da região do Tapajós, ou os Menbengôcrê do alto Xingú, ainda são referências locais, mas não se sabe por quanto tempo conseguem resistir à globalização.

Pois bem, nesse cenário de mistura étnica e cultural, chegaram no final do século XIX muitos Judeus do Marrocos, Espanha e Península Ibérica para a região Amazônica. A grande maioria era muito pobre, muito religiosa e muito apegada à tradição. Vinham de uma condição de extrema necessidade e precisavam encontrar um lugar onde pudessem recomeçar a vida.

A adaptação teve percalços normais, mas que não comprometeram a eficácia do processo, principalmente porque as prerrogativas que o local impunha já faziam parte dos valores culturais que os imigrantes traziam na bagagem. Assim como as comunidades indígenas, os primeiros Judeus da
Amazônia trataram com imenso respeito os recursos que a terra lhes oferecia. E assim, foram bem aceitos por ela.

Sobreviver na Amazônia dependia apenas de predisposição para o trabalho e respeito, muito respeito pelas raízes locais. Em sua maioria, como os demais semitas que migraram para lá naquela época, eram mercadores, e aos poucos foram se organizando em comunidade.

Diante dessa realidade, surgiu nesse século, na Amazônia um movimento de retorno às raízes da cidadania universal, preconizada nos princípios éticos judaicos. Diversos eventos e projetos voltados à educação ambiental, à produção cultural, à pesquisa de alternativas para melhoria da qualidade de vida da população têm sido implementados e apoiados pela comunidade judaica na Amazônia.

E nesse cenário tem tido um destaque muito significativo o Congresso Internacional Israelita de Sociosfera na Amazônia, o CISA, concebido e sediado em Belém, no Pará. Dedica-se a estudos profundos dos problemas inerentes a Amazônia, a sua contextualização no cenário nacional e internacional em busca de incessantes alternativas para proporcionar e consolidar o crescimento e o desenvolvimento regional aproveitando o potencial humano que nela habita.

Quando os Judeus da Amazônia se identificam como uma pequena comunidade, a sociedade em geral não acredita. Tem a impressão que são muito mais numerosos. Assim como o grande número de descendentes que ainda trazem alguns sinais de identificação. Isto se deve a que a maioria deles pertence à classe média e é frequente encontrá-los em ambientes de atividades acadêmicas, recreacionais e culturais, profissionais e empresariais e incorporados á atividades de relevância regional e nacional.

Devemos reconhecer a contribuição de destacados indivíduos de origem judaica por seu espírito empreendedor ao acervo cultural, nacional, na ciência e na indústria desta nação, como David José Perez e Jaime Jacinto Aben Athar.

Porém, o ente coletivo Judeu pela sua obstinação em conservar suas características diferenciadas e pelo seu esforço por manter viva suas tradições e costumes ancestrais, constitui para os outros Amazônidas motivo de incompreensão. Sentem-se desconfortáveis pela sua persistência em casarem 
entre si, e sentem como se fosse uma rejeição a sua amazonilidade. Como se não fosse seu desejo incorporarem-se cabalmente na vida nacional.

O povo Judeu nunca gostou do exílio, sua disposição é de encontrar um lugar onde possa sentir-se em casa, terminar o largo itinerário na busca de um lugar seguro para viver com liberdade. Por tudo isso ele, muito rapidamente, se adapta, sente como sua a terra ancestral que lhe dá refúgio e, em pouco tempo de estabelecido, ele demonstra seu amor e já arrisca sua vida por ela.

Lamentavelmente, nem sempre esta é uma relação correspondida. Existem aqueles que por ciúmes e desconfianças divulgam o temor de que os Judeus vão se apoderar do que é deles. Nestes dias quando ainda permanece a ameaça da internacionalização da Amazônia, então, essa preocupação está sempre na pauta dos habitantes da região. Não importa que isso nunca tenha ocorrido nos países onde os Judeus estiveram no passado.

Contudo, eles já estão integrados nesta mescla tão bonita e sábia que deu forma a população da Amazônia, e os tornou um povo tolerante, simples, hospitaleiro com relação à diversidade de etnias como os índios, quilombolas, ribeirinhos e os caboclos da região.

Hoje, ainda que o Judeu se sinta tentado a escapar da sorte que o colocou como um joguete da história, ele tem o compromisso com essa mesma história e com o passar dos séculos tem confirmado sua convicção de que "não deve dar-se por vencido o homem que optou ser diferente". (É muito difícil porque a sociedade não aceita que sejamos diferentes e tenhamos os mesmos direitos).

Às vezes, permanecer sendo Judeu, sendo aquele que apenas por ser Judeu viu assassinado um terço do seu povo, representa um compromisso mais forte que o seu desejo egoísta de esquecer o passado e entregar-se aos prazeres da despreocupação nesta aventurosa região, porque, ainda que insistam em ser diferentes, está em jogo, o conceito mesmo de ser humano.

Não existem razões justas para desconfiar daqueles que professam outras religiões.

Amar ao Brasil, a Espanha, Portugal, Israel, Itália ou qualquer outro lugar ao que se está sentimentalmente ligado por razões históricas ou intelectuais, não implica deixar de amar sua pátria e não poder manifestar sua dedicação e lealdade àquele País que o viu nascer e quer ver prosperar seus filhos.

\section{A Torah não contradiz isso!}

Em um mundo onde a convivência do fraco com o forte e a Justiça Social não estão garantidos, o compromisso do homem é com todos os homens, não para que triunfem uns sobre os outros e imponham suas crenças, mas para que triunfe o pluralismo, o direito de todos os povos a permanecer sendo o que são e como são.

O Judeu luta hoje para ser aceito como ente coletivo. Sua participação individual é mais clara e evidente, porém com o tempo sua contribuição como entidade que tem depositado sua confiança no país será reconhecida, assim como seu empenho para vê-lo sair de suas dificuldades será reconhecida.

Sua dedicação à filantropia,não é só para aliviar a carga do Estado Brasileiro, e não apenas no que diz respeito à velhice, à saúde e à educação dos seus cidadãos Judeus menos afortunados, mas por sua contribuição generosa e o trabalho voluntário na constituição de entidades dedicadas a servir com esses fins as populações da Amazônia mais necessitadas e sua dedicada colaboração com instituições nacionais e privadas em matéria de saúde, educação, cultura, meio ambiente, pobreza, ciência, infância abandonada.

É indiscutível que a influência da nação no Judeu Brasileiro e Amazônida, sobrepassa a modesta contribuição de uma comunidade pequena e com apenas 200 anos.

São muitas e grandes as lições aprendidas pelos Judeus da Amazônia: a tolerância é uma delas, graças a qual, a maioria dos Judeus nascidos no país tem tido a mesma oportunidade que os demais amazônidas de chegar a receber inclusive educação superior, em muitos casos gratuita.

Essas qualidades insuperáveis levam a presença de outras, uma das mais valiosas conquistas do homem, a liberdade, que no Brasil, na Amazônia, se respira como o ar.

A informalidade, a simplicidade no trato, a hospitalidade, a amizade, a dedicação e respeito que dedicam aos anciãos, o que não é frequente em outros povos e sociedades, a limpeza corporal, o desempenho pelas artes 
manuais, o sentido do ritmo, a sensibilidade artística, a facilidade de aprender e adaptar-se ao seu humor sadio, a delicadeza, a resignação com a que aceitam as dificuldades e as diferenças sociais chamavam a atenção dos recém-chegados.

Enquanto que a deliciosa culinária regional é absorvida pela gastronomia judaica local, mulheres judias conseguiram verdadeiros milagres adaptando os sabores dos pratos regionais aos seus cardápios, respeitando as leis da dietética mosaica.

Não há registros de aparecimento de manifestações antissemitas.

Durante a Cabanagem, contrariando alguns autores, o que sucedeu foi uma disputa pelo mercado competitivo.

\section{Conclusão}

Os Judeus da Amazônia, ao longo da história, estiveram sempre atentos, pesquisando seu passado, as ideias, o ideal e o mistério da sua sobrevivência, buscando no passado o sentido para suas realizações contemporâneas dedicadas à Amazônia, sem esquecer o Estado de Israel e o Sionismo que ocupa um lugar central na vida espiritual e tradicional da comunidade, para onde converge a satisfação pelos resultados morais das suas ações como Judeus Brasileiros e Amazônidas.

O particularismo da visão judaica não os restringe, ao contrário, permite relacionar-se com todos os segmentos da sociedade pública e privada, com Israel, e com as comunidades judaicas do mundo, através da divulgação da proposta do movimento sobre a temática Ecologia e Judaísmo, que estimula a abordar e investigar dentro da tradição ancestral, a temática humana e propicia a identificação simultânea do particular e o universal. E, consequentemente, proporciona também maior identificação e aproximação da população Judaica e seus descendentes com a comunidade e com a região, que não estão envolvidas nem com a política comunitária nem com a religião, porém se identificam com os valores universais, cuja fonte está no judaísmo; isto confere hoje à população Judaica da Amazônia a posição singular de cidadania.

Na Amazônia, os níveis de saúde, educação, habitação, previdência, lazer e outros que se constituem em indicadores do Bem Estar Social de um povo, esse nível de Bem Estar é em função do grau de desenvolvimento alcançado pela região ou país em que essa população se acha inserida.

Há, portanto, a necessidade de conceber o "recurso humano" em uma acepção dinâmica, humana e social. O sucesso de uma política voltada para a Amazônia se caracteriza pela adoção do homem que nela habita, na qualidade de sujeito da ação política e não como objeto e vítima dessa ação.

$\mathrm{O}$ fato dos Judeus não terem perdido sua identidade judaica, depois de tantas gerações, participando como cidadãos Judeus Brasileiros da Amazônia em tempo em que ameaças de destruição e dominação se apresentam, ao mesmo tempo em que a sobrevivência da Amazônia e do planeta Terra tem significado para a humanidade e corresponde à responsabilidade de todos nós, é aí que surge o CISA - movimento formidável que vem de baixo pra cima, que reúne o povo e o governo em torno de ações solidárias e comuns e atua em benefício da Amazônia, tendo o homem da Amazônia como o centro de sua atenção, expandindo ações através da Ecologia Humana.

A ecologia na Amazônia surge como o grito dos povos, exemplo de identidade e cidadania em nossos dias.

Nós, Judeus da Amazônia, sempre buscamos a paz. Apesar das adversidades em nossa nação, no Brasil estamos identificados com um exército que combate doenças e promove educação, com generais que nunca fizeram uma guerra; são soldados de um país com vocação para a Paz.

\section{Referências Bibliográficas:}

BENCHIMOL, Samuel - Estrutura Geo-Social e Econômica da Amazônia $-1966$.

Excedente Social - PLADES - UFPa/NAEA

BENTES, Abraham- Das ruínas de Jerusalém a verdejante Amazônia Formação da $1^{\text {a }}$ Comunidade Israelita Brasileira - 1987

SERRUYA, Reina - Filhos de Quem Somos - 2000

BECHIMOL, Samuel - Judeus no Ciclo da Borracha - 1994 
TORRES, Benigno Jorge Durval - As Migrações Internas na Amazônia 1997 - UNAMA

BECHIMOL, Samuel - Amazônia Formação Social e Cultural - 1999
O dilema da educação judaica formal numa comunidade judaica diáspora

Anita Brumer ${ }^{2}$

\section{Introdução}

— undada há aproximadamente um século, a comunidade judaica de Porto 1 Alegre, situada no extremo sul do Brasil, começa a preocupar-se com a questão de sua própria continuidade. Um dos seus principais dilemas parece ser o da educação das novas gerações, que se defronta com vários desafios, tais como a diminuição do número de crianças e jovens frequentando escolas judaicas, o financiamento de seus custos, a decisão sobre o conteúdo e a quantidade do tempo dedicado ao programa de estudos judaicos e o recrutamento de professores responsáveis pela transmissão da língua hebraica e da cultura e tradições judaicas. Todas essas dificuldades são o resultado de mudanças mais amplas que ocorreram na comunidade judaica local durante as últimas décadas, tais como a crescente assimilação e secularização de seus membros.

Este texto tem dois objetivos primordiais: (a) explicar a emergência dessas mudanças; (b) examinar a problemática da educação judaica com a qual a comunidade judaica tem se defrontado. Os dois temas relacionam-se com a questão da continuidade numa pequena comunidade da Diáspora ${ }^{3}$.

O ponto principal, conforme indicado por Levy (1987, p.161), está em como a socialização de uma minoria étnica específica pode ser feita,

\footnotetext{
${ }^{1}$ Uma versão anterior deste texto foi apresentada no 12th World Congress of Jewish Studies, realizado em Jerusalém, de 29 de Julho a 5 de Agosto de 1997. Agradeço a Iosef Goldstein os comentários à versão do texto apresentado naquela ocasião, bem como a indicação do seu próprio texto e do texto de Daniel C. Levy, que foram muito úteis na formulação da versão atual. ${ }^{2}$ Doutora em Sociologia Universidade Federal do Rio Grande do Sul.

${ }^{3}$ A noção de 'pequena' é obviamente relativa. Consideramos a comunidade judaica de Porto Alegre como pequena, quando comparada com as comunidades judaicas de São Paulo e do Rio de Janeiro, mas ela é certamente maior do que outras, como as comunidades do interior do estado do Rio Grande do Sul. Comparando com São Paulo e Rio de Janeiro, por exemplo, Porto Alegre oferece um menor número de opções em termos de educação judaica. O grau de autoconhecimento da população judaica provavelmente também é maior.
} 
num contexto de crescente assimilação e secularização no qual estão em disputa diferentes concepções de como os grupos devem orientar-se em termos de uma identidade nacional.

\section{Imigração e integração}

A imigração judaica para o Rio Grande do Sul teve início no século XIX, com poucos indivíduos e famílias, sem que se tenha formado uma comunidade judaica organizada ${ }^{4}$. Essa organização passa a ocorrer quando, no início do século XX, a Jewish Colonization Association OCA) adquiriu terras no estado do Rio Grande do Sul, fundando algumas colônias agrícolas judaicas, tais como Philippson (1904) e Quatro Irmãos (1909). Devido a dificuldades econômicas, culturais e políticas, a maioria dos colonos abandonou as colônias cerca de duas décadas depois, indo para cidades próximas, como Santa Maria e Erechim, ou para Porto Alegre, a capital do Estado. Outros imigrantes, desde o final da primeira década desse século, começaram a imigrar, de forma individual, diretamente para Porto Alegre.

Desde sua chegada como um grupo, os imigrantes judeus começaram a construir os alicerces necessários para sua organização comunitária. Entre suas prioridades estavam a prática religiosa, a solidariedade com os novos imigrantes da mesma origem geográfica e a educação das crianças. A educação judaica formal era transmitida inicialmente para pequenos grupos de crianças, adotando o modelo do cheder $^{5}$ que já era praticado em seus lugares de origem, por membros da própria comunidade preparados para isso, e posteriormente, em 1922, foi fundada uma escola elementar judaica.

${ }^{4}$ A presença de alguns judeus no Rio Grande do Sul originários da região da Alsácia-Lorena, em disputa entre a França e Alemanha, no final do século XIX, foi destacada por Egon e Frieda Wolff (Wolff, 1975: p. 485-96). Por outro lado, a confirmação de que os açorianos que fundaram Porto Alegre no século XVIII eram de origem judaica (o que foi sugerido por Egon e Frieda Wolff, 1975: p.485) e a inclusão de alguns judeus entre os imigrantes alemães que vieram para o Estado, a partir de 1824, ainda está por ser devidamente documentada, havendo alguns indícios de que isso tenha ocorrido (como a existência de ruas com o sugestivo nome de 'Rua dos Judeus' em algumas cidades de colonização alemã do interior do Rio Grande do Sul e de símbolos judaicos em regiões de imigração açoriana). Com base em informações de fontes diversas, Egon Wolff contabilizou a presença de quase uma centena de judeus no Rio Grande do Sul durante o século XIX (Egon e Frieda Wolff, 1993-1994: p.20).

${ }^{5}$ Asheri caracteriza o cheder como "Escola elementar judaica, que geralmente funciona após as horas escolares comuns". (Asheri, 1995: p.348)
A origem dos imigrantes era diversa. A maioria (entre 1500 a 2000 famílias) era de ashkenazim e veio da Europa Oriental (principalmente da Rússia, Polônia e România), um pequeno grupo de cerca de 250 famílias veio da Alemanha e outro grupo de cerca de 250 famílias sefaraditas veio da Turquia e do Egito. Como resultado, apesar de ser uma comunidade judaica relativamente pequena, ela era bastante heterogênea.

A população judaica do Rio Grande do Sul, de acordo com os censos oficiais do IBGE, era de aproximadamente 6.619 indivíduos em 1940, 8.048 em 1950, 11.165 em 1960 e 8.330 em 1980 (Wolff, 1993-1994: p.33). A comunidade judaica apoiava-se em seis sinagogas, três associações culturais, esportivas e sociais, organizações femininas e beneficentes, uma escola e diversas outras organizações.

Muitos dos imigrantes judeus iniciaram sua atividade econômica como mascates e, logo que possível, abriram suas próprias lojas. Outras atividades comuns entre os primeiros imigrantes eram a confecção de roupas e a fabricação de móveis, assim como a construção civil (Scliar, 1990).

Na década de 1960, muitas mudanças já podiam ser observadas na comunidade judaica do estado. Imigrantes judeus ou seus descendentes começaram a deixar as pequenas cidades onde se haviam estabelecido uma ou duas décadas antes, mudando-se para a capital do estado. Alguns jovens saíram até mesmo do estado do Rio Grande do Sul, procurando melhores oportunidades em outros estados brasileiros (São Paulo e Rio de Janeiro, preferencialmente) ou no exterior (principalmente Israel). A maioria dos jovens pôde frequentar a Universidade, tornando-se médicos, engenheiros, advogados, professores universitários ou funcionários públicos municipais, estaduais ou federais. Também ocorreram mudanças nas organizações da comunidade judaica, decorrentes principalmente da diminuição da frequência em serviços religiosos regulares e em eventos sociais e culturais.

Numa pesquisa realizada em 1992-3 (ver Brumer, 1994), a população judaica do Rio Grande do Sul pôde ser estimada entre 11 e 12 mil indivíduos $^{6}$ (números que provavelmente são menores atualmente),

\footnotetext{
${ }^{6}$ Uma diferença entre a estimativa proporcionada por essa pesquisa e a dos censos do IBGE é que esses últimos utilizam o critério da religião como identificação judaica, enquanto que a pesquisa promovida pela Federação Israelita do Rio Grande do Sul considerou a autoidentificação como judeu ou judia como critério principal.
} 
caracterizada como predominantemente urbana, com $90 \%$ do total residindo em Porto Alegre. Os dados dessa pesquisa permitiram verificar, ainda, uma maior distribuição espacial dentro da cidade entre os mais jovens do que entre os mais velhos, e um alto nível educacional, também maior entre os mais jovens do que entre os mais velhos. Ao mesmo tempo, o processo de assimilação e secularização era demonstrado pela diminuição das práticas religiosas, pelo aumento no número de casamentos mistos e pela diminuição da participação em atividades regulares da comunidade judaica.

Apesar do aumento da assimilação e da secularização de seus membros, grande parte da população entrevistada na pesquisa referida acima manifestou sua autoidentificação como judeus, variando no entanto nos critérios de identificação, sejam religiosos, culturais ou de descendência. Este tipo de identificação aproxima-se bastante do que Cardoso de Oliveira (1978) chamou de identidade contrastiva, considerando que o conceito de identidade inclui tanto a autorrepresentação do indivíduo como a maneira como ele é visto pelos outros ${ }^{7}$.

Levando em consideração as características empíricas dos judeus contemporâneos, de acordo com os termos formulados por Barth (1976), eles podem ser considerados como um grupo étnico. Barth (1976: p.11) indica que a expressão 'grupo étnico' é utilizada na literatura antropológica para referirse a comunidades que: 1) em grande extensão perpetuam-se biologicamente; 2) partilham valores culturais básicos como uma unidade manifestada através de expressões culturais; 3) integra um campo de comunicação e interação; 4) é formada por membros que se identificam e são identificados por outros como uma categoria distinta de outras categorias do mesmo tipo. De acordo com Barth, algumas dessas características deveriam ser mais bem examinadas, enquanto que outras deveriam ser acrescidas à lista. Para começar, ele argumenta que as expressões culturais partilhadas dos grupos étnicos deveriam ser consideradas antes como uma consequência do que uma característica elementar e definitiva de sua organização. Ele considera também que as formas culturais manifestas refletem uma história tanto da adaptação do grupo a um dado meio ambiente quanto as circunstâncias externas às quais os atores individuais tiveram que se adaptar. Em consequência, ele acredita que o mesmo grupo de indivíduos, tendo ideias e

${ }^{7}$ Uma discussão sobre o conceito de identidade judaica é apresentado em Brumer, 1994: p. 29-49. valores semelhantes, pode ter adotado diferentes padrões de vida e institucionalizado diferentes padrões de comportamento quando confrontado com diferentes oportunidades oferecidas pelo ambiente e circunstâncias (Barth, 1976: p.134). Ao mesmo tempo, a cultura do grupo é transmitida de geração para geração, com o resultado de que mesmo quando alguns indivíduos viveram em diferentes ambientes, eles ainda partilham muitas características comuns.

Outro aspecto que deve ser incluído no conceito de grupo étnico é sua organização, com base em que os atores individuais usam sua identidade étnica para categorizar a si próprios e aos outros, estabelecendo quem pode e quem não pode pertencer ao grupo. Um grupo étnico é ainda um grupo político no sentido de que ele é um grupo de interesses. Como tal, seus membros lutam pelo direito de impor uma definição legítima das divisões do mundo social e, dessa maneira, influenciam o fazer e o desfazer dos grupos (Bourdieu, 1989: p.113).

O fato de que a escola judaica tenha tanta relevância como um meio de consolidar e transmitir a identidade judaica pode ser visto, num primeiro olhar, como uma contradição, quando se considera o baixo nível de práticas religiosas entre os judeus. No entanto, uma grande parte da população judaica de Porto Alegre não vê isso como contraditório, principalmente devido a sua adesão a uma identidade judaica secular. Levy (1987, p.157), citando Barylko, constata este fato, indicando que os judeus latinoamericanos são majoritariamente seculares, sendo a "não centralidade da sinagoga" justaposta à "centralidade da escola". A questão que permanece é se o judaísmo pode realmente ser transmitido através das gerações sem seus elementos religiosos básicos.

\section{Mudanças nas comunidades judaicas}

Diferentemente de outras religiões, o judaísmo nunca foi adepto do proselitismo, isto é, tentar convencer não judeus a tornar-se judeus. Entretanto, a conversão para o judaísmo é às vezes aceita, embora com relutância. Para converterem-se, homens devem ser circuncidados, cerimônia que é seguida de imersão no banho ritual (miqveh). Devem também aprender os rudimentos da religião judaica e da língua hebraica (com a finalidade de poder rezar juntamente com outros judeus em sua 
congregação) e declarar sua aceitação das kabbalat mitzvot (isto é, aceitação da prática dos mandamentos) (Asheri, 1995: p.267-9).

É desnecessário dizer que mesmo os que nascem judeus devem aprender os rudimentos do judaísmo e da língua hebraica. A obrigatoriedade desse aprendizado concerne principalmente aos membros da comunidade do sexo masculino, pois, de acordo com a ortodoxia judaica, apenas os homens são incluídos no minyan (quorum religioso de homens que celebraram seu bar mitzvah) necessário para os serviços religiosos na sinagoga. Nas congregações não ortodoxas, porém, as mulheres podem participar das práticas religiosas, necessitando, para isso, de aprendizado sobre religião e língua semelhante ao dos homens. Ortodoxas ou não, no entanto, as mulheres devem conhecer os fundamentos da prática da religião judaica, uma vez que representam a principal fonte de transmissão e prática do judaísmo no lar.

Nas comunidades judaicas tradicionais, durante um período de aproximadamente dois mil anos, a pertença definia-se basicamente pela afiliação religiosa. A conexão entre os membros era feita através da prática religiosa e de um 'governo' interno baseado em suas próprias leis, cujas raízes estavam nas sagradas escrituras. A única maneira de entrar nessa comunidade era através da conversão e para sair dela era necessário renegar a afiliação religiosa.

Nas últimas décadas do século XVIII, como resultado dos ideais e valores disseminados pela Revolução Francesa e das inúmeras transformações que ocorreram no mundo logo depois, as comunidades judaicas da Europa Ocidental foram afetadas. A principal mudança que atingiu as comunidades judaicas foi a adoção do princípio da igualdade civil de todos os cidadãos, que colocou em questão sua pertença a uma comunidade com base quase exclusivamente na religião. Cidadãos de diferentes religiões adquiriram direitos iguais de acordo com a lei e então puderam ter vários tipos de identificação, de acordo com a profissão, afiliação política e outras.

Sorj (1993: p.10-1) caracteriza o judaísmo moderno, que surgiu das ideias divulgadas pela Revolução Francesa, da seguinte maneira: 1) procura de absorção, integração e legitimação do judaísmo nos valores modernos, mostrando que o judaísmo é capaz de conviver e se expressar em termos 'universais'; 2) adoção de um estilo doutrinário, discursivo, lógico, sistemático do judaísmo moderno; 3 ) intervenção em partidos políticos, como partícipes dos principais movimentos ideológicos de seu tempo liberalismo, socialismo e nacionalismo - que colocavam projetos de engenharia social, via sistema político, como seus objetivos centrais; 4) centralização na questão da identificação da essência do judaísmo e do significado de ser judeu, procurando identificar que parte do judaísmo tradicional poderia ser abandonada pelos judeus sem perder sua condição de judeus; 5) tentativa de justificar o direito de existência do povo judeu, com base em sua contribuição para a humanidade ou em sua impossibilidade de assimilar-se; 6) reforço da crise de identidade dos indivíduos entre tradição e modernidade, entre lealdade aos laços primários e ao conjunto da sociedade, entre o privado e público, entre sentimento e razão. Sorj (1993: p.12) mostra que o judaísmo moderno pode ser dividido em duas correntes, a religiosa e a nacionalista, ambas desejosas de integrar o judaísmo à vida social e política moderna. Os caminhos dessas duas correntes eram distintos, pois enquanto os movimentos de renovação religiosa tomaram como referência a tradição rabínica, procurando relaxar as suas exigências e disciplina, o judaísmo nacionalista, majoritariamente socialista, formulou uma nova cultura judaica, secular, desvinculada da tradição rabínica.

De acordo com Sorj (1993: p.12-3), o judaísmo pós-moderno - iniciado em meados do século XX - sofreu tanto os efeitos da dinâmica da sociedade moderna quanto os do novo contexto mundial. Os movimentos antissemitas e o Holocausto mostraram que as ideologias da igualdade, da liberdade e da fraternidade poderiam ser facilmente anuladas por forças políticas capazes de promover xenofobia e o terrorismo de Estado, com grande apoio social. Como resultado, os judeus perderam a ilusão de que poderiam algum dia ser completamente integrados na sociedade: igualdade decretada pela lei não elimina a eventualidade da discriminação e estigmatização. Quando o Estado de Israel foi fundado, em 1948, a maioria dos judeus sentiu-se identificada com ele. Além disso, o sionismo tornou-se a ideologia predominante entre os judeus, provocando a emergência de um ideal de construção de uma nova cultura judaica baseada em princípios seculares.

A criação do Estado de Israel teve dois efeitos principais sobre o povo judeu: primeiramente, ele mudou a autoimagem dos judeus, que se voltaram para ele como uma fonte de identificação; em segundo lugar, ele estabeleceu a língua hebraica como a língua oficial de todos os seus cidadãos. A cultura israelense também influencia o povo judeu em todo o 
mundo, principalmente através da arte, música, dança e literatura. Juntas, essas influências abriram o caminho para considerar-se o povo judeu principalmente como um grupo étnico.

A sociedade moderna também contribuiu para intensificar a tendência de assimilação e secularização dos judeus. Para a maioria dos judeus, tanto a família quanto sua vida diária perderam muito dos aspectos religiosos e tradicionais que permeavam a família e a vida diária de seus antepassados. Como resultado, de modo a promover a continuidade do judaísmo, os meios formais de educação judaica tornam-se fundamentais ${ }^{8}$.

\section{Os problemas da educação judaica formal em Porto Alegre}

Existem diversas maneiras de proporcionar a educação judaica formal de crianças e jovens. Uma delas é, através da educação judaica em tempo parcial, geralmente oferecida em centros comunitários ou sinagogas, complementar a sua frequência regular a escolas laicas. Outra é a formação completa numa escola judaica, onde crianças e jovens recebem tanto uma formação judaica quanto aprendem os conteúdos laicos. Algumas comunidades oferecem adicionalmente o ensino de alguns aspectos do judaísmo, limitado a um ou dois encontros por semana. Adicionalmente, as crianças recebem aulas especiais para preparar-se para o Bar-Mitzvah ou Bat-Mitzvah. Como poderia esperar-se, essas várias formas de ensino judaico formal divergem na ênfase dada ao estudo de temas religiosos e na participação mais ou menos ativa de líderes religiosos em suas atividades.

Desde seu início, durante a primeira década do século XX, a educação das crianças foi uma das principais preocupações da comunidade judaica de Porto Alegre. Logo que a primeira sinagoga foi fundada em Porto Alegre - a sinagoga União Israelita, fundada em 1910 -, seus membros passaram a oferecer a educação judaica complementar (Cheder), após o horário escolar regular. Outros cheders funcionavam em residências particulares (Eizirik, 1984: p.70).

${ }^{8}$ Não se pode dizer que antes do período que se pode denominar de judaísmo moderno a educação formal também não fosse fundamental para a transmissão do judaísmo. A diferença principal é que ela concernia principalmente os meninos e jovens do sexo masculino e centrava-se no estudo da Torah.
Em 1922, a escola judaica complementar que funcionava na Sinagoga União Israelita foi transformada numa escola integral - o atual Colégio Israelita Brasileiro -, que oferecia tanto a educação judaica quanto a educação secular. A escola começou com 70 alunos e dois professores trazidos da Palestina (hoje, Israel). Em 1924, a escola mudou-se para o prédio da Sinagoga Centro Israelita, recentemente inaugurado. Ela mudouse novamente em 1948, para um prédio independente. Finalmente, em 1956, transferiu-se para um prédio próprio, onde está até hoje.

De acordo com Kliemann (1992), por ser paga, a escola judaica teve muitas dificuldades em recrutar estudantes, pois, embora reconhecendo sua importância, a maioria das famílias judias da capital era pobre e as crianças já frequentavam outras escolas da cidade. Em parte devido a isso, os problemas financeiros da escola eram cíclicos. Kliemann (1992: p.43-4) relata que, em 1943 e 1944, quando a escola tinha 164 estudantes, estava tão endividada que quase fechou. Seus problemas financeiros foram finalmente solucionados com o auxílio da comunidade judaica local, graças a uma campanha de coleta de fundos e busca de novos patrocinadores para a escola. Em 1947, a escola tinha 254 alunos e, com o apoio financeiro da comunidade judaica, seus dirigentes começaram a planejar a construção de um prédio próprio e a abertura de uma escola secundária.

No que diz respeito ao ensino de uma língua identificadora do judaísmo, durante as primeiras décadas de funcionamento da escola adotouse o ensino do Yiddish. Posteriormente, durante o período do Estado Novo (1937-1945), o governo brasileiro, liderado por Getúlio Vargas, promulgou uma lei proibindo o ensino de línguas estrangeiras em escolas primárias e secundárias $^{9}$ de todo o País. Como resultado, durante este período apenas o ensino de religião pôde ser incluído entre os temas judaicos ensinados no Colégio Israelita Brasileiro (Eizirik, 1984: p.71). Depois que o Estado de Israel foi fundado, em 1948, alguns professores e pais passaram a defender a suspensão do ensino do Yiddish e sua substituição pelo hebraico, numa clara identificação com aquele Estado. No início dos anos 1960, o ensino do Yiddish foi finalmente abandonado, permanecendo o hebraico como a língua judaica 'oficial' da escola, embora seu ensino, na escola, nunca tenha

${ }^{9}$ Neste aspecto, a comunidade judaica partilhou uma situação semelhante à enfrentada por outros grupos étnicos, que também foram proibidos de ensinar alemão, italiano, polonês ou outra língua estrangeira em suas escolas. 
tido o apoio de todos os pais de seus alunos. Na base da controvérsia estava a questão do tempo a ser destinado a seu estudo, uns defendendo seu aumento, outros propondo sua diminuição ou total eliminação, considerando a necessidade de aumentar o tempo dedicado a estudos seculares e a línguas estrangeiras mais úteis, como o inglês. Para esses pais, a alocação de tempo insuficiente para o estudo da língua estrangeira dificultaria seu aprendizado, sendo este, então, inútil.

No começo, o Colégio Israelita Brasileiro pôde apenas oferecer o curso elementar, logo seguido pelo acréscimo do jardim de infância. Em 1956, foi implementado o curso secundário. Com a exceção de um curto período (um ou dois anos, de acordo com Eizirik, 1984: p.71), em que houve uma outra escola primária judaica - o Colégio Borochov - o Colégio Israelita Brasileiro permaneceu como a única escola judaica de Porto Alegre até a chegada de um rabino do movimento Beit Chabad e sua esposa, nos anos oitenta, que fundaram uma nova escola.

Quando a escola do Beit Chabad foi fundada em Porto Alegre, em 1984, ela atendia à demanda de alguns pais desejosos de oferecer uma educação judaica tradicional a seus filhos. Entretanto, por mais que as atividades desenvolvidas pelo rabino e sua esposa sejam positivamente avaliadas por muitos membros da comunidade judaica local, o número de pais com uma orientação judaica mais tradicional permanece sendo relativamente pequeno e a escola nunca teve uma população estudantil superior a 40, na qual estão incluídos os filhos do próprio casal de administradores e de professores da escola. Decorrem disso tanto a dificuldade de oferecer mais do que algumas séries da escola elementar quanto a baixa capacidade de fazer face a seus custos, muitos dos quais são fixos, independentemente do número de alunos. Por outro lado, o Colégio Israelita Brasileiro, com mais de 800 alunos, mantém atualmente um jardim de infância, todas as oito séries da escola elementar (primeiro grau) e as três séries da escola secundária (segundo grau).

É claro que a escolha entre as duas escolas judaicas de Porto Alegre não decorre exclusivamente do número de séries escolares que elas oferecem. Embora as duas escolas tenham a preocupação de incluir no currículo escolar todos os assuntos programáticos considerados como seculares, adequados a cada uma das séries de ensino, no que se refere ao ensino das temáticas judaicas, as principais diferenças entre elas são tanto ideológicas quanto qualitativas. Enquanto que o Beit Chabad insiste em transmitir, na escola, os principais aspectos da prática religiosa tradicional, juntamente com o aprendizado da língua hebraica, o Colégio Israelita Brasileiro é mais secular, apesar de sua priorização do ensino dos valores, história, filosofia e cultura judaicas, lado a lado com o aprendizado do hebraico. Outra diferença principal está no tempo dedicado ao ensino das temáticas judaicas (língua hebraica e outros assuntos judaicos), uma vez que o Beit Chabad aloca para elas o dobro do tempo que o Colégio Israelita Brasileiro.

Apesar de seu caráter secular, como já indicamos acima, não existe consenso entre os pais dos alunos matriculados no Colégio Israelita Brasileiro com relação à quantidade e conteúdo da educação judaica a ser ministrada na escola. Embora a escola do Beit Chabad não tenha este tipo de preocupações, ela se defronta com sua incapacidade de oferecer todas as séries do curso elementar, bem como o curso secundário, o que obriga seus alunos a transferirem-se mais tarde para uma escola judaica secular como o Colégio Israelita Brasileiro, ou para uma escola não judaica, pública ou particular.

Como se poderia esperar, praticamente não há cooperação entre as duas escolas judaicas da cidade, nem em atividades educacionais nem em atividades extracurriculares. A principal razão para essa falta de cooperação está em suas respectivas orientações relativamente à prática religiosa, com o Beit Chabad - que tem sua própria sinagoga - colocando maior ênfase nisso que o Colégio Israelita Brasileiro. Outra razão é o maior rigor requerido pelo Beit Chabad na definição de quem é judeu, mantendo-se dentro dos princípios da Halachá (lei judaica), que considera como judia uma criança nascida de mãe judia; no Colégio Israelita Brasileiro não são estabelecidos critérios de definição de quem é e de quem não é judeu, sendo suficiente a autoidentificação dos pais.

A breve história do Beit Chabad em Porto Alegre, juntamente com o pequeno número de crianças que frequentam ou frequentaram a escola até agora, tornam prematura a análise dessa escola e sua influência na formação e transmissão da identidade judaica. Por isso, neste momento, nossa análise restringir-se-á ao Colégio Israelita Brasileiro.

A base de nossos dados está em entrevistas com alguns adultos que estudaram na escola, adultos sem prévia experiência de educação judaica formal, jovens recém-saídos da escola, pais de alunos que frequentam a escola atualmente e professores da área judaica da escola. Alguns dados 
quantitativos nos foram generosamente oferecidos pela atual administração do Colégio Israelita Brasileiro.

Como já informamos anteriormente, como uma escola judaica, o conteúdo transmitido aos alunos inclui tanto disciplinas seculares quanto disciplinas judaicas. A parte secular compreende diferentes assuntos, tais como língua portuguesa, matemática, desenho geométrico, história do Brasil, história geral, geografia, química, física, biologia, língua inglesa e filosofia. Ela inclui ainda a prática de artes, teatro, música, esportes e informática. Uma vez que um alto nível de ensino é exigido em cada um desses temas, a maior parte do tempo que as crianças passam na escola é dedicado a eles, o mesmo ocorrendo em outras escolas particulares da Capital. Para que tenham também o aprendizado de temáticas judaísmo isto é, cultura judaica, história judaica, literatura judaica e israelense, língua hebraica e danças israelenses - as crianças devem permanecer um tempo adicional na escola, tempo que, caso não estivessem matriculados numa escola judaica, poderia ser alocado para o desenvolvimento de seus interesses individuais.

Diversos problemas de recrutamento de alunos repetiram-se nos últimos 78 anos, em grande parte devido a diferentes concepções do conteúdo a ser ministrado na escola. De acordo com Kliemann (1992: p.33), alguns temas de discussão entre os pais estão presentes desde os primeiros anos da escola, permanecendo até os dias atuais. Alguns desses temas são: 1) a escola pertence à comunidade ou deve dedicar-se à comunidade?; 2) a escola deve enfatizar a educação secular ou a educação religiosa?; 3) as crianças devem aprender mais sobre judaísmo ou ser preparados para ser tanto judeus como brasileiros? Outras questões que vêm se repetindo, por um lado dizem respeito à resistência de muitas crianças ao aprendizado do iídiche ou do hebraico, em grande parte dificultado pela utilização de métodos inadequados, e por outro lado referem-se à falta de apoio financeiro suficiente da comunidade judaica local ou do exterior. De fato, muitos membros da comunidade parecem mais dispostos a apoiar financeiramente um projeto de construção de um novo prédio escolar, ou reformar o prédio já existente, do que contribuir para a manutenção das atividades cotidianas da mesma escola.

Kliemann (1992: p.37) relata que novos métodos de ensino foram introduzidos nos anos 1940, mas a escola continuou a ter problemas em arregimentar professores competentes de iídiche ou hebraico. Como indica a historiadora, alguns dos professores de língua estrangeira conheciam a língua, mas não estavam suficientemente motivados ou não eram pedagogicamente preparados (Kliemann, 1992: p.37). Este problema não foi completamente resolvido até agora, principalmente porque Porto Alegre não conta com uma escola de formação de professores de língua hebraica, religião e cultura judaicas.

Como relata Kliemann (1992: 68), em 1954, dois professores de língua hebraica vindos de Israel foram demitidos como resultado de incompatibilidade com os interesses da administração da escola. Eles "reclamavam do salário e do tratamento recebido, faltavam a muitas aulas e justificavam seu proceder pelo fato de não conseguirem se adaptar ao ambiente" ${ }^{, 10}$ O envio de professores de Israel para o Colégio Israelita Brasileiro, de acordo com Goldstein (1993), fez parte de uma estratégia do movimento sionista, no início dos anos 50, de aprimorar a educação judaica na diáspora com o auxílio do governo de Israel. Já naquela época, o judaísmo brasileiro sofria os efeitos do isolamento cultural e de um ambiente político que pressionavam à assimilação (Goldstein, 1993: p.42). Na cúpula do Departamento de Educação e Cultura para a Diáspora de Israel, dependendo de sua direção, dava-se uma tensão ideológica entre, de um lado, a concepção de hebraização da educação por uma abordagem centralizadora governamental, que enfatiza o Estado de Israel e o processo de reunião das diásporas, via emigração para Israel (alia), concepção que privilegiava o ensino do hebraico, o estudo de Tanach e o conhecimento de Israel; e, de outro, a concepção que favorece a continuidade judaica nas comunidades ocidentais e se satisfaz com instrução e auxílio através de shlichim (professores de Israel) (Goldstein, 1993: p.42-5). À parte esta disputa, permanecia a questão: seria melhor trazer professores de Israel ou preparar professores locais com o auxílio do movimento sionista? Acabou prevalecendo a ideia de atribuir maior independência às comunidades do Ocidente, cabendo à organização sionista apenas o auxílio às necessidades básicas e à preparação dos professores locais.

Como informam nossos entrevistados, da mesma forma que alguns professores enviados de Israel tiveram problemas de incompatibilidade com a

${ }^{10}$ Um exame detalhado dos conflitos existentes na época, que também ocorreram em escolas judaicas do Rio de Janeiro e de São Paulo, é feito por Goldstein (1993). 
administração do Colégio Israelita Brasileiro, outros se integraram muito bem, prestando excelentes serviços. De qualquer modo, Levy (1987, p.179) indica que os principais problemas enfrentados com os shlichim na América Latina eram: 1) as despesas necessárias para o transporte, instalação, aprendizado da língua local (espanhol ou português) e rápido 'turnover'; 2) problemas de comunicação, pois quando chegavam a aprender a língua local iam embora; 3) medo dos pais de que os shlichim acabassem recrutando seus filhos para emigrar para Israel. Uma professora da área judaica do Colégio Israelita Brasileiro entrevistada informou que apenas em meados dos anos 1980 a escola deixou de receber professores enviados de Israel para o ensino do hebraico. Para ela, um dos motivos para a interrupção desse tipo de colaboração foi a falta de continuidade da atuação desses professores, pois eles vinham a Porto Alegre como shlichim, por um período determinado, retornando a Israel ao término de sua missão (o rápido turnover' indicado por Levy). A esse motivo, somava-se o fato de que a orientação políticoideológica desses shlichim variava de acordo com as mudanças políticoideológicas do governo de Israel. Mas, como salienta Levy, "o principal problema estava na demonstração de que essas comunidades, de um modo geral autônomas e bem sucedidas, não conseguem produzir profissionais dispostos a assumir um dos mais importantes papéis na preservação da identidade judaica" (Levy, 1987: p.180).

Já nos anos 50, um problema tornou-se evidente: "como adequar o ensino da religião e do hebraico ao ensino leigo, sem que um prejudicasse o outro e de maneira que os estudantes saíssem da escola com uma boa formação judaica, mas também preparados para competir em sua profissionalização" (Kliemann, 1992: p.68). Durante os anos seguintes, em várias ocasiões, quando os professores de hebraico ou o Vaad Hachinuch (Departamento de Educação), sediado no Rio de Janeiro, requeriam horas suplementares a serem dedicadas ao ensino de hebraico, professores das disciplinas seculares opunham-se a isso, argumentando que as disciplinas seculares ficariam prejudicadas. Eles também reagiam à intrusão de uma instituição de fora, o Vaad Hachinuch, nos assuntos internos da escola.

Durante toda a história do Colégio Israelita Brasileiro, tem variado a importância dada ao ensino das temáticas judaicas, assim como os métodos aplicados também sofreram transformação. Durante um desses períodos, conforme relatado por Kliemann (1992: p.74-5), o judaísmo era praticado na escola principalmente através das comemorações das festividades judaicas: Pessach, Rosh Hashana, Lag Baomer e muitas outras. Isso fez uma ex-diretora da escola concluir que "Nós não fomos os melhores incentivadores do ensino judaico na escola. Um dos defeitos no tempo em que eu trabalhei foi a falta de consciência de que o processo (de ensino) era um todo' (citado por Kliemann, 1992: p.75).

Como já foi indicado acima, outro aspecto sobre o qual nunca existiu consenso na escola é o estudo da língua hebraica. Os pais que defendem sua eliminação utilizam dois argumentos principais. $\mathrm{O}$ primeiro é a necessidade de diminuir o número de horas que as crianças permanecem na escola, tendo em vista que, em comparação com o ensino ministrado em outras escolas particulares da Capital, o estudo das matérias judaicas requer horas adicionais. $\mathrm{O}$ outro é a avaliação de que as crianças terminam sua escolaridade no Colégio Israelita Brasileiro sem dominar a língua, em decorrência do tempo relativamente pequeno dedicado a seu estudo. Ocasionalmente, os opositores ao estudo do hebraico manifestam sua posição, mas até o presente os que são favoráveis a ele têm predominado, e o hebraico continua a ser ministrado na Escola. Para compensar o relativamente pequeno número de horas dedicado a seu estudo, a Escola tem investido em novas metodologias de ensino, inclusive com o auxílio da informática.

Dois outros temas sobre os quais não existe consenso são: 1) determinar como deve ser o ensino e a prática da religião judaica; 2) a observância dos feriados religiosos. No que se refere ao ensino da religião e prática religiosa, a Mantenedora da Escola ${ }^{11}$, refletindo a visão da maioria dos pais - basicamente seculares e frequentadores da sinagoga apenas nas festividades judaicas mais significativas (Rosh Hashana e Yom Kipur) -, tende a reduzi-lo ao mínimo, o que nem sempre é bem aceito pelos líderes religiosos das sinagogas locais ${ }^{12}$, encarregados de ensinar a religião judaica na Escola ${ }^{13}$. Esses professores

${ }^{11}$ A Mantenedora da Escola é o órgão administrativo que coordena as atividades da Escola. Ela é formada por pais de alunos, eleitos pela Assembleia de Pais da Escola, e por seus diretores (da área didática e administrativa). Como regra, a seção de estudos judaicos não está representada nesse corpo administrativo.

12 Porto Alegre conta com sete sinagogas, mais uma no Lar de Velhos e outra no Colégio Israelita Brasileiro. Até há pouco tempo, apenas uma, a do Beit Chabad, mantinha um rabino confirmado, o que recentemente aconteceu com mais uma, que acaba de contratar um rabino com formação ortodoxa. Outras três sinagogas contam com um líder religioso. Todos os rabinos ou líderes religiosos que atuam na cidade vêm do exterior, principalmente da Argentina.

${ }^{13}$ A modalidade adotada recentemente, e que parece agradar mais aos alunos e aos pais, é uma atividade chamada de "Conversando com o Rabino", em que, em lugar de preparar uma 
também reclamam do fato de ensinar uma temática considerada como um assunto estranho tanto às crianças como a suas famílias. Quanto ao segundo, os que são favoráveis à observância do Shabbat predominam: a Escola permanece fechada tanto aos sábados como nos feriados judaicos. Em acréscimo, às sextas-feiras à tarde as atividades escolares terminam mais cedo (o que leva alguns pais a reclamar que os alunos que estudam à tarde, embora paguem as mesmas mensalidades, têm menos horas de estudo que os que estudam de manhã) e comemora-se o Shabbat na sinagoga da Escola, a cada semana organizado por um grupo distinto de alunos. As festividades judaicas também são comemoradas na Escola, e no conteúdo programático está incluído o conhecimento de seus significados.

O fechamento da escola aos sábados e nos feriados judaicos é provavelmente uma das diferenças mais visíveis da escola judaica em relação às escolas não judaicas. O efeito prático disso é que, quando são necessárias aulas extras, como as oferecidas a alunos da última série do curso secundário que se preparam para o exame de ingresso à Universidade (vestibular), elas são dadas em horários extraclasse, durante a semana, ou aos domingos pela manhã.

De um modo geral, ao longo de sua história, o Colégio Israelita Brasileiro tem sido considerado como uma das melhores escolas de Porto Alegre, o que é atestado pelos índices de aprovação de seus egressos em exames vestibulares. Esta qualidade parece ser comum a outras escolas judaicas da América Latina, pois, como indica Levy (1987), num contexto no qual as escolas financiadas pelo Estado são precárias, as escolas judaicas incluem-se entre as escolas particulares (ou comunitárias) ${ }^{14}$, geralmente destinadas à elite desses países. Em comparação com as escolas públicas, as escolas particulares ou comunitárias remuneram melhor seus professores, que assim são mais incentivados a investir em novas e mais atrativas metodologias de ensino, são mais bem equipadas, têm um horário escolar mais longo e são menos sujeitas a interrupções devido a greves de professores.

temática determinada para ensinar às crianças, os líderes religiosos e o Rabino do Beit Chabad que atuam em Porto Alegre alternam-se em seções em que as crianças fazem perguntas às quais eles respondem.

${ }^{14}$ A distinção entre escolas particulares e comunitárias é que as primeiras têm fins lucrativos enquanto que as últimas não têm, mas ambas sobrevivem fundamentalmente com o pagamento de mensalidades.
A necessidade de manutenção do nível de excelência do Colégio Israelita Brasileiro é um dos aspectos em que há consenso entre os pais dos alunos. A percepção de queda de sua qualidade, como ocorreu no início dos anos 90, tem como consequência imediata a retirada de um número relativamente grande de alunos da Escola. Mas esse motivo certamente não é o único a explicar a queda no número de alunos matriculados, registrada na década de 90, pois apesar de a Escola logo ter recuperado sua fama de elevada qualidade, o número de alunos não aumentou.

A perda de alunos na escola judaica não é uma exclusividade do Colégio Israelita Brasileiro. Nessa Escola, após um crescimento contínuo entre 1984 e 1991, quando ela chegou a ter cerca de 1.100 alunos matriculados, houve uma queda substancial. Entre 1991 e 1996, a Escola perdeu 268 estudantes (i.e., 23\% do total), mantendo desde então um número aproximado de quase 900 estudantes. Um relato sobre as escolas judaicas do Rio de Janeiro, feito no Encontro de Estudos Judaicos, na Universidade Estadual do Rio de Janeiro em 1999, indicou que todas as escolas judaicas daquela cidade perderam cerca de $25 \%$ de seus alunos nos últimos seis anos. De forma semelhante, um relatório de pesquisa feito pela Comunidad Judia Argentina (Amia), em 1993, revelou que, entre 1980 e 1993, os jardins de infância frequentados por crianças judaicas perderam cerca de $20 \%$ de sua clientela (Amia, 1993).

O que surpreende, no caso do Colégio Israelita Brasileiro e no das escolas judaicas do Rio de Janeiro, é o curto período de tempo em que ocorreu a diminuição em cerca de $25 \%$ do número de alunos e a dificuldade de captar novos alunos para a Escola nos últimos anos. O significado disso é que diminuiu a proporção de crianças judias frequentando escolas judaicas, que no pico chegou a uns $80 \%$ do total e atualmente deve estar entre $40 \%$ e $50 \%$ do total ${ }^{15}$.

Uma das consequências da rápida diminuição do número de alunos judeus frequentando a escola judaica é que muitos dos jovens atualmente matriculados em escolas particulares não judaicas frequentaram

${ }^{15}$ Sobre este aspecto, Levy (1987) destaca a relativa maior participação de crianças judias em escolas judaicas na América Latina, quando se compara com outros países da Diáspora: enquanto que, na América Latina, a frequência a uma escola judaica em tempo integral pode atingir cerca de metade das crianças judias, na Diáspora em geral atinge apenas 13\%, com mais $24 \%$ das crianças recebendo educação judaica em escolas complementares (Levy, 1987: p.158) 
anteriormente, pelo menos por um curto período, a escola judaica, mas isso provavelmente não ocorrerá com uma nova geração de crianças que fará toda sua escolaridade numa escola não judaica. Neste sentido, a ligação que muitos desses jovens sentem com o judaísmo, que os leva a participar de grupos de dança folclórica israelita, por exemplo, não ocorrerá talvez com os que não tiverem nenhum contato com a escola judaica.

No estudo encomendado pela Amia, os principais motivos apontados para a diminuição do número de alunos matriculados em jardins de infância judaicos são os seguintes: 1) a abertura de jardins de infância particulares não judaicos em bairros com grande concentração de população judaica, aumentando a oferta de escolas; 2) uma distribuição provavelmente inadequada das escolas judaicas em relação à distribuição geográfica da população judaica jovem de Buenos Aires $^{16}$; 3) a apreciação, por muitos judeus, de que as escolas judaicas são frequentadas pelos ricos (sendo então elitistas); 4) a imagem de que as escolas judaicas são sectárias, isolando as crianças da sociedade argentina; 5) a rejeição, por alguns pais, da ideia das crianças terem uma socialização judaica durante a fase do jardim de infância; 6) pouca informação oferecida aos pais sobre a importância de uma educação judaica precoce; 7) a falta (ou perda) de diferenciais de qualidade entre as escolas particulares judaicas e não judaicas; 8) pouca difusão das experiências bem sucedidas das escolas judaicas; 9) aparentemente, custos mais elevados das escolas judaicas, quando comparadas com as não judaicas; 10) dificuldades enfrentadas por muitas famílias para pagar os custos da escola judaica; 11) a forma atualmente praticada de distribuição de bolsas de estudos, que faz com que muitos pais se sintam embaraçados em solicitá-las.

Grande parte dos motivos relacionados acima também se aplicam provavelmente à explicação da diminuição no número de alunos matriculados na escola judaica em Porto Alegre, apesar de os pais entrevistados em nossa pesquisa indicarem fundamentalmente a diminuição da qualidade do ensino secular da Escola. Há outros motivos, porém, e essa questão merece um exame mais detalhado.

${ }^{16}$ É provável que em Buenos Aires tenha ocorrido algo semelhante ao registrado em Porto
Alegre, onde os judeus mais jovens tendem a uma dispersão maior entre os bairros da cidade

Alegre, onde os judeus mais jovens tendem a uma dispersão maior entre os bairros da cidade
do que os judeus mais idosos (ver Brumer, 1994),
Para começar, deve-se levar em conta que, em diferentes períodos, variaram os motivos para a perda de alunos da Escola. Nos anos 1991 e 1992, quando as maiores quedas no número de alunos matriculados deramse no jardim de infância e nas primeiras séries do curso elementar, os pais estavam motivados principalmente a encontrar uma melhor escola para seus filhos, tendo em vista a avaliação corrente de que a Escola havia decaído em termos de qualidade. Após 1993, com a introdução de novos métodos de ensino e aumento das exigências de estudo feitas aos alunos, quando as maiores perdas deram-se nas últimas séries do curso secundário, o afastamento de muitos alunos pode em grande parte ser explicado pelo maior rigor utilizado na avaliação e aumento das pressões sobre os estudantes, resultando em dificuldades enfrentadas por alguns deles em acompanhar suas exigências.

Outro aspecto a ser considerado é a crise econômica que se abateu sobre grande parte da classe média brasileira desde o início da década de 90 , como resultado dos ajustes promovidos pelo governo federal. Dentre os aspectos que mais afetaram a classe média, na qual se situa a maioria dos judeus brasileiros, estão o aumento do número de desempregados, o congelamento dos salários, a diminuição da renda média da população e o aumento dos juros. Como resultado, muitos pais que poderiam enviar seus filhos ao Colégio Israelita Brasileiro não podem pagar as mensalidades, ao mesmo tempo em que relutam em solicitar uma bolsa de estudos. De qualquer modo, uma das políticas da Escola é não oferecer bolsas integrais e os pais de alunos bolsistas devem pagar pelo menos $20 \%$ das mensalidades, assim como devem assumir o custeio do material escolar utilizado e de todas as atividades extraclasse, tais como escolinhas de ginástica, inglês ou dança, excursões e passeios. Por outro lado, sendo uma escola comunitária, sem fins lucrativos, a Escola oferece anualmente cerca de 150 bolsas de estudo, atingindo aproximadamente $11 \%$ de seus alunos ${ }^{17}$. A crise econômica afeta também pais de alunos não bolsistas, uma vez que cerca de $8 \%$ do total pagam as mensalidades com atraso ou simplesmente deixam de pagá-las.

Como a maior parte do custeio da Escola é feito pelos pais dos alunos com condições de pagar as mensalidades e há o 'adicional judaico'

17 Campanhas para angariar fundos entre os membros da comunidade judaica de Porto Alegre são apenas relativamente bem sucedidas, $e$ o resultado permite cobrir menos de $10 \%$ das despesas da Escola. 
representado pelas aulas e atividades referentes aos conteúdos judaicos, o valor das mensalidades escolares é relativamente alto, situando-se o Colégio Israelita Brasileiro entre as escolas particulares mais caras de Porto Alegre. Conforme observação de Levy (1987), para as escolas judaicas da América Latina, o Estado não interfere na programação da escola judaica, uma vez atendido o currículo mínimo secular, mas também não oferece recursos diretamente ou auxilia na forma de bolsas de estudo. Sua contribuição é importante, porém, através da isenção de pagamento de impostos e contribuições sociais, situação que o Colégio Israelita Brasileiro partilha com outras escolas comunitárias sem fins lucrativos da Capital.

Outra explicação para a diminuição do número de alunos matriculados no Colégio Israelita Brasileiro é a existência de escolas alternativas. Aqui, deve ser considerada a escolha, por um lado, entre escolas públicas e escolas particulares e, de outro lado, entre as escolas particulares ou comunitárias existentes em Porto Alegre.

A opção entre escolas públicas ou particulares depende principalmente de dois fatores: a qualidade da escola pública e a capacidade dos pais de pagar as mensalidades escolares de uma escola particular ou comunitária. Nestes aspectos, durante os anos 80, os dois fatores foram favoráveis às escolas particulares, especialmente devido ao fato de que as escolas públicas perderam em qualidade devido à falta de investimento em equipamentos e de qualidade de ensino, e também por pagar muito pouco a seus professores, o que resultou em várias greves que perturbaram as atividades normais das escolas por muito tempo. Ao mesmo tempo, a classe média brasileira parecia passar por uma situação econômica melhor do que a que passou a enfrentar posteriormente.

No que diz respeito às escolas pagas, a questão principal está nos tipos de escolas existentes na cidade em diferentes épocas. Neste sentido, é importante considerar que até as décadas de 70 e 80 , as escolas comunitárias ou particulares existentes em Porto Alegre eram clericais, mantidas por congregações católicas ou protestantes (evangélicas, metodistas, batistas, etc.). O conteúdo religioso dominante nessas escolas fazia parte de seu currículo regular e era muito difícil para os praticantes de uma outra religião adaptar-se. Um aluno judeu era considerado como um estranho nessas escolas, em graus diversos, dependendo da ênfase colocada na formação religiosa e na tolerância prevalecente (neste sentido, havia uma maior preferência dos estudantes judeus por escolas protestantes de orientação norte-americana do que por escolas protestantes de orientação germânica). Mudanças começaram a ser observadas no início dos anos 90 , quando, por um lado, as escolas católicas e protestantes tornaram-se mais seculares e, de outro, foram fundadas novas escolas seculares não vinculadas a nenhum grupo étnico ou congregação religiosa em particular. Uma dessas escolas, fundada por um ex-professor do Colégio Israelita Brasileiro, tornou-se especialmente atrativa para pais judeus, devido tanto a sua ênfase na preparação para os exames de ingresso para a Universidade quanto a seu caráter secular.

Um exemplo da mudança na orientação de algumas escolas comunitárias e particulares não judaicas e do processo de secularização que enfrentaram é oferecido por De Boni, em sua análise dos imigrantes italianos do Rio Grande do Sul e de sua religião:

$\mathrm{Na}$ medida em que a secularização foi atingindo o Rio Grande do Sul, entrou em crise o mundo católico, e constatou-se a ineficiência de muitas das estruturas que o suportavam, entre as quais o sistema educacional. O colégio católico começou a perder seu sentido, por não mais formar católicos, nem preparar os líderes com que a Igreja esperava contar. Sua função limitou-se, sempre mais, a fornecer ensino aos interessados, passando para plano secundário as convicções religiosas de seus alunos e, seguido, mesmo as de seus professores. (De Boni, 1980: p.251).

Durante a última década, o Colégio Israelita Brasileiro acompanhou a tendência de secularização que afetou outras escolas confessionais de Porto Alegre. Assim como grande parte dos professores e quase a totalidade dos funcionários são não judeus (a exceção é a área temática judaica da Escola, onde todos os professores são judeus), a Escola também se tornou atrativa para alunos não judeus, que representam cerca de $10 \%$ do total. Algumas dessas crianças frequentam a escola judaica porque seu pai ou sua mãe trabalha na escola, como professor(a) ou funcionário(a), habilitando-os ao recebimento de uma bolsa de estudos, mas outros estão lá por escolha dos pais.

É possível que a participação de alunos não judeus na escola judaica cause a eles problemas de identidade semelhantes aos enfrentados por alunos judeus matriculados em escolas não judaicas. No entanto, alunos não judeus que estudam no Colégio Israelita Brasileiro sabem que não são judeus e que o aprendizado da língua hebraica e da cultura judaica não os 
transformará em judeus. De maneira semelhante, alunos judeus que estudam em escolas não judaicas continuam sendo judeus, embora algumas vezes eles possam não saber exatamente o que isto significa.

Outra característica de grande parte dos alunos matriculados no Colégio Israelita Brasileiro é serem filhos de pais com origem mista, em que um lado da família é formado por judeus e outro lado é composto por não judeus. Mesmo quando o cônjuge de origem não judaica converteu-se ao judaísmo, sua família de origem continua sendo de não judeus, o que faz com que a criança, embora frequentando uma escola judaica, tenha contato com festas cristãs, como o Natal, e compareça à Igreja ou ao Templo por ocasião de casamentos, batizados ou outras cerimônias envolvendo membros de sua família. Como resultado, o contato de muitas dessas crianças com o judaísmo é apenas parcial, e a escola judaica representa praticamente seu único contato com o judaísmo.

A secularização da maior parte da população judaica de Porto Alegre - representada pela diminuição das práticas religiosas, aumento no número de casamentos mistos e diminuição da participação em atividades da comunidade judaica local - é provavelmente o principal motivo para explicar as atitudes dos pais em relação à escola judaica. Seu interesse principal está em que a Escola ofereça a seus filhos uma educação de excelência - que lhes permita competir na sociedade capitalista, assumindo no futuro posições de liderança - e, ao mesmo tempo, transmita-lhes o conteúdo básico do judaísmo, para que as crianças conheçam suas origens e orgulhem-se delas. Eles desejam que as crianças sejam judias, mas dentro de certos limites, porque se elas tiverem muito conhecimento religioso poderão contestar suas próprias vidas seculares.

\section{Perspectivas futuras}

Considerando as mudanças internas e externas que afetaram a escola judaica, resultando tanto na diminuição no número de seus alunos quanto em dificuldades financeiras, existem poucas perspectivas de melhora. Podese considerar que não existe perspectiva de reversão da tendência de secularização entre os membros da comunidade judaica de Porto Alegre, apesar do fato de alguns jovens terem sido atraídos pela prática do judaísmo tradicional, seguindo a liderança do movimento Beit Chabad, e da ocorrência de algumas conversões de não judeus. Em consequência, ao mesmo tempo em que parte desta população afasta-se da religião e evita participar de eventos na comunidade judaica, ela também pode considerar desnecessário o envio de seus filhos a uma escola judaica.

São evidentes os esforços feitos pelos administradores e professores do Colégio Israelita Brasileiro para corrigir qualquer aspecto considerado negativo, reforçar os aspectos positivos e inovar, sendo pioneiros em conteúdos e métodos de ensino. No entanto, mesmo que a Escola seja considerada excelente em termos da educação secular, existe uma oferta razoável de escolas na cidade com as mesmas características, sendo o único diferencial da escola judaica sua programação em conteúdos judaicos. Neste sentido, assim como a oferta desses conteúdos atrai uma parte dos potenciais candidatos a alunos, afasta uma outra parte. No confronto entre pais que desejam para seus filhos componentes diferenciados de educação judaica, a escola judaica tem duas alternativas: aumentar sua ênfase em judaísmo - religião, hebraico e cultura judaica -, com o risco de perder grande parte dos alunos não judeus e parte dos alunos judeus cujas famílias são seculares; ou diminuir a ênfase em judaísmo, perdendo assim seu papel de formar e consolidar a identidade judaica.

Em síntese, sendo a escola judaica atualmente um dos principais meios de transmitir a identidade judaica, a própria continuidade da comunidade judaica de Porto Alegre, nas duas ou três próximas gerações, pode ser questionada.

\section{Referências bibliográficas}

AMIA (Comunidad Judia de Buenos Aires). Comision para el Desarrollo de ia Educacion Judia Formal. Conclusiones; Proyecto del Programa para el Mejoramiento del Sistema de Educacion Judia en la Argentina. Buenos Aires, AMIA, out. 1993. 20p. (Relatório não publicado)

ASHERI, Michael. O judaísmo vivo; as tradições e as leis dos judeus praticantes. Rio de Janeiro, Imago, 1995. 367p.

BARYLKO, Jaime. In Latin America, We are What We are Plus What Latin America is. Jewish Frontier, 16, March 1981. Apud LEVY (1987). 
BARTH, Fredrik. Introducción. In: BARTH, Fredrik (compilador). Los grupos etnicos y sus fronteras. Mexico, Fondo de Cultura Económica, 1976. p.9-49.

BOURDIEU, Pierre. O poder simbólico. Lisboa/Rio de Janeiro, DIFEL/BERTRAND, 1989.

BRUMER, Anita. Identidade em mudança; pesquisa sociológica sobre os judeus do Rio Grande do Sul. Porto Alegre, Federação Israelita do Rio Grande do Sul, 1994. 143p.

CARDOSO DE OLIVEIRA, Roberto. Identidade e estrutura social. Brasília, Universidade de Brasília. Série Antropologia Social, n.21, 1978. $27 \mathrm{p}$

DE BONI, Luis Alberto. O catolicismo da imigração: do triunfo à crise. In: DACANAL, José H. \& Gonzaga, Sergius (org.). RS: Imigração \& Colonização. Porto Alegre, Mercado Aberto, 1980. pp. 234-55.

EIZIRIK, Moysés. Aspectos da vida judaica no Rio Grande do Sul. Porto Alegre, Escola Superior de Teologia São Lourenço de Brindes; Caxias do Sul, Editora da Universidade de Caxias do Sul, 1984. $184 \mathrm{p}$.

GOLDSTEIN, Iosef. O Estado de Israel, o movimento Sionista e a educação judaica no Brasil, 1948-1955. Anuário do Instituto do Judaísmo Contemporâneo, da Universidade Hebraica de Jerusalém, n.8, 1993. p.39-66. (Em hebraico) (Traduzido por Paulo André Fridman, para utilização neste trabalho).

KLIEMANN, Luiza Helena Schmitz. Colégio Israelita Brasileiro: 19221992; “Que eu me lembre foi assim...”. Porto Alegre, Colégio Israelita Brasileiro, 1992. 114p.

LEVY, Daniel C. Jewish Education in Latin America. In: ELKIN, J. L.; MERKX, G. W (eds). The Jewish presence in Latin America. Winchester, MA: Allen \& Unwin, 1987. p.157-184.

SCLIAR, Moacyr. Caminhos da Esperança; a presença judaica no Rio Grande do Sul (Pathways of Hope; the Jewish Presence in Rio Grande do Sul). Porto Alegre, Instituto Cultural Judaico Marc Chagall, 1990. 120p.
SORJ, Bernardo. Introdução; o judaísmo moderno em perspectiva histórica; do judaísmo rabínico ao judaísmo pós-moderno. In: SORJ, Bernardo; GRIN, Monica (org.). Judaísmo e modernidade; metamorfoses da tradição messiânica. Rio de Janeiro: Imago, 1993. p.7-19.

WOLFF, Egon; WOLFF, Frieda. Judeus no Brasil Imperial; uma pesquisa nos documentos e no noticiário carioca da época. São Paulo: Universidade de São Paulo, Centro de Estudos Judaicos, 1975. 549p.

WOLFF, Egon; WOLFF, Frieda. Documentos $V$; O judeu na topografia e toponímia do Brasil no século XIX; Os recenseamentos demográficos oficiais do século XX. Rio de Janeiro, 1993-1994. 131p. 


\section{Educação para a diversidade}

Cheila Szuchmacher Huf

\section{Tecnologia, autonomia e cidadania.}

realidade contemporânea aponta para questões emergentes no contexto das novas tecnologias e da Educação. Dentro dessa nova concepção de mundo, o papel da escola deve ser transformado; devemos estar atentos à interação entre escola e os meios de comunicação, à informática e às línguas estrangeiras.

A possibilidade de levarmos para dentro do ambiente escolar toda essa tecnologia permitirá que os alunos adquiram conhecimentos, retendoos mais facilmente. Segundo Lévy (1996): Quanto mais ativamente uma pessoa participar da aquisição de um conhecimento, mais ela irá integrar e reter aquilo que aprender (p.40).

$\mathrm{Na}$ verdade, a escola deve permanecer conectada com o mundo. De acordo com Lévy (1996) toda essa transformação tecnológica contribui para o rompimento das fronteiras, tornando o mundo um território cosmopolita.

Conforme referido anteriormente, nos deparamos com este grande desafio, que é o de colocar a escola no caminho da modernidade. Este desafio leva à reflexão sobre as questões que envolvem os recursos tecnológicos dentro do contexto educacional.

Tendo em vista esta nova realidade, na qual a disponibilidade de informações em tempo real é uma grande oportunidade para o ambiente escolar, torna-se indispensável aos agentes que participam da escola refletir e avaliar continuamente sobre benefícios e riscos que envolvem o uso das novas tecnologias de informação sem critérios e objetivos bem definidos.

Destacando outro aspecto, percebemos a importância de pensarmos nos alunos, atendendo à sua diversidade. Precisamos de uma escola que respeite cada aluno, no sentido de desenvolver suas potencialidades, respeitando suas possibilidades. De acordo com Gardner (1995): nem todas as pessoas têm os mesmos interesses e habilidades; nem todos aprendem da mesma maneira (p.16).

Nessa linha de raciocínio, a escola atual deve estar voltada para o indivíduo, não só respeitando seus desejos, interesses, sua história de vida, suas possibilidades; como também estimulando sua criatividade, espírito crítico, atitudes reflexivas e transformadoras.

Cada aluno tem seu próprio ritmo no processo de construção do conhecimento. Nesse contexto, a postura do educador deve ser dinâmica e reflexiva, no sentido de trazer para o ambiente escolar alternativas democráticas que permitam aos estudantes escolher seus caminhos na produção do conhecimento.

Com a intenção de esclarecer o que foi citado, podemos apresentar um exemplo: uma professora de Hebraico, ao lançar um conteúdo como verbos, poderá oferecer diversas alternativas de trabalho para a turma, ou seja, um grupo de alunos poderá optar por trabalhar ao computador, outro com desafios preparados pela professora, outro com jogos referentes ao conceito estudado, outro fora da sala de aula, onde também é possível construir ambientes específicos e outro ainda com o livro ou apostila didática.

Diante deste exemplo, surgem algumas reflexões sobre as tarefas diversificadas propostas no ambiente escolar, como também sobre a postura do corpo docente, da comunidade e dos alunos diante das mesmas.

Tendo em vista a educação como instrumento do desenvolvimento humano, é indispensável pensar o sujeito e sua inserção no social. Frigotto (1999) nos ajuda a refletir sobre o papel da escola, criando alternativas nas salas de aula, de tal forma que, trabalhando com as multiplicidades, tenhamos a possibilidade de formar um cidadão autônomo e participativo na construção do conhecimento e de uma sociedade mais justa.

Considerando que na sociedade pós-moderna o conhecimento se torna cada vez mais valorizado, participar da luta pela universalização do ensino significa estar de acordo com os ideais de justiça, igualdade e democracia.

Tendo em mente a emergente necessidade de mudança, algumas escolas judaicas vêm passando por um processo de reformulação e transformação em suas modalidades de ensino.

\footnotetext{
${ }^{1}$ Mestre em Educação / UFRJ.
} 
Três escolas judaicas do Estado do Rio de janeiro promoveram a reforma curricular em suas instituições com um curso realizado na Universidade de Tel-aviv, em janeiro de 1999. Todos que participaram, professores, orientadores, coordenadores e diretores, tiveram a oportunidade não só de estudar como também de conhecer algumas escolas.

O Ministério da Educação de Israel vem adotando, desde 1973, um projeto por ele chamado Educação para a Diversidade.

Ao participarmos do curso e das visitas, nos deparamos com escolas que trabalham com o mesmo projeto, porém, com características marcadamente diferentes. Torna-se evidente, nessa concepção de educação, que não somente os alunos têm diferentes possibilidades, mas que também os professores têm estilos e características diversificadas.

Percebendo o alto índice de repetência escolar, os pesquisadores envolvidos no projeto ofereceram ao Ministério de Educação e Cultura uma sugestão inicial ao programa de pesquisa e ação. Depois de três anos como projeto experimental, o Ministério da Educação e Cultura de Israel ofereceu o programa para todas as escolas do país. Atualmente, $70 \%$ das escolas israelenses optaram por adotar esta proposta pedagógica.

De acordo com Brikner, (1996) a Educação para a Diversidade é uma concepção que reconhece a diferença entre os estudantes, reconhece o pluralismo cultural e social e acredita que a função da escola é de atender essas diferenças através da adequação do ambiente educativo às necessidades dos alunos e aos objetivos do programa de estudos.

Sob este prisma, o aluno se torna centro do processo educativo, possibilitando que tenha o ritmo de estudo e desenvolvimento adequado a si mesmo, oferecendo-lhe objetivos pedagógicos, culturais e pessoais de acordo com suas possibilidades, tendências e necessidades, através de sua participação ativa no processo pedagógico, garantindo seu progresso como indivíduo e como membro do grupo social.

Brikner (1996) sustenta que Educação para a Diversidade enfoca o progresso dos alunos em suas características cognitivas, sociais e pessoais. Dessa forma, seu objetivo é possibilitar que os alunos aprendam cultivando a autonomia e estimulando suas potencialidades para trabalhar em equipe, respeitando ao próximo.
Dentro dessa concepção de educação, não há mais espaço para o ensino tradicional, no qual todos os alunos recebem os mesmos conteúdos da mesma forma, como se a turma de alunos fosse homogênea. De acordo com esta nova proposta pedagógica, é necessário reconhecer a heterogeneidade existente em cada sala de aula.

(...) existe a variedade de razões que impulsionam cada um de nós a agir e as diferenças entre os seres humanos. Apelar aos sujeitos envolve encontrar uma quase infinita variedade em qualquer de suas dimensões (Sacristán, 1999, p. 34).

O princípio orientador da aplicação da Educação para a Diversidade é a adequação da escola para que cada estudante desenvolva ao máximo seus potenciais, não valorizando apenas os que têm habilidades lógicomatemática e linguística, mas sim as possibilidades diferentes de cada aluno: artísticas, psicomotoras e interpessoais, entre outras.

Para alcançar essa adequação, propõe-se articular estratégias de ensino, aprendizagem e avaliação diversificadas e flexíveis, que incluem a criação de um ambiente pedagógico rico e variado, através de uma nova cultura escolar, pedagógica e social. O ambiente escolar deve promover a flexibilidade do programa de estudos que contém a diferenciação entre objetivos comuns a todos e objetivos pessoais adequados aos diferentes estudantes, o progresso dos processos de ensino, às tendências e preferências dos alunos, a utilização de uma larga variedade de técnicas, métodos e recursos, a flexibilidade do tempo de estudo e âmbitos de aprendizagem, o desenvolvimento de critérios e meios de avaliação e a colaboração do aluno nos diferentes processos.

No presente projeto, percebemos o aluno como um indivíduo capaz de desenvolver ao máximo suas potencialidades, e ensejamos que, através de um ambiente alternativo lhe seja permitido ousar, solucionar desafios, criar, experimentar, pesquisar e desenvolver os aspectos cognitivos, sociais e emocionais.

A Educação para a Diversidade privilegia aspectos como o estudo pela de busca de informações, tendo como instrumento as tecnologias de informação. Desse modo, se torna fundamental preparar o estudante para a vida na sociedade atual. 
Sob este ponto de vista, almeja-se contribuir na formação de um estudante autônomo e responsável. O professor deixa de ser o centro do processo pedagógico, tornando-se um orientador que na relação cotidiana de sala de aula, auxilia os alunos tanto na busca quanto na produção do conhecimento.

No que se refere às avaliações tradicionais do sistema de ensino, percebemos que não há mais espaços para as mesmas. Sendo assim, os alunos participam ativamente no processo de avaliação, acompanhando seu desenvolvimento, por intermédio de verificações dos resultados de estudo em folha de acompanhamento, autoexame e outras técnicas.

A informática e outras máquinas audiovisuais favorecem uma interação intermediária, pois confrontam o aluno com mecanismos programados pelo homem para lhe servir de parceiro. Papert (1981) fala do computador como uma máquina para pensar junto (Perreenoud, 1999,p.112).

Sob tal ótica, o objetivo da avaliação é a percepção do aluno em relação ao seu próprio desenvolvimento. Nesse momento, a utilização do computador é de grande valia tanto para professores quanto para os alunos.

A avaliação não tem como objetivo classificar o aluno, nem tornar público os conteúdos que não foram alcançados, mas sim possibilitar o reconhecimento das novas etapas que estão para ser conquistadas no desenvolvimento do educando.

Ir em direção a uma avaliação mais formativa é transformar consideravelmente as regras do jogo dentro de sala de aula. Em uma avaliação tradicional, o interesse do aluno é o de iludir, mascarar suas falhas e acentuar seus pontos fortes. O ofício do aluno consiste principalmente em desmontar as armadilhas colocadas pelo professor, decodificar suas expectativas, fazer escolhas econômicas durante a preparação e a realização das provas, saber negociar ajuda, correções mais favoráveis ou a anulação de uma prova malsucedida (Perrenoud, 1999,p.151).

Este projeto, adotado pelas escolas judaicas do Rio de Janeiro a partir de 1999, conta com o compromisso de pais, equipe escolar, alunos e todos aqueles que estão envolvidos com a Educação.

\section{Considerações finais}

Constatou-se a importância da "Educação para a Diversidade" como um projeto político-pedagógico, num contexto democrático, que oferece um rumo, uma direção para a comunidade escolar, não se restringindo a uma tentativa de mudança de um professor isolado em uma das classes do ensino fundamental.

Sem dúvida estamos diante de paradigmas para os educadores e alunos, que sugerem um repensar para o cotidiano escolar, proporcionando um caminho espiral de sucesso na construção de sua autonomia, espírito crítico e responsabilidade, visando a democratização de ensino e a inclusão escolar.

Referências bibliográficas:

BRIKNER, Reli. Educação para a diversidade - desenvolvimento e mudança. Rio de Janeiro: Vaad Hachinuch, 1999.

FRIGOTTO, Gaudêncio. Educação e a crise do capitalismo real. São Paulo: Cortez, 1996.

FRIGOTTO, Gaudêncio. A Produtividade da escola improdutiva. São Paulo: Cortez, 1999.

GARDNER, Howard. Inteligências múltiplas. Porto Alegre: Artes Médicas, 1995.

LÉVV, Pierre. As Tecnologias da inteligência. SP: Literatura S/C, 1996.

PERRENOUD, Philippe. Avaliação: da excelência à regulação das aprendizagens - entre duas lógicas. Porto Alegre: Artes Médicas Sul, 1999.

PERRENOUD, Philippe. Pedagogia diferenciada: das intenções à ação. Porto Alegre: Artes Médicas Sul, 2000.

SACRISTÁn, J. Gimeno. Poderes instáveis em educação. Porto Alegre, Artes Médicas, 1999. 


\section{Mulheres judias, profissionais brasileiras: entre a identidade e cidadania}

Helena Lewin ${ }^{1}$

\section{Da pesquisa}

- ste estudo, de natureza qualitativa, resultou de uma pesquisa realizada durante os anos de 1998 e 1999, no Rio de Janeiro, tendo como objeto de investigação um grupo de mulheres judias brasileiras, de inserção profissional ativa no mercado de trabalho cuja faixa etária compreendia o intervalo entre 30 a 55 anos. $O$ objetivo que norteou este trabalho foi verificar como essas mulheres lidavam com a questão de sua identidade judaica e de como sua descendência manipulava esta categoria vivencial. Dito em outros termos, o objetivo era perceber como ocorreu a socialização de seus filhos no que se refere à proposta filosófico-religiosa da continuidade judaica intergeracional, além de apreender o significado atribuído aos denominados processos assimilatórios.

Construiu-se uma amostra de 36 entrevistadas sobre as quais se elaborou o perfil educacional, cultural, profissional, conjugal e familiar das mesmas, procurando-se, deliberadamente, contemplar a variedade de combinações possíveis em função das seguintes dicotomias: religiosa/laica e matrimonialidade endogâmica/exogâmica.

Os dados permitiram tecer o perfil das entrevistadas: $100 \%$ eram brasileiras, assim como seus cônjuges; $80 \%$ casadas, $18 \%$ separadas ou divorciadas; as restantes, $2 \%$ de solteiras. Elevada escolaridade: $95 \%$ têm instrução superior e entre essas $35 \%$ com pós-graduação, instrução mais elevada que a de seus respectivos maridos. A elevada escolaridade dessas entrevistadas, filhas de imigrantes, revela e confirma o alto valor que os judeus atribuem à instrução como projeto de vida na medida que é avaliada como investimento no futuro de sua descendência, configurando-se, portanto, como um capital profissional. Observa-se, também, que essas mulheres refletem a divisão sexual das carreiras do sistema educacional

\footnotetext{
${ }^{1} 1$ - Doutora em Sociologia/USP, Programa de Estudos Judaicos - UERJ
}

brasileiro, visto alocarem-se, preferentemente, no campo feminino das ciências sociais, humanas e letras.

Contudo, há uma relação inversa entre idade e carreira feminina, ou seja, quanto mais jovens eram as entrevistadas, tanto maior era sua inserção nas carreiras que se tornaram mistas, isto é, aquelas nas quais as proporções entre os sexos eram relativamente idênticas, seguindo de perto as tendências e as mudanças no sistema educacional brasileiro.

Aquelas que trabalhavam no momento da entrevista perfaziam $85 \%$, enquanto os demais $15 \%$ já haviam trabalhado no passado e provinham majoritariamente da área das humanas, sendo que $85 \%$ delas desenvolviam sua atividade laboral no campo do magistério e como profissionais liberais (Direito, Psicologia). Quanto à descendência, 56\% tinham dois filhos, 12\% tinham um filho e o mesmo percentual para aquelas que declararam ter 3 filhos, sendo que metade destes tinha mais de 15 anos.

As mulheres entrevistadas mostraram-se altamente receptivas frente ao convite de participar deste trabalho de pesquisa. Suas falas foram além do roteiro organizado para tal fim, parecendo, às vezes, que estavam à procura ou à espera de uma circunstância fortuita que lhes proporcionasse a oportunidade de expressar-se sobre sua condição feminina, sua cidadania e identidade. Apesar da grande variação etária, esse foi o comportamento dominante, extrapolando para itens da intimidade de sua história de vida.

No seu quadro conjugal, verificamos que $70 \%$ das mulheres judias eram casadas com judeus, $16 \%$ casadas com não judeus, $7,5 \%$ de mulheres eram não judias (não convertidas) casadas com judeus, 4,5\% divorciadas, mas anteriormente casadas com judeus e $2 \%$ eram solteiras Essa composição não foi aleatória. Buscou-se contemplar uma ampla gama de situações matrimoniais na medida em que entre as variáveis comportamentais importantes dentro do judaísmo situa-se a endogamia como mecanismo de reforço da continuidade/perpetuação da identidade intergeracional.

Condição conjugal das entrevistadas

Judias casadas com judeus

Judias casadas com não judeus

Não judias casadas com judeus

$70,0 \%$

Divorciadas casadas com judeus $\quad 4,5 \%$

Solteiras $\quad 2,0 \%$

Total 
Por outro lado, uma outra clivagem foi realizada a partir da religiosidade das entrevistadas, no que se refere 'a conceituação de judaísmo e religião. Assim, a amostra teve a seguinte configuração:

\section{Mulheres religiosas:}

$\begin{array}{ll}\text { Ortodoxas } & 18,75 \% \\ \text { Liberais } & 12,50 \%\end{array}$

$31,25 \%$

Mulheres judias não religiosas:

Perfil tradicional

Perfil progressista

\section{$30,00 \%$}

$30,00 \%$

Subtotal:

$61,25 \%$

Mulheres não judias:

Subtotal:

$7,50 \%$

Total:

$100,00 \%$

Este quadro permite afirmar que as mulheres judias representadas nesta amostra eram majoritariamente laicas situando-se relativamente idênticas em termos numéricos entre os perfis tradicionais e progressistas e no grupo denominado de judias religiosas as ortodoxas representavam $60 \%$ do total deste segmento. Quando se procede o cruzamento das variáveis idade e comportamento religioso verifica-se que as mulheres mais velhas estão mais concentradas no segmento laico de orientação progressista enquanto as faixas etárias mais jovens se distribuem na categoria ortodoxa parecendo confirmar o fenômeno, relativamente recente, do chamado "religious survival" - renascimento religioso - que também se encontra presente entre os religiosos liberais, embora com menor intensidade.

\section{Do Contexto}

A questão referida à identidade tem sofrido modificações sucessivas acompanhando os processos sociais da modernidade. No passado, nas pequenas e tradicionais comunidades judaicas da Europa e daquelas nos países afro-asiáticos, o judaísmo era uma característica habitual na vida das pessoas porque relativamente confinadas e não se perguntavam e nem se questionavam se eram judeus ou o que é ser judeu. A dúvida era inexistente. Não fazia parte de sua visão de mundo. Naturalmente havia exceções, mas eram raras e o controle social era intenso a fim de não permitir transpor as fronteiras simbólicas de sua territorialidade judaica.
Ser judeu era um elemento constitutivo de sua vivência, uma condição idêntica para todos e de todos os membros da sua comunidade. Esta caracterização não comportava dúvidas ou incertezas "nascer judeu, viver judeu e morrer judeu" era a perspectiva consensualmente compartilhada. Ou seja, a dúvida - o grande aporte do Iluminismo no despertar da modernidade - ainda não havia penetrado nas camadas sociais religiosas profundamente arraigadas aos hábitos e costumes tradicionais vigentes nas pequenas comunidades.

Atualmente ser judeu não é apenas uma questão de nascimento. Além da descendência, é necessário haver um ato de vontade em permanecer judeu e construir uma continuidade judaica permanente porque poderosos fatores de natureza centrífuga estimulam sua incorporação ao "out-group" em contraface com o "in-group".

A modernidade instituiu e separou as categorias de cidadania e identidade, e as de nacionalidade e religião. Embora pudesse haver dissonância e conflito entre esses pares de variáveis, a força da modernidade como um processo avassalador criou condições para que os indivíduos, em todas as partes do mundo, inclusive no Brasil, expusesse seu judaísmo sem necessidade de encobrir sua condição judaica na medida que a cidadania se baseava no princípio da igualdade individual de seus membros, embora muitas vezes, mais formal do que real pois que os preconceitos e as discriminações não foram suficientemente combatidos e eliminados. Este "vir á luz" de uma categoria até então reprimida, foi um fator estimulador para a busca de representações sobre a identidade ou a religiosidade como forma de manifestação desta.

A vida judaica sempre se caracterizou por uma situação de permanente tensão interna que resulta da atuação de um campo de forças em que se enfrentam dois movimentos contrários. De um lado, situa-se o esforço deliberado para conservar, permanecer e dar continuidade à trajetória judaica, e, de outro lado, localiza-se a tendência à mudança e à transformação adaptando-se e assimilando-se às condições concretas de seu entorno sociocultural decorrente de seu status de minoria ou frente à impregnante influência da modernidade e seus recursos de divulgação e penetração em todos os aspectos da vida social e política da atualidade.

Em outras palavras, forças centrípetas e centrífugas sempre disputaram o coração e a mente dos judeus e do judaísmo - ao nível individual ou na 
dimensão grupal e comunitária - com intensidade e extensão variáveis dependendo do "espaço-tempo" em que se encontravam as comunidades judaicas. E os dados desta pesquisa sobre as mulheres judias, profissionais brasileiras, confirmam esta tese.

Há um intenso debate interno, geralmente extremamente tenso, sobre como articular e combinar as demandas dessas forças contraditórias. Essa tensão que, por vezes, chega a ser conflitual, leva a que algumas das mulheres acabem optando prioritariamente por um dos elementos em detrimento do outro, não alcançando o possível equilíbrio esperado.

Contudo, é interessante ouvir a fala das mulheres quando perguntadas sobre a questão de sua identidade na qual transparece uma certa elaboração sobre esta categoria. Cada fala ou discurso emitido ao longo das entrevistas serão apenas identificados pela idade e profissão que estarão entre parêntesis, guardando, assim, o anonimato garantido.

Conviver com pessoas de outras religiões é saudável, a não ser que queiramos viver em um gueto fechado. Não é isso que nós, judeus, nos propomos, a gente tem que mostrar nosso judaísmo. Acabou aquela época de esconder que somos judeus (33 anos, Qui)

Eu acho que a maturidade faz com que a gente assuma, mais abertamente, a sua condição judaica (49 anos, Edu)

Hoje, com minha idade, tenho mais tranquilidade, orgulho e dignidade para me declarar judia, em todas as situações, sejam de conflito ou de amor. Acho que essa abertura de declarar-se judia tem muito a ver com a maturidade.( 52 anos, Edu)

No passado, eu achava o judaísmo que conheci muito cerceante, hoje, pelo contrário, ela é libertadora não só para mim, mas para muitas pessoas. Tenho trabalhado na comunidade com mulheres judias na sinagoga do ponto de vista da religião. Eu sou a única feminista que fala sob a ótica religiosa e não apenas do ponto de vista cultural. Eu promovo também esse diálogo com mulheres cristãs, buscando algum tipo de entendimento. (35 anos, Psi)

O judaísmo é uma filosofia de vida. A história judaica me fascina. Eu sou uma judia cultural. (44 anos, Edu).

Eu sou uma brasileira judia. Afetivamente eu sou judia. Minha relação com o Brasil é de compromisso político. Eu sempre lutei contra o Estado brasileiro no que ele tem de injustiça social. Eu acho que hoje eu sou brasileira e judia, mas acima de tudo brasileira (38 anos- Soc)

Eu sou muito brasileira. É o país que nasci, é onde formei minha família, é onde eu tive meus filhos, é onde eu me escolarizei até a universidade, é onde eu tenho recebido as oportunidades de vida. E onde vivo o dia a dia, é onde sofro e tenho tristezas e alegrias com todas as nossas situações, boas ou não (49 anos, Edu).

Um número significativo de mulheres reiterou que sua presente maturidade etária e psicológica lhes permitiu assumir e exibir seu judaísmo de modo mais transparente, de maneira mais convicta e com maior naturalidade do que no passado. A atribuição à maturidade, embora sentida por essas mulheres como propiciadora de sua "coragem" para identificar-se aberta e publicamente como judias, não se configura como explicação suficiente para apreender a totalidade deste fato. Por isso, faz-se necessário acrescentar outras variáveis explicativas para compor o complexo quadro sociocultural que interfere na liberdade de expressão dos indivíduos para se exprimir sem medo - uma situação que sempre foi historicamente carregada de muitos preconceitos e discriminação.

No caso brasileiro, os processos de redemocratização do país e suas respectivas constituições, principalmente após o Estado Novo, contemplam o princípio legal de igualdade cidadã cuja influência foi decisivamente determinante quanto ao direito de ser igual para todos os cidadãos, independente de origem étnica, religiosa e racial. Mas serão os posteriores movimentos sociais que terão lugar na sociedade brasileira, a partir dos meados da década dos 70 , que introduzirão a temática quanto aos direitos de ser diferente, embora todos sejam iguais perante a Constituição. Esses movimentos sociais foram responsáveis pela abertura da discussão em relação às várias manifestações culturais que compõem a nacionalidade brasileira, conseguindo impor o princípio da diferença como corolário democrático do princípio de ser igual. É esse clima de abertura que vai propiciar trazer à tona identidades reprimidas ou guardadas em silêncio. Entre estas, pode-se citar a condição judaica e sua identidade.

Outrossim, há um outro fator coadjuvantemente responsável neste amplo processo de expressão identitária. Trata-se da constituição do Estado de Israel cujo progresso tecnológico e científico foram objeto de admiração além do tratamento dispensado à questão ambiental, "via reconversão do 
deserto em pomar", ademais da política de absorção dos massivos contingentes de imigrantes de todas as partes do mundo convertendo-os em cidadãos produtivos e dos programas de preservação cultural da memória e do patrimônio histórico, entre outros "sucessos" que tornaram Israel, em sua primeiras décadas de existência, sujeito de assombro por parte da comunidade internacional e pelos judeus, em especial, contribuindo para a eliminação da pecha de parasitas de cuja marca os judeus vinham se ressentindo secularmente.

Assim, será o conjunto de muitas variáveis, e não apenas a questão da maturidade, capaz de explicar essa transmutação da identidade judaica, "do porão à cena aberta".

Quando perguntadas como definiam "ser judeu", a maior parte respondeu não se tratar apenas de descendência biológica "tout court" mas sim de uma construção cultural que é urdida ao longo dos tempos históricos e, por isso mesmo, passível de diferenciações mas sem abdicar de seus princípios fundantes que são comuns a todos os judeus e que permite categorizar-se como tal.

Ser judeu é manter as tradições, identificar-se com meu grupo, manter-se dentro desse grupo. Se fosse religiosa seria guardar todos os mandamentos prescritos. Eu me sinto judia no momento em que celebro os feriados judaicos, abertamente, no momento em que me declaro judia - coisa que não podia fazer há’ alguns anos atrás, talvez eu não teria tanta liberdade para falar como agora, talvez por esse "revival" que está' havendo, essa volta às origens que está' ocorrendo com todas as religiões. Hoje em dia se fala com muito mais naturalidade... Antigamente era ótimo ser ateu! Eu gosto de me dizer judia, não nego a ninguém, em canto algum. (45 anos, Qui)

As pessoas laicas se viram, depois dessas recentes crises mundiais que abalaram os grandes sistemas ideológicos, sem uma identidade. O fato de elas irem para a sinagoga é sinal que estão buscando uma identidade como judeus, (37 anos, Jur)

Há um movimento pendular entre as declarações das mulheres entrevistadas. Em um dos polos situam-se aquelas que definem sua identidade judaica como um apêndice da sua cidadania que é a sua determinante em última instância, e no polo oposto estão as mulheres que afirmam que a identidade é mais importante porque ela se carrega no coração - é emoção, é sentimento e, portanto, independe de espaço e tempo.
A partir das diferenciadas respostas obtidas nesta pesquisa, foi possível construir uma taxionomia de identidade judaica revelando múltiplos olhares sobre o judaísmo:

- Judia cultural

- Judia ecumênica

- Judia histórica

- Judia assimilada

- Judia laica

- Judia religiosa

- Judia liberal

- Judia convertida.

As falas das mulheres entrevistadas quando inquiridas a definir como sentem sua identidade judaica permitem perceber, a partir das autodefinições anteriormente apontadas, que existem várias "entradas" no judaísmo e, portanto, passível de múltiplas conceituações e interpretações. Dessa forma, refletem questões como memória, história, religião, pertencimento grupal exclusivo, sentimento atávico, adesão racional a princípios éticos, fé, emoções - um 'weltschauung' que variará de acordo com os itens que cada qual privilegia na construção de sua equação identitária.

Minha identidade judaica é a grande força afetiva, depois vem o resto, o primeiro impacto é afetivo. Não acredito que ser judeu é uma questão racional. Tem certas coisas que nós somos escolhidos muito cedo, quer dizer, você não apaga e não é para apagar felizmente, nós somos memória, para nossa glória e para nossa tristeza. Essas coisas fazem parte do meu acervo e de todos os judeus, queiramos ou não. Essa é a bagagem ( 54 anos, Psi).

Identidade judaica é um sentimento de pertença... é uma coisa ligada inexoravelmente à questão das histórias das suas origens. Pra mim, é mais uma questão de enraizamento que de religião, a religião vem como consequência... Meus filhos não tem a mesma identidade judaica que a minha... a diferença é que eles não nasceram num lar de pai e mãe judeus. Não acho que sendo ambos os pais judeus seja uma garantia da identidade judaica dos filhos porque vai depender de como os pais vivem sua condição judaica objetivamente. ... O que mantém a sobrevivência do povo judeu é o sentimento muito forte de fratria. Isso se reproduz nas gerações embora o discurso seja diferente porque o discurso é geracional, ele vai se modificando de acordo com a modificação da cultura. Ou seja, o discurso muda mas 
há uma repetição de alguma coisa que é nuclear Eu acho que muda a letra mas a música e' a mesma. (43 anos, Psi).

"Não consigo colocar a identidade judaica de forma racional, intelectualizada. Para mim é um sentimento, é um ato de vontade pessoal porque somente ter nascido de família judaica não garante o judaísmo. Meu marido pensa sua identidade judaica como um qualificativo de sua condição de cidadão do mundo por conta de sua trajetória de esquerda. Somente a escola judia não é suficiente para formar a identidade judaica, mas ajuda bastante ( 49 anos, Edu).

Identidade judaica é a minha referência cultural e histórica. O meu judaísmo é sem religião e sem sionismo. Sou uma pessoa a-religiosa, o que nada tem a ver com minha identidade judaica. Eu me sinto autenticamente judia. É tão forte em mim que meu marido que não é judeu, respeita muito esse meu lado. (35 anos, Soc).

Identidade judaica é a representação das leis e da essência filosófica da Torá.(33 anos, Edu).

É gostar de sua religião e passar isso para outras pessoas compartilharem desta alegria. É identificar-se. (29 anos, Edu).

Eu sou uma cidadã do mundo. A nacionalidade é racional e reflexiva, enquanto a identidade é emocional e menos reflexiva. Mesmo aqueles que se afastaram do judaísmo, não conseguem se desligar totalmente de sua identidade judaica, vivenciam um sentimento de culpa, de dívida ( 45 anos, Jur)

Um dos itens tratados nas entrevistas refere-se ao preconceito, discriminação e antissemitismo. Os depoimentos dessas mulheres variaram em função de sua vivência, quer no trabalho quer em outras esferas da sociedade brasileira. Não cabe neste paper fazer uma discussão aprofundada desses mecanismos de exclusão e intolerância de um determinado grupo social em relação a outro, prejulgando o comportamento deste de forma arbitrária, baseado em mitos e percepções que não tem uma base real de identificação histórico-cultural e que servem de motivação e justificativa para gerar movimentos de perseguição, de segregação, de ostracismo ou expulsão que podem ter uma fundamentação religiosa, étnica, ideológica ou política.

De um modo geral, as mulheres entrevistadas falaram de sua experiência como sujeitas ao preconceito sendo que como profissionais fazem um esforço extraordinário para cumprir rigorosamente suas tarefas acima das expectativas para se tornarem sujeitas de reconhecimento social dentro de seu grupo de trabalho. É evidente que este esforço de excelência não é exclusividade das judias, é também um esforço deliberado que as mulheres fazem no bom desempenho de suas funções na luta pelo princípio da igualdade entre os sexos. Um dos momentos em que sentem mais intensamente a discriminação refere-se à contratação de emprego, à promoção ou a outras marcas de status ou distinção social.

Eu já senti discriminação direta por ser judia, eu perdi um emprego por ser judia, com Madre Maria do Rosário, lá em São Paulo, que trabalha com meninos de rua. Quando cheguei ao Brasil, eu tinha uma promessa de trabalho lá. Ela me entrevistou, tudo ia bem. Aí ela perguntou meu sobrenome. Ela parou a entrevista, perguntou se eu era judia e lamentou que eu fosse judia e me despediu. Na hora foi tão frontal que não tive a menor condição de responder. Fique perplexa! Essa mulher é uma alta autoridade na área de atendimento a meninos de rua. Atualmente, ela é presidente da... (38 anos, Soc).

Eu estudava o $2^{\circ}$ grau no Colégio Arte e Instrução, em Cascadura. Era a mais nova da turma. Havia um professor de Biologia, médico. Meu nome nos papéis era Chaia e eu explicava que a tradução do mesmo era Vida. Um dia na hora da chamada, o professor me chamou de cajá e de jaca afirmando que doravante meu nome iria ser jaca. A turma toda caiu na gargalhada, eu me senti tão ofendida que comecei a chorar. Aí o professor gritou: pare de chorar! Eu estou brincando com você! Aliás, judeu não sabe brincar, judeu só sabe ganhar dinheiro e ser rico, porque no Nordeste os judeus são incestuosos. Foi a primeira vez que escutei a palavra incesto apesar de estar no $2^{\circ}$ grau. Continuou: Vocês casam irmãos com irmãs, só falta casar pai com filha para perpetuar a espécie e o dinheiro. (47 anos, Edu)

Não concordo que o antissemitismo seja produto da ignorância. Há uma grande parcela de irracionalidade. Acho que isso faz parte de uma estrutura psíquica deformada. É uma maneira de expressão muito profunda porque fala de uma estrutura psíquica que não suporta a diferença...( 54 anos, Psi)

Quando fui trabalhar no Colégio Pedro II, chegaram perto de mim e disseram: você é uma judia diferente e eu falei, você é um antissemita igual. Mas quis saber porque tal afirmação e a resposta é que eu não tinha esse negócio de dinheiro. Não sei se essa discriminação corre só por conta da ignorância, porque as pessoas que eu lido são pessoas de um certo nível; são pessoas que leram. Há 
realmente ignorância ou não conhecimento do que seja o povo judeu, historicamente falando. Mas eu acho que existe um fator relevante que favorece esse lado que é a Igreja. Além disso, a nossa cultura está impregnada de preconceitos. (45 anos, Edu).

Tem muita gente enrustida que diz: Ah, que povo unido, que coisa legal' mas, no fundo, quer dizer que é um povo que se fecha pra caramba e não quer se abrir pra ninguém. Quando dizem 'povo unido' estão querendo dizer, de uma forma meio irônica, que é um povo seletivo, egocêntrico. (32 anos, Eng).

Tenho uma amiga não judia casada com judeu. Temos ótimo relacionamento. Perguntei-lhe porque não aceitava meus convites para me visitar aqui no Rio ou em Teresópolis. Respondeu que sua mãe era católica e não queria que a filha convivesse com casais judeus e que até hoje, ela não aceita seu casamento com judeu (33 anos , Jur).

Eu aprendi com meu pai que o judeu tem uma postura muito cômoda na vida. Porque como ele não tem pátria teoricamente e ele se considera um povo que independe de ter nascido em qualquer lugar do mundo, porque ele vai ser sempre judeu. Então com a pátria de Israel que se conseguiu, eles passam a ter uma postura muito cômoda no universo, no mundo inteiro, em função disso. Porque o meu pai acha que é muito fácil arrumar as malas e ir pra Israel quando a bomba estourar. Ele pensa assim e eu aprendi a achar isso certo. Então, quando D... tira o corpo fora da situação brasileira, de que não tem culpa, eu acho que está muito associado a isso. É a minha forma figurativa de ver Ah, Israel está lá te esperando a qualquer hora que você se aborreça com isso daqui, você vai pra lá. É isso que penso. Seria o traço negro da raça. O judeu é judeu em qualquer lugar, ele faz questão de ser. Então ele não é brasileiro, ele é judeu. Se você tiver que perguntar para um judeu, você é brasileiro? Ele vai dizer que é judeu. Por haver sempre essa necessidade de manifestar que é judeu, de se intitular como um povo, eu acho que é aí que está esse aspecto não patriótico. Porque acima de tudo, se você é brasileiro, você não é judeu. (30 anos, Adv, não judia casada com judeu )

As diversificadas falas registradas permitem observar a manifestação antissemita em seus variados tons desde aquela de tipo clássico, a religiosa, passando pela ótica econômica até as mais sofisticadas em termos ideológicos assentando-se em questões políticas e de fundo nacionalista. Percebe-se, por outro lado, que essa variedade de visões sobre os judeus captada nos discursos das entrevistadas convivem, historicamente, no interior da sociedade brasileira desde o processo de colonização submetido à coroa portuguesa até a contemporaneidade de nossos dias.

Não é possível desconhecer que os judeus incorporam a cultura brasileira e processam uma certa simbiose gerando um judaísmo próprio - o judaísmo brasileiro - fato que ocorre em todos os países e lugares nos quais os judeus vivem. Quando se introduziu na pesquisa a questão da assimilação, verificou-se que a quase totalidade das mulheres entrevistadas entendiam o significado do termo na acepção semântica produzida pelas comunidades judaicas e cujo conteúdo compreende o fenômeno relacionado ao sentimento de indiferença e de apatia em relação ao judaísmo, à quebra de laços de solidariedade grupal e o desarraigamento do judeu frente sua religião e seu patrimônio histórico-cultural.

$\mathrm{Na}$ visão das mulheres religiosas ortodoxas, a ênfase foi colocada no fato de ser um "afastamento de uma alma judaica de sua religião" ou, em afirmações mais contundentes, elas declaravam tratar-se do judeu que não gosta de sua religião e a abandona definitivamente ou a troca por outra saída definitiva do judaísmo. Por outro lado, as não religiosas - tradicionais ou progressistas - também concordaram que a assimilação é uma forma de alienação frente à cultura judaica; "é um desconhecimento de suas raízes históricas"; "é um não participar deliberadamente de sua comunidade" e, finalmente, é um desprezar dos princípios e valores que constituem a identidade judaica.

Algumas mulheres afirmaram não acreditar em assimilação total, mesmo tratando-se da conversão. Afirmaram que nenhuma pessoa poderá estar assimilada no sentimento, este persiste e aflora de forma inesperada, desequilibrando sua equação emocional. Paralelamente, a fala de outras mulheres chamava atenção para o fato de que "autodeclarações de judaísmo não eram suficientes para caracterizar um judeu: era preciso viver judaicamente".

A análise do material da pesquisa permitiu estabelecer, segundo as depoentes, três tipos de judeus assimilados:

- Aqueles que se afastam deliberadamente do judaísmo negando ou ocultando sua identidade judaica;

- Aqueles que se afastam inconscientemente do judaísmo decorrente do pouco conhecimento de suas origens 
associado à desvalorização progressiva de sua diferença cultural;

- Aqueles que apesar de se afirmarem judeus, o são apenas ao nível formal, exteriorizado e sem conteúdo pois nunca praticam e nem vivem judaicamente a sua cotidianidade.

Associado a este tema, a questão da endogamia/exogamia matrimonial coloca-se como uma discussão importante dentro do judaísmo moderno. Isso não significa dizer que a preocupação sobre este fenômeno não tenha habitado muitos momentos da história judaica, mas, atualmente, tem assumido grande relevância apontando para uma tendência de crescimento acelerado da denominada assimilação.

Das entrevistas efetuadas, observa-se que as mulheres judias afirmaram ser o chamado casamento misto, ou seja, fora do grupo, uma consequência direta do processo de assimilação previamente comentado. Para as mulheres religiosas, principalmente, este fato representa o fim gradativo e inexorável do judaísmo em termos de processo histórico pela dissolução de seus valores básicos.

A problematização da exogamia é um tema carregado de elevada carga emocional pela família judaica e "por mais desligados que sejam os pais, eles querem casamento endogâmico para seus filhos". A socialização dos valores matrimoniais judaicos é muito acentuada gerando a síndrome da interdição, "eu tenho uma censura muito grande comigo mesma". O entendimento desta questão faz parte da visão de mundo sobre o futuro judaico enquanto religião, história e cultura. Isto porque, a continuidade judaica se assegura pelo fortalecimento dos laços de união e solidariedade que decorrem do pertencimento a um passado comum e da responsabilidade pessoal e coletiva pelo destino futuro.

Esta preocupação com o "matrimônio in-group" marca o comportamento dos judeus em todos os períodos de sua historiografia, como um mecanismo de preservação de sua identidade judaica, em situações adversas. Vivendo espalhados em inúmeras comunidades, sem um centro religioso unificador, e até sem contato entre elas, decorrente da condição diaspórica de fragmentação e dispersão, a manutenção do judaísmo durante tantos séculos só poderia se basear no fortalecimento do princípio do "nós" ancorado pela endogamia. Desse modo, a resistência à sua dissolução passava pela recomposição intergeracional da comunidade. E o casamento endogâmico preenchia esta função.

Algumas das entrevistadas analisaram o processo de assimilação como sendo uma tendência natural em curso e que deve ser encarada como parte da aculturação promovida nas sociedades democráticas abertas, em que mesmo havendo algumas formas de preconceito - o acesso aos serviços societários e às áreas de decisão política estão garantidas legalmente.

Contudo, a visão dessas mulheres - quer admitindo como prenúncio trágico o fim da judaiedade, quer postulando como um processo natural que resultará em adaptações sucessivas com a introdução de características novas do judaísmo futuro - porta uma unanimidade quanto às dificuldades geradas para os filhos de casamentos mistos. As crianças são consideradas as grandes vítimas porque "não vão transitar em terreno algum". A postura de neutralidade assumida pelos pais de que os filhos, quando crescerem, irão decidir quem são, cria problemas de ambiguidade identitária, de difícil resolução pois manipula-se o tempo como uma categoria que determinará sua identidade que deve ficar entre parênteses, sem forma e conteúdo, esperando um tempo hipotético para se definir.

Algumas das mulheres judias casadas com não judeu, entrevistadas nesta pesquisa, apresentaram comportamento diferencial no sentido de garantir, desde logo, sua descendência como judaica, enviando-a para escolas e espaços de convivência judaica, como clubes, movimentos juvenis, entre outros. Os cônjuges negociaram, a priori, o destino identitário de seus filhos marcando o território simbólico no qual deverão se circunscrever. Todas as entrevistadas judias, casadas com judeus ou não, apontaram a escola como instrumento fundamental para a formação judaica de seus filhos na medida que lhes restava pouco tempo devido sua inserção no mercado de trabalho para prover uma base sólida de conhecimentos e um consistente processo de socialização. A questão da sociabilidade de seus filhos passava, necessariamente, pela frequência à escola e aos diversos espaços de lazer e esportes dos clubes judaicos na medida que, diferentemente do passado no qual a comunidade vivia conglomerada em alguns bairros e quase todos se conheciam, a dispersão e a mobilidade geofísica da comunidade fragmenta o relacionamento entre as crianças e, principalmente, entre os jovens conferindo à escola o lugar privilegiado de contato mais prolongado para estabelecer amizades "in-group". 
Nos casamentos mistos, o conflito entre marido e mulher é pequeno, porém fatalmente vai surgir com os filhos. Se o casal chega a se casar apesar de suas diferenças religiosas, creio que o conflito deve ser pequeno ou nenhum. Eles vão querer se firmar quando chegam os filhos porque vão ter que tomar muitas decisões. Vão fazer circuncisão ou não, colocar em escola judaica ou não, vai seguir a religião do pai ou da mãe, vai celebrar bar ou bat Mitzvá ou não, etc. A tendência é a criança seguir a religião da mãe por conta da maior convivência dela com o filho. (33 anos - Jur)

A criança, filha de casamento misto, fica muito mexida e até desorientada. Tome como exemplo, o caso de um menino matriculado em escola judaica e que na hora de assinar o sobrenome, simplesmente tirou o nome da mãe - o nome judeu - e só assina com o sobrenome do pai. (45 anos $-\mathrm{Edu}$ )

Sou casada com católico e as festividades ficam misturadas porque eu comemoro os meus feriados e ele participa e gosta. Eu participo das celebrações cristãs, coloco árvore de Natal. Em casa tenho o Novo Testamento assim como a Torá e a Mezuzd. Ambos respeitamos a religião do outro. A cabeça do meu filho não está com problemas frente a essa diversidade. (40 anos - Let)

$\mathrm{Na}$ minha cabeça, eu jamais poderia dizer para meus pais que eu estava apaixonada por um não judeu. Não tive coragem de dizer para minha mãe e, então, eu menti. Essa mentira me fez muito mal durante o tempo que prevaleceu. Foi meu namorado que contou para meus pais, porém eu, antes, já havia estabelecido com ele que a concordância do casamento estava associada ao fato dos futuros filhos poderem ser judeus e ele concordou. Os filhos foram circuncidados, celebraram o bar Mitzvá - o rito de passagem aos 13 anos - participam da comunidade embora não tenham estudado em escola judaica. ( 43 anos - Psi )

Eu não acredito que casar com não judeu , o judaísmo vai acabar, vai morrer. O rompimento com o judaísmo não ocorre, necessariamente, por conta do casamento exogâmico porque tem judeu casado com judeu que não está nem aí para o judaísmo e seus valores. (54 anos - Psi)

\section{Referências bibliográficas:}

ARENDT, Hannah (1978) - The Jews as pariah. Jewish Identity and Politics in modern age. New York: Grove Press.

ARIFS, P \& DUBY, G (1992.) - História da Vida Privada - 5 vol. São Paulo: Cia das Letras.

AVNI, Haim (1988) - "Jews in Latin America. The Contemporary Jewish Dimension" in Amuar (org) Judaica Latinoamenricana: estudios historico-sociales. Jerusalem: Hebrew Univ. Press

BAUM, C; HYMAN, P; MICHEL, S (1977) -The Jew Woman in America. NY:Plume Books.

BELL, Daniel (1977) - "The return of the sacred? The argument on the future of religion" London: The British Journal of Sociology.

CARNEIRO, ML Tucci (1988) - Antissemitismo na era Vargas (19301945). SP: Brasiliense

CASCUDO,L Câmara (1980) - Mouros, Franceses e Judeus. São Paulo: Perspectiva

CUNHA, MC (1979) - "Ethnicidade: da cultura residual mas irredutível" São Paulo: Revista de Cultura Política-CEDEC no 1

DAVIDOVICZ, Lucy (1977) - The Jewish Presence: essays on identity and history. New York: Holt, Rinehart \& Winston

GUINSBURG, Jacob (1979) - O Judeu e a Modernidade. São Paulo: Perspectiva.

KOLTUN, Elizabeth (1976) - The Jewish Woman. New York: Schocken Books

LEWIN, Helena (1992) - "A Mulher Judia e as controvérsias entre o tradicional e o moderno" RJ: Congresso Internacional América 92: Raízes e Trajetórias. USP/UFRJ

(1994) - O Desocultamento: primeiro passo para entender a diferenciação (análise da comunidade judaica do Rio de Janeiro). Brasília: CNPq 
(1997) - “A Economia Errante: a inserção dos imigrantes judeus no processo produtivo Brasileiro" AMILAT (org) - Judaica Latinoamericana: estudios historico-sociales, op cit

\& KUPERMAN, D ( org) (1977) - Judaísmo, Memória e Identidade $-2^{\circ}$ vol Rio de Janeiro: Ed. UERJ

(1997) -"O olhar do jovem sobre sua identidade" in Lewin \& Kuperman (org), op cit

(2001) - “A construção do 'diferente': o judeu nos arquivos secretos brasileiros" in: AMILAT (org) - Judaica Latinoamenricana - estudios historicos-sociales, op cit

POLIAKOV, León (1986)- História do Antissemitismo. São Paulo: Perspectiva, $4^{\circ}$ vols.

SHAKED, Gerson (1988) - Sombras de Identidade. São Paulo: Perspectiva

SORJ, B \& GRIN, M (1993) - Judaísmo e Modernidade - metamorfose da tradição messiânica. Rio de Janeiro: Imago Editora.

VIEIRA, Nelson (org) (1994) - Construindo a Imagem do Judeu. Rio de Janeiro: Imago Ed.
O pacto da memória: interpretação e identidade na fonte bíblica

Cláudia Andréa Prata Ferreira

S patriarcas e as matriarcas têm como elemento comum um pacto com Deus, no qual se estabelece um compromisso mútuo, que se ratifica a cada geração na transmissão de valores e pela circuncisão. De acordo com o texto bíblico, Avraham, o primeiro hebreu, abandona o lar na Mesopotâmia em cumprimento à ordem divina, na direção de um novo destino. A circuncisão é a formalização do pacto entre Avraham e Deus por meio de um sinal físico (Gn 17, 10-11). O pacto se renova com o filho de Avraham, Isaac $(\mathrm{Gn} 26,24)$ e, por sua vez, a promessa divina se repete também com Jacó, filho de Isaac e neto de Avraham (Gn 28, 13-15).

${ }_{1}$ E disse o Eterno a Abrão (Avram): Anda de tua terra e da tua parentela e da casa de teu pai, para a terra que te mostrarei. ${ }_{2} \mathrm{E}$ farei de ti uma grande nação, e abençoar-te-ei, e engrandecerei teu nome, e serás uma bênção. (TORA, Gn 12, 1-2 p.29.)

10 Esta é a Minha aliança, que guardareis entre Mim e vós (os de agora,) e a tua semente depois de ti: Será circuncidado em vós todo varão. ${ }_{11}$ E circundareis a carne de vosso prepúcio, e será' por sinal de aliança entre Mim e vós. (TORA, Gn 17, 10-11 p.39.).

${ }_{13} \mathrm{E}$ eis que o Eterno estava sobre ela, e dizia: Eu sou o Eterno, Deus de Abraão, teu pai, e Deus de Isaac; a terra em que tu jazes sobre ela, a ti a darei e à tua semente. ${ }_{14} \mathrm{E}$ será a tua semente como o pó da terra, e te fortalecerás, ao oeste, ao leste, ao norte e ao sul; e por ti serão benditas todas as famílias da terra, e por tua posteridade. ${ }_{15} \mathrm{E}$ eis que $\mathrm{Eu}$ estou contigo, e te guardarei por onde quer que fores, e te farei voltar a esta terra; porque não te abandonarei até que Eu faça o que falei por ti. (TORA, Gn 28 13-15p.79.).

Na palavra hebraica Israel temos as iniciais dos nomes dos patriarcas e das matriarcas, a família original que dá origem a Israel. Na passagem de Gênesis 32, 29, a etimologia sugere o significado de Israel: "E disse: Não, Jacob não será mais teu nome, senão Israel, pois lutaste com (o anjo de)

${ }^{1}$ Professora Doutora e Coordenadora do Setor de Hebraico da Faculdade de Letras da UFRJ 
Deus e com homens e venceste" (TORÁ, Gn 32, 29 p.95.). Temos literalmente sara "ele lutou"- ki saríta in Elohim "porque lutaste com Deus" e el "Deus". O verbo sara tem o sentido de "lutar", "combater" e pede o uso das preposições el "para", et "indicativo de objeto direto definido - sem equivalência na língua portuguesa" e im "com". A maior parte dos dicionários prefere indicar como significado e etimologia incertos e fornecem apenas o sentido de nome masculino e gentílico. Na palavra Israel, encontramos o sêmen, a semente do significado para a realização de um pacto entre Deus e Israel, que manterá a memória e identidade de um grupo através dos tempos e definirá as regras de sua relação com o divino.

Mencionamos anteriormente, que as iniciais dos nomes dos Patriarcas (Abraão, Isaac e Jacó) e das Matriarcas (Sara, Rebeca, Lia e Raquel) formam a palavra ISRAEL. O acrograma acima é perfeito com os nomes em hebraico. Em português, tem-se uma ideia aproximada.

A família original se transferiu para a terra do Egito devido a um período de seca em Canaã. Inicialmente, os descendentes de Avraham foram beneficiados pelo posto ocupado por José, filho de Jacó, na estrutura política egípcia. No livro de Éxodo, encontramos o relato de que em determinado momento da história egípcia, um novo rei, que não conhecera José, escravizou os filhos de Israel, que permaneceram no Egito na condição de escravos durante um período de aproximadamente quatrocentos anos (Ex 1).

Esse episódio constitui motivo de recordação e reflexão que marcam a festividade de Pessach, a Páscoa Judaica, que celebra a libertação do cativeiro egípcio. Esse episódio marca não somente a intervenção divina, agindo histórica e concretamente em benefício dos descendentes dos patriarcas, com os quais tinha um pacto, mas reafirma esse pacto com a revelação do que posteriormente conhecemos como Torá (Pentateuco). Esse pacto cria o judaísmo propriamente dito como uma religião com seu texto de referência, estatutos, normas de conduta de vida revelados coletivamente aos descendestes dos patriarcas, os filhos de Israel, que trazem em seu nome a marca do pacto realizado com seus antepassados. Essa marca continuará no nome Israel, mas terá um novo alcance com o que foi revelado no Monte Sinai.

A Torá estabelece o terceiro elemento do pacto entre Deus e os patriarcas. Se anteriormente a relação pactual era terra-povo, a partir de
Moisés e do pacto sinal tico, o pacto se renova com uma tríplice condição: terra-povo-Torá. Terra, povo e Torá são os elementos interdependentes que formam um tripé, que sustentam o judaísmo.

$\mathrm{O}$ ato de lembrar torna-se imperativo no judaísmo, pois é ele que garante através da perpetuação da memória que os acontecimentos fundamentais e constitutivos para a formação desse grupo (o judaico) e do pacto com Deus não se percam na memória dos filhos de Israel. Não se trata mais de um grupo de famílias divididas pelas origens das tribos ou de uma revelação individual que passa de pai para filho por fidelidade ao clã, ao patriarca. A lembrança da saída do Egito é fundamental para a compreensão do nascimento do povo e da própria religião. A saída do Egito marca o início do povo judeu como um grupo organizado e regido por suas próprias leis, reveladas ao povo por Moisés, sete semanas após a saída do cativeiro egípcio. Podemos inferir que muitas das leis presentes no texto bíblico tenham sido criadas sob o impacto do efeito do cativeiro egípcio sobre o povo judaico. Encontramos um número expressivo de leis que tratam de questões sociais que se referem ao pobre, ao estrangeiro, aos órfãos e viúvas, trabalhadores, atitudes de tolerância e benevolência, nos quais a lembrança do cativeiro egípcio é frequentemente mencionada através de um leitmotiv que funciona como um imperativo de lembrança "E lembrarás que servo foste na terra do Egito" (Dt 5, 15) e que perpassa o texto bíblico em diversas passagens. Essa lembrança justifica todas as orientações da legislação social com o intuito de estabelecer procedimentos justos para com os menos favorecidos.

A memória judaica não se encontra restrita à narrativa. Manter a memória restrita ao âmbito da narrativa poderia fazer com que a mesma ficasse paralisada no tempo e sem sentido para as gerações futuras. A memória judaica ganha sentido e realidade somente quando, através da repetição do ritual, o tempo histórico é destruído e podemos experienciar de novo o tempo verdadeiro das origens, o tempo originário. Na festividade de Pessach, reproduzimos a cada ano a experiência da saída do cativeiro egípcio, a libertação, em que cada indivíduo judeu refaz a sua história como se ele próprio tivesse saído do Egito. O relato dessa saída é vivencial e se destina a todos; não se pretende que as pessoas tenham uma aquisição intelectual do fato, ao contrário, o objetivo é a repetição simbólica da experiência original, que auxilia a compreensão de um fato passado e 
simultaneamente, um fato presente na vida de cada um que revive essa experiência.

A raiz hebraica para designar memória é composta pelas letras $z k r$ (zchr). Essa raiz se faz presente na literatura e na liturgia para nos recordar o dever da lembrança ${ }^{2}$

A memória judaica foi essencialmente preservada pela transmissão oral e pela tradição como um mandamento coletivo, conforme observamos nas passagens do livro de Deuteronômio.

E lembrarás que servo foste na terra do Egito, e que de lá te tirou o Eterno, teu Deus, com mão forte e com braço estendido. (Torá, Dt 5 , 15 p.522.)

Quando te perguntar teu filho amanhã, dizendo: Que significam os testemunhos, os estatutos e os juízos que o Eterno, nosso Deus, vos ordenou? E dirás a teu filho: Escravos fomos do Faraó no Egito, e nos tirou o Eterno do Egito com mão forte; e nos fez o Eterno sinais e milagres grandes e maus contra o Egito, contra o Faraó e contra toda

\footnotetext{
${ }^{2}$ A liturgia judaica costuma se referir a Rosh Hashand (o ano novo judaico) como o iam házikaron "Dia da Recordação", período de lembrança de Deus e do homem e conceito central durante o período de Iamim Noraim "Dias intensos", período entre Rosh Hashand e Iom Kipur "Dia do Perdão". Há uma parte litúrgica conhecida como zichronot "Recordações", que compreende os versículos bíblicos que mencionam as lembranças de Deus daqueles que não o esquecem.

Estrutura da uma parte litúrgica conhecida como zichronot "Recordações".

a) Ata zocher (Tu recordas os feitos do mundo) - Oração introdutória a zichronot que enfatiza a imagem de que Deus nesses dias tem diante de Si um registro de todos os atos e intenções de cada indivíduo. Deus tem a lembrança de quem temos sido.

b) Os dez versos contêm a raiz zkr (zchr) "lembrança".

Eloheinu ve-Elohei Avoteinu (Nosso Deus e Deus de nossos antepassados). Bênção que introduz o toque do shofar e que solicita de acordo com o tema desse segmento: zochrenu bezikaron lefanecha (Lembra-nos como uma boa recordação diante de Ti).

c) Toques do shofar.

* shofar - pequena trombeta feita com o chifre do carneiro, que se toca sobretudo nas festividades de Rosh Hashand e Iom Kipur "Dia do Perdão".

No judaísmo pós-bíblico, a raiz $z k r(z c h r)$ é usada pelos rabinos para mostrar respeito a Deus. Os rabinos referem-se frequentemente à Quarta letra do nome inefável de Deus como azkard "recordação", vem da raiz zkr (zchr), palavra aramaica também usada para uma cerimônia em memória dos mortos (geralmente realizada no $30^{\circ}$ dia após o falecimento). Temos ainda o serviço de Izkor "que Ele se lembre", palavra inicial da oração realizada em memória dos mortos no serviço de Iom Kipur e em tempos mais recentes, também recitado nas festividades de Pessach, Shavuot "Semanas" e Sucot "Cabanas".
}

a sua casa, ante os nossos olhos. E a nós, nos tirou de lá para nos trazer e para nos dar a terra que jurou a nossos pais. E ordenou-nos o Eterno observar todos estes estatutos, e que temêssemos ao Eterno nosso Deus, para que seja bem para nós, todos os dias, e para deixarnos viver, como até hoje. (Tora', Dt 6, 20-24 p.525-526.)

${ }_{17}$ Recorda-te do que te fez Amalec no caminho quando saíeis do Egito, ${ }_{18}$ que te encontrou pelo caminho e feriu todos os desfalecidos que ficavam atrás de ti, e tu estavas sedento e cansado, e Amalec não temeu a Deus. ${ }_{19}$ Quando, pois, o Eterno, teu Deus, te der descanso de todos os teus inimigos em redor, na terra que o Eterno, teu Deus, te está dando por herança para possuí-la, apagarás a memória de Amalec de debaixo dos céus; não te esquecerás. (Torá, Dt 25, 17-19 p.577.)

Neste dia, o Eterno, teu Deus, te ordena cumprir estes estatutos e os juízos; e os guardarás e os observarás com todo teu coração e com toda tua alma. (Torá, Dt 26, 16 p.580.)

Lembra-te dos dias da antiguidade, atentai para os anos das gerações sucessivas; pergunta a teu pai e ele te informará; aos teus anciãos e eles te dirão. (Torá, Dt 32, 7 p.600.).

O conteúdo da memória judaica foi primeiramente a saga coletiva tal como registrada na fonte bíblica e posteriormente, em coletividade, os rituais rememorando esses acontecimentos. $\mathrm{O}$ significado central do passado bíblico é o pacto, o pacto da memória, a garantia de que Israel seguirá através da história o plano divino. A memória judaica é essencialmente um reconhecimento de Deus, do pacto e de sua revelação através da Torci, memória fundadora da identidade judaica. A lealdade para com Deus, parte constitutiva do pacto da memória, que tirou seu povo do cativeiro egípcio, se torna elemento constitutivo de Israel. A Torci, além de ser dom divino, aparece como tarefa do povo, pois o povo vivenciando seus ensinamentos preserva o sentido da existência e faz com que estes ensinamentos sejam um zikaron "lembrança", "memória" do que foi, é e será.

No texto bíblico, a lembrança é fundamental. O verbo hebraico lizkór "lembrar" aparece em várias conjugações, tendo como tema Israel ou Deus, uma vez que ambos estão ligados pelo Pacto da Memória.

No livro de Gênesis, encontramos o mundo primevo de tempo-sonho dos arquétipos, representado pela história do paraíso. O tempo histórico 
tornou-se real após a saída de Adão e Eva do Jardim do Éden. O homem é lançado na história contra a sua vontade. No pensamento hebraísta, o homem veio para afirmar a sua existência histórica e, gradualmente, descobre que Deus o revela a ele próprio durante o decurso da história. Os rituais e as festas de Israel Antigo não são mais repetições de arquétipos míticos destinados a acabar com o tempo histórico. Na evocação do passado não se trata mais do passado primevo, mas do passado histórico, no qual ocorrem os momentos marcantes da histórica de Israel. A manifestação religiosa bíblica está impregnada de história e não pode ser concebida apartada da história. Deus só se torna conhecido quando Ele se revela para a coletividade que saiu do Egito, mais que isso, quando Ele se revela historicamente como o agente que possibilitou a saída dos hebreus do cativeiro egípcio: "Vai-te, junta os anciões de Israel e dize-lhes: O Eterno Deus de vossos pais apareceu a mim; o Deus de Abraão, Isaac e Jacob, dizendo: Tenho-vos visitado e o que vos está sendo feito no Egito" (Torci, Ex 3, 16 p.159.). Quando Deus se apresenta no Sinai para todo o povo, não temos uma descrição de sua essência ou atributos, mas o que ele fez por esse povo: "Eu sou o Eterno, teu Deus, que te tirei da terra do Egito, da casa dos escravos" (Torci, Ex 20, 2 p.214.). O povo sabe o que é Deus, devido àquilo que Ele fez na história. Dessa forma, a memória tornouse o elemento fundamental para sua fé e, por extensão, para sua própria existência. A lembrança é um imperativo religioso direcionado a todo o povo.

${ }_{17}$ Recorda-te do que te fez Amalec no caminho quando saíeis do Egito, ${ }_{18}$ que te encontrou pelo caminho e feriu todos os desfalecidos que ficavam atrás de ti, e tu estavas sedento e cansado, e Amalec não temeu a Deus. (Torá, Dt 25, 1 7-18 p.577.)

Lembra-te dos dias da antiguidade, atentai para os anos das gerações sucessivas; pergunta a teu pai e ele te informará; aos teus anciãos e eles te dirão. (Torá, Dt 32, 7 p.600.).

Jacó, lembra-te disso, Israel: tu és meu servo, eu te modelei como servo para mim; tu, Israel, não me decepcionarás. (TEB, Is 44, 21 p.484.).

Povo meu, lembra-te do que tramava Balaq, rei de Moab, do que lhe respondeu Bileitm, filho de Beor, na passagem de Shitim a Guilgal, e então reconhecerás as vitórias do Senhor. (TEB, Mq 6, 7p.667.).

Embora o ato de lembrar seja imperativo para a existência e compreensão de Israel, devemos destacar que não é a história, como supomos, mas apenas o tempo mítico que se repete. A travessia do Mar Vermelho, enquanto tempo histórico, só pode ser atravessada pelo povo uma única vez, mas a lembrança desse acontecimento, nos permite realizar várias travessias através dos tempos, e realizando essa travessia pela narrativa podemos vivenciar um fato passado no tempo presente tão somente tentando extrair-lhe o sentido da nossa própria existência. O tempo histórico pode ser único e, como tal, acontece uma única vez, mas o pacto entre Deus e Israel, o Pacto da Memória continua eternamente: "E não somente convosco eu faço esta aliança e este juramento, mas com aquele que hoje está aqui presente diante do Eterno, nosso Deus, e com aquele que hoje não está aqui conosco". (Torá, Dt 29, 13-14 p.590.).

Encontramos mais uma passagem significativa entre memória e tempo:

${ }_{6}$ Quando amanhã vossos filhos vos perguntarem: "Que significam essas pedras para nós?”, 7 dir-lhes-eis: "É que as águas do Jordão foram cortadas diante da arca da aliança do Senhor, quando ela passou pelo Jordão! As águas do Jordão foram cortadas e essas pedras servirão de memorial para os filhos de Israel para sempre". (TEB, Js 4, 6-7 p.250.).

Não a pedra em si, mas sim a memória transmitida pelos antepassados é decisiva, se a memória contida na pedra tiver que ser invocada a reviver o acontecimento para as gerações futuras. Não podemos retornar ao Sinai, mas podemos participar dele através da memória de que a pedra é portadora.

O apelo que encontramos no texto bíblico para lembrança e memória tem pouca relação com uma curiosidade sobre o passado. Os bnei Israel "Filhos de Israel" são instruídos apenas para ser um reino de sacerdotes e um povo sagrado e não um povo de historiadores. Israel não tem a obrigação de recordar todo o passado, mas sim de parte dele, dos atos de intervenção divina na história, e as respostas do homem, negativas ou positivas.

${ }_{10}$ E quando te levar o Eterno, teu Deus, à terra que jurou a teus pais, a Abraão, a Isaac e a Jacob, e de te der cidades grandes e boas que não edificaste; ${ }_{11}$ e casas cheias de todas as boas coisas que tu não encheste; e poços cavados que não cavaste; vinhas e oliveiras que não plantaste; e comeres e te fartares, 12 guarda-te de não esquecer ao Eterno, que te tirou da terra do Egito, da casa dos escravos. (Tora', Dt 6, 10-12p.525.) 
${ }_{11}$ Guarda-te que não te esqueças do Eterno, teu Deus, deixando de observar os Seus mandamentos, os Seus juízos e os Seus estatutos, que te ordeno hoje, 12 para não suceder que, depois de teres comido e estares farto, depois de teres edificado boas casas e habitado nelas, ${ }_{13} \mathrm{e}$ teu gado e teu rebanho se terem multiplicado, e tua prata e o teu ouro se terem aumentado, e tudo que possuíres se ter multiplicado, ${ }_{14}$ por isso tudo, se orgulhe o teu cotação e te esqueças do Eterno, teu Deus, Quem te fez sair da terra do Egito, da casa dos escravos; ${ }_{15}$ Quem te conduziu pelo deserto grande e temível, em que há cobras, serpentes abrasadoras e escorpiões, lugar árido onde não há água; Quem fez sair para ti água da rocha forte; ${ }_{16}$ Quem no deserto te fez comer Maná que teus pais não conheceram; para te afligir e para te provar, para te fazer bem afinal. 17 Quiçá dirás no teu coração: "A minha força e a fortaleza da minha mão conseguiram estes bens!" ${ }_{18}$ Mas, antes te lembrarás do Eterno, teu Deus, porque é Ele quem te da' força para conseguires riqueza, a fim de confirmar Sua aliança, que jurou a teus pais, como o faz hoje. (Tora', Dt 8, 11-18 p.530-531.).

A memória fluiu basicamente através de dois canais, o ritual e a narrativa. Mesmo quando preservando os seus laços orgânicos com os ciclos naturais do ano agrícola - exemplo da festividade de Pessach, a Páscoa judaica, que cai no início da primavera - as grandes peregrinações e as festividades da Páscoa e do Tabernáculo foram transformadas em comemorações do Êxodo do Egito e do período de estada no deserto. Temos, no livro de Deuteronômio, um exemplo de junção entre ritual e narrativa a serviço da memória, por ocasião da cerimônia dos primeiros frutos, na qual o celebrante traz seus frutos para o santuário e deve fazer a seguinte declaração, que encontramos em Deuteronômio 26, 5-10:

${ }_{5}$ E falarás em voz alta e dirás diante do Eterno, teu Deus: "Labão (Laván), o arameu, quis fazer perecer o meu pai, e este desceu ao Egito e peregrinou ali com pouca gente, e ali veio a ser nação grande, forte e numerosa. ${ }_{6} \mathrm{E}$ nos trataram mal os egípcios, nos afligiram e nos impuseram duros trabalhos. 7 E clamamos ao Eterno, Deus de nossos pais, e ouviu o Eterno nossa voz, e viu nossa aflição, nossa fadiga e nossa opressão; 8 e tirou-nos o Eterno do Egito com mão forte, com braço estendido e com grande temor, e com sinais e com milagres. ${ }_{9}$ E trouxe-nos a este lugar e nos deu esta terra, terra que emana leite e mel. ${ }_{10}$ Eis que agora eu trouxe as primícias do fruto da terra que me deste, á Eterno!" E pousarás o cesto diante do Eterno, teu Deus, e te prostrarás diante do Eterno, teu Deus. (Torá, Dt 26, 510 p.578-579.)

A passagem acima contém uma história sintetizada nos seus aspectos essenciais do que deve ser lembrado sob uma forma ritualizada. Encontramos as origens patriarcais na Mesopotâmia, o surgimento da nação hebraica, a escravidão no Egito e a libertação, a conquista da terra prometida e, perpassando todo esse painel histórico, a consciência de Deus como o senhor da história.

A necessidade e o dever da lembrança não ficaram restritos ao corpus bíblico do Pentateuco, mas estenderam-se, igualmente, à narrativa histórica de livros como Josué, Samuel I e II, Reis I e II, Crônicas I e II, além da produção literária profética. A história bíblica tem em sua essência uma narrativa dos atos divinos, mas está igualmente repleta das ações humanas e dos feitos de Israel e das nações. Admite-se que a narrativa histórica de Israel Antigo tem suas raízes na crença de que a história era uma teofania, e que, sendo assim, os acontecimentos, basicamente, deveriam ser interpretados sob a ótica dessa fé.

A interpretação do texto bíblico já aparece desde a época anterior aos anos 70 E.C., como atividade religiosa por excelência e desemboca numa intensa atividade exegética na literatura rabínica. Essa atividade rabínica de interpretar o texto bíblico e criar uma hermenêutica elaborada tem como fonte de inspiração a própria fonte bíblica. O sentido de Midrash como um processo de "interpretação e exposição" já estaria presente na própria Bíblia numa espécie de processo de Bíblia que gera Bíblia ${ }^{3}$. A Bíblia é ela própria um texto interpretado, os profetas interpretam a Torá (Pentateuco), e fonte de toda uma tradição de interpretação, a fonte talmúdica. De acordo com essa perspectiva, a Bíblia é o substrato de um longo processo exegético no qual os livros do corpus bíblico interpretam-se uns aos outros e que a Bíblia é a primeira intérprete de si mesma. A hermenêutica rabínica que fundamentalmente é o comentário da Bíblia e, posteriormente, o comentário do comentário, dessa forma, dá continuidade a esse processo interpretativo que já estaria presente na Bíblia. A interpretação na tradição judaica é caracteristicamente um intenso processo de procura do sentido da palavra divina e uma forma de perpetuar a memória dessa relação entre Deus e

${ }^{3}$ Ver o estudo realizado por TREBOLLE BARRERA, J. (1995) p.513-520. 
Israel através dos tempos. Dessa maneira, a necessidade de compreender o sentido da existência tem como resposta o Pacto da Memória realizado entre Deus e Israel. A memória acaba por gerar o ato interpretativo como um ato de procura de sentido. Longe de esgotarmos essa atitude midráshica no texto bíblico, que inspirou a literatura rabínica, trazemos alguns casos para ilustrar o que cometamos acima.

Destacamos o papel dos profetas na atualização e interpretação das tradições de Israel. Podemos observar como o profeta Jeremias usa a legislação do divórcio para contrastar a relação entre Deus e o povo.

Deuteronômio 24, 1-4

${ }_{1}$ Quando um homem tomar uma mulher e se casar com ela, e se ela não for agradável aos seus olhos, por haver achado nela alguma coisa indecente, escrever-lhe-d uma carta de divórcio, e a dará em sua mão e a despedirá de sua casa. ${ }_{2} E$ tendo ela saído da sua casa, poderá ir e tornar- se mulher de outro homem. 3 E se este último homem dela se aborrecer e lhe escrever uma carta de divórcio, a der na sua mão e a despedir de sua casa, ou se este último homem que a tomou para si por mulher vier a morrer, ${ }_{4}$ não poderá seu primeiro marido, que a despediu, tornar a tomá-la para que seja sua mulher depois de contaminada; pois isso é abominável diante do Eterno, e não farás condenar a terra que o Eterno, teu Deus, te deu por herança. (Torá, Dt 24, 1-4 p.573.)

Jeremias 3,1

Suponhamos que um homem repudie uma mulher e esta o deixe, para pertencer a outro: será que o primeiro vai querer voltar a ela? Não ficaria aquela terra irremediavelmente profanada? E tu que te prostituíste com tantos parceiros, voltarias a mim? - Oráculo do Senhor! (TEB, Jr 3,1 p.511.).

Em Ezequiel 16, podemos encontrar a reutilização midráshica de antigos materiais da história de Israel.

Êxodo $32,2-4$

2 E disse-lhes Aarão: Tirai os aros de ouro das orelhas de vossas mulheres, de vossos filhos e de vossas filhas e trazei-os a mim. ${ }_{3} \mathrm{E}$ tirou todo o povo os aros de ouro de suas orelhas e os levaram a Aarão. ${ }_{4}$ E tomou-os de suas mãos e os trabalhou com o buril, e fez um bezerro fundido. E disseram: Estes são teus deuses, é Israel, os que te fizeram subir da terra do Egito. (TORA, Ex 32, 2-4 p.259-260.)

Ezequiel 16, 17-19

17 Tomaste os teus enfeites de ouro e prata, que eu te dera, e com eles fabricaste imagens de homens, com os quais te prostituíste. ${ }_{18}$ Tomaste também os teus vestidos bordados e as cobriste. Ofereceste o meu azeite e o meu incenso diante delas. ${ }_{19} \mathrm{O}$ pão que te dei - a flor de farinha -, o azeite e o mel com que te alimentei, tu os ofereceste diante delas como um perfume destinado a apaziguá-las. (BSJ, Ez 16, 17-19p.1622.)

Em outros casos, encontramos narrativas inteiras que reelaboram e adaptam narrativas anteriores. O livro de Crônicas é uma reescrita dos livros de Samuel e dos Reis, com pontos de vista diferentes. No livro de Gênesis, a nova ordem imposta após o dilúvio, reflete-se no paralelismo encontrado nas palavras de Deus dirigidas ao primeiro homem (Gn 1, 2630) e as dirigidas à nova humanidade, Noé e seus filhos (Gn 9, 1-7). Contudo, entre as duas passagens bíblicas observamos significativas mudanças, tais como a nova relação do homem com a criação, lei do sangue e a nova lei dietética.

Gênesis 1, 26-30

${ }_{26}$ E disse Deus: "Façamos homem à nossa imagem segundo a nossa semelhança; e que domine sobre o peixe do mar e sobre a ave dos céus, e sobre o quadrúpede e em toda a terra, e em todo réptil que se arrasta sobre a terra!" ${ }_{27}$ E criou Deus o homem à sua imagem, à imagem de Deus o criou; macho e fêmea criou-os. ${ }_{28} \mathrm{E}$ abençoou-os Deus e disse-lhes Deus: "Frutificai e multiplicai, e enchei a terra subjugai-a, e dominai sobre o peixe do mar e sobre a ave dos céus, e em todo animal que se arrasta sobre a terra". ${ }_{29}$ E disse Deus: "Eis que vos tenho dado toda erva que dá semente que (se acha) sobre a face de toda a terra, e toda árvore em que há fruto de árvore que dê semente: a vós servirá para comer. ${ }_{30} \mathrm{E}$ para todo animal da terra $\mathrm{e}$ toda ave dos céus, e tudo o que se arrasta sobre a terra, em que haja alma viva; e toda verdura de erva (será) para comer". E foi assim. (Tora', Gn 1, 26-30p.3-4.)

Gênesis 9, 1-7

${ }_{1}$ E abençoou Deus a Noé e a seus filhos, e lhes disse: "Frutificai, multiplicai-vos e enchei a terra. ${ }_{2} \mathrm{E}$ vosso temor e vosso medo será 
sobre todo animal da terra, e sobre toda ave dos céus, sobre tudo o que a terra produz do que se arrasta nela, e sobre todos os peixes do mar; em vossas mãos foram entregues. ${ }_{3}$ Todo réptil que vive, a vós será para comer; (como a verdura de erva,) dei a vós tudo. ${ }_{4}$ Porém, a carne com sua alma (estando com vida) e seu sangue, não comereis. ${ }_{5} \mathrm{E}$ por certo o vosso sangue de vossas almas requererei; da mão de todo animal a requererei; e da mão do homem; da mão do varão (que é como) seu irmão, requererei a alma do homem. ${ }_{6}$ Aquele que derrama o sangue do homem, pelo homem, seu sangue será derramado, pois à imagem de Deus fez o homem. ${ }_{7} \mathrm{E}$ vós, frutificai, $\mathrm{e}$ multiplicai-vos, aumentai na terra e multiplicai-vos nela". (Toni, Gn 9, 1-7p,22.).

Outro ponto que destacamos são as tipologias intrabíblicas, ou a descrição de determinado personagem com características ou em contextos próprios de outro. A estrutura tipológica de um personagem é calcada em outro. Como constatamos pelas citações do livro de Gênesis acima, temos Noé como um novo Adão e também, em Js 1, Josué é apresentado como Moisés libertador; em 1 Rs 19, Elias é um novo Moisés.

Numerosos salmos e cânticos condensam em estrofes rítmicas as extensas narrativas dos acontecimentos da salvação. O Cântico de Moisés em Ex 15 é um exemplo de desenvolvimento a partir de um antigo verso "Cantarei ao Eterno, que gloriosamente Se enalteceu; cavalo e seu cavaleiro jogou no mar" (Tord, Ex 15, 1 p.197.), completado com estrofes que relembram os prodígios de Deus até levar o povo desde o Egito até o Monte do Templo.

Nessas releituras sapienciais destaca-se a tendência a reinterpretar as antigas tradições de Israel no livro da Sabedoria; exemplo típico são as releituras da grande aventura do êxodo e da passagem pelo deserto (Sabedoria 16-19)

\section{Números 21, 6-9}

${ }_{6} \mathrm{E}$ enviou o Eterno para o povo as serpentes abrasadoras, e morderam o povo; e morreu muita gente de Israel. ${ }_{7} \mathrm{E}$ veio o povo a Moisés, e disse: Pecamos, porquanto falamos contra o Eterno e contra ti, ora ao Eterno para que tire de sobre nós a serpente. E orou Moisés pelo povo. ${ }_{8} \mathrm{E}$ disse o Eterno a Moisés: "Faze para ti uma serpente abrasadora e põe-na sobre uma haste; e acontecerá que todo aquele que for mordido, olhando para ela viverá". ${ }_{9} \mathrm{E}$ fez Moisés uma serpente de cobre e a pôs sobre a haste; e eis que, se por acaso a serpente mordia a alguém, este olhava para a serpente de cobre e vivia. (Toni, Nm 21, 6-9p.453.).

Sabedoria 16, 5-12

${ }_{5} \mathrm{E}$ mesmo quando $\mathrm{o}$ furor terrível dos animais venenosos desencadeou-se contra os teus,/ que pereciam sob a mordida das serpentes sinuosas, tua cólera não permaneceu até o fim 6 . Como advertência foram perturbados por pouco tempo, pois tinham um penhor de salvação que lhes recordava o mandamento de tua Lei Com efeito, todo aquele que se voltava era salvo, não pelo objeto que contemplava, / mas por ti, o Salvador de todos 8 . E assim provaste a nossos inimigos que és tu quem liberta de todo malg. A eles, mataram-nos as picadas dos gafanhotos e das moscas, / sem que se encontrasse remédio para preservar sua vida, / pois mereciam ser castigados por tais feras ${ }_{10}$. A teus filhos, ao contrário, nem o dente das serpentes venenosas pôde vencer, pois tua misericórdia veio ao seu encontro e os curou 11 . Para que se lembrassem de tuas palavras eram aguilhoados, / mas foram logo libertados / para que, tombados em esquecimento profundo, / não fossem subtraídos à tua ação benfazeja. ${ }_{12} \mathrm{E}$ não foi erva nem pomada que os remediou, / mas tua Palavra, Senhor, que a todos cura. (TEB, Sb 16, 5-12 p.1120-1121.).

Compreendemos o texto bíblico como um grande mosaico na qual as partes dialogam entre si, procurando um sentido. Esse processo de procura de compreensão e sentido do texto terá continuidade com a segunda parte do cânone judaico, denominada de fonte talmúdica, na qual os rabinos travam debates, comentários e criam uma hermenêutica peculiar, em particular o estilo Midrash "interpretação" explorando o texto bíblico em todas as possibilidades.

Os rabinos, estudiosos e sábios da Tradição Judaica fizeram do Tanach (Bíblia Hebraica) um laboratório de textos, impedindo seu fechamento e cuidando de preservá-lo como uma Obra aberta e com sentido para o cotidiano através das gerações.

Inferimos que o texto bíblico se transforma em linguagem e essa linguagem revela toda a dimensão da vida humana. A tentativa de perpetuar, compreender e interpretar o Pacto realizado entre Deus e os bnei Israel "Filhos de Israel" revela um estado de procura que se desenvolve e toma corpo na palavra, no ato de narrar donde, o surgimento de uma 
tradição oral que, posteriormente, se transforma em tradição escrita. Essa tradição escrita divide-se em duas fontes básicas: a bíblica e a talmúdica, que é essencialmente um vasto campo interpretativo desenvolvido pelos rabinos, que se dedicavam a interpretar a fonte bíblica à luz de sua época.

\section{Conclusão}

Uma das características do texto bíblico é a justaposição de fontes com relatos de acontecimentos e características de uma época com os de outra. A cronologia, de modo geral, é respeitada, pois existe um sentido de fluxo de tempo histórico e das mudanças que nele ocorrem, sendo assim, não vamos encontrar Abraão como observante das leis mosaicas. Os editores que periodicamente editaram esse patrimônio literário redigiram as fontes que tinham à sua disposição sem as nivelar completamente. Temos um texto bíblico unificado, em cujo interior desfilam diferentes autores em épocas diversas com aspectos linguísticos peculiares de cada autor e período. Esse material é fruto de um longo processo de transmissão oral e, posteriormente, escrita, que vai sendo compilado e transmitido de geração a geração ao longo do tempo. O fechamento do cânone bíblico, em Iavné, Israel, por volta do ano 100 E.C. confere ao texto bíblico um caráter singular, no qual a história de um povo tornou-se parte de sua literatura sagrada. Com um corpus textual definido pela canonização, a leitura pública desse material e o seu trabalho de cópia e transmissão faz surgir uma nova etapa do Pacto da Memória, entrando em cena os rabinos, sábios, estudiosos da fonte bíblica que, no intuito de continuar o dever da lembrança e procurando o sentido desse texto, geram um novo tipo de material denominado genericamente de fonte talmúdica.

O corpus talmúdico é um vasto campo de literatura rabínica que se dedica a interpretar, à luz de sua época, o texto bíblico. O texto bíblico em si mesmo não precisa de interpretação, quem procura pelo seu sentido não é o próprio texto bíblico, mas o homem dotado da capacidade de transformar em linguagem aquilo que ele interpreta desse texto. A procura de sentido do texto é uma necessidade de perpetuar o Pacto da Memória realizada entre Deus e os homens. O homem de cada tempo recebe o texto bíblico e o Pacto, e interpreta esse Pacto de acordo com os valores do interpretador (homem) e do espírito da época para que esse Pacto se perpetue com sentido através dos tempos para o homem. O que significa dizer que o judaísmo é fundamentalmente interpretação do texto bíblico, pois que este não existe sem o homem para recebê-lo e interpretá-lo.

\section{Referência Bibliográfica:}

ARANDA PEREZ, Gonzalo et alii. Literatura judaica intertestamentdria. $1^{a}$ ed. Trad. Mário Gonçalves. São Paulo, Ave- Maria, 2000. 522 p. (Introdução ao Estudo da Bíblia, 9)

BONDER, Nilton. Rosh Ha-Shana e Iom Kipur: dias intensos. 1.ed. Rio de Janeiro; imago, 1990. 132 p. (Diversos).

FERREIRA, Cláudia Andréa Prata. Riobaldo: o indivíduo à procura da compreensão do seu Ser. Rio de Janeiro: UFRJ, Faculdade de Letras, 1995. 124 fl. Mimeo. Dissertação de mestrado em Ciência da Literatura - Teoria Literária.

. O pacto da memória: interpretação e identidade nas fontes bíblica e talmúdica. Rio de Janeiro: UFRJ, Faculdade de Letras, 2002. 274 fl. mimeo. Tese de Doutorado em Ciência da Literatura - Poética.

CLEMENTS, R.E. (org.). O mundo do Antigo Israel: perspectivas sociológicas, antropológicas e políticas. Trad. João R.Costa. Ver. Honório Dalbosco. São Paulo, Paulus, 1995. 412 p. (Bíblia e Sociologia).

ENCICLOPÉDIA Judaica. 1.ed. Trad. Elias Davidovich (et al.). Rio de Janeiro, A.Koogan, 1990. 10V.

GOTTWALD, Norman K. Introdução socioliterária à Bíblia Hebraica. Trad. A.Alvarez. São Paulo, Paulinas, 1988. 639 p. (Bíblia e sociologia).

TREBOLLE BARRERA, Julio. A Bíblia judaica e a Bíblia cristã: introdução à história da Bíblia. Trad. Ramiro Mincato. Petrópolis, RJ: Vozes, 1995. 741 p.

YERUSHALMI, Yosef Hayim. Zakhor: história judaica e memória judaica. Trad. (da $2^{\mathrm{a}}$ ed. original) Lina G. Ferreira. Rio de Janeiro, Imago, 1992. 168 p. (Bereshit). 
BÍBLIA, A. Tradução Ecumênica (TEB). São Paulo, Loyola: Paulinas. 1995. $1567 \mathrm{p}$.

BÍBLIA Sagrada de Jerusalém, A (BSJ). s.ed. São Paulo, Paulinas, 1991. $2366 \mathrm{p}$.

TORA. A Lei de Moisés. Edição revisada e ampliada da obra A Lei de Moisés e as Haftarót.

Inclui a tradução das Cinco Meguilot por David Gorodovits e Ruben Najmanovich.

1.ed. São Paulo, Sefer, 2001. 685 p.

Citação de datas:

Segue a tendência internacional para pesquisas de culturas não cristãs:

a.E.C. $($ antes da Era Comum $)=$ a.C. $($ antes de Cristo $)$

E.C. $($ Era Comum $)=$ d.C. $($ depois de Cristo $)$

Este trabalho é parte integrante de nossa pesquisa de doutorado intitulada:

FERREIRA, Cláudia Andréa Prata. O pacto da memória: interpretação e identidade nas fontes bíblica e talmúdica. Rio de Janeiro: UFRJ,

Faculdade de Letras, 2002. 274 fl. mimeo. Tese de Doutorado em Ciência da Literatura - Poética. (@Cláudia Andréa Prata Ferreira. 2001-2002.)

Artigos na internet:

http://www.estudosjudaicos.com/

http://www.pletz.com

http://www.moadon.com.br Ver ainda:

ESTUDOS JUDAICOS - Lista de debates. Temática - Estudos Judaicos e Língua Hebraica. http://www.estudosjudaicos. com/

\section{A diáspora brasileira: solução neurótica, anomalia e viver parcial?}

Leopoldo O. C. de Oliveira

Z $\mathrm{m}$ 1984, A. B. Yehoshua, um dos maiores romancistas vivos de Israel, publicou uma coletânea de cinco artigos sobre sociedade israelense, sionismo e diáspora. $\mathrm{O}$ volume intitula-se Pelo direito à normalidade e dele gostaria de destacar dois ensaios: "Judeu, israelense, sionista: revisão de conceitos" e "A diáspora: uma solução neurótica". Nesses ensaios, Yehoshua examina aspectos importantes da estrutura societária israelense, contrastando-os com os da diáspora. Neste texto, pretendo examinar sucintamente em que extensão as ideias de Yehoshua sobre o viver diaspórico coincidem com a realidade social e identitária de comunidades e indivíduos judeus no Brasil, ou dela divergem.

\section{Judeu $\mathrm{x}$ israelense: anomalia $x$ normalidade?}

Como é de conhecimento geral para aqueles que estão familiarizados com o judaísmo, mas não para o grande público, talvez não haja conceito mais intrincado do que o conceito de judeu, devido ao fato de que o termo passou gradativamente, ao longo de sua história, a significar indivíduos, comportamentos e backgrounds culturais muito díspares entre si e ainda pelo uso e conteúdo que cada um atribui a ele ${ }^{2}$. A definição canônica e religiosa sobre quem deve ser considerado judeu (em relação a comunidade judaica) está contida na Halachá: "judeu é filho de mãe judia ou aquele que se converteu ao judaísmo segundo a Halachá". Neste ponto, antes do exame do conceito, deve-se indagar o porquê de uma definição deste tipo estar contida na Halachá. Provavelmente porque, à época de sua compilação, já havia alguma dúvida para os próprios judeus sobre quem poderia ser considerado judeu, devido à dispersão do povo por lugares distantes, em meio às mais variadas culturas.

\footnotetext{
${ }^{1}$ Doutorando em Literatura Brasileira / UERJ.

${ }^{2}$ Assim, por exemplo, o conceito de judeu de um antissemita não será o mesmo que o de um judeu religioso, que, por sua vez, não será o mesmo que o de um judeu laico etc.
} 
Na verdade, mais do que traços culturais específicos, o que está por trás da definição haláchica é a manutenção da religião. O condicionamento à ascendência materna não é aleatório, o componente, em sua essência, não é racial. Se o fosse, mais provável seria o condicionamento à ascendência paterna, que se ajustaria melhor a uma sociedade patriarcal (vide o exemplo da definição de cigano: "filho de pai cigano"). No judaísmo, é a mãe quem cuida da educação religiosa do filho, de seu nascimento até que tenha idade para frequentar o Cheder, ficando a seu encargo inculcar-lhe os valores básicos da religião.

Segundo Yehoshua, a definição haláchica clássica define um judeu sem atribuir-lhe um componente de conteúdo. Na verdade, não há razão plausível para que a Halachá repetisse em sua definição o óbvio. Pressupõe-se que aquele que é considerado judeu deva incorporar em sua conduta, seu componente de conteúdo, todo o corpo de preceitos, práticas e crenças contidos na própria Halachá. Por isso, há ênfase na segunda parte da definição haláchica: se preconiza a conversão segundo as normas da Halachá, o que ainda hoje é um princípio do qual os ortodoxos não abrem mão, é porque estas mesmas normas exigem um componente de conteúdo e de conduta do converso que o defina enquanto judeu.

Apesar das pressões de grupos religiosos, a primeira formulação da Lei do Retorno, que vigeu durante dez anos foi: "Judeu é aquele que declara sê-lo". Pode-se relacionar esta "frouxidão" no conceito com a necessidade da imigração em massa para povoar o jovem Estado (orientação "demográfica"). Era mais importante povoar o Estado com uma população judia do que verificar em detalhes a judaicidade da mesma.

Dez anos depois, entrou em vigor a segunda formulação da Lei do Retorno: "Judeu é o filho de mãe judia ou convertido ao judaísmo". Definição próxima à definição haláchica, admitindo, implicitamente, a conversão ao judaísmo por outros meios que não os preconizados pela Halachá. Não basta mais se declarar judeu. O maior rigor da segunda formulação está relacionado às pressões crescentes de grupos ortodoxos e ultraortodoxos e à diminuição da necessidade da imigração maciça. No entanto, a relutância em se acrescentarem ao conceito de judeu presente na Lei do Retorno os termos “... convertido ao judaísmo segundo a Halachá deve-se ao fato de que não era prudente abrir um precedente que pudesse dar mais fôlego às pretensões dos ortodoxos de que Israel fosse governado pela lei religiosa (teocracia). O governo israelense também não poderia, com essa mudança, negar legitimidade a outras formas de judaísmo, dentro do país e na diáspora.

Para o conceito de judeu presente na Lei do Retorno, A. B. Yehoshua propõe a seguinte reformulação: "Judeu é quem se autoidentifica como judeu". A definição de Yehoshua busca, na verdade, esvaziar ao máximo o componente religioso da definição de judeu, deixando-o como um dos muitos componentes possíveis. Isso se dá para que o termo se adapte à realidade do mundo atual, no qual a tônica é a laicização e também para não dar mais ensejo às pretensões de grupos fundamentalistas de que Israel se torne uma teocracia. Pondo a identificação como judeu nas mãos do próprio indivíduo, Yehoshua procura, também, acentuar o grau de compromisso e de responsabilidade assumido por esta decisão quanto ao judaísmo.

Yehoshua afirma que o que determina um judeu é sua identificação com o judaísmo, não necessariamente, ou principalmente, com a religião; embora não deixe claro que outros parâmetros de identificação seriam possíveis, a não ser a livre e espontânea vontade de autoidentificação judaica, não negando a influência da família, da sociedade e da cultura, mas asseverando que nada disso é suficiente para determinar a identificação.

Um judeu que abandona o judaísmo, por livre e espontânea vontade, deixa de sê-lo, como já está previsto na própria Halachá e como até mesmo judeus marxistas/trotskistas (DEUTSCHER, 1970, passim) admitem. Um não judeu que se autoidentifica como judeu, mesmo que não passe pela conversão formal religiosa, segundo a definição de Yehoshua, é um judeu legítimo. O autor nega que a identificação "de fora" (do antissemita, por exemplo $)^{3}$ tenha qualquer peso na definição de um indivíduo como judeu. $\mathrm{O}$ que vale é sua liberdade de escolha, sua autoidentificação voluntária, o que, segundo ele, facilita de imediato a sensação de responsabilidade do judeu para com seu judaísmo.

O que não se menciona é que, determinantes ou não, imagens e definições "de fora" existem e podem ter influência na mudança ou criação

\footnotetext{
3 DEUTSCHER (1970: 48), nesta questão, tem um posicionamento diferente do de Yehoshua, quando assevera que "o maior "re-definidor" da identidade judaica foi Hitler" e que "Auschwitz foi o terrível berço da nova nação e da nova consciência judaica" e, ainda, que "o que vem recriando constantemente essa consciência judaica e injetando-lhe, sempre, nova vitalidade tem sido o hostil ambiente não judeu que o cerca" (p.46).
} 
de novos modelos, ao menos na "livre e espontânea" vontade de criá-los ou modificá-los. É o caso da imagem do novo judeu construída pela Halachá, do novo hebreu dos princípios da nova colonização judaica na Palestina e do Movimento Canaanita das décadas de 30 e 40, todas criadas como uma tentativa de negação de estereótipos judaicos aceitos como modelo a ser rechaçado. As imagens e definições "de fora" podem também criar a necessidade de impor a criação ou adaptação de modelos. É o caso do desejo dos colonos veteranos de Israel em absorver os judeus orientais em sua cultura hebreia/ocidental. É o caso também de judeus religiosos que não reconhecem judeus seculares ou assimilados como judeus, apesar de serem judeus segundo a definição da Halachá, procurando impor a ortodoxia como única forma válida de judaísmo.

Para o autor, não existe algo como "destino judaico", uma espécie de maldição que não permite aos judeus escapar do judaísmo, uma vez que o que sempre determinou a identidade judaica de um indivíduo foi uma escolha pessoal de autoidentificação. O que há é a realidade de cada povo e linhas nacionais de caráter que se foram moldando através da história, criando modelos que se repetem, mas que podem ser mudados e adaptados aos dados da realidade objetiva. Acrescenta ainda que o conceito de "judeu" é um conceito parcial, que só pode aparentar totalidade. Seria um conceito que se enquadra a situação existencial na diáspora, do que me ocuparei a partir daqui.

Diferenciando os termos judeu e israelense, o autor estabelece que: 1) judeu se vincula com dois fatos concretos: a) fé religiosa dos filhos de Israel e b) vida dos judeus na diáspora e 2) israelense é o judeu religioso ou secular que vive uma vida judia em sua totalidade, cujos signos distintivos são o país, a língua e o contexto social independente; embora não fique claro, por exemplo, o porquê de uma experiência religiosa na diáspora, em si mesma, abstraindo questões contextuais, deva ser considerada essencialmente diferente de uma vivência religiosa em Israel.

Assim, assevera que a vida judaica na diáspora era e é parcial, pois as questões de segurança, economia e política não dependiam de sua decisão. Hoje, aumentou consideravelmente a participação dos judeus da diáspora em todos os aspectos da vida dos lugares onde se estabelecem, mas sua atividade judaica, ainda segundo o autor, diminuiu na mesma medida, restringindo-se, no melhor dos casos, à práticas religiosas, pois os sistemas sociais de que fazem parte não são judaicos (educação, economia, defesa etc.).
Argumenta o ensaísta que, no caso de Israel, todos os aspectos da vida se converteram em atividades judaicas, ao menos na época de sua criação. Hoje em dia, há no país uma separação entre atividades judaicas e atividades israelenses. No primeiro grupo, estão relacionadas todas as atividades que têm a ver com a religião e com atividades relacionadas com os judeus da diáspora; no segundo, todas as atividades normais do dia-a-dia, da relação entre concidadãos. Sigamos, nos próximos parágrafos, a linha de raciocínio de A. B. Yehoshua.

Apesar de ser um país judaico, de ter como língua a língua judaica original, um sistema educacional judaico, das relações sociais e dos objetivos serem judaicos, para muitos, o modo de vida israelense não é considerado como expressão completa e total do ser judeu. Parece que falta "algo mais". Nesse sentido, Israel apenas reproduz a situação existencial da diáspora e reitera, paradoxalmente, a "anomalia" daquela; só que apresenta o efeito sem a causa, ou seja: os judeus de Israel não são uma minoria entre povos não judeus.

Para alguns este "algo mais" é a religião, que se cobre com o nome generalizante de "religião judaica" ou "judaísmo". Este posicionamento pode estar encobrindo a verdadeira natureza do problema, que é o desejo de alguns de tornar o Estado de Israel em um estado religioso. Se se trata de religião, isso deve ser feito explicitamente e averiguar quais são os aspectos religiosos na substância israelense, pois o conceito de judaísmo não é igual ao conceito de judeu.

A mescla de religião com conceitos como "consciência judia" é enganosa, pois pode ser que haja israelenses que tenham a mais profunda consciência judia e, mesmo assim, não creiam em Deus. O engano se dá por, a se acreditar na boa-fé dos que se enganam, dois fatos: a) memória histórica: durante séculos, a identidade judaica só poderia ser definida pela religião (vivendo na diáspora, território, língua e sociedade judia total não eram possíveis) e b) a existência de não judeus no seio da sociedade israelense.

A presença de minorias não judaicas no meio israelense não deve diminuir o israelismo dos mesmos, pois judeus na França não diminuem o francesismo dos franceses nem minorias não iranianas no Irã diminuem a consciência iraniana. $\mathrm{O}$ autor toma a posição surpreendente de que quem deve sofrer a esquizofrenia da dupla identidade são as minorias, não os israelenses. Se o conflito da dupla identidade for grave, aqueles podem assimilar-se à 
identidade israelense ou abandonar o país, dirigindo-se para onde sua identidade específica seja compartilhada pela maioria. No caso da assimilação, esta não seria problemática, pois o assimilado estaria em meio a uma maioria judaica, não havendo o perigo de transportar consigo rasgos de identidade não judaica que pudessem comprometer a identidade israelense da maioria.

Quanto mais o judeu se converte em israelense (tendo como base de sua identidade e cultura o território, a língua, realidade social judia integral e soberania absoluta), mais se aprofundam suas raízes no país; quanto mais se identifica como judeu, pela religião ou por qualquer outro componente parcial, maiores são as possibilidades que deixe o país. Vê-se por este posicionamento, então, que o conceito de judeu formulado por Yehoshua é apenas retórico, pois não busca solucionar a "anomalia" judaica na diáspora, mas apenas facilitar sua integração em Israel e tornar menores as barreiras para que um maior número de judeus possa fazer sua aliá, com a vantagem de que qualquer componente parcial que seja o formador de sua identidade judia será solapado pela realidade contextual israelense, tornando mais fácil, assim, sua "conversão" de judeu a israelense.

Com relação à parcialidade da vida judaica na diáspora, o autor, paradoxalmente, reforça que esse caráter não diz respeito à sua consciência judia, que é íntegra e completa, mas sua realidade como judeu não o é, pois, segundo suas possibilidades e horizontes, que a si fixaram os próprios judeus e o judaísmo, estão limitados e se veem bloqueados pelo sistema de relações sociais não judaicas nos países em que vivem.

Aos que protestam contra a assimilação do judeu em israelense (aos modos de vida ocidental), Yehoshua assinala que ninguém se assimila no próprio país, somente se transforma. A identidade israelense é só uma transformação da identidade judaica, devido a fatores inerentes ao contexto (língua, território, sociedade judaica plena), o que reforça sua responsabilidade judaica no sentido de que aquilo que sucede com a sociedade israelense adquire um caráter "obrigante", pois há fatos que os israelenses escolhem e promovem e fatos que lhes são impostos, mas todos são parte de sua história, pois neles intervêm.

Todos os fatos do cotidiano dos israelenses estão expostos ao exame das crenças, valores, condutas e sonhos judaicos e quem se preocupa com a continuidade destes valores deve julgá-los na prática, e não na teoria, como ocorre na diáspora. Em consequência, tudo o que ocorre em Israel põe a prova o judaísmo, pois este é examinado pelo que faz na prática, não só na teoria.

Quanto aos judeus da diáspora, que são “mais livres” para decidirem "serem judeus ou não o serem mais", a definição de Yehoshua só terá maior importância para aqueles que desejarem viver seu judaísmo em Israel, como cidadãos do país. É certo que "the jewish way of life" de Israel influi no pensamento e na vida da diáspora, podendo ser por esta elogiado ou criticado, aprovado ou reprovado, abençoado ou amaldiçoado, mas aí será uma questão muito mais "filosófico-existencial" do que no próprio Estado Judaico, onde todas as questões sociais e políticas e mesmo a vida cotidiana devem ser conduzidas por uma concepção de judaicidade.

Não é exagero, então, afirmar que, quando Yehoshua formula o novo conceito de judeu, está, na verdade, formulando primordialmente um conceito de israelense. A suposta parcialidade do viver judaico diaspórico não se aplicaria aqui, pois o componente específico de judaicidade de um indivíduo em Israel é uma questão de foro íntimo, determinante, decerto, em sua vida pública, mas não será jamais o único componente de judaicidade da sociedade como um todo, pois este não é parcial, e sim total. Israelense será, portanto, o judeu residente em Israel que respeite a pluralidade de concepções judaicas particulares e, ao mesmo tempo, tenha um compromisso claro e inequívoco com as aspirações e projetos nacionais, dirigidos por uma concepção de um viver judaico total.

Entende-se, portanto, algumas acusações feitas ao autor, como, por exemplo, Miron (1998: 116), de que suas ideias representam um Sionismo antidiáspora, pois é quase impossível separar conceitos como "normalidade" e "anomalia" de julgamentos de valor e de um certo sentimento de superioridade do "normal" para com o "anômalo". Fica a impressão de que o que o autor na verdade diz, cotejando a anomalia da diáspora à normalidade pretendida para Israel, é que se ser israelense não é a única forma de ser judeu, ao menos é a melhor e mais completa, mais "normal". Não é à toa que em outros textos seus, Yehoshua aplica à Galut termos como solução neurótica (1984) e aos judeus caracteriza como seres andróginos (1999), diluindo em muito essa "androginia" quando se trata dos israelenses.

Nesse sentido, a par de uma orientação demográfica explícita ("quanto mais judeus em Israel, melhor"), pode-se ver seu conceito de sionista como uma porta aberta à "redenção" daqueles judeus que não 
estejam satisfeitos com seu viver "neurótico", "andrógino" e "parcial", na diáspora e que desejem à "normalidade sadia" do estado judaico. Serão bem-vindos, desde que se tornem israelenses, assumindo todos os traços culturais do país, as premissas pluralistas, segundo o novo conceito de judeu, do Estado Judaico e toda uma gama de deveres e direitos, a cujas relações e implicações se submetem de livre espontânea vontade.

Por este parâmetro, os judeus da diáspora não estão em posição tão melhor ou diferente da que se encontram os árabes israelenses, pois o que se pede aos dois grupos é que abandonem seu background cultural em prol de um israelismo total, sem o qual é melhor que os primeiros permaneçam na diáspora e os segundos deixem o país.

\section{A diáspora brasileira}

Esta parte do trabalho não tem a pretensão de analisar detidamente a diáspora brasileira segundo os parâmetros da teoria de Yehoshua sobre o viver diaspórico, mas sim o de apontar possíveis caminhos e posturas para uma pesquisa e análise mais acuradas e quantitativamente mais significativas da realidade judaica no Brasil. Portanto, deve-se desculpar o autor pela pouca extensão que dedica ao assunto, comparativamente á exposição minuciosa das ideias de Yehoshua.

Segundo o último censo brasileiro, existem atualmente no país cerca de cem mil judeus. De acordo com alguns demógrafos, como Sérgio Della Pergola, há uma certa distorção nesse número, devendo a comunidade judaica no Brasil contar com algo em torno de cento e cinquenta mil indivíduos, em sua maioria concentrados nos grandes centros urbanos das regiões Sul e Sudeste. Embora ainda seja grande a carência de pesquisas sociológicas de campo sobre as comunidades judaicas no Brasil, com uma coleta vigorosa de dados e a interpretação dos mesmos ${ }^{4}$, pode-se traçar algumas características gerais dos indivíduos e grupos judaico-brasileiros.

De maneira geral, pode-se dizer que os judeu estão bem integrados à sociedade brasileira, marcando presença em todos os ramos de atividades profissionais e em todas as esferas econômicas e educacionais; porém, com uma maior concentração na classe média. Vê-se bem tal integração judaica

\footnotetext{
${ }^{4}$ Algumas pesquisas desse tipo foram empreendidas por Anita Brumer, Helena Lewin e Sylvana Hemsi.
}

ao ambiente nacional, que, para muitos, representa uma assimilação, pelo fato de que problemas que atingem o todo da sociedade brasileira também os atingem, como a má distribuição de renda, a pobreza e o desemprego (Menorah, 2001: pp. 6-14).

A despeito disso, a história das comunidades judaicas no Brasil sempre foi relativamente tranquila, pois o antissemitismo nunca fixou raízes entre nós. Mesmo no período da ditadura do Estado Novo, no qual a política getulista para com os judeus refugiados de guerra da Europa era a de uma restrição de sua entrada no país, como reflexo da política nacionalista e xenófoba de então, a atitude do todo da população brasileira em relação aos judeus continuou sendo a de sua aceitação no seio da sociedade. Nesse período, houve inclusive uma melhoria nos indicadores socioeconômicos e educacionais da judiaria brasileira, com o aumento de seu acesso e ingresso nas universidades.

Atualmente, há grande preocupação das lideranças comunitárias sobre certas características sociológicas e identitárias que vêm se consolidando na diáspora brasileira, reflexo do que ocorre na diáspora em geral e da integração judaica ao Brasil, sobretudo nas concentrações urbanas, como o crescimento no número de casamentos exogâmicos (i.e., entre judeus e não judeus), o declínio de práticas e usos tradicionais no seio da família e o esvaziamento da vida comunitária (decréscimo de frequência ao clube e à sinagoga, por exemplo).

Sylvana Hemsi (1999: pp. 63-65) relata que em pesquisa para sua dissertação de mestrado em Estudos Judaicos pela USP 5 observou que todos os seus entrevistados, judeus paulistanos na faixa de 35 a 45 anos, pais de crianças de 5 a 13 anos, tinham a consciência de ser judeus e assim se consideravam, embora muitos não soubessem expressar, ou o expressavam de modo difuso e pessoal, como se dava tal identificação; que, via de regra, atém-se agora à repetição de práticas rituais, repassadas por seus pais, descurando da parte ética das mesmas.

Entretanto, quando se examinam a ação e o pensamento de indivíduos judeus que são figuras públicas na sociedade brasileira, como artistas, acadêmicos, escritores, jornalistas etc., não se consegue separar

\footnotetext{
5 HEMSI, Sylvana. Identidade judaica: um modelo paulistano liberal (dissertação de
mestrado em Língua Hebraica, Literatura e Cultura Judaicas, sob orientação da Professora

5 HEMSI, Sylvana. Identidade judaica: um modelo paulistano liberal (dissertação de
mestrado em Língua Hebraica, Literatura e Cultura Judaicas, sob orientação da Professora Doutora Nancy Rozenchan). São Paulo: USP, 1997
} 
suas atitudes e declarações de seu judaísmo, embora também sejam vistos em seu componente de "brasilidade". O que sugiro aqui é que, mais do que uma mistificação do caráter judaico desses sujeitos ou mais do que fruto de sua maior "visibilidade" no cenário cultural do país, seu componente de judaicidade é ressaltado, embora alguns se declarem indiferentes a ele, justamente pelos ideais de universalidade e de justiça social (já presente desde o período dos juízes e profetas) de que o judaísmo paulatinamente passou a se revestir desde a primeira dispersão, consolidando essas características com o advento do judaísmo reformista.

As preocupações com as liberdades políticas e civis de um Herzog, os trabalhos em prol da melhoria do nível educacional dos brasileiros empreendidos pelo ex-presidente da Academia Brasileira de Letras, Arnaldo Niskyer, o ativismo político e ambiental de Carlos Minc, só para citar alguns exemplos, apontam para uma preocupação humanística e universal com o bem-estar do coletivo; basicamente imputado a seus contatos, em diferentes níveis e graus, com uma educação judaica liberal.

Voltando a considerar o que diz Yehoshua sobre a diáspora, relacionando seus arrazoados especificamente à situação identitária dos judeus brasileiros, creio que não há aqui, e talvez nem em outras comunidades diaspóricas, as alegadas neurose e parcialidade do viver. A identidade judaica brasileira está em mudança, como bem observa Anita BRUMER (1994), com os conflitos próprios da tentativa de adaptarem-se os valores tradicionais aos modos contemporâneos de vida e sociabilidade que o desenvolvimento econômico e tecnológico traz. Tais mudanças não são apenas características apenas das comunidades da diáspora, mas atingem também, e com implicações mais sérias, a sociedade israelense.

É questionável a alegada "totalidade" do viver judaico sabra frente à parcialidade diaspórica, uma vez que, quando se refere aos sonhos, aspirações e valores judaicos totais, que presidiriam todos os atos e pensamentos dos cidadãos israelenses, Yehoshua está, na verdade, se referindo aos valores dominantes do establishment ashkenazita ocidentalizado. Ora, como se sabe, a sociedade de Israel é um mosaico de etnias (árabes, judeus sefarditas, judeus orientais e norte-africanos), correntes religiosas (muçulmanos, cristãos, judeus ortodoxos, conservadores e reformistas, judeus laicos) e modos específicos de vivenciar o judaísmo.
A identidade judaico-israelense também se encontra em processo de mudança, como de resto ocorre com as identidades nacionais específicas no mundo inteiro, com a participação cada vez maior desses grupos de status minoritário, mas que quantitativamente representam maioria, em todas as esferas de sua sociedade, portando consigo seus sonhos, valores e aspirações judaicos próprios.

Em textos e entrevistas posteriores, o próprio Yehoshua (BESSER, 1990: disperso) suaviza suas opiniões sobre a diáspora, reconhecendo sua importância para o estágio atual daquilo que se define como identidade israelense, e admite que mesmo os israelenses apresentam um componente de neurose e rigidez comportamental, advindas, respectivamente, do constante estado de conflito bélico com os árabes e da educação sionista, que por muito tempo foi a base ideológica do país. É de se perguntar, então, se as condições em que se deu a nova colonização judaica na Palestina e as relações dos israelenses com seus vizinhos árabes tivessem tomado outro rumo, não estaríamos hoje diante de uma identidade israelita, ou judaicoisraelense, totalmente diferente da atual? Creio que sim.

Assim também ocorre em relação à diáspora brasileira e à diáspora em geral: as condições históricas, socioeconômicas e culturais mudam, e com elas mudam e adaptam-se as identidades. E de todas as identidades étnicas, talvez a judaica tenha sido a que mais mudanças e adaptações sofreu ao longo de sua trajetória histórica e espacial, a ponto de podermos conjeturar se seu aspecto plural e cambiante não seria justamente sua característica principal, em todos os tempos e em todos os lugares.

\section{Referências Bibliográficas:}

BESSER, Yaakov (entrevistador). Má ani betoch ha-vikuach ha-gadol? 10 que sou eu dentro do grande debate?). In: Iton 77. Israel: número 124-125, mai-jun, 1990, pp. 26-28.

BRUMER, Anita. Identidade em mudança; pesquisa sociológica sobre os judeus do Rio Grande do Sul. Porto Alegre: Federação Israelita do Rio Grande do Sul, 1994.

DEUTSCHER, Isaac. O judeu não judeu e outros ensaios. Rio de Janeiro: Civilização Brasileira, 1970. 
EISENSTADT, S. N. Sociedade israelense. São Paulo: Perspectiva, 1977

GAVISON, Ruth. Jewish and democratic? a rejoinder to the "ethnic democracy" debate In: Israel Studies, 4(1), 1999.

GUIVELDER, Zevi. A trajetória judaica. Jornal de Letras, Rio de Janeiro, nov. 1998, p. 13.

HEMSI, Sylvana. Judaísmo e continuidade em São Paulo. In: Faculdade de Filosofia Letras e Ciências Humanas/USP. Vértices, revista da Pósgraduação em Língua Hebraica, Literatura e Cultura Judaicas. São Paulo: Humanitas FFLCH/USP, n 1, pp. 63-68, 1999.

JOHNSON, Paul. A história dos Judeus. 2. ed. Rio de Janeiro: Imago, 1989.

MENORAH. Pobreza: a face oculta do judaísmo. In. Menorah. Rio de Janeiro: ano 41, n 507, pp. 6-14, dezembro de 2001.

MIRON, Dan. Literatura hebraica moderna: perspectivas sionistas e realidades israelenses. In: Faculdade de Filosofia, Letras e Ciência Humanas/USP. Cadernos de Língua e Literatura Hebraica. São Paulo: Humanitas FFLCH/USP, n 1, p. 93- 119, ago. 1998.

OLIVEIRA, Leopoldo O. C. de. Questão de identidade: quem é judeu? O que é ser judeu? In: Faculdade de Filosofia Letras e Ciências Humanas/USP. Vértices, revista da Pós-graduação em Língua Hebraica, Literatura e Cultura Judaicas. São Paulo: Humanitas FFLCH/USP, ${ }^{\circ}{ }^{\circ}$, pp. 127-142, 2001.

ROSENBERG, Roy A. Guia conciso do judaísmo: história, prática e fé. Rio de Janeiro: Imago, 1992.

YEHOSHUA, A. B. BeZchut Hallormaliut [Pelo direito à normalidade]. Jerusalém/Tel-aviv: Shokan, 1984.

Judio, israelí, sionista: redefinición de conceptos. In: División y Capacitación para la Diáspora. Centenario del Primer Congreso Sionista. Jerusalém, 1996.

O pavio duplo dos israelenses. In: Caderno Cultural Na'antat Pioneiras s/l: ano VI, n 22, p. 23-26, ago. 1999.

\section{Criação de uma fundação de estudos e pesquisas sefaradis}

Max Nahmias ${ }^{1}$

— sta breve comunicação diz respeito à criação de uma Fundação de Estudos e Pesquisas Sefaradis.

Antes, porém, para avaliarmos a importância da criação desta Fundação, gostaria de traçar uma rápida trajetória dos judeus sefaradis desde que foram expulsos da Península Ibérica até chegarem ao Brasil, em diversas levas imigratórias.

Foi na Península Ibérica, no período compreendido entre os séculos X e XV que Judeus, Mouros e Cristãos, convivendo em harmonia e agregando conhecimentos, produziram o mais duradouro e fecundo ciclo de prosperidade e saber de toda a Europa. Essa fase da história é denominada, com justa razão, A Idade de Ouro da Humanidade.

A reconquista do sul da Espanha pelos exércitos cristãos, com a queda do último bastião muçulmano na cidade de Granada, em janeiro de 1492, associada à expulsão dos judeus, interrompeu de forma abrupta, esse período de grande esplendor cultural.

Centenas de milhares de Judeus tiveram de abandonar às pressas seus lares, em busca de refúgio em terras mais seguras. Espalharam-se por Portugal e demais países do Mediterrâneo, carregando consigo os poucos objetos que tiveram permissão para retirar de suas casas. Muitos chegaram a levar a chave de suas portas, na vã esperança de poder um dia retornar. Todavia, o bem mais precioso que os refugiados conseguiram preservar não estava acondicionado nos seus singelos fardos e baús.

Os Sefaradis levaram para os países que os acolheram sua música, sua culinária, sua poesia, seu idioma, sua cultura e, o mais importante de tudo, sua fé. Nas novas terras, reencontraram seus irmãos que tinham permanecido no Oriente. A maioria dos judeus que se refugiaram em Portugal foi convertida à força poucos anos depois, e muitos acabaram vindo para o Brasil na época dos descobrimentos e da colonização. A

${ }^{1}$ Museu Judaico do Rio de Janeiro / Presidente. 
própria Nau de Cabral conduzia um passageiro de origem judaica: o intérprete Gaspar da Gama.

O cultivo da cana de açúcar, inicialmente em Fernando de Noronha e posteriormente no Brasil Continental por iniciativa do Cristão-Novo Duarte Coelho, um homem de grande visão, teve a participação de muitos judeus portugueses. Alguns engenhos do Nordeste chegaram mesmo a abrigar Sinagogas e apesar das perseguições a que estavam sujeitos, muitos Sefaradis portugueses e brasileiros continuaram observando os preceitos da lei mosaica.

Em 1630, os holandeses conquistaram Recife e Olinda e concederam liberdade religiosa aos seus moradores. Nesse período foi instalada a primeira Sinagoga das Américas, a Zur Israel, na Rua dos Judeus em Recife e seu líder espiritual, o Rabino Sefaradi Isaac Aboab da Fonseca, além de coordenar os serviços religiosos, teve a preocupação de fundar também uma escola judaica.

A partir do início do século XIX, Sefaradis provenientes do Marrocos começaram a chegar à Bacia Amazônica, desbravando seus rios e igarapés e dedicando-se à extração e comercialização da castanha do Pará e da borracha. Nas primeiras décadas do século XX, tem início um processo contínuo de chegada de judeus sefaradis no Sul e Sudeste do país, provenientes de Países do antigo Império Otomano, que começavam uma lenta e progressiva fragmentação. Falavam o árabe, o turco, o grego e o francês. Em casa, conversavam em ladino, um espanhol arcaico mesclado com expressões árabes e turcas. Eram bastante religiosos e nas Sinagogas que erigiram e frequentavam com assiduidade, intercalavam o hebraico e o ladino em rezas entoadas com forte musicalidade oriental.

$\mathrm{Na}$ metade do século XX, novas levas de Judeus Sefaradis começaram a migrar para o Brasil, em sua maioria procedentes da Síria, Líbano e Egito. Em comum com os seus irmãos que já estavam no país há mais tempo, demonstravam uma vontade inabalável de reconstruir suas vidas em nosso país, além de procurar manter acesa a chama de suas tradições religiosas.

A cultura Sefaradi, que abrange 15 séculos de presença na Península Ibérica e outros cinco nos demais países do Mediterrâneo e no Brasil, corre o risco de ser riscada da memória em apenas uma ou duas gerações. Não podemos ficar de braços cruzados e assistir como meros espectadores o desaparecimento dessa rica tradição que produziu sábios como Maimônides, poetas como Ibn Gabirol e Ibn Shaprut, estadistas do porte de Isaac Abravanel e Disraeli, cientistas como Abraão Zacuto e Benjamin de Tudela, empresários como Doria Gracia Mendes, médicos do quilate de Garcia de Horta e Amado Lusitano e tantos outros nomes ilustres.

É inegável que esteja havendo um verdadeiro "revival" da cultura Sefaradi, tanto em Israel quanto na Europa e Estados Unidos, com um despertar do orgulho pela nossa história e tradição.

No Brasil, depois do grande sucesso alcançado com as realizações do $1^{\circ}$ Congresso Sefaradi no Rio e do $2^{\circ}$ em São Paulo, achamos que o momento é extremamente oportuno para a criação de uma Fundação de Estudos e Pesquisas Sefaradis (FEPS) que tem como objetivos: a recuperação, preservação e divulgação da história dos judeus de origem ibérica e oriental, especialmente nos aspectos relacionados às manifestações literárias, filosóficas, artísticas, musicais, folclóricas e culinárias, assim como os demais componentes de sua cultura.

Para essa missão, a FEPS se propõe a congregar pesquisadores, professores, historiadores, sociólogos e outros profissionais interessados na cultura Sefaradi.

A Fundação terá sede na cidade do Rio de Janeiro e as comunidades Sefaradis brasileiras serão incentivadas a participar de suas atividades, com vistas a elaborar projetos de pesquisas sobre a contribuição dos judeus ibéricos e orientais na construção do país.

A Fundação de Estudos e Pesquisas Sefaradis incentivará o intercâmbio cultural com entidades congêneres do Brasil e do exterior.

\section{Prioridades}

$1^{\text {a }}$ - Elaboração de um acervo de apoio para os profissionais envolvidos no projeto.

$2^{\text {a }}$ - Investigação científica sobre as diferentes correntes migratórias humanas, oriundas do Norte da África, Egito, Grécia, Turquia, Líbano, Síria e demais países do Mediterrâneo que se dirigiram para o Brasil. 
$3^{\mathrm{a}}$ - Divulgação dos resultados das pesquisas em publicações especializadas e edição de uma revista da própria Fundação.

$4^{\mathrm{a}}$ - Promoção de congressos, conferências, audições musicais, sessões cinematográficas, mostras de arte, espetáculos teatrais e atividades correlatas direcionadas aos estudiosos do tema e à população em geral.

$5^{\mathrm{a}}$ - Trazer a lume textos inéditos de grandes escritores, filósofos, teatrólogos, poetas e artistas judeus e cristãos-novos ainda desconhecidos do grande público.

Para viabilizar o nosso projeto, contaremos principalmente com os incentivos fiscais proporcionados pela Lei Federal de Incentivo à Cultura, também conhecida como Lei Rouanet, que permite abater do Imposto de Renda as quantias doadas às entidades, dedução essa que vale tanto para as pessoas físicas quanto para as jurídicas.

Por oportuno, quero citar trechos de uma comunicação à 6 Conferência da Associação de Estudos Judaicos Latino-Americanos, na Universidade de Maryland (outubro, 1991) e um poema em ladino do séc. XVI.

A sobrevivência da cultura judeu-espanhola durante cinco séculos é um exemplo raro de tenacidade de uma cultura desenraizada separada da Espanha desde 1492 - que se manteve em condições que normalmente a destinariam ao desaparecimento.

$O$ romanceiro sefaradi guarda, de modo transparente, um universo de signos culturais, de motivos folclóricos, tomados de empréstimo a outros povos sefaradis, colocando à luz o caráter multifacetado de sua poesia.

Esses romances, essas coplas - os chamados cantos seculares, inspirados na vida cotidiana - que constituem o romanceiro judeuespanhol, estas histórias não interessam apenas pela sua narrativa de vida no sentido de busca da identidade, mas pela recuperação de culturas inteiras, grupos de população que por perseguições tiveram que se calar, esquecer para sobreviver, recalcar. A História, nós o sabemos agora, é tecida desses silêncios e desses retornos do recalcado.

A maioria dos sefaradis não foi para muito longe depois de 1492: atravessou o estreito que separa a Europa da África, entre Espanha e Marrocos, e se instalou no norte africano. Outros, porém, se espalharam em torno da Bacia Mediterrânea, do Egito a Constantinopla, do sul da França à Palestina. Salônica (na atual Grécia) e Esmirna (hoje Turquia) foram algumas de suas terras de eleição.

Em Salônica e outras partes, os romances eram cantados como cantigas de ninar, cantigas de parto, para as noivas, ou simplesmente para se lembrar a vida dos antepassados, manter a identidade cultura sefaradi. É significativo o espaço no teatro desses romances: a fusão da prosa e da poesia, do enredo e do canto, que termina pelo triunfo do canto e da poesia. A fala poética é ela própria história de vida.

E para concluir, um Poema Ladino do séc. XVI

Por amar una doncella, de aquí d'este lugar

Ah, yo la amoo, yo la quero, yo sali n su búsquida.

Se la demandí a su padre, guerra grande m'hiz'armar.

Se la demandí a su a madre, de palabras m'hizo'nganar.

Se la demandí a su'rmano, com cuchillo me queria matar

\section{Tradução}

Por amar uma donzela daqui deste lugar

Como a amo, como a quero, pus-me então em sua busca. A seu pai pedi-lhe a mão, guerra grande a mim declarou. À sua mãe pedi-lhe a mão, com palavras me enganou. Ao irmão pedi-lhe a mão, com o punhal quis me matar 


\section{Imigração e território: \\ o papel de Israel na construção da identidade judaica da Diáspora ${ }^{1}$}

Adriana Spilki e Anita Brumer ${ }^{3}$

\section{Introdução}

E

ste trabalho focaliza a importância de Israel para a construção e o fortalecimento da identidade dos judeus da diáspora, examinando as viagens de ida e de retorno de judeus entre o Brasil e Israel. Tem como objetivo principal a análise da migração de judeus brasileiros a Israel, inserindo-a no contexto das migrações internacionais, através de três momentos: 1) a viagem de ida a Israel, contemplando principalmente as motivações do(a) viajante, bem como o conteúdo social e cultural de sua 'bagagem' (desterritorialização); 2) a adaptação ao novo território (reterritorialização); 3) a viagem de retorno ao Brasil, incluindo o processo de readaptação e o conteúdo social e cultural da 'bagagem' adquirida naquele país.

O exame da 'migração' dos judeus da diáspora a Israel suscita, assim, uma série de questões. A primeira diz respeito às motivações para a viagem e estadia naquele país por um tempo superior ao que é comum em viagens de turismo (é evidente que nem todos os jovens judeus têm esta motivação e, entre os que vão a Israel, as motivações são diversas). A segunda diz respeito às facilidades e dificuldades no processo de adaptação a um país com língua, cultura, economia e políticas distintas. Outra se refere aos motivos para o retorno, mesmo quando a previsão anterior era de uma estadia mais longa. Por fim, ressalta a questão da reintegração dos 'migrantes' à sociedade de origem, através das relações que se estabelecem após o retorno, isto é, como os jovens utilizam sua experiência, e em que medida essa experiência contribui para a construção de sua identidade judaica na diáspora.

\footnotetext{
${ }^{1}$ Este texto representa uma abordagem inicial de uma pesquisa em andamento.

${ }^{2}$ Graduanda em Psicologia, na UFRGS.

${ }^{3}$ Professora Titular do Departamento de Sociologia da UFRGS
}

O trabalho visa, assim, verificar também a relevância do território israelense na construção e reforço da identidade dos judeus da diáspora, examinando a forma de compatibilização entre integração à sociedade brasileira e o reforço à identidade étnica de imigrantes judeus e seus descendentes.

A principal questão do trabalho diz respeito à identidade judaica confrontada com o fato dos judeus serem minoria ${ }^{4}$ no Brasil e maioria em Israel e com os aspectos referentes à integração de jovens brasileiros numa cultura diferente da brasileira. A situação de constituírem uma minoria pode explicar em grande parte o movimento de retorno ao país de origem, enquanto que, a situação de imigrantes no país em que os judeus são maioria coloca os imigrantes potencialmente numa nova situação de minoria, nesse caso como brasileiros. Por outro lado, na situação de retornados ao país de origem, torna-se necessária uma nova adaptação, nem sempre fácil.

Jardim (2000), ao dissertar sobre a identidade étnica de palestinos residentes no Brasil, considera que:

A discussão sobre "grupos minoritários" tem como diálogo a relação estabelecida entre Estado Nacional e a capacidade desses grupos de inserirem-se na sociedade nacional como 'nacionais', ou seja, a relação entre o étnico como origem da nação e dos nacionais e, de outra parte, entre 'grupos étnicos' que sublinham sua diferença com relação aos nacionais (Jardim, 2000: p.30).

Para fundamentar o presente trabalho, torna-se necessário explicitar o conceito de identidade étnica e examinar a questão das migrações internacionais, assunto relativamente novo na literatura sociológica brasileira.

\footnotetext{
${ }^{4}$ O termo minoria foi conceituado por Banton (apud Seyfert, 1986) em torno da noção de limite, já que considera que, em relações intergrupais, as minorias se definem por si mesmas e pela maioria. Os limites aos quais o autor se refere são: exclusão e inclusão. O limite de exclusão ocorre por um posicionamento à parte da minoria, o que faz com que a maioria responda com a construção de um limite, provocando a exclusão da minoria de certas relações sociais. A resposta da maioria impõe à minoria a construção de limites inclusivos a partir dos próprios interesses do grupo minoritário em questão. O conceito de minoria não se baseia em dados numéricos. Para o estudo proposto, consideraremos os conceitos de minoria étnica e minoria nacional.
} 


\section{O conceito de identidade étnica}

No estudo da identidade judaica, a noção da identidade étnica oferece um marco conceitual de referência. Diversos autores têm examinado questões referentes à identidade e à identidade étnica. Barth, por exemplo, sintetizando a perspectiva analítica dos antropólogos que tratam dessa questão, indica que a identidade étnica leva em conta quatro aspectos: 1) como os indivíduos se veem; 2) como são vistos pelos outros; 3) como veem os outros; 4) como acham que são vistos pelos outros. Assim, um grupo étnico caracteriza-se por perpetuar-se biologicamente, partilhar valores culturais fundamentais e contar com membros que se autoidentificam e são identificados por outros, constituindo uma categoria distinguível de outras categorias de mesma ordem. Além desses aspectos, Barth acrescenta que as características levadas em consideração por um grupo étnico não são meras somas de diferenças objetivas, mas aquelas consideradas como significativas pelos próprios atores. Outra questão enfatizada por Barth diz respeito às fronteiras entre os grupos étnicos. Essas fronteiras não são referidas como meramente territoriais, embora Barth não ignore a importância das mesmas. Porém, esse autor trabalha com o conceito de fronteiras sociais, que implicam em uma complexa organização de relações sociais e comportamentais.

Segundo Jacques (1998), identidade pode ser caracterizada em termos de identidade pessoal e identidade social (incluindo a identidade étnica, a identidade religiosa e a identidade sexual, entre outras), determinada a partir do confronto ou mediação do outro. Como diz Jacques, "as características humanas historicamente desenvolvidas se encontram objetivadas na forma de relações sociais que cada indivíduo encontra como dado existente, como formas históricas de individualidade, e que são apropriadas no desenrolar de sua existência através da mediação do outro" (Jacques, 1998: p.162). Para a autora, o emprego do vocábulo 'apropriação' tem por objetivo destacar o caráter ativo da relação do indivíduo com o social: "o contexto sócio-histórico é resultante da ação humana enquanto externalização do seu psiquismo, que volta a se interiorizar transformado, num processo contínuo de articulação entre o individual e o social" (Jacques, 1998: p. 163).

Numa perspectiva da ciência política, Martin (1992), ao conceituar identidade étnica, acrescenta às características apontadas por Barth a relação com o passado e com o espaço social e, ainda, a integração da história e do espaço social com a cultura. Nesse aspecto, o papel de Israel na configuração da identidade judaica da Diáspora encontra sua justificativa. Sem ser a origem geográfica da maioria dos imigrantes judeus que vieram ao Brasil, a identidade judaica, através dos tempos, fundou-se na ideia da origem, naquele território, há mais de cinco mil anos; e judeus vivendo durante séculos em várias partes do mundo tinham em comum, entre outros aspectos, a ideia do retorno a Jerusalém. Essa ideia consubstanciou-se na criação do Estado de Israel pela ONU, em 1948, e a partir daquela data tornou-se comum a identificação de Israel como o território 'de origem', como parte da identidade da maioria dos judeus, tanto os que vivem em Israel como os da diáspora. Outrossim, muitos judeus da diáspora consideram a relação com o Estado de Israel (assim como a sobrevivência do mesmo) como parte necessária de sua própria sobrevivência, como um anteparo à disseminação do antissemitismo, que levou ao extermínio de cerca de seis milhões de judeus durante a II Guerra Mundial.

Em síntese, no exame da identidade de um grupo étnico merecem destaque alguns elementos: a história e a memória, a religião, a tradição, a língua, a cultura (música, danças, artefatos, comidas típicas, etc.) e o território de origem. Além disso, também assumem importância as representações que os próprios membros do grupo têm sobre sua inclusão ou não no grupo.

Num estudo sobre o processo de educação não formal na construção da identidade judaica, verificou-se que, apesar de não envolverem mais de um terço da totalidade dos jovens judeus de Porto Alegre, para os que estão envolvidos, tanto os movimentos juvenis quanto os grupos de dança, mesmo tendo objetivos distintos, contribuem para a formação e afirmação da identidade judaica. Em ambos, estão presentes aspectos como o contato com outros membros da comunidade judaica, reforçando o sentimento do 'nós'; o uso de símbolos judaicos e de expressões em língua hebraica; referências à história judaica e ao Estado de Israel como território (em termos políticos e culturais, como se evidencia no resgate da música e do folclore daquele país). Além disso, verificou-se que os movimentos juvenis se diferenciam dos demais grupos de jovens, por incluírem aspectos ideológicos, enquanto os grupos de dança destacam-se por enfatizarem os aspectos culturais e históricos, e, principalmente, a interação com o público, reforçando nesse confronto tanto a identidade dos participantes quanto a dos que assistem às 
apresentações. Constatou-se ainda a integração entre movimentos juvenis e grupos de dança, tendo em vista que cada movimento juvenil tem seu próprio grupo de dança e muitos membros dos movimentos juvenis participam de outros grupos de dança além do grupo do próprio movimento ${ }^{5}$.

No decorrer dessa investigação, verificou-se que a relação dos jovens da diáspora com o Estado de Israel vai além do resgate de música, danças, comidas típicas e história daquele país. Uma parte significativa dos judeus da diáspora mantém contatos com aquele país, através de visitas de turismo, permanência no país para estudos ou trabalho ${ }^{6}$, contatos com amigos e familiares que residem ou que fixaram residência lá. Constatou-se que a ida de judeus, principalmente jovens, a Israel, por determinado período de tempo, é comum e, de certa forma, incentivada pelos movimentos juvenis e por outras organizações judaicas.

O interesse dos judeus da diáspora por Israel, demonstrado pelas viagens àquele país, pode ser aferido através dos dados do censo realizado junto à coletividade judaica do Rio Grande do Sul (Brumer,1994: p.121), quando se constatou que cerca de $33 \%$ dos entrevistados em Porto Alegre já viajaram pelo menos uma vez a Israel e 4,6\% dos entrevistados viajaram quatro vezes ou mais ou residiram naquele país. Os dados do censo também revelam que aproximadamente $4 \%$ dos filhos dos entrevistados em Porto Alegre residem no exterior (Brumer, 1994: p.75).

Um estudo recente realizado no Uruguai, com egressos do curso secundário da rede formal de educação judaica, revelou que cerca de $20 \%$ viviam fora do país por ocasião da pesquisa. O perfil da emigração judaica é distinto do perfil da emigração uruguaia como um todo: enquanto a

\footnotetext{
${ }^{5}$ Esta pesquisa foi coordenada pela professora Anita Brumer, contando com Adriana Spilki como bolsista de Iniciação Científica. Dessa pesquisa resultou o texto "Educação Não Formal e Identidade Judaica: Movimentos Juvenis e Grupos de Dança na Construção do Judeu Contemporâneo". O trabalho foi apresentado por Adriana Spilki, bolsista PIBIC, no Salão de Iniciação Científica 2000 e no Seminário sobre Imigração Judaica no Rio Grande do Sul, realizado pelo Instituto Cultural Judaico Marc Chagall em maio de 2000. A professora Anita Brumer apresentou um trabalho semelhante no II Encontro de Assuntos Judaicos, realizado na UERJ, em novembro de 1999.

${ }^{6}$ Na pesquisa realizada pela Federação Israelita do Rio Grande do Sul em 1993, 38,3\% dos judeus entrevistados em Porto Alegre tinham ido a Israel pelo menos uma vez; 4,6\% dos entrevistados tinham viajado para aquele país quatro ou mais vezes ou haviam residido lá por algum tempo. (Brumer, 1994: p.121)
}

emigração uruguaia tem como destino, principalmente, países como Argentina, Brasil, Estados Unidos, Austrália, Canadá, Venezuela, Espanha e Itália, a emigração judaica destina-se prioritariamente a Israel $(60 \%$ dos emigrantes) e aos Estados Unidos (23\% dos emigrantes), seguidos pela Argentina (8\%). Outra característica diferencial diz respeito ao nível socioeconômico e educacional dos emigrantes, em que os judeus uruguaios apresentam perfil superior ao da média nacional (Berenstein, Porzecanski, 2001: p.11-12).

Jardim (2000), em sua análise dos imigrantes palestinos na região do Chuí, no Rio Grande do Sul, ao abordar uma visão mais dinâmica da etnicidade (visto que leva em conta os mecanismos de produção da etnicidade), aproxima nacionalismo e etnicidade como fenômenos de mesma qualidade. Em suas próprias palavras:

Identidades nacionais emergentes redimensionam questões sobre etnicidade e nacionalismo. No cenário dos debates sobre fenômenos étnicos parece que nem só de tradições (mesmo recriadas) constituem-se coletividades. O direito a autodeterminação do povo palestino fora reconhecido por organismos da Organização das Nações Unidas, no entanto, as definições territoriais não foram igualmente asseguradas. Assim, devem ser buscados outros parâmetros explicativos para a compreensão da constituição de lealdades ou do trânsito entre etnicidade e nacionalismo, especialmente para um segmento em diáspora ou, em outras palavras, em uma situação que prima pela indefinição e que parece ter de inventar suas origens, tradições e, portanto, suas especificidades. (Jardim, 2000:p. 41)

\section{O contexto das migrações internacionais}

A ida de judeus a Israel relaciona-se à temática das migrações ${ }^{7}$ internacionais, sobre a qual já existem alguns estudos relativos a outros grupos étnicos ou a outros países. O Japão, por exemplo, vivencia uma

\footnotetext{
7 No artigo "Migrações", publicado na Internet, as migrações são definidas como "movimentos de pessoas de uma região para outra. São internas quando ocorrem dentro de um mesmo país e externas quando se dão de um país para outro". Como variações desse conceito aparecem emigrações (saída da população de um lugar) e imigração (entrada de estrangeiros em um lugar).
} 
experiência interessante em relação aos processos migratórios ${ }^{8}$. A partir da primeira década do século XX, muitas famílias japonesas migraram para o Brasil devido a acordos diplomáticos entre estes países e incentivo do próprio governo japonês. Essas famílias vieram trabalhar nas lavouras de café e buscar uma vida melhor do que a vida que tinham no seu país de origem. Porém, pode-se notar, como um fenômeno relativamente recente, a migração de brasileiros de origem japonesa para o Japão. Supõe-se que esse fenômeno migratório (denominado dekassegui) tenha tido início devido à expansão econômica japonesa, a partir da década de 80 , associada à crise econômica brasileira. Embora ambos os exemplos sejam considerados migrações, eles se diferenciam em alguns aspectos básicos: os japoneses que vieram para o Brasil no início do século passado vieram para o trabalho na agricultura, prática que também exerciam no seu país de origem, enquanto que o movimento dos dekasseguis se caracteriza por serem eles imigrantes chamados para o trabalho em fábricas ou nos mais diversos serviços no Japão, o que, em geral, não corresponde à prática do sujeito em seu país de origem. Em relação ao fenômeno dekassegui, pode-se dizer que houve dois momentos. De acordo com Elisa Sasaki ${ }^{9}$, em um primeiro momento, eram homens solteiros ou chefes de família que emigravam e mandavam dinheiro para suas famílias no Brasil. Esses homens não divulgavam sua ida para o Japão, pois isso significaria seu fracasso frente à sua comunidade. Em um segundo momento, no entanto, devido à ideia de proximidade cultural, passou-se a valorizar a emigração para o Japão como uma forma de aproximação à terra de origem, à terra dos ancestrais. Nessa época, tornou-se mais comum a emigração de famílias inteiras ou de jovens recém-casados para o Japão.

Outro exemplo marcante de fenômeno migratório refere-se à emigração de brasileiros para os EUA. Um dos exemplos mais significativos desse movimento ocorreu no final da década de 80 e início da década de 90 , quando foi percebido um representativo movimento migratório originado da cidade de Governador Valadares, localizada em Minas Gerais, em direção aos Estados Unidos. A maioria desses valadarenses emigra principalmente para

${ }^{8}$ Informações sobre migrações internacionais foram obtidas na Internet, no endereço http://www.comciencia.br/reportagens/migrações

${ }^{9}$ Cujo depoimento foi incluído na reportagem "Migração japonesa e o fenômeno dekassegui: do país do sol nascente para uma terra cheia de sol” In: BRASIL: migrações internacionais e identidade [sem referência a autor]. os estados de Massachusetts, Nova Jersey e Nova Iorque, com o objetivo de melhorar o padrão de vida. É bastante comum o estabelecimento clandestino de brasileiros nos Estados Unidos, o que limita as possibilidades de trabalho, em geral considerado como "subemprego". Outra característica comum a esse movimento migratório é o envio de dinheiro pelos imigrantes para a família que permanece no Brasil. Segundo Valéria Cristina Scudeler, esse movimento sustenta-se através da construção de uma 'cultura migratória' (definida por ela como "uma predisposição, motivada por fatores de ordem histórica, cultural e socioeconômica, a deslocamentos geográficos, tanto internos como externos a um território nacional") e de um 'imaginário coletivo' a respeito da América.

João Fábio Bertonha questiona a ideia de um desligamento total por parte do imigrante em relação a seu país de origem. Segundo Bertonha, apesar dessa ideia ter um 'fundo de verdade', já que os imigrantes estão envolvidos com sua adaptação em um novo país que, em geral, fala outra língua e que apresenta cultura e costumes distintos dos seus, não se pode falar em um desligamento total em relação ao país de origem, pois em estudos a respeito de imigrantes constata-se que a maioria aglomera-se em bairros, buscando apoio na comunidade e mantendo hábitos comuns ao país de origem. Bertonha acrescenta ainda que muitos imigrantes demonstram uma preocupação constante em relação aos acontecimentos de sua terra natal, estando com o olhar voltado para suas origens. Examinando atitudes de imigrantes italianos, ibéricos, japoneses, alemães e outros, no Brasil, nas décadas de 30 e 40 , Bertonha constatou que esse interesse se comprovava em ocasiões nas quais as relações de uma comunidade estrangeira com uma outra sofriam alterações que dependiam das relações do Brasil com as nações de origem, e da sua nação de origem com outra.

Uma situação interessante ocorre com os árabes residentes no Brasil (com uma forte comunidade no Chuí-RS). De acordo com Jardim (2000), esses imigrantes realizam viagens à Palestina, visando a objetivos diversos, com viagens tanto familiares quanto individuais. A autora considera a viagem como uma iniciação dos jovens, proporcionada e planejada pela família, resultando na redescoberta e recriação da pertinência do tema de origem comum. Ela considera que essas viagens, de certa forma, singularizam, embora demonstrem os caminhos de uma experiência coletiva. A viagem, nesse caso, é vista como um importante mecanismo social, pois permite o 
domínio sobre a família árabe (seus possíveis modelos e características) e, também, sobre o idioma. Segundo palavras da autora:

As viagens efetuadas pelos filhos de migrantes, ou aquelas que serão
feitas, pois fazem parte do seu horizonte de possibilidades, permitem
traçar uma comunidade imaginada. Especificamente as viagens
internacionais ocasionam não só uma revitalização do idioma étnico,
mas prioritariamente inscrevem-se nas experiências individuais
enquanto instrumentos necessários para produzir essa "comunidade
imaginada", instrumentos que possibilitam o deslize do étnico para o
nacional e vice-versa. (Jardim, 2000: p.319)

A ideia de território está, portanto, presente na análise das migrações. Em termos gerais, território pode ser conceituado como espaço onde se dá a sociabilidade, sendo derivado de uma construção social. Nesse espaço, concorrem e sobrepõem-se territorialidades distintas (locais, nacionais, regionais, mundiais) que apresentam diferentes percepções, valores e atitudes territoriais, podendo gerar relações de complementação, de cooperação e de conflito (Gómez, 1998). À medida que um indivíduo ou grupo deixa o território no qual nasceu e onde estabeleceu laços familiares, sociais, culturais, econômicos e políticos, pode-se falar em desterritorialização, que foi definida por Gómez (1998) como um processo de perda do território decorrente da dinâmica territorial (no caso do presente trabalho, a dinâmica territorial está constituída pelo próprio ato de migrar). Ao ingressar em um espaço territorial e tentar adaptar-se ao mesmo, está-se diante da reterritorialização, que visa dar conta de dimensões espaços-temporais, econômicas, culturais e políticas que ultrapassam as fronteiras dos estados.

Outro conceito que se encontra atrelado ao tema das migrações é o de multiculturalismo. Para Machado (2000), multiculturalismo é todo agrupamento social que conjuga uma diversidade cultural oriunda do encontro de várias etnias. Vásquez (2001) agrega a ideia de que o multiculturalismo amplia o horizonte social e histórico, no qual interagem diversas culturas que apresentam sua identidade própria, existindo um reconhecimento da diversidade e um espaço onde cada cultura se encontra em busca de porções de identidade constitucional.

\section{O processo de adaptação dos imigrantes}

$\mathrm{Na}$ abordagem das correntes migratórias dos dias atuais, Clifford (1994) utiliza a expressão diásporas.

Numa ideia semelhante, ao tratar do tópico das migrações de estrangeiros para o Brasil, Lesser (2001, p.22) considera que "a assimilação (na qual a cultura pré-migratória da pessoa desaparece por completo) foi um fenômeno raro, enquanto a aculturação (a modificação de uma cultura em resultado do contato com uma outra) foi comum". Neste sentido, afirma que "a homogeneização da identidade nacional e cultural jamais veio a ocorrer" (Lesser, 2002: p.23).

$\mathrm{O}$ autor coloca em evidência o conflito existente entre os nacionais e os imigrantes, portadores de culturas estranhas ao país, demonstrando as dificuldades de adaptação dos imigrantes ao novo território no qual se estabelecem. Pode-se pensar em um jogo 'interétnico' no qual se mostra difícil discernir de onde vem a resistência à total assimilação à cultura local: dos próprios moradores do país ou dos migrantes, na tentativa de preservar sua própria cultura o mais intocada possível? A dificuldade em responder a essa pergunta pode ser explicada pelo conceito de grupo étnico referido por Barth e já exposto anteriormente, em que o autor leva em consideração para definir grupo étnico a relação estabelecida entre o 'nós' do grupo e os 'outros'.

Lesser (2001) propõe que parte das dificuldades enfrentadas por imigrantes provenientes de vários países, ao tentar negociar uma 'identidade nacional', decorre dos preconceitos existentes na população brasileira. Ao salientar este aspecto, ele realça a noção de 'fronteira', referida por Barth, como um importante elemento da identidade étnica.

Há vários estudos sobre a imigração de europeus ao Brasil, principalmente sobre os alemães e italianos ${ }^{10}$, que representavam a maioria dos imigrantes ingressos no Brasil a partir do século XIX. Mais raros são estudos sobre imigrantes de outras etnias ${ }^{11}$, numericamente menos significativos.

\footnotetext{
${ }^{10}$ Entre os quais, pode-se mencionar: Roche (1969); Manfroi (1975), Seyferth (1986) e uma coletânea sobre imigração no Rio Grande do Sul (Lando, 1980).

${ }^{11}$ Ver, por exemplo, um trabalho sobre os sírios e libaneses em São Paulo (Truzzi, 1997), e um estudo sobre a imigração japonesa (Saito e Maeyama, 1973).
} 
Grande parte dos imigrantes europeus que se instalaram no Brasil dedicou-se à agricultura, provavelmente porque esta era a atividade produtiva dominante durante o século XIX. Para os que ingressaram no país no século XX, a agricultura já não era a ocupação principal.

Os judeus que vieram ao Brasil tinham diversas ocupações, destacando-se a agricultura (graças ao estabelecimento de algumas colônias agrícolas, principalmente no Rio Grande do Sul), o comércio (inicialmente como vendedores ambulantes) e as atividades artesanais (marcenaria, costura, entre outras) (Scliar, 1990). E, da mesma forma como grande parte dos judeus que se estabeleceram no Brasil, começaram a vida como mascates, apoiados por uma rede local de imigrantes já estabelecidos no país (Scliar,1990). Jardim (2000) ressalta a atividade comercial como fundamental para a inserção dos árabes na cultura brasileira, pois o comércio era o único espaço possível de atuação na fase inicial da sua instalação no país. Como mostra Jardim (2000), os mascates aprendiam o ofício com os árabes que já estavam mascateando há mais tempo. Nos estudos sobre a imigração judaica, fica evidente a mobilidade profissional na geração de filhos desses imigrantes que, graças ao estudo, têm oportunidades mais diversificadas. $\mathrm{O}$ mesmo pode-se esperar que ocorra com os descendentes dos imigrantes palestinos.

Quando se trata do estudo das migrações em outros países, são destacadas também as características da legislação ${ }^{12}$, a dificuldade de aprendizagem da língua (ou das línguas) falada no país, a necessidade de inserção (e às vezes reciclagem) profissional, a educação dos filhos, a aprendizagem das normas e valores vigentes, assim como a possibilidade de existirem tensões nas relações com a população local, devido aos estereótipos existentes e à ideia de que os imigrantes competem em termos de emprego e oportunidades educacionais e benefícios sociais.

No que diz respeito às migrações de judeus para Israel, foram feitas algumas pesquisas naquele país nas décadas de 50 e 60, após a declaração de criação do Estado de Israel, em 1948, motivadas pelo fato de o país ter recebido inúmeros imigrantes de diversas origens num período de tempo relativamente curto. Entre os estudos desenvolvidos em torno da questão da

${ }^{12}$ Como é caso do Japão, que é apresentado por Chaudhry como tendo uma política inflexível em relação aos imigrantes, mesmo quando são casados com um japonês nativo e tem filhos com essa nacionalidade. integração/adaptação de imigrantes à nova realidade destacam-se os trabalhos desenvolvidos por S. N. Eisenstadt e sua equipe de pesquisadores da Universidade Hebraica de Jerusalém. Num desses trabalhos (1970), Eisenstadt esclarece o problema geral da pesquisa, como sendo o exame das condições sob as quais se dá uma adaptação de imigrantes bem sucedida.

$\mathrm{Na}$ pesquisa, adaptação foi definida em termos amplos como a capacidade efetiva dos imigrantes de exercer com sucesso os papéis básicos inerentes às principais esferas institucionais (familiares, econômicas, políticas, etc.) da estrutura social do país de absorção. Esta capacidade efetiva foi subdividida em três esferas principais: 1) o aprendizado efetivo de novos papéis sociais e sua utilização em diferentes esferas; 2) a amplitude da participação social estável com antigos habitantes do país, tanto em grupos existentes quanto em novos grupos; 3) a evolução ou manutenção de identificação positiva com a nova estrutura social e seus valores, e a minimização de comportamento agressivo contra ela. $\mathrm{O}$ autor reconhece que a obtenção de uma adaptação máxima decorre de um processo lento, gradual e desigual, que pode ser atingido - se isso for possível - em condições específicas, entre as quais estão: 1) as que se referem às motivações e predisposições dos próprios imigrantes para agir no novo campo social; e 2) as que se relacionam com as condições existentes no novo campo social, que definem as oportunidades disponíveis para os novos imigrantes e as atitudes existentes para com eles (Eisenstadt, 1970).

Ben David (1970) prefere situar a problemática da migração e da adaptação de imigrantes em termos de mudança social. Para ele, o importante é, por um lado, distinguir entre a permanência de determinados traços culturais dos imigrantes e a existência de diversos sistemas culturais; e, por outro, enfatizar o significado funcional de cultura e de seus vários elementos na vida cotidiana dos indivíduos envolvidos. Sua análise iniciase com o exame do efeito da migração para Israel sobre a personalidade do indivíduo, mostrando que um fenômeno que caracteriza uma situação deste tipo é o empobrecimento do ego, principalmente porque, no novo habitat, a organização dos papéis sociais em torno dos quais o ego foi construído não servem mais como guias, resultando, para o indivíduo, em sensação de insegurança. Os sentimentos de insegurança, frustração e ansiedade acentuam-se devido ao encolhimento considerável dos relacionamentos primários, íntimos, possibilitados pelos laços familiares, que podem propiciar ao indivíduo algum encorajamento durante os períodos de crise 
que ele irá enfrentar; ao mesmo tempo, mesmo os indivíduos que migram em companhia de suas famílias podem ter problemas, devido a mudanças na posição social em relação à que tinham no país de origem. Entre os problemas decorrentes da desorganização do ego, Ben David chama a atenção para a ênfase em necessidades biológicas em sua forma primitiva, não social, como uma posição central na estrutura da personalidade; e a dependência emocional em determinadas pessoas no novo meio ambiente, afetando a capacidade do indivíduo de planejar seu futuro de forma independente, numa espécie de regressão. Por certo, a esses fatores, podemse acrescentar a presença ou não de amigos e parentes no novo país; a bagagem cultural do imigrante, que pode facilitar ou não o tipo de trabalho que ele poderá obter e o meio social no qual ele poderá se inserir; o conhecimento ou não da língua falada no país, assim como a possibilidade de comunicação em sua própria língua nativa. O importante, de qualquer modo, é que, na nova sociedade, o indivíduo enfrenta a questão da autoidentificação: "um indivíduo que deixa de ser membro de uma sociedade e torna-se membro de outra muda sua identidade pessoal de alguma maneira" (Ben David, 1970: p.382).

Como resultado de sua análise, Ben David (1970: p.371) conclui que "o processo de ajustamento de indivíduos ou grupos à nova sociedade somente pode ser entendido como resultado da configuração de fatores, que aparecem sob diferentes formas em cada caso individual, entre os quais está o pertencimento a um grupo étnico em particular".

\section{A pesquisa}

\section{a) Método de coleta de dados}

Para a coleta de informações, foram feitas entrevistas semiestruturadas com diferentes categorias de sujeitos: os que estiveram em Israel com a finalidade de estudo (programas Ayanot e Shnat) ${ }^{13}$, os que viajaram com o

objetivo de estabelecer residência e que ainda permanecem no país, os que viajaram com o objetivo de estabelecer residência, mas retornaram ao Brasil ${ }^{14}$.

Devido à variedade de situações existentes, as entrevistas procuraram dar conta das singularidades de cada experiência, obtendo, assim, maior abrangência de dados para análise qualitativa.

Dentre os judeus que foram para Israel com o objetivo de lá estabelecer residência, fazem parte da amostra homens e mulheres com origem em Porto Alegre, com idade mínima de 20 anos, e que permaneceram em Israel por período de tempo igual ou superior a dois anos. Também fazem parte da amostra judeus que estão em Israel atualmente há pelo menos um ano e que tinham por objetivo a fixação de residência naquele país. Integram a amostra, ainda, jovens com pelo menos 18 anos, que permaneceram em Israel por pelo menos um ano, retornando a Porto Alegre posteriormente.

Para a seleção dos integrantes da amostra, a partir da escolha de alguns sujeitos que preencheram os critérios estabelecidos acima, indicados por informantes "chave", foram incluídos novos sujeitos indicados pelos próprios entrevistados (efeito "bola de neve").

A pesquisa prevê a coleta de dados com os emigrantes principalmente através da Internet, por meio de correio eletrônico. A utilização desse procedimento de coleta de dados possibilita a realização de 'entrevistas' com sujeitos que não residem em Porto Alegre, embora possa ocorrer um viés no sentido da exclusão, da amostra, de pessoas que não têm acesso a este meio eletrônico de comunicação. Algumas entrevistas têm sido realizadas pessoalmente em Porto Alegre, aproveitando o período de férias de algumas pessoas, o que em parte contorna o viés mencionado acima.

Até o presente, foram feitas quinze entrevistas, quatro através da Internet e onze pessoalmente (das quais três com judeus porto-alegrenses residentes em Israel e uma com um 'retornado' dessa migração). Os entrevistados apresentam as seguintes características: dos que residem em Israel, são quatro mulheres e um homem. Desses, três mulheres e um homem têm faixa etária entre 20 e trinta anos e residem em Israel há pelo menos quatro anos; uma das mulheres entrevistadas, residente em Israel, tem 60 anos

\footnotetext{
${ }^{14}$ A pesquisa está em andamento e deverão ser entrevistados ainda cerca de 10 ou 12 sujeitos.
} 
de idade e mora em Israel há mais de trinta anos. Dentre os que retornaram de Israel para o Brasil, está um homem com cerca de 50 anos e de nacionalidade argentina, duas mulheres e três homens com idade entre vinte e trinta anos, e que permaneceram em Israel por cerca de um ano e meio, e os demais, na maioria do sexo masculino, oriundos de programas com um ano de permanência naquele país, também com idades entre 20 e 25 anos.

\section{b) Principais resultados}

\section{... a viagem de ida a Israel}

Uma das características dos judeus brasileiros que vão residir em Israel é a idade, pois a maioria de nossos entrevistados decidiu fazer uma viagem de longa duração àquele país quando eram jovens (entre 20 e 25 anos). Esses jovens também eram solteiros por ocasião da viagem.

Os motivos que levam jovens judeus brasileiros a migrarem para Israel são bem diferentes dos que provocam a ida de japoneses ao Japão, dos descendentes de alemães e italianos para os países de origem de seus antepassados e de brasileiros para os Estados Unidos, Canadá e outros países.

Com base nas entrevistas realizadas, verificou-se que os principais motivos para a emigração de judeus brasileiros para Israel são: 1) crença religiosa ou ideológica; 2) dificuldade de obter emprego ou ter sucesso profissional no Brasil; 3) desejo de independência ou de viver novas experiências. Esses motivos podem ocorrer isoladamente ou podem estar associados, como no caso de uma porto-alegrense que viajou para Israel com o propósito de 'viver uma aventura' e de passear, mas que ao conhecer aquele país, identificou-se com o funcionamento do mesmo e lá permanece até hoje, totalizando atualmente cinco anos de residência em Israel. Existe também a possibilidade de um jovem viajar a Israel para estudar ou especializar-se em sua profissão e por motivos diversos (tal como identificação religiosa ou ideológica, oferta de emprego ou casamento) decidir permanecer no país.

A migração para Israel por motivos econômicos, no caso de judeus brasileiros, é menos frequente que as migrações motivadas por motivos ideológicos. Esta motivação pode estar caracterizando parte da migração a Israel de judeus argentinos, cujo país enfrenta uma grave crise políticoeconômica neste período. Kliksberg (2002) divulga a estimativa de que cerca de 50.000 judeus argentinos estejam abaixo da linha de pobreza, ou seja, não têm o necessário para a alimentação, e a comunidade judaica Argentina foi atingida de forma avassaladora pela crise econômica pois as ocupações mais comuns dos judeus argentinos (como o comércio, por exemplo) foram as mais prejudicadas pela política econômica que vigorou no país. Muitos desses argentinos empobrecidos encaram a alternativa de sair do país e, entre os judeus, a ida a Israel coloca-se como um dos destinos possíveis.

Por volta dos anos de 1980, a Rússia vivenciou uma crise econômica e política grave, ocorrendo um fenômeno semelhante ao da Argentina atualmente em relação à comunidade judaica. De acordo com LoBue (2002), durante o governo de Brezhnev, a estagnação econômica da Rússia atingiu seu pico. O governo encontrava-se apático aos problemas mais básicos. Nesse contexto, muitos judeus russos migraram para Israel com o intuito de buscar uma vida melhor. Armstrong (2002) traz a informação de que, entre 1989 e 1995, houve quase 700.000 desembarques de russos em Israel, país que é composto atualmente por cerca de $40 \%$ de população imigrante. Segundo Armstrong, os imigrantes da antiga União Soviética se diferenciaram dos outros imigrantes, pois trouxeram ferramentas profissionais e saber político, causando impacto imediato na sociedade israelense. A maioria dos migrantes possuía avançado nível técnico em diversas áreas do conhecimento e foram rapidamente absorvidos pelo mercado de trabalho israelense, que se encontrava carente de mão de obra qualificada em diversos âmbitos.

Em contraposição à situação atual da Argentina e ao caso da Rússia, há o exemplo dos Estados Unidos da América, que também têm vários representantes judeus residindo em Israel. No caso desse país, os motivos para a migração são principalmente religiosos e ideológicos, pois a situação econômica dos que vão para Israel é geralmente favorável nos Estados Unidos.

... o processo de adaptação em Israel

O processo de integração de judeus em Israel é facilitado pela existência de uma estrutura oficial, com caráter assistencial, de oferta de cursos de língua hebraica e de especialização profissional e, com frequência, dependendo do caso, de subsídio à instalação e de pagamento de uma bolsa de manutenção durante o período de aprendizado da língua ou de treinamento profissional. 
A integração ou não de judeus brasileiros em Israel está em grande parte relacionada com os motivos que os levaram a estabelecer residência naquele país. Para os que buscam uma vida melhor no que se refere à situação financeira e profissional, a permanência ou não naquele país está atrelada ao sucesso profissional, à estabilidade financeira e às melhorias nas condições de vida. Em Israel, o custo de vida é mais alto, mas os salários também são relativamente mais elevados que no Brasil. Muitos migrantes não encontram empregos satisfatórios nas mesmas ocupações que tinham no Brasil, e precisam receber treinamento em outra profissão. Também há casos de pessoas que no Brasil tinham ocupações como autônomos e em Israel precisam inserir-se no mercado de trabalho como empregados. É interessante verificar, porém, que embora possam ocorrer dificuldades momentâneas referentes ao trabalho, aqueles que já se encontram no país relutam em voltar - por um lado, são influenciados por sua identificação com o país e, por outro, pelas dificuldades que se colocariam no retorno, após terem feito um investimento financeiro e pessoal na mudança. Os que apresentam menor dificuldade de integração são os que migram por motivos religiosos ou ideológicos.

Um aspecto que, em muitas situações de migração, pode dificultar a inserção dos migrantes são as ideias preconcebidas (estereótipos) da população local em relação à etnia ou religião dos recém-chegados. No caso em exame, os judeus brasileiros que migram a Israel não encontram estereótipos desfavoráveis e mesmo que tenham dificuldades de relacionarse de imediato com a população local, inserem-se facilmente nos grupos de brasileiros e latino-americanos residindo naquele país.

A religião também aparece como aspecto importante na adaptação do indivíduo a Israel. A religião judaica é majoritária naquele país, mas mesmo sem ser praticante, o jovem migrante identifica-se com aquele país nesse sentido, pois os feriados judaicos são obrigatórios, não sendo necessário explicar no trabalho o motivo pelo qual não se pode trabalhar. Um problema pode ocorrer no que se refere ao casamento, caso o jovem migrante decida casar-se com um não judeu, com alguém que tenha se convertido ao judaísmo de acordo com uma linha liberal ou conservadora (a linha ortodoxa predomina no país) ou com um indivíduo separado ou divorciado, é o fato de o casamento ter caráter apenas religioso em Israel, visto que não existe casamento civil.
Também foi referida pelos entrevistados, de forma bastante enfática, a importância das redes de apoio social para a permanência em Israel (amigos, namorado, familiares e colegas de trabalho). Muitos migrantes, antes de viajar, já têm conhecidos vivendo naquele país e, através desses, conseguem ampliar sua rede de relações. Um fator importante é a inserção imediata, logo após a chegada no país, em cursos de língua, Universidade ou cursos de treinamento profissional, nos quais os contatos com pessoas em situação semelhante são facilitados.

O aprendizado da língua, em cursos de cerca de cinco meses, além de proporcionar a ampliação do circulo de amizades, viabiliza o relacionamento com a população local.

Um aspecto que dificulta a integração dos migrantes e, em alguns casos, justifica o retorno ao Brasil, é o conflito que se estabelece entre o estado de Israel e a população palestina. Os entrevistados relatam que, diferentemente do Brasil, não temem ser assaltados quando saem à rua, em Israel há sempre o temor de um ataque terrorista. Ao mesmo tempo, os migrantes raramente chegam muito perto do conflito, pois não vão para o exército ou à frente de batalha. São raros os casos como o de um judeu do interior do Rio Grande do Sul morto quando fazia a guarda em um assentamento de colonos judeus na Cisjordânia ou o do viúvo de uma judia gaúcha que decidiu vender sua residência na cidade e mudar-se para um desses assentamentos.

\section{... o retorno ao Brasil}

Para os que retornam ao Brasil, após uma relativamente longa estadia em Israel, a reintegração à sociedade brasileira torna-se uma questão importante. A reintegração é facilitada pelos laços familiares, relações com os pares e pela experiência adquirida em Israel. No entanto, é dificultada pela necessidade de (re)iniciar a vida profissional.

Em alguns casos, percebemos o aproveitamento de conhecimentos e habilidades aprendidos em Israel como 'capital cultural' por aqueles que retornam ao Brasil. É o caso, por exemplo, de vários 'retornados', após longa estada em Israel e aprendizagem forte do idioma, que ao voltar ao Brasil são contratados por instituições de ensino para lecionar a língua hebraica ou são absorvidos por outras instituições judaicas locais. 
A vivência num outro país, ao qual o sujeito precisou adaptar-se, graças ao aprendizado da língua oficial e de normas e valores, resulta numa experiência multicultural, que pode ser aproveitada por ocasião do retorno ao país de origem: o 'retornado' tem facilidades nos relacionamentos com estrangeiros e, além da língua oficial do país, provavelmente praticou uma ou mais de uma língua estrangeira (principalmente espanhol e inglês), o que poderá ser útil numa sociedade cada vez mais globalizada.

Uma situação peculiar é a de um judeu argentino, que residiu em Israel por seis anos e, após casar com uma brasileira, veio morar no Brasil. No seu caso, a desterritorialização foi dupla, primeiro em Israel, com relação à Argentina, e depois no Brasil, com relação a Israel. Para esse homem,"a maior dificuldade foi o idioma, os costumes, o jeitinho brasileiro, a falta de oportunidade de trabalhar naquilo que realmente o país e a gente necessita,"

\section{Conclusões}

Através da análise dos dados coletados, foi possível verificar que as principais motivações de jovens judeus que migram ou que viajam a Israel pelo período de pelo menos um ano é a identificação com o judaísmo, seja este visto no aspecto religioso ou ideológico (sionista).

$\mathrm{Na}$ experiência de ir a Israel e retornar ao Brasil a identidade judaica passa por alterações: durante a estada em Israel, a identificação como judeu (judia) evidencia-se principalmente face ao confronto entre israelenses e palestinos, mas surgem novas questões de identificação, principalmente aquelas relacionadas à religião, já que existem em Israel diversas modalidades de judaísmo, sendo predominante a ortodoxa, e à ideologia (várias modalidades de sionismo e não sionismo); no retorno ao Brasil, a identificação como judeus passa por nova configuração, graças ao reforço do 'território' como critério central, o que aparece na relação com os judeus locais e com os não judeus. A identificação dos jovens judeus como sefaraditas, ashkenazitas ou orientais não foi associada, pelos entrevistados, a dificuldades ou facilidades de adaptação em Israel, pois, naquele país, sua identificação dá-se preferentemente como brasileiros.

A integração em Israel é facilitada pela origem étnica (brasileira), devido à inserção do judeu brasileiro em grupos de brasileiros e latino- americanos residentes em Israel e à inexistência, naquele país, de uma imagem negativa (estereótipo) em relação aos brasileiros, mas é dificultada por fatores tais como a ausência de laços familiares (pais ou cônjuges) e formação profissional insuficiente para proporcionar uma inserção profissional com remuneração adequada aos padrões de vida israelense e que corresponda às expectativas que podem ter motivado a migração, assim como a situação conflituosa em relação aos palestinos.

A identidade judaica também parece adaptar-se a cada situação. Isso ocorre, pois, na situação de retorno, os judeus que residiram por um certo período em Israel trazem uma 'marca' que os distingue dos demais judeus, ampliando a distância (fronteira) entre eles e os judeus locais e entre eles e os não judeus. A diferença identitária que se estabelece entre judeus que nunca moraram em Israel e judeus que já o fizeram parece ter sua base no orgulho coletivo cultivado pela "Eretz" (terra de Israel). O fato de alguém ter morado naquele país é valorizado tanto por quem já teve quanto por aqueles que nunca tiveram esta experiência.

\section{Referências bibliográficas}

ARMSTRONG, James. Imigration to Israel: Sociological Perspectives. Disponível em: http://muse.jhu.edu/demo/sho/ 19.3armstrong.html. Consultado em: 29/04/2002.

BARTH, Fredrik. Grupos Étnicos e suas Fronteiras. In: POUTIGNAT, Philippe e STREIFF-FENART, Jocelyne. Teorias da Etnicidade. São Paulo: Fundação Editora da UNESP, 1998. pp. 185-227

BEN DAVID, Joseph. Ethnic Differences or Social Change? In: EISENSTADT, S.N.; BAR YOSEF, Rivkah; ADLER, Haim (eds.) Integration and Development in Israel. Jerusalem: Israel Universities Press, 1970. pp.368-87.

BERENSTEIN, Nicole; PORZECANSKI, Rafael. Perfil de los egresados de la Red Formal de Educación Judia Uruguaya. Montevideo, Fundación L. A. Pincus para ao Educación Judia en la Diáspora (Israel); Consejo de Educación Judia del Uruguay, 2001. 
BERTONHA, João Fábio. Migrações internacionais e política no Brasil nos anos 30 e 40. In: Brasil: migrações internacionais e identidade.

http://www.comciencia.br/reportagens/migrações/migr06.htm. Acesso em 09/06/2001.

BRASIL: migrações internacionais e identidade [sem referência a autor]. Conexão Brasil-Estados Unidos

http://www.comciencia.br/reportagens/migrações/migr15.htm. 09/06/2001. (1)

BRASIL: migrações internacionais e identidade [sem referência a autor]. Migração japonesa e o fenômeno dekassegui: do país do sol nascente para uma terra cheia de sol.

http://www.comciencia.br/reportagens/migrações/migr19.htm. 09/06/2001. (2)

BRASIL: migrações [sem referência a autor]. "Migrações". http://frigoletto.vila.bol.com.br/GeoPop/migrações.htm. 17/06/2001

BRUMER, Anita. Identidade em mudança; pesquisa sociológica sobre os judeus do Rio Grande do Sul. Porto Alegre: Federação Israelita do Rio Grande do Sul, 1994.

CHAUDHRY, Imtiaz A. Japanese Government's Mysterious Policies. UMJ News, vol. 2. Disponível em: http://www.utj.gol.com/newsletter/

CLIFFORD, James. Diasporas. Cultural Anthropology, American Antropological Association, vol.3, n.9, 1994.

EISENSTADT, S. N. The Process of Absortion of New Immigrants in Israel. In: EISENSTADT, S.N.; BAR YOSEF, Rivkah; ADLER, Haim (eds.). Integration and Development in Israel. Jerusalem: Israel Universities Press, 1970. pp.341-67.

GOMEZ, Gustavo Montariez \& MAHECHA, Ovídio Delgado. Espaço, Território e Região: conceitos básicos para um projeto nacional. In: Cuadernos de Geografia, 1998.

www.hurnanas.unal.edu.co/geografia/cuadernos/ano1998/montanez.pdf

JACQUES, Maria da Graça Corrêa. Identidade. In: STREY, Marlene Neves (org.). Psicologia Social Contemporânea. Petrópolis, RJ: Vozes, 1998.
JARDIM, Denise Fagundes. Palestinos no extremo sul do Brasil: identidade étnica e os mecanismos sociais de produção de etnicidade - Chuí/RS. Rio de Janeiro: 2000. 376 f.

KLIKSBERG, Bernardo. A comunidade judaica da Argentina em perigo. In: Morashá. São Paulo: CBSP, 2002. Ano X, n 36. Pg. 60-63.

LESSER, Jeffrey. Construindo o espaço étnico. In: A negociação da identidade nacional: Imigrantes, minorias e a luta pela etnicidade no Brasil. São Paulo: Editora UNESP, 2001.

LOBUE, Christopher M. Capitalism in Russia. In. www.argate.net/ xlobue/history.HTM 2002.

MACHADO, Irene. Para além do Multiculturalismo: Argumentos em defesa da Semiodiversidade. In: XXIII Congresso Brasileiro da Comunicação. Universidade do Amazonas, 2000.

www.intercom.org.br/papers/xxiii-ci/gt08al.pdf (consultado em maio de 2002).

MANFROI Olívio. A colonização italiana no Rio Grande do Sul; implicações econômicas, políticas e culturais. Porto Alegre: Grafosul/Instituto Estadual do Livro, 1975.

MARTIN, Denis-Constant. Des Identités en Politique, 42(4); 582-593, Aôut, 1992.

ROCHE, Jean. A colonização alemã e o Rio Grande do Sul. Porto Alegre: Globo, 1969. 2 vol.

LANDO, Aldair e outros. RS: Imigração \& Colonização. Porto Alegre: Mercado Aberto, 1980.

SAITO, Hiroshi; MAEYAMA, T. (eds.) Assimilação e integração dos japoneses no Brasil. Petrópolis, Vozes/ São Paulo: Edusp, 1973.

SASAKY, Elisa. In: BRASIL: migrações internacionais e identidade [sem referência a autor]. Migração japonesa e o fenômeno dekassegui: do país do sol nascente para uma terra cheia de sol. 
SCUDELER, Valéria Cristina. Imigrantes valadarenses nos EUA. In: Brasil: migrações internacionais e identidade: Disponível em: http://www.comciencia.br/reportagens/migrações/migr17.htm. 09/06/2001

SCLIAR, Moacyr. Caminhos da Esperança: a presença judaica no Rio Grande do Sul. Porto Alegre, Instituto Cultural Judaico Marc Chagal, 1990.

SEYFERTH, Giralda. Imigração, colonização e identidade étnica; notas sobre a emergência da etnicidade em grupos de origem europeia no sul do Brasil. Revista de Antropologia, 1986.

TRUZZI, Oswaldo Mário Serra. Patrícios; sírios e libaneses em São Paulo. São Paulo, Hucitec, 1997.

VÁSQUEZ, Guillermo Hoyos. Trois espaces linguistiques face aux défis de la mondialisation. Paris, março de 2001. In: Identidade $e$ Multiculturalismo. Disponível em

www.francophonie.org/oif/actions/20mars2001/hoyos_p.pdf

(consultado em maio de 2002).

\section{A construção o de um lugar judeu no Recife}

\section{Rosa Bernarda Ludemir}

trabalho aqui apresentado é parte de uma pesquisa mais ampla, onde se investiga a existência de um modo judeu de uso e apropriação do espaço urbano e sua expressão na escolha e transformação de parte do bairro da Boa Vista, na cidade do Recife, entre as duas Guerras Mundiais. A pesquisa, desenvolvida no Programa de Pós-graduação em Desenvolvimento Urbano na Universidade Federal de Pernambuco, pretende contribuir para a construção de um conceito de lugar judeu que se aplique a essa parte da cidade entre os anos de 1914 e 1939.

\section{A cidade conta a sua história}

As cidades trazem em si a história de cada um dos seus elementos e a história de sua própria existência. Em seus espaços, as paisagens resultam de um conjunto de forças que interagem e definem modos e formas das relações entre indivíduos e objetos, das intenções, preferências e possibilidades de cada sociedade. Nos lugares e fatos urbanos sobrepõem-se tempos e valores.

\section{A instituição de um modo judeu de uso do espaço urbano}

Um modo judeu de uso e apropriação do espaço urbano se teria criado, consolidado e transformado dentro de um processo de confrontações e lutas pela conquista do poder e pela manutenção de hegemonias, pontuado por transmigrações e deslocamentos (Arendt, 1979), inserido num contexto histórico e cultural marcado por eventos que constituem, segundo Milton Santos (1997) os "vetores da metamorfose que une objetos e ações".

\subsection{A história}

A história do povo judeu é pontuada por deslocamentos e dispersões, sobretudo por lutas de conquistas e perdas de um espaço físico onde se

${ }^{1}$ Arquiteta / Universidade Federal de Pernambuco. 
instala a vida cotidiana. Os caminhos do povo judeu contam a história do movimento, formação e estruturação da nação e da cultura judaica e, também, o modo judeu de tratar o espaço. É uma história que começa no século XX a.E.C. com a saída de Abraão da Caldéia em busca de uma terra que se revela em sonho, a Terra Prometida e aos poucos conquistada. $\mathrm{Na}$ visão de Bloomfield (1996), Abraão seguiu construindo altares a Adonai, ato de apropriação da terra. Seria essa a raiz longínqua das práticas espaciais judaicas e do modo judeu de apropriação do espaço. Contribuem significativamente para a consolidação desse modo judeu em seu formato atual as tantas e tão frequentes migrações, a vida social em diáspora, o caráter simbólico de Jerusalém, a instituição dos guetos desde a Idade Média e a existência, na Idade Contemporânea, de um território internacional - a Zona de Assentamento como uma nova Babel - para onde foram enviados judeus de vários cantos da Europa Central e Oriental. Modelaram um modo próprio de uso do espaço.

\subsection{Jerusalém conquistada / Jerusalém virtual}

Lynch (1985) discorre sobre a importância da prática ritual e da existência de centros urbanos para a gestão territorial no surgimento das civilizações. Sem uma cidade simbólica não floresceram grandes povos. Jerusalém, cidade conquistada pelos judeus, capital do reino unificado de Israel e Judá, é o primeiro centro ritual desse povo e parece simbolizar, desde então, um território judeu virtual.

Em Jerusalém, Salomão construiu o Templo, destruído e reconstruído, insistentemente ameaçado pelos conquistadores de Israel numa comprovação de sua importância simbólica sobrevivente até os dias atuais: é para as ruínas do Templo, para o Kotel ou Muro das Lamentações, que os judeus voltam suas faces na oração.

Embora importante centro da judeidade, Jerusalém parece ter sido, desde tempos remotos, local simbólico. Quando Ciro I da Pérsia dominou a Babilônia onde os judeus da diáspora viviam em exílio e permitiu-lhes voltar a Jerusalém, em 539 a.E.C., o retorno só foi realizado por uma minoria (Eban, 1973). "As margens do Eufrates nos assentamos $e$ choramos. Que seque minha destra mão se eu me esquecer de ti, ó erusalém”, diz o salmo 137. Para Geiger (1998), esse salmo demonstra que Jerusalém, mais que uma cidade, era um símbolo; mesmo que os judeus preferissem a vida na Babilônia, mesmo que estivesse relegada à memória, Jerusalém representava a virtualidade territorial do mundo judeu.

Szekely (1940) propõe que Jerusalém, como arquétipo, se tenha repetido, dentro das condições possíveis, em cada um dos assentamentos judaicos da diáspora. Ainda nesse sentido acrescente-se que, mesmo quando não há intenção explícita ou condições materiais ou históricas de retorno, os judeus finalizam suas orações recitando "Em Jerusalém no• ano que vem."

\subsection{Torah: a pátria portátil dos judeus}

Leopold Zunz, historiador da religião judaica no século XIX citado em artigo da revista Morashá (2001) diz que a Torah é "a pátria portátil dos judeus". Ideia semelhante havia sido expressa nove séculos antes pelo rabino Saádia (citado no mesmo artigo): "Israel é um povo porque tem a Torah."

O comportamento de grupos e o sentimento do migrante, sua inserção no ambiente novo e sua participação na construção da nova paisagem são discutidos por Milton Santos (1997). Quando, na página 262 do livro A Natureza do Espaço, fala sobre os migrantes no lugar: da memória à descoberta, diz que o indivíduo "estava submetido a uma convivência longa e repetitiva com os mesmos objetos, os mesmos trajetos, as mesmas imagens, de cuja construção participava”. Migrar é deixar atrás uma cultura herdada e encontrar uma outra. Defrontar com um espaço que não ajudou a criar, cuja história desconhece, cuja memória lhe é estranha, é sede de uma vigorosa alienação. Segue na página 263 dizendo:

"Para os migrantes, a memória é inútil. Trazem consigo todo um cabedal de lembranças e experiências criado em função de outro meio, e que de pouco thes serve para a luta cotidiana. [...] Deixam a paisagem concreta e trazem a paisagem imaginada."

Finaliza Santos dizendo que, ultrapassado um primeiro momento de espanto e atordoamento, "o espírito alerta se refaz, formulando a ideia de futuro".

Josué de Castro (1954, p.43) em sua Fisiologia dos Tabus, coloca a relação intercultural em outros termos. Diz que:

De fato cada cultura é um mundo fechado ao entendimento das outras culturas, não na sua aparência, mas na sua interpretação fundamental. 
Não há nunca uma absoluta compreensão mas, quando muito, um simples contágio entre culturas. (...J Serão sempre estranhas uma a outra, em vários pontos; exatamente nos pontos mais sensíveis, nos núcleos mais profundos da personalidade, onde ela reflete o inconsciente coletivo, a alma ancestral e ao mesmo tempo sobrevivente das culturas diferentes.

Szekely (1940) retoma a ideia da pátria portátil e diz que, além da Jerusalém arquetípica, a Torah é, como memória coletiva, também elemento criador do modo judeu de uso e apropriação do espaço, o que justificaria a semelhança espacial entre tantos assentamentos judaicos localizados em lugares distintos. Ao contrário de adotarem padrões espaciais existentes nos locais onde se instalam, os judeus mantêm seu modo de uso do espaço e intervenção na paisagem. Imigrantes, parecendo por fora se submeter totalmente e conformar-se com as expectativas do meio externo, "de fato metaforizam a ordem dominante" (de Certeau, 1994).

\section{O gueto}

Na Europa medieval, os judeus ficaram fora das principais correntes da vida política, social e cultural. Formavam uma classe à parte, sem direitos de cidadão. Eram segregados espacialmente e isolados do contato social com o mundo não judeu a seu redor. Segregação e exclusão (Gomes, 1998) são "clássicos ícones do processo de cristalização, no espaço, das práticas sociais".

Esse isolamento foi simbolizado pela instituição do gueto - palavra que data com esse significado do ano de 1516 quando, na República de Veneza, se ordenou a segregação dos judeus num bairro especial, anteriormente conhecido como o "Ghetto Nuovo" ou "Fundição Nova". Os judeus se localizavam na face externa das muralhas da cidade e eram-lhes fechados os portões em determinadas circunstâncias e horários. Esse formato de segregação espacial já se fazia presente em outras localidades. É paulatinamente abolido a partir de 1789 com a Revolução Francesa, cujas ideias levaram à emancipação dos judeus nos países conquistados por Napoleão Bonaparte. Em 1940 os guetos foram reinstituídos no império alemão em condições infinitamente mais restritivas.

Eban (1973) diz que, se no gueto o indivíduo se via privado em seu confinamento, a vida judaica em grupo florescia. "Surgiu no gueto uma forma de organização comunitária que foi quase uniforme em todas as cidades da Europa". Diferente do que acontece em outros assentamentos étnicos, nos guetos a segregação permitiu a manutenção de uma sociedade singularmente judaica.

Para Szekely (1940), o gueto é uma via de mão dupla - imposta pelos não judeus e pretendido pelos judeus. Os preceitos religiosos e a prática social própria aos judeus levam à sua manutenção. A segregação dos guetos é protetora da identidade cultural e religiosa e, em certas circunstâncias históricas, da idoneidade física dos membros das comunidades judaicas tanto quanto foi impedimento ao exercício de cidadania e inserção dos judeus nas sociedades das quais viviam à margem. Graças à segregação espacial e à exclusão social foi possível manter a identidade judaica ao longo dos séculos da diáspora.

Ao analisar os guetos urbanos e a distribuição espacial de minorias étnicas, Vaughan $(1994,1999,2000)$ discute a sua instituição e coloca a sua importância para a manutenção da identidade cultural do grupo. A palavra gueto, inicialmente usada para descrever tanto o enclausuramento imposto aos judeus como o agrupamento espontâneo de imigrantes ou minorias sugere, segundo Vaughan, que a percepção do gueto está relacionada a duas noções: segregação e nicho (ou cluster). Faz estudos comparativos entre diversos nichos judeus e não judeus, num fenômeno por ela denominado clustering by choice, para concluir que "o gueto é uma questão de percepção e não necessariamente de fatos" e que "a inteligibilidade do assentamento judeu, e não simplesmente seu grau de segregação, o distingue de outros assentamentos em nicho"3. Há um modo judeu de uso e apropriação do espaço. Suas práticas sociais têm como reflexo certas práticas espaciais.

\section{Bairros étnicos}

Pesquisadores de diversas áreas do conhecimento vêm estudando o fenômeno dos bairros étnicos, na sua existência e conformação marcadas

\footnotetext{
${ }^{2}$ Tradução minha para o texto original "Ghettoisation is a matter of perception and not necessarily of facts".

${ }^{3}$ Tradução minha para o texto original "the intelligibility of the Jewish settlement, and not simply its degree of segregatton, ditinguishes it from other cluster settlements".
} 
culturalmente pela presença de pessoas ou grupos estranhos ao meio onde se inserem.

Rouanet (1993) discute fatores que condicionam o comportamento, a percepção e a interação de pessoas com meios que lhes são estranhos. "Como ver uma cidade estrangeira sem os fantasmas culturais que moram em nós?" Citando Freud, refere-se ao sentimento do viajante, do migrante em particular, que o faria buscar a identificação e se agrupar em torno de seus semelhantes, ressaltando a ambivalência da viagem como "uma experiência avassaladora porque significa enfrentar perigos desconhecidos, e uma fonte de remorsos porque implica o desejo culposo de libertar-se de uma vida de família vivida como insatisfatória”.

Berger e Luckmann (1991) falam da coesão social decorrente de experiências compartilhadas, que se reforça pela segregação espacial, importante para a liberdade de expressão e compreensão da exteriorização dos gestos de membros de um mesmo grupo.

Expostos a experiências comuns nos seus lugares de origem e enfrentando situações semelhantes de inserção na nova sociedade, imigrantes tendem a se agrupar em torno de uma nacionalidade. Judeus das mais variadas procedências, com importantes diferenças de hábitos, condições materiais e memórias agrupam-se, não em torno de uma nacionalidade em comum, mas em torno do fato de serem judeus, reforçando a ideia da Torah como pátria portátil.

Rachel Mizrahi (2000), ao falar dos imigrantes judeus do Oriente Médio em São Paulo, assinala que esse grupo no Brasil, à semelhança de outros lugares, assentou-se em bairros já ocupados por imigrantes. Fania Fridman (2002) faz constatação semelhante com relação ao assentamento dos imigrantes judeus no Rio de Janeiro.

Também assim aconteceu em Recife na primeira metade do século $\mathrm{XX}$, indica nossa pesquisa. Na então cidade cosmopolita viviam em Recife diversos estrangeiros, inseridos individualmente ao longo do tecido urbano. Apenas um grupo, os ingleses da Fundição Aurora, assentaram-se em conjunto ao redor da fábrica, nas imediações do Cais José Mariano (Menezes, 1988). É exatamente na vizinhança desse cais que se estabelece o assentamento judaico em Recife.

\section{A presença dos judeus em Pernambuco}

A presença de judeus no Brasil vem de datas anteriores e com grau maior de importância do que costumam citar alguns livros de História do Brasil. A instalação da Santa Inquisição na Península Ibérica no final do século XV forçou a conversão de judeus em cristãos-novos ou marranos que daí fugiram e buscaram no Novo Mundo liberdade de expressão religiosa (Eban, 1973). A presença dos judeus em Pernambuco é marcada por três etapas distintas.

\subsection{Os marranos no Brasil colonial}

Há indicações da presença de judeus e marranos já na esquadra de Pedro Álvares Cabral em 1500. Mello (1989) diz que no período entre o descobrimento e as primeiras expedições colonizadoras, a exploração de recursos naturais e a proteção da costa brasileira foram entregues a um consórcio de judeus capitaneado por Fernando de Noronha. Também Tomé de Souza, governador-geral do Brasil, teria origem judaica. A importância da capitania de Pernambuco nesse período histórico trouxe judeus professantes e marranos para a administração dos negócios da coroa e para a instalação dos engenhos de açúcar.

\subsection{Os sefaradim no século XVII}

Durante a Idade Média, na Espanha (Sefarad), em Portugal e nas costas do Mar Mediterrâneo prosperaram as comunidades de judeus sefaradim. Falavam o ladino, idioma parecido com o português, escrito com alfabeto hebraico. Com a instalação da Santa Inquisição, foram expulsos da Espanha e de Portugal e seguiram, entre outros destinos, para a Holanda (Eban, 1973). Chegaram a Pernambuco no século XVII com a Companhia das Índias Ocidentais e a corte do príncipe Maurício de Nassau e formaram a primeira comunidade a se instalar em Recife e no Novo Mundo. Eram detentores do conhecimento de comércio internacional e donos das redes de comunicação. A expulsão dos holandeses, com a reinstalação do governo português e a presença do Tribunal do Santo Ofício, representou a dissolução dessa comunidade. É possível que alguns judeus tenham ficado nas terras afastadas do litoral, assumindo a postura dos marranos ou cripto-judeus, 
como parecem demonstrar estudos de hábitos e crenças do povo nordestino que se assemelham a hábitos e tradições judaicas (Cascudo, 1970).

\subsection{Os ashkenazim no século $X X$}

Um conjunto de situações econômicas, sociais e políticas provocou uma grande onda de emigração de judeus ashkenazim do leste europeu nos finais do século XIX. Essa onda se acentuou a partir de 1914, com a Guerra Mundial I e de 1917, com a Revolução Russa. O destino de desejo de muitos desses judeus era os Estados Unidos. O Immigration Act estabeleceu já no início do século XX um sistema de cotas e um rigoroso controle que restringiu a imigração para os Estados Unidos. Outros países do continente americano, entre eles o Brasil, foram incluídos como possíveis destinos de fuga dos pogroms ${ }^{4}$. Recife era o primeiro porto para muitas rotas que se iniciavam na França, Espanha, Portugal e norte da África.

A partir de 1914 começam a chegar em Recife grupos mais numerosos de judeus. Diz Tânia Kaufman (2000) que "em 1911 havia oito rapazes judeus em Recife. Em 1914, havia mais de 4 minianim". Falando iídiche, provenientes predominantemente dos shetlech da Bessarábia, Polônia, Ucrânia, Galícia e Lituânia, uma minoria oriunda de cidades grandes como Viena, Kiev e Odessa, foram aos poucos se inserindo no mercado de trabalho na sociedade local. Uns poucos judeus que chegaram a Pernambuco nesse momento dirigiram-se para vilas rurais na zona de produção açucareira do Estado. A demora para a liberação de títulos provisórios de posse de terra e a falta de um meio cultural adequado interromperam essa experiência. Logo também esses ocuparam a Boa Vista.

\section{A boa vista do Recife}

Se tomamos a cidade como um discurso estruturado, como o faz Barthes (1986), podemos ler nas ruas da Boa Vista parte de como foi escrita a sua história. Tentamos identificar elementos existentes e introduzidos

${ }^{4}$ Pogroms eram perseguições aos judeus realizadas no Pale ou Zona de Assentamento, que se intensificaram no final do século XIX. Caracterizavam-se pelo alto grau de violência, com ataques físicos, saques e violação de propriedade.

${ }^{5}$ Uma minian (minianim no plural) é o grupo mínimo de dez homens aptos a ler a Torah, sem o qual não se realizam as celebrações coletivas judaicas. pelos judeus entre os anos de 1914 e 1939 que contribuíram para criar um espaço judeu na Boa Vista ${ }^{6}$.

\subsection{Segregação espacial}

Eban (1973) cita a insistência com que os rabinos desde a Antiguidade até a Idade Contemporânea repetiam: "Construam um muro em torno da Torah!" Esse comando, mais uma indicação que uma lei a ser cumprida, foi seguido pelas comunidades judaicas da diáspora (Szekely, 1940) e talvez tenha contribuído para que se estabelecesse um modo judeu de uso do espaço urbano.

A parte da Boa Vista ocupada pelos judeus entre os anos de 1914 e 1939 tinha muros ou estruturas que a isolavam do tecido urbano imediatamente vizinho, como mostram os mapas apresentados por Menezes (1988). Limitava-se a norte e sul pelo Rio Capibaribe e cais José Mariano e por uma fazenda para além da Rua José de Alencar por onde não se caminhava e, a leste e oeste, pelo terreno alagado dos Coelhos e pela Rua Formosa ou Avenida Conde da Boa Vista que até hoje parece dividir o bairro em duas seções distintas, uma de ruas tortuosas e estreitas, ocupadas pelos judeus, e outra de traçado regular pombalino. Assim configurado, esse setor da cidade era um lugar de parada, nunca de passagem. Era, se usarmos o vocabulário de Vaughan (1994) em suas análises da morfologia urbana, segregado por barreiras, com baixo grau de permeabilidade.

\subsection{Outros lugares do Recife}

Outros lugares do Recife poderiam ser parecidos com a Boa Vista. Os traçados dos vizinhos bairros de Santo Antônio e São José apresentam características semelhantes. Segundo dados encontrados em pesquisas de jornais da época, os preços de locação de imóveis aí também equivaliam aos da Boa Vista. Apesar de não serem objeto de nosso estudo no presente trabalho e de não terem sido o lugar escolhido pelos judeus, indicamos aí uma grande concentração de edifícios religiosos católicos, igrejas e sedes de congregações e irmandades. Segundo Freud, alguns elementos urbanos

${ }^{6}$ A Boa Vista é um bairro maior que a área em estudo. Denomina-se aqui Boa Vista parte do
bairro com esse nome delimitada pelo Rio Capibaribe e por terreno não loteado a norte e sul, bairro com esse nome delimitada pelo Rio Capibaribe e por terreno não lotead
e pela avenida Conde da Boa Vista $e$ o alagado dos Coelhos a leste e oeste. 
podem estar associados a significados pessoais ou de grupo de maneira a se configurarem como elementos de repulsa. Alguns judeus relataram que sentiam medo nesses lugares.

\subsection{Um padrão}

Os judeus da comunidade ashkenazi a se instalarem em Pernambuco no século XX não ocuparam o Bairro do Recife, onde se havia constituído a comunidade sefaradi do século XVII. Ney Dantas (1998) fala das grandes reformas do Bairro do Recife no começo do século XX, que ampliava seu porto e construía uma nova imagem, a imagem moderna da cidade. Isso poderia significar altos preços de locação de imóveis, como confirmam os anúncios de jornais, incompatíveis com a situação econômica dos recémimigrados. Entretanto, a relação física entre as duas comunidades judaicas em Recife repete um padrão identificado por Friesel (1990). Friesel se refere a um padrão de inserção e expansão dos assentamentos judaicos, que se repete no tecido velho da Europa como no tecido novo da América, variando em função de três categorias classificatórias: a implantação de uma comunidade nova; a existência de uma comunidade instalada desde a Idade Média ou Moderna e que se expande ou cria novos núcleos; ou a existência de uma comunidade judaica anteriormente instalada e sem continuidade. Nesse caso, uma segunda comunidade tende a se instalar na margem oposta ao rio, como se constata em Recife.

\subsection{Morfologia urbana}

Estrangeiros, fugitivos de perseguições racistas e religiosas, os imigrantes judeus encontraram em parte da Boa Vista um traçado urbano que lhes era adequado. As quadras, circundadas por elementos edificados, mantinham pátios internos livres. Aí era possível realizar as celebrações coletivas judaicas, diferentes dos rituais católicos a que estava acostumada a população recifense, sem que se expusessem os judeus à curiosidade ou interferências de outro tipo. Essa mesma morfologia de quadras permitia, na realização das atividades cotidianas, que se estabelecesse um tipo de relação interpessoal em Recife semelhante à do shtetl. Vários são os relatos sobre quintais compartilhados, sobre muros intencionalmente demolidos para permitir a proximidade entre vizinhos.
Apesar de segregada da malha urbana por barreiras naturais, essa parte da Boa Vista era próxima ao mercado consumidor dos prestamistas ou mascates, ocupação frequente entre os recém-imigrados.

\subsection{A implantação das estruturas simbólicas}

Em seu livro Imigrantes Judeus, Escritores Brasileiros, Regina Igel (1997) dedica um vasto capítulo às Memórias do Espaço Urbano. Vários escritores por ela estudados relatam o processo de apropriação do espaço urbano e de construção de um modo judeu de viver no Brasil. Citam a chegada de novos patrícios, a implantação das sinagogas, das primeiras salas de aula, da construção das escolas, da coleta de fundos para as campanhas diversas. Tânia Kaufman (2000) apresenta relatos de judeus imigrantes no Recife com referências semelhantes.

É a partir da instalação dessas estruturas simbólicas que se constrói o lugar judeu em Recife. Ou, como diz Geiger (1988), "chegando a novos lugares, a judeidade imprime sua marca nos territórios”. Dentro de um polígono com pouco mais de 35 hectares, foram-se instalando as instituições e as residências, num processo inominado mas como que intencional de dar densidade judaica ao lugar.

Atividades religiosas e educacionais ocupavam o mesmo espaço físico nos momentos iniciais da comunidade. As sinagogas se multiplicaram e se fizeram distintas entre sefaradim e ashkenazim. A escola mudou-se várias vezes para comportar o número crescente de alunos. Cerca de 15 entidades culturais, sociais e esportivas se implantaram. Os grêmios e clubes de leitura se faziam presentes. Às entidades de ajuda mútua somaram-se as entidades juvenis e as sociedades femininas de serviço.

Uma lista dessas instituições indica, entre outros, o crescimento populacional e organizacional da comunidade judaica do Recife. Um mapa dessas instituições demonstra a apropriação do espaço. Com uma população inferior a 1000 pessoas, segundo dados pouco precisos e carentes de verificação do Censo de 1940 do IBGE, os judeus tornaram- se maioria naquela parte da Boa Vista. Ali "sentiam-se em casa" conforme significativos relatos. 


\subsection{Di idiche ghesheftn}

O processo de apropriação se coloca em sua expressão máxima na ocupação da Rua da Imperatriz, rua de maior integração do lugar judeu da Boa Vista. Antes rua de largos sobrados com uso residencial e pequeno uso comercial, a partir da chegada dos judeus tornou-se a Rua do Comércio. Em depoimento a Tânia Kaufman (2000), Tamara Jacobovits Grinfeld faz um minucioso relato de cada uma das lojas de judeus instaladas na Rua da Imperatriz e nas suas imediações para concluir que ali ficava Di Idiche Guesheftn ${ }^{7}$. Até o final dos anos 1970, quando da implantação dos shopping centers no Recife, a Rua da Imperatriz se mantinha hegemônica como a Rua do Comércio da Cidade.

\subsection{A Praça Maciel Pinheiro}

Igualmente importante é a ambiência da Praça Maciel Pinheiro, ponto final da Rua da Imperatriz e ponto de confluência das ruas onde se localizaram as residências das famílias judaicas. Ali se instalaram, simultaneamente ou em diferentes momentos dentro do horizonte temporal de 25 anos que estamos estudando, grandes e pequenas lojas comerciais, a escola, o clube, restaurantes e hospedarias para judeus, quitandas com alimentação kasher $^{8}$, consultórios médicos, escritórios de advocacia e contabilidade e prestadores de serviço diversos gerenciados ou direcionados para os usuários judeus.

Vários depoimentos de antigos moradores judeus e não judeus da Boa Vista realçam a importância da Praça Maciel Pinheiro para os judeus. Era ali que as mulheres se encontravam quando iam às compras, que os velhos tomavam sol enquanto discutiam "os destinos do mundo", que as crianças se encontravam depois da escola, era ali que os homens se reuniam depois do trabalho e antes dos ofícios religiosos. De um dos depoimentos extraímos o seguinte trecho:

Na Praça Maciel Pinheiro se juntava aquela gente estranha, diferente. Quando o comércio fechava e aqueles homens saíam das lojas, os meninos voltavam da escola, todo mundo junto a falar aquela língua

\footnotetext{
${ }_{8}^{7}$ O Comércio Judeu.

${ }^{8}$ Adequado às leis judaicas
}

diferente... Aquele povo que vendia roupas caras estava ali vestindo uma outra moda. (...) E quando se danavam a cantar, aí então, pronto. Eram legais, queriam ser amigos, falavam com a gente tentando dizer coisas em português. E que português! Só não chegasse perto deles quando era a hora do noticiário. Também, chegar perto prá que? A gente não entendia nada mesmo! E eles não desgrudavam do rádio para nada nessa hora. Ah, aquilo nem era Recife; parecia um outro lugar do mundo.

O depoimento de um desses judeus que se reunia, no final dos anos 1930, na Praça Maciel Pinheiro, faz referência aos mesmos fatos. Conclui, entretanto, com um sentido bastante diferente.

Era ali que a gente se encontrava. Era ali que a gente via que a comunidade estava viva e crescia reunida. Era ali que a gente sentia saudade, ficava feliz por ter conseguido fugir e chorava pelos que morriam lã longe. Ai ai ai, era na Praça Maciel Pinheiro que eu mais me sentia em casa. Quanto mais velho a gente fica, menina, mais saudade vai carregando dentro do peito. Sei que não dá para trazer de volta os que partiram, mas se pudesse eu restaurava alguma coisa, não sei bem o que, alguma coisa na Praça, na vida...

\subsection{A dispersão}

A partir de 1939, mais ou menos 25 anos depois da chegada dos primeiros contingentes de imigrantes, já inseridos social e economicamente na sociedade, os judeus se espalharam. Acompanharam a classe média e alta na ocupação do território da cidade do Recife. Dispersam-se, ao contrário da concentração inicialmente observada.

... Graças a esta dispersão interior, graças a esta vacuidade, inclusive no espaço do pensamento, conquistam a liberdade exterior. Lançamse no mundo da liberdade de movimentos e ganham a liberdade interna. \{...) Uma efervescência que os faz não se localizarem. É isto que o nazismo quer quebrar e reconcentrar ... o campo de concentração. (Medan, 1993, p.22)

\section{Perguntas recorrentes}

Essas constatações nos levam a algumas suposições e à formulação de novas hipóteses que direcionam outras etapas da pesquisa. 
Na primeira parte do trabalho, discutimos a existência de um modo judeu de uso e apropriação do espaço que se teria estruturado em decorrência da sua história e do seu conjunto de crenças, do formato de vida em diáspora, da existência de guetos, de shtetlech e do Pale ou Zona de Assentamento, nas tantas migrações e nas características das sociedades onde se inserem os judeus, carregando consigo a Torah e a Jerusalém virtual junto com o sentimento de migrar.

Referimo-nos à existência de bairros étnicos que expressam a cultura dos seus ocupantes, apontando a Boa Vista como evidência desse fenômeno ou, colocado de outra forma, como práticas sociais contêm ou desencadeiam expressões espaciais.

Para caracterizar o universo humano de que estamos tratando, fazemos a distinção dos momentos diversos da presença de judeus em Pernambuco - os marranos dos primórdios da colonização, os sefaradim que vieram com os holandeses e, finalmente, os ashkenazim do século XX.

Considerando a cidade como um discurso estruturado, buscamos ler nas ruas do Recife a história que elas podem contar. Analisamos a Boa Vista sob uma perspectiva morfológica, identificando no modo de inserção da comunidade judaica do Recife a concordância com certos padrões judeus de uso do espaço urbano. A morfologia das quadras e a relação do bairro da Boa Vista com o tecido da cidade podem ter condicionado a escolha do lugar.

A apropriação se evidencia com a densidade de ocupação, com a instalação do comércio judeu e com a transformação da paisagem exemplificada pela Praça Maciel Pinheiro. A inserção dos judeus na sociedade se comprova com a dispersão. Construído um lugar judeu no Recife, aparece o brasileiro que preserva sua identidade judaica.

\section{Referências bibliográficas}

ARENDT Hannah. As Origens do Totalitarismo - Antissemitismo, Instrumento do Poder; Uma Análise Dialética. $2^{\circ}$ edição brasileira, Rio de Janeiro, Editora Documentário, 1979.

BARTHES, Roland. 'Semiology and the Urban'. In GOTTDIENER, M. and LAGOPOULOS, A. The City and The Sign: An lntroduction to Urban Semiotics, New York, Columbia University Press, 1986.
BERGER Peter 8c LUCK_MANN, Thomas. The Social Construction of Reality - A Treatise in the Sociology of Knowledge. London, Penguin Books. 1991.

BLOOMFIELD, Sônia R. 'Eretz Yisroel: Território e Identidade Judaica', pp.47-61, in Revista Espaço e Cultura no. 6, UFRJ/NEPEC, Rio de Janeiro. 1994.

CASTRO, Josué. Fisiologia dos Tabus. 2 edição, Rio de Janeiro, Companhia Lithographica Ypiranga, 1954.

CERTEAU, Michel de. A Invenção do Cotidiano - artes de fazer. Petrópolis, Editora Vozes, 1994.

DANTAS, Ney Brito. Chaos in the Drawing Room: Image Making and Image Breaking in the Experience of Urban Regulation in Recife. Tese de Doutorado apresentada na Architectural Association School of Architecture, Open University, Londres, 1998, gentilmente cedida pelo autor.

EBAN, Abba. A História do Povo Judeu. Rio de Janeiro, Bloch Editores S.A., 1973

EINSTEIN, Stephen \& KUKOFF, Lydia. Every Person's Guide toJudaism. New York, UAHC Press, 1989.

FREUD, Sigmund. Totem e Tabu. In P edição Standard Brasileira das Obras Psicológicas Completas de Sigmund Freud, Rio de Janeiro, 1970.

FREYRE, Gilberto. Sobrados e Mucambos - Decadência do Patriarcado Rural e Desenvolvimento do Urbano. 2' edição, São Paulo, Livraria José Olympio Editora, 1951.

FRIDMAN, Fania e EARP, Fábio. 'Mascates Judeus no Rio de Janeiro'. Trabalho apresentado no III Encontro de Estudos Judaicos, ainda não publicado. Citação autorizada.

FRIESEL, Evyatar. Atlas of Modern Jewish History. Jerusalem, Carta - the Israel Map and Publishing Company Ltd., 1990.

GEIGER, Pedro Pinchas. 'O povo judeu e o espaço', pp.86-104 in Revista Território, n.5, Rio de Janeiro, LAGET/UFRJ/ Garamond, 1998. 
IGEL, Regina. Imigrantes Judeus, Escritores Brasileiros. São Paulo, Editora Perspectiva; Associação Universitária da Cultura Judaica; Banco Safra, 1997.

JOHNSON, Paul. História dos Judeus. Rio de Janeiro: Imago, 1987.

KAUfMAN, Tânia. Passos Perdidos, História Recuperada. A presença Judaica em Pernambuco. Recife, Editora Bagaço, 2000.

LYNCH, Kevin. La buena forma de la ciudad. Barcelona, Colección Arquitectura/Perspectivas, Editorial Gustavo Gili, 1985.

LYNCH, Kevin. L'Image de la Cité Paris, Bordas, 1976.

MEDAN, Allan. 'L'Espace Temps des Juifs'. In Espace et Societé, no.12, pp.9-29. Paris, 1993.

MENEZES, José Luiz Mota. Atlas Histórico Cartografico do Recife. Recife, FUNDAJ e Editora Massangana, 1988.

MEZAN, Renato. Caminhos do povo judeu. três volumes. São Paulo: Federação Israelita do Estado de São Paulo, departamento de publicações. 2' edição, 1982.

MIZRAHI, Rachel. Imigrantes judeus do Oriente Médio em São Paulo e no Rio de Janeiro. Tese de doutoramento. USP. 2000.

SANTOS, Milton. A NATUREZA DO ESPAÇO - Técnica e Tempo. Razão e Emoção. 2. Edição, São Paulo, HUCITEC, 1997.

SETTE, Mário. Arruar - História Pitoresca do Recife Antigo. y edição, Recife, Coleção Pernambucana, Volume XII, Governo do Estado de Pernambuco, Secretaria de Educação $e$ Cultura, 1978.

SZEKELY, Béla. El Antisemitismo. Su Historia - Su Sociologia - Su Psicologia. Buenos Aires: Editorial Claridad, 1940

TUAN, Yi-fu - Espaço e Lugar: a perspectiva da experiência. São Paulo. DIFEL, 1983.

VAUGHAN, L. The Jews in London 1695 6- 1895 . London, University College London, master's thesis. 1994 - gentilmente cedida pela autora.
VAUGHAN, L. Clustering, Segregation and the 'Ghetto': the spatialisation offewisk settlement in Manchester and Leeds in the 19th century, Ph.D. Thesis, University College London, 1999, gentilmente cedida pela autora.

VAUGHAN, L. \& PENN, A. The Jewish 'Ghetto' - Formation and Spatial Structure. Trabalho apresentado no Space Syntax Symposium, Atlanta, 2000, gentilmente cedido pela autora. 
Censo 2002: perfil da comunidade judaica do Rio

Daniel Sasson

\section{Introdução}

$\mathrm{M}$

uito se pergunta, quando o assunto é demografia judaica no Brasil, qual o número de judeus residentes em cada Estado ou cidade. $\mathrm{Na}$ verdade, muito se opina sem base científica, uma vez que os poucos dados disponíveis (aqueles obtidos a partir dos Censos Demográficos realizados pelo IBGE) são pouco explorados e pouco divulgados, além de muito questionados. Poucas também tem sido as iniciativas de realização de estudos com fontes primárias ou secundárias alternativas, tais como matrículas em escolas judaicas, óbitos e sepulta- mentos em cemitérios judaicos etc. Algumas comunidades no Brasil, entretanto, já realizaram trabalhos consistentes de pesquisas e recadastramentos.

A ideia de realizar um Censo Judaico no Rio de Janeiro, para suprir as carências de informação sobre a comunidade local não era nova. Em 2001, a Federação Israelita do Estado do Rio de Janeiro - FIERJ conseguiu viabilizar o projeto e deu início, em março daquele ano, à execução dos trabalhos. É importante salientar e reforçar que esta pesquisa só foi possível graças ao apoio financeiro do Fundo Comunitário (que contribuiu com cerca de $80 \%$ do orçamento total), do Bank Hapoalim (com os $20 \%$ restantes) e do Instituto de Tecnologia ORT (sem desembolso, mas responsável pela digitação e processa- mento dos questionários).

Sob a direção de Roberto Stryjer, a FIERJ montou uma equipe formada pelos seguintes técnicos: Daniel Sasson (coordenador do Censo, estatístico da Fundação CIDE - Governo do Estado do Rio de Janeiro), Mauro Sinder (economista do IBGE), Beatriz Kushnir (historiadora) e Elias Zebulun (analista de sistemas). A equipe contou ainda com duas consultoras, que não apenas acompanharam o planejamento e a execução da pesquisa, como participaram ativamente de todo o projeto, conferindo-lhe também a credibilidade necessária: Helena Lewin (socióloga e grande ativista comunitária) e Alicia Bercovich (demógrafa, coordenadora do Censo 2000 do IBGE).

\section{Antecedentes}

Como base de conhecimento para realização do Censo da Comunidade Judaica do Rio de Janeiro, partiu-se de uma análise prévia, realizada a partir dos dados do Censo Demográfico do IBGE de 1991. Alguns dados e conclusões sobre a realidade social e econômica da comunidade judaica do Rio de Janeiro podem ser destacados:

- $\quad$ Estabilização numérica da população judaica a partir da segunda metade do século XX. Alguns fatores podem explicar a estabilidade numérica experimentada pela comunidade fluminense desde 1950, um período em que a população brasileira cresceu $183 \%$ e a do Estado do Rio 174\%. Entre eles podemos citar:

1. Baixa fecundidade, isto é, as mulheres judias têm poucos filhos;

2. Alta mortalidade devido à estrutura etária, bastante envelhecida (característica das populações de países desenvolvidos);

3. Fim da imigração, os últimos fluxos significativos ocorreram na década de 50;

4. Emigração para outros estados (principalmente São Paulo) ou outros países (inclusive Israel);

5. Assimilação ou perda de identidade judaica.

- A população judaica recenseada foi de 26.192 pessoas. Entretanto, utilizando-se o conceito de população judaica estendida, ou seja, o número de pessoas que vivem em domicílios onde pelo menos uma das pessoas declarou-se judia, descontados os empregados domésticos, pensionistas e outros agregados, chegamos a um total de 33.783 pessoas. Dentre os quais 7.591 pessoas que não se declararam judias e vivem em domicílios onde pelo menos um dos moradores declarou-se judeu. Ainda, se considerarmos apenas

${ }^{1}$ Estatístico / IPLAN. 
a família nuclear, isto é, casal e filhos, a população passa de 24.772 para 31.607 pessoas, isto é, 6.835 cônjuges ou filhos não judeus.

- $\quad$ Alto nível de instrução - o número médio de anos de estudo entre a população judaica de 15 anos ou mais é de 12,3 anos. Na população fluminense é de apenas 6,3. Na faixa etária de 7 a 17 anos (correspondente aos Ensinos Fundamental e Médio), a frequência à escola é de $96,2 \%$, enquanto na população total é de $81,7 \%$. A taxa de alfabetização atinge $99,6 \%$ da população de 15 anos ou mais, enquanto no total da população do Estado é de $90,7 \%$.

- $\quad$ Alto nível de renda - além do rendimento mensal bastante superior à média estadual (13,4 salários mínimos, em média, contra 3,5) o alto padrão de vida pode ser observado nas informações sobre posse de bens. A comparação com a população total do Estado evidencia esta diferença: $80 \%$ dos domicílios onde pelo menos uma pessoa é judia são próprios (na população total são $68 \%$ ), $48 \%$ têm freezer (13\% na população total), $77 \%$ têm máquina de lavar roupa (28\% no total), $64 \%$ têm automóvel particular (26\% no total) e $94 \%$ têm pelo menos uma linha telefônica $(25 \%$ no total). Apesar desta situação, a comunidade possui famílias com situação econômica desfavorável. No conjunto da população judaica encontramos quase 900 famílias cuja renda mensal não atinge 2 salários mínimos, correspondendo a quase 3.000 pessoas. Cerca de 100 famílias não têm sequer geladeira em casa.

- Casamentos mistos - a partir dos dados originais do Censo de 1991, obtém-se estimativas sobre a ocorrência de casamentos mistos. Dos 8.149 casais encontrados na população judaica estendida, 3.181 (ou $39 \%$ ) eram mistos, isto é, um dos cônjuges era não judeu. A partir da informação sobre a idade da união é possível verificar como se intensificou a ocorrência de casamentos mistos ao longo do tempo. Dentre os casamentos realizados há mais de 25 anos, $18 \%$ são mistos. Mas entre os casamentos realizados a menos de 5 anos, dois terços são mistos (67\%).

Todos estes dados, entretanto, embora riquíssimos para uma análise socioeconômica e demográfica da população judaica, não fornecem muitas pistas sobre as questões culturais e religiosas da comunidade. Foi esta falta de dados específicos que motivou, de início, a realização deste Censo.

\section{Objetivo}

As diversas entidades judaicas do Rio de Janeiro desempenham suas inúmeras atividades em benefício da comunidade, envidando seus melhores esforços no sentido de atingir suas metas e objetivos. Estamos falando de programas assistenciais ou de integração social para pessoas necessitadas, captação de alunos para escolas judaicas, programações esportivas, culturais e recreativas nos clubes e sinagogas, entre outros. Sabe-se, porém, que a maior parte dessas iniciativas é realizada com base no conhecimento empírico e na abnegação dos dirigentes e ativistas comunitários, faltandolhes informações mais objetivas.

Desta forma, definiu-se como objetivo principal do Censo, obter informações de forma a permitir aos dirigentes a definição e o planejamento de metas e ações com base no pleno conhecimento da estrutura, das necessidades e dos costumes desta comunidade, tornando possível a elaboração de projetos para sua valorização, do ponto de vista socioeconômico, cultural e religioso.

Depreende-se, daí, que se pretende fortalecer e garantir a continuidade da comunidade judaica do Rio de Janeiro pelo fortalecimento de suas instituiçõos e, consequentemente, da própria FIERJ.

\section{Conceitos e outras definições prévias utilizados}

O principal conceito a ser discutido era a definição de judeu. A pesquisa não poderia ser realizada sem antes definir com precisão o sujeito de sua contagem. Várias eram as soluções possíveis:

1. Judeu é todo aquele que tem mãe judia. Neste caso não são considerados os filhos de casais mistos nos quais a esposa é não judia (mesmo que pratiquem o judaísmo), os convertidos ou os filhos de convertidas, mas são incluídos todos aqueles que, embora de mãe judia, abandonaram a religião ou adotaram outra;

2. Judeu é aquele que professa a religião, ou seja, aquele que segue alguns princípios mínimos e mantém as tradições que o conservam ligado ao judaísmo. Aqui, além da dificuldade de se definir quais seriam esses princípios mínimos, poderíamos estar excluindo aqueles que não seguem esses princípios mínimos, mas ainda assim se consideram judeus. 
3. Judeu é aquele ligado, de alguma forma, a uma entidade judaica. É claro que muitos judeus não são ligados formalmente a qualquer instituição judaica.

4. Judeu é aquele que se declara judeu. Neste caso são excluídos aqueles que, embora judeus por qualquer um dos critérios adotados, preferem, por algum motivo, não declarar sua religião.

O único levantamento de abrangência nacional que pesquisa a religião dos entrevistados é o Censo Demográfico do IBGE. Esse levantamento adota o quarto critério, ou seja, cada entrevistado declara sua religião. É também o critério mundialmente aceito para esse tipo de pesquisa, não só no que se refere à religião, mas também a cor, idade, ocupação, renda entre tantos outros.

Para efeito desta pesquisa utilizou-se como conceito de judeu o mais amplo possível, não se limitando aos conceitos estabelecidos acima. A ampliação do conceito leva a uma definição de judeu como sendo todo aquele que assim se considera ou assim é considerado pela sua comunidade ou pela sociedade envolvente. Para dar conta dessa abordagem, o questionário deveria incluir questões que permitissem a identificação dos aspectos que levam uma pessoa a se declarar judia (aspectos práticos, religiosos, culturais etc.). A formação do cadastro (como indicada abaixo) deveria permitir indicações do que seja uma pessoa ser considerada judia por sua comunidade.

A população-alvo da pesquisa foi então composta pelos judeus (como definido acima) e pelos não judeus residentes em domicílios onde residiam judeus, isto é, a população judaica estendida.

Para um outro conjunto de conceitos utilizados, tais como família (e as relações de parentesco), trabalho (incluindo ocupação principal, posição na ocupação, atividade), frequência à escola (e instrução), número de filhos, posse de bens, entre outros, foram utilizadas as definições adotadas pelo IBGE em suas pesquisas. Procurou-se, assim, em alguma medida, manter alguma comparação com os Censos Demográficos.

Quanto aos conceitos que envolviam aspectos religiosos, tais como acendimento de velas, alimentação kasher, seder de Pessach, origem ashkenazi ou sefaradi, cerimônias judaicas (Brit milá, Simchat Bat, Bar/Bat
Mitzvá), entre outros, considerou-se que o senso comum garantiria uma uniformidade dos critérios adotados pelos respondentes.

Outro aspecto importante era a data de referência da pesquisa, aquela a qual todas as informações deveriam estar referidas. Tendo em vista o extenso tempo de coleta e a dificuldade que a adoção de uma data acarretaria no caso do autopreenchimento, preferiu-se desconsiderar uma data específica, perdendo precisão das respostas, mas simplificando o entendimento das perguntas.

\section{Aspectos metodológicos}

Entendeu-se que a forma mais econômica e que permitiria exercer-se maior controle era o envio e devolução dos questionários pelo correio. Para isso, deveria ser elaborado um cadastro inicial, composto dos nomes constantes dos diversos cadastros das entidades federadas. Todas as principais entidades (isto é, as maiores) enviaram seus cadastros impressos ou em meio digital: todos os clubes e escolas, as principais sinagogas, o Fundo Comunitário, a própria FIERJ, entre outras.

A esses cadastros foram agregadas as indicações solicitadas através do próprio questionário enviado, na técnica conhecida como bola de neve (snow bali). Desta forma procurava-se incluir pessoas que não estivessem ligadas a nenhuma das entidades judaicas e, portanto, não cadastradas.

Muito se discutiu, na fase de planejamento, a possibilidade de não cadastrar todas as pessoas judias. Uma das hipóteses aceitas era de que todas as pessoas que se considerassem judias teriam, de alguma forma, algum tipo de contato com alguma entidade ou com alguma pessoa judia, não sendo razoável, portanto, que um judeu se mantivesse totalmente isolado de sua comunidade.

Na prática, ocorreram diversos problemas, alguns já previstos, outros só percebidos durante a execução do projeto:

1. nomes repetidos em diversos cadastros e, portanto, duplicados no cadastro único

2. nomes repetidos mas com endereços diferentes (seriam homônimos ou o endereço estava desatualizado?) 
3. pessoas da mesma família com endereços diferentes (qual o mais atualizado)

4. o nome da mesma pessoa com grafias diferentes (qual o correto?)

5. excessivo número de endereços errados (algo estimado em torno de $20 \%)$

6. grande número de pessoas falecidas constantes do cadastro

7. baixo número de indicações (dificultando a técnica snow bali)

Tais problemas foram decorrentes, principalmente da precariedade da maioria dos cadastros recebidos, a maioria deles bastante desatualizada.

A divulgação foi feita a partir dos veículos de comunicação da comunidade judaica, tanto os vinculados às entidades judaicas (programa de televisão, informativos institucionais etc.) quanto os independentes, no intuito de que toda a comunidade tomasse conhecimento e apoiasse a proposta e a realização do Censo. Também foram utilizados recursos como colocação de cartazes e distribuição de folhetos alusivos.

Um questionário preliminar foi elaborado a partir das discussões da equipe técnica. Partiu-se dos temas prioritários para coleta de dados (caracterização socioeconômica e demográfica, trabalho, instrução, identificação com o judaísmo), formulando-se as perguntas mínimas para alcance dos objetivos. Procurou-se simplificar os conceitos adotados e diminuir o número de questões inicialmente proposto em função da forma de coleta de dados (autopreenchimento).

Numa segunda etapa, o questionário foi encaminhado a todas as entidades judaicas para que formulassem suas críticas, sugestões ou comentários. Algumas alterações foram feitas em função dessas observações e uma reunião com representantes de todas as entidades foi convocada para validar o questionário final.

$\mathrm{O}$ teste da pesquisa foi feita em duas etapas. Na primeira, o questionário seria aplicado a 50 famílias. Uma parte delas escolhida aleatoriamente a partir do cadastro e a outra para pessoas conhecidas. Desta forma, esperava-se garantir o retorno de um número razoável de respostas. Também, parte dos questionários foi entregue em mãos, parte foi enviada pelo correio e parte endereçada para facilitar a devolução. Nesse teste constataram-se alguns problemas que puderam ser solucionados:

i. endereços errados entre as famílias sorteadas do cadastro;

ii.baixo número de respostas

iii. extravio de respostas enviadas pelo correio

O segundo teste, já com o questionário definitivo foi enviado a cerca de 420 famílias, entre dirigentes comunitários e sorteados do cadastro. Pretendia-se, desta vez, testar a receptividade da comunidade e o apoio que seria dado pelas entidades. Também foi enviado envelope para resposta selado e pré-endereçado. Novamente constatou-se um elevado número de endereços errados. Não se verificou, desta vez, extravio pelo correio. O número de respostas para este grupo foi bem superior à média geral: mais de $30 \%$.

De forma a facilitar ainda a devolução dos questionários e, principalmente, reduzir os custos da coleta, firmou-se um contrato com os Correios para a utilização do serviço de Carta Resposta. Adicionalmente, esse serviço reduz drasticamente a possibilidade de extravio das respostas, uma vez que não há distribuição (os questionários eram recolhidos na sede dos Correios).

Para o questionário final, as seguintes perguntas foram formuladas, dentro dos temas considerados:

\section{Questionário para a família}

Dados cadastrais da família

- Endereço residencial, Telefone, Número de pessoas residentes no domicílio. Pessoas residentes no domicílio (exceto empregados domésticos e seus familiares)

- $\quad$ Nome, Sexo, Data de nascimento.

Algumas informações socioeconômicas

- Condição de ocupação do imóvel onde reside (Próprio, Alugado, Cedido, Outro). 
- $\quad$ Propriedade de bens das pessoas residentes no domicílio (Automóveis, casa de veraneio, TV por assinatura, Computador).

- Número de banheiros na residência (exceto lavabos).

- $\quad$ Acesso à Internet.

- Dispõe de uma biblioteca em casa? Se sim, aproximadamente quantos volumes?

Observação dos costumes judaicos

- Nesta casa acendem-se velas no shabat, come-se kasher, faz-se seder de Pessach (na casa, ou na casa de parentes ou amigos)

- $\quad$ Pessoas residentes no domicílio que se mudaram do Estado do Rio de Janeiro a partir de 1970

- $\quad$ Nome, Sexo, Data de nascimento, Ano da partida, Destino, Se regressou, o ano. Pessoas judias ou famílias onde existam judeus (parentes, amigos, conhecidos ou vizinhos) que deveriam receber o questionário, mas não sabe se receberam

- $\quad$ Nome, Endereço, Telefone.

\section{Questionário individual}

Dados pessoais

(Cidade, Estado, País).

- Nome, Sexo, Data de nascimento, Local de nascimento

- $\quad$ Se não nasceu no município onde reside, o ano de chegada.

- Relação com o chefe da família (chefe, cônjuge, filho, enteado, pai/ mãe etc.).

- $\quad$ Estado conjugal.

Dados de educação

- Qual a situação ou formação escolar? (estudante em escola judaica - série; estudante em escola não judaica - série; estudante universitário - período e curso; não é mais estudante - grau de instrução e curso de nível superior).

- Conhecimento de línguas (Inglês, Francês, Espanhol, Alemão, Árabe, Hebraico, Iídiche, Ladino).

Dados de trabalho (Somente para pessoas de 15 anos ou mais)

- Trabalhou nos últimos 12 meses.

- Se está trabalhando atualmente, qual a posição na ocupação, qual a ocupação, cargo ou função atual, qual o setor de atividade.

- Se não está trabalhando indicar a situação ou ocupação atual (procurando trabalho, aposentado ou pensionista, vive de rendas, afazeres domésticos, estudante, sem ocupação). função desejada

- Se está procurando trabalho, qual a ocupação, cargo ou

Dados de fecundidade (Somente para mulheres de 15 anos ou mais)

- $\quad$ Número de filhos que teve, Número de filhos que estão vivos, Data de nascimento do último filho.

Identificação com o judaísmo

- $\quad$ Éjudeu?

- $\quad$ Quanto à mãe (sefaradi, ashkenazi, judia mas não sei ou outra origem, não judia).

- Quanto ao pai (sefaradi, ashkenazi, judeu mas não sei ou outra origem, não judeu)

Mitzvá).

- Cerimônias judaicas (Brit milá/ Simchat Bat, Bar/Bat

- Conhecimento dos preceitos religiosos.

- Conhecimento de história judaica.

- $\quad$ No Shabat, vai à sinagoga; Guarda o shabat.

- $\quad$ Em Yom Kipur, vai à sinagoga; Em Yom Kipur, jejua. 
- Lê jornais/ revistas da imprensa judaica. universitário.

Frequenta ou frequentou movimento juvenil e/ ou grupo

- Viagens a Israel (Shnat/ machon, tapuz, turismo/ família, negócios/ estudos, outras).

- Tem ou teve alguma atividade comunitária.

- Tem ou teve atividade político-partidária ou atividade político-partidária judaica.

Algumas questões não foram compreendidas pela população-alvo da pesquisa, em geral não familiarizada com este tipo de levantamento. Podemos citar como exemplo a dificuldade da resposta da ocupação principal (que é aquela em que o respondente obtém a maior parte de sua renda de trabalho) ou a seleção de duas opções excludentes como Aposentado ou Pensionista e Procurando trabalho.

Apesar da garantia de que as informações seriam sigilosas, muitas pessoas questionavam o porquê de se perguntar se possuía estes ou aqueles bens. Qual seria a utilidade de se saber o número de banheiros? Nesses dois casos, as informações solicitadas visavam substituir a informação sobre renda, frequentemente omitida ou respondida de forma não satisfatória. Estudos mostram que o número de banheiros é altamente correlacionado à renda, sendo um dado mais confiável e menos sigiloso e constrangedor para os respondentes.

O maior obstáculo para o pleno sucesso da pesquisa foi o desconhecimento da população. Observou-se que, de um modo geral, os esforços empreendidos para dar ampla publicidade ao projeto não foram suficientes para atingir toda a comunidade judaica. Por si só, este já seria um indicador de falta de integração da comunidade, uma vez que veículos de comunicação não atingem seus objetivos, a população não procura se informar sobre os eventos comunitários e as informações não circulam entre os círculos de conhecimento das pessoas.

Um endereço de e-mail (censocomunidade@yahoo.com.br) foi colocado à disposição da população judaica para esclarecimento de dúvidas, críticas, sugestões, solicitação de questionários etc. Dentre algumas dezenas de mensagens recebidas, destacamos duas, representativas do sentimento da população em relação ao Censo.

Fiquei realmente muito satisfeito ao ler a notícia (...) de que se inicia agora o censo da comunidade judaica do Rio de Janeiro. É chegada a hora! É um projeto fundamental para o nosso povo, deve ser feito com muita seriedade (...) e deve ser muito estimulado.

Prezados Srs.

Recebi seu pedido para preenchimento do formulário do censo. Não atenderei, porque sou radical- mente contra a iniciativa. Graças ao censo, os nazistas conseguiram arrebanhar as comunidades judaicas e enviá-las aos campos de concentração.

A qualidade do preenchimento dos questionários foi, de certa forma, dentro das expectativas para uma pesquisa em que se utilizou um questionário extenso, com conceitos sutis (apesar das tentativas em contrário), aparentemente extenso, aplicado a uma população com boa participação de idosos e estrangeiros. Ou seja, muitas dificuldades foram encontradas, algumas questões foram sistematicamente mal respondidas (as referentes ao trabalho, por exemplo) ou desconsideradas. Assim, algumas questões serão de pouca utilidade para análises mais elaboradas, em que se exigiria uma precisão maior.

\section{Alguns resultados e conclusões preliminares}

Foram remetidos (através do correio ou entrega domiciliar) cerca de 11.800 questionários (já incluindo parte destes como reenvio em função da constatação de endereço errado ou extravio). Destes, foram preenchidos e devolvidos 1.220 questionários, compreendendo pouco mais de 3.250 pessoas. Para uma relação mais precisa do percentual de respostas é necessário desconsiderar pelo menos $20 \%$ de questionários que não atingiram seu destino. Assim, o percentual de respostas foi próximo dos $13 \%$. Este retorno é bastante aquém do esperado para um Censo, mas dentro das expectativas de pesquisas desta natureza (voluntário e com autopreenchimento).

O início da análise dos dados obtidos permite alguns comentários, ainda bastante superficiais: 
- A distribuição espacial pela cidade do Rio de Janeiro parece não ter se alterado significativamente, a não ser pelo expressivo número de moradores na Barra da Tijuca (acompanhando a tendência de toda população carioca): $30 \%$ dos questionários respondidos vieram de Copacabana, $12 \%$ da Tijuca, $11 \%$ de Ipanema, vindo na sequência Leblon, Flamengo, Botafogo e Barra. Dentre estes bairros, porém, Copacabana e Flamengo apresentam o menor número de pessoas por domicílio (cerca de 2,5 em média) e a Barra o maior $(3,2)$, podendo indicar o deslocamento de famílias com mais jovens.

- $\quad$ Dentre as pessoas que responderam ao questionário, 91,9\% declararam-se judias, 6,6\% não judias e 1,6 não declararam sua religião. Este percentual de não judeus é bastante inferior aos cerca de $25 \%$ encontrados no Censo do IBGE de 1991, o que nos leva a crer (já identificando um viés nos questionários recebidos) que responderam a pesquisa da FIERJ, preferencialmente, as famílias com poucos casamentos mistos e, talvez, mais identificadas com o judaísmo e preocupadas com os rumos da comunidade.

- Dentre os judeus podemos estabelecer a seguinte classificação quanto à origem judaica dos pais: $89,1 \%$ de pai e mãe judeus; 4,2\% de mãe judia e pai não judeu; $3,2 \%$ de pai judeu e mãe não judia; $1,9 \%$ de pai e mãe não judeus; os restantes $1,6 \%$ não declararam origem do pai ou da mãe. Podemos ainda classificar em ashkenazim 59,9\% (pai e mãe ashkenazim), sefaradim $15,6 \%$ (pai e mãe sefaradim), outras formas, $22,6 \%$ (pai e mãe de origens diferentes, necessitando de estudos mais aprofundados para estabelecer uma classificação adequada) e 1,9\% convertidos (pai e mãe não judeus).

- $\quad$ Cerca de $77 \%$ dos jovens judeus em idade escolar (Ensinos Fundamental e Médio) que responderam ao Censo declararam estudar em escola judaica. É bom lembrar que embora este percentual seja relativamente alto, o número absoluto de judeus em idade escolar tem diminuído nos últimos tempos e as escolas de nossa comunidade têm sofrido bastante com esta situação. A estratégia dos últimos anos tem sido a fusão de escolas visando otimizar a infraestrutura existente. Um estudo mais aprofundado dos números obtidos pode vir a mostrar que não há mais um "mercado" muito grande para o crescimento do número de alunos e o fortalecimento isolado de alguma escola pode significar o enfraquecimento de outra.
Os pontos relacionados para uma análise bastante inicial não incluem todos os temas levantados e ainda não consideram nenhum tipo de avaliação de consistência ou crítica à representatividade dos resultados e foram destacados apenas para dar uma mostra de possíveis estudos a serem aprofundados pelos pesquisadores interessados nas questões judaicas. Os dados estão colocados à disposição, resguardados os aspectos que garantam o sigilo das informações individuais. 


\section{Atividade judaica na visão ampla do terceiro setor}

\section{Edda Bergmann ${ }^{1}$}

A'nai B'rith é a maior entidade judaica internacional de Direitos Humanos. Existe há 157 anos e atua em 58 países, tendo assento na ONU e em vários organismos internacionais das áreas cultural, assistencial e política. todos.

Tem lutado por um mundo melhor, mais equitativo e mais justo para

A B'nai B'rith do Brasil visa promover o desenvolvimento humano, cultural, social e solidário em nosso país.

Criada sob a égide das ideias democráticas de liberdade, surgiu no Brasil quando os cerceamentos do individual e do coletivo, as ameaças à vida e à sobrevivência do judaísmo se acirraram na Europa com o advento do nazismo na Alemanha e o início da ascensão política de Adolf Hitler ao poder em 1931, e quando as perspectivas sombrias de uma II Guerra Mundial toldavam o horizonte.

O resgate de sua história é algo muito importante para as novas gerações.

Procurou salvar vidas humanas e salvaguardou princípios éticos, morais e religiosos de um mundo em chamas que desmoronava, ajudando na formação das principais entidades judaicas brasileiras.

Nasce com vocação para a modernidade e formação da cidadania participativa.

É nessa direção que ela tem se organizado. A partir do conhecimento da nossa realidade socioeconômica, cultural e política tem orientado sua dinâmica de atuação acompanhada de um contínuo desenvolvimento e aprimoramento.

Deve ser um marco na construção da democracia brasileira, na formação de uma inteligência criativa e na integração entre a comunidade judaica brasileira e a sociedade ampla.

\footnotetext{
${ }^{1}$ Doutora em História / B'nai B'rith do Brasil.
}

Viabiliza parcerias com outros setores desta mesma sociedade e para isso aperfeiçoa constantemente sua capacitação com mecanismos de mobilização de pessoal e de infraestrutura para prestação de serviços com técnicas de aprimoramento.

Promove, através de suas Lojas e grupos de atuação, o acesso ao conhecimento e à capacitação.

A área de Direitos Humanos é o centro e o polo orientador de análises, articulações e ações bem como de aconselhamento e de atuação política não partidária.

Desenvolve-se na luta incessante contra a discriminação, o racismo, e o cerceamento de direitos a quem quer que seja.

Mobiliza-se contra a pobreza, o descalabro social, as diferenças inaceitáveis, a miséria, a fome, a falta de acesso aos bens da civilização e do conhecimento, às necessidades básicas, enfim, de um ser humano completo e aos seus plenos direitos de cidadão feliz e realizado no desenrolar da sua vida no planeta terra.

Os direitos da criança, do adolescente, do idoso, do deficiente, do incapacitado, constituem uma de suas preocupações básicas.

A saúde mental e física, o desenvolvimento harmonioso no crescimento individualizado do ser humano rumo a um destino menos cruel e a uma vida digna faz da valorização dos fatores individuais e coletivos um dos seus pilares de atuação em prol da vivência completa e saudável, promovendo o acesso aos bens culturais.

$\mathrm{Na}$ consolidação de sua autonomia como entidade não governamental sem fins lucrativos, está capacitada para conseguir recursos através de esforços coordenados de um planejamento capaz de manter o elevado padrão de qualidade de sua atuação diversificada.

À entidade compete também divulgar o potencial cultural e moral judaicos e desenvolver uma imagem positiva do judeu e do judaísmo, de seus valores éticos e morais, sua solidariedade como cidadão consciente de seus deveres e de sua atuação participativa, de sua colaboração em compasso com o mundo e como parte integrante deste mesmo mundo. 
A fraternidade é um dos pontos mais fortes da instituição e sua área de ação alcança a todos.

A B'nai B'rith escolheu como símbolo o Candelabro de 7 braços, a Menorah, o mais antigo símbolo judaico. Cunhada por Bezalel durante a travessia do Exxodo no deserto acompanhou a Arca Santa em todas as suas andanças. Levada pelo rei Salomão ao Templo de Jerusalém, hoje existe um exemplar em cada sinagoga.

Quando da $1^{\text {a }}$ estada do Papa João Paulo II no Brasil entregamos-lhe como símbolo do convívio entre as religiões um exemplar de prata criado pelo arquiteto Lívio Levi, e a Dra. Zilda Arns, ao receber a medalha de Direitos Humanos da B'nai B'rith brasileira, em fins de 1999, recebeu também uma Menorá como marco do reconhecimento pelo seu imenso trabalho em prol da vida, da justiça e contra o descalabro da elevada taxa de mortalidade infantil.

A Menorá simboliza a luz e a vida. Quando uma mulher dá à luz, dá a vida a um novo ser humano. Seus 7 braços representam: Luz, Justiça, Paz, Verdade, Beneficência, Fraternidade e Harmonia, preceitos estes que indicam opções e valores a serem defendidos e trabalhados em prol da humanidade em geral e do ser humano em particular.

A B'nai B'rith brasileira desde os seus primórdios atuou na área de Direitos Humanos, tanto no sentido do resgate de vidas humanas oprimidas pelas ditaduras, quanto na área de solidariedade e auxílio às carências de pessoas necessitadas, refugiadas, a fim de reintegrá-las no processo produtivo e na vida atuante do dia-a-dia.

Assim é que criou a Gota de Leite B'nai B'rith, que se transformou pela união com outros grupos de trabalho no que é hoje a Unibes, entidade modelo na área de serviço social, que atua em parceria, inclusive, com a Comunidade Solidária e que acaba de receber o prêmio de "Bem Eficiente" da Fundação Kanitz \& Associados S.A.

Ao completar 70 anos de existência no Brasil, podemos dizer que a entidade sempre atuou na defesa da democracia, de uma democracia compartilhada e vivida dentro do âmbito de respeito à pessoa humana, ao seu desenvolvimento e adequação.
Na promoção da cidadania, da solidariedade e de valores e princípios enaltecedores do indivíduo e de sua inserção na sociedade ampla, na visão de que a exclusão e a marginalização não promovem a existência de uma sociedade justa e equitativa.

Há 18 anos promove um programa em escolas da periferia de São Paulo, visando sanar e detectar problemas de visão, buscando a adequação da criança ao desenvolvimento e sua capacitação ao estudo, através de consultas de oftalmologistas, da distribuição de óculos, quando necessário e de cirurgias de recuperação da visão.

Tem atendido a mais de 22.000 crianças e continua atuando neste setor, partindo da premissa de que a saúde integral é um direito da criança e que o estudo e o aproveitamento do ensino não é plausível sem uma visão completa.

A distribuição de material escolar em escolas que dele necessitam para adequação do ensino, com distribuição regular de kits de material individual para cada criança, o que, geralmente, os pais não podem fazer com seus poucos recursos, que mal dão para o sustento alimentar da família.

A montagem de bibliotecas escolares infanto-juvenis para incentivo à leitura e ao desenvolvimento integrado da criança e do jovem, tão atingidos pela disseminação da violência e dos programas negativos da televisão, promovendo o contato com valores uni- versais, com o desenvolvimento do sonho, do belo e dos anseios que não fazem parte de suas vidas sofridas e mal-adequadas à uma sobrevivência difícil; também é preciso poder e saber sonhar para algum dia conseguir transformar estes sonhos em realidade.

Numa tentativa de não marginalizar o adolescente da periferia da cidade grande tão atingida pelos desvios comportamentais das gangues e das drogas.

A montagem de brinquedotecas infantis em hospitais como a Santa Casa de São Paulo, onde a criança internada se recupera mais facilmente ao poder utilizar brinquedos que desenvolvam sua criatividade e vontade de sarar e de viver uma vida feliz.

Brinquedotecas em pronto-socorro infantil, onde a criança também permanece, às vezes por tempo prolongado, lutando pela sobrevivência em ambientes muito deprimentes e desencorajadores. O incentivo à recuperação mais rápida e mais eficiente. 
Quanto vale o sorriso de uma criança? A montagem de brinquedoteca infantil em cadeia pública de mulheres, onde os pequenos compartilham das celas com as mães detentas num ambiente terrivelmente negativo para o desenvolvimento infantil rumo a uma vida adequada e nos moldes de convivência normal. Experiência em Porto Alegre.

A distribuição de leite para recém-nascidos, cujas mães, portadoras de AIDS, não podem e não devem amamentar a criança, com risco de tornála infectada por essa doença incurável.

Através de uma campanha bem estruturada e completa, a entidade promoveu um estudo em relação às carências do interior do Ceará e chegou à conclusão que a mortalidade infantil aumentava no período das águas, ou seja, era maior em época de chuva que em época de seca.

Ao verificar as causas, percebeu-se que, apesar da água clorada e desinfetada dentro dos potes de barro, a inserção de uma caneca ou de uma concha com a mão suja e de objetos não adequados em termos de limpeza, contaminava a água para beber e o pote aberto facilitava a criação de mosquitos portadores do dengue.

Foi assim que a B'nai B'rith do Brasil se engajou numa campanha chamada das Torneirinhas e forneceu 250.000 torneirinhas que foram instaladas nos potes de barro das famílias interioranas em grande número de municípios do Ceará. E acompanhando o trabalho foi possível verificar o grande decréscimo na taxa da mortalidade infantil e na propagação da Dengue.

A entidade tem ajudado a fundação dos cegos, inclusive importando de Israel há alguns anos a primeira máquina de escrever para as pessoas carentes de visão.

Ajuda o hospital do Câncer em várias ocasiões, inclusive no momento, com a doação de lençóis e fronhas.

Doações em espécie e serviços para entidades que distribuem alimentos em quentinhas para a população carente.

Apoio e doações continuadas a orfanatos e adequação às suas necessidades de sobrevivência, para superar a crise econômica que o país enfrenta. Realiza campanha dos agasalhos, cobertores e mantimentos, sempre que necessário, para vítimas de enchentes, desabrigados ou calamidades públicas.
O quanto vale uma amizade?

\section{Realmente não tem preço!}

Partindo desta premissa, a B'nai B'rith mantém e desenvolve há muitos anos a Tarde da Amizade para pessoas idosas, em tardes recreativas e de convívio social em ambiente especialmente preparado para um gostoso chá completo, com atividade cultural e social.

Mantém ainda e desenvolve um excelente coral, que proporciona satisfação e atualização musical a seus integrantes e satisfação plena à entidade.

A B'nai B'rith do Brasil tem uma Editora, que publica uma revista trimestral de altíssimo nível e a distribui por todos os rincões deste imenso Brasil.

Entidade composta por voluntários, que dedicam e desenvolvem seus esforços de atuação em tudo o que foi relatado acima em termos de Brasil, e que está estruturada nas cidades de São Paulo, Rio de Janeiro, Curitiba, Porto Alegre e Campinas, como polos principais, mantendo contato com Brasília e Belém.

Em suas ligações internacionais se ocupa com o Bem Estar do Menor, a capacitação do jovem para o mercado de trabalho, a melhora no desenvolvimento da infância e nos programas de desenvolvimento sustentável que não firam o ecossistema do planeta Terra.

Acompanha o desenvolvimento científico na erradicação de doenças e no exercício pleno dos direitos individuais e coletivos.

Luta pelo entendimento entre os povos e as nações e pela compreensão plena e o desenvolvimento de amizade recíproca entre as religiões em termos de diálogo inter-religioso em alto nível sem premissas conversionistas e discriminatórias.

Atua no conselho de Fraternidade Cristão Judaico, do qual é uma das fundadoras e na Comissão do Diálogo Católico Judaico da CNBB.

Acompanha os trabalhos do CLAI (Conselho Latino-Americano de Igrejas Evangélicas), do Conselho Mundial de Igrejas às andanças Vaticanas, desenvolve esforços rumo a uma identidade comum do ser humano perante a natureza e as origens de um mundo criado. 
Parte da premissa de que todos os homens são iguais, com iguais direitos e iguais deveres e de que a consciência é a maior dádiva divina que o ser humano possui.

Defende o direito a uma vida saudável, com educação e oportunidades de trabalho, de realização pessoal, de desenvolvimento de aptidões.

A Alimentação Alternativa, programa de preparação de alimentos ricos em proteínas e sais minerais, elaborados de forma simples com as partes das verduras, cascas e leguminosas geralmente desprezadas nas feiras livres, com a cabeça de peixe, a casca do ovo, a casca da banana, da batata e outras; numa apresentação agradável à vista e de paladar gostoso e até sofisticado.

Ensinando às mães das crianças das escolas e das creches e às mães carentes em geral, fazendo com que sua família se torne mais bem alimentada, a baixo custo financeiro.

Este programa entra no espírito do desenvolvido pela pastoral da criança, sob a exímia e competente batuta da Dra. Zilda Arns.

Empreendeu também a entidade um Programa de Combate ao uso de Drogas para crianças e adolescentes, que chegou a ser um empreendimento em parceria com o governo em Curitiba, Campinas e teve grande repercussão em São Paulo.

Trata-se de um preparo para os pais se comunicarem melhor na abordagem de seus filhos e dialogar com eles de maneira franca e aberta sobre os perigos da utilização de drogas e entorpecentes, que geralmente lhes são oferecidos por colegas da mesma faixa etária, pessoas que às vezes até convivem com eles, ou por influências de envolvidos com o vício.

Nada é melhor do que o diálogo entre pais e filhos em ambiente de amor e carinho, com firmeza, de maneira clara e sem subterfúgios.

A melhor forma de querer bem a seus filhos é adverti-los a tempo, antes que seja tarde demais.

A B'nai B'rith do Rio de Janeiro tem em andamento um belíssimo projeto chamado Voluntários da Aliança. Convém lembrar que o nome da entidade significa Filhos da Aliança; da primeira Aliança feita por Abrão com Deus de seguir os preceitos de um Monoteísmo Ético e Absoluto.
É o surgimento da ideia da existência de um Deus único e igual para todos.

E o pacto de Abrão com Deus de se transformar no pai de um grande povo e numa benção para a humanidade inteira.

O judaísmo é teocrático, mas não é teocêntrico, ou seja, coloca Deus e o Homem numa mesma linha de relacionamento, no sentido de que o ser humano é participe na Criação. O mundo não foi criado perfeito. Cabe ao homem aperfeiçoá-lo, a cada um de nós, em separado e em conjunto.

Esta é a Base Ética e Moral do termo:

- Direitos Humanos: compete a cada um zelar por eles e ser o guardião, para que todos possam promovê-los, utilizá-los e usufruí-los.

O ser humano também não foi criado perfeito, e é na ajuda mútua, na transmissão de conhecimentos, na capacitação e no desenvolvimento de aptidões inatas, na adequação a interesses adquiridos, no desenvolvimento de atividades construtivas, na complementação e na criação de motivações, na convivência e na solidariedade que ele deve se aperfeiçoar.

Os Voluntários da Aliança lidam com a constituição de cooperativas, microcrédito, banco de empregos, capacitação e recapacitação profissional, atendimento médico gratuito a famílias que não conseguem mais pagar os planos de saúde e outras áreas congêneres.

Neste sentido, atua também a B'nai B'rith Latino-americana nos países que abrange, com muito afinco, dedicação e resultados positivos.

A organização se compõe de voluntários, tendo iniciado com voluntários do sexo masculino, conta hoje principalmente com a participação de casais, ou com trabalho de pessoas de ambos os sexos.

Participando, através de sua área específica de Direitos Humanos, da elaboração da Constituição Brasileira em vigor, no que tange aos direitos das minorias e à área de combate ao racismo e à discriminação em seu sentido abrangente.

Esteve atuante e participativa na elaboração de todas as leis que se referem a esta área tão importante dos direitos do cidadão, como na le "Afonso Arinos", na lei "Ibsen Pinheiro", na lei “Alberto Goldman”, e na lei 
"Paulo Paim", que é um exemplo claro e inequívoco para muitos outros países do mundo.

Foi uma honra para nós ter recebido em nossa sede nacional o nobre Deputado Paulo Paim para receber uma homenagem e nos apresentar detalhes da lei que leva o seu nome e que é um exemplo de respeito à cidadania plena $\mathrm{e}$ participativa dos direitos do indivíduo na sociedade brasileira.

A B'nai B'rith entrega de dois em dois anos, em sua Convenção Nacional, uma medalha de Direitos Humanos à personalidades nacionais que se destacaram em atuação nesta área, em cerimônia pública sempre muito concorrida e prestigiada, sendo que o nome da pessoa a ser agraciada é escolhido por votação em pré-convenção na qual participam Irmãos e Irmãs de todo o Brasil.

O combate ao neonazismo e a suas premissas discriminatórias contra judeus, negros, estrangeiros e outros grupos é prioritário, bem como a defesa do direito à liberdade de expressão e de participação do indivíduo nos destinos do país, dentro de um regime de estabilidade democrática, de respeito pela opinião do outro e do direito de ser diferente, de pensar de forma diferenciada e de atuar dentro dos seus princípios da vida.

A liberdade de pensamento e a liberdade religiosa são pontos intocáveis dos princípios defendidos pela organização no Brasil e no mundo.

Participamos de forma atuante da Eco 92, no Rio de Janeiro, na qual a B'nai B'rith brasileira representou o Board of Jewish Organizations.

Assuntos como os direitos da mulher, no Fórum do Flamengo, o entrosamento das religiões junto ao Dalai Lama, a apresentação da experiência dos princípios da alimentação alternativa para as representantes dos países africanos, mereceram todo o nosso empenho.

A agenda 21 da defesa do Ecossistema, a preocupação com um desenvolvimento sustentável, com a sobrevivência de uma vida saudável no Planeta Terra.

A preocupação com a natureza, com a despoluição e o abastecimento de água para todos os povos, o direito à erradicação de doenças, fizeram parte das temáticas abordadas.
A B'nai B'rith promove simpósios, cursos, palestras nas mais variadas áreas do conhecimento e, através de debates, procura envolver várias faixas etárias numa atualização constante e no desenvolvimento de interesses os mais variados e abrangentes.

Esta é a B'nai B'rith que nós vivenciamos no dia-a-dia, a cada hora e a cada minuto. Uma organização a serviço do mundo. 


\section{Capítulo}

\section{O DiÁlogo INTER-RELIGIOSO: UMA VIA DE MÃo DUPLA}

Eu e tu: diálogo plural

\section{Hélio Albuquerque ${ }^{1}$}

$\mathrm{N}$

o mundo globalizado de hoje, a interdependência entre os povos e as nações é uma realidade evidente e palpável. Hoje, nenhum povo, nenhuma nação vive isolada.

Nessa grande sociedade humana inter-relacional se dá uma forte tensão entre participar da convivência com o outro, por um lado, e, por outro, manter a própria identidade. É uma tensão entre o "Eu" e o "Tu": "eu" preciso me relacionar, mas mantendo a minha própria identidade, enquanto devo esperar, sinceramente, que o outro deseje e precise manter e expressar a própria identidade.

Existe nesse inter-relacionamento humano a possibilidade da ocorrência de duas posições limites: de um lado a intolerância, que pode levar à guerra; de outro, o diálogo, que tende a levar à paz. Na intolerância, dá-se a tentativa de impor ao outro a própria identidade ou de a defender diante do outro.

O diálogo tem sido identificado pelo espírito humano como o melhor caminho para levar à paz e à convivência fraterna entre os povos. Prova disso foi a proclamação, pela ONU, do ano de 2001 como "O Ano Internacional do Diálogo entre as civilizações".

No que tange a essa paz tão desejada pelos povos, mormente no momento atual em que a violência irrompe por toda a parte, vem ao caso a tese defendi- da, há alguns anos, por um teólogo católico, o Pe. Huns Kung,

\footnotetext{
${ }^{1}$ Doutorando em Teologia / PUC-RJ.
}

no sentido de que não haveria paz no mundo sem uma paz entre as religiões ${ }^{2}$. Por isso, H. Kung defende a necessidade de uma ética - para além da doutrina filosófica e religiosa - sobre os valores e as normas que devem orientar as nossas decisões e ações; isto porque a convivência humana não subsiste sem o mínimo que seja de um consenso fundamental, no que tange a valores, normas e posturas que tornem possível a existência de uma comunhão maior e de uma convivência melhor ${ }^{3}$. Huns Kung lembra que a tese histórico-cultural, defendida há poucas décadas, de que a religião estaria no fim ou em extinção, evidencia-se como falsa: nem a humanidade ateísta de Feuerbach, nem o socialismo ateísta de Marx e tampouco a ciência ateísta de Freud ou Russell conseguiram substituir a religião. Hoje, ao contrário, fala-se antes em uma era pós-ideologias do que em uma era pós-religiosa ${ }^{4}$. As religiões, portanto, não podem ser consideradas como algo do passado, mas sim como realidades psíquica e socialmente vivas. Por sinal, isto se constitui em uma característica fundamental da pós-modernidade ${ }^{5}$.

E esse diálogo inter-religioso, indispensável para a promoção da paz, não pode ser solto, ou seja, sem o embasamento normativo da própria religião: não se pode entrar no diálogo abdicando-se da própria fé, nem

${ }^{2}$ H. Kung se embasa nas conclusões da Conferência Mundial das Religiões em Favor da Paz, realizada em Quioto, no Japão, em 1970, que expressou o que poderia ser uma "ética das religiões mundiais a serviço da sociedade mundial", mediante alguns pontos que a pregação das diversas religiões têm em comum. São eles: "a convicção acerca da unidade fundamental da família humana, da igualdade e da dignidade de todas as pessoas": "uma sensibilidade para a inviolabilidade do indivíduo e de sua consciência; um sentimento para o valor da comunidade humana"; "o conhecimento de que poder não é idêntico a direito, que o poder humano não pode se satisfazer consigo mesmo e que não é absoluto"; "a fé de que o amor, a compaixão, o desprendimento e a força do espírito e da veracidade interna, em último caso, têm mais poder do que o ódio, a inimizade e o interesse próprio"; " sensibilidade para a responsabilidade, para estar do lado dos pobres e oprimidos contra os ricos e os opressores"; e, por Ultimo, "a profunda esperança de que, por fim, a boa vontade há de vencer" (cf. Cf. H. Küng, Projekt Weltetbos, Munchen, 1990; tradução portuguesa: Projeto de Ética Mundial, São Paulo, Paulinas, 19982, pp. 94-95.108).

${ }^{3}$ Esse consenso fundamental mínimo supõe algumas regras: 1) "a paz interna, que pressupõe a concordância de que se pode resolver conflitos sociais de uma forma não violenta"; 2 ) "uma ordem econômica e uma ordem jurídica, que pressupõem a concordância no desejo de orientar-se por determinadas ordenanças e leis"; e 3) "instituições que sustentem estas ordens, que pressupõem o desejo de, pelo menos silenciosamente, concordar sempre de novo com elas, apesar de suas constantes transformações" (cf. H. Küng, Op. cit., pp. 48-49).

${ }^{4}$ Cf. ibid., p. 70

${ }^{5}$ Ibid., p. 73. 
mesmo à guisa de respeito pela posição do outro. É preciso antes esperar que o outro, por princípio, considere o seu caminho como um caminho igualmente válido. É preciso haver, de forma dinâmica, uma firmeza de posição, mas em uma atitude de abertura: o diálogo não se destina a destruir a fé que se tem, mas a enriquecê-la. A disposição para o diálogo precisa ser, de fato, autêntica disposição para a paz. Desta forma, as religiões não podem ser omissas no seu papel singular de promotoras da paz.

No mês de outubro de 1999, realizou-se no Vaticano uma Assembleia inter-religiosa, que fez parte das preparações para a abertura do Grande Jubileu do Ano 2000. Essa Assembleia contou com a participação de cerca de 200 representantes de umas 20 tradições religiosas, provenientes de 21 países. Na Mensagem final, os participantes apontaram a educação como a chave para promover a harmonia inter-religiosa, através do respeito pelas diferentes tradições religiosas; afirmaram ainda a importância da educação para promover a compreensão, a cooperação e o respeito mútuo; e indicaram também os meios para tal educação: o apoio à família, a ajuda para a formação da consciência dos jovens, a difusão de uma informação objetiva sobre as religiões, sobretudo através dos livros de educação religiosa, a revisão dos manuais de ensino da História e, por fim, o respeito pelas religiões por parte dos meios de comunicação social, para que cada grupo se possa reconhecer na imagem que dele se projeta ${ }^{6}$.

No que tange ao caso particular do diálogo judeu-cristão, esses dois grupos, tendo por apoio os seus preceitos religiosos e morais, têm muito que oferecer ao mundo de hoje: Claude Geffré, pensador e teólogo francês, tem enfatizado que a dupla Israel-Igreja constitui uma realidade irredutível ${ }^{7}$. De fato, adoram o mesmo Deus, que professam Um e Único; os mandamentos judaicos e cristãos têm todo um apelo moral comum na conduta do homem diante de Deus, do seu semelhante e diante da obra da criação, do qual o homem é constituído como o administrador. $\mathrm{E}$ ainda judeus e cristãos não apenas podem promover um diálogo para a paz, como podem também anunciar ao mundo de hoje, o projeto original de Deus quanto à meta escatológico-salvífica, que aponta para o arremate desta história humana, com

${ }^{6}$ Cf. E Card. Arinze, O dever de todos é educar para o diálogo, em L'Osservatore Romano (port.), 30 de dezembro de 2000, 5 .

${ }^{7}$ Cf. C. Geffré, A fé na era do pluralismo religioso, em E Teixeira, Diálogo de pássaros, Nos caminhos do diálogo inter-religioso, São Paulo, Paulinas, 1993, pp. 61-74, aqui p. 64. uma promessa de vida eterna que transcende os umbrais da morte. Ou seja, este mundo não tem a última palavra sobre o destino final do homem; mas esta palavra está contida nas promessas reveladas por Deus àqueles homens e mulheres inspirados por Seu Espírito e que enchem de viva esperança a todos aqueles que dão uma resposta positiva aos ditames da Lei de Deus, inscritos no recôndito da consciência de cada qual.

O diálogo judaico-cristão em nosso país, em particular aqui no Rio de Janeiro, tem demonstrado possuir essa consciência da necessidade da educação para o diálogo, como meio de preparação para o empreendimento desse trabalho comum. Essa educação para o diálogo, diz respeito não somente às crianças e aos jovens como também aos adultos, pois essa aprendizagem precisa ser contínua.

É hora, pois, de judeus e cristãos, na superação de divisões e rupturas do passado, trabalharmos juntos, honrando, cada qual, a partir de sua própria expressão de fé, o chamado de Deus à construção daquele estado de paz e de justiça mais digno de quem anseia e espera pela concretização em plenitude do Reino de Deus. 


\section{Dabru Emet}

Leon Mayer ${ }^{1}$

$\mathrm{P}$ or seu significado no Dialogo Cristão Judaico, achei por bem, para uma melhor compreensão desta declaração que significa "Fale a verdade", declaração judaica sobre os cristãos e a cristandade, fazer um resumo de três trabalhos feitos por David Rosen, Rabino de Jerusalém, Diretor do American Jewish Committee para o Conselho Internacional para Cristãos e Judeus, Irving Greenberg, Rabino, Presidente da Jewish Life Network (JLN) e Victoria Barnett, da Christian Century (www.christiancentury.org).

A declaração foi preparada sob os auspícios do Baltimore Institute for Christian and Jewish Studies, que garantiu a sua americanocentricidade. Ela foi anunciada no New York Times e no Baltimore Sun, e, tendo em vista que o New York Times é a verdadeira Bíblia americana dos nossos dias, - a declaração foi largamente difundida e reconhecida.

No entanto, essa é apenas uma explicação parcial para o entusiasmo que a declaração provocou nos círculos cristãos, e não apenas nos Estados Unidos. Alguns de nós ficamos muito surpresos com a forte reação positiva. Embora eu próprio fosse um signatário da Dabru Emet (um dos poucos não americanos), não considerei o texto tão extraordinariamente importante. $\mathrm{Na}$ verdade, na minha opinião, as perspectivas judaicas na declaração do ICCJ Theology Committee, intitulada "judeus e cristãos em busca de uma base religiosa comum para contribuir para um mundo melhor", por exemplo, vão além de Dabru Emet. No entanto, essas picuinhas institucionais, ou questões sobre por que outras declarações não são tão bem conhecidas, não têm importância. O que é significativo é que Dabru Emet foi reconhecida, até em discursos públicos e artigos, por pessoas da estatura dos Cardeais Kaspar e Keeler, do erudito protestante Walter Bruegemann e do Arcebispo de Canterbury, George Carey, não apenas como um documento histórico, mas como o arauto de uma nova era nas relações judaico-cristãs.

\footnotetext{
${ }^{1}$ B'nai B'rith do Rio de Janeiro.
}

Com a publicação de "Dabru Emet", pela primeira vez em mais de 1.900 anos, importantes líderes do judaísmo e do cristianismo encontram-se face a face, vendo-se uns aos outros como servidores do mesmo Deus, até mesmo como membros de um povo que fez com Ele uma aliança, quaisquer que sejam as diferenças não resolvidas entre as duas comunidades de fé. A transformação religiosa, que deu origem a "uma declaração judaica sobre os cristãos e o cristianismo", é mentalmente perturbadora; suas raízes remontam a mais de dois milênios.

No entanto, o próprio processo do diálogo, com sua inerente comunicação de mão dupla, inevitavelmente levou a uma nova apreciação judaica dos pontos positivos do cristianismo. O testemunho pessoal, por exemplo. Atormentado pelo Holocausto, entrei no diálogo judaico-cristão para exigir que os cristãos parassem de espalhar o ódio contra os judeus, sob o pretexto de um Evangelho de Amor. Cheguei para repreender, mas sob o impacto de encontrar cristãos arrependi- dos, e ouvir seu testemunho religioso, fiquei para elogiar o cristianismo, por sua autopurificação exemplar e pela vitalidade de sua vida religiosa.

Agora temos "Uma declaração judaica sobre os cristãos e a cristandade", a mais positiva apreciação do cristianismo jamais feita por um grupo judaico. Ela afirma, inequivocamente, que os cristãos adoram o Deus de Israel e se baseiam legitimamente na Bíblia judaica - apesar de nossas contradições. A declaração confirma a ética cristã e elogia a possibilidade de uma parceria judaico-cristã, em prol da paz e da justiça. Ela avalia a culpa dos cristãos pelo Holocausto, mas separa corretamente o cristianismo do nazismo.

João Paulo II tinha expressado essa vontade de cooperar no diálogo desde do dia 16 de novembro de 1980, durante sua viagem a Osnabruck; que confirmou-se em Lyon, Sydney, Varsóvia, Los Angeles e Estrasburgo.

Foi em Estrasburgo, no dia 9 de novembro de 1988, que ele pronunciou, diante dos delegados da comunidade judaica, um discurso rico em substância preciosa: "Queremos cooperar com vocês, com o maior respeito pela identidade judaica e sem o menor traço de proselitismo". Numa notável visão ele acrescentou: "Na aurora de um novo milênio, a Igreja, anunciando o Evangelho de Jesus Cristo para a Europa, descobre cada vez mais a alegria os valores comuns, cristãos e judaicos, através dos quais nos reconhecemos uns aos outros como irmãos". Na Sinagoga de Roma, em 1986, já tinha declarado. "Vocês são nossos irmãos e, de alguma forma, nossos irmãos mais velhos". 


\section{Educação para o diálogo}

Vera Porto ${ }^{1}$

omos todos chamados a cooperar na promoção da paz, da justiça, dos direitos humanos, da concórdia e do respeito à vida. $\mathrm{O}$ diálogo é o meio por excelência e prioritário que abre aos valores universais e à Transcendência.

O Papa João Paulo II declara que o diálogo "é uma atividade que apresenta motivações, exigências, dignidade própria" (Redemptoris Missio, 56); através dele pretende-se fomentar o potencial unificador e libertador de toda religião, mostrando assim a relevância da religião para o bem-estar humano, a justiça e a paz mundial. Os fiéis de outras religiões são nossos próximos; os elementos comuns de nossas heranças religiosas e de nossos empreendimentos humanos nos forçam a estreitar os laços, baseando-os em valores éticos universalmente aceitos. Ser religioso hoje equivale a ser interreligioso no sentido de que a relação positiva com os fiéis de outras religiões é uma exigência num mundo onde existe pluralismo religioso. $\mathrm{O}$ diálogo estende a mão ao mistério de Deus ativo nos outros.

A pessoa humana é digna de respeito e em como tarefa a autorrealização, assumindo, como sujeito, sua condição corporal e psíquica, graças ao sentido que confere à sua existência. $O$ ser humano é digno de respeito porque, não nascendo pronto, tem o direito de percorrer o seu itinerário singular, buscando na liberdade um sentido para a sua vida.

A pessoa define-se também pela reciprocidade, traço que tem suas implicações na compreensão da dignidade humana. A pessoa humana constitui-se na relação com o outro. Nesse sentido descobre-se a própria dignidade, quando se reconhece essa mesma dignidade espelhada no outro. $\mathrm{O}$ respeito à dignidade acontece no mútuo reconhecimento e responsabilidade recíproca. Violar a dignidade do outro significa negar a própria.

A escola, como instituição de cultura, é articuladora de todo e qualquer processo de educação que promova o reencontro da razão com a vida. Ela abre perspectivas para a evolução diferencial do Eu e de sua determinação subjetiva para a relação interativa global do Nós. O seu

\footnotetext{
${ }^{1}$ Graduada em Educação Musical e Teologia.
}

compromisso é abrangente. Envolve a sociedade por inteiro, oferecendo-lhe princípios, critérios, horizontes amplos, concepção de valores, mecanismos que favoreçam a qualificação da vida, em vista da inserção e da integração de pessoas num mundo concreto, com desafios a superar, espaços a conquistar e projetos a construir.

A inserção dos valores fundamentais da vida no contexto global da educação visa tornar as relações do saber mais solidárias e participativas, ajudando a descobrir instrumentos eficazes para a compreensão e a ação transformadora da realidade social. Devemos contribuir na formação de atores sociais sensíveis às diferenças e leitores críticos da realidade, capazes de agir de modo a concretizar uma ética humana e social.

A pluralidade é uma característica da pós-modernidade. Nos estabelecimentos de ensino ela está realmente presente, inclusive na dimensão religiosa, nos impulsionando a ver o quanto é possível conviver com as diferenças, crescendo com elas, não tendo assim uma postura que impeça a aceitação do outro. Ao contrário, leva cada indivíduo a reafirmar sua própria identidade.

Os Parâmetros Curriculares Nacionais - PCN'S - têm uma clara intenção de fornecer elementos de reflexão para que as escolas se encaminhem, cada vez mais, em direção a um processo educacional includente, mostrando que a diversidade e a pluralidade são riquezas a serem compartilhadas. Propõem conteúdos relacionados às situações e acontecimentos do dia-a-dia e geradores de outros valores, como a honestidade, a justiça, a solidariedade, a gratuidade, o respeito, a responsabilidade, o amor, a esperança e outros. Na dimensão antropológica mostram a importância de uma relação consigo mesmo, com o outro, com o Transcendente, procurando despertar para a sensibilidade diante de situações desumanas, que ferem a dignidade humana.

Nas escolas é necessário articular as disciplinas, construir o texto escolar. Ser cada um capaz de realizar ações de integração. É fundamental superar uma pedagogia fragmentária e fragmentada, em que o ensino analisa o conhecimento em si e não em suas múltiplas relações. Trabalhar com projetos propicia um percurso interessante, pois é dada a ênfase ao que se quer ensinar em um currículo interdisciplinar. A construção de uma prática interdisciplinar contém como subtexto a percepção da diferença, a 
admissão da falta, do limite, da complementaridade e, ao mesmo tempo, a busca discriminada da tarefa comum.

Saber ler a história é uma conquista de sensibilidade por parte dos profissionais de educação, pois o processo escolar não é algo descontextualizado.

A linguagem é a maneira que o ser humano criou para se relacionar com o mundo. Ela faz a humanidade ser e dialogar, possibilitando ao homem situar-se no tempo e no espaço.

O diálogo com o mundo através da linguagem só é possível porque, para produzir condições necessárias à vida, são desenvolvidas ao mesmo tempo ações que transformam a realidade. $\mathrm{O}$ resultado individual e coletivo dessas ações permite à humanidade apropriar-se do mundo.

A pessoa humana precisa ter em mente as seguintes vertentes/ disposições:

1. o diálogo da vida, que requer espírito de abertura, de troca, compartilhando alegrias e dores, tudo o que fez parte da experiência da vida humana;

2. o diálogo da ação, que visa ajudar na libertação de pessoas, para que a existência delas possa ser integrada e integradora;

3. o diálogo da experiência religiosa, que aceita as tradições religiosas e compartilha suas riquezas espirituais, como fé e busca do Absoluto, oração e contemplação;

4. o diálogo do intercâmbio teológico, que aprofunda a compreensão de suas respectivas heranças religiosas e aprecia os valores espirituais uns dos outros.

Para um terceiro milênio mais pacífico e mais solidário é necessário romper com qual- quer resquício de intolerância. Reconhecer o pluralismo é condição básica para o verdadeiro diálogo inter-religioso. Diálogo implica numa interlocução de pessoas que se comunicam com a totalidade de sua fé, que têm identidade religiosa, uma convicção própria.

Deus é Deus. Ama a todos igualmente. Manifesta sua intimidade àqueles que se propõem a amá-lo. Não existe um só caminho para encontrar a Deus. O mistério de Deus é o mistério da verdade, que nunca se esgota.
Tudo é graça: nossa vida, nossas descobertas, nossos encontros e desencontros humanos. Como Pai misericordioso e justo acolhe em seus braços todos os seus filhos, sem distinção.

Aprender a sair de si revela maturidade humana e espiritual, e possibilita dialogar verdadeiramente, com disposição interna de construir um mundo novo, que saia da mediocridade para a humanização, cultivando a reconciliação com toda a vida do planeta.

Acreditar na potencialidade inscrita no coração humano é também lapidar a alma do espírito humano.

Aleluia!

Louvai a lahweh, nações todas,

glorificai-o, todos os povos!

Pois seu amor por nós é forte,

e sua verdade é para sempre!

(S1 117)

\section{Referências Bibliográficas}

DECRETOS DA CONGREGAÇÃO GERAL XXXIV -XV desde a restauração da Companhia 1995. Ed. Loyola, 1995.

BINGEMER, Maria Clara Lucchetti. Alteridade e Vulnerabilidade Experiência de Deus e pluralismo religioso no moderno em crise. São Paulo: Loyola, 1993.

\section{PARÂMETROS CURRICULARES NACIONAIS - MEC}

JOÃO PAULO II, Papa. Carta Encíclica - sobre o empenho ecumênico. São Paulo: Ed. Loyola, 1995. 


\section{O Shabat e o diálogo entre judeus e adventistas no Brasil}

Reinaldo Siqueira ${ }^{1}$

\section{Introdução:}

Shabat ("sábado"), como dia de descanso, santificado a Deus, é uma das características básicas e fundamentais tanto do Judaísmo como do Adventismo.

No Judaísmo, a fundamental importância do Shabat pode ser claramente o percebida nas palavras de Dayan I. Grunfeld, na sua popularização em inglês das ideias do famoso rabino Samson Raphael Hirsch, ao dizer que "the Sabbathcr) epitomizes the whole of Judaism" f"o sábado tornou-se a epítome da totalidade do Judaísmo") (Grunfeld, 1956: 11 ); ou na famosa frase de Ahad Ha'am: "Mais do que o povo judeu tem guardado o sábado; o sábado tem guardado o povo judeu” (Ha’am, 1965: 286).

Para os Adventistas do Sétimo Dia, a importância do Shabat pode ser vista pelo fato dele estar incorporado ao próprio nome que os define: "Adventistas do Sétimo Dia". Assim, a guarda e santificação do sábado, o sétimo dia da semana, e a esperança no breve advento do Messias correspondem aos dois ele- mentos mais característicos do Adventismo como comunidade religiosa.

É o propósito desta apresentação sugerir que, sendo um ponto comum e de fundamental importância para ambas as comunidades, o Shabat poderia servir de plataforma privilegiada para um diálogo inter-religioso entre judeus e adventistas, a começar do Brasil, e creio que esse diálogo teria repercussões mundiais para ambas comunidades.

$\mathrm{Na}$ fundamentação desta proposta, creio que existem bases extremamente sólidas para sustentá-la:

1. Na própria teologia bíblica do Shabat, que serve em si mesma como um elemento catalisador de diálogo e confraternização entre os seres humanos.

${ }^{1}$ Doutor em Teologia / UNASP.
2. Na perspectiva judaica acerca do Shabat, visto que tanto a tradição judaica acerca do Shabat, como a sua interpretação no pensamento judaico da atualidade fazem do mesmo um elemento ideal para o diálogo inter-religioso.

3. Na perspectiva Adventista do Sétimo Dia, baseando-se na compreensão adventista do Shabat, de sua universalidade, sua importância fundamental na compreensão de Deus e a relevância profético-escatológica desse dia para toda humanidade.

4. Na prática: $\mathrm{O}$ fato de duas comunidades que guardam e santificam o mesmo dia, em si mesmo, já tem criado uma realidade na qual temos tido de relacionar-nos em busca de uma cooperação mútua e, às vezes, tem nos levado até mesmo a lutar lado a lado pelos nossos interesses em comum. Em níveis práticos, o inter-relacionamento já existe, ainda que pouco conhecido, desenvolvido, ou até mesmo conscientemente aceito pela maioria dos membros de ambas comunidades. Creio que chegou a hora de passarmos juntos a um outro nível de relacionamento, fundamentado em um diálogo franco, aberto e respeitoso, diálogo este que possa promover uma verdadeira amizade, maior conhecimento e cooperação entre ambas comunidades.

\section{A teologia bíblica do Shabat e o diálogo:}

O Shabat está inteiramente relacionado com alguns dos fundamentos bíblicos que servem de base para o diálogo inter-religioso entre judeus e cristãos (International Council of Christians and Jews, 1993; National Jewish Scholars Project, 2000):

1. A crença comum no mesmo Deus, Criador do mundo e de toda humanidade: O Shabat está intimamente ligado à teologia da Criação (Gênesis 2:1-3; Êxodo 20:8-11). A razão básica para a observação do Shabat, na Bíblia, é o reconhecimento de Deus como Criador e Soberano. A soberania de Deus está envolvida, porque foi Ele quem ordenou a santificação do Shabat ("E abençoou o dia sétimo e o santificou" [Gênesis 2:31; "lembrá-te do dia de sábado para o santificar. Seis dias trabalharás e farás toda a tua obra. Mas o sétimo dia é o sábado do Senhor teu Deus; não farás nenhum trabalho..." [Êxodo 20:8-101). O Seu ato criativo é a base mesmo dessa ordem ("E havendo Deus terminado no dia sétimo a Sua obra, que fizera, descansou nesse dia de toda a Sua obra que tinha feito" [Gênesis 
2:2); "porque, em seis dias, fez o Senhor os céus e a terra, o mar e tudo o que neles há e, ao sétimo dia, descansou; por isso, o Senhor abençoou o dia sétimo e o santificou" [Êxodo 20:11D.

2. Nossa crença comum na Bíblia como Palavra de Deus e como base importante para o diálogo e para a fundamentação de nossos pontos de vista: O Shabat é um tema essencialmente bíblico que ocupa um espaço importante tanto na Bíblia Hebraica, o Tanach, como no Novo Testamento (o termo "Shabat", se referindo ao sétimo dia da semana, aparece uma centena de vezes na Bíblia Hebraica e 68 vezes no Novo Testamento).

3. A importância dos 10 Mandamentos para toda a humanidade: O Shabat é o quarto dos 10 Mandamentos dados por Deus no monte Sinai (Êxodo 20:2-17; Deuteronômio 5:6-21).

Os aspectos acima são importantes e fundamentais quanto à teologia do Shabat, e foram profusamente trabalhados tanto por judeus como cristãos que se atinaram a explorar esse tema da teologia bíblica. Gostaria, no entanto, de me deter em um aspecto particular: Inerente à própria natureza bíblica do Shabat existem os aspectos do "Diálogo" e do "Encontro" como elementos fundamentais da própria existência humana (Doukhan, 1996: 22). Esses dois aspectos podem ser claramente percebidos nos textos bíblicos básicos acerca do Shabat:

Segundo o relato da Criação (Gênesis 1:1-2:3), o homem foi criado no sexto dia (Gênesis 1:26-31), assim o primeiro dia completo da existência humana foi um Shabat (Gênesis 2:1-3). Esta sequência do relato bíblico implica que a natureza fundamental do Shabat é bem mais uma questão de "comunhão/ relacionamento" do que de um mero descanso após seis dias de trabalho (ainda que este último aspecto seja importante):

1. Relacionamento com Deus: Tendo sido acabado de ser criado, o primeiro dia da existência humana foi passado em adoração e comunhão com Deus, o Criador e Senhor de tudo. O Shabat é assim um convite a um tempo de diálogo e de encontro com o Criador.

2. Relacionamento com o "Outro/Próximo": Homem (Adam) e Mulher (Ishá) passaram o seu primeiro dia de vida em relacionamento um com o outro. O Shabat é o tempo de diálogo e de encontro humano, do relacionamento do casal, da família, da comunida- de, da humanidade. Todos os seres humanos estão representados no relato bíblico, como o uso dos nomes genéricos Adam ("Adão", mais precisamente "homem”) e Ishá ("mulher") o indicam. Essa estrutura relacional humana, própria à natureza do Shabat, aparece também na sequência do relato bíblico, quanto tomamos em consideração o paralelo das estruturas dos dois relatos da Criação: A) No primeiro relato, Gênesis 1:1-2:3, o Shabat aparece como o clímax do mesmo (Gênesis 2:1-3); B) Já no segundo relato, Gênesis 2:4- 25, o "casamento/ união" entre homem e mulher é o clímax (Gênesis 2:21-25). Assim Shabat e casamento são duas ideias em paralelo e intimamente ligadas na Bíblia, fato que inspirou profusamente toda a teologia judaica acerca do Shabat como uma Kalá, uma "noiva" (Heschel, 1966: 54-55; Schaum, editors e Schachter, 1973:107-108).

3. Relacionamento com o "Mundo/Criação": O primeiro dia do ser humano foi passa- do em comunhão e no desfrutar a perfeita criação de Deus (animais e natureza em geral). O Shabat tem assim um aspecto ecológico, o homem é chamado à comunhão e diálogo com o mundo criado.

Os aspectos de "Diálogo" e de "Encontro" são ainda mais explícitos na descrição do $4^{\circ}$ mandamento (Êxodo 20:8-11):

1. Relacionamento, encontro e diálogo com Deus: "Lembra-te do dia de sábado para o santificar" (Êxodo 20:8), ou seja, o homem é chamado a dedicar esse dia totalmente a Deus. "Seis dias trabalharás e farás toda a tua obra. Mas o sétimo dia é o sábado do Senhor teu Deus" (Êxodo 20:9-10).

2. Relacionamento, encontro e diálogo com o "Próximo" e a "Natureza": "Não farás nenhum trabalho, nem tu, nem teu filho, nem tua filha, nem teu servo, nem a tua serva, nem o teu animal, nem o forasteiro das tuas portas para dentro" (Êxodo 20:10). Todos se acham descritos aqui, implicando assim que o Shabat é um mandamento de comunhão universal. A cessação de trabalho proveria tempo livre, tempo a ser gasto na adoração de Deus e também no encontro de um com o outro: Pais e filhos (encontro em família); senhores e servos (promovendo o respeito e igualdade humana); homem e animais (promovendo o respeito e cuidado pelos animais e nos lembrando que eles como nós também são criaturas de Deus); israelita e estrangeiro (indicando a unidade da humanidade e sua igualdade diante de Deus). Tudo isto deveria ocorrer "das tuas portas para dentro", no lugar mais íntimo do ser humano, sua habitação, seu lar. 
O Shabat na Bíblia é assim a epítome da comunhão, do encontro, do momento para o diálogo: Com Deus, com os homens, com a natureza. Nisto, o Shabat resume em si a essência mesmo dos mandamentos: Amar a Deus sobre todas as coisas (Deuteronômio 6:5) e ao próximo como a si mesmo (Levítico 19:34).

Essa ideia relacional, intimamente ligada ao Shabat, aparece claramente explorada em outros textos da Bíblia. Em Isaías 58, por exemplo, a busca e dedicação a Deus, aqui representada pela prática do jejum (Isaías 58:1-5), aparece ligada à prática do bem ao necessitado e aflito, ou seja, ao próximo (Isaías 58:6-10), à contribuição humana para a redenção do mundo, o Tiqum haOlam (Isaías 58:11-12), e à guarda do Shabat (Isaías 58:13-14).

\section{O Shabat e o Diálogo a Partir da Perspectiva Judaica:}

Ao abordar esse tema aqui, o faço como um leitor da literatura judaica sobre a questão. Nessa análise da perspectiva judaica, tanto tradicional como moderna, acerca do Shabat, creio que podemos encontrar vários elementos básicos que fazem do Shabat uma plataforma privilegiada para um diálogo inter-religioso.

Antes, no entanto, de prosseguir nessa linha de pensamento, creio que seria necessário lidar com uma aparente contradição à mesma: Ao tratar da questão da guarda do Shabat por não judeus, a Mishná (Tratado Shabat 16:6) declara: "Se um gentio vem [no dia de Shabat apagar [um fogo), não devemos dizer-lhe nem 'apague' ou 'não apague', pois o Shabat não é [obrigatório] para eles". Do mesmo modo o Livro dos Jubileus (literatura judaica do segundo século antes da Era Comum) declara que: "Ele [Deus) não permitiu que nenhum outro povo, ou povos, guardasse o Shabat nesse dia, exceto Israel somente; só a ele, Deus concedeu comer, beber e guardar o Shabat" (Livro dos Jubileus 2:31). Aparentemente, a lógica que estaria por detrás dessas duas declarações seria o ponto de vista de que o Shabat é um sinal exclusivo da aliança entre Deus e Israel (Êxodo 31:12-17), um memorial da redenção da escravidão do Egito (Deuteronômio 5:12-15), evento exclusivo da história de Israel e não das nações.

Este ponto de vista da tradição judaica parece colocar em cheque tudo o que estamos tentando construir aqui, e alguns poderiam, com base nessa linha de pensamento, se opor totalmente à relevância do Shabat para o diálogo interreligioso. No entanto, creio que não deveríamos nos deixar levar pelas primeiras impressões, pois encontramos na literatura judaica toda uma série de passagens que falam da importância e relevância do Shabat também para os gentios. No próprio Livro dos Jubileus 2:1 lemos: "Deus descansou no Shabat, do sétimo dia, e o santificou por todas as eras, e o designou como um sinal para todas as Suas criaturas". Filo de Alexandria (20 a.E.C. - 50 E.C.) em sua obra Criação, 89, enfatizou que o Shabat existia desde a Criação e que era um "festival não de uma única cidade, nem de um só país, mas do universo, e somente ele, estritamente falando, merece ser chamado de feriado público, pertencente a todos os povos".

O valor universal do Shabat no Judaísmo aparece claramente na compreensão judaica da universalidade dos 10 Mandamentos. A crença nessa universalidade é inequívoca nas tradições religiosas ligadas à festa de Shavuo ("Pentecostes"), festa que celebra o "Recebimento da Lei" (Matan Torá). Segundo a tradição judaica (Ross, 1994: 115), a Torá foi dada no deserto, terra de ninguém, para que nenhum povo, nem mesmo o povo eleito (Israel) pudesse reclamá-la como sua propriedade exclusiva. Ao ser proclamada, ela o foi simultaneamente em 70 línguas diferentes (as línguas das 70 nações do mundo, segundo Gênesis 10), para que cada nação da terra pudesse entendê-la e aceitá-la. Nesse contexto, o papel de Israel seria o de vivenciar e zelar pelos preceitos da Torá, como uma nação santa e reino de sacerdotes em meio às outras famílias da terra, tornando assim conhecidas a todos verdades universais que estão disponíveis a qualquer um, independente de seu sexo, raça ou nacionalidade. Essa ideia é reiterada, em Shavuot, pela ênfase que é dada durante essa festa ao livro de Rute (ver Mindel, 1986: 23), uma mulher estrangeira (moabita) que aceita a fé e o povo de Israel, e se torna uma das matriarcas de Israel, vindo a ser a bisavó do grande rei Davi. Como mulher e estrangeira, Rute pertencia ao tipo de pessoas que mais facilmente tem sido alienado e desconsiderado em qualquer sociedade através da história. Essa ênfase na história de Rute realça a universalidade da Torá, ela é para todos aqueles que a desejarem.

A noção da universalidade do Shabat aparece vivamente no pensamento e escritos de vários teólogos e filósofos judeus modernos:

Para Samuel Dresner, o Shabat provê "dentro de seu limites um dos meios mais seguros de se encontrar a paz, no atormentado domínio da alma. 
Ele é uma das instituições básicas da humanidade -- uma ideia com potencialidades infinitas, com poder infinito e infinita esperança... Através do sábado, o Judaísmo conseguiu materializar seus maiores ensinos [na ideologia] de um dia" (Dresner, 1970: 14).

Já, para Erich Fromm: "O sábado é o dia de completa harmonia entre o homem e a natureza. 'Trabalho' é qualquer tipo de distúrbio do equilíbrio homem-natureza. $\mathrm{Na}$ base dessa definição geral, nós podemos entender o ritual do sábado... O sábado simboliza um estado de união entre homem e a natureza e entre o homem e o homem" (Fromm, 1966: 195-198).

Analisando a natureza e singularidade do tempo em contraste com a do espaço, Abraham J. Heschel enfatizou a universalidade do Shabat observando que:

... o espaço está exposto à nossa vontade; nós podemos moldar e mudar as coisas no espaço, segundo o nosso desejo. Tempo, no entanto, está além do nosso alcance, além do nosso poder... Ele pertence exclusivamente a Deus.

Tempo, portanto, é singularidade/ diferença [otherness], um mistério que plana acima de todas as categorias... Ainda assim, é somente dentro do tempo que existe comunhão e união/ relacionamento [togethernessl de todos os seres.

Cada um de nós ocupa um pedaço do espaço. Isto se passa de modo exclusivo. A porção do espaço que meu corpo ocupa é tomada por mim em exclusão de qualquer outro. No entanto, ninguém possui o tempo. Não existe um só momento o qual eu possa possuí-lo exclusivamente. Este exato momento pertence tanto a todos os homens vivos como ele pertence a mim. Nós compartilhamos o tempo, nós possuímos o espaço (Heschel, 1966: 99).

Segundo Heschel, enquanto outras religiões santificam o espaço (um lugar santo, uma montanha, etc...), Judaísmo santifica sobretudo o tempo. O Shabat é o presente mais precioso que a humanidade recebeu dos tesouros de Deus -- um "Palácio no tempo" (em vez de no espaço), um santuário de tranquilidade, serenidade, paz, descanso e adoração, universal e onipresente, que pode ser compartilhado por todos, ao mesmo tempo e em qualquer lugar (ibid., 13-24, 79-83).

“O sábado é um dia de harmonia e paz, paz entre os homens, paz no homem, e paz com todas as coisas... ele é profunda harmonia consciente entre o homem e o mundo, uma simpatia por todas as coisas e uma participação no espírito que une o que está aqui embaixo e o que está em cima. Tudo o que é divino no mundo é levado à união com Deus. Isto é o sábado, e a verdadeira alegria do universo" (ibid., 3 1-32).

A perspectiva de um diálogo inter-religioso, fundamentado na universalidade do Shabat, parece ainda mais reforçada com base na interpretação judaica das palavras proféticas de Isaías 56:1-8. Esta passagem de Isaías tem sido compreendida normalmente (Melamed, 1978: 218) como indicando que, de todas as festas judaicas, o Shabat é a única obrigatória a todos os estrangeiros que se unem a Deus e aceitam a fé bíblica (uma outra festa obrigatória, segundo Zacarias 14:16, seria a festa das Cabanas, Sucot, mas isto somente durante o reino messiânico). Para Moshe Greemberg, segundo essa passagem de Isaías, duas categorias de povo deveriam ser incluídas na nova comunidade de adoradores do Deus de Israel: O "estrangeiro" e o "eunuco", duas categorias antes proibidas de unir-se à comunidade de Israel. Após a restauração de Israel do Exílio, Deus mesmo traria estes dois novos tipos à Sua adoração no templo de Jerusalém. A palavra utilizada para "estrangeiro" não é "ger" (que conota um prosélito), mas sim "ben hanechar", ou seja, realmente um estrangeiro". Segundo Isaías, esse estrangeiro iria unir-se a Deus, e não "aos judeus". As condições para admissão na comunidade seriam: Primeiro, guardar o Shabat; e segundo, "não praticar o mal" -- abraçando assim a "Aliança de Deus". Os direitos e os deveres impostos sobre esses "novos membros" da comunidade seriam os mesmos impostos sobre Israel; no entanto, eles permaneceriam como um grupo distinto. "Em outras palavras, eles seriam um grupo de status igual a Israel, embora distinto de Israel" (ver Jerusalem House of Prayer for Ali Peoples, 1997).

\section{O Shabat e o diálogo na perspectiva adventista do Sétimo Dia:}

Para os Adventistas do Sétimo Dia (General Conference of Seventhday Adventists, 1988: 248-266), o Shabat tem um caráter universal e eterno. Estabelecido na Criação (Gênesis 2:1-3), ele é um memorial perpétuo da mesma, e é parte integrante e central dos 10 Mandamentos (Êxodo 20:811), a Lei de Deus eterna e universal, escrita pelo próprio Deus em tábuas de pedra como uma transcrição do Seu caráter santo e ético. Guardar o Shabat é reconhecer a Deus como Criador e, sobretudo, como Senhor. É 
uma experiência de fé, pois fé não é somente crer, mas crer e se submeter a Deus (através do reconhecimento de Sua autoridade e direito como Deus e Senhor pela obediência ao que Ele ordenou). Assim, o Shabat se torna um sinal de "santificação", ou seja, de uma autosseparação, voluntária, para servi-Lo, amá-Lo e obedecê-Lo (Êxodo 31:13). O Shabat é um símbolo da salvação pela graça de Deus, através da fé em Cristo, pois no Shabat o homem é convidado a descansar, deixar de lado as suas próprias "obras" e repousar em Deus, usufruindo do Seu "descanso" (Shabat), da Sua graça (Hebreus 4:9-11).

O Shabat é importante para os cristãos, devendo ser o dia de guarda dos mesmos. Em nenhum lugar do Novo Testamento o Shabat foi abolido por Deus e outro dia ordenado em seu lugar (algumas passagens do NT têm sido tiradas fora do seu contexto e utilizadas para provar algo que elas não estão tratando, ex.: Jesus e o sábado, em Mateus 12:1-14; Paulo e a Lei, em Colossenses 2:16-17; etc...). Jesus guardou o Shabat (Lucas 4:16; Mateus 24:20) e assim fizeram os seus discípulos (Paulo - Atos 16:13; 17:1-2; as mulheres que seguiam a Jesus - Lucas 23:56). O estudo da história demonstra que foi somente a partir da metade do $2^{\circ}$ século E.C., ou seja, cerca de 120 anos após Jesus, que grupos de cristãos começaram a abandonar o Shabat a favor do primeiro dia da semana (Bacchiochi, 1977).

O Shabat é uma questão atual e importante, pois segundo o livro de Apocalipse 14:6- 7, o advento final do Messias e o estabelecimento do reino messiânico são precedidos por uma proclamação mundial, de origem divina, conclamando todos os homens a temer a Deus, o Criador, e a darLhe glória pois é chegada a hora do Seu juízo, e a adorar "Aquele que fez o céu, e a terra, e o mar, e as fontes das águas". A renovação da fé em Deus como o Criador e Senhor, evidenciada pela guarda do Shabat e dos mandamentos de Deus (Apocalipse 12:7, 17), é um dos eventos finais que precedem o advento do Messias.

Segundo Isaías 66:23, o Shabat será celebrado na Nova Jerusalém e na nova terra, por todos os redimidos e por toda a eternidade.

Vários autores adventistas, trabalhando sobre a teologia do Shabat, reconhecem no mesmo um elemento importante para o "Encontro" e "Diálogo" entre os seres humanos:
Para Samuele Bacchiochi, uma maneira pela qual "a verdadeira guarda do sábado nos capacita a experimentar o descanso de Cristo é pela quebra das barreiras sociais, raciais e culturais. A incapacidade, ou falta de vontade, de apreciar e aceitar a cor da pele de uma outra pessoa, sua cultura, língua ou status social, é uma causa fundamental de muito tumulto, ódio e tensão em nossa sociedade contemporânea. Após a Queda, como observado no capítulo $\mathrm{V}$, uma importante função do sábado tem sido a de ensinar a igualdade e respeito por todo membro da sociedade humana. A cada sete dias, a cada sete anos (ano sabático) e a cada sete semanas de anos (ano do jubileu), todas as pessoas, animais e propriedades deveriam tornar-se livres diante de Deus. E verdadeira liberdade conduz à igualdade" (Bacchiochi, 1986: 223).

Richard Davidson, no seu estudo sobre o Salmo 92 (o Salmo para o dia de Shabat), argumenta que o Shabat nos indica que a verdadeira fonte de todo sentido é Deus. E a comunhão com Deus nas horas santas do sábado, além do nos levar ao ponto essencial da existência humana -- a adoração de Deus -- nos leva também à comunhão entre os companheiros de adoração:

Uma experiência com o Deus do sábado transforma a melodia da nossa vida em uma celebração e louvor. O cântico [salmo\} para o sábado se torna no nosso grande ode de louvor. Nos unimos aos nossos companheiros que guardam o sábado no entoar a canção de amor ao sábado, o salmo da vida. O coro vai aumentando até que realizamos que somos parte de uma multidão de cantores, um coro cósmico composto de todos os seres inteligentes do universo. Então toda a Criação, animada e inanimada, levanta as suas incontáveis vozes num crescendo sem paralelo.

De acordo com uma antiga alegoria judaica, até mesmo o sábado personificado se une ao coro:

Então o Sábado se levantou de seu assento e prostrou-se diante de Deus, dizendo: Bom é render graças ao Senhor. E toda a Criação completou: E render louvores ao Teu Nome, ó Altíssimo'.

Companheiros cantores da canção do sábado, o tamanho do coro sabático pode parecer pequeno agora, visto pelos olhos humanos. Mas, apesar das aparências, pela autoridade da Escrituras e no amor pelo Santo Cordeiro, venha, deixemos nossas vozes continuar a irromper com o cântico para o sábado (Davidson, 1988: 120-121). 
Para Jacques Doukhan:

"Esta santidade do sábado, a qual coloca a parte os fiéis, não deveria no entanto separá-los de seus próximos. Pelo contrário, no sábado a abertura ao 'Outro' divino é completada pela abertura ao 'outro' humano. A dimensão social do sábado se encontra implícita na referência ao evento da Criação, a qual nos relembra da origem comum de todos os homens e mulheres. Isto é também explicitamente indicado no quarto mandamento, o qual se refere ao 'outro' humano, ou seja, o servo e o estrangeiro que participam durante este dia dos mesmos privilégios de liberdade e descanso com os israelitas. Este é o dia quando cada um deve lembrar-se do próximo como igual, e portanto a ser respeitado. O sábado é também descrito por Isaías como o lugar de reunião de todos os povos de Deus (Isaías 56:3-8) (Doukhan, 1991: 157).

\section{A realidade prática e o diálogo:}

Judeus e adventistas têm mantido muito pouco diálogo entre si, e o pouco que se tem feito tem ocorrido somente em um nível muito individual e personalizado. No entanto, na prática, as características e crenças que compartilhamos nos têm levado a lutar juntos em várias ocasiões e a nos servimos mutuamente, suprindo as necessidades um do outro onde necessário, por exemplo:

1. O Shabat e as obrigações cívicas (ver Tyner, 1991; Rosenthal, 1991): Em épocas de eleição que caem no sábado, ou no caso de objetores de consciência que envolvam atividades no sábado (como no serviço militar), vemos rabinos e pastores adventistas, representantes jurídicos e membros influentes de ambas comunidades frequentando os mesmos escritórios de políticos e autoridades civis e militares, lutando pela mesma causa comum. A vitória de um é o benefício também do outro.

2. O Shabat e a escola: Vestibulares e aulas ao sábado são desafios comuns que crianças e jovens judeus praticantes e adventistas frequentemente enfrentam. Esta realidade provoca um bom nível de stress e preocupação constantes nos lares e nas congregações de ambas comunidades. Face a essas dificuldades, judeus e adventistas têm "cooperado" mutuamente, servindo um ao outro de certo modo "naturalmente". Nas Faculdades Renascença, em São Paulo, mais de 300 alunos são adventistas do sétimo dia, formando um dos maiores blocos do corpo estudantil daquela instituição judaica. Por outro lado, muitas famílias judias têm colocado seus filhos nas escolas adventistas, que se encontram espalhadas por todo Brasil.

3. Na área de saúde: Hospitais adventistas têm servido uma grande parcela da comunidade judaica brasileira, especialmente nas grandes capitais onde não existem instituições judaicas de saúde, como é o caso, por exemplo, do Rio de Janeiro (onde o Hospital Adventista Silvestre consta com milhares de associados judeus), de Belém do Pará e de Manaus. É relativamente grande também o número de judeus que frequentam os restaurantes vegetarianos adventistas devido ao pequeno número de restaurantes Kosher existentes no Brasil. A fábrica de alimentos adventista Superbom tem uma longa tradição na preparação de alimentação saudável, tendo desenvolvido nos últimos anos toda uma linha de alimentos vegetais Kosher, certificada aqui no Brasil por rabinos representantes da Orthodox Union americana, especialmente para servir a comunidade judaica.

4. Nos momentos de crises: A nossa crença comum no Shabat realmente nos aproxima mais do que imaginamos, e isto se revelou claramente em um recente episódio na França, no qual judeus e adventistas tiveram de lutar lado a lado a fim de enfrentar um momento de crise comum. Durante os anos de 1994 a 1997, as comunidades judaicas e adventistas na França enfrentaram sérias dificuldades com uma série de novas leis "antisseitas" que tornavam obrigatória, na compreensão de muitos diretores das escolas francesas, a presença às aulas no dia de sábado. Estas leis permitiam também às autoridades legais punir financeiramente as famílias cujos filhos faltassem às aulas mais de uma vez por mês, por questões religiosas, e até mesmo leválas a juízo sobre a guarda dessas crianças, permitindo assim que se retirassem essas crianças do seio de suas famílias. Judeus praticantes e adventistas enfrentaram grandes dificuldades, chegando mesmo a ter várias famílias enfrentando processos judiciários e sendo ameaçadas de perderem seus filhos para a tutela do estado. Esta crise levou aos departamentos jurídicos de ambas comunidades e seus escritórios responsáveis pela liberdade religiosa a lutarem intensamente juntos, nas cortes e nos escritórios do governo, até conseguirem resolver a situação em 1997, quando o ministro da educação francês assinou um decreto permitindo aos estudantes judeus praticantes e adventistas do sétimo dia se ausentarem da escola no dia de Shabat (ver Adventist News Network, July 15, 1997). 


\section{Conclusão:}

Olhando para a parte prática, nossas crenças em comum nos têm levado a cooperarmos mais do que a média das comunidades religiosas cooperam entre si. Olhando para a parte teológica, judeus e adventistas não somente compartilham de vários pontos em comum, especialmente o Shabat, mas têm pontos de vistas semelhantes acerca desses pontos. Olhando para a Bíblia, a base de fé e prática de todos aqueles que se veem como "povo do livro", somos incentivados pela Palavra de Deus a nos abrirmos uns aos outros e a nos engajarmos em um verdadeiro "Encontro" e "Diálogo".

A tragédia, no entanto, é que, como judeus ou adventistas, nós mal nos conhecemos. O que pensamos um acerca dos outro está normalmente cheio de estereótipos emprestados de terceiros, que pouca simpatias têm tanto pelos judeus como pelos adventistas. Vemo-nos com os olhos dos outros.

Creio que já é hora de nos encontrarmos face a face, de enxergar um ao outro com os nossos próprios olhos, ouvir a voz do outro e responder. Sim, creio que já é hora de nos engajarmos em verdadeiro e real diálogo, a partir do Brasil, diálogo que possa até envolver o mundo. Um diálogo que possa resultar naquilo que a nossa crença comum no Shabat preconiza, ou seja, um verdadeiro Shabat Shalom!

\section{Referências bibliográficas:}

ADVENTIST NEWS NETWORK (July 15, 1997). French Government Reinstates Adventists Rights.

http://rnembers.tripod.com/ rccsda/news.html,

Acessado 22 de abril de 2002.

BACCHIOCHI, Samuele (1977). From Sabbath co Sunday: A Historical Investigation of the Rise of Sunday Observance in Early Christianity. Rome: The Pontifical Gregorian University Press.

(1986). Divine Rest for Human Restlessness: A Theological Study of the Good News of Me Sabbath for Today. Berrien Springs, MI: Biblical Perspectives.

DAVIDSON, Richard M. (1988). A Lave Song for Me Sabbath: How to Experience the Joy that God Intended When He Gave Us Me Sabbath. Washington, DC: Review and Herald.
DOUKHAN, Jacques (1991). Loving the Sabbath as a Christian: A Seventh-day Adventist Perspective. In: Tamara C. ESKENAZI, Daniel J. HARRINGTON, S.J., e William H. SHEA (eds.). The Sabbath in Jewish and Christian Traditions. New York: Crossroad, pp. 149-168.

. (1996). Hebrew Scriptures: Like a Tree in the Wilderness. What Does It Mean to Keep the Sabbath? Shabbat Shalom, agosto de 1996, pp. 19-23.

DRESNER, Samuel H. (1970). The Sabbath. New York: Burning Bush Press.

FROMM, Erich (1966). You Shall Be as Gods. New York: Holt Rinehart \& Winston.

GENERAL CONFERENCE OF THE SEVENTH-DAY ADVENTISTS (1988). Seventh-day Adventists Believe. A Biblical Exposition of 27 Fundamental Doctrines. Washington, DC: Ministerial Association.

GRUNFELD, Dayan I. (1956). The Sabbath: A Guide to Its Understanding and Observance. London: Sabbath League of Great Britain.

HKAM, Ahad (1965). Collected Works. Reimpressão. Tel-aviv: Dvir. Web.)

HESCHEL, Abraham J. (1966). The Sabbath: Its Meaning for Modern Man. Expanded edition. New York: Harper \& Row.

INTERNATIONAL COUNCIL OF CHRISTIANS AND JEWS (1993). Jewish-Christian Relations: Jews and Christians in Search of a Common Religious Basis for Contributing Towards a Better World. http://www.jcrelations.net/stmnts/iccj_theol_statement.html, Acessado 22 de abril de 2002.

JERUSALEM HOUSE OF PRAYER FOR ALL PEOPLE (1997). 3rd Symposium Among the Three Monotheistic Religions (Judaism, Christianity and Islam). Notre Dame Center - Jerusalem - 17th and 18th February 1997.

http://www.christusrex.org/wwwl/ofm/sbf/SBEsyal.html, Acessado 22 de abril de 2002. 
MELAMED, Rabino Meir Matzliah (1978). A Lei de Moisés e as "Haftarot". $3^{\circ}$ ed. Rio de Janeiro: Congregação Religiosa Israelita Beth-El.

MINDEL, Rabino Nissan (1986). A história completa de Shavuot. Chabad News, sivan 5746, pp. 8-39.

NATIONAL JEWISH SCHOLARS PROJECT (2000). The Institute for Christian \& Jewish Studies: "Dabru Emet": A Jewish Stament on Christians and Christianity.

http://www.bc.edu/bc_org/research/cjI/Documents/dabru_emet.html, Acessado 22 de abril de 2002.

ROSENTHAL, Saul E (1991). A Jewish Perspective on Sabbatarianism. In: Tomara C. ESKENAZI, Daniel J. HARRINGTON, S.J., e William H. SHEA (eds.). The Sabbath in Jewish and Christian Traditions. New York: Crossroad, pp. 259-261.

ROSS, Lesli Koppelman (1994). Celebrate! The Complete Jewish Holidays Handbook. Northvale, NJ: Jason Aronson.

SCHAUM, Murray, EDITORS e Rabbi Zalman SCHACHTER (1973). Shabbat. In: Richard SIEGEL, Michael e Sharon STRASSFELD (eds.). The First Jewish Catalogue. Philadelphia: The Jewish Publication Society of America, pp. 103-115.

TYNER, Mitchell A. (1991). The Sabbath and the State: Legal Implications of Sabbatarianism. In: Tamara C. ESKENAZI Daniel J. HARRINGTON, S.J., e William H. SHEA (eds.). The Sabbath in Jewish and Christian Traditions. New York: Crossroad, pp. 245-258.

\section{Neopentecostais e neo-ortodoxos em São Paulo: diferenças e semelhanças nas estratégias de recrutamento de novos membros}

Matha Topel ${ }^{1}$

\section{A modo de introdução}

Censo brasileiro de 2000, cujos dados foram divulgados em maio de 2002, revela um crescente aumento dos cultos evangélicos em todo o País, constituindo a segunda opção religiosa depois do Catolicismo. O aumento de $15 \%$ entre as religiões evangélicas se concentra maciçamente nas igrejas denominadas pentecostais e neopentecostais e, em menor proporção, naquelas vertentes ligadas ao protestantismo histórico, como as igrejas Presbiteriana, Adventista, Luterana e a das Testemunhas de Jeová.

No que diz respeito à religião judaica, não foram divulgados dados censitários. Todavia, apesar da falta de dados frios, um fenômeno é irrefutável no que se refere à cidade de São Paulo: o crescente aumento e visibilidade da ortodoxia. Este fenômeno, que começou a se perfilar no começo da década de 90 , e que se consolidou nos últimos anos, não obedece a um crescimento vegetativo e sim, à incorporação de novos membros ao grupo: os baalei teshuváa . Uma expressão dessa mudança observa-se facilmente na reconfiguração do espaço judeu paulistano, com a constante criação de novas instituições ortodoxas, como yeshivot ${ }^{3}$, kolelim $^{4}$, creches, sinagogas, mikves ${ }^{5}$, centros de estudo informal, bibliotecas e fitotecas circulantes, restaurantes e supermercados kasher ${ }^{6}$ e espaços de lazer em geral. Um dado não menos importante é o aumento do número de

${ }^{1}$ Doutora FFLCH / USP

${ }^{2}$ Baal Teshuvá: expressão hebraica utilizada para designar os judeus laicos que abraçaram a ortodoxia. Para mais dados e reflexões sobre o movimento de teshuvá na cidade de São Paulo, cf. Topei, M. 2001 e 2002.

${ }^{3}$ Yeshivot: (hebraico): plural de yeshivá: Academia de estudos religiosos para jovens.

${ }^{4}$ Kolelim: (hebraico): plural de kolel: Academia de estudos religiosos para homens casados.

${ }^{5}$ Mikve: (hebraico): Ritual de purificação e casa de banhos onde o mesmo se realiza.

${ }^{6}$ Kasher: (hebraico): termo que designa que um alimento está apto para o consumo de um judeu pio. 
rabinos ortodoxos na cidade. Se na década de 50, São Paulo contava com menos de dez rabinos ortodoxos, hoje, dados encontrados na FISESP ${ }^{7}$ apontam à existência de mais de uma centena.

Já que o propósito deste ensaio é fazer um contraponto entre os modos de cooptação de novos membros entre igrejas pertencentes ao neopentecostalismo e congregações judias ortodoxas, com o objetivo fundamental de iluminar os procedimentos utilizados por estas últimas, devo confessar - já que de religiões se trata - que a minha experiência com o movimento evangélico no Brasil é mínima, restringindo-se à leitura dos clássicos sobre o tema ${ }^{8}$, a desordenadas incursões em cultos organizados pela Igreja Universal do Reino de Deus e a cinco entrevistas em profundidade, realizadas com adeptos dessa igreja e de outras similares.

Uma limitação destaca-se no exercício que pretendo levar a cabo: a falta de simetria entre meu conhecimento etnográfico das sinagogas e congregações cujo objetivo é converter à ortodoxia judeus laicos, vis-à-vis a superficialidade de minhas vivências no mundo evangélico. Todavia, e postas estas afirmações, espero me apegar ao necessário rigor metodológico que possibilite um contraste entre ambos fenômenos.

\section{O verdadeiro e novo inimigo: algumas receitas para enfrentá-lo. \\ Primeira parte}

A afirmação de Paul Tillich (1992) em relação ao protestantismo, que sem maiores problemas pode se extrapolar ao neopentecostalismo, aponta a uma realidade religiosa, social, política e cultural altamente diversificada, com tal pluralidade de confissões e denominações, que jamais nos permitirá definir, em termos concludentes, o que é o protestantismo. No presente trabalho, irei me remeter, exclusivamente, ao neopentecostalismo originado no Brasil a partir da década de 70, e não ao protestantismo de imigração ou às igrejas de transplante (Bastian, 1986). Este neopentecostalismo, cujo auge começou a partir de 1990, pode definir-se como um protestantismo de

\footnotetext{
${ }^{7}$ ISESP: Federação Israelita do Estado de São Paulo, organização-teto da comunidade judaica paulistana.

Cf. Alves, R. Protestantismo e Repressão; Gutiérrez B. F.\& Campos, L.S. (orgs): Na força do espírito: os pentecostais na América Latina; Pierucci, F.\& Prandi, R.: A realidade social das religiões no Brasil: religião, sociedade e política; Bastian, J, P.: Breve Historia del Protestantismo en América Latina
}

saúde e prosperidade, que busca a bênção de Deus em termos materiais, e que tem incorporado elementos da cultura popular, aos quais se soma um significativo componente messiânico (Platero, 1999).

Existe um consenso entre os estudiosos do tema sobre a difusão do neopentecostalismo, predominantemente em regiões marginais, tanto no âmbito rural como em regiões periféricas das grandes cidades (Platero, 1999; Pierucci \& Prandi, 1996). Autodefinidas como religiões eminentemente missionárias, é ampla a experiência proselitista de pastores, obreiros e congregações, que vai desde a aproximação porta a porta ou a abordagem de pessoas na via pública, até a veiculação de ideias através de emissoras de rádio, da TV e da imprensa escrita. Em suma, o aumento do poder das igrejas neopentecostais é diretamente proporcional ao incremento e condensação das diversas estratégias para recrutarem novos fieis. Todavia, num mercado de bens religiosos altamente diversificado como o brasileiro (Brandão, 1986, 1994; Moreira, A \& Zicman, 1994; Pace, E. 1997) cabe perguntarmo-nos quais as razões para o sucesso do neopentecostalismo.

Supera os limites deste trabalho encontrar uma resposta sociológica a um fenômeno de tamanha magnitude, cujas consequências influenciam, inclusive, as áreas política e partidária do País. Todavia, se focamos a atenção em como os fieis explicam a sua eleição pelo pentecostalismo, obteremos um rico material de análise, que nos permitirá estabelecermos alguns contrastes com as estratégias de recrutamento de novos membros empregadas pelas sinagogas ortodoxas. Assim, tanto os meus interlocutores como depoimentos encontrados em diversas pesquisas, referem-se basicamente a curas, tanto de doenças físicas como psíquicas - ou espirituais, como são conhecidas pelos fiéis -, ao abandono das drogas e do alcoolismo, e a uma melhoria significativa na qualidade de vida de adeptos e familiares, geralmente expressa numa rápida mobilidade ascendente. A este bem-estar adquirido a partir do processo de conversão religiosa, devese acrescentar o seu modo de operar: o milagre. Citarei um trecho de um depoimento que servirá como exemplo:

Depois daquela primeira vez na qual o pastor orou e eu me contorci de forma tal que oito pessoas tiveram que me segurar, quando voltei em mim me transformei num mar de calma: fui libertada. E graças a Deus, acabaram os pesadelos horríveis que me atormentaram durante dezesseis anos. Estava ficando louca! Você pergunta como aconteceu isto e eu lhe digo o que digo a todos: assim como existe Deus, existe 
o seu opositor, que faz pactos com todos os que se afastam de Deus. Da mesma forma que existe um Deus que nos criou para sermos bons e para a sua glória, existe o outro, Lúcifer, o Demônio, que tenta tomar o seu lugar. E para tirá-lo de você, precisa da ajuda de uma pessoa ungida que ore por você, que a abençoe, que a liberte.

Estas palavras constituem uma ilustração daquilo a que se refere Brandão (1986: 142), quando afirma: "Havendo uma única origem do mal, que só burla aos homens não iluminados pelo Espírito Santo, apresentandose perante eles sob inúmeras formas fabulosas que ocultam sua verdadeira identidade, só existe uma lógica de ação de cura". Uma lógica, cujo conhecimento é monopólio da religião "verdadeira", que concretiza a cura através de orações e benções que promovem a manifestação in situ do Espírito Santo

Chegados a este ponto, é preciso explicar melhor ambas características: a cura milagrosa e a proveniência do mal. Um aspecto que considero fundamental, no que diz respeito ao milagre, não reside exclusivamente na sua centralidade na teologia e liturgia neopentecostais, mas sim, no seu caráter público. Em outras palavras; o milagre se produz durante a realização dos cultos, geralmente multitudinários, agindo como recurso para a salvação daquelas pessoas possuídas pelo espírito do mal, ao mesmo tempo em que funciona como meio de recrutamento de novos membros. Mais precisamente, as sessões de cura ou "descarrego" operam como um fator de deslumbramento entre um número significativo de presentes ao culto, que não só ouvem depoimentos de doenças que desapareceram instantaneamente pela ação do Espírito Santo, mas também afirmam ter observado pessoas levantando-se de cadeiras de rodas ou clamando que já não precisam de bengalas ou muletas. Além do mais, os próprios fieis explicam que as pessoas que recorrem à igreja quando "já nada mais faz efeito", isto é, quando doenças e toda classe de prejuízos e danos continuam mostrando-se imbatíveis frente à ação dos médicos, assistentes sociais ou as autoridades religiosas de outros cultos.

No que diz respeito à origem do mal, o Demônio, é cada vez mais frequente a sua identificação com entidades pertencentes aos cultos afrobrasileiros (Brandão, 1986) que parecem ter-se convertido na verdadeira cruzada do neopentecostalismo. Em suma, o mais perigoso entre todos os inimigos é o macumbeiro, o Pai de Santo, o espírita, frente aos quais, só os ungidos e a religião "verdadeira" têm poder.

\section{O verdadeiro e novo inimigo: algumas receitas para enfrentá-lo Segunda parte}

Dois aspectos centrais - que distinguem o judaísmo de todas as correntes cristãs e que serão fundamentais para a presente discussão remetem à falta de experiência proselitista do primeiro e ao fato de que, sendo uma religião eminentemente ortoprática, o judaísmo ortodoxo se recria no lar e não no templo (Danzger, 1987). Ambas características, somadas à inextricável relação entre etnia e religião inerente ao judaísmo, exercem um papel fundamental nos mecanismos desenvolvidos pelos rabinos ortodoxos para converter judeus laicos e liberais à ortodoxia Assim, uma religião ortoprática ${ }^{9}$ como é o judaísmo ortodoxo, i.e., uma religião que coloca a ênfase no correto desempenho de condutas normatizadas, em lugar de privilegiar crenças ou doutrinas teológicas, redunda no desenvolvimento de processos singulares, principalmente entre pessoas que optaram pela ortodoxia em idade adulta. Por sua vez, esta característica intrínseca ao judaísmo, terá implicações no que diz respeito às estratégias utilizadas pelos rabinos doutrinários para aproximar judeus laicos e liberais à ortodoxia. Desta forma, as rígidas leis alimentares judaicas, somadas aos inúmeros costumes seguidos pelos judeus pios como, por exemplo, em que horário exato acender as velas para a celebração do descanso sabático ou de que modo deve cobrir a cabeça um homem ortodoxo, são só três exemplos da rígida obediência à Halachá ${ }^{10}$, e de como esta permeia todas as áreas da vida do indivíduo, bem como a sua relação com a família, com o grupo e com a sociedade mais ampla.

Contudo, é na análise de como encaram os rabinos doutrinários o recrutamento de novos membros numa sociedade na qual os judeus são uma minoria étnica, que observaremos diferenças substanciais em relação ao trabalho missionário das igrejas neopentecostais. Em suma, o fato de os judeus paulistanos estarem inseridos numa sociedade eminentemente

${ }^{9}$ Para uma análise mais abrangente das diferenças entre religiões ortopráticas e ortodoxas, cf, Mircea Eliade: The Encyclopedia of Religion, vol. 11 e Catherine Bell: Ritual: Perspectives and Dimensions (191-197).

10 Halachá (hebraico: caminho): compêndio dos preceitos e costumes que devem seguir os judeus ortodoxos para não se desviarem do caminho correto, aquele revelado pelo Deus israelita 
cristã ${ }^{11}$, anula in toto a possibilidade de "caçar almas" utilizando os modelos praticados pelos neopentecostais, como a conquista de espaços televisivos e radiofônicos, a aproximação porta a porta, ou a divulgação de material religioso nas Universidades, estações de metrô ou centros comerciais. Mas mesmo enfrentando esse empecilho - que poderíamos denominar de estrutural -, os primeiros rabinos ortodoxos que, na década de setenta, se impuseram como missão atrair judeus laicos à ortodoxia, tentaram estratégias similares às desenvolvidas pelas igrejas neopentecostais. Estou referindo-me, basicamente, aos "tanques das mitzvot ${ }^{12 "}$ que rodavam pelas ruas do bairro dos Jardins e de outros bairros com uma significativa concentração de judeus, no afã de convencer homens judeus a colocarem os filactérios ${ }^{13}$. Às mulheres judias, presenteavam com as duas velas e a reza necessárias para a celebração do ritual sabático.

Outra estratégia de recrutamento de novos membros - que vigora até os dias de hoje - é a reunião de grupos de jovens ortodoxos (geralmente, novos ortodoxos pertencentes à corrente Chabad-Lubavitch ${ }^{14}$ ) nas entradas do clube Hebraica, espaço que utilizam para ensinar homens judeus a colocarem os filactérios e recitarem a bênção correspondente à consumação deste preceito. Todavia, essas estratégias de cooptação de novos membros não constituem nem as mais difundidas na atualidade, nem as mais eficazes.

É por esta razão que o exclusivismo que caracteriza ao movimento de teshuvá fora de Israel não poderá ser compreendido se não analisarmos ainda que brevemente - as formas através das quais, no judaísmo, identidade étnico-nacional e identidade religiosa se entrelaçam. Retomarei esta questão a seguir. Vejamos agora como, em menos de uma década, os rabinos doutrinários de São Paulo lograram decuplicar a quantidade de adeptos da ortodoxia.

\footnotetext{
${ }^{11}$ Em Israel esta situação é diferente por razões óbvias, e observam-se estratégias similares com o neopentecostalismo nas estratégias que desenvolvem os rabinos e instituições

ortodoxas para o recrutamento de novos adeptos.
${ }^{2}$ Mitzvot, (hebraico, pl. de mitzvá): preceitos contidos na Halachá, e cuja observância é obrigatória para os judeus ortodoxos.

${ }^{13}$ A colocação dos filactérios (tefilin) pela manhã, é um dos preceitos mais importantes que devem seguir os judeus ortodoxos

${ }^{14}$ Corrente chassídica cujo líder, o sexto Rebbe de Lubavitch, foi a primeira figura ortodoxa que se impôs como objetivo preeminente para acelerar a Era Messiânica, a aproximação de judeus laicos e liberais à ortodoxia.
}

Para lograr este objetivo, é necessário lembrar o contexto que serve como pano de fundo para compreender como foi que o movimento de teshuvá ${ }^{15}$ paulistano se originou num momento histórico determinado que remonta à década de oitenta, para cristalizar-se e conformar-se segundo características próprias no início dos anos noventa. Este objetivo, mais uma vez, nos remete a certas tendências do campo religioso brasileiro. Mais precisamente, a como o religioso começou a ocupar, moldar e transformar espaços e grupos diversos. Tal fenômeno decorreu da crescente dessecularização de importantes segmentos da sociedade brasileira ou, dito em outras palavras, do vigor com que o religioso começou a erigir-se, para se constituir num dos organizadores de dotação de sentido mais importantes entre grandes segmentos da população brasileira. Desta forma, e como fora analisado por diversos estudiosos, esse processo levou ao desenvolvimento e organização de novas instâncias sócio-comunitárias, através do fortalecimento das igrejas históricas ou de sua reformulação, assim com da formação de novas igrejas, seitas, grupos de estudos místicos, congregações espiritualistas e outras formações institucionais, cuja missão e objetivos se moldam ao redor do fator religioso.

Chegados neste ponto, e com o objetivo de lograr um equilíbrio que nos permita observar - através do contraponto proposto no início deste trabalho - as diferenças e semelhanças entre os métodos de recrutamento de novos membros desenvolvidos pelas duas religiões aqui contempladas, utilizarei no caso do judaísmo a mesma metodologia desenvolvida para compreender o poder de deslumbramento que a nova religião exerce entre os neopentecostais. Eis, então, trechos de conversas que mantive com alguns baalei teshuvá, nas quais me contaram por que, existindo tantas formas de serem judeus, optaram pela ortodoxia como sistema de vida ${ }^{16}$.

É que eu gosto muito de estar na sinagoga, sinto-me muito bem lá, não só pelo ritual, mas como diz o Tania, é onde consegui entrar em contato com pessoas e ter mais relacionamentos. São pessoas, segundo a minha opinião, que gostam de mim e eu gosto das pessoas que encontro na sinagoga. O que posso dizer? Isso me atraiu muito! Mais ainda, esse pode ser um dos fatores que me retém na teshuvá

${ }^{15}$ É assim como se designa o processo através do qual judeus laicos se transformam em ortodoxos. Teshuvá (hebraico): retorno. Neste contexto, trata-se de um retorno ao caminho do bem.

${ }^{16}$ Para uma compreensão do fenômeno de teshumi em outros contextos, cf. Aviadj. 1983; Danzger, H. 1987; Kaufman,D. R. 1991; Davidman, L. 1993. 
No meu entender, a própria palavra ortodoxia quer dizer doutrina correta; parece que em grego é a tradução da coisa certa. Então, nós queremos escolher o que deve ser, o que é melhor para nós. Eles (os rabinos ortodoxos) me mostraram a Torá, a beleza da Torá, a força da Torci Então, para mim, nada mais lógico que aprender com quem ensina a Torci da maneira mais pura, da forma mais correta. Eu não preciso que alguém pegue essa Torci e a reforme para mim, que me seja dada reformada; eu prefiro tomá-la da forma mais pura, da forma mais correta e serei eu quem faça a minha própria reforma para o meu próprio estilo de vida.

Porque, ou é, ou não é; não existe esse meio termo: o reformismo. A própria palavra reformismo o diz: que está reformando, que não é o original. Mas, se queremos algo, queremos o original, queremos o bom, queremos qualidade.

A esses depoimentos, é importante acrescentar a importância do shabat no processo de re-etnização religiosa, apontado pela grande maioria dos meus interlocutores como um ideal muito desejado, não só pela sua beleza ritual, mas também porque durante a ceia do shabat a família judia se reúne. Além do mais, as famílias extensas de rabinos e ortodoxos de nascença são vistas como um modelo a ser seguido, tanto por homens como por mulheres. É aqui onde constatamos a centralidade do lar - e não do templo - no recrutamento de novos membros. Assim, tanto no shabat como em outras celebrações religiosas, as casas dos rabinos se veem lotadas de convidados, ortodoxos potenciais, que aprendem a viver o judaísmo "autêntico", no seio de um "verdadeiro" lar judeu.

Uma vez que para a grande maioria de rabinos, o shabat constitui uma das formas mais eficazes de atrair judeus à ortodoxia, poder-se-ia concluir que se trata de uma combinação entre curiosidade e prazer, do lado dos baalei teshuvá, compensados pelos rabinos doutrinários quando convidam homens e mulheres a passar o shabat com eles e suas famílias. "Cada rabino tem seu sistema Ide aproximar judeus. Meu sistema é pela boca, chamar a pessoa para comer em shabat na minha casa. Passaram centenas de judeus em todos estes anos e posso-lhe assegurar que todos gostaram", disse-me um rabino. Outros dois rabinos, relatam assim a sua experiência:

A primeira coisa que nós fazemos é convidar as pessoas a passar o shabat conosco. Porém, isso é muito pouco, é quase que um trabalho individual. Porque: quantas pessoas eu posso convidar num sábado?
Três, quatro, cinco. É uma vivência judaica alegre, mas às vezes preferimos combinar uma data e fazer uma atividade para muitas pessoas, como uma sorvetada ou pizzada kasher.

Meu objetivo é trazer pessoas para a sinagoga e que cada um se encontre, que cada judeu descubra que seu lugar é na sinagoga, que o lugar onde ele vai se sentir bem, onde vai se reconfortar, vai se elevar é na sinagoga. Eu vou tentar mostrar-lhe isso de todas as formas possíveis, que venha, que reverencie, que venha comer, que venha dançar, mas que venha e que descubra que isto aqui é como água para um peixe.

No que diz respeito a outros mecanismos postos em prática pelos rabinos doutrinários para atrair judeus laicos e liberais, assinalei a criação de uma ampla gama de instituições ortodoxas. A isto, deve somar-se a constante organização de uma ampla gama de atividades (tardes de estudo para as mulheres, madrugadas de estudo talmúdico para os homens, noites para singles, conferências, cursos e minicursos, finais de semana fora da cidade, shabatonim, churrascos e sushis estritamente kasher, só para mencionar alguns $)^{17}$. A mulher de um rabino, pertencente ao Byniam Olam $^{18}$ me explicou da seguinte maneira o objetivo da sua instituição:

Nosso primeiro objetivo é tornar o judaísmo acessível, com poucos argumentos. Deixar de lado todos os preconceitos, isto $e$, que se você for a uma reunião de religiosos, não pense que eles têm antenas, que vieram de outro planeta ou que são seus inimigos.

\section{Uma visão não muito diferente é a de um rabino:}

A nossa missão é dar oportunidade para que as pessoas conheçam a Torá, que ela sempre foi transmitida, como viver de acordo com a Torá, mostrar que é uma coisa atual, que não é uma coisa de outro mundo... talvez dar oportunidade às pessoas para exercerem o livre arbítrio. Livre arbítrio é o que você escolhe... mas existe uma certa falha nessa definição porque nem sempre o que eu quero é um exercício do livre arbítrio... Muitas coisas que as pessoas pensam

${ }^{17}$ É importante assinalar, por outro lado, que essas atividades são divulgadas através das quatro revistas gratuitas veiculadas por instituições ortodoxas que circulam atualmente na cidade, bem como por meio de panfletos e cartas que chegam aos lares de todos os judeus que estão vinculados a alguma instituição comunitária.

${ }^{18}$ Congregação identificada com a versão lituana do judaísmo ortodoxo, cujo objetivo é aproximar ao judaísmo jovens com idade para cursar estudos universitários. 
sobre o judaísmo são influências da mídia ... e muitas imagens que as pessoas têm do judaísmo são imagens distorcidas... e quando existem estereótipos, isso não é optar.

Assim, rabinos e esposas de rabinos de todas as correntes ortodoxas que atuam em São Paulo realizam inúmeros esforços para se apresentarem perante o seu público como "judeus normais" - expressão curiosa e paradoxal que utilizam de forma recorrente. De modo algum querem ser identificados como inimigos de outros judeus. Isto último porque, na realidade, existe um poderoso inimigo, o inimigo verdadeiro, identificado com a crescente assimilação dos judeus à sociedade mais ampla, com a consequente consumação de matrimônios interétnicos e a perda do repertório cultural e religioso que caracterizou o judaísmo anterior à Hascalá $^{19}$. Esse processo, denominado na década de 40 pelo sexto Rebbe da dinastia Chabad, como o "holocausto espiritual" do povo judeu, segundo os rabinos doutrinários, só poderá ser revertido através de um processo maciço de teshuvá, um de cujos objetivos é acelerar os tempos da Era messiânica.

Estas reflexões e muitas outras com as quais me deparei durante o trabalho de campo e a posterior escrita de alguns textos sobre o movimento de teshuvá em São Paulo não foram suficientes, todavia, para ocultar a minha surpresa quando, após uma longa conversa, ouvi as seguintes palavras proferidas por uma rebbetzim: "Marta, eu estou fazendo História, a História dos tempos do Messias, e você tem uma grande felicidade: você a escreverá".

\section{Conclusão}

São muitas as diferenças existentes entre as estratégias de recrutamento de novos membros, implementadas pelo neopentecostalismo e pelo judaísmo ortodoxo. Todavia, é possível assinalar algumas semelhanças. Isto último, como resultado de que ambas religiões atuam no que conhecemos como mercado brasileiro de bens religiosos, cujas características, basicamente, são uma marcada tendência sincrética, e um nomadismo acentuado que se expressa na peregrinação dos fieis pelos diferentes cultos e denominações

\footnotetext{
19 Iluminismo judaico. Movimento que, a partir de finais do século XVIII, começou a questionar o judaísmo ortodoxo e tentar novas formas de identidade judaica tendo como base as ideias da Ilustração.
}

religiosas (Brandão, 1986,1994; Moreira, A. \& Zicman, 1994; Pace, E. 1997). $\mathrm{E}$ se bem nas religiões contempladas este fenômeno não significa um sincretismo manifesto, ainda assim, tanto baalei teshuvá como neopentecostais, demonstram uma dificuldade - ou talvez, uma falta de interesse - em se manter ligados a uma única congregação. Assim, se no caso judeu, o que se observa é uma transumância entre sinagogas chassídicas e lituanas, sefaraditas e ashkenazitas; entre os neopentecostais não existe um mecanismo que impeça aos fieis de participarem em atividades de várias igrejas ao mesmo tempo.

Outro traço comum a ambas religiões se relaciona com o status especial que recebe o novo adepto, no que se refere à sua relação com o Deus monoteísta, fenômeno expressado na certeza dos fieis de estarem seguindo a religião "verdadeira". Todavia, se bem o judaísmo segue o princípio da matrilinearidade, são só os baalei teshuvá quem cumprem com a missão Divina outorgada pelo Deus de Israel ao seu povo: guardar e respeitar os mandamentos para se transformar no povo eleito, numa comunidade de sacerdotes e, através desse processo, acelerar a chegada do Messias. O rabino Shabsi Alpern, um dos primeiros emissários do Rebbe de Lubavtich no Brasil, explica este componente intrínseco ao judaísmo com as seguintes palavras: "Veja bem, o dia da Redenção está fixado. Nada, nenhuma infâmia ou mau procedimento que o homem faça poderá atrasá-lo. Porém, as boas ações podem antecipar este momento glorioso ${ }^{20 "}$.

De maneira similar atua o neopentecostalismo ao afirmar que os seus adeptos se tornam membros especiais do povo de Deus, quando, na qualidade de profetas e orientados por pastores ungidos, pregam a palavra Divina (Rolim, 1979; Stadler, 2002). Por último, tanto o judaísmo ortodoxo como o neopentecostalismo - à exceção, talvez, da Igreja Universal do Reino de Deus - recebem um importante financiamento externo que provém, basicamente, dos Estados Unidos.

No que diz respeito às divergências, são tantas, que me limitarei às que considero mais significativas. Assim, não há dúvidas que as funções sociais desenvolvidas por ambas religiões divergem como consequência do segmento social que têm por objetivo de converter. $\mathrm{O}$ neopentecostalismo, como foi assinalado, concentra os seus esforços entre a população de menor

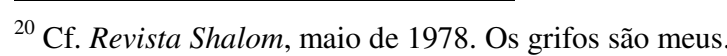


poder aquisitivo, que o modelo político-social brasileiro degrada, segregando-a à periferia física, social e espiritual. Como bem assinala Dreher (1999), o neopentecostalismo substitui a sociedade dominada pelo diabo, por um sistema compensatório. "Na sociedade latino-americana, quem não tem alimento, roupa, educação, [medicina] reconhecimento nem expressão, tem de elaborar um sistema no qual esses bens, ou parte deles, sejam considerados nocivos.... Assim, vale que o cristão não fume, não beba, não vá ao cinema nem ao teatro... Através da disciplina, o cristão chega à riqueza e ao prestígio social" (Dreher, 1999: 15/16) ${ }^{21}$. Em outras palavras, e por mais que tal asseveração possa despertar críticas, existe uma relação clara entre o neopentecostalismo e a aquisição de uma cidadania ${ }^{22}$.

Para os rabinos doutrinários, a missão é diferente. Dirigidos os seus esforços missionários a uma minoria étnico-religiosa - grande parte dela pertencente às classes média e média alta - a sua função mais importante reside em estreitar as fronteiras do grupo, através de atividades que redundem no cessar de matrimônios exogâmicos. É por esta razão que concentram seus esforços em transformar os espaços de reetnização religiosa em lugares de confraternização, nos quais se respira uma atmosfera de comunidade, no sentido em que esta categoria foi utilizada por Tõennies. Daí, que muitos baalei teshuvá destaquem, no seu processo de conversão religiosa, o aspecto social: ter encontrado novos amigos, sentir-se "em casa" na sinagoga, ter com quem falar sobre temas judaicos. Em relação ao papel das mitzvot como reestruturadoras da experiência do indivíduo, o convívio próximo com baalei e baalot teshuvá deixou claro que um dos sentimentos mais significativos despertados naquele que começa a cumprir um preceito é o arraigo, tanto no seu sentido emocional, quanto normativo e existencial. Essa sensação de enraizamento, expressa em frases como "indo à sinagoga no shabat sinto que estou em casa", "comer kasher me fez entender que estou no caminho certo", ou "fazer teshuvá por fim me devolveu ao judaísmo", acaba funcionando como estímulo para a incorporação de novos rituais judaicos.

${ }^{21}$ É importante assinalar, todavia, que entre os estudiosos do movimento neopentecostal no Brasil, existem divergências enquanto a se esta função deve ser considerada "libertadora" ou "opressora" (Dreher, 1999). Tradução da autora.

${ }^{22}$ Este fenômeno se observa cada vez mais nas sociedades latino-americanas, principalmente, na atual crise, através da assistência social, médica, organização de alimentação popular, redes de educação formal e informal, etc.
Outro aspecto que distingue o judaísmo do neopentecostalismo na cooptação de novos membros é a ausência do milagre nas cerimônias religiosas. Assim, e no que diz respeito ao movimento de teshuvá, tanto nos rituais religiosos como nos cursos e conferências ditadas pelos rabinos, é a palavra destes o mecanismo principal que atua como fator de deslumbramento entre adeptos potenciais, não existindo expressões místicas do fenômeno religioso, como as encontradas no neopentecostalismo, a exemplo da possessão, transe, cura ou milagre. Além do mais, apesar de as correntes chassídicas reconhecerem o milagre e demonstrarem uma tendência a celebrá-lo, ele é compreendido como monopólio de Grandes Rabinos de épocas passadas e não como um recurso que os atores possam manipular a seu favor, através de comportamentos específicos ${ }^{23}$.

Isto nos conduz às Ultimas observações que me parecem eloquentes e que remetem à inextricável relação entre identidade étnica e identidade religiosa no judaísmo, uma de cujas expressões se tornou, durante as primeiras fases do meu trabalho de campo, num verdadeiro quebra-cabeça. De fato, nas mais de quarenta entrevistas que mantive com baalei e baalot teshuvá, foram escassas as vezes em que ouvi deles a palavra Deus. Fenômeno bastante curioso entre pessoas que passaram por um processo de reconversão religiosa; e uma situação que se contrapõe de maneira gritante ao discurso dos neopentecostais, cujo discurso é pleno em referências a Deus, a Jesus Cristo e ao Espírito Santo. Em contraste, os novos ortodoxos falam muito sobre a Torá e sobre as mitzvot, e sobre um tempo em que o judaísmo foi vivido na sua forma "autêntica", isto é, unindo a seu redor todos os filhos de Israel. Foi essa a pista que me levou a compreender que para os baalei teshuvá abraçar a ortodoxia é mais do que um ato de fé, constituindo um verdadeiro retorno ao passado - imaginado, inventado ou reinventado - no sentido de poder participar de uma vida comunitária nos marcos do grupo étnico ao qual pertencem, que a configuração do judaísmo da cidade de São Paulo, nas últimas décadas, desvirtuou, ou pela falta de objetivos claros entre as instituições não ortodoxas, ou pela perda dos referentes identitários que os caracterizaram em épocas anteriores.

\footnotetext{
${ }^{23}$ Em relação a esse tema, um rabino destacou o seguinte: Muitas das pessoas que se aproximam de nós demonstram um interesse exagerado em conhecer a kabalá. Todavia, nós explicamos que antes de se aprofundar na kabalá, deve-se conhecer a Torá; e você sabe: a Torá está cheia de histórias tão belas e difíceis de compreender, que aos poucos, a kabalá
} passa a um segundo plano. 
Finalmente, e como síntese do meu trabalho em instituições pertencentes a ambas religiões, gostaria de relatar a seguinte experiência. No que diz respeito às igrejas neopentecostais, a mesma se repetiu nas três escolhidas para satisfazer a minha curiosidade antropológica. Assim, foi só entrar e algum dos obreiros notou a minha presença; depois de me cumprimentar cordialmente e perguntar meu nome e sobrenome, convidoume a participar do culto. Quando este teve início, do púlpito, o pastor disse o nome, um por um, de todos os adventícios, benzendo-nos individualmente. Essa recepção é semelhante à acolhida que recebem todos os visitantes que pela primeira vez entram em alguma sinagoga ortodoxa, e imediatamente, são cumprimentados com afeto pelos rabinos e suas esposas, e convidados a participar das atividades planificadas para esse dia. Boas-vindas extraordinárias e não pouco comovedoras, em um mundo que nos introduziu no anonimato: a era dos não lugares.

\section{Referências Bibliográficas:}

ALVES, R. A. Protestantismo e Repressão. São Paulo: Ática, 19179.

AVIAD, J. Return to Judaism: Religious Renewal in Israel. Chicago: The University of Chicago Press, 1983.

BASTIAN, J. P. Breve Historia del Protestantismo en América Latina, México: Casa Unida de Publicaciones, 1986

BELL, C. Ritual, Perspectives and dimensions. New York: Oxford University Press, 1977.

BRANDÃO, C.R. "A crise das instituições tradicionais produtoras de sentido" em Moreira e Zickman (orgs): Misticismo e Novas religiões. Petrópolis: Vozes, 1994.

BRANDÃO, C. R. "O festim dos bruxos - relações sociais e simbólicas na prática do curanderismo no Brasil" en Religião e Sociedade, ${ }^{\circ} 13$, vol. 3, 1986

DANZGER, M.H. Returning to Tradition: The Contemporary Revival of Orthodox Judais New Haven: Vale University Press, 1989

DAVIDMAN, L. Tradition in a Rootless World: Women Turn to Orthodox Judaism. California: University of California Press, 1991.
DREHER, M. N. "Protestantismo na América Meridional" em IX Jornadas sobre Alternativas Religiosas em América Latina, Rio de Janeiro, 1999

ELIADE, M. The Encyclopedia of Religion, vol. 11.

GUTIÉRREZ, B. F. \& CAMPOS, L. S. (orgs): Na força do Espírito: os pentecostais na América Latina. São Paulo: AIPRAL, 1996.

KAUFMAN, D. R. Rachel's Daughters: Newly Orthodox Jewish Women. New Jersey: Rutgers University Press, 1991.

MARIANO, R. "Balanço da teoria sociológica clássica sobre o crescimento pentecostal" em VIII Jornadas sobre Alternativas Religiosas en América Latina, Buenos Aires, 1997.

MOREIRA, A. \& ZICMAN, R. Misticismo e Novas Religiões. Petrópolis: Vozes, 1994

PACE, E. "Religião e Globalização" em Oro, A. P. \& Steil, C.A. (orgs). Globalização e Religião. Petrópolis: Vozes, 1997.

PIERUCCI, A. F. \& PRANDI, R. A realidade social das religiões no Brasil: religião, sociedade e política. São Paulo: Hucitec, 1996.

PLATERO, S. "Globalización y reconversión religiosa, ¿un reto a la identidad latinoamericana?, trabajo presentado en las IX Jornadas sobre Alternativas Religiosas en América Latina, Rio de Janeiro, 1999.

ROLIM, F. C. Pentecostais no Brasil: uma interpretação sócio-religosa. Rio de Janeiro: Vozes, 1985

STADLER, H. "Conversão ao pentecostalismo e alterações cognitivas e de identidade" em Revista REVER, Publicación electrónica de la PUC/SP, 2001.

TILLICH, P. A Era Protestante. São Paulo: Ciências da Religião, 1992.

TOPEI, M. "Do retorno ao passado e da construção do futuro: algumas observações sobre os baalei teshuvá de São Paulo" en Revista de Língua e Literatura Hebraica, ${ }^{\circ}$ 3, 2002.

TOPEI, M. "Os espaços de re-etnização religiosa e a construção de uma nova identidade: o baal teshuvá paulistano" em Revista ILHA, vol. 3, $\mathrm{n}^{\circ} 1,2001$. 


\section{CAPítulo}

\section{Política e Comportamento Judaico}

\subsection{O DISCURSO ANTISSEMITA E SUAS MÚLTIPLAS EXPRESSÕES}

\section{Demônios renascidos das cinzas: reflexões acerca da intolerância no século XX e XXI}

\section{Maria Luiza Tucci Carneiro ${ }^{1}$}

\section{Reciclando velhos argumentos:}

importância deste estudo está na sua atualidade. A partir das últimas décadas do século XX, a mídia colocou em pauta, quase que diariamente, duas temáticas que dizem respeito às minorias nacionais: a da limpeza étnica e a crise do Oriente Médio. Essas questões nos levam a refletir sobre a fragilidade da condição humana diante das calamidades e dos mitos. Em todos os períodos da História em que a palavra limpeza foi adjetivada e empregada no discurso político em composição com outra ("limpeza de sangue", "limpo de judeus", "limpeza étnica"), tragédias coletivas aconteceram. Articulando a retórica da exclusão em privilégio dos mais puros tivemos no passado o Tribunal do Santo Ofício e os regimes nazifascistas. Distintos em sua argumentação - por fundamentos teológicos, pseudocientíficos ou étnico-culturais -- estes discursos pregavam a higienização da sociedade que, segundo seus mentores, deveria se libertar dos elementos ditos indesejáveis ou malditos.

\footnotetext{
${ }^{1}$ Maria Luiza Tucci Carneiro, doutora do Departamento de História da Universidade de São Paulo. Autora, dentre outros livros, de $O$ antissemitismo na Era Vargas: fantasmas de uma geração. $3^{\mathrm{a}}$ ed. São Paulo: Perspectiva, 2001; Brasil, um refúgio nos trópicos. São Paulo: EDUSP, 1997; Holocausto. Crime contra a Humanidade. São Paulo: Ática, 2000.
}

Nas últimas décadas do século XX, a ideia de limpeza étnica ressurgiu subsidiando propostas de extermínio de grupos considerados como indesejáveis. Retomou-se, de certa forma, o antigo conceito romano de bárbaro: aquele que não pertence ao Império e por isso não tem direito de usufruir seu convívio e seus benefícios. Este é um racismo diferenciado daquele que norteou a escravidão colonial e o nazismo, podendo ser identificado como uma nova forma de intolerância. Dependendo do inimigo-objetivo e do contexto político em que esse discurso se insere podemos nos referir a um neorracismo cultural e, até mesmo, a um novo tipo de antissemitismo.

Em ambos os casos, retoma-se o conceito de estrangeiro, enquanto símbolo do intruso ou invasor. Hoje se fala numa "Alemanha para os alemães" e não mais, como antes, numa "Alemanha para os arianos". Dentre os grupos extremistas identificados com essa ideia temos os skinheads que se apresentam como defensores da supremacia branca e adotam a Ku Klux Klan e o nazismo como modelos enfatizando a ideia de que "Hitler não estava errado". Expressam seu ódio aos negros, judeus, homossexuais e mendigos, além de retomarem o mito da conspiração judaica para dominar o mundo ${ }^{2}$. Jovens tatuados, física e mentalmente, alimentam-se de um substancioso material de propaganda racista que circula via Internet por toda Europa, Estados Unidos e América Latina.

Textos impressos sob a forma de fanzines (revistas produzidas artesanalmente) funcionam como verdadeiros manuais de práticas racistas. Mesmo no Brasil, esses grupos não devem ser ignorados, se avaliados no contexto das grandes migrações, processo constantemente renovado. Lembraria que o fluxo migratório é hoje uma consequência da miséria, do analfabetismo, do desemprego e dos baixos salários que caracterizam o Norte e o Nordeste do Brasil.

\footnotetext{
${ }^{2}$ Sobre o mito da conspiração judaica, ver Raoul Girardet, Mitos e Mitologias Políticas. Trad. Maria Lucia Machado, 1987; Taciana Wiazovski, Bolchevismo \&Judaísmo. A Comunidade Judaica sob o olhar do Deops. Módulo IV- Comunistas. Inventário Deops. São Paulo: Imprensa Oficial; Arquivo do Estado, 2001; Maria Luiza Tucci Carneiro, "O mito da conspiração judaica e a Polícia Política na Era Vargas”, In: Minorias Silenciadas. História da Censura no Brasil. São Paulo: Edusp; Fapesp, 2002, pp.263-308; Rodrigo Patto Sá Motta "O mito da conspiração judaico-comunista", In: Revista de História. São Paulo: USP; FFLCH, O 138, 1998.
} 
Também se propaga a ideia de uma Dinamarca para os dinamarqueses, uma Suécia para os suecos, uma França só de franceses. O argumento utilizado não é o da preservação de uma raça pura ou superior justificada com base em teorias científicas, como aconteceu em toda a Europa e, inclusive, no Brasil, a partir das últimas décadas do século XIX. O neorracismo cultural defende o direito de ser diferente, mas com um sentido discriminatório: cada um no seu lugar, cada povo em seu país. Através de um nacionalismo extremado alega-se que a cultura e a etnia nacional estão sendo ameaçadas em sua "pureza" ao serem infectadas por estrangeiros.

Constatamos que, nestas últimas décadas, renasceu na Europa desenvolvida uma mentalidade segregacionista, apoiada na ideia de que o continente precisa ser preservado da invasão de estranhos: os pobres emigrantes do Terceiro Mundo e as levas de desempregados dos antigos países socialistas do Leste Europeu. O preconceito emerge como reação e solução para a crise econômica, para a instabilidade mundial e para a explosão demográfica. Aponta-se o inimigo - o imigrante pobre - pelo fato deste estar disputando o mercado de trabalho. A ideologia do trabalho emerge travestida de outras máscaras.

Foi sobre esse prisma que a imprensa internacional denunciou a campanha de limpeza étnica levada a cabo pelos sérvios contra os kosovares e os albaneses. Estimava-se em 200 mil o total de albaneses étnicos que, expulsos de suas casas, foram dados como "desaparecidos" (leia-se aqui, como mortos, presos ou escondidos em colinas e florestas). Um número alarmante de kosovares perambulou sem rumo pelo território, clamando pela ajuda internacional. Representantes da ONU, em missão humanitária, tentaram estabelecer o nível de prejuízos humanos e materiais causados pela repressão servia. Os jornais anunciaram nos últimos dias do mês de maio de 1999 a intensificação da campanha de limpeza étnica desencadeada no momento em que a Organização do Tratado do Atlântico Norte (OTAN) liberava a Operação Força Aliada contra a Iugoslávia, destinada a obrigar o presidente Slobodan Milosevic, a retirar suas tropas de Kosovo e encerrar a repressão ${ }^{3}$.

\footnotetext{
${ }^{3}$ Brasileiro diz ter provas de limpeza étnica sérvia (Reuters, Ansa, EFE, Associated Press, Franco Presse e DPA) In O Estado de S. Paulo, 25 de maio de 1999, p. A20.
}

Nesse clima de guerra e intolerância, os refugiados transformam-se, novamente, no alvo das atenções. Segundo o Alto Comissariado para os Refugiados (Acnur), órgão da ONU, cerca de 20 mil deles cruzaram no dia 24 de maio de 1999 a fronteira Macedônia e mais de 4 mil, a albanesa, num trabalho "muito bem organizado pela polícia servia". Essa foi mais uma das ofensivas servias para expulsar os kosovares, muitos dos quais foram levados para campos de concentração em Belgrado e forçados a abrir trincheiras para o Exército. Autoridades albanesas previam um desequilíbrio étnico no país. Mas, o que há de especial em todas essas manobras que, certamente, nos deixam perplexos?

O inacreditável é que, mesmo depois da II Guerra Mundial e do Holocausto, nações ditas civilizadas continuem a insistir no mesmo erro, submergindo num total estado de amnésia e de miopia. Se retrocedermos na História da Europa e da América, inclusive do Brasil contemporâneo, verificaremos que a questão dos refugiados sempre se fez presente, pontuando as políticas nacionais e internacionais, seja como país de origem ou como país de destino. Altos-Comissariados, Comitês executivos e Comitês administrativos se apresentaram como formas repetitivas de soluções formuladas por aqueles que, diante do mundo, queriam ser reconhecidos como estados soberanos, independente das diferenças de poder. Este enfoque, segundo Montserrat Guibernau, talvez se preste a explicar a proliferação de tantas instituições internacionais que, com características humanitárias, passaram a existir após a I Guerra Mundial. Participar ou não dessas comissões transformou-se em passaporte para o reconhecimento, em termos de igualdade, de todo Estado que se pretende moderno, nacional. Isto porque "um estado não pode se tornar soberano a não ser dentro de um sistema de outros estados soberanos, sendo a sua soberania reconhecida por estes ... ${ }^{4}$.

Sob este prisma, avaliamos o posicionamento do governo brasileiro que, enquanto Estado-Nação, renegou -- nas décadas de 30, 40 e no período imediato do pós-guerra - os refugiados judeus, tratando-os como "raça

\footnotetext{
${ }^{4}$ Montserrat Guibernau, Nacionalismos. O Estado Nacional e o nacionalismo no século XX.
Trad. Mauro Gama e Cláudia M. Garoa. Rio de Janeiro: Jorge Zahar Editor, 1997;

${ }^{4}$ Montserrat Guibernau, Nacionalismos. O Estado Nacional e o nacionalismo no século XX.
Trad. Mauro Gama e Cláudia M. Garoa. Rio de Janeiro: Jorge Zahar Editor, 1997;
} GIDDENS, A. The Nation State and Violence. Cambridge: Polity Press, 1985, p. 199. 
indesejável”. Um estudo com tais características nos coloca diante de distintos processos históricos vivenciados por países europeus e americanos, a partir do momento em que esses tomaram conhecimento das perseguições antissemitas empreendidas pelo Reich. Analisando a documentação oficial produzida durante o desenrolar do Holocausto, temos a oportunidade de conhecer as atitudes e as reações dos governos latinoamericanos e, em especial do Brasil, que se valeram do antissemitismo como instrumento político.

Alguns ensaios nessa direção já foram desenvolvidos por Haim Avni, da Universidade Hebraica de Jerusalém, que investigou o papel assumido pelo Peru, Bolívia, México, Bermuda e Santa Rosa diante do resgate de judeus durante o Holocausto ${ }^{6}$. A mesma problemática em outros países como Argentina, Chile, México, Cuba, Canadá e Peru - foi amplamente analisada por Leonardo Senkman, Mario Sznadjer, Graciela Ben-Dror, Judit Bolkser Liwerant, Rosa Perla Raicher, Daniel Lvovich, Miguel Galante e Adrian Melnizky, David Sheinin, Juan Luís Orrego Penagos ${ }^{7}$. No caso do Brasil cabe citar as obras de Avrahan Milgram, Jeffrey Lesser, Fábio Koifman e Maria Luiza Tucci Carneiro ${ }^{8}$.

${ }^{5}$ Maria Luiza Tucci Carneiro, $O$ antissemitismo na Era Vargas. $3^{\text {a }}$ ed. São Paulo: Perspectiva, 2001; Cidadão do Mundo. O Brasil diante da questão dos refugiados judeus (1933-1948). Tese apresentada para o Concurso de Livre Docência junto a FFLCH/USP, 2001.

${ }^{6}$ Haim Avni, "Peru y Bolívia. Dos naciones andinas y los refugiados judios durante la Era Nazi". Separata de El Genocídio ante la História y la Natureza Humana, Op. cit., pp. 327361; "El Antisemitismo bajo regimenes democráticos y sistemas dictatoriales: la experiencia de las comunidades judias latinoamericanas". Separata de Maïshavot/Pensamientos. Ano XXXIII, n 1-2, enero-junio 1994. Tevet-Sivan 5754, pp.7-42; "Cárdenas, México y los refugiados 1938-1940. Separata de E. I. A. L v. 3, n 1, 1992, Universidad de Tel Aviv, pp. 5-22”; Entre Bermuda y Santa Rosa. El rescate de judíos durante el Holocausto en perspectiva mexicana. Separata da Revista Mexicana de Ciencias Políticas y Sociales. UNAM, Ano XLI, octubre-diciembre 1996, n 166, pp.133-163.

Os estudos destes autores estarão reunidos na coletânea $O$ Antissemitismo nas Américas. História e Memória, organizada por Maria Luiza Tucci Carneiro. São Paulo: Editora Perspectiva (no prelo).

${ }^{8}$ Jeffrey Lesser, A questão judaica. Imigração, Diplomacia e Preconceito. Rio de Janeiro: Imago, 1995; Avrahan Milgram, Os judeus do Vaticano. A tentativa de salvação de Católicos não arianos da Alemanha ao Brasil através do Vaticano (1939-1942). Rio de Janeiro: Imago, 1995; Marcos Shor Maio, Nem Rotschild nem Trotsky. O pensamento antissemita de Gustavo Barroso. Rio de Janeiro: Imago, 1992; Fábio Koifman, Quixote nas trevas. O Embaixador Souza Dantas e os refugiados do nazismo. Rio de Janeiro: Record, 2002.
No seu conjunto, estudos desta natureza nos permitem compor um amplo painel expressivo do papel desempenhado pela América Latina no salvamento dos judeus durante o Holocausto e no acobertamento de refugiados nazistas no pós-guerra. Ao analisarmos a posição internacional assumida pelo Brasil -- principalmente após o ano de 1938, quando ocorreu a anexação da Áustria pela Alemanha, e após 1941, quando a Alemanha invadiu a Rússia e deu início ao extermínio em massa dos judeus -- temos a oportunidade de avaliar o processo de configuração do expansionismo nazifascista em território nacional. Nessa mesma época, o governo americano através da figura do Presidente Roosevelt convocava todos os países a participar da Conferência de Evian (1938) de forma a tornar pública seus esforços para salvar as vítimas alemãs e austríacas do inferno nazista. Percebemos que quanto mais que se agravavam as perseguições antissemitas empreendidas pelo III Reich, mais os países da América Latina emergiam como lugares apropriados para refúgio. E, para alguns desses países latino-americanos, os refugiados judeus eram ainda uma incógnita, se considerarmos que as grandes comunidades judaicas estavam concentradas na Argentina e no Brasil' .

Hoje - ao lermos nos jornais as notícias sobre Kosovo, a ação bárbara de grupos neonazistas que pedem a morte de ciganos, homossexuais, judeus e negros e as críticas contra Israel - temos a impressão de estarmos lidando com uma velha história. Imagens veiculadas pela TV nos fazem recordar antigos pogrons: lojas abandonadas, galerias saqueadas, vidraças estilhaçadas, velhos e crianças andando a esmo em busca de um abrigo. A violência simbólica é sempre o ponto de partida para a violência física, material. Casas bombardeadas e queimadas e aldeias vazias se contrapõem aos acampamentos superlotados habitados pelas vítimas dos extremismos. Sombras nas janelas espreitam sem mostrar seus rostos assustados, transfigurados pelo desespero. $\mathrm{O}$ medo mora nessas almas desalojadas pela intolerância. De repente, o mundo - observado através dos multicanais - encontra-se possuído por novos demônios renascidos das cinzas do Inferno.

O antissemitismo retorna com algumas de suas características seculares: de reorganização do mundo a partir de uma teoria que, para este

${ }^{9}$ Haim Avni, "Peru y Bolívia. Dos naciones andinas y los refugiados judíos durante la Era Nazi”, Op. cit., p. 327. 
século XXI, assumiu novas variáveis. Assim, o componente "nazista" no discurso antissionista não é casual. Segundo Senkman, em palestra recente na Universidade de São Paulo, pretende-se (des)legitimar o Estado de Israel enquanto Estado-nação e desumanizar o judaísmo. Retoma-se a teoria da conspiração lapidada com novos motivos, responsabiliza-se Israel pelo conflito no Oriente Médio, além de colocar os judeus como aliados do imperialismo americano. Mitos mobilizadores - cujo sucesso não deve ser ignorado nas décadas de 1930-1940- vão sendo (re)semantizados e inseridos no circuito da globalização ${ }^{10}$.

Persiste o princípio da viscosidade e da barbárie interpretado como inerente à natureza judaica. A multiplicação do ódio aos judeus continua a não tem nenhum compromisso com a razão e enquanto fenômeno sociopolítico deve ser denunciado e abominado. Cabe aos intérpretes desta realidade - jornalistas, historiadores e cientistas políticos - reconstituir, de forma multidisciplinar, a gênese desse sentimento que tem suas raízes na deflagração da modernidade.

\section{A velha tradição antissemita}

Inúmeros são os intelectuais que, engajados na política, defendem o conceito de um novo antissemitismo para a história da intolerância no século XXI. Dentre estes estão Bernard-Henri Lévy, pensador francês da atualidade, e Leonardo Senkman, historiador da Universidade Hebraica de Jerusalém. Entrevistado em julho de 2002, Lévy declarou acreditar em um novo tipo de antissemitismo que é, ao mesmo tempo, original e antigo:

É novo porque é centrado num novo argumento, que é o ódio a Israel. $\mathrm{O}$ argumento principal é a diabolização de Israel, a satanização de Ariel Sharon e a identificação de todos os judeus com o primeiroministro israelense. Mas, como sempre na história do antissemitismo, temos uma reformulação de velhas histórias, com antigos argumentos retornados e sendo reciclados ${ }^{11}$.

\footnotetext{
${ }^{10}$ Cf. Leonardo Senkman em palestra de abertura do workshop Identidades coletivas, antissemitismo e representações da alteridade. São Paulo/USP: Centro de Estudos Judaicos, Programa de Pós-Graduação de Língua Hebraica, Literatura e Cultura Judaicas e Internacional Center for University Teaching of Jewish Civilization/Israel, 2002.

${ }^{11}$ Bernard-Henri Lévy, "Existe um novo tipo de antissemitismo". Entrevista realizada por Anel Finguerman. $O$ Globo, 2/06/2002. Reproduzido em:
}

Esse novo antissemitismo, na opinião de Lévy, nada mais é do que velho tema enterrado na memória do Ocidente e que voltou num novo formato. A título de exemplo temos a recuperação das imagens do judeu errante (representado na figura do judeu apátrida, sem terra e sem pátria por tradição), do judeu deicida (dos judeus assassinos de Cristo e de crianças), do judeu estrangeiro (o estranho na terra dos outros) e do judeu conspirador. Tomando estes elementos como referência, veremos que, tanto a mídia nacional como a internacional, se alimentam de uma velha tradição antissemita para interpretar a crise do Oriente Médio. Valores antissionistas e antissemitas são empregados de forma a confundir a opinião pública que, nem sempre, interpreta os fatos levando em consideração a perspectiva histórica. A maioria dos discursos tem como fonte a realidade em marcha delineada pela crise entre palestinos e israelenses, que extrapola as fronteiras do conflito propriamente dito para além do político, assumindo dimensões culturais.

A atual situação no Oriente Médio cria uma certa porosidade que propicia a proliferação de ideias antissemitas, muitas das quais se encontram em constante estado de hibernação. E toda vez que o antissemitismo emerge enquanto fenômeno social e instrumento político retrocedemos no árduo processo de democratização e reconhecimentos dos Direitos Humanos. Avaliando a produção das notícias sobre a crise no Oriente Médio pelo viés da macromemória, constatamos que o mundo se esqueceu do que foi o Holocausto enquanto crime hediondo praticado pelo Nazismo.

Líderes políticos, profissionais da imprensa e jovens ativistas - como que envolvidos por uma ilusão comovedora - apelam para um vocabulário que bordeja um tenebroso abismo. Tanto a seleção de imagens quanto os textos "construídos" pelos articulistas da mídia encontram-se filtrados por um ideário antissemita de tradição secular fundamentado na mentira, na distorção e omissão de informações históricas. E os silêncios propositais, como muito bem já atestou a História, abrem fissuras - ainda que sutis para a prática do racismo sem limites. Haja vista a onda de intolerância ocorrida desde o final do ano 2000 na Itália, Bélgica, França e Ucrânia quando sinagogas e cemitérios judaicos foram alvos de agressões antissemitas. E não devemos aqui ignorar a tradição antissemita da França que, em fins do século XIX e primeiras décadas do XX, produziu uma

http://oglobo.globo.com/Mundo/22112307.htm 
ampla literatura antijudaica, consumida como matriz teórica por outros intelectuais antissemitas, inclusive brasileiros.

É nesse contexto - o da distorção da História e o lugar da memória que insistimos sobre o perigo do discurso antissemita que, nos dias atuais, prolifera tanto entre os partidários da extrema-direita como entre os adeptos da esquerda, ambos "contaminados" por esse veneno secular. Para sermos justos, não devemos pesar na mesma balança os atos nazistas, sionistas e terroristas. Avaliações simplistas ofuscam a interpretação dos fatos que, atualmente, se faz modelada por valores maniqueístas. Como muito bem frisou o escritor israelense Amos $\mathrm{Oz}$, estão em questão dois projetos políticos distintos que merecem nosso total apoio: o da nação palestina de libertar-se da ocupação e tornar realidade a criação de um Estado palestino independente; e o da nação de judaica de ter o seu Estado reconhecido enquanto direito natural. Condenar a sobrevivência do Estado judeu, livre e soberano ou a criação de um Estado palestino significar ignorar o direito que ambos os povos têm à terra.

Terrorismo e fanatismo não devem servir de ingredientes para uma guerra que se diz "Santa" em Terra Santa. É neste contexto - o da desrazão - que o antissemitismo encontra campo para proliferar comprometendo as negociações de Paz, já desgastadas pelo constante processo de manipulação das versões sobre o conflito. É incrível a dificuldade que as nações ditas civilizadas têm para se desvencilhar dos mitos, alguns seculares. Dentre estes, o do judeu errante, o do judeu deicida, o do judeu estrangeiro, invasor e o judeu conspirador.

E o Brasil não pode deixar-se contaminar pelo ódio e a intolerância que, num passado não tão longínquo, marcaram seu passado de nação. Haja vista que o governo brasileiro, em diferentes momentos de sua história política, oscilou entre o diálogo democrático e o monólogo autoritário. Colocando-se a favor da destruição de Israel e da expulsão dos judeus de sua terra, nós brasileiros - judeus e não judeus - estaremos apoiando o fanatismo desenfreado, pautado na ignorância. $O$ que os fanáticos não querem entender é que sionismo não é imperialismo; enquanto que terrorismo é uma guerra travada pelo Islã fanático.

Não podemos ignorar que em 1975 rompeu-se a equidistância pragmática (de conciliação) sustentada pelo governo brasileiro desde a criação do Estado de Israel. Atingido pela crise mundial do petróleo, o
Brasil optou por uma postura radical: votou na Assembleia Geral da ONU a favor da Resolução $\mathrm{n}^{\circ} 3.379$ que qualificava o sionismo como forma de racismo e discriminação racial. E, a partir da Intifada, a mídia brasileira reforça a associação negativa entre sionismo/ racismo ao rotular Israel de "potência racista e exterminadora", cujo regime é comparado ao apartheid da África do Sul. Essas imagens - deturpadas pela ignorância, interesses políticos e econômicos - implicam parcialidade de julgamentos, expressando as condições limitadas daqueles que as interpretam.

Não é de hoje que um antissemitismo velado serpenteia pela mídia brasileira que, desde 1947 e principalmente a partir da Guerra dos Seis Dias (5 a 11/6/1967), ignora que a formação do Estado de Israel tem uma dimensão histórica. Matérias comprometidas com as percepções dos sentidos (paixões e emoções) apresentam Israel como um país "expansionista", "usurpador de cidadania", "força de ocupação", "opressor" etc., versão reforçada pelos livros didáticos de História e Geografia Geral. Os países árabes aparecem como vítimas massacradas pelos judeus, estes descritos como "povo armado e dominador"; Israel é descrito como o vilão da história. Massacre e chacina tornaram-se palavras usuais para classificar as ações militares do Estado de Israel.

Em 1947, a imprensa carioca mostrou-se emocionada com o enforcamento de dois sargentos ingleses sequestrados pelo Irgun (milícia clandestina judaica) sem, no entanto, mostrar qualquer indignação ante as façanhas praticadas em represália pela soldadesca britânica em Tel-aviv que, além de metralhar o povo nas ruas, incendiou dois cafés de propriedade judaica e investiu de carro contra a multidão que assistia ao enterro de cinco vítimas dessa chacina. Alguns jornalistas - sem distinguir "terroristas" de "partisans" - chegaram a comparar os métodos do Irgun ao da Gestapo, polícia política do III Reich. Em 1967, o Jornal do Brasil retomou essa tática discursiva ao comparar as investidas militares israelenses às táticas nazistas, ao mesmo tempo em que os terroristas palestinos eram tratados como "guerrilheiros", "ativistas" e "desalojados"12.

\footnotetext{
${ }^{12}$ Cf. Revista Aonde Vamos?, 7.08.47 Jornal do Brasil, 1/06, 6/06 e 1/07/1067. Um amplo levantamento nesta direção foi realizado por Diana Kuperman, "Mídia e Oriente Médio: uma relação de guerra e paz" In: Norma Breda dos Santos (org.), Brasil e Israel. Diplomacia e Sociedade. Brasília: Eunb, 2000, pp. 235-264.
} 
Em janeiro de 2001, o sociólogo Emir Sader, comprometido com sua visão parcial acerca dos conflitos no Oriente Médio, publicou na coluna Opinião da Folha de S. Paulo, suas críticas a Israel fundadas no velho discurso "à moda dos Protocolos". Essa mesma coluna abriu espaço em fevereiro de 2002 para a "opinião" de Gabriela Wolters que, para compor seu artigo "Os guetos de Sharon", apelou para uma análise sobre a dimensão da barbárie israelense igualada, genericamente, à barbárie nazista. Ao acusar os israelenses de estarem enclausurando os palestinos em "guetos e campos de extermínio semelhantes àqueles criados pelos nazistas durante a II Guerra Mundial", a autora ignora conceitos históricos, reafirmando a sua hipótese de que "os segregados de ontem são os segregadores de hoje".

No entanto, essa apropriação do discurso nazista não é um "demérito" apenas de intelectuais brasileiros. Em março de 2002, o escritor português José Saramago - Prêmio Nobel de Literatura e autor popular em Israel, com livros traduzidos para o hebraico - comparou a repressão israelense a "uma forma mais perversa de apartheid". Após ter se encontrado com o líder palestino Arafat em Ramallah, José Saramago fez jus ao título de uma de suas obras mais recentes Ensaio sobre a Cegueira: comparou o sofrimento dos palestinos, sob a ocupação das tropas israelenses, com o sofrimento dos judeus nos campos de concentração nazistas. Referindo-se aos campos palestinos observou: “... tudo isso tem um ar de campo de concentração que me faz lembrar de Auschwitz...". Nessa mesma data, um atentado suicida num hotel da cidade de Netania, praticado por um extremista palestino do Hamas, deixava pelo menos 16 mortos e 130 feridos ( $24 \mathrm{em}$ estado grave). No momento do ataque, as vítimas (todas civis) reuniam-se para comemorar o início do Pessach (Páscoa judaica).

\section{O lugar da memória}

Constatamos que o velho antissemitismo não desapareceu com a morte de Hitler em 1945 e que a singularidade de Auschwitz não se esgotou com o julgamento de Nuremberg, quando dirigentes nazistas foram julgados por crimes contra a humanidade. O nazismo, com certeza, não se esgotou no Holocausto judeu, e as consequências dessa tragédia ainda não foram totalmente avaliadas, dada a dimensão da sua monstruosidade, até hoje incompreensível. Aliás, essa é uma das forças do antissemitismo: de renascer das cinzas e retornar disfarçado de modernidade, de se manter e se propagar conseguindo sempre novos adeptos. E toda vez que o antissemitismo emerge enquanto fenômeno social e pretexto político, retrocedemos no árduo processo de democratização e reconhecimento dos Direitos Humanos.

Poderíamos aqui citar exemplos de candidatos políticos, jornalistas, renomados escritores e intelectuais (alguns dos quais brasileiros) que, em seus artigos e pronunciamentos recentes se apropriaram do discurso nazista para explicar a crise no Oriente Médio ou o problema dos sem-terra no Brasil. Ao invés de informar, desinformam, confundindo aqueles que não conseguem distinguir o Holocausto de outros genocídios. Daí a necessidade de explicarmos aos nossos jovens (e porque não, também os adultos professores e militantes políticos, principalmente?) o significado da Solução Final para as minorias étnicas perseguidas pelos nazistas.

Espinosa, em uma de suas reflexões a respeito das coisas humanas, afirmou: “... devemos procurar sempre não rir, não chorar, não se indignar, mas compreender". No entanto, sabemos o quanto é difícil (até mesmo impossível) compreender o que foi o Holocausto. Renomados cineastas escolheram representá-lo através do humor; outros optaram por recriar cenas tão próximas a realidade que conseguiram tocar fundo a alma dos espectadores mais insensíveis. Mas, em qualquer situação, é difícil não se indignar diante do grau de degradação humana vivenciada por aqueles que estiveram em um campo de concentração. Este "estado de espírito", cineasta algum conseguirá recriar em filme dada a dimensão de tragédia alcançada pela Shoá. Mas, nada nos impede de reconhecer que cada vítima tem um valor absoluto se considerado o grau de injustiça cometido contra ela. Cada fato, como Auschwitz ou Hiroshima, tem lugar próprio no espaço da memória, tanto individual quanto coletiva.

\section{Estratégias de luta contra o novo antissemitismo}

Cabe a nós, através da educação formal e informal sensibilizar nossos jovens para a singularidade de Auschwitz e para a capacidade inesgotável do ser humano de fazer o Mal. Não podemos deixar que o mundo fique cego e que a memória se apague. $\mathrm{E}$, se isso acontece, o todo se converte em Nada, porque o homem, preocupado em julgar, se abstêm do passado histórico. É quando retrocedemos aos escombros da ignorância. É como se todos procurassem fazer, à moda do escritor José Saramago, um "ensaio sobre a cegueira". Às vezes, me parece que o mundo esqueceu-se do que foi 
o Holocausto enquanto crime hediondo praticado pelo Nazismo. É com esta preocupação - a de não esquecer, de lembrar sempre - que insisto na importância de assumirmos o Holocausto como um tema permanente na educação, formal e informal, dos nossos jovens. E esta questão diz respeito também aos não judeus, reprodutores incansáveis do antissemitismo, cujos limites devem ser constantemente avaliados.

Rememorar o Holocausto nos coloca em estado de alerta contra uma possível reprodução das circunstâncias históricas que deram origem ao plano de extermínio arquitetado pelos nazistas. Mas é preciso lembrar, ainda que parcelas da sociedade estejam interessadas em silenciar ou, então, em distorcer os fatos. Precisamos estar atentos a esta produção intencional de silêncios procurando compreender a razão do não dito, pois nem sempre o silêncio é sinônimo de "implícito" ou de "não querer lembrar". O não dizer está, na maioria das vezes, ligado à história e à ideologia. Portanto, não deve ser interpretado como um mero acidente de linguagem, mas como um "ato de intenção". E, para isso, os nossos jovens têm que estar instrumentalizados (sensibilizados) para perceber os silêncios e as deturpações. Muitos estudantes sequer conhecem as verdadeiras dimensões do que foi o nazismo ou as consequências das absurdas teorias racistas de Hitler e seus seguidores para a humanidade. E a ignorância conquista espaço em meio a este mundo em que a violência e assassinatos em massa emergem como métodos aceitáveis e, até mesmo, justificáveis.

Aqui está o desafio: em "quebrar" a corrente do silêncio, ajudando a lembrar. Lembrar sempre que foi o Estado nazista que arquitetou, de forma lógica e sistemática, a destruição de um povo: o povo judeu. Que foi a mente maquiavélica e calculista de Hitler que, subsidiada pelo aparelho burocrático do Estado, espalhou o ódio contra os judeus, homossexuais, ciganos, comunistas, testemunhas de Jeová e outras tantas minorias. A Ciência, ao invés de apenas salvar os homens da morte, também foi acionada para matar. $\mathrm{O}$ primeiro apoio que Hitler recebeu foi das universidades. Foi nos institutos de pesquisa nazistas que antropólogos, psiquiatras, médicos e geneticistas decidiram, através de seus estudos, os limites entre a vida e morte. Portanto, ao rever a história do III Reich, constatamos que as universidades também "formam monstros": é nos centros de educação que os nossos jovens aprendem a pensar (para o Bem ou para o Mal).
Isto nos mostra que a educação só tem sentido se for humanizada. Portanto, cabe a nós educadores - numa ação conjunta com os representantes da sociedade civil - formular políticas públicas de combate às ideologias racistas. Estratégias devem ser adotadas em dois níveis distintos: na infância e na adolescência. Tanto Janusz Korczak como Theodor Adorno enfatizaram a importância de mudarmos a educação; caso contrário, não conseguiremos mudar o mundo. $\mathrm{O}$ estudo interdisciplinar do Holocausto poderá colaborar para a afirmação de uma série de princípios democráticos que, no seu conjunto, devem reger a vida social e política de toda a nação que valoriza a dignidade humana e a igualdade de direitos.

Iniciativas nesta direção já estão sendo desenvolvidas pela Universidade de São Paulo que, nestes últimos anos, tem oferecido cursos sobre as múltiplas formas de expressão da intolerância. Nos anos 70, Anita Novinsky foi pioneira ao introduzir os estudos inquisitoriais com o objetivo de mudar a visão de mundo de nossos jovens universitários. A partir de 1990, cursos específicos sobre racismo e antissemitismo começaram a ser ministrados pelo Departamento de História e pelo Programa de PósGraduação em Língua Hebraica, Literatura e Cultura Judaicas, ambos da FFLCH. Teses inéditas produziram conhecimentos sobre as práticas antissemitas, o Holocausto, políticas imigratórias e imprensa antissemita no Brasil. Em junho de 2002, organizamos a I Jornada Interdisciplinar sobre Holocausto, dedicada a orientar professores de I e II graus, e universitários. Em 25 de novembro próximo, será inaugurado na USP o Laboratório de Estudos sobre a Intolerância presidido por Anita Novinsky, projeto pioneiro de incentivo a pesquisa sobre a intolerância, o primeiro na América Latina.

$\mathrm{O}$ que mais poderemos fazer, além de incentivar a pesquisa, ministrar cursos e seminários? Experiências podem ser retomadas e aprimoradas, como, por exemplo,: incentivar os sobreviventes dos campos de concentração a escreverem suas memórias e a publicarem seus diários; tornando disponível às escolas e aos pesquisadores um banco de dados sobre os sobreviventes do Holocausto radicados no Brasil; divulgar entre os jovens a obra de Lasar Segall, enquanto libelo social contra a intolerância e a guerra; empreender uma revisão dos livros didáticos que silenciam sobre o antissemitismo; criar jornadas educacionais permanentes, dedicadas a recuperar o sentido da vida e da morte nos momentos de degeneração do eu. Enfim, a preservação da memória da Shoá -- ainda que uma página triste na história da Humanidade -deve ser (re) vista como uma das formas possíveis de luta e de repúdio ao 
antissemitismo. E a educação tem aqui um importante papel a cumprir, como muito bem lembrou um aluno ao seu professor:

\section{Caro professor:}

Eu sou um sobrevivente de um campo de concentração. Meus olhos viram o que nenhum ser humano deveria testemunhar: câmaras de gás construídas por engenheiros ilustres, crianças envenenadas por médicos altamente especializados, recém-nascidos mortos por enfermeiras diplomadas, mulheres e bebês assassinados e queimados por gente formada em ginásio, colégio e Universidade. Por isso, caro professor eu duvido da educação.E eu lhe formulo um pedido:

Ajude seus estudantes a se tornarem humanos. Seu esforço, professor, nunca deve produzir monstros eruditos e cultos, psicopatas e Eichmans educados.

Ler e escrever aritmética são importantes somente se servirem a tornar nossas crianças seres mais humanos.

\section{As comunidades judaicas e o exercício da cidadania: do direito à vida, à liberdade e à segurança}

\section{Sinaida de Gregório Leão}

Presente artigo se propõe a analisar o efetivo exercício da cidadania pela comunidade judaica brasileira, no que se refere aos direitos fundamentais assegurados aos cidadãos brasileiros pela Constituição Federal: o direito à vida, à liberdade e à segurança, direitos esses ameaçados pelo preconceito - compreendido como o sentimento de superioridade de um grupo sobre outro - e pela discriminação compreendida como o ato gerado pelo sentimento de superioridade, ou seja, a concretização do preconceito.

Buscar-se-á analisar a qualidade e a efetividade das leis brasileiras de proteção aos cidadãos brasileiros, vítimas da discriminação, e principalmente avaliar de que forma os judeus brasileiros, enquanto cidadãos, têm exercido sua cidadania na defesa de seus direitos fundamentais, seja através de mecanismos jurídicos, seja através de mecanismos sociais, e que podem ser resumidos no simples direito do povo judeu de existir na sua individualidade. Mais do que respostas prontas, pretende-se fazer um convite a todos, um convite à reflexão sobre o comportamento dos indivíduos judeus, enquanto cidadãos brasileiros, de confissão religiosa judaica, e enquanto vítimas de preconceito e discriminação, ainda que velados na sociedade brasileira.

Há mais de uma década, o professor israelense Nathan Lerner, em palestra no Instituto dos Advogados Brasileiros (IAB), tratando das diversas formas de preconceito e discriminação, explicou a imensa dificuldade em se combater o preconceito velado, mascarado pela sociedade, como o que existe na sociedade brasileira, uma dificuldade muito maior do que combater o preconceito declarado e ostensivo, como por exemplo o manifestado através do "apartheid" na África do Sul.

${ }^{1}$ Mestre em Direito / UFF. 
As Constituições Brasileiras, desde a primeira constituição republicana de 1890 , se preocuparam com o preconceito, daí a inserção desde aquela época do princípio da igualdade: "todos são iguais perante a lei". Ao longo do tempo, os direitos fundamentais dos indivíduos, aqueles já preconizados na Declaração dos Direitos do Homem editada pelos revolucionários franceses, foram cada vez mais reafirmados textualmente ou formalmente nas constituições pátrias, embora na realidade as garantias de tais direitos oscilassem ao longo do tempo de acordo com o período histórico vivenciado, isto é, de acordo com o maior ou menor nível de democracia usufruído.

Nesse contexto, merece destaque a Constituição de 1946, uma das constituições brasileiras, formalmente, mais democráticas e que, editada no imediato pós-guerra, preocupou-se em garantir de forma minuciosa os direitos à liberdade de pensamento, crença e expressão, desde que não contrários aos bons costumes e a ordem democrática. A Constituição de 1988 veio complementar o trabalho da de 1946, elevando à égide constitucional a previsão do crime de racismo, até então visto como simples contravenção penal, ilícito de menor importância, determinando que a prática do racismo constitui-se em crime inafiançável e imprescritível.

$\mathrm{Na}$ verdade, o repúdio ao preconceito já figura logo nos princípios fundamentais da Constituição Federal Brasileira, editada em 1988, que dispõe em seu artigo $3^{\circ}$, inciso IV, que:

Constituem objetivos fundamentais da República Federativa do Brasil:

IV - promover o bem de todos, sem preconceitos de origem, raça, sexo, cor, idade e quaisquer outras formas de discriminação.

Em seguida, em seu artigo $5^{\circ}$, proclama a $\mathrm{CF} / 88$ :

Todos são iguais perante a lei, sem distinção de qualquer natureza, garantindo-se aos brasileiros e aos estrangeiros residentes no País a inviolabilidade do direito à vida, à liberdade, à igualdade, à segurança e à propriedade, nos termos seguintes:

E complementa em seus incisos:

XLI - a lei punirá qualquer discriminação atentatória dos direitos e liberdades fundamentais;
XLII - a prática do racismo, constitui crime inafiançável e imprescritível, sujeito à pena de reclusão nos termos da lei.

Complementando a disciplina constitucional, o legislador ordinário editou uma série de leis, visando coibir e punir a prática do racismo. Primeiramente tem-se a Lei 7716 de 5 de janeiro de 1989, que define em vários artigos os crimes resultantes de preconceito de raça ou de cor. Em 1990, editouse a Lei 8081 prescrevendo a punição para a prática, indução e incitação ao racismo realizada através dos meios de comunicação. Em 1994 foi editada a Lei no. 8882, que aludindo claramente ao antissemitismo, prescreveu a punição a quem fabrica, comercializa, distribui ou veicula qualquer símbolo ou propaganda com a cruz suástica ou gamada, para fins de divulgação do nazismo. Em 1997, foi editada a Lei 9459, definindo novos crimes resultantes do preconceito, prevendo a destruição do material de cunho racista apreendido, bem como incluindo no Código Penal uma agravante ao crime de injúria - a referência a elementos de raça, cor, etnia, religião ou origem.

Como proclama o caput do artigo $5^{\circ} \mathrm{da} \mathrm{CF}$, o direito à vida, à liberdade, à igualdade, à segurança e à propriedade são assegurados a todos os cidadãos brasileiros. Mas, ocasionalmente, verifica-se que tais direitos, no que se referem aos judeus, enquanto brasileiros, são maculados, através de ameaças e de atitudes flagrantemente antissemitas. O que ora se coloca em questão é não só a efetividade destas normas, ou seja, se elas tem sido capazes verdadeiramente de coibir e punir o antissemitismo, mas fundamentalmente como os judeus brasileiros têm atuado, no exercício de sua cidadania, para reivindicar a garantia de tais direitos, quando violados.

O paper que motivou este artigo foi elaborado há cerca de um ano. Naquele pequeno resumo narrou-se o que havia motivado a abordagem deste tema. No ano de 2001, causou surpresa a informação em jornais de grande circulação acerca do ressurgimento de grupos neonazistas no Brasil e no Exterior. Esta notícia causou imediatamente uma preocupação junto a toda a comunidade judaica. Que conduta tomar? E se os clubes judeus, a sinagoga, ou o cemitério fossem atacados? O quê fazer? A quem se dirigir? Alegando o quê? Mães começaram a ficar preocupadas com os filhos nas escolas, saindo à noite; enfim, o antissemitismo, que muitos achavam assunto do passado, se fazia muito presente, e muito próximo. Coincidentemente nesta época algumas instituições judaicas sofreram pichações e atos de suposto vandalismo. Logo as comunidades judaicas 
foram instruídas a se protegerem, através das conhecidas advertências: "tomem cuidado", "não se exponham no lado de fora das instituições". Essa situação causou um sentimento de revolta e impotência imensos, compartilhados por toda a comunidade judaica, já que não se podia fazer absolutamente nada para impedir que ideias antissemitas fossem propagadas, pois a imprensa não divulgava o local de reunião destes grupos, protegida pelo direito constitucional de liberdade de imprensa, que resguarda o sigilo da fonte, e porque tais grupos encontram-se, a princípio, também protegidos pelo direito constitucional de liberdade de expressão e pensamento. Ou seja, a única alternativa parecia ser assistir a tudo passivamente, até que algum dia, e espera-se que este dia nunca chegue, algum ativista mais ousado se dispusesse a cometer um ato antissemita contra alguma instituição ou indivíduo.

E aí se faz necessário colocar em relevo os seguintes incisos do artigo $5^{\circ} \mathrm{da} \mathrm{CF} / 88$

IV - é livre a manifestação do pensamento, sendo vedado o anonimato;

VI - é inviolável a liberdade de consciência e de crença, sendo assegurado o livre exercício dos cultos religiosos e garantida, na forma da lei, a proteção dos locais de culto e a suas liturgias;

VIII - ninguém será privado de direitos por motivo de crença religiosa ou de convicção filosófica ou política, salvo se as invocar para eximir-se de obrigação legal a todos imposta e recusar-se a cumprir prestação alternativa, fixada em lei;

XIV - é assegurado a todos o acesso à informação e resguardado o sigilo da fonte, quando necessário ao exercício profissional;

XVII - é plena a liberdade de associação para fins lícitos, vedada a de caráter paramilitar;

Estes dispositivos, como se vê, consagram a liberdade de expressão, pensamento, crença, associação e a liberdade de imprensa, mas quanto à sua aplicabilidade prática detecta- se que ainda são poucos os casos de invocação da tutela jurisdicional por instituições ou membros da comunidade judaica, reivindicando a garantia de tais direitos. Tal inércia pode ser atribuída a vários fatores, desde a falta de credibilidade da comunidade judaica na ação desses grupos organizados, até a própria acomodação comunitária frente a uma "simples" ameaça, o que consiste num grave perigo.

A legislação brasileira antirracismo é eficaz quando o ato com que se depara possui um caráter inequívoco ou evidente de racismo, e quando os responsáveis por atos antissemitas praticados sem nenhum pudor assumem a autoria de tais atos. Deve-se ressaltar, porém, que em muitos casos, há uma resistência por parte das autoridades e muitas vezes, porque não dizer, por parte da própria comunidade judaica em aceitar que certos atos tenham cunho antissemita, preferindo-se enquadrá-los como atos de vandalismo. Não se deve ceder a tal ilusão. Neste momento, a comunidade judaica da França clama fortemente por ajuda; vítima de mais de 400 atos antissemitas desde setembro de 2000, aquela comunidade esbarra na resistência das autoridades francesas em aceitar o cunho antissemita dos ataques, preferindo acreditar que tais atos sejam obra de jovens vândalos. Recentemente, na Alemanha, os judeus de Berlim, face a dois ataques antissemitas ocorridos, foram "aconselhados" pela polícia local a esconderem sua identidade, não portarem solidéus ou quaisquer símbolos judaicos, como estrelas de David, e nem se exporem na parte exterior das sinagogas.

O grande obstáculo à eficácia das leis antirracismo brasileiras está nos casos em que o antissemitismo ou a propaganda antissemita é anônima, e clandestina, e principalmente quando não se viabiliza concretamente através de um ato atentatório das liberdades constitucionais, como a simples existência daqueles grupos citados pelo jornal mencionado. Poder-se-ia perguntar: como impedir a atuação destes grupos neonazistas ou antissemitas, se estes grupos também estão resguardados pelos mesmos direitos constitucionais que são assegurados à comunidade judaica. A doutrina jurídica opina de modo acertado que o direito de um grupo de se manifestar tem seus limites no direito dos outros indivíduos que compõem o grupo social, isto é, o direito de expressão e pensamento deve ser exercido com responsabilidade e não pode violar os direitos fundamentais de outros indivíduos.

Por outro lado, se cerceados ou suprimidos os direitos de expressão e pensamento de outros grupos, amanhã não poderia a própria comunidade judaica ter seus direitos atingidos, se vitimada por uma onda antissemita no Brasil? O documentário "Skokie", que gira em torno da tentativa de realização de uma passeata neonazista numa pequena cidade americana em 
que $90 \%$ da população são judeus, vítimas ou descendentes de vítimas do Holocausto, retrata bem esse dilema por que passa um advogado judeu.

E o que fazer se esses grupos são clandestinos? Poder-se-ia pensar, também, numa restrição à liberdade de imprensa, através da quebra do sigilo da fonte, mas se tal fosse implementado, provavelmente nunca se saberia da existência de tais grupos, que se recusariam evidentemente a serem noticiados. Será, então, que essa restrição não seria mais prejudicial no que se refere ao combate ao antissemitismo?

No combate ao antissemitismo, dois caminhos se descortinam. Primeiramente, quando ameaçado concretamente ou vitimado por um ato antissemita, todo cidadão brasileiro judeu pode e deve recorrer ao Poder Judiciário para requerer que os seus direitos individuais e fundamentais sejam assegurados, seja individualmente, ou através das lideranças comunitárias, o que seria sem sombra de dúvida mais aconselhável, pela própria autoridade e amplitude que se alcançaria. Neste aspecto, há que se ressaltar a importância de lideranças comunitárias fortes e atuantes. E mais do que isso, sobre a importância da união de toda a comunidade judaica. Colocar as diferenças religiosas à parte, restringindo-as à matéria de respeitosa discussão interna e aprofundamento cultural, mais do que nunca, parece ser uma alternativa sábia, num mundo que sempre considerou e ainda considera o povo judeu em sua totalidade, simplesmente como judeus, sem diferenças, um dos únicos povos da Antiguidade que sobreviveu com suas crenças, cultura e tradição até os dias de hoje. A Torá faz de cada indivíduo judeu responsável por outro indivíduo judeu. Antigamente, quando um judeu era reduzido à escravidão a outro povo, era obrigação da comunidade resgatá-lo, pagando o preço devido. A História, além de tornar um judeu responsável pelo outro, fez de cada judeu, um representante de todo o povo judeu. Infelizmente, muitos só percebem isso nos graves momentos em que ameaçados em seu simples direito de existência. Por isso, urge que a comunidade judaica se conscientize da importância de sua atuação fïme, seja individual ou coletiva, no que tange à invocação dos órgãos jurisdicionais brasileiros na defesa de seus direitos.

Além das medidas judiciais, que apesar de eficazes, não chegam a combater as causa do antissemitismo, um outro caminho destina-se a prevenir a propagação de ideias antissemitas, atingido a raiz do problema a educação e a conscientização da população.
A maioria da população brasileira não tem acesso à educação, muitos não sabem ler nem escrever, são cidadãos formais sem cidadania real. Há uns dez anos atrás a Federação Israelita do Rio de Janeiro saiu às ruas fazendo uma pesquisa: perguntava-se a cada passante o que era um judeu? Naquela ocasião uma senhora bem humilde, respondeu, “...Ai, meu filho, é uma coisa tão ruim, que eu não quero nem dizer?"

As raízes do antissemitismo são muitas. Há que se ressaltar as raízes históricas do antissemitismo, determinantes de toda a argumentação psicológica, filosófica ou ideológica de cunho racista. $\mathrm{Na}$ verdade, o antissemitismo ou antijudaísmo foi alimentado durante tantos séculos, que conseguiu penetrar não só no consciente como no inconsciente de muitas pessoas. Por isso, torna-se tão difícil combatê-lo.

O professor e jurista Celso Antônio Bandeira de Mello em artigo virtual intitulado "A democracia e suas dificuldades contemporâneas" opina:

A História da Humanidade, inobstante a progressiva evolução em todos os campos, confirma, tanto quanto fatos e episódios ainda muito recentes, que a prevalência de ideias generosas ou o sepultamento de discriminações odiosas e preconceitos de toda ordem mantém correlação íntima com as situações coletivas de bem estar e segurança. E duram tanto quanto duram estas.

Observa-se geralmente nesta difícil tarefa de combater o antissemitismo através da educação - e a realização deste encontro concretiza este aspecto - que os humildes diante do Saber, que admitem sua ignorância sobre um determinado assunto e se dispõem a aprender, ou que se colocam abertos ao Conhecimento e à revisão de seus pontos de vista, estão plenamente dispostos a aprender, entender e respeitar a cultura e tradição judaicas, e a renunciar ao antissemitismo.

No entanto tudo se torna mais difícil diante dos antissemitas convictos e daqueles que já tem o antissemitismo tão profundamente arraigado no inconsciente, que por vezes nem mesmo eles se dão conta dos sentimentos que possuem. Diante desses, as palavras de esclarecimento inicialmente soarão como expressões parciais, merecedoras de descrédito e até de desprezo. Mas não se deve desistir. Se o discurso antissemita foi durante séculos incutido na mente da população, não se pode ter a ilusão de que poderá ser erradicado em um dia, um mês ou um ano. É um trabalho 
longo, de gerações, mas que jamais pode ser abandonado, pois é o único que pode realmente atingir a causa do antissemitismo.

Albert Einstein, com sua grande sabedoria, já afirmava: "Época triste é a nossa em que é mais difícil quebrar um preconceito do que um átomo". Nesta simples frase Einstein sintetiza o drama da Humanidade, que desde o início dos tempos tem conhecido cada vez mais progressos científicos e tecnológicos, mas que caminhou bem pouco, se é que caminhou, no aperfeiçoamento do espírito humano.

Enfim, o verdadeiro combate ao antissemitismo, e o exercício pleno da cidadania dos judeus brasileiros somente poderá ser viabilizado de forma satisfatória através da utilização consciente das medidas judiciais de que se dispõe, garantidoras das liberdades dos cidadãos brasileiros judeus; da permanente reflexão acerca do exercício responsável das liberdades individuais de expressão, pensamento e crença, pelo povo brasileiro como um todo; e pela incansável disposição de transmitir conhecimentos que conduzam ao respeito e à tolerância das tradições e da cultura judaicas.
Relações entre a polícia política e a comunidade judaica na era Vargas

\section{Isabela Andrade Lima}

Estado Novo, regime instaurado no Brasil a partir de 1937, representa um momento histórico em que a discussão sobre a temática do autoritarismo e do controle foi tomada como determinante para o desenvolvimento da nação.

O discurso da nacionalidade emanava do Estado. Enfatiza-se a consciência nacional, definida por um conjunto de lealdade política, A questão da raça passa a ser discutida, fornecendo justificativas para o atraso brasileiro frente às nações europeias. Retoma-se o conceito de eugenia para construir-se uma nação forte e autenticamente brasileira ${ }^{2}$. O questionamento da formação étnica brasileira e a busca de uma identidade nacional já despertava o interesse da intelectualidade desde os anos 20, intensificando-se nos anos 30 e 40, vê-se então o retorno das ideias de intelectuais como Silvio Romero, Euclides da Cunha, Nina Rodrigues, Alberto Torres, sobressaindo autores como Oliveira Vianna e Affonso Arinos de Melo Franco.

O nacionalismo pregado durante o governo estadonovista se empenhará na construção de uma nova nação e do Homem Novo brasileiro que deve ser patriótico, honesto, bondoso, saudável, limpo, trabalhador, nacionalista e católico ${ }^{3}$. Para a construção de um novo paradigma social, a ideologia política retoma a função tradicional dos mitos e das religiões para guiar as posições da sociedade e garantir o consenso social ${ }^{4}$. Na era Vargas, a Igreja Católica e o Estado compartilham o poder. Desde novembro de

${ }^{1}$ Mestranda do Programa de Pós-Graduação em Antropologia pela Universidade Federal de Pernambuco - UFPE e Membro do Grupo Interdisciplinar de Estudos Judaicos da UFPE. Email de contato: isadelima@bol.com.br - Universidade Federal Rural de Pernambuco.

${ }^{2}$ SCHWACZ, Lilia M. O Espetáculo das Raças: cientistas, instituições e questão racial no Brasil 1870-1930. São Paulo: Companhia das Letras, 1993.

${ }^{3}$ GOMES, Angela de Castro. A Invenção do Trabalhismo. São Paulo: Vértice. Rio de Janeiro. IUPRJ, 1988.

${ }^{4}$ COLOMBO, Eduardo. El Imaginário Social. $3^{\circ}$ Ed., Montevideo: Editorial Altamira, 1993. 
1937 a Igreja reassume seu papel na liderança cultural, enquanto o Estado se ocupa em organizar as relações sociais e econômicas.

O Estado necessitava do discurso catequético, haja vista que a ruptura da unidade católica era tida como um prenúncio da desordem e da anarquia. A Igreja, por sua vez, tentava recuperar o poder perdido com a laicização do Estado. É nesse sentido que 1937 é tido como o período de recatolização do Brasil $^{5}$.

Fazia parte do projeto político-religioso a construção de uma sociedade baseada nos preceitos do catolicismo. E com essa imagem de verdadeiro homem brasileiro que se codifica padrões de alteridade que servem para identificar o "outro", a antítese do homem ideal, nessa perspectiva sobressai a imagem dos judeus.

A aliança entre Igreja e Estado com a finalidade de "guiar" a nova sociedade, reforça a afirmação de Eduardo Colombo de que "o simbolismo político-religioso permaneceu e permanece amarrado, como consubstanciado nas estratégias de dominação",

O objetivo desta comunicação é identificar e analisar os mecanismos e as estratégias utilizadas pela comunidade judaica em Pernambuco, no sentido de garantir seu espaço num contexto de vigilância, repressão e controle e, ao mesmo tempo, preservar sua identidade cultural-religiosa.

Os judeus já traziam um legado de serem nocivos. Antes do séc. XIX o antissemitismo manifestava-se de diferentes formas, sendo ele classificado como antissemitismo tradicional, onde o ódio aos judeus apoiava-se no antagonismo entre duas crenças: o catolicismo e o judaísmo. E mesmo quando alguns judeus converteram-se, a política de exclusão contra os mesmos permaneceu. A partir do séc. XIX o antissemitismo passa a apoiar-se em pseudoteorias científicas, antropológicas e etnológicas, empregadas para justificar as ações contra os judeus (antissemitismo moderno $)^{7}$. Sendo assim, o antissemitismo tradicional (religioso) soma-se ao antissemitismo moderno (científico) e os judeus serão identificados

${ }^{5}$ ALMEIDA, Maria das Graças Andrade Ataíde de. A Construção da Verdade Autoritária. No prelo, 2002.

${ }^{6}$ COLOMBO, Eduardo. El Imaginário Social. 3 Ed., Montevideo: Editorial Altamira, 1993

${ }^{7}$ ARENDT, Hannah. O Sistema Totalitário. Lisboa: Dom Quixote, 1978. como indivíduos hostis à civilização, desrespeitadores da fé cristã, antissociais, uma anomalia do ponto de vista racial e político.

No início do século XIX os judeus serão apontados como aqueles que pretendem dominar o mundo secretamente através de uma organização que visava controlar a imprensa, o governo e as finanças, sendo esta ideia influenciada pelo Mito dos Protocolos dos Sábios de Sião, considerada como uma das maiores falsificações do século". Assim, "a pureza de sangue, mito da Idade Média e Moderna, soma-se a ideia de complô judaico, inspirado nos Protocolos" $"$.

A imprensa brasileira através do doutrinamento diário e persuasivo, investe num discurso que traz a tona expressões tanto do antissemitismo tradicional como do antissemitismo moderno. É nesse sentido que os judeus são apresentados como elementos que não se adequavam à nova sociedade, pois eram tidos como nocivos do ponto de vista religioso, racial, étnico, político, social, moral.

A imprensa pernambucana, seja laica ou religiosa, também absorveu e divulgou o discurso antissemita, trazendo a tona a acusação de que os judeus eram um povo deicida, matadores de Cristo, e como tais, deveriam sofrer pelo pecado cometido. Ataíde, nos alerta para observar como o antissemitismo encontrava na própria Bíblia inspiração para acusar os judeus de povo maldito. Sobressaindo passagens bíblicas onde Deus repreende o povo judeu. Por outro lado, textos que revelavam uma linguagem de amor e promessas de restauração de Jeová para com o povo judeu, não eram sequer evidenciados ${ }^{10}$.

Discursos que trazem a baila expressões de antissemitismo moderno, bem como a influência dos Protocolos dos Sábios de Sião, também são evidenciados pela propaganda. Em 1939 circula em Pernambuco um selo com o seguinte teor: "SALVEMOS O BRASIL DA INVASÃO JUDAICA: Por

${ }^{8}$ CARNEIRO, Maria Luiza Tucci. A Trajetória de um Mito no Brasil; os Protocolos dos Sábios de Sião. In. NOVINSKY, Anita e KUPERMAN, Diane (orgs.) Ibéria-Judaica: Os Roteiros da Memória. Rio de Janeiro: Expressão e Cultura. São Paulo: EDUSP, 1996.

9 ALMEIDA, Maria das Graças Andrade Ataíde de. O Discurso da Igreja na Era Vargas, no Brasil, construindo o mito do imigrante indesejável: o judeu. IN: LISOCKA-JAEGERMANN, Bogumila. Dicionário Analítico El Espacio En La Cultura Latinoamericana. 4. Varsóvia: CESLA/Universidad de Varsóvia, 1998

${ }^{10}$ Ibidem. 
causa do judaísmo internacional o Brasil não tem: petróleo, trigo, borracha, tranquilidade, estando sempre ameaçado na sua economia".

$\mathrm{O}$ autor do selo desejando colaborar com a campanha nacionalista que a Revista "Fronteiras" promovia nesta cidade, resolve consultar uma autoridade do Estado para imprimir e divulgar os ditos "selos". Assim, entra em contato com Manuel Lubambo, Secretário da Fazenda da Interventoria Agamenon Magalhães e Diretor da Revista Fronteiras, este, alega que não via inconveniência em divulgar os selos, pois achava que "combater o judaísmo era colaborar com o Estado Novo”. Assim, foram impressos cinco mil selos desta espécie ${ }^{11}$.

$\mathrm{Na}$ campanha contra os judeus, sobressai um discurso que responsabiliza-o também pela infiltração do comunismo no Brasil. Sob essa temática, destaca-se a propaganda integralista. Em um panfleto intitulado "Ação Integralista Brasileira", estimula os homens a meditarem sobre os dois rumos: o do comunismo e o do integralismo, já que o comunismo é apontado como: "destruidor das Religiões, ficando assim o homem subordinado aos seus instintos. Perde a sua liberdade moral e torna-se um autômato, subordinado ao ateísmo do Estado, que é o mais intolerante dos fanatismos.... O comunismo pretende acabar com as Pátrias. Em última análise, transforma todos os países em colônias subordinadas aos interesses de uma minoria de especialistas financeiros. Será o domínio dos judeus como já’ está sendo na Rússia...”

Com o objetivo de combater o seu maior inimigo: o comunismo, o integralismo se empenha em uma propaganda onde aponta os judeus russos como destruidores da propriedade, da família e da religião, em contraposição ao lema integralista: "Deus, Pátria e Família". Sendo assim, todas as propagandas anticomunistas terão também como alvo os judeus, transformando-se em propagandas antissemitas.

Em dezembro de 1935 é criada a Delegacia de Ordem Política e Social - DOPS, com o objetivo de controlar os indivíduos coibindo suas ações a fim de garantir a ordem social ${ }^{12}$, contando com o apoio de uma polícia

\footnotetext{
${ }^{11}$ DOPS/PE. Prontuário $n^{\circ} .1468$

${ }^{12}$ PEREIRA, Márcia G. et. alli.. DOPS: A lógica da desconfiança. Rio de Janeiro: Secretaria de Estado de Justiça, Arquivo Público do Estado, 1993.
}

política tida como agente social da instabilidade social ${ }^{13}$. Nesse momento, têm-se a dupla face da censura, a imprensa e a DOPS contra a imigração judaica para o Brasil ${ }^{14}$.

Vitimados pelas perseguições nazi-fascistas, muitos judeus procuravam auxílio no Brasil que, entretanto, fechou-lhes as portas adotando medidas restritivas em nome da construção de uma nação. Segundo Cancelli, "aparentemente, a maneira como os judeus estavam sendo tratados na Alemanha não produzia qualquer atitude de solidariedade entre as autoridades brasileiras, pelo contrário, reforçava as medidas de controle policial sobre os judeus 15 “. Sendo assim, se vê inúmeros decretos-leis e circulares secretas impedindo a entrada de judeus no país ${ }^{16}$.

Os investigadores da DOPS/PE com o objetivo de coibir qualquer reação que comprometesse a "ordem e a segurança pública", perseguiram todos os indivíduos que não se adequavam à nova ordem. Inúmeros foram os casos de perseguições aos considerados opositores do regime, no entanto, a diferença em relação ao judeu é que bastava esta condição para que fosse considerado suspeito e perigoso à nação. "Judeu" era a palavrachave que designava o verdadeiro inimigo do país.

O controle que a polícia política pernambucana exercia sobre a comunidade judaica de Pernambuco é evidenciado através do olhar vigilante ao Centro Cultural Israelita de Pernambuco. Como forma de controlar os passos desta instituição eram apreendidos estatutos do Centro, relatórios contendo a composição da diretoria, listagens da quantidade de sócios e de bens pertencentes ao respectivo centro ${ }^{17}$.

O lazer de toda a comunidade judaica era vigiado pela polícia. Em 24 de setembro de 1938, o presidente do Círculo Israelita envia uma

${ }^{13}$ CANCELLI, Elizabeth. Ação e repressão policial num circuito integrado internacionalmente IN. PANDOLFI, Dulce, (org.) Repensando o Estado Novo. Rio de Janeiro: Ed. FGV, 1999. p. 309.

${ }^{14}$ ALMEIDA, M. das Graças A. Ataíde. A Dupla Face da Censura: Imprensa e DOPS contra a imigração judaica para o Brasil. na Era Vargas. In. II Encontro Brasileiro de Estudo Judaicos - Presença Judaica no Brasil dos 500 anos: a Construção do Judeu Brasileiro. ${ }^{15}$ CANCELLI, Elizabeth. O mundo da Violência - a policia na era Vargas. Brasília: UNB 1994. p. 126.

${ }^{16}$ Sobre a criação de decretos-leis e circulares secretas impedindo a entrada de judeus no Brasil durante a Era Vargas, vide: CARNEIRO, Maria Luiza Tucci. O Antissemitismo na Era Vargas. São Paulo: Brasiliense, 1995.

${ }^{17}$ DOPS/PE. Prontuário $n^{\circ} 413$. 
solicitação para que o Delegado de Ordem Política e Social "se digne em permitir a realização na sede citada de missas e festas religiosas no período de 25 deste mês de Setembro à 25 de Outubro próximo vindouro". No dia 29 de Outubro de 1945, o vice-presidente do Centro Cultural Israelita envia ao Delegado de Ordem Política e Social a seguinte solicitação: "O Centro Cultural Israelita de Pernambuco, pretendendo realizar um pic-nic no próximo dia 4, na praia de Gaibú, vem pedir a VS. a devida permissão para a realização do referido pic-nic”.

Em março de 1936 a Sociedade Beneficente das Damas Israelitas de Pernambuco, promove uma festa comemorativa ao "Purim" (comemora-se a salvação dos judeus da Pérsia pela rainha Ester) no Centro Israelita de PE, na Rua da Glória, 115. Esta festa é patrocinada pelas senhoras que mantém uma sociedade com o título "Relif Comité". O investigador que está presente e atento à festa expõe em um relatório enviado à DOPS, os fins da sociedade e da festa: - Composta por senhoras; - sem legislação (o que complicado para o momento visto que o Estado Novo através da centralização, controlava e ditava as leis); - arrecada contribuições que são convertidas para os paupérrimos da Colônia desta capital e de outras, daí ser uma organização universal e não local, pois mantém correspondência com outros Estados (observa-se um discurso policial baseado na retórica de internacionalização). Ao final o investigador relata que:- A data que comemora, foi em regozijo à morte do rei da Rússia "Achaskeverct" e de seu ministro "Amon", no momento em que estes tentavam uma nova organização para seu povo, e os judeus não se conformando concorreram moral e materialmente para que fossem assassinados aqueles que estavam oprimindo-os.

O antissemitismo moderno, com a ideia do complô judaico é também evidenciado no discurso policial dos investigadores da DOPS/PE. Em fevereiro de 1943, um investigador realizou um levantamento de todos os judeus representantes de fábricas e filmes cinematográficos. Assim, se vê a influência dos Protocolos dos Sábios de Sião, já que este tinha o objetivo demonstrar que os judeus tentavam dominar o mundo através do controle do governo, das finanças e também da imprensa.

A reprodução do termo "apátrida" é constante nos relatórios policiais quando se trata de apresentar o judeu. Expressões como "expatriado", "desapatriado", "não tem pátria", remontam a ideia de ser a comunidade judaica povos sem Estado. Um exemplo disso encontra-se no prontuário da
Delegacia de Estrangeiros do Distrito Federal ${ }^{18}$, onde se vê vários ofícios destinados ao Secretário de Segurança Pública de Pernambuco, sobre a concessão de vistos à estrangeiros desembarcados no Brasil, um deles, datado de 15 de julho de 1942, tem o seguinte teor: "Nr. 2093 - Comunico V.Excia. haver Ministério Justiça negado autorização Visto permanente favor francezes $E$. W e sua mulher A.E Wvg ambos atualmente na Francanegou autorisação para concessão visto temporário favor senhora L. S. vg apátrida vg origem russa vg atualmente na Argentina..."

Com isso, reforça-se a ideia de Hannah Arendt de que: “A noção de que o problema do apátrida era primariamente judeu foi um pretexto usado por todos os governos que tentaram resolver o problema ignorando-o" ${ }^{19}$,

A análise da documentação dos prontuários do acervo da DOPS-PE, permite que seja compreendido o processo de construção de um imaginário social onde todo indivíduo que não se enquadrasse no projeto nacionalista do governo Vargas seria visto como suspeito, mau cidadão. É nessa perspectiva que o judeu se insere como elemento passivo de controle, censura e vigilância.

Obter o controle do imaginário coletivo é estratégico para legitimação do poder, pois é através do imaginário que as sociedades constroem sua identidade, nesse caso, a apropriação do imaginário pelo poder tem a finalidade de "impregnar as mentalidades com novos valores e fortalecer a sua legitimidade ${ }^{, 20}$. Desta forma, inimigos são criados para servirem de "trampolins simbólicos dos quais se opera a progressão conjunta dos medos, ódios e esperanças",21.

Analisar o acervo da DOPS/PE nos possibilita por um lado verificar como a polícia política se organizou para vigiar e controlar os indivíduos judeus, e, por outro lado nos possibilita verificar como a comunidade judaica estabeleceu algumas estratégias para preservar o patrimônio cultural religioso.

Segundo Kaufmann, os judeus que se encontravam em Pernambuco preservaram sua identidade deslocando o núcleo religioso para o cultural. A

${ }^{18}$ DOPS/PE. Prontuário $n^{\circ} 29695$

19. ARENDT, Hannah. Origens do Totalitarismo. São Paulo: Companhia das Letras, 1989.p. 323.

${ }^{20}$ BACZKO, Bronislaw. Imaginação Social, In. Enciclopédia Einaude. Portugal: Imprensa Nacional/Casa da Moeda, 1985. p. 320.

${ }^{21}$ Ibidem. p. 302. 
imigração e a integração do europeu de origem judaica no Brasil, teve como cenário um processo que incluía, por um lado, o temor de novas perseguições - que o levava a buscar estratégias para ser aceito como cidadão do país de destino e, por outro lado, a vontade de preservar o patrimônio religioso-cultural ${ }^{22}$.

Ao analisar o impacto cultural e religioso sofrido pela comunidade judaica ao migrar para Pernambuco na década de 30, devemos considerar o contexto de normas, valores e comportamento tanto da comunidade judaica quanto da sociedade pernambucana.

Considerando que são os traços culturais que riscam a linha de demarcação entre os grupos ${ }^{23}$ e que esses mesmos traços culturais não são uma coisa qualquer, mas se formam no curso de uma história comum, que a memória coletiva do grupo transmite e interpreta, de modo seletivo, por meio de um trabalho do imaginário social, transformando determinados fatos e determinados personagens lendários em símbolos significativos da identidade étnica ${ }^{24}$. Torna-se essencial identificar esses símbolos identitários criados pela comunidade judaica num contexto marcado por relações interétnicas e por diferenciações culturais entre a sociedade brasileira e a comunidade judaica imigrante.

A comunidade judaica presente na sociedade pernambucana durante $o$ período varguista tentava preservar sua identidade cultural, haja vista o número de solicitações enviadas à DOPS/PE, para realizações de festas, missas e bailes. Por outro lado, o desejo de ser aceito como cidadão do país era evidenciado quando a própria comunidade envia à DOPS/PE essas solicitações.

Em fevereiro de 1938 o presidente do Circulo envia uma solicitação ao delegado de Ordem Política e Social para a realização de uma conferência sobre os últimos acontecimentos na Palestina, e, acima da solicitação escreve: "OBS: Como pede, desde que a conferência seja proferida em português e assistida pela polícia".

${ }^{22}$ KAUFMAN, Tânia Neumann. Passos Perdidos - História Recuperada: a presença judaica em Pernambuco. Recife: Edição do Autor, 2000.

${ }^{23}$ BARTH, Fredrik. Grupos Étnicos e suas Fronteiras. In. POUTIGNAT, Philippe e STREIFF-FENART, Jocelyne. Teorias da Etnicidade. São Paulo: Fundação Editora da UNESP, 1998

${ }^{24}$ POUTIGNAT, Philippe e STREIFF-FENART, Jocelyne. Teorias da Etnicidade. São Paulo: Fundação Editora da UNESP, 1998.
O que se observa na comunidade judaica de Pernambuco é o desenvolvimento da "etnicidade simbólica",25, onde as especificidades culturais de um grupo tornam-se fontes de mobilidade coletiva quando as minorias deixam de viver em colônias e se acham diretamente confrontadas com os outros grupos.

A organização interna da comunidade judaica em Pernambuco, num momento em que se verifica um contraste entre a herança cultural e religiosa do imigrante judeu e o patrimônio cultural brasileiro, permite identificar o que Cornelius Castoriadis chama de "significação imaginária social" ${ }^{26}$. Assim, não podemos negar que, diante de um contexto marcado pela vigilância, repressão e controle, os judeus que conseguiram imigrar para Pernambuco estabeleceram, preservaram e criaram traços culturais que marcaram a identidade coletiva judaica.

\footnotetext{
${ }^{25}$ GANS, H. J. Symbolic Ethnicity: The Future of Ethnic Groups and Culture in America. Ethnic and Racial Studies. v. 2, n ${ }^{\circ} 1,1979$.

${ }^{26}$ CASTORIADIS, Cornelius. A Instituição Imaginária da Sociedade. Paz e Terra, 2000.
} 


\section{Humanus ou a construção do antissemitismo}

\section{Saul Kirschbaum ${ }^{1}$}

$\mathrm{O}$ objeto da minha apresentação é uma revista anual intitulada Humanus. O primeiro número saiu em janeiro de 2000, o segundo em janeiro de 2001. A revista é ligada a uma entidade denominada Centro Espiritual Beneficente União do Vegetal, com sede em Campinas, SP. O que desperta o meu interesse é que, sem ser uma publicação judaica, a revista dedica a temas judaicos um número de artigos e um espaço que não se compara com qualquer outro vértice, excetuada a própria União do Vegetal.

Para não consumir todo o espaço disponível, vou citar apenas alguns poucos exemplos desta concentração da revista em judeus e judaísmo: no primeiro número, entre outros, o artigo As grandes fraudes do século $X X$ (17 páginas) é dedicado a Freud e a Einstein; outro artigo, $O$ Ritual da Carne, dedica amplo espaço ao subtítulo $O$ ritual Kosher.

O segundo número, já na primeira contracapa, justapõe a citação de Alfred Rosenberg, identificado como ideólogo do nazismo: "Nunca neste mundo se alcançou algo grande sem entusiasmo", à de Theodor Herzl, identificado como ideólogo do sionismo: "Se quiserem, isto não será um sonho"; o artigo Ciência sem Consciência trata da "(...) atitude dos cientistas que se envolveram nas pesquisas nucleares cujas consequências trágicas são bem conhecidas", alusão óbvia à participação de Einstein no desenvolvimento da bomba atômica norte- americana; o ponto alto deste segundo número é o artigo Sionismo x Nazismo - a semelhança dos opostos, num total de 21 páginas; o artigo Psicoterapia - uma forma de fugir de si assinala que "(...) a psicoterapia, como se sabe, nasceu da psicanálise, cujo pai é Sigmund Freud. E a psicanálise foi uma proposta de cura de patologias psíquicas que não serviu para curar nem seu próprio fundador, uma vez que ele mesmo não conseguiu deixar de ser um cocainômano e um obsessivo sexual até o fim de seus dias."; e assim por diante.

\footnotetext{
${ }^{1}$ Doutorando em Língua, Cultura e Literatura Hebraica/USP
}

Esta presença maciça de assuntos judaicos é coerente com a participação de judeus no Conselho Editorial da revista: segundo a jornalista responsável, ela mesma e pelo menos $50 \%$ dos membros são de origem judaica; e talvez também indicie o porquê de a revista ter recebido cartas elogiosas de leitores judeus, como se vê na seção Cartas dos Leitores, no segundo número. Em consequência, parece oportuno abordar a revista num contexto de "Identidade e Cidadania: como se expressa o judaísmo brasileiro?", temática central deste Encontro.

Entre tantos artigos a reclamarem uma leitura cuidadosa, acho merecedor de profunda reflexão o texto Sionismo $x$ Nazismo $-a$ semelhança dos opostos. A frase que o sintetiza é: "Se não são iguais, são bem parecidos". O articulista propõe que "(...) aquele que conseguir lançar um olhar atento e sóbrio sobre o conflito será capaz de enxergar, por trás do mar agitado e tempestuoso da discórdia, o mais interessante fenômeno de espelhamento que pode se dar nas relações humanas. E chegará à conclusão de que o círculo violento só poderá ser rompido quando cada uma das partes começar a refletir seriamente sobre si mesma, ao invés de descarregarem nos outros seus problemas de consciência." Tentemos, então, lançar um olhar "atento e sóbrio" sobre "o conflito".

$\mathrm{O}$ articulista evita prudentemente manifestar qualquer simpatia pelos atos nazistas. Afinal, “(...) são conhecidas várias características negativas do nacional-socialismo. $\mathrm{O}$ fundo racista de sua ideologia, o recurso ao terror como forma de tratar os oponentes, as ideias imperialistas, tudo isso são aberrações condenáveis". Porém, identifica o sionismo como sendo o outro polo de uma relação bipolar, e denuncia o funcionamento de uma indústria do Holocausto, que se dedica a promover a "(...) renúncia a uma compreensão satisfatória dos acontecimentos históricos, que se tornam totalmente absurdos e prontos para serem instrumentalizados demagógica e propagandisticamente. (...) foi em decorrência dela [isto é, a instrumentalização demagógica do Holocausto] que, no imaginário do pósguerra, o nacional-socialismo se tornou o símbolo do mal radical e absoluto". E remata: "E também a condenação do nacional-socialismo tem sido hoje usada como um escudo protetor capaz de esconder muita hipocrisia. Principalmente porque, através de uma inversão estrategicamente planejada, a acusação de nazista pode ser usada para desqualificar exatamente aqueles que procuram denunciar essa hipocrisia". 
O autor associa a presença judaica na elite financeira internacional, que em sua análise remonta à era dos primeiros passos do capitalismo, com o que considera o núcleo da ideologia judaica: "Foi então que o velho ressentimento, que havia muito rondava a mentalidade judaica, encontrou um eficiente canal de expressão prática. Pois aquela elite financeira logo percebeu que o poder do dinheiro tornava finalmente realizável um projeto latente no subconsciente judaico, e que sempre havia parecido apenas uma quimera: dominar efetivamente o conjunto da sociedade gentia. " [grifo meu] O sionismo, então, não é nada mais do que o braço político-militar encarregado da execução daquele projeto multissecular, tão longamente reprimido.

A questão de fundo, repito, é que o judaísmo é tão nefasto quanto o nazismo. As acusações levantadas pelos judeus contra os nazistas não diferem, em essência, das acusações que os nazistas brandiam contra os judeus. Generosamente, o articulista sugere: “(...) talvez seja o caso de se considerar se não seria mais inteligente e proveitoso realizar um sério exame autocrítico a fim de investigar se tais acusações não terão algum fundamento".

Vejamos, pois, de perto em que consistem as "acusações" que pesam sobre os judeus:

O problema de origem consiste na importância dada pelos judeus à questão da "pureza racial", somente comparável à importância que os próprios arianos deram à mesma questão. E isso remeteria a um formidável equívoco cometido pelos judeus em relação ao tema bíblico da "eleição": "Os descendentes de Abrahão não souberam compreender a sentença que (...) Jeová disse ao patriarca: que sua estirpe era escolhida entre todas". Especificamente: o povo judeu estaria predestinado a receber o Messias, Divindade encarnada, portador de uma Mensagem universal, “(...) mensagem de conciliação que declararia todos os povos como filhos do mesmo Deus". No entanto, “(...) os antigos hebreus interpretaram a 'eleição' em um sentido exclusivista".

Agora o articulista salta até a Idade Média, para assinalar que “(...) milênios de imigrações, escravizações e privações" não tinham conseguido que os judeus percebessem a impossibilidade da “(...) ideia religiosa do povo eleito e sua tradução na ideologia da supremacia política. (...) ao que se sabe, não houve, por parte dos judeus, uma real tentativa de revisão das bases de sua fé". Ao contrário, os judeus teriam trabalhado o sofrimento de forma absolutamente masoquista: "É isso que dá ao sofrimento o sabor de um verdadeiro troféu entre os judeus, um troféu digno de ser lembrado por todas as gerações em todos os milênios". Em consequência, os judeus, de forma totalmente espontânea, se isolam, étnica e socialmente, formando guetos. Esta tendência ao isolamento seria consequência da perplexidade dos judeus ante “... um paradoxo aparentemente insolúvel: o povo eleito (e supostamente superior) é ao mesmo tempo sofredor. E como podem sofrer os eleitos de Deus?". Então, é natural que sejam rejeitados pelos cristãos: “(...) na Europa totalmente cristianizada, (...) pesava sobre eles a terrível acusação de deicídio e (...) era comum a crença de que se tratava de uma raça de adoradores do demônio e de feiticeiros, que envenenavam as fontes e raptavam crianças cristãs para imolá-las em suas reuniões." E pouco mais adiante: "Em uma época eminentemente supersticiosa, em que a religiosidade determinava a maneira de pensar e agir, é natural [grifo meu] que essas representações dessem lugar a grandes e violentas perseguições, além de exclusões forçadas. À autossegregação espontânea dos judeus somou-se então uma forte segregação exterior, em parte explicável pela primeira”. [grifo meu] $\mathrm{O}$ que eu quero ressaltar neste trecho é a naturalização do preconceito contra os judeus.

Segundo a análise desenvolvida no artigo, a teimosia judaica, esta obstinação em não reconhecer a verdade do cristianismo e sua Mensagem universal de tolerância e fraternidade traz, como consequência inevitável, que agora os judeus são os únicos responsáveis por quaisquer tragédias que venham a sofrer. "É como se a História houvesse condensado em doze anos [o período nazista] todo o desenvolvimento milenar das tendências negativas do espírito judaico de modo a apresentá-las em uma imagem amplificada, que os judeus deveriam aprender a utilizar como instrumento de um doloroso mas necessário autoconhecimento". Em outras palavras, o nazismo é a resposta lógica ao judaísmo, o Holocausto não passa de um instrumento pedagógico colocado por Deus nas mãos dos nazistas para que, finalmente, os judeus aprendam a lição.

O artigo Sionismo e Nazismo simula condenar o nazismo, mas, no mínimo, reconhece-lhe alguns méritos: ao falar dos terríveis problemas enfrentados pela Alemanha em consequência de sua derrota na I Guerra Mundial, conclui: "E foi essa situação o que tornou possível a ascensão dos nacional-socialistas, que prometiam a solução de todos os problemas sociais. E o fato é que realmente conseguiram solucionar a maioria deles" [grifo meu] e mal consegue reprimir uma simpatia, certamente ambígua, 
pelo próprio Adolf Hitler: "Mas isso não significa que por trás do estadista violento e obsessivo não pudesse ainda haver algo digno de ser resgatado. $\mathrm{O}$ esforço de Einstein, e de todos os que se opuseram a Hitler (supondo que quisessem a paz) teria de ser no sentido não de destruí-lo mas sim de sensibilizá-lo até atingir algo do jovem pintor que demonstrava um anseio interior de paz e harmonia". E: "Muitos dirão que esta atitude era impossível para Einstein, pois o nazismo não possuía nenhum lado bom. Responderemos então que nenhum movimento pode agregar tantos seres humanos se não possuir qualquer coisa de positivo".

O artigo acusa os judeus de acalentarem, há séculos, um projeto para dominar efetivamente o conjunto da sociedade gentia, ou seja, o mundo; na verdade, os judeus já teriam implementado este projeto: "Durante séculos uma elite financeira de judeus esteve à frente das principais casas bancárias, não só alemãs como de toda a Europa, as quais tiveram na usura uma importante fonte de enriquecimento. Paralelamente (...) o poder político do capital financeiro havia gerado uma rede de influências de dimensões potencialmente mundiais. Composta preponderantemente por financistas judeus, essa rede de interesses pairava como um poder supranacional oculto por sobre todas as nações, que se submetiam secretamente a ela, quando não eram dominadas diretamente por seus representantes".

As ideias expostas no artigo podem ser remetidas a uma obra que teve ampla disseminação na época em que foi publicada, o livro The International Jew, do notório antissemita Henry Ford e, a partir dele, aos Protocolos dos Sábios do Sião, cuja impressão e divulgação nos Estados Unidos foram patrocinadas por Ford de seu próprio bolso. Entre 1920 e 1922, Ford publicou no jornal The Dearborn Independent, órgão oficial da Ford Motor Co., uma série de artigos com o objetivo de "esclarecer a história e a natureza do judaísmo e do farisaísmo, desde os dias de Cristo" e denunciar "a manipulação, pelos judeus, dos negócios internacionais", com vistas à "dominação do mundo". Cada artigo era epigrafado por uma citação dos Protocolos, e o sexto artigo lhe era inteiramente dedicado: Uma Introdução aos "Protocolos Judaicos".

Assim, a ideia de que a segregação dos judeus na Idade Média fosse espontânea, originada dentro das próprias comunidades judaicas, está exposta no ensaio Victims or Persecutors?, capítulo 3 do livro. A ideia de que o povo judeu entende a "eleição" como um mandato para buscar o domínio do mundo pode ser encontrada no mesmo ensaio; igualmente, a ideia do domínio judaico mundial, do supergoverno sobre todas as nações do mundo, é o tema do ensaio The world's foremost problem, capítulo 13 do livro.

Acho importante observar que esta aproximação entre a revista Humanus, os Protocolos dos Sábios de Sião e O Judeu Internacional de Henry Ford revela uma coincidência alarmante: A marca particular dos Protocolos não está nas acusações que fazem aos judeus. Na verdade, as alegações de que os judeus conspiram pelo domínio mundial, manipulam as finanças internacionais, controlam os órgãos de imprensa, etc., começaram a circular desde a Revolução Francesa. No início, as acusações eram dirigidas contra os maçons; com o passar do tempo, foram redirigidas para os judeus. O que sim torna os Protocolos uma peça única no arsenal antissemita é o fato de que são apresentados como textos escritos por judeus. Como todos sabemos, seriam atas de sessões altamente secretas dos "Sábios de Sião", reunidos para desenvolver e implementar os planos judaicos de dominação mundial. Ora, como vimos antes, Lidia Carmeli, jornalista responsável pela Humanus, em resposta à carta de um leitor, esclarecia: “(...) eu, a jornalista responsável pelo anuário, sou de origem judaica, e pelo menos $50 \%$ dos membros do Conselho Editorial também o são, conforme se pode notar por seus sobrenomes, publicados no Expediente". Ou seja, estamos de novo diante de textos escritos por judeus, repetindo-se a estrutura dos Protocolos ${ }^{2}$. Por mais evocativa do fenômeno de "auto-ódio" que seja essa associação entre judeus e sobrenomes, a questão de saber se esses "sobrenomes" correspondem a pessoas físicas reais, com RG e CPF, é secundária. Mesmo que sejam pessoas reais, efetivamente de "origem judaica", isto não é nenhuma garantia de que tenham percebido o real conteúdo dos textos que endossaram. E também fazem parte da história judaica os muitos casos de convertidos", como Torquemada, fundador da Inquisição Espanhola, que, ao deixarem de ser judeus, fizeram contra os judeus o que poucos nazistas ousaram fazer.

Wânia Milanez é diretora da União do Vegetal e da revista Humanus; ela escreveu diversos livros para divulgar as doutrinas da entidade e as muitas virtudes do chá Oaska, que estão à venda até mesmo nas livrarias da Edusp. Um desses livros, Oaska, o Evangelho da Rosa, contém uma

\footnotetext{
2 Agradeço à Dra. Eva Landa que, em comunicação pessoal, indiciou essa semelhança
} estrutural entre os Protocolos dos Sábios do Sião e a revista Humanus. 
preciosidade que eu vou me permitir transcrever. Entrevistando o mestre geral da União do Vegetal, Wânia pergunta:

“- Mestre, o que significa essa estrela amarela de cinco pontas que a UDV usa?” E o mestre responde:

“- Em primeiro lugar, estrela só existe uma, e tem cinco pontas. Com menos ou mais pontas, não é estrela. Pode ser uma figura geométrica composta de dois triângulos entrelaçados ou outra qualquer, mas estrela não é. Estrela, só de cinco pontas" 3 ".

Todos nós sabemos que a Estrela de David, em tempos bíblicos, não era símbolo religioso, apenas um objeto decorativo. Mas retirar dela o conteúdo simbólico imposto pelo nazismo é negar à vítima até mesmo a dignidade de sua condição de vítima. É ofender a memória de quantos pereceram em assassinatos de massa, justificados por motivos étnicos ou religiosos. Partindo de uma entidade que se diz "Centro Espiritual Beneficente", e da qual participam tantos judeus, esta postura enfatiza a urgência e a importância de debatermos as questões de Identidade $e$ Cidadania, procurarmos entender como se expressa o judaísmo brasileiro.

\footnotetext{
${ }^{3}$ MILANEZ, Wânia - Oaska: o Evangelho da Rosa. 6 edição. Campinas: Sarna, 2001, p. 200. ( $1^{\circ}$ edição: 1988$)$
}

\subsection{MiLITÂNCIA POLÍtica DOS JUdEUS BRASILEIRos}

\section{Nem bandidos, nem heróis: os militantes judeus de esquerda mortos sob tortura no Brasil [1969/1975]}

Beatriz Kushnir ${ }^{2}$

As nossas mortes não são nossas

São de vocês.

Elas terão o sentido que vocês lhes derem.

A reflexão acima, que se encontra no documentário "Lamentamos A Informar", de Barbara Sonneborn, f19981, se centra na guerra do Vietnã. A cineasta tinha 24 anos quando recebeu um soldado americano à sua porta com notícias de seu marido dizendo: "lamentamos informar que..." No Brasil de meados dos anos de 1960 e 1970, os parentes dos mortos e desaparecidos na luta armada ficavam sabendo do destino reservado aos seus filhos, filhas, maridos, irmãs, por intermédio dos jornais.

$\mathrm{Na}$ época os periódicos publicavam as notas oficias relatando o falecimento dos militantes. Geralmente, a informação oficial era a versão mentirosa de um tiroteio ou de uma resistência à prisão. Quase sempre, o jornal informava, na véspera, um fato que viria a acontecer no dia seguinte. Ou seja, eram mortes anunciadas ${ }^{3}$. Frequentemente, os corpos eram entregues às famílias em caixões lacrados, ou desapareciam em valas comuns. Tentavam, assim, esconder a prática da tortura. Muitos familiares,

\footnotetext{
${ }^{1}$ Esse texto é um resumo de um capítulo de mesmo nome e que está publicado no livro Perfis cruzados: trajetórias e militância política no Brasil [Rio de Janeiro, editora Imago, 2002], por mim organizado.

${ }^{2}$ Doutora em História pela UNICAMP, Pesquisadora associada ao Núcleo de História e Linguagens Políticas, da UNICAMP.

3 Acerca da colaboração de parte da imprensa com a ditadura civil-militar ver também KUSHNIR, Beatriz. 2001. "Cães de guarda: jornalistas e censores, do AI-5 à Constituição de 1988". Campinas, Tese de doutoramento em História/UNICAMP
} 
infelizmente, nem isso tiveram. Seus parentes estão nas listas dos "desaparecidos políticos"...

O tema da militância armada à ditadura civil-militar do pós-1964 ganhou a ponderação acadêmica no início dos anos de 1980. Diferente do caso argentino, a participação de judeus nesses episódios ainda não foi analisada aqui. Os estudos sobre a imigração receberam a prioridade de nossas considerações. Certamente é o momento de nos debruçarmos sobre a segunda e terceira gerações das comunidades judaicas no país. É oportuno pensar como se deu as inserções desse grupo nas décadas de 1950 a 1970, tendo como parâmetros tanto as claves econômicas quanto, principalmente, as definições políticas.

Para tal, é relevante perceber que, tão mítica quanto as histórias da imigração, a militância política de esquerda dos anos de 1960 e 1970 demonstra que não há "nem bandidos, nem heróis", e que para esses militantes que centram a presente análise e para muitos outros, "ser judeu era ser brasileiro". Vale destacar também que se confere as narrativas da imigração um glamour que justificaria o abundante estudo realizado até aqui. Creio que, se existe qualquer elan ou se ele é apenas uma construção, este está sempre no olhar do pesquisador que se debruça no passado e muitas vezes se apaixona por seus objetos. Neste sentido, "milito" na ideia de que as décadas mais contemporâneas merecem o nosso olhar reflexivo. A partir daqui, um pouco dessas trajetórias.

Entre novembro de 1969 - nos primeiros dias do governo do general Emílio Garrastazu Médici \{1969/74\}, empossado em 25 de outubro - e outubro de 1975 - no segundo ano da distensão do general Ernesto Geisel [1974/78]-, dez militantes de esquerda e de ascendência judaico-brasileira foram mortos sob tortura nos porões da ditadura civil-militar implementada no país após 31 de março/ $1^{\circ}$ de abril de 1964. Esse regime autoritário, que teve o seu endurecimento com a decretação do Ato Institucional $n^{\circ} 5$ [AI5], em 13/12/1968, viveu a partir dali o que a historiografia consagrou como "os anos de chumbo".

A análise que se segue é resumo de uma pesquisa em andamento que busca mapear a participação de judeus na luta armada contra esse regime; no fundo há também uma discussão acerca do conceito de identidade judaica na época contemporânea. Fruto e herança da tradição liberal e igualitária judaica, revisitados e transformados, para esses militantes e para muitos outros, há uma profunda identidade com a pátria, como também com a visão internacional das Revoluções sociais [socialistas] dos anos de 1960.

Portanto, o mote dessa reflexão merece uma explicação. Quando não se é "descendente de militantes" e se propõe a estudar tal período, surgem muitas narrativas até então desconhecidas. Ao desvendá-las para mim, quis ampliar o leque, para que outros também as conheçam. Assim, essas dez histórias reúnem perfis de diferentes militantes pertencentes a diversas alas das esquerdas armadas no Brasil. O ponto em comum é que tinham uma ascendência judaica, mas não exerciam uma militância judaica. Não eram, por exemplo, sionistas; eram brasileiros lutando por seu país. E o interessante para essa consideração é justamente isso: uma geração posterior à fundação do Estado de Israel que não está preocupada com a pátria para o povo judeu, e sim com a terra para a qual seus avós vieram há quase meio século.

Diferentes trajetórias de participação política cruzam-se nesses dez casos; contudo, é fundamental destacar que a maioria deles não tinha uma tradição familiar de esquerda engajada. Nem todos tiveram parentes na célula judaica do Partido Comunista Brasileiro [PCB] dos anos de 1930 e 1940, por exemplo. Eram jovens românticos e velhos militantes, todos juntos em organizações diferentes, que optaram por se filiar à luta armada, para eles a única forma de reverter o quadro repressivo que o Brasil vivia. Fariam parte integrante de uma geração, que Michael Uiwy e Robert Sayre definiram como "romantismo revolucionário", influenciada pelo espírito transformador de maio de 1968.

Desvendando o cenário, é preciso nos reportar ao dia 4 de novembro de 1969, quando Corinthians e Santos disputavam uma partida de futebol. Às 21 horas, a transmissão de rádio e de TV foram suspensas e se anunciou a morte do mais famoso, no jargão da polícia da época, terrorista. Carlos Marighela fora assassinado, em uma emboscada na alameda Casa Branca, depois da queda dos freis dominicanos do Convento de Perdizes, na cidade de São Paulo. O quadro em que essa notícia foi dada revela muito das análises atuais sobre a participação da sociedade no processo de implantação da ditadura no país. Vista como encastelada, a maior parte da sociedade civil assistiu como plateia em um jogo de futebol ou como espectadora em um evento. Torcia por um ou outro lado, mas pouco se

${ }^{4}$ Michael Lõwy e Robert Sayre, Romantismo e política. São Paulo, Paz e Terra, 1993 
envolvia. Às vezes até, depois de tanta campanha de parte da imprensa, denunciava as atividades das esquerdas armadas. Elas não caíram nas graças do povo.

Vinte dias depois da morte de Marighela, a versão oficial que o $\mathrm{II}^{\circ}$ Exército enviou para os arquivos do DEOPS/SP diz que haviam sido presos, no Rio de Janeiro, três militantes da organização Var-Palmares [Vanguarda Armada Revolucionária-Palmares].

Entre eles se encontrava o estudante de medicina paulista Chael Charles Schreier, o primeiro de origem judaica entre os 364 militantes mortos sob tortura ou em emboscadas e batidas policiais. Detidos após violento tiroteio, os três foram levados para o Hospital Central do Exército, onde Chael, segundo o atestado de óbito, morreu devido à "contusão abdominal C..) e hemorragia interna". Por esse documento ficou evidenciado que Chael era o primeiro caso comprovado de morte sob tortura após detenção.

É importante aqui fazer um esclarecimento. A Var-Palmares, na qual Chael militava, era uma das 18 organizações clandestinas que optaram por combater a ditadura civil-militar pós 1964 pelo uso da luta armada. A VarPalmares era fruto da fusão, em 1968, da ORM [Organização Revolucionária Marxista), da Polop [Política Operária) de São Paulo e da seção paulista do MNR [Movimento Nacional Revolucionário). Sua principal figura pública foi o capitão Carlos Lamarca, que desertou do ${ }_{4} 0$ Regimento de Infantaria do quartel de Quitaúna, no município de Osasco [SP), em 24 de janeiro de $1969^{5}$.

Retornando à trajetória de Chael: o seu enterro, no Cemitério Israelita do Butantã, em SP, foi cercado pelo Exército. Os parentes fizeram questão

\footnotetext{
${ }^{5}$ Em 1969, a VPR [Vanguarda Popular Revolucionária] aglutinou-se novamente o com o Comando de Libertação Nacional [Colina], adotando, a partir daí, a nomenclatura Vanguarda Armada Revolucionária-Palmares [VAR-Palmares]. Em setembro de 1969, ocorreu uma cisão, fazendo ressurgir a VPR. Em 1970, a organização esteve envolvida no sequestro dos diplomatas japonês, alemão e suíço, como também nas tentativas de guerrilha rural do Vale do Ribeira [SP]. As divergências e prisões marcaram o ano de 1971. Nesse período, Lamarca deixou a organização. A VPR passou a receber orientações de Onofre Pinto, do exterior, executadas por Cabo Anselmo, no Nordeste. Mais tarde, descobriu-se que este era um agente infiltrado e que foi responsável por uma série de prisões e mortes, como a dos militantes mortos em Pernambuco. A VPR teve 37 militantes mortos pela ditadura.
}

de cumprir os ritos judaicos da lavagem do corpo e persuadiram o Exército a deslacrar o caixão de metal onde Chael estava. O jornalista Bernardo Kucinski, amigo da família, relatou o episódio em uma matéria da revista Veja. O primo de Chael, Jaime Schreier, que participou da lavagem do corpo definiu com uma frase a brutalidade sofrida: "ele apanhou como um cavalo!". Há, assim, uma longa e cruel distância entre a versão oficial, que mais tarde divulgou um ataque cardíaco como a causa da morte de Chael, e o que realmente aconteceu. Na narrativa emocionada e lúcida de Kucinski para o semanário, fica-se sabendo que

nos enterros não se julgam os mortos. (...) No enterro de Chael, onde as pessoas não se falavam e mesmo amigos íntimos evitavam os cumprimentos e procuravam não estar juntos, não se julgava o caminho de Chael. (...) Estavam em julgamento certas formas de aplicação da justiça brasileira e métodos empregados para combater o terrorismo. As circunstâncias estranhas de sua morte levavam a crer que o caso Chael era a primeira prova real de morte violenta durante um interrogatório policial.

As dores daquelas sessões de tortura foram tão grandes que Maria Auxiliadora Lara Barcelos, presa com Chael, jamais se recuperou. Banida do Brasil para o Chile, em janeiro de 1971, na troca de presos políticos pelo embaixador suíço, suicidou-se, em 1974, aos 29 anos, jogando-se sob os trilhos do metrô de Berlim, às vésperas de completar seu curso de medicina ${ }^{6}$.

Mas o que certamente o jornalista Bernardo Kucinski não poderia prever, enquanto reportava o enterro de Chael, é que ele mesmo, cinco anos depois, em abril de 1974, no início do governo Geisel - que prometia o fim do terror - teria que regressar às pressas da Europa em busca de sua irmã, a professora de Química da USP, Ana Rosa Kucinski Silva. Ana Rosa e seu marido, Wilson Silva, eram militantes da ALN. O corpo de Ana Rosa jamais apareceu. Em dezembro daquele mesmo ano, o general Golbery do Couto e Silva - chefe do Gabinete Civil do governo Geisel - reconheceu que Ana Rosa estava presa em uma instituição da Aeronáutica. Por intermédio do cardeal Arns, famílias de desaparecidos encontraram-se com o general Golbery. Dias depois o ministro da Justiça, Armando Falcão, noticiava que Ana Rosa era considerada uma "terrorista foragida". Ela e seu marido foram provavelmente levados para a "casa da morte" em Petrópolis e lá assassinados.

${ }^{6}$ Acerca dessa história, ver Reinaldo Guarany. A fuga. São Paulo, Brasiliense, 1984. 
A "casa da morte" era um dos locais clandestinos de torturas do Centro de Informações do Exército $\{\mathrm{CIE}]$, localizado no município de Petrópolis, no Rio de Janeiro. O comandante do DOI-Codi do I Exército, coronel Adir Fiúza de Castro, chefiava também as torturas naquela casa, do mesmo modo que o capitão-médico Amílcar Lobo atendia os presos nos dois lugares. Inês Etienne Romeu, única militante sobrevivente do lugar, afirma que por lá passaram pelo menos onze presos políticos, alguns deles considerados "desaparecidos" até hoje. Com alguns, ela chegou a ter contato pessoal, outros ouviu sendo torturados e sobre os demais teve informações através de torturadores, que se vangloriavam de tê-los matado. Esse não era o único centro de torturas clandestino que funcionava no País. No Rio de Janeiro havia pelo menos mais dois e em São Paulo outros dois ${ }^{7}$.

Assim, a história da repressão à militância contra a ditadura a partir do AI-5 é a narrativa de uma escalada crescente de crueldade, com seus ingredientes de torturas, mortes, laudos de autópsia forjados, enterros clandestinos, declarações oficiais enganosas. Traços presentes nas trajetórias do estudante de economia carioca José Roberto Spiegner, militante do MR-8, participante do sequestro do embaixador americano no Rio, em setembro de 1969, morto aos 21 anos em fevereiro de 1970. A geração de Beto incluía a maioria dos participantes daquele sequestro. Dividiu, naquele momento, um aparelho com o artista plástico Carlos Zílio, que em 1996, expôs no MAM, do Rio, sua arte e política entre 1966 e 1976. Escapou do cerco policial que prendeu e matou Beto, mas um mês depois foi preso, ficando encarcerado até julho de 1972. Ao sair, a maioria dos seus amigos ou estavam mortos, ou presos, ou no exílio. No catálogo da exposição, a dedicatória é para José Roberto Spiegner e diz:

fico espantado em pensar como tão jovens tínhamos a certeza de poder mudar o mundo e modelar a história. As mortes e o sofrimento me comovem. Experimentamos a dura realidade da derrota.

(...) Gostaria de dedicar esta exposição a todos que morreram nesta luta, alguns, inclusive, de maneira bastante cruel. Mas queria homenagear, sobretudo, José Roberto Spiegner. Foi meu primeiro amigo a morrer De certo modo, devo-lhe a vida.

\footnotetext{
${ }^{7}$ Ao me referir a Amílicar Lobo, gostaria de lembrar de Helena Besserman Vianna, que corajosamente o denunciou e escreveu Não conte nada a ninguém. Rio de Janeiro, Imago, 1994.
}

Trajetórias semelhantes tiveram o acadêmico de medicina Gelson Reicher, 22 anos, assassinado em São Paulo em fevereiro de 1972, e Ana Maria Nacinovic, carioca, filha de pai judeu, morta em São Paulo em julho de 1972. A mesma Ana Maria, ironicamente condenada à revelia a 12 anos de prisão, em outubro de 1973, apesar de sua morte oficialmente decretada.

É importante aqui uma ressalva. Se essas dez histórias apontam para uma atitude radical de esquerda, existem outras diametralmente opostas. O médico legista que assinou os atestados de óbito de Ana Maria Nacinovic e Gelson Reicher, foi Isaac Abramovitch. Se no caso de Ana Maria, ele não declarou dois tiros levados por ela, no caso de Gelson, um rapaz que conhecia de infância, Abramovitch formulou um outro laudo para as causas de sua morte e atestou-lhe o nome falso de Emiliano Sessa. O corpo foi encaminhado para o cemitério de Perus e, após um telefonema anônimo à família de Gelson, provavelmente do próprio Abramovitch, foi então removido para o Cemitério Israelita do Butantã.

Nesse período conturbado, o ex-militante da ALN Reinaldo Guarany registrou em suas memórias e definiu como

éramos como galinhas de quitanda do interior, expostas à visitação pública; o freguês chegava e escolhia a mais gordona. Depois era só quebrar o pescoço.

(...) As quedas eram quase diárias, as prisões enchiam-se, aterrorizávamo-nos com os relatos de tortura, 'desbundadas' em massa eram empreendidas em direção ao Chile, enquanto nutríamos um misto de desprezo e pena pelos companheiros que caíam e, não suportando os choques e paus-de-arara, abriam e abriam, provocando mais quedas $\{1984$, pp. 12 e 37$)$.

Paralela a essas imagens despontam também personagens emblemáticas, mitos e mistos de liberdade e busca. Como Iara Iavelberg. Para todas as mortes de militantes, há sempre duas versões: para a de Iara não seria diferente. Teria ela se suicidado ou não, quando cercada pela polícia em um apartamento em Salvador, naquele 20 de agosto de 1971 ?

Pela biografia de Iara, - a mulher de Carlos Lamarca, o capitão do Exército brasileiro que deserta levando armas do quartel de Quitaúna, em 
São Paulo -, escrita pela jornalista Judith Patarra ${ }^{8}$, sabe-se que, muito jovem, aos 16 anos, casou-se na comunidade com o médico Samuel Haberkorn. Mas é o seu percurso pelas organizações das esquerdas armadas que revela o perfil de semelhanças do período. Dois dos seus três irmãos, Raul e Samuel, também tomam a mesma direção, o engajamento na luta, mas se exilam. No livro de Patarra, é interessante a reconstituição dos laços dessa geração, mas também as outras relações desse grupo para fora do universo dos amigos judeus. Compreender o que os levou à opção pela luta armada, de onde vieram, que perfil tinham. Toda essa gama de "afinidades eletivas" que formam gerações, grupos e espaços de sociabilidade.

Iara militou na Polop e da cisão desta, formou-se a VPR, na qual conheceu Lamarca e, quando este se transfere para o MR-8, ela o segue. Se há uma nuvem de glamour que envolve a militância armada até o sequestro do embaixador americano, em 1969, o que vem depois, entre fins de 1969 e 1972, é o massacre. Os que ficam aqui, como sobreviventes e fora das prisões, têm a opção do exílio. Lamarca não a quis e Iara o acompanhou nas tentativas de resistência rural no Vale do Ribeira e em Brotas de Macatába, na Bahia.

$\mathrm{Na}$ esteira da gana da polícia política pelos líderes do movimento armado, Marighela já havia morrido. Seu sucessor, Joaquim Câmara Ferreira, o Toledo, foi assassinado em outubro de 1970. Desses dirigentes maiores, faltava capturar Lamarca, que vai cair em setembro de 1971.

Um mês antes, então com 27 anos, Iara fora localizada e morta. Iara, a mítica, a mulher do ex-capitão do Exército desertor. No desenho de Patarra, ela é a simbiose da liberdade e da angústia. Mas o que lhe teria acontecido nos seus últimos momentos permaneceu não revelado até as últimas semanas de 2000. Depois de 29 anos, os impasses sob as circunstâncias da morte de Iara começam a ser esclarecidos. A 1. Câmara de Direito Privado do Tribunal de Justiça de São Paulo decidiu, por maioria, que a família da militante política Iara Iavelberg tem o legítimo direito de trasladar seus restos mortais da área reservada aos suicidas no Cemitério Israelita do Butantã. Assassinada por militares em 1971, Iara foi dada como suicida na versão oficial dos órgãos de repressão: teria se matado com um tiro em seu apartamento, para escapar à prisão. Seu irmão, Samuel

\footnotetext{
8 Judith Lieblich Patarra. Iara: reportagem biográfica, 4a. ed. Rio de Janeiro: Rosa dos Tempos, 1993
}

Iavelberg, sempre contestou tal versão, mas, de acordo com os costumes judaicos, Iara foi sepultada em área separada, reservada aos que "dão a morte a si próprios".

"A decisão judicial é mais um reconhecimento de que houve homicídio e que os laudos da época são falsos, como aconteceu com assassinatos de vários militantes no período da ditadura", disse o deputado estadual Renato Simões [PT], presidente da Comissão de Direitos Humanos da Assembleia Legislativa de São Paulo, que acompanha o caso. Investigações posteriores indicaram que Iara foi morta com uma rajada de metralhadora disparada pelo sargento Rubem Otero, da Marinha, de acordo com relato do contra-almirante Lamartine Andrade Lima. O deputado Simões critica a própria comunidade israelita, que não aceitou sepultá-la de acordo com os ritos normais, "uma vez que a exumação do corpo para comprovar o homicídio foi dificultada pela tradição religiosa".

Bem perto do local onde Iara está sepultada, em uma área quase limítrofe ${ }^{9}$, encontra-se o corpo do jornalista Vladimir Herzog, um dos últimos a morrer nos porões da ditadura por suas ligações com o PCB. O caso de Herzog, assassinado em outubro de 1975, detonou uma crise na cúpula do governo Geisel e mostrou que a abertura "lenta e gradual" esbarrava com uma ainda quente máquina de tortura. Sete dias após o assassinato do jornalista na sede da Operação Bandeirantes [Oban] da rua Tutóia, a cidade de São Paulo vivenciou uma das maiores manifestações políticas de repúdio à ditadura: a missão ecumênica na Catedral da Sé.

Mas no dia seguinte ao dia em que Herzog foi barbaramente assassinado, um colega seu de profissão fazia um comentário hediondo na imprensa. O jornalista Cláudio Marques, conhecido por suas posições a favor do sistema repressivo imposto no pós-1964 e, principalmente no pós1968 , redigiu a seguinte nota,

há certas horas em que a gente, com o mais puro sentimento de coleguismo, fica preocupado com os novos hóspedes do Tutóia Hilton.

No entanto, já após 1972, encurralados, capturados, presos ou mortos, poucos eram os militantes ainda vivos ou fora dos cárceres. Entre eles, Pauline Philippe Reichstul, uma judia suíça de 25 anos, que possuía

${ }^{9}$ A área delimitada aos suicidas do Cemitério Israelita do Butantã localiza-se no setor G entre as quadras 25 e 28 . Iara está no G/quadra 26/lápide 57 e Herzog no G/28/64. 
ligações tanto com a Anistia Internacional como com a VPR, organização na qual atuava um famoso agente infiltrado, o cabo Anselmo. Pauline chegou da Europa em fins de 1972, literalmente para a morte, em janeiro do ano seguinte, quando quatro homens e duas mulheres foram massacrados em Recife pela equipe do delegado Fleury, muito provavelmente por indicação do cabo.

Concomitante a essas ações, entre abril de 1972 e fins de 1974, o PC do $\mathrm{B}$ realizou uma experiência de guerrilha rural que ficou conhecida como a "Guerrilha do Araguaia". Chega-se assim aos dois últimos personagens dessas dez histórias: Maurício e seu filho, André Grabois. A luta travada no Araguaia entre os militantes e o Exército é a narrativa de uma chacina, de uma guerra praticamente sem prisioneiros. As mortes ali giram em números imprecisos de 59 a 92 militantes, dos quais todos são desaparecidos políticos.

Maurício, um dos 14 deputados do PCB eleitos para a Assembleia Nacional Constituinte de 1946, chegou ao Araguaia em 1967, um dos primeiros, e desapareceu em um cerco do Exército no Natal de 1973, aos 61 anos. Seu filho, André, ou o José Carlos, seu nome de guerra, morrera dois meses antes, em 14 de outubro de 1973, aos 27 anos. Não chegou a conhecer seu filho, João Carlos Grabois, com Crimeia de Almeida, que voltou a São Paulo para tê-lo.

Quando se estuda a luta armada, um conceito é recorrente: o da sobrevivência. Os que ficaram para contar se autointitulam "sobreviventes". Essas dez histórias são dos que não conseguiram chegar a esse patamar, tombaram antes. Para Daniel Aarão Reis Filho, ele mesmo um ex-militante do MR-8, e hoje titular de História Contemporânea da UFF "foi exatamente nessas circunstâncias, sem válvulas de escape, que alguns grupos de esquerda - desesperados e desesperançosos - se lançaram à luta armada. Constituídos fundamentalmente por jovens estudantes, audaciosos mas inexperientes, foram destroçados em uma luta desigual contra os aparelhos da repressão. Bravos jovens! Radicais, equivocados, mas generosos! A rigor, a ditadura, sempre segundo essas versões, fora a grande responsável pela luta armada, redimensionada como uma reação desesperada à falta de alternativas" (Reis Filho, 2000. Ditadura militar, esquerdas e sociedade. Rio de Janeiro, Jorge Zahar Editor. p. 8).

Em tão rápidas pinceladas, as dez trajetórias dessa narrativa estão muito longe de qualquer análise que as vitime. Envolvidos com os pressupostos do socialismo, esses bravos jovens acreditavam no internacionalismo. Portanto, eram múltiplos: eram judeus, eram brasileiros, eram do mundo. Essa geração de contestadores, de militantes, de guerreiros está envolta por uma gama de "afinidades eletivas" que formam grupos e espaços de sociabilidade. Para Michael Lõwy, a força e a combustão gerada por essas "aproximações por escolha", são

um movimento de convergência, de atração recíproca, de confluência ativa, de combinação capaz de chegar até a fusão. (...) Essa força é a afinidade, determinando a combinação dos corpos heterogêneos numa união que é uma espécie de casamento, de enlace químico, que procede antes do amor que do ódio. (...) A afinidade eletiva não se dá no vazio ou na placidez da espiritualidade pura: ela é favorecida (ou desfavorecia) por condições históricas e sociais. ${ }^{10}$

Engajados em uma "viagem" semelhante, mas não igual, há várias gerações de intelectuais brasileiros; esses militantes desejavam a utopia dos românticos revolucionários. Netos ou mesmo imigrantes, não precisavam sair daqui para construir um mundo melhor. Era nesse território, místico e mestiço, que queriam "ousar lutar, ousar vencer"!
${ }^{10}$ A reflexão sobre esse conceito baseia-se na definição de Michael Löwy [Redenção e utopia: o judaísmo libertário na Europa central. São Paulo, Companhia das Letras, 1989. pp. 13-18] 
Judeus e Estado no Brasil: repensando o conceito de integração

Esther Kuperman ${ }^{1}$

Quem controla o passado,

controla o futuro, quem controla

o presente, controla o passado.

(1984. George Orwell)

$\mathrm{E}$ ste artigo tem por objetivo fazer uma reflexão sobre as relações estabelecidas entre o Estado brasileiro e a comunidade judaica no Brasil, entre as décadas de 1930 e 1950, a partir de fontes existentes no Arquivo Público do Estado do Rio de Janeiro. A documentação produzida pela polícia política, através de seus órgãos DESPS, DPS, DOPS e DGIE, possui valor inestimável, tanto para o estudo da história da comunidade judaica no Rio de Janeiro quanto para entendermos a maneira como o Estado brasileiro observava e analisava esta mesma comunidade desde as primeiras décadas deste século.

Nossa compreensão da história possui como referência um espaço e um tempo. É mediada pelas ideias que nos formaram e pelas opções ideológicas que nos atrevemos a assumir. O reconhecimento da identidade com os fatos e da proximidade com as fontes a serem utilizadas não significa que possamos nos confundir com o objeto, abrindo mão do discurso histórico. Pretendemos, em verdade, chamar a atenção para a necessidade da reconstituição de episódios da nossa História recente que dizem respeito às relações entre duas identidades nacionais distintas, convivendo em um mesmo território, por força de circunstâncias diversas e que, de uma maneira ou de outra, contribuíram para as ideias que pretendem definir a nação brasileira. Na medida em que o historiador também é parte deste contexto, por se encontrar imerso na sua comunidade nacional, ele é também parte deste processo. Recuperar estes episódios e transformá-los em uma reflexão sobre os conflitos existentes entre

${ }^{1}$ Possui mestrado em História Social pela Universidade Federal do Rio de Janeiro (1992) e doutorado em Ciências Sociais pela Universidade do Estado do Rio de Janeiro (2008). estes dois grupos sociais pode ser um importante instrumento para entendermos a natureza das questões que produzem as identidades nacionais e suas vinculações com o Estado.

A concepção de uma nacionalidade brasileira composta por um amálgama de nações, fruto de um feliz entrelaçamento cultural, histórico e até religioso, ignorando os conflitos produzidos pela existência de diferenças étnicas já não é mais consenso entre a maior parte dos historiadores. Faz-se necessário, então, produzir uma versão da História que se distancie de um discurso ideológico, o que torna inevitável a busca de outras fontes e de fatos ainda não abordados, abrindo caminho para a produção de novas interpretações que possam contestar a representação vigente de "paz social" e "paraíso das raças", recuperando a história daqueles cuja memória pretendia-se eliminada.

No texto de Tuadides que acabo de comentar, há uma palavrinha que, que eu saiba, não chamou a atenção dos exegetas: é a palavra 'cada um'. Quando os espartanos decidiram fazer os hilotas que se haviam destacado desaparecer, sua decisão dizia respeito a uma coletividade cujos contornos eles próprios haviam delimitado com a participação de suas vítimas, mas cada morte, evidentemente, era individual. Cada vítima tinha sua própria história, e sempre ignoraremos como a morte era administrada: individualmente, coletivamente ou em pequenos grupos. A última hipótese é, porém, a mais provável, pois mais bem adaptada às técnicas da época, artesanais e não industriais. De qualquer forma, as fontes de que o historiador dispõe são incontornáveis, e sempre caberá a ele interpretá-las ${ }^{2}$.

A noção da integração dos judeus no Brasil, alvo de intensos debates na historiografia contemporânea, teria como justificativa a ideia de que, ao adquirirem uma cidadania jurídica, estes passavam a ser equiparados aos demais cidadãos, principalmente do ponto de vista das instituições políticas brasileiras, apesar da manutenção de suas características culturais e de uma organização comunitária autônoma. Tal tipo de elaboração distancia- se dos fatos e testemunhos examinados, necessitando uma urgente revisão por parte dos historiadores. Esta ideia também encontra sua crítica mais contundente na concepção de que uma integração não pode ser admitida apenas como um mero status jurídico. Este debate deverá sempre levar em conta que a

${ }^{2}$ VIDAL-NAQUET, Pierre. Os assassinos da memória: um Eichman de papel e outros ensaios sobre o revisionismo. Campinas, S.P.: Papirus, 1988. Pág. 157. 
inexistência de uma integração não resulta das leis que a conduzem, mas sim das contradições existentes entre o Estado e a sociedade burguesa ${ }^{3}$.

A tentativa de eliminação dos conflitos sociais existentes no interior das sociedades, transformando-os em diferenças ou embates de caráter nacional constituiu uma prática recorrente, principalmente ao longo dos séculos XIX e XX. Este fenômeno, já analisado pela historiografia contemporânea, foi uma das principais vias para a consolidação das propostas políticas mais conservadoras, cuja expressão encontramos no ultranacionalismo e no nazifascismo europeus ${ }^{4}$.

No Brasil dos anos 30 e 40, a tentativa de suprimir a fragmentação da sociedade em grupos hostis entre si, negando as lutas sociais, a existência de ricos e pobres, trabalhadores e possuidores, produzia um discurso de unidade que apontava para a existência de uma única contradição: brasileiros e não brasileiros. Nestes momentos ressurge o sentimento nacionalista, alimentado pelas agências do Estado, buscando produzir o consenso.

O sentimento nacionalista, segundo W. Reich ${ }^{5}$, está intimamente ligado a sentimentos religiosos mais ou menos obscuros, mais ou menos apresentados com roupagens racionalizantes. O nacional socialismo e a Igreja se apoiam na afetividade mística das massas e têm êxito nisso. Neste sentido, a construção de um ideário que propunha a unidade dos "iguais" e a marginalização dos "diferentes", calcado no estigma do "estrangeiro", o estranho", o "outro", aquele que não faz parte da comunidade nacional e que deve ser observado, vigiado, controlado, para que não cause danos à tão almejada unidade nacional.

Ao examinarmos os grandes fluxos migratórios de judeus para o Brasil no século XX, constataremos que estas se deram nos anos 30, 40 e 50, principalmente em momentos de crise da ideologia nacional, que se refletia na ascensão de uma ideologia nacionalista ${ }^{6}$. Partindo da ideia de que o discurso nacionalista expressa a apropriação de uma ideologia nacional

${ }^{3}$ MARX, Karl. A questão judaica. São Paulo: Editora Moraes, 1991.

${ }^{4}$ FONTES, Virgínia. História e conflito. In MATTOS, Marcelo Badaró (org), História pensar e fazer. Niterói: Laboratório Dimensões da História. UFF, 1998.

5 REICH, Wilhelm. Psicologia de massa do fascismo. Cidade do Porto: Publicações Escorpião, 1974.

${ }^{6}$ ALMEIDA, Lucio Flavio de. Ideologia nacional e nacionalismo. São Paulo: Educ, 1995. por uma ou mais classes ou fração de classe ${ }^{7}$, podemos compreender os mecanismos que geraram a estruturação da ideia de uma união nacional ou "união dos brasileiros", excludente em relação às demais nacionalidades.

Durante a vigência do Estado Novo, o discurso oficial procurava legitimar uma certa ordem política e social. Dirigido à "alma coletiva", não era um discurso abstrato, mas sim baseado em experiências históricas anteriores, em um passado comum. Combinando o individual com o coletivo e definindo o Estado como a corporificação do indivíduo, a nova ordem apontava para o fortalecimento de uma "brasilidade" que excluía e se contrapunha a tudo o que não tivesse nela contido. $\mathrm{O}$ esforço para edificar uma união nacional, na verdade, se constituía na tentativa de anular os conflitos sempre presentes em uma sociedade de classes.

A estreita vigilância sobre os imigrantes, e em especial sobre a comunidade judaica e a produção de documentos informando sobre suas instituições - seu funcionamento, objetivos - por parte das polícias políticas demonstra a existência destas duas questões: em primeiro lugar a desconfiança sobre todos aqueles que, organizados, poderiam constituir uma ameaça à "paz social" e, em segundo lugar a necessidade de assegurar que a atuação dos não brasileiros não comprometeria a tão almejada união nacional.

No início dos anos 40, este fenômeno encontra sua versão mais explícita: o antissemitismo que se apresentava como uma espécie de paixão. Uma forma de ódio ou ira. Não se tratando de um antijudaísmo, mas sim de uma nova forma de ódio aos judeus, que se opunha à sua assimilação ${ }^{8}$, evidenciando a ideia de serem uma nação não contida na comunidade nacional em que se encontravam:

Os judeus que atuam a domicilio, que não pagam impostos, cujas mercadorias não têm sequer o selo de imposto de consumo, possuem uma organização perfeita - uma verdadeira máquina de guerra dirigida por um Estado Maior oculto, constituído de capitalizadores e contrabandistas que vivem à tripa forra, ostentando as suas enxúndias nos banhos de mar em Copacabana e frequentando os 'grills' em busca de relações sociais...Dividiu este Estado Maior a cidade em 'setores'. Assim, Jacob, vendedor de 'fourrures' em Botafogo, não pode ir aos lares de Copacabana que pertencem, no ramo, ao patrício

\footnotetext{
${ }^{7}$ ALMEIDA, Op. cit.

${ }^{8}$ TRAVESSO, Enzo. Les Marxistes et la Question Juive. Paris. La Bréche, 1990
} 
David. Quem negocia com 'fourrures' não pode, por outro lado, vender fazendas. Quando a freguesa precisa de um corte de seda, ele encaminha outro. Fecha-se, assim o círculo.(...)

Enquanto isso, o comércio varejista, que tem pesados encargos, vai sofrendo a concorrência desleal. Tão forte, que muitas casas já adotaram o sistema das prestações com os judeus disfarçados...

Uma praga os tais judeus. Lesam o fisco. Prejudicam o comércio honrado. Promovem a dissolução da família. Urge varrer daqui esse lixo social ${ }^{9}$.

A conjuntura desta década era bastante propícia a publicações deste tipo e à explicitação destes conceitos. Disseminava-se a ideia de um darwinismo social, difundindo a noção de que o "não brasileiro" poderia ser o responsável pelos males do país. Mas este é precisamente o momento em que o modelo econômico e político encontra-se em crise e é necessário mover a atenção das massas para aqueles que são entendidos como sendo alheios à comunidade. A noção de que o antissemitismo seria sintoma de uma decomposição da sociedade já era defendida, no início do século, por Rosa Luxemburgo. Como na República Velha, encontrava-se nova saúva, representada principalmente pelo judeu, imigrante que ocupava espaços numa economia em crise, organizava programas de solidariedade e ajuda mútua, construindo formas de manutenção da coesão social em sua comunidade. Era o "outro", uma nação alheia, ingerida na "grande nação" em construção no Brasil, que deveria ser preservada. Tal procedimento ia de encontro à necessidade de produzir um objeto de curiosidade, desconfiança e hostilidade:

Segundo Sartre, se um homem atribui, no todo ou em parte os problemas do país e seus próprios problemas à presença de elementos judeus na comunidade, ele se propõe a remediar esse estado de coisas privando os judeus de certos direitos, afastando-os de certas funções econômicas e sociais, expulsando-os do território ou exterminando-os a todos, diz-se que ele tem opiniões antissemitas ${ }^{10}$. Mas a situação sobre a qual nos debruçamos se estende para além da opinião, ou de

${ }^{9}$ HOLANDA, Rafael. Raça eleita. Rio de Janeiro. Ed. Alba, 1940. folheto número 153 da Coleção DESPS do APERJ, Pág. 13

${ }^{10}$ SARTRE, Jean-Paul. A Questão Judaica. São Paulo: Ática, 1995 comportamentos individuais, pois nos remete à ação do Estado brasileiro em relação aos judeus no período abordado.

Além das questões acima, ainda pesava sobre os judeus uma suposta associação entre judaísmo e comunismo. Com o crescimento do movimento comunista no Brasil em meados da década de 1930 e, principalmente, após o levante de 1935, políticos e intelectuais como Gustavo Barroso e a própria imprensa chamavam a atenção da população para as origens judaicas de Harry Berger e Olga Benário, militantes do Partido Comunista, por ocasião de sua prisão.

Com a ascensão dos regimes totalitários, o mito explicativo expresso pelo antissemitismo ganhou maiores proporções e passou a fazer parte do discurso oficial. A extensão deste fato não se limitou à Europa. No Brasil, as políticas públicas demonstram claramente a existência deste fenômeno. A burocracia do Estado, durante a Era Vargas, defendia limites cada vez mais rígidos para a política imigratória, limitando ou encerrando a entrada de judeus, o que será estabelecido pelo Itamaraty em $1937^{11}$.

Na década de 1940, além de elaborar uma política de imigração, na qual o Conselho de Imigração e Colonização - C.I.C. - debatia formas legais de restringir a chegada de "raças indesejáveis" (africanos, japoneses e judeus), o Estado buscava também se assegurar de que os judeus que já se encontravam aqui radicados e organizados em instituições comunitárias não constituiriam uma ameaça à segurança pública.

Em 1944, com a criação do Departamento Federal de Segurança Pública, subordinado diretamente ao Ministério da Justiça, foi extinta a DESPS. Em seu lugar organizou-se a Divisão de Polícia Política e Social DPS. O objetivo desta mudança administrativa era aprofundar as investigações, principalmente sobre integralistas e estrangeiros, em especial os originários dos países do Eixo. Com o fim da Segunda Guerra e o advento de uma nova conjuntura - a Guerra Fria - os estrangeiros visados pelas investigações passaram a ser todos aqueles que vinham dos chamados países comunistas.

A DESPS - Delegacia Especial de Segurança Política e Social exercia vigilância sobre as instituições e os membros das comunidades

${ }^{11}$ LESSER, Jeffrey. O Brasil e a Questão judaica - imigração, diplomacia e preconceito. Rio de Janeiro: Imago, 1994. 
formadas por imigrantes estrangeiros, principalmente os de origem judaica, norteada por dois princípios: prevenção e repressão. Tendo como pressuposto a ideia de que toda e qualquer instituição poderia abrigar uma conspiração contra o Estado e que qualquer indivíduo era passível de fazer parte desta conspiração, tudo deveria ser estreitamente vigiado: sindicatos, jornais, partidos políticos, clubes, associações, escolas e até sinagogas. Cabia então à polícia política a função de reunir e analisar o maior número possível de informações, com o objetivo de garantir a ordem política da nação brasileira, possibilitando ações repressivas capazes de recuperar a "paz social" e eliminar qualquer tipo de ameaça.

A estrutura destas instituições e o volume de informações colhidas pelos seus integrantes - policiais e investigadores - podem nos fornecer uma ideia da sua importância neste período. Constituíam ferramentas fundamentais para a política de vigilância e repressão empreendida pelo regime e nos dão uma ideia de como a comunidade judaica foi objeto de suspeição por parte do Estado, sendo intensamente vigiada pela polícia política.

Desta forma foram fichadas, nos órgãos de segurança do Rio de Janeiro todos os tipos de instituições pertencentes à comunidade judaica, independente dos seus propósitos ou de seus objetivos. As fichas encontradas em um primeiro levantamento pertencem às seguintes organizações:

Agência Judaica, American Jewish Joint Distribution Committee, Banco Israelita Brasileiro S/A, Biblioteca Israelita Brasileira Scholem Aleichem, Biblioteca Israelita Engenheiro Michael Kleipfisz, Biblioteca Israelita H. N. Bialick, Brigada Judaica, Centro da Comunidade Israelita, Centro e Escola Israelita Brasileira Max Nordau, Centro Israelita Bene Hertzl, Clube dos Cabiras, Clube Hebraico Brasileiro, Colégio Hebreu Brasileiro, Colégio Israelita I.L. Peretz, Colégio Talmud Torá, Comitê Centenário do Centro Hebreu Brasileiro, Comitê de Socorro aos Israelitas Vítimas da Guerra, Comitê Auxiliar do Joint de São Paulo, Comitê Auxiliar do Joint do Rio de Janeiro, Comitê Central do Keren Kaiemeth da Palestina, Comitê da Organização Sionista Revisionista do Brasil, Comitê de Ação Sionista, Comitê de Auxílio aos Imigrantes Judeus Yugoslavos, Comitê de Socorro aos Israelitas da Bessarábia, Comitê de SOS aos Israelitas Sobreviventes de Ostrowiecz, Comitê do Keren Kayemet do Brasil, Comitê do Keren Hayessod, Comitê do Keren Kaiemet de Israel, Comitê dos Bessarabianos do Rio de Janeiro, Comitê dos Israelitas da Bessarábia, Comitê dos Judeus de Ostrowiz,
Comitê Juvenil Unido de Emergência Pro Haganah, Comitê Karen Ha Herut, Comitê Pro Assirei Sion, Comitê Pró Yeshivot do Lubavitcher, Confederação Israelita do Brasil, Confederação das Sociedades Judaicas do Brasil, Congresso Judaico, Congresso Mundial Judaico, Congresso Mundial Sionista, Convenção Sionista Interestadual, Departamento Juvenil da Biblioteca Israelita Brasileira Scholem Aleichem, Embaixada do Estado de Israel, Escola Hebreu Brasileiro, Executivo Sionista Jerusalém, Federação das Sociedades Israelitas do Rio de Janeiro, Firma Jacob Steinberg, Grêmio Cultural Esportivo H. B. Chaim Weizman,, Grêmio Cultural e Esportivo Macabi, Grêmio Cultural e Recreativo Macabeus, Grêmio Cultural e Recreativo Macabi, Grêmio Cultural e Recreativo Stefan Zweig, Grêmio Recreativo Cadima, Instituto Científico Israelita de Nova Iorque, Instituto Científico Weizman do Rio de Janeiro, Instituto Judaico de Educação e Cultura, Instituto Popular Israelita de Cultura e Educação, Jornal Israelita Ilustrado, Jornal Israelita, Juventude Israelita Brasileira, Liga Hebraica do Rio de Janeiro, Liga Obreira Pró Palestina, Movimento Israelita Contra o Racismo e o Antissemitismo, Movimento de Resistência Judaica na Palestina, Organização Feminina Sionista, Organização Juvenil Poalei Sion, Histadrut, Organização Juvenil Sionista Unificadora do Brasil, Organização Juvenil Socialista Dror, Organização Magirt Hameuchedet, Organização Mundial Judaica de Imigração, Organização Mundial Judeus Sefaradim, Organização Sefaradim Universal, Organização Sionista do Brasil, Organização Sionista Feminina Wizzo, Organização Sionista Mundial, Organização Sionista Revisionista Unida do Brasil, Organização Sionista Unificada de São Paulo, Organização Wizzo Juvenil, Representação Israelita do Rio de Janeiro, Revista Aonde Vamos, Sociedade Brasileira dos Amigos da Universidade Hebraica de Jerusalém, Sociedade Brasileira dos Amigos da Universidade Hebraica de Jerusalém em São Paulo, Sociedade Beneficente Israelita, Sociedade dos Amigos da Universidade de Jerusalém, Sociedade dos Israelitas da Polônia, Sociedade dos Israelitas de Ostrowiecz, Sociedade Israelita de Educação, Sociedade Israelita de Organização e Reconstrução e Trabalho ORT, Sociedade Israelita Sefaradim, Sub Comitê dos Israelitas Poloneses, Teatro Israelita de Amadores, União Associação Beneficente Israelita, União Beneficente Maghen David, União dos Israelitas Sefaradins do Brasil ${ }^{12}$.

${ }^{12}$ ARQUIVO PÚBLICO DO ESTADO DO RIO DE JANEIRO. Relatório de Assuntos Indexados em Microfilme. Fundo DPS. Série "Fichas Verdes". Rio de Janeiro, 1988. 
As instituições listadas acima possuem origens e propósitos bastante diferentes. Umas destinavam-se a promover auxílio financeiro aos recém chegados, refugiados da Europa em guerra, outras eram associações culturais que cultivavam e disseminavam literatura, música e teatro. Algumas eram instituições de caráter político, tendo, inclusive, vínculos com partidos que atuavam clandestinamente no Brasil. Encontramos na listagem agremiações sionistas ao lado de escolas e clubes meramente esportivos e recreativos ou de associações religiosas. Todas eram fichadas e controladas indiscriminadamente, independente de seu caráter e objetivo, o que demonstra que a vigilância exercida pelo Estado brasileiro não se limitava àquelas que possuíam fins políticos ou partidários, mas a toda e qualquer forma de organização comunitária.

Além dos fichamentos, os investigadores procuravam, através da troca de informações e relatórios, entender as funções de cada uma das instituições apontadas. Para isso, muitas vezes descreviam as reuniões, nomeando cada um dos presentes, anotando os temas discutidos e as decisões tomadas. No dossiê intitulado "Biblioteca Israelita Scholem Aleichem", encontram-se as seguintes informações, datadas de 5 de outubro de 1942:

Promovida pela Biblioteca Israelita Brasileira Scholem Aleichem, realizou-se, hoje no Instituto Nacional de Música, uma noite líteromusical, em benefício das vítimas dos torpedeamentos de navios nacionais. Abrindo a sessão, o Sr. Schaia Lozinski falou sobre a cooperação dos judeus na luta contra Hitler, não só no Brasil como também nos exércitos russos, onde eles perfazem um total de cinco milhões de homens. Em seguida, usou da palavra o Sr. Jacob Vainstock, representante do Grêmio Hebreu Brasileiro, que reafirmou, mais uma vez, a solidariedade hipotecada ao Governo do Brasil pelo aludido Grêmio, quando do rompimento com os países do Eixo ${ }^{13}$.

Outro relatório, datado de 22 de novembro de 1942, descreve a eleição da diretoria da Biblioteca Israelita Brasileira Scholem Aleichem BIBSA, indicando o nome de cada um dos membros escolhidos.

A BIBSA era alvo de intermitente vigilância, dado o seu caráter político e a orientação ideológica de seus membros, mas, nem mesmo as

${ }^{13}$ ARQUIVO PÚBLICO DO ESTADO DO RIO DE JANEIRO. Relatório Reservado $n$. 230. Departamento Federal de Segurança Pública. Fundo Polícias Políticas do Rio de Janeiro. Setor Geral. Pasta 39. atividades das sinagogas passavam despercebidas dos investigadores. No Dossiê "Sinagoga Religiosa Israelita Agudat Israel", além da narrativa minuciosa da reunião em que se realizou a eleição da diretoria, listando os nomes de todos os seus membros, encontra-se a seguinte anotação:

Julio Pustilnick, membro da Diretoria da Sinagoga Religiosa Israelita Agudat Israel, figura registrada na S-4, em virtude de haver sido preso em 5.11.1937, por suspeitas de exercer atividades comunistas, sendo posto em liberdade em 9.11.1937, visto nada ficar apurado contra a sua pessoa. Tal fato, devido a sua pronta solução, segundo opina a S-2, não é de molde a inibi-lo de exercer o cargo para o qual foi escolhido ${ }^{14}$.

Em alguns documentos são transmitidas ordens expressas, no sentido de:

Deter os responsáveis pela 'Biblioteca Israelita H. N. Bialick', que fez realizar uma campanha financeira pelo aumento da 'Biblioteca', pelo sistema denominado 'Cadeia pela Imprensa' e contrariando a orientação desta D.E. ao usar formulários impressos em idioma israelita sem a devida tradução, o que implica o desprezo ao caráter brasileiro da agremiação assim registrada no M.J.N.I.

Tomar declarações, adverti-los e pondo-os, em seguida, em liberdade ${ }^{15}$.

O documento em pauta, apreendido pelos investigadores, encontra-se anexado ao dossiê produzido pela polícia política sobre a Biblioteca Bialik. Um exame preliminar já contesta a acusação contida no relatório: tratava-se de um documento bilíngue. Em um lado o formulário estava escrito em português e em outro em iídiche, idioma corrente entre os judeus originários da Europa. Intitulado "Campanha pela Imprensa", trazia a chancela da Biblioteca N. Bialick e seu endereço, o que demonstrava ser uma instituição legalizada e pública.

\footnotetext{
${ }^{14}$ ARQUIVO PÚBLICO DO ESTADO DO RIO DE JANEIRO. Dossiê "Sinagoga Religiosa Israelita Agudas Israel”. Departamento Federal de Segurança Pública. Fundo Polícias Políticas do Rio de Janeiro. Setor Diversos. Pasta 8

${ }^{15}$ ARQUIVO PÚBLICO DO ESTADO DO RIO DE JANEIRO. Dossiê "Biblioteca Israelita H. N. Bialik". Departamento Federal de Segurança Pública. Fundo Polícias Políticas do Rio de Janeiro. Setor Geral. Pasta 2.
} 
A Biblioteca Bialik era alvo de vigilância constante. Em dezembro de 1955, o Chefe da Seção da DPS encaminhava ao Departamento Federal de Segurança Pública a seguinte informação:

Relativamente à 'Biblioteca Israelita H. N. Bialick', consta nessa Seção o seguinte: 'Embora seja uma agremiação de caráter cultural, trata-se da antiga Organização da Juventude Sionista 'Hatchia', dissolvida em 1938, em virtude do Decreto n. 383, por ser de caráter político. Posteriormente foi reorganizada sob a denominação acima, estando atualmente, exercendo francamente atividades sionistas, isto em 1948.

Quanto aos membros da Diretoria da mesma, apenas figuram aqui registrados:

Moises Fang e Caron Chaimson, nomes idênticos fichados na Seção Secreta desta Divisão ${ }^{16}$

O trabalho de investigação não tinha como objetivo apenas o controle sobre a atuação dos membros da comunidade judaica. Era preciso também produzir algum conhecimento sobre as funções de cada instituição e entender os laços existentes entre elas para melhor controlar seu funcionamento, podendo, assim, intervir, caso viessem a representar algum perigo para a nação brasileira. No memorando n. 35, datado de 29 de dezembro de 1955, o Chefe da Seção procura fornecer uma explicação sobre o que era a Organização Sionista Unificada do Brasil:

Trata-se de uma espécie de federação de diversos grupos sionistas políticos, que tem por finalidade a restauração de um Estado Judaico na Palestina e o incremento da imigração judaica naquele país. Fazem parte da citada organização os seguintes grupos:

Sionistas Gerais (moderados)

Organização Mizrachi (Sionistas religiosos)

‘Wizo’ Organização Feminina Sionista

Bloco Pro Palestina Operária (esquerda sionista ou socialistasionistas) - Este último grupo é por sua vez constituído de:

\author{
Organização Dror' \\ Hashomer Hatzair do Brasil \\ Histadrut" $" 17$
}

É importante ressaltar que estes últimos relatórios foram produzidos na década de 1950, momento que, dado o fim da Guerra e a implantação de novas relações entre o Estado e sociedade no Brasil, a historiografia passa a considerar como um interregno democrático. No entanto, o volume de documentos produzidos pelas polícias políticas neste período não é menor do que o produzido no período anterior, assim como suas características não diferem fundamentalmente daqueles que foram feitos durante o regime autoritário de Vargas, o que nos leva também a um questionamento a respeito da ideia de redemocratização a partir de 1945 , e à constatação de que o Estado brasileiro mantém, sobre a comunidade judaica, o mesmo olhar de suspeição existente no período anterior.

Os anos que compreendem o final do século XX e a possibilidade de rupturas estruturais, expressas pela existência de profundas crises sociais, principalmente pelo colapso da relação entre trabalho e capital nos levam a refletir sobre a possibilidade do ressurgimento dos sectarismos políticos e de novas atmosferas de restrição social, apesar do decantado "fim das ideologias". Portanto, a proposta de reiniciar uma discussão sobre as ideologias e políticas públicas de caráter excludente encontra suas bases no exame destas ideias e ações em nosso passado recente.

A documentação produzida pelas polícias políticas acerca dos judeus no Rio de Janeiro possui uma enorme riqueza de informações a respeito do passado desta comunidade, sendo importante instrumento para repensar as suas relações com o Estado brasileiro. As políticas oficiais elaboradas com vistas a garantir a integridade da nação brasileira frente a uma possível ameaça representada pelos judeus vindos da Europa e aqui radicados constituem expressões importantes sobre estas relações e exprimem a forma como o Estado e a nação brasileiros percebiam os judeus nas décadas de 1930,1940 e 1950.

17 ARQUIVO PÚBLICO DO ESTADO DO RIO DE JANEIRO. Memorandum n. 35 da SAE. Departamento Federal de Segurança Pública. Fundo Polícias Políticas do Rio de Janeiro. Setor Estados. Pasta 9. 


\section{Fontes Secundárias:}

ALMEIDA, Lúcio Flávio de. Ideologia nacional e nacionalismo. São Paulo: Educ, 1995.

DE FONTETTE, François. História do Antissemitismo. Rio de Janeiro. Ed. Zahar, 1989.

FONTES, Virgínia. "História e Conflito". In MATTOS, Marcelo Badaró (org.) História - pensar e fazer. Niterói: Laboratório Dimensões da História. UFF, 1988.

LESSER, Jeffrey. O Brasil e a Questão Judaica - imigração, diplomacia e preconceito. Rio de Janeiro: Imago, 19995.

MARX, Karl. A questão judaica. São Paulo: Editora Moraes, 1991.

SARTRE, Jean-Paul. A questão judaica. São Paulo: Ática, 1995. Reflexões sobre o racismo. São Paulo. Ed. Difel, 1968.

TRAVESSO, Enzo. Les Marxistes et la Question Juive. Paris. La Bréche, 1990.

VIDAL-NAQUET, Pierre. Os assassinos da memória: um Eiáman de papel e outros ensaios sobre o revisionismo. Campinas, S.P.: Papirus, 1998.

\section{Fontes Primárias:}

ARQUIVO PÚBLICO DO ESTADO DO RIO DE JANEIRO. Relatório de Assuntos Indexados em Microfilme. Fundo DPS. Série "Fichas Verdes". Rio de Janeiro, 1988.

ARQUIVO PÚBLICO DO ESTADO DO RIO DE JANEIRO. Relatório reservado n. 230. Departamento Federal de Segurança Pública.

ARQUIVO PÚBlICO DO ESTADO DO RIO DE JANEIRO. Dossiê "Sinagoga Religiosa Israelita Agudas Israel". Departamento Federal de Segurança Pública. Fundo Polícias Políticas do Rio de Janeiro. Setor Diversos. Pasta 8.

ARQUIVO PÚBLICO DO ESTADO DO RIO DE JANEIRO. Dossiê "Biblioteca Israelita H. N. Bialik". Departamento Federal de
Segurança Pública. Fundo Polícias Políticas do Rio de Janeiro. Setor Geral. Pasta 2.

ARQUIVO PÚBLICO DO ESTADO DO RIO DE JANEIRO. Relatório encaminhado em resposta ao Memorandum n. 43 da S.A.E. Departamento Federal de Segurança Pública. Fundo Polícias Políticas do Rio de Janeiro. Setor Diversos. Pasta 8.

ARQUIVO PÚBLICO DO ESTADO DO RIO DE JANEIRO. Memorandum n. 35 da S.A.E. Departamento Federal de Segurança Pública. Fundo Polícias do Rio de Janeiro. Setor Estados. Pasta 9.

HOLANDA. Rafael. Raça eleita. Rio de Janeiro: Ed. Alba, 1940. Folheto número 153 da Coleção DESPS do ARQUIVO PÚBLICO DO ESTADO DO RIO DE JANEIRO. 


\section{“Quando o calo aperta...”: uma análise do imaginário político de jovens judeus da cidade do Rio de Janeiro}

Marcelo Gruman ${ }^{1}$

$\mathrm{O}$ objetivo deste artigo é analisar o comportamento político de um grupo de jovens judeus cariocas. Sendo o exercício da atividade parlamentar uma das maneiras de afirmar e defender a identidade étnica, me propus descobrir o que estes jovens pensavam sobre a política, os políticos, os partidos, em quem votavam e por quê. A maioria deles não se lembrava do nome do candidato em quem haviam votado nas últimas eleições ${ }^{2} \mathrm{e}$, muito menos, do partido ao qual estava filiado. Tendo em vista que o jogo político, à maneira da arena econômica, funciona na relação entre "oferta" (os candidatos) e a "demanda" (os eleitores), realizei, também, entrevistas com políticos judeus que, na época, faziam parte do governo municipal, atuavam na Assembleia Legislativa do Estado do Rio de Janeiro, na Câmara de Vereadores e com um ex-presidente da FIERJ (Federação Israelita do Estado do Rio de Janeiro) que já atuou na arena política por mais de um mandato.

$\mathrm{O}$ resultado das entrevistas, tanto com os jovens eleitores quanto com os políticos judeus, me permite afirmar a existência do chamado "voto étnico". Isto significa que o candidato preferido é parte integrante do grupo étnico em questão, defendendo seus interesses corporativos na Assembleia Legislativa, ou apenas seu simpatizante, sendo, assim, considerado "amigo dos judeus". Ele, por sua vez, quando reconhecida sua legitimidade perante seus "iguais", toma como missão a defesa de sua comunidade, prometendo desenvolver projetos que visem bem-estar e segurança aos potenciais eleitores ou, se já eleito, reforçando seus compromissos.

Este grupo de jovens é o mesmo de minha dissertação de mestrado. Então, interessava-me analisar os processos por ele utilizados na elaboração de sua identidade judaica, levando em conta sua inserção na sociedade brasileira, sem a sombra do antissemitismo, ao menos na forma

\footnotetext{
${ }^{1}$ Mestre em Sociologia pelo PPGSA/UFRJ/IFCS.

${ }^{2}$ Trata-se das eleições do ano 2000, quando se renovou a Câmara de Vereadores e se elegeu o novo prefeito
}

institucionalizada que caracterizou uma parte da história europeia e brasileira anterior. Queria entender o significado que esses jovens davam à sua judeidade, o porquê de se afirmarem enquanto parte de uma minoria num país que tem, na ideologia assimilacionista, a base de suas relações sociais, e o valor dado à endogamia, historicamente um importante determinante na definição de quem é ou não judeu.

Os entrevistados são parte das camadas médias urbanas, cujas idades variam entre 20 e 30 anos; moradores da zona sul da cidade; estudaram em escolas judaicas até a faculdade ou pelo menos até a $8^{\mathrm{a}}$ série do ensino fundamental; se socializaram em movimentos juvenis sionistas e quase todos já viajaram a Israel num dos programas financiados por instituições sionistas ou com as próprias famílias; realizaram os rituais de passagem da religião judaica, o "brit-milá" (circuncisão) e o "bar-mitzvá" (maioridade religiosa aos 13 anos de idade) para os rapazes e, muito mais raramente, o "bat-mitzvá" (maioridade religiosa aos 12 anos de idade) para as moças. Não se consideram religiosos, ao contrário, não seguem os preceitos religiosos da alimentação (a "kashrut") e das rezas diárias nem fazem o descanso semanal, considerado um dos principais mandamentos de Deus. Todos trabalham ou fazem algum tipo de estágio na área em que pretendem continuar profissionalmente.

Devemos ter em mente que esta maneira de exercer a judeidade, através da representação política, não é nova. Porém, o apoio explícito a um candidato da comunidade judaica e a leis por ele criadas quando eleito, para atender especificamente esta parcela da população, desafiam certas premissas importantes na definição da nacionalidade brasileira. $\mathrm{O}$ orgulho de se afirmar membro de um grupo particular, sem abdicar de uma pretensa brasilidade, de expressar esse pertencimento em público e de lutar por direitos no âmbito legislativo traz à tona a tensão entre o "público" e o "privado", "indivíduo/ cidadão" e "pessoa" e, acima de tudo, coloca em discussão a ideologia nacional da "morenidade", símbolo da ausência de preconceito racial no Brasil. O processo de integração à sociedade brasileira e a atual conjuntura sociopolítica nos fornecem dados que permitem uma melhor compreensão do fenômeno da política étnica e sua maior legitimidade nos dias de hoje. 


\section{Integração e assimilação à luz da situação racial brasileira}

A facilidade com que os imigrantes judeus, e seus descendentes, foram absorvidos pela sociedade brasileira como um todo é compreendida a partir de duas premissas constituintes de uma certa identidade nacional: a miscigenação racial e a assimilação cultural.

A formação do povo brasileiro, enquanto uma "raça pura" dotada de características intrinsecamente positivas, seria possível através do "cadinho de raças", da miscigenação de todos os tipos de imigrantes que aqui desejassem fixar-se com os lusitanos colonizadores, negros (escravos e, posteriormente, libertos) e os indígenas nativos. Diferentemente do que postulavam os teóricos racistas europeus, os apologistas da mistura racial no Brasil acreditavam que, apenas na união dos diversos "sangues", cada qual com algo positivo para doar, é que o país alcançaria o desenvolvimento econômico, cultural e moral.

A boa vontade com os que vinham de fora, com os imigrantes, impediu a formação de um antissemitismo inserido na ideologia nacionalista. $\mathrm{O}$ nacionalismo brasileiro (excetuando curtos períodos, como durante o Estado Novo), ao invés de romper com o estrangeiro, símbolo da opressão, via nele o futuro promissor do país. A ideia de que o pecado original (Sorj:1997) - a união entre negros, índios e portugueses - seria redimido com o tempo tem, na ideologia do branqueamento, a contrapartida para o surgimento de uma sociedade integrada e homogênea.

Neste sentido, os judeus, enquanto brancos, não tiveram, na aparência, um obstáculo para sua integração à sociedade brasileira. Por outro lado, a ideologia brasileira referente às relações inter-raciais ou interétnicas é assimilacionista, ou seja, espera-se que o indivíduo de outra origem que não a luso-brasileira abandone sua herança cultural em favor de uma suposta "cultura nacional". O exercício da etnicidade, portanto, sofre um revés na medida em que a tolerância às minorias endogâmicas e etnocêntricas é pequena. Veremos que este é um ponto importante na análise do chamado "voto étnico" e da política étnica.

A utopia da homogeneidade racial brasileira empresta uma ideia de amorfismo social, uma sociedade indiferenciada, sem clivagens internas. Naquelas em que o sistema político baseou-se nos princípios da liberdade e da igualdade prevaleceu a noção de "indivíduo": consciente, independente, autônomo, livre e anterior à própria constituição da sociedade (Dumont:1995). No Brasil, entretanto, há uma outra categoria que faz a mediação das relações sociais, a "pessoa". Ao contrário do "eu individual", o "eu social" é construído através de relações morais, fundadas em valores como "intimidade", respeito", "honra", "vergonha", "consideração". Neste contexto, prevalece a máscara social, a "persona", responsável pela identidade assumida. Somos membros de grupos com fronteiras bem definidas, a família, por exemplo, compartilhando com os outros aqueles valores, um passado e um futuro em comum.

Como é que os judeus brasileiros se apropriaram dessas ideias? O judaísmo moderno transportado para cá trouxe os ideais universalistas. Muitos dos movimentos juvenis se alinhavam à doutrina socialista, além de serem nacionalistas judaicos. A partir de meados dos anos 60 (Grun:1994), tomando por base as eleições municipais e estaduais em São Paulo, o discurso político dos candidatos judeus passou a ter um teor mais "tribal", de defesa dos interesses corporativos, dos membros tomados não somente como brasileiros, mas judeus. Obviamente que, devido ao clima de nacionalismo vigente de maneira mais incisiva a partir do golpe de 64, esta mudança de estratégia ainda não era explícita.

Porém, hoje, vivemos um mundo diferente. Vivemos um "mundo estilhaçado" (Geertz:2000), onde não existem mais os blocos antagônicos e é preciso repensar conceitos que, por vezes, eram concebidos de maneira integradora e totalizante. É na discussão do que é a "nação", a "cultura" ou a "identidade" que podemos iniciar a caminhada em direção a uma maior compreensão do que é a afirmação, no âmbito político, de um pertencimento étnico ou religioso.

Os jovens entrevistados se dizem judeus e brasileiros, afirmam sua condição judaica sem abdicar de formas culturais elaboradas aqui, no Rio de Janeiro, em contato com os diversos grupos que compõem a estrutura social da cidade. Somente pela não essencialização do que é ser judeu ou brasileiro, e pela percepção de que não são termos antagônicos, podemos compreender o significado do "voto étnico". Os programas de ação afirmativa para negros, a luta pela legalização da união matrimonial entre homossexuais, camisas do tipo "100\% negro", revistas voltadas para os públicos negro, gay e feminino, entre outros exemplos, nos levam a 
reavaliar o que é isso que chamamos de Brasil. Retomando a pergunta de DaMatta (DaMatta:2000), “o que faz o brasil, Brasil?”.

Veremos que a ideologia miscigenascionista ainda influencia o discurso do político judeu, tornando-o ambíguo. Ser cidadão brasileiro não está mais em contradição com a cidadania judaica, e a representação dos interesses da comunidade na esfera legislativa faz parte do novo significado dado à democracia. A intenção, aqui, é tentar entender como jovens judeus cariocas encaram a atividade legislativa neste ambiente de pluralidade cultural e étnica e estabelecem o diálogo com os candidatos surgidos no interior da comunidade judaica e a ela simpáticos.

\section{Políticos legítimos e ilegítimos}

O primeiro ponto a ser destacado é a importância, histórica, de um político que faça a ponte entre a comunidade judaica e a "comunidade maior", pela atividade legislativa, numa versão moderna do "judeu de corte",3. Não é obrigatório que essa ponte seja construída por um judeu, já que um prefeito, governador ou deputados e vereadores não judeus, mas identificados com a comunidade judaica, são considerados "amigos dos judeus", "de confiança". Quando o político é judeu, faz parte da prestação de contas a peregrinação por clubes e sinagogas, acompanhando autoridades locais juntamente com seus assessores, mostrando aos eleitores que a comunidade deve sentir-se lisonjeada por ter um representante em contato com as altas esferas do poder. Destaca-se, aqui, a notoriedade do político junto à comunidade judaica, devido à sua aparição junto a esses representantes, sejam do âmbito municipal, estadual ou federal.

A comunidade se sente dignificada quando vê autoridades não judias prestar homenagem à comunidade judaica. Eu trouxe, para a comunidade, todos os presidentes, com exceção do Collor, que vieram na Biblioteca Bialik prestar homenagem ao Dia do Holocausto e no dia de aniversário do Estado de Israel. Eu convidei aqueles que eu achava corretos, honestos, e senadores e

\footnotetext{
${ }^{3}$ O "judeu de corte" era o financiador dos Estados Nacionais europeus em sua fase de expansão econômica, nos séculos XVIII e XIX. Geralmente, eram banqueiros que se associavam ao Estado no intuito de conseguir privilégios. Ao mesmo tempo, faziam a mediação entre a população miserável judaica e os poderes constituídos, tornando-a sua dependente.
}

deputados...por isso, eu sou muito conhecido como o homem da relação com o mundo político brasileiro (...). Quando eu faço amizade, como vereador, com o Conde, o César Maia ou o Garotinho, eu faço sob o ponto de vista alto, não sob o ponto de vista de partido, sob o ponto de vista social, judaico e não judeu (...). Eu sou visto de outra maneira (...). É por isso que eu sou aceito em qualquer lugar, porque eu sempre me coloco acima e, por isso, me tornei presidente desta casa (câmara de vereadores). Eu sou o único judeu que ocupa as maiores posições numa casa política (X, então vereador pelo PFL)

É fundamental para a comunidade judaica, que é burra, que não entende de política, que nós levemos os políticos para dentro da comunidade. Para eles verem com quem eles estão tratando e eles assumirem compromissos com a gente. (...) Levei pra mostrar que tipo de compromisso eles tinham que ter com aquela comunidade, que tem uma religião diferente, que precisa de apoio, de carinho, de cuidado, precisava de responsabilidade governamental em cima dela. (...) Eu consegui mobilizar a mentalidade das pessoas, no sentido de que eu era uma esperança no relacionamento entre a política nacional e a comunidade judaica. Que eu poderia ser uma ponte de relacionamento entre a legislação, os legisladores, e a comunidade. Eu acendi a chama da esperança na cabeça das pessoas, no coração das pessoas" (Y, ex-presidente da Federação Israelita do Estado do RJ, ex-vereador e ex-parlamentar por partidos tidos de "centrodireita", grifo meu)

O segundo ponto é a questão da segurança. O político respeitado e digno do voto étnico é aquele que carrega a bandeira da luta contra o antissemitismo. Deve-se lembrar que a história do povo judeu sempre foi marcada por perseguições étnicas e religiosas, desde a época da escravidão no Egito, passando pela Inquisição e culminando na II Guerra Mundial. Para a maioria dos jovens entrevistados, o Holocausto faz parte de sua própria história de vida, principalmente pelo fato de haver, nas famílias, sobreviventes de campos de concentração ou imigrantes fugidos antes e durante o conflito. A decisão do voto passa, então, pela coadunação da proposta do candidato com a memória social que localiza, na barbárie nazista, aspectos fundamentais na construção da judeidade. A ameaça de uma nova tragédia, apesar de não sofrerem discriminação e não considerarem os brasileiros um povo antissemita, da mesma maneira como encaram os alemães ou poloneses, é um fator importante na escolha do candidato: 
Eu acho importante, pra defender as vontades, o que a comunidade acha importante. Precisa ter alguém representando pra não deixar que, sei lá vai que alguém, um louco, quer colocar uma lei que vai prejudicar a gente. Tem que ter uma voz (S, estudante de desenho industrial)

Sempre procurava, entre todos, um judeu ou alguém que goste da comunidade judaica. (...) Tem muita gente que gosta, que isso que aquilo, mas na hora que chegar alguém e resolver botar uma lei antissemita lá na parada, só o cara que for judeu mesmo que vai chegar e falar 'não, não, isso aqui tá...'. Nunca fez p...nenhuma pra comunidade judaica, mas na hora que botar a lei de discriminação, o cara vai bater o martelo e vai dizer 'não, não, não, essa p.. não'. O cara que é judeu, ele vai sentir isso, quem não é às vezes nem repara, nem percebe, não tá nem ligando. Na hora de ver é que a parada pega" (D., estudante de administração)

Ser eleito com o voto étnico, quando era esta a intenção, é motivo de orgulho para o político. Y, ex-presidente da FIERJ e ex-parlamentar, é um deles. Sua trajetória comunitária serviria como uma amostra de sua competência administrativa e vontade de defender os interesses do grupo no âmbito legislativo.

Eu fui o primeiro judeu eleito com voto judaico para a Câmara de Vereadores do Rio de Janeiro. (...) Eu não preciso fazer propaganda pra comunidade judaica, porque eles me conhecem (...) Eles sabem o que eu tinha que fazer e o que estava fazendo. Eu fui presidente da Federação, eu criei o programa de televisão (chamado "Comunidade na TV com duração de mais ou menos 20 minutos), vários programas de rádio, jornal, eles sabem o que eu penso

O importante, aqui, é a relação de confiança e de cumplicidade construída entre o eleitor e o candidato judeus (Kushnir:1996). O discurso passa a ideia de um pertencimento ao grupo étnico e um compartilhamento de valores necessários à sua eleição. Na verdade, a relação entre a propaganda pessoalizada e o voto, uma economia da troca simbólica, baseia-se nas ideias de "confiança", "amizade", "carinho" e "solidariedade". Dizer que os eleitores o conhecem significa que entende todas as carências que afligem essa comunidade.

A comunidade judaica não tá preocupada com projeto nenhum que você quer fazer (...) "o que você vai fazer e o que não vai fazer", alguns até estão, mas a maioria tá mais preocupada tipo "quem é o cara que vai me representar melhor". (...) É essa a grande questão, a segurança, era esse o peixe que tinha que ser vendido. ( $Z$, então candidato a vereador pelo PL)

Uma vez na câmara, o político legítimo deve colocar os interesses corporativos acima da opção partidária. Ele irá incorporar os desejos da comunidade judaica aos direitos do cidadão carioca, brasileiro. Esta nova maneira de conceber a cidadania judaica joga com o apelo à etnia e a marcação do pertencimento à sociedade brasileira, permitindo o trânsito entre as diferentes esferas, política e comunitária. A ideologia assimilacionista brasileira é utilizada para justificar a não discriminação do político judeu em relação à população não judaica na hora de elaborar leis. Surge, aqui, o discurso ambíguo.

0 judeu na Assembleia, na Câmara, se tem identificação com a comunidade e se pede voto na comunidade, ele tem que defender a comunidade acima de tudo. Este é o problema" (Y, ex-parlamentar)

Eu não sou religioso, eu respeito Yom Kipur (Dia do Perdão, quando os judeus devem jejuar) como uma tradição, nunca me passou pela cabeça que isso fosse importante do ponto de vista individual meu. Mas do ponto de vista da cidadania brasileira, é fundamental que os judeus tenham seus direitos respeitados. Então, eu fiz essa lei pra ficar consignado o aspecto da cidadania judaica no Brasil, da cidadania dos brasileiros que têm religião judaica e que, pela constituição, têm que ser respeitados como os outros segmentos religiosos. De 40 leis, apenas duas foram dirigidas para a comunidade judaica. Ela se beneficia das outras 38 (Idem, grifo meu)

Lei pra comunidade judaica é muito difícil, bem ou mal não deixa de ser discriminação, entendeu? Agora, poderia mobilizar a guarda municipal pra ficar perto das sinagogas no 'shabat', ou talvez numa sexta ou sábado de manhã para que as senhoras pudessem ir mais tranquilas. (Z, candidato pelo PL)

Eu votei no $X$ não pelo fato dele ser judeu, mas pelo fato de que, através dele, o Shomer virou 'utilidade pública', e aí deixou de pagar IPTU. E o Shomer tem uma dívida de IPTU que eles estavam ameaçados de perder a casa. Então, o X conseguiu livrar o Shomer dessa dívida e, fora disso, transformou o Shomer em 'utilidade pública'. Eu acho que eu devo isso a ele, eu passei excelentes momentos da minha vida no Shomer, e eu não queria, nunca, ver a casa do Shomer penhorada (I., advogada) 
A defesa do bem-estar da comunidade judaica carioca passa, como vimos, pela ponte entre as altas esferas do poder público e os interesses corporativos, representados pelo político (na maioria das vezes) judeu. A visita de políticos não judeus a sinagogas ou bibliotecas mostra o interesse do poder público relativo a questões privadas, ocorrendo um amálgama entre os dois campos. O caminho inverso também é possível, ou seja, uma das maneiras de criar um compromisso da esfera pública com a comunidade judaica é homenagear personalidades do mundo da política ou da cultura, preferencialmente ligados à comunidade e judeus. $\mathrm{O}$ evento, organizado pelo broker, reúne autoridades do Legislativo, Executivo e Judiciário, além das famílias judaicas convidadas por meio de carta personalizadas (por exemplo, "À Família X"). É realizado tanto na Câmara de Vereadores quanto na Assembleia Legislativa.

O Presidente da Câmara Municipal do Rio de Janeiro, e o Presidente da Comissão de Justiça, vereador X, convidam para a solenidade em homenagem ao $54^{\circ}$ aniversário do Estado de Israel, a se realizar no próximo dia 22 de abril (de 2002), segunda-feira às $18 \mathrm{~h}$, no plenário desta Casa de Leis. Na ocasião, será homenageado com a Medalha do Mérito Pedro Ernesto o sr. Eitan Surkis, cônsul geral do Estado de Israel. O evento contará, ainda, com a participação especial de um coro de 100 alunos da rede pública municipal. Após o evento será servido coquetel.

Este exemplo é emblemático. Já não é uma via de mão única, ou seja, a ida de autoridades locais e nacionais para dentro das instituições judaicas, mas vemos também a apropriação do espaço público por um grupo e suas reivindicações tomadas por legítimas defendidas por seus representantes. Ser um judeu brasileiro, eliminando a escolha entre uma ou outra identidade, possibilita esse tipo de homenagem já que Israel, para muitos judeus brasileiros, não é o lar dos judeus, mas fonte espiritual importante na construção de sua identidade étnica. A cidadania passa a afirmar-se menos por motivações nacionalistas e universalistas do que pelo pertencimento ao grupo, à família judaica.

A maior ou menor legitimidade do político judeu perante a comunidade, segundo os entrevistados, depende de diversos fatores. $\mathrm{O}$ primeiro deles, negativo, é a "traição" em relação a um padrão de conduta considerado ideal, que reforce uma imagem positiva dos judeus perante a opinião pública brasileira. Lembremos que a identidade judaica brasileira foi construída de modo a esquecer o passado comercial em favor de um novo mito de origem, no qual a figura do "judeu culto" e de "povo de intelectuais" deveria sobressair (Grun:1997). Assim, qualquer tentativa de utilizar a política como comércio, como é feito de modo mais recorrente e explícito por descendentes de árabes (o caso de Paulo Maluf, em São Paulo, é emblemático), é veementemente condenada, havendo controle por parte da comunidade judaica sobre as ações parlamentares (Grun:1999). A imagem da coletividade, simbolizada pelo político corrupto, ficaria abalada.

Se for um cara da comunidade, que está se elegendo, mas que tá usando isso pra adquirir votos, porque o cara é um merda, porque o cara só tem interesse única e exclusivamente em ganhar dinheiro, em se projetar e nem tiver nenhum tipo de preocupação, não vai me adiantar em nada, porque não vai tá seguindo o que eu tô pensando. Vou preferir votar numa pessoa que nem é da comunidade. (...) Eu nem me lembro em quem votei, não tenho muito interesse em política (S., estudante de marketing)

Judeu vota em judeu, a não ser que seja um judeu que vá denegrir a imagem da comunidade, que a gente não tenha confiança. Se tiver um judeu honesto, a gente vai votar no judeu honesto, se houver um judeu desonesto a gente não vai votar num judeu desonesto, porque aí é propaganda negativa, aí não vale a pena $(\mathrm{H}$, empresário)

Em alguns casos, porém, a própria idoneidade do político judeu torna-se irrelevante, contanto que as fronteiras comunitárias estejam defendidas contra ataques antissemitas. Dois jovens expressaram este sentimento, de que "os fins justificam os meios", colocando no centro da discussão os limites entre o interesse público e o privado, em que medida os dois podem se relacionar sem prejuízo para os demais grupos sociais e a possibilidade de surgir, aqui, uma relação do tipo patrão-cliente entre o candidato judeu e o jovem eleitor.

Eu tô c...se ele (o candidato em quem votou) já roubou ou não. Eu quero alguém na Câmara para, se tiver uma suástica aqui na parada (aponta para uma loja) alguém com moral lá na Câmara pra vir aqui e prender o cara da loja. E não é qualquer um que tem isso, pra isso existe a FIERJ, pra defender a comunidade e, pra isso, tem que ter um candidato judeu dentro da Câmara. Porque, se não, meu amigo... é f.., nego trepa, nego f. .com judeu mesmo, nego é racista. O presidente da Câmara atual é árabe (?) e não gosta de judeu. Já fez discurso racista na Câmara de Vereadores, o Sami Jorge. E tinham 
judeus na Câmara, A., G., não falaram nada. Aí, o X se levantou e começou a quebrar o pau com ele, ele teve que se retratar senão era preso. (D.; "promoter" de festas)

Fez merda a vida toda (falando de X), foi preso por corrupção ${ }^{4}$ e o c.... Na comunidade, o quê que ele faz? Ele pega uma sinagoga que tá devendo R $\$ 10$ mil, conversa com o prefeito e manda anistiar, anistia. Então, toda vez que ele vai a essa sinagoga, ele é recebido com tapete vermelho. Como ele ficou como vereador muito tempo sozinho, as pessoas procuravam ele e ele tinha uma boa relação com o prefeito e conseguia resolver esses problemas. Nisso, ele ficou conhecido (D., estudante de administração)

A vontade de ser reconhecido como único representante legítimo da comunidade judaica e de receber muitos votos, importantes porém não suficientes para a eleição, pode levar a tentativas de desqualificar outros potenciais defensores dos interesses corporativos da etnia, como ficou provado no depoimento acima. A., então secretário de urbanismo da cidade do RJ e, na época do incidente, vereador pelo PV (Partido Verde), nega ambos os fatos, a inércia de uns e o antissemitismo (aberto) de outros.

Existe, entre alguns políticos judeus, uma verdadeira psicose da disputa pra ver quem é o representante mais digno da comunidade

Em segundo lugar, há jovens que não votariam num candidato judeu da mesma faixa etária devido à sua suposta inexperiência política, mas há os que fariam questão de colocá-lo "lá dentro" exatamente por ser jovem, sinônimo de vitalidade e renovação. Ser jovem, aqui, é ser agente de mudanças, pelo menos é essa a ideia que tenta ser passada pelo candidato. Relações pessoais, internas à comunidade, podem facilitar este "voto étnico jovem".

Porque ele é jovem, porque os jovens sempre trazem novas ideias, eles trazem certa revolução de pensamento. As instituições estão impregnadas de velhos, se tivesse mais jovens, se os jovens se preocupassem com as instituições que a gente tem, as coisas estariam bem melhores (...). Os velhos têm medo de mudar. (...) O Z. (o candidato jovem) ia trazer. ..se você apoia um jovem, você tá apoiando uma nova geração, gente jovem que ta' a fim de ser líder também. Ele foi meu 'chanich' (pupilo, no movimento juvenil),

\footnotetext{
${ }^{4} \mathrm{Na}$ verdade, X não foi preso, mas sim teve seu mandato cassado por corrupção nos anos 60 .
}

particularmente eu conheço ele, então, 'lama ló' ? ("por que não?”, em hebraico) (I., advogada)

A campanha que eu fazia na comunidade era "vocês têm três opções: Uma ta' com noventa anos, uma tá com sessenta e uma tá com dezoito anos. Vocês podem votar em quem vocês quiserem, mas um tá pra morrer, digamos, sem querer... mas ele já não anda, anda com muita dificuldade; tem outro que já tentou três vezes e tentou agora e não entrou, que era o]. (do PSB), e tem um cara novo que ta' tentando'. Então, a propaganda era essa, o foco principal era 'pô! vocês têm um cara jovem', entendeu? Isso dava resultado, a primeira vez que você fala assim, as pessoas realmente... (Z, candidato pelo PL)

Em terceiro lugar, a atuação além das fronteiras comunitárias, atendendo populações carentes da cidade do Rio de Janeiro, pode ser tanto um "filão" de votos quanto uma de monstração de falta de interesse ou independência frente ao voto étnico para sua eleição.

Eu sei que o X é um cara que faz, ele não só faz pelos judeus. Todos os taxistas do RJ votam nele, ali naquela favela em frente ao Fundão Complexo da Maré $)^{5}$, pê, ele é unanimidade ali. Ele é um cara que, não só o fato de tê-lo como judeu, porque seguramente se você chegar a ele com algo que tá acontecendo aos judeus, ele vai se movimentar com isso...Ele entrou dentro da sociedade carioca, não é um cara que defende os judeus, taí pra fazer e acontecer pelo povo, entendeu? (1., advogada)

\footnotetext{
${ }^{5}$ X. realiza um trabalho de assistência social no Complexo da Maré, perto do campus da UFRJ, na Ilha do Fundão. Como médico, atuava de graça atendendo a população miserável do local, por volta de 1968. "Hoje em dia, conta, a minha satisfação é que lá, na Maré, tá tudo pavimentado, tem postos de saúde, tem escolas, tem meus centros sociais gratuitos, médicos, cabeleireiros, encaminhamento para tirada de documentos...As pessoas não tinham nenhum documento, nem certidão de nascimento". Na edição de $1^{\circ}$ de setembro de 2001 do jornal "O Globo", lia-se a manchete "Ética do jeito que vereador gosta" na primeira página do caderno "Rio". Neste artigo, informam-se as modificações, exigidas por alguns vereadores, no código de ética criado para a atividade legislativa. Um dos pontos, que restringia a ajuda governamental a centros sociais controlados por vereadores, foi amenizado: "O item que impedia que os centros sociais mantidos pelos vereadores recebessem verbas do município ou firmassem contratos com o poder público sofreu uma cirurgia plástica e, na prática, não ficou tão severo. A restrição, que atingia também as entidades controladas por parentes de até terceiro grau dos parlamentares, foi reduzida no substitutivo de autoria do vereador X. (PFL), que mantém um centro social na Favela da Maré".
} 
Foi no J. (então candidato pelo PSB). O X., na época a gente fica na dúvida, mas o que meu pai falou foi que o $\mathrm{X}$. teria mais votos mesmo (ênfase), então seria melhor favorecer..que o X. teria votos fora da comunidade (B., estudante de medicina)

Em quarto lugar, há a rejeição de ser cooptado pela comunidade judaica e suas exigências. Neste caso, o político judeu se transforma num "judeu político", ou seja, é aquele indivíduo que faz política sem levar em conta sua condição étnica. Este tipo de político não tem boa aceitação entre os jovens entrevistados, nem ele faz questão de ser visto enquanto representante comunitário. Apenas dois jovens disseram votar de acordo com a noção de "cidadania" desvinculada da etnia. Símbolo deste "judeu político" é A, do Partido Verde.

Colocando-se contra a mistura do judaísmo com a política, invoca sua trajetória pessoal e política para defender sua visão de mundo, baseada em ideais universais condizentes com uma postura socialista. Participou do movimento estudantil de 1968, foi membro da guerrilha urbana quando o Brasil viveu os anos de repressão da ditadura militar, sendo obrigado a se exilar em 1971. Na época, era um "revolucionário guevarista de extrema esquerda" e hoje se define como adepto da ecologia política aliada à socialdemocracia. Adaptado e integrado à sociedade brasileira, acha o projeto brasileiro, uma sociedade multicultural e multiétnica, a ideal, pois pode ser parte da "geleia geral". Seu tipo de preocupação, voltada para questões universais e bem de acordo com os ideais do judaísmo moderno, se relaciona às ideologias políticas que nortearam a atuação de muitos políticos até os anos 60 e o início da crise do socialismo. Sua ilegitimidade perante a comunidade judaica não o preocupa, pois nunca se propôs a ser seu representante. É importante frisar que não foi lembrado por nenhum entrevistado como representante comunitário.

Eu nunca fiz política comunitária judaica (...). Nunca me apresentei como representante da comunidade judaica, que não sou e não quero ser, eu sou um brasileiro, carioca, que, por acaso, é judeu porque minha mãe é judia, porque todo o meu lado cultural é judeu, porque meus antepassados são judeus e eu também não abro mão deste legado cultural. Mas, pra mim, isso é muito mais um legado cultural do que compromisso étnico ou religioso com a comunidade judaica (A, do $P V)$
Eu voto como cidadã brasileira. Se o candidato que eu votar for judeu, ótimo. Mas não é isso que vai definir em quem eu vou votar. Se ele for bom e judeu, 'pô, que legal ! Ele é judeu !', mas não é uma obrigação votar no candidato só porque é judeu (M., historiadora)

Faz parte da cultura política brasileira o eleitor votar no candidato e não no partido cuja ideologia ele, teoricamente, representaria. Entre os jovens entrevistados, também há uma tendência a definir o voto mais pela proposta individual de cada candidato do que pelo programa de governo estabelecido pela legenda.

Eu nunca votei pelo partido, não gosto, aqui todo mundo muda, essa fidelidade partidária não sai... Cada um, de acordo com sua conveniência, muda sua maneira de pensar, entendeu? (L, advogada)

No Brasil, esse negócio de partidário (sic) não é muito forte, cá entre nós, então não é a coisa principal. (...) Como é importante a comunidade estar representada politicamente, eu busco direcionar meu voto de vereador e deputado estadual para a comunidade judaica (B., estudante de jornalismo)

Constatei que muitos ignoravam o partido do candidato escolhido, muitos se identificavam como capitalistas e espantavam-se ao saber que acabaram votando num candidato que concorreu pelo Partido Socialista. Seguindo este raciocínio, de que se vota na pessoa, a justificativa para os casos acima estaria dada, porém a situação é mais complexa. Houve uma significativa ascensão social por parte da segunda e terceira gerações de descendentes de imigrantes, que geralmente se alinhavam às ideias socialistas. Este processo de aburguesamento fez com que o voto judaico migrasse para os partidos considerados de centro-direita, que não mais eram identificados com o antissemitismo. A esquerda judaica se enfraqueceu, aliado ao fato de a União Soviética apoiar a causa palestina e os países árabes na época da Guerra Fria. Tudo isso, ligado aos massacres impetrados pelo regime comunista, principalmente no período stalinista, minou a força que os partidos de esquerda exerciam no interior da comunidade judaica carioca.

Talvez, se esses jovens soubessem que a sigla do candidato era o PSB, pensariam duas vezes antes de decidir o voto. Porém, o que parece ter grande peso, hoje, é a sua trajetória comunitária, independentemente se essa se iniciou no seu interior ou se foi incorporada aos poucos. Aquele que se 
identifica com a questão judaica, basicamente a segurança, pode conseguir boa quantidade de eleitores.

O exemplo do deputado estadual W., do Partido dos Trabalhadores, mostra como o fato de estar ligado a uma sigla que representa a esquerda mais ideológica não impede sua aceitação pelo "establishment" comunitário. $\mathrm{O}$ trabalho com a questão ambiental alternativa, ligada a uma política mais geral de combate às injustiças sociais, está, para ele, atrelado ao ideário socialista. A ecopolítica, portanto, não estaria acima das preferências partidárias.

Uma coisa é a ecologia do tipo 'vamos cuidar dos jardins, viva o mico-leão-dourado', a outra coisa e organizar a população pra ter transparência nisso tudo, mudar as tecnologias das empresas, impedir que os trabalhadores sejam contaminados dentro e fora das empresas, preservar o meio ambiente. Enfim, imputar custos pesados a quem se apropria de forma privada do patrimônio público, que é a base de nossa qualidade de vida. Então, como qualquer tema, o tema da terra pode ser apropriado de forma capitalista (...). Na verdade, é como você trata cada um desses temas, a forma como nós tratamos a questão ambiental não é tratada pela direita (...)

Esta trajetória combativa, iniciada fora do âmbito comunitário, nunca o impediu de ter certa entrada política na comunidade judaica carioca. Segundo ele, os judeus que costumavam elegê-lo eram, principalmente, profissionais liberais e intelectuais "que liam o Globo e o JB", que achavam-no uma pessoa honesta e, ainda por cima, era judeu. Assim como A, nunca foi um ativista comunitário, mas neste último mandato participou mais intensamente dos problemas que afligem os judeus. Criou, juntamente com outros parlamentares, o Centro de Referência contra o Racismo e o Antissemitismo, cuja ação se fez presente no fechamento da sede de uma das facções do clube de futebol Flamengo, "Nazistas da Baixada". Acreditava que o número de eleitores judeus aumentaria de 1.200 (5\% do total) para 3 ou quatro mil nas próximas eleições ${ }^{7}$ devido a essa ação.

${ }^{6}$ Jornais de grande circulação na cidade do Rio de Janeiro, símbolos de uma classe média intelectualizada.

${ }^{7}$ Lembro que este artigo foi escrito antes das eleições de 2002. Sabe-se agora, outubro de 2002, que W. reelegeu-se deputado estadual. Seria interessante saber se o número de eleitores judeus que o escolheram realmente aumentou.
No que a coisa pegou (o Centro de Referência), teve essa história forte de nazismo, o pessoal sentiu que eu era, além de ser um bom ecologista, um deputado ético, um cara que tava nas paradas, era um cara que ia com a polícia federal e prendia nazistas. Acho que esse foi um divisor de águas, uma coisa forte, a suástica grande pintada é uma coisa muito forte. Eu fui lá com a polícia, com a televisão, saiu em todos os jornais do país, no Jornal Nacional (da Rede Globo) e, a partir daí, eu comecei a ser chamado pra coisas que, normalmente, eu não era (debates, almoços, palestras)

Chamando para eventos no seu interior, a comunidade tenta enquadrá-lo nas suas reivindicações e torná-lo um "político judeu". O ponto de virada, o fechamento dos "Nazistas da Baixada", revela a importância dada à questão da segurança, um dos pontos principais para o político que deseja votos judeus, no caso aqui de parcela de sua juventude. Um outro fator que pode limpar sua imagem de "esquerdista" é a sua preocupação com a ecologia que, apesar de não a desvincular dos problemas mais globais (a ecologia é, por si só, um tema global), não é vista pelos jovens como um tema ideologizado. Na verdade, parece que é exatamente o que W. não considera como ecologia, "vamos cuidar dos jardins, viva o micoleão-dourado", a definição para a maioria das pessoas não familiarizadas com o tema. Sem dúvida, a ecologia, transcendendo as lutas sociais, aliada à luta contra o antissemitismo alavanca o voto étnico judaico.

Percebe-se que as motivações, que tempos atrás estariam circunscritas à questão da "direita" versus "esquerda", se abrem para questões particulares. Combater o antissemitismo, que seria uma forma de combater qualquer tipo de preconceito através de uma pessoa da comunidade", ou seja, individualizar a discriminação, é uma afirmação de pertencimento a um grupo específico. Talvez seja um dos motivos pelos quais o Centro de Referência se refere a "racismo" $e$ "antissemitismo", e não simplesmente "preconceito racial e étnico". O resultado desta incursão pela comunidade judaica e sua reação, especificamente de parte de sua juventude, só poderá ser avaliada nas próximas eleições ${ }^{8}$. O problema do preconceito afasta $\mathrm{W}$ de $\mathrm{A}$, na medida em que este não faz política como judeu e defende a ideia de que o antissemitismo é um mal que, no Brasil, é menos intenso do que em relação a outros grupos minoritários e que deveria ser combatido como qualquer outro tipo de racismo. Esta visão não está de

${ }^{8}$ Ver nota anterior 
acordo com o que um "candidato etnicizado" pensa ou diz que pensa, já que a universalização do discurso afasta potenciais eleitores.

Eu acho errado alimentar a paranoia na juventude judaica em torno desse tipo de coisa (o medo de antissemitismo). (...) Eu acho que o antissemitismo é uma das formas menores de racismo que existem no Brasil, o racismo contra os negros, japoneses, nordestinos é muito mais intenso do que o racismo contra os judeus, pelo menos dentro do RJ. (...) Não vejo que o antissemitismo, neste momento, seja um grande problema até dentro do espectro de manifestações racistas que possam existir (A, do PV)

Ainda em relação ao caso dos "Nazistas", o então candidato a vereador pelo PSB (Partido Socialista Brasileiro), J., enviou cartaspropaganda às residências judias do Rio de Janeiro. Ela dizia o seguinte:

Como você acompanhou pela imprensa, fundamos, em 5 de julho deste mês, junto com a companheira R. e o deputado W o Centro de Referência contra o Racismo e o Antissemitismo, na Secretaria de Segurança Pública do Estado do Rio de Janeiro. No dia 3 de agosto, recebemos uma denúncia e, baseados na lei federal n.7716, convocamos a polícia federal e fechamos uma associação, dita esportiva, com o nome 'Nazistas da Baixada', que apresentava duas grandes suásticas em sua porta de entrada. O presidente da referida entidade jd foi preso e autuado, e prosseguem as diligências visando a punição de todos os responsáveis. Nós, que temos o compromisso de ações concretas contra o antissemitismo, continuamos a desenvolver nosso trabalho parlamentar priorizando a defesa da comunidade judaica e dos princípios democráticos da nossa sociedade (grifos dele).

Há uma foto de W. e J. na frente da tal associação e, na frente da correspondência há a frase "Quando o calo apertar, com quem podemos contar?". Esta ideia, de que a consciência aflora em momentos de crise, aparece nos depoimentos dos jovens, por exemplo, quando um rapaz (já citado) afirma que este episódio fez W. se voltar para a sua comunidade. Além dessa frase, chama a atenção a ausência da sigla do partido pelo qual J. concorre, embora haja o número a ser digitado na urna eletrônica.

Quanto mais ideológico o partido, com um programa de governo bem definido e ainda dividindo os campos entre "direita" e "esquerda", menor a possibilidade de etnicizar o discurso político. É provável que o poder de convencimento de um candidato do PSB seja menor que o de um outro do PMDB, embora o conhecimento, pelo jovem eleitor, da filiação partidária de cada um não leve, inexoravelmente, ao abandono do representante socialista. Se ele desvincular os projetos econômicos e sociais do partido de suas pretensões relativas ao bem-estar comunitário, a filiação vai tornar-se irrelevante. Note-se que o problema só ocorre com relação à esquerda do espectro político, especificamente aquela que ainda carrega a imagem de "revolução operária", do "perigo vermelho", do "anarquismo" e da "bagunça". A trajetória do candidato desacreditável é utilizada como meio de desvinculá-lo deste estigma ${ }^{10}$.

Eu até percebo o quê que é. Muitas vezes, o cara quer o voto da comunidade. Como ele sabe que a comunidade é menos progressista, então ele diz 'sou J', sou judeu e sou médico, fui presidente da federação e meu número é tal'. Numa dessas, ele achava que o nome (do partido) ia tirar alguns votos, não sei... Isso é uma probabilidade (W, do PT)

Esta linha de raciocínio, de que se vota na pessoa e não no partido, também parece ter influenciado na escolha da legenda de Z., o PL. Neste caso específico, o que contava a seu favor era o fato deste partido não estar envolvido em escândalos políticos ou financeiros, eventos que poderiam manchar a imagem de respeitabilidade e confiança dos candidatos a ele

\footnotetext{
${ }^{9}$ É interessante o depoimento de uma das jovens entrevistadas para o mestrado, referente à participação num dos movimentos juvenis socialistas, o Hashomer Hatzair: "Porque minhas amigas tavam indo e eu fui na aba. Na época eu sabia (a ideologia), hoje em dia.. .A Shomer eu sei que é o movimento mais revolucionário, mais pra fazer 'aliá7 (emigrar para Israel), tem muita coisa também da parte política (...) Eu não sei explicar isso...eles seguiam uma linha mais rigorosa, eram mais tumultuados. Não era aquela coisa 'ah! A paz', era tudo pro tumulto. Eu entrei pra conhecer gente." Esta moça disse não ser socialista. Apesar da esquerda ser relacionada aqui ao "tumulto", a ideologia sionista e socialista deixa de ser um motivo, ao menos o principal deles, que induz o jovem a entrar no movimento.

${ }^{10}$ Considerando-se "de direita" e abertamente favorável à economia de mercado, baseada na livre iniciativa e na lei da oferta e da procura, Y afirma: "Não acredito na economia socializada, não acredito no Estado gigantesco tomando conta de tudo, eu não quero isso. Eu prefiro um Estado enxuto cuidando de funções básicas que ele tem que cuidar que é principalmente da política nacional e da política internacional". Ele próprio divide o espectro político entre capitalistas e socialistas. Seria uma incoerência, portanto, apoiar um candidato filiado ao PSB, como fez nas últimas eleições. Vê-se, então, que a lógica da política, neste caso, não passa pela adesão a uma corrente de pensamento universalista, mas se conforma ao discurso etnicizado e particularista.
} 
filiados. É interessante notar que Z. acredita num possível desgaste político devido à crescente influência da Igreja Universal do Reino de Deus (inclusive sendo um de seus bispos o presidente nacional do partido), acusada de charlatanismo. O exemplo mais forte usado pelos adversários da seita é o dos encontros que ocorriam no estádio do Maracanã, quando milhares de fiéis lotavam as arquibancadas e doavam objetos e dinheiro. $\mathrm{Na}$ televisão, apareciam funcionários carregando enormes sacos com tudo o que havia sido arrecadado, daí surgindo a imagem, construída por parcela da mídia, de exploradores e charlatões.

(...) é um partido que, obviamente eu li o estatuto antes de me filiar, é um partido que eu achei muito bom. Inclusive as, digamos assim.. .o estatuto muito bom. Se são praticados é outro papo, mas pelo estatuto tem uns ideais muito bons. Achei que era um partido tranquilo, partido que não tava envolvido em escândalos, ninguém ouvia muito falar do PL, um partido 'light'

A ascensão social de boa parte da 2' e $3^{\text {a }}$ gerações de judeus, já nascidos no país, levou a uma guinada para os partidos classificados como de centro-direita. Contudo, como pude constatar neste grupo de jovens judeus cariocas, a utilização de argumentos posicionais (Grun: op.cit), ou seja, que procuram entender as opções políticas em função de seu posicionamento na estrutura social, parece não ter validade inconteste. Creio que a questão étnica, se apropriada de modo "correto" pelo candidato "de esquerda", se sobrepõe à questão de classe. Postular um cargo legislativo por uma legenda à esquerda do espectro político, por si só, não significa rejeição imediata, tudo dependendo da margem de manobra do candidato referente à possibilidade de utilizar um discurso particularista, direcionado ao grupo étnico, desligando-se das propostas gerais do partido. Isso é mais plausível quanto menos ideológico ele for.

O voto, quando compreendido na sua dimensão sociocultural, significa adesão a uma facção da sociedade (Kushnir: op.cit). Essa adesão ocorre por uma afinidade simbólica, representada pelo voto de confiança e honestidade do candidato, incorporado ao universo cultural do grupo em questão. Ele entende suas preocupações, sente da mesma maneira suas angústias. No caso deste grupo de jovens, a legitimidade do político está relacionada a um comportamento tido como "normal", aceito socialmente. Trava-se, no seu interior, uma luta pelo poder de definir quais as regras a serem utilizadas pelo político na defesa dos interesses corporativos. Seu papel social projeta a própria imagem que a comunidade judaica, enquanto instituição, deseja apresentar à sociedade brasileira, e certos atributos (idade, caráter, tipo de relação com os não judeus etc.), articulados ou não, são tornados coletivos, étnicos. Sua maior ou menor legitimidade varia em função dessa luta simbólica ${ }^{11}$.

A política étnica é uma consequência da crise do judaísmo moderno (Grin:1997). Nessa fase, havia uma intensa reflexão discursiva relativa à condição judaica e sua adaptação aos ideais universalistas surgidos com o Iluminismo. Ele queria ser incorporado aos movimentos políticos-ideológicos com propostas transnacionais e era plural, com diferentes definições. O que era tomado como oposição, etnicidade/ cidadania nacional ou público/ privado, hoje passa a ser uma relação complementar. O exercício da cidadania está ligado à liberdade de expressar seu modo de ser, ainda que diferente de uma suposta maioria, e a ambiguidade de certos políticos judeus, que querem proteger sua comunidade sem ferir a ideologia da mestiçagem brasileira, mostra como a ideia de cidadania judaica ainda soa estranha aos ouvidos. A noção de igualdade está intimamente relacionada à de liberdade, ser diferente e lutar por seus direitos no domínio público. O direito universal passa a ser a defesa do particular sem que haja contradição entre estes termos, misturando, "à brasileira", judeidade a brasilidade.

\section{Referências bibliográficas:}

BOURDIEU, Pierre "A representação política. Elementos para uma teoria do campo político" in BOURDIEU, Pierre. O poder simbólico, RJ, Bertrand Brasil, 2000.

DAMATTA, Roberto O que faz o brasil, Brasil?, RJ, Rocco, 2000.

DUMONT, Louis "Introdução" in Homo hierarchicus: o sistema de castas e suas implicações, SP, EDUSP, 1995.

GEERTZ, Clifford "O mundo em pedaços: cultura e política no fim do século" in Nova luz sobre a antropologia, RJ, Jorge Zahar Editor, 2001.

GOFFMAN, Erving Estigma, RJ, Guanabara, 1988[19631

${ }^{11}$ É importante frisar que os candidatos que não se comprometem com a coletividade não podem ser considerados "desviantes" na medida em que assumem outro papel social, o de "judeu político". 
GRIN, Mônica "Diáspora minimalista: a crise do judaísmo moderno no contexto brasileiro" in SORJ, Bila (org) Identidades judaicas no Brasil contemporâneo, RJ, Imago, 1997

GRUMAN, Marcelo Sociabilidade e aliança entre jovens judeus no Rio de Janeiro, Dissertação de mestrado, PPGSA/IFCS/ UFRJ, 2002

GRUN, Roberto "Identidade e representação: os judeus na esfera política $e$ a imagem da comunidade" in Revista Brasileira de Ciências Sociais, n.26, ano 9 , outubro/94

"Intelectuais na Comunidade Judaica Brasileira" in SORJ, Bila (org) Identidades judaicas no Brasil contemporâneo, RJ, Imago, 1997

KUSHNIR, Karina "Cultura e representação política no Rio de Janeiro" in PALMEIRA, Moacir \& GOLDMAN, Márcio (orgs) Antropologia, voto e representação política, RJ, Contracapa, 1996

MAUSS, Marcel "Uma categoria do espírito humano: a noção de pessoa, a noção do eu" in Sociologia e Antropologia, SP, EDUSP, 1974

NOGUEIRA, Oracy Tanto preto quanto branco, SP, T.A Queiroz, 1985

POLLAK, Michael "Memória e identidade social" in Estudos Históricos, RJ, vol.5, n.10, 1992, pp.200-212.

"Sociabilidade brasileira e identidade judaica" in SORJ, Bila (org) Identidades judaicas no Brasil contemporâneo, RJ, Imago, 1997

VELHO, Gilberto "Introdução" in VELHO, Gilberto (org) Desvio $e$ divergência: uma crítica da patologia social, RJ, Jorge Zahar Editor, 1989

\subsection{DisCUTINDO O CONFLITO ISRAEL / PALESTINA \\ SOB A PERSPECTIVA BRASILEIRA}

\section{Brasil e Oriente Médio nas Nações Unidas: equidistância, pragmatismo e realismo}

Norma Breda dos Santos ${ }^{1}$

D outros Boutros-Ghali comenta que ao iniciar seu mandato de secretário-geral da ONU, em 1991, a experiência então acumulada pela organização internacional no que dizia respeito ao Oriente Médio, e especialmente com relação aos problemas árabe-israelenses, fazia com esta que fosse vista como devedora por todas as partes envolvidas. "As Nações Unidas", afirma, "contribuíram para a descolonização da maioria dos países árabes e a criação do Estado de Israel, mas ainda não resolveu o problema da descolonização da Palestina, nem teve sucesso no gerenciamento do conflito árabe-israelense. As resoluções adotadas tanto pelo Conselho de Segurança quanto pela Assembleia Geral, que se contam às centenas, serviram somente para exacerbar a dupla crise de confiança relativamente às Nações Unidas. Para Israel, as Nações Unidas eram uma verdadeira máquina de guerra feita para condenar, isolar e enfraquecer o Estado judeu. Para o mundo árabe, as Nações Unidas eram uma organização que dependia de maneira feudal dos Estados Unidos, em que as resoluções pró- árabes de apoio à causa palestina não eram jamais implementadas"2

As ponderações de Boutros-Ghali remetem ao paradoxo que encerram as relações entre os países do Oriente Médio e a ONU. Como lembra o ex-secretário-geral, muitos dos países da região tiveram na organização internacional uma garantia para a própria existência ${ }^{3}$. A

${ }^{1}$ Cientista Política / Universidade de Brasília.

2 BOUTROS-GHALI, Boutros. Unvanquished. A U.S.-U.N. Saga. New York: Random House, 1999, p. 180

${ }^{3}$ No Líbano e na Síria, o domínio francês finda com a II Guerra Mundial. Em 1946, por decisão da ONU, tropas francesas abandonam os dois países. A Resolução 181 da Assembleia Geral, de 1947, aprova o Plano de Partilha que levou à criação de Israel em maio de 1948. Nas décadas de 50 e 60, numa onda de descolonização que tem o respaldo da ONU, 
particularidade geopolítica da região fez da participação desses países na ONU um instrumento importante de sua inserção internacional, sendo os mecanismos institucionais ali oferecidos sempre largamente utilizados. Nem por isso se pode falar de uma percepção generalizada de eficiência da ONU com relação à solução das questões médio- orientais, como é, de resto, aliás, o caso de sua atuação quando considerada mais amplamente. $\mathrm{O}$ que se poderia concluir, então? Provavelmente, não se trata simplesmente de um problema de déficit institucional, visto que aplicações pragmáticas da Carta foram possíveis ao longo dessas mais de cinco décadas de existência da ONU. No caso do Oriente Médio, em particular, pode-se lembrar da criação da primeira força de manutenção da paz (Força de Emergência das Nações Unidas I-FENU I), manifestação da aplicação do "espírito" da Carta, ainda que se fugisse de seus termos formais.

A resposta à questão do grau de eficiência da ONU está, pelo menos em parte, ligada à necessidade de percebê-la como instrumento para a realização dos interesses de seus membros, uma vez que não se pode analisar a eficiência dos foros multilaterais a partir de um ponto de vista puramente formal, mas sim avaliando as condicionantes políticas. Em uma palavra: identificando o que seus membros buscam ao dela participar. Assim, o grau de eficiência no gerenciamento dos problemas médioorientais na ONU tem a ver com as contradições do sistema internacional que tem na ONU um reflexo bastante evidente, bem como contradições inerentes às relações entre os países do Oriente Médio - fazem parte da região 17 Estados árabes, três não árabes e os palestinos, que se consideram árabes e são membros da Liga Árabe, fundada em $1945^{4}$. Um bom exemplo

os seguintes países tornam-se independentes: Líbia, em 1951; Sudão, Tunísia e Marrocos, em 1956; Mauritânia, 1960; Kuait 1961; Argélia, 1962; 1êmen, 1967. Obviamente, há que se considerar também a relevância da Liga dos Estados Árabes, fundada em março de 1945. Cf. DELGADO, Paulo Gabriel G. Processo de paz no Oriente Médio. In: Relações entre Brasil e o mundo árabe: construção e perspectivas (Seminário internacional realizado no Itamaraty, sob os auspicias do Ministério, da Funag e do Conselho de Embaixadores Árabes em Brasília, em 2000). Brasília: Funag, 2001, p. 165.

" O termo "Oriente Médio" foi utilizado pela primeira vez em 1902 e sua extensão geográfica tem variado bastante segundo a análise que se empreenda. Fred Halliday, internacionalista especializado na região, utiliza o termo para cobrir os seguintes países: Arábia Saudita, Argélia, Bahrein, Catar, Egito, Emirados Árabes Unidos, Iêmen, Irã, Iraque, Israel, Jordânia, Kuait, Líbano, Líbia, Marrocos, Omã, Síria, Sudão, Tunísia e Turquia. Cf. o importante trabalho HALLIDAY, Fred. Is/um and Me Myth of Confrontation. London/New York: I.B.Tauris Publishers, 1996, p. 219. do último fenômeno é justamente a solidariedade à causa palestina por parte dos Estados árabes, que praticamente não tem ido além de argumentos retóricos, servindo, na prática, a fins de legitimidade interna desses Estados que, além disso, manipulam a resistência palestina em benefício próprio 5 .

Historicamente, o Oriente Médio tem tido relativamente pouco peso na política externa do Brasil ${ }^{6}$. Essa é provavelmente uma das razões pelas quais pouco se escreva sobre o tema. $\mathrm{Na} \mathrm{ONU}$, o Brasil tem tido uma ação constante e exerceu oito vezes o mandato bianual de membro não permanente do Conselho de Segurança, principal órgão da organização internacional em matéria de segurança e manutenção da paz internacional (1946-1947, 1951-1952, 1954-1955, 1963-1964, 1967-1968, 1988-1989, 1993-1994, 1998- 1999). A bibliografia sobre a participação do Brasil no debate sobre diversos temas na ONU é relativamente vasta, ainda que, nesse âmbito, estudos sobre os posicionamentos brasileiros com relação ao Oriente Médio sejam mais do que raros ${ }^{7}$.

${ }_{6}^{5}$ Ibid., p. 33

${ }^{6}$ Nesse sentido, comenta Osmar V. Chohfi (Chefe-de-Gabinete do ministro Celso Lafer, 2001) que nos "anos 70, diversos fatores ligados à ordem econômica mundial produziram um aprofundamento dos vínculos políticos e econômicos entre nossos países [Brasil e países árabes). As duas últimas décadas do século XX não lograram, entretanto, sustentar o mesmo ritmo de desenvolvimento nos planos diplomático e econômico, tendo em vista dificuldades internas e da conjuntura internacional. (...) Compartilhamos o sentimento de que muito pode e precisa ser feito para dinamizar o relacionamento entre Brasil e os Países Árabes (...) As relações entre os dois lados se situam muito aquém da capacidade de seus mercados e de suas necessidades de desenvolvimento.” Relações entre o Brasil e amando árabe: construção e perspectivas: construção e perspectivas, $O p$. cit., Apresentação, p. 10-11

${ }^{7}$ Ver, por exemplo, PIMENTEL, João Vicente. O padrão de votação brasileiro na ONU e a questão do Oriente Médio, In: DUPAS, Gilberto \& VIGEVANI, Tullo. Israel \& Palestina: a construção da paz vista de uma perspectiva global. São Paulo: Editora UNESP, 2002, p. 287302. Este livro resulta de um seminário internacional que reuniu intelectuais israelenses, palestinos e brasileiros, realizado pelo Instituto de Estudos Avançados (USP), em 2000. Sobre as relações com Israel na ONU, ver dois capítulos particularmente em BREDA DOS SANTOS, Norma (org.). Brasil e Israel: diplomacia e sociedades. Brasília: Editora Universidade de Brasília, 2000: BREDA DOS SANTOS, Norma. O Brasil e a questão israelense nas Nações Unidas: da criação do Estado de Israel ao pós(?)-sionismo, p. 19-70, e VIGEVANI, Tullo \& KLEINAS, Alberto. Brasil e Israel: da partilha da Palestina ao reconhecimento diplomático (1947-1949), p. 71-113. Sobre as relações do Brasil com o Oriente Médio: DEN HARTOG, Carlos A. O Brasil e o Oriente Médio. In: DANESE, Sérgio França. Ensaios de história diplomática do Brasil (1930-1986). Brasília: Funag/IPRI, 1989, p. 143-152; LESSA, Antônio Carlos. Israel e o mundo árabe no cruzamento das escolhas internacionais do Brasil. In: 
Este trabalho tem por objetivo examinar como o Brasil tem se posicionado na ONU com relação à região médio-oriental. A lista de questões debatidas nesse âmbito é extremamente longa. Pretende-se aqui privilegiar somente o que se considerou relevante com o fim de estabelecer um perfil dessa atuação. Note-se, desde já, que na documentação diplomática consultada no Arquivo Histórico do Itamaraty e na documentação publicada pelo Ministério (sobretudo o Relatório Apresentado ao Presidente da República - relatório anual publicado até 1988, e Resenha de Política Exterior do Brasil, publicada de 1975 a 1995) predomina notoriamente a questão israelo-palestina ${ }^{8}$. Aqui, a expressão Oriente Médio abrangerá os países que, no Itamaraty, são tratados pela Divisão de Oriente Próximo (DOP): Arábia Saudita, Bahrein, Catar, Egito, Emirados Árabes Unidos, Iêmen, Irã, Iraque, Israel, Jordânia, Kuait, Líbano, Omã, Síria e assuntos referentes à Autoridade Palestina.

José Vicente Pimentel afirma que o padrão de voto brasileiro na ONU relativamente ao Oriente Médio desde 1947 "revela um consistente pragmatismo em defesa dos interesses brasileiros, que são condicionados por elementos da realidade, tais como: a) relevância político diplomática da região no contexto internacional e, em particular, para um país como o Brasil, que busca adequar sua inserção e visibilidade aos seus objetivos permanentes e imediatos; b) os meios disponíveis para uma atuação consequente; c) a presença no Brasil de expressivas e influentes comunidades árabe e judaica; d) a manifesta preferência das lideranças dessas comunidades por um encaminhamento pacífico das pendências do Oriente Médio, uma vez que a paz providenciaria o cenário adequado à intensificação do intercâmbio, seja no âmbito familiar, seja no econômicosocial; e) a importância estratégico-econômica do Golfo Árabe/ Pérsico, região onde se concentra cerca de metade das reservas mundiais de petróleo, e o fato de os países do Golfo, tradicionais fornecedores de

BREDA DOS SANTOS, Norma. Brasil \& Israel..., Op. cit., p. 149-186; Relações entre o Brasil e o mundo árabe: construção e perspectivas, Op. cit. Mais numerosa é a bibliografia que enfoca as relações socioculturais do Brasil com a região que, entre outros aspectos, tem tratado da imigração para o Brasil de libaneses e sírios, resultado principalmente da desintegração do Império Otomano ao longo e no final da I Guerra Mundial.

${ }^{8}$ Pôde-se contar com a consulta de documentos do Arquivo Histórico do 1tamaraty somente até o começo dos anos 80 , uma vez que a regra geral para que seus documentos tornem ostensivos é de 20 anos. petróleo ao Brasil, constituírem importante mercado consumidor/ reexportador, além de serem investidores internacionais ${ }^{9 ”}$.

Embora corretas, porque, de fato, correspondem a elementos de continuidade nas relações entre o Brasil e o Oriente Médio na ONU, essas observações não dão conta de alterações importantes que acontecem ao longo das últimas quase seis décadas de funcionamento da organização internacional. Nesse sentido, o "estado da arte" permite-nos avançar desde já o argumento de que as mudanças ocorridas no sistema internacional, assim como o padrão de relacionamento do Brasil com os Estados Unidos, afetaram marcadamente a percepção e a ação da diplomacia brasileira na ONU com relação ao Oriente Médio, configurando uma ação governamental de autonomia relativa. Além disso, não se pode propriamente falar em uma política brasileira para a região de médio ou longo prazo, mas de uma diplomacia sobretudo reativa, guiada por interesses imediatos ou pela ausência dos mesmos ${ }^{10}$. Considerando-se que a força motriz da política externa brasileira tem sido a busca de meios para garantir o desenvolvimento do país, a percepção da existência ou não de ocasiões para responder a tal imperativo é a principal linha de continuidade que se pode perceber.

Consideradas essas características gerais, pode-se falar de três períodos de atuação do Brasil na ONU com respeito ao Oriente Médio. O primeiro vai da criação da ONU até o final da década de 60, caracterizado pela equidistância, qualificação utilizada pelo próprio Itamaraty. O segundo período tem início durante o governo Geisel, que tenta responder aos constrangimentos do cenário internacional - em destaque a primeira crise petrolífera -, de maneira mais autônoma e pragmática. As votações brasileiras na ONU serão tendencialmente pró-árabes. O terceiro período começa ao longo dos anos 80 , com a redemocratização do Brasil, o fim da Guerra Fria e a busca da atualização da política externa brasileira. A atuação multilateral brasileira continua a ser regular e, apesar de variações de cinco mandatos presidenciais (Sarney, Collor, Itamar, Cardoso, Cardoso) parece ter-se, afinal, caracterizado, pelo menos em questões relativas à paz

${ }^{9}$ PIMENTEL, José Vicente. O padrão de votação brasileiro na ONU..., Op. cit., p. 287 288. O autor foi diretor do Departamento de África e Oriente Próximo, do Itamaraty, até o inicio de 2001.

${ }^{10}$ Cf. BREDA DOS SANTOS, Norma. O Brasil e a questão israelense nas Nações Unidas ..., Op. cit., p. 22-23. Os parágrafos que seguem também estão baseados no trabalho referido. 
e a segurança internacionais, pela adesão ou baixo grau de resistência ao forte grau de hegemonia exercido pelos Estados Unidos. A política para o Oriente Médio combina, assim, essa resposta realista aos condicionamentos da cena internacional com posicionamentos tradicionais - como a defesa do direito da existência de Israel, a necessidade de resolver-se a questão palestina e a busca de soluções diplomáticas para a região.

\section{Primeiro período: a equidistância (1945-1974)}

Durante os primeiros anos de funcionamento da ONU, a política brasileira caracteriza-se pelo alinhamento com os Estados Unidos em "questões capitais que envolvam a adoção de medidas de defesa da coligação ocidental contra o expansionismo soviético" ". O Brasil tem ação constante na organização internacional, participando dos diversos debates ocorridos na Assembleia Geral e no Conselho de Segurança onde, de 1946 a 1968, exerceu cinco mandatos bianuais de membro não permanente. Os votos brasileiros com relação ao Oriente Médio, região em que Guerra Fria não se manifesta em sua plenitude até meados dos anos 50, demonstram relativa independência, a busca de posicionamentos equitativos e soluções de compromisso. Distante geograficamente da região, com interesses comerciais modestos tanto nos países árabes quanto em Israel, e contando com a presença de comunidades judias e árabes no país, a diplomacia brasileira se pauta no período pela posição equidistante nas diversas questões trazidas a debate, ou seja, mantém "uma política de imparcialidade e neutralidade, embora não de indiferença" 12 .

Em pelo menos três temas debatidos na ONU as posições brasileiras são exemplos dessas características do período: o Plano de Partilha da Palestina, a internacionalização de Jerusalém, a Resolução 242.

\footnotetext{
${ }^{11}$ BRASIL, Ministério das Relações Exteriores, Relatório apresentado ao Presidente da República dos Estados Unidos do Brasil pelo Ministro das Relações Exteriores (Relatório), 1957, p. 24-25.

${ }^{12}$ Relatório, 1971, p. 57.
}

\section{a) O Plano de Partilha da Palestina}

Tullo Vigevani e Alberto Kleinas ${ }^{13}$, ao estudar de modo aprofundado a posição do Brasil na questão da partilha da Palestina, demonstram que, ainda que hajam, afinal, prevalecido posições que se enquadram na caracterização do período - a equidistância -, tensões importantes entre as autoridades no Rio de Janeiro e os representantes brasileiros em Nova Iorque antecederam esse resultado. Tendo como quadro de referência o governo Dutra, os autores apontam as divergências que aparecem na troca de correspondência sobre o tema. De um lado estava o ministro das Relações Exteriores, Raul Fernandes, preocupado com a expansão do comunismo e acreditando que o estreitamento de vínculos com os Estados Unidos coûte que coûte traria benefícios para o Brasil, que deveria, portanto, votar contra a União Soviética e sempre seguir o voto norte-americano. É importante lembrar que naquele ano - 1947 - o Brasil rompia relações diplomáticas com a União Soviética. Do outro lado estava o então representante brasileiro na ONU, Oswaldo Aranha, simpático aos Estados Unidos, porém ciente da necessidade de utilizar o alinhamento como instrumento de barganha nas negociações internacionais. Aranha percebia que o Brasil e a América Latina já não tinham a relevância dos tempos de guerra e que os interesses norte-americanos tinham se deslocado para a Europa e para a Ásia, envolvidos mais diretamente pela Guerra Fria. Daí o Brasil dever utilizar a estreita margem de manobra que lhe restava a fim de atenuar a grande assimetria que caracterizava seu relacionamento com os Estados Unidos.

Durante os meses de abril e maio de 1947, em que se realiza a sessão extraordinária da Assembleia Geral para discutir sobre a questão da Palestina, e em outubro e novembro do mesmo ano, quando a Assembleia reúne-se em sessão anual ordinária, a delegação brasileira enfrenta a difícil tarefa de respeitar as instruções de Raul Fernandes, uma vez que, na realidade, Estados Unidos e União Soviética tinham posições muito próximas no que se referia à questão da partilha da Palestina, o que "chegava mesmo a criar constrangimentos" à delegação ${ }^{14}$.

Esse tipo de problema, que ganha proporções caricaturais com a distância temporal, é demonstrado na troca de correspondência entre a

\footnotetext{
${ }^{13}$ VIGEVANI, Tullo \& KLEINAS, Alberto. Brasil e Israel: da partilha da Palestina ..., Op. cit. ${ }^{14}$ VIGEVANI, Tullo \& KLEINAS, Alberto. Brasil e Israel: da partilha da Palestina ...Op. cit. p. 94
} 
delegação em Nova Iorque e o Rio de Janeiro ${ }^{15}$. Talvez pela dificuldade em conseguir demonstrar a fidelidade brasileira aos Estados Unidos ao mesmo tempo em que rechaçava as posições da União Soviética, que, como referido, entendiam-se sobre a questão da Palestina, em 20 de outubro, poucos dias antes da sessão histórica em que o Plano de Partilha é votado, a Secretaria de Estado instruía Aranha para que se abstivesse na votação sobre o Plano, "dada a oposição dos árabes e a existência no Brasil de uma grande colônia sírio-libanesa". E completava as instruções: "Todavia, se esse voto nulo impedir os dois terços necessários para a aprovação da resolução da partilha, devemos votar de acordo com as grandes potências, às quais incumbirá a responsabilidade de pô-la em prática. Vossa Excelência, em todo caso, procederá de acordo com seu próprio ponto de vista se for diverso do que deixamos indicado, dado que seus elementos de informação são mais completos" ${ }^{\text {". }}$.

No dia 29 de novembro, foi aprovada a Resolução 181, que estabelecia a proteção dos lugares santos, o estatuto internacional de Jerusalém - que ficaria sob tutela da ONU -, e o Plano de Partilha da Palestina.

O Brasil justificaria seu voto de 29 de novembro declarando que "quaisquer que sejam as críticas à partilha - e as mais procedentes se referem à ineficácia da implementação prevista para a manutenção tanto [da] divisão política, quanto da unidade econômica - não há [como] negar que ela era,

\footnotetext{
${ }^{15}$ Em 15 de outubro de 1947, Aranha solicita instruções: “1) A Delegação norte-americana pede o nosso concurso em favor da inclusão de um soviético no novo Comitê a ser criado, com o fim de apresentar um plano concreto relativo à Palestina. 2) Tendo definitivamente entendido da correspondência com Vossa Excelência que não deve a Delegação brasileira favorecer, nem mesmo indiretamente, o acesso soviético a qualquer posição da ONU, agradeceria instruções de Vossa Excelência a fim de poder responder aos norte-americanos. 3) Peço instruções em assunto tão corriqueiro, porque fui informado de que se insinua aí eu ser favorável ao bloco russo e até antiamericano. (grifo da autora) A insinuação é tão absurda e contrária à validade que não deveria merecer referência; faço-a, entretanto, porque estou convencido de que incumbe ao Itamaraty e ao seu eminente chefe defender-nos contra tão infame tentativa para deturpar a verdade. Arquivo Histórico do Itamaraty (AHI), Aranha a Fernandes, 15 de outubro de 1947. Citado por VIGEVANI, Tullo \& KLEINAS, Alberto. Brasil e Israel: da partilha da Palestina ..., Op. cit., p. 94.

16 AHI, Secretaria de Estado à Delegação do Brasil junto à Assembleia Geral da ONU, telegrama 187, 20 de outubro de 1947. Citado por VIGEVANI, Tullo \& KLEINAS, Alberto. Brasil e Israel: da partilha da Palestina..., Op. cit., p. 86
}

dentro das circunstâncias, a única solução plausível”"17. Além de confirmar a estreita margem de manobra com que atuavam os delegados brasileiros na ONU, devendo atender às instruções de Raul Fernandes, ditadas por seu ferrenho anticomunismo ${ }^{18}$, a afirmação reflete o sentimento de que a implementação da Resolução 181 estava largamente comprometida, uma vez que não fora aceita pelos palestinos nem pelos Estados árabes.

\section{b) A internacionalização de Jerusalém}

Embora tenha votado em favor do Plano de Partilha da Palestina e, assim, contribuído à criação de Israel, o Brasil absteve-se na votação na Assembleia Geral com relação à adesão israelense à $\mathrm{ONU}$, em maio de 1949, por causa do descumprimento da Resolução 181 e das resoluções relativas aos refugiados palestinos. Jerusalém encontrava-se ocupada por Israel (cidade nova) e pela Transjordânia, que em junho de 1949 adota o nome de Jordânia (cidade velha). Entre os membros latino-americanos, El Salvador e o Brasil mantêm uma clara posição de condicionar a adesão à "estrita implementação por Israel das resoluções relativas à internacionalização de Jerusalém e à questão dos refugiados árabes", nas palavras de um delegado salvadorenho ${ }^{19}$. O governo brasileiro só estabeleceu relações diplomáticas plenas com Israel em 1952.

\footnotetext{
${ }^{17}$ Do total dos 56 votos à Resolução 181, 34 foram favoráveis, 12 contra (Afeganistão, Arábia Saudita, Cuba, Egito, Grécia, índia, Irã, Iraque, Líbano, Paquistão, Síria e Turquia) e 10 membros abstiveram-se de votar, entre as quais 6 de países latino-americanos (Argentina, Chile, Colômbia, El Salvador, Honduras, México) Cf. United Nations Resolutions on Palestine and Arab-Israeli Conflict (UNR), v. 1, p. 1-6, e AHI, Envio de estudo sobre a Questão da Palestina, Missão do Brasil junto às Nações Unidas para Exteriores, 2 de junho de 1967, Confidencial, Ofícios Recebidos, Cx. 150, p. 2-3.

${ }^{18} \mathrm{O}$ que não deixa de ser surpreendente para alguém com sua experiência internacional. Recorde-se aqui a atuação brilhante de Raul Fernandes na Liga das Nações. Para alguns estudiosos da Liga, Fernandes foi o delegado brasileiro que mais prestígio e influência trouxe para o Brasil em Genebra. O delegado tornou-se conhecido nos meios da organização internacional principalmente por sua participação na redação do Estatuto da Corte Permanente de Justiça Internacional. Cf. BREDA DOS SANTOS, Norma. Lis Brésil et la Sociéte des Nations. Tese de doutorado, Institut universitaire de hautes études internationales, Genebra, 1996

${ }_{19}^{19}$ GLICK, Edward B. Latin America and the Palestine Problem. New York: Theodor Herzl Foundation, 1950, p. 33.
} 
O governo brasileiro enfrentaria dificuldades face à política israelense de querer ver legitimada sua presença em Jerusalém. Em 1963, insistia Israel, oficiosamente, para que o Brasil transferisse sua representação diplomática de Tel-aviv para Jerusalém, sua capital desde 1950, alegando que quatro países latino-americanos já o haviam feito (Venezuela, Uruguai, Guatemala e Panamá), e oferecendo a doação de uma sede "condigna para aquela Missão"20.

A proposta não deixou de encontrar adeptos no Itamaraty, convencidos da irreversibilidade da situação. Posições provavelmente mais consequentes mostravam aqueles que se ocupavam diretamente dos assuntos relativos ao Oriente Médio, avaliando a questão de outra perspectiva. Defendiam o ponto de vista de que aceitar tal proposta significaria contribuir para uma situação de fato, em contradição com os reiterados votos brasileiros pela internacionalização de Jerusalém. Considerando o peso da comunidade católica no Brasil, entendiam que se deveria levar em conta o posicionamento do Vaticano, que não alterara sua posição favorável à internacionalização de Jerusalém. Além disso, ao se pensar na "aura financeira da comunidade judaica", dever-se-ia, igualmente, lembrar que a decisão desagradaria aos países árabes, com os quais o Brasil tinha bom relacionamento e interesses comerciais a defender. $O$ resultado das démarches israelenses em nada resulta, mantendo o Brasil sua embaixada em Tel-aviv.

Dois anos mais tarde, novamente o governo brasileiro viu-se na desconfortável situação de resistir às pressões israelenses para aceitar Jerusalém como local da assinatura de um convênio suplementar ao "Acordo Básico de Cooperação Técnica", firmado entre os dois governos em 1962. O convênio em negociação versava sobre a utilização de energia atômica para fins de pesquisa científica e uso pacífico. $\mathrm{O}$ então embaixador de Israel em Brasília, Yossef Nahmias, argumentava junto ao Itamaraty que diversos acordos com vários países vinham sendo assinados em Jerusalém e que seria inaceitável pensar-se em criar precedentes que pudessem colocar em questão a

${ }^{20}$ AHI, Carlos Alfredo Bernardes (Secretário Geral) ao Ministro das Relações Exteriores, 14 de maio de 1963. Confidencial, Memorandos, Pareceres e Requerimentos. Cx. Todos 1963, Recebidos e Enviados. À época, além das embaixadas latino-americanas em Jerusalém, nove países haviam também instalado suas embaixadas na cidade: Holanda, Grécia, Costa do Marfim, Nigéria, Dahomei, Alto Volta, República Centro-Africana, Gabão e Congo. Portanto, nenhuma grande potência. tendência crescente da comunidade internacional de aceitar Jerusalém como capital de Israel. Produzia-se aí um impasse: de um lado, o Itamaraty relutando em assinar o convênio em Jerusalém e em politizar a assinatura de um acordo técnico; de outro, o governo israelense fechando questão em torno dessa cerimônia em Jerusalém, sem o que o convênio não se realizaria.

Ao longo das trocas de memorandos entre setores que lidavam com a questão no Itamaraty, avançou-se a posição, que o tempo confirmaria como a mais acertada, de que o governo brasileiro deveria resistir às pressões israelenses, notadamente porque, pela própria natureza do convênio a ser estabelecido, os dois países beneficiavam-se de sua realização e que, portanto, barganhar qualquer tipo de vantagem política seria inconcebível. Além disso, ao firmar e manter acordos com Israel, o governo brasileiro já prestava apoio indireto à sua aceitação como Estado na região. O Convênio sobre a Utilização da Energia Nuclear para Fins Pacíficos viria a ser assinado, em 1966, no Rio de Janeiro, e o imbróglio não chegou a inserir elementos críticos no relacionamento entre os dois países.

\section{c) A Resolução 242}

Considera-se que, ao dar início à Guerra dos Seis Dias, no dia 5 de junho de 1967, o governo israelense tenha reagido à hostilidade de seus vizinhos, sobretudo do Egito de Nasser $^{21}$. Daí o imediato apoio da comunidade internacional em seu favor.

Nas horas seguintes ao início do conflito, o Conselho de Segurança reúne-se e, depois de longas conversações, adota, no dia 6 de junho, a Resolução 233, que pede o imediato cessar-fogo e o cessamento de toda atividade militar na área, como "primeiro passo" para a solução do problema - a retirada das tropas israelenses das áreas ocupadas durante conflito era condicionada à cessação da beligerância. Nessas reuniões do Conselho, a Argentina e o Brasil, então membros do órgão, limitam sua atuação praticamente a questões de ordem humanitária. A Resolução 237, por exemplo, aprovada em 14 de junho, foi copatrocinada pelos dois países e pela Etiópia. Inter alia, a resolução solicita ao governo israelense garantir a segurança dos habitantes das áreas afetadas pelo conflito e que todas as

${ }^{21}$ Cf. LALL, Arthur. The UN and the Middle East Crisis, 1967. New York/Londres: Columbia University Press, 1968, p. 47. 
partes nele envolvidas respeitassem os princípios humanitários das Convenções de Genebra de 1949.

No dia 13 de junho, o representante soviético solicita a convocação da Assembleia Geral. A quinta sessão especial de emergência da Assembleia Geral reúne-se em junho- julho com a missão formal de assegurar o retorno ao status quo anterior a 5 de junho. O sentimento geral $e$ o de que a sessão deveria buscar uma fórmula que servisse de base para a paz justa e duradoura no Oriente Médio. Ao contrário das reuniões do Conselho, o Brasil, conjuntamente com a Argentina, tem nessa sessão um desempenho significativo. No entanto, tampouco logra a Assembleia Geral resultados sobre possíveis fórmulas para a solução do conflito ${ }^{22}$.

O Conselho de Segurança retoma, então, a questão em outubro. Argentinos e brasileiros participam novamente de maneira coordenada e contribuem significativamente para os resultados alcançados nessa ocasião $^{23}$. As duas delegações apresentam uma proposta de projeto de resolução que contempla os seguintes itens: retirada das forças israelenses de todos os territórios ocupados simultaneamente à cessação do estado de beligerância, garantia de livre navegação nas águas internacionais da região, criação de zonas desmilitarizadas e solução para o problema dos refugiados. Argentina e Brasil decidem, ainda, que apoiariam qualquer projeto de resolução cujos termos respeitassem os mesmos princípios e tivessem chances de ser aceitos pelas partes em conflito ${ }^{24}$.

No começo de novembro, um projeto de resolução é apresentado pela Grã-Bretanha, com texto bastante similar ao projeto de resolução argentinobrasileiro, o que convence argentinos e brasileiros a apoiá-lo. O Conselho de Segurança adota enfim, por unanimidade, em 22 de novembro de 1967, a Resolução 242, que determina "a retirada das forças armadas israelenses dos territórios ocupados durante o conflito recente"; o fim do estado de beligerância e o direito de todos os Estados da região viverem em paz em seus territórios, delimitados por fronteiras seguras e reconhecidas; a liberdade de navegação nas águas internacionais da região; a necessidade de

\footnotetext{
${ }^{22}$ LALL, Arthur, Op. cit., p. 159.
}

${ }^{23}$ O governo argentino enfrenta uma "imensa pressão" norte-americana e israelense. Cf. AHI, Geraldo de Carvalho Silos para Exteriores, 30 de outubro de 1967, Secreto, Cartas e Telegramas, Cx. 54

${ }^{24}$ Relatório, 1967, p. 120. encontrar-se solução equitativa para a questão dos refugiados; a inviolabilidade territorial e independência política dos Estados da área através do estabelecimento de zonas desmilitarizadas, e a nomeação pelo Secretário-Geral de um Representante Especial, com a missão de encontrar uma solução pacífica, aceita pelas partes envolvidas e que respeitasse os demais dispositivos da resolução ${ }^{25}$.

\section{Segundo período: o pragmatismo (1974-1985)}

Nos anos que precedem ao período Geisel (1974-1979), percebe-se na documentação diplomática uma crescente atenção do governo brasileiro dirigida ao Oriente Médio que, "por sua posição estratégica por suas reservas petrolíferas, pela riqueza e multiplicidade de sua composição racial, cultural e religiosa, é zona de influência importantíssima na balança de poder mundial [...]. ${ }^{26 ، ~ E s s a ~ a t e n c ̧ a ̃ o ~ a u m e n t a r a ́ ~ v i s i v e l m e n t e ~ c o m ~ o ~ i n i ́ c i o ~}$ do governo Geisel, uma vez que o sucesso de seu projeto de desenvolvimento, que dá ênfase à diversificação e modernização industrial, depende dramaticamente da importação de petróleo. Já em 1974, por exemplo, o Brasil é o maior importador do produto entre os países em desenvolvimento e o sétimo em escala mundial. Os mesmos $15 \%$ da receita

\footnotetext{
${ }^{25}$ UNR, v.1, p. 143. Em relatório sobre a reunião do Conselho de Segurança registra-se a atuação brasileira "de primeiro plano, contribuindo assim, de maneira substancial, para o acordo a que se chegou [J. A imparcialidade e objetividade da nossa posição permitiram que a Delegação do Brasil chegasse ao término daquelas negociações contando com a confiança e o reconhecimento dos representantes de Israel e dos países árabes. A decisão do Conselho de Segurança representou, do ponto de vista político, grande vitória para Israel e as potências ocidentais e assim assinalou a maior derrota da União Soviética nas Nações Unidas.” AHI, Geraldo de Carvalho Silos a José de Magalhães Pinto, Ministro das Relações Exteriores, 8 de janeiro de 1968, Secreto, Ofícios Recebidos, Cx. 60. Nas sessões anuais da Assembleia Geral dos anos seguintes, o Brasil repetirá em diversas ocasiões o apelo para que a Resolução 242 seja respeitada, por considerá-la "base justa e segura para o estabelecimento da paz no Oriente Médio". Aqui deve ser, porém, notado que, apesar do caráter crítico que atinge a situação no Oriente Médio, por vezes, a diplomacia brasileira, com respeito ao problema, é de extremo perfil baixo. É o que se observa na Assembleia Geral de 1973, ano da Guerra do Yom Kippour e do aumento do preço do petróleo. Cf. A palavra do Brasil nas Nações Unidas, 1946-1985, Op. cit., p. 286-287

${ }^{26}$ Relatório, 1971, p. 57; 1972, p. 73; 1973, p. 79-80.
} 
das exportações brasileiras que eram em 1972 destinados à compra de petróleo, saltam para cerca de $40 \%$ dois anos mais tarde ${ }^{27}$.

Concomitantemente, os constrangimentos internacionais ganham largas proporções. Com a Guerra do Yom Kippour, de 1973, a unidade afro-árabe reforça-se. Doravante, os Estados que apoiem Portugal, África do Sul ou Israel arriscam ter o fornecimento de petróleo suspenso. Em 24 de novembro de 1973, é passada uma resolução entre 15 Estados africanos que incluía o Brasil entre os seis países a sofrerem boicote diplomático e no fornecimento de petróleo caso não cessassem de apoiar o governo de minoria branca sul-africano. Manifestações árabes no mesmo sentido aconteceriam nos meses seguintes ${ }^{28}$. Importando cerca de $80 \%$ do total do petróleo consumido, o Brasil apresenta uma grande vulnerabilidade face ao drástico aumento do preço do petróleo do final de 1973.

Na realidade, poucos dias antes do final do governo Médici, o ministro das Relações Exteriores, Gibson Barboza anuncia a grande mudança da política externa brasileira para o Oriente Médio. Em janeiro de 1974, o ministro recebe oficialmente Fouad Naffah, chanceler libanês e representante da Liga dos Estados Árabes, e declara ser o Brasil a favor da imediata retirada israelense de todos os territórios ocupados em 1967 e da solução para a questão palestina. O adjetivo "equidistante" não será mais utilizado para caracterizar as posições brasileiras com relação à região médio-orienta $\mathrm{l}^{29}$.

A partir de então, as relações com países em desenvolvimento, sobretudo a América Latina e a África, tornam-se prioritárias. A dimensão multilateral da política externa brasileira passa a orientar-se pelo esforço do governo em modificar a hierarquia internacional e assegurar avanços em suas relações bilaterais, notadamente com os países árabes ${ }^{30}$. Na ONU, os países do terceiro mundo aproveitam sua vantagem numérica para enfrentar a liderança ocidental. O Grupo dos 77, que reúne esses países (mais de uma

${ }^{27}$ Cf. Crise energética impõe novas vias de cooperação. Discurso do embaixador Paulo Cabral de Mello, representante brasileiro à Conferências Mundial sobre Energia, Paris, 7 de abril de 1975. Resenha de política exterior do Brasil, abr./maio/ jun. 1975, 2, Brasília: Ministério das Relações Exteriores, p. 96.

${ }^{28}$ SELCHER, Wayne. Brazil's Multilateral Relations. Between First and Third Worlds. Boulder: Westview Press, 1978, p. 111

${ }^{29}$ Ibid., p. 111 e 112, e DEN HARTOG, Carlos Alberto M. Op. cit., p. 148-149.

${ }^{30}$ SELCHER, Wayne A. Op. cit., p. 11, 231, 215. centena, na realidade), passa a comandar grande parte das comissões e subcomissões dos diversos órgãos da ONU.

\section{a) A Resolução 3379}

O voto brasileiro na sessão ordinária da Assembleia Geral de 1975, em favor da Resolução 3379, representa uma mudança aguda no padrão de voto da diplomacia brasileira, orientado pela equidistância. É verdade que o Brasil enfrenta então enormes constrangimentos internacionais resultantes de sua dependência do petróleo árabe e que o governo israelense encontrase isolado na ONU desde o final do conflito de 1967 por não aceitar o recuo dos territórios ocupados. Ainda assim, a correspondência trocada entre o Itamaraty e os delegados brasileiros na ONU demonstra que houve um erro de cálculo na avaliação das repercussões que teria o apoio brasileiro à Resolução que qualifica o sionismo como forma de racismo e de discriminação racial.

Pouco após a votação, o embaixador brasileiro em Nova Iorque, Sérgio Corrêa da Costa, comenta sua surpresa quanto às reações que a aprovação da resolução, "de valor declaratório", havia suscitado na Europa e na América Latina. Os delegados brasileiros sentem seus contatos esfriarem-se com muitas delegações ${ }^{31}$.

Ernesto Geisel diria sobre o assunto, mais de vinte anos depois, que era contra a maneira evasiva, típica da diplomacia, se posicionar, e contra o hábito do Itamaraty abster-se em votações quando era sabido que desagradaria aos norte-americanos. "Não aceitei isso, dizendo que era uma covardia. Se o Brasil tem uma opinião, ele tem que defender o seu ponto de vista e votar de acordo com sua convicção. Estou convencido até hoje de que o sionismo é racista. Não sou inimigo dos judeus, inclusive porque em matéria religiosa sou muito tolerante. Mas como é que se qualifica o judeu, quando é que o indivíduo é judeu? Quando a mãe é judia. O judaísmo se transmite pela mãe. O que é isso? Não é racismo? [...) Por que eu não posso declarar isso ao mundo?” Acrescentaria que o Brasil não tinha produção de armas suficiente que pudesse justificar, como fora suposto, o voto favorável à Resolução 3379. Ou seja, não procedia o argumento de que, com o voto, o

31 AHI, Sérgio Corrêa da Costa para a Secretaria de Estado, novembro de 1975. Confidencial, Ofícios, Cx. 70. 
governo pretendera agradar os países árabes com vistas a patrocinar a venda de armas de produção brasileira àqueles países ${ }^{32}$.

Walder de Góes, jornalista que cobriu de maneira muito próxima o período Geisel, afirma que "o Chanceler Azeredo da Silveira levou o assunto ao presidente depois de motivado por um telefonema de Nova Iorque. Como a votação se faria no dia seguinte, Geisel autorizou o voto favorável à proposta que considerava o sionismo uma forma de discriminação racial. No dia seguinte, constatado o equívoco político do voto, Geisel pediu à chancelaria que modificasse a posição adotada. $\mathrm{O}$ voto brasileiro foi proferido na terceira Comissão (Comissão Política) e somente cinco dias depois a votação definitiva se faria na Assembleia-Geral. $O$ Brasil iria recuar do voto originalmente dado, por ter o presidente verificado que a pressa e a insuficiência de informações induziram-no a erro de decisão. Não o fez, todavia, porque, naquele ínterim, o Departamento de Estado norte- americano, através de porta-voz, criticou a posição do Brasil, ferindo os brios nacionais brasileiros" 33 .

Outra versão é dada pelo Sr. Eliézer Burla, líder da comunidade judaica no Rio de Janeiro e consultor de empresas à época. O Sr. Burla tinha contato pessoal e regular com o presidente da República, assim como com Golbery do Couto e Silva e pessoas do entourage do presidente. Hospedava-se, inclusive, no Palácio do Planalto nos dois dias que passava regularmente por semana em Brasília. Após ter sido dado o voto em plenária da Assembleia Geral, o presidente Geisel teria solicitado ao Sr. Burla que viesse ao Palácio do Planalto para uma conversa sobre o assunto. O Sr. Burla relata que o presidente teria explicado que o governo não tinha tido condições de mudar seu voto. $\mathrm{O}$ então embaixador norte-americano no Rio de Janeiro havia-lhe escrito solicitando que o Brasil mudasse sua posição, carta que havia sido publicada em diversos jornais. Não admitindo essa atitude, que entendia como pressão, Geisel decide manter o voto favorável à resolução antissionista. Conta ainda o Sr. Burla que, depois da entrevista com o presidente, conversara a sós com Golbery do Couto e Silva

\footnotetext{
${ }^{32}$ D'ARADJO, Maria Celina \& CASTRO, Celso (orgs.) Ernesto Geisel . 3. ed. Rio de Janeiro: Fundação Getúlio Vargas, 1997, p. 342-343.

${ }^{33}$ GÓES, Walder de. O Brasil do general Geisel: estudo do processo de tomada de decisão no regime militar-burocrático. Rio de Janeiro: Nova fronteira, 1978, p. 30. A versão de Góes é confirmada por Vasco Mariz, embaixador do Brasil em Israel de 1977 a 1982. Cf. MARIZ, Vasco. O Oriente Médio hoje e amanhã. Defesa nacional, n. 762, out./dez. 1993, p. 95
}

e contara-lhe que quem havia, na verdade, mandado publicar a carta na imprensa fora o ministro das Relações Exteriores, Azeredo da Silveira, para evitar que o presidente decidisse pela mudança do voto, lamentando o fato de o presidente estar sendo manipulado por pessoas de sua confiança ${ }^{34}$.

\section{b) Os palestinos}

Ao final da guerra entre judeus e árabes de 1948-49, cerca de $650 \mathrm{mil}$ palestinos árabes deslocam-se em direção dos países vizinhos, estabelecendo-se especialmente na Jordânia e no Egito ${ }^{35}$. Viu-se que a abstenção do Brasil na votação de adesão de Israel à ONU, em 1949, deviase ao não cumprimento da Resolução 181 e ao desrespeito às resoluções adotadas com relação aos refugiados palestinos. A Resolução 194, de dezembro de 1948, estabelece inter alia o direito dos refugiados retornarem aos seus lares e a indenizações pelos bens daqueles que decidirem não regressar aos seus lares e pelos bens perdidos e/ ou danificados ${ }^{36}$.

A gravidade da situação dos refugiados palestinos não é desconhecida do Itamaraty, mas acaba, com o avançar dos anos, sendo relegada à retórica condenatória a Israel, sem grandes consequências para esse Estado, como a questão de Jerusalém. Em 1948, escrevia do Cairo T. Graça Aranha: “O Embaixador Americano, que está regressando de sua viagem à Palestina, ao Líbano e à Síria, onde foi verificar a situação dos refugiados árabes emigrados dos territórios palestinenses ocupados, disse-me que se encontrava muito impressionado com a situação dessa pobre gente, numa indescritível miséria. Viu mais de 1500 crianças em desamparo, quase todas contaminadas por terríveis doenças. Não acha solução para o assunto, nenhum país querendo receber esses refugiados e a volta deles à Palestina parecendo coisa muito

\footnotetext{
${ }^{34}$ Eliézer Burla contou esses fatos no momento da apresentação deste trabalho no III Encontro de Estudos Judaicos, em abril de 2002, e os confirmou posteriormente em entrevista à autora.

${ }^{35}$ Cf. REICHMAN, Shalom, Partition and Transfer: Crystallization of the Settlement Map of Israel Following the War of Independence, 1948-1950. In: KARK, Ruth (ed.). The Land that became Israel. Studies in Historical Geography. New Haven e Londres: Vale University Press, 1990, p. 324.

${ }^{36}$ Israel vota contra a Resolução 194, contra as resoluções da Assembleia Geral que todos os anos a têm reiterado, e continua a rejeitar qualquer retorno de refugiados. Cf. DEMAND, Peter. A temporada dos escorpiões: há uma saída para a crise no Oriente Médio? Política externa, v. 11, n. 1, jun./jul./ago. 2002, p. 18
} 
problemática. Enquanto isso, acrescentou o Embaixador, os judeus do mundo inteiro, mormente dos Estados Unidos, enviam continuamente somas enormes ao Estado de Israel.".

A Assembleia Geral cria, em 1949, a Agência de Auxílio e Obras das Nações Unidas para os Refugiados do Oriente Médio (United Nations Relief and Works Agency, UNRWA), com mandato para prestar assistência humanitária aos refugiados palestinos. O Brasil vota favoravelmente à resolução que cria a Agência e tem votado a favor das resoluções que chamam a atenção da comunidade internacional para a necessidade de apoiar seu trabalho, assim como as ações em geral de apoio ao povo palestino. Em 1964, por exemplo, com relação à sessão da Assembleia Geral daquele ano, a diplomacia brasileira registrava que "[n] a discussão sobre os refugiados árabes da Palestina evidenciou-se, mais uma vez, o tradicional antagonismo das posições árabes e hebraica, cujo veemente diálogo absorveu dois terços do debate geral. A situação da UNRWA é precária (...). A iniciativa de um projeto de resolução equidistante (...) este ano como nos derradeiros coube à delegação dos Estados Unidos, maior contribuinte para a manutenção da Agência. O Brasil, coerente com sua atitude costumeira, não participou do debate, limitando-se a votar favoravelmente à proposta norte-americana, no que foi acompanhado pelos latino- americanos (...)."

A partir de 1974, o governo brasileiro passa a defender mais explicitamente o direito palestino de autodeterminação e manifesta-se com maior frequência contra ocupação territorial pela força na região, não chegando, porém, a aprovar atos terroristas ou resoluções da ONU que questionassem a existência do Estado de Israel ou propusessem sua expulsão da organização internacional. Na imprensa brasileira abranda-se a censura às notícias relativas aos palestinos e aos regimes radicais árabes. Evita-se mencionar o terrorismo palestino, enquanto reitera-se a importância e as vantagens da intensificação do comércio e a cooperação entre o Brasil e os países do Oriente Médio. De toda maneira, a política israelense já é bastante contestada à época e a defesa reiterada da causa dos árabes palestinos afina-se com a simpatia que passa a granjear internacionalmente, principalmente na ONU, onde o terceiro mundo aponta como força decisiva ${ }^{37}$.

\footnotetext{
${ }^{37}$ SELCHER, Wayne A. Op. cit., p. 115.
}

O discurso de Azeredo da Silveira, novo chanceler brasileiro, na sessão da Assembleia Geral de 1974, enuncia as mudanças da política externa brasileira. Explicita o apoio do Brasil à independência da África portuguesa, condena veementemente o apartheid e nos seis parágrafos dedicados à situação do Oriente Médio - o dobro do máximo que a região ocupara até então nessas ocasiões - não deixa de mencionar a situação dos palestinos na região: "O drama do Oriente Médio se amplia e se universaliza na medida em que envolve aspectos humanos que não podem ser ignorados. É impossível à comunidade das Nações omitir-se nos seus esforços inclusive junto aos povos do Oriente Médio para que atendam, com as medidas adequadas, ao sofrimento do povo palestino. É desumano pensar que será equitativa e ilusório esperar que será duradoura qualquer solução que não atenda aos seus direitos. ${ }^{38 ، " ~ N a q u e l e ~ a n o, ~ o ~ B r a s i l ~ v o t a ~}$ favoravelmente à resolução que convida a Organização para a Libertação da Palestina (OLP) a participar da Assembleia Geral a título de observador ${ }^{39}$.

Vê-se, pois, que além da diversificação de parcerias externas tão almejada no período Geisel, há que se mencionar novamente a magnitude que ganha a causa palestina no período, fenômeno que se beneficia, de um lado, do maior peso do movimento terceiro-mundista na ONU e, de outro, da condenação à política israelense, percebida cada vez mais como intransigente e inaceitável.

A Assembleia Geral de 1977 estabelece que o dia 29 de novembro, dia em que fora aprovado o Plano de Partilha da Palestina em 1947, seria comemorado todos os anos como o Dia Internacional de Solidariedade ao Povo Palestino. O Brasil apoia a decisão, mas ausenta-se durante a votação da Resolução 31/20, que prevê a criação de um Estado palestino na Faixa de Gaza e na Cisjordânia, com a administração interina da ONU e posterior transferência à OLP. A prudência do governo, que justifica sua posição pela necessidade de se aprofundar as discussões, não deixa de frustrar os delegados árabes e fazê-los saber que não poderiam contar com o apoio incondicional brasileiro ${ }^{40}$.

\footnotetext{
${ }^{38}$ A palavra do Brasil nas Nações Unidas, 1946-1985. Brasília: FUNAG, 1995, p. 307.

${ }^{39}$ UNR, v. 1, p. 12-13. Fato interessante a ser observado nessa votação: os Estados Unidos votam contra a resolução, enquanto Israel abstém-se.

${ }^{40}$ SELCHER, Wayne, Op. cit., p. 116-117.
} 
As relações formais entre o Brasil e os palestinos têm início em $1975^{41}$, quando o governo brasileiro autoriza a OLP a designar representante em Brasília, no escritório da Liga dos Estados Árabes. Em 1993, a representação passa à categoria de "Delegação Especial Palestina" e, em abril de 1998, já figura na lista do Corpo Diplomático, no item "Países e Delegações". Atualmente, a Delegação Especial Palestina possui embaixador e delegado de Missão, cargos exercidos por Musa Salim Odeh ${ }^{42}$.

\section{Terceiro periodo: o realismo (1985-2002)}

Para melhor compreender as posições brasileiras na ONU com relação ao Oriente Médio a partir de 1985 e, principalmente, a partir do final da Guerra Fria, é interessante observar a percepção da diplomacia brasileira sobre a conjuntura internacional e o que resulta como orientação e prioridades para buscar então a inserção internacional adequada para o Brasil. Nesse sentido, Alexandra de Mello e Silva analisa os pronunciamentos diplomáticos brasileiros desse contexto e observa que dois momentos distintos aparecem: o primeiro pós-Guerra Fria e o segundo pós-Guerra Fria.

O primeiro pós-Guerra Fria vai da queda do Muro de Berlim, em 1989, à Guerra do Golfo em 1990/91. Nele a diplomacia brasileira mostrase otimista e satisfeita com a ordem internacional, pois considera que predominam internacionalmente forças de integração. Estas forças engendram a constituição de uma comunidade internacional, pois seus membros partilham dos mesmos valores básicos (as regras do mercado e da democracia liberal). O papel da ONU é revalorizado. O Conselho de Segurança, não mais paralisado pelos vetos constantes de Estados Unidos e União Soviética, passa a mostrar-se mais eficaz, a exemplo de sua atuação durante a Guerra do Golfo.

O segundo pós-Guerra Fria começa com a desintegração da União Soviética e da antiga Iugoslávia. Ganham força os conflitos intraestatais, de natureza étnica, religiosa, etc. Os problemas que surgem nas diversas

\footnotetext{
${ }^{41}$ Segundo Selcher, o governo demora em aceitar a solicitação da OLP para a representação em escritório no Brasil. Ibid., p. 117.

${ }^{42}$ MAJZOUB, Ismail. Desenvolvimento das relações árabe-brasileiras. In: Relações entre o Brasil e o mundo árabe..., Op. cit., p. 78.
}

operações de paz estabelecidas no período (na Bósnia e na Somália), bem como a atuação o Conselho de Segurança durante a crise no Haiti, fazem do órgão o alvo de muitas críticas e sua reforma e ampliação é rediscutida. $\mathrm{O}$ otimismo e a crença no bom funcionamento do sistema internacional dá lugar, portanto, a uma orientação realista, que entende que as instâncias internacionais devem adequar-se à existência de novos polos de poder. $\mathrm{O}$ sistema internacional redefine então suas regras e o Brasil, por reunir uma série de atributos que o qualificam a uma maior participação na elaboração dos novos mecanismos regulatórios das relações internacionais, coloca-se como candidato a um assento permanente no Conselho de Segurança ${ }^{43}$.

É no contexto do Segundo Pós-Guerra Fria que o Brasil exerce seu oitavo mandato bianual no Conselho de Segurança, entre janeiro de 1998 e dezembro de 1999. Entre outubro de 1997 e fevereiro de 1998, acontece mais uma das graves crises entre o Iraque e os Estados Unidos/ Conselho de Segurança. Ver-se-á que, mesmo com contradições, a atitude que a diplomacia brasileira assume no episódio (janeiro/ fevereiro de 1998) pode ser compreendida como resultado da leitura que o Itamaraty tem da cena internacional e das margens de manobra que o Brasil desfruta. A duplicidade da diplomacia brasileira na ocasião, assumindo posições diversas em frentes diferentes, permite que se constate a coexistência de uma visão pautada na equidistância e na busca de soluções jurídicas diplomáticas, de um lado, e uma visão realista das relações internacionais, de outro. Esse realismo difere daquele que inspira o Pragmatismo Responsável do período Geisel, nacionalista e preocupado com a ampliação das bases de autonomia do país. O novo realismo não confronta o hegemon, aceitando servir-lhe, inclusive, caso este seja o caminho para galgar uma nova posição na hierarquia internacional.

\section{a) A crise Iraque/Estados Unidos/Conselho de Segurança (outubro 1997-fevereiro 1998)}

Em consequência da invasão iraquiana ao Kuait, em agosto de 1990, o Conselho de Segurança adota a Resolução 678, que autoriza seus membros a utilizar "os meios necessários" (leia-se: a força) para assegurar a implementação de suas demais resoluções que exigiam a retirada do Iraque

${ }^{43}$ MELlO E SILVA, Alexandra. O Brasil e o Conselho de Segurança da ONU. Carta Internacional, n. 68, Ano VI, outubro de 1998. 
do Kuait e o restabelecimento da paz e da segurança internacionais na área. Com base nessa resolução, a aliança militar liderada pelos Estados Unidos dá início às operações militares contra o Iraque, em 17 de janeiro de 1991. Em 28 de fevereiro, é estabelecido o cessar-fogo, sob condição de que o Iraque destrua seu arsenal de armas de destruição massiva. Uma equipe é criada pela ONU para inspecionar a destruição desses arsenais (United Nations Special Commission, Unscom).

Em outubro de 1997, Richard Butler, novo chefe da Unscom, equipe que trabalha no Iraque há mais de sete anos, entrega ao Secretário-Geral da ONU um relatório em que se afirma não ter o governo iraquiano cumprido com suas obrigações sobre desarmamento, fazendo especialmente menção à existência de armas biológicas. Duas semanas mais tarde, o Iraque proíbe a participação de cidadãos norte-americanos na Unscom e nas semanas seguintes a situação deteriora-se: Saddam Hussein passa a proibir a inspeção dos palácios presidenciais; os Estados Unidos anunciam que intervirão militarmente (operação Trovão no Deserto); Madeleine Albright, secretária de Estado, visita os países do Golfo em busca de apoio para a intervenção militar; Estados Unidos e Grã-Bretanha concentram tropas no Golfo e buscam, no Conselho de Segurança - onde China, França e Rússia insistem sobre a necessidade de uma saída diplomática - o sinal verde para a intervenção $\operatorname{armada}^{44}$.

$\mathrm{O}$ ataque ao Iraque não se concretiza imediatamente como desejam os Estados Unidos e a Grã-Bretanha, já que o apoio dos países do Golfo não é conseguido e o Conselho de Segurança não dá autorização para a intervenção. Nesse ínterim, entre as várias démarches diplomáticas norte-americanas, está de buscar o apoio dos membros não permanentes, entre eles, o Brasil.

É com esse objetivo que Bill Richardson, embaixador dos Estados Unidos na ONU, encontra-se no dia 6 de fevereiro de 1998, no Brasil, com o presidente Fernando Henrique Cardoso e com o ministro Luiz Felipe Lampreia. Após o encontro o ministro Lampreia anuncia que "se a solução diplomática não for possível, o Brasil dispõe-se a apoiar uma solução militar" ${ }^{, 4}$. No dia 15 , reitera-se essa posição: "Consoante sua tradição

\footnotetext{
${ }^{44}$ Brazil in the Security Council,1998-1999, Ministério das Relações Exteriores, s/l, s/d, p. 169-170, e Saiba tudo sobre o Iraque, Folha de São Paulo, Mundo, 22/2/1998, p. 15.

${ }^{45}$ Cf. Nossa posição é que se faça o máximo esforço para que se consiga uma solução pela
} via da pressão diplomática. O Estado de São Paulo, 7/2/98, A, p. 18. diplomática, o Brasil estima que se devam esgotar todos os recursos de negociação com o Iraque. (...) Considera, no entanto, que, diante da gravidade a situação, todas as opções permanecem sobre a mesa. Não exclui, portanto, o recurso a outros meios, esgotados os esforços diplomáticos."

Essas declarações apresentam como novidade o fato de o governo brasileiro admitir que a intervenção militar norte-americana pudesse se dar sem a devida autorização do Conselho de Segurança, posição que contraria aquilo que a própria representação brasileira no Conselho de Segurança defende há anos, ou seja, a necessidade de uma saída diplomática e a exclusão da utilização da força sem autorização do órgão ${ }^{46}$.

Fica evidenciada, pois, a duplicidade que assumem as manifestações em Nova Iorque e Brasília. Essa ambiguidade é assinalada por alguns jornais de grande circulação, onde se lamenta o fato de o Brasil não manter a posição de independência e neutralidade que mantivera até o momento com relação a várias questões trazidas ao Conselho. Alguns veem nessa atitude a tentativa de angariar a simpatia das autoridades norte-americanas para também obter seu apoio à candidatura brasileira ao assento permanente no Conselho, caso este fosse reformado ${ }^{47}$.

No dia 23 de fevereiro é anunciado o acordo entre o secretário-geral, Kofi Annan, e Saddam Hussein para a solução pacífica da crise. Os Estados Unidos são constrangidos a recuar da decisão de intervir militarmente.

Embora não seja fácil avaliar os eventuais benefícios do duplo posicionamento do Brasil nessa ocasião, deve-se, mais uma vez, observar que, sobretudo durante 1998-1999, os pronunciamentos brasileiros perante o Conselho demonstram a insistência sobre a necessidade soluções diplomáticas para problemas que surgem com o Iraque. Demonstram, ainda, a constante preocupação com a população civil iraquiana e defendem o abrandamento das obrigações impostas ao Iraque, bem como a expansão do mecanismo oil-for-food, estabelecido pela Resolução 986, em 1995.

${ }^{46}$ Brazil in the Security Council,1998-1999..., Op. cit., p. 170-179.

47 Editorial da Folha de São Paulo, 9/2/98, p. 2, por exemplo, lamenta "a posição incomodamente ambígua em relação a uma eventual ação militar contra o Iraque". Vamireh Chacon critica a posição do governo brasileiro e membro que, de fato, "[selo Brasil não apoiar claramente os Estados Unidos, não ganhará seu apoio para ingressar no Conselho de Segurança como membro permanente". Sem engajamento militar. Correio Braziliense, 15/2/98, p. 30. 
Contrastam em muito, portanto, com o rápido apoio obtido em Brasília após a visita do representante norte-americano e demonstram que, lado a lado à coerência histórica desses apelos diplomáticos, encontram-se atitudes mais realistas ou visivelmente mais imediatistas, manifestadas por altas autoridades no Itamaraty. Embaladas pela possibilidade de alcançar maior status internacional para o Brasil, abandonam a um segundo plano posições já historicamente consolidadas.

\section{Conclusão}

Há mais de vinte anos, o processo de paz entre Israel e os palestinos tem sido conduzido, sobretudo, bilateralmente, com o patrocínio da administração norte-americana. No âmbito da ONU, a Resolução 3379, que considerava o sionismo como uma forma de racismo e de discriminação racial, foi anulada pela Assembleia Geral de 1991, com o voto favorável do Brasil, que continua a manifestar sua preocupação com os lugares santos e com o destino dos palestinos. O Brasil atualmente não é membro do Conselho de Segurança, mas os representantes brasileiros na ONU têm se dirigido ao órgão "para deplorar fortemente os ataques terroristas e a utilização de homens-bomba que visam alvos civis israelenses, bem como o excessivo uso da força pelos militares israelenses também contra alvos civis e com o objetivo de destruir a infraestrutura dos territórios palestinos ocupados." Conclamam também as partes a retomar o diálogo com base nas resoluções 242 e $338^{48}$. Em discurso inaugural à sessão da Assembleia Geral de setembro 2002, o ministro das Relações Exteriores, Celso Lafer, reiterou o apoio brasileiro à criação de um Estado palestino e ao direito à existência do Estado de Israel, dentro de fronteiras reconhecidas ${ }^{49}$.

Com relação ao problema iraquiano, o governo tem tido posições mais brandas do que o anunciado em 1998 pelo ministro Lampreia, que admitia apoiar ações militares norte- americanos mesmo sem a necessária autorização do Conselho de Segurança. Celso Lafer tem afirmado que "o uso da força no plano internacional somente pode ser admitido se esgotadas todas as

\footnotetext{
${ }^{48}$ Intervenção do embaixador Gelson Fonseca Jr., Representante Permanente do Brasil, no Conselho de Segurança da ONU sobre a Situação no Oriente Médio, Nova Iorque, 3 de abril de 2002

${ }^{49}$ Discurso do Senhor Ministro de Estado das Relações Exteriores na Abertura da Assembleia Geral da ONU - Nova Iorque, 12 de setembro de 2002.
}

alternativas de solução diplomática. (...) No caso específico do Iraque, o Brasil sustenta que cabe ao Conselho de Segurança decidir as medidas necessárias para assegurar o pleno cumprimento das resoluções pertinentes ${ }^{50,}$

O ministro Lafer também tem chamado a atenção para o fato de que "o Conselho de Segurança precisa ser reformado de modo a aumentar sua legitimidade e criar bases mais sólidas para a cooperação internacional na construção de uma ordem internacional justa e estável” e que "o Brasil já manifestou - e o reitero neste momento - que está pronto a dar a sua contribuição para o trabalho do Conselho de Segurança e a assumir todas as suas responsabilidades". Não se abandonou, portanto, a pretensão ao assento permanente no Conselho de Segurança, mas os discursos oficiais têm dado maior ênfase à visão grociana que o Brasil tem do mundo, onde dificilmente caberia o aval à utilização da força para dirimir conflitos internacionais ${ }^{51}$.

Enfim, apesar da complexidade que encerram as relações do Brasil com a região médio-oriental no âmbito da ONU, tentou-se neste estudo caracterizar, ainda que aproximativamente, momentos diversos dessas relações. Pela distância temporal e o acesso a uma gama bastante razoável de documentação e bibliografia, pôde-se tratar com maior detalhe e precisão dos dois primeiros períodos. Com efeito, tanto a equidistância quanto o pragmatismo parecem suficientemente ilustrados pela existência de momentos paradigmáticos. Quanto à equidistância, há que pensar particularmente no voto favorável que o Brasil dá ao Plano de Partilha, de interesse de Israel, ao mesmo tempo em que respeita a internacionalização de Jerusalém, a despeito das pressões israelenses. O pragmatismo é claramente demonstrado pelo apoio do Brasil à resolução que considera o sionismo como forma de racismo e de discriminação racional, ainda que se tenha lá chegado por caminhos bastante tortuosos. Finalmente, para dimensionar as alterações que aparecem no período qualificado neste estudo como realista, vale lembrar a reação do presidente Geisel às supostas pressões norte-americanas quando da votação da resolução antissionista e, como contraponto, mais de vinte anos mais tarde, a reação do ministro Lampreia à visita do representante norte-americano na ONU, em busca do apoio brasileiro à intervenção militar no Iraque. Provavelmente pensando-se na possibilidade de obter o apoio norte- americano à candidatura brasileira a

${ }^{50}$ Ibid.

${ }^{51}$ Ver LAFER, Celso. Em defesa do multilateralismo. Correio Braziliense, 14/9/2002. 
um assento permanente no Conselho de Segurança da ONU, atua-se realisticamente, convergindo com a potência norte-americana, ainda que em detrimento, repita-se, de posições historicamente consolidadas.
Brasil e Israel: da partilha da Palestina ao reconhecimento diplomático

Alberto Kleinas Tullo Vigevani ${ }^{1}$

D rocuraremos no decorrer desse trabalho mostrar a inexistência de uma política brasileira voltada ao Oriente Médio durante o governo do general Eurico Gaspar Dutra, e os porquês da diplomacia brasileira em votar a favor da partilha da Palestina em 1947 e reconhecer o Estado de Israel somente um ano após a sua constituição, em 7 de fevereiro de 1949.

O Brasil que no pós-guerra disputou intensamente um lugar, na política internacional, junto às potências vencedoras do conflito, conseguiu alguns dividendos menores do que esperava. Não conseguiu uma vaga permanente no Conselho de Segurança das Nações Unidas, como havia lhe prometido o governo dos EUA, mas conseguiu uma cadeira como membro temporário desse mesmo comitê. Isso posto, como outros acontecimentos desse período, o Brasil do general Dutra foi lutando por maior espaço internacional, contando com a sua participação na II Guerra junto aos aliados. Assim, muitos pesquisadores assumem que o Brasil era um país não muito diferente em termos de política exterior da última fase do governo Vargas. Muito tem-se dito a respeito desses aspectos da diplomacia brasileira da época, como Gerson Moura no seu livro "Sucessos e Ilusões: Relações Internacionais do Brasil durante e após a II Guerra Mundial”:

O governo do general Eurico Gaspar Dutra é conhecido, de modo geral, como o período de redemocratização que se seguiu aos oito anos de ditadura do Estado Novo (1937-1945)... A política externa brasileira desse período é geralmente considerada uma continuação da política posta em ação pelo governo Vargas nos últimos anos do seu primeiro governo, isto é, uma política de alinhamento aos Estados Unidos. (Moura, p. 59)

No entanto, são necessárias algumas considerações sobre o período de pós-guerra abordado. Como bem sabemos, ao término da II Guerra Mundial, o mundo caminhou para uma bipolarização entre Estados Unidos e União

${ }^{1}$ Alberto Kleinas, professor do Centro Universitário FMU e mestrando da Universidade de São Paulo (USP) e Tullo Vigevani, professor da Universidade Estadual Paulista (UNESP) e pesquisador do Centro de Estudos de Cultura Contemporânea (CEDEC). 
Soviética. O governo Dutra estava convencido que o mundo caminhava a passos largos para um novo conflito global, num embate definitivo entre a democracia e o comunismo. Assim sendo, não cabia ao Brasil, segundo nosso chanceler à época Raul Fernandes, destoar do voto americano na ONU. Votar junto com os americanos era votar contra o comunismo internacional e consequentemente contra a União Soviética. Esse pensamento extremamente simplista criava certos constrangimentos junto à delegação brasileira na $\mathrm{ONU}$ e em particular com Osvaldo Aranha (chefe da delegação e representante na ONU). Essa mesma delegação, por sua experiência em assuntos internacionais e acompanhamento mais acurado dos últimos acontecimentos na política mundial, tinha muito certo que a tal III Guerra Mundial não ocorreria no final da semana. Assim sendo, objetava Aranha com relação a postura assumida pelo Itamaraty de servo absoluto dos interesses norteamericanos. Aranha nunca foi antipático aos interesses americanos, mas também, resguardava certo orgulho e sentimentos nacionais. Assumia uma postura de defesa de interesses brasileiros e não poderia deixar de opor-se a uma postura que qualificava como subalterna. Também essa mesma delegação via com olhos tolerantes às investidas soviéticas por maiores parcelas de poder político internacional. Dessa forma, Osvaldo Aranha era tratado com suspeita pelo Itamaraty e em particular pelo sr. Raul Fernandes. Para entendermos um pouco melhor o que se passava nestes conturbados anos apoiamo-nos em Gerson Moura:

Também a política exterior brasileira desse período só aparentemente continuava a política de alinhamento aos EUA praticada nos últimos anos do governo Vargas... De qualquer modo, o governo Dutra estava convencido de que o Brasil deveria manter laços especiais com o 'mundo ocidental', tendo em vista a possibilidade de um conflito generalizado (Terceira Guerra Mundial). Esperava-se que esse alinhamento aos Estados Unidos daria ao país algumas vantagens especiais: $1^{\mathrm{a}}$ ) a manutenção de sua superioridade militar no conjunto da América do Sul, advinda da participação na guerra; 2') participação plena nas conversações de paz do pós-guerra e na construção de uma nova ordem internacional. (Moura, p. 59)

Como bem apontou Gerson Moura, a política internacional brasileira tinha interesses específicos, em particular no tocante à América do Sul. Assim conseguimos compreender melhor onde pretendia chegar o governo brasileiro à época. A rivalidade entre o Brasil e a Argentina estava na ordem do dia das preocupações brasileiras. Além do mais, neste período a
Argentina era governado por Perón, que estabelecera uma série de conflitos com os Estados Unidos, que estendiam-se desde a posição de neutralidade da Argentina no conflito mundial findo, até a sua resistência aos ditames de Washington. Assim sendo, o Brasil tinha uma política internacional com dois enfoques principais: $1^{\circ}$ ) uma preocupação global (ou macro) embasada numa ideologia antissoviética/anticomunista e, $2^{\circ}$ ) uma preocupação no plano Sul Americano, no tocante à supremacia militar e econômica na região. Quanto a essa política externa, Gerson Moura explica bem a seguir:

A combinação do 'combate ao comunismo internacional', derivado das preocupações do governo Dutra com a ordem interna, com o 'alinhamento à política internacional dos Estados Unidos constituíam a linha-mestra da política externa brasileira no pós-guerra, seguida de modo absolutamente consistente de 1946 a 1950. (Moura, p. 59)

Durante o governo Dutra, a atuação do Brasil na ONU guiou-se pela regra de seguir o voto dos EUA em todas as questões importantes, com uma única exceção: quando dos conflitos entre EUA e Argentina, procurou-se preservar a solidariedade aos EUA, sem ser hostil à Argentina. Essa adesão não lhe concedeu, porém, os resultados que imaginava ter direito a receber (Moura, pp. 59-60)

Essa política externa refletia-se no plano interno com o medo de conflitos sociais e à negativa em promover reformas sociais exigidas pelo movimento operário organizado no Brasil. Assim podemos entender melhor a identidade política externa durante o governo Dutra, identificado com os países conservadores e governos ditatoriais.

$\mathrm{O}$ alinhamento automático ao voto americano na ONU era, portanto, uma política deliberada do governo brasileiro e, assim sendo, não deveria ser desrespeitado pela sua delegação nas Nações Unidas. Não deveria, mas não o foi em algumas ocasiões. Há muito a delegação brasileira na ONU tinha uma visão da política internacional diferente e muitas vezes conflitante do chanceler Raul Fernandes, em particular o próprio Osvaldo Aranha. A simples duplicação do voto americano nas Nações Unidas não era agradável e aconselhável ao ver da delegação presidida por Aranha. Em muitas ocasiões ele se opôs à política externa do governo brasileiro. A delegação brasileira dava mostras de que a política externa norte-americana não caminhava para um conflito com a União Soviética e, muito pelo contrário, buscava uma acomodação no status quo internacional. Essa mesma delegação via com olhos tolerantes a busca soviética em ocupar 
espaços de poder correspondentes a sua força internacional. Mas a discordância foi uma constante nas relações entre o Itamaraty e a delegação na ONU, justamente por essa divergência de perspectivas de política internacional. Segundo Moura:

Se a Conferência de Paris deu ao Brasil a sensação de importância no plano internacional em 1946, no ano seguinte a presença do exministro Osvaldo Aranha como chefe da delegação brasileira na ONU magnificou essa impressão. Aranha foi eleito presidente do Conselho de Segurança em fevereiro, presidente da AssembleiaGeral Extraordinária em abril e presidente da II Assembleia-Geral em setembro de 1947 e, de modo geral, foi considerado hábil e capaz.

Essa situação permitiu à delegação brasileira desenvolver uma visão mais complexa da situação internacional e levou os representantes brasileiros a assumirem uma atitude mais aberta independente em muitas ocasiões. Paradoxalmente, essa orientação entrava em contradição com a disposição estrita da Secretaria de Estado de 'seguir os EUA a qualquer preço'. Desde 1947 o Itamaraty era chefiado por Raul Fernandes, jurista conservador, que se convencera de que a guerra entre Leste e Oeste era inevitável - e talvez desejável, como a única maneira de evitar a dominação bolchevista na Europa -, de modo que o Brasil deveria integrar uma 'frente ocidental unida' em torno dos EUA. Isso significava, evidentemente, seguir sem restrições o voto americano nas reuniões internacionais.

Osvaldo Aranha era conhecido como 'campeão da causa americana' quando chefiou o Itamaraty entre 1938-44, mas, em contato com a delegação brasileira no fórum cosmopolita da ONU, percebeu que não haveria guerra global entre Estados Unidos e União Soviética, que algum grau de colaboração era visível entre as duas grandes potências e que os EUA não estavam interessados no continente americano, mas jogavam para valer na Europa e Ásia. Por isso, ele aconselhava discrição nos envolvimentos brasileiros. Osvaldo Aranha era admirador da civilização norte- americana, mas, em contraste com Raul Fernandes, era capaz de reconhecer não apenas as reivindicações soviéticas de poder como também a busca de hegemonia por parte dos Estados Unidos. Ele concluía que a política brasileira deveria estar do lado americano, mas devia estar consciente da verdadeira natureza das disputas internacionais, ou, de outro modo, 'agiria como um cego'.
Essas diferentes orientações produziriam dois grandes conflitos entre a Secretaria de Estado e a delegação brasileira na ONU a propósito de um voto para preencher vaga no Conselho de Segurança e a propósito da própria eleição de Osvaldo Aranha para a presidência da II Assembleia-Geral. A delegação brasileira advertia que a solidariedade não é servidão ao governo americano, enquanto o Itamaraty considerava dever da delegação brasileira 'ajustar-se aos Estados Unidos sem qualquer indecisão'.

Um exame acurado das questões que provocaram as disputas entre a Secretaria de Estado e a delegação brasileira mostra que um dos elementos mais importantes era a relação mantida com o bloco soviético na ONU. O Itamaraty guiava-se por uma equação em que 'votar com os Estados Unidos' significava necessariamente 'votar contra o bloco soviético' e exigia essa coerência de sua delegação. O antissovietismo da política externa brasileira envolvia uma atitude de permanente ataque a tudo aquilo que fosse identificado pelo Itamaraty como ação comunista internacional. Essa política ligava-se ao medo de conflitos sociais e à negativa em promover reformas sociais exigidas pelo movimento operário organizado no Brasil. Essa matriz ajuda a entender a identidade da política externa brasileira com os regimes extremamente conservadores e governos ditatoriais, assim como os esforços por apoiar a política colonialista de algumas potências europeias. (Moura, p.63)

Vale lembrar dois fatos ocorridos no âmbito das Nações Unidas para ilustrar a relação espinhosa entre o chanceler Raul Fernandes e Oswaldo Aranha. Os casos da candidatura da Ucrânia ao Conselho de Segurança e o episódio da reeleição de Aranha para a presidência da Assembleia Geral da ONU. Os Estados Unidos pediram ao representante brasileiro que votasse a favor da Ucrânia e, logo depois, mudaram de posição apoiando a candidatura da Índia sem nada comunicar a delegação brasileira. $\mathrm{O}$ impensável ocorreu na hora da votação, com o Brasil votando contra os interesses americanos. O Itamaraty, através de Raul Fernandes, repreendeu Aranha que indignou-se, pois votara a favor da admissão da Ucrânia por solicitação americana e, no caso da mudança de orientação, eles (EUA) deveria procurá-lo e não o contrário.

A nossa solidariedade não pode ser nunca uma servidão. Não me prestaria a esse papel e, creio, nenhum brasileiro se aceitaria essa missão. (Carta de 9 de outubro de 1947, Aranha a Fernandes, NY, CPDOC, AOA) 
Queria Oswaldo Aranha que houvesse reciprocidade nas consultas e não que partisse somente do Brasil, como se propunha o Itamaraty. O próprio Aranha considerava-se amigo dos americanos, "mas não caudatário do Departamento de Estado, o que qualificava como traição".

Oswaldo Aranha prossegue em outra carta justificando o seu voto a favor dos russos.

(...) nunca demos um voto aos russos que não houvesse sido pedido pelos americanos e com eles combinados (...) Tornarmo-nos (...) mais realistas que o rei seria uma impertinência. (Carta de 17 de outubro de 1947, Aranha a Fernandes, CPDOC, AOA).

O anticomunismo do governo brasileiro embaçava a visão da realpolitik e os ajustes entre Estados Unidos e União Soviética. O radicalismo brasileiro pode ser tomado por uma falta de responsabilidade pelos destinos mundiais e assim, o Chanceler Raul Fernandes, acreditando na eminência de uma nova Guerra Mundial, julgava como fracassada a estratégia do Departamento de Estado. Talvez imaginasse numa Santa Aliança Ocidental comandada pelos Estados Unidos para dar cabo do perigo vermelho representado pelos soviéticos. Assim Aranha continuava escrevendo a Raul Fernandes:

Mais uma vez, seremos levados pelos Estados Unidos a colaborar com os russos. (...) Não direi que a estratégia americana, que o senhor considera fracassada, deixe de continuar. Mas cedeu e cederá muito mais. (Carta de 17 de outubro de 1947, Aranha a Fernandes, $\mathrm{NY}, \mathrm{CPDOC}, \mathrm{AOA})$

Nessa época o Brasil armava o rompimento diplomático com a União Soviética. O governo brasileiro continuava sendo mais realista que o rei, e seu reacionarismo e anticomunismo evidenciavam isso. $\mathrm{O}$ rompimento diplomático causou estranheza junto ao Departamento de Estado que, tentou interferir e contornar esta atitude.

A bem da verdade, o governo Dutra tentava de todas as formas tornar-se viável para os investimentos americanos. Assim continuava a reprimir o movimento operário através de uma campanha anticomunista. $\mathrm{O}$ liberalismo econômico acompanhava o perfil dessa democracia tão autoritária. Tudo ao gosto do freguês.
Já no âmbito continental, o Brasil prosseguiu com a mesma orientação de apoio ao projeto americano, ou seja, o pan-americanismo. Segundo Moura:

Apesar das dificuldades apresentadas pelo conflito político entre EUA e Argentina durante a guerra e nos dois anos seguintes, o sistema interamericano alcançou o alto grau de formalização política e militar de 1946 a 1948. Esses esforços de formalização não se orientaram para a edificação de um sistema puramente defensivo, mas objetivavam a consolidação do sistema de poder americano. (Moura, p. 64)

A subserviência brasileira aos ditames do Departamento de Estado continuavam marcados pela ideologia do governo Dutra, que acreditavam num novo conflito mundial, só que agora patrocinados pelas duas superpotências. Para o Departamento de Estado a América Latina era interessante nesse momento de rivalidade e competição com os soviéticos. Tinham objetivos muito claros e definidos com relação aos países ao sul do Rio Grande:

(...) consolidar uma frente antirrussa, eliminar centros de propaganda antiamericana e organizar politicamente a defesa hemisférica (...) um flanco estável, seguro e amigável (...) promover a segurança nacional dos Estados Unidos. (Moura, p. 64)

A constituição do Tratado Interamericano de Assistência Recíproca (TIAR) em 1947 durante a Conferência Interamericana do Rio de Janeiro seguia os propósitos de Washington. A delegação brasileira foi chefiada pelo próprio Raul Fernandes, que trabalhou estreitamente com a delegação americana chefiada por George Marshall. As preocupações do governo brasileiro, representado por Fernandes, voltavam-se para um possível rearmamento argentino que iria desequilibrar as forças na América do Sul.

Apesar de todas as evidências em contrário, os dirigentes brasileiros conduziram as relações Brasil - EUA no pressuposto de que o Brasil ocupava a posição de 'aliado especial' dos EUA no continente americano, devido à sua participação na guerra, e de que essa situação asseguraria uma permanente preeminência militar do Brasil na América Latina, especialmente em face ao poder argentino. Basicamente por essa razão, eles estavam dispostos a aceitar os programas militares e econômicos americanos para o país como o 
melhor caminho para preservar aquela situação de 'aliado especial. (Moura, p. 66)

Ainda no campo continental, Washington tinha interesse no que chama de "desenvolvimento econômico interamericano", definida por três pontos:

1. exportações latino-americanas para os EUA;

2. comércio entre os países do continente;

3. industrialização nas repúblicas americanas.

\section{Segundo Moura:}

$\mathrm{O}$ primeiro item, naturalmente, acentuava o caráter primárioexportador das economias do continente e o último, aparentemente, contrabalançava essa tendência. Entretanto, o exame mais acurado da política americana nos mostra que o governo Roosevelt era definitivamente contra a criação de indústrias de bens de capital na América Latina, porque elas 'se provariam antieconômicas em sua operação'; em seu lugar, ele propunha a criação de indústrias leves, de modo que as repúblicas americanas pudessem livrar-se da dependência da Europa e da Ásia'. Quanto à América Latina, o governo Roosevelt estava interessado na produção de matériasprimas e admitia indústrias de bens de consumo que não ameaçassem as exportações norte-americanas. (Moura, p. 64)

O governo Truman não saiu modificou as principais linhas políticas econômicas de Roosevelt para a América Latina. Volta Redonda, nesse caso, foi uma excepcionalidade marcada pelas conveniências políticas da guerra. Acabara-se a guerra, e portanto, não tinha mais razão de ser. Assim sendo, as autoridades brasileiras tiveram que despertar do sonho de criar outras "Volta Redondas" com capital americano. Quando chegou a comissão "Abbink". Esta comissão foi constituída em 1948 pelos governos americano e brasileiro para estudar a situação econômica do país e encaminhar um projeto de desenvolvimento. Segundo o livro de Amado Luiz Cervo e Clodoaldo Bueno "História da Política Exterior do Brasil", Washington tinha diretrizes muito definidas para essa comissão técnica:

A Comissão deve dar particular atenção à capacidade do Brasil para a expansão econômica através do uso máximo de seus recursos internos. A Comissão não deve se dedicar à apreciação dos méritos de projetos específicos ou analisar a desejabilidade de obter financiamentos externo, A Comissão, no entanto, deve considerar medidas destinadas a encorajar o fluxo de capital privado para o Brasil. (Cervo \& Bueno, p. 248)

$\mathrm{O}$ Brasil mantinha-se à margem dos acontecimentos. No período inicial da guerra fria, os países latino-americanos observavam de longe os acontecimentos que se passavam sobretudo na Europa e na Ásia. O momento, porém, era propício à reafirmação de lealdades fundamentais e os EU A empenhar-se-iam em solidificar sua preeminência no Hemisfério.

1947 é o ano que assinala o início de uma fase de alinhamento do Brasil com os EUA. Na expectativa de que a aliança com os EUA criasse as condições necessárias para o desenvolvimento do país, a exemplo do que ocorreria na Europa Ocidental e no Japão, a diplomacia brasileira passa a praticar política de bloco. A pretexto de um incidente com diplomata da Embaixada em Moscou, as relações diplomáticas Brasil-URSS são rompidas (outubro de 1947). Na ONU, a delegação do Brasil toma invariavelmente partido dos EU A nas votações de questões vinculadas à polaridade Leste-Oeste. $\mathrm{Na}$ Conferência do Rio de Janeiro para a Manutenção da Paz e da Segurança no Continente, em que se aprovou o Tratado Interamericano de Assistência Recíproca (TIAR), a diplomacia brasileira apóia ativamente as postulações americanas sobre a defesa da região. (A Palavra do Brasil na Nações Unidas - 1946-1995)

O governo Dutra nutria esperanças de um plano de fomento norteamericano para o desenvolvimento do Brasil, aos moldes do Plano Marshall. O próprio Aranha já havia percebido em Nova Iorque, que os EUA jogavam todas as fichas na Europa e na Ásia. A América Latina ficou para a Comissão Abbink e seu imobilismo, baseado nos recursos internos e no incentivo ao aporte de capital privado, para o desenvolvimento nacional.

Que triste fim para o governo Dutra em matéria de desenvolvimento econômico. Segundo Moniz Bandeira em seu livro "Presença dos Estados Unidos no Brasil - Dois Séculos de História:

Quando o Governo Dutra se instalou, em 31 de janeiro de 1946, o Brasil possuía 322.505.472.144 quilos de ouro. Dois anos depois, em 31 de dezembro de 1948, essas reservas baixaram para 281.569.564.200 quilos de ouro. (...) Em 1947, o valor das importações ultrapassara o da exportação, deixando um déficit de 55 milhões de dólares. A situação da balança comercial, nos anos seguintes, melhorou, ligeiramente, mas os saldos, que apareceram, da 
ordem de 88 e 17 milhões de dólares, eram insuficientes para cobrir os compromissos do País no Exterior, sobretudo os serviços da dívida externa. Assim, entre 1947 e 1949, o déficit do balanço de pagamentos aumentou em 335 milhões de dólares, coberto com empréstimos oficiais e pelo afluxo de capitais estrangeiros, que representariam maiores encargos para o futuro, drenando as finanças do país (...) (Bandeira, pp. 314-315).

Segundo Cervo e Bueno, o governo brasileiro contava que, após a sua redemocratização, de ter sido aliado dos norte-americanos na $2^{\mathrm{a}}$ Guerra e colaborador estreito da política exterior americana para a América Latina, seria implementado um novo momento de "relações especiais" entre os dois países. O tratamento dado pelo governo americano às solicitações brasileiras foram substituídas por um "sistema planetário de segurança que privilegiava a cooperação com a Europa, o Oriente Próximo, o Extremo Oriente e a África na aplicação de seus recursos”. (Cervo \& Bueno, p. 248).

Ainda segundo os mesmos autores, as diferentes concepções entre os dois países sobre a cooperação para o desenvolvimento eram marcadas pela questão política internacional: enquanto o governo brasileiro insistia no caráter político da ajuda, o governo americano, além de outras divergências, entendia que os programas de desenvolvimento eram assuntos para serem tratados junto ao BIRD. Parte daí a formação da Comissão Abbink e o soterramento dos interesses brasileiros em ver um "Plano Marshall" para a América Latina e, em particular, para o Brasil - "aliado preferencial".

Muitas são as cartas-telegrama da representação brasileira em Washington sobre o Plano Marshall para a Europa Ocidental e Japão.

"Washington, em 16 de dezembro de 1947.

Os Estados Unidos e a América Latina.

Senhor Ministro,

Comunico a Vossa Excelência que o Senhor Summer Welles, em artigo para o "Washington Post"(9 de dezembro de 1947), intitulado "Latin American Help", diz que toda a verdadeira cooperação econômica e financeira interamericana terminou com o advento do regimem Byrnes e que a esperança de que o Secretário de Estado Marshall reparasse os seus danos não se tornou realidade. Continuando, diz que, apesar de Marshall haver se cercado de pessoas de capacidade excepcional em assuntos latino-americanos, atualmente a autoridade está dividida no Departamento de Estado, não podendo este enfrentar os graves problemas latino-americanos sem que seja formulada, do alto, uma orientação política e econômica. Adiante, mostra que as dificuldades econômicas latinoamericanas só poderão ser resolvidas satisfatoriamente se a produção aumentar, se a inflação for evitada, se os mercados exteriores forem restabelecidos e se os outros países americanos puderem obter créditos e as mercadorias necessitadas pelos seus consumidores, que só são encontradas nos Estados Unidos e, para sua compra, é necessário possuir-se dólares. Durante o ano passado, prossegue Summer Welles, o México usou a metade de suas reservas em ouro e dólar, e a Argentina, o Brasil e o Chile pelo menos um terço das suas. Antes da Guerra, a América Latina tinha uma balança favorável no seu comércio com os Estados Unidos e este ano terá uma balança comercial desfavorável de, pelo menos, dois milhões de dólares. Continuando em suas considerações, Summer Welles diz que as repúblicas americanas avaliam perfeitamente o que representa a situação de emergência em que se acha a Europa e a magnitude do esforço que os Estados Unidos devem fazer dentro do Plano Marshall para a reabilitação da Europa. O que eles não podem compreender é a razão pela qual o Secretário Marshall achou necessário, não somente proclamar que a reabilitação europeia deveria ter prioridade sobre a reabilitação do Hemisfério, como não haver dado nenhum passo para coordenar a reabilitação europeia com a continental.

2. Acentua, em seguida, Summer Welles que o Governo americano insiste em divorciar os dois problemas, e achou que, ao ser elaborada a legislação de auxílio à Europa, deveria ela estar ligada à reabilitação continental. Põe em relevo o fato dos países americanos ressentirem essa atitude negligente dos Estados Unidos, dizendo que esses sentimentos estão sendo expressos na Conferência de Havana. O mal está, pensa Welles, em que o presente Governo, embora tenha demonstrado Ma vontade em relação à América Latina, pouco de prático tem realizado. Apesar do Senado ter-se mostrado mais esclarecido, com a iniciativa de ratificação do Tratado do Rio de Janeiro pelo Senador Vandenberg, sua ação não será suficiente para combater a inflação. Torna-se necessária uma política de ação construtiva e uma volta imediata à efetiva cooperação econômica entre os Estados Unidos e as outras repúblicas americanas, para o benefício comum de todos os povos do continente. 
Aproveito a oportunidade para renovar a Vossa Excelência os protestos da minha respeitosa consideração". (Carta-telegrama da Embaixada brasileira ao Itamaraty, Arquivo Histórico do Itamaraty, $16 / 12 / 1947)$

Seguindo as considerações de Gerson Moura, o governo Dutra, através de seu Ministro Raul Fernandes, aprendeu bem apenas uma parte da política externa do final do governo Vargas: o alinhamento com os Estados Unidos. Mas não conseguiu prosseguir na sua substância mais interessante, ou seja, como instrumento de barganha em suas negociações internacionais. Os possíveis ganhos, durante o governo Dutra, passaram para o terreno da esperança e do ufanismo pretensioso do "Brasil Potência", do "aliado especial", do "prestígio internacional" que, continuaram os mesmos, mas com menos contato com a realidade que no governo Vargas.

Devemos ponderar que, os objetivos do governo americano se deslocaram do continente para a Europa e Ásia, regiões mais atingidas pela guerra e suas posteriores transformações. Estas regiões eram o verdadeiro palco onde se transcorria a política internacional bipolar (EUA $x$ URSS). Para os Estados Unidos, o Brasil, como toda a América Latina, era zona de pacífica hegemonia americana, o que significava não serem necessários muitos esforços e recursos.

Mas o Brasil continuava insistindo durante esse período (1946 a 1950) num alinhamento total e apoio incontestável aos desígnios norte-americanos.

Assim sendo, no plano interno continuou reprimindo duramente as reivindicações operárias, vistas como extensão do comunismo internacional, como ditava a cartilha norte-americana de "Contenção da URSS".

Infelizmente, para o governo Dutra, o Brasil não teve a contrapartida que teve no âmbito militar transposta para o âmbito econômico. Enquanto os militares dos dois países viviam a mais completa harmonia, o Brasil continuava pleiteando melhores condições de financiamento para o seu desenvolvimento econômico.

\section{O conflito no Oriente Médio e a possibilidade da paz}

Nizar Messari

G speculações sobre os eventos que levaram o Oriente Médio à crise que conhece desde setembro de 2000, ou seja, desde o início da segunda Intifada, são de natureza diversa. Dependendo do lado que se defende, afirma-se que se chegou a este ponto devido à falta de visão do líder Palestino Yasser Arafat, aos ataques suicidas ou à fragmentação do movimento Palestino. Desde o ponto de vista adverso, afirma-se que se chegou a esta crise com a eleição da Ariel Sharon para o cargo de primeiroministro de Israel ou com a visita do mesmo Sharon, em setembro de 2000, como líder do partido de oposição Likud, à mesquita Al Aqsa, ou com o assassinato de Ytzhaq Rabin em 1995. Afirma-se também que o fracasso das negociações de Camp David - sem entrar no mérito da culpa -, no verão de 2000, pode ser considerado a causa inicial do desencadeamento do processo de violência.

Analisamos cada uma destas prováveis causas separadamente, começando pela falta de visão do líder Palestino. Repete-se em Israel e até entre alguns palestinos que se Arafat tivesse tido um pouco da sabedoria do líder sul-africano Nelson Mandela, a região estaria em condições melhores. Arafat é acusado de não ser nem um líder democrático, nem um político com visão. Para assentar sua liderança após a criação formal da Autoridade Nacional Palestina em 1995, Arafat, que havia sido legitimamente eleito pela população palestina, tinha duas vias. Por um lado, havia a via integracionista, através da qual Arafat poderia ter proposto um pacto de unidade nacional a todas as tendências palestinas, dentro e fora da OLP, FDLP, FPLP, Hamas e Jihad Islâmica; elas poderiam ter entrado num processo do qual o líder deveria beneficiar-se mais, mas no qual, também, este mesmo líder deveria arcar com os custos da união. Foi o que Nelson Mandela fez com as diferentes facções na África do Sul, ao permitir ao Inkhata e seu líder Buthelezi regalias e vantagens

${ }^{1}$ Doutor em Relações Públicas/Universidade da Florida; Instituto Relações Internacionais/ PUC-RJ 
que garantiram sua participação na consolidação da transição para uma sociedade pós-Apartheid.

No lugar disto, Arafat optou por contar de maneira quase exclusiva com os membros do seu grupo, Al Fatah, e marginalizou com isso os demais grupos, inclusive os representantes dos "Palestinos de dentro" que eram Faissal Husseini e Hanan Achraoui. Para poder fazer isso, Arafat teve que montar um extenso aparelho policial, com cinco forças diferentes e competitivas, restringiu as liberdades de expressão, atentou contra os direitos humanos e isolou os grupos extremistas, Jihad Islâmica e Hamas. Como se isto não bastasse, Arafat não hesitou em fechar os olhos aos flagrantes casos de corrupção das autoridades palestinas. Sua legitimidade, oriunda da sua aura como líder do movimento nacional, foi enfraquecendo, o que reforçava sua dependência das elites corruptas e do aparelho policial-repressivo. Ativistas dos movimentos de direitos humanos passaram a expressar abertamente suas críticas contra a ANP e Arafat, e Hanan Achraoui se demitiu do governo, passando a ter voz ativa contra os abusos praticados pelos representantes da ANP e contra o desrespeito dos direitos humanos.

Ao contrário do que outros líderes árabes estavam fazendo na década de 90, Arafat teve uma relação ambígua com os ativistas islâmicos e, principalmente, com os membros e a liderança do Hamas. Ao passo que Arafat reprimia os ativistas islâmicos no plano interno, por considerá-los uma ameaça a sua autoridade entre os palestinos, ele usou a existência destes mesmos grupos de ativistas islâmicos para negociar e pressionar os israelenses. Aos israelenses, ele cobrava alto para reprimir os ativistas islâmicos e não lhes permitir atuar contra Israel. O uso dos ativistas islâmicos não foi inaugurado por Arafat, já que os regimes do Egito, da Tunísia e do Marrocos - para citar apenas estes três - haviam usados seus próprios ativistas islâmicos como instrumento de pressão. Estes regimes usaram os ativistas islâmicos de maneira dupla. Por um lado, o Islamismo foi incentivado por estes regimes como estratégia para se contraporem aos movimentos radicais de esquerda nas décadas de 60 e 70. Por outro lado, nas décadas de 80 e 90, os regimes destes países passaram a usar a ameaça dos ativistas islâmicos para se afirmar como polos da luta contra o Islamismo, o que permitiu aos regimes forçar a adesão das elites nacionais a sua liderança nessa luta. Portanto, o uso do ativismo islâmico na balança de poder político nacional não é nenhuma novidade no mundo árabe. $\mathrm{O}$ problema, no caso de Arafat, era duplo. Por um lado, a situação de Arafat era diferente da situação dos regimes árabes acima citados. Arafat precisa forjar um consenso nacional, enquanto os líderes daqueles países árabes lidavam com situações mais estáveis e estabilizadas. Por outro lado, nos acordos de paz de Oslo, ele se comprometeu a nunca usar o terrorismo como arma de pressão ou de negociação. Portanto, a ambiguidade de Arafat com os ativistas islâmicos era um sinal negativo em relação a seu compromisso com a paz. Uma observação relevante aqui é que esta ambiguidade passou a se afirmar cada vez mais após a morte de Rabin, ou seja, quando o processo de paz começou a perder seu rumo inicial.

Os atentados suicidas são, portanto, e de certa forma, ligados à falta de visão de Arafat. Os grupos Hamas e Jihad Islâmica nunca se sentiram engajados no processo de paz. Para eles, o sucesso do processo de paz ia contra suas crenças (já que, para eles, Israel não deveria existir), fortalecia seu adversário político entre os palestinos (o próprio Arafat), além de não terem nada a ganhar a não ser o que eles consideravam a "paz dos fracos". Ao cometer os atentados suicidas contra Israel, os ativistas islâmicos reforçavam sua imagem de única e verdadeira resistência à Israel entre os jovens palestinos. Isto significa que o Hamas e a Jihad Islâmica tinham tudo a ganhar e muito pouco a perder ao insistir nos atentados suicidas contra civis israelenses. No cálculo político do Hamas e da Jihad Islâmica, a população palestina necessariamente compararia sua resistência contra Israel com a atitude submissa da ANP. Para o Hamas e a Jihad Islâmica, sua intensa luta armada contra Israel e a endêmica corrupção da ANP acabariam certamente por torná-los os principais representantes do povo palestino, substituindo assim a OLP/ANP.

Pelo lado israelense, a falta de compromisso com a paz é tão flagrante quanto pelo lado de Arafat. O assassinato do primeiro-ministro Rabin em 1995 pode ser indicado como o momento em que a ambiguidade israelense em relação à paz começou a oscilar entre momentos agudos e outros mais brandos. Rabin era um militar com fama de falcão que não precisava provar aos seus cidadãos que tinha uma preocupação estratégica com a segurança de Israel. Quando assinou o tratado de paz com Arafat, as acusações da oposição do Likud segundo as quais ele estava pondo em perigo a segurança de Israel não vingaram, pois sua imagem entre os israelenses era de um homem público que colocava a segurança de Israel em primeiro lugar. Com sua morte e sua substituição por Shimon Peres, a equação se inverteu. Peres tinha uma fama de pombo, e, por isso, a 
população israelense suspeitava que ele pudesse pôr em risco a segurança de Israel devido a suas convicções pacifistas. Por isso, Peres precisava "provar" aos seus cidadãos que era um duro, e que não havia nenhum risco de prejudicar a segurança de Israel para assinar um tratado de paz. Para conseguir isto, nos meses que separaram a morte de Rabin (em novembro de 95) e das eleições legislativas (junho de 96), Peres seguiu uma linha dura com Arafat. Com isso, Peres conseguiu duas façanhas: por um lado, enfraqueceu Arafat ao congelar o processo de paz, e, por outro lado, deu motivos ao Hamas para acelerar o ritmo de seus ataques suicidas contra civis israelenses. Nessa lógica, o Hamas acabou ganhando, pois assentou sua reputação de dura resistência contra Israel em detrimento da reputação doravante conciliadora de Arafat e causou a derrota de Peres e dos Trabalhistas nas eleições legislativas de 1996.

Com a vitória do Likud, sob a liderança de Benjamin Netanyahu, o processo de paz entrou numa de suas fases mais difíceis. Netanyahu era um jovem líder do Likud que havia se posicionado contra os acordos de Oslo. Sua retórica como líder da oposição era a de recusa total da política de Rabin e Peres em relação aos palestinos, e de apoio aos setores mais radicalmente favoráveis aos assentamentos judaicos nos territórios ocupados. Na sua opinião, a assinatura dos acordos de Oslo por parte de Rabin equivalia a uma traição dos ideais defendidos pelos fundadores de Israel. Sua longa experiência de vida nos Estados Unidos teve dois efeitos sobre seu mandato como primeiro-ministro. Por um lado, lhe permitiu conseguir uma grande familiaridade com a televisão como instrumento de comunicação de massa. Com isso, Netanyahu tornou-se um dos políticos mais eficientes como comunicadores em Israel. Suas aparições na televisão costumavam ter muito sucesso, por sua capacidade de passar mensagens claras e mobilizadoras de maneira eficiente. Por outro lado, Netanyahu adquiriu uma grande familiaridade com o sistema político norte-americano, conseguindo assim utilizar de maneira perfeita os apoios de que Israel dispõe nos Estados Unidos para atuar a seu favor dentro do sistema político norte-americano.

O período que Netanyahu passou no cargo de primeiro-ministro foi marcado por desconfiança mútua entre ele e Arafat. Os atentados terroristas, geralmente com vítimas civis israelenses, eram sempre condenados por Arafat e a ANP. No entanto, Netanyahu responsabilizou Arafat por de maneira consistente. Segundo Netanyahu, por ser Arafat o responsável pela segurança em várias cidades palestinas, ele era, portanto, o responsável pela ação dos militantes palestinos que cometiam os atos de terror. Com isso, o tempo passava, e os acordos de Oslo não eram implementados. As negociações entre os dois lados se tornaram cada vez mais difíceis e, às vezes, até inexistentes. Netanyahu passou a defender a necessidade de encurtar o processo de Oslo e começar a negociar imediatamente os acordos do status final. Segundo ele, os passos intermediários não estavam cumprindo o objetivo de incrementar a confiança mútua entre as duas partes, enquanto a negociação final teria a vantagem de levar as partes ao que interessava mesmo, ou seja, os contornos finos da relação entre os dois povos.

A mediação da administração Clinton entre Netanyahu e Arafat tentava desbloquear a situação entre os dois beligerantes, mas raramente encontrou sucesso. O presidente americano conseguiu juntar os dois líderes, algumas vezes em torno de mesas de negociação, de maneira direta e na presença de outros atores, mas não havia a confiança necessária para que cada parte fizesse as concessões necessárias. Nas poucas vezes em que acordos foram firmados entre Arafat e Netanyahu, uma das partes não implementava suas obrigações, dando cobertura para a outra parte não cumprir sua parte também. Em diversos momentos, Netanyahu recorreu diretamente aos amigos de Israel nos EUA para fugir das pressões que a administração Clinton estava fazendo sobre ele para levá-lo a posições mais maleáveis. Assim, a administração Clinton passou a perceber Netanyahu como um obstáculo à paz maior que Arafat e, de certa forma, se resignou a esperar a troca de liderança em Israel.

Tal troca de liderança ocorreu com a chegada de Ehud Barak ao poder, liderando o partido Trabalhista. Barak tinha a fama de ser um chefe militar habilidoso e um herói nacional. Estas duas características eram similares às características de Rabin. Isso fez com que a população israelense confiasse nele para levar a cabo as negociações com a ANP sem prejudicar a segurança de Israel. Logo no início de seu governo, Barak procurou assentar uma maioria parlamentar mais confortável para poder governar. Trouxe o partido Shass ao seu governo, o que lhe deu uma ampla maioria para governar. Essa habilidade de negociador e político pareceu se confirmar com uma opção que indicou muita audácia política por parte de Barak. No lugar de investir todas suas cartas na negociação com os palestinos, Barak tentou sua chance na frente Síria, ao mesmo tempo que iniciou a implementação da sua promessa 
eleitoral de retirar os soldados israelenses do Sul do Líbano. A negociação com a Síria, em particular, indicava uma alta aposta por parte de Barak. Conseguindo um acordo com a Síria, ele teria simultaneamente se mostrado um negociador hábil e bem intencionado, capaz de fazer concessões, e ele teria rompido a unidade dos árabes. Em outros termos, um acordo com a Síria teria significado pontos de bônus com os israelenses, com os árabes e com os americanos, além de um enfraquecimento dos palestinos. Mas a negociação com a Síria e a retirada do Líbano, que pareciam indicar uma grande engenhosidade política, acabaram se voltando contra ele. Barak, de fato, não conseguiu avançar na negociação com a Síria, e acabou perdendo um precioso tempo do seu mandato de primeiro-ministro sem negociar seriamente com Arafat. Perdeu, portanto, a boa vontade do eleitorado israelense e a capacidade de pedir sacrifícios a seus concidadãos. Ao retirar os soldados do exército israelense do sul do Líbano, ele acabou mandando um sinal errado aos palestinos. De fato, a retirada israelense do sul do Líbano pareceu se suceder aos ataques do Hezbollah libanês contra o exército de Israel. Isso parecia dizer aos palestinos mais radicais que a via da luta armada contra Israel poderia levar a resultados melhores que a negociação política e diplomática. Essa, claramente, não era a intenção de Barak, mas foi essa a leitura que enfraqueceu não apenas o próprio Barak, mas também o líder palestino Arafat.

Uma das diferenças entre Netanyahu e Barak era que os atentados terroristas palestinos não eram colocados na conta de Arafat por parte de Barak. Barak sabia nitidamente que tanto ele quanto Arafat tinham seus radicais, que procurariam enfraquecê-los. Mais do que isto, Barak aproveitou a disposição e o total engajamento da administração Clinton no processo de paz no Oriente Médio para usar a mediação americana para conseguir avanços com os palestinos. Acordos foram assinados entre Israel e a ANP, e concessões foram feitas por ambas as partes. Observa-se aqui, por exemplo, que Barak também queria passar para o estágio das negociações finais imediatamente sem passar pelos estágios intermediários. No entanto, ao contrário de Netanyahu, ele aceitou firmar um último acordo intermediário com os palestinos, mostrando assim sua capacidade de fazer concessões e ganhando, também, a confiança dos negociadores palestinos.

O momento das negociações finais entre Yasser Arafat e Ehud Barak merece uma atenção especial. $O$ então ministro interino das relações exteriores de Israel, Shlomo Ben Ami, teve um artigo publicado no diário espanhol El País, no qual explicava que a cúpula de Camp David era a última chance para se conseguir a paz, visto que tanto o primeiro- ministro israelense quanto o presidente americano se encontravam em final de mandato. Barak estava ainda no seu segundo ano de mandato como primeiro-ministro, mas sua popularidade estava em baixa, e sua legitimidade era questionada. O tempo que ele havia perdido nas negociações com a Síria - que acabaram resultando em nada - e a já mencionada retirada dos soldados israelenses do Sul do Líbano arranharam sua legitimidade e diminuíram o grau de paciência da população israelense com ele. Clinton, por sua parte, estava literalmente em fim de mandato. Os encontros de Camp David ocorreram semanas antes da convenção do partido democrata que indicou $\mathrm{Al}$ Gore como candidato do partido para as eleições presidenciais daquele ano, o que indicava que Gore estava prestes a se tornar o novo líder do partido no lugar de Clinton. As eleições propriamente ditas estavam distantes quatro meses, e a posse do novo presidente estava a menos de seis meses. Portanto, Clinton e Barak estavam dispostos a encontrar uma solução, um para salvar sua herança, e o outro para salvar seu mandato.

Várias versões sobre as negociações de Camp David durante o verão de 2000 filtraram-se para a opinião pública. Na versão oficial, claramente expressada por Clinton após o fracasso das negociações, o responsável pelo fracasso era o líder palestino Arafat. Mas em que consistia Camp David? Camp David era a oportunidade de se chegar a uma solução final e definitiva sobre o equilíbrio das forças e a manutenção da paz na região. Isso incluía a forma, a estrutura e as fronteiras do eventual Estado Palestino, o futuro de Jerusalém, o futuro dos refugiados palestinos e a questão dos assentamentos judaicos, assim como questões cruciais, mas de menor expressão, como a exploração dos escassos recursos hídricos, por exemplo. A base da negociação seria a divisão de territórios entre Israel e a ANP, que prevaleceu após a última retirada do exército de Israel de algumas cidades e áreas da Cisjordânia.

Segundo o presidente Clinton - e outros representantes da administração americana -, Arafat foi responsável pelo fracasso das negociações de Camp David, por não ter percebido que Barak havia ido mais longe que qualquer outro primeiro-ministro israelense antes dele. Aos olhos do presidente Clinton, Barak havia feito todas as concessões possíveis para um dirigente israelense, e Arafat, com sua intransigência, foi incapaz de reconhecer isto. A história, desde então, tem dado razão a esta leitura. 
Em Camp David, Arafat havia recusado a proposta de Barak de criar um Estado Palestino devido às insuficiências que aquele Estado teria. Hoje, Arafat não apenas não tem mais uma proposta similar, como nem governa mais os territórios que a ANP já controlava antes do início de Camp David. Aliás, Arafat sequer tem mais uma perspectiva de criar um Estado Palestino no curto prazo. No entanto, as poucas informações que se filtraram após o fracasso de Camp David indicam que a proposta de Barak não era uma proposta irrecusável do ponto de vista de Arafat. Parece que, segundo a proposta, os palestinos teriam pouco acesso a Jerusalém, sem poder controlar os bairros árabes da cidade. Parece também que a proposta de Barak supunha a permanência de tantos assentamentos judaicos dentro do eventual Estado Palestino que qualquer controle palestino sobre seus territórios seria necessariamente parcial e incompleto. Falou-se naquele momento em um Estado queijo-suíço para os palestinos, tantas seriam as áreas fora do controle da autoridade palestina que a proposta de Barak supunha. De qualquer modo, a história parece também ter dado razão a Arafat num primeiro momento: nos encontros em Taba, no Sinai, pouco mais tarde, palestinos e israelenses parecem quase ter chegado a um acordo satisfatório para os dois lados. Ambas as partes parecem ter feito concessões maiores, ter se colocado na pele do outro e tentado entender as limitações do outro mais dramaticamente. As concessões de Barak em Camp David não eram então o máximo que um primeiro-ministro israelense poderia fazer, como mostrou Taba, e o que estava na mesa em Camp David ficou ultrapassado em Taba. Mas, devido às eleições para primeiro-ministro que ocorreriam em fevereiro de $2001 \mathrm{em}$ Israel, e que indicavam claramente que Barak perderia seu cargo, este teve a grandeza política de não querer comprometer seu sucessor num acordo que ele não havia negociado. Barak acabou retirando seus negociadores de Taba. Com isto, Taba fica na história como a oportunidade que indicou os contornos quase definitivos de qualquer acordo que fosse duradouro e justo entre israelenses e palestinos. Uma pergunta fica pendente com isso. Arafat mostrou falta de visão ao recusar os termos de Camp David ou mostrou muita habilidade de negociação ao apostar que Camp David não era a Ultima palavra de Barak e algo como o que esteve na mesa em Taba seria possível?

A nova Intifada teve início precisamente entre Camp David e Taba. Ela tem sido interpretada tanto como uma resposta a uma provocação feita pelo então líder da oposição israelense, quanto como uma manobra de
Arafat para pressionar Barak. Segundo a primeira versão, a visita que Ariel Sharon, então líder do partido Likud que estava na oposição em Israel, fez à mesquita Al Aqsa em setembro de 2000, era pura provocação. Segundo esta versão, após a derrota de Netanyahu nas eleições legislativas em 1999, o partido Likud ficou sem liderança. Netanyahu havia sido derrotado eleitoralmente e precisava responder a certos processos na justiça por abuso de poder. Mas, fora ele, não havia nenhuma liderança expressiva para liderar o Likud, e os líderes mais novos não queriam assumir o partido numa situação tão desastrosa. A solução que o Likud encontrou foi nomear Sharon como líder interino. Essa posição de líder interino era em si uma vitória para Sharon, que até então era declarado morto politicamente devido a seu envolvimento nos massacres dos campos de refugiados de Sabra e Chatila em 1982 no Líbano. De fato, alguns em Israel consideravam a invasão do Líbano um erro e culpavam Sharon por isso. Portanto, o fato de Sharon ter sido nomeado líder do Likud - ainda que interino - era uma indicação de reabilitação da sua figura política. Mas, como o poder é doce, e dados os problemas enfrentados por Barak como primeiro-ministro, o cargo de líder do Likud passou a ter cada vez mais atrações para Sharon, já que poderia levá-lo a uma reabilitação ainda maior: o cargo de primeiroministro. Portanto, quando no início de setembro, Netanyahu foi inocentado de todos os processos judiciais contra ele, Sharon percebeu que seu concorrente ia querer voltar à liderança do Likud. Sharon entendeu então que era preciso tomar alguma atitude expressiva para reverter a provável e forte ameaça de Netanyahu. Ele decidiu então ir à mesquita $\mathrm{Al} \mathrm{Aqsa,} \mathrm{ciente}$ do impacto que tal ato teria nas populações israelense e árabe. Sharon sabia que ao fazer aquela visita, conquistaria a admiração de certos setores do eleitorado israelense e dentro do seu próprio partido e que provocaria a ira dos palestinos. As duas coisas ocorreram de fato.

Segundo a outra explicação, Arafat teria provocado a Intifada para pressionar Barak. Segundo esta explicação, Arafat entendeu a primeira Intifada como um grande momento na história da luta do povo palestino por um estado independente. Para ele, a primeira Intifada trouxe simpatia da opinião pública internacional pela causa do povo palestino e pôs novamente a questão palestina na pauta internacional após o esquecimento no qual havia caído após o exílio da liderança palestina na Tunísia. De certa forma, sem a primeira Intifada, Arafat não teria feito a declaração formal do Estado Palestino em 15 de outubro de 1988, e não se teria dirigido às Nações Unidas, 
naquele mesmo ano, chamando a atenção mais uma vez, para o sofrimento palestino. Portanto, e aos olhos de Arafat, uma segunda Intifada poderia obter para ele os mesmos resultados: a simpatia do mundo e o consequente maior poder de barganha à mesa de negociação com Barak. Na tradição populista de Arafat, isso seria uma grande aliança direta entre o líder e as massas para conseguir um interesse comum. Segundo esta versão, Arafat aproveitou da visita de Sharon à mesquita $\mathrm{Al}$ Aqsa, mas se Sharon não tivesse visitado a mesquita, Arafat teria se aproveitado de qualquer outra oportunidade para agir nesse sentido. A visita de Sharon à mesquita Al Aqsa representaria, então, apenas o motivo legitimador da Intifada. O problema para Arafat é que, após alguns semanas de Intifada, ele já não a controlava mais. A Intifada, com suas mortes quase diárias e seus enterros frequentes, acabou adquirindo uma dinâmica própria que acabou impondo sua lógica ao próprio Arafat. Em vez de a Intifada ter aberto para ele mais uma opção política, tornou-se uma armadilha política para ele, já que sua legitimidade de líder passou a depender do grau de sua identificação com a Intifada. Assim, em vez de Arafat usar a Intifada, ele passou a ser usado por ela. Mais ainda, todos os ganhos políticos e territoriais que o povo palestino teve só foram conseguidos à mesa de negociação e nunca através do uso da força.

A eleição de Sharon veio para congelar o processo de paz. A desconfiança e as segundas intenções entre o governo israelense e a ANP passaram a dominar novamente. Com a Intifada tornando-se mais violenta devido aos atentados suicidas cometidos contra a população civil israelense, a repressão exercida pelas forças militares israelenses se tornou também mais violenta. Num círculo infernal de ações e retaliações, as vítimas civis se fizeram cada vez mais frequentes e numerosas, mesmo com o lado palestino tendo mais vítimas que o lado israelense. Sharon, que possui a mesma atitude relutante diante do processo de paz que Netanyahu, não deu nenhuma chance às negociações políticas. A eleição de George W. Bush à presidência americana e a política deste de evitar o mesmo engajamento no conflito no Oriente Médio que seu predecessor reforçaram a política de Sharon. Os eventos trágicos do 11 de setembro de 2001 confirmaram Sharon na sua política intransigente. De fato, Sharon passou a tratar Arafat e a ANP como parte do terrorismo internacional do qual a administração Bush tem falado. Com isso, Sharon passou a aplicar a Arafat a mesma receita que Bush aplica a Bin Laden e a Al Qaeda. Para Sharon, de nada vale negociar com Arafat, porque este não aceita a paz. Segundo Sharon, Arafat e a OLP querem criar um Estado Palestino para poder em seguida agredir Israel. Sharon considera que todas as concessões e todos os compromissos feitos por Israel não são correspondidos por parte de Arafat. Portanto, a força é a única maneira de lidar com Arafat e a ANP/ OLP. Seguindo esta política, Sharon acabou invadindo os territórios até então controlados pela ANP, e passou a reprimir os Palestinos cada vez mais violentamente. Por não dar nenhum crédito aos palestinos, Sharon acabou fechando todos os caminhos para a paz. A questão agora é como retomar o caminho da paz.

Consideramos os argumentos usados por ambos os lados. Palestinos e israelenses rejeitam qualquer tipo de responsabilidade no fracasso do processo de paz. Ambas partes consideram que fizeram todas as concessões possíveis e que o outro lado não fez nenhuma concessão significante. Israelenses e palestinos argumentam que estão comprometidos com a paz e que o outro lado não quer a paz. Israelenses e palestinos chamam a atenção aos seus sofrimentos históricos e pedem um Estado para poder viver em paz. Por fim, israelenses e palestinos rejeitam qualquer responsabilidade pela piora que o Oriente Médio tem vivido desde setembro de 2002. Fica evidente, então, que os argumentos de ambas as partes se contemplam num espelho. São argumentos muito parecidos, para não dizer iguais, e opostos apenas na hora de se atribuir culpa e inocência. A capacidade de cada um se colocar na pele do outro e entender os constrangimentos um do outro praticamente desapareceu do léxico da relação entre ambas as partes. Nem os israelenses nem os palestinos consideram os sofrimentos do outros como reais e as reivindicações do outro como legítimas. Ambas as partes entendem os constrangimentos do outro como simples subterfúgios para fugir da obrigação de cumprir seus compromissos. Em suma, nem os israelenses nem os palestinos aceitam entender um ao outro na sua complexidade, e na sua integridade.

Desde o início da Intifada, muito sangue foi derramado em ambos os lados, o que torna a capacidade de entendimento muito mais remota. Os palestinos dizem que é impossível entender-se com Sharon, enquanto os israelenses alegam que é impossível entender-se com Arafat. Mas o fato é que ambos os líderes carregam muito peso na sua história, e muita inimizade um em relação ao outro, ao ponto de a relação pessoal entre os dois estar impossibilitando o entendimento entre o governo de Israel e a ANP. Ambos foram democraticamente eleitos e ambos podem ser reeleitos 
democraticamente em eleições em janeiro de 2003. A questão é: são capazes de levarem seus povos a um futuro melhor.

Condenar Arafat por sua falta de visão ou sua falta de democracia é justo e merecido. No entanto, Arafat levou seu povo até onde chegou, e quase conseguiu realizar o sonho de um Estado. Condenar Sharon por sua truculência ou seu excessivo uso da força pode também ser justo, mas é difícil condenar totalmente o método forte usado por Sharon em termos de eficiência, diante dos atentados contra a população civil israelense e da matança sofrida por pessoas indo ao trabalho, indo se divertir ou saindo de um serviço religioso,. Há cada vez menos atentados e as células estão sendo desmontadas aos poucos. A única condenação possível de Arafat e de Sharon é que nenhum dos dois defende mais uma mensagem de paz, a única capaz de trazer segurança e tranquilidade duradouras a ambos os povos da região. Está na hora de levar estes dois líderes à aposentadoria compulsória e abrir caminho a novos líderes comprometidos com a paz para um futuro melhor. Nenhuma parte será capaz de viver em paz enquanto a outra parte estiver se sentindo injustiçada ou na posição de vítima, e as políticas de Arafat e de Sharon levam precisamente a isso.

O futuro da região reside precisamente no reconhecimento mútuo das reivindicações de ambos os povos e da sede de ambas as partes por segurança e paz. Isto só se tornará possível se ambos reconhecerem o outro na sua complexidade, como um legítimo outro, e não como apenas uma derivação de uma representação que se faz dele. Aceitar o outro é o mais difícil, mas é também o caminho mais seguro para se conseguir uma paz duradoura. Palestinos e Israelenses quase conseguiram isso e podem consegui-lo outra vez. A história nos ensina que a convivência entre Muçulmanos e Judeus não apenas é possível, mas é também natural e produtiva para ambos. Da Andaluzia à África do Norte, Judeus e Muçulmanos têm convivido juntos, e o Oriente Médio pode muito bem se tornar mais um exemplo dessa convivência pacífica.

\section{$O$ veto brasileiro ao sionismo}

e o "pragmatismo responsável" do governo Geisel

Monique Sochaczewski ${ }^{1}$

\section{Introdução}

A política externa do regime militar constituiu por um bom tempo uma 1 lacuna historiográfica, mas que nos últimos tempos vem atraindo a atenção de inúmeros pesquisadores, sendo o período em que o general Ernesto Geisel (1974-1979) presidiu a República o mais largamente estudado na bibliografia disponível.

Trata-se da política externa conhecida como Pragmatismo Responsável e Ecumênico, capitaneada pelo chanceler Antônio Francisco Azeredo da Silveira. Alguns aspectos marcantes dessa política, como a abstenção brasileira à proposta de suspensão das sanções a Cuba e sua integração ao sistema interamericano (reunião de Consulta dos Chanceleres da OEA, Quito, novembro 1974 e San José, julho 1975), o restabelecimento de relações diplomáticas com a República Popular da China (agosto 1974), o reconhecimento da independência de Angola (novembro 1975), assim como sua "Opção Europeia", já ganharam análises aprofundadas². Porém, no que diz respeito à progressiva aproximação aos países árabes, que culminou no voto a favor da Resolução 3379 das Nações Unidas, de 10 de novembro de 1975, que dizia ser o sionismo uma forma de racismo e de discriminação racial, embora seja um evento histórico bastante lembrado, ainda não ganhou até o presente um estudo pormenorizado.

Buscando participar deste esforço por um melhor conhecimento da política externa dos governos militares e, em especial, do governo Geisel,

\footnotetext{
${ }^{1}$ Mestranda em História das Relações Internacionais - UERJ.

2 Ver: PINHEIRO, Letícia de Abreu. Foreign Policy decision-making under the Geisel government: the president, the military and the foreign ministry. London School of Economics and Political Science, 1995. (PhD Thesis) e SARAIVA, Miriam Gomes. A Opção Europeia nos marcos do Pragmatismo responsável: a política externa brasileira para países europeus de 1974 a 1979. Instituto de Relações Internacionais PUC-Rio, 1990 (Dissertação de mestrado).
} 
assim como da história das relações Brasil -Oriente Médio ${ }^{3}$ - região tão em destaque nos últimos tempos e na realidade tão pouco conhecida - é que me proponho tratar nesta comunicação de alguns aspectos da investigação que conduzo presentemente sobre esse tema.

Vale ressaltar que se trata de uma pesquisa recém-iniciada, no corrente ano, no âmbito do Programa de Pós-Graduação em História, linha de pesquisa de História das Relações Internacionais, da UERJ, que haverá de resultar em dissertação de mestrado a ser defendida somente no final de 2003. Encontro-me assim em uma fase de muitas leituras, levantamento de fontes (algumas recém-abertas aos pesquisadores) e questionamentos, ainda, pois, sem conclusões definitivas.

Na primeira seção deste artigo, procurarei tratar do ambiente no qual foi apresentado e votado o projeto de resolução que condenava o sionismo no âmbito das Nações Unidas, e que contou com o voto brasileiro, e na segunda parte procurarei analisá-lo sob a ótica da política externa brasileira de então.

\section{O voto}

Entre os dias 31 de agosto e 7 de setembro do ano de 2001, ocorreu em Durban, (África do Sul), a Conferência Mundial contra o Racismo, a Discriminação Racial, a Xenofobia e a Intolerância Correlata, patrocinada pela $\mathrm{ONU}^{4}$. Esse fórum internacional teve por objetivo debater, discutir, denunciar e combater as formas atuais de discriminação racial, étnica, religiosa e de qualquer gênero, visando elaborar uma declaração de princípios sobre tais assuntos. Embora contasse com representantes de cerca de 170 países, a Conferência aparentemente acabou por se esvaziar com o abandono das delegações dos Estados Unidos e de Israel. Este afastamento foi acompanhado da ameaça dos países da Comunidade Europeia de seguir as duas delegações, sob a alegação de que o encontro havia se politizado em demasia e perdido seu sentido com a forte campanha da Liga Árabe, cujo objetivo era o de obter uma declaração que estabelecesse a equivalência entre sionismo e racismo.

\footnotetext{
${ }^{3}$ Vale destacar as publicações recentes dos livros "Brasil e Israel: diplomacia e sociedades" organizado pela Prof. Norma Breda dos Santos e "Israel e Palestina: a construção da paz vista de uma perspectiva global" organizado por Tullo Vigevani \& Gilberto Dupas.

${ }^{4}$ Ver: Conferência Mundial contra o racismo e a intolerância correlata - Instituto Interamericano de Direitos Humanos, 2001.
}

Se em 2001, em plena vigência da forte polêmica, o Brasil, que contava com a segunda maior delegação, estando atrás somente da África do Sul, oficialmente não se envolveu no debate sobre esse tema específico, preferindo se dedicar a questões relacionadas aos negros, aos índios, aos homossexuais e à AIDS, o mesmo não se pode dizer do que ocorreu entre os meses de outubro e novembro de 1975. Naquela ocasião, quando o tema do sionismo entrou em discussão, sob pena de ser condenado como uma forma de racismo, em comissões, sessões especiais e finalmente na Sessão da $\mathrm{XXX}^{\mathrm{a}}$ Assembleia Geral das Nações Unidas, o Brasil, juntamente com outros 69 países votou a favor da resolução 3379, pela qual o sionismo sofreu uma moção negativa

O projeto que culminou na resolução aprovada foi apresentado pela Liga Árabe ${ }^{5}$ no início de outubro de 1975 e entrou na pauta da Comissão Social, Humanitária e Cultural. O texto em questão dizia-se embasado em declarações e em compromissos assumidos anteriormente pelos países no âmbito das Nações Unidas, remetendo a outras resoluções aprovadas, como a de número 1904, de 20 de novembro de 1963, que proclamava a eliminação de todas as formas de discriminação racial, em particular a afirmação de que "qualquer doutrina de diferenciação racial ou superioridade é cientificamente falsa, moralmente condenável, socialmente injusta e perigosa", e a de número 3151, de 14 de dezembro de 1973, que condenou, inter alia, a aliança entre o racismo sul-africano e o sionismo.

O projeto fazia ainda referência a outras conferências e encontros ocorridos também em 1975, como a Conferência Mundial do "Ano Internacional da Mulher", realizada no México, entre 19 de junho e 2 de julho, a Assembleia dos Chefes de Estado e Governo da Organização da Unidade Africana, ocorrida em Uganda, de 28 de julho a ${ }^{10}$ de agosto e a

$3^{5}{ }^{5}$ Liga Árabe - A Liga dos Estados Árabes foi fundada no Cairo em 1945 pelo Egito, Iraque, Líbano, Arábia Saudita, Síria, Transjordânia (Jordânia, a partir de 1950), e Iêmen. Os estados que posteriormente se juntaram foram: Argélia (1962), Bahrain (1971), Camarões (1993), Djibouti (1977), Kuwait (1961), Líbia (1953), Mauritânia (1973), Marrocos (1958), Oman (1971), Qatar (1971), Somália (1974), Iêmen do Sul (1967), Sudão (1956), Tunísia (1958), e Emirados Árabes Unidos (1971). A Organização pela Libertação da Palestina foi admitida em 1976. A participação do Egito foi suspensa em 1979, após ter assinado o tratado de paz com Israel; O quartel-general da Liga mudou-se do Cairo, Egito para Tunis, Tunísia. Em 1987, os líderes árabes decidiram renovar ligações diplomáticas com o Egito, que foi então readmitido na Liga em 1989 e o quartel-general da Liga mudou-se de volta para o Cairo. Fonte: http://www.arabji.com/ArabGovt/ArabLeague.htm 
Conferência dos Ministros das Relações Exteriores dos Países Não Alinhados, ocorrida no Peru, de 25 a 30 de agosto. Em absolutamente todos estes eventos, fizeram-se críticas nominais ao sionismo, comparando-o ao regime do Apartheid da África do Sul e deles saíram declarações formais que, de uma forma ou de outra, o incluíam como "uma forma de racismo e de discriminação racial". Assim, a proposta final também na ONU foi a de declarar o sionismo como uma forma de racismo e de discriminação racial, sem contudo explicitar o que é entendido por sionismo.

O Brasil tinha várias alternativas a respeito da resolução: não comparecer à votação; comparecer e abster-se; apoiar uma resolução mais branda ou votar a favor da proposta árabe, mas acompanhando o voto com uma declaração capaz de justificá-lo e reduzir, talvez, seu provável impacto.

A delegação brasileira na ONU, chefiada pelo diplomata Sérgio Corrêa da Costa, solicitou instruções urgentes no sentido de como agir a respeito do tema, uma vez que o voto na III Comissão seria dado na mesma semana em que o projeto foi apresentado.

Nesse primeiro momento, porém, o voto teria mais caráter declaratório, ao contrário do que seria dado na Assembleia Geral, quando resultaria numa resolução. O Itamarati, em telefonema ao embaixador, deu a opção do governo brasileiro, comunicando que se votasse a favor.

Segundo o ex-ministro Antônio Azeredo da Silveira, em depoimento concedido ao CPDOC, o combinado com o presidente Geisel seria o apoio ao voto na Comissão Social, Humanitária e Cultural, uma vez que se tratava basicamente de um voto sem consequências para as relações nos planos multilaterais e bilaterais, enquanto no plenário deveria haver abstenção. Porém, nesse meio tempo uma carta enviada pela embaixada norteamericana em Brasília, tida como desaforada, praticamente os obrigou a mudar de ideia e manter o veto ao sionismo também na Assembleia-Geral:

Minha inclinação sempre foi o voto de abstenção, mas o presidente Geisel, certo ou errado, quando assumiu o governo ele acreditava que o Brasil devia se afirmar nos organismos internacionais votando a favor ou contra. Ele tinha aversão ao voto de abstenção. Então, deuse na comissão e nesse momento, dos países latino-americanos, só votaram a favor o México e o Brasil. O Terceiro Mundo votou massivamente contra Israel, mas nós éramos um país de não alinhamento automático e não tínhamos nenhuma razão para seguir cegamente estes votos. Eu acho que o voto de abstenção era suficiente. Então, ia se dar o voto em plenário e o combinado era de nós nos abstermos em plenário que era o voto que realmente importava. O voto da comissão é voto apenas declaratório, de simpatia por uma posição. E havia o entendimento entre o presidente e eu de que nós nos absteríamos, mas nesse meio tempo eu parti para a Inglaterra para visitar aquele que havia sido primeiro-ministro e era então ministro das Relações Exteriores, Calagham, pessoa que depois em que fiquei muito ligado por laços de entendimento, de trocas de informações muito grandes.

Nesse meio tempo, chegou uma nota americana muito desaforada, contra o voto brasileiro na comissão. Houve então uma decisão do governo de votar a favor também em plenário, de não modificar o voto $^{6}$.

Na realidade, além do México, citado pelo ex-chanceler Azeredo da Silveira, o voto brasileiro na Comissão (17/10/1975) foi acompanhado pelos de outros três países latino- americanos, a saber: Cuba, Chile e Guiana. Segundo a imprensa da época, o voto de Cuba pôde ser entendido como o de um país alinhado automaticamente com a União Soviética; o do México, como o de um país interessado em obter a nomeação de um mexicano como Secretário Geral na Organização, e o do Chile, que muito surpreendeu na ocasião, interpretado como uma forma de conquistar o apoio árabe contra as acusações de que vinham sendo alvos as autoridades chilenas, em relação à tortura e outras violências contra os direitos humanos cometidas pelo recém-inaugurado regime de Pinochet ${ }^{7}$. O governo brasileiro, assim como Chile, Guiana e México, realmente recebeu uma carta da embaixada norte-americana condenando o voto ${ }^{8}$. Nesta, o governo dos Estados Unidos, entre outros pontos, dizia estar profundamente desapontado com o voto dado pelo Brasil e que essa ação contrastava com os princípios humanistas que por tanto tempo motivaram tanto o povo brasileiro como o norte-americano. Dizia ainda que, se endossado no plenário da Assembleia Geral, a decisão tomada na III Comissão teria por efeito a destruição da força moral e as ações das Nações Unidas para combater o racismo e a discriminação racial e que na visão norte-americana

${ }^{6}$ Depoimento prestado por Antônio Francisco Azeredo da Silveira ao CPDOC em 15/05/1979 - Fita 3/ ladoB

${ }^{7}$ Não há referências quanto às motivações da Guiana.

${ }^{8}$ CPDOC-AAS mre/vm 1974.06.13 - V.7 
a caracterização do sionismo como uma forma de racismo e de discriminação racial não só, grosseiramente, não representava a natureza do sionismo como também encorajava a forma de racismo conhecida como antissemitismo. $\mathrm{O}$ documento concluía afirmando esperar que a resolução não fosse endossada na Assembleia e que o governo brasileiro instruísse sua delegação a votar contra ${ }^{9}$.

A sessão de 10 de novembro de 1975 da Assembleia Geral, no entanto, apresentou um outro desfecho. Alegando sentir-se ultrajado com a tentativa norte-americana de interferência na sua soberania, o Brasil acompanhou 69 países ao confirmar seu voto condenatório. O Chile foi único país latino-americano a mudar de posição.

Segundo a matéria intitulada "Na defensiva", publicada na revista Veja de 19 de novembro de 1975:

\begin{abstract}
A segunda-feira da semana passada, 10 de novembro, bem que poderá ser comemorada no futuro como o Dia do Pragmatismo Responsável, se a história ainda por ser escrita das relações internacionais der razão ao patrono da nova política externa brasileira, chanceler Antônio Francisco Azeredo da Silveira. Pois, nesse dia - e antes mesmo que os países do bloco socialista o fizessem -, o Brasil reconheceu a independência angolana e, implicitamente, a hegemonia política do Movimento Popular para a Libertação de Angola (MPLA) na antiga colônia portuguesa. E confirmou no plenário das Nações Unidas (...) o voto que já havia dado na Comissão de Assuntos Sociais, Humanitários e Culturais da ONU a favor da resolução que condena o sionismo como 'uma forma de racismo e de discriminação racial.
\end{abstract}

É fato que o voto brasileiro a favor do projeto condenatório do sionismo teve a mais ampla repercussão, não só na ONU e nos Estados Unidos, mas também internamente. Muitos que se pronunciaram sobre o tema não deixaram de mencionar a "contradição histórica" entre a condenação brasileira ao sionismo e os esforços desenvolvidos na ONU em 1947 por Oswaldo Aranha, enquanto presidente da Assembleia Geral, em favor da criação do Estado de Israel.

Oswaldo Aranha Filho, então vice-presidente da Associação Comercial do Rio de Janeiro e suplente de senador pelo MDB, considerou no mínimo "estranho" chamar de discriminação racial "uma força agregadora como a do sionismo, que deu coesão e meios de sobrevivência a uma raça, que tem proporcionado pelo tempo dos tempos, uma das mais fecundas contribuições à humanidade" ${ }^{\text {. }}$.

Interessante também ressaltar o envolvimento pessoal do embaixador Sérgio Côrrea da Costa nos dois momentos significantes das relações Brasil-Israel na ONU. Segundo nos conta em seu livro recentemente publicado, Brasil: segredo de estado ${ }^{11}$, era então, em 1947, um jovem diplomata e não só acompanhou o drama que culminou no voto favorável na sessão das Nações Unidas presidida por Oswaldo Aranha à partilha da Palestina, como manteve consigo por quase 20 anos o bloco (roll call) em que o secretário da Assembleia havia anotado os votos sobre a resolução. Em outras palavras: a certidão de nascimento do estado de Israel. $\mathrm{O}$ diplomata, que foi genro de Oswaldo Aranha, conta que, no final da década de 60, a doou ao kibutz de brasileiros Bror Chail, em Israel, por conta da inauguração de um centro cultural no local. Já no final do ano de 1975, foi de sua voz que saiu o voto brasileiro favorável à Resolução 3379.

Mas, façamos as principais perguntas: por que tal voto causou tanta comoção? O que estava por trás dele? No que efetivamente resultou o voto favorável do Brasil? Procurarei a seguir tratar brevemente de algumas destas questões.

\section{O voto e o pragmatismo responsável}

A mudança de posição do Brasil em relação ao Oriente Médio, de uma equidistância para uma posição favorável aos países árabes, deu-se na pós-crise do petróleo em 1973. No início do ano em questão, o chanceler Mario Gibson Barboza realizara uma viagem ao Egito e a Israel ${ }^{12}$ buscando $^{2}$ nesta frisar a posição brasileira de equilíbrio em relação às duas partes.

\footnotetext{
${ }^{10}$ Veja $(19 / 11 / 1975)$

${ }^{11}$ COSTA, Sérgio Corrêa da. Brasil: segredo de Estado. Rio de Janeiro: Record, 2001, pp.361-366

${ }^{12}$ De 28 a 31 de janeiro estivera no Egito, de $1^{\circ}$ a 4 de fevereiro no Quênia e de 408 de fevereiro em Israel. Mano Gibson Barbosa diz que o Egito exigia que não se passasse diretamente do seu território para o de Israel, fazendo-se necessário visitar, antes, um país intermediário. De praxe escolhia-se o Chipre, mas preferira utilizar o Quênia como "ponte", pois, além de ser um país de relevo da África subsaariana, era parceiro importante na
} 
Foi, porém, no governo Geisel, tendo como chanceler Antônio Francisco Azeredo da Silveira, que o Brasil se aproximou cada vez mais dos países árabes, principalmente nos foros multilaterais. A política externa conhecida como "pragmatismo responsável e ecumênico", defendia que o Brasil deveria buscar vantagens no cenário internacional, independentemente de regime e ideologia; que as questões ideológicas não contaminariam a política externa e que deveriam ampliar-se as parcerias desejadas, prescindindo de afinidades ideológicas e políticas em escala planetária, isto é, para além do âmbito hemisférico, onde a hegemonia americana não poderia ser desafiada ${ }^{13}$.

É dentro desta perspectiva que se procura explicar o voto brasileiro favorável ao projeto de resolução proposto pela Liga Árabe: marcaria o não alinhamento automático do Brasil com os Estados Unidos num foro multilateral, muito pelo contrário até, marcando sua independência e "revolta" com a carta tida como "desaforada", declarada à imprensa antes mesmo de enviada ao Itamarati, e seria ao mesmo tempo, uma forma de agradar os países árabes, em especial o Iraque e a Arábia Saudita, que supriam o Brasil de petróleo e que potencialmente serviriam de mercado para produtos brasileiros, como alimentos, serviços e armamentos. Países aos quais Ernesto Geisel, em especial, já buscava aproximar-se desde seus tempos como presidente da Petrobrás (1969-1973) ${ }^{14}$.

Vale aqui, abrir um parêntese e dizer que, no momento das discussões na ONU, entre os dias 24 e 31 de outubro de 1975, se encontrava no Iraque uma missão preparatória para uma possível visita ao país por parte do chanceler Azeredo da Silveira ${ }^{15}$. Esta era chefiada pelo Chefe do Departamento de Promoção Comercial do Ministério das Relações Exteriores, Paulo Tarso Flecha de Lima, e tinha como objetivo negociar um acordo de cooperação técnica entre os dois países, assim como proceder a

comercialização do café e era credor de uma visita oficial em retribuição à do Ministro dos Negócios Estrangeiros Nyroge Mungai, em 1972. (BARBOZA, Mano Gibson. Na diplomacia, o traço todo da vida. Rio de Janeiro: Record, 1992, p.217)

3 VIZENTINI, Paulo Fagundes. A Política Externa do regime Militar Brasileiro. Porto Alegre: Ed. UFRGS, 1998, p.208.

${ }^{14}$ Ver CASTRO, Celso e D’Araújo, Maria Celina. Ernesto Geisel. Rio de Janeiro: FGV, 1997, p. 245.

${ }^{15}$ Segundo telegramas enviados pela embaixada em Bagdá (AAS mre/vm 1974.06.13 -v. 7), a princípio esta se iniciaria em 30 de novembro de 1975 uma avaliação objetiva das possibilidades de concretização, a curto, médio e longo prazos, de iniciativas de caráter comercial e econômicos estudadas por parte das autoridades iraquianas. Nas conclusões do relatório enviado pelo chefe da missão ao chanceler brasileiro, aquele fala das vantagens já obtidas com o voto brasileiro favorável à Resolução 3379:

A primeira conclusão que se impõe é a de que as relações entre os dois países, no plano político, não poderiam constituir melhor quadro para a expansão das relações econômico-comerciais. Encontrei em todos os meus interlocutores, praticamente sem exceção, lembrança, que não deixei de avivar, da atitude assumida pelo Brasil por ocasião do bloqueio do petróleo iraquiano pela IPC, a consciência da importância do nosso intercâmbio comercial, e a gratidão pela atitude assumida pelo Brasil com relação ao Oriente Médio. É nesse contexto, inegável que o recente voto brasileiro, na Comissão Social da XXX' Assembleia Geral, de muito terá contribuído para a acolhida reservada à Missão. Recebi reiterados agradecimentos pela atitude brasileira, tanto de altos funcionários do Ministério do Exterior como de várias autoridades com que me avistei ${ }^{16}$.

Aparentemente as vantagens obtidas pelo voto foram colhidas antes mesmo que esse fosse confirmado na Assembleia Geral, em 10 de novembro. Tal impressão é reforçada pelo relatório enviado de Londres ao presidente Geisel, narrando encontro com o Secretário de Estado para Negócios Estrangeiros da Inglaterra, James Callaghan, em 23 de outubro de 1975, no qual Azeredo da Silveira diz que:

Callaghan, antes de me dar as boas vindas formais, adiantou que estava chegando de encontro com o príncipe Fand, da Arábia Saudita. Nessa ocasião, disse-me inteirado de que terminado o encontro anglo-saudita, Callaghan viria a meu encontro, o príncipe Saud, ministro dos Negócios Estrangeiros da Arábia Saudita, pediulhe reiterada e expressamente que me transmitisse (...J a satisfação que experimentara por ocasião de nosso encontro em Nova Iorque, as perspectivas que antecipava poderem ser exploradas para uma colaboração mais intensa entre o Brasil e a Arábia Saudita e a expectativa com que aguardava, em novembro ou dezembro no mais tardar, minha visita a Riad) ${ }^{17}$.

\footnotetext{
${ }^{16}$ CPDOC - AAS mre/d 1974.03.26 - v7

${ }^{17}$ Ibid.
} 
Um ponto que surge da análise da documentação e que merece destaque é que esse tema específico muito envolveu o chanceler Azeredo da Silveira. Em seu depoimento concedido ao CPDOC, o tema é recorrente em quase todas as entrevistas e em seu arquivo pessoal constam inúmeros documentos relacionados à questão, sendo que dois destes, uma vez que se encontram no dossiê intitulado $\mathrm{XXX}^{\mathrm{a}}$ Assembleia Geral e VIII Sessão Especial - 1975, da Série ONU, estão fechados à consulta. Assim, parece ser importante examinar o episódio do voto antissionista procurando compreender a visão do chanceler sobre o tema com mais acuidade.

\section{Observações finais}

Enfim, de todas as informações aqui apresentadas, é válido lembrar, novamente, tratarem-se do início de uma jornada. Falta ainda um maior embasamento teórico, assim como um maior diálogo com as fontes. E, em alguns casos, diálogos reais, uma vez que existe a vontade de realizar uma série de entrevistas com diplomatas e outras pessoas envolvidas com a questão.

Documentos importantes, que certamente muito ajudarão na pesquisa, só recentemente foram liberados aos pesquisadores e demandarão um bom tempo de consulta.

Porém, fica a certeza de tratar-se de um tema de estudo importante da história recente da política externa brasileira, que certamente colaborará para um melhor entendimento das relações de então e de hoje.

\section{Referências Bibliográficas}

D'ARAúJO, Maria Celina e Castro, Celso (org). Ernesto Geisel. Rio de Janeiro: FGV, 1997.

D’ARAÚJO, Maria Celina e Castro, Celso (org). Dossiê Geisel. Rio de Janeiro: FGV, 2002.

PINHEIRO, Letícia de Abreu. Foreign Policy decision-making under the Geisel government: the president, the military and the foreign ministry. London School of Economics and Political Science, 1995. (PhD Thesis)
SARAIVA, Minam Gomes. A Opção Europeia nos marcos do Pragmatismo responsável: a política externa brasileira para países europeus de 1974 a 1979. Instituto de Relações Internacionais PUCRio, 1990 (Dissertação de mestrado).

SANTOS, Norma Breda (org). Brasil e Israel: Diplomacia e Sociedades. Brasília, UnB, 2000.

VIGEVANI, Tullo \& DUPAS, Gilberto (org). Israel e Palestina: a construção da paz vista de uma perspectiva global. São Paulo: Unesp, 2002.

VIZENTINI, Paulo Fagundes. A Política Externa do Regime Militar Brasileiro. Porto Alegre: Ed. UFRGS, 1998. 


\section{História de um conflito}

Paulo Geiger

A maior parte da mídia internacional, um grande número de formadores de opinião, políticos, intelectuais, líderes de estados e de nações, líderes religiosos, organizações e instituições não governamentais, governamentais e internacionais, pessoas comuns, alguns movidos por intencional má-fé (no sentido de apresentar versões que lhe interessam como se fossem fatos), outros por desinformação, ou desaviso, reduzem toda a essência do conflito palestino-israelense em sua fase atual a uma luta de oprimidos (os palestinos) contra seu opressor (Israel), que ocupa seu território e lhe impede o livre exercício de seus direitos de nação. À luz dessa redução simplista e maniqueísta, desenham-se os perfis do mocinho e do bandido. Toda ação palestina, inclusive terror sanguinário e violência contra civis indefesos, é vista como parte de uma luta justa, na qual os fins justificam os meios. Todas as operações de Israel em sua luta contra o terror são vistas como crimes de guerra, violação dos direitos humanos. Não são poucos os que, mesmo condenando o terror em todas as suas formas, veemno, neste caso, como consequência inevitável da ocupação, e nesta a única causa do conflito. Ou seja, com sua 'política militarista', com sua 'opressão', com sua negação dos 'direitos dos palestinos' pela força, Israel seria o único causador e alimentador do conflito, cabendo-lhe, e só a ele, solucioná-lo com a retirada incondicional que propiciaria o estabelecimento do estado palestino e, com isso, o fim do conflito.

Considerando que a ocupação realmente existe, e que ela contraria de fato a aspiração dos palestinos a um estado próprio, aspiração que, independentemente de sua validade ou justificação histórica, assumiu o status de um direito internacionalmente reconhecido, essa maneira de ver e de concluir poderia parecer autêntica, não fosse a grande distorção, proposital ou desavisada, de 'congelar' a essência do conflito em seu aspecto atual. Proposital ou desavisadamente, não se percebe a ocupação como uma das fases - longa embora - de um complexo conflito que perdura por mais de 80 anos, conflito que, como este artigo demonstrará adiante, não foi desencadeado nem alimentado em nenhum momento pela recusa judaica, sionista ou israelense de admitir e aceitar a instalação de mais um entre os muitos estados árabes do Oriente Médio e da África - um estado dos árabes que habitavam a antiga Palestina -, mas sim pela recusa destes, e de todo o mundo árabe, de aceitar, ao lado desse estado dos árabes palestinos, a existência de um único estado judaico no único lugar no mundo em que poderia existir.

A compreensão de que a ocupação é apenas uma fase desse longo conflito, exigindo soluções muito mais complexas do que a simples retirada de Israel - que não levaria, por si mesma, ao fim do conflito -, exige o conhecimento de todo o processo histórico que levou a ela, o que não cabe nos espaços das agências de notícias e dos comentaristas de plantão. Muito mais simples e vendáveis são as imagens de atentados sanguinários, de meninos atirando pedras em tanques, de helicópteros atingindo carros e casas, a emblemação caricata de Sharon, as frases feitas sobre repressão, 'massacres', violações de direitos. A consequência não é só desinformação, mas a consolidação de uma opinião, de uma atitude, que acaba contaminando decisões e medidas anti-israelenses, sem falar na munição farta que se oferece ao que, sob o pretexto do anti-sharonismo, logo se configura como anti-israelismo, antissionismo e antissemitismo.

Apenas como exemplo desse gatilho rápido movido a distorção de informação e reforçado por preconceitos e pré-conceitos: a TV mostrou ao mundo inteiro como um oficial norueguês que chefiava uma comissão da ONU, depois de um breve passeio pelas ruínas dos quarteirões de Jenin, onde se travara uma batalha entre as forças de Israel e palestinos armados (na qual morreram 23 israelenses e 56 palestinos), ainda sob a falsa denúncia, veiculada por palestinos - e mais tarde refutada pela própria ONU -, de um suposto 'massacre' de centenas de pessoas, declara que "indubitavelmente ali ocorrera um crime de guerra". Depois da II Guerra Mundial, um tribunal internacional reunido em Nuremberg para julgar criminosos de guerra nazistas, levou semanas apresentando testemunhas, documentos, filmes, com pleno direito de defesa dos acusados, para concluir que houvera crimes de guerra e para condenar os acusados, e ainda absolver alguns. O norueguês e sua comissão precisaram apenas de alguns minutos para chegar ao veredicto e anunciá-lo ao mundo.

Este artigo destina-se a preencher essa lacuna de informação objetiva sobre a história do conflito, e levará à compreensão de que a ocupação que 
caracteriza a situação atual não é sua causa, mas sua consequência, e foi a recusa árabe de aceitar a existência de Israel como estado judaico - e não uma recusa sionista e israelense de aceitar um estado palestino - que se constituiu na raiz conceituai e histórica que o engendrou e que, no fundo, o alimenta ainda hoje.

A origem do conflito do Oriente Médio está ligada à questão do direito histórico dos judeus de terem uma pátria no lugar em que se formaram como nação, e que alimentou durante 2 mil anos seu sonho de retorno, sua percepção de convergência e, portanto, sua unidade como povo em busca de um futuro comum. Visto erroneamente por muitos como apenas uma religião, o judaísmo é na verdade um amálgama de identidades: uma identidade histórica grupai (percepção de pertinência a um povo), uma identidade espiritual e cultural - forjada na religião, mas extensiva a conceitos filosóficos, éticos e comportamentais - e uma identidade de destino, que seria o 'retorno' à identidade inicial em Sion, presente na gênese do povo judeu e parte importante de seu óritos e de seu ethos. O retorno a Sion, portanto, sempre foi parte da própria percepção que o povo judeu tinha da essência de seu ser, e fator decisivo de sua visão de redenção pela volta às origens.

O movimento sionista moderno, criado no fim do século XIX, alimentado pelos ideais libertários da emancipação, dos direitos do homem e das nações, trouxe para a categoria do direito internacional o sonho milenar de redenção dos judeus. Assim como todos os povos, o povo judeu teria direito à autodeterminação, e o novo movimento sionista foi criado como instrumentador dessa autodeterminação, mais adequado, em sua conceituação e métodos, à modernidade do que os sonhos messiânicos e o misticismo da escatologia judaica. O sionismo moderno é a bimilenar tensão do retorno traduzida na linguagem dos novos tempos, reconhecível por todos os povos, equiparada aos direitos de todos os povos. Visava a construir uma pátria para um povo sem pátria e nela estabelecer um estado-nação para uma nação histórica, na terra que era o berço de sua existência e o porto visado de sua longa travessia. Em 51 anos o sionismo realizou essa tarefa, viabilizada politicamente e endossada, afinal, pela decisão majoritária das nações organizadas de todo o mundo ${ }^{1} \mathrm{O}$ Estado de Israel, que o povo judeu vê como um direito histórico da nação de Israel, surgiu como um estado legitimamente criado pela consciência universal desse direito.

Por outro lado, é um erro de avaliação histórica interpretar a reivindicação de um lar nacional para o povo judeu (expresso num moderno estado-nação), e o reconhecimento internacional de que essa reivindicação constituía um direito, apenas como fruto da necessidade de amenizar os efeitos do Holocausto. A percepção da nacionalidade e o anseio por uma vida nacional normal sempre foram parte da identidade judaica na dispersão, e são expressas na religião e cultura judaicas, ao longo de 2.000 anos. O ideal de retorno a Sion não foi inventado pelo sionismo moderno, nem pela ONU. Theodor Herzl ${ }^{2}$ percebeu a necessidade de um lar nacional para o povo judeu ante a resistência do antissemitismo à emancipação e às ideias libertárias do século XIX, mas com isso ele não estava criando a ideia, e sim dando-lhe um rationale e um contexto modernos. A ideia do lar nacional judaico e do moderno estado-nação para o povo judeu é fruto da própria história dos judeus e de seu apego a sua identidade histórica.

Também é preciso entender que os 2.000 anos de dispersão fizeram dos judeus bons cidadãos das nações que os abrigaram, mas que uma religião comum não é a única marca de sua unidade. Os judeus não são apenas um conjunto disperso de correligionários, mas membros de uma entidade histórica, uma nação, que se reconhece como tal e que aspira a um futuro, e o direito ao estado-nação para aqueles que o quiserem, ou dele necessitarem.

$$
* * *
$$

A Palestina nunca foi, ao longo de 2.000 anos, desde que deixara de ser um estado judaico soberano (com a destruição do segundo Templo, em 70, e a derrota final para os romanos, em 135), estado de nenhum outro povo ou qualquer outra nação. Passou de mão em mão, foi varrida por guerras de conquistas e reconquistas, mas nenhuma consciência política de pertinência à terra e a seu destino substituiu a que os judeus levaram

${ }^{1}$ Em 1897 realizou-se o primeiro Congresso Sionista, em Basiléia, Suíça. Em 1947 a ONU decidia a partilha da Palestina para a criação de dois estados nacionais: um para os árabes palestinos, um para o povo judeu. Em 1948 foi criado o Estado de Israel.

${ }^{2}$ Jornalista judeu, idealilizador do sionismo moderno e organizador do Primeiro Congresso Sionista. 
consigo para a Diáspora e de lá a exercitaram, sonhando com a volta a Sion. Mas, no curso de uma das conquistas, a conquista árabe, que durou cerca de quatrocentos anos (do século VII ao século XI), uma população de camponeses e pequenos comerciantes árabes muçulmanos lá se estabeleceu. Aos poucos, tornaram-se majoritários, mas nunca aspiraram a transformar essa predominância demográfica em fato político. Não reivindicaram soberania em nenhum dos momentos das seguidas ocupações (a partir do século XI) dos turcos seldjucos, cruzados, mamelucos, e turcos otomanos. Foi essa presença física de uma população árabe de cerca de 700 mil pessoas no território que a ONU destinara ao estado judaico que serviu de pretexto para a recusa árabe em aceitar uma solução partilhada para a dupla reivindicação nacional sobre a mesma terra.

Já a proposta sionista de um estado nacional judaico na Palestina nunca se baseara na exclusão da população árabe local. A imigração judaica a partir de fins do século XIX estabelecera-se em terras compradas aos árabes e em terras devolutas - terrenos pedregosos ou pântanos infestados de malária -, que foram redimidas para a agricultura. Aos poucos a população judaica crescera e criara uma infraestrutura econômica e social que seriam as bases para o futuro estado. Nas duas primeiras décadas do século XX, líderes árabes de países vizinhos, como o emir Faiçal e o rei Abdallah, em sua luta pela libertação do colonialismo francês e inglês, viam com bons olhos o estabelecimento judaico na Palestina, e aceitaram a ideia de uma nação judaica ao lado das nações árabes independentes que surgiriam na região ${ }^{3}$. A frustração que lhes foi imposta pelas potências coloniais acarretou o rompimento com essa ideia, e uma oposição ferrenha a ela, que redundou no conflito que perdura até hoje. A partir daí, não foram raros choques violentos entre as comunidades árabe e judaica, insuflados pelos líderes árabes dos países vizinhos, e que atingiram em alguns momentos $(1920,1936)$ as proporções de um quase pogrom.

O movimento sionista e o establishment judaico na Palestina, por outro lado, tinham a consciência de que a realização nacional judaica em Erets Israel ${ }^{4} \mathrm{e}$ as aspirações nacionais dos árabes não eram excludentes. Entenda-se que a Palestina de então compreendia terras em ambas as

\footnotetext{
${ }^{3}$ Houve entendimento nesse sentido entre o emir Faiçal e Chaim Weizmann, presidente da Organização Sionista, entendimento expresso pelo primeiro por escrito.
}

${ }^{4}$ Em hebraico, 'Terra de Israel', termo com que os judeus denominavam a Palestina. margens do rio Jordão, ou seja, os atuais territórios de Israel, Cisjordânia, Jordânia e Gaza. Essa foi a Palestina que a Liga das Nações, após a I Guerra Mundial, outorgou à responsabilidade mandatária da Inglaterra, com o fim precípuo de lá propiciar a criação de um lar nacional para o povo judeu ${ }^{5}$. Um dos primeiros atos dos ingleses, no entanto, ainda em 1922, foi entregar a maior parte da Palestina, a margem oriental do Jordão (a Transjordânia), à família haxemita do rei Abdallah, bisavô do atual rei da Jordânia, para que lá se estabelecesse um reino árabe soberano. O movimento sionista aceitou a ideia, convencido de que, realizada assim a aspiração nacional dos árabes da Palestina, seria mais fácil partir para a realização nacional judaica no que restara da Palestina, a margem ocidental.

Mas a oposição dos árabes não arrefeceu, demonstrando que ela não partia do temor de que a presença judaica e suas aspirações nacionais pudessem prejudicar as suas próprias, mas sim de sua recusa em aceitar in limine qualquer realização nacional judaica na Palestina. Os ataques aos judeus continuaram, até que, em 1937, uma comissão internacional, a Comissão Peel, chegou à Palestina - agora só a margem ocidental - para estudar a situação e sugerir uma solução. A solução proposta foi uma segunda partilha: dividir o que restara da Palestina entre os dois povos. De novo os judeus aceitaram, de novo a recusa árabe foi peremptória. A proposta da comissão Peel evoluiu para a proposta afinal apresentada na ONU em 1947, e aprovada por grande maioria na Assembleia Geral.

Os judeus da Palestina e do mundo comemoraram a solução da Partilha; os árabes prometeram um banho de sangue e começaram a atacar os judeus ainda antes da saída dos ingleses. No dia em que estes embarcaram no último navio, 14 de maio de 1948, o Comitê Nacional judaico proclamou o estabelecimento do Estado de Israel no território que lhe fora destinado pela ONU, e no mesmo dia os exércitos de cinco países árabes invadiram o recém-criado estado. No decorrer da guerra, dos cerca de 740 mil árabes que vivam nos territórios do novo estado, entre 580.000 e 650.000 o abandonaram, quer por pressão das forças invasoras, que os estimularam a fazê-lo prometendo que retornariam depois de sua vitória na guerra, quer por medo, quer por terem sido expulsos pelas forças

${ }^{5}$ Em novembro de 1917 o ministro de Exterior da Inglaterra, lorde Balfour, exarava uma
declaração que reconhecia o estabelecimento de um lar nacional judaico na Palestina, sem declaração que reconhecia o estabelecimento de um lar nacional judaico na
prejuízo dos direitos da população árabe ou dos judeus dispersos pelo mundo. 
israelenses. A maioria desses árabes não foi absorvida nos países árabes vizinhos; foram tratados como refugiados, em acampamentos precários, sustentados em parte por recursos da ONU e dos países árabes. Foram, assim, mantidos como refugiados, eles e seus descendentes, não por razões humanitárias, mas - até hoje - como um instrumento de pressão política e moral sobre Israel, mesmo tendo sido o problema criado por uma guerra que os próprios árabes haviam desencadeado. Por outro lado, numa situação simétrica, em consequência do conflito um número equivalente de judeus (mais de 600.000) abandonaram às pressas os países árabes nos quais viviam durante gerações, como o Iraque, a Síria, o Iêmen, o Marrocos, o Egito, a Argélia, a Líbia, o Líbano. A grande maioria foi levada a Israel em operações especiais, praticamente dobrando em um ano a população do país. Depois de tempos difíceis em acampamentos (maabarot), foram totalmente absorvidos pela sociedade israelense. A Declaração de Independência de Israel confirmava a visão não excludente do sionismo sobre os direitos dos dois povos, conclamando os árabes de Israel, da Palestina e dos países da região a viverem em paz com o novo estado, para juntos construírem uma era de progresso e justiça no Oriente Médio.

O armistício de 1949 estabeleceu as fronteiras - reconhecidas internacionalmente - entre o Estado de Israel e o território destinado ao estado dos árabes da Palestina, este territorialmente dividido entre a Cisjordânia e a faixa de Gaza. No entanto, durante os 18 anos e meio em que estes territórios estiveram à disposição dos árabes para isso, nenhum estado palestino foi estabelecido. A questão árabe não era - como nunca fora somente a questão do direito nacional dos árabes da Palestina de terem seu estado. A questão árabe era a hegemonia total sobre toda a Palestina, ou seja, a negação de qualquer direito judaico a uma afirmação nacional, a um estado judaico. A Transjordânia anexou a Cisjordânia, criando o reino da Jordânia. O Egito anexou a faixa de Gaza. Não interessava criar um estado palestino e com isso esvaziar o conteúdo essencial da visão estratégica árabe: uma Palestina árabe-muçulmana integral, sem Israel, sem direitos nacionais judaicos. Confundindo identidade nacional com religião, essa Palestina árabe era chamada de 'estado laico e democrático', como se laicos e democráticos fossem os estados árabes existentes, como se Israel fosse um estado teocrático e seu judaísmo se restringisse à religião, como se democracia não existisse no único estado democrático de toda a região. Os refugiados árabes foram mantidos como peões da 'legalidade' da causa árabe; o não reconhecimento de Israel, o boicote econômico a Israel, depois o terrorismo contra Israel e os israelenses, foram as armas invocadas e aplicadas a partir do primeiro dia após o armistício.

Em 1964, ainda quando Cisjordânia e Gaza eram territórios sob controle árabe, numa conferência pan-árabe foi criada a OLP, Organização de Libertação da Palestina, sob a chefia de Yasser Arafat, o líder da principal organização terrorista anti-israelense, a Al Fatah. A Palestina que devia, então, ser 'libertada', era a das terras do Estado de Israel em suas fronteiras internacionalmente reconhecidas. Na mesma conferência foi aprovada a Carta Palestina, que preconizava explicitamente a extinção, por via armada, do Estado de Israel e de sua população. Apenas os que lá viviam antes de 1917 teriam permissão para ficar'. Amplamente 'argumentada', essa decisão invocava que só a aspiração nacional dos árabes da Palestina era legítima, pois os judeus não eram um povo e não tinham direito sobre aquela terra. A Carta Palestina foi, até pelo menos meados da década de 1990, o instrumento ideológico da luta árabe pela eliminação de Israel e estabelecimento de um estado palestino em toda a Palestina, não deixando dúvida quanto a seus objetivos estratégicos. Seus instrumentos já foram mencionados: boicote, terrorismo, ameaças, pressão política através de uma ONU reconfigurada pelo terceiro-mundismo, contando com o apoio do bloco soviético, em sua guerra fria com o bloco ocidental.

Em 1967, três anos após ter sido exarada a Carta Palestina, talvez insuflados por falsa denúncia soviética de que Israel concentrava tropas e preparava ataque contra a Síria, o Egito e a Síria, e, logo depois, a Jordânia mobilizaram-se para o que denominaram ser a guerra decisiva contra Israel, visando a seu extermínio. Tropas egípcias e sírias, fortemente armadas pelos soviéticos, movimentaram-se para as fronteiras com Israel. O Egito pediu e obteve imediatamente de U-Thant, secretário-geral da ONU, a retirada das tropas da ONU que garantiam a paz no Sinai desde a guerra de $1956^{7}$, deslocou seu exército através do deserto até a fronteira israelense e bloqueou o estreito de Tiran aos navios israelenses, única saída de Israel

\footnotetext{
${ }^{6}$ Ano da Declaração Balfour, primeiro documento oficial a reconhecer a aspiração sionista. ${ }^{7} \mathrm{Na}$ Campanha do Sinai, juntamente com a França e o Reino Unido, Israel combateu as tropas egípcias, e avançou na península do Sinai até o canal de Suez. Sob pressão americana e por decisão das Nações Unidas, retirou-se do Sinai, que foi ocupado por tropas da ONU
} como guardiães da paz. 
para o oceano Índico, via de seu comércio com a Ásia e a África. Mensagens irradiadas do Cairo, em hebraico, avisavam os israelenses de que eles seriam degolados e lançados ao mar. Apesar da ameaça imediata, apesar do bloqueio marítimo, em si um ato de guerra, nem a ONU nem qualquer iniciativa internacional foram mobilizadas para encontrar uma solução pacífica. Em 5 de junho, Israel atacou as forças egípcias e, logo depois, as sírias, destruiu a maior parte de seus efetivos militares e ocupou o Sinai e as colinas de Golan. Apesar dos pedidos de Israel ao rei Hussein para que se mantivesse fora do conflito, o exército jordaniano atacou Israel. Em três dias, Israel ocupou a Cisjordânia, inclusive a cidade-velha de Jerusalém. Em seis dias, a guerra terminara e Israel ocupava militarmente todo o Sinai, a faixa de Gaza, a Cisjordânia e o planalto de Golan.

Logo após o cessar-fogo, o governo israelense de Levi Eshkol propôs a devolução dos territórios ocupados num acordo de paz definitiva. A resposta árabe veio da Conferência de Cartum, no Sudão: não a negociações com Israel, não ao reconhecimento de Israel, não à paz com Israel. A partir de então, a ocupação desses territórios tornou-se um fato político bem caracterizado pelo direito internacional, como consequência de uma guerra e no aguardo do contrato político que desse fim à guerra, contrato que a não negociação, o não reconhecimento e o não à paz tornaram inexequível. $\mathrm{O}$ terrorismo, principalmente atentados contra civis, assumiu proporções cada vez maiores contra israelenses e judeus, em Israel e em qualquer parte do mundo. Mas no momento em que, entre 1977 e $1979^{8}$, o Egito aceitou as negociações que haviam sido propostas por Israel ainda em 1967, acabou sendo assinado o primeiro tratado de paz entre Israel e um país árabe, e o território ocupado, o Sinai, foi integralmente devolvido.

O presidente egípcio signatário da paz foi combatido por todo o mundo árabe, e afinal assassinado. Boicote, terrorismo e recusa de negociar, o apego árabe à visão estratégica da eliminação de Israel continuaram a impedir uma solução negociada e definitiva que permitisse a devolução de territórios num contexto de paz, única alternativa possível para essa

\footnotetext{
${ }^{8}$ Em 1977 o primeiro-ministro egípcio Anuar Sadat, realizou surpreendente e dramática visita ao Estado de Israel, dando início a negociações que levaram, em 1979, ao acordo de Camp David (entre Sadat, Jimmy Carter, presidente norte-americano, e Menachem Beigin, primeiro-ministro de Israel) e à posterior assinatura do acordo de paz entre Israel e o Egito, que incluía a troca de embaixadores. Em 1982 Israel tinha devolvido todo o Sinai ao Egito.
}

devolução. Como poderia Israel entregar territórios para que se constituísse um estado que, programaticamente, teria como estratégia eliminá-lo do mapa e dizimar sua população, com fronteiras a $16 \mathrm{~km}$ de seu núcleo mais densamente povoado?

Novas esperanças surgiram em 1994, quando israelenses e palestinos, primeiro em Madrid, depois em Oslo, pareciam concordar quanto a haver chegado o momento de negociar uma solução de convivência que levasse a uma paz definitiva e ao estabelecimento do estado palestino nos territórios a serem devolvidos por Israel, o que implicou, ao menos oficialmente, o arquivamento, por exigência de Israel, da Carta Palestina de 1964. As negociações, depois de mais de setenta anos de antagonismo, ódio e incompreensão, e de milhares de mortes, pareciam afinal, mesmo com fases de paralisia e de retomada, estar se aproximando de um desfecho promissor, quando em 2000 se reuniram, de novo em Camp David, o primeiro-ministro Ehud Barak, chefiando a delegação israelense, Yasser Arafat, presidente da Autoridade Palestina, chefiando a delegação palestina, e o presidente norteamericano Bill Clinton como host e mediador.

O que aconteceu em Camp David, depois das gentilezas televisadas do 'you first, please', não tem ainda relato oficial. A síntese das versões indica que havia sobre a mesa uma proposta israelense que os próprios israelenses consideraram 'generosa', e que, objetivamente, oferecia: a devolução de c. $95 \%$ das terras da Cisjordânia, com negociação dos $5 \%$ restantes (permutas, compensações); estabelecimento do governo palestino em Jerusalém, que seria, assim, também a capital palestina, mas sem dividir a cidade; estabelecimento de um estado palestino nesses territórios, em condições de paz contratual com Israel. $\mathrm{O}$ que Israel seguramente não aceitou foi a possibilidade de 'retorno' de quase 4 milhões de descendentes de refugiados palestinos para dentro de Israel, e não do estado palestino, o que afetaria decisivamente o equilíbrio demográfico do país, transformando- o em pouco tempo, pela via demográfica, no estado palestino integral preconizado pela Carta Palestina aposentada.

Quais os motivos de Arafat, então, para abandonar o quase-acordo de Camp David e desfechar a nova intifada, que em dois anos levou a uma situação de renovado e trágico impasse? Alega-se que havia má-fé israelense, pois o cronograma de Oslo estava sendo descumprido. Alega-se que a visita de Sharon ao Monte do Templo, diante da mesquita do Domo 
da Rocha, foi uma provocação israelense. Alega-se que as condições de Israel desrespeitavam o que havia sido combinado em Oslo. Quaisquer que sejam as alegações, mesmo que sinceramente Arafat e os palestinos estejam convencidos de que são verdadeiras, elas seriam motivo suficiente para interromper uma negociação que chegara tão perto de um acordo e voltar à estaca zero da violência e do impasse? Sharon não representava então o governo de Israel, tinha o direito de estar ali como cidadão de Israel, e além do mais, a visita fora comunicada e combinada com as autoridades palestinas. Não cumprimento de cronogramas é uma questão operacional, e não conceituai. E as condições de uma paz estavam em negociação. As negociações Beigin-Sadat-Carter passaram por crises, mas era realmente vontade das partes chegar a um acordo. Então é válido perguntar: Arafat queria mesmo chegar a um acordo? Se queria, por que recuou?

Podem-se aventar três hipóteses:

- Arafat não conseguiu reunir coragem para vencer as pressões dos palestinos mais radicais, que nunca abandonaram a estratégia da Carta Palestina e recusam a paz e convivência com Israel ${ }^{9}$. Não quis ou não pôde enfrentar sua própria gente, como fizera Barak, para tentar convencê-la de que só com concessões mútuas se chegaria a um acordo que seria apenas o início de um longo processo de paz e desarmamento.

- Arafat não quis aceitar uma resolução que não contemplasse $100 \%$ de suas exigências, inclusive a volta dos refugiados e a divisão de Jerusalém, por exemplo. O temor de um resultado negociado que exigisse compromissos dos palestinos o teria levado ao confronto, na esperança de conseguir, sem compromissos, mais do que aquilo que já estava a seu alcance com uma simples assinatura.

- $\quad$ Os palestinos nunca quiseram realmente uma paz definitiva com Israel que levasse a seu reconhecimento e ao enterro definitivo dos objetivos estratégicos da Carta Palestina, objetivos para cuja obtenção o estado palestino negociado seria apenas uma etapa (como definido na Carta). A exigência da 'volta' de milhões de refugiados para dentro de Israel, e não do novo estado palestino, parece ser um indício consistente

${ }^{9}$ Movimentos extremistas e fundamentalistas islâmicos, como o Hamas, a Jihad Islâmica e o Hezbollah continuam explicitamente a recusar uma solução que admita 'dois estados para dois povos' e têm como objetivo estratégico a eliminação do Estado de Israel. dessa visão, exigência muito mais voltada para o enfraquecimento e a inviabilização de Israel como estado judaico do que para o fortalecimento e a viabilização do estado palestino.

O que se seguiu, os altos e baixos da violência, com os altos cada vez mais frequentes, põem à prova, uma vez mais, as intenções verdadeiras dos dois lados. Independentemente de qual a tendência política do governo de Israel num dado momento (nos últimos dez anos Israel teve cinco líderes de estilos e concepções não idênticas: Rabin, Peres, Netaniahu, Barak e Sharon), ou quais venham a ser os governos israelense e palestino após eleições em ambos os campos, as alternativas para o Oriente Médio não mudaram, e se resumem a quatro possibilidades:

- Vitória total da visão dos extremistas palestinos, com a extinção de Israel como estado judaico no melhor dos casos, e, no pior dos casos, eliminação ou expulsão da maior parte de sua população;

- Vitória total da visão nacionalista extremista israelense, que se opõe ao estabelecimento de qualquer estado palestino a oeste do Jordão, mesmo em convivência pacífica com o estado judaico; isso exigiria ou a continuação da ocupação, ou a expulsão ou eliminação da população palestina;

- Continuação indefinida do impasse e do conflito, os palestinos recorrendo ao assassinato e ao terror metódicos como forma de desestabilizar a sociedade judaica de Israel, e afinal conduzindo à hipótese a); para os extremistas israelenses, repressão aos palestinos e criação de fatos consumados (mais ocupação, mais colônias) que levariam, afinal, à hipótese b); para ambos, a continuação das mortes, da insegurança quanto ao futuro, do desgaste econômico;

- Acordo de convivência de dois estados para dois povos, que seria o início de um processo de paz que levaria, com o tempo, ao desarmamento psicológico, ao fim do ódio e da educação para o ódio ${ }^{10}$, aos benefícios da cooperação e, por fim, à paz verdadeira, que, segundo Rui Barbosa, é aquela que emana do coração dos povos.

${ }^{10}$ Durante dezenas de anos as crianças palestinas têm sido educadas a odiar os judeus e, a não reconhecer Israel. Os movimentos extremistas as preparam para o autossacrifício em atentados terroristas. Matar judeus é uma das formas de chegar ao paraíso 
Por mais irreal que pareça hoje esta hipótese $d$ ), diante do clima de ódio e conflito exacerbado, diante da desconfiança, diante da quase certeza de que são muitos os fatores que trabalham conscientemente contra ela, diante da evidência de que o objetivo estratégico dos palestinos - e seu simétrico de alguns setores israelenses - ainda é a eliminação de Israel ${ }^{11}$, por mais utópica que essa hipótese possa parecer, nenhuma das outras lhe é preferível como caminho para o futuro, seja para que lado for. Para viabilizá-la, os israelenses teriam de assumir que, independentemente de arrazoados de natureza histórica ou religiosa, de uma alegada, e talvez tecnicamente correta, a-historicidade de uma nação árabe palestina reivindicada como base para um estado palestino árabe, o fato é que se formou uma 'identidade palestina' reconhecida internacionalmente, que é tão fato consumado quanto a presença judaica - independentemente de sua inequívoca razão histórica - e a do estado judaico. $\mathrm{E}$ os palestinos, qualquer que seja o nível de seu radicalismo, terão de se convencer de que o estado judaico, baseado no inegável direito histórico do povo judeu, como o de todos os povos, é legítimo e irreversível. E o mundo terá de se convencer de que, nesse contexto, nenhuma retirada de Israel pode ser exigida fora do contexto de um acordo de paz que reconheça a legitimidade de ambas as aspirações e elimine de uma vez por todas o objetivo estratégico de extinguir o estado judaico.

O sionismo construiu sua visão de uma nação judaica restabelecida com base no direito dos judeus de serem uma nação como todas as outras, $o$ que inclui também seu respeito aos direitos de todas as outras. Esse respeito, ante a reiterada intenção de grande parte dos palestinos de encararem qualquer acordo apenas como um passo a mais para a programada eliminação de Israel", representa sem dúvida um risco para o estado judaico e sua população judaica. Por isso é importante a consciência de que nenhum acordo, nenhuma assinatura, levará por si só à paz. A verdadeira paz terá de ser construída através da convivência contratual, e da progressiva neutralização - pelos benefícios percebidos da paz - dos extremismos e dos fundamentalismos. Levará anos, talvez mais de uma

\footnotetext{
${ }^{11}$ Ainda em julho de 2005, nas vésperas da anunciada retirada israelense de toda a faixa de Gaza, quando oficialmente a Autoridade Palestina declara adotar um caminho de negociações e acordo para a existência de 'dois estados para dois povos', um líder do Hamas, em entrevista à imprensa italiana, reitera a oposição histórica de seu movimento à existência do estado judaico, anunciando o futuro desaparecimento do Estado de Israel.
}

geração. É um risco calculado, com ares de utopia, num período em que a segurança e a defesa ainda serão prioritárias, mas a única tentativa válida para uma solução definitiva. Enquanto isso, o povo judeu, o sionismo e o estado judaico devem esperar e trabalhar para que - do outro lado desse conflito - prevaleçam vozes e ações lúcidas que entrem em ressonância com essa ideia, para criar um novo ciclo, agora virtuoso, de entendimento e convivência pacífica. 